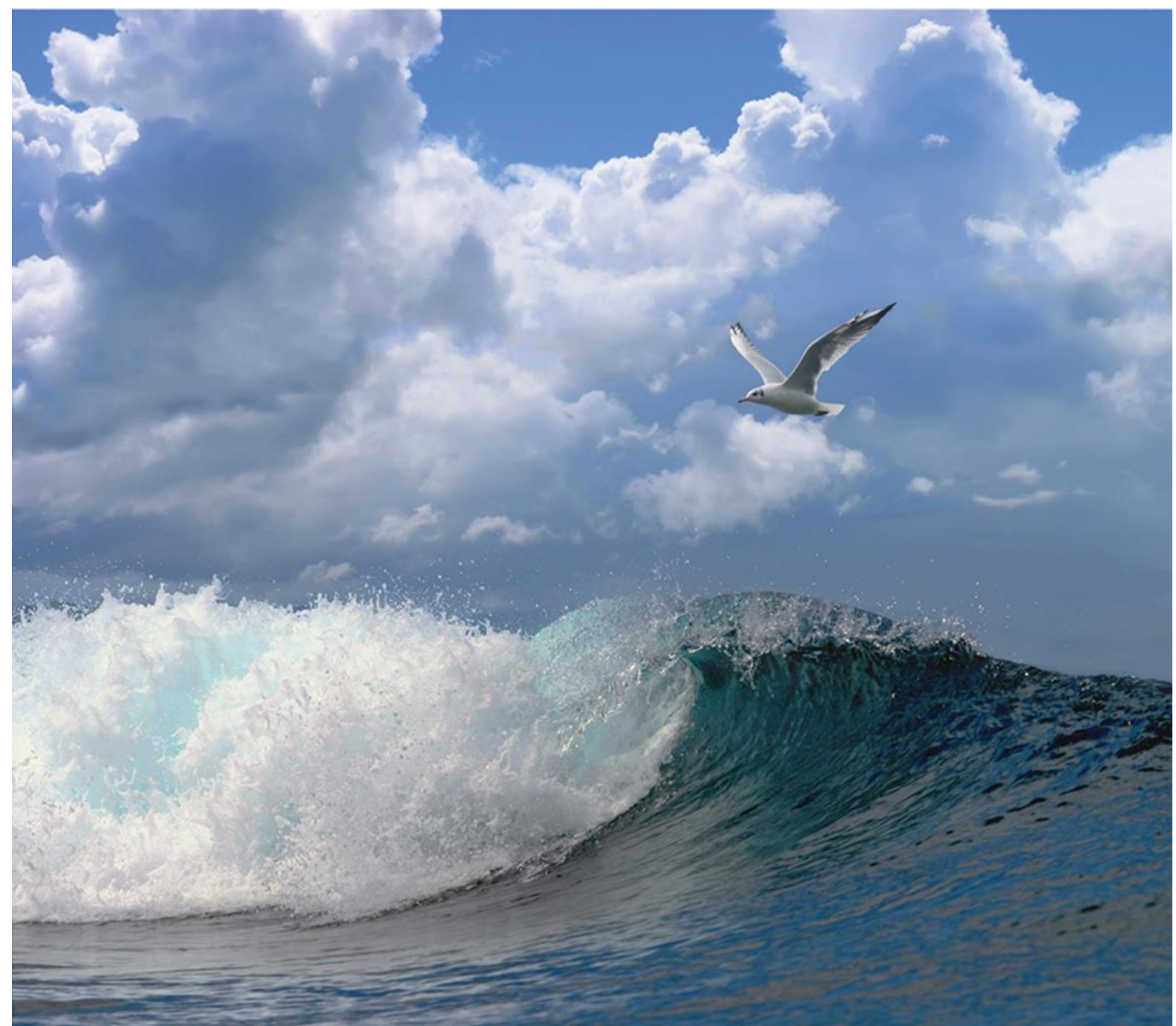

\title{
Vismonitoring Rijkswateren t/m 2019 Deel 1: Toestand en trends
}




\section{Vismonitoring Rijkswateren t/m 2019}

Deel 1: Toestand en trends

Auteur(s):

J.C. van Rijssel, O. A. van Keeken, en J.J. de Leeuw

Wageningen Marine Research

IJmuiden, 1 december 2020

Wageningen Marine Research rapport C105/20 
Keywords: Vismonitoring, Rijkswateren, Natura 2000, KRW, Visstand, Trend, Vissoorten

Opdrachtgever: Rijkswaterstaat

Dienst Water, Verkeer en Leefomgeving

T.a.v.: ir. Charlotte Schmidt

Zuiderwagenplein 2

8224 AD Lelystad

Ministerie van LNV

T.a.v.: ir. V. van der Meij

Postbus 20401

2500 EK Den Haag

Bascode: WOT-05-001-006 en WOT-05-001-007

Dit rapport is gratis te downloaden van https://doi.org/10.18174/536268

Wageningen Marine Research verstrekt geen gedrukte exemplaren van rapporten.

RWS rapport nr: BM 20.17

Wageningen Marine Research is ISO 9001:2015 gecertificeerd.

(c) Wageningen Marine Research

Wageningen Marine Research, instituut binnen de rechtspersoon Stichting

Wageningen Research, hierbij

vertegenwoordigd door

Dr. ir. J.T. Dijkman, Managing director

KvK nr. 09098104,

WMR BTW nr. NL 8113.83.696.B16.

Code BIC/SWIFT address: RABONL2U

IBAN code: NL 73 RABO 0373599285
Wageningen Marine Research aanvaardt geen aansprakelijkheid voor gevolgschade, noch voor schade welke voortvloeit uit toepassingen van de resultaten van werkzaamheden of andere gegevens verkregen van Wageningen Marine Research. Opdrachtgever vrijwaart Wageningen Marine Research van aanspraken van derden in verband met deze toepassing.

Alle rechten voorbehouden. Niets uit deze uitgave mag weergegeven en/of gepubliceerd worden, gefotokopieerd of op enige andere manier gebruikt worden zonder schriftelijke toestemming van de uitgever of auteur. 


\section{Inhoud}

\section{Samenvatting}

Trends algemene soorten per KRW-lichaam 12

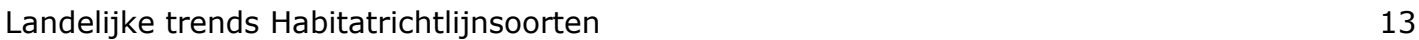

Toetsing Waddenzee, Noordzeekustzone en Deltawateren $\quad 13$

Ecologische Kwaliteitsratio's $\quad 14$

Trends in blankvoorn $\quad 15$

$1 \quad$ Inleiding

$\begin{array}{lll}1.1 & \text { Vismonitoringsprogramma's } & 16\end{array}$

$\begin{array}{ll}1.2 & \text { Informatiebehoefte opdrachtgevers } \\ 1.3 & 16\end{array}$

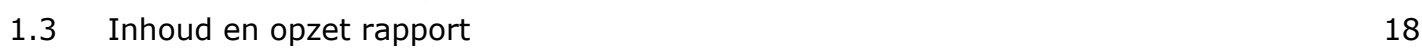

2 Trends per KRW-lichaam $r 20$

IJsselmeer \& Markermeer $\quad 22$

$\begin{array}{ll}\text { Randmeren } & 22\end{array}$

$\begin{array}{ll}\text { Rivieren } & 23\end{array}$

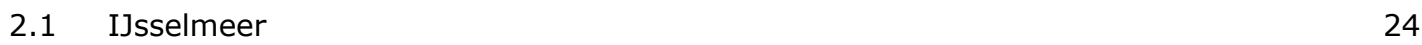

$\begin{array}{lll}2.1 .1 & \text { Open water } & 24\end{array}$

$\begin{array}{lll}2.1 .2 & \text { Oever } & 28\end{array}$

$\begin{array}{lll}2.1 .3 & \text { Aalvangsten } & 31\end{array}$

2.1.4 Schubvis- en aalvangsten $\quad 33$

$\begin{array}{lll}2.2 & \text { Markermeer } & 35\end{array}$

$\begin{array}{lll}2.2 .1 & \text { Open water } & 35\end{array}$

$\begin{array}{lll}2.2 .2 & \text { Oever } & 39\end{array}$

2.3 Randmeren-Oost (open water en oeverzone) 42

$\begin{array}{lll}\text { 2.3.1 Aalvangsten } & 45\end{array}$

2.4 Randmeren-Zuid (open water en oeverzone) 46

$\begin{array}{lll}2.4 .1 & \text { Aalvangsten } & 49\end{array}$

2.5 Benedenloop Gelderse IJssel (IJssel) $\quad 50$

2.5.1 Benedenloop Gelderse IJssel hoofdstroom (open water en oeverzone) 50

2.5.2 Benedenloop Gelderse IJssel zijwateren $\quad 54$

$\begin{array}{lll}2.5 .3 & \text { Aalvangsten } & 56\end{array}$

$\begin{array}{lll}2.6 & \text { Bovenloop Gelderse IJssel (IJssel) } & 57\end{array}$

2.6.1 Bovenloop Gelderse IJssel hoofdstroom (open water en oeverzone) 57

$\begin{array}{lll}\text { 2.6.2 } & \text { Bovenloop Gelderse IJssel zijwateren } & 60\end{array}$

$\begin{array}{lll}2.6 .3 & \text { Aalvangsten } & 62\end{array}$

2.7 Rijn (Boven Rijn, Waal) 63

2.7.1 Rijn hoofdstroom (open water en oeverzone) 63

$\begin{array}{lll}2.7 .2 & \text { Rijn zijwateren } & 67\end{array}$

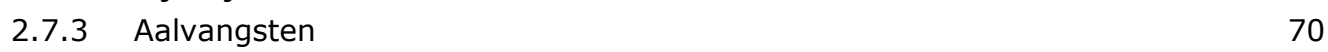

$\begin{array}{lll}2.8 & \text { Grensmaas } & 71\end{array}$

2.8.1 Grensmaas hoofdstroom (open water en oeverzone) 71

$\begin{array}{lll}2.8 .2 & \text { Grensmaas zijwater } & 74\end{array}$

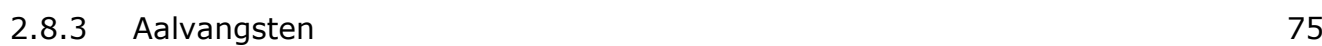


2.9 Zandmaas (Zandmaas en Bedijkte Maas)

2.9.1 Zandmaas hoofdstroom (open water en oeverzone) 76

$\begin{array}{lll}2.9 .2 & \text { Zandmaas zijwateren } & 80\end{array}$

$\begin{array}{lll}2.9 .3 & \text { Aalvangsten } & 83\end{array}$

2.10 Bovenloop Nederrijn (Nederrijn, Lek) $\quad 84$

2.10.1 Bovenloop Nederrijn hoofdstroom (open water en oeverzone) $\quad 84$

$\begin{array}{lll}2.10 .2 & \text { Bovenloop Nederrijn zijwateren } & 88\end{array}$

$\begin{array}{ll}2.10 .3 \text { Aalvangsten } & 90\end{array}$

2.11 Bovenloop Waal (Boven Rijn, Waal) 91

2.11.1 Bovenloop Waal hoofdstroom (open water en oeverzone) 91

\begin{tabular}{ll}
2.11 .2 & Bovenloop Waal zijwateren \\
\hline
\end{tabular}

$\begin{array}{lll}2.11 .3 & \text { Aalvangsten } & 97\end{array}$

2.12 Benedenloop Nederrijn (Nederrijn, Lek) 98

2.12.1 Benedenloop Nederrijn hoofdstroom (open water en oeverzone) 98

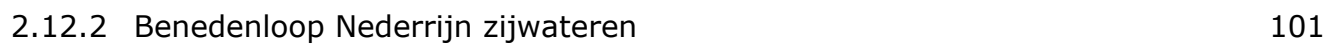

$\begin{array}{ll}2.12 .3 \text { Aalvangsten } & 103\end{array}$

2.13 Benedenloop Waal (Boven Rijn, Waal) 104

2.13.1 Benedenloop Waal hoofdstroom (open water en oeverzone) 104

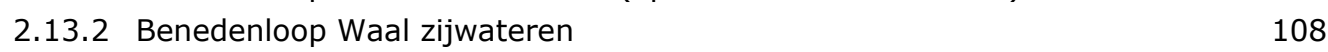

$\begin{array}{ll}2.13 .3 \text { Aalvangsten } & 110\end{array}$

2.14 Getijden Lek (Oude Maas) 111

2.14.1 Getijden Lek hoofdstroom (open water en oeverzone) 111

2.14.2 Getijden Lek zijwateren $\quad 115$

$\begin{array}{ll}2.14 .3 \text { Aalvangsten } & 118\end{array}$

2.15 Getijden Maas (Beneden Maas) 119

2.15.1 Getijden Maas hoofdstroom (open water en oeverzone) 119

2.15.2 Getijden Maas zijwateren 122

$\begin{array}{ll}2.15 .3 \text { Aalvangsten } & 124\end{array}$

2.16 Afgedamde Maas (Afgedamde Maas Zuid) 125

2.16.1 Afgedamde Maas hoofdstroom (open water en oeverzone) 125

$\begin{array}{ll}2.16 .2 \text { Afgedamde Maas zijwateren } & 129\end{array}$

$\begin{array}{ll}2.16 .3 \text { Aalvangsten } & 131\end{array}$

2.17 Heusdensch Kanaal (Afgedamde Maas Zuid) 132

2.17.1 Heusdensch Kanaal hoofdstroom (open water en oeverzone) 132

2.17.2 Aalvangsten 134

2.18 Noordwaard (Brabantse Biesbosch) 135

$\begin{array}{ll}2.18 .1 \text { Noordwaard (oeverzone) } & 135\end{array}$

2.18.2 Aalvangsten 136

2.19 Nieuwe Merwede (Dordtse Biesbosch) 138

2.19.1 Nieuwe Merwede hoofdstroom (open water en oeverzone) 138

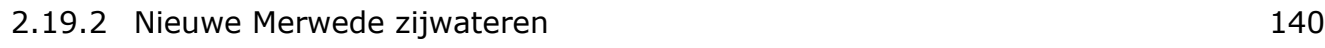

$\begin{array}{ll}2.19 .3 \text { Aalvangsten } & 142\end{array}$

2.20 Hollands(ch)e IJssel 143

2.20.1 Hollandse IJssel hoofdstroom (open water en oeverzone) 143

$\begin{array}{lll}2.20 .2 & \text { Aalvangsten } & 145\end{array}$

2.21 Oude Maas 146

2.21.1 Oude Maas hoofdstroom (open water en oeverzone) 146

$\begin{array}{lll}2.21 .2 & \text { Oude Maas zijwateren } & 148\end{array}$

$\begin{array}{ll}2.21 .3 \text { Aalvangsten } & 149\end{array}$

2.22 Hollandsch Diep (Haringvliet-Oost) 150

2.22.1 Hollandsch Diep hoofdstroom (open water en oeverzone) 150

2.22.2 Aalvangsten 152

2.23 Haringvliet-West 153 
2.23.1 Haringvliet-West hoofdstroom (open water) 153

2.23.2 Haringvliet-West zijwater 157

2.23.3 Chinese wolhandkrab 157

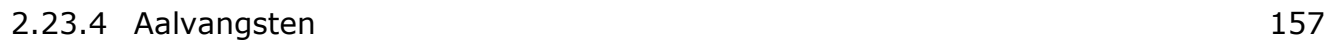

2.24 Volkerak 158

2.24.1 Volkerak hoofdstroom (open water en oeverzone) 158

$\begin{array}{ll}2.24 .2 \text { Volkerak zijwater } & 161\end{array}$

$\begin{array}{lll}2.24 .3 & \text { Aalvangsten } & 163\end{array}$

2.25 Zoommeer (Zoommeer, Eendracht) 164

2.25.1 Zoommeer hoofdstroom (open water en oeverzone) 164

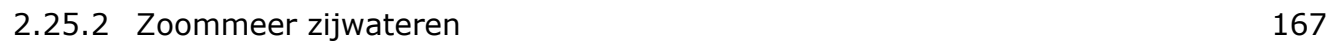

$\begin{array}{ll}2.25 .3 \text { Aalvangsten } & 168\end{array}$

$\begin{array}{lll}2.26 & \text { Veerse Meer } & 169\end{array}$

2.26.1 Veerse Meer hoofdstroom (open water en oeverzone) 169

$\begin{array}{ll}2.26 .2 \text { Aalvangsten } & 171\end{array}$

$\begin{array}{ll}2.27 & \text { Grevelingen(meer) } \\ & 172\end{array}$

2.27.1 Grevelingenmeer hoofdstroom (open water) 172

$\begin{array}{ll}2.27 .2 \text { Aalvangsten } & 174\end{array}$

2.28 Nieuwe Waterweg $\quad 175$

2.28.1 Nieuwe Waterweg hoofdstroom (open water) 175

$\begin{array}{ll}2.28 .2 \text { Aalvangsten } & 177\end{array}$

$\begin{array}{ll}2.29 & \text { Noordzeekanaal } \\ \end{array}$

2.29.1 Noordzeekanaal hoofdstroom (open water en oeverzone) 178

$\begin{array}{ll}2.29 .2 \text { Noordzeekanaal zijwateren } & 180\end{array}$

$\begin{array}{ll}2.29 .3 \text { Aalvangsten } & 182\end{array}$

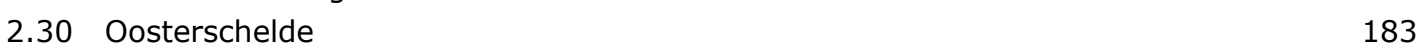

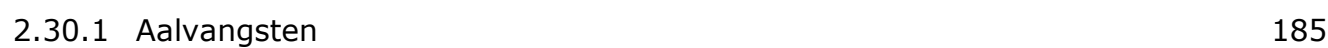

2.31 Westerschelde 186

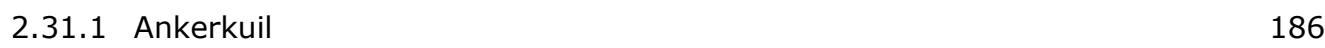

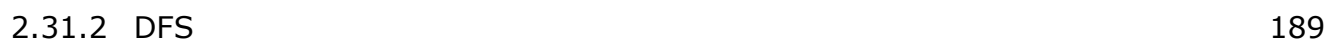

2.31.3 Chinese wolhandkrab 191

$\begin{array}{ll}2.31 .4 \text { Aalvangsten } & 191\end{array}$

2.32 Eems-estuarium $\quad 192$

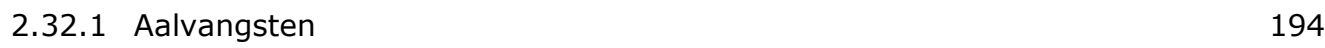

2.33 Vergelijking tussen overgangswateren $\quad 195$

$\begin{array}{lr}2.34 & 197\end{array}$

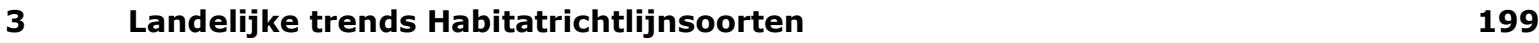

$\begin{array}{llr}3.1 & \text { Inleiding } & 199\end{array}$

3.1.1 Vereisten rapportage Habitatrichtlijn 199

$\begin{array}{lll}3.1 .2 & \text { Dataselectie } & 199\end{array}$

$\begin{array}{lll}3.1 .3 & \text { Trendanalyse } & 200\end{array}$

$\begin{array}{lll}3.1 .4 & \text { Expert judgement } & 200\end{array}$

$\begin{array}{lll}3.2 & \text { Barbeel } & 201\end{array}$

$\begin{array}{lll}3.2 .1 & \text { Ecologie } & 201\end{array}$

$\begin{array}{lll}3.2 .2 & \text { Historische ontwikkeling } & 201\end{array}$

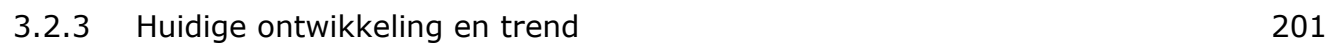

$\begin{array}{lll}3.3 & \text { Elft } & 204\end{array}$

$\begin{array}{lll}3.3 .1 & \text { Ecologie } & 204\end{array}$

$\begin{array}{lll}\text { 3.3.2 Historische ontwikkeling } & 204\end{array}$

$\begin{array}{lll}\text { 3.3.3 Huidige ontwikkeling en trend } & 204\end{array}$

$\begin{array}{llr}3.4 & \text { Fint } & 206\end{array}$

$\begin{array}{lll}3.4 .1 & \text { Ecologie } & 206\end{array}$ 
3.4.2 Historische ontwikkeling 206

3.4.3 Huidige ontwikkeling en trend 206

$3.5 \quad$ Noordzeehouting $\quad 208$

$\begin{array}{lll}3.5 .1 & \text { Ecologie } & 208\end{array}$

3.5.2 Historische ontwikkeling 208

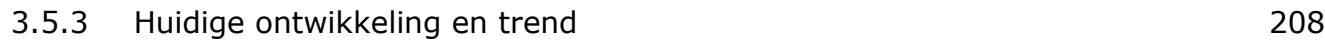

$\begin{array}{lll}3.6 & \text { Rivierprik } & 211\end{array}$

$\begin{array}{lll}3.6 .1 & \text { Ecologie } & 211\end{array}$

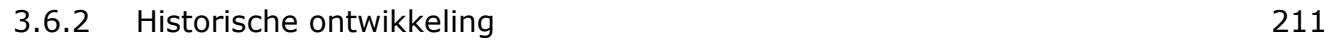

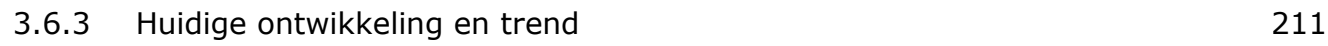

3.7 Zeeprik 213

3.7.1 Ecologie $\quad 213$

$\begin{array}{lll}\text { 3.7.2 Historische ontwikkeling } & 213\end{array}$

3.7.3 Huidige ontwikkeling en trend 213

3.8 Zalm 216

3.8.1 Ecologie 216

3.8.2 Historische ontwikkeling 216

3.8.3 Huidige ontwikkeling en trend $\quad 216$

$\begin{array}{lll}3.9 & \text { Discussie en conclusies } & 219\end{array}$

$4 \quad$ Evaluatie Natura 2000-gebieden 220

4.1 Inleiding en methode $\quad 220$

4.2 Ecologie Habitatrichtlijn soorten $\quad 222$

$\begin{array}{lll}4.2 .1 & \text { Rivierdonderpad } & 222\end{array}$

$\begin{array}{lll}4.3 & \text { Waddenzee } & 224\end{array}$

$\begin{array}{lll}4.3 .1 & \text { Zeeprik } & 224\end{array}$

$\begin{array}{lll}4.3 .2 & \text { Rivierprik } & 229\end{array}$

$\begin{array}{lll}4.3 .3 & \text { Fint } & 234\end{array}$

$\begin{array}{lll}\text { 4.3.4 Conclusies per soort Waddenzee } & 239\end{array}$

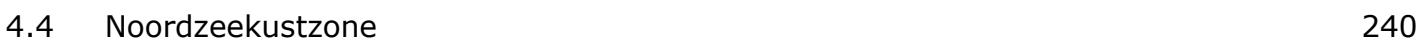

$\begin{array}{lll}4.4 .1 & \text { Zeeprik } & 241\end{array}$

$\begin{array}{lll}4.4 .2 & \text { Rivierprik } & 241\end{array}$

$\begin{array}{lll}4.4 .3 & \text { Fint } & 243\end{array}$

4.4.4 Conclusies per soort Noordzeekustzone $\quad 244$

$\begin{array}{lll}4.5 & \text { Hollandsch Diep } & 245\end{array}$

$\begin{array}{lll}4.5 .1 & \text { Zeeprik } & 245\end{array}$

$\begin{array}{lll}4.5 .2 & \text { Rivierprik } & 247\end{array}$

$\begin{array}{lll}4.5 .3 & \text { Fint } & 249\end{array}$

$\begin{array}{lll}4.5 .4 & \text { Elft } & 250\end{array}$

$\begin{array}{lll}4.5 .5 & \text { Zalm } & 250\end{array}$

4.5.6 Conclusies per soort Hollandsch Diep 254

4.6 Haringvliet $\quad 255$

$\begin{array}{lll}4.6 .1 & \text { Zeeprik } & 255\end{array}$

$\begin{array}{lll}4.6 .2 & \text { Rivierprik } & 256\end{array}$

$\begin{array}{lll}4.6 .3 & \text { Fint } & 258\end{array}$

$\begin{array}{lll}4.6 .4 & \text { Elft } & 259\end{array}$

$\begin{array}{lll}4.6 .5 & \text { Zalm } & 259\end{array}$

$\begin{array}{lll}4.6 .6 & \text { Rivierdonderpad } & 260\end{array}$

4.6.7 Conclusies per soort Haringvliet $\quad 262$

$\begin{array}{lll}4.7 & \text { Westerschelde \& Saefthinghe } & 263\end{array}$

$\begin{array}{lll}4.7 .1 & \text { Zeeprik } & 263\end{array}$

$\begin{array}{lll}4.7 .2 & \text { Rivierprik } & 264\end{array}$

$\begin{array}{lll}4.7 .3 & \text { Fint } & 265\end{array}$ 
$\begin{array}{llr}5.1 & \text { Inleiding } & 268\end{array}$

$\begin{array}{lll}5.2 & \text { Watertypen en waterlichamen } & 270\end{array}$

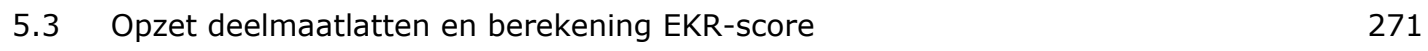

$\begin{array}{lll}5.4 & \text { EKR-score berekening } & 272\end{array}$

$\begin{array}{lll}5.5 & \text { Selectie gegevens } & 273\end{array}$

$\begin{array}{lll}5.6 & \text { Aquokit } & 275\end{array}$

$\begin{array}{lll}5.7 & \text { EKR-beoordeling per waterlichaam } & 276\end{array}$

$\begin{array}{lll}5.8 & \text { Uitwerking van EKR-score en toelichting } & 279\end{array}$

$6 \quad$ Trends in blankvoorn $r 299$

6.1 Inleiding $\quad 299$

$\begin{array}{lll}6.1 .1 & \text { Migratie } & 300\end{array}$

$\begin{array}{lll}6.1 .2 & \text { Bedreigingen } & 300\end{array}$

$\begin{array}{lll}6.2 & \text { Blankvoorn trends per KRW-lichaam } & 304\end{array}$

$\begin{array}{ll}6.3 & \text { IJsselmeer } \\ \end{array}$

$\begin{array}{lll}6.3 .1 & \text { Open water } & 305\end{array}$

$\begin{array}{lll}6.3 .2 & \text { Oever } & 305\end{array}$

$\begin{array}{lll}6.4 & \text { Markermeer } & 308\end{array}$

$\begin{array}{lll}6.4 .1 & \text { Open water } & 308\end{array}$

$\begin{array}{lll}6.4 .2 & \text { Oever } & 308\end{array}$

6.5 Randmeren-Oost $\quad 311$

6.5.1 Open water 311

$\begin{array}{lll}6.5 .2 & \text { Oever } & 311\end{array}$

$\begin{array}{lll}6.6 & \text { Randmeren-Zuid } & 314\end{array}$

$\begin{array}{lll}6.6 .1 & \text { Open water } & 314\end{array}$

$\begin{array}{lll}6.6 .2 & \text { Oever } & 314\end{array}$

$\begin{array}{lll}6.7 & \text { Benedenloop Gelderse IJssel } & 316\end{array}$

$\begin{array}{lll}\text { 6.7.1 Hoofdstroom (open water) } & 316\end{array}$

$\begin{array}{lll}6.7 .2 & \text { Hoofdstroom (oever) } & 316\end{array}$

6.7.3 Zijwateren (open water) 316

6.7.4 Zijwateren (oever) 316

$\begin{array}{lll}6.8 & \text { Bovenloop Gelderse IJssel } & 319\end{array}$

6.8.1 Hoofdstroom (open water) 319

6.8.2 Hoofdstroom (oever) 319

6.8.3 Zijwateren (open water) 319

$\begin{array}{lll}6.8 .4 & \text { Zijwateren (oever) } & 319\end{array}$

$\begin{array}{lll}6.9 & \text { Rijn } & 322\end{array}$

6.9.1 Hoofdstroom (open water) $\quad 322$

6.9.2 Hoofdstroom (oever) $\quad 322$

6.9.3 Zijwateren (open water) $\quad 322$

6.9.4 Zijwateren (oever) 322

$\begin{array}{ll}6.10 & \text { Grensmaas } \\ \end{array}$

$\begin{array}{lll}6.10 .1 & \text { Hoofdstroom } & 325\end{array}$

$\begin{array}{lll}6.10 .2 & \text { Zijwateren } & 325\end{array}$

$\begin{array}{ll}6.11 & \text { Zandmaas } \\ \end{array}$

6.11.1 Hoofdstroom (open water) 327

6.11.2 Hoofdstroom (oever) 327

6.11.3 Zijwateren (open water) 327

$\begin{array}{ll}6.11 .4 & \text { Zijwateren (oever) } \\ \end{array}$ 
6.12 Bovenloop Nederrijn

6.12.1 Hoofdstroom (open water) 330

$\begin{array}{ll}6.12 .2 \text { Hoofdstroom (oever) } & 330\end{array}$

6.12.3 Zijwateren (open water) 330

6.12.4 Zijwateren (oever) 330

6.13 Bovenloop Waal $\quad 333$

6.13.1 Hoofdstroom (open water) 333

6.13.2 Hoofdstroom (oever) 333

6.13.3 Zijwateren (open water) 333

6.13.4 Zijwateren (oever) 333

6.14 Benedenloop Nederrijn 336

6.14.1 Hoofdstroom (open water) 336

6.14.2 Hoofdstroom (oever) 336

6.14.3 Zijwateren (open water) $\quad 336$

6.14.4 Zijwateren (oever) 336

6.15 Benedenloop Waal $\quad 339$

$\begin{array}{lll}6.15 .1 & 339\end{array}$

6.15.2 Hoofdstroom (oever) $\quad 339$

6.15.3 Zijwateren (open water) $\quad 339$

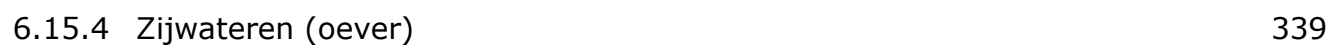

6.16 Getijden Lek $\quad 342$

6.16.1 Hoofdstroom (open water) $\quad 342$

6.16.2 Hoofdstroom (oever) 342

6.16.3 Zijwateren (open water) $\quad 342$

6.16.4 Zijwateren (oever) 342

$\begin{array}{ll}6.17 \text { Getijden Maas } & 345\end{array}$

$\begin{array}{lll}6.17 .1 & \text { Hoofdstroom (open water) } & 345\end{array}$

6.17.2 Hoofdstroom (oever) $\quad 345$

6.17.3 Zijwateren (open water) $\quad 345$

6.17.4 Zijwateren (oever) $\quad 345$

$\begin{array}{ll}6.18 & \text { Afgedamde Maas } \\ \end{array}$

$\begin{array}{ll}6.18 .1 \text { Hoofdstroom (open water) } & 348\end{array}$

$\begin{array}{ll}6.18 .2 \text { Hoofdstroom (oever) } & 348\end{array}$

$\begin{array}{lll}6.18 .3 & \text { Zijwateren (open water) } & 348\end{array}$

6.18.4 Zijwateren (oever) 348

6.19 Heusdensch Kanaal $\quad 351$

$\begin{array}{lll}6.19 .1 \text { Hoofdstroom } & 351\end{array}$

$\begin{array}{ll}6.19 .2 \text { Oever } & 351\end{array}$

6.20 Noordwaard $\quad 353$

6.20.1 Oever schepnet 353

6.20.2 Oever zegen 353

6.21 Nieuwe Merwede $\quad 355$

6.21.1 Hoofdstroom (open water) 355

6.21.2 Hoofdstroom (oever) 355

6.21.3 Zijwateren (open water) 355

$\begin{array}{lr}6.22 & 357\end{array}$

6.22.1 Hoofdstroom $\quad 357$

$\begin{array}{ll}6.22 .2 \text { Oever } & 357\end{array}$

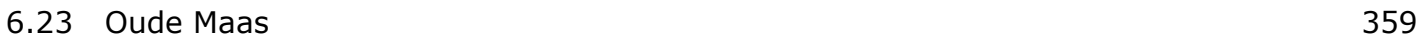

6.23.1 Hoofdstroom (open water) 359

6.23.2 Hoofdstroom (oever) 359

6.23.3 Zijwateren (oever) 359

$\begin{array}{ll}6.24 & 362\end{array}$ 
6.24.1 Hoofdstroom 362

6.24.2 Oever $\quad 362$

6.25 Haringvliet-West $\quad 364$

6.25.1 Hoofdstroom (open water) 364

6.25.2 Zijwater (open water)

6.26 Volkerak 366

6.26.1 Hoofdstroom (open water) 366

6.26.2 Hoofdstroom (oever) 366

6.26.3 Zijwater (open water) 366

6.27 Zoommeer $\quad 369$

6.27.1 Hoofdstroom en oever 369

6.28 Noordzeekanaal $\quad 371$

$\begin{array}{lll}6.28 .1 & \text { Hoofdstroom (open water) } & 371\end{array}$

$\begin{array}{ll}\text { 6.28.2 Zijwateren (open water) } & 371\end{array}$

$\begin{array}{lll}6.29 & \text { Discussie } & 373\end{array}$

$7 \quad$ Kwaliteitsborging $\quad 380$

$\begin{array}{lr}\text { Literatuur } & 381\end{array}$

$\begin{array}{lr}\text { Verantwoording } & 389\end{array}$

$\begin{array}{llr}\text { Bijlage } 1 & \text { Ecologische gildes } & 390\end{array}$

Bijlage 2 Totaal aangelande jaarlijkse vangsten beroepsvissers per gebied in kilo's (bron:LNV) $\quad 392$

$\begin{array}{lll}\text { Bijlage } 3 & \text { IJsselmeer open water } & 393\end{array}$

$\begin{array}{llr}\text { Bijlage } 4 & \text { IJsselmeer oever } & 397\end{array}$

$\begin{array}{llr}\text { Bijlage } 5 & \text { Markermeer open water } & 400\end{array}$

$\begin{array}{llr}\text { Bijlage } 6 & \text { Markermeer oever } & 402\end{array}$

$\begin{array}{llr}\text { Bijlage } 7 & \text { Randmeren-Oost } & 405\end{array}$

$\begin{array}{llr}\text { Bijlage } 8 & \text { Randmeren-Zuid } & 410\end{array}$

$\begin{array}{llr}\text { Bijlage } 9 & \text { Figuren 1992-1996 } & 413\end{array}$

Bijlage $10 \quad$ Benedenloop Gelderse IJssel hoofdstroom 434

$\begin{array}{llr}\text { Bijlage } 11 & \text { Benedenloop Gelderse IJssel zijwateren } & 438\end{array}$

Bijlage 12 Bovenloop Gelderse IJssel hoofdstroom 4442

$\begin{array}{llr}\text { Bijlage } 13 & \text { Bovenloop Gelderse IJssel zijwateren } & 446\end{array}$

$\begin{array}{llr}\text { Bijlage } 14 & \text { Rijn hoofdstroom } & 450\end{array}$

$\begin{array}{llr}\text { Bijlage } 15 & \text { Rijn zijwateren } & 454\end{array}$ 
Bijlage 16 Grensmaas hoofdstroom 456

$\begin{array}{llr}\text { Bijlage } 17 & \text { Grensmaas zijwateren } & 458\end{array}$

Bijlage 18 Zandmaas hoofdstroom 460

Bijlage 19 Zandmaas zijwateren $\quad 464$

$\begin{array}{llr}\text { Bijlage } 20 & \text { Bovenloop Nederrijn hoofdstroom } & 468\end{array}$

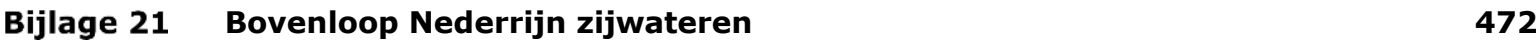

Bijlage 22 Bovenloop Waal hoofdstroom 476

Bijlage 23 Bovenloop Waal zijwateren $\quad 480$

Bijlage $24 \quad$ Benedenloop Nederrijn hoofdstroom 44

Bijlage $25 \quad$ Benedenloop Nederrijn zijwateren 486

$\begin{array}{llr}\text { Bijlage } 26 & \text { Benedenloop Waal hoofdstroom } & 488\end{array}$

Bijlage 27 Benedenloop Waal zijwateren $\quad 490$

Bijlage 28 Getijden Lek hoofdstroom 4492

Bijlage 29 Getijden Lek zijwateren $\quad 496$

$\begin{array}{llr}\text { Bijlage } 30 \quad \text { Getijden Maas hoofdstroom } & 500\end{array}$

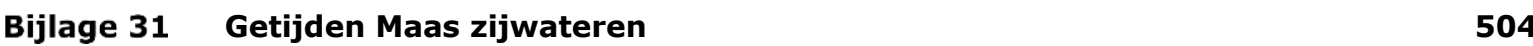

$\begin{array}{llr}\text { Bijlage } 32 & \text { Afgedamde Maas hoofdstroom } & 508\end{array}$

$\begin{array}{llr}\text { Bijlage } 33 & \text { Afgedamde Maas zijwateren } & 510\end{array}$

$\begin{array}{llr}\text { Bijlage } 34 & 512\end{array}$

$\begin{array}{llr}\text { Bijlage } 35 \quad \text { Noordwaard } & 514\end{array}$

$\begin{array}{llr}\text { Bijlage } 36 & 516\end{array}$

$\begin{array}{llr}\text { Bijlage } 37 & \text { Nieuwe Merwede zijwateren } & 520\end{array}$

$\begin{array}{llr}\text { Bijlage } 38 & \text { Hollandse IJssel hoofdstroom } & 521\end{array}$

$\begin{array}{llr}\text { Bijlage } 39 & \text { Oude Maas hoofdstroom } & 523\end{array}$

$\begin{array}{llr}\text { Bijlage } 40 & \text { Oude Maas zijwateren } & 527\end{array}$

$\begin{array}{llr}\text { Bijlage } 41 & 528\end{array}$

Bijlage 42 Haringvliet-West hoofdstroom 532 
$\begin{array}{llr}\text { Bijlage } 44 \quad \text { Zoommeer hoofdstroom } & 535\end{array}$

$\begin{array}{llr}\text { Bijlage } 45 \quad \text { Zoommeer zijwateren } & 537\end{array}$

$\begin{array}{llr}\text { Bijlage } 46 & \text { Volkerak hoofdstroom } & 538\end{array}$

$\begin{array}{llr}\text { Bijlage } 47 & \text { Volkerak zijwateren } & 540\end{array}$

$\begin{array}{llr}\text { Bijlage } 48 \quad \text { Veerse Meer hoofdstroom } & 542\end{array}$

$\begin{array}{lll}\text { Bijlage } 49 & \text { Grevelingenmeer hoofdstroom } & 544\end{array}$

$\begin{array}{lll}\text { Bijlage } 50 \quad \text { Nieuwe Waterweg hoofdstroom } & 546\end{array}$

$\begin{array}{llr}\text { Bijlage } 51 & \text { Noordzeekanaal hoofdstroom } & 548\end{array}$

$\begin{array}{llr}\text { Bijlage } 52 & \text { Noordzeekanaal zijwateren } & 550\end{array}$

Bijlage $53 \quad$ Oosterschelde (DFS) 552

$\begin{array}{llr}\text { Bijlage } 54 & \text { Westerschelde (Ankerkuil) } & 554\end{array}$

$\begin{array}{llr}\text { Bijlage } 55 & \text { Westerschelde (DFS) }\end{array}$

$\begin{array}{llr}\text { Bijlage } 56 & \text { Eems-estuarium } & 558\end{array}$

Bijlage 57 Selectie en opwerking voor de trends Habitatrichtlijnsoorten 560

Beschikbare gegevens en kaders $\quad 560$

Kaders voor dataselectie en -opwerking $\quad 560$

Kaders voor de statistische analyse $\quad 560$

$\begin{array}{ll}\text { Dataselectie en -opwerking } & 561\end{array}$

Selectie monitoringsprogramma's per soort $\quad 561$

Gegevensselectie per soort $\quad 562$

$\begin{array}{llr}\text { Bijlage } 58 & \text { Wegingsfactoren waterlichamen EKR scoreberekening } & 570\end{array}$

$\begin{array}{llr}\text { Bijlage } 59 & 5 \mathrm{KR} \text { Indicator \& deelmaatlatscores }\end{array}$ 


\section{Samenvatting}

Het vismonitoringprogramma in de Rijkswateren wordt uitgevoerd volgens het Programmaplan Vis-en Biotamonitoring 2018-2023 van Rijkswaterstaat en het Wettelijke Onderzoekstaken (WOT) Visserij programma in opdracht van het Ministerie van LNV. Jaarlijks wordt gerapporteerd in drie delen: Deel I 'Toestand en trends' waarin de resultaten worden geïnterpreteerd, Deel II "Toegepaste methoden" waarin de gebruikte methodieken staan beschreven en Deel III "Data" waarin de gegevens via een dataportal worden ontsloten.

In het voorliggende rapport (Deel I) worden de volgende trends gepresenteerd: (i) trends in de tien meest algemene vissoorten en wolhandkrab per Kaderrichtlijn Water (KRW) lichaam en trends van aalen schubvisvangsten per KRW-lichaam door de beroepsvisserij, (ii) landelijke trends in Habitatrichtlijnsoorten, en (iii) toetsing van de Natura 2000 gebieden Waddenzee, Noordzeekustzone en Deltawateren (Haringvliet, Hollandsch Diep en Westerschelde \& Saeftinghe), (iv) ecologische kwaliteitsratio's en ( $v$ ) trends van blankvoorn per KRW-lichaam. In dit rapport is gebruik gemaakt van de gegevens die binnen de verschillende vismonitoringsprogramma's op de Rijkswateren (zie Tabel 1.1) worden verzameld, aangevuld met gegevens uit andere bronnen, zoals commerciële aanlandingen. Het vangstsucces in de monitoringsprogramma's (vangst per eenheid inspanning) wordt gebruikt als indicator voor de ontwikkeling in de bestandsgrootte over de jaren heen.

\section{Trends algemene soorten per KRW-lichaam}

De analyses van de visstand in de Rijkswateren zijn uitgevoerd per KRW-lichaam. Hiervoor zijn gegevens gebruikt uit visserij-onafhankelijke monitoringprogramma's: de actieve vismonitoring op het open water van het IJsselmeer en Markermeer, in de Randmeren en op de grote rivieren. Ook zijn de gegevens uit ankerkuilbemonsteringsprogramma's in de Westerschelde en het Eems-estuarium gebruikt. Daarnaast zijn ook de gegevens van de Demersal Fish Survey (DFS) gebruikt voor de Ooster- en Westerschelde en het Eems-estuarium.

Van de tien meest algemene vissoorten (op basis van aantal en biomassa) zijn per KRW-lichaam de trends in vangstsucces weergegeven, welke een indicatie vormen voor de trend in de grootte van de visbestanden. Daarnaast zijn er voor de KRW-lichamen waar deze regelmatig voorkomt, trends van wolhandkrab weergegeven.

Meest opvallend zijn de afnames van cyprinide soorten zoals brasem, kolblei en blankvoorn in de verschillende KRW-lichamen vanaf de periode 2010-2012. Niet alleen cyprinide soorten maar ook andere soorten zoals pos, rivierdonderpad, barbeel en bermpje laten opvallende afnames zien. Voor sommige van deze soorten (rivierdonderpad, bermpje) valt de afname samen met de toename van invasieve exotische soorten zoals de zwartbekgrondel. Het is nog onduidelijk of de invasieve soorten (ook) een effect hebben gehad op de afname van andere soorten. Naast een afname van veel soorten lijken sommige soorten, zoals baars, snoekbaars en aal, de laatste paar jaar juist toe te nemen. De oorzaak van de toename van de baarsachtigen is vooralsnog onduidelijk. De toename van aal heeft mogelijk te maken met maatregelen genomen vanuit het aalbeheerplan (o.a. gesloten aalvisserij op de grote rivieren sinds 2011, gesloten aalvisserij tijdens de migratiemaanden sinds 2009, verbeterde migratiemogelijkheden) in combinatie met een hogere glasaalintrek in 2013 en 2014.

Alhoewel het er de afgelopen twee jaar op leek dat de zwartbekgrondel wellicht op zijn retour was, werd deze in 2019 in veel KRW-lichamen weer meer gevangen en domineerde in sommige wateren zowel de aantallen als de biomassa. De aanlandingen van aal lijken in voor aalvisserij belangrijke KRW-lichamen (IJsselmeer, Markermeer, Randmeren) te zijn toegenomen terwijl er in deze wateren geen duidelijke stijging is van aal in de verschillende monitoringen. 
In deze rapportage wordt voor het eerst de status van de wolhandkrabben in de monitoring besproken. Over het algemeen lijkt er de laatste paar jaar een toename van het aantal wolhandkrabben te zijn met 2019 als hoogtepunt, vooral in de benedenrivieren. In het IJsselmeer daarentegen lijkt er de laatste paar jaren een afname van wolhandkrabben te zijn.

\section{Landelijke trends Habitatrichtlijnsoorten}

Om de zes jaar rapporteert Nederland de status van Habitatrichtlijn (HR)-soorten aan de Europese Commissie. Een onderdeel van die rapportage is een beoordeling van de trend in de landelijke bestandsgrootte over de laatste twaalf jaar, dat wil zeggen de laatste 2 rapportcycli. Voor zeven HRsoorten (barbeel, elft, fint, houting, rivierpik, zeeprik en zalm) is hiertoe de landelijke trend in vangstsucces (aantal vissen per fuiketmalen of $\mathrm{km}$ ) in de visserij-onafhankelijke monitoringprogramma's geanalyseerd. In 2019 is een analyse uitgevoerd met de gegevens van 2006-2017 (2 rapportcycli - zie rapport 2019). De resultaten hiervan worden in dit rapport nog eens kort herhaald. Voor de soorten waarover genoeg gegevens beschikbaar waren is een statistische analyse uitgevoerd met Trendspotter, conform de werkwijze van het Centraal Bureau voor de Statistiek. Voor weergave van de trends zijn in dit rapport ook de jaren 2018 en 2019 meegenomen; dit fungeert ook als een 'tussenstand'.

De twee HR-soorten waarvan de trend in vangstsucces statistisch onderzocht kon worden, barbeel en zalm, laten allebei een statistisch significante afname in vangstsucces over de periode 2006-2017 zien.

Houting en zeeprik lijken af te nemen gedurende grofweg de laatste tien jaren in de kerngebieden van voorkomen. Hiervan is echter geen consistente tijdreeks over de hele periode beschikbaar. De tijdreeksen van rivierprik en fint zijn nog te kort om uitspraken te kunnen doen. Wat betreft rivierprik wordt dan ook aanbevolen om de uitvoer van de diadrome vissurvey in december (die sinds 2014 wordt uitgevoerd) voort te blijven zetten. Elft komt te weinig voor in de monitoringsreeksen om een betrouwbare uitspraak te kunnen doen.

\section{Toetsing Waddenzee, Noordzeekustzone en Deltawateren}

Om beheerplannen van Natura 2000-gebieden te kunnen evalueren met betrekking tot de status van de beschermde vissoorten (Habitatrichtlijn Annex II soorten), is beoordeeld of de gestelde N2000instandhoudingsdoelstellingen per soort per N2000-gebied zijn behaald of niet, of dat kennis voor een beoordeling ontbreekt. In het voorliggende rapport zijn de Waddenzee, Noordzeekustzone en Deltawateren (Hollandsch Diep, Haringvliet, Westerschelde \& Saeftinghe) getoetst.

De Waddenzee is in 2009 aangewezen als Natura 2000-gebied. De vissoorten die in het beheerplan van de Waddenzee zijn opgenomen zijn zeeprik, rivierprik en fint. De doelstelling voor alle drie de soorten is uitbreiding van de populatie. De monitoringprogramma's die hier plaatsvinden zijn de Demersal Fish Survey (DFS) met de boomkor, diadrome vissen survey FDIA (Kornwerderzand, Den Oever aan de IJsselmeerzijde), diadrome vissen survey DIADROOM (Kornwerderzand aan de Waddenzee zijde) met fuiken en de NIOZ-fuik op Texel. Voor de zeeprik, rivierprik en fint is de trend onzeker of is er een afname, waarmee de doelstellingen van deze soorten niet zijn gehaald. Voor rivierprik en zeeprik is de verwachting dat de soort in de toekomst mogelijk zal toenemen zodra de Vismigratierivier is geïmplementeerd.

De Noordzeekustzone is in 2009 aangewezen als Natura 2000-gebied. De vissoorten die in het beheerplan van de Noordzeekustzone zijn opgenomen zijn zeeprik, rivierprik en fint. De doelstelling voor alle drie de soorten is uitbreiding van de populatie. De monitoringprogramma's die hier plaatsvinden zijn de Demersal Fish Survey (DFS) met de boomkor, DIADROOM (Kornwerderzand aan de Waddenzeezijde) met fuiken en de NIOZ-fuik op Texel. Net als voor de Waddenzee zijn de trends voor de zeeprik, 
rivierprik en fint onzeker of is er een afname, waarmee de doelstellingen van deze soorten niet zijn gehaald. Voor rivierprik en zeeprik is de verwachting dat de soort in de toekomst mogelijk zal toenemen zodra de Vismigratierivier is geïmplementeerd.

Het Hollandsch Diep is in 2013 aangewezen als Natura 2000-gebied en het Haringvliet in 2015. De vissoorten die in het beheerplan van het Hollandsch Diep zijn opgenomen zijn zeeprik, rivierprik, fint, elft en zalm, voor het Haringvliet komt daar de rivierdonderpad nog bij. De doelstelling voor alle zes de soorten is uitbreiding van de populatie. Het monitoringprogramma dat hier plaatsvindt is de actieve monitoring van de rivieren (FGRA). Aangezien dit geen geschikte monitoring voor migrerende soorten is, zijn de FDIA monitoring gegevens van het Haringvliet gebruikt voor de toetsing van deze soorten. Daarnaast zijn voor de zalm ook de gegevens van de zalmstekenmonitoring op de Waal gebruikt. Voor zowel het Hollandsch Diep als het Haringvliet zijn er voor de rivierprik, zeeprik en zalm sterke afnames of is de trend onzeker, voor fint lijkt de trend onzeker of stabiel, elft is niet gevangen en voor de rivierdonderpad is de trend ook onzeker. Hiermee wordt geen van de doelstellingen gehaald.

De Westerschelde is in 2009 aangewezen als Natura 2000-gebied. De vissoorten die in het beheerplan van de Westerschelde zijn opgenomen zijn zeeprik, rivierprik en fint. De doelstelling voor alle drie de soorten is uitbreiding van de populatie. Het monitoringprogramma dat hier plaats vindt is de Westerschelde Ankerkuil Survey (WAV). Voor alle drie de soorten is de trend onzeker en daarmee zijn de doelstellingen niet gehaald.

\section{Ecologische Kwaliteitsratio's}

Voor de Kaderrichtlijn Water (KRW) wordt de toestand van de Nederlandse wateren (zoete wateren en een deel van de overgangswateren) beoordeeld volgens Ecologische Kwaliteitsratio's (EKR's). Hiertoe zijn de Rijkswateren ingedeeld naar watertype (kustwater $(K)$, overgangswater $(\mathrm{O} 2)$, rivieren $(R)$ en meren (M)) met daaronder subtypen. 'Vis' is geen biologisch kwaliteitselement voor kustwateren (K) en dit watertype wordt derhalve niet getoetst op vis. Voor de andere watertypen geldt dat deze voor de verschillende kwaliteitselementen worden beoordeeld aan de hand van maatlatten. De maatlatbeoordeling levert een EKR-score op tussen 0 en 1. In kunstmatige of sterk veranderde wateren, zoals de wateren in Nederland, is de maximale score het Goed Ecologisch Potentieel (GEP), dat per waterlichaam verschilt. De EKR-scores worden berekend per KRW-waterlichaam.

In 2020 zijn de EKR-scores voor M-, R- en O2-watertypen berekend met het programma Aquokit, aan de hand van de gegevens van de visserij-onafhankelijke actieve monitoringsprogramma's. Ook konden fuikgegevens ingelezen worden en zijn M21b en R-watertypen getoetst inclusief fuikgegevens. Bij overgangswateren wordt onderscheid gemaakt tussen $\mathrm{O} 2 \mathrm{a}$, waarbij bemonsterd is met een ankerkuil en $\mathrm{O} 2 \mathrm{~b}$, waarbij bemonsterd is met een boomkor. Voor O2b zijn toetsingen in Aquokit ingebouwd en uitgevoerd. Voor O2a zijn de berekeningen ook in Aquokit ingevoerd, maar deze wijken momenteel nog af van controleberekeningen in Excel. Om die reden worden de gegevens van O2a wateren nog niet gepresenteerd. Aquokit gebruikt de ruwe meetgegevens als invoer en berekent hieruit de EKR-scores en deelmaatlatten.

Voor de M-, R- en O2-waterlichamen is een EKR-score bepaald en de EKR-scores zijn beoordeeld aan de hand van het GEP-doel. Een verklaring voor variatie in EKR-scores tussen jaren en een EKR-score lager dan GEP is veelal complex. Vaak wordt een lage EKR-score veroorzaakt door lage scores van meerdere deelmaatlatten en dit kan per jaar variëren door bijvoorbeeld aan- of afwezigheid van soorten in de vangst van dat jaar. Deelmaatlatscores van de watertypen worden ook gepresenteerd en verschillen worden besproken. 


\section{Trends in blankvoorn}

Naar aanleiding van de voorgaande rapportage waaruit bleek dat de visstand van de cypriniden in veel KRW-lichamen achteruit is gegaan, wordt er in deze rapportage specifiek naar de trends van blankvoorn gekeken. In veel KRW-lichamen is in één of twee periodes een afname van blankvoorn zichtbaar. De eerste periode is tussen 2002 en 2005 de tweede periode is tussen 2009 en 2012. De afnames worden in de meeste KRW-lichamen veroorzaakt door een afname van meerjarige individuen. In sommige KRWlichamen lijken de aantallen en biomassa van blankvoorn zich wel deels te herstellen, maar hierbij worden de oudere individuen niet meer gevangen.

De aantallen van de blankvoorn worden meestal gedomineerd door nuljarige blankvoorn terwijl de biomassa meestal gedomineerd wordt door meerjarige blankvoorn. In een aantal KRW-lichamen zien we dat deze verdeling anders ligt, wat in veel gevallen toe te schrijven is aan de karakteristieke eigenschappen van het waterlichaam (b.v. relatief veel brak water) of relatief laag voorkomen van de blankvoorn in deze wateren.

Er zijn verschillende bedreigingen voor blankvoorn (zoals voedseltekort, klimaatverandering, waterkrachtcentrales, visserij, predatie) die allemaal van invloed geweest kunnen zijn op de hierboven beschreven afnames. Het afnemen van voornamelijk meerjarige, paairijpe blankvoorn kan met de huidige kennis dus niet specifiek worden toegewezen aan één oorzaak, en genoemde mogelijke oorzaken zijn voornamelijk speculaties. Het is mogelijk dat er onder de juveniele blankvoorn zoveel sterfte is dat veel van hen het volwassen/paairijpe stadium niet bereiken. Aan de andere kant kan het ook zijn dat juist meerjarige blankvoorn meer wordt blootgesteld aan bepaalde bedreigingen dan juveniele blankvoorn. 


\section{$1 \quad$ Inleiding}

\subsection{Vismonitoringsprogramma's}

De monitoringsprogramma's op de Rijkswateren (Tabel 1.1) worden uitgevoerd in opdracht van Rijkswaterstaat (RWS) en het Ministerie van Landbouw, Natuur en Voedselkwaliteit (LNV). De visstandbemonsteringen die in opdracht van RWS plaatsvinden maken deel uit van een uitgebreider programma: de Monitoring van de Waterstaatkundige Toestand des Lands (MWTL). De visstandbemonsteringen die in opdracht van LNV plaatsvinden maken deel uit van de Wettelijke Onderzoekstaken Visserij (WOT). Het gehele WOT Visserij-programma wordt gecoördineerd door het Centrum voor Visserij Onderzoek (CVO).

In de loop der tijd is uit pragmatische overwegingen de uitvoering en financiering van de visstandbemonsteringen verdeeld over RWS en LNV, waarbij grofweg RWS de vismonitoring in de rivieren en de Zeeuwse Delta aanstuurt en LNV de vismonitoring in het IJsselmeer en Markermeer. Hiermee is voorzien in een monitoringsopzet waarmee met een efficiënte inzet van middelen de verplichte en noodzakelijke vismonitoringsgegevens voor de Rijkswateren voor de verschillende overheden beschikbaar komen. In deze rapportage worden vrijwel alle bemonsterde rijkswateren meegenomen behalve de Noordzee en de Waddenzee; bemonsteringen van deze laatste twee wateren worden elders gerapporteerd (ICES, 2020)

\subsection{Informatiebehoefte opdrachtgevers}

Het Ministerie van LNV en Rijkswaterstaat vragen om vismonitoringsgegevens en om beoordeling en interpretatie hiervan in verschillende kaders, zodat aan de volgende informatiebehoeften wordt voldaan:

- Europese Aalverordening en Data Collection Framework (DCF): populatiestatus van glasaal, rode aal en schieraal en inzicht in aalvangsten door de recreatieve en beroepsvisserij op landelijk en regionaal niveau. De overkoepelende rapportage over aal wordt jaarlijks apart uitgewerkt in het rapport "Report on the eel stock, fishery and other impacts in the Netherlands" (van Rijssel \& van der Hammen 2020). In de voorliggende rapportage worden alleen de trends in totale bestandsgrootte en in de commerciële aalvangsten per Kaderrichtlijn Water (KRW)-lichaam besproken. De resultaten van de monitoring van de regionale wateren die voor de Kaderrichtlijn Water wordt uitgevoerd door de waterschappen zijn te vinden in de 3-jaarlijkse evaluatie van het aalbeheerplan (van de Wolfshaar et al. 2018).

- Beheer visstanden en wolhandkrab: inzicht in de ontwikkelingen van visbestanden en -vangsten, bevist door de recreatieve en beroepsvisserij.

- $\quad$ Europese Habitatrichtlijn (HR): inzicht in de landelijke trends (aantallen, verspreiding en habitat) van zeven HR-soorten ten behoeve van het Natura 2000-beleid. De rapportage aan de Europese Commissie over de landelijke staat van instandhouding van deze soorten vindt 6-jaarlijks plaats via een zogenaamde HR Artikel 17-rapportage. In de voorliggende rapportage wordt volgens deze HR Artikel 17-systematiek een kort overzicht gegeven van tussenstand wat betreft de landelijke trend in aantallen, om een vinger aan de pols te houden.

- Kaderrichtlijn Water: de ecologische kwaliteitsratio's per waterlichaam.

- Toetsing Natura 2000 gebieden Waddenzee, Noordzeekustzone en Deltawateren (Haringvliet, Hollandsch Diep en Westerschelde \& Saeftinghe).

- Trends van blankvoorn per KRW-waterlichaam en lengte-frequentie verdelingen. 
Tabel 1.1. Overzicht van de verschillende vismonitoringsprogramma's in de Rijkswateren. WOT=Wettelijke Onderzoekstaken Visserij; MWTL= Monitoring Waterstaatkundige Toestand des Lands. LNV = Ministerie van Landbouw, Natuur en Voedselkwaliteit. RWS= Rijkswaterstaat. Tenzij anders aangegeven, is de bemonstering jaarlijks.

\section{IJsselmeer en Markermeer}

1 Openwatermonitoring IJsselmeer en Markermeer met actieve vistuigen

2 Oevermonitoring IJsselmeer en Markermeer met actieve vistuigen

3 Openwatermonitoring IJsselmeer en Markermeer met kieuwnetten

$4 \quad$ Diadrome vismonitoring Kornwerderzand (Waddenzee) met fuiken

$5 \quad$ Vangstregistratie beroepsvissers zeldzame vis IJsselmeer en Markermeer (gestopt)

\section{Grote rivieren en Delta}

Kuil vanaf 1966, sinds 1989 gestandaardiseerd en opgevolgd door verhoogde boomkor sinds 2013. Daarnaast elektrokor sinds 1989

Elektroschepnet en zegen, sinds 2007.

Kieuwnetten (staandwant) met diverse maaswijdtes, sinds 2014

Fuiken, sinds 2001

Registratie van zeldzame vis door commerciële aal- en wolhandkrabvissers, in 1994-2013, met diverse veranderingen in opzet door de jaren heen.
6 Monitoring grote rivieren en delta met actieve vistuigen

Elektroschepnet en boomkor vanaf 1992, gestandaardiseerd sinds 1997. Hoeveelheid locaties is toegenomen van 14 in 1997 naar 27 in 2018. Deels jaarlijks, deels eens per 3 jaar. Daarnaast sommige locaties eenmalig, en sommige locaties ook met zegen of stortkuil.

Zalmsteken, 1994 op 2-5 locaties en gestandaardiseerd in 1997. Vanaf 2014 op 3 locaties waarvan 1 jaarlijks en 2 om het jaar.

Stort- en wonderkuil sinds 1991 en gestandaardiseerd in 2007: drie clusters van meren welke ieder eens per drie jaar worden bemonsterd. Daarnaast elektroschepnet sinds 2011.

\section{Randmeren}

$8 \quad$ Monitoring Randmeren met actieve vistuigen

\section{Alle gebieden}

9 Diadrome vismonitoring zoete Rijkswateren met fuiken

Fuiken, sinds 2012 (najaar) en 2014 (voorjaar). Deel locaties (5 belangrijkste in- uittreklocaties) jaarlijks, deel eens per 3 jaar. December eens per 2 jaar, op 2 locaties.

Vangstregistratie van commerciële aalvissers, vanaf 1981 kleinschalig en niet gestandaardiseerd op grote rivieren, IJssel- en Markermeer en Delta; in gestandaardiseerde vorm sinds 1993. Het aantal locaties is van 33 teruggelopen naar 11 in 2013, en 2 vanaf 2014

11 Glasaalmonitoring op intreklocaties

Kruisnet, op 11 plaatsen verspreid langs de Nederlandse kust. De langstlopende bemonstering vindt sinds 1938 plaats in Den Oever.

\section{Overgangswateren}

12 Ankerkuil bemonstering Westerschelde

13 Ankerkuil bemonstering Eems-estuarium

14 Boomkor bemonstering Oosterschelde en Westerschelde

\section{Actief}

Actief

Passief

Passief

Passief

LNV

WOT-LNV

WOT-LNV

\section{Actief MWTL-RWS}

Passief MWTL-RWS

Actief MWTL_RWS

Passief

WOT-LNV \&

MWTL-RWS

Passief MWTL-RWS 


\subsection{Inhoud en opzet rapport}

Alle vismonitoringsprogramma's op de Rijkswateren worden samen gepresenteerd in een rapportage bestaande uit drie delen: Deel I Toestand en trends, Deel II Toegepaste methoden (van Keeken et al. 2020) en Deel III Data, dat digitaal beschikbaar is via de dataportal "https://wmropendata.wur.nl/zoetwatervis/". Via deze dataportal kan de data van alle zoetwatermonitoringen uitgevoerd door/in opdracht van WMR geraadpleegd worden (m.u.v. data van de ankerkuil bemonsteringen in het Eems-estuarium en de Westerschelde).

Deel I (het voorliggende rapport) is gericht op het leveren van opgewerkte gegevens die in de informatiebehoefte van het Ministerie van LNV en RWS voorzien. In Deel II is de bemonstering in detail beschreven (locaties, tuigen, tijdstip, etc.). Deel III bevat de metadata en de visvangsten (aantal, gewicht, lengte, etc.). Naast een informatiebehoefte vanuit het Ministerie van LNV en RWS, is deze er ook nog vanuit verschillende visstandbeheercommissie's (VBC's). Er zijn 15 VBC's die betrokken zijn bij de Rijkswateren (waarvan het soms onduidelijk is hoe actief deze VBC's nog zijn)

(www.visstandbeheercommissie.nl).

1. VBC IJsselmeer

2. VBC Noordzeekanaal

3. VBC Zuidelijke Randmeren

4. VBC Veluwe Randmeren

5. VBC IJssel Plus

6. VBC Twentekanaal

7. VBC Amsterdam-Rijnkanaal

8. VBC Neder Rijn Plus
9. VBC Waal Plus
10. Opgeheven
11. VBC Zandmaas
12. VBC Grensmaas
13. VBC Benedenrivieren en Haringvliet
14. VBC Volkerak-Zoommeer
15. VBC Grevelingenmeer
16. VBC Veerse Meer

Ten opzichte van de voorgaande rapportage is er voor deze rapportage gekozen om ook trends van wolhandkrabben die in de monitoringen zijn gevangen per KRW-lichaam weer te geven. Daarnaast zijn de trends van de monitoringen in de Oosterschelde, Westerschelde en Eems-estuarium toegevoegd. Eveneens zijn de aanlandingen van aal per KRW-lichaam weergegeven in plaats van gegroepeerde landelijke aanlandingen. Naar aanleiding van de afname van cypriniden in veel KRW-lichamen is er dit jaar gekozen om ook de trends van blankvoorn per KRW-lichaam uitgebreider te bespreken in een apart hoofdstuk.

De trends in visbestanden, vangsten, en HR-soorten worden gerapporteerd in aparte hoofdstukken. Per hoofdstuk worden conclusies getrokken op basis van de gerapporteerde trends.

- Trends meest algemene vissoorten (hoofdstuk 2): bevat de bestandsontwikkelingen van de tien meest algemene soorten en de wolhandkrab per KRW-lichaam, weergegeven als aantal en biomassa per vistuig/habitat. Dit wordt uitgedrukt in de catch per unit effort (CPUE, aantal of kilo per hectare of kilometer afhankelijk van het tuig). Daarnaast worden de trends van alle overige vissen samen getoond. Voor alle soorten is het ecologische gilde en de habitatvoorkeur beschreven aan de hand van Noble et al. (2007), zie Bijlage 1. Waar beschikbaar worden de inspanning en de vangsten van de beroepsvisserij weergegeven en besproken. Sinds 2009 monitort WMR de Nederlandse recreatieve visserij. Het doel van dit onderzoeksprogramma is om het inzicht in de aantallen recreatieve vissers en de hoeveelheden onttrokken vis op landelijk niveau te verhogen. Alle vangstschattingen zijn gebaseerd op een landelijk logboekprogramma onder 2500 recreatieve vissers over een periode van 12 maanden (van maart tot maart) maar kunnen vanwege de grote onzekerheid van de data helaas niet worden omgezet naar vangsten per KRW-lichaam. Meer informatie over landelijke aantallen recreatieve vissers en vangsten is te vinden in van der Hammen et al. (2019). 
- $\quad$ Trends HR-Soorten (hoofdstuk 3): behandelt de landelijke trends wat betreft de bestandsgrootte (in aantallen) van de HR-vissoorten barbeel, elft, fint, houting, rivierpik, zeeprik en zalm. Om de zes jaar rapporteert Nederland de status van alle HR-soorten aan de Europese Commissie. Een onderdeel van die rapportage is een beoordeling van de trend in de landelijke bestandsgrootte over de laatste 12 jaar. Voor de zeven genoemde HR-soorten wordt de landelijke trend (aantal per fuiketmalen of $\mathrm{km}$ ) geanalyseerd, met de gegevens die verzameld zijn in monitoringsprogramma's op de Rijkswateren. De statistische analyses zijn uitgevoerd met de gegevens van 2006-2017 conform de werkwijze van het Centraal Bureau voor de Statistiek (Tien et al. 2019). Voor de weergave van de trends zijn de gegevens uit 2018 en 2019 ook opgenomen.

- Toetsing Natura 2000 gebieden (hoofdstuk 4): de beheerplannen met betrekking tot de status van de beschermde vissoorten (Habitatrichtlijn Annex II soorten) worden in dit hoofdstuk geëvalueerd voor de Waddenzee, Noordzeekustzone en Deltawateren (Haringvliet, Hollandsch Diep en Westerschelde \& Saeftinghe). Hiermee kan t.a.v. de Rijkswateren beoordeeld worden of de gestelde N2000-instandhoudingsdoelstellingen per soort zijn behaald of niet, of dat kennis voor een beoordeling ontbreekt.

- Ecologische Kwaliteitsratio's (hoofdstuk 5): in dit hoofdstuk wordt de toestand van de Nederlandse wateren beoordeeld aan de hand van Ecologische Kwaliteit Ratio's (EKR) waarmee de staat van de Nederlandse wateren wordt vergeleken met de staat van een vergelijkbaar type water waar menselijke invloeden niet of in zeer beperkte mate aanwezig zijn (geweest).

- Trends blankvoorn per KRW-lichaam (hoofdstuk 6): in de meeste KRW-lichamen gaat de blankvoorn achteruit. In dit hoofdstuk wordt deze achteruitgang in kaart gebracht en worden er mogelijke oorzaken genoemd. 


\section{Trends per KRW-lichaam}

De gegevens van de verschillende bemonsteringen (Figuur 2.1) zijn opgewerkt door alle vangsten van een trek per soort per jaar bij elkaar op te tellen en deze te middelen over de vangststations. Vervolgens zijn deze gemiddelde vangsten per station weer gemiddeld over de soorten en jaren.

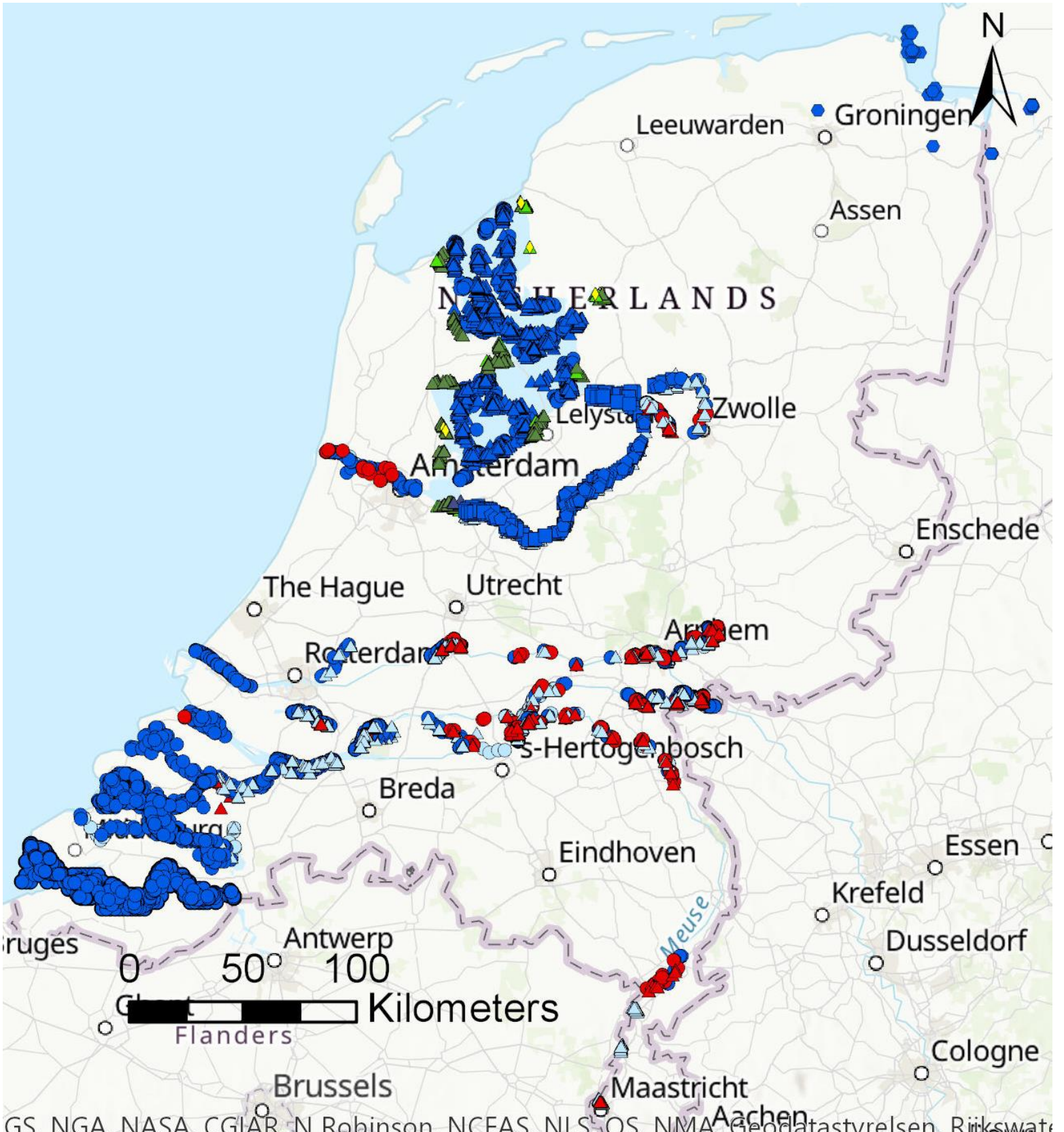

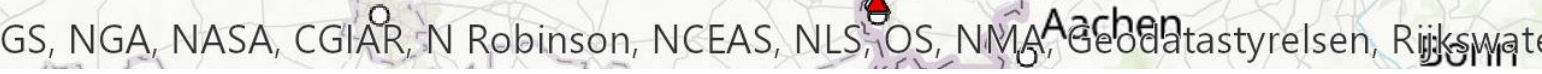
Figuur 2.1 Kaart met alle gebruikte bemonsteringslocaties voor dit hoofdstuk. Verschillende symbolen staan voor verschillende bemonsteringsmethoden. Verklaringen van de symbolen worden vermeld in de kaarten van de bemonsteringslocaties per KRW-lichaam.

De tien meest algemene soorten zijn per KRW-lichaam geselecteerd op basis van voorkomen in aantal en in biomassa in verschillende tuigen over de gehele bemonsteringsperiode. Op basis hiervan worden er top-tien-lijsten samengesteld. Deze top-tien-lijsten verschillen vaak nogal tussen bemonsteringsmethoden, daarom wordt voor een gecombineerde top-tien-lijst gekozen. Bijvoorbeeld, 
wanneer er met een boomkor en een elektroschepnet in een KRW-lichaam wordt bemonsterd wordt er viermaal een top-tien-lijstje samengesteld (boomkoor aantal; boomkor biomassa; schepnet aantal; schepnet biomassa). Vervolgens worden alle soorten geselecteerd die minimaal in drie van vier lijsten voorkomen. Wanneer dit nog niet voldoende is om een gecombineerde top-tien-lijst samen te stellen worden de soorten geselecteerd die in twee van de vier top-tien-lijsten voorkomen. Van deze soorten komen de soorten met de hoogste gemiddelde ranking in de gecombineerde top-tien-lijst die voor de trends in de figuren wordt gebruikt. Er is geen statistische analyse uitgevoerd om te beoordelen of de waargenomen trends significant zijn; dit ligt buiten de scope van dit rapport.

Voor de KRW-lichamen waar Chinese wolhandkrab (Eriocheir sinensis) voorkomt worden voor deze soort ook trends weergegeven. De Chinese wolhandkrab komt zowel in zoet- als zoutwater voor. Het oorspronkelijke verspreidingsgebied ligt in China en Korea, maar de soort werd per ongeluk geïntroduceerd in Noord-Europa (Panning, 1939). Van de eerste Europese introductie van de Chinese wolhandkrab in Duitsland in 1912 wordt aangenomen dat deze zijn meegekomen in ballastwater van schepen (Cohen \& Carlton, 1997; Fladung, 2000). In de periode van 1920-1930 breidde het verspreidingsgebied zich verder uit, en werden wolhandkrabben aangetroffen in de rivieren Eems, Weser, Elbe, Havel, Oder en de Rijn. Hierdoor kon de soort zich verder verspreiden naar Denemarken, ZuidoostZweden, Zuid-Finland, Polen, Tsjechië, Slowakije, België, Nederland, Noord-Frankrijk en Engeland (Veldhuizen \& Stanisch, 1999). In Nederland is de wolhandkrab voor het eerst gesignaleerd in 1931. De eerste meldingen van wolhandkrabben in Nederland kwamen van verschillende locaties waaronder Groningen, Friesland en de haven van Rotterdam. Vier jaar later werd de soort in vrijwel alle Nederlandse provincies aangetroffen (Kamps 1937, Soes et al., 2007). De allereerste introductie in Nederland is nog altijd discutabel, maar het is zeer aannemelijk dat de Chinese wolhandkrab door dispersie afkomstig is van de gevestigde populatie in de Aller, een zijrivier van de Weser in Duitsland (Kamps 1937; Soes et al., 2007). De soort komt tegenwoordig algemeen voor en houdt zich met name op in de grote rivieren en allerlei wateren rondom de overgang tussen zoet en zout water. De grootste dichtheden zijn te vinden in het Haringvliet, Hollandsch Diep, Amer, Nieuwe Waterweg, Noordzeekanaal, IJsselmeer en het gebied rondom de afsluitdijk (Soes et al., 2007).

De beroepsvissers geven sinds 2010 verplicht hun wekelijkse aalvangsten op bij het Ministerie van LNV. Sinds 2012 zijn de beroepsvissers daarnaast verplicht om informatie te verstrekken over de ingezette aantallen en typen vistuigen. De aalvangsten van de beroepsvisserij zullen per KRW-lichaam besproken worden en een overzicht van de vangsten van alle gebieden is te vinden in Bijlage 2. In een groot aantal gebieden in Nederland is het sinds 2011 jaarrond verboden om op aal te vissen vanwege te hoge gehaltes dioxinen en dioxine-achtige PCB's. In sommige van deze voor aalvangst gesloten gebieden wordt nog wel enige aal aangeland (Bijlage 2). Dit komt doordat in sommige gebieden de overheid een huurovereenkomst heeft met beroepsvissers of dat er in bepaalde wateren van sommige gebieden wordt gevist die niet in open verbinding staan met de rest van het gebied of dat er een deel van het gebied is dat nog wel bevist mag/mocht worden. In Nederland is het aantal te gebruiken aalvistuigen gelimiteerd door het aantal vergunningen. Aan de vistuigen dienen 'merkjes' bevestigd te worden. Het was tot 2012 onduidelijk welk deel van de vergunningen daadwerkelijk wekelijks werd ingezet door de beroepsvissers (de Graaf et al., 2016). Vandaar dat per KRW-lichaam ook het gebruik van tuigen in kaart zal worden gebracht om inzicht te verkrijgen in welke tuigen het meeste waar worden gebruikt.

Voor de gegevens van de recreatieve visserij is er alleen landelijke data beschikbaar, daarvoor verwijzen we naar het "Recreational fisheries" rapport (van der Hammen, 2019).

Uitgebreidere informatie met betrekking tot aal is terug te vinden in de overkoepelende rapportage over aal die jaarlijks wordt gepubliceerd "Report on the eel stock, fishery and other impacts in the Netherlands" (van Rijssel \& van der Hammen, 2020). 


\section{IJsselmeer \& Markermeer}

Vanaf 1989 wordt de visstand in het open water met zowel een grote kuil als een elektrostramienkor gestandaardiseerd gemonitord. Aanvankelijk was de monitoring met de elektrostramienkor vooral gericht op aal. Vanaf 1995 werden ook de overige soorten gemonitord. In 2013 is overgestapt van bemonstering met een grote kuil naar bemonstering met een verhoogde boomkor. De relatie tussen de vangsten in die twee tuigen is niet robuust en vangstvergelijkingen per soort hangen af van veel verschillende voorwaarden (zie rapport deel II). Vanwege pragmatische redenen worden zowel vangsten met de grote kuil als met de verhoogde boomkor worden hierna "boomkor"-vangsten genoemd.

Sommige soorten (zoals snoek, karper en winde) en/of bepaalde lengteklasses houden zich niet of nauwelijks op in het open water, maar vooral in de oeverzone. Vanaf 2007 wordt daarom de oeverzone apart bemonsterd, de steen-/rietoevers en oevers met een vooroever met een elektrisch schepnet, de zandoevers met een zegen.

De zijwateren van het IJssel- en Markermeer en de diepe putten worden niet bemonsterd. De zijwateren bestaan voornamelijk uit havengebieden.

De tien meest algemene soorten zijn gebaseerd op het voorkomen in zowel de boomkor als de elektrokor op basis van zowel aantal als biomassa. Hieronder zullen de trends in voorkomen per habitat per tuig en per eenheid (aantal en biomassa) besproken worden. Voor alle soorten is het ecologische gilde en de habitatvoorkeur beschreven in de bijbehorende bijlages aan de hand van Noble et al. (2007).

Voor de aal en schubvisvangsten wordt er in de aangeleverde data geen onderscheid gemaakt tussen het IJssel-/ en Markermeer vandaar dat deze vangsten gecombineerd zijn weergegeven.

\section{Randmeren}

De randmeren worden bemonsterd met actieve tuigen (stortkuil, wonderkuil, elektrisch schepnet). Voor het open water worden de stort- en wonderkuil gebruikt. De wonderkuil wordt ingezet in gebieden met een waterdiepte tot 1.5 meter, wat te ondiep is voor de stortkuil, met doorgaans veel waterplanten. In de diepere gebieden ( $>1.5$ meter) met veel waterplanten wordt de stortkuil ingezet. Sinds 2011 wordt de oeverzone bemonsterd met het elektrisch schepnet.

De resultaten van de bemonsterde randmeren worden per KRW-lichaam gepresenteerd, wat inhoudt dat sommige bemonsteringsgebieden zijn samengevoegd:

- 'Ketelmeer en Vossemeer', bestaande uit bemonsteringsgebieden Ketelmeer en Vossemeer. Dit KRW-lichaam is echter voor het laatst in 2017 bemonsterd en wordt niet in dit rapport besproken aangezien dit gebied in de voorgaande versie van dit rapport al besproken is (van Rijssel et al. 2019a).

- 'Zwarte Meer', bestaande uit bemonsteringsgebied Zwarte Meer. Ook dit KRW-lichaam is voor het laatst bemonsterd in 2017 en zal niet in de huidige rapportage besproken worden. De trends van dit KRW-lichaam zijn te vinden in van Rijssel et al. (2019a).

- 'Randmeren-Oost', bestaande uit bemonsteringsgebieden Drontermeer, Veluwemeer, Wolderwijd en Nuldernauw.

- 'Randmeren-Zuid', bestaande uit bemonsteringsgebieden Eemmeer, Gooimeer en Nijkerkernauw. Dit gebied is maar eenmaal in 2018 met de wonderkuil bemonsterd, de resultaten van dit vangtuig worden hier dan ook niet getoond.

Niet alle randmeren worden ieder jaar bemonsterd, de meeste randmeren worden eens per drie jaar bemonsterd (zie Deel II, van Keeken et al. 2020). 


\section{Rivieren}

Vanaf 1997 wordt de visstand in het open water van de grote rivieren met een boomkor gestandaardiseerd in het voor- of najaar gemonitord. In de jaren 1992-1996 zijn sommige KRWlichamen ook al bemonsterd. Vanwege de afwijkende locaties en de niet-gestandaardiseerde vangstmethodes worden deze gegevens voor het beoordelen van de trends echter buiten beschouwing gelaten. Deze gegevens zijn in deze rapportage wel in Bijlage 9 weergegeven waarbij de figuren op dezelfde manier zijn samengesteld als voor de trendanalyse per KRW-lichaam. Aangezien de monitoring in die periode niet gestandaardiseerd was en de bemonsteringslocaties ook veelal sterk verschillen met de periode vanaf 1997, kunnen deze gegevens niet vergeleken worden met de trends weergegeven per KRW-lichaam na 1997. Daarnaast komt het ook regelmatig voor dat de bemonsteringslocaties tussen de bemonsteringsjaren 1992-1996 verschillen, waardoor een onderlinge vergelijking tussen de jaren in deze gevallen ook niet wordt aangeraden.

Sommige soorten en/of bepaalde lengteklasses houden zich niet of nauwelijks op in het open water, maar vooral in de oeverzone. Daarom wordt in veel KRW-lichamen de oeverzone apart bemonsterd met een elektrisch schepnet.

Hieronder zullen per bemonsteringsgebied van de actieve monitoring op de rivieren de trends van de meest voorkomende vissoorten per tuig worden weergegeven. De bemonsteringsgebieden komen in grote lijnen overeen met de KRW-lichamen. Uitzonderingen hierop zijn de volgende KRW-lichamen:

- Brabantse Biesbosch: bemonsteringsgebieden Amer en Noordwaard vallen beide onder dit KRWlichaam. Aangezien er alleen in 2013 en 2014 in de Amer is bemonsterd worden alleen de resultaten van de bemonstering in de Noordwaard gebruikt voor de trendweergave.

- IJssel: zowel bemonsteringsgebied Benedenloop Gelderse IJssel als Bovenloop Gelderse IJssel vallen onder dit KRW-lichaam.

- Oude Maas: zowel bemonsteringsgebied Oude Maas als Getijden Lek vallen onder dit KRWlichaam.

- Nederrijn en Lek: zowel bemonsteringsgebied Benedenloop Nederrijn als Bovenloop Nederrijn vallen onder dit KRW-lichaam.

- $\quad$ Boven Rijn en Waal: zowel bemonsteringsgebied Bovenloop, Benedenloop Waal als Rijn vallen onder dit KRW-lichaam.

- $\quad$ De Zandmaas en de Bedijkte Maas zijn samengevoegd tot gebied Zandmaas

De trends van de bovenstaande bemonsteringsgebieden zullen apart gepresenteerd worden waarbij het bijbehorende KRW-lichaam tussen haakjes vernoemd wordt wanneer dit afwijkt van het bemonsteringsgebied. Bemonsteringsgebied Bovenmaas is alleen in 1999 bemonsterd en wordt daarom niet meegenomen in de analyse. Het bemonsteringsgebied Haringvliet-West wordt pas sinds 2011 jaarlijks gestandaardiseerd bemonsterd, waardoor eerdere bemonsteringsjaren (2000-2003) niet in de trendanalyse zijn meegenomen. Het Twentekanaal wordt sinds 2015 niet meer bemonsterd en dus ook niet meer in deze rapportage besproken aangezien de trends van dit gebied al in het voorgaande rapport zijn besproken (van Rijssel et al. 2019a). De laatste keer dat het Zwarte Water is bemonsterd was in 2017; dit is al in de voorgaande rapportage besproken (van Rijssel et al. 2019a) en zal dus ook niet in de huidige rapportage besproken worden.

Aangezien er inmiddels voor vele jaren zijwateren bemonsterd zijn, worden deze in dit rapport ook apart per KRW-lichaam gepresenteerd. Waar mogelijk worden in ieder KRW-lichaam de zijwateren bemonsterd. De zijwateren zijn divers en kunnen onder andere bestaan uit jachthavens, wateren voor kunstwerken (waterkrachtcentrales/sluizen), nevengeulen en rivieruitsparingen.

De trends van de Chinese wolhandkrab worden ook per KRW-lichaam gegeven, indien deze daar gevangen zijn. De boomkor lijkt efficiënter te zijn voor het vangen van de wolhandkrab dan het elektroschepnet; alleen de resultaten van de vangsten met de boomkor worden daarom gepresenteerd. 


\section{$2.1 \quad$ IJsselmeer}

\subsubsection{Open water}

\subsubsection{Algemene soorten}

De bemonsteringslocaties over de periode 1989-2019 zijn weergegeven in Figuur 2.2.

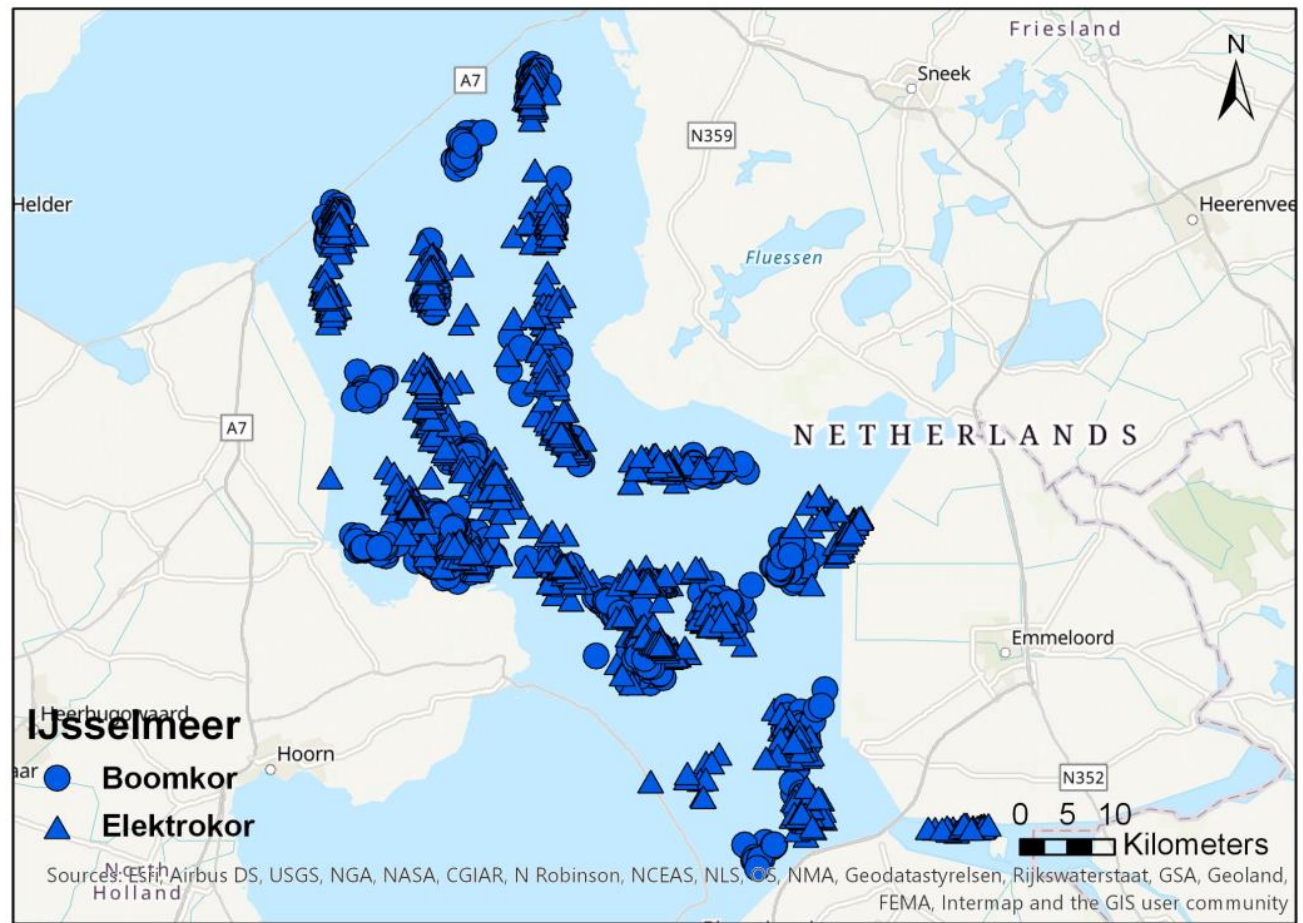

Figuur 2.2 Bemonsteringslocaties van de openwatermonitoring op het IJsselmeer van 1989-2019.

De tien meest algemene soorten in het open water van het IJsselmeer voor de gehele periode 1989-2019 zijn pos, baars, spiering, brasem, blankvoorn, snoekbaars, Pontische stroomgrondel, zwartbekgrondel, bot en aal. Aangezien aal zich veel beter laat vangen met de elektrokor dan met de boomkor laten we deze soort voor de boomkor buiten beschouwing.

De tien meest algemene soorten omvatten meer dan $99 \%$ van het totale gemiddelde aantal en biomassa voor zowel de vangsten met de boomkor als met de elektrokor (Bijlage 3). Sinds 1989 is te zien dat met name brasem en blankvoorn in biomassa achteruit gaan (Figuur 2.3) met extreem lage hoeveelheden in de laatste jaren. Spiering fluctueert sterk over de jaren, maar lijkt ook af te nemen, met een historisch dieptepunt in 2018. Baars lijkt daarentegen relatief stabiel door de jaren heen en de vangsten zijn de laatste jaren toegenomen. Snoekbaars fluctueert sterk door de jaren heen. Pos is, na een stevige toename in de jaren 2000, flink afgenomen in de laatste vijf jaren. Aal is sinds de jaren 2000 afgenomen alhoewel er de laatste drie jaar weer wat meer aal gevangen wordt (Figuur 2.3). De zwartbekgrondel en de Pontische stroomgrondel, twee exoten, nemen vooral sinds 2015 sterk toe, alhoewel vangsten in 2018 en 2019 weer wat lager zijn. Sinds 2012 is er een toename geweest van verschillende exoten (zwartbekgrondel, Pontische stroomgrondel, Kesslers grondel, marmergrondel, Figuur 2.3; Tien et al. 2019). Vóór die tijd werden inheemse bentische soorten zoals bot en de rivierdonderpad nog met enige regelmaat gevangen (Tien et al. 2019). De afname van de inheemse bentische soorten zou met het toenemen van de invasieve soorten in verband kunnen staan. In het geval van de pos zien we dat de biomassa afneemt vanaf het moment dat de biomassa's van Pontische stroomgrondels en zwartbekgrondels toenemen (2015, Figuur 2.3). Het zou interessant zijn om te onderzoeken of dit inderdaad een causaal verband is, en of dit door directe voedsel- en nestcompetitie komt (Copp et al., 
2008, Vanderploeg et al., 2002; Poos et al. 2010; van Kessel et al. 2011) of doordat deze invasieve grondels mogelijk ook visseneieren eten (Corkum et al. 2004, Chotkowski and Marsden, 1999, French and Jude, 2001, Jude et al. 1995). Verder valt op dat er in 2018 en 2019 relatief weer wat minder invasieve grondels zijn gevangen, evenals weinig overige bentische soorten (Figuur 2.3). Tenslotte is te zien dat de totale vangsten in de elektrokor ieder jaar gestaag afnemen sinds 2008/2009. De lengtefrequentieverdelingen per tuig per soort over alle jaren van de monitoring van dit KRW-lichaam zijn via deze link te bekijken: https://wmropendata.wur.nl/site/zoetwatervis/43/waterlichaam/ 


\section{IJsselmeer open water}
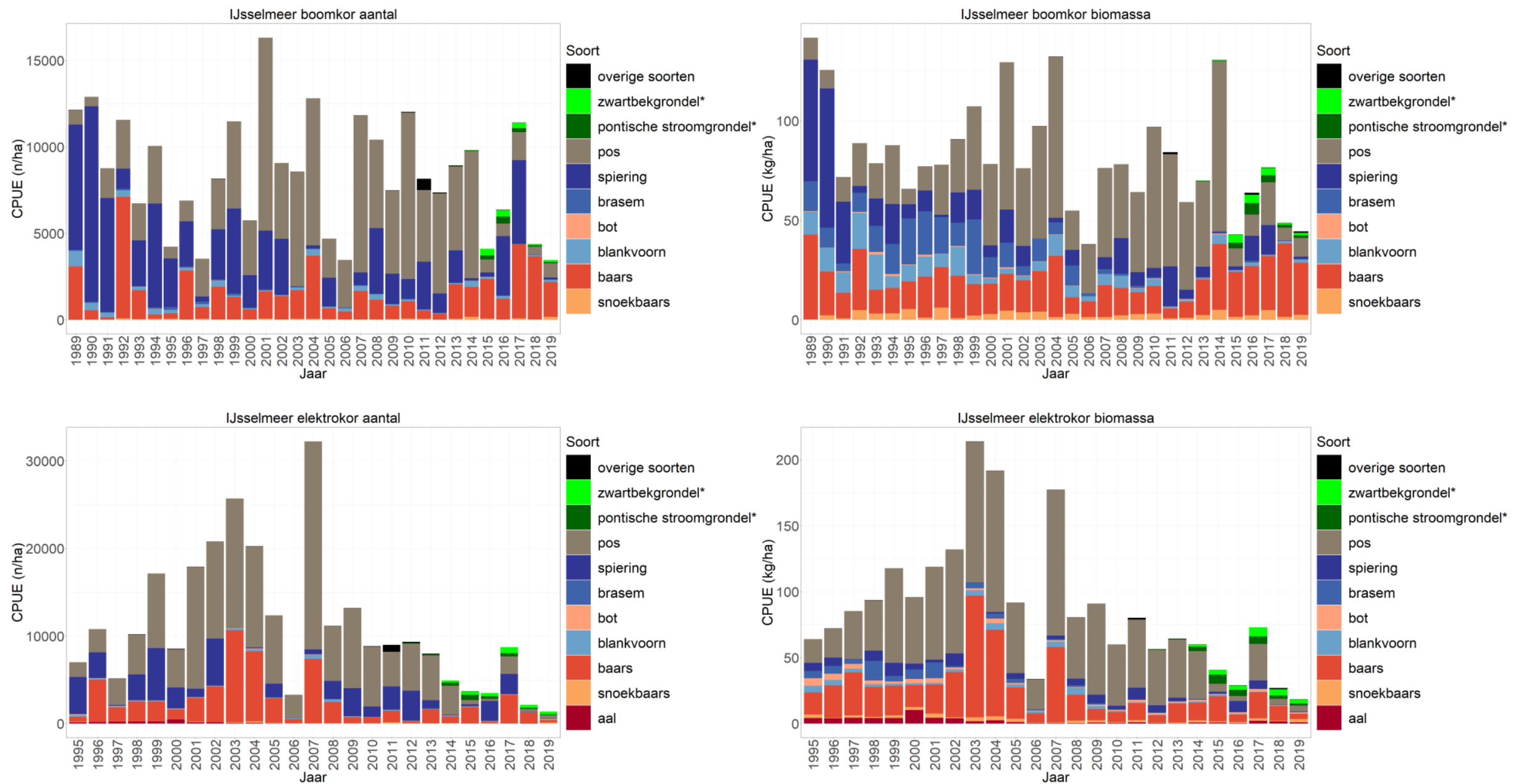

Figuur 2.3 Gemiddelde CPUE ( $\mathrm{n} / \mathrm{ha}$ en $\mathrm{kg} / \mathrm{ha}$ bevist oppervlak) per jaar van de negen/tien meest algemene soorten en overige soorten in het open water van het IJsselmeer (gevangen met de boomkor en de elektrokor). Aal wordt alleen in de elektrokor vangsten weergegeven, * $=$ exoot. 


\subsubsection{Chinese wolhandkrab}

De Chinese wolhandkrab is sinds 1932 aanwezig in het IJsselmeer (Kamps, 1937) en wordt sinds 2002 in het IJsselmeer gevangen met de boomkor en de elektrokor. Op basis van onderstaande figuren lijken geen grote verschillen te zijn in de vangstefficiëntie van beide tuigen voor deze soort. Beide tuigen laten zien dat de aantallen Chinese wolhandkrab vanaf 2002-2009 redelijk stabiel zijn met fluctuerende aantallen, tot er in 2010 een flinke toename is. Hierna lijken de aantallen vanaf 2015 weer te stabiliseren op het niveau van vóór 2010, met relatief lage vangsten in 2019 (Figuur 2.4, Figuur 2.5).

IJsselmeer Boomkor aantal

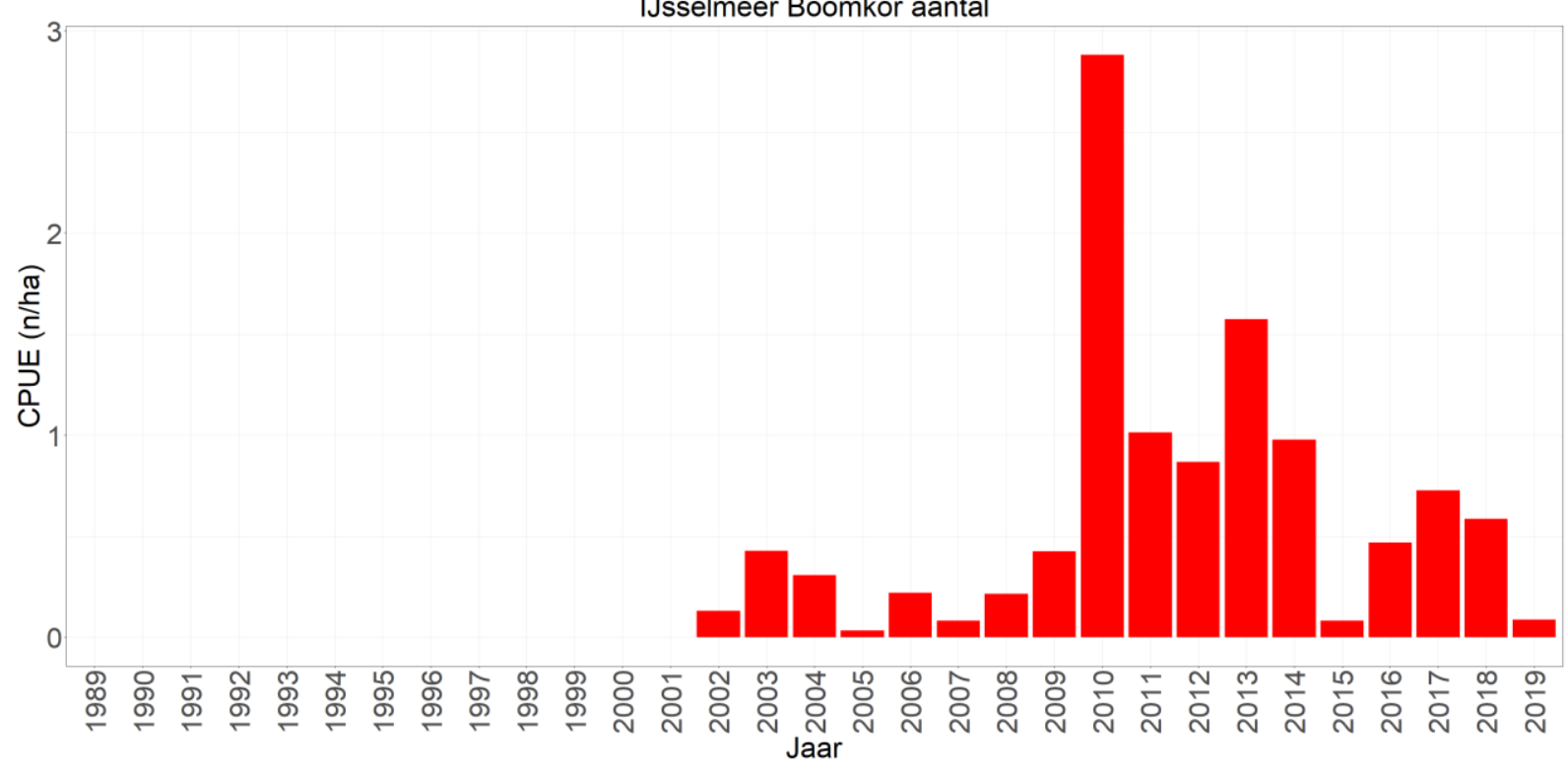

Figuur 2.4 Gemiddelde CPUE (n/ha bevist oppervlak) per jaar van de Chinese wolhandkrab in het open water van het IJsselmeer gevangen met de boomkor.

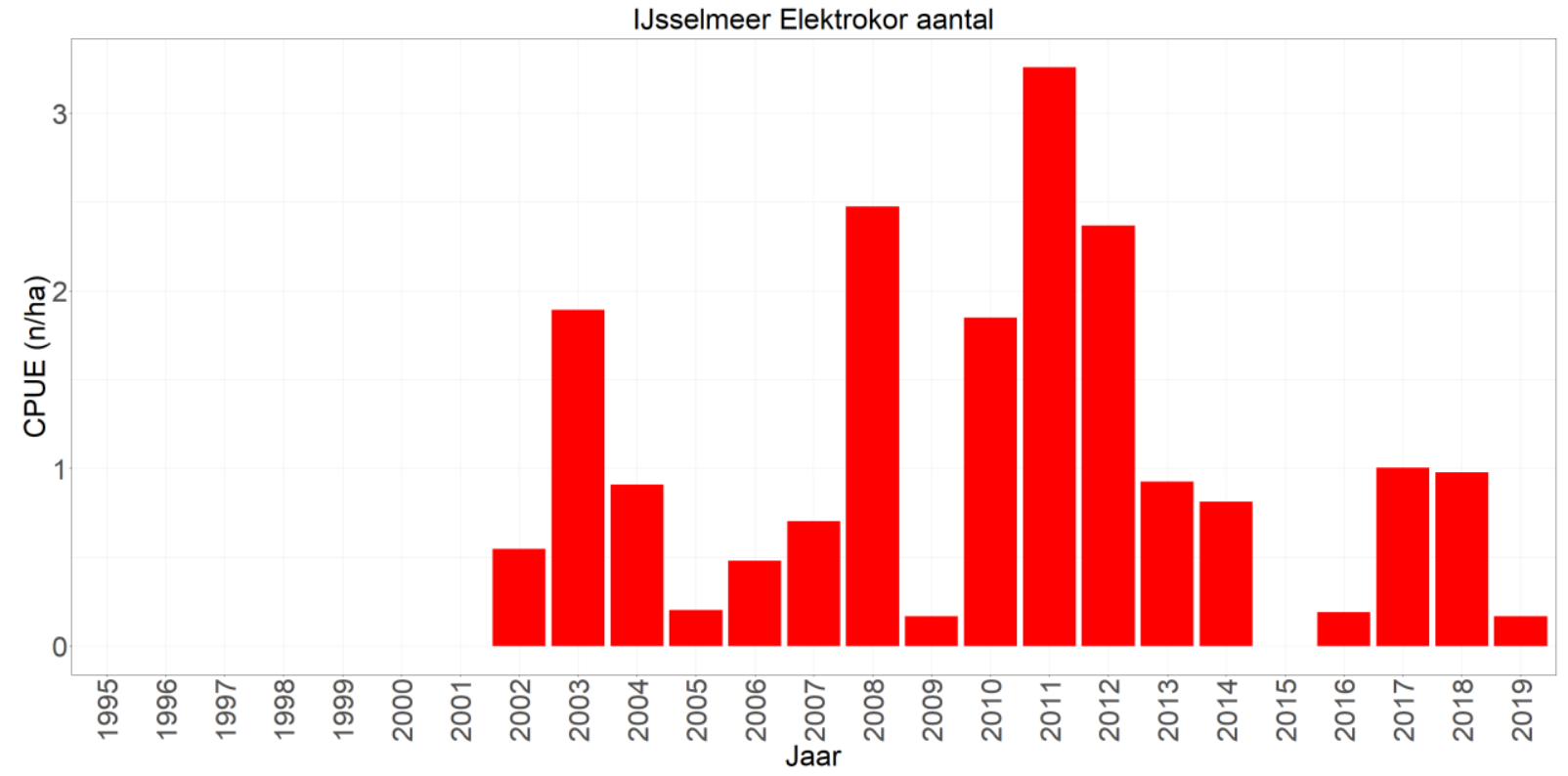

Figuur 2.5 Gemiddelde CPUE (n/ha bevist oppervlak) per jaar van de Chinese wolhandkrab in het open water van het IJsselmeer gevangen met de elektrokor. 


\subsubsection{Oever}

De bemonsteringen van de verschillende typen oevers wordt met verschillende typen vangtuigen uitgevoerd. Omdat de eenheid van de CPUE's van deze vangtuigen verschillend is, worden de resultaten hieronder gescheiden gepresenteerd; eerst de resultaten van de vangsten langs de steen- en rietoevers, daarna die van de zandige oevers. De gegevens zijn zo geselecteerd dat alleen bemonsteringsstations zijn meegenomen die consistent door de jaren heen zijn bemonsterd. Hierdoor ontbreken bijvoorbeeld enkele vangsten met de zegen bij zanderige oevers in 2007 omdat er in dat jaar bij stations is bemonsterd die in latere jaren niet of nauwelijks meer zijn bemonsterd.

In oevers bestaande uit steen of riet (Figuur 2.6) zijn in de afgelopen 10 jaar aal, winde, blankvoorn, baars, zwartbekgrondel, brasem, snoekbaars, karper, roofblei en de Pontische stroomgrondel het meest met het elektrisch schepnet gevangen (Bijlage 4). De oeverbemonsteringen van oevers met riet en stenen zijn gecombineerd weergegeven (rekening houdend met de ruimtelijke verdeling van de verschillende oevers).

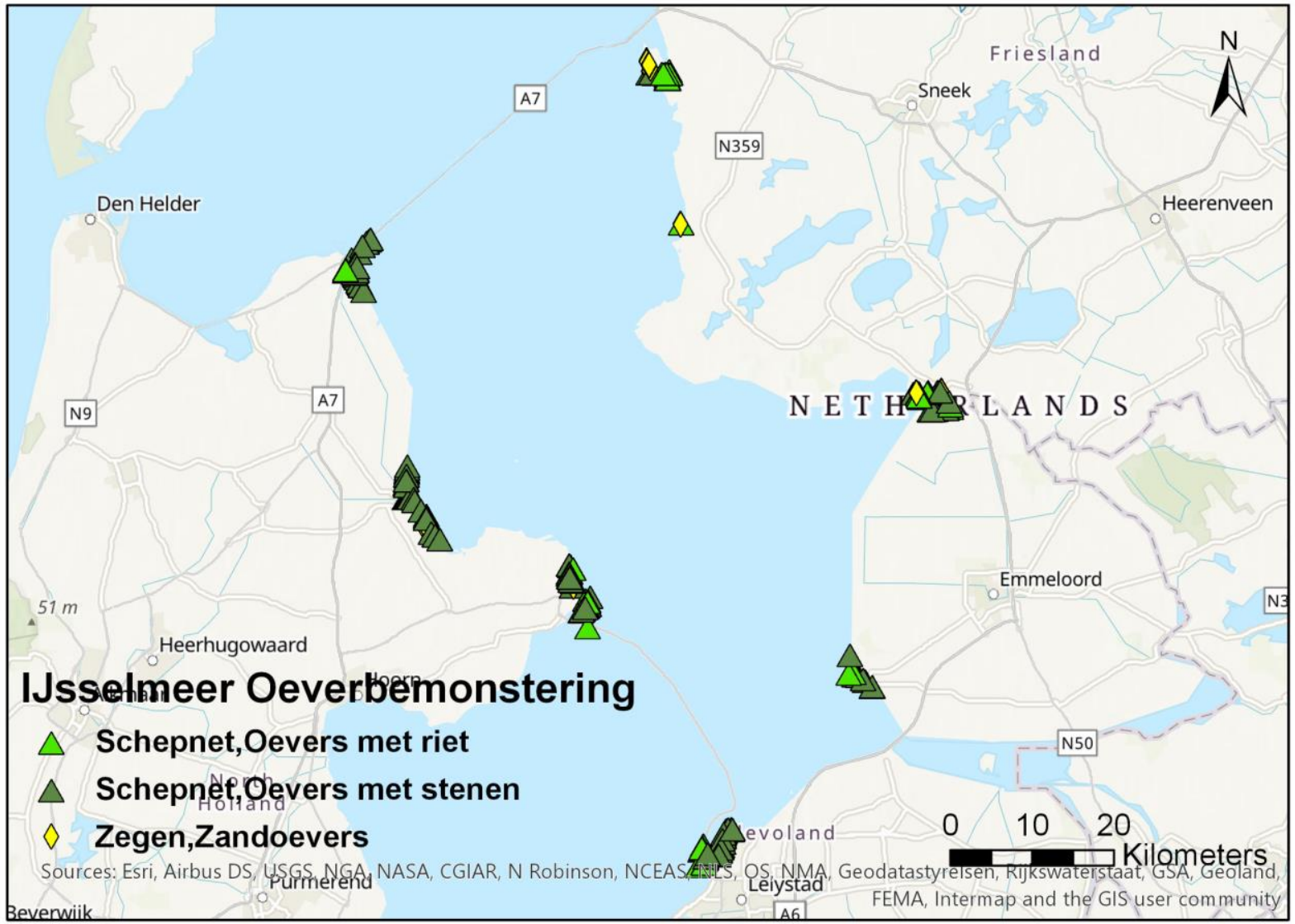

Figuur 2.6 Bemonsteringslocaties van de oeverbemonstering op het IJsselmeer van 2007-2019.

\subsubsection{Oevers met riet en stenen}

In aantallen wordt er in de oeverbemonstering veel blankvoorn gevangen (Figuur 2.7, linksboven). De laatste jaren zijn langs de riet- en steenoevers van het IJsselmeer met name de aantallen van zwartbekgrondel, blankvoorn en in mindere mate aal gestegen, alhoewel in 2019 weinig blankvoorn werd gevangen (Figuur 2.7, linksboven). Dit is deels ook terug te zien in de biomassa van deze soorten (Figuur 2.7, rechtsboven). De toename van het aantal blankvoorns is opvallend, vooral aangezien er in het open water de laatste jaren juist een sterke afname te zien is (Figuur 2.3). Van blankvoorn worden de laatste jaren nauwelijks nog grotere exemplaren gevangen tijdens de oeverbemonstering, maar voornamelijk kleine, 0-1 jarige blankvoorn (zie paragraaf 6.3.2). Winde en karper fluctueren sterk van 
jaar tot jaar, waarbij karper (maar ook snoek, valt onder overige soorten) voornamelijk langs rietoevers wordt gevangen. Baars lijkt in 2017 en 2018 toe te nemen maar is, net als in het open water, in 2019 weer weinig gevangen (Figuur 2.3). De grote soorten (karper, aal, winde) maken qua aantallen een veel kleiner deel van de totale vangsten uit dan qua biomassa (Figuur 2.7, boven). Dit illustreert dat vangsten van enkele grote vissoorten het beeld van de biomassa sterk kunnen beïnvloeden.

\subsubsection{Zandoevers}

Jaarlijks worden in dezelfde periode als de oevers met riet en stenen, de zanderige oevers bemonsterd met een zegen. De toename van blankvoorn, zoals gezien bij de oevers met riet en stenen, is in mindere mate ook te zien bij de zandoevers in 2017 en 2018, net als de lagere vangsten in 2019 (Figuur 2.7, onder). De vangsten van baars fluctueren sterk door de jaren heen. Winde wordt het meeste gevangen bij de zandoevers maar de hoeveelheden fluctueren sterk van jaar tot jaar. Voor de winde geldt overigens dat er bij zandoevers zowel veel kleine als relatief grote exemplaren worden gevangen. Sinds 2015 nemen de zwartbekgrondel en met name de Pontische stroomgrondel toe (beide exoten), alhoewel beide in 2018 en 2019 weer een wat minder zijn gevangen. Pos behoorde in de voorgaande rapportage (van Rijssel et al. 2020) tot de top 10 maar is dit jaar vervangen door snoekbaars. Net zoals in het open water van het IJsselmeer zou er hier sprake kunnen zijn van dat de inheemse bentische soorten zware competitie (voor voedsel, territorium, reproductie) ondervinden van de invasieve soorten. Onderzoek hiernaar zou de snelle toename van de invasieve soorten kunnen helpen verklaren en inzicht kunnen geven in het toekomstig verloop van de soortensamenstelling. 


\section{IJsselmeer stenen/riet oevers algemene soorten}
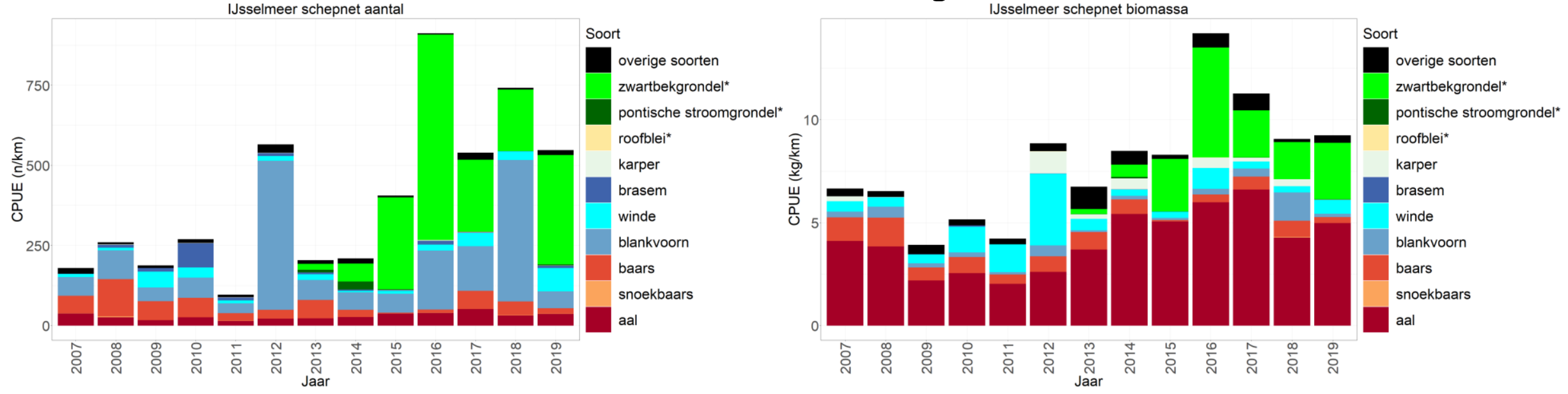

IJsselmeer zandoevers algemene soorten

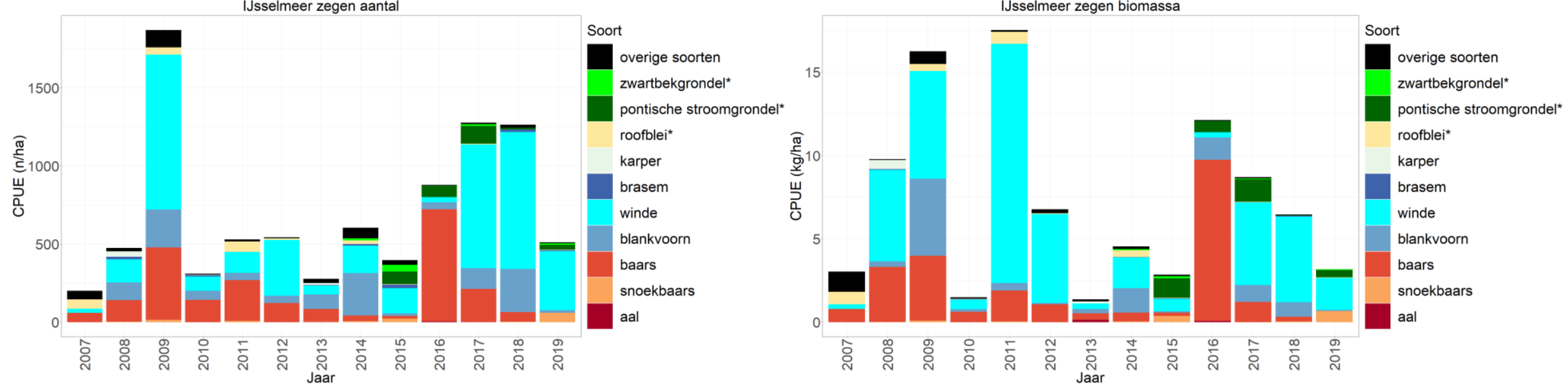

Figuur 2.7 Gemiddelde CPUE van de tien meest algemene soorten en overige soorten bij stenen en riet oevers gevangen met een elektroschepnet ( $\mathrm{n} / \mathrm{km}-\mathrm{kg} / \mathrm{km}$ bevist oppervlak) en bij zanderige oevers gevangen met een zegen ( $\mathrm{n} / \mathrm{ha}-\mathrm{kg} / \mathrm{ha}$ bevist oppervlak) in het IJsselmeer tijdens de oeverbemonstering, $*$ = exoot. 


\subsubsection{Aalvangsten}

De aanlandingen uit het IJssel- en Markermeer, waar verreweg het grootste deel (68\%) van de totale aalvangsten werd gerealiseerd, zijn ook in 2019 weer toegenomen. Deze waren van 2011 tot 2016 vrij stabiel (Figuur 2.8) maar zijn dus de laatste drie jaar aan het toenemen.

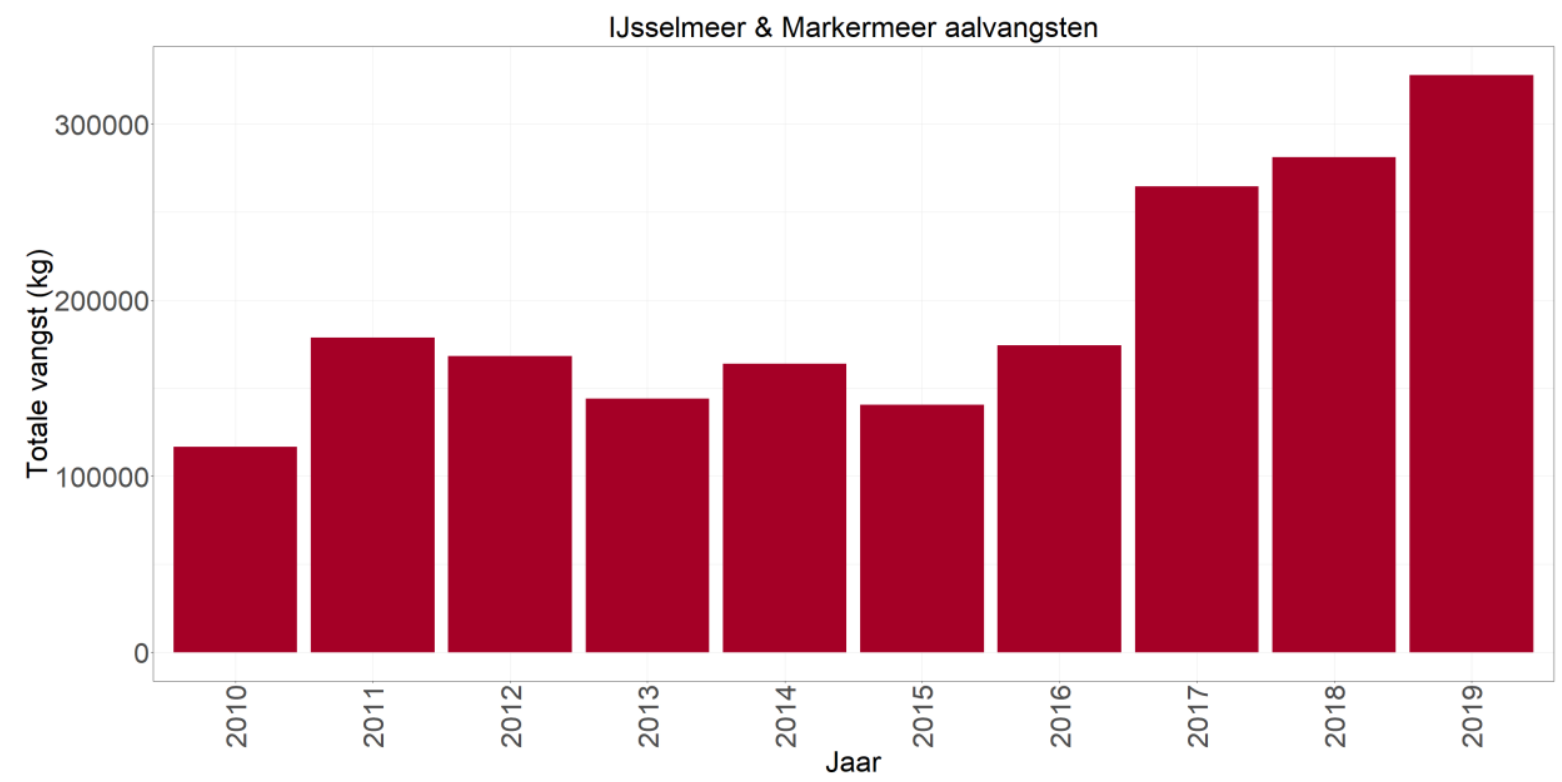

Figuur 2.8 Aalvangsten ( $\mathrm{kg}$ ) van de beroepsvisserij in het IJsselmeer en Markermeer.

\section{Aanlandingen en inspanning}

De toegenomen vangsten in het IJsselmeer en Markermeer in 2019 (Figuur 2.8) komen door hogere vangsten met schietfuiken en hokfuiken. Het gebruik van de aalkist is in 2019 wat toegenomen vergeleken de afgelopen jaren (Figuur 2.9). In 2019 werd het grootste gedeelte van de vangst gerealiseerd met hokfuiken ( $48 \%$, ook aalfuik of grote fuik genoemd), daarna volgen de schietfuiken $(33 \%)$ en het aalhoekwant $(17 \%)$.

Het aantal ingezette fuiken, evenals het aantal tuigweken daalde de laatste jaren op het IJsselmeer en Markermeer, maar is de laatste drie jaar weer toegenomen, voornamelijk door het gestegen aantal schietfuiken (Figuur 2.9). Het gebruik van aalkisten nam tot 2017 af, maar in 2018 en 2019 is er weer aanzienlijk meer mee gevist. In 2019 werden schietfuiken het meest gebruikt (70\%). De inzet van de verschillende type aalvistuigen in het IJssel- en Markermeer in 2019 is ook door de weken heen weergegeven in Figuur 2.9. Om volwassen aal de kans te geven naar zee te trekken om zich voort te planten, geldt er van 1 september tot en met 30 november een wettelijk gesloten tijd voor het gebruik van diverse aalvistuigen door heel Nederland. Daarnaast is het in het IJssel- en Markermeer verboden te vissen met hok- en schietfuiken in de periode van 1 januari tot en met 30 april. In Figuur 2.9 is te zien dat er - binnen de toegestane periode (week 16-36) - weinig temporele variatie in de inzet is. De vissers lijken tijdens de gehele periode maximaal gebruik te maken van hun visvergunning, alhoewel er in de zomer een afname zichtbaar is van met name schietfuiken, wat wellicht met de hoge (water)temperaturen te maken heeft en de problemen die dit oplevert voor het bewaren van aal.

\section{LPUE (Landings Per Unit Effort)}

De LPUE (Landings Per Unit Effort) van aal is op het IJssel \& Markermeer sinds 2012 toegenomen in drie tuigen: hokfuiken, schietfuiken en aalhoekwant (Figuur 2.9). De efficiëntie van de aalkisten lijkt door de tijd heen te fluctueren. Daarnaast is in deze figuur ook te zien dat er in 2017 en 2018 ook met het elektrovisapparaat is gevist. 

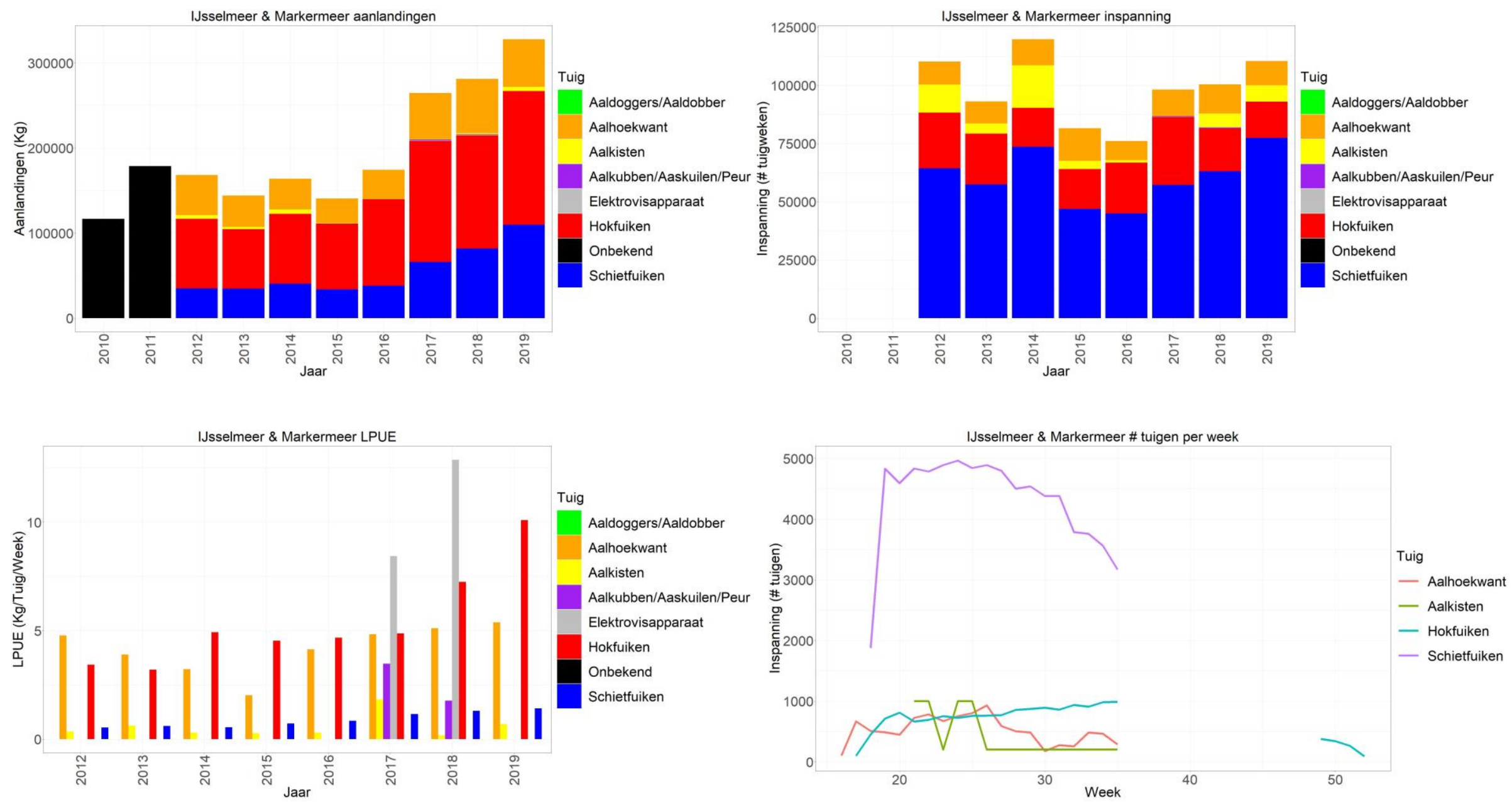

Figuur 2.9. Overzicht van de ontwikkeling van de vangsten ( $k g$ per tuigtype, linksboven), inspanning (aantal tuigen*aantal weken, rechtsboven), LPUE (kg per tuig per week, links onder) en wekelijkse inzet (aantallen van 2019) gesplitst per type tuig, door beroepsvissers in het IJsselmeer/Markermeer van 2012-2019. (Bron: Ministerie LNV). Van 1 september tot en met 30 november geldt er een wettelijke gesloten tijd voor het gebruik van diverse aalvistuigen door heel

Nederland. Daarnaast is het in het IJssel- en Markermeer verboden te vissen met hok- en schietfuiken in de periode van 1 januari tot en met 30 april. 


\subsubsection{Schubvis- en aalvangsten}

\subsubsection{Aanlandingen schubvis en aal IJssel- en Markermeer}

De aanlandingen van schubvis in de Rijkswateren worden alleen voor het IJssel- en Markermeer systematisch geregistreerd (Figuur 2.10). Van de overige KRW-lichamen is weinig informatie beschikbaar over de onttrekking van schubvis door de beroepsvisserij. Uit de visplannen voor de verschillende VisstandBeheerCommissies (VBC's) in de Rijkswateren kwam duidelijk naar voren dat er een gebrek is aan betrouwbare gegevens over vangsten en inspanning van zowel de beroeps- als de recreatieve visserij op schubvis (de Graaf et al. 2016). Daarom worden alleen vangsten voor IJsselmeer en Markermeer hier getoond.

Voor het IJsselmeer en Markermeer zijn vanaf 1966 historische gegevens beschikbaar over de hoeveelheden onttrokken vis die via de afslagen zijn verhandeld; dit is de 'Productschap Vis (PVIS) datareeks (1966-2011)'. Daarnaast is vanuit de Producenten Organisatie (PO) IJsselmeer een reeks beschikbaar vanaf 2000 van de aanlandingen op het IJsselmeer/Markermeer, zoals door de vissers doorgegeven aan de PO (2000-2019; Figuur 2.10). Deze twee reeksen samen geven een beeld van de ontwikkeling in aanlandingen uit de twee meren. Daarnaast worden er sinds 2016 ook logboeken door de vissers ingevuld waarbij de aanlandingen ook vermeld worden. Voor deze rapportage houden we vooralsnog voor de huidige data, de gegevens van de PO aan.

Ook aal wordt hier getoond, omdat dit een andere - langere - tijdreeks betreft dan in sectie 2.1.3. besproken. De tijdreeks zoals in 2.1 .3 besproken, is ook toegevoegd aan de grafiek en wordt hier de 'LNV aal' reeks genoemd.

De gerapporteerde aanlandingen van aal en baars uit het IJsselmeer en Markermeer (Figuur 2.10) zijn in de afgelopen 50 jaar afgenomen. Snoekbaarsaanlandingen zijn afgenomen na de jaren '70, maar vertonen sinds de eeuwwisseling weer wat hogere pieken. In de laatste jaren en dan met name in 2019 zijn de snoekbaarsaanlandingen aan het toenemen. De vangsten fluctueren in de afgelopen 20 jaar echter sterk. De brasemvangsten fluctueren ook sterk en hebben lage of dalende vangsten in het afgelopen decennium. De blankvoorn-aanlandingen fluctueren ook sterk, maar er is een stijging te zien in de afgelopen vier jaar. Ook voor spiering zien we een daling. Het gebrek aan spieringvangsten in de laatste 15 jaar is echter ook een gevolg van veranderingen in beleid; de spieringvisserij in het voorjaar werd na 2003 alleen opengesteld in 2006, 2009 en 2012. In 2012 is er bij wijze van proef nog op spiering gevist. Vanaf 2013 hebben de provincies geen vergunningen meer uitgegeven en is de spieringvisserij weer gesloten.

\subsubsection{Verschillen tussen aanlandingen PVIS, PO en de logboeken}

De historische vangstgegevens van PVIS zijn gebaseerd op de hoeveelheden verhandelde vis op de verschillende afslagen rond het IJsselmeer en Markermeer. Hierin kan dus de vis die buiten de afslagen om werd verhandeld ontbreken, hoewel gevangen pootvis in sommige gevallen ook aan de PO wordt doorgegeven. De vangstgegevens van de PO bevatten de vangsten die door de leden worden doorgegeven. Dit horen officieel alle vangsten te zijn, zowel via de afslagen of buiten de afslagen om. De vangsten zoals gerapporteerd aan de PO zijn doorgaans dan ook hoger dan (of gelijk aan) de vangsten op basis van de aanlandingen bij de afslagen zoals verzameld door PVIS.

Het is echter niet waarschijnlijk dat de gegevens van de PO ook daadwerkelijk álle buiten de afslag om verhandelde vis bevatten. Een indicatie daarvoor komt uit de door het Ministerie van LNV geregistreerde aalvangsten; deze zijn namelijk weer systematisch hoger dan de vangsten zoals gerapporteerd aan de PO IJsselmeer. In 2019 was het verschil tussen PO aalvangsten (149 t) en LNV aalvangsten (328 t) aanzienlijk. Terwijl de PO gegevens een afname laten zien, laten de LNV gegevens een toename van aal aanlandingen zien. De LNV aalvangsten zijn de afgelopen jaren tot 2018 consequent ongeveer anderhalf keer hoger dan die van de PO en in 2019 zelfs twee keer hoger, het verschil lijkt met de jaren groter te worden. Het is onduidelijk waardoor dit aanzienlijke verschil veroorzaakt wordt, maar het geeft wel aan dat er problemen zijn met de betrouwbaarheid en kwaliteit van de verschillende bronnen van aanlandingen. Daarnaast zijn sinds een aantal jaar enkele vissers geen lid meer van de PO. De inschatting is dat zij hun vangsten ook niet meer doorgeven aan de PO. 
De aanlandgegevens aangeleverd door de PO kunnen op hun beurt, afhankelijk van de vissoort, nogal verschillen van de gegevens die in de logboeken worden gerapporteerd. Voor snoekbaars en baars verschillen de bronnen vrijwel niet; dit is ook te verwachten aangezien deze soorten hoofdzakelijk via de afslag worden verkocht. Echter, voor blankvoorn en vooral brasem verschillen de schattingen wel (Tien et al. 2020). Voor brasem speelt mee dat deze soort in de statistieken onder verschillende categorieën valt; naast de categorie 'brasem' wordt deze vis ook ondergebracht bij 'blei' (samen met kolblei, in de PO-reeks) en bij pootvis (samen met wellicht andere levend verhandelde vis, in de PO- en PVIS- reeks). De 'blei'-categorie is meegenomen in de brasem-reeks hier, maar de pootvis niet, omdat onbekend is welk aandeel brasem uitmaakt in deze categorie, en het effect van pootvis toevoegen op de totale hoeveelheden (vooral de eerste jaren) enorm is. Samengevat is de tijdreeks van de brasemaanlandingen waarschijnlijk het minst representatief van alle soorten. Waarom de blankvoornvangsten tussen de POen logboek-reeks zo afwijken is onbekend (Tien et al. 2020).
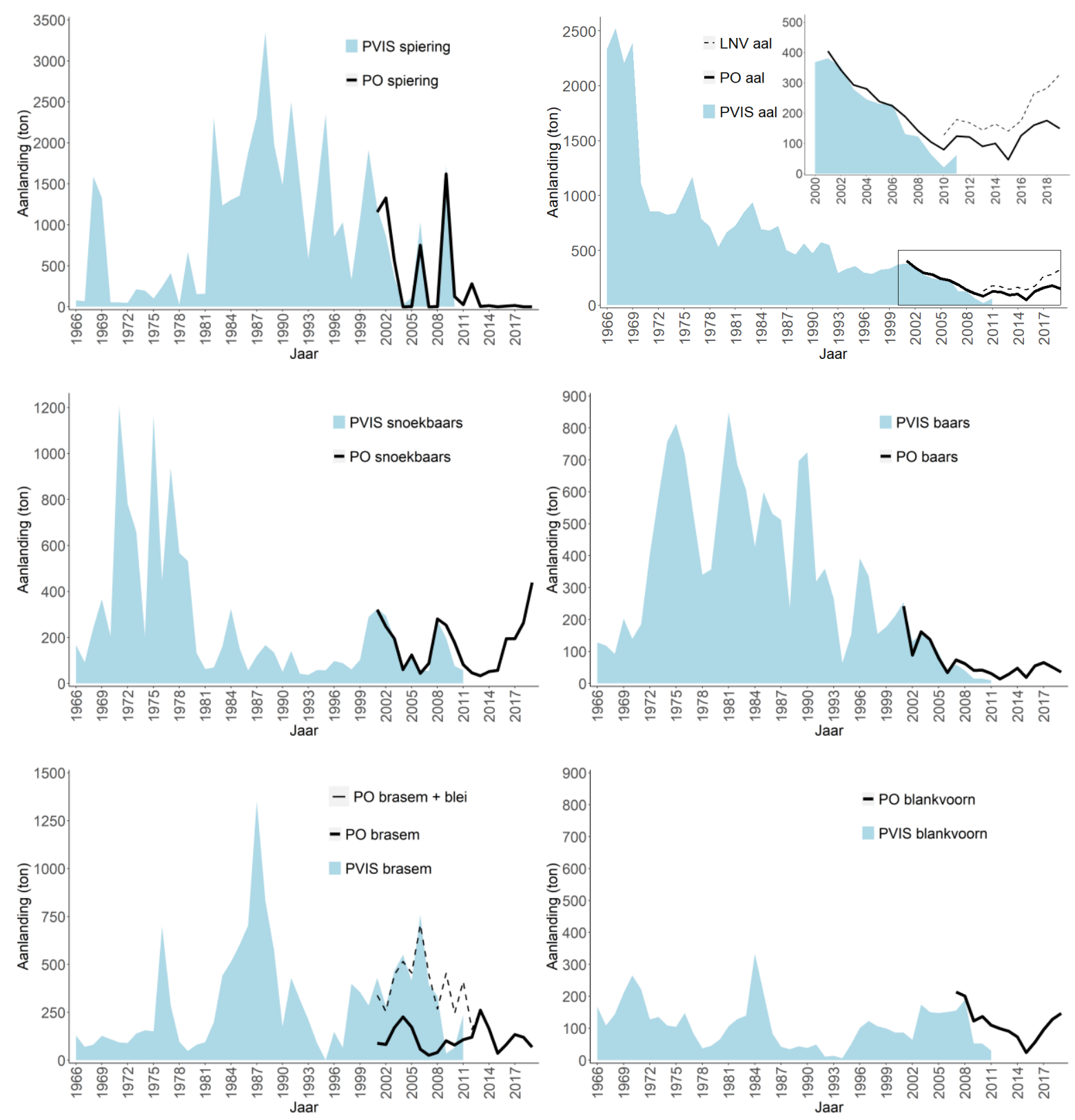

Figuur 2.10 Geregistreerde aanlandingen van de belangrijkste vissoorten uit het IJsselmeer/Markermeer (Bron: Productschap Vis, Producenten Organisatie IJsselmeer en Ministerie LNV). De dataset van PVIS stopt in 2011 door opheffing van de Productschappen. Brasem- en kolbleivangsten zijn ook gecombineerd weergegeven aangezien beide soorten vaak onder dezelfde naam worden aangeland. 


\subsection{Markermeer}

\subsubsection{Open water}

\subsubsection{Algemene soorten}

De bemonsteringslocaties over de periode 1989-2019 zijn weergegeven in Figuur 2.11.

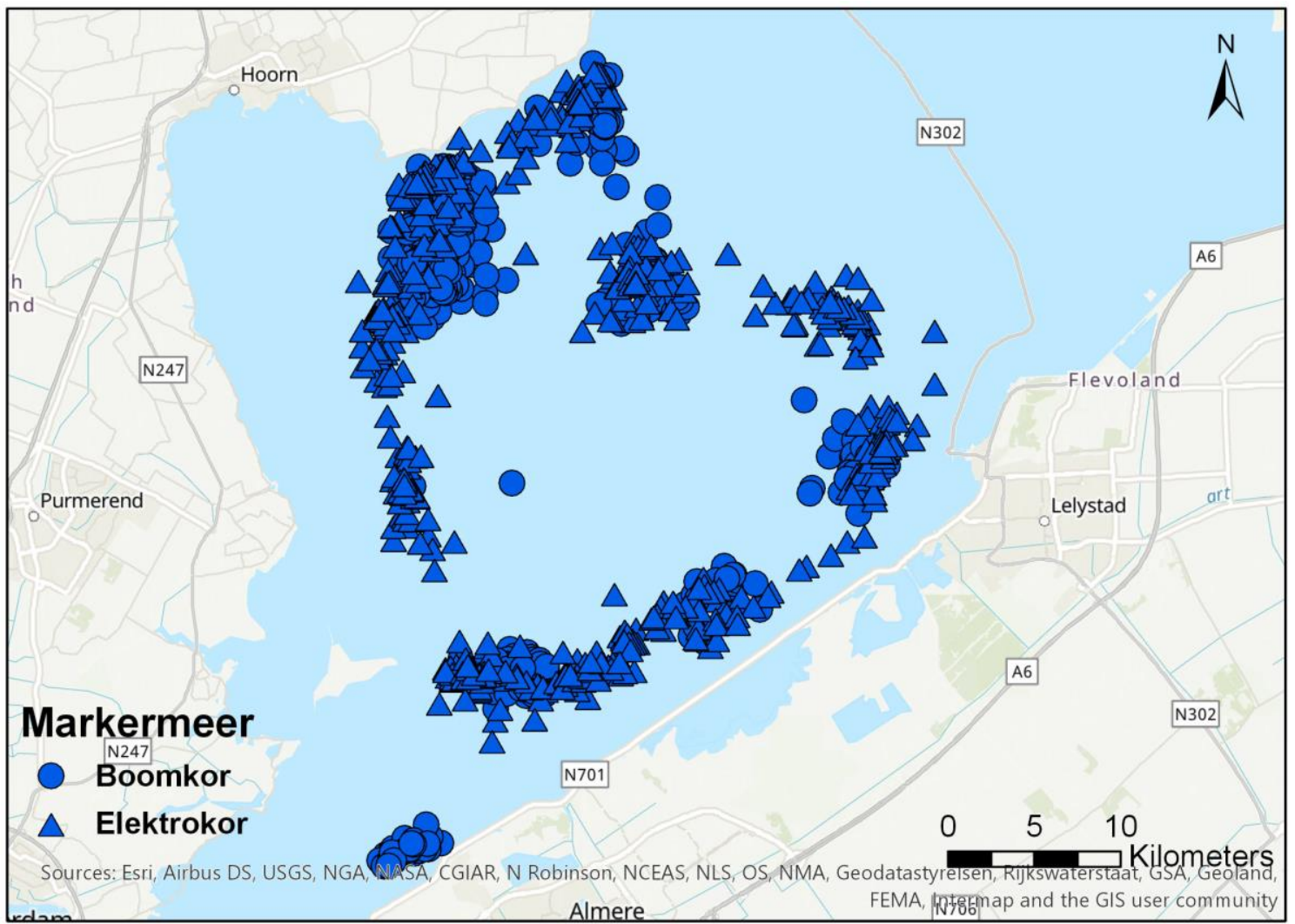

Figuur 2.11 Bemonsteringslocaties van de openwatermonitoring op het Markermeer van 1989-2019.

De tien meest algemene soorten voor de gehele periode 1989-2019 op basis van voorkomen zijn pos, baars, spiering, brasem, blankvoorn, snoekbaars, Pontische stroomgrondel, zwartbekgrondel, rivierdonderpad en de driedoornige stekelbaars. Negen van deze soorten zijn ook het meest algemeen in het IJsselmeer, alleen bot komt nauwelijks voor in het Markermeer. In plaats daarvan behoort de rivierdonderpad hier tot de tien meest algemene soorten. Aangezien aal zich veel beter laat vangen met de elektrokor dan de boomkor laten we deze soort voor de boomkor buiten beschouwing.

De tien meest algemene soorten omvatten meer dan 99,8\% van het totale gemiddelde aantal en biomassa, voor zowel de vangsten met de boomkor als met de elektrokor (Bijlage 5). Net als in het IJsselmeer zien we sinds 1989 dat met name brasem achteruit gaat (Figuur 2.12). Bij blankvoorn is deze afname wat minder sterk dan bij brasem en in de laatste drie jaar zien we dat er zelfs wat meer blankvoorn gevangen wordt. Net als in het IJsselmeer neemt de spiering in de loop der jaren af met zeer lage hoeveelheden in 2018 en 2019. Bij baars zien we ook een afname door de tijd heen, alhoewel er in 2017 een duidelijke opleving was. Dit was ook het geval voor blankvoorn, pos en snoekbaars. De toename van deze soorten in 2017 is veel sterker geweest op het Markermeer dan op het IJsselmeer. Over het algemeen is te zien dat de ontwikkeling van de biomassa per soort door de jaren heen grilliger is op het Markermeer dan op het IJsselmeer. Verder valt op dat het aandeel van brasem in het Markermeer vrij laag is t.o.v. in het IJsselmeer, en dat de relatieve biomassa van snoekbaars een stuk hoger is in het Markermeer t.o.v. het IJsselmeer. Snoekbaars fluctueert op het Markermeer sterk door de jaren heen met in recente jaren lage dichtheden tot 2016 en een opleving vanaf 2017. Pos wordt de laatste jaren steeds minder gevangen met de boomkor; maar wordt met de elektrokor nog relatief goed gevangen. De zwartbekgrondel en de Pontische stroomgrondel, twee exoten, nemen vooral in de periode 
2012-2014 sterk toe. Vanaf 2015 lijkt er weer een afname te zijn, hoewel de vangsten in 2019 wellicht weer hoger waren. Aangezien er in het IJsselmeer vanaf 2015 juist een toename van deze exoten is, is het waarschijnlijk dat de afname in het Markermeer te maken heeft met de verdere verspreiding in en naar het IJsselmeer. In 2019 zijn er in beide meren weer iets meer van deze exoten gevangen dan in 2018. Aal is sinds de jaren 2000 afgenomen, alhoewel er de laatste drie jaar weer een lichte toename te zien is, net als op het IJsselmeer (Figuur 2.3, Figuur 2.12).

De lengte-frequentieverdelingen per tuig per soort over alle jaren van de monitoring van dit KRWlichaam zijn via deze link te bekijken: https://wmropendata.wur.nl/site/zoetwatervis/45/waterlichaam/ 


\section{Markermeer open water}
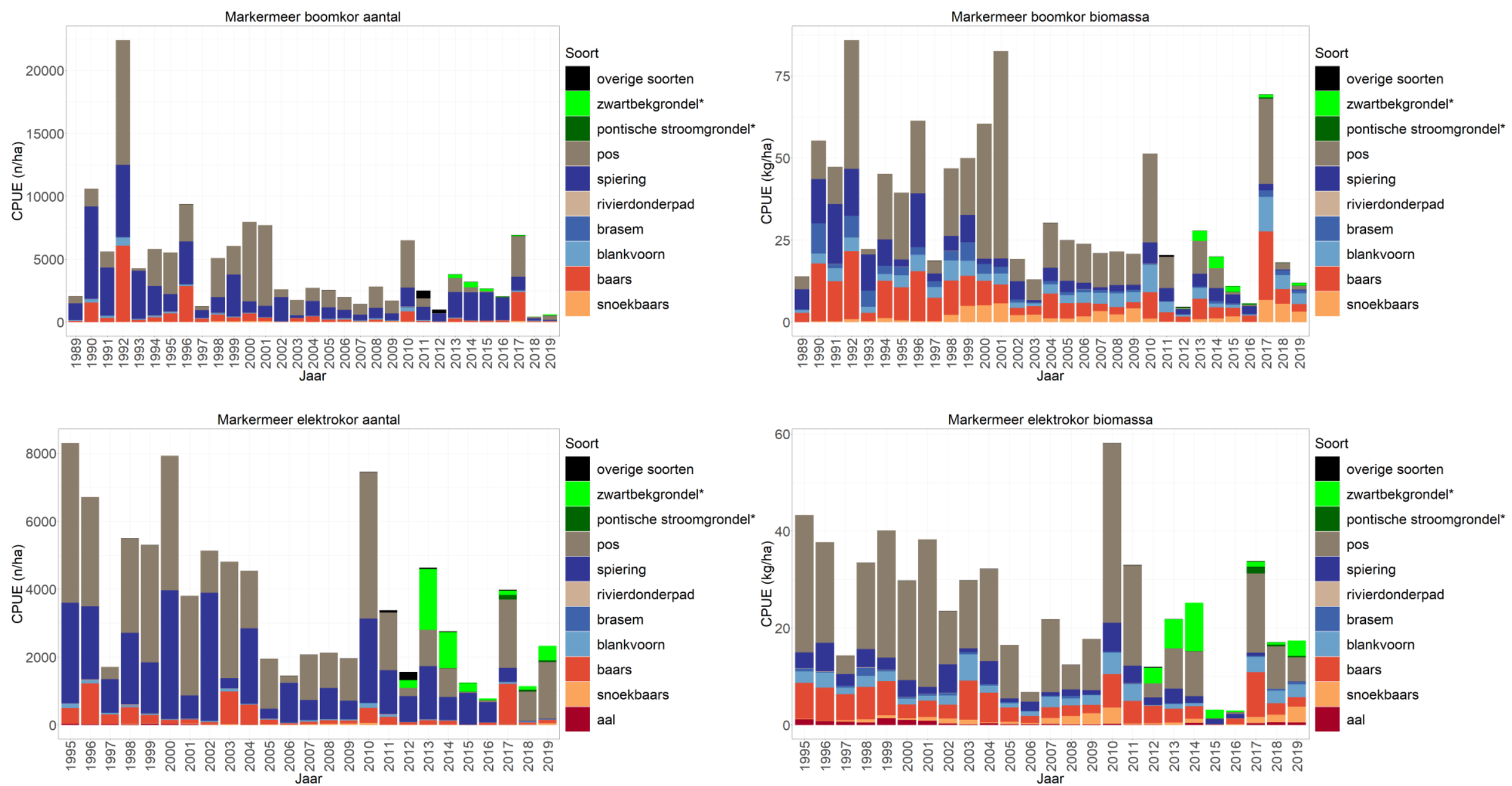

Figuur 2.12 Gemiddelde CPUE ( $\mathrm{n} / \mathrm{ha}$ en $\mathrm{kg} / \mathrm{ha}$ bevist oppervlak) van de negen/tien meest algemene soorten en overige soorten in het open water van het Markermeer (gevangen met de boomkor en de elektrokor). Aal wordt alleen in de elektrokor vangsten weergegeven, $*=$ exoot. 


\subsubsection{Chinese wolhandkrab}

De Chinese wolhandkrab is sinds 1932 aanwezig in het Markermeer (Kamps 1937) en wordt sinds 2002 in het Markermeer gevangen met de boomkor en de elektrokor. Beide tuigen laten zien dat de Chinese wolhandkrab vanaf 2002 een enkele keer gevangen wordt, wat beduidend minder vaak is dan in het IJsselmeer (Figuur 2.13, Figuur 2.14).

\section{Markermeer Boomkor aantal}

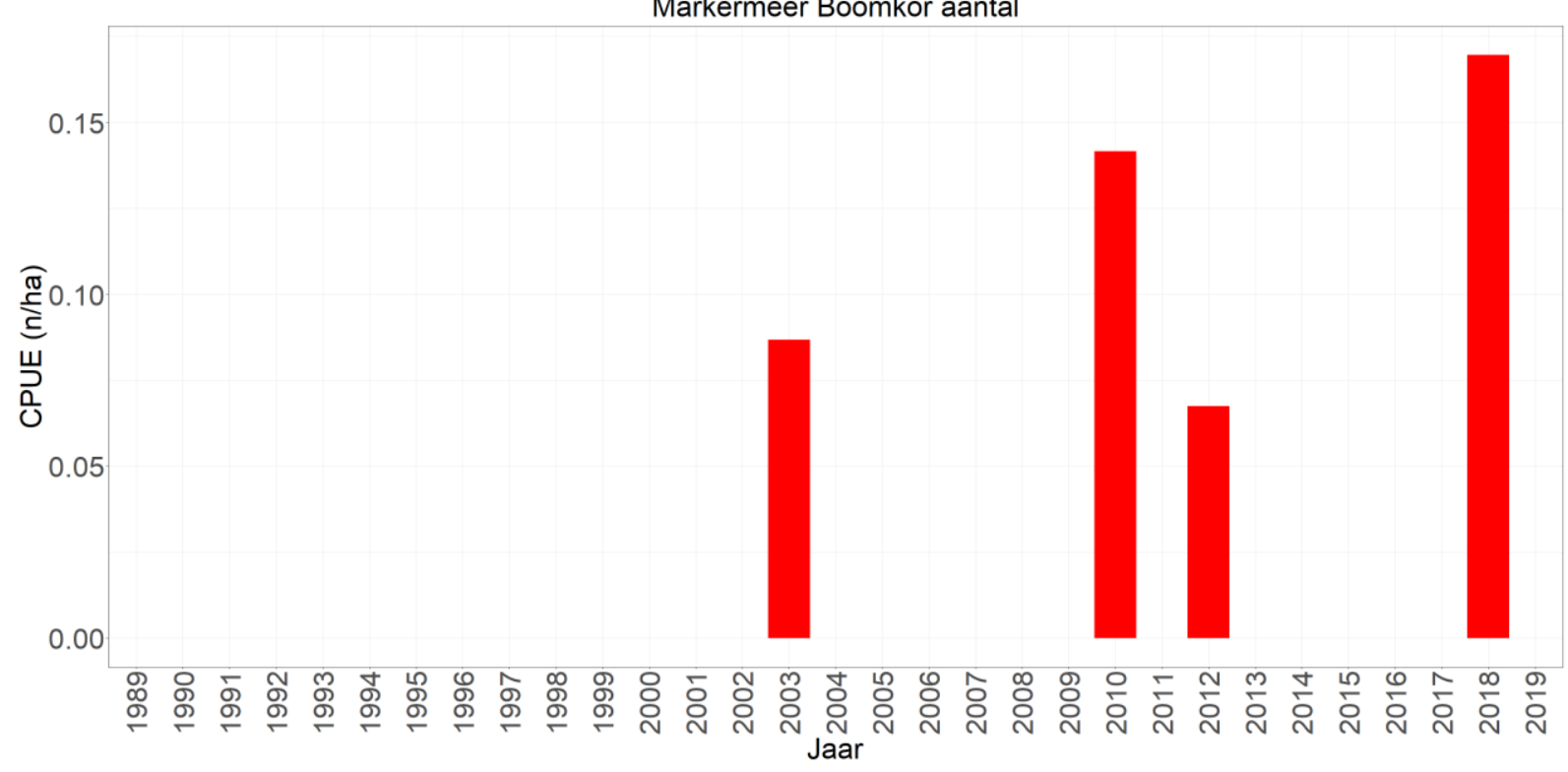

Figuur 2.13 Gemiddelde CPUE (n/ha bevist oppervlak) per jaar van de Chinese wolhandkrab in het open water van het Markermeer gevangen met de boomkor.

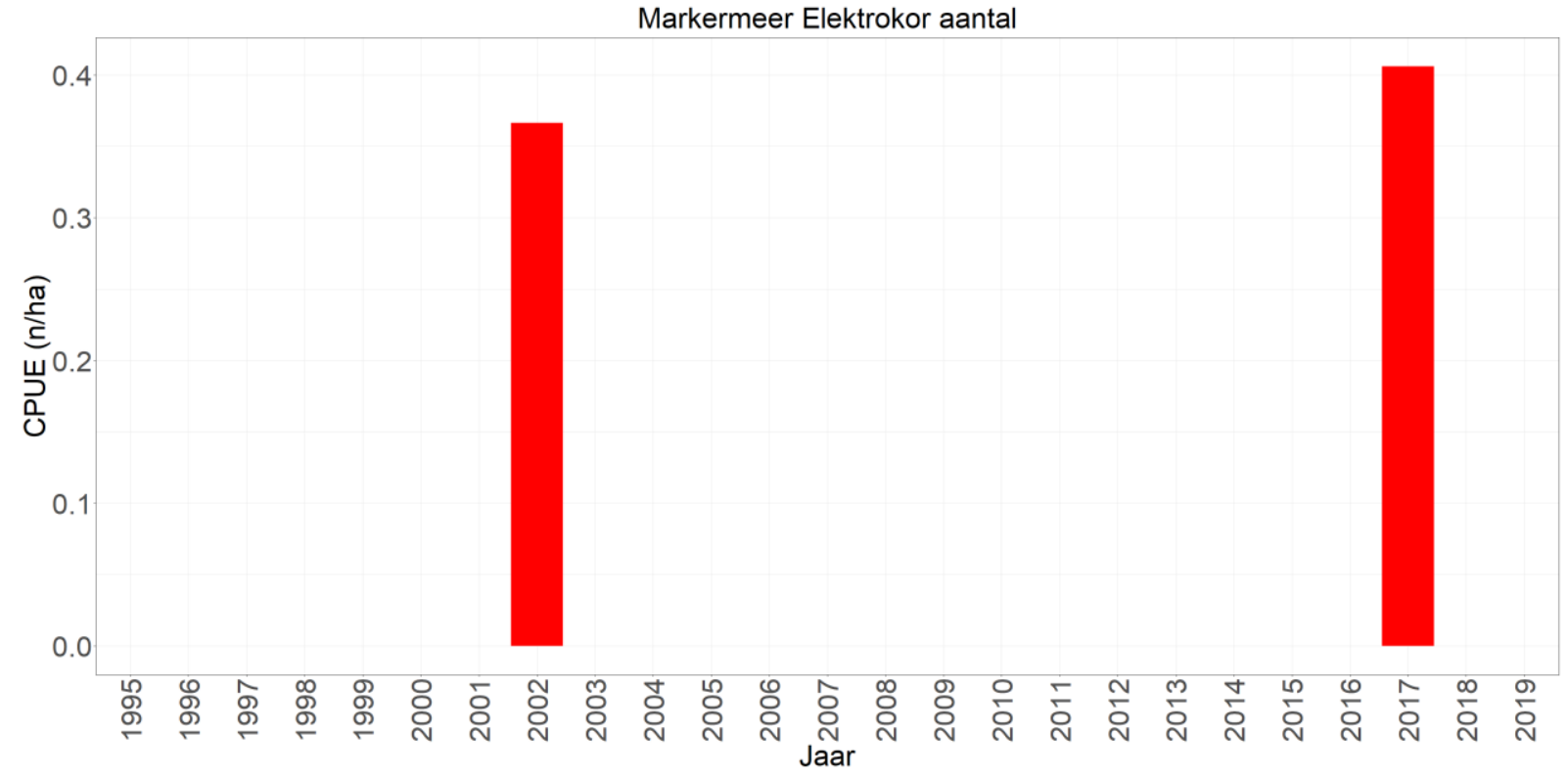

Figuur 2.14 Gemiddelde CPUE ( $\mathrm{n} /$ ha bevist oppervlak) per jaar van de Chinese wolhandkrab in het open water van het Markermeer gevangen met de elektrokor. 


\subsubsection{Oever}

Naast steen- en rietoevers zijn er in het Markermeer ook oevers met een vooroever bemonsterd met een elektroschepnet. De zandige oevers zijn bemonsterd met een zegen (Figuur 2.15). Aal, winde, blankvoorn, baars, zwartbekgrondel, brasem, pos, rietvoorn, alver en kolblei zijn in de afgelopen 10 jaar het meest gevangen (Bijlage 6). Ten opzichte van de voorgaande rapportage (van Rijssel et al. 2020) behoren dit jaar alver en kolblei tot de tien meest algemene soorten in plaats van snoek en karper. In vergelijking met het IJsselmeer zijn er drie andere soorten geselecteerd: in plaats van roofblei, de karper en de Pontische stroomgrondel zijn de rietvoorn, de alver en de kolblei wat algemener langs de oevers van het Markermeer. De oeverbemonsteringen van oevers met riet, stenen en vooroevers zijn gecombineerd weergegeven (rekening houdend met de ruimtelijke verdeling van de verschillende oevers over het gehele Markermeer waarbij het grootste gedeelte van de oevers uit stenen bestaat).

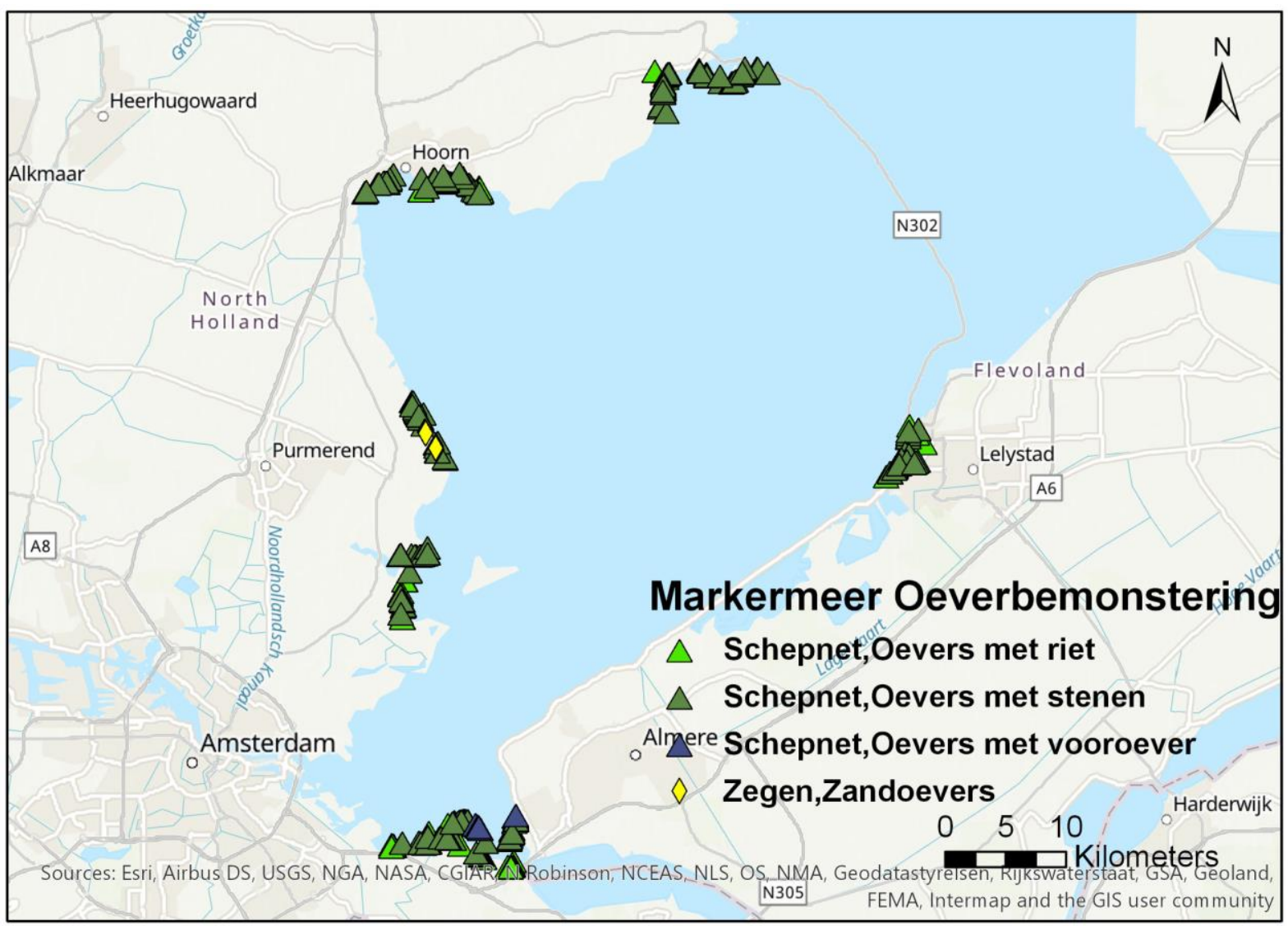

Figuur 2.15 Bemonsteringslocaties van de oeverbemonstering op het Markermeer van 2007-2019.

\subsubsection{Oevers met riet, stenen en vooroevers}

De hoeveelheden langs oevers met riet, stenen en vooroevers van het Markermeer lijken door de jaren heen grofweg gelijk te blijven met een lichte fluctuatie, in 2019 is een is er qua aantallen wat minder gevangen (Figuur 2.16, boven). Vanaf 2012 maakt de invasieve zwartbekgrondel deel uit van het systeem en is deze qua aantallen een van de dominante soorten. Vanaf dat moment zijn de aantallen baars en blankvoorn vrij laag alhoewel blankvoorn zich in de latere jaren lijkt te herstellen (op 2019 na). In tegenstelling tot in het IJsselmeer, lijkt er de laatste drie jaar ook in het open water van het Markermeer een toename van de biomassa van blankvoorn te zijn. De biomassavangsten van aal nemen na een dip in 2014 de laatste jaren weer gestaag toe. Winde wordt de laatste jaren steeds minder gevangen. Net als in het IJsselmeer worden karper en snoek voornamelijk langs rietoevers gevangen (in tegenstelling tot oevers met stenen). Deze vallen onder overige soorten, vooral zichtbaar in de biomassa grafiek, evenals rietvoorn. In de oevers met vooroevers wordt voornamelijk blankvoorn gevangen. De grote soorten (karper, aal, snoek) maken qua aantallen een veel kleiner deel van de totale vangst dan 
qua biomassa (Figuur 2.16, boven). Dit illustreert dat vangsten van enkele grote vissoorten het beeld van de biomassa sterk kunnen beïnvloeden.

\subsubsection{Zandoevers}

Jaarlijks wordt in dezelfde periode als de oevers met riet, stenen en vooroevers, twee zandige oevers bemonsterd met een zegen. Het geringe aantal locaties zorgt waarschijnlijk voor het grillige verloop van de vangsten door de tijd heen (Figuur 2.16, onder). De totale gevangen biomassa en aantallen zijn in 2019 ongeveer gelijk aan 2018. Wel is te zien dat qua aantallen brasem en zwartbekgrondel zijn toegenomen terwijl qua biomassa winde en rietvoorn zijn toegenomen. Daarentegen lijken de hoeveelheden blankvoorn te zijn afgenomen in 2019. De hoge biomassa van baars en winde in de afgelopen jaren is voornamelijk toe te schrijven aan een aantal grote gevangen exemplaren van deze soorten. Wat verder opvalt is dat (de uitschieters van) de aantallen een stuk hoger liggen dan op de zandoevers van het IJsselmeer. Wat ook opvallend is, is dat er net als in het IJsselmeer relatief weinig invasieve grondels bij de zandoevers gevangen worden t.o.v. het open water en de overige oevers, alhoewel er in 2019 een behoorlijke toename is van de hoeveelheden gevangen zwartbekgrondels. In 2019 zijn ook de Kesslers grondel en de rietvoorn voor het eerst gevangen langs de zandoevers van het Markermeer. 

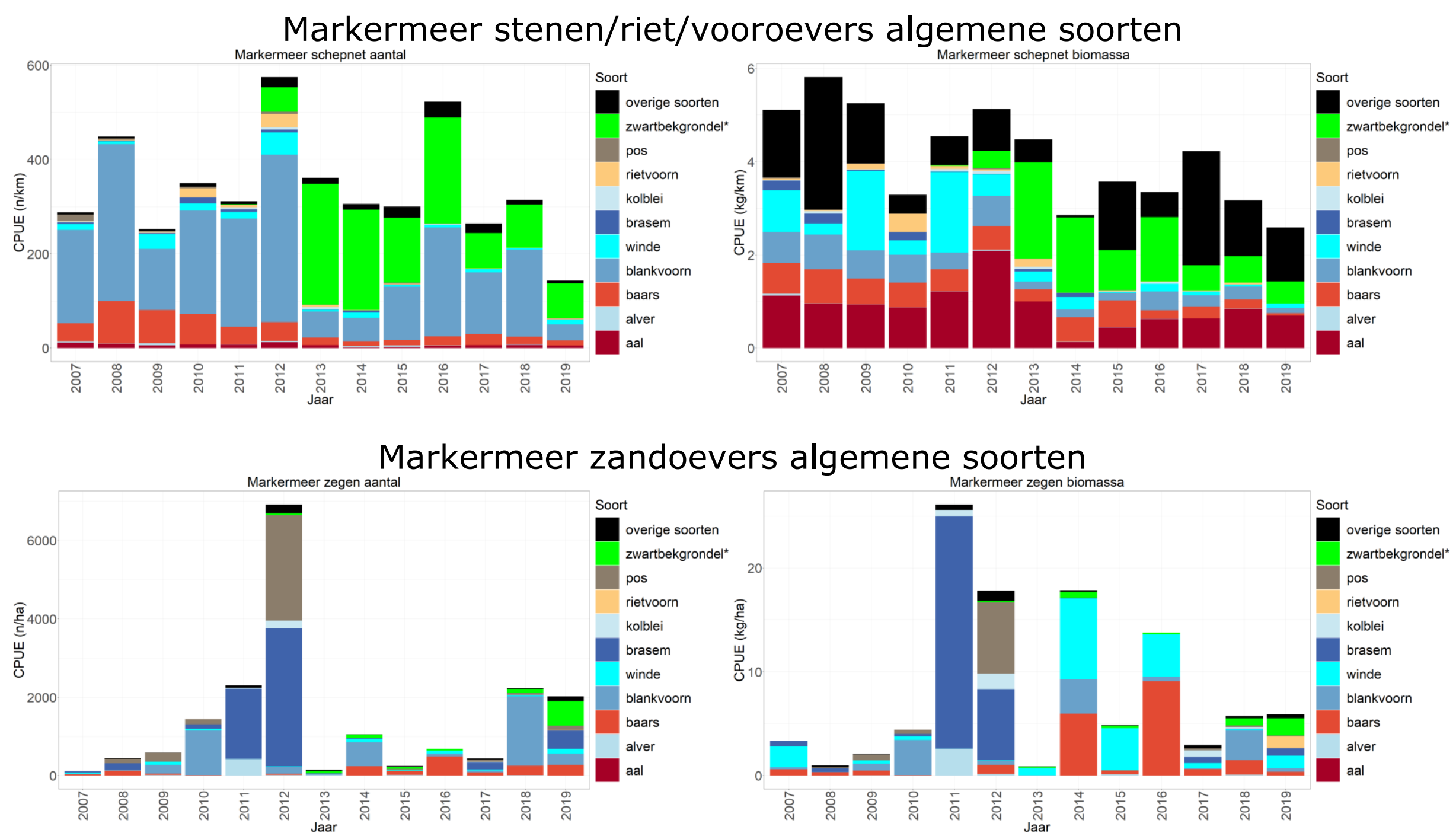

Figuur 2.16 Gemiddelde CPUE van de tien meest algemene soorten en overige soorten bij stenen en rietoevers gevangen met een elektroschepnet ( $\mathrm{n} / \mathrm{km}-\mathrm{kg} / \mathrm{km}$ bevist oppervlak) en bij zanderige oevers gevangen met een zegen ( $\mathrm{n} / \mathrm{ha}-\mathrm{kg} / \mathrm{ha}$ bevist oppervlak) in het Markermeer tijdens de oeverbemonstering, $*=$ exoot. 


\subsection{Randmeren-Oost (open water en oeverzone)}

De bemonsteringslocaties over de periode 2007-2019 zijn weergegeven in Figuur 2.17.

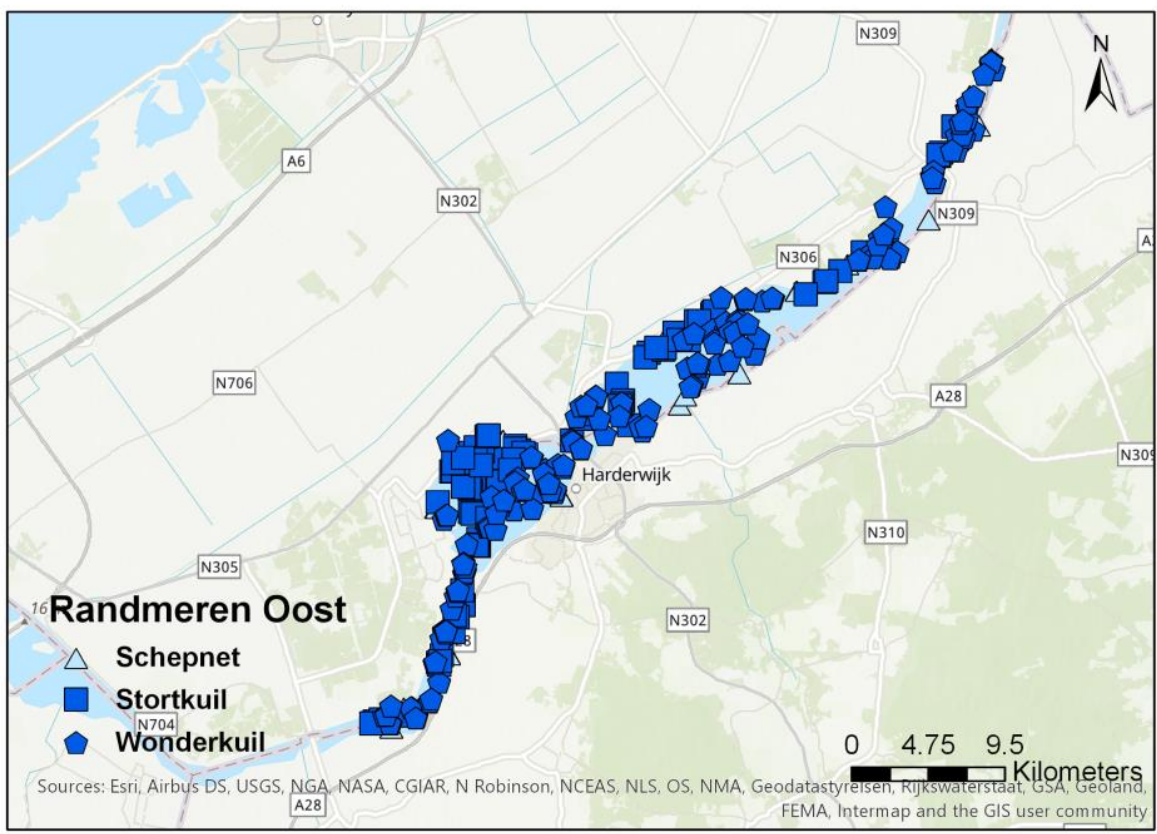

Figuur 2.17 Bemonsteringslocaties van de actieve monitoring in de Randmeren-Oost in de periode 2007-2019 per tuig.

De tien meest algemene soorten in de Randmeren-Oost voor de gehele periode 2007-2019 zijn zwartbekgrondel, pos, snoek, kolblei, karper, brasem, blankvoorn, baars, snoekbaars en aal. Deze omvatten meer dan $97 \%$ van het totale gemiddelde aantal en biomassa voor zowel de vangsten met de stortkuil, wonderkuil en het schepnet (Bijlage 7). De Chinese wolhandkrab is niet in de RandmerenOost gevangen.

In het open water (stortkuil) zijn pos, brasem, blankvoorn, baars, snoek en snoekbaars de dominante soorten (Figuur 2.18 boven). Aal wordt in de Randmeren-Oost nauwelijks gevangen met de stortkuil. Vanaf 2016 zien we dat de pos sterk is afgenomen terwijl de zwartbekgrondel (exoot) is toegenomen. Kolblei is ook een soort die na 2007 niet vaak meer wordt gevangen. Opvallend is dat zwartbekgrondel de enige exoot is die vrij algemeen is in de Oostelijke Randmeren terwijl in de Noordelijke Randmeren (Ketelmeer, Vossemeer, Zwarte Meer) de Pontische stroomgrondel of de Kessler's grondel ook vrij algemeen is (van Rijssel et al. 2020). Net als in de Noordelijke Randmeren zijn blankvoorn, brasem, snoekbaars en baars zowel qua aantal als qua biomassa redelijk stabiel met lichte fluctuaties. Een toename van de zwartbekgrondel (exoot) is pas vanaf 2016 te zien, terwijl dit in andere KRWlichamen al eerder te zien is (2012-2015).

De vangsten met de wonderkuil in het open water zijn qua soortensamenstelling vrijwel gelijk aan die van de stortkuil (Figuur 2.18 onder). Qua trends is te zien dat de pos afneemt met de jaren en dat baars, brasem en blankvoorn relatief stabiel zijn. Wat ook opvalt is dat er in 2016 relatief veel kolblei is gevangen met de wonderkuil, in tegenstelling tot met de stortkuil.

In de oeverzone (schepnet) zijn baars, blankvoorn, brasem en vanaf 2016 ook de zwartbekgrondel qua aantal de dominante soorten. Qua biomassa zijn dit snoek, karper en aal (Figuur 2.19). Ook langs de oever is de zwartbekgrondel pas in 2016 veel gevangen en niet al in 2013 zoals in veel andere KRW-lichamen. In 2019 valt voornamelijk de toename van blankvoorn aantallen en de biomassa toename van aal op en zijn de Kesslers grondel en de roofblei voor het eerst gevangen langs de langs de oevers van de Randmeren-Oost.

De lengte-frequentieverdelingen per tuig per soort over alle jaren van de monitoring van dit KRWlichaam zijn hier te vinden: https://wmropendata.wur.nl/site/zoetwatervis/50/waterlichaam/ 

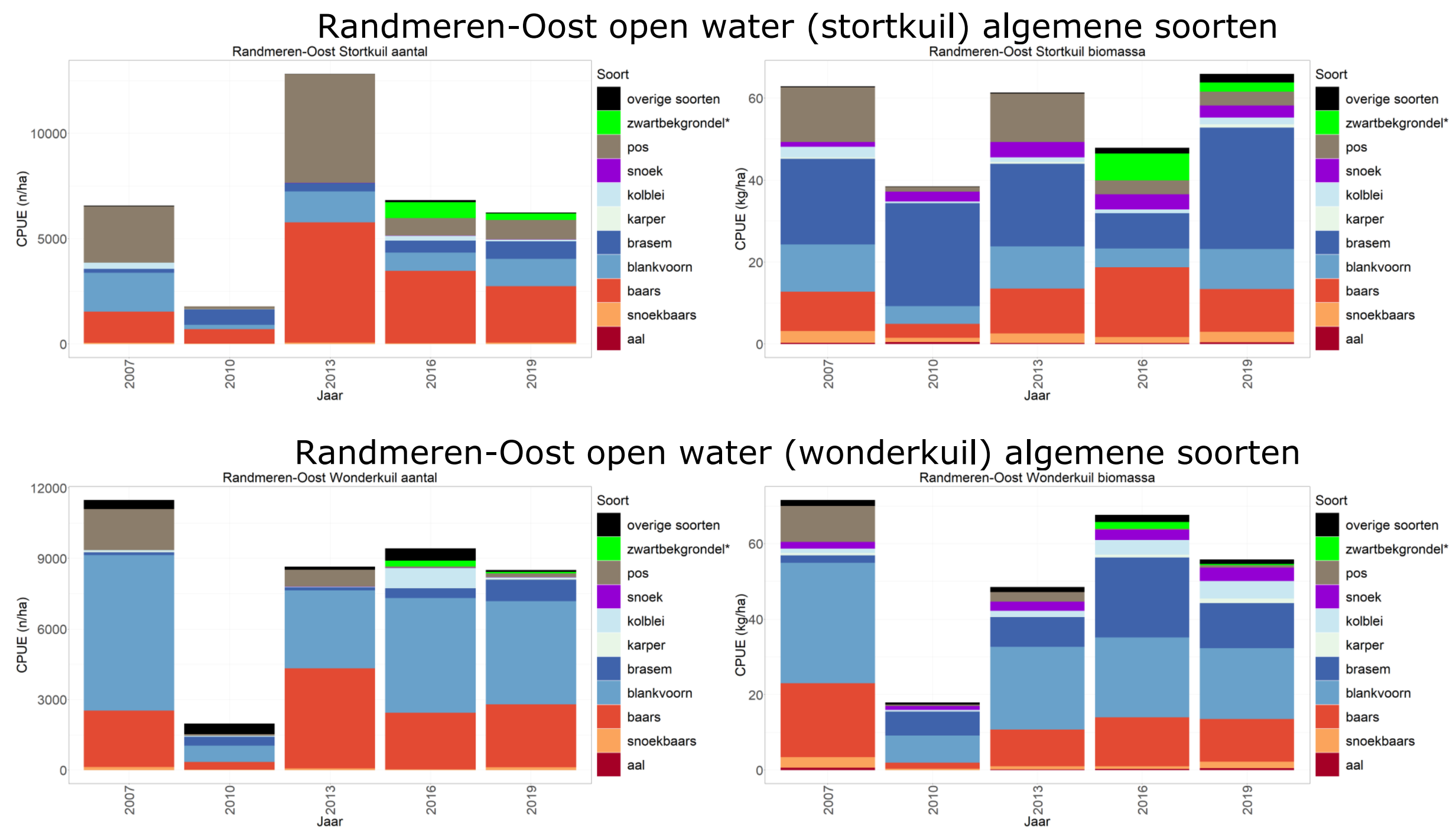

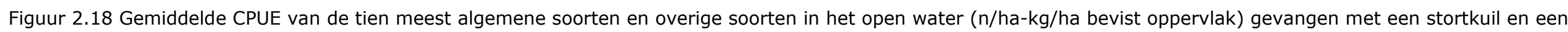
wonderkuil in de Randmeren-Oost tijdens de actieve monitoring van 2007-2019, * = exoot. 


\section{Randmeren-Oost oever}

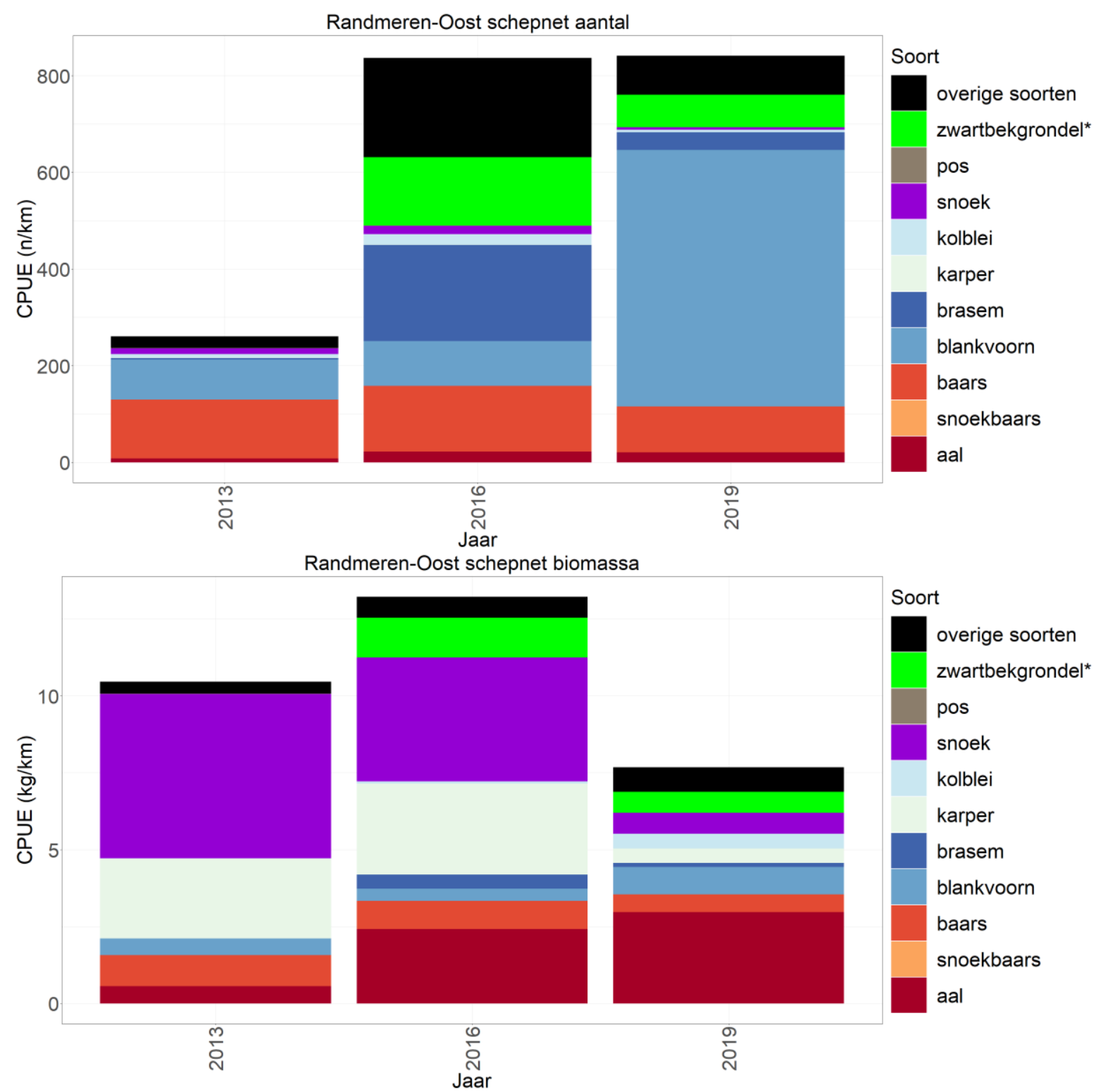

Figuur 2.19 Gemiddelde CPUE van de tien meest algemene soorten en overige soorten langs de oever ( $\mathrm{n} / \mathrm{km}-\mathrm{kg} / \mathrm{km}$ bevist oppervlak) gevangen met een elektroschepnet in de Randmeren-Oost tijdens de actieve monitoring van 2013-2019, * = exoot. 


\subsubsection{Aalvangsten}

Voor de aalaanlandingen van KRW-lichaam Randmeren-Oost zijn de gegevens van de "Veluwe Randmeren" gebruikt (Bijlage 2). De aanlandingen in de Randmeren-Oost zijn de afgelopen drie jaar weer toegenomen na een daling in 2016 en zijn inmiddels weer op het niveau van 2010-2015 (Figuur 2.20). De toename komt voornamelijk door de hogere vangsten met schietfuiken (welke ook het meest ingezet worden, Figuur 2.21). Dit terwijl de vangsten met hokfuiken het afgelopen jaar zelfs wat af namen ten opzichte van voorgaande jaren, voornamelijk vanwege het verlaagde gebruik ervan (Figuur 2.21). Aalkisten worden de laatste jaren niet meer gebruikt.

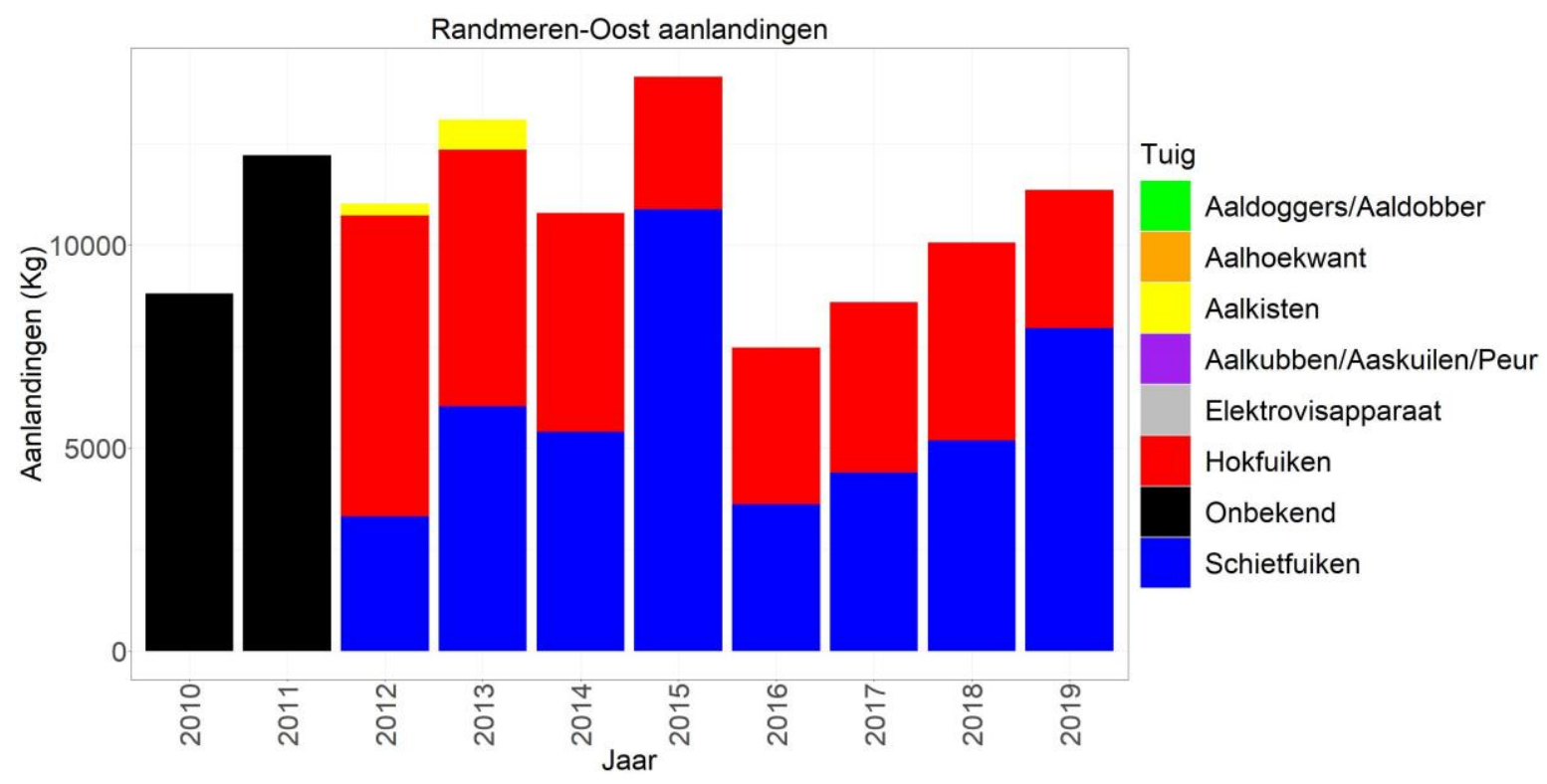

Figuur 2.20 Aanlandingen $(\mathrm{kg})$ van aal door de beroepsvisserij per tuig in de Randmeren-Oost. Sinds 2012 zijn aalvissers verplicht de inspanning van het vistuig op te geven aan het ministerie van LNV.

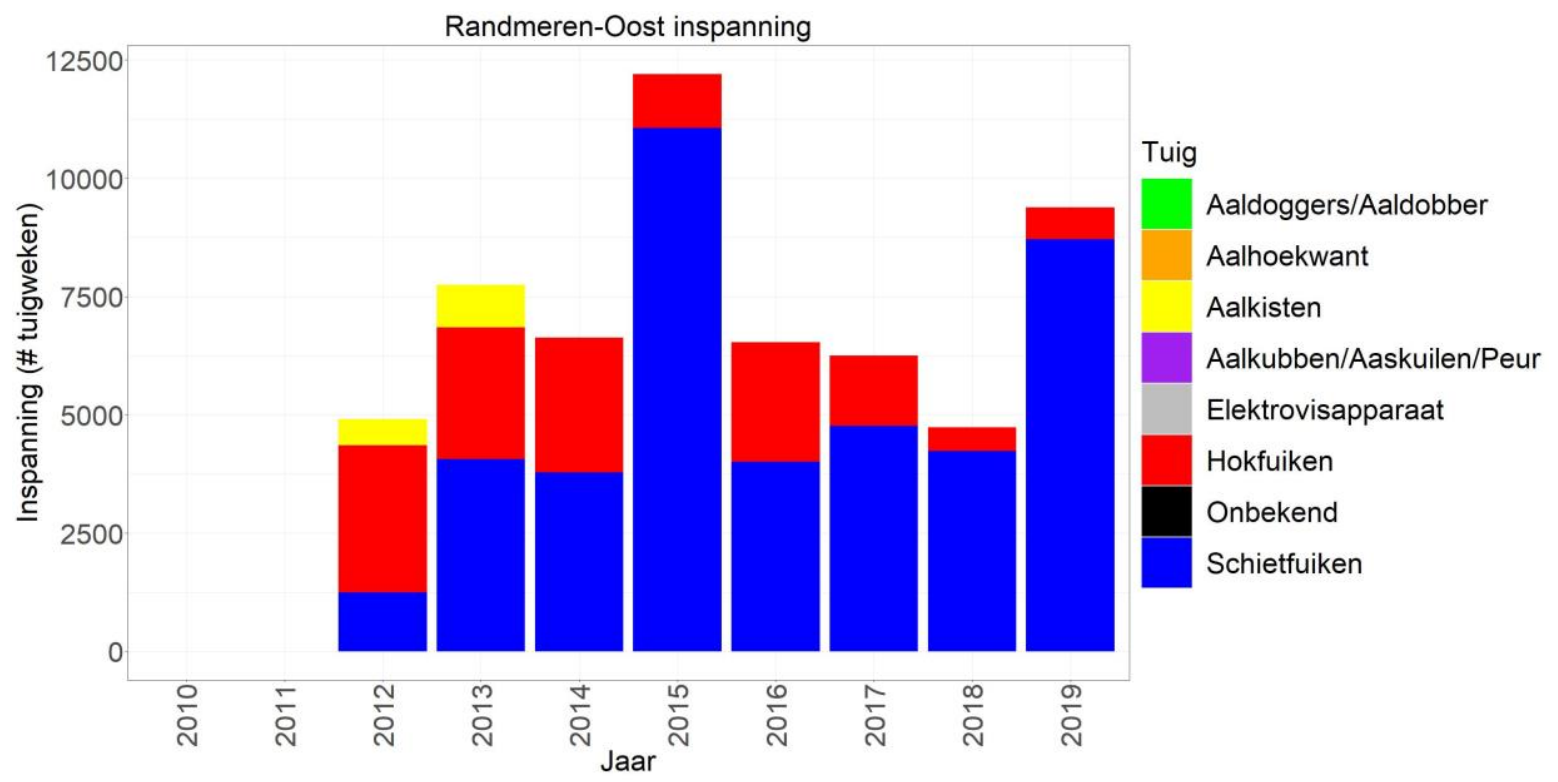

Figuur 2.21 Inspanning (aantal tuigweken) van de beroepsvisserij per tuig in de Randmeren-Oost. 


\subsection{Randmeren-Zuid (open water en oeverzone)}

De bemonsteringslocaties over de periode 2009-2019 zijn weergegeven in Figuur 2.22.

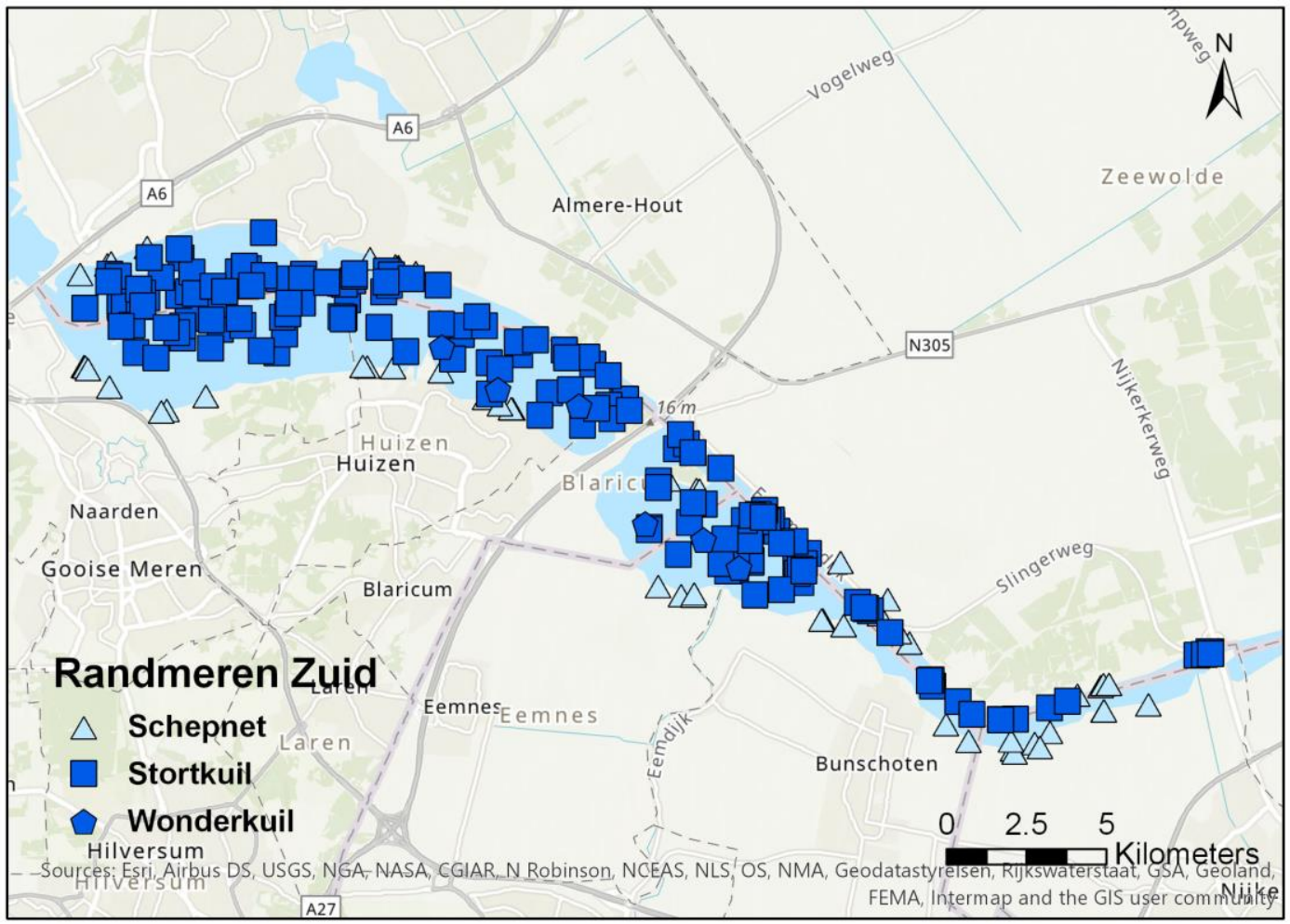

Figuur 2.22 Bemonsteringslocaties van de actieve monitoring in de Randmeren-Zuid in de periode 2009-2019 per tuig.

Voor de Randmeren-Zuid ontbreekt er een bemonstering in het Nijkerkernauw met de stortkuil in 2015. Daarnaast is de bemonstering met de wonderkuil in de Randmeren-Zuid voor de trend buiten beschouwing gelaten aangezien dit vooralsnog alleen nog maar in 2018 is uitgevoerd.

De tien meest algemene soorten in de Randmeren-Zuid voor de gehele periode 2009-2019 zijn zwartbekgrondel, pos, spiering, rietvoorn, driedoornige stekelbaars, brasem, blankvoorn, baars, snoekbaars en aal. Deze omvatten meer dan $99 \%$ van het totale gemiddelde aantal en biomassa voor zowel de vangsten met de stortkuil als met het schepnet (Bijlage 8). Ten opzichte van voorgaande rapportage (van Rijssel et al. 2019a) valt nu de rietvoorn in de top tien meest algemene soorten in plaats van de kleine modderkruiper. De Chinese wolhandkrab is alleen in 2018 in zeer lage aantallen gevangen in de Randmeren-Zuid.

In het open water (stortkuil) waren, net als in de Oostelijke Randmeren, pos, brasem, blankvoorn, baars en snoekbaars de dominante soorten (Figuur 2.23 boven). Aal wordt in de Randmeren-Zuid nauwelijks gevangen met de stortkuil. Vanaf 2009 al zien we dat de pos sterk afneemt. In tegenstelling tot de andere randmeren worden er hier relatief weinig invasieve grondels in het open water gevangen. Wat ook opvalt is dat de driedoornige stekelbaars in relatief hoge aantallen wordt gevangen in 2009 en 2012. Blankvoorn en brasem zijn qua biomassa redelijk stabiel maar fluctueren sterker qua aantal. Baars en snoekbaars lijken qua biomassa ook redelijk stabiel. Als laatste valt op dat de aantallen van alle soorten in 2018 vrij laag zijn. Dit zou kunnen komen doordat de monitoring in 2018 later heeft plaats gevonden dan voorgaande jaren. Later in het jaar vertonen veel van de gevangen soorten clustering waardoor de kans dat vissen niet gevangen worden toeneemt, alhoewel er in 2019 ook in begin oktober is gevist en de aantallen weer overeenkomen met de ordegrootte van de voorgaande jaren. De lage vangsten van 2018 zouden ook te maken kunnen hebben met het verleggen van een aantal vaartrekken en de aanwezigheid van grote hoeveelheden waterplanten. De relatief hoge biomassa van 2018 (t.o.v. de aantallen) kunnen verklaard worden doordat er enkele grotere individuen zijn gevangen. 
In de oeverzone (schepnet) zijn baars, blankvoorn, aal en vanaf 2015 de zwartbekgrondel de dominante soorten qua aantal en biomassa (Figuur 2.23 onder). In tegenstelling tot het open water worden er langs de oevers wel veel zwartbekgrondels gevangen. In 2019 zijn de gevangen aantallen blankvoorn relatief hoog en is de hybride cyprinide voor het eerst gevangen langs de oevers van de Randmeren-Zuid.

De lengte-frequentieverdelingen per tuig per soort over alle jaren van de monitoring van dit KRWlichaam zijn hier te vinden: https://wmropendata.wur.nl/site/zoetwatervis/51/waterlichaam/ 


\section{Randmeren-Zuid open water}
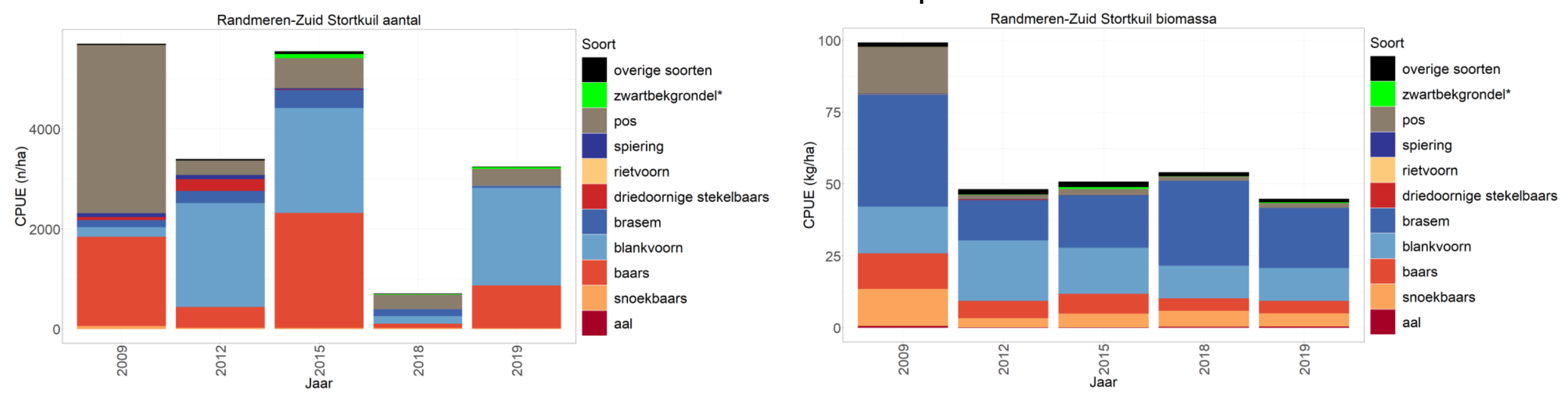

Randmeren-Zui d oever
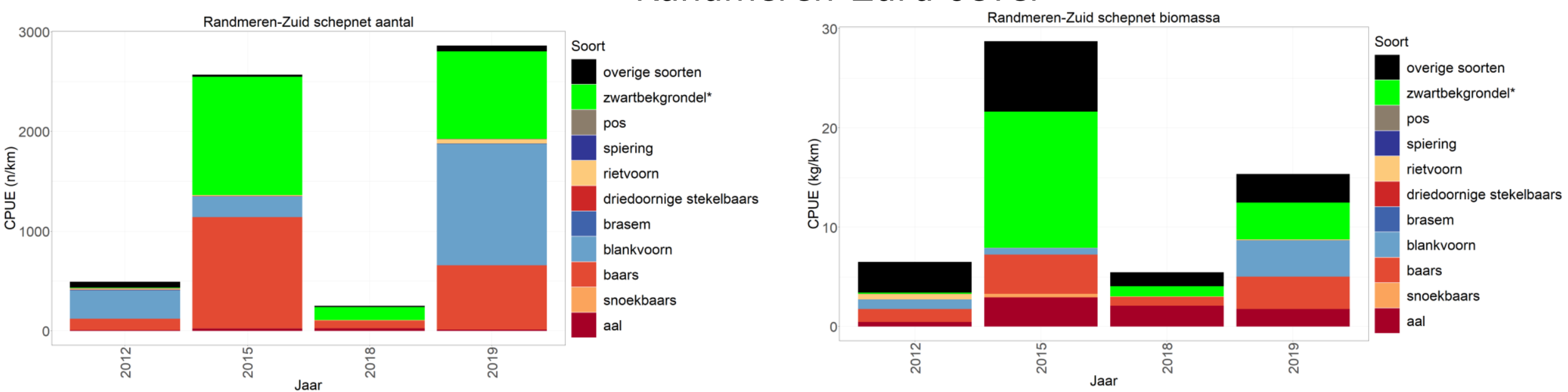

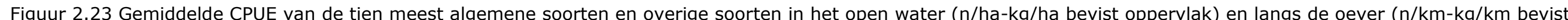
oppervlak) gevangen met een stortkuil en elektroschepnet in de Randmeren-Zuid tijdens de actieve monitoring van 2009-2019, * exoot. 


\subsubsection{Aalvangsten}

Voor de aanlandingen van KRW-lichaam Randmeren-Zuid zijn de gegevens van de "Zuidelijke Randmeren" gebruikt (Bijlage 2). De aanlandingen van aal in de Randmeren-Zuid zijn in 2017 en 2018 weer toegenomen na een daling in 2016 en waren op of boven het niveau van 2010-2015 (Figuur 2.24). In 2019 is er een behoorlijke toename van de aanlandingen. De toename komt door de hogere vangsten met hokfuiken. Hokfuiken worden sinds 2017 als vrijwel het enige tuig ingezet (Figuur 2.25). Sinds 2018 wordt er niet meer met schietfuiken wordt gevist. Dit in tegenstelling tot de RandmerenOost, waar de meeste aangelande aal is gevangen met schietfuiken. Het aalhoekwant lijkt steeds minder gebruikt te worden alhoewel er in 2019 weer mee gevist is.

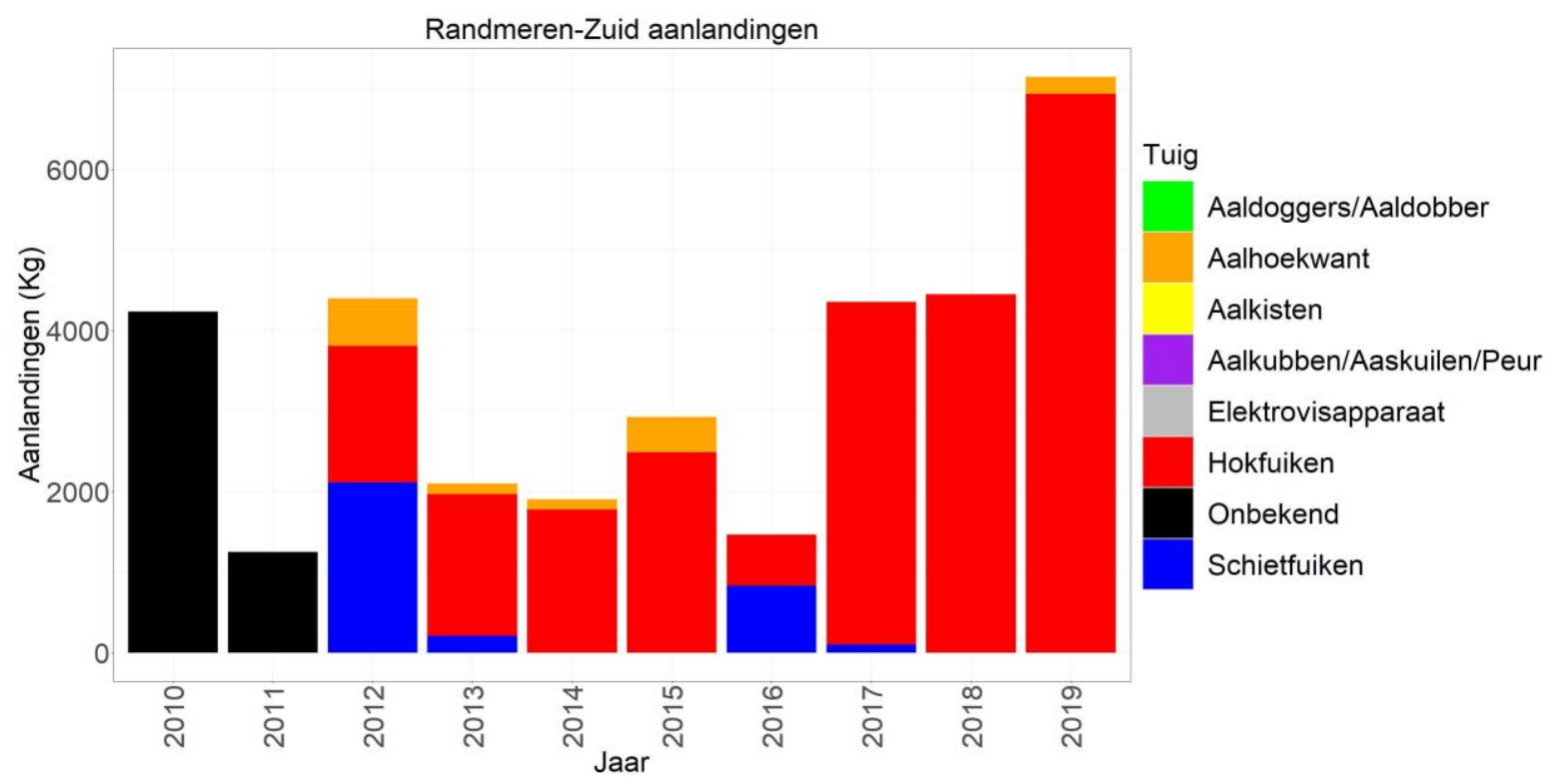

Figuur 2.24 Aanlandingen (kg) van de beroepsvisserij per tuig in de Randmeren-Zuid. Sinds 2012 zijn aalvissers verplicht de inspanning van het vistuig op te geven aan het ministerie van LNV.

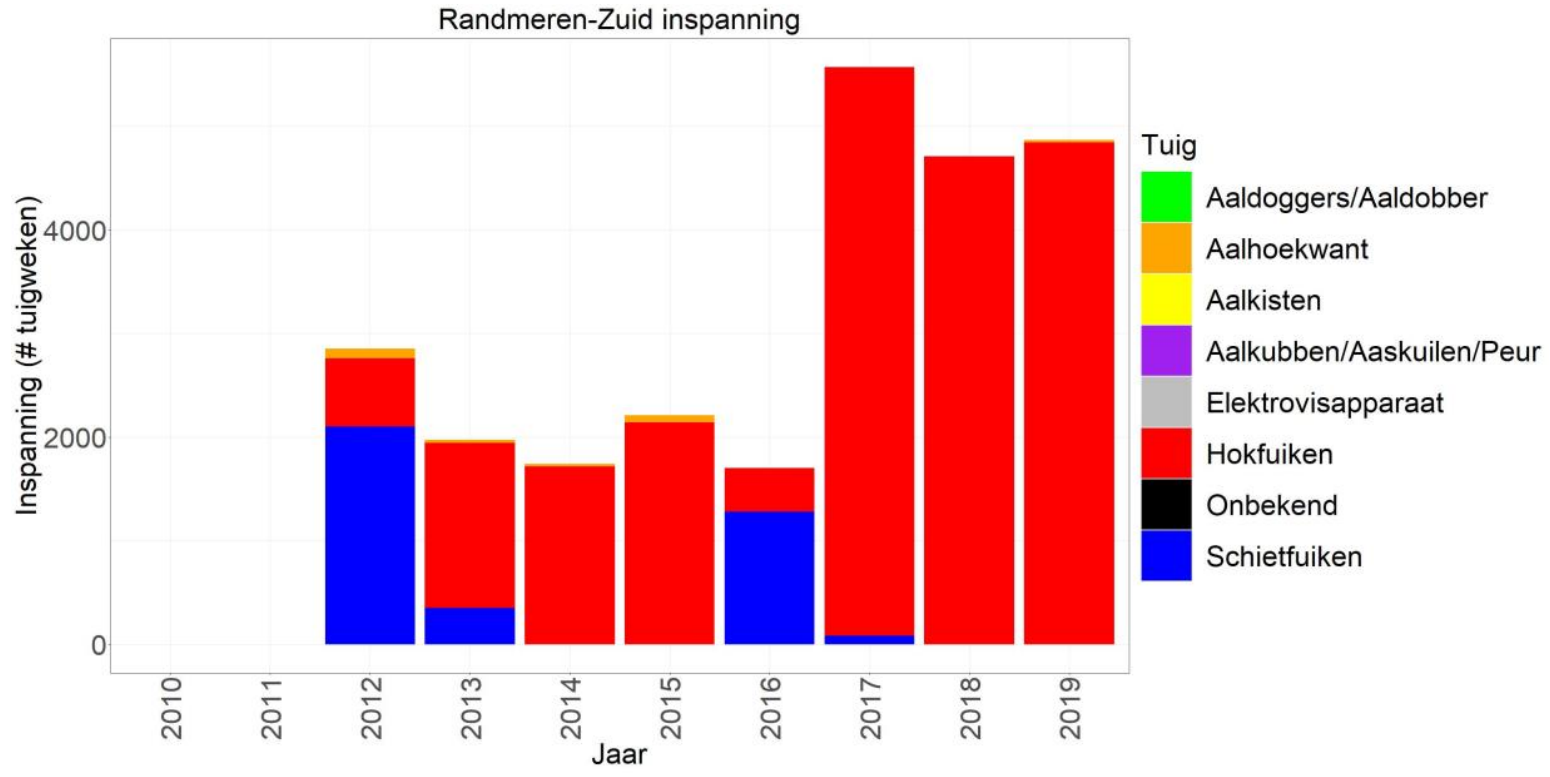

Figuur 2.25 Inspanning (aantal tuigweken) van de beroepsvisserij per tuig in de Randmeren-Zuid. 


\subsection{Benedenloop Gelderse IJssel (IJssel)}

De bemonsteringslocaties over de periode 1997-2019 zijn weergegeven in Figuur 2.26.

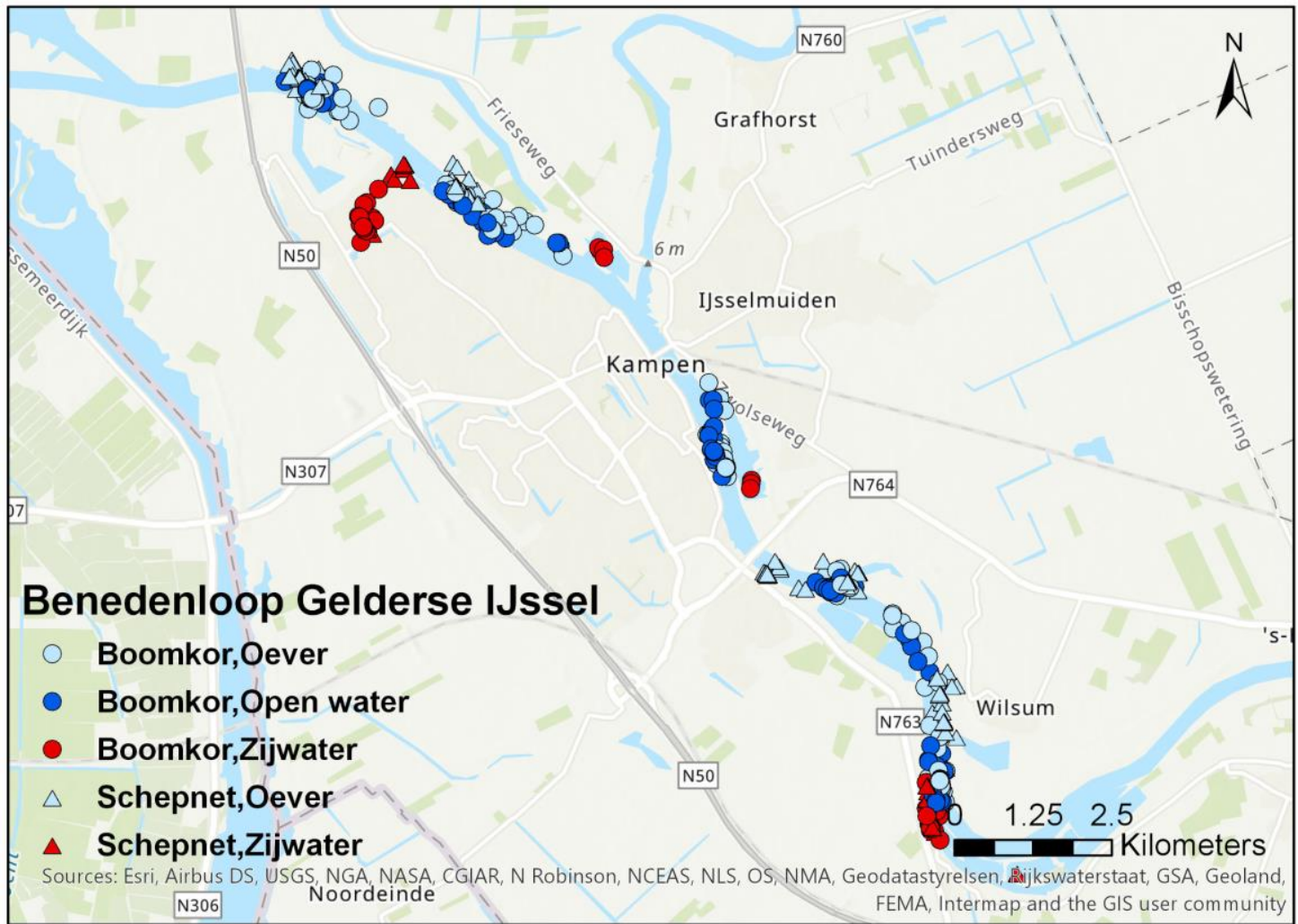

Figuur 2.26 Bemonsteringslocaties van de actieve monitoring in de Benedenloop Gelderse IJssel van 1997-2019 per tuig per habitat.

\subsubsection{Benedenloop Gelderse IJssel hoofdstroom (open water en oeverzone)}

De Benedenloop Gelderse IJssel wordt sinds 1997 ieder jaar in het voorjaar met de boomkor en het elektroschepnet bemonsterd. In de periode 1997-2007 werd dit gebied in maart bemonsterd, vanaf 2008 meestal in februari (behalve in 2010, 2011, 2016, 2017, toen er weer in maart werd bemonsterd).

De tien meest algemene soorten in de hoofdstroom van de Benedenloop Gelderse IJssel voor de gehele periode 1997-2019 zijn spiering, pos, kolblei, karper, brasem, winde, blankvoorn, baars, snoekbaars en aal. Deze omvatten meer dan $97 \%$ van het totale gemiddelde aantal en biomassa voor zowel de vangsten met de boomkor als het schepnet (Bijlage 10).

In het open water en langs de oever (boomkor) zijn spiering, pos, blankvoorn, brasem, kolblei en snoekbaars de dominante soorten zowel qua aantal als qua biomassa (Figuur 2.27 boven). Het jaar 1997 lijkt een erg goed spieringjaar te zijn geweest en spieringhoeveelheden zijn daarna vrij laag gebleven. Blankvoorn fluctueert sterk door de jaren heen met een afname in de laatste 10 jaar en qua aantal is er een sterke daling van pos in de laatste paar jaar en worden er ook geen

rivierdonderpadden meer gevangen (Bijlage 10). Verder lijkt snoekbaars de laatste paar jaar weer toe te nemen. Zowel bij brasem als bij kolblei is er een sterke daling geweest qua biomassa sinds 2010 (met uitzondering van 2017). Wat opvalt is dat er in het jaar 2017 weer relatief veel cypriniden (blankvoorn, brasem, kolblei) zijn gevangen. Hoge vangsten van (andere) vissoorten waren er ook in 2017 voor het IJssel- en Markermeer. De lage vangsten van 2018 hebben wellicht met de lage watertemperatuur te maken tijdens de bemonstering in februari $\left(1^{\circ} \mathrm{C}\right)$, in 2017 en 2019 lag de watertemperatuur rond de $6-7^{\circ} \mathrm{C}$.

Langs de oever (schepnet) zien we eenzelfde trend van de spiering als voor de vangsten in het open water en langs de oever met de boomkor (Figuur 2.27 onder). In de eerste tien jaar van de monitoring waren blankvoorn, brasem, winde en pos de dominante soorten. Al deze vier soorten zijn 
de laatste jaren sterk afgenomen. Karper wordt de laatste jaren ook minder gevangen. Wel zien we een toename van aal en snoek (valt onder overige soorten), alhoewel aal in 2018 en 2019 niet veel is gevangen met schepnet. Wellicht is er nauwelijks aal gevangen met het elektroschepnet in 2018 vanwege zeer lage watertemperatuur $\left(1^{\circ} \mathrm{C}\right)$, alhoewel er ook weinig aal is gevangen in 2019 toen de watertemperatuur alweer iets hoger lag. In 2019 is de blauwband voor het eerst gevangen langs de langs de oevers van de Benedenloop Gelderse IJssel.

De lengte-frequentieverdelingen per soort, per tuig voor de hoofdstroom en de zijwateren gecombineerd over alle jaren van de monitoring van de Benedenloop en Bovenloop Gelderse IJssel gecombineerd zijn hier te vinden: https://wmropendata.wur.nl/site/zoetwatervis/42/waterlichaam/ 

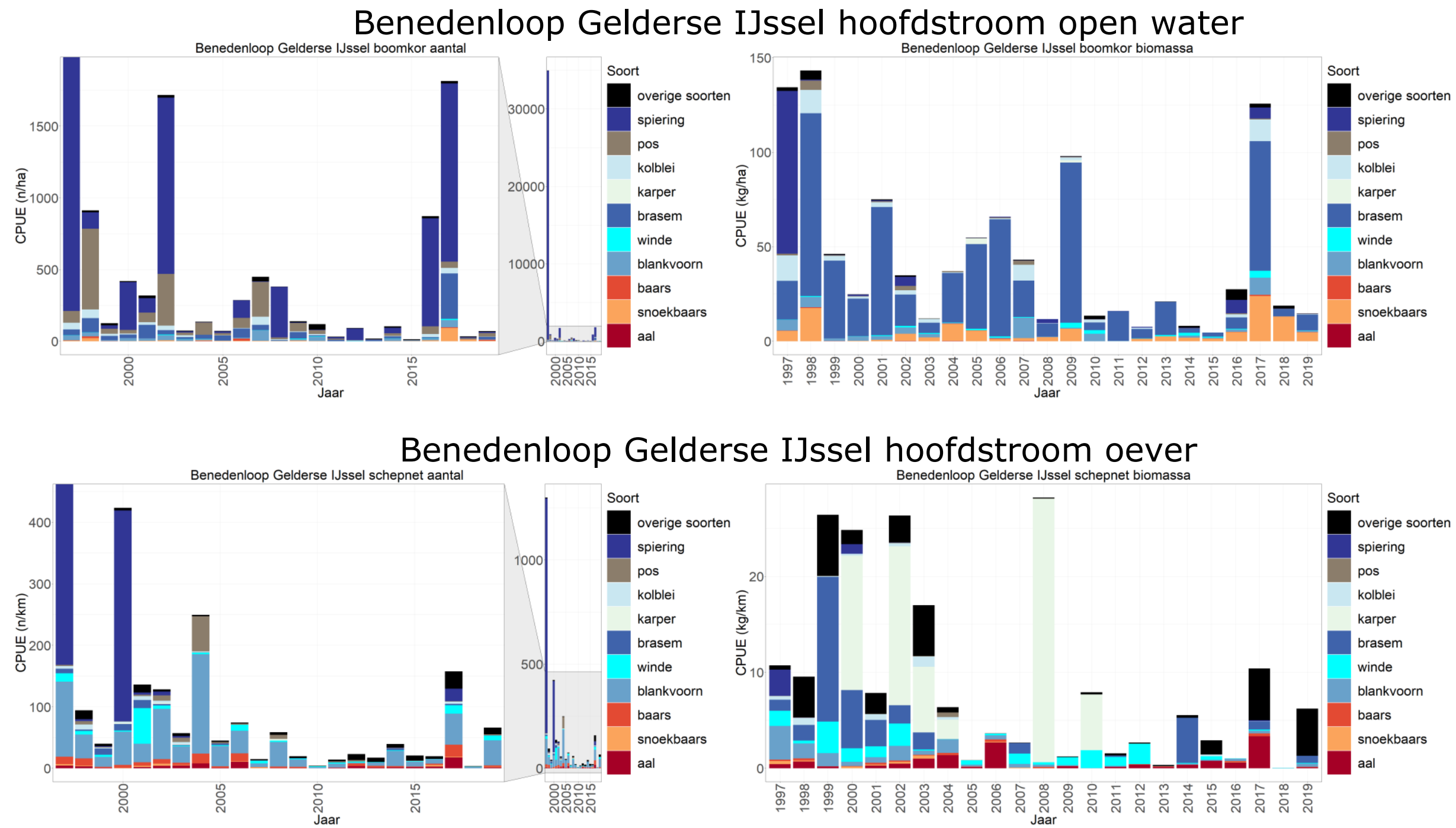

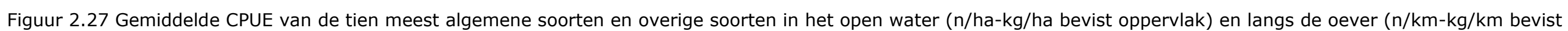
oppervlak) gevangen met een boomkor en elektroschepnet in de hoofdstroom van de Benedenloop Gelderse IJssel tijdens de actieve monitoring van 1997-2019. 


\subsubsection{Chinese wolhandkrab}

De Chinese wolhandkrab wordt een enkele keer gevangen in de hoofdstroom van de Benedenloop Gelderse IJssel (Figuur 2.28).

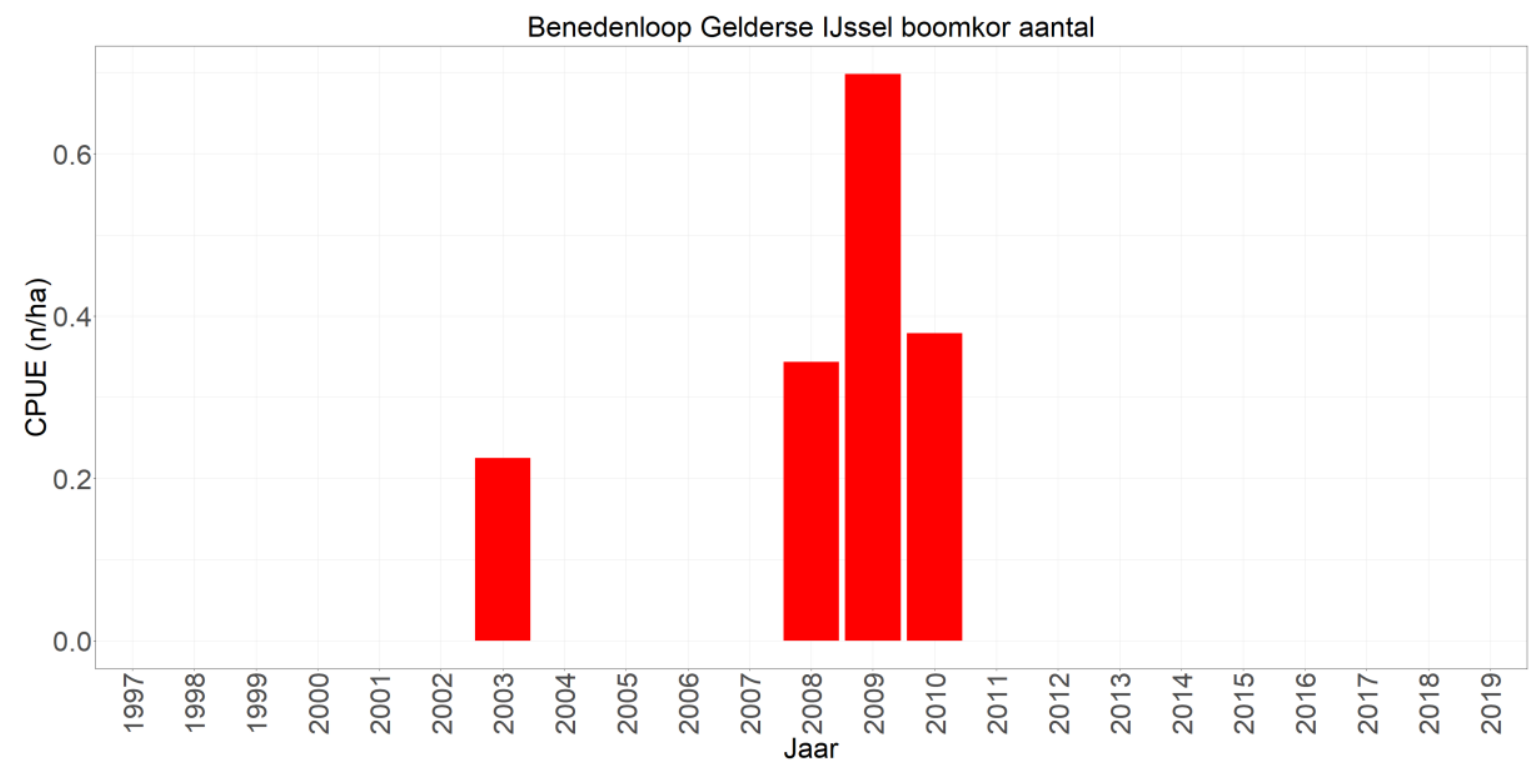

Figuur 2.28 Gemiddelde CPUE (n/ha bevist oppervlak) per jaar van de Chinese wolhandkrab in de hoofdstroom van het open water van de Benedenloop Gelderse IJssel gevangen met de boomkor. 


\subsubsection{Benedenloop Gelderse IJssel zijwateren}

Langs de Benedenloop Gelderse IJssel zijn een jachthaven, twee inhammen en een nevengeul bemonsterd in het open water met de boomkor en langs de oever met het schepnet.

De tien meest algemene soorten in deze zijwateren voor de gehele periode 1997-2019 zijn: spiering, snoek, pos, kolblei, brasem, winde, blankvoorn, baars, snoekbaars en alver. Deze omvatten meer dan $97 \%$ van het totale gemiddelde aantal en biomassa voor zowel de vangsten met de boomkor als het schepnet (Bijlage 11). De Chinese wolhandkrab is niet in de zijwateren gevangen.

In het open water (boomkor) zijn, net als in de hoofdstroom spiering, pos, blankvoorn, brasem, kolblei en snoekbaars de dominante soorten, zowel qua aantal als qua biomassa (Figuur 2.29 boven). Ook hier is te zien dat spiering in 1997 in groten getale aanwezig was. Een afname van de cyprinide soorten (blankvoorn, brasem en kolblei) is net als in de hoofdstroom duidelijk waarneembaar vanaf het begin van de monitoring. Ook pos wordt de laatste jaren steeds minder gevangen. Wat opvalt is dat aal ontbreekt in de top tien van de zijwateren, zijn plaats is ingenomen door de alver. Daarnaast komen er ook in de zijwateren geen invasieve grondelsoorten voor in de top tien. In 2019 is de giebel voor het eerst gevangen in het open water van de zijwateren van de Benedenloop Gelderse IJssel, deze soort werd al eerder in de hoofdstroom gevangen. Het valt op dat er met name veel hogere aantallen vis worden gevangen in de zijwateren ten opzichte van de hoofdstroom.

In de oeverzone van de zijwateren (schepnet) zijn blankvoorn, brasem en winde de dominante soorten (Figuur 2.29 onder). Wat opvalt is dat er in 2005 erg veel blankvoorn is gevangen en dat in de jaren daarna relatief weinig vis wordt gevangen in de zijwateren waarbij qua aantallen baars de dominante soort is. Ook in de zijwateren is er in 2018 nauwelijks vis gevangen, wellicht door de lage watertemperatuur. In 2019 is de kleine modderkruiper voor het eerst gevangen langs de oevers van de zijwateren van de Benedenloop Gelderse IJssel, dit soort werd al eerder in de hoofdstroom gevangen. 


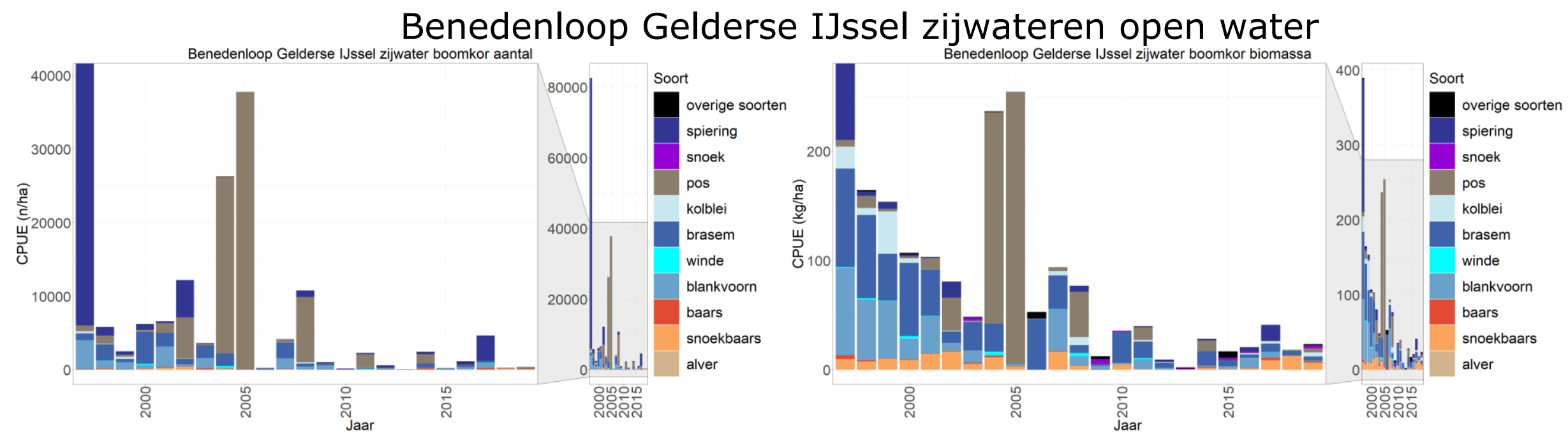

Benedenloop Gelderse IJssel zijwateren oever

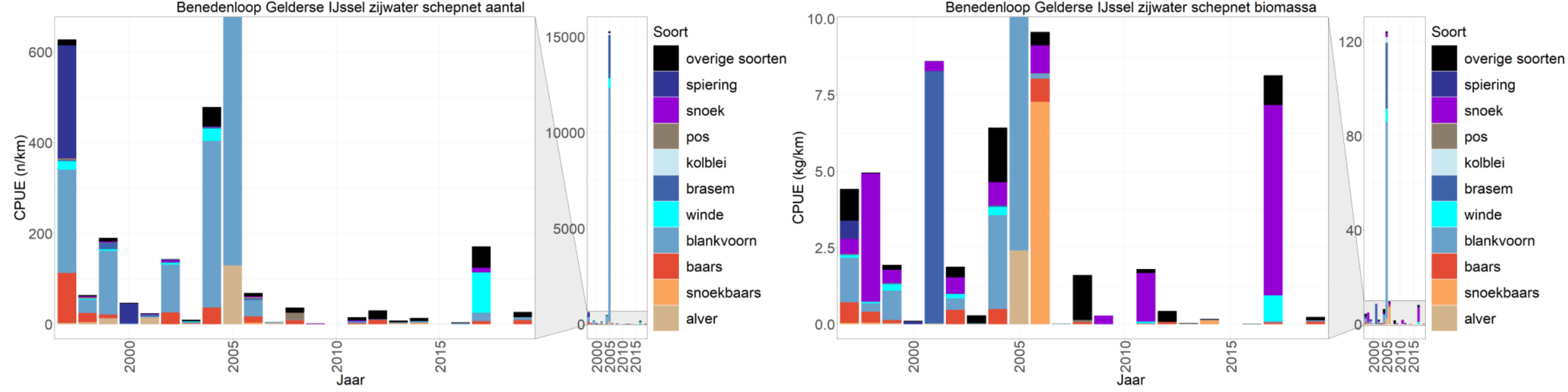

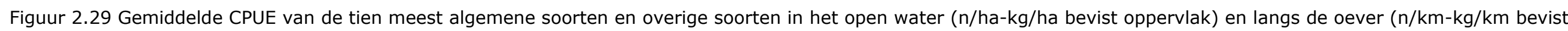
oppervlak) gevangen met een boomkor en elektroschepnet in zijwateren van de Benedenloop Gelderse IJssel tijdens de actieve monitoring van $1997-2019$. 


\subsubsection{Aalvangsten}

Voor de aanlandingen van KRW-lichamen Ketel- \& Vossemeer, Zwarte Meer, Zwarte Water en Benedenloop Gelderse IJssel zijn de gegevens van de "IJssel Plus" gebruikt (Bijlage 2). In 2011 is een grote afname t.o.v. 2010 van de aalaanlandingen te zien wat waarschijnlijk een effect is van het verbod op aalvisserij in de grote rivieren en het grootste deel van het Ketelmeer in verband met te hoge dioxine- en PCB-gehaltes in aal. Dit betekent dat de aanlandingen van de IJssel Plus vanaf 2011 voornamelijk gebaseerd zijn op het Vossemeer, Zwarte Meer en het Zwarte Water. Vanaf 1 januari 2015 is het ook niet meer toegestaan in het Vossemeer op aal te vissen, wat betekent dat de aanlandingen vanaf dat jaar voornamelijk uit het Zwarte Meer en Zwarte Water komen. Na een afname in 2016 lijken de aanlandingen relatief stabiel waarbij de meeste aal gevangen is met hokfuiken en het elektrovisapparaat (met uitzondering van 2018 waarin er relatief veel aal met het aalhoekwant is aangeland en er geen aal is aangeland gevangen met het elektrovisapparaat, Figuur 2.30). In 2017 is er ook nog aal aangeland die gevangen is met aalkubben, aaskuilen of een peur. Schietfuiken worden steeds minder vaak gebruikt. Opvallend is de relatief hoge inspanning van het aalhoekwant in 2019 met een relatief lage hoeveelheid aanlandingen (Figuur 2.31).

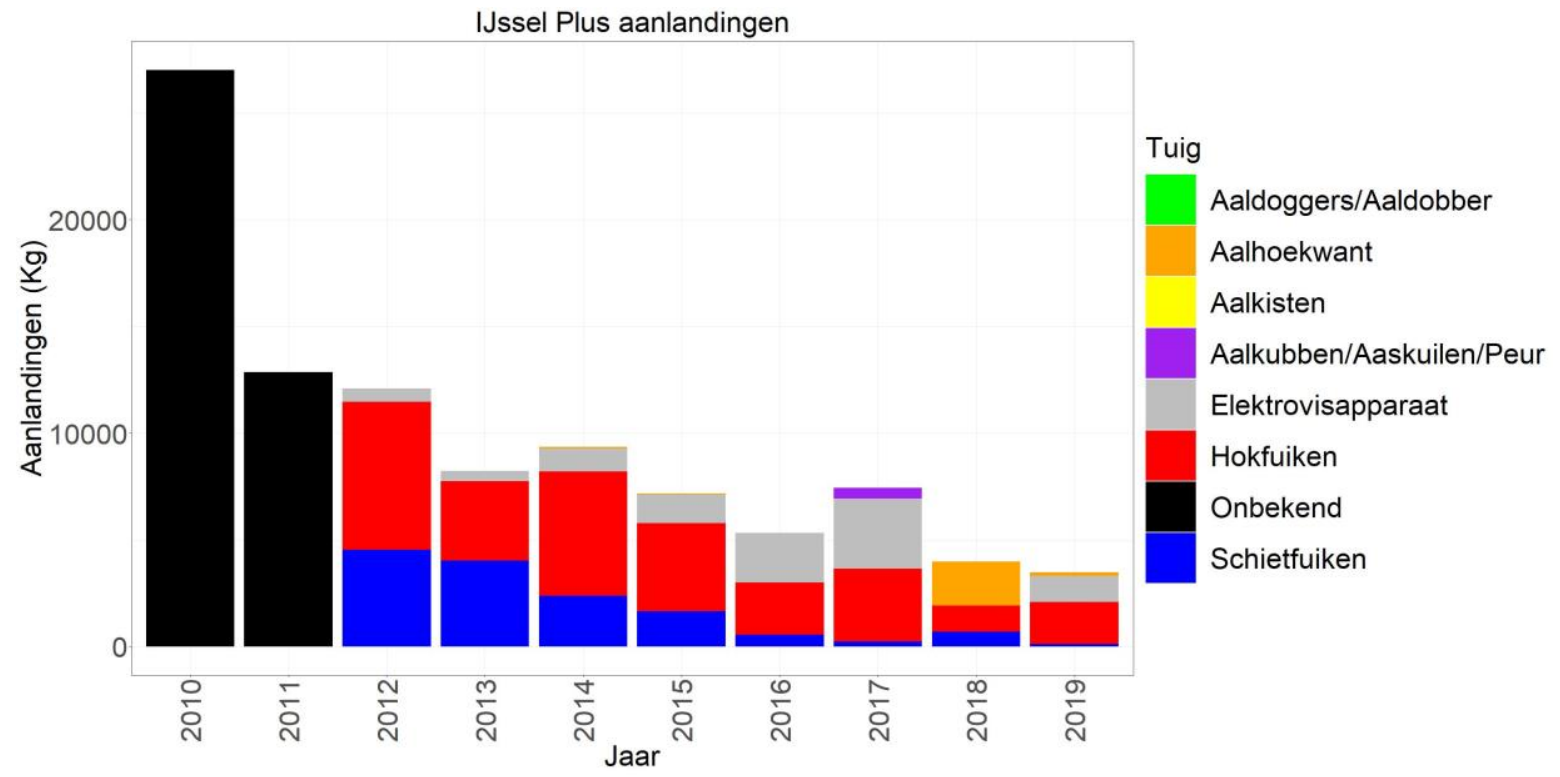

Figuur 2.30 Aanlandingen $(\mathrm{kg})$ van de beroepsvisserij per tuig in de IJssel Plus (Ketel- \& Vossemeer, Zwarte Meer, Zwarte Water en Benedenloop Gelderse IJssel). Sinds 2012 zijn aalvissers verplicht de inspanning van het vistuig op te geven aan het ministerie van LNV.

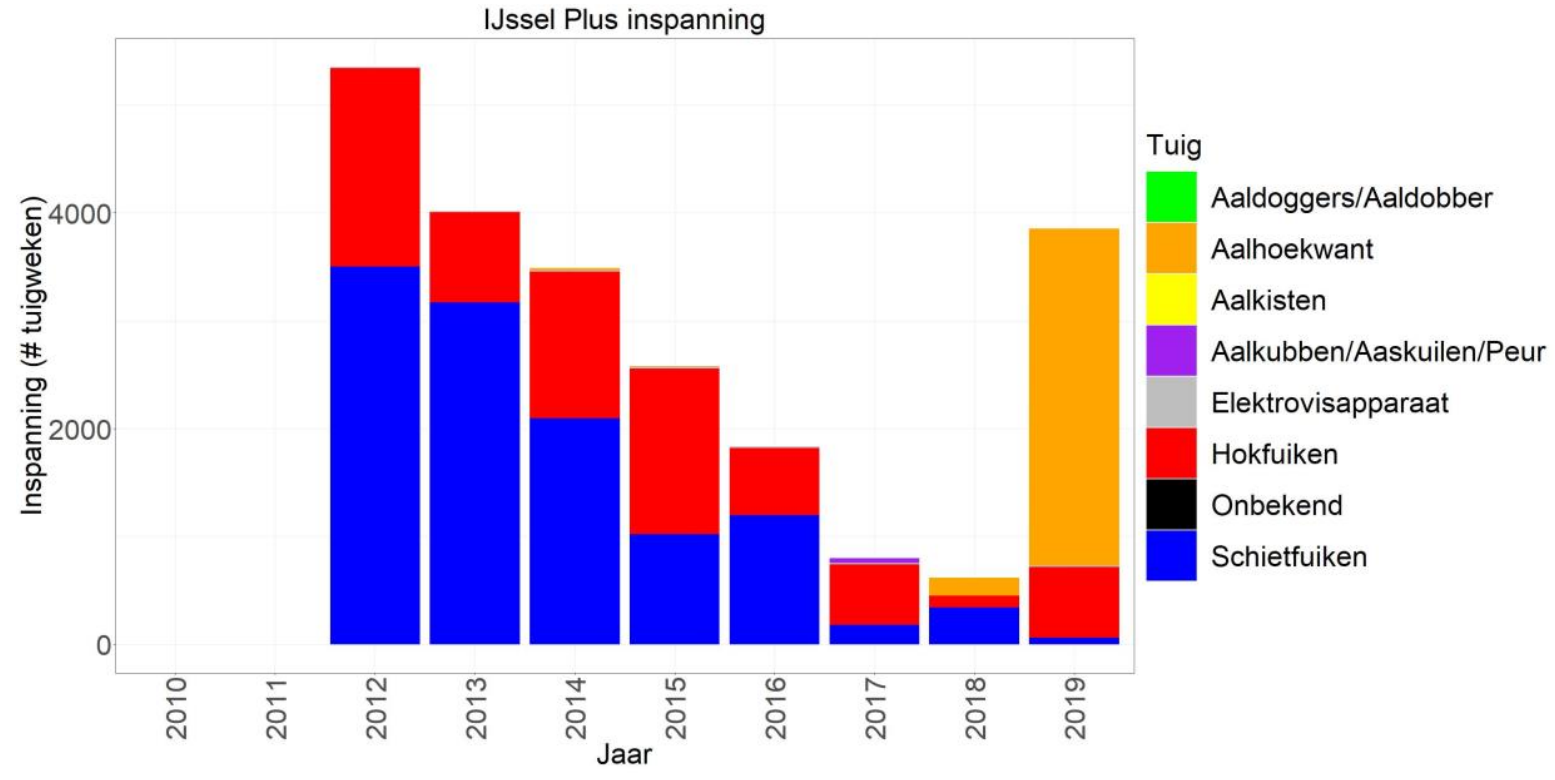

Figuur 2.31 Inspanning (aantal tuigweken) van de beroepsvisserij per tuig in de IJssel Plus. 


\subsection{Bovenloop Gelderse IJssel (IJssel)}

De bemonsteringslocaties over de periode 1997-2019 zijn weergegeven in Figuur 2.32.

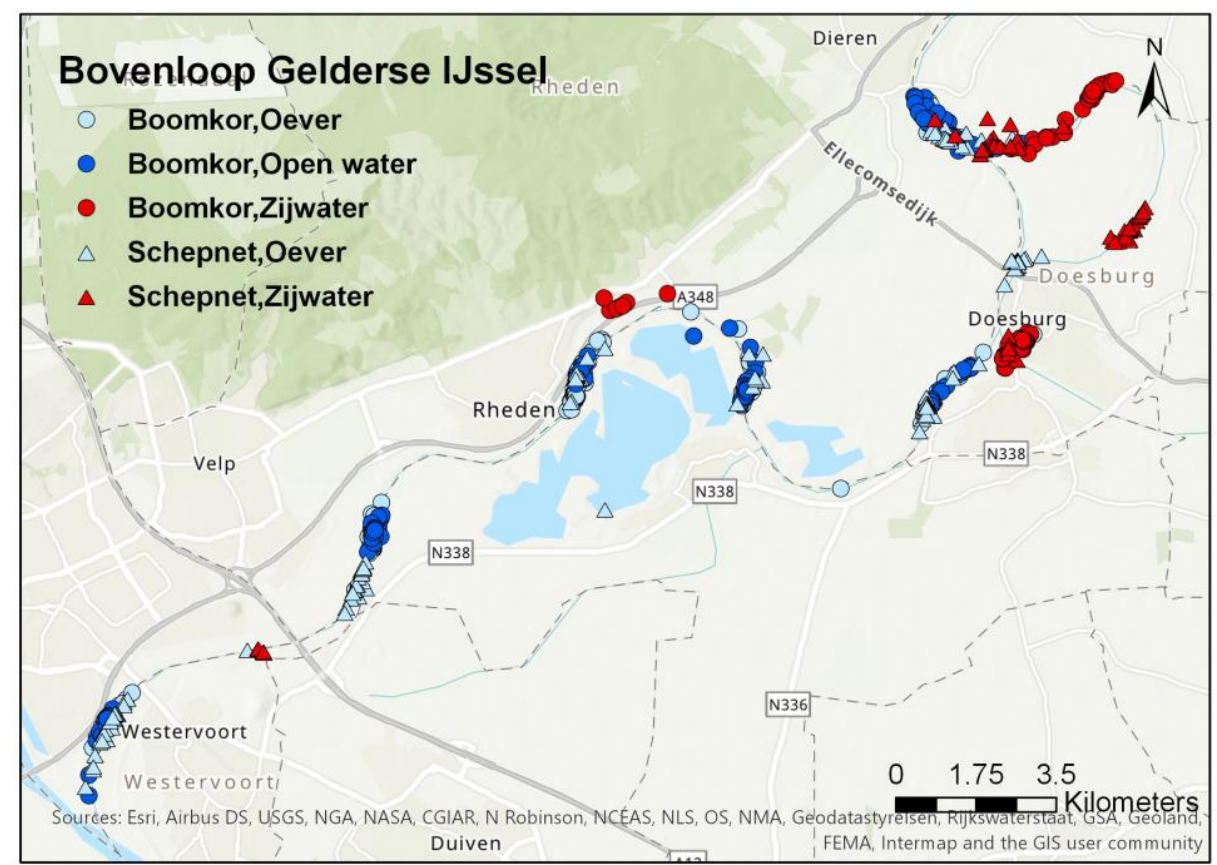

Figuur 2.32 Bemonsteringslocaties van de actieve monitoring in de Bovenloop Gelderse IJssel van 1997-2019 per tuig per habitat.

\subsubsection{Bovenloop Gelderse IJssel hoofdstroom (open water en oeverzone)}

De Bovenloop Gelderse IJssel wordt sinds 1997 ieder jaar in het voorjaar met de boomkor en het elektroschepnet bemonsterd. In de periode 1997-2007 werd dit gebied in maart en april bemonsterd, vanaf 2008 meestal alleen in maart (behalve in 2012, toen er weer in maart en april werd bemonsterd).

De tien meest algemene soorten in de hoofdstroom van de Bovenloop Gelderse IJssel voor de gehele periode 1997-2019 zijn zwartbekgrondel, pos, kolblei, brasem, winde, blankvoorn, barbeel, baars, snoekbaars en aal. Deze omvatten meer dan $95 \%$ van het totale gemiddelde aantal en biomassa voor zowel de vangsten met de boomkor als het schepnet (Bijlage 12).

In het open water en langs de oever (boomkor) zijn blankvoorn, brasem, winde en kolblei de dominante soorten, zowel qua aantal als qua biomassa (Figuur 2.33 boven). De laatste tien jaar zijn de hoeveelheden van deze soorten echter sterk afgenomen, met name kolblei en brasem worden steeds minder gevangen. Pos werd qua aantallen aan in de periode 2005-2009 relatief veel gevangen, dit komt overeen met de periode waarin er ook nog veel pos in het IJsselmeer werd gevangen. Verder valt op dat er regelmatig barbelen worden gevangen, alhoewel de vangsten hiervan sinds 2011 weer minder zijn (zie 3.2.2). Opvallend is dat de invasieve grondels in dit watersysteem relatief weinig worden gevangen met de boomkor, net als in de Benedenloop Gelderse IJssel. In 2019 is de winde de dominante soort in de vangsten.

Langs de oever (schepnet) is blankvoorn qua aantal de dominante soort (Figuur 2.33 onder). Ook worden er relatief veel windes en vanaf 2011 zwartbekgrondels gevangen, deze laatste nemen ook weer af vanaf 2015. Net als in het open water zijn de totale vangsten langs de oever qua aantallen de laatste jaren afgenomen. Qua biomassa zien we dat aal en winde voornamelijk de dominante soorten zijn in de vangsten. Aal is, op een opleving in 2017 na, wel afgenomen de afgelopen jaren. Voorheen leken blankvoorn en brasem qua biomassa ook tot de dominante soorten te horen. De overige soorten bestaan voornamelijk uit snoek.

De lengte-frequentieverdelingen per soort, per tuig voor de hoofdstroom en de zijwateren gecombineerd over alle jaren van de monitoring van de Benedenloop en Bovenloop Gelderse IJssel gecombineerd zijn hier te vinden: https://wmropendata.wur.nl/site/zoetwatervis/42/waterlichaam/ 


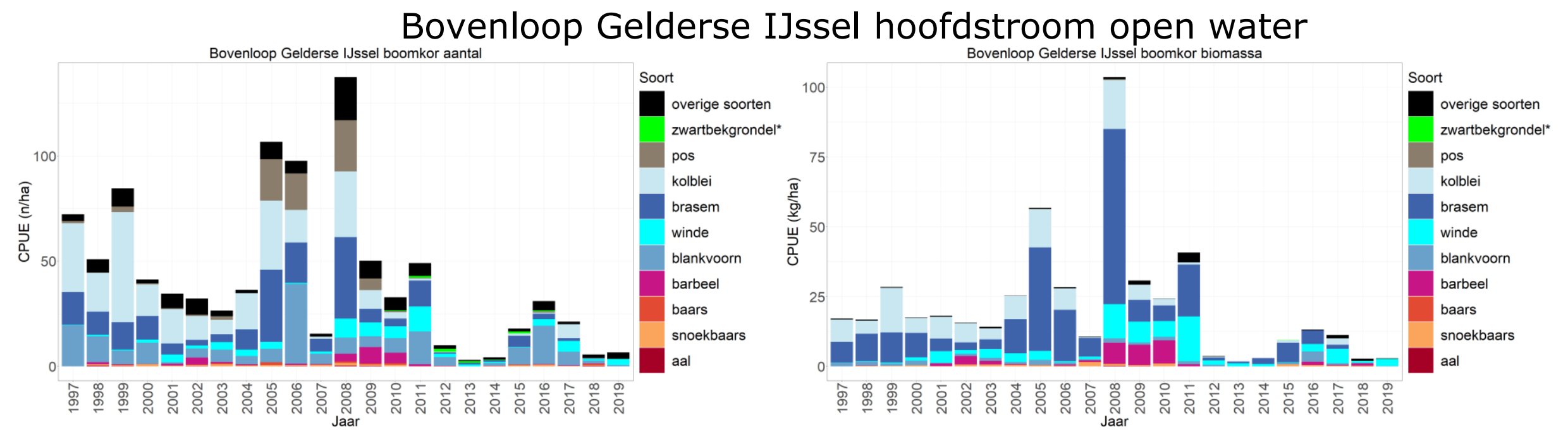

Bovenloop Gelderse IJssel hoofdstroom oever

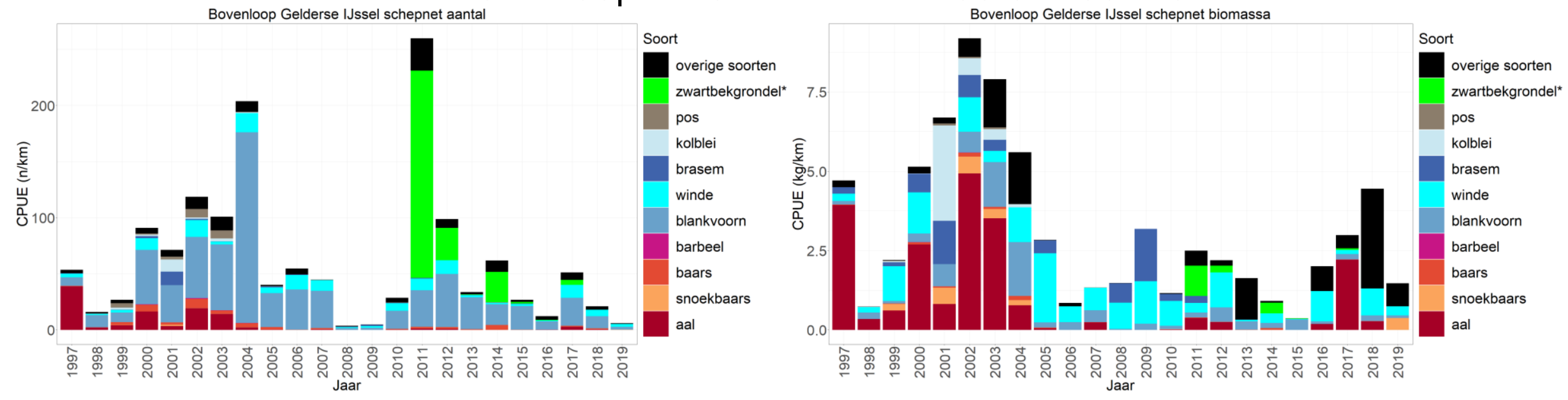

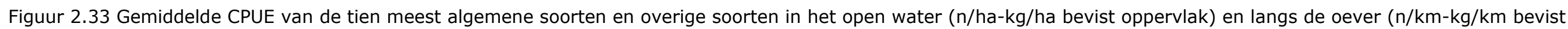

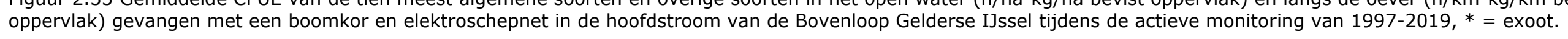




\subsubsection{Chinese wolhandkrab}

De Chinese wolhandkrab wordt een enkele keer gevangen in de hoofdstroom van de Bovenloop Gelderse IJssel (Figuur 2.34).

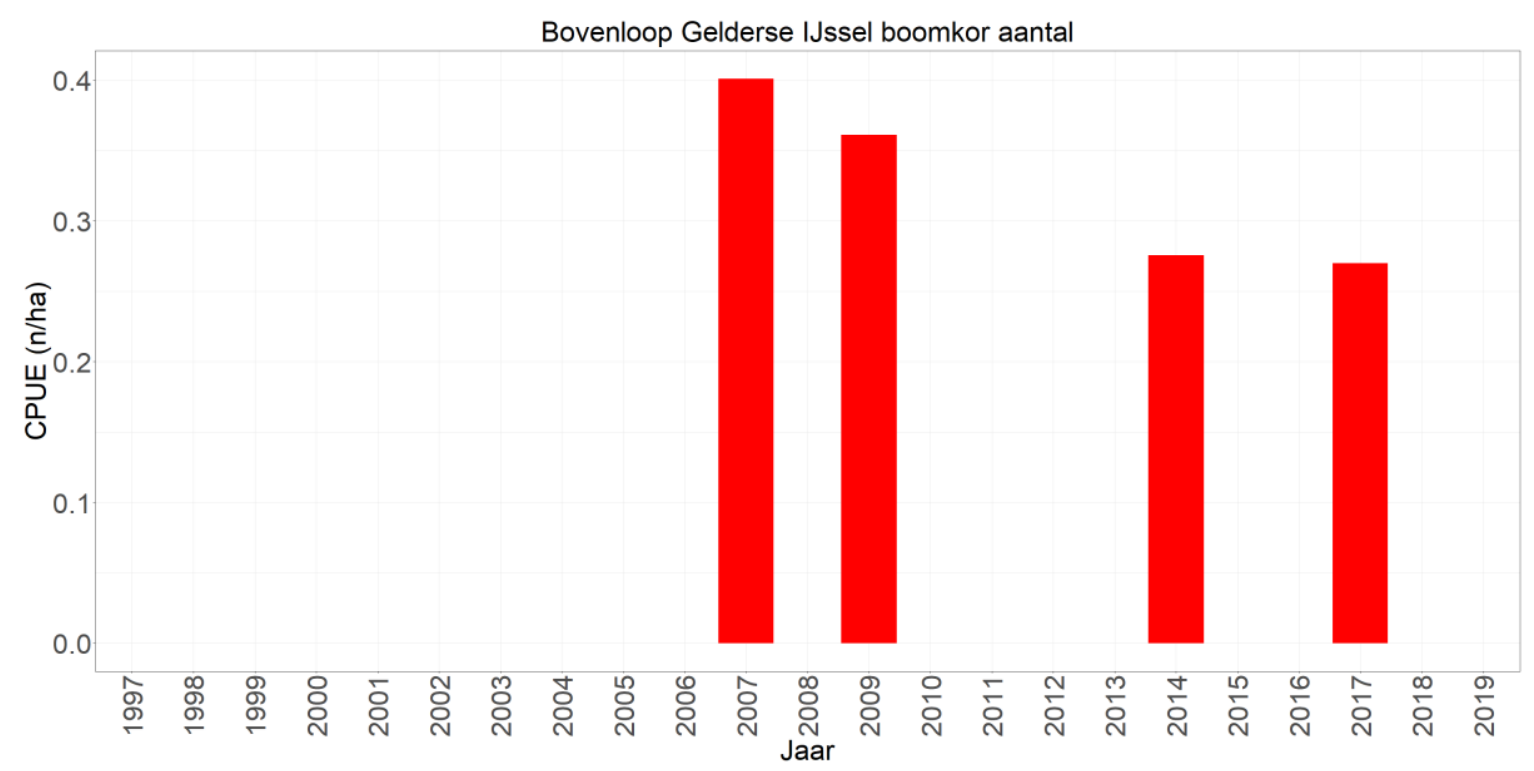

Figuur 2.34 Gemiddelde CPUE (n/ha bevist oppervlak) per jaar van de Chinese wolhandkrab in de hoofdstroom van het open water van de Bovenloop Gelderse IJssel gevangen met de boomkor. 


\subsubsection{Bovenloop Gelderse IJssel zijwateren}

Langs de Bovenloop Gelderse IJssel zijn een jachthaven, drie inhammen en een nevengeul bemonsterd in het open water met de boomkor en langs de oever met het schepnet. In 2019 is een van de stations over een langere lengte bevist waarbij de uitlaat van het Broekhuizerwater is meegenomen vanwege het geschikte habitat voor rheofielen (stroomminnende soorten). Deze zijn hier dan ook aangetroffen (o.a. winde, serpeling en kopvoorn).

De tien meest algemene soorten in deze zijwateren voor de gehele periode 1997-2019 zijn pos, snoek, kolblei, brasem, winde, blankvoorn, baars, snoekbaars aal en de zwartbekgrondel. Deze omvatten meer dan $97 \%$ van het totale gemiddelde aantal en biomassa voor zowel de vangsten met de boomkor als het schepnet (Bijlage 13). De zwartbekgrondel is dit jaar nieuw in de top tien van de meest algemene soorten van de zijwateren, deze vervangt de hybride cyprinide (kruising tussen bijvoorbeeld blankvoorn en brasem). De dichtheden van vis in de zijwateren van de Bovenloop Gelderse IJssel lijken beduidend hoger te zijn dan in de hoofdstroom.

Opvallend is dat de barbeel ontbreekt in de top tien van de zijwateren, terwijl deze wel tot de top tien behoort in het open water en langs de oever van de hoofdstroom van de Bovenloop Gelderse IJssel. Zijn plaats in de top tien is ingenomen door snoek.

Net als in het open water van de hoofdstroom zijn brasem, blankvoorn en kolblei de dominante soorten in de boomkorvangsten, zowel qua aantal als qua biomassa (Figuur 2.35 boven). Net als in de hoofdstroom, nemen deze soorten de laatste jaren af. In 2017 en 2018 is echter wel weer een piek in aantallen van blankvoorn te zien, hetzelfde geldt in 2018 voor de biomassa van blankvoorn en brasem. Daarnaast is er ook een wat hogere biomassa van brasem in 2019 zichtbaar, welke voor een groot deel in de haven van Doesburg gevangen zijn (Niemeijer \& Wullink 2019). Pos en snoekbaars werden in het verleden vrij veel gevangen maar de vangsten daarvan zijn de laatste jaren ook afgenomen. Snoekbaars lijkt overigens meer in de zijwateren voor te komen dan in de hoofdstroom. Opvallend is de toename van kleine baarzen in 2018 en 2019. Het valt op dat er veel hogere aantallen worden gevangen in de zijwateren ten opzichte van de hoofdstroom.

In de oeverzone van de zijwateren (schepnet) is blankvoorn qua aantal de dominante soort, samen met snoek, snoekbaars en aal qua biomassa (Figuur 2.35 onder). Ook langs de oever zien we een afname van de meeste algemene soorten, met name van blankvoorn en aal. De vangsten van snoekbaars, snoek en baars fluctueren sterk qua biomassa. Dit komt waarschijnlijk doordat het vangen van (enkele) grote exemplaren een grote invloed heeft op de vangst. 


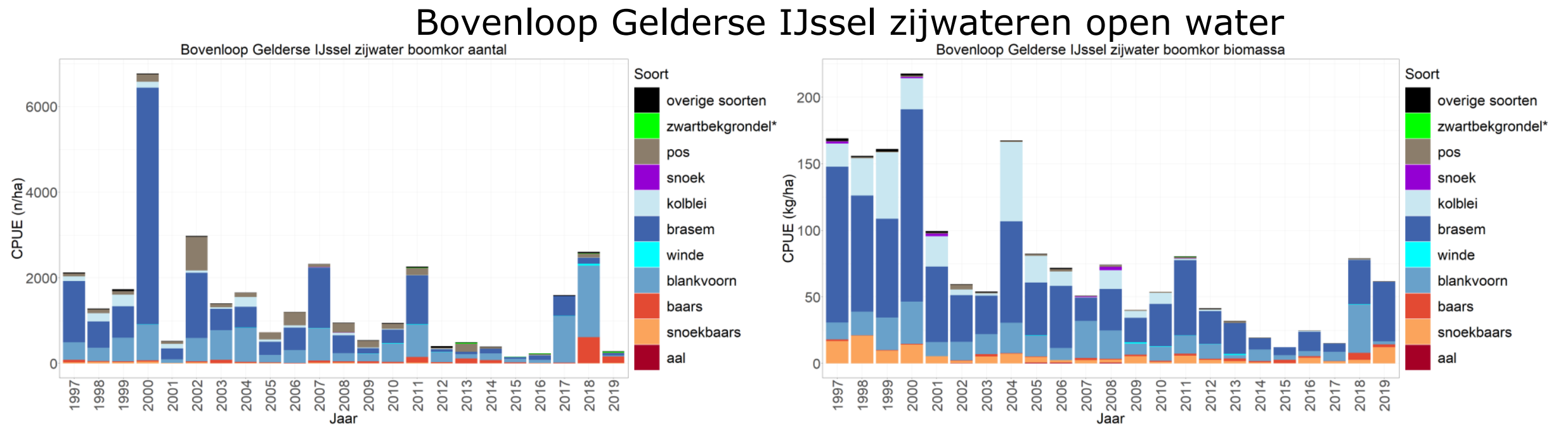

Bovenloop Gelderse IJssel zijwateren oever

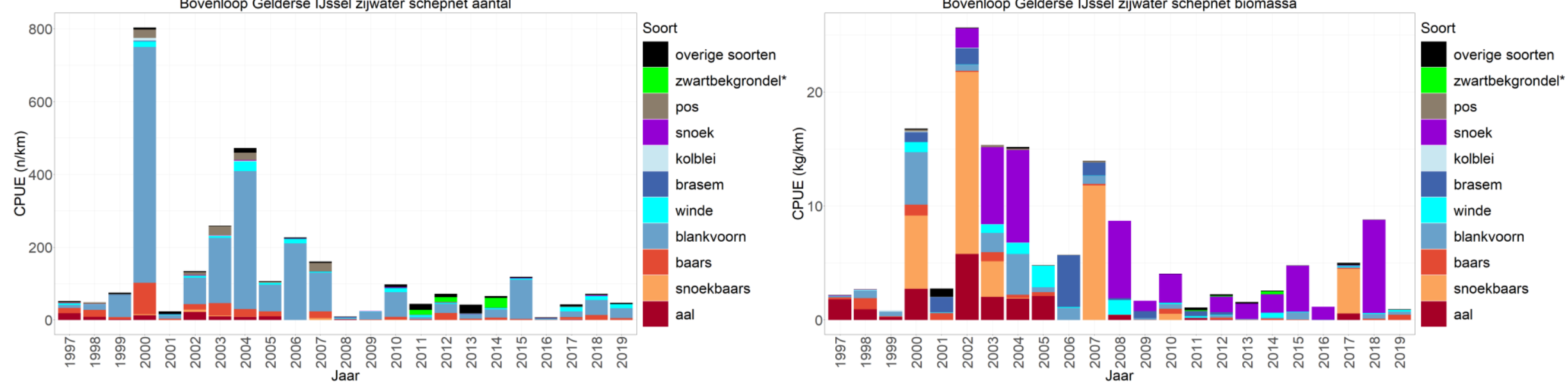

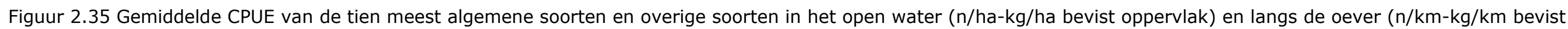
oppervlak) gevangen met een boomkor en elektroschepnet in de zijwateren van de Bovenloop Gelderse IJssel tijdens de actieve monitoring van $1997-2019$. 


\subsubsection{Chinese wolhandkrab}

De Chinese wolhandkrab werd van 2002 tot 2006 met enige regelmaat gevangen in de zijwateren van de Bovenloop Gelderse IJssel (Figuur 2.34).

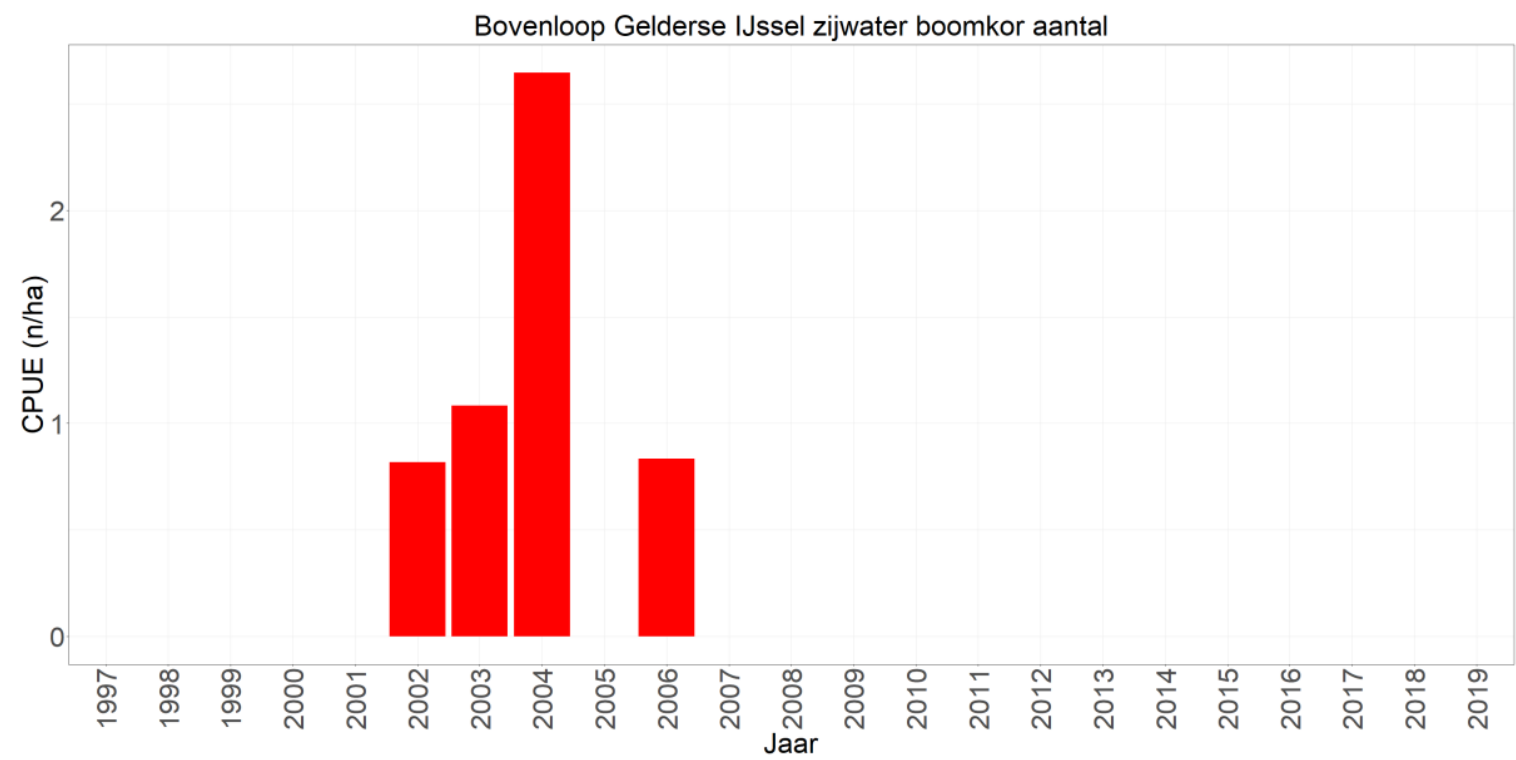

Figuur 2.36 Gemiddelde CPUE ( $\mathrm{n} / \mathrm{ha}$ bevist oppervlak) per jaar van de Chinese wolhandkrab in de zijwateren van de Bovenloop Gelderse IJssel gevangen met de boomkor.

\subsubsection{Aalvangsten}

Voor de aanlandingen van KRW-lichamen Bovenloop Nederrijn, Benedenloop Nederrijn en Bovenloop Gelderse IJssel zijn de gegevens van de "Nederrijn Plus i. o." gebruikt (Bijlage 2). In 2011 is het verbod op aalvisserij in de grote rivieren ingegaan in verband met te hoge dioxine- en PCB-gehaltes in aal, waardoor er alleen aanlandingen uit 2010 zijn. In dit jaar is er 15.342 kilo aan aal aangeland (Bijlage 2). 


\subsection{Rijn (Boven Rijn, Waal)}

De bemonsteringslocaties over de periode 1997-2019 zijn weergegeven in Figuur 2.37.

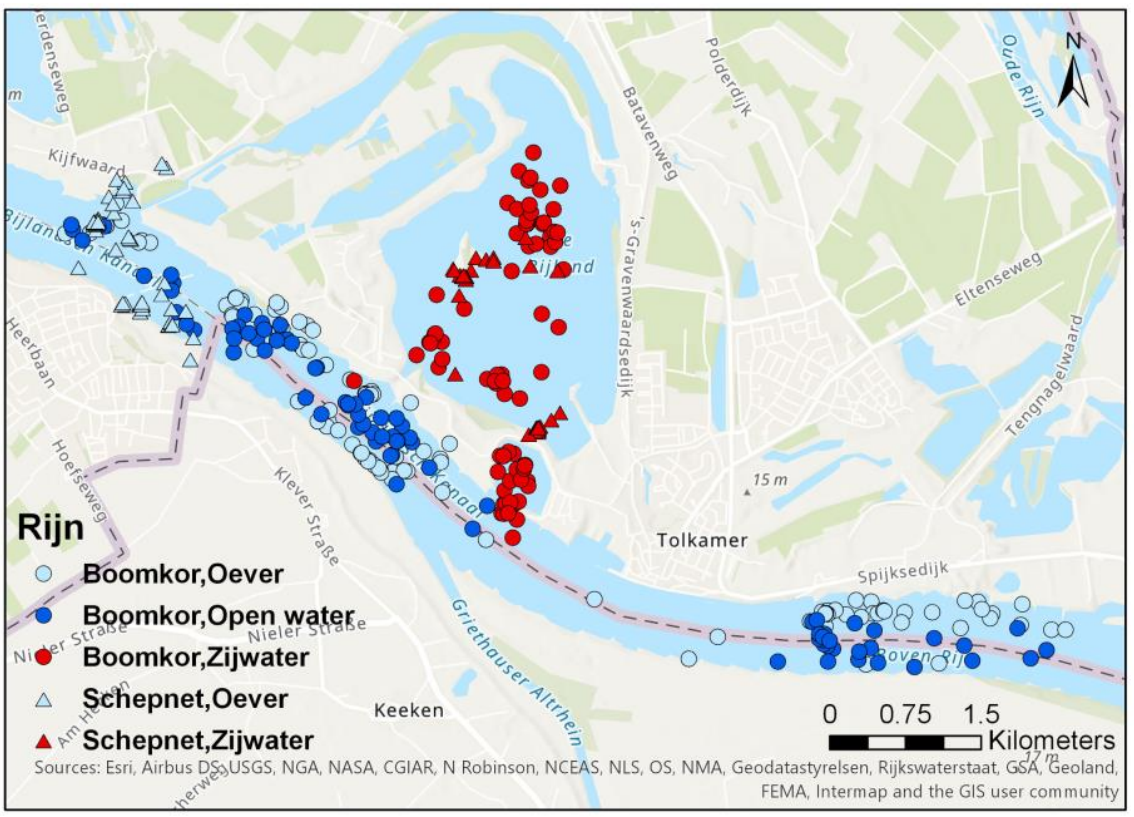

Figuur 2.37 Bemonsteringslocaties van de actieve monitoring in de Rijn van 1997-2019 per tuig per habitat.

\subsubsection{Rijn hoofdstroom (open water en oeverzone)}

De Rijn wordt sinds 1997 ieder jaar in het voorjaar met de boomkor en het elektroschepnet bemonsterd. In de periode 1997-2007 werd dit gebied in maart en april bemonsterd, vanaf 2008 meestal alleen in maart (behalve in 2010-2012, toen er weer in maart en april werd bemonsterd).

De tien meest algemene soorten in de hoofdstroom van de Rijn voor de gehele periode 1997-2019 zijn zwartbekgrondel, pos, snoekbaars, roofblei, kolblei, brasem, winde, blankvoorn, alver en aal. Deze omvatten meer dan $94 \%$ van het totale gemiddelde aantal en biomassa voor zowel de vangsten met de boomkor als het schepnet (Bijlage 14).

In het open water en langs de oever (boomkor) waren blankvoorn, brasem en kolblei de dominante soorten, zowel qua aantal als qua biomassa (Figuur 2.38 boven). Sinds 2012 zijn de hoeveelheden van deze soorten sterk afgenomen, alhoewel er in 2017 vrij veel jonge, kleine blankvoorn en brasem werd gevangen. Dit is voor blankvoorn ook het geval in 2019. Vanaf 2000 worden er regelmatig windes gevangen en dit lijkt de enige soort te zijn die redelijk stabiel is door de tijd heen. Pos werd tot 2009 nog regelmatig gevangen, daarna in geringe mate. Vanaf 2010 wordt de invasieve zwartbekgrondel regelmatig gevangen. Dit is ook het geval in de eerstvolgende stroomafwaartse vertakkingen van de Rijn (Bovenlopen van de Waal, Nederrijn en IJssel). De zwartbekgrondel wordt in meer stroomafwaartse aftakkingen van de Rijn pas later in groten getale aangetroffen (behalve de Getijden Lek). Dit is een indicatie dat de zwartbekgrondel onder andere vanuit de Donau, via het in 1992 geopende Main-Donau kanaal en de Duitse Rijn Nederland is binnengetrokken (van Kessel et al. 2014). In sommige wateren relatief dichtbij de kust is de zwartbekgrondel echter in 2010, en soms al eerder, in grote getalen aangetroffen (Volkerak, Noordzeekanaal, Hollandsch Diep, Oude Maas, Nieuwe Merwede). Dit is een indicatie dat de zwartbekgrondel al eerder via ballastwater vanuit de Ponto-Kaspische regio of Noord-Amerika Nederland heeft bereikt (Mombaerts et al. 2014). De toename van de zwartbekgrondel zou de bijna algehele verdwijning van pos kunnen verklaren (middels competitie voor voedsel/leefgebied). Wat overigens ook opvalt is dat baars niet tot de tien meest algemene soorten behoort, net als in de Bovenloop Waal (Figuur 2.61).

Langs de oever (schepnet) zijn blankvoorn, winde, brasem en aal qua aantal en biomassa de dominante soorten (Figuur 2.38 onder). Sinds 2011 worden er ook veel zwartbekgrondels gevangen, alhoewel hoeveelheden vanaf 2015 weer een stuk lager zijn. In tegenstelling tot het open water zijn 
de vangsten langs de oever de laatste jaren relatief hoog gebleven. Er geldt voor alle soorten dat er een zeer sterke fluctuatie is in gevangen aantallen en biomassa tussen de jaren. Wat opvalt is dat de roofblei (exoot) vanaf 2012 nauwelijks nog wordt gevangen, net als snoekbaars vanaf 2009. De overige soorten in 2018 bestaan voornamelijk uit snoek. Ook langs de oever zien we in 2019 een toename van blankvoorn, net als in het open water.

De lengte-frequentieverdelingen per soort, per tuig voor de hoofdstroom en de zijwateren gecombineerd over alle jaren van de monitoring van de Rijn, Bovenloop en Benedenloop Waal gecombineerd zijn hier te vinden: https://wmropendata.wur.nl/site/zoetwatervis/34/waterlichaam/ 

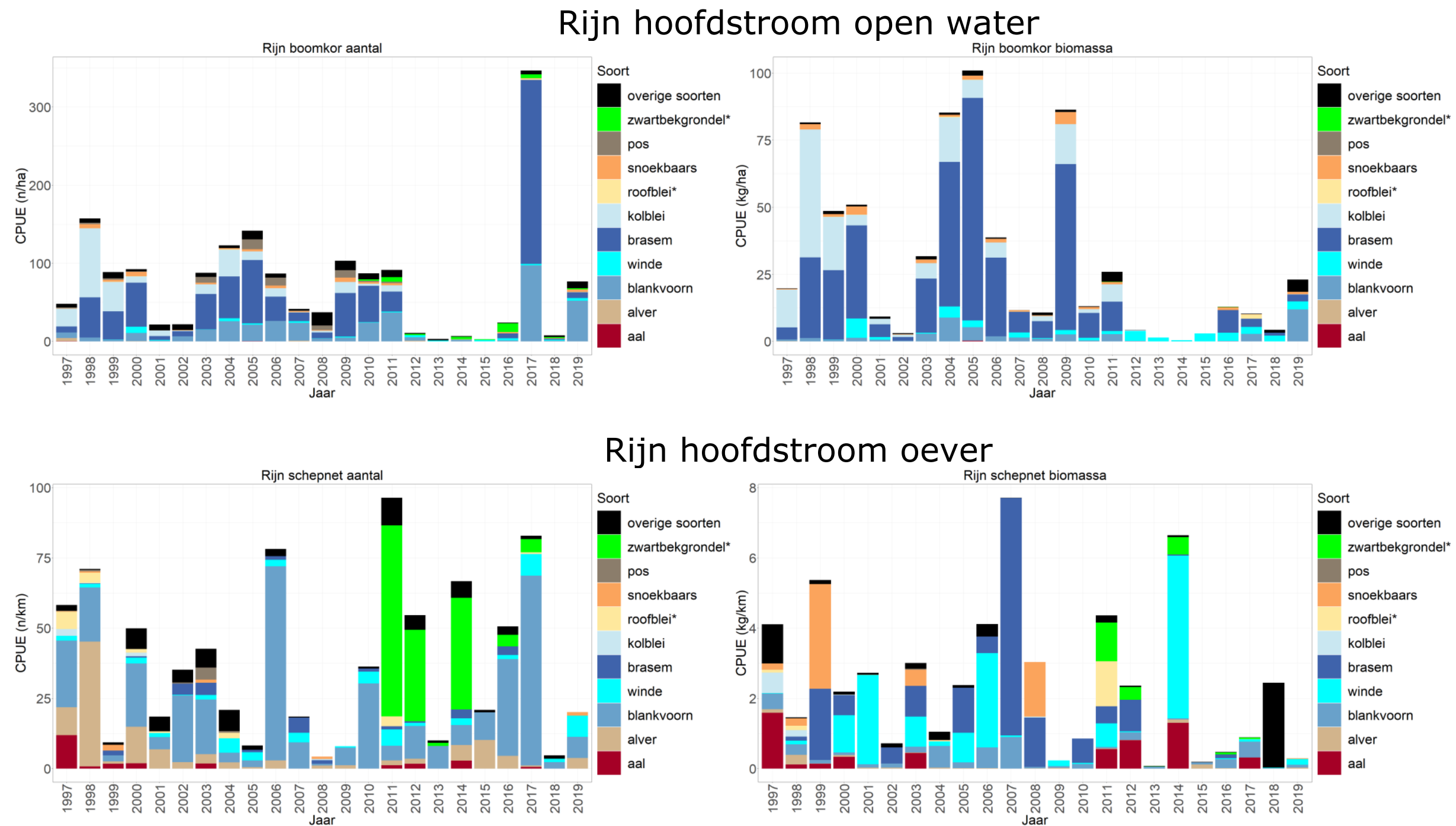

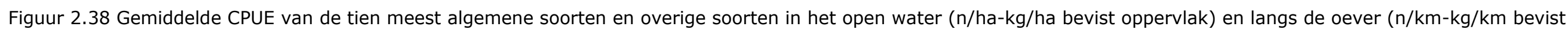
oppervlak) gevangen met een boomkor en elektroschepnet in de hoofdstroom van de Rijn tijdens de actieve monitoring van 1997-2019, * = exoot. 


\subsubsection{Chinese wolhandkrab}

De Chinese wolhandkrab wordt regelmatig gevangen in de hoofdstroom van de Rijn. Vanaf 2002 is er een duidelijke toename tot 2007, vanaf dat jaar dalen de aantallen weer en deze lijken vanaf 2017 relatief stabiel te zijn. Het is opvallend dat er in de jaren 2013-2016 geen wolhandkrabben gevangen zijn (Figuur 2.39).

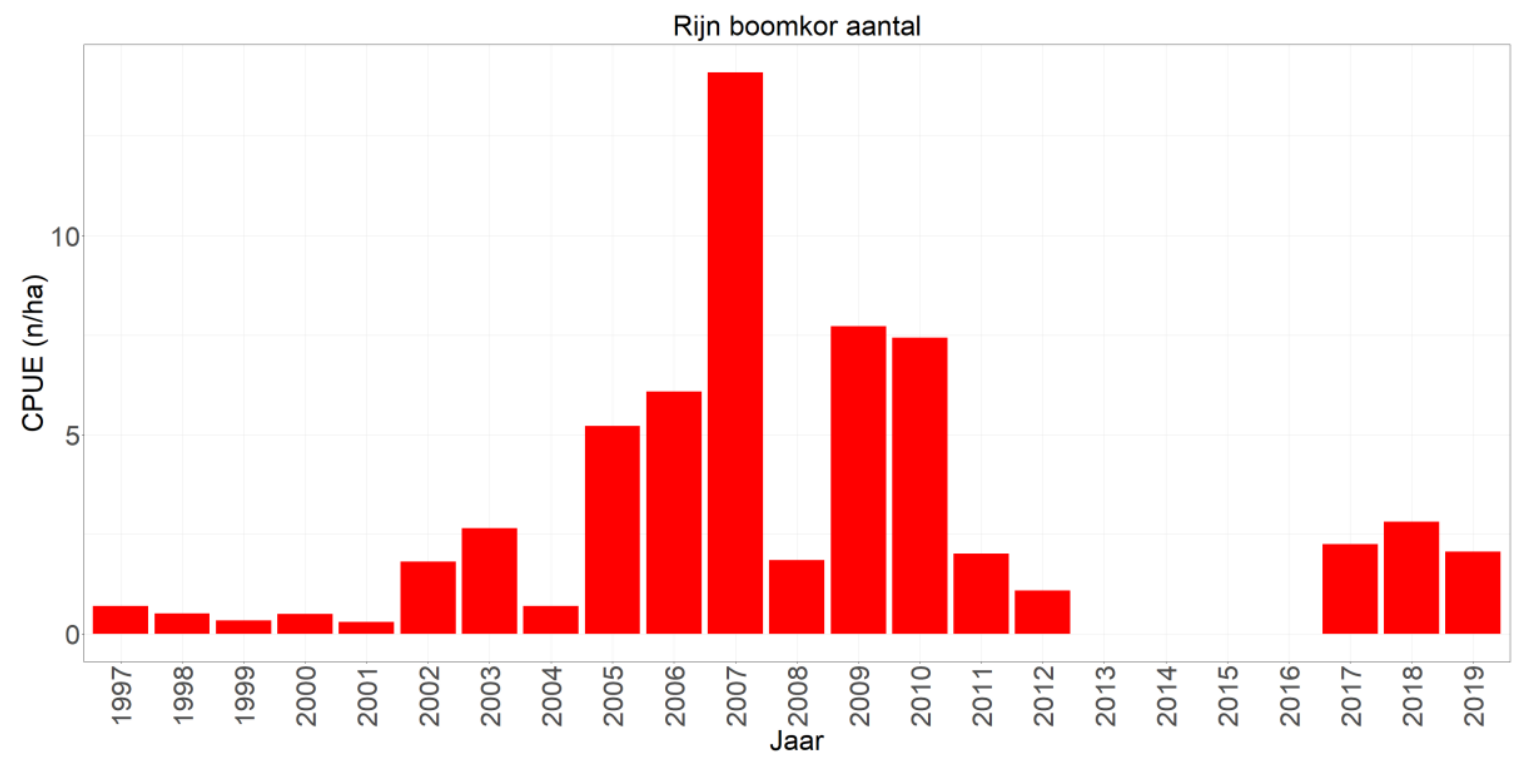

Figuur 2.39 Gemiddelde CPUE (n/ha bevist oppervlak) per jaar van de Chinese wolhandkrab in de hoofdstroom van het open water van de Rijn gevangen met de boomkor. 


\subsubsection{Rijn zijwateren}

Langs de Rijn zijn een vluchthaven en een recreatieplas bemonsterd, in het open water met de boomkor en langs de oever met het schepnet.

De tien meest algemene soorten in deze zijwateren voor de gehele periode 1997-2019 zijn zwartbekgrondel, pos, snoek, kolblei, brasem, winde, blankvoorn, baars, snoekbaars en aal. Deze omvatten meer dan $95 \%$ van het totale gemiddelde aantal en biomassa, voor zowel de vangsten met de boomkor als het schepnet (Bijlage 15). Qua aantallen lijkt de dichtheid in de zijwateren hoger maar qua biomassa lijkt de dichtheid in de hoofdstroom juist het hoogst (voor de tien meest algemene soorten).

Het valt op dat er qua biomassa relatief veel snoekbaars wordt gevangen in vergelijking met de hoofdstroom. Opvallend is ook dat de alver en roofblei ontbreken in de top tien van de zijwateren, terwijl deze wel tot de top tien behoren in het open water en bij de oever van de hoofdstroom van de Rijn. Hun plaats in de top tien is ingenomen door snoek en baars.

Net als in de hoofdstroom behoren brasem en blankvoorn tot de dominante soorten in de boomkorvangsten, zowel qua aantal als qua biomassa (Figuur 2.40 boven). Qua biomassa komt daar in de zijwateren snoekbaars nog bij. Daarnaast wordt er relatief veel pos en beduidend minder kolblei gevangen in de zijwateren. Snoekbaars lijkt dus in hogere dichtheden in de zijwateren voor te komen dan in de hoofdstroom, net als in de Bovenloop van de Gelderse IJssel. Overigens lijkt er de laatste drie jaar, na een dip in 2012-2016, weer een flinke toename van snoekbaars te zijn. Sinds het begin van de monitoring lijken de totale hoeveelheid vis qua biomassa en aantal af te nemen in deze zijwateren, waarbij er vanaf 2012 zeer lage hoeveelheden worden gevangen. In 2019 liggen voornamelijk de biomassavangsten echter weer wat hoger. In 2019 is ook de blauwneus voor het eerst gevangen in het open water van de zijwateren van de Rijn, deze soort werd al eerder in de hoofdstroom gevangen.

In de oeverzone van de zijwateren (schepnet) was blankvoorn qua aantal de dominante soort, samen met snoekbaars qua biomassa (Figuur 2.40 onder). Ook in de schepnetvangsten zien we een afname van de meeste algemene soorten, met name blankvoorn en snoekbaars. Daarnaast zien we dat vanaf 2011 de zwartbekgrondel regelmatig wordt gevangen maar dat hoeveelheden vanaf 2016 weer gedaald zijn. In 2019 is er relatief veel baars gevangen langs de oevers. 


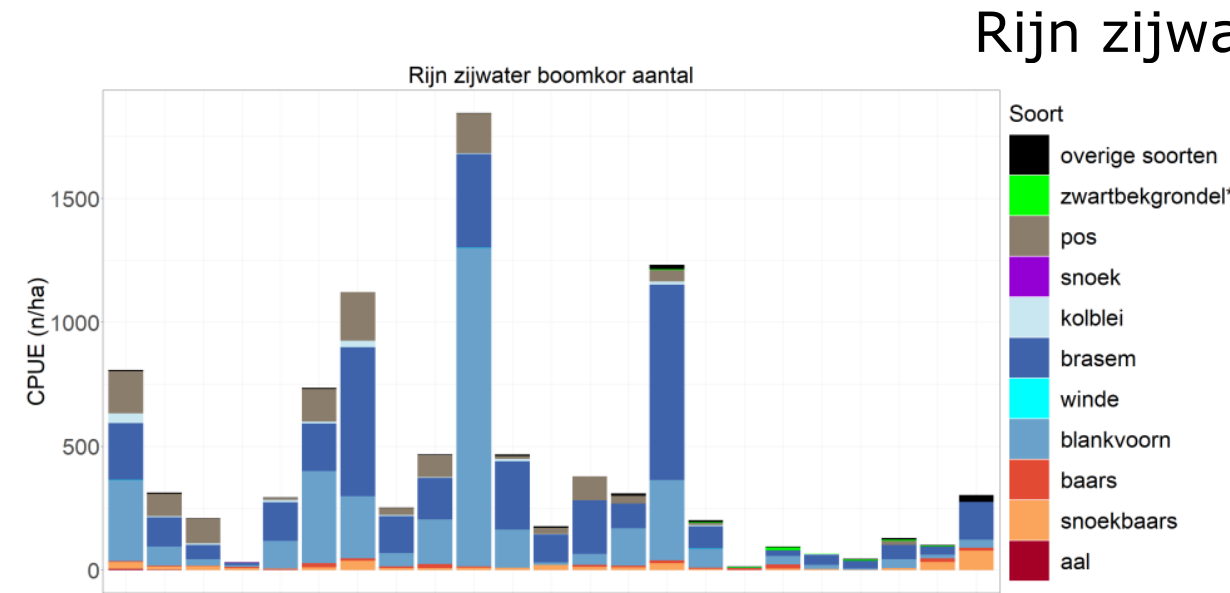

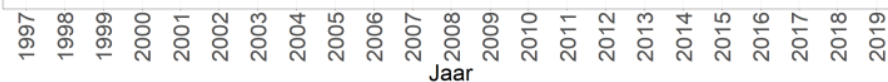

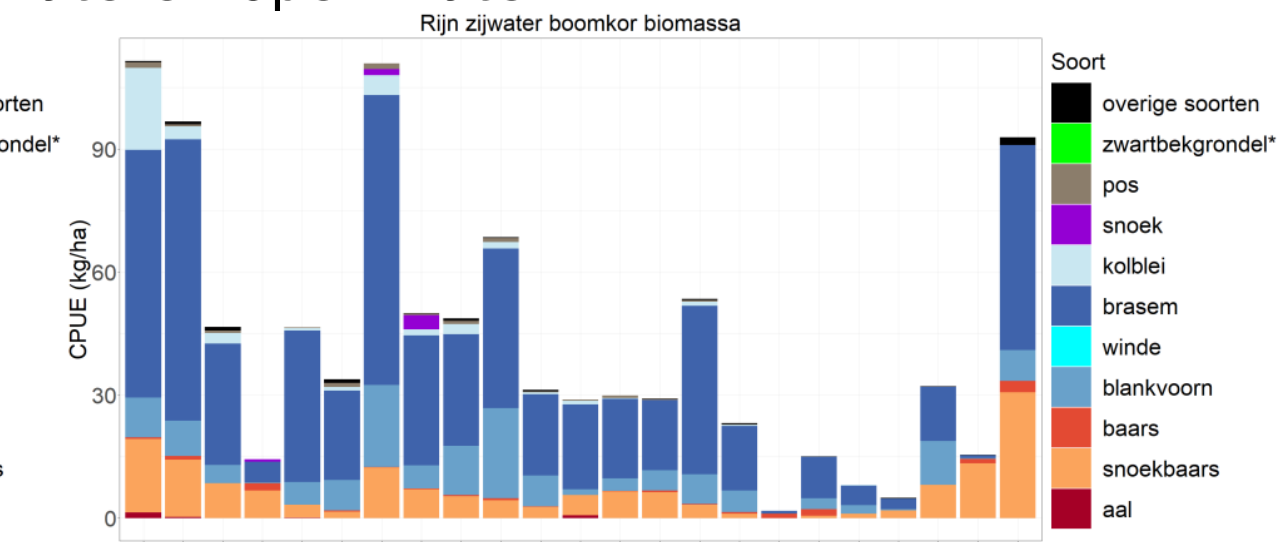

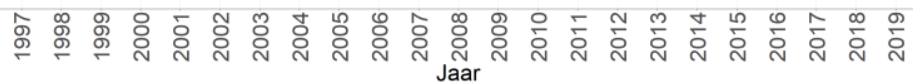

\section{Rijn zijwateren oever}

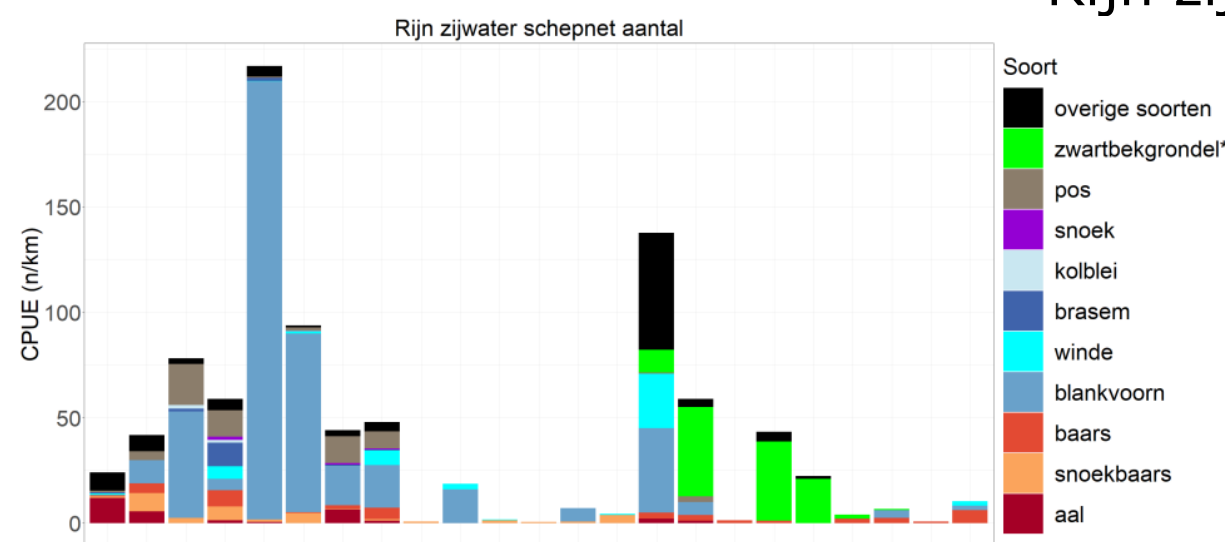

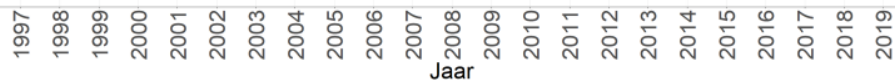

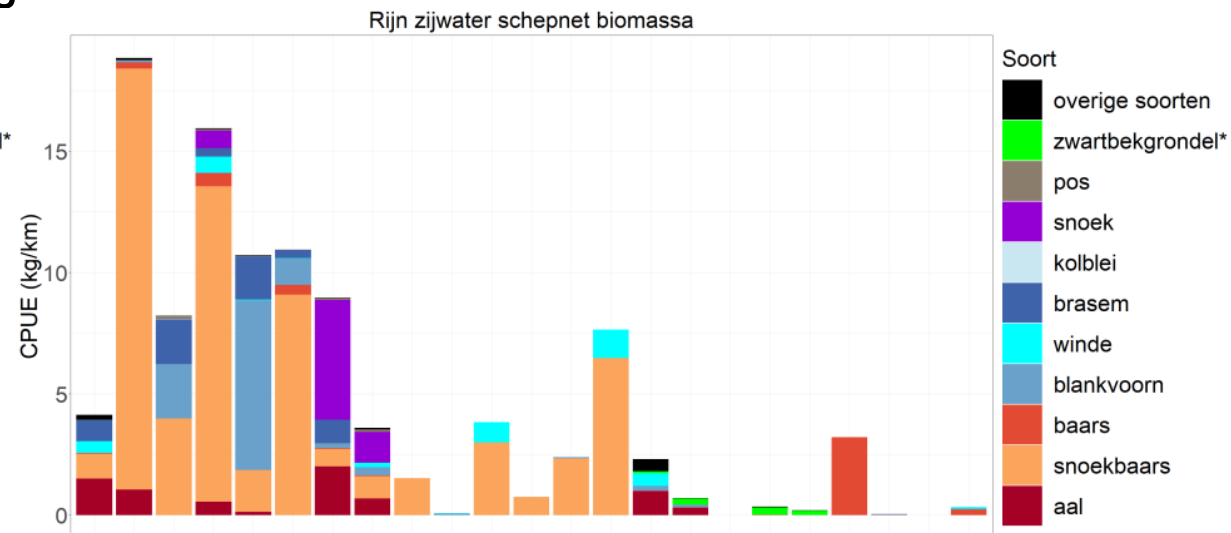

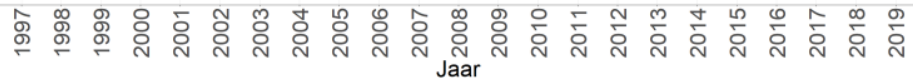

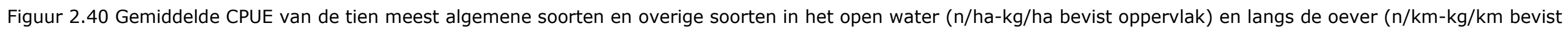
oppervlak) gevangen met een boomkor en elektroschepnet in de zijwateren van de Rijn tijdens de actieve monitoring van 1997-2019, * = exoot. 


\subsubsection{Chinese wolhandkrab}

Net als in de hoofdstroom wordt de Chinese wolhandkrab regelmatig gevangen in de zijwateren van de Rijn. Deze vangsten lijken alleen veel sterker te fluctueren (regelmatig jaren zonder wolhandkrabben) zonder een duidelijke trend. In 2018 en 2019 zijn relatief veel wolhandkrabben gevangen in de zijwateren (Figuur 2.41).

Rijn zijwater boomkor aantal

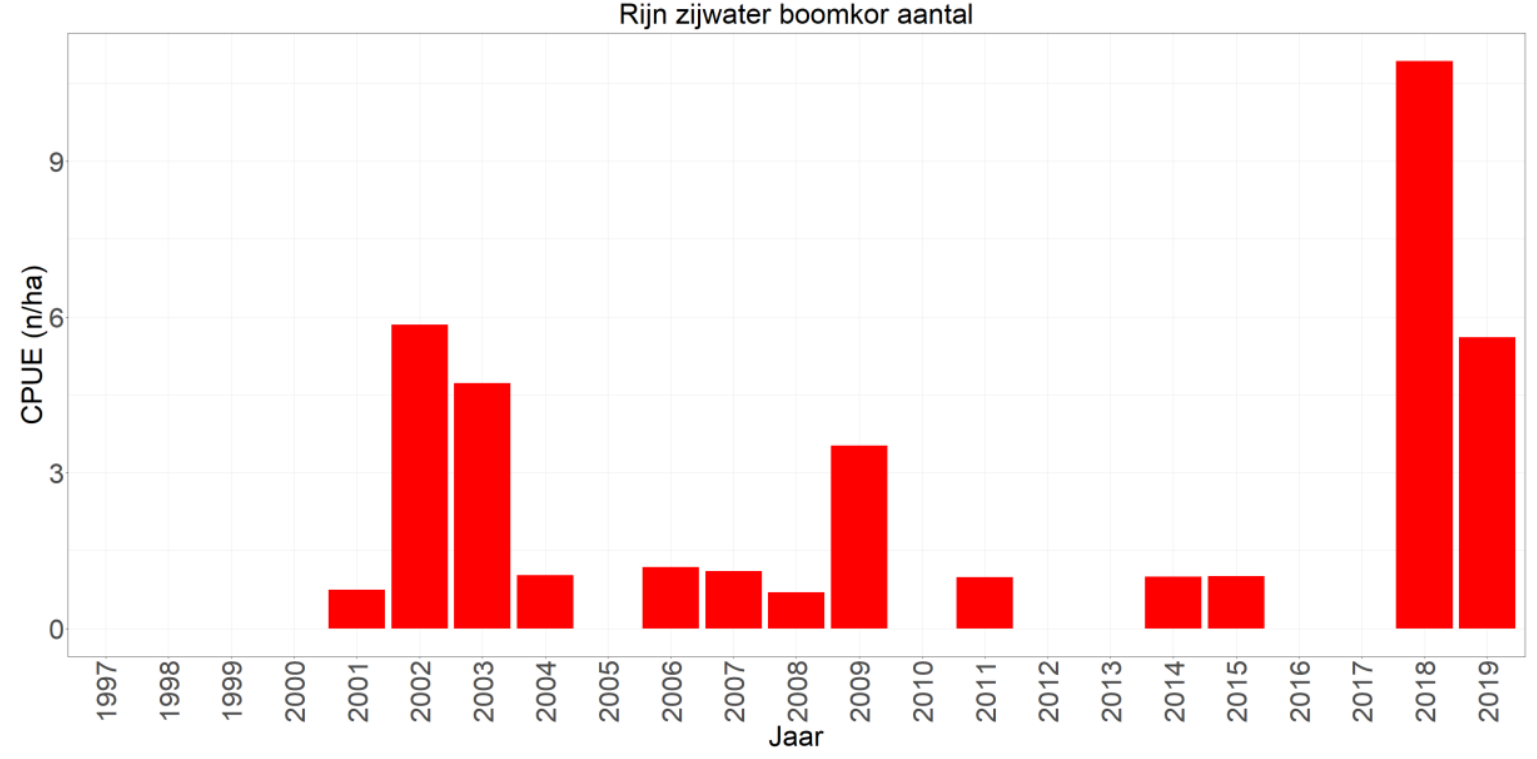

Figuur 2.41 Gemiddelde CPUE (n/ha bevist oppervlak) per jaar van de Chinese wolhandkrab in de hoofdstroom van het open water van de Rijn gevangen met de boomkor. 


\subsubsection{Aalvangsten}

Voor de aanlandingen van KRW-lichamen Benedenloop Waal, Bovenloop Waal en Rijn zijn de gegevens van de "Waal Plus" gebruikt (Bijlage 2). In 2011 dalen de aanlandingen (nagenoeg) naar 0 als gevolg van het verbod op aalvisserij in de grote rivieren. (Figuur 2.42). Desondanks zijn er in 2014, 2018 en 2019 kleine hoeveelheden aal aangeland met een lage inspanning (Figuur 2.43), die gevangen zijn met het elektrovisapparaat en/of hokfuiken. Dit is toegestaan vanwege de "heerlijke visrechten" die 1 visser hier bezit.

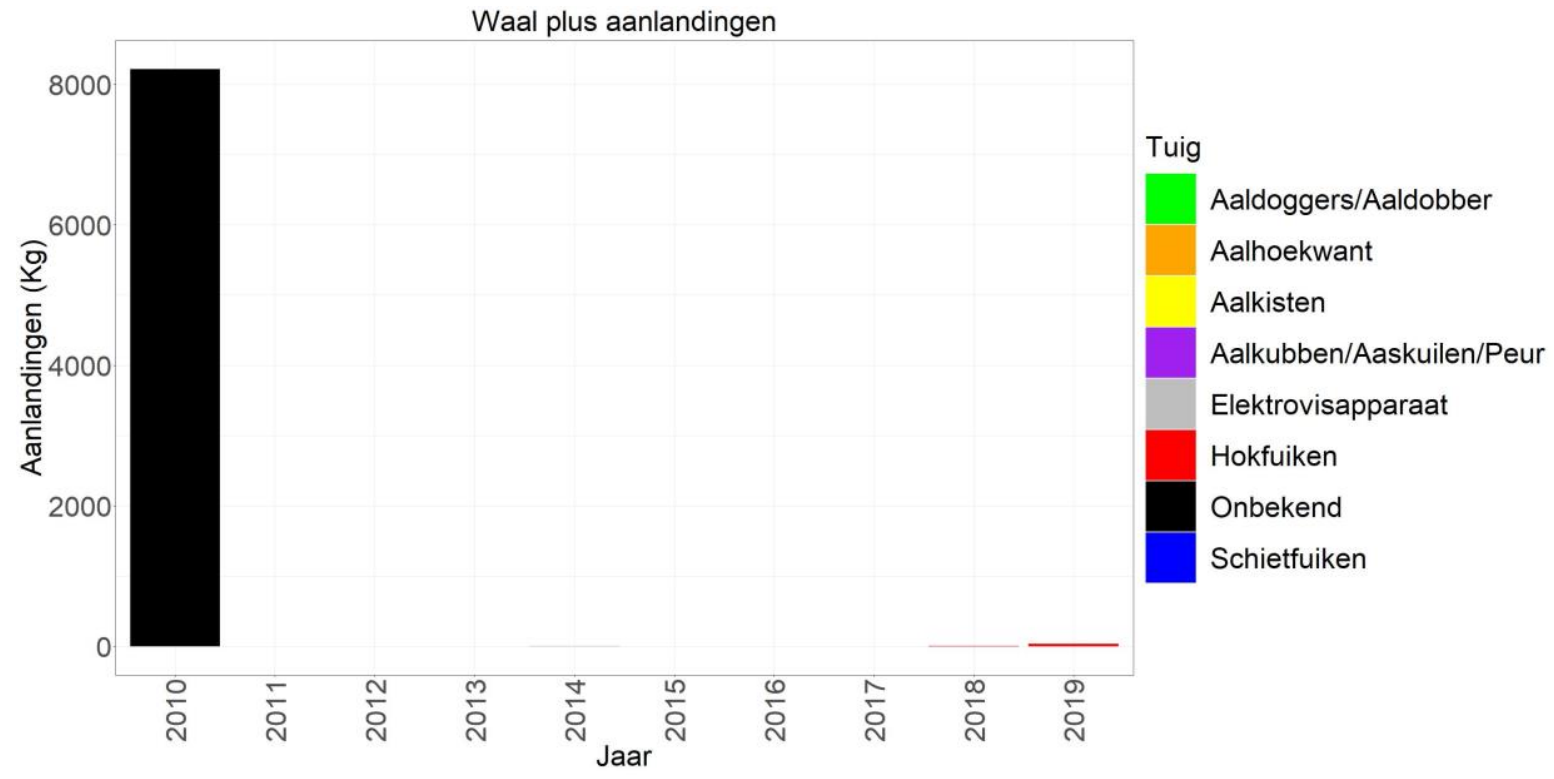

Figuur 2.42 Aanlandingen ( $\mathrm{kg}$ ) van de beroepsvisserij per tuig in de Waal Plus (Benedenloop Waal, Bovenloop Waal en Rijn). Sinds 2012 zijn aalvissers verplicht de inspanning van het vistuig op te geven aan het ministerie van LNV.

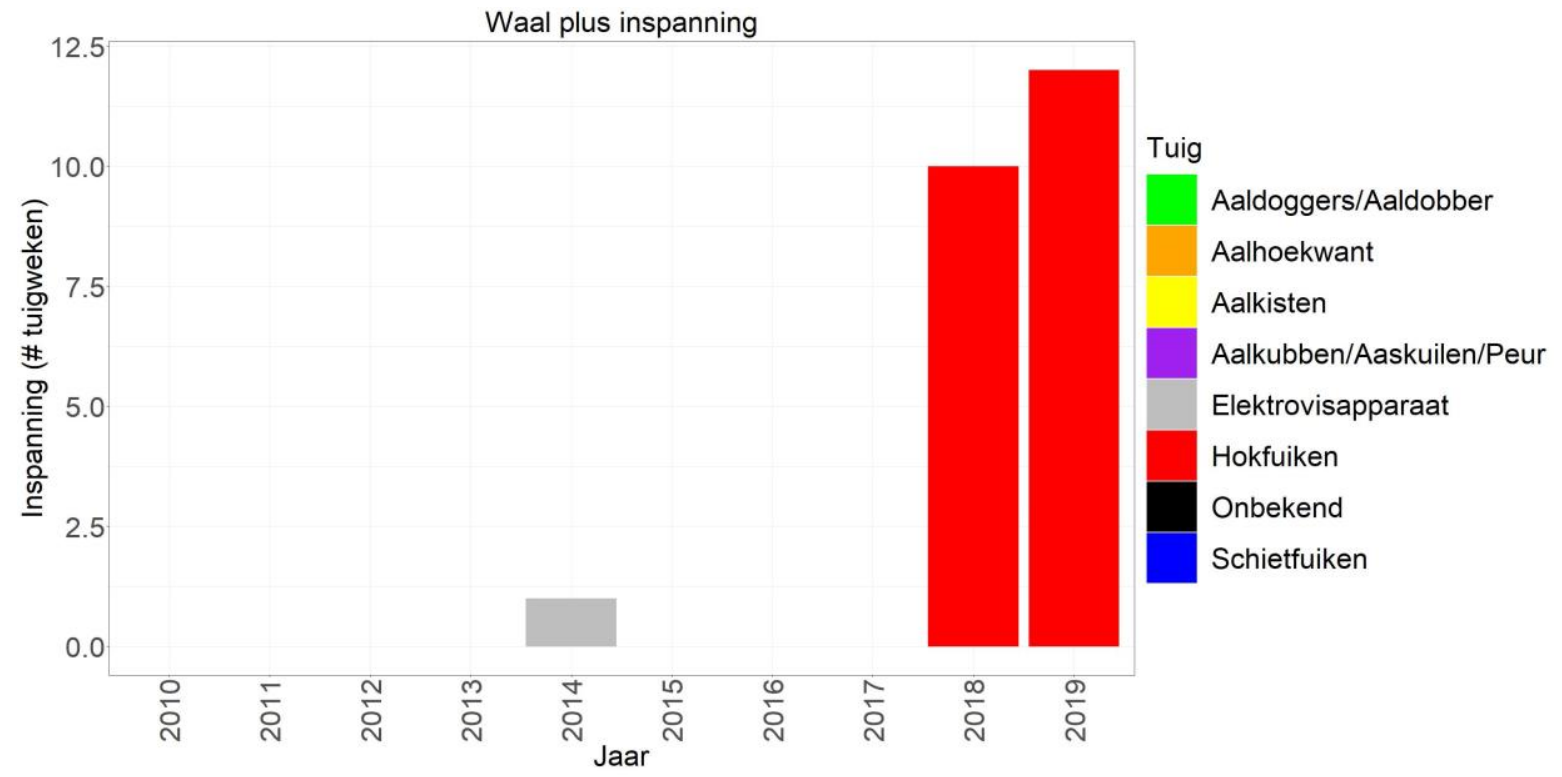

Figuur 2.43 Inspanning (aantal tuigweken) van de beroepsvisserij per tuig in de Waal Plus. 


\section{$2.8 \quad$ Grensmaas}

De bemonsteringslocaties over de periode 1997-2019 zijn weergegeven in Figuur 2.44.

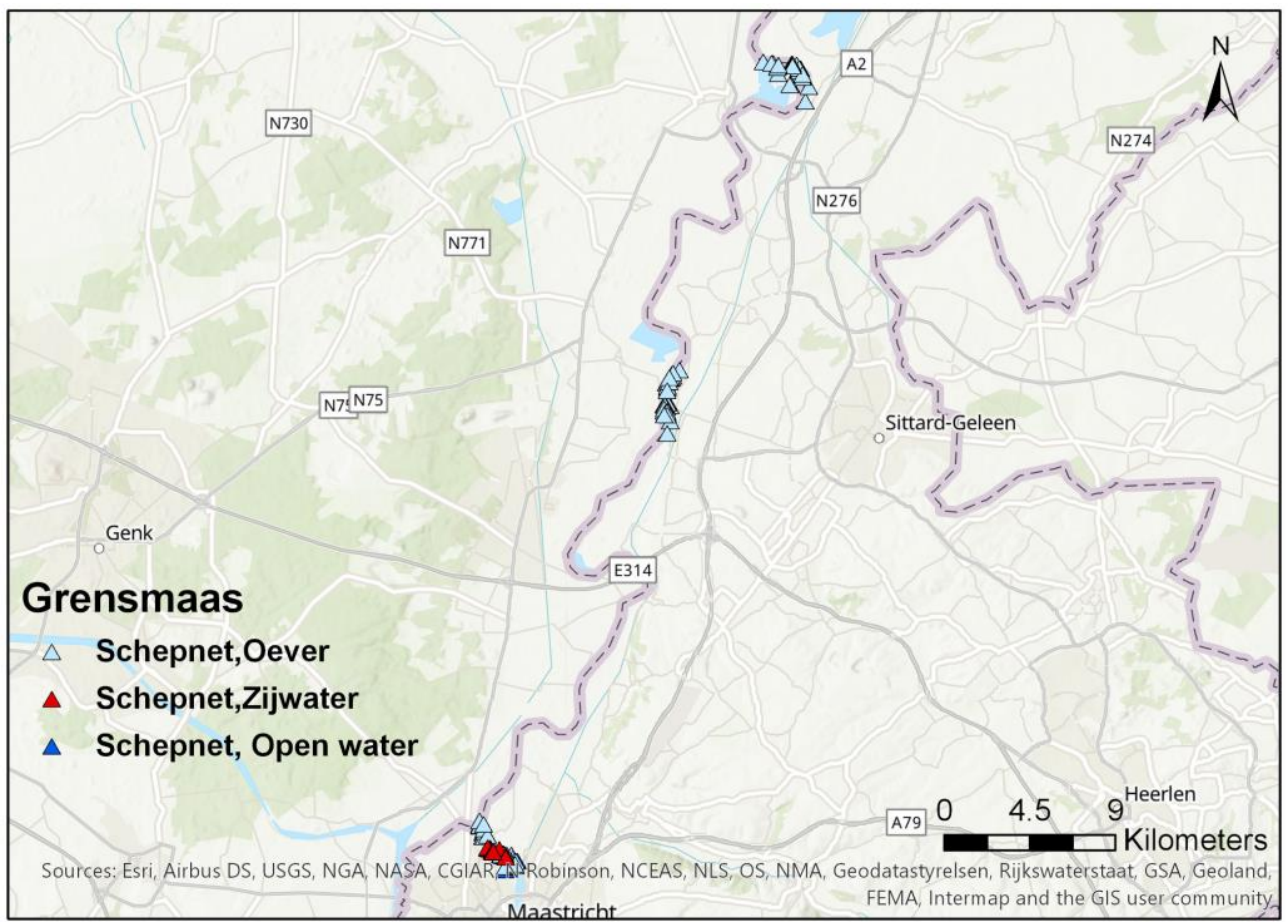

Figuur 2.44 Bemonsteringslocaties van de actieve monitoring in de Grensmaas van 1997-2019 per tuig per habitat.

\subsubsection{Grensmaas hoofdstroom (open water en oeverzone)}

De Grensmaas wordt sinds 1997 ieder jaar in het voorjaar met het elektroschepnet bemonsterd. In de periode 1997-2014 werd dit gebied in mei bemonsterd, vanaf 2015 in april. Daarnaast zijn de oevers vanwege herinrichting van verschillende stations (in 2018) sterk veranderd en is de bemonstering van in ieder geval 1 station in 2019 weinig representatief vanwege de lage vangstefficiëntie.

De tien meest algemene soorten in de hoofdstroom van de Grensmaas voor de gehele periode 19972019 zij: zwartbekgrondel, snoek, kopvoorn, brasem, blankvoorn, barbeel, snoekbaars, baars, alver en aal. Deze omvatten meer dan $90 \%$ van het totale gemiddelde aantal en biomassa voor de vangsten met het schepnet (Bijlage 16). Dit relatief lage percentage is een indicatie van een hoge biodiversiteit. Ten opzichte van de voorgaande rapportage (van Rijssel et al. 2019a) behoren de marmergrondel en de Europese meerval niet meer tot de top tien algemene soorten, hun plek is ingenomen door snoekbaars en alver. In de hoofdstroom van de Grensmaas is de Chinese wolhandkrab niet gevangen.

Aangezien de Grensmaas de enige grindrivier in Nederland is, zien we een aantal soorten in de top tien die bij andere wateren niet in de top tien staan of zelfs zelden tot nooit gevangen worden (Figuur 2.45 boven). Zo behoren kopvoorn en barbeel zowel qua aantal als biomassa tot de dominante soorten, samen met blankvoorn, baars en aal. Vanaf 2009 zien we dat de invasieve marmergrondel regelmatig wordt gevangen (behoort tot overige soorten), hetzelfde geldt vanaf 2014 voor de invasieve zwartbekgrondel. In 2019 valt de toename van snoekbaars in biomassa op. Tot slot valt het op dat dat sinds 2012 de biomassa van barbeel afneemt en vanaf 2015 worden ze nauwelijks nog gevangen. Of de afname van de barbelen een gevolg is van de toename van de invasieve grondelsoorten is nog onduidelijk. Van Kessel et al. $(2013,2014,2016)$ hebben wel onderzoek gedaan of de opkomst van de invasieve grondels de reden is geweest voor de afname van de rivierdonderpad, wat inderdaad in veel gevallen zo lijkt te zijn. Aangezien de barbeel in andere gebieden ook lijkt af te nemen de laatste jaren (Bovenloop Waal, Bovenloop Gelderse IJssel) zou er ook een andere gemeenschappelijke oorzaak kunnen zijn die voor deze afname zorgt. Een andere reden zou bijvoorbeeld kunnen zijn dat de Europese meerval (valt onder overige soorten), die in dit water sinds 2013 een groot deel van de biomassa voor zijn rekening neemt, predeert op barbelen. In andere rivieren in Europa (Ebro, Tarn) vormen barbeelachtigen en cypriniden een belangrijk onderdeel van 
het dieet van de Europese meerval (Carol et al. 2009, Syväranta et al. 2010). De Europese meerval staat er ook om bekend opportunistisch te zijn en voornamelijk vissen in het dieet op te nemen die abundant zijn (Copp et al. 2009). Hierdoor is het niet ondenkbaar dat barbelen een belangrijk onderdeel van het dieet van de Europese meerval in de Grensmaas zijn. Het zou zeer interessant zijn het dieet van meervallen te onderzoeken in deze en andere KRW-lichamen. Verder zou de lagere waterstand en het af en toe droogvallen van delen van de Grensmaas ervoor gezorgd kunnen hebben dat de locaties waar bemonsterd wordt geen goed habitat meer vormen voor grote(re) vissoorten zoals de barbeel waardoor er voornamelijk nog kleine individuen worden gevangen.

De lengte-frequentieverdelingen per soort, per tuig voor de hoofdstroom en de zijwateren gecombineerd over alle jaren van de monitoring van dit KRW-lichaam zijn hier te vinden: https://wmropendata.wur.nl/site/zoetwatervis/37/waterlichaam/ 

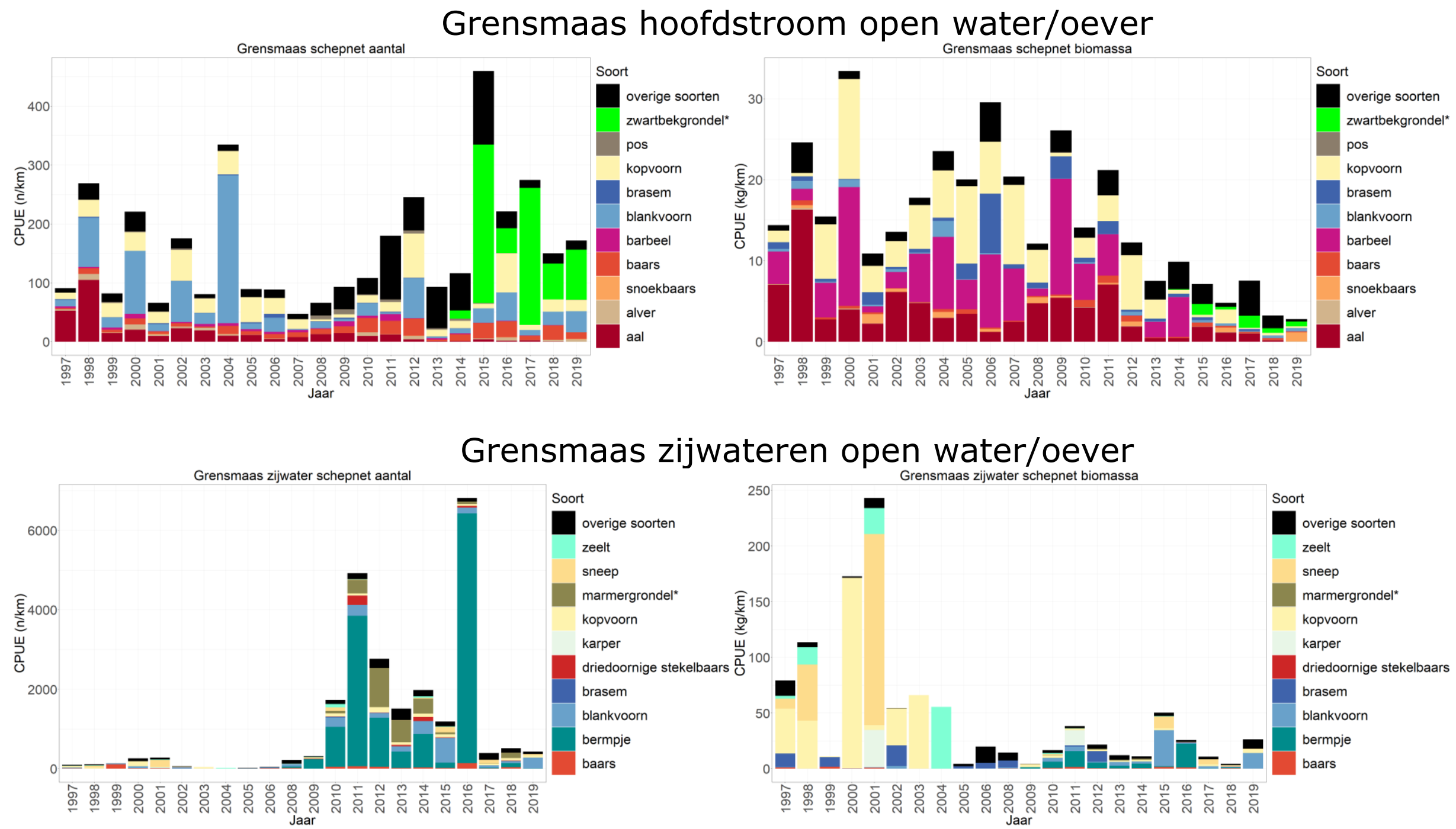

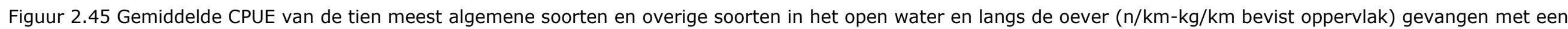
elektroschepnet in de hoofdstroom en de zijwateren van de Grensmaas tijdens de actieve monitoring van 1997-2019, * = exoot. 


\subsubsection{Grensmaas zijwater}

Langs de Grensmaas wordt één zijkanaal bemonsterd, in het open water en langs de oever met het schepnet.

De tien meest algemene soorten in dit zijwater voor de gehele periode 1997-2019 zijn zeelt, sneep, marmergrondel, kopvoorn, karper, driedoornige stekelbaars, brasem, blankvoorn, bermpje en baars. Deze omvatten meer dan $94 \%$ van het totale gemiddelde aantal en biomassa voor de vangsten met het schepnet (Bijlage 17). Qua aantallen en biomassa lijkt de dichtheid van de tien meest algemene soorten in de zijwateren hoger dan in de hoofdstroom. In het zijwater van de Grensmaas is de Chinese wolhandkrab niet gevangen.

In dit zijwater zien we ook veel soorten in de top tien die bij andere wateren niet in de top tien staan of zelden tot nooit gevangen worden (Figuur 2.45 onder). Zo behoren kopvoorn, bermpje en sneep tot de dominante soort zowel qua aantal als biomassa. Opvallend is ook het grote verschil in soortensamenstelling tussen de hoofdstroom en het zijwater. De zwartbekgrondel, snoek, Europese meerval, barbeel en aal ontbreken in de top tien van de zijwateren, terwijl deze wel tot de top tien behoren van het open water en de oever van de hoofdstroom van de Grensmaas. Hun plaats in de top tien is ingenomen door zeelt, sneep, karper, driedoornige stekelbaars en het bermpje. Vanaf 2011 zien we dat de invasieve marmergrondel regelmatig wordt gevangen en tot de dominante soorten gaat behoren, dit geldt hier overigens niet voor de zwartbekgrondel, terwijl dit vanaf 2014 in de hoofdstroom wel het geval is voor deze soort. Daarnaast is het zo dat vanaf 2015 er weer beduidend minder marmergrondels worden gevangen. Het valt op dat sinds 2009 de aantallen en biomassa van het bermpje sterk toenemen, hoewel er weer een sterke afname is in de laatste drie jaar die samen valt met algehele lage vangsten. Verder valt op dat kopvoorn en sneep voorheen regelmatig werden gevangen maar de laatste 15 jaar beduidend minder. In de laatste drie jaar werd er aanzienlijk minder vis gevangen dan in de voorgaande jaren, wellicht heeft dit met de lage waterstand in de Grensmaas van de afgelopen jaren te maken of met andere veranderde omstandigheden (verandering oevers/vangst efficiëntie). In 2019 is de roofblei voor het eerst in dit zijwater gevangen, alhoewel deze al eerder in de hoofdstroom is gevangen. 


\subsubsection{Aalvangsten}

Voor de aanlandingen van KRW-lichaam Grensmaas zijn de gegevens van de "Grensmaas" gebruikt (Bijlage 2). In 2011 is een grote afname van de aanlandingen te zien als gevolg van het verbod op aalvisserij in de grote rivieren in verband met te hoge dioxine- en PCB-gehaltes in aal (Figuur 2.46). Desondanks is er in 2017 toch nog bijna $100 \mathrm{~kg}$ aal aangeland welke met schietfuiken is gevangen (Figuur 2.46, Figuur 2.47). Dit zou aal uit de Boschmolenplas kunnen zijn, waar de Staat een huurovereenkomst met een beroepsvisser op aal heeft.

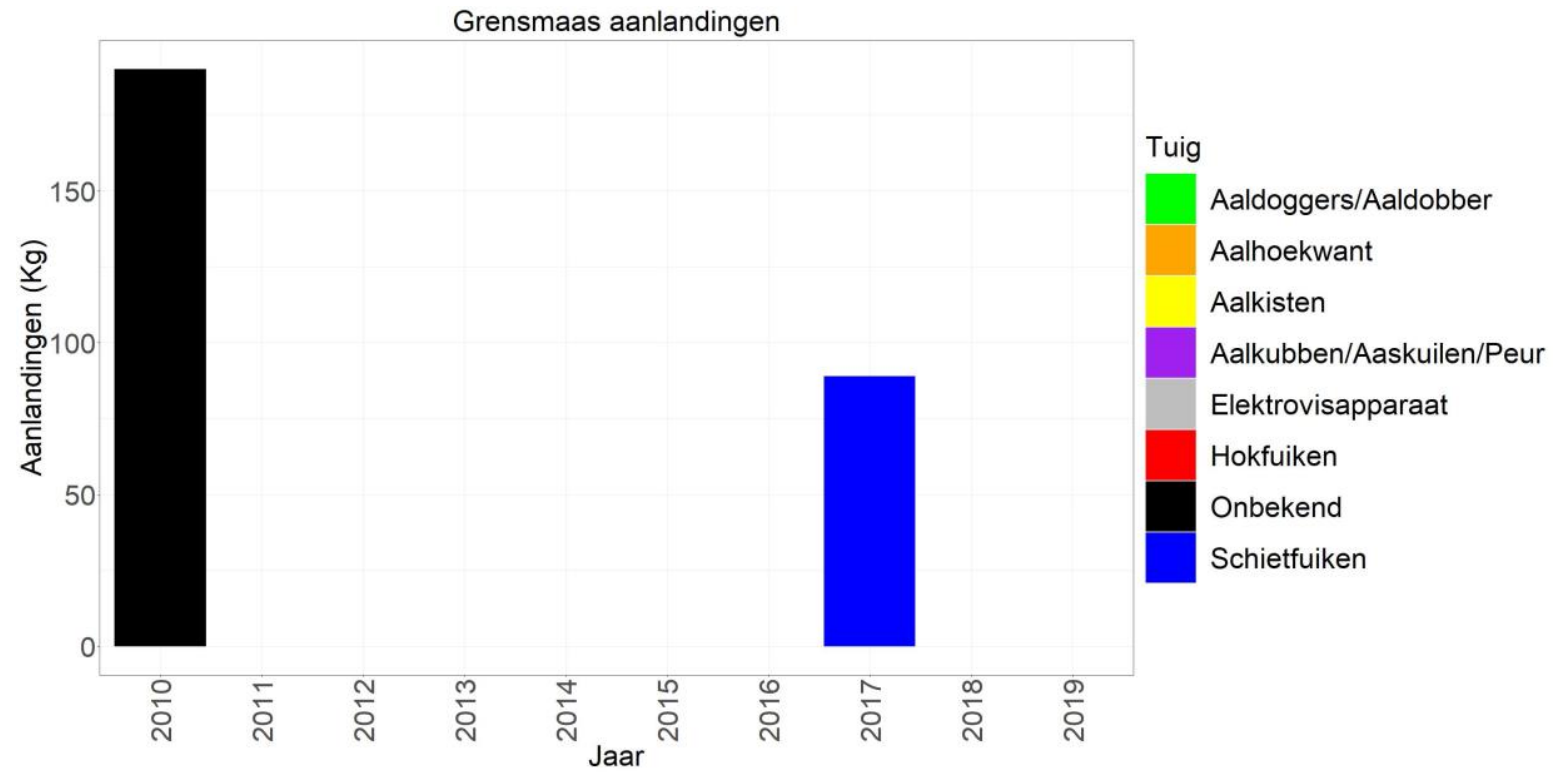

Figuur 2.46 Aanlandingen (kg) van de beroepsvisserij per tuig in de Grensmaas. Sinds 2012 zijn aalvissers verplicht de inspanning van het vistuig op te geven aan het ministerie van LNV.

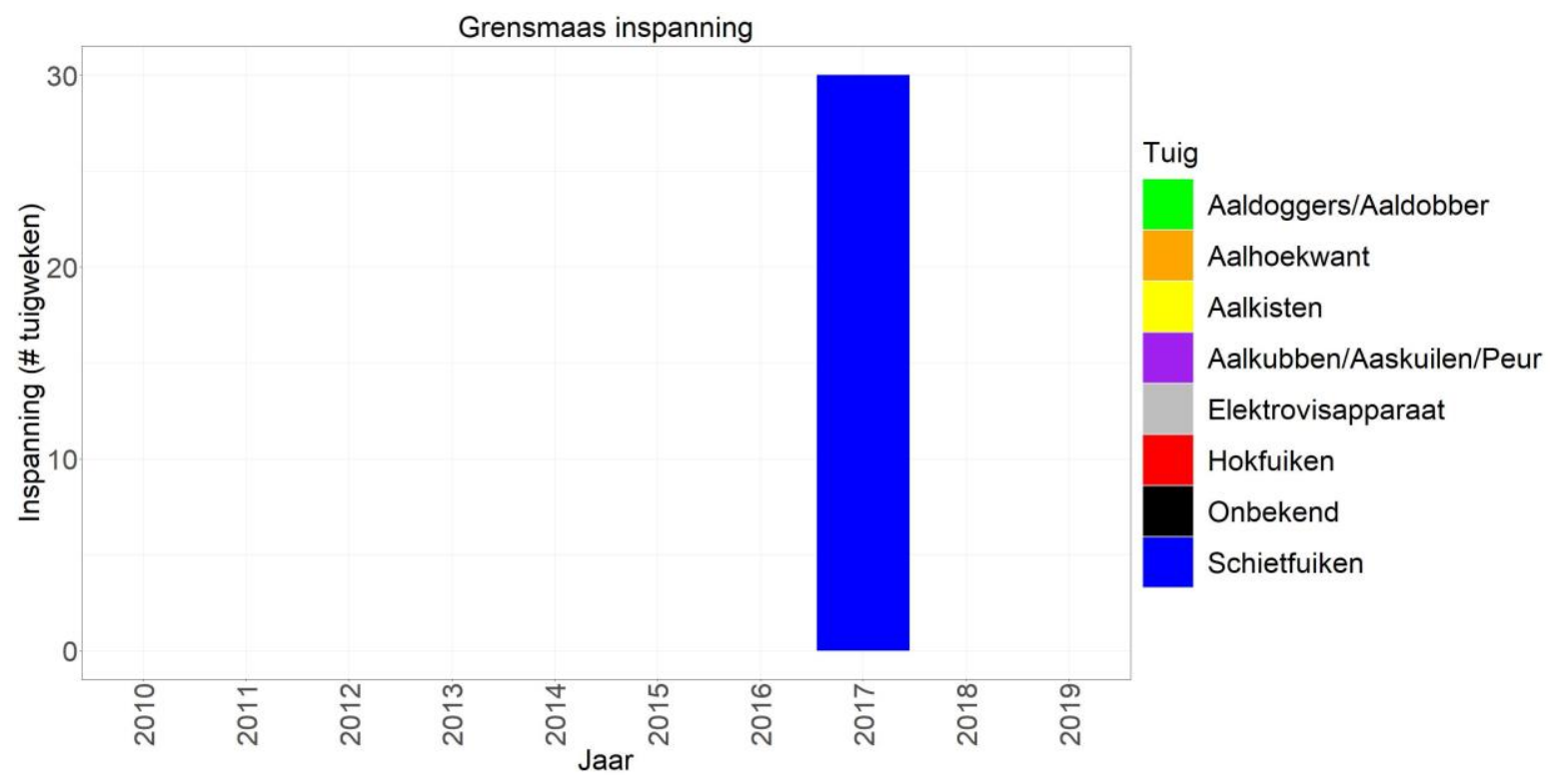

Figuur 2.47 Inspanning (aantal tuigweken) van de beroepsvisserij per tuig in de Grensmaas. 


\subsection{Zandmaas (Zandmaas en Bedijkte Maas)}

De bemonsteringslocaties over de periode 2008-2019 zijn weergegeven in Figuur 2.48.

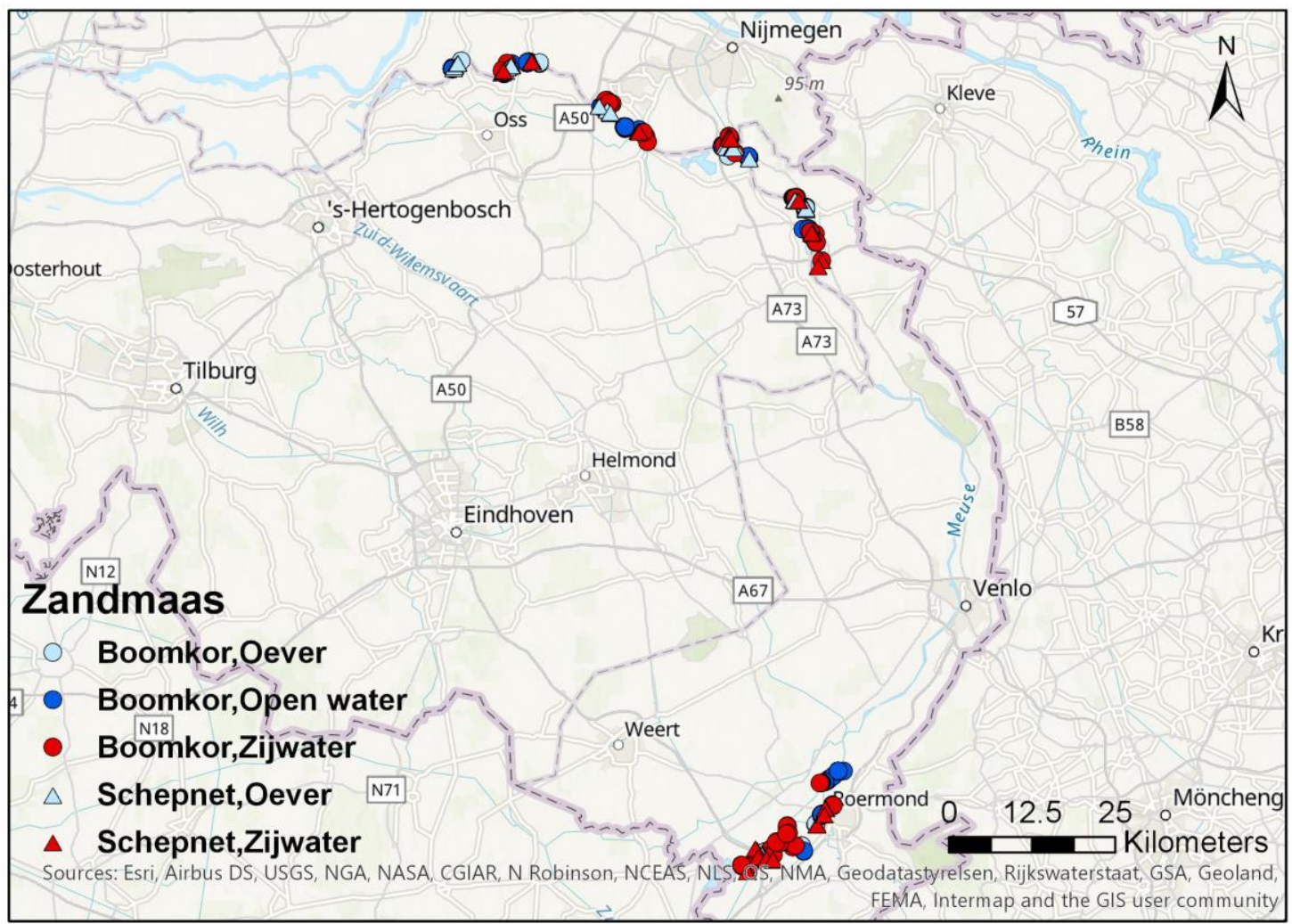

Figuur 2.48 Bemonsteringslocaties van de actieve monitoring in de Zandmaas van 2008-2019 per tuig per habitat.

\subsubsection{Zandmaas hoofdstroom (open water en oeverzone)}

De Zandmaas wordt sinds 2008 ieder jaar in het voorjaar met de boomkor en het elektroschepnet bemonsterd. In de periode 2008-2017 werd dit gebied voornamelijk in maart bemonsterd, vanaf 2018 zowel in maart als april. In 2013, 2014 en 2016 is de Zandmaas niet bemonsterd.

De tien meest algemene soorten in de hoofdstroom van de Zandmaas voor de gehele periode 20082019 zijn zwartbekgrondel, pos, kolblei, snoek, brasem, winde, blankvoorn, baars, snoekbaars en aal. Deze omvatten meer dan $94 \%$ van het totale gemiddelde aantal en biomassa voor zowel de vangsten met de boomkor als het schepnet (Bijlage 18).

In het open water en langs de oever (boomkor) zijn blankvoorn en brasem de dominante soorten in de boomkorvangsten, zowel qua aantal als qua biomassa (Figuur 2.49 boven). Daarnaast worden baars, snoekbaars, kolblei, pos en winde regelmatig gevangen, alhoewel pos sinds 2012 nauwelijks nog wordt gevangen. De vangsten van de zwartbekgrondel nemen sinds 2012 juist toe. Kolblei wordt sinds 2012 ook nauwelijks nog gevangen, een trend die we ook in andere wateren zien. Vangsten van blankvoorn, baars en snoekbaars fluctueren nogal maar lijken enigszins stabiel. In de laatste drie jaar zien we dat er minder van alle soorten wordt gevangen, net als in 2012 . In 2019 is de rietvoorn voor het eerst met de boomkor gevangen, langs de oever met het schepnet werd deze al eerder gevangen.

Langs de oever (schepnet) waren blankvoorn, snoekbaars, aal en winde t/m 2011 qua aantal en biomassa de dominante soorten (Figuur 2.49 onder). Sinds 2012 is dit qua aantal voornamelijk de zwartbekgrondel, welke met name in 2017 in groten getale werd gevangen. Sinds 2015 domineert aal qua biomassa en in 2019 geldt dit voor de zwartbekgrondel. Soorten die voorheen regelmatig werden gevangen, zoals winde en snoekbaars, worden de laatste jaren nauwelijks nog gevangen langs de 
oever van de Zandmaas. In 2019 is de roofblei voor het eerst langs de oever met het schepnet gevangen, met de boomkor werd deze al eerder gevangen.

De lengte-frequentieverdelingen per soort, per tuig voor de hoofdstroom en de zijwateren gecombineerd over alle jaren van de monitoring van dit KRW-lichaam zijn hier te vinden: https://wmropendata.wur.nl/site/zoetwatervis/68/waterlichaam/ 


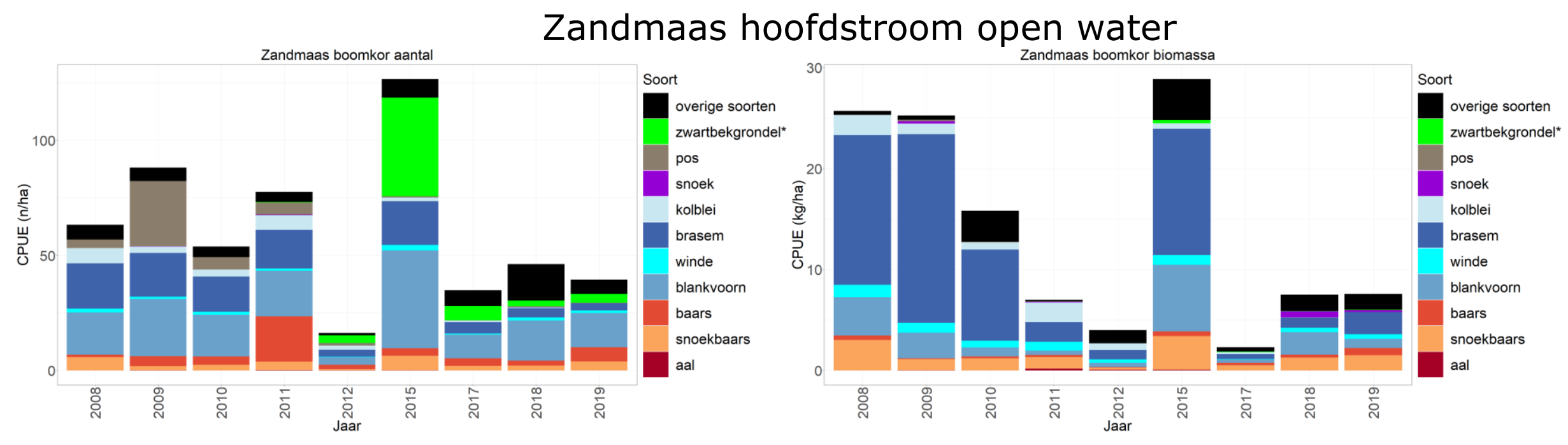

\section{Zandmaas hoofdstroom oever}
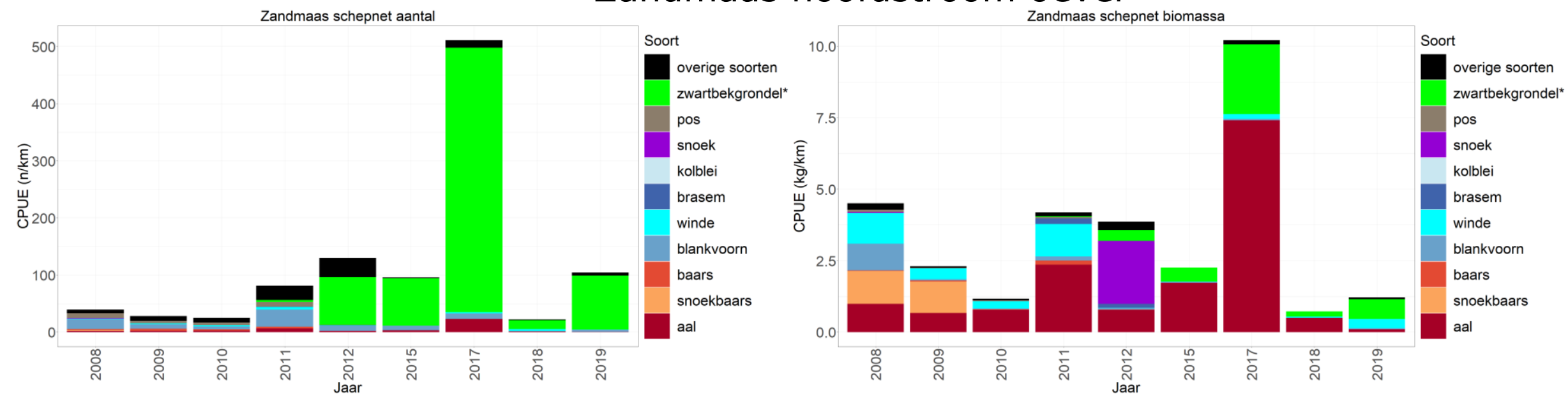

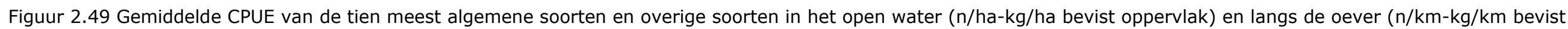
oppervlak) gevangen met een boomkor en elektroschepnet in de hoofdstroom van de Zandmaas tijdens de actieve monitoring van $2008-2019, *=$ exoot. 


\subsubsection{Chinese wolhandkrab}

De Chinese wolhandkrab wordt een enkele keer gevangen in de hoofdstroom van de Zandmaas en de vangsten zijn de laatste twee jaar wat lager dan de jaren ervoor (Figuur 2.50).

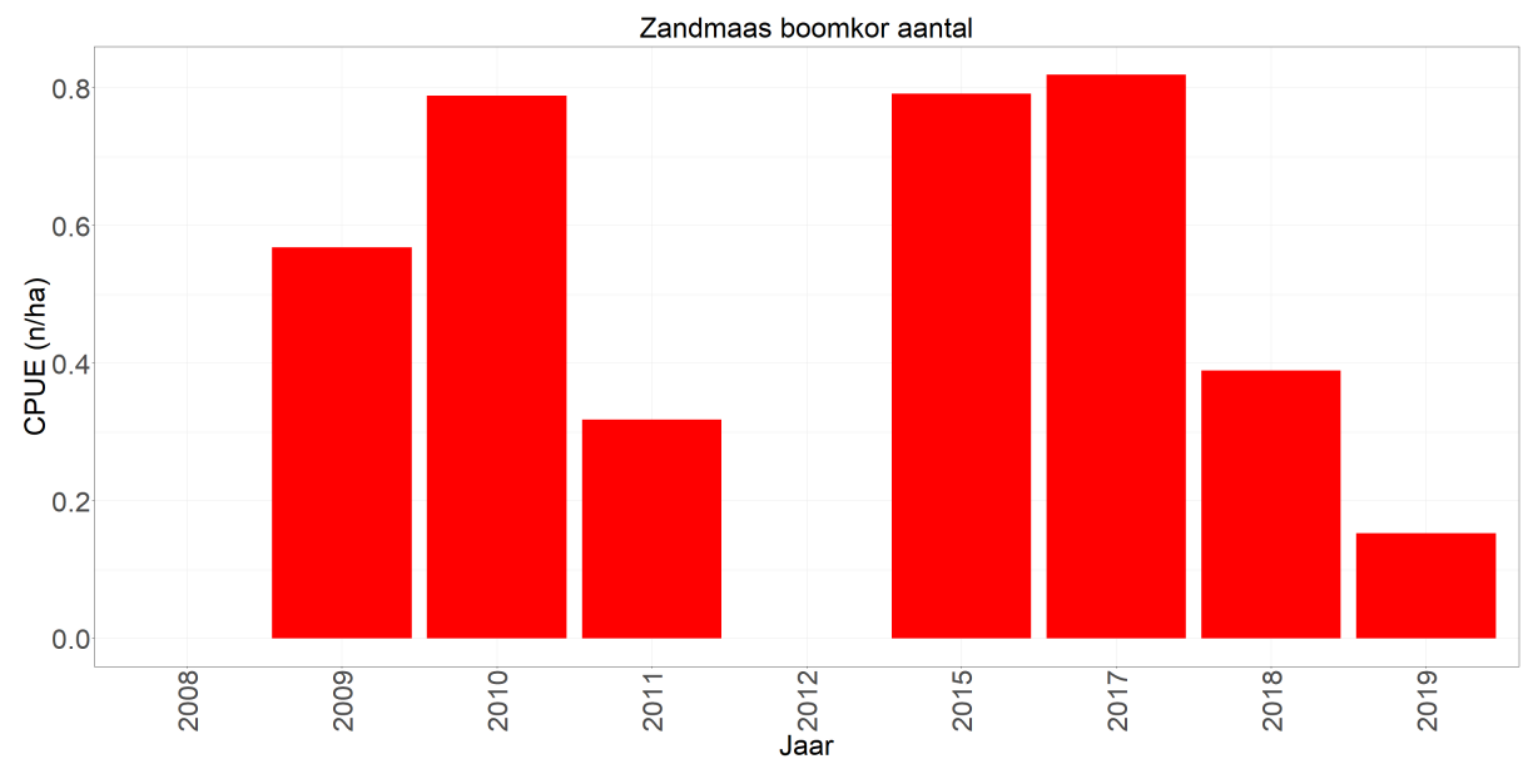

Figuur 2.50 Gemiddelde CPUE (n/ha bevist oppervlak) per jaar van de Chinese wolhandkrab in de hoofdstroom van het open water van de Zandmaas gevangen met de boomkor. 


\subsubsection{Zandmaas zijwateren}

Langs de Zandmaas zijn nevengeulen, inhammen, jachthavens en een zijrivier bemonsterd, in het open water met de boomkor en langs de oever met het schepnet.

De tien meest algemene soorten in deze zijwateren voor de gehele periode 2008-2019 zijn zwartbekgrondel, pos, snoek, brasem, winde, blankvoorn, baars, snoekbaars, aal en alver. Deze omvatten meer dan $90 \%$ van het totale gemiddelde aantal en biomassa voor zowel de vangsten met de boomkor als het schepnet (Bijlage 19). Qua aantallen lijkt de dichtheid van de tien meest algemene soorten in de zijwateren hoger dan in de hoofdstroom, qua biomassa lijkt dit ongeveer gelijk te zijn. Dit is een indicatie dat er in deze zijwateren voornamelijk jonge (kleine) individuen worden gevangen.

Opvallend is dat de kolblei hier ontbreekt terwijl deze wel tot de top tien behoort in de hoofdstroom. Hiervoor in de plaats is alver meer aanwezig in de zijwateren.

Net als in het open water van de hoofdstroom zijn brasem, blankvoorn de dominante soorten in de boomkorvangsten, zowel qua aantal als qua biomassa (Figuur 2.51 boven). Net als in de hoofdstroom worden daarnaast baars, snoekbaars, kolblei en pos regelmatig gevangen. Ook hier wordt pos steeds minder gevangen vanaf het moment dat de zwartbekgrondel in wat meer aanwezig is (2017). Daarnaast valt ook op dat er in 2019 veel meer vis is gevangen dan voorheen.

In de oeverzone van de zijwateren (schepnet) waren blankvoorn qua aantal en aal, brasem en snoek qua biomassa de dominante soorten (Figuur 2.51 onder). Sinds 2015 is de zwartbekgrondel qua aantal de dominante soort. De vangsten van snoekbaars, baars en blankvoorn fluctueren sterk maar lijken met de jaren af te nemen (behalve voor blankvoorn). In 2019 vallen een hoge dichtheid van zwartbekgrondel in aantallen en van aal in biomassa op en is de giebel voor het eerst gevangen alhoewel deze soort al eerder in de hoofdstroom is gevangen. 


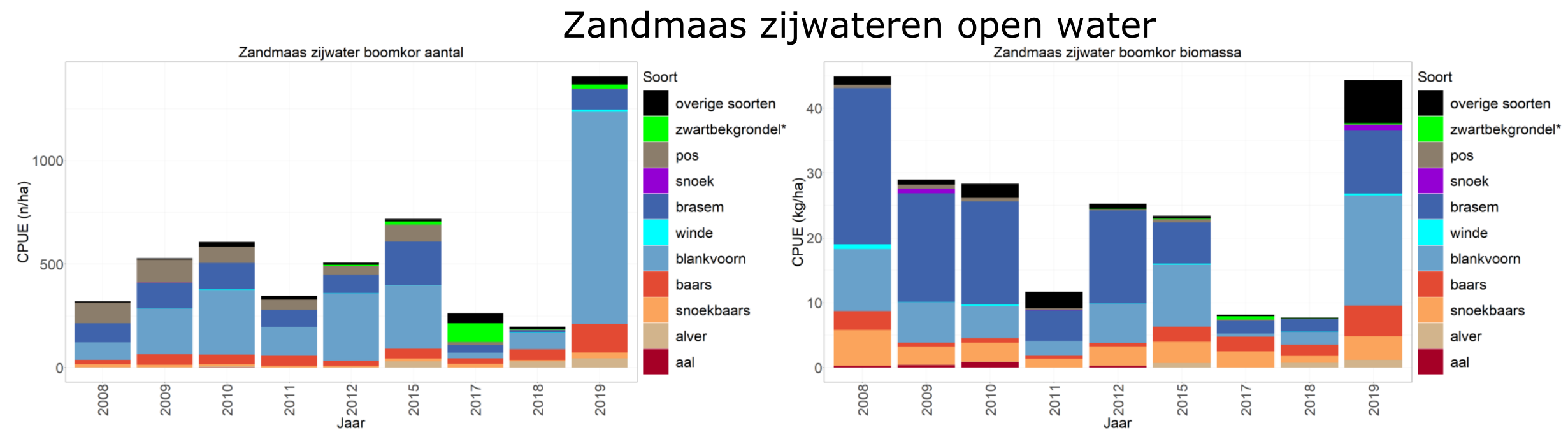

\section{Zandmaas zijwateren oever}
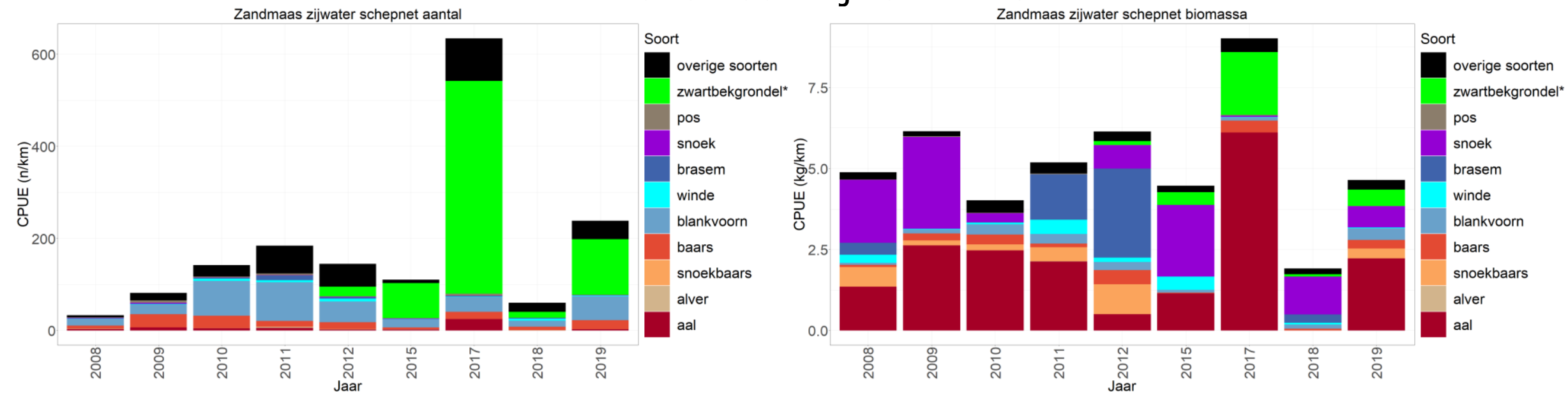

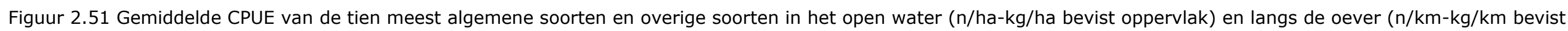
oppervlak) gevangen met een boomkor en elektroschepnet in de zijwateren van de Zandmaas tijdens de actieve monitoring van $2008-2019, *$ exoot. 


\subsubsection{Chinese wolhandkrab}

De Chinese wolhandkrab wordt vaker in de zijwateren gevangen dan in de hoofdstroom van de Zandmaas. Hier is een toename van de vangsten tot 2011, daarna wordt de wolhandkrab in 2017 en 2018 nog maar een enkele keer gevangen (Figuur 2.52).

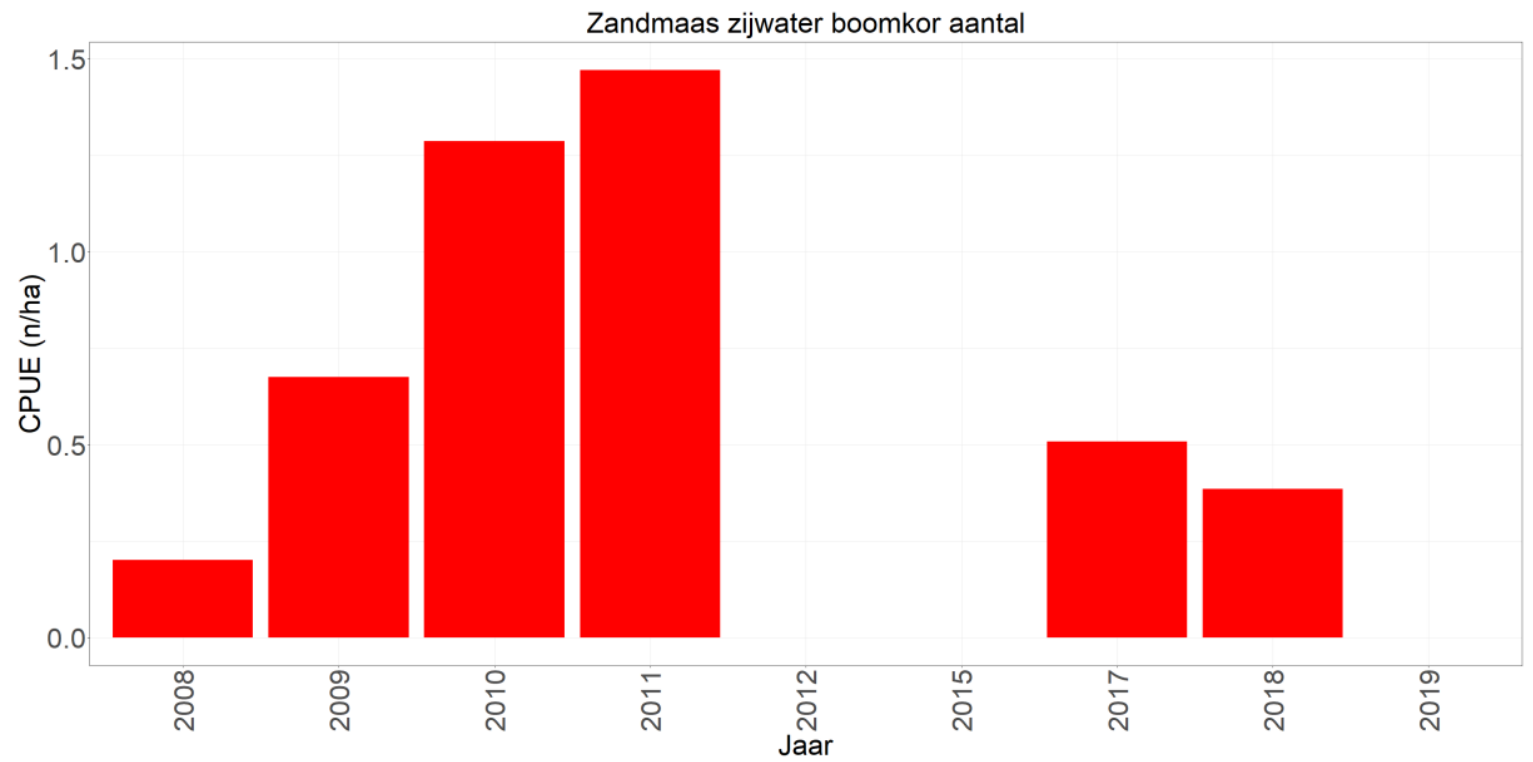

Figuur 2.52 Gemiddelde CPUE ( $\mathrm{n} /$ ha bevist oppervlak) per jaar van de Chinese wolhandkrab in de zijwateren van de Zandmaas gevangen met de boomkor. 


\subsubsection{Aalvangsten}

Voor de aanlandingen van KRW-lichaam Zandmaas zijn de gegevens van de "Zandmaas (incl. Limburgse kanalen)" gebruikt (Bijlage 2). In 2011 is ook hier een sterke afname van de aanlandingen te zien als gevold van het verbod op aalvisserij in de grote rivieren (Figuur 2.46). Vanaf 1 januari 2015 is ook het kanaal Wessem-Nederweert gesloten voor aalvisserij. Desondanks worden er bijna in ieder jaar toch nog behoorlijke hoeveelheden aal aangeland, die voornamelijk met schietfuiken gevangen zijn. Vooral in 2012 was er nog een vrij grote inspanning (Figuur 2.54). Net als in de Grensmaas, zou dit aal uit de Boschmolenplas kunnen zijn. Daarnaast heeft de Staat ook hier een huurovereenkomst met een beroepsvisser op aal. Deze aal zou ook uit de Limburgse kanalen kunnen komen waar geen verbod op aalvisserij geldt.

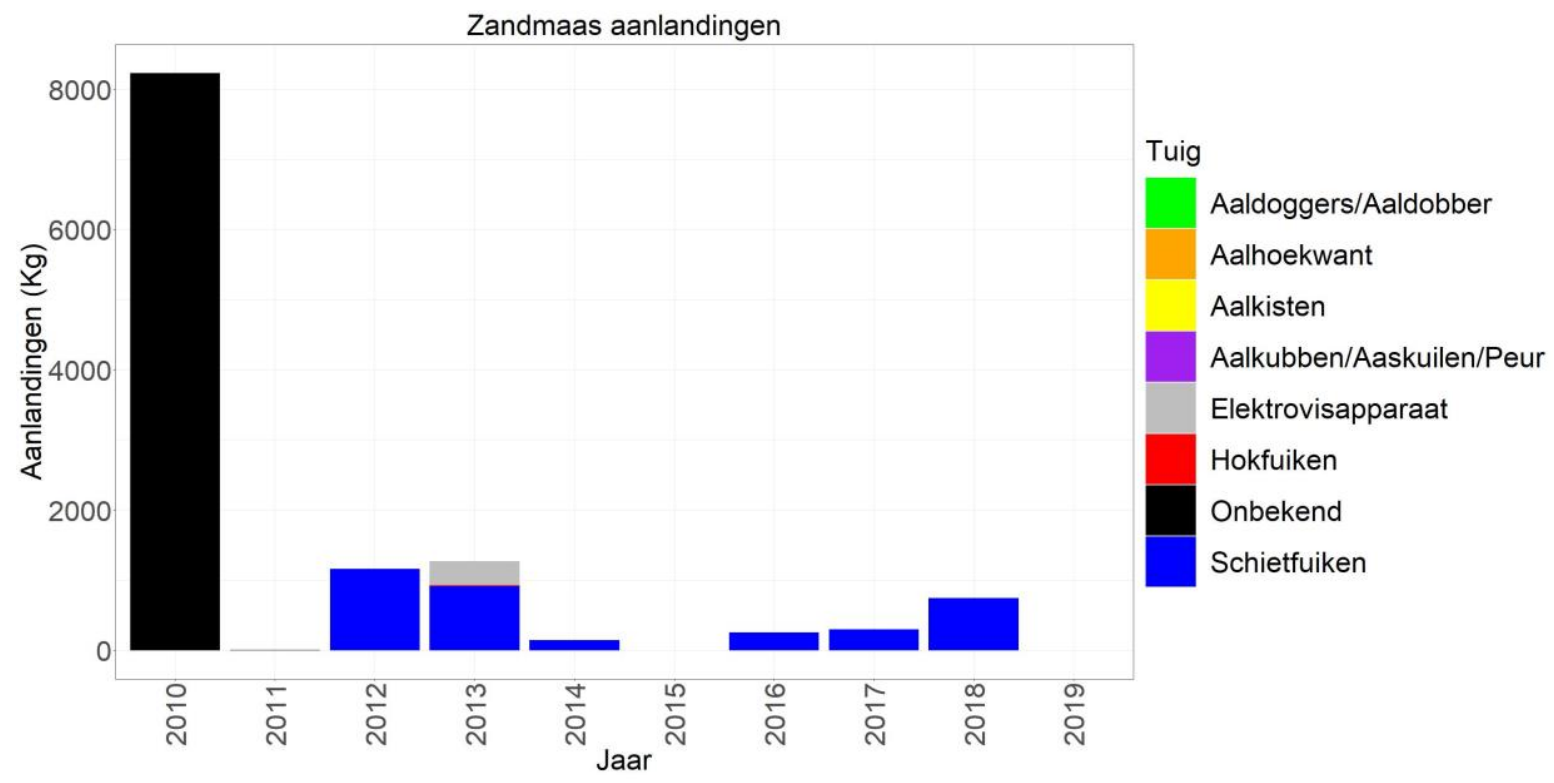

Figuur 2.53 Aanlandingen (kg) van de beroepsvisserij per tuig in de Zandmaas. Sinds 2012 zijn aalvissers verplicht de inspanning van het vistuig op te geven aan het ministerie van LNV.

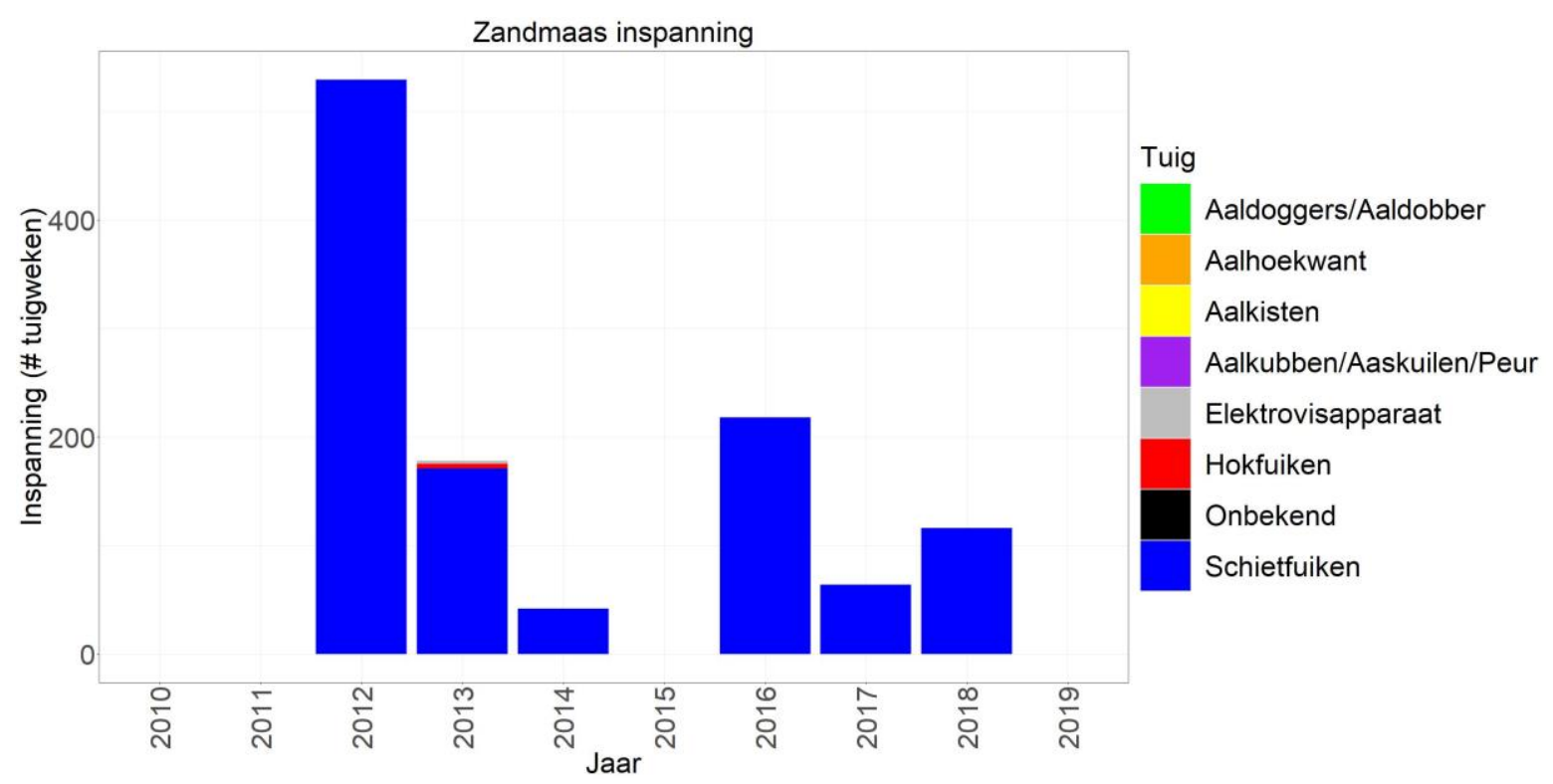

Figuur 2.54 Inspanning (aantal tuigweken) van de beroepsvisserij per tuig in de Zandmaas. 


\subsection{Bovenloop Nederrijn (Nederrijn, Lek)}

De bemonsteringslocaties over de periode 1997-2019 zijn weergegeven in Figuur 2.55.

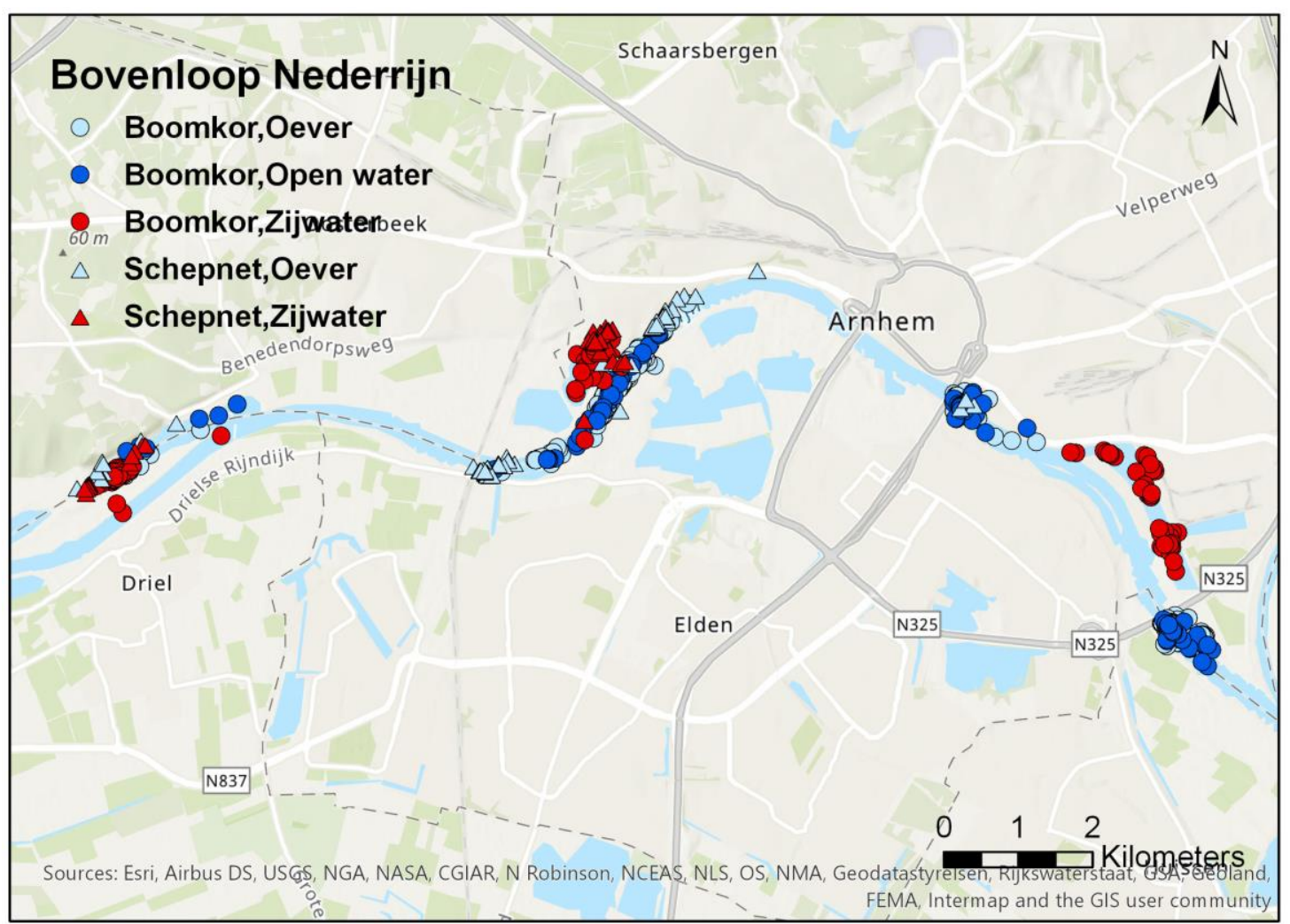

Figuur 2.55 Bemonsteringslocaties van de actieve monitoring in de Bovenloop Nederrijn van 19972019 per tuig per habitat.

\subsubsection{Bovenloop Nederrijn hoofdstroom (open water en oeverzone)}

De Bovenloop Nederrijn wordt sinds 1997 ieder jaar in het voorjaar met de boomkor en het elektroschepnet bemonsterd. In de periode 1997-2003 werd dit gebied in maart en april bemonsterd (behalve in 1998 alleen in maart), vanaf 2004 meestal alleen in maart (behalve in 2011 en 2012, toen er weer in maart en april werd bemonsterd).

De tien meest algemene soorten in de hoofdstroom van de Bovenloop Nederrijn voor de gehele periode 1997-2019 zijn snoek, pos, kolblei, brasem, winde, blankvoorn, baars, snoekbaars, alver en aal. Deze omvatten meer dan $96 \%$ van het totale gemiddelde aantal en biomassa voor zowel de vangsten met de boomkor als het schepnet (Bijlage 20).

In het open water en langs de oever (boomkor) zijn blankvoorn, brasem en kolblei de dominante soorten zowel qua aantal als qua biomassa (Figuur 2.56 boven). In alle drie de soorten zien we een sterke afname tussen 2000 en 2015. Vanaf 2015 lijken de hoeveelheden blankvoorn en brasem weer toe te nemen, alhoewel deze toename de laatste twee jaar niet doorzet en dit wellicht een korte opleving was. Hetzelfde geldt voor de hogere vangst qua biomassa van winde in 2015 en 2016. Snoekbaars wordt ook met enige regelmaat gevangen en lijkt relatief stabiel door de jaren heen. De laatste twee jaar is snoekbaars de dominante soort. Net als in sommige andere watersystemen werd er in 2018 opvallend weinig gevangen, wat wellicht met de relatief lage watertemperatuur te maken kan hebben $\left(4^{\circ} \mathrm{C}\right.$ in 2018 i.p.v. $8^{\circ} \mathrm{C}$ in 2017 en 2019), alhoewel de vangsten in 2019 ook behoorlijk laag waren. Wat verder opvalt is dat de invasieve grondelsoorten in de Bovenloop Nederrijn niet tot de tien meest algemene soorten horen. In 2019 is de Europese meerval voor het eerst met de boomkor in dit gebied gevangen, deze soort werd al wel eerder met het schepnet langs de oever gevangen.

Langs de oever (schepnet) is blankvoorn samen met baars en winde qua aantal de dominante soort (Figuur 2.56 onder). Ook worden er vanaf 2011 zwartbekgrondels gevangen (vallen onder overige soorten). Qua biomassa zien we dat er wat meer diversiteit is in de dominante soorten dan in 
aantallen; blankvoorn, brasem, winde, snoekbaars, snoek en aal dragen allemaal veel bij aan de biomassa. De vangsten fluctueren sterk per jaar maar in de laatste paar jaar is er een afname van blankvoorn (op 2017 en 2018 na), brasem en winde te zien. Baars en snoekbaars lijken ook steeds minder te worden gevangen. Aal lijkt relatief stabiel met sterke fluctuaties in biomassa en is zelfs de dominante soort in 2019.

De lengte-frequentieverdelingen per soort, per tuig voor de hoofdstroom en de zijwateren gecombineerd over alle jaren van de monitoring van de Bovenloop en Benedenloop Nederrijn gecombineerd zijn hier te vinden: https://wmropendata.wur.nl/site/zoetwatervis/65/waterlichaam/ 
Bovenloop Nederrijn hoofdstroom open water

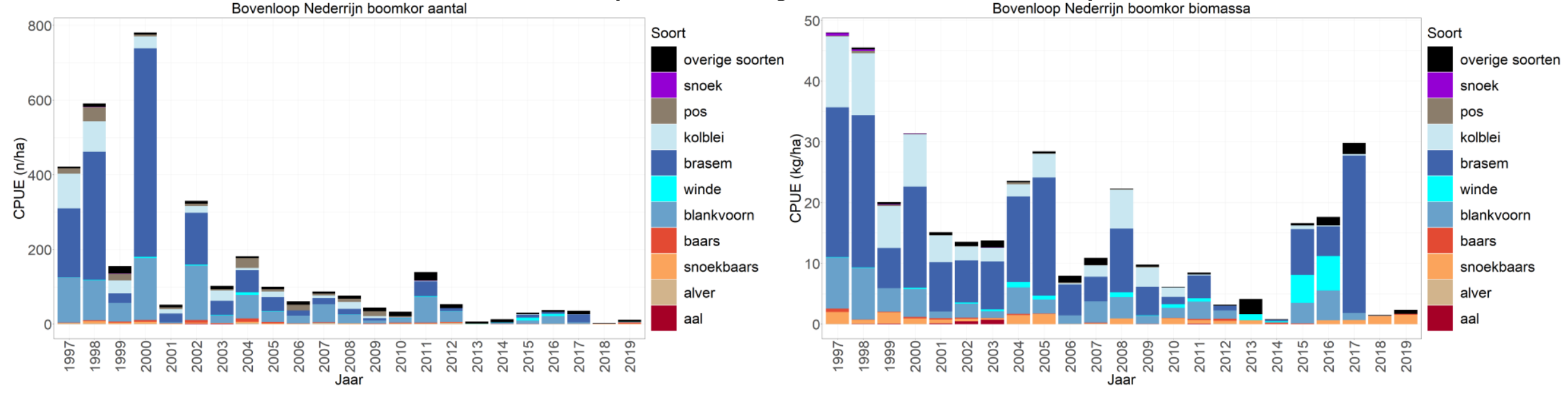

Bovenloop Nederrijn hoofdstroom oever

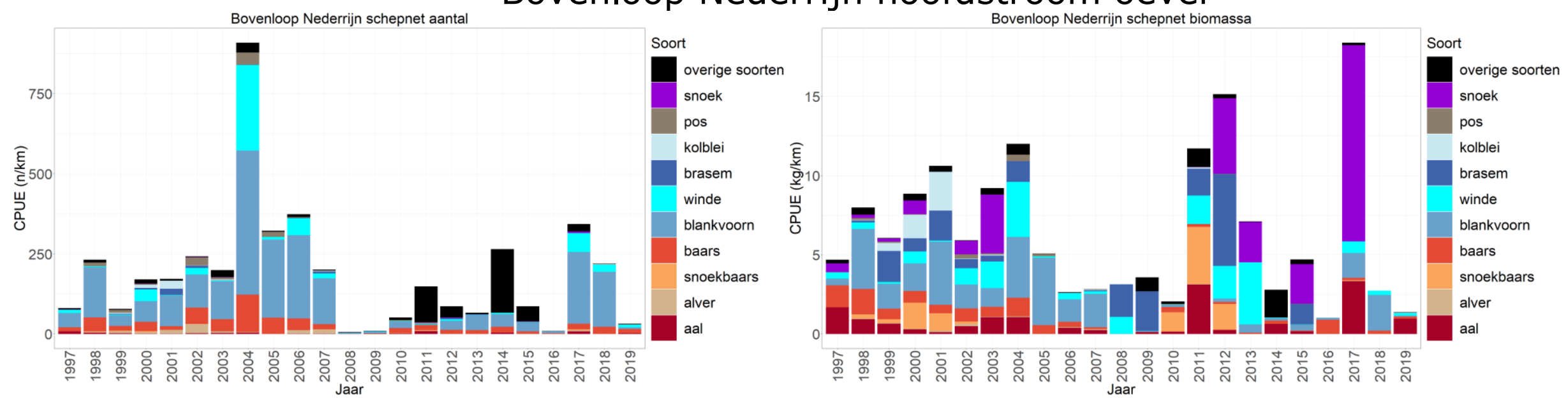

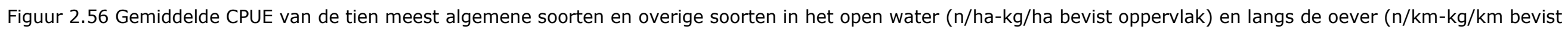
oppervlak) gevangen met een boomkor en elektroschepnet in de hoofdstroom van de Bovenloop Nederrijn tijdens de actieve monitoring van $1997-2019, *$ exoot. 


\subsubsection{Chinese wolhandkrab}

Net als in de Rijn wordt de Chinese wolhandkrab regelmatig gevangen in de hoofdstroom van de Bovenloop Nederrijn. De vangsten fluctueren, maar wat opvalt is de piek in 2007 en dat net als in het meer bovenstrooms gelegen stuk van de Rijn er een periode is geweest (2012-2015) waarin geen wolhandkrabben zijn gevangen (Figuur 2.57).

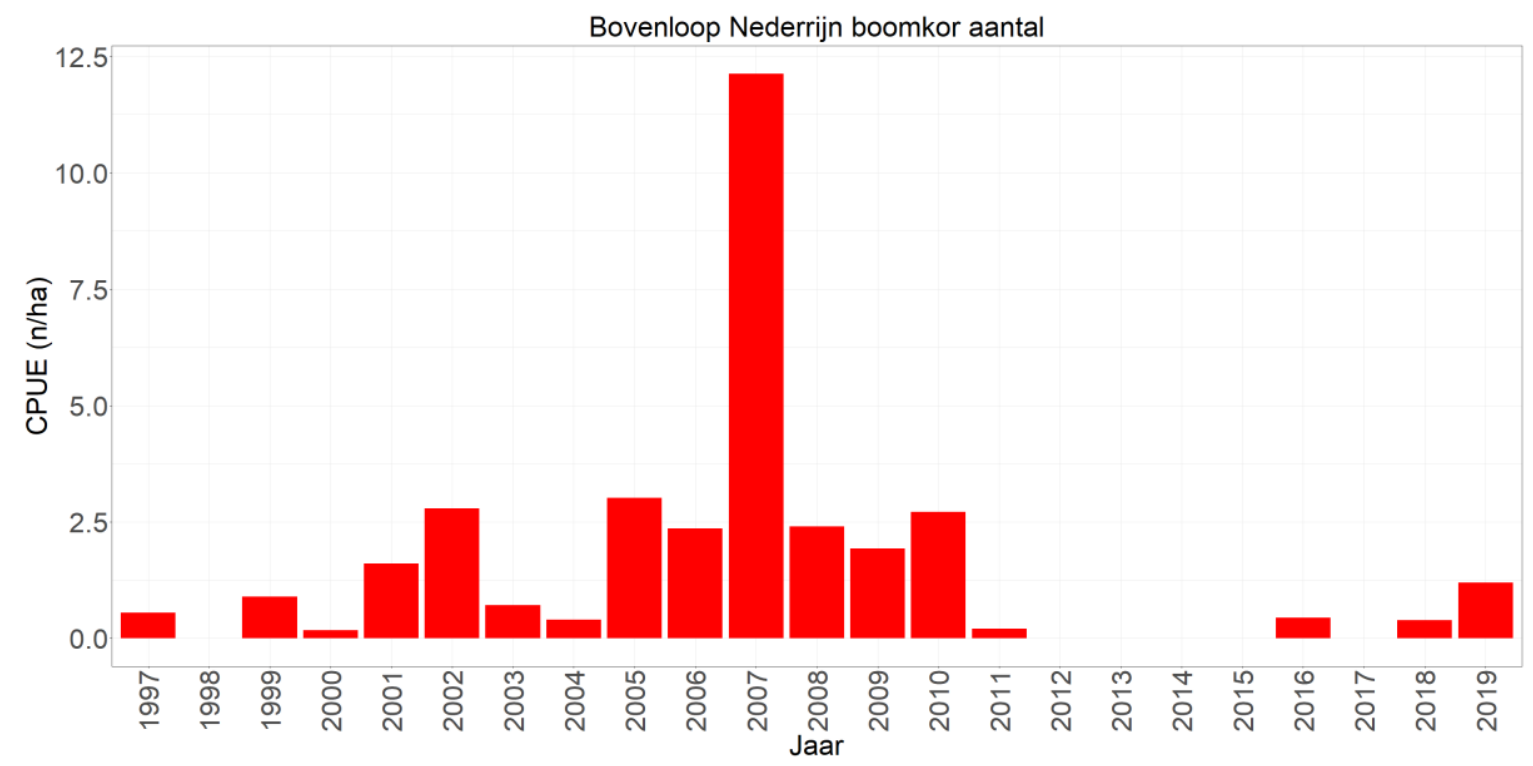

Figuur 2.57 Gemiddelde CPUE ( $\mathrm{n} /$ ha bevist oppervlak) per jaar van de Chinese wolhandkrab in de hoofdstroom van het open water van de Bovenloop Nederrijn gevangen met de boomkor. 


\subsubsection{Bovenloop Nederrijn zijwateren}

Langs de Bovenloop Nederrijn zijn een haven, een inham en een nevengeul bemonsterd, in het open water met de boomkor en langs de oever met het schepnet.

De tien meest algemene soorten in deze zijwateren voor de gehele periode 1997-2019 zijn: zwartbekgrondel, pos, kolblei, brasem, winde, blankvoorn, baars, snoekbaars, alver en aal. Deze omvatten meer dan $96 \%$ van het totale gemiddelde aantal en biomassa voor zowel de vangsten met de boomkor als het schepnet (Bijlage 21). Qua aantallen lijkt de dichtheid van de tien meest algemene soorten in de zijwateren hoger dan in de hoofdstroom, qua biomassa lijkt dit ongeveer gelijk te zijn. Dit is een indicatie dat er in deze zijwateren voornamelijk jonge individuen worden gevangen.

Wat opvalt is dat de invasieve zwartbekgrondel in de zijwateren wel tot de tien meest algemene soorten behoort terwijl deze voor de hoofdstroom hier net buiten valt.

Net als in het open water van de hoofdstroom zijn brasem en blankvoorn de dominante soorten in de boomkorvangsten, zowel qua aantal als qua biomassa (Figuur 2.58 boven). Ook hier namen deze soorten grofweg af sinds 2005/2007. In de laatste twee jaar worden deze soorten nauwelijks nog gevangen. Pos werd in het verleden ook vrij veel gevangen maar de vangsten daarvan zijn de laatste jaren sterk afgenomen. Mogelijk heeft deze afname ook hier te maken met de opmars van de zwartbekgrondel zoals gesuggereerd voor andere watersystemen. Snoekbaars lijkt hier ook relatief veel voor te komen in de zijwateren. In 2019 is er relatief veel baars gevangen ten opzichte van andere soorten.

Langs de oever (schepnet) waren baars en blankvoorn qua aantal de dominante soorten. Met de opkomst van de invasieve zwartbekgrondel in 2011 werd dit de dominante soort, maar sinds 2016 lijkt blankvoorn weer de dominante soort te zijn met juist een afname van de zwartbekgrondel (Figuur 2.58 onder). Qua biomassa zien we dat baars de dominante soort is, samen met snoek (valt onder overige soorten). Er wordt qua aantallen en biomassa opvallend weinig gevangen in de laatste jaren. 


\section{Bovenloop Nederrijn zijwateren open water}

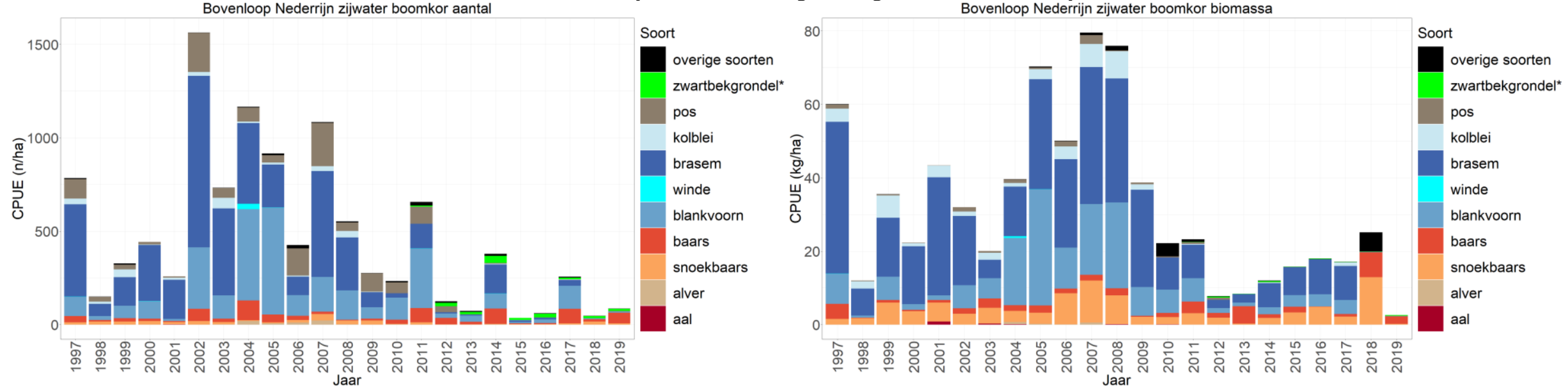

\section{Bovenloop Nederrijn zijwateren oever}

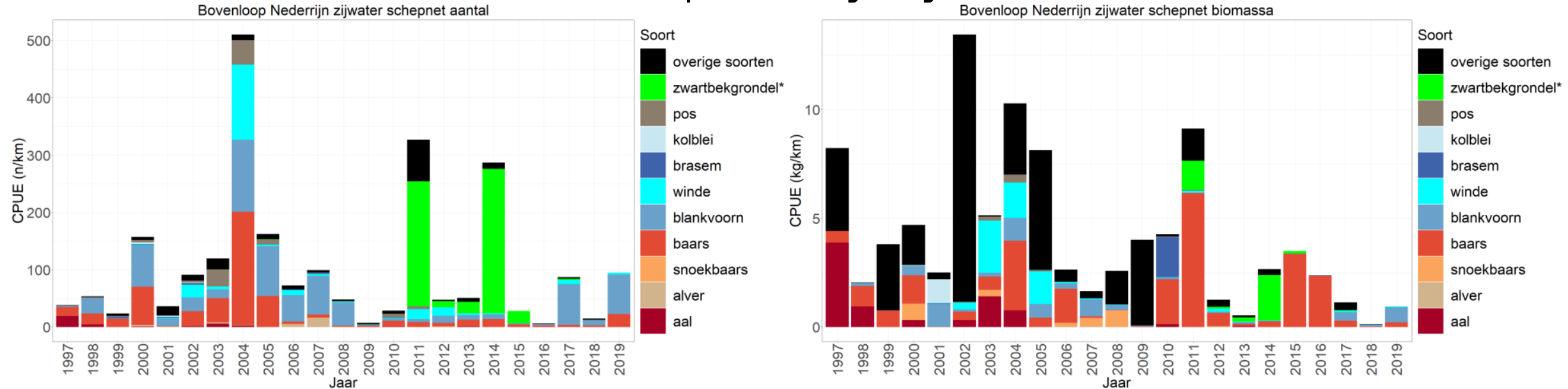

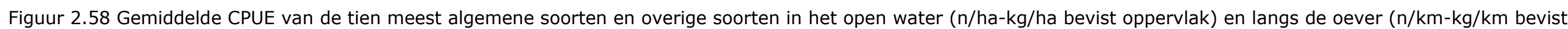
oppervlak) gevangen met een boomkor en elektroschepnet in de zijwateren van de Bovenloop Nederrijn tijdens de actieve monitoring van 1997-2019, * = exoot. 


\subsubsection{Chinese wolhandkrab}

Net als in de hoofdstroom wordt de Chinese wolhandkrab regelmatig gevangen in zijwateren van de Bovenloop Nederrijn (Figuur 2.59). De vangsten in de zijwateren lijken alleen wat meer te fluctueren (regelmatig jaren zonder wolhandkrabben) zonder een duidelijke trend maar een piek in 2007 (net als in de hoofdstroom).

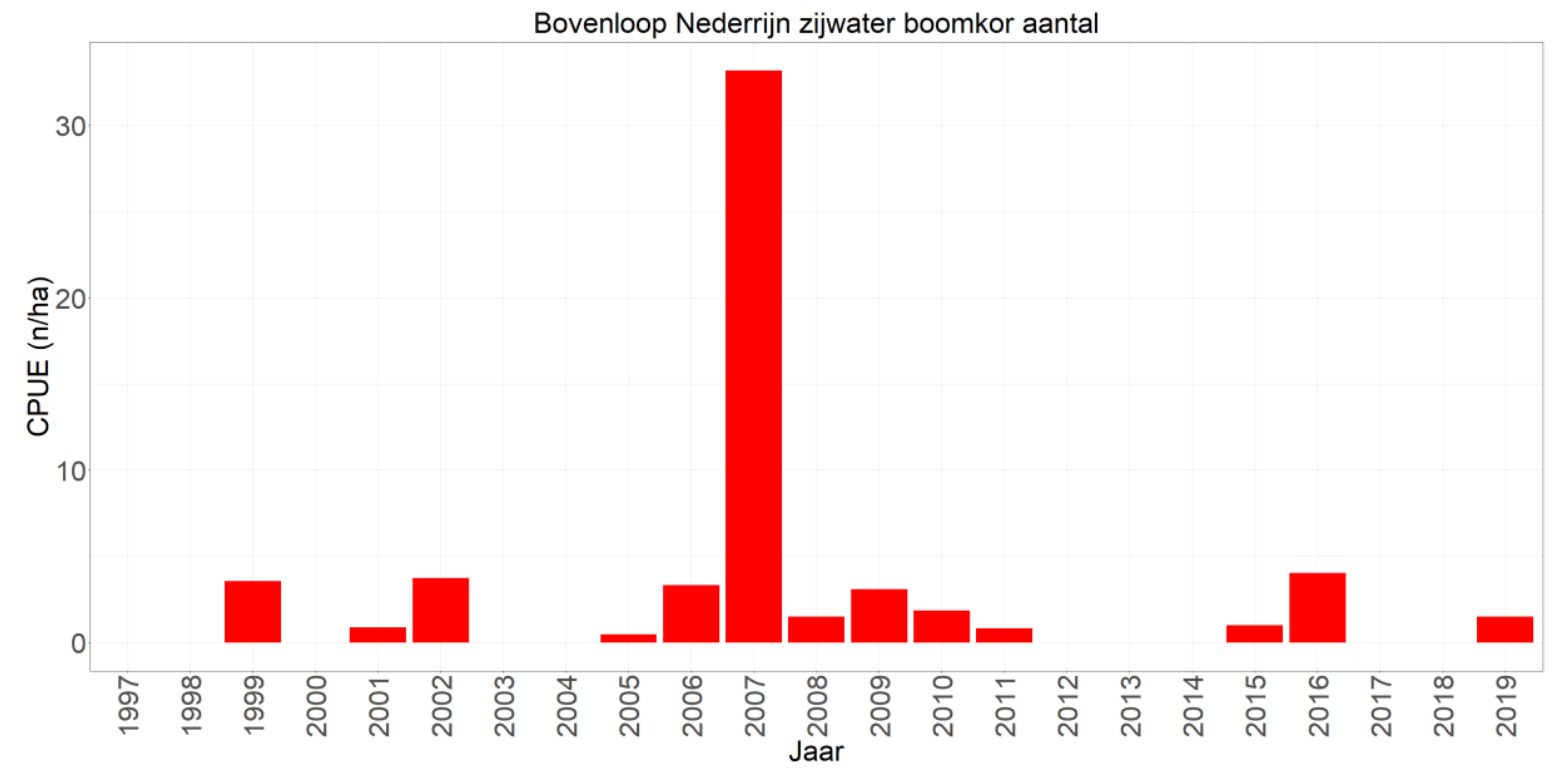

Figuur 2.59 Gemiddelde CPUE (n/ha bevist oppervlak) per jaar van de Chinese wolhandkrab in de zijwateren van de Bovenloop Nederrijn gevangen met de boomkor.

\subsubsection{Aalvangsten}

Voor de aanlandingen van KRW-lichamen Bovenloop Nederrijn, Benedenloop Nederrijn en Bovenloop Gelderse IJssel zijn de gegevens van de "Nederrijn Plus i. o." gebruikt (Bijlage 2). In 2011 is het verbod op aalvisserij in de grote rivieren in verband met te hoge dioxine- en PCB-gehaltes in aal ingegaan waardoor er alleen aanlandingen uit 2010 zijn. In dat jaar is er 15.342 kilo aan aal aangeland (Bijlage 2). 


\subsection{Bovenloop Waal (Boven Rijn, Waal)}

De bemonsteringslocaties over de periode 1997-2019 zijn weergegeven in Figuur 2.60.

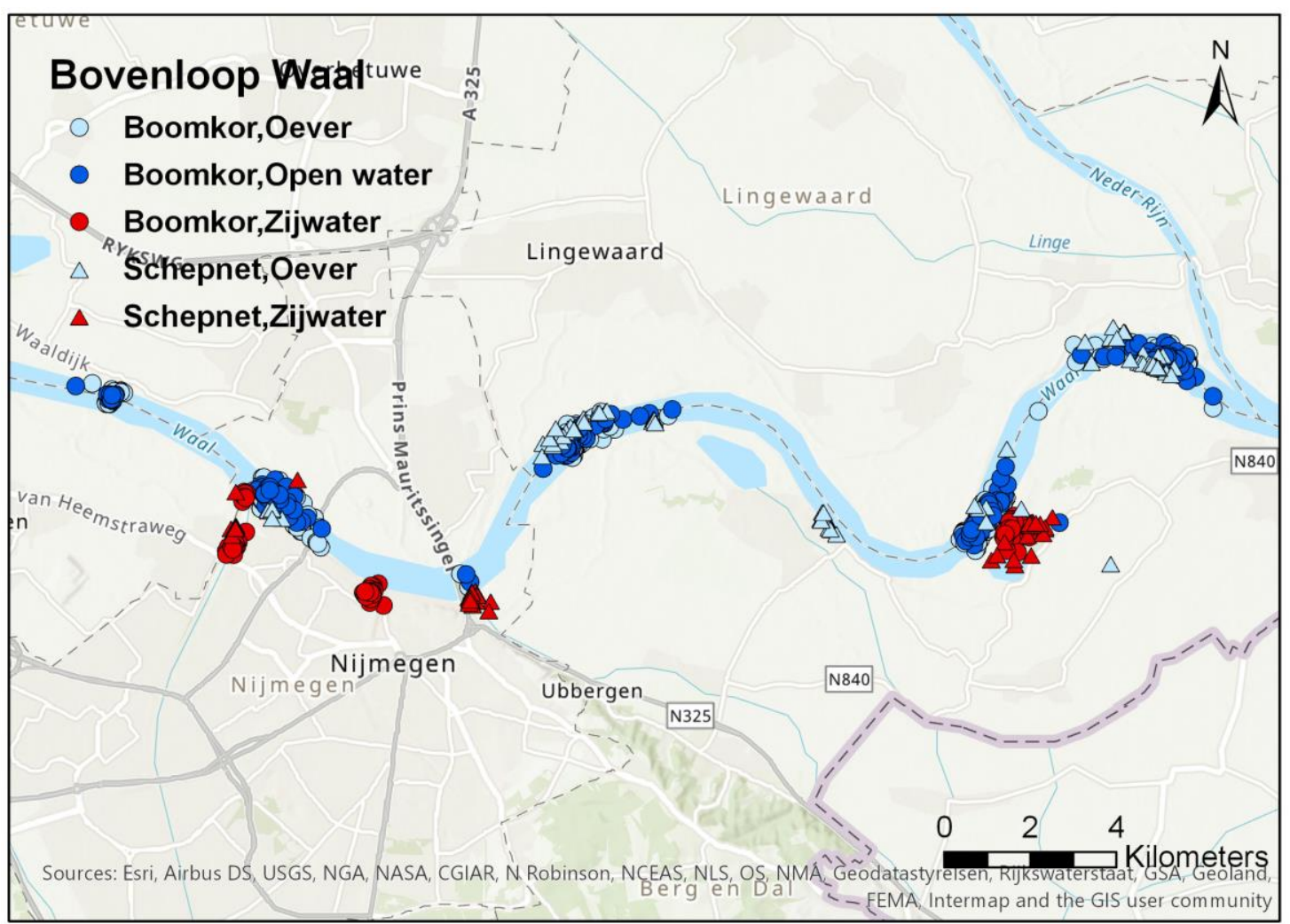

Figuur 2.60 Bemonsteringslocaties van de actieve monitoring in de Bovenloop Waal van 1997-2019 per tuig per habitat.

\subsubsection{Bovenloop Waal hoofdstroom (open water en oeverzone)}

De Bovenloop Waal wordt sinds 1997 ieder jaar in het voorjaar met de boomkor en het elektroschepnet bemonsterd. In de periode 1997-2004 werd dit gebied in maart en april bemonsterd, vanaf 2005 meestal alleen in maart (behalve in 2011 en 2012, toen er weer in maart en april werd bemonsterd). Vanwege de verhoogde waterstand zijn in 2019 veel trajecten verplaatst, verkort of zelfs vervallen. Er zijn veel nulvangsten gedaan. Hiermee is naar verwachting geen representatief beeld verkregen van de visstand in 2019.

De tien meest algemene soorten in de hoofdstroom van de Bovenloop Waal voor de gehele periode 1997-2019 zijn zwartbekgrondel, snoekbaars, rivierprik, kolblei, Europese meerval, brasem, winde, blankvoorn, barbeel en aal. Deze omvatten meer dan $92 \%$ van het totale gemiddelde aantal en biomassa voor zowel de vangsten met de boomkor als het schepnet (Bijlage 22). Dit percentage is relatief laag vergeleken met de overige watersystemen wat betekent dat er een relatief hoge diversiteit aan vissoorten is.

In het open water en langs de oever (boomkor) zijn blankvoorn, brasem, kolblei en winde de dominante soorten, zowel qua aantal als qua biomassa (Figuur 2.61 boven). De laatste acht jaar zijn de hoeveelheden van deze soorten sterk afgenomen, hoewel er in 2017 en 2018 wat meer blankvoorn en brasem werd gevangen. Vergeleken met andere watersystemen is er een aantal opvallende soorten die hier algemeen zijn en in veel andere watersystemen niet, zoals de barbeel, rivierprik en Europese meerval. Dit is ook een van de weinige watersystemen waarbij baars juist níet algemeen is. Barbelen werden voorheen regelmatig gevangen, maar sinds 2011 is er een sterke afname (zie 3.2.2). De Europese meerval werd daarentegen voor het eerst in 2005 hier gevangen en neemt sindsdien qua biomassa toe. Verder valt op dat ook hier de invasieve zwartbekgrondel sinds 2011 regelmatig wordt gevangen. Het zou erg interessant zijn om te onderzoeken of de afname van de inheemse cypriniden (blankvoorn, brasem, kolblei, winde) en de barbeel het resultaat is van predatie door de Europese meerval (wat wellicht ook het geval is in de Grensmaas, zie 2.8.1) of door predatie van 
eieren/competitie van de zwartbekgrondel (zie Discussie). Het valt op dat in 2019 er qua aantal veel zwartbekgrondels en witvinriviergrondels (valt onder overige soorten) zijn gevangen en dat barbeel de biomassa domineert. Bij deze toenames moet wel in acht worden genomen dat de vangsten van 2019 niet als representatief gezien kunnen worden (zie boven).

Langs de oever (schepnet) was aal (tot 2005) samen met blankvoorn qua aantal de dominante soort (Figuur 2.61 onder). Dit is opvallend, aangezien aal in de schepnetvangsten van andere watersystemen meestal de dominante soort is qua biomassa, en niet qua aantal. Qua biomassa was aal samen met winde ook de dominante soort. In de periode 2005-2009 is er een duidelijke afname geweest van aal maar ook andere soorten in de schepnetvangsten. Vanaf 2010 nemen de vangsten weer toe, hoewel deze dan voornamelijk uit zwartbekgrondel, Europese meerval en brasem bestaan. Net als in het open water wordt er sinds 2012 ook af en toe een Europese meerval gevangen met het schepnet. De laatste twee jaar lijken er weer minder alen voor te komen. Ook hier zien we weer dat de schepnetvangsten in 2018 zeer laag zijn. In 2019 valt een toename van de biomassa van snoekbaars op en de geringe aanwezigheid van de zwartbekgrondel (net zoals in 2018). Voor het schepnet geldt ook dat de representativiteit van de vangsten in 2019 ter discussie staat.

De lengte-frequentieverdelingen per soort, per tuig voor de hoofdstroom en de zijwateren gecombineerd over alle jaren van de monitoring van de Rijn, Bovenloop en Benedenloop Waal gecombineerd zijn hier te vinden: https://wmropendata.wur.nl/site/zoetwatervis/34/waterlichaam/ 

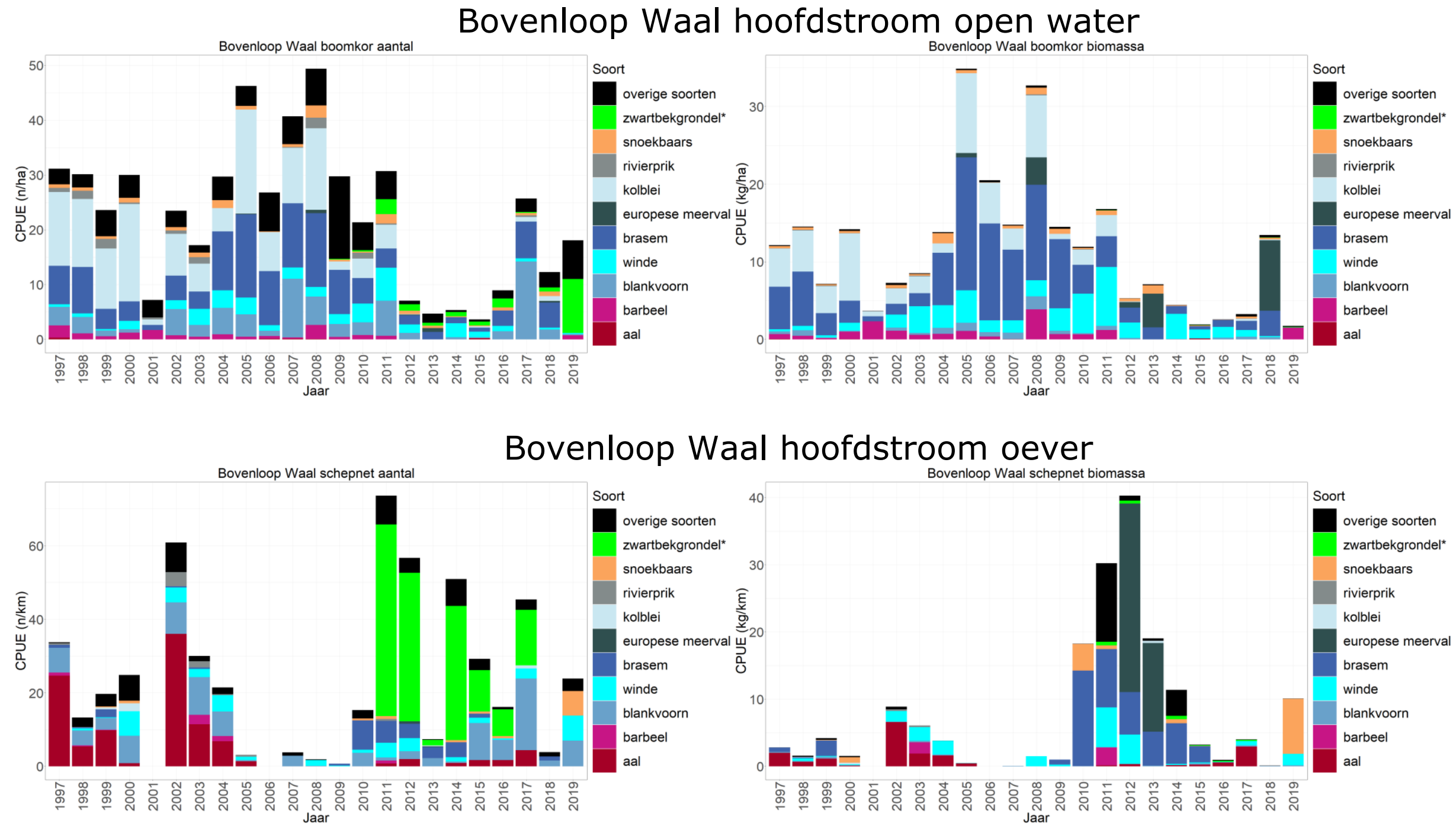

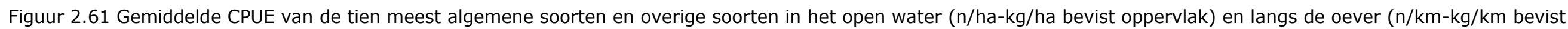
oppervlak) gevangen met een boomkor en elektroschepnet in de hoofdstroom van de Bovenloop Waal tijdens de actieve monitoring van $1997-2019, *=$ exoot. 


\subsubsection{Chinese wolhandkrab}

De Chinese wolhandkrab wordt regelmatig gevangen in de hoofdstroom van de Bovenloop Waal. Vanaf 2005 is er een toename tot 2009 (m.u.v. 2008), waarna de gevangen aantallen weer afnemen. Vanaf 2016 lijken de aantallen weer toe te nemen, maar in 2019 zijn geen wolhandkrabben gevangen. Ook hier is er een periode van vier jaar (2012-2015) waarin nauwelijks wolhandkrabben zijn gevangen (Figuur 2.62).

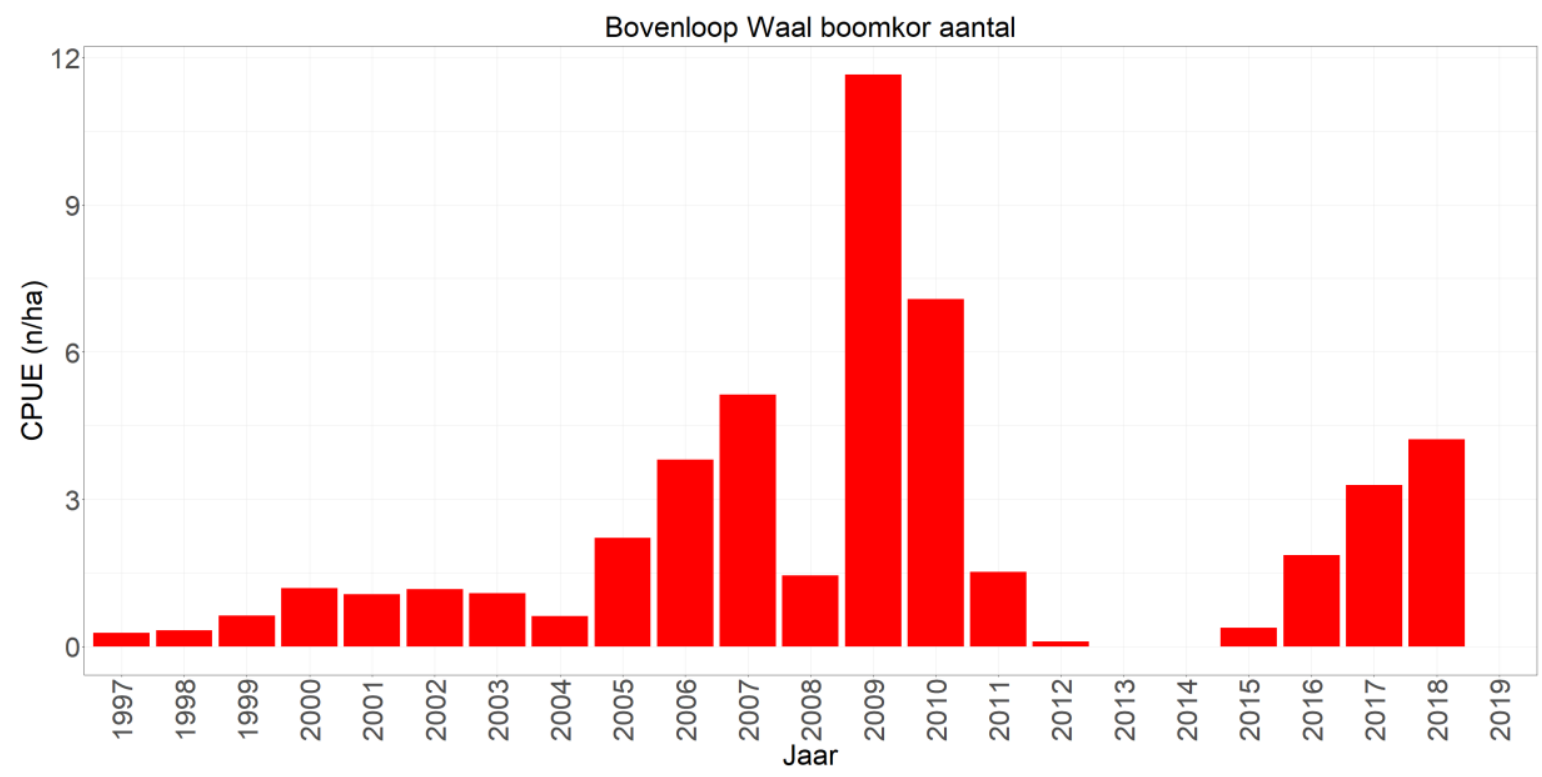

Figuur 2.62 Gemiddelde CPUE (n/ha bevist oppervlak) per jaar van de Chinese wolhandkrab in de hoofdstroom van het open water van de Bovenloop Waal gevangen met de boomkor. 


\subsubsection{Bovenloop Waal zijwateren}

Langs de Bovenloop Waal zijn een inham, haven en twee zijkanalen bemonsterd, in het open water met de boomkor en langs de oever met het schepnet.

De tien meest algemene soorten in deze zijwateren voor de gehele periode 1997-2019 zijn zwartbekgrondel, pos, kolblei, brasem, winde, blankvoorn, baars, snoekbaars, alver en aal. Deze omvatten meer dan $93 \%$ van het totale gemiddelde aantal en biomassa voor zowel de vangsten met de boomkor als het schepnet (Bijlage 23). Qua aantallen is de gevangen dichtheid van de tien meest algemene soorten in de zijwateren hoger dan in de hoofdstroom, qua biomassa zijn deze ongeveer gelijk. Dit is een indicatie dat er in deze zijwateren voornamelijk jonge individuen worden gevangen.

Opvallend is dat de barbeel, rivierprik en Europese Meerval ontbreken in de top tien van de zijwateren, terwijl deze wel tot de top tien behoren in het open water en bij de oever van de hoofdstroom van de Rijn. Hun plaats in de top tien is ingenomen door baars, pos en alver.

Net als in het open water van de hoofdstroom zijn brasem, blankvoorn en kolblei de dominante soorten in de boomkorvangsten, zowel qua aantal als qua biomassa (Figuur 2.63 boven). De totale biomassavangsten leken tot voor kort relatief stabiel maar lijken de laatste paar jaar iets af te nemen. Pos werd in het verleden regelmatig gevangen maar de vangsten daarvan zijn de laatste jaren afgenomen. Snoekbaars wordt ook vrij veel gevangen en lijkt stabiel door de jaren heen.

Langs de oever (schepnet) is blankvoorn qua aantal de dominante soort, samen met brasem, snoekbaars en aal qua biomassa (Figuur 2.63 onder). In de schepnetvangsten zien we lage vangsten van de meeste algemene soorten in de laatste jaren met als dieptepunt de laatste twee jaren. De biomassa van overige soorten bestaat voornamelijk uit snoek. Deze werd de laatste jaren overigens niet gevangen. 


\section{Bovenloop Waal zijwateren open water}
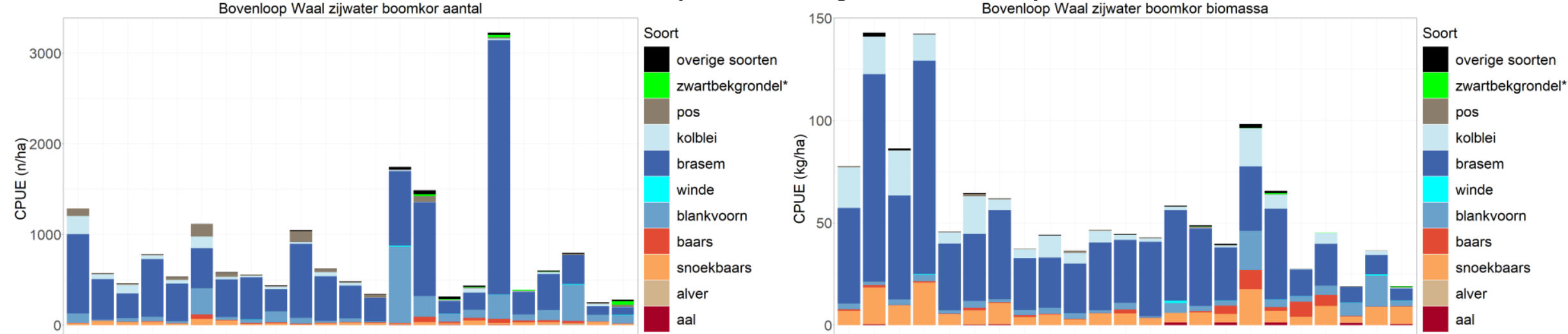

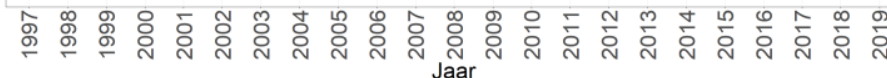

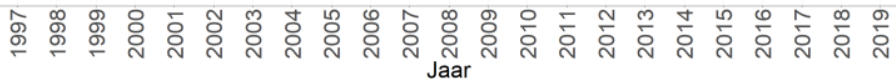

\section{Bovenloop Waal zijwateren oever}
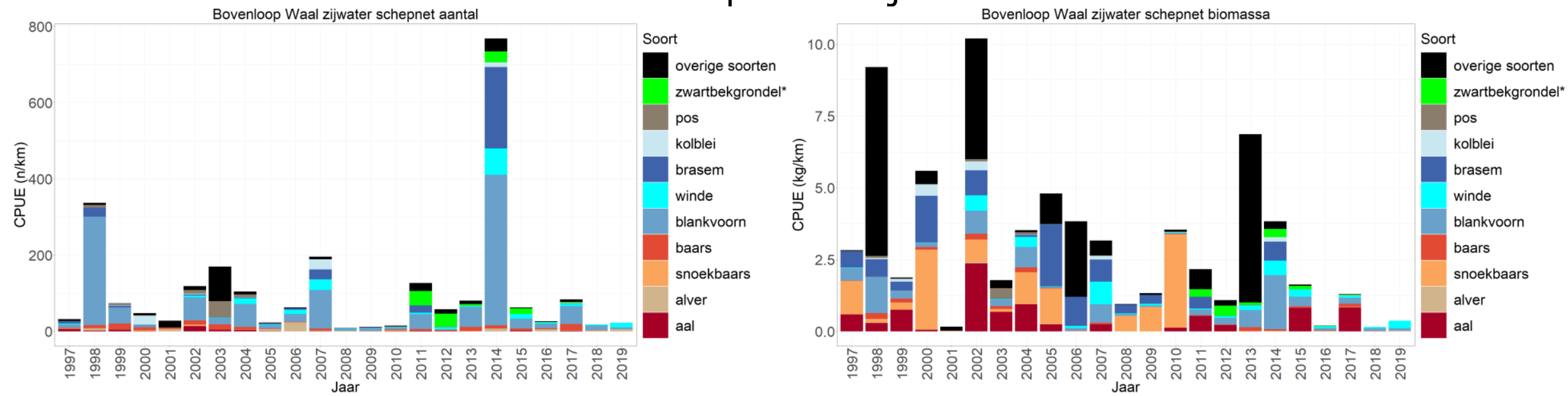

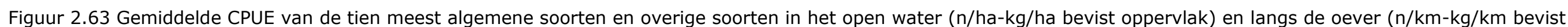
oppervlak) gevangen met een boomkor en elektroschepnet in de zijwateren van de Bovenloop Waal tijdens de actieve monitoring van $1997-2019, *=$ exoot. 


\subsubsection{Chinese wolhandkrab}

Net als in de hoofdstroom wordt de Chinese wolhandkrab regelmatig gevangen in de zijwateren van de Bovenloop Waal. De vangsten fluctueren, met periodes van relatief hoge (2006-2008) en relatief lage (2003-2005) of geen (2012-2016) vangsten. Vanaf 2017 lijken de aantallen weer toe te nemen (Figuur 2.64).

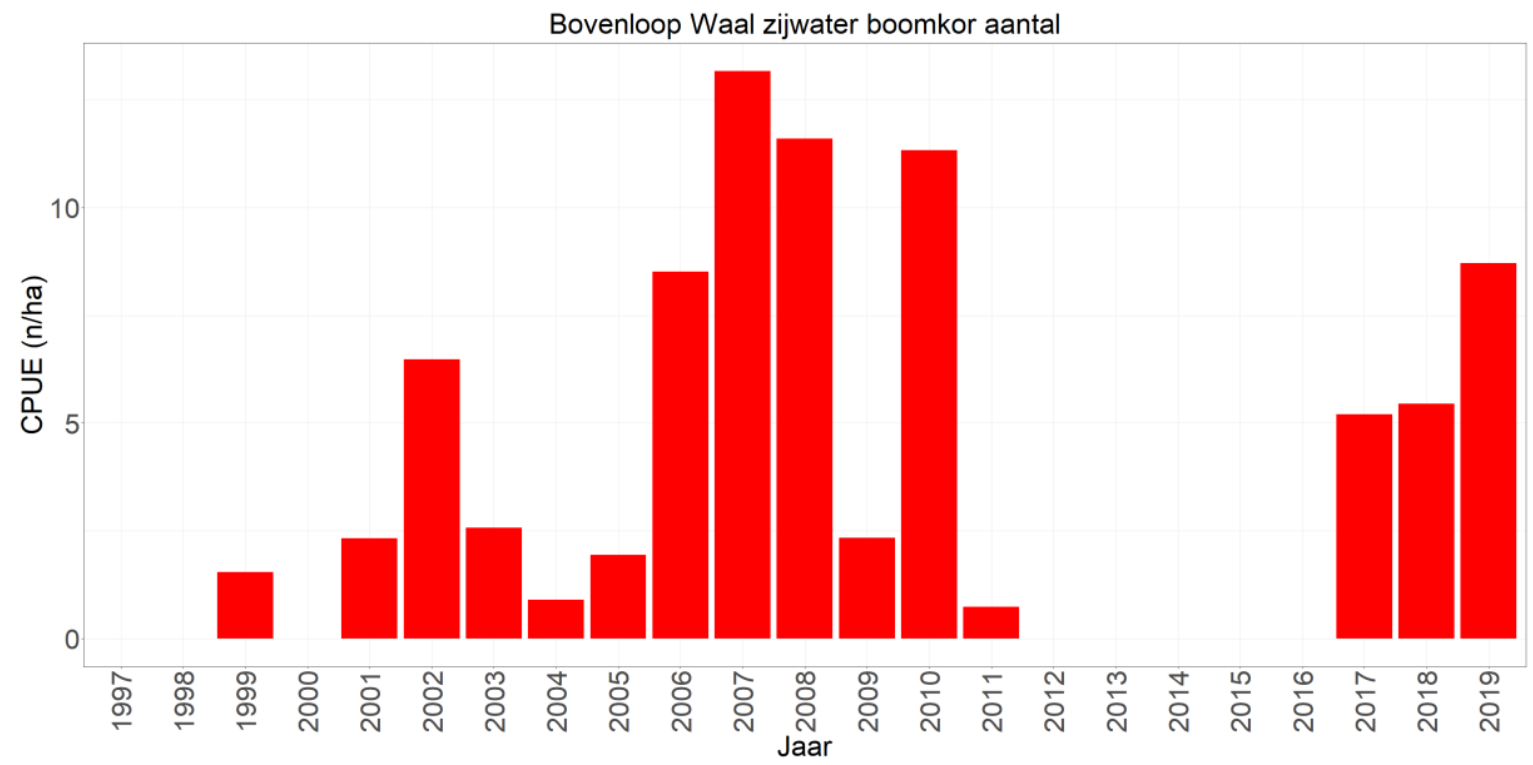

Figuur 2.64 Gemiddelde CPUE (n/ha bevist oppervlak) per jaar van de Chinese wolhandkrab in de zijwateren van de Bovenloop Waal gevangen met de boomkor.

\subsubsection{Aalvangsten}

Voor de aanlandingen van aal voor KRW-lichaam Bovenloop Waal zijn de gegevens van de "Waal Plus" gebruikt (Bijlage 2) en deze zijn weer gegeven in Figuur 2.42. 


\subsection{Benedenloop Nederrijn (Nederrijn, Lek)}

De bemonsteringslocaties over de periode 2013-2019 zijn weergegeven in Figuur 2.65.

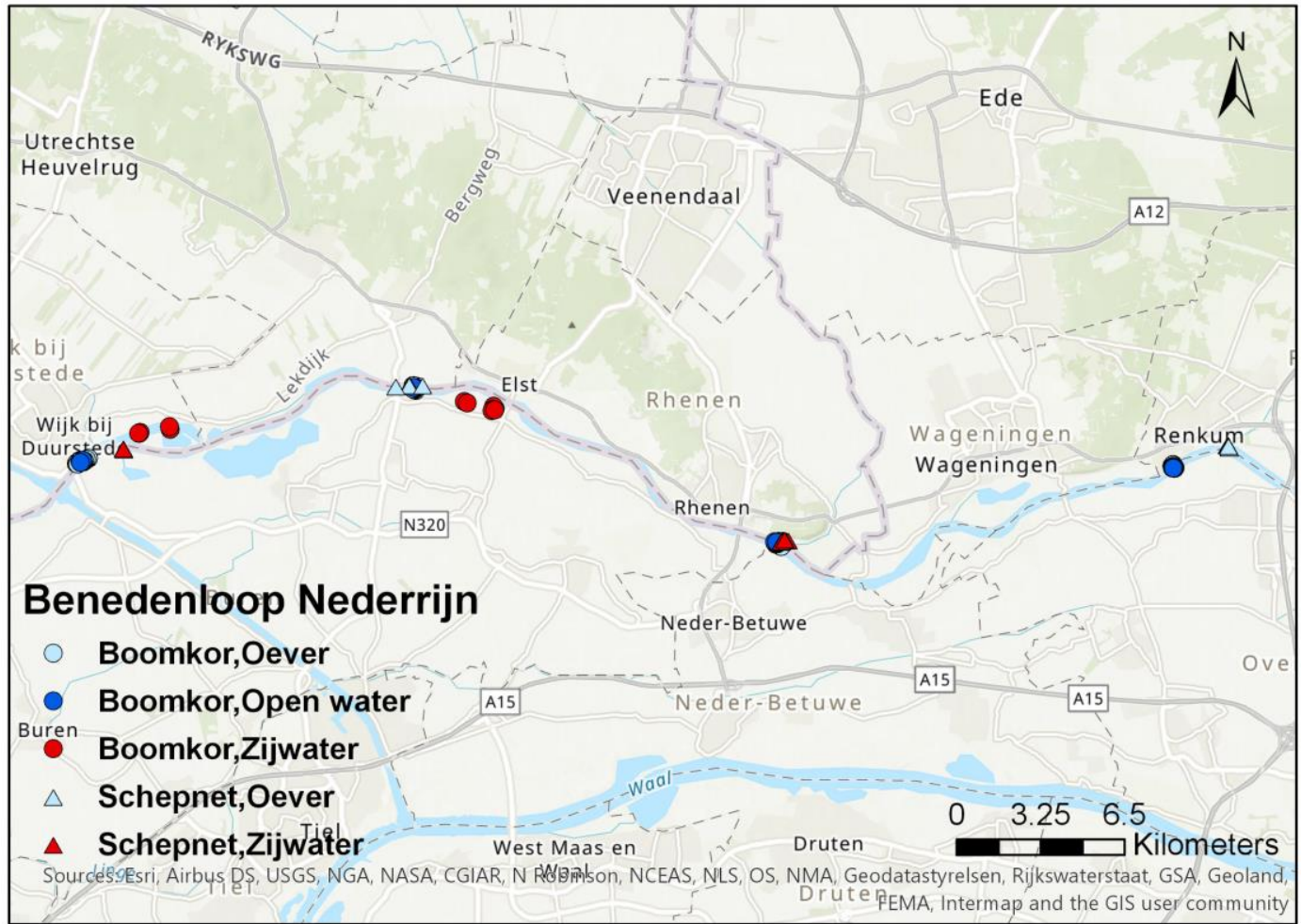

Figuur 2.65 Bemonsteringslocaties van de actieve monitoring in de Benedenloop Nederrijn van 20132019 per tuig per habitat.

\subsubsection{Benedenloop Nederrijn hoofdstroom (open water en oeverzone)}

De Benedenloop Nederrijn wordt sinds 2013 ieder jaar in het voorjaar (maart) met de boomkor en het elektroschepnet bemonsterd.

De tien meest algemene soorten in de hoofdstroom van de Benedenloop Nederrijn voor de gehele periode 2013-2019 zijn: zwartbekgrondel, snoek, brasem, winde, blankvoorn, barbeel, baars, snoekbaars, alver en aal. Deze omvatten meer dan $95 \%$ van het totale gemiddelde aantal en biomassa voor zowel de vangsten met de boomkor als het schepnet (Bijlage 24).

In het open water en langs de oever (boomkor) zijn blankvoorn, brasem en winde de dominante soorten in de boomkorvangsten, zowel qua aantal als qua biomassa (Figuur 2.66 boven). De zwartbekgrondel wordt in aantallen ook veel gevangen. Brasem wordt de laatste drie jaren steeds minder gevangen, terwijl de blankvoornvangsten sterk fluctueren. De invasieve Pontische stroomgrondel wordt qua aantal ook relatief veel gevangen (valt onder overige soorten). In 2018 en 2019 is te zien dat de vangsten voor alle soorten opvallend laag zijn, behalve voor de biomassa van karper (valt onder overige soorten). In 2019 is baars relatief veel gevangen en is daardoor de dominante soort. Hoewel de water temperatuur in 2018 en 2019 vrij laag was (respectievelijk $5^{\circ} \mathrm{C}$ en $8^{\circ} \mathrm{C}$ ), is de watertemperatuur tijdens de bemonstering vanaf 2013 nooit boven de $8^{\circ} \mathrm{C}$ geweest. Watertemperatuur is dus niet een (sluitende) verklaring voor de lage vangsten van de afgelopen twee jaar.

Langs de oever (schepnet) zijn de invasieve zwartbekgrondel en blankvoorn qua aantal de dominante soorten, qua biomassa zijn dit snoek en aal (Figuur 2.66 onder). De vangsten van alle soorten fluctueren sterk en net als in de boomkorvangsten werd er in 2018 en 2019 opvallend weinig gevangen.

De lengte-frequentieverdelingen per soort, per tuig voor de hoofdstroom en de zijwateren gecombineerd over alle jaren van de monitoring van de Bovenloop en Benedenloop Nederrijn gecombineerd zijn hier te vinden: https://wmropendata.wur.nl/site/zoetwatervis/65/waterlichaam/ 

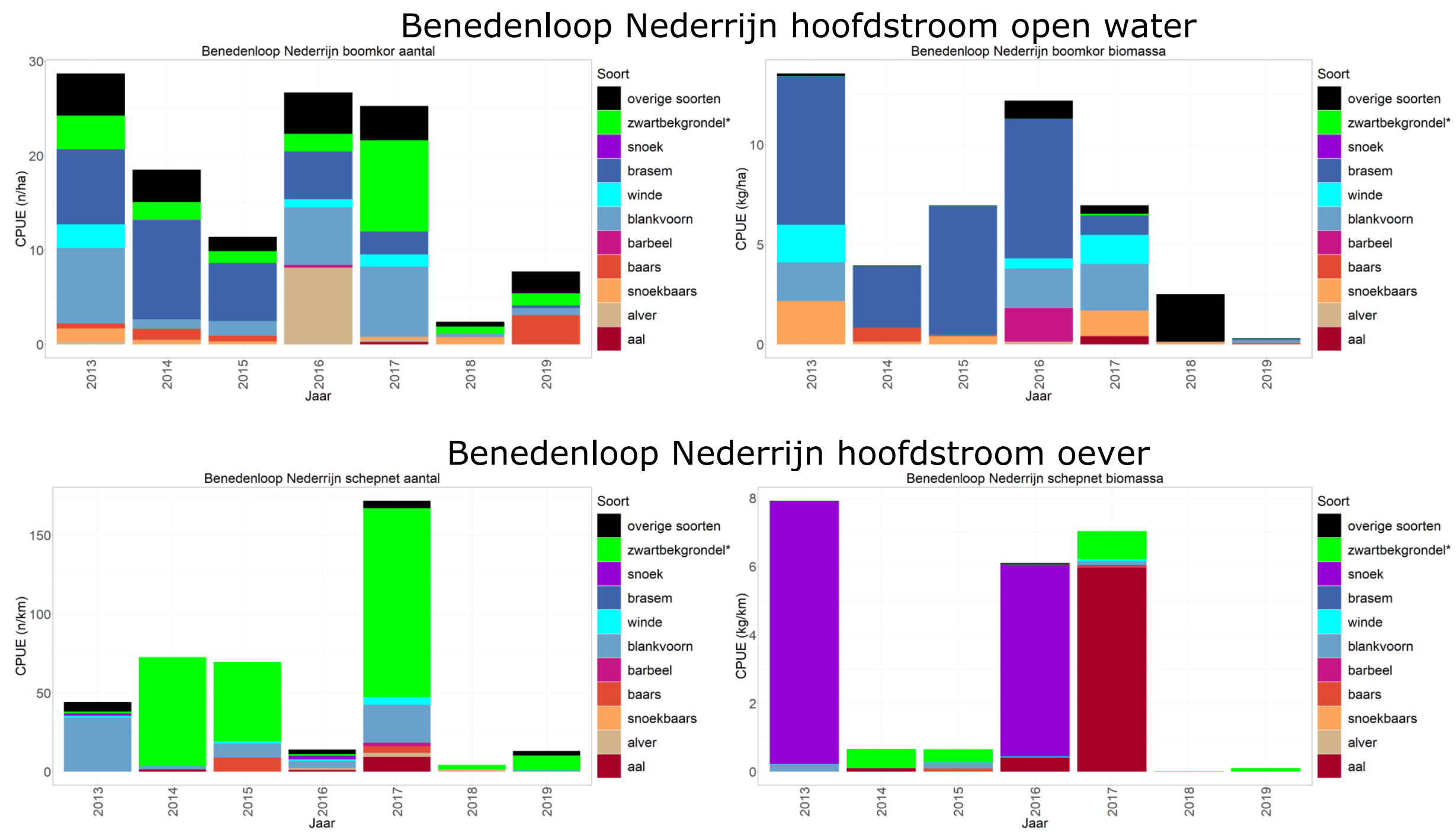

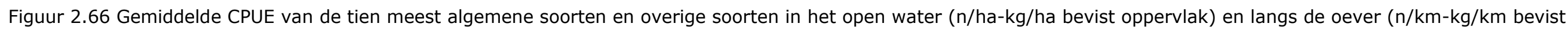

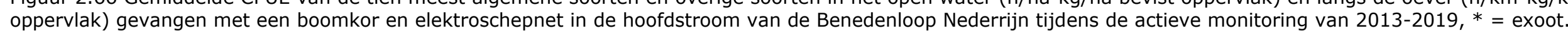




\subsubsection{Chinese wolhandkrab}

De Chinese wolhandkrab wordt sinds 2015 wel eens gevangen in de hoofdstroom van de Benedenloop Nederrijn, met relatief hoge vangsten in 2016. In 2019 zijn geen wolhandkrabben gevangen (Figuur 2.67).

Benedenloop Nederrijn boomkor aantal

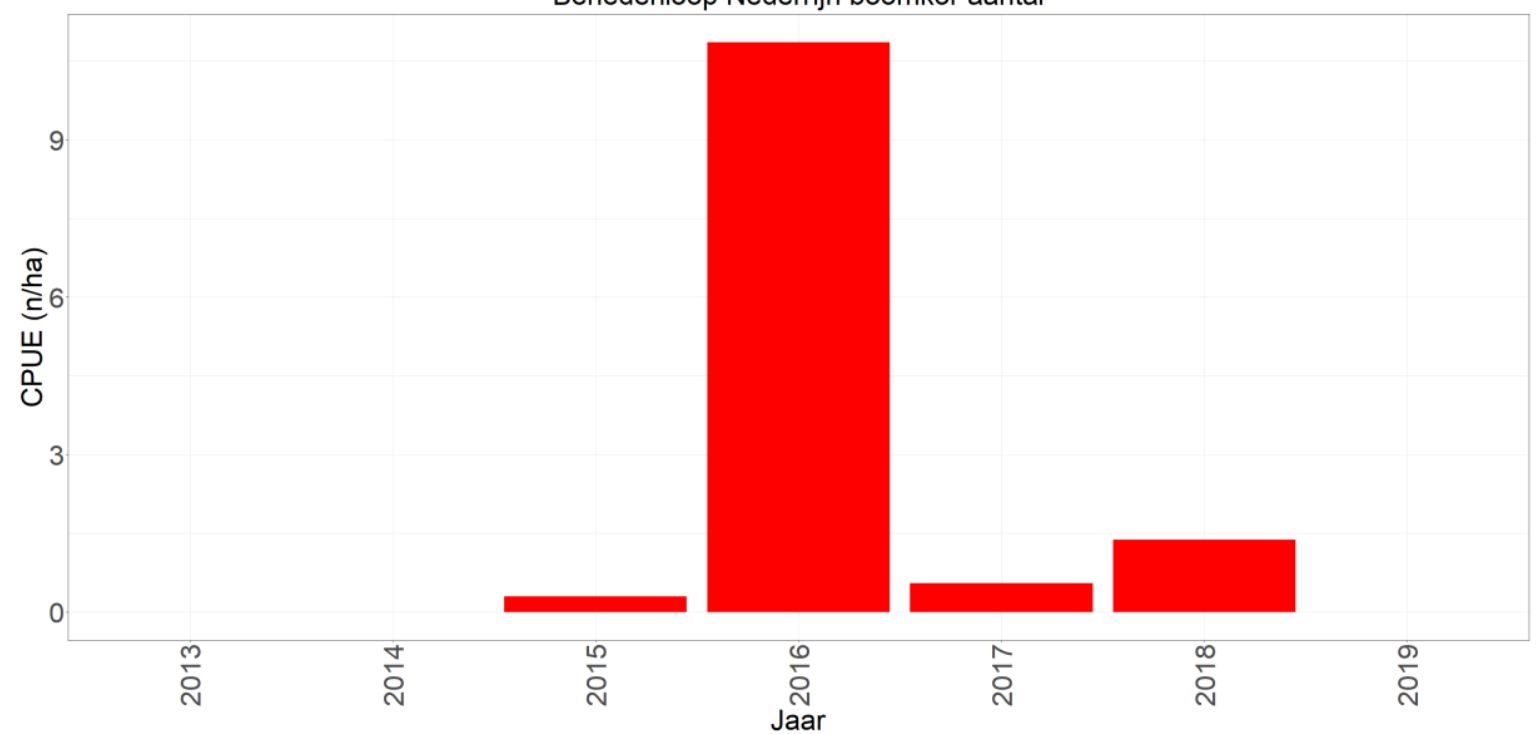

Figuur 2.67 Gemiddelde CPUE (n/ha bevist oppervlak) per jaar van de Chinese wolhandkrab in de hoofdstroom van het open water van de Benedenloop Nederrijn gevangen met de boomkor. 


\subsubsection{Benedenloop Nederrijn zijwateren}

Langs de Benedenloop Nederrijn zijn een zijkanaal en twee inhammen bemonsterd, in het open water met de boomkor en langs de oever met het schepnet.

De tien meest algemene soorten in deze zijwateren voor de gehele periode 2013-2019 zijn: zwartbekgrondel, Pontische stroomgrondel, pos, snoek, kolblei, brasem, blankvoorn, baars, snoekbaars en aal. Deze omvatten meer dan $96 \%$ van het totale gemiddelde aantal en biomassa voor zowel de vangsten met de boomkor als het schepnet (Bijlage 25). Qua aantallen lijkt de dichtheid van de tien meest algemene soorten in de zijwateren hoger dan in de hoofdstroom, qua biomassa lijkt dit ongeveer gelijk te zijn. Dit is een indicatie dat er in deze zijwateren voornamelijk jonge individuen worden gevangen.

Opvallend is dat snoek, barbeel en alver ontbreken in de top tien van de zijwateren, terwijl deze wel tot de top tien behoren in het open water en bij de oever van de hoofdstroom van de Benedenloop Nederrijn. Hun plaats in de top tien is ingenomen door de Pontische stroomgrondel, pos en kolblei.

Net als in het open water van de hoofdstroom zijn brasem en blankvoorn de dominante soorten in de boomkorvangsten, zowel qua aantal als qua biomassa (Figuur 2.68 boven). Snoekbaars en baars worden ook relatief veel gevangen in de zijwateren. De vangsten van alle soorten fluctueren sterk van jaar tot jaar maar lijken de laatste drie jaar iets toe te nemen.

Langs de oever (schepnet) zijn, net als in de hoofdstroom, blankvoorn en de invasieve zwartbekgrondel qua aantal de dominante soorten, samen met snoek (overige soorten), baars en aal qua biomassa (Figuur 2.68 onder). Ook de schepnetvangsten zien we jaarlijks sterk fluctueren, met bijna alleen maar blankvoorn in 2019. 

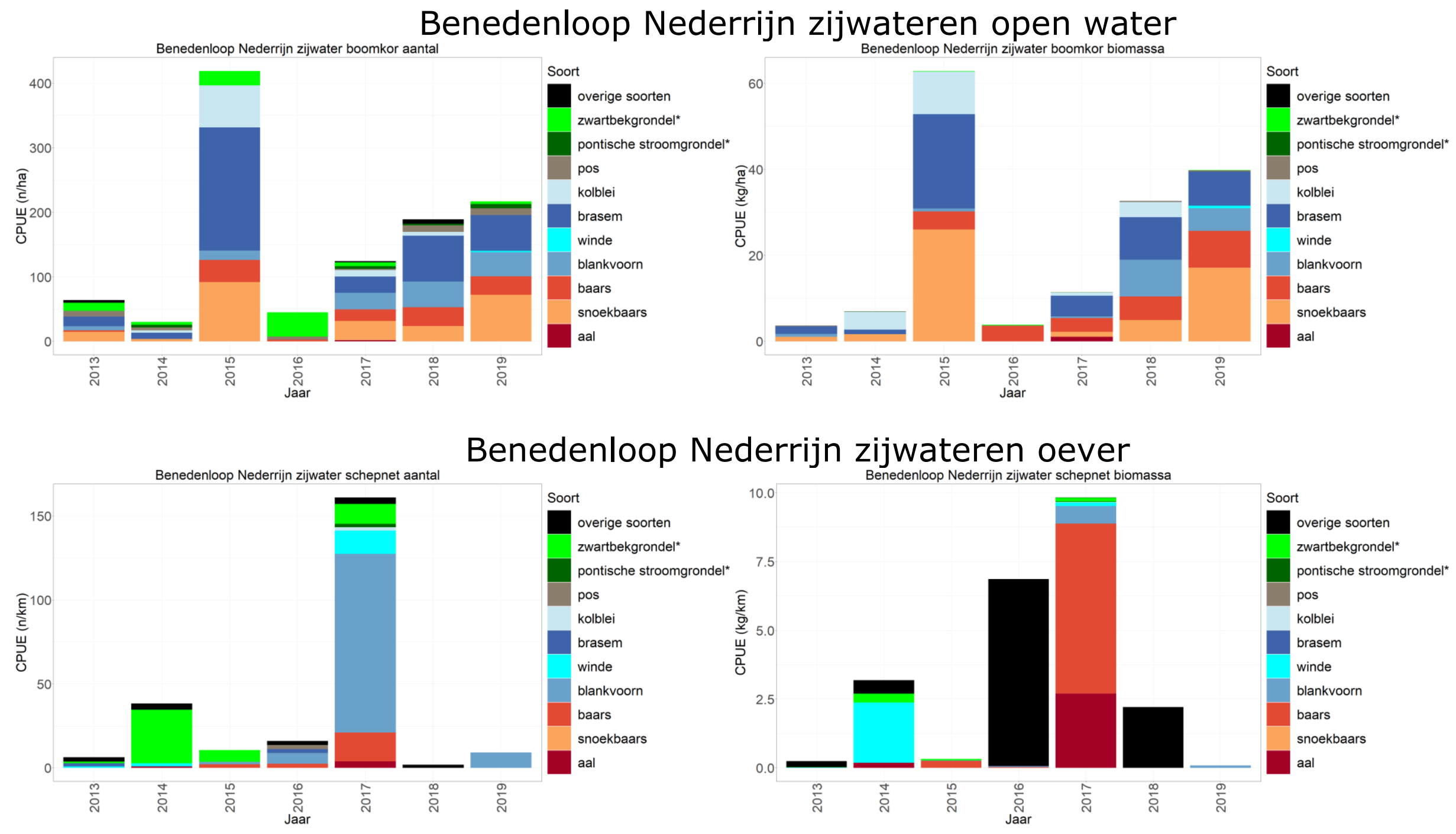

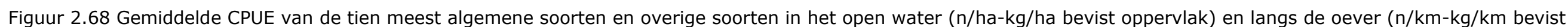
oppervlak) gevangen met een boomkor en elektroschepnet in de zijwateren van de Benedenloop Nederrijn tijdens de actieve monitoring van $2013-2019, *=$ exoot. 


\subsubsection{Chinese wolhandkrab}

De Chinese wolhandkrab is alleen in 2019 gevangen in de zijwateren van de Benedenloop Nederrijn (Figuur 2.69).

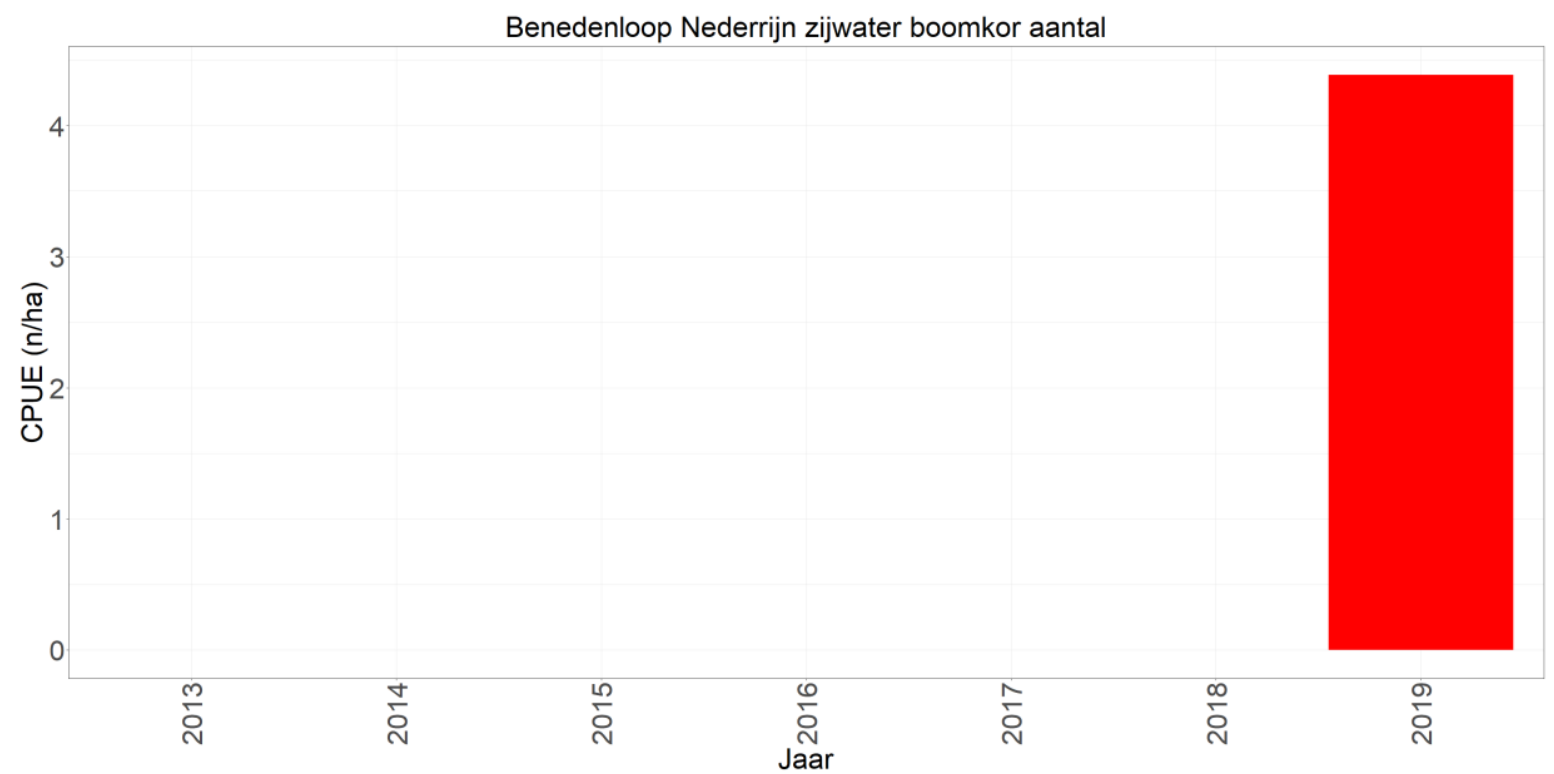

Figuur 2.69 Gemiddelde CPUE (n/ha bevist oppervlak) per jaar van de Chinese wolhandkrab in de zijwateren van de Benedenloop Nederrijn gevangen met de boomkor.

\subsubsection{Aalvangsten}

Voor de aanlandingen van KRW-lichamen Bovenloop Nederrijn, Benedenloop Nederrijn en Bovenloop Gelderse IJssel zijn de gegevens van de "Nederrijn Plus i. o." gebruikt (Bijlage 2). In 2011 is het verbod op aalvisserij in de grote rivieren in verband met te hoge dioxine- en PCB-gehaltes in aal ingegaan, waardoor er alleen aanlandingen uit 2010 zijn. In dat jaar is er 15.342 kilo aan aal aangeland (Bijlage 2). 


\subsection{Benedenloop Waal (Boven Rijn, Waal)}

De bemonsteringslocaties over de periode 2013-2019 zijn weergegeven in Figuur 2.70.

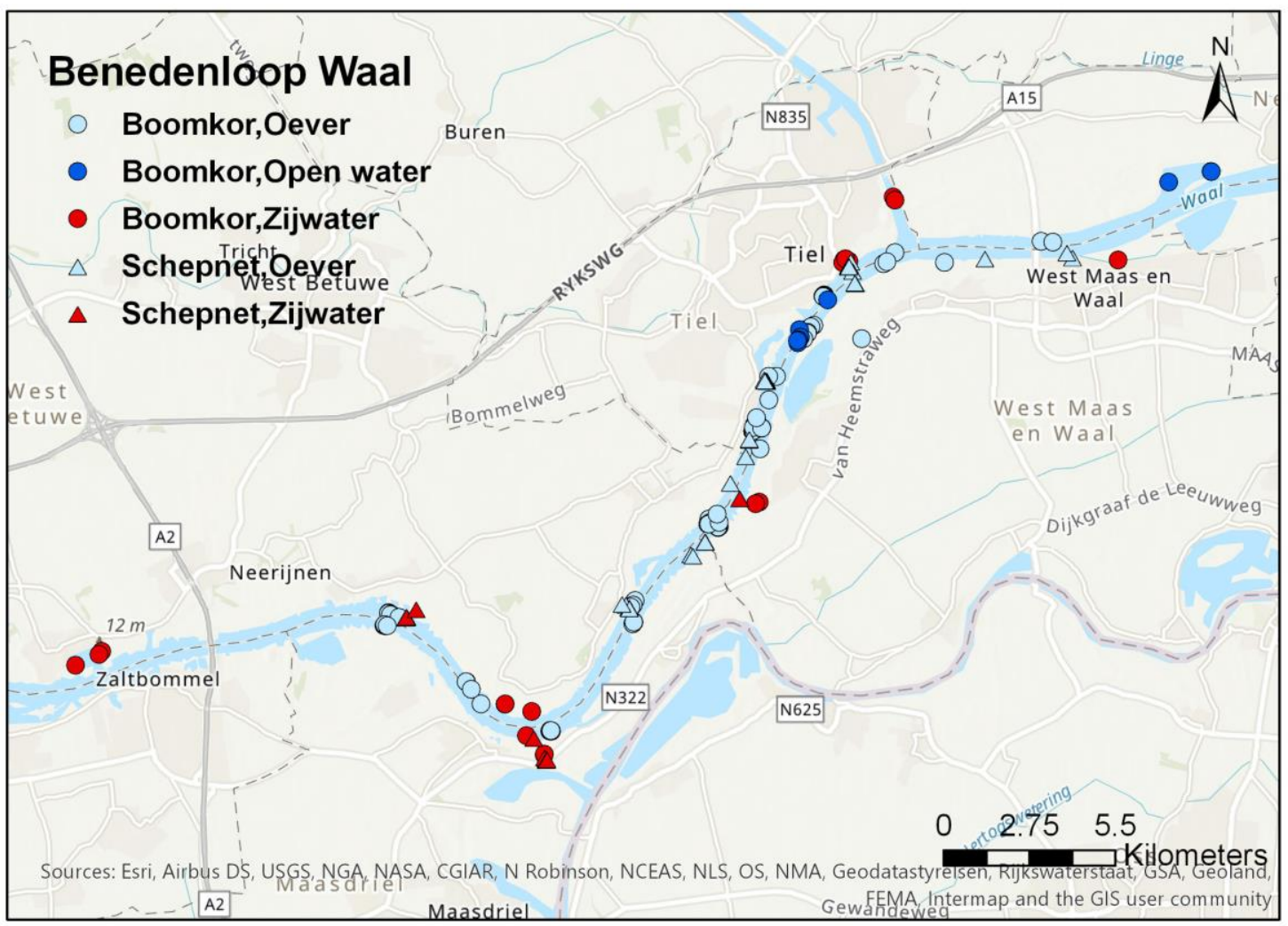

Figuur 2.70 Bemonsteringslocaties van de actieve monitoring in de Benedenloop Waal van 2013-2019 per tuig per habitat.

\subsubsection{Benedenloop Waal hoofdstroom (open water en oeverzone)}

De Benedenloop Waal wordt sinds 2013 ieder jaar in het voorjaar (maart) met de boomkor en het elektroschepnet bemonsterd. Vanwege de verhoogde waterstand zijn in 2019 veel trajecten verplaatst, verkort of zelfs vervallen. Er zijn veel nulvangsten gedaan. Hiermee is in 2019 naar verwachting geen representatief beeld verkregen van de visstand.

De tien meest algemene soorten in de hoofdstroom van de Benedenloop Waal voor de gehele periode 2013-2019 zijn: zwartbekgrondel, Kesslers grondel, kolblei, Donaubrasem, brasem, winde, blankvoorn, baars, snoekbaars en aal. Deze omvatten meer dan 95\% van het totale gemiddelde aantal en biomassa voor zowel de vangsten met de boomkor als het schepnet (Bijlage 26). Ten opzichte van de voorgaande rapportage (van Rijssel et al. 2019a) behoort de Kesslers grondel tot de top tien meest algemene soorten in plaats van de roofblei.

In het open water en langs de oever (boomkor) zijn blankvoorn, brasem en kolblei de dominante soorten zowel qua aantal als qua biomassa (Figuur 2.71 boven). De vangsten fluctueren sterk van jaar tot jaar. Snoekbaars leek de laatste jaren wat toe te nemen (maar niet in 2019), ende gevangen biomassa van winde de laatste jaren relatief lager is. Verder valt op dat er drie exoten, de Donaubrasem, de Kesslers grondel en de zwartbekgrondel met enige regelmaat worden gevangen; de zwartbekgrondel voornamelijk in 2019, een opleving die we in veel andere wateren ook zien. De Donaubrasem behoort in geen van de andere KRW-lichamen in de top tien meest algemene soorten. Dit is gedeeltelijk te verklaren doordat er relatief weinig verschillende soorten in de Benedenloop Waal worden gevangen (Bijlage 26). In 2019 zien we dat de biomassa van aal aanzienlijk is toegenomen, alhoewel er net als voor de Bovenloop Waal geldt dat 2019 niet als een jaar met representatieve vangsten gezien kan worden.

Langs de oever (schepnet) is blankvoorn samen met de invasieve zwartbekgrondel qua aantal de dominante soort (Figuur 2.71 onder). De vangsten van beide soorten fluctueren sterk van jaar tot 
jaar. Qua biomassa zien we dat aal de dominante soort is in de vangsten, behalve in de laatste jaren. Ook hier zien we dat er in 2018 en 2019 opvallend weinig is gevangen met het schepnet, maar ook hier geldt weer de representativiteit van de vangsten van 2019 ter discussie staat.

De lengte-frequentieverdelingen per soort, per tuig voor de hoofdstroom en de zijwateren gecombineerd over alle jaren van de monitoring van de Rijn, Bovenloop en Benedenloop Waal gecombineerd zijn hier te vinden: https://wmropendata.wur.nl/site/zoetwatervis/34/waterlichaam/ 


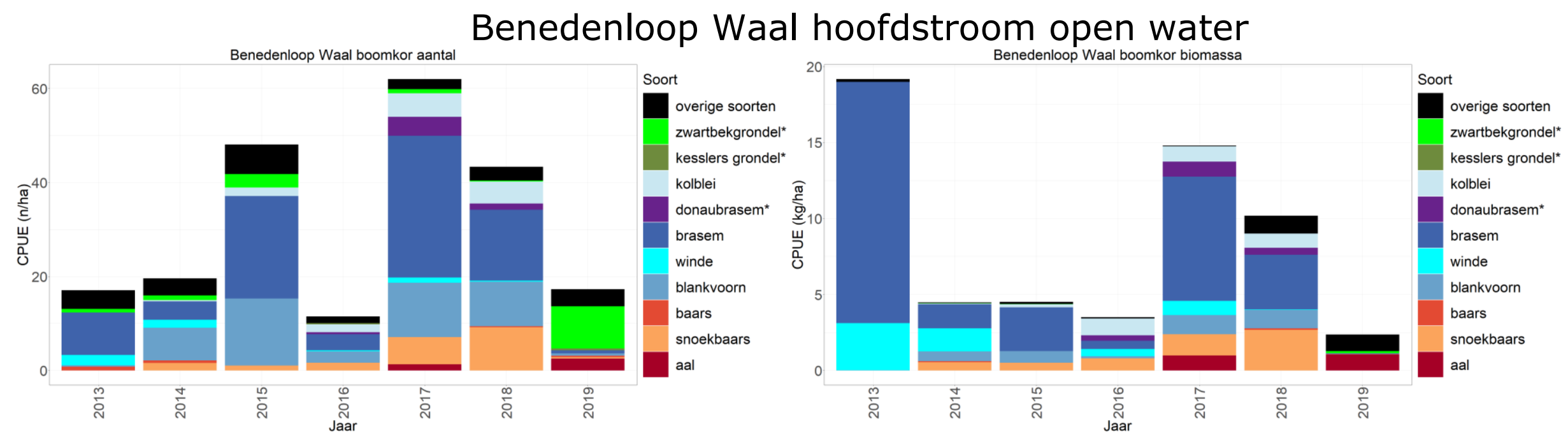

\section{Benedenloop Waal hoofdstroom oever}

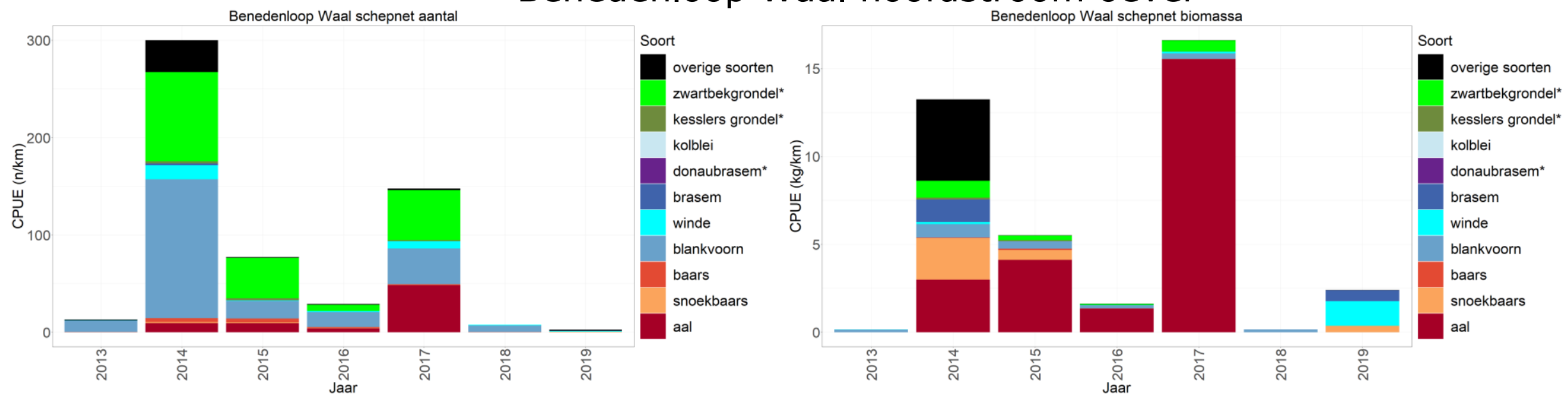

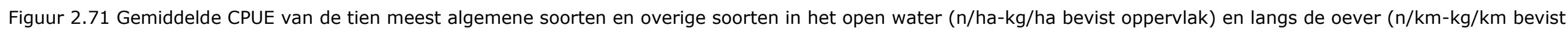
oppervlak) gevangen met een boomkor en elektroschepnet in de hoofdstroom van de Benedenloop Waal tijdens de actieve monitoring van $2013-2019, *=$ exoot. 


\subsubsection{Chinese wolhandkrab}

De Chinese wolhandkrab wordt sinds 2015 regelmatig gevangen in de hoofdstroom van de Benedenloop Waal, de vangsten waren in 2018 en 2019 relatief laag. (Figuur 2.72).

Figuur 2.72 Gemiddelde CPUE (n/ha bevist oppervlak) per jaar van de Chinese wolhandkrab in de Benedenloop Waal boomkor aantal

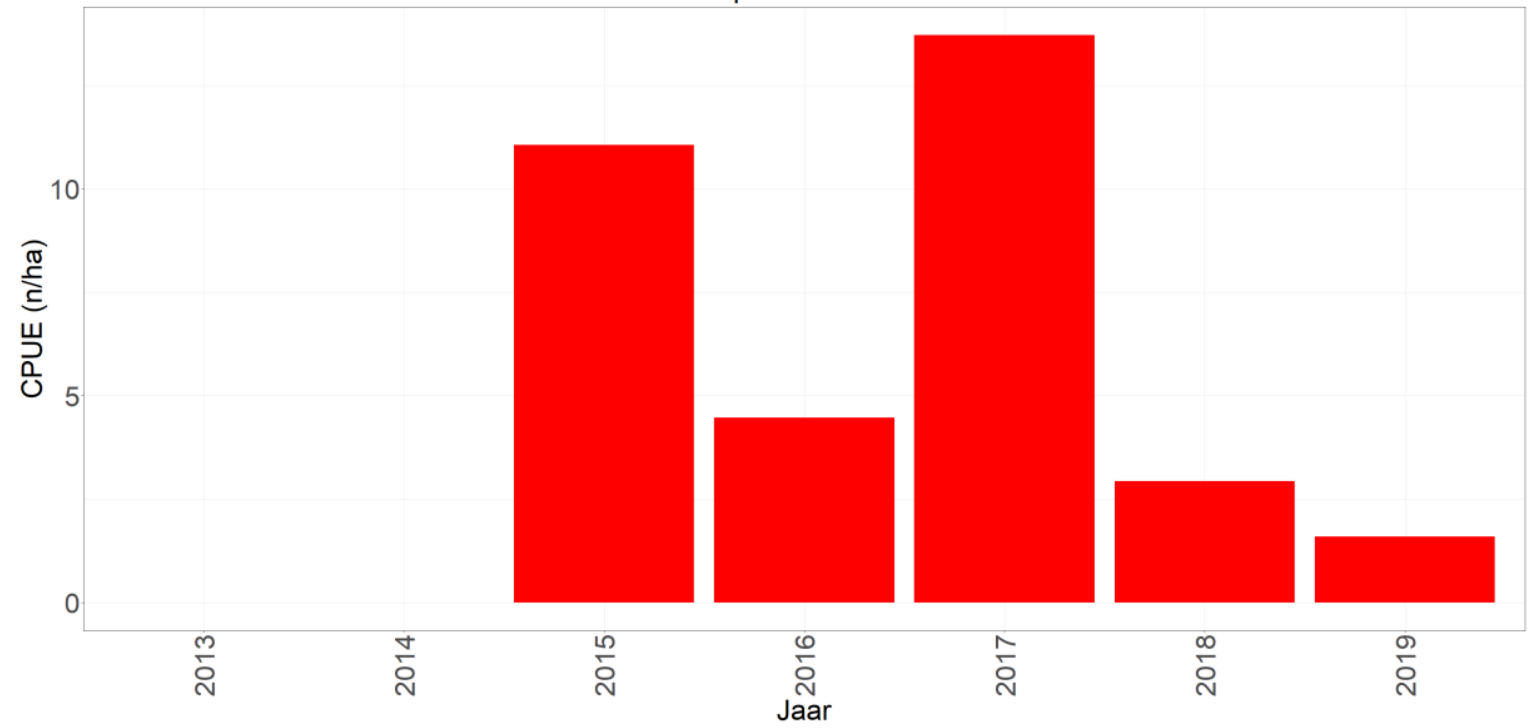

hoofdstroom van het open water van de Benedenloop Waal gevangen met de boomkor. 


\subsubsection{Benedenloop Waal zijwateren}

Langs de Benedenloop Waal zijn vijf inhammen, een vluchthaven en twee zijkanalen bemonsterd, in het open water met de boomkor en langs de oever met het schepnet.

De tien meest algemene soorten in de zijwateren van de Benedenloop Waal voor de gehele periode 2013-2019 zijn zwartbekgrondel, roofblei, kolblei, brasem, winde, blankvoorn, baars, snoekbaars, alver en aal. Deze omvatten meer dan $99 \%$ van het totale gemiddelde aantal en biomassa voor zowel de vangsten met de boomkor als het schepnet (Bijlage 27). Qua aantallen lijkt de dichtheid van de tien meest algemene soorten in de zijwateren hoger dan in de hoofdstroom, qua biomassa lijkt dit ongeveer gelijk te zijn. Dit is een indicatie dat er in deze zijwateren voornamelijk jonge individuen worden gevangen.

Opvallend is dat de Donaubrasem ontbreekt in de top tien van de zijwateren, terwijl deze wel tot de top tien behoort in het open water en bij de oever van de hoofdstroom van de Benedenloop Waal. Zijn plaats in de top tien is ingenomen door de alver.

Net als in het open water van de hoofdstroom zijn brasem, blankvoorn, snoekbaars en kolblei de dominante soorten in de boomkorvangsten, zowel qua aantal als qua biomassa (Figuur 2.73 boven). De vangsten van blankvoorn en brasem lijken de laatste jaren wat af te nemen. De invasieve zwartbekgrondel wordt regelmatig gevangen. De soort leek af te nemen in 2017 en 2018 maar de vangsten zijn in 2019 weer hoger. In 2019 is de witvinriviergrondel ook voor het eerst gevangen in de zijwateren, deze soort werd al wel eerder gevangen in de hoofdstroom.

Langs de oever (schepnet) is blankvoorn qua aantal de dominante soort, samen met winde en aal qua biomassa (Figuur 2.73 onder). Ook in de zijwateren, net als in de hoofdstroom, werd er opvallend weinig gevangen in 2018 en 2019 met het schepnet. 


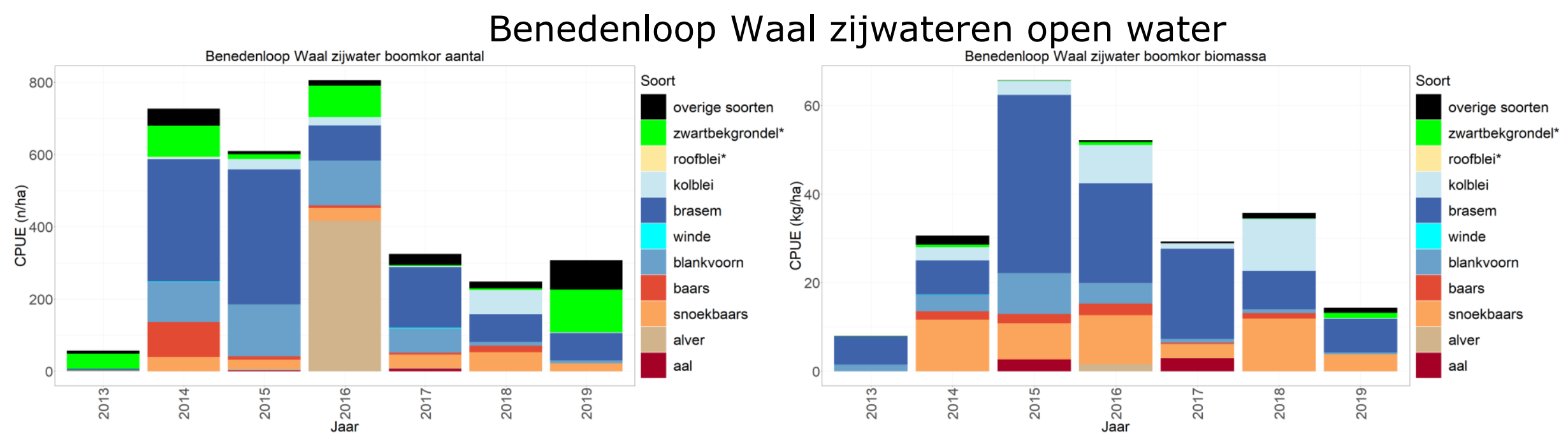

\section{Benedenloop Waal zijwateren oever}
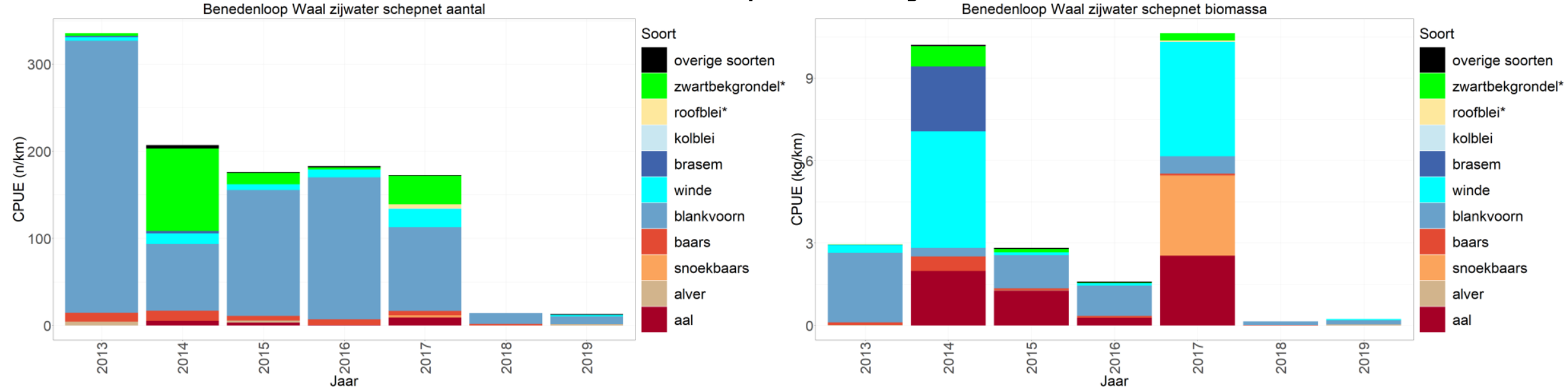

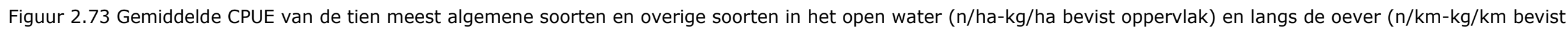
oppervlak) gevangen met een boomkor en elektroschepnet in de zijwateren van de Benedenloop Waal tijdens de actieve monitoring van $2013-2019, *$ exoot. 


\subsubsection{Chinese wolhandkrab}

De Chinese wolhandkrab wordt sinds 2016 regelmatig gevangen in de zijwateren van de Benedenloop Waal. In 2019 zijn er extreem veel (kleine) wolhandkrabben gevangen (Figuur 2.74).

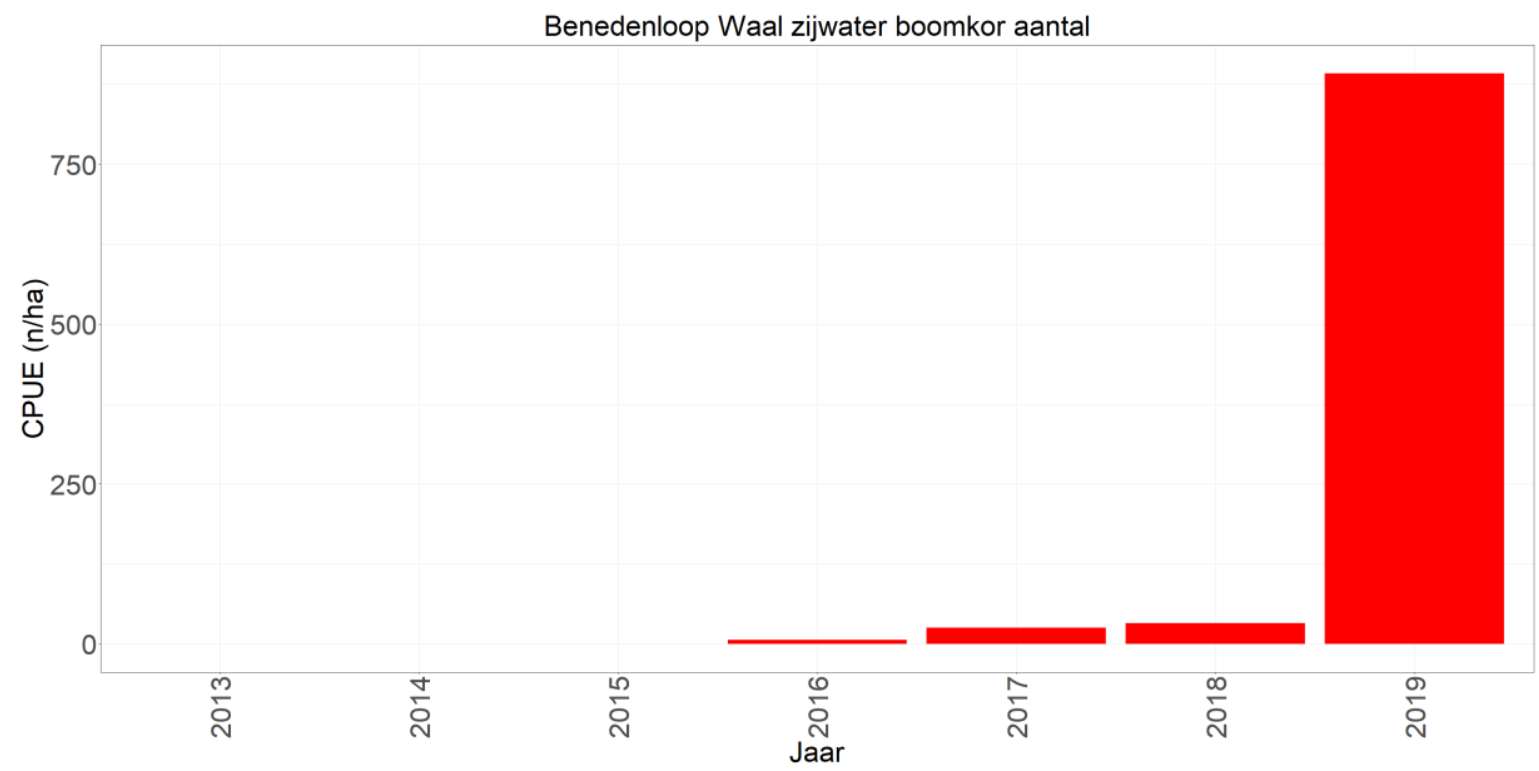

Figuur 2.74 Gemiddelde CPUE (n/ha bevist oppervlak) per jaar van de Chinese wolhandkrab in de zijwateren van de Benedenloop Waal gevangen met de boomkor.

\subsubsection{Aalvangsten}

Voor de aanlandingen van aal voor KRW-lichaam Benedenloop Waal zijn de gegevens van de "Waal Plus" gebruikt (Bijlage 2) en deze zijn weer gegeven in Figuur 2.42. 


\subsection{Getijden Lek (Oude Maas)}

De bemonsteringslocaties over de periode 1997-2019 zijn weergegeven in Figuur 2.75.

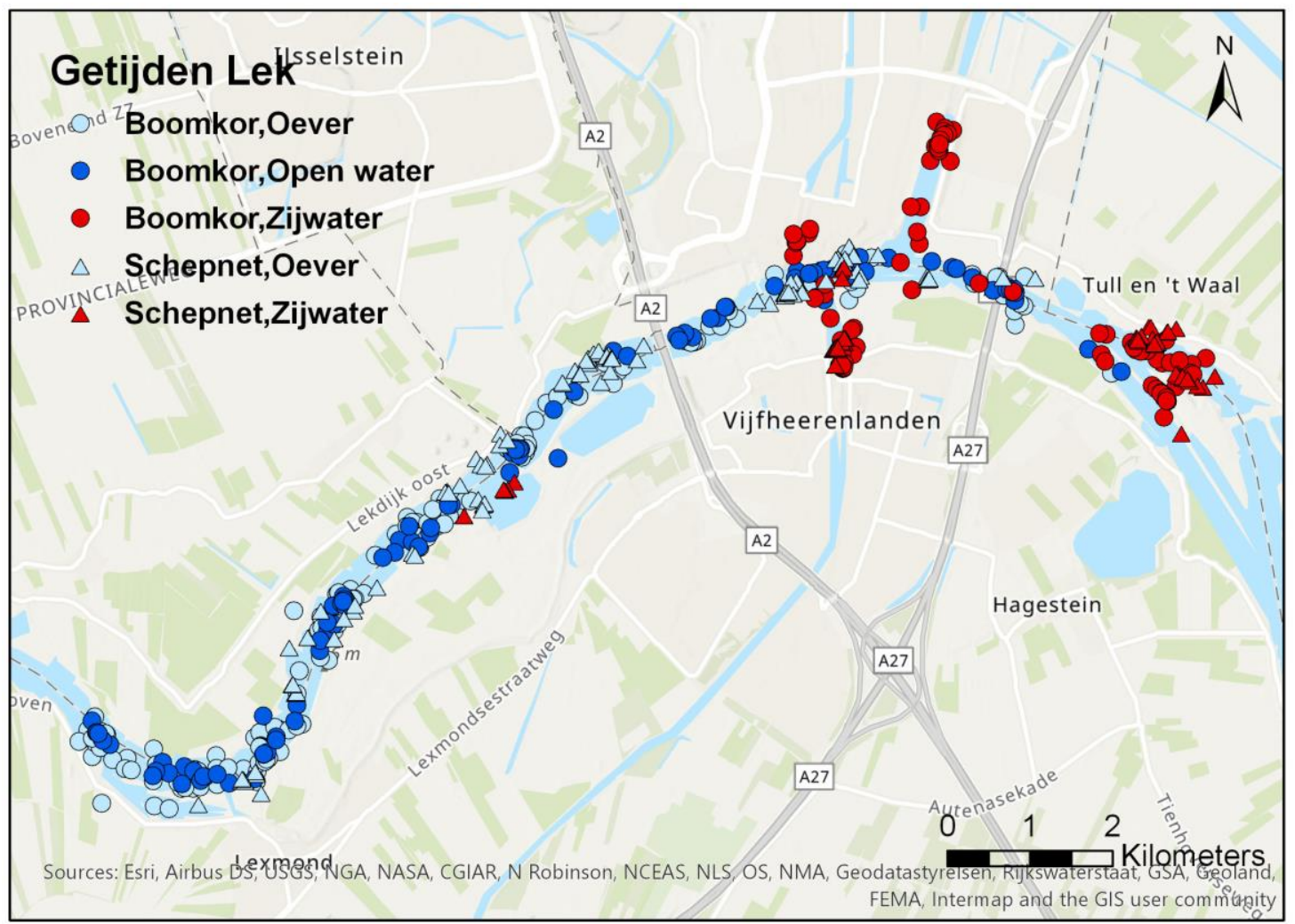

Figuur 2.75 Bemonsteringslocaties van de actieve monitoring in de Getijden Lek van 1997-2019 per tuig per habitat.

\subsubsection{Getijden Lek hoofdstroom (open water en oeverzone)}

De Getijden Lek wordt sinds 1997 ieder jaar in het najaar met de boomkor en het elektroschepnet bemonsterd. In de periode 1997-2012 werd dit gebied in oktober en/of november bemonsterd, vanaf 2013 alleen in oktober.

De tien meest algemene soorten in de hoofdstroom van de Getijden Lek voor de gehele periode 19972019 zijn zwartbekgrondel, Pontische stroomgrondel, kolblei, brasem, bot, winde, blankvoorn, baars, snoekbaars en aal. Deze omvatten meer dan $95 \%$ van het totale gemiddelde aantal en biomassa voor zowel de vangsten met de boomkor als het schepnet (Bijlage 28).

In het open water en langs de oever (boomkor) zijn bot, blankvoorn, brasem en kolblei de dominante soorten zowel qua aantal als qua biomassa (Figuur 2.76 boven). De laatste tien jaar zijn de hoeveelheden van brasem en kolblei sterk afgenomen. Opvallend is dat er qua aantallen vrij veel bot wordt gevangen, waarbij de aantallen sterk fluctueren. Er worden ook vrij hoge aantallen bot gevangen in de jaren dat er ook veel zwartbekgrondels en Pontische stroomgrondels (beide exoten) worden gevangen (vanaf 2009). Dit impliceert dat bot wellicht niet concurreert voor voedsel en/of habitat met deze invasieve grondel soorten, zoals deze dit wellicht wel doen voor andere benthische soorten zoals pos en bermpjes. De hoeveelheden van deze invasieve grondels lijken (sinds 2009) relatief stabiel. Verder wordt er relatief veel snoekbaars gevangen. In tegenstelling tot veel andere wateren wordt er in de Getijden Lek in 2018 wel relatief veel vis gevangen, wellicht heeft dit te maken met het verschil in jaargetijde van de vangsten. Bovenstaande wateren zijn in het voorjaar bemonsterd, terwijl de Getijden Lek in het najaar wordt bemonsterd. De totaal gevangen biomassa van 2019 is daarentegen weer relatief laag ten opzichte van 2018 en de bovenstaande wateren.

Langs de oever (schepnet) zijn blankvoorn en winde qua aantal de dominante soorten (Figuur 2.76 onder). Vanaf 2003 worden er echter relatief veel windes en weinig blankvoorns gevangen. Vanaf 2009 worden er ook relatief veel zwartbekgrondels gevangen, met weer wat lagere vangsten eind 
2016-2018. Qua biomassa zijn brasem, aal en winde de dominante soorten. Aal wordt sinds 2012 wat meer gevangen, wat mogelijk een effect is van de gesloten visserij op de rivieren sinds 2011. In 2019 is de meeste aal gevangen sinds het begin van de monitoring.

De lengte-frequentieverdelingen per soort, per tuig voor de hoofdstroom en de zijwateren gecombineerd over alle jaren van de monitoring van de Getijden Lek en de Oude Maas gecombineerd zijn hier te vinden: https://wmropendata.wur.nl/site/zoetwatervis/66/waterlichaam/ 

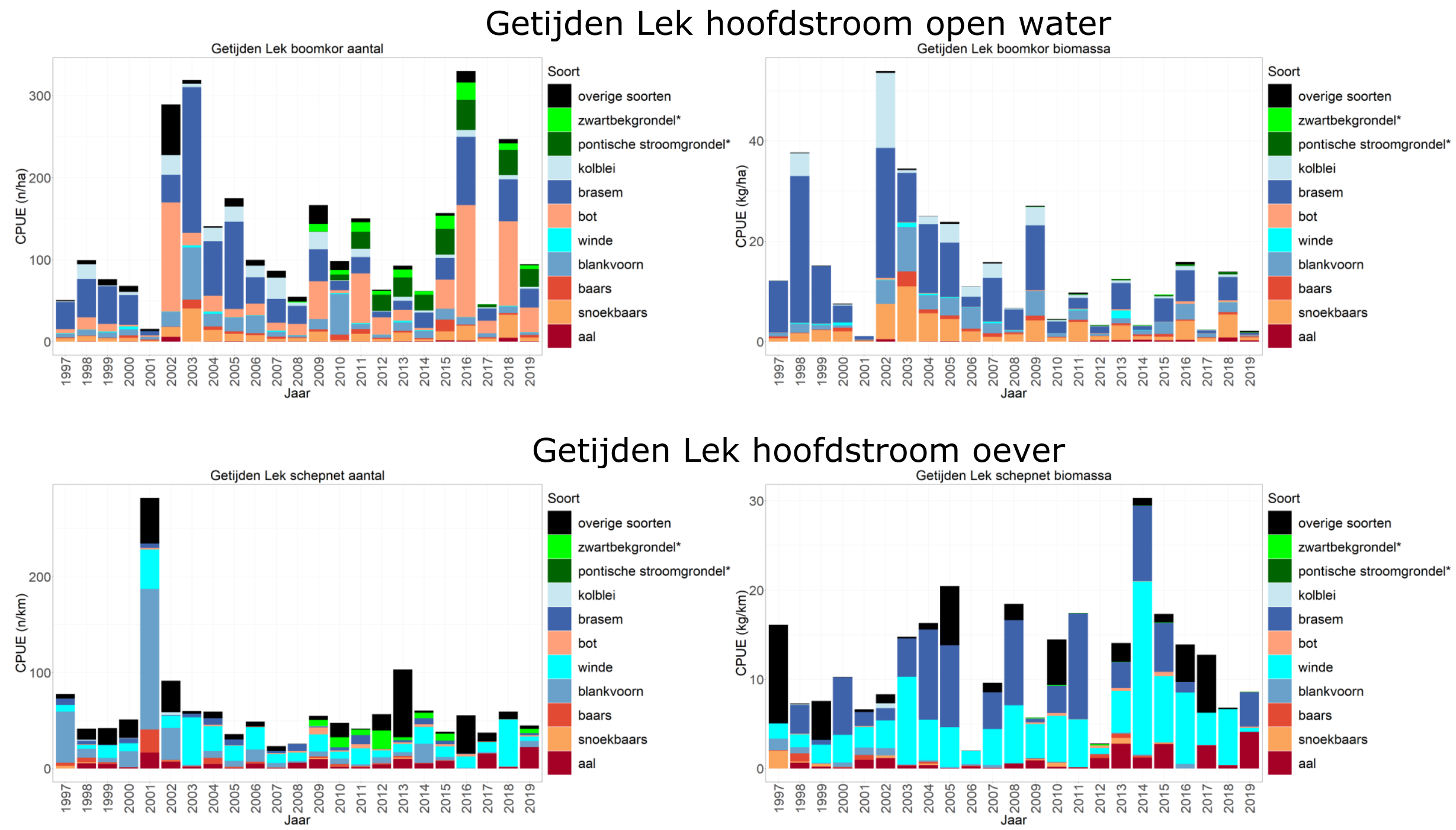

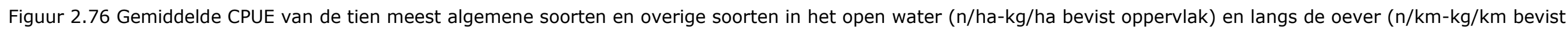
oppervlak) gevangen met een boomkor en elektroschepnet in de hoofdstroom van de Getijden Lek tijdens de actieve monitoring van $1997-2019, *$ exoot. 


\subsubsection{Chinese wolhandkrab}

De Chinese wolhandkrab wordt regelmatig gevangen in de hoofdstroom van de Getijden Lek. De aantallen fluctueren, waarbij in 2013 en 2014 geen wolhandkrabben werken gevangen. In 2016 en 2019 werden juist meer wolhandkrabben gevangen dan voorheen (Figuur 2.77).

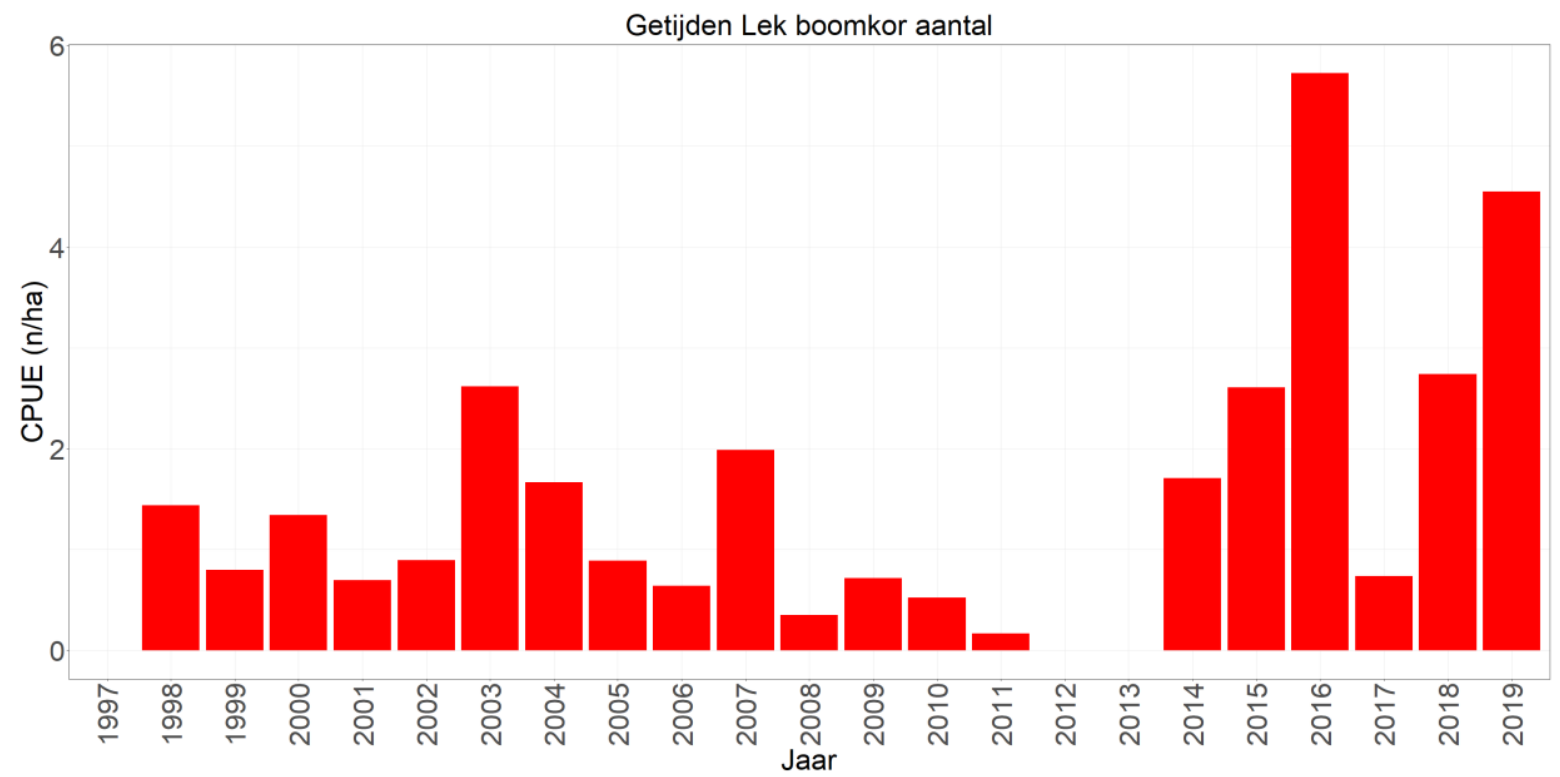

Figuur 2.77 Gemiddelde CPUE ( $\mathrm{n} / \mathrm{ha}$ bevist oppervlak) per jaar van de Chinese wolhandkrab in de hoofdstroom van het open water van de Getijden Lek gevangen met de boomkor. 


\subsubsection{Getijden Lek zijwateren}

Langs de Getijden Lek zijn twee nevengeulen, drie zijkanalen en een jachthaven bemonsterd, in het open water met de boomkor en langs de oever met het schepnet.

De tien meest algemene soorten in de zijwateren van de Getijden Lek voor de gehele periode 19972019 zijn zwartbekgrondel, pos, kolblei, brasem, bot, winde, blankvoorn, baars, snoekbaars en aal. Deze omvatten meer dan $96 \%$ van het totale gemiddelde aantal en biomassa voor zowel de vangsten met de boomkor als het schepnet (Bijlage 29). Ten opzichte van de voorgaande rapportage (van Rijssel et al. 2019a) is karper vervangen door kolblei als een van de tien meest algemene soorten. Qua aantallen in de hoofdstroom lijkt de dichtheid van de tien meest algemene soorten in de zijwateren hoger dan in de hoofdstroom, qua biomassa lijkt dit ongeveer gelijk te zijn. Dit is een indicatie dat er in deze zijwateren voornamelijk jonge individuen worden gevangen.

Opvallend is dat de Pontische stroomgrondel ontbreekt in de top tien van de zijwateren, terwijl deze wel tot de top tien behoort in het open water en bij de oever van de hoofdstroom van de Getijden Lek. Zijn plaats in de top tien is ingenomen door pos.

Net als in het open water van de hoofdstroom zijn brasem en blankvoorn de dominante soorten in de boomkorvangsten (kolblei in veel mindere mate), zowel qua aantal als qua biomassa (Figuur 2.78 boven). Net als in de hoofdstroom, nemen deze soorten de laatste jaren echter af. Snoekbaars werd in het verleden ook vrij veel gevangen maar de vangsten daarvan zijn de laatste jaren ook afgenomen (m.u.v. 2019). Ook opvallend zijn de hoge aantallen brasem en blankvoorn in 2012, deze vangsten lijken voornamelijk uit jonge individuen te bestaan.

Langs de oever (schepnet) is blankvoorn qua aantal de dominante soort, samen met baars, snoekbaars en aal qua biomassa (Figuur 2.78 onder). Ook in de schepnetvangsten langs de oever zien we een afname van de meeste algemene soorten, met name blankvoorn, baars en snoekbaars. De vangsten van aal en winde fluctueren sterk qua biomassa. Sinds 2017 is aal de dominante soort qua biomassa. Sinds 2009 behoort de zwartbekgrondel ook tot de dominante soorten qua aantallen. 


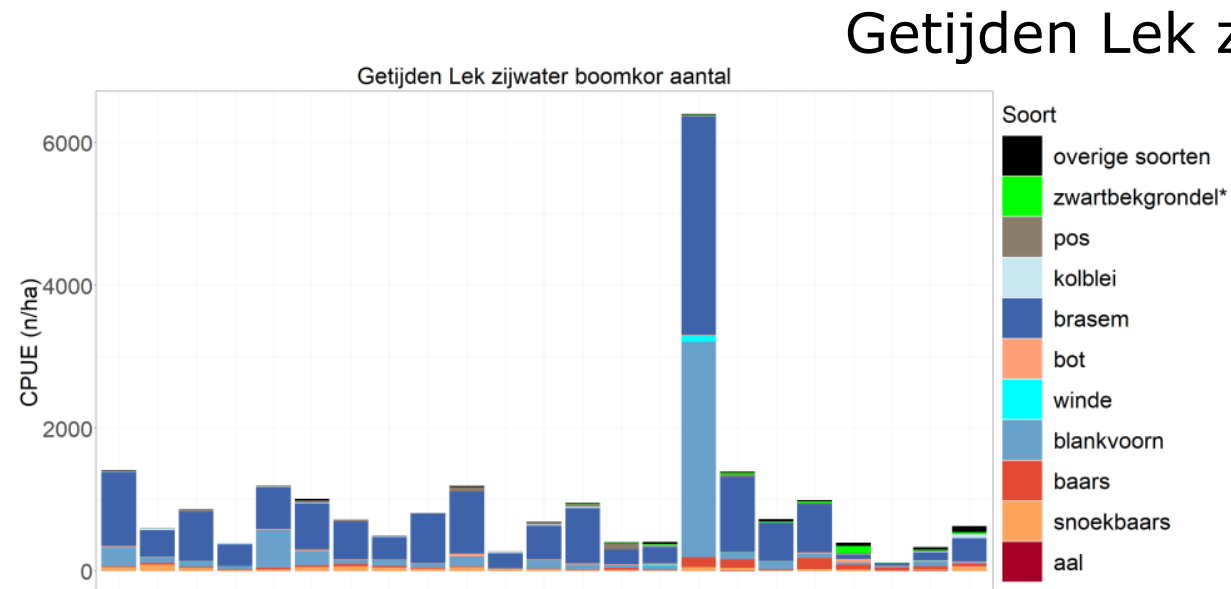

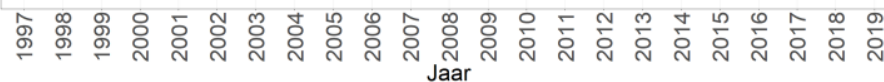

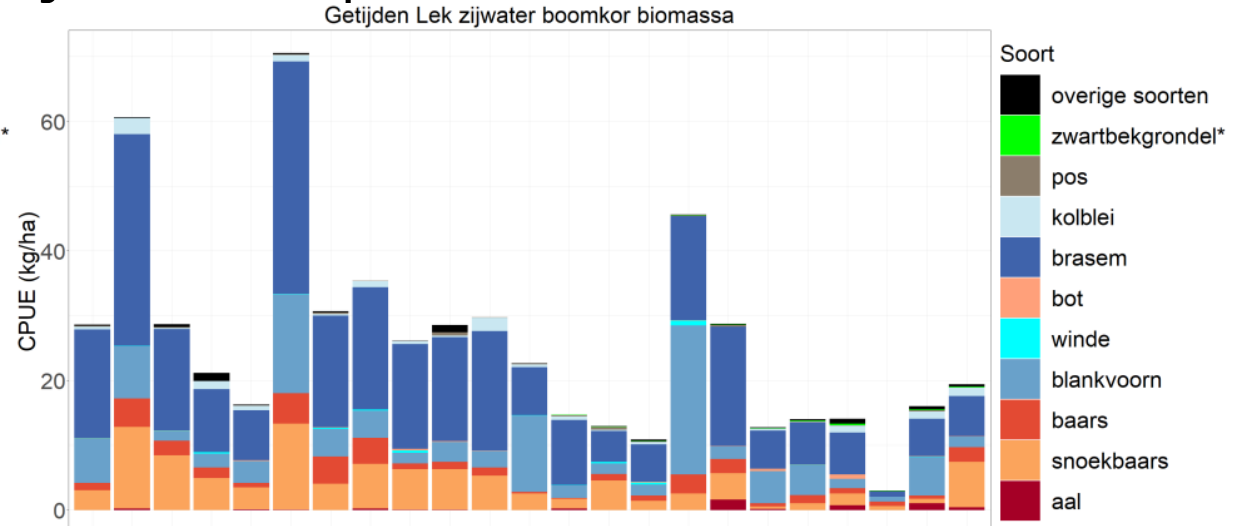

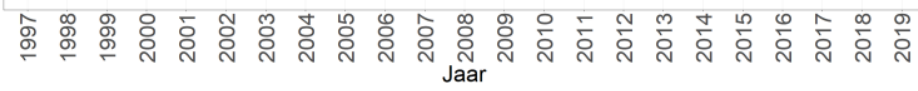

Getijden Lek zijwateren oever

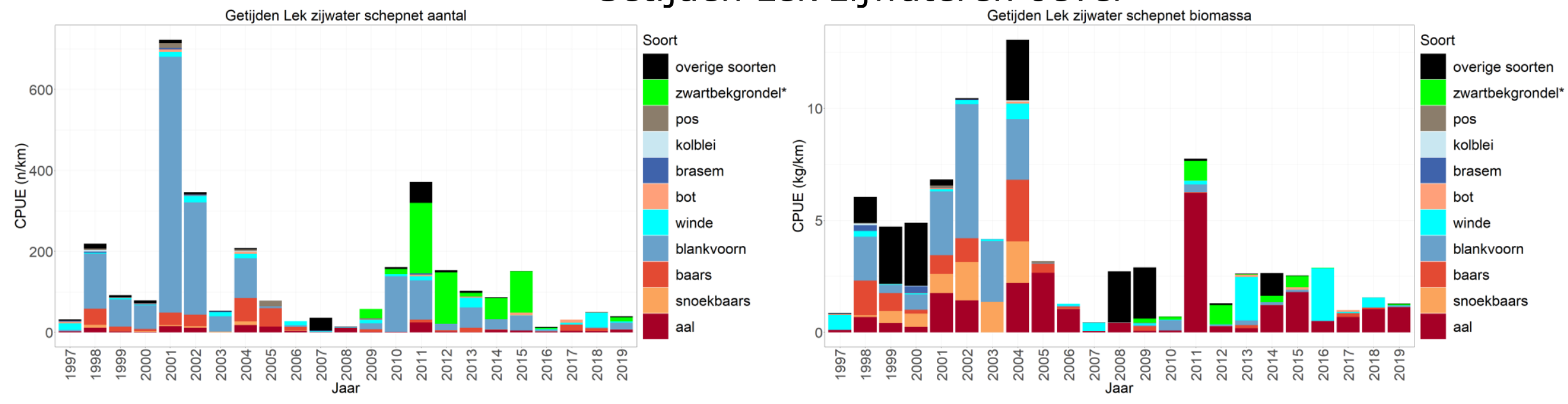

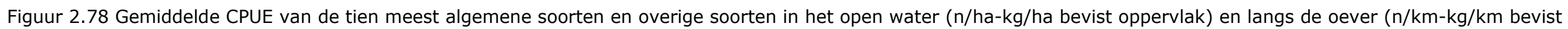
oppervlak) gevangen met een boomkor en elektroschepnet in de zijwateren van de Getijden Lek tijdens de actieve monitoring van $1997-2019$, $*$ exoot. 


\subsubsection{Chinese wolhandkrab}

De Chinese wolhandkrab wordt, net als in de hoofdstroom, regelmatig gevangen in de zijwateren van de Getijden Lek. Ook hier fluctueren de aantallen, met een aantal jaar zonder vangsten. Vanaf 2014 worden er weer regelmatig wolhandkrabben gevangen met relatief hoge aantallen in 2019 (Figuur 2.79).

Getijden Lek zijwater boomkor aantal

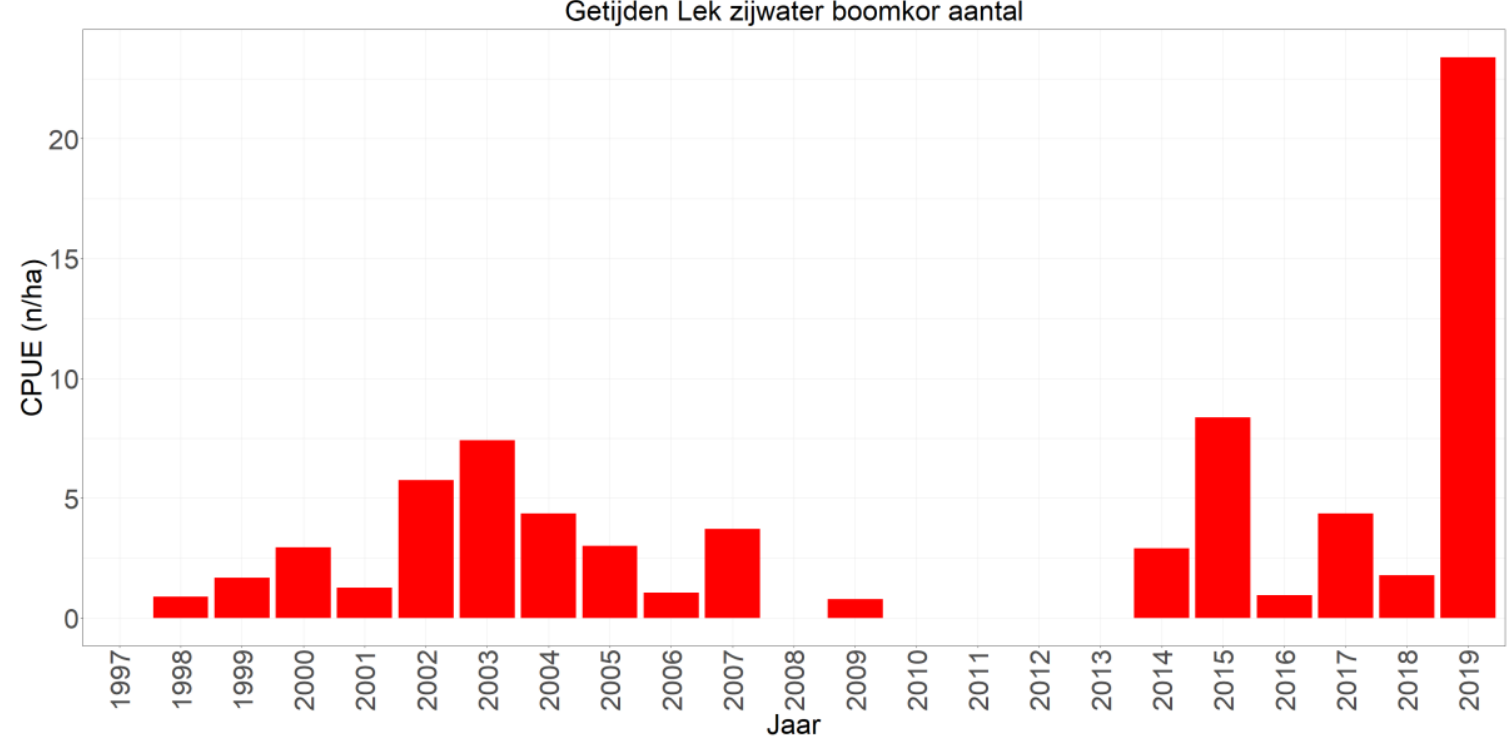

Figuur 2.79 Gemiddelde CPUE (n/ha bevist oppervlak) per jaar van de Chinese wolhandkrab in de zijwateren van de Getijden Lek gevangen met de boomkor. 


\subsubsection{Aalvangsten}

Voor de aanlandingen van KRW-lichamen Haringvliet, Hollandsch Diep, Oude Maas, Nieuwe Merwede, Heusdensch kanaal, Afgedamde Maas, Getijden Maas, Getijden Lek, Hollandse IJssel en Noordwaard zijn de gegevens van de "Benedenrivieren en Haringvliet i.o." gebruikt (Bijlage 2). In 2010 werd er nog veel aal gevangen, daarna nauwelijks nog. Dit is het gevolg van het verbod op aalvisserij in de grote rivieren in verband met te hoge dioxine- en PCB-gehaltes in aal (Figuur 2.80). Desondanks zijn er in 2011, en 2015 kleine hoeveelheden aal aangeland, gevangen zijn met het elektrovisapparaat en/of hokfuiken, terwijl dit wettelijk verboden was (Figuur 2.81).

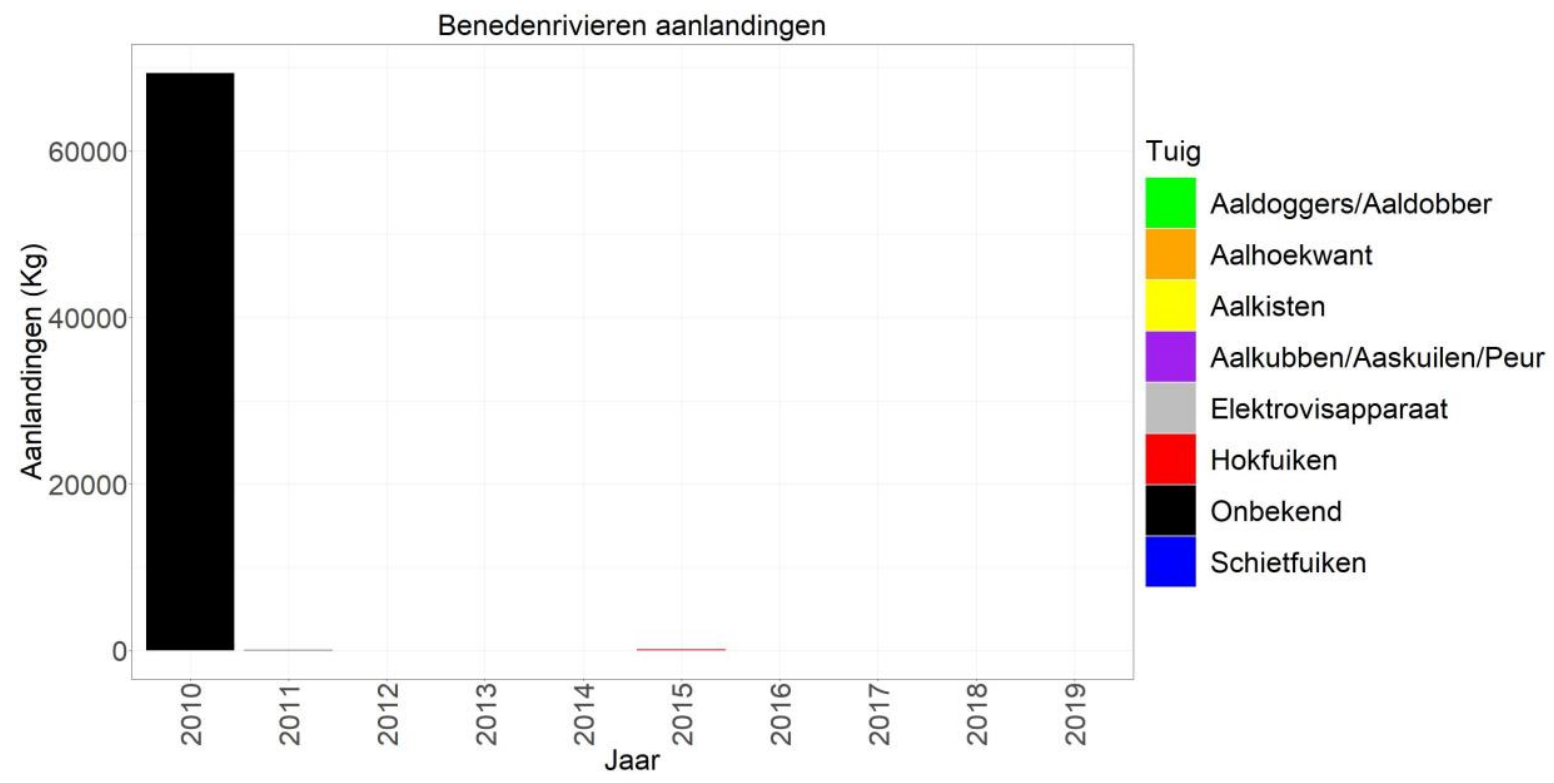

Figuur 2.80 Aanlandingen ( $\mathrm{kg}$ ) van de beroepsvisserij per tuig in de Benedenrivieren (Haringvliet, Hollandsch Diep, Oude Maas, Nieuwe Merwede, Heusdensch kanaal, Afgedamde Maas, Getijden Maas, Getijden Lek en Hollandse IJssel). Sinds 2012 zijn aalvissers verplicht de inspanning van het vistuig op te geven aan het ministerie van LNV.

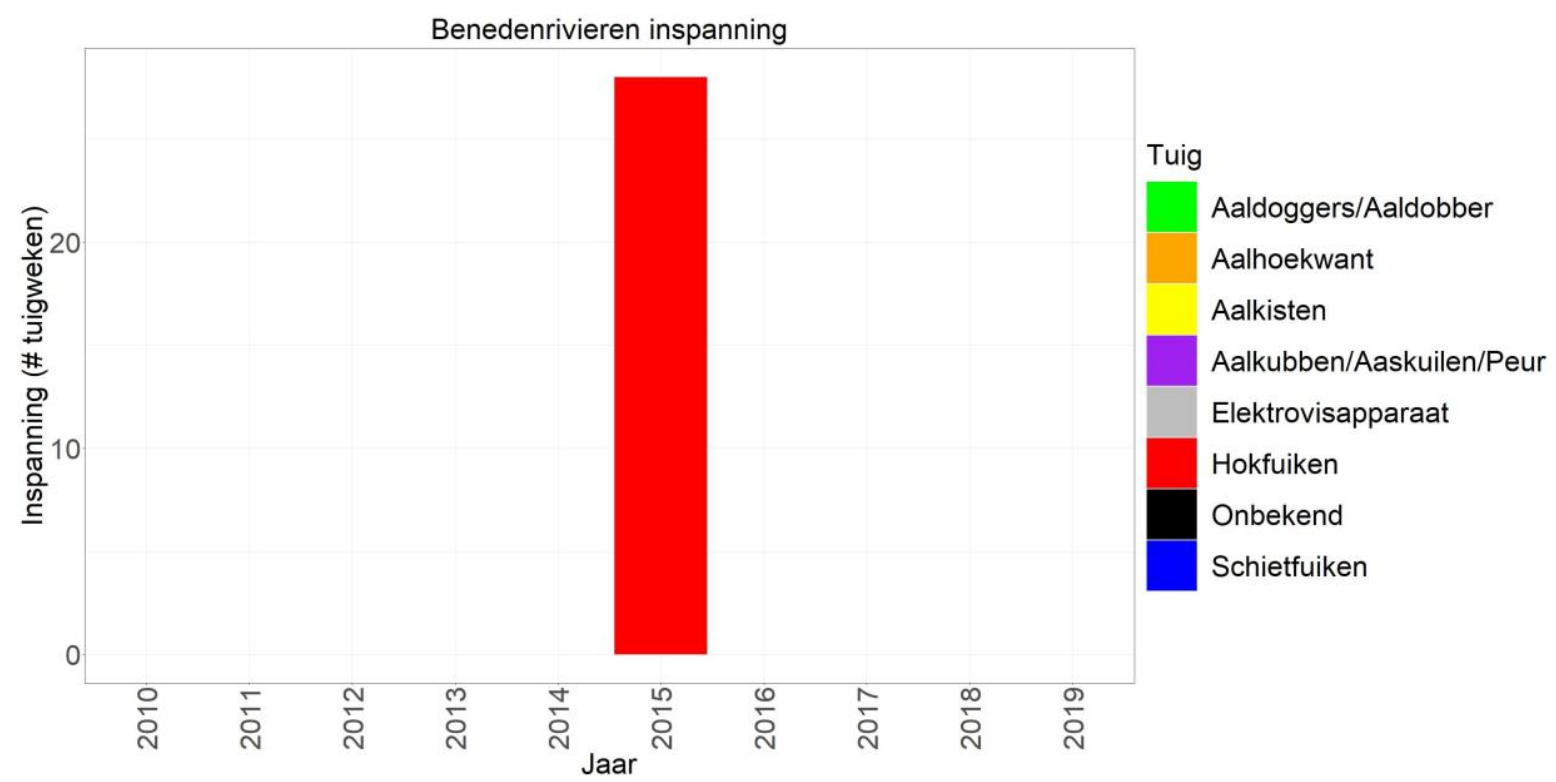

Figuur 2.81 Inspanning (aantal tuigweken) van de beroepsvisserij per tuig in de Benedenrivieren. 


\subsection{Getijden Maas (Beneden Maas)}

De bemonsteringslocaties over de periode 1997-2019 zijn weergegeven in Figuur 2.82.

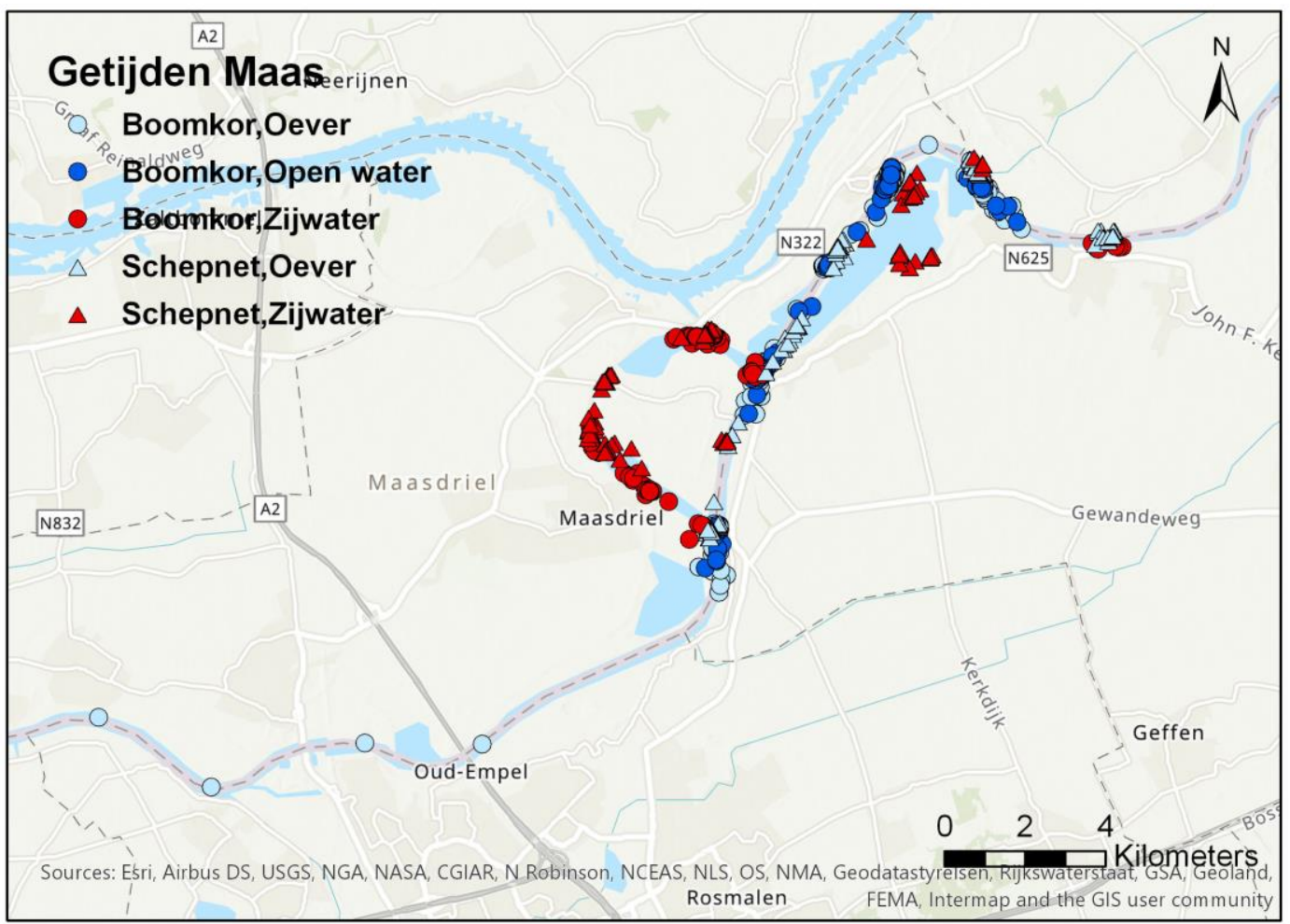

Figuur 2.82 Bemonsteringslocaties van de actieve monitoring in de Getijden Maas van 1997-2019 per tuig per habitat.

\subsubsection{Getijden Maas hoofdstroom (open water en oeverzone)}

De Getijden Maas wordt sinds 1997 ieder jaar in het najaar met de boomkor en het elektroschepnet bemonsterd. In de periode 1997-2012 werd dit gebied in november bemonsterd (behalve 1998 in oktober), vanaf 2013 alleen in oktober.

De tien meest algemene soorten in de hoofdstroom van de Getijden Maas voor de gehele periode 1997-2019 zijn zwartbekgrondel, pos, roofblei, brasem, winde, blankvoorn, baars, snoekbaars, alver en aal. Deze omvatten meer dan $93 \%$ van het totale gemiddelde aantal en biomassa voor zowel de vangsten met de boomkor als het schepnet (Bijlage 30).

In het open water en langs de oever (boomkor) zijn blankvoorn, brasem, pos, snoekbaars en baars de dominante soorten zowel qua aantal als qua biomassa (Figuur 2.83 boven). Sinds 2011 zijn de hoeveelheden van brasem, blankvoorn en pos sterk afgenomen. Baars daarentegen, lijkt de afgelopen 10 jaar te zijn toegenomen. Sinds 2012 wordt de invasieve zwartbekgrondel regelmatig gevangen met een sterke opleving in 2019 zoals we die in veel andere wateren ook zien. In 2019 is hier barbeel voor het eerst met de boomkor gevangen, deze werd wel al eerder met het schepnet gevangen langs de oever.

Langs de oever (schepnet) is blankvoorn qua aantal de dominante soort (Figuur 2.83 onder). Ook worden er relatief veel windes en vanaf 2011 zwartbekgrondels gevangen. Qua biomassa zien we dat aal en winde voornamelijk de dominante soorten zijn in de vangsten. Windes lijken met de jaren minder te worden gevangen terwijl de vangsten van aal sterk fluctueren. Naast hogere vangsten van blankvoorn vallen ook de hogere vangsten van de zwartbekgrondel op in 2019.

De lengte-frequentieverdelingen per soort, per tuig voor de hoofdstroom en de zijwateren gecombineerd over alle jaren van de monitoring van de Getijden Maas, Afgedamde Maas en het Heusdensch Kanaal gecombineerd zijn hier te vinden:

https://wmropendata.wur.nl/site/zoetwatervis/64/waterlichaam/ 

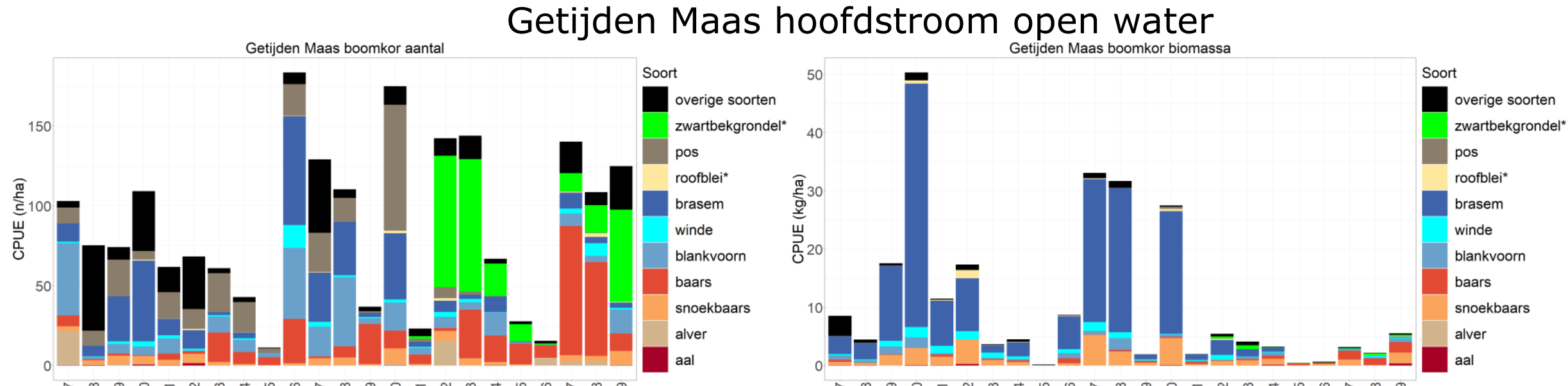

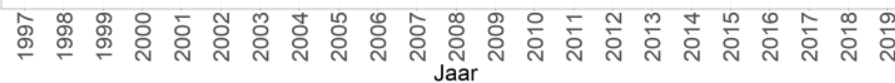

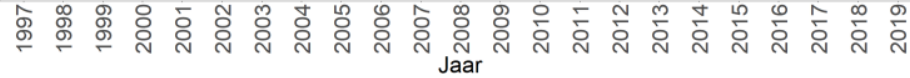

\section{Getijden Maas hoofdstroom oever}

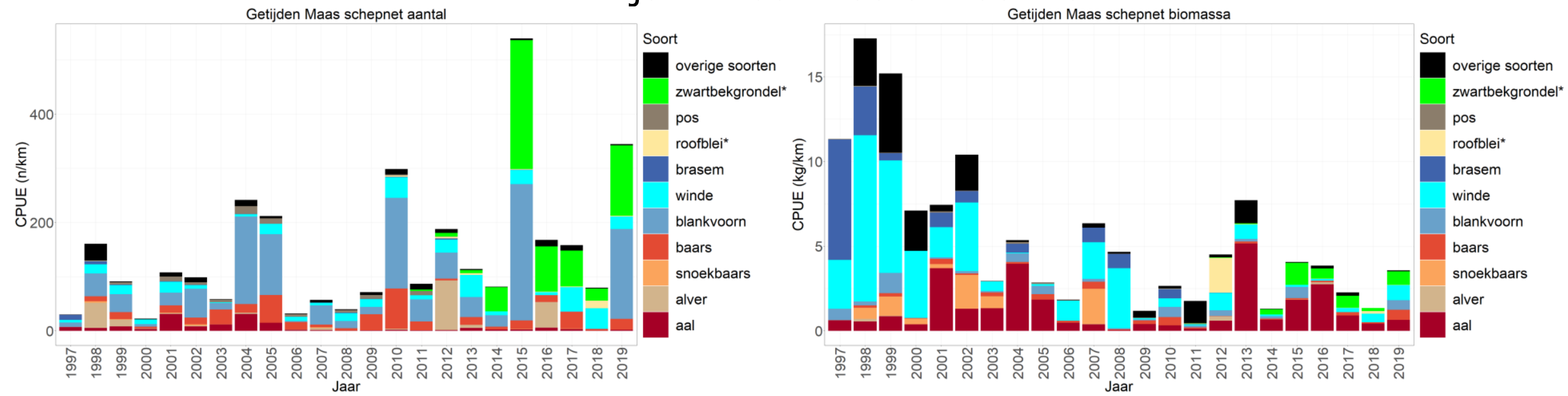

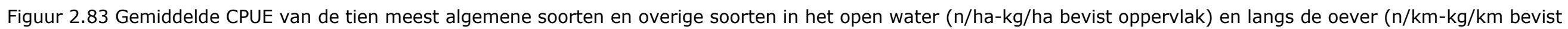
oppervlak) gevangen met een boomkor en elektroschepnet in de hoofdstroom van de Getijden Maas tijdens de actieve monitoring van $1997-2019, *=$ exoot. 


\subsubsection{Chinese wolhandkrab}

De Chinese wolhandkrab wordt met enige regelmaat gevangen in de hoofdstroom van de Getijden Maas. De vangsten lijken tot 2008/2009 grofweg toe te nemen (m.u.v. 2006), gevolgd door een aantal jaar met geen tot lage vangsten. In 2018 en 2019 werden er weer relatief hoge aantallen wolhandkrabben gevangen (Figuur 2.84).

Getijden Maas boomkor aantal

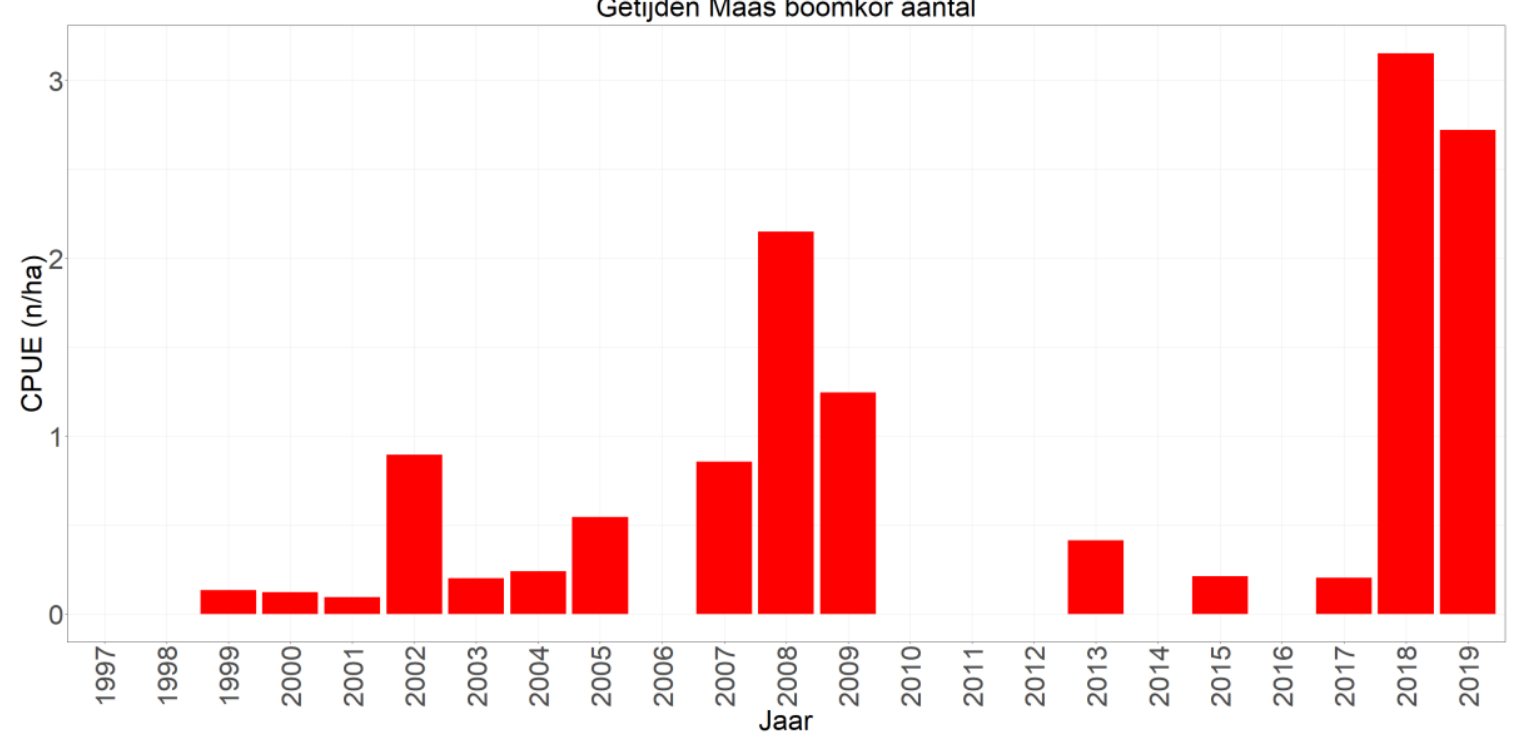

Figuur 2.84 Gemiddelde CPUE (n/ha bevist oppervlak) per jaar van de Chinese wolhandkrab in de hoofdstroom van het open water van de Getijden Maas gevangen met de boomkor. 


\subsubsection{Getijden Maas zijwateren}

Langs de Getijden Maas zijn nevengeulen, inhammen, jachthavens en een zijrivier bemonsterd in het open water met de boomkor en langs de oever met het schepnet.

De tien meest algemene soorten in deze zijwateren voor de gehele periode 1997-2019 zijn zwartbekgrondel, pos, snoek, brasem, winde, blankvoorn, baars, snoekbaars, alver en aal. Deze omvatten meer dan $98 \%$ van het totale gemiddelde aantal en biomassa voor zowel de vangsten met de boomkor als het schepnet (Bijlage 31). Qua aantallen in de hoofdstroom lijkt de dichtheid van de tien meest algemene soorten in de zijwateren hoger dan in de hoofdstroom, qua biomassa lijkt dit ongeveer gelijk te zijn. Dit is een indicatie dat er in deze zijwateren voornamelijk jonge individuen worden gevangen.

Opvallend is dat de roofblei ontbreekt in de top tien van de zijwateren, terwijl deze wel tot de top tien behoort in het open water en bij de oever van de hoofdstroom van de Getijden Maas. Zijn plaats in de top tien is ingenomen door snoek.

Net als in het open water van de hoofdstroom zijn blankvoorn, brasem, pos, snoekbaars en baars de dominante soorten in de boomkorvangsten, zowel qua aantal als qua biomassa (Figuur 2.85 boven). Net als in de hoofdstroom nemen worden deze soorten de laatste jaren gemiddeld wat minder gevangen, op baars na, waarvan we de laatste jaren juist een toename zien.

Voor de schepnetvangsten zijn blankvoorn en baars qua aantal de dominante soorten, en aal en winde qua biomassa (Figuur 2.85 onder). De invasieve zwartbekgrondel wordt sinds 2010 ook vaak gevangen. Waar baars in het open water juist toe neemt, lijkt deze langs de oever af te nemen. De laatste jaren worden er meer windes gevangen en in 2019 zien we relatief zeer hoge vangsten van blankvoorn, zowel in aantallen als in biomassa. De hoeveelheden gevangen aal zijn daarentegen de laatste twee jaar weer afgenomen. 

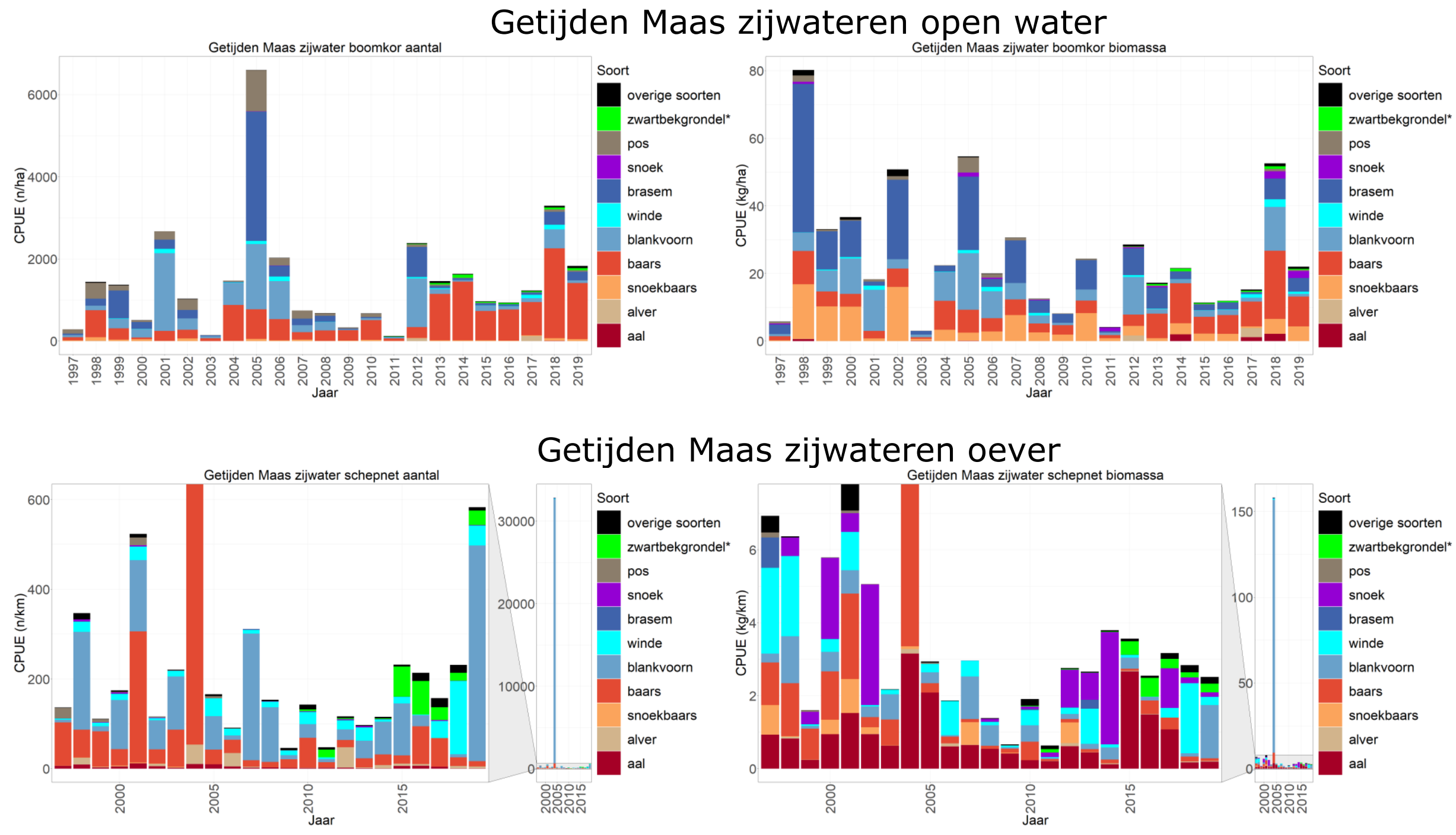

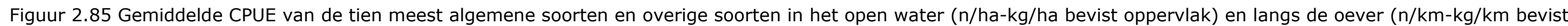
oppervlak) gevangen met een boomkor en elektroschepnet in de zijwateren van de Getijden Maas tijdens de actieve monitoring van $1997-2019, *$ exoot. 


\subsubsection{Chinese wolhandkrab}

De Chinese wolhandkrab wordt met enige regelmaat gevangen in de zijwateren van de Getijden Maas. De vangsten fluctueren sterk van jaar op jaar met veel jaren waar in geen wolhandkrabben worden gevangen en ook hier weer een aaneengesloten periode van vijf jaar zonder vangsten (2011-2015). Vanaf 2017 worden er meer wolhandkrabben gevangen dan voorheen, ook veel meer dan in de hoofdstroom (Figuur 2.86).

Getijden Maas zijwater boomkor aantal

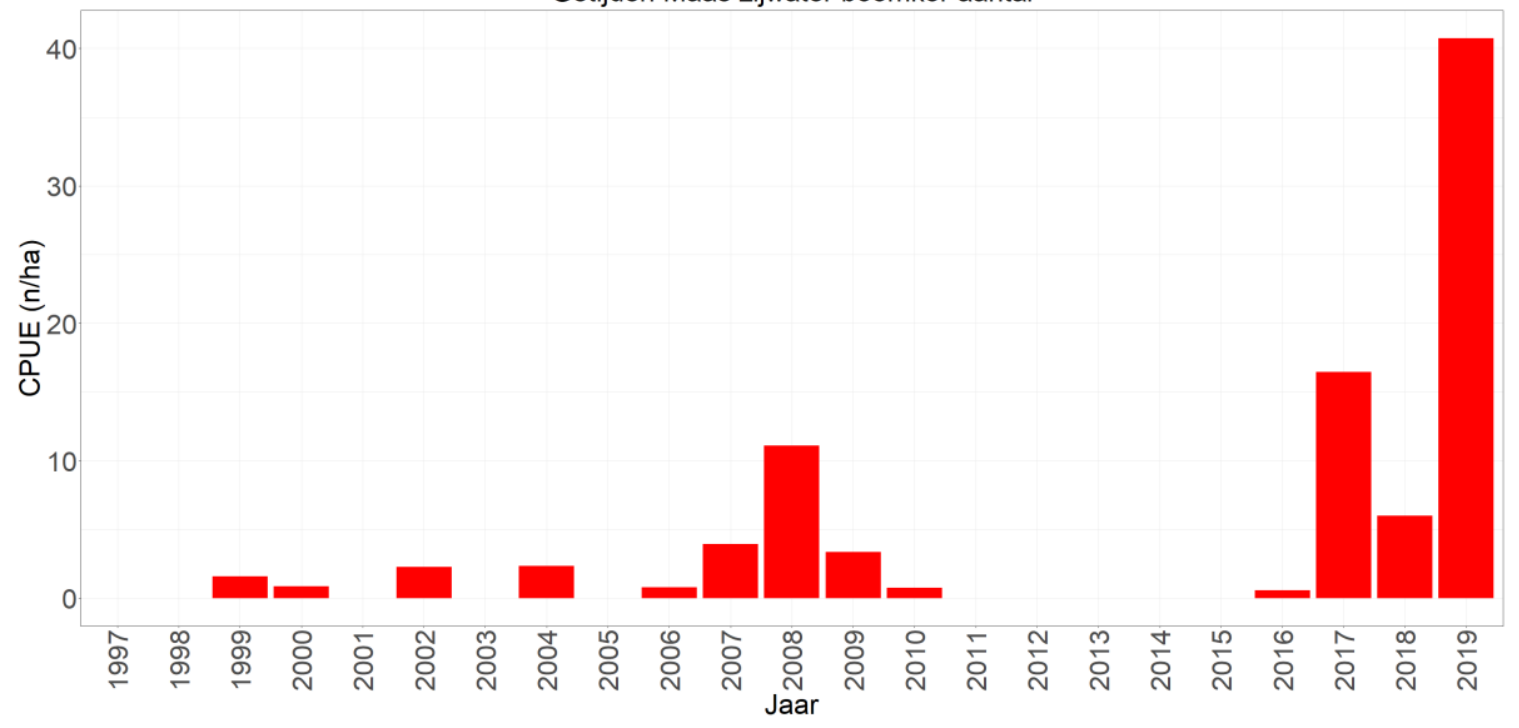

Figuur 2.86 Gemiddelde CPUE ( $\mathrm{n} / \mathrm{ha}$ bevist oppervlak) per jaar van de Chinese wolhandkrab in de zijwateren van de Getijden Maas gevangen met de boomkor.

\subsubsection{Aalvangsten}

Voor de aanlandingen van aal voor KRW-lichaam Getijden Maas zijn de gegevens van de "Benedenrivieren en Haringvliet i.o." gebruikt (Bijlage 2) en deze zijn weer gegeven in Figuur 2.80. 


\subsection{Afgedamde Maas (Afgedamde Maas Zuid)}

De bemonsteringslocaties over de periode 2010-2019 zijn weergegeven in Figuur 2.87.

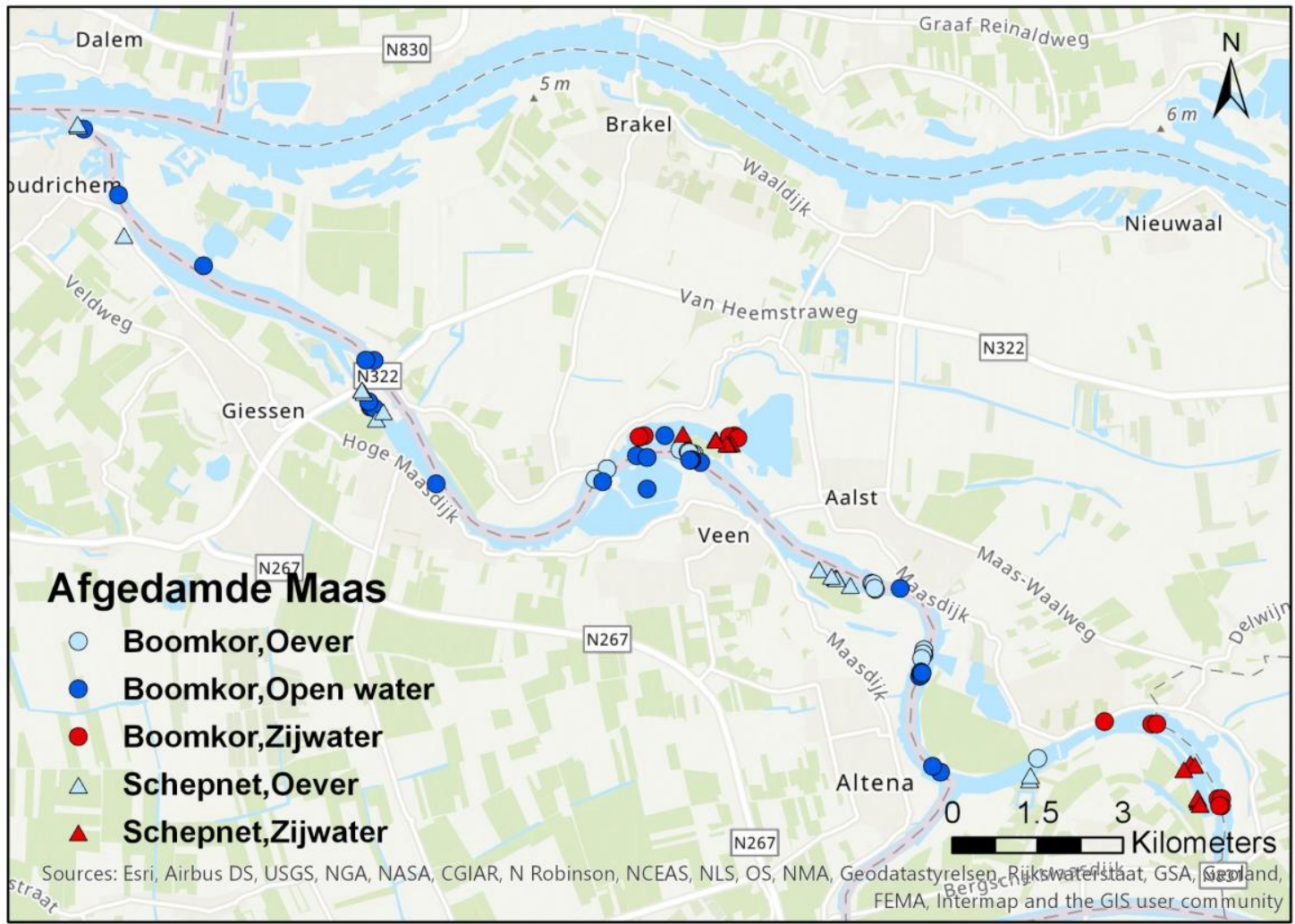

Figuur 2.87 Bemonsteringslocaties van de actieve monitoring in de Afgedamde Maas van 2010-2019 per tuig per habitat.

\subsubsection{Afgedamde Maas hoofdstroom (open water en oeverzone)}

De Afgedamde Maas wordt sinds 2010 ieder jaar in het najaar met de boomkor en het elektroschepnet bemonsterd. In de periode 2010-2011 werd dit gebied in november bemonsterd, vanaf 2012 alleen in oktober.

De tien meest algemene soorten in de Afgedamde Maas voor de gehele periode 2010-2019 zijn zwartbekgrondel, marmergrondel, Kesslers grondel, pos, snoek, brasem, winde, blankvoorn, baars en aal. Deze omvatten meer dan $98 \%$ van het totale gemiddelde aantal en biomassa voor zowel de vangsten met de boomkor als het schepnet (Bijlage 32).

In het open water en langs de oever (boomkor) is baars zowel qua aantal als qua biomassa de dominante soort (Figuur 2.88 boven). Zowel brasem als blankvoorn werden van 2011 tot 2017 nauwelijks nog gevangen, in 2018 weer iets meer, maar in 2019 weer nauwelijks. In de laatste drie jaar zijn de baarsvangsten sterk toegenomen. Verder is te zien dat de invasieve grondels (marmergrondel en met name zwartbekgrondel) sinds 2011 duidelijk aanwezig zijn en de gevangen aantallen hiervan hoog waren in 2018, maar weer wat lager in 2019. Dit is een van de weinige KRWlichamen waar er maar liefst drie verschillende invasieve grondelsoorten tot de top tien algemene soorten behoren.

In de oeverzone (schepnet) is de zwartbekgrondel qua aantal de dominante soort, en de aal qua biomassa (Figuur 2.88 onder). In 2010 (en dus wellicht ook daarvoor) leken dit blankvoorn en brasem te zijn. De hoeveelheden zwartbekgrondel fluctueren sterk per jaar maar lijken eerder toe dan af te nemen. De biomassa van aal is de laatste vijf jaar wat hoger dan de vijf jaren daarvoor. Wellicht komt dit doordat er de laatste jaren meer vrouwelijke dan mannelijke alen zijn net als in het IJsselmeer; vrouwtjes worden groter en zwaarder dan mannen (Van de Wolfshaar et al. 2018). De alen lijken geen hinder van de territoriale zwartbekgrondel te ondervinden en de grondel dient wellicht zelfs wel als voedselbron, zoals ook wordt gesuggereerd voor het Kiel Kanaal in het noorden van Duitsland 
(Hempel 2017). Het zou interessant zijn om te onderzoeken of de invasie van de verschillende grondelsoorten deels verantwoordelijk is voor de toename van de aal in de verschillende watersystemen. Ook hier zien we zowel qua aantal als biomassa hoge vangsten in 2019.

De lengte-frequentieverdelingen per soort, per tuig voor de hoofdstroom en de zijwateren gecombineerd over alle jaren van de monitoring van de Getijden Maas, Afgedamde Maas en het Heusdensch Kanaal gecombineerd zijn hier te vinden:

https://wmropendata.wur.nl/site/zoetwatervis/64/waterlichaam/ 


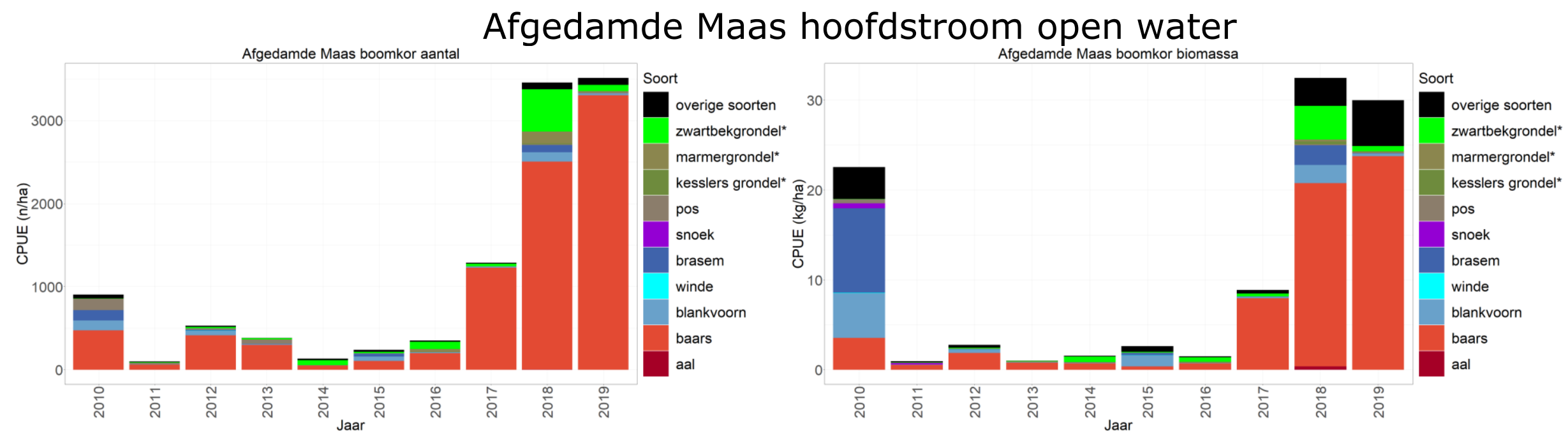

Afgedamde Maas hoofdstroom oever

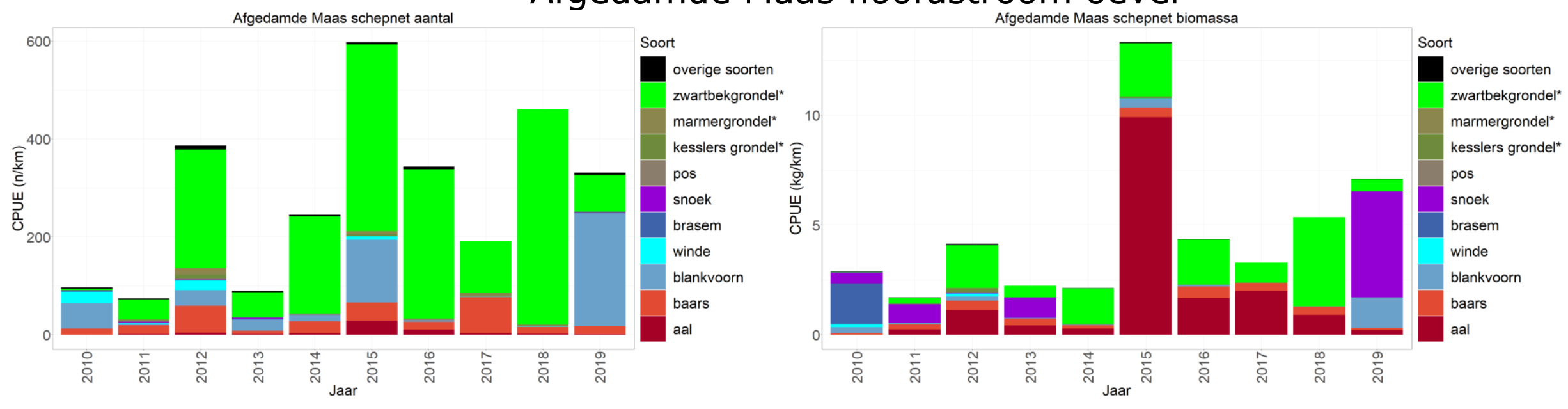

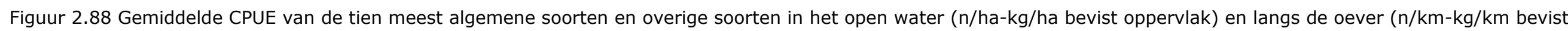
oppervlak) gevangen met een boomkor en elektroschepnet in de hoofdstroom van de Afgedamde Maas tijdens de actieve monitoring van $2010-2019, *={ }^{*}$ exoot. 


\subsubsection{Chinese wolhandkrab}

De Chinese wolhandkrab werd in 2017 en 2018 gevangen in de hoofdstroom van de Afgedamde Maas (Figuur 2.89).

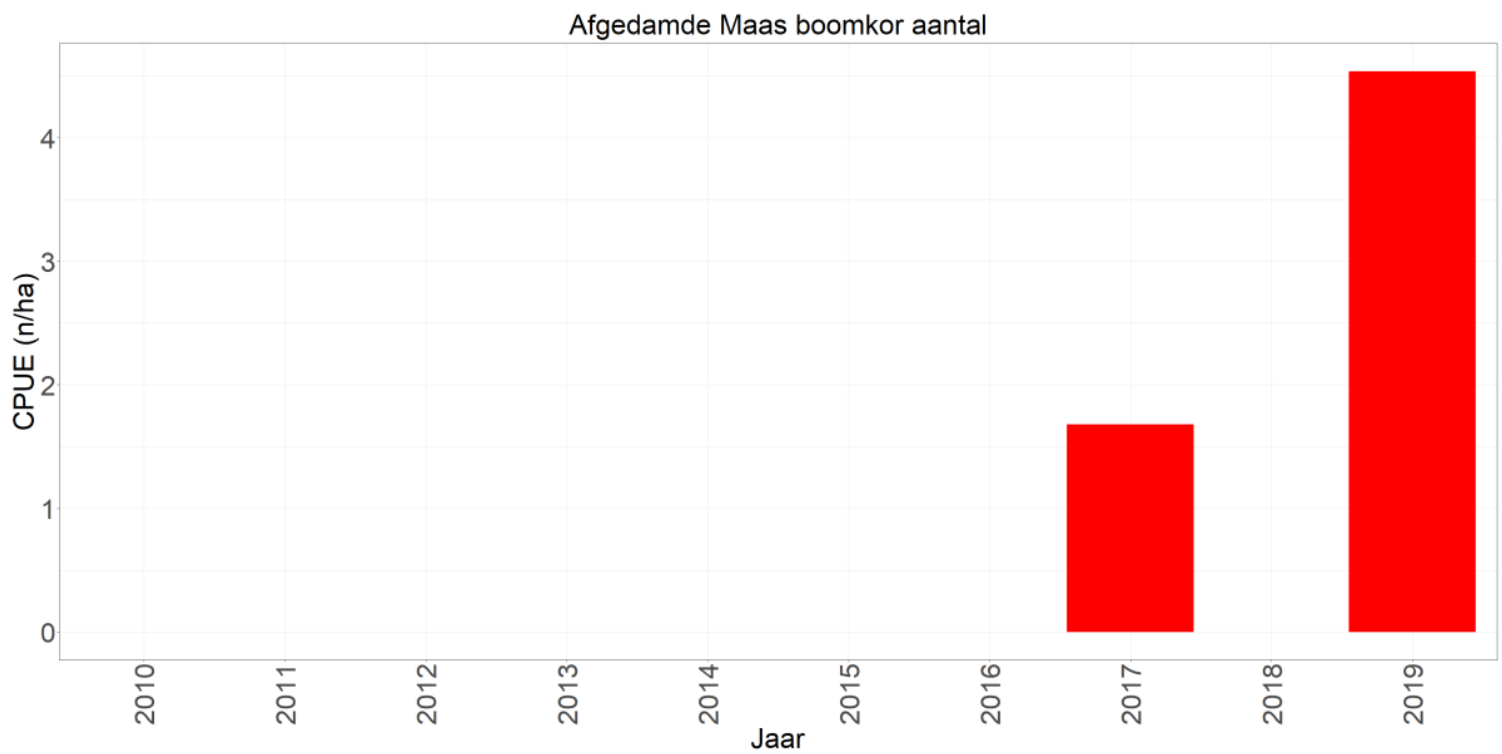

Figuur 2.89 Gemiddelde CPUE (n/ha bevist oppervlak) per jaar van de Chinese wolhandkrab in de hoofdstroom van het open water van de Afgedamde Maas gevangen met de boomkor. 


\subsubsection{Afgedamde Maas zijwateren}

Langs de afgedamde maas zijn een nevengeul en een inham bemonsterd met de boomkor in het open water en met het schepnet langs de oever.

De tien meest algemene soorten in de gehele periode 2010-2019 in deze zijwateren zijn zwartbekgrondel, pos, snoek, kolblei, brasem, winde, blankvoorn, baars, snoekbaars en aal. De tien meest algemene soorten omvatten meer dan $96 \%$ van de het totale gemiddelde aantal en biomassa. Dit geldt voor zowel de vangsten met de boomkor als met het schepnet (Bijlage 33). Qua aantallen en biomassa lijkt de dichtheid van vis tussen de hoofd- en zijwateren ongeveer gelijk te zijn.

Opvallend is dat de invasieve marmergrondel en Kesslers grondel ontbreken in de top tien van de zijwateren, terwijl deze wel tot de top tien behoren in het open water en bij de oever van de hoofdstroom van de Afgedamde Maas. Hun plaats in de top tien is ingenomen door kolblei en snoekbaars.

Net als in de hoofdstroom is baars de dominante soort in de boomkorvangsten zowel qua aantal als qua biomassa (Figuur 2.90 boven). De laatste twee jaar maakt blankvoorn echter ook een groot deel van de vangsten uit. In de jaren voor 2018 werden blankvoorn en brasem nauwelijks nog gevangen. Net als in de hoofdstroom, is in de laatste drie jaar de hoeveelheid baars zeer sterk toegenomen in de zijwateren. In contrast met de hoofdstroom is te zien dat van de invasieve grondelsoorten alleen de zwartbekgrondel in relatief lage hoeveelheden voorkomt. Wellicht dat het habitat van deze zijwateren meer geschikt is voor de invasieve zwartbekgrondel dan voor de overige invasieve grondelsoorten.

In de oeverzone van de zijwateren (schepnet) is baars qua aantal de dominante soort en samen met snoek en aal ook qua biomassa (Figuur 2.90 onder). De biomassa van snoek fluctueert sterk, vooral doordat het vangen van een enkele grote snoek met het schepnet een hele grote invloed heeft op de vangsten. Verder is het opvallend dat er in de laatste drie jaar zeer lage vangsten van alle (op snoek na) soorten zijn langs de oevers van de zijwateren. 


\section{Afgedamde Maas zijwateren open water}

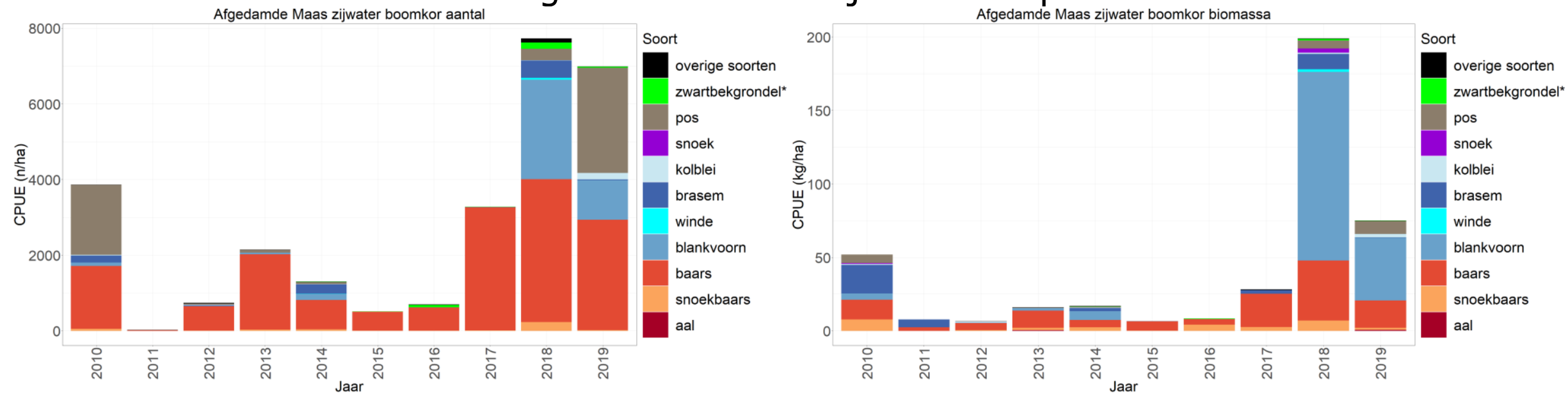

Afgedamde Maas zijwateren oever
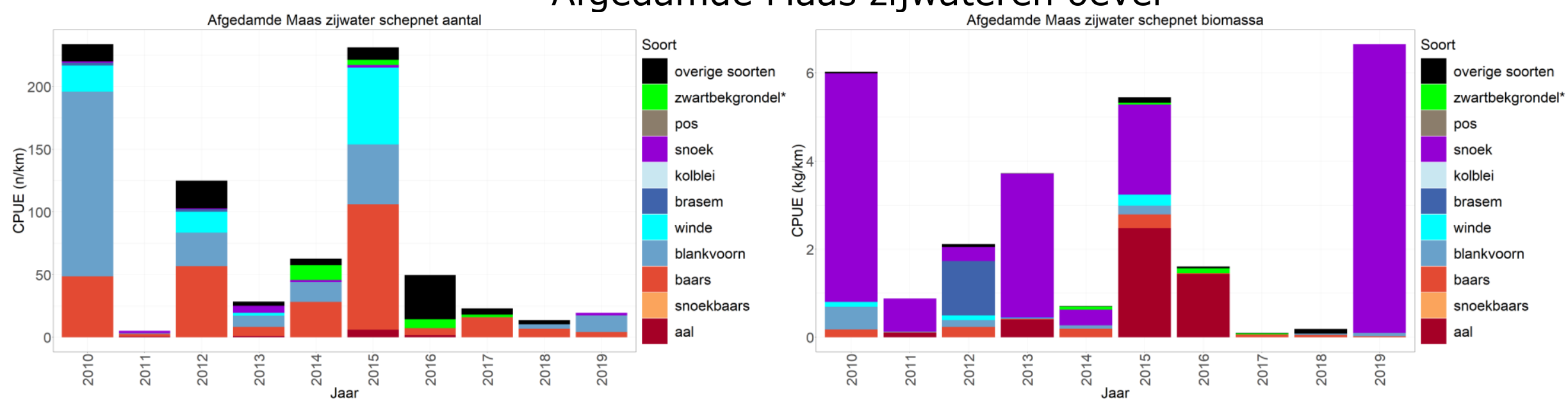

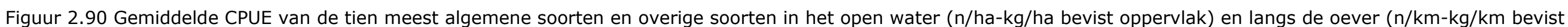
oppervlak) gevangen met een boomkor en elektroschepnet in de zijwateren van de Afgedamde Maas tijdens de actieve monitoring van $2010-2019, *=$ exoot. 


\subsubsection{Chinese wolhandkrab}

De Chinese wolhandkrab is alleen in 2012 in de zijwateren van de Afgedamde Maas gevangen (Figuur 2.91).

Afgedamde Maas zijwater boomkor aantal

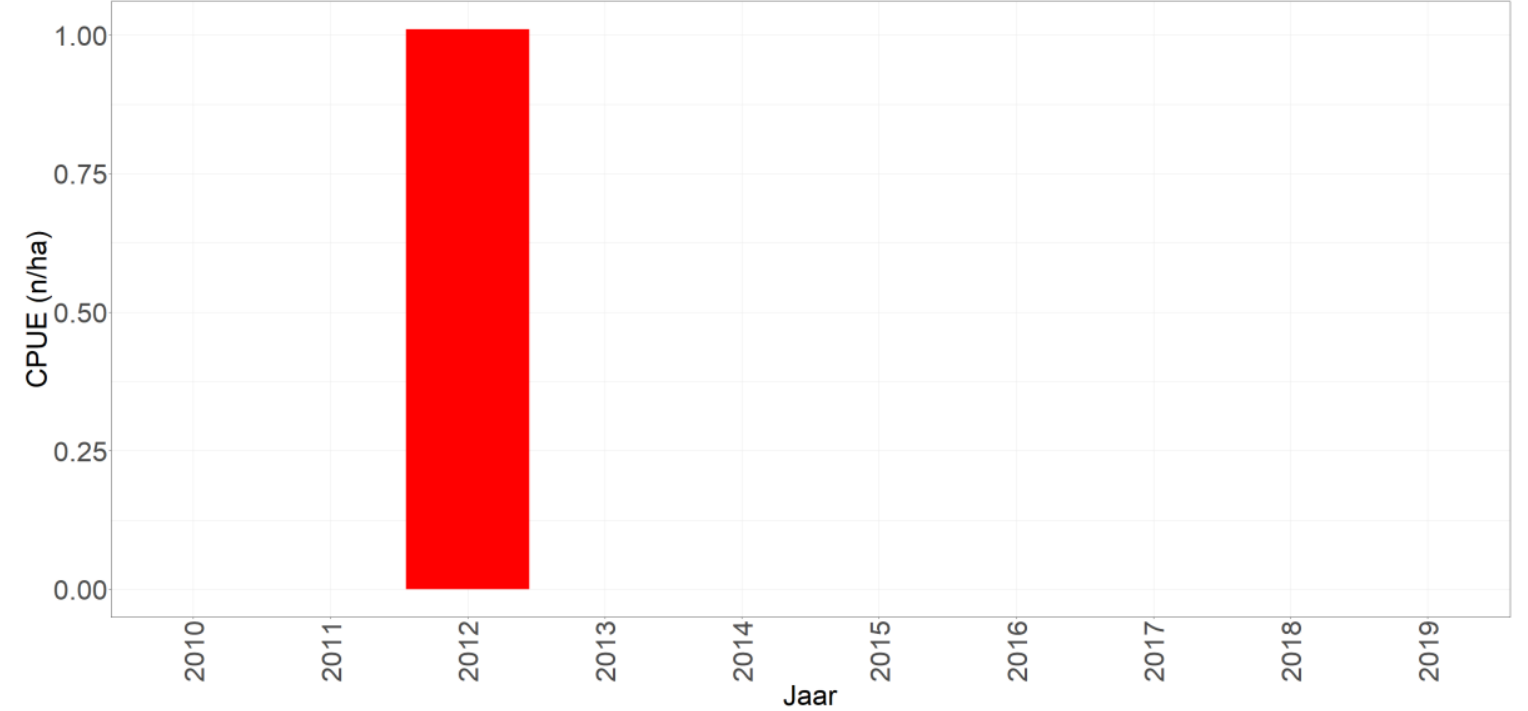

Figuur 2.91 Gemiddelde CPUE (n/ha bevist oppervlak) per jaar van de Chinese wolhandkrab in de zijwateren van de Afgedamde Maas gevangen met de boomkor.

\subsubsection{Aalvangsten}

Voor de aanlandingen van aal voor KRW-lichaam Afgedamde Maas zijn de gegevens van de "Benedenrivieren en Haringvliet i.o." gebruikt (Bijlage 2) en deze zijn weer gegeven in Figuur 2.80. 


\subsection{Heusdensch Kanaal (Afgedamde Maas Zuid)}

De bemonsteringslocaties over de periode 2010-2019 zijn weergegeven in Figuur 2.92.

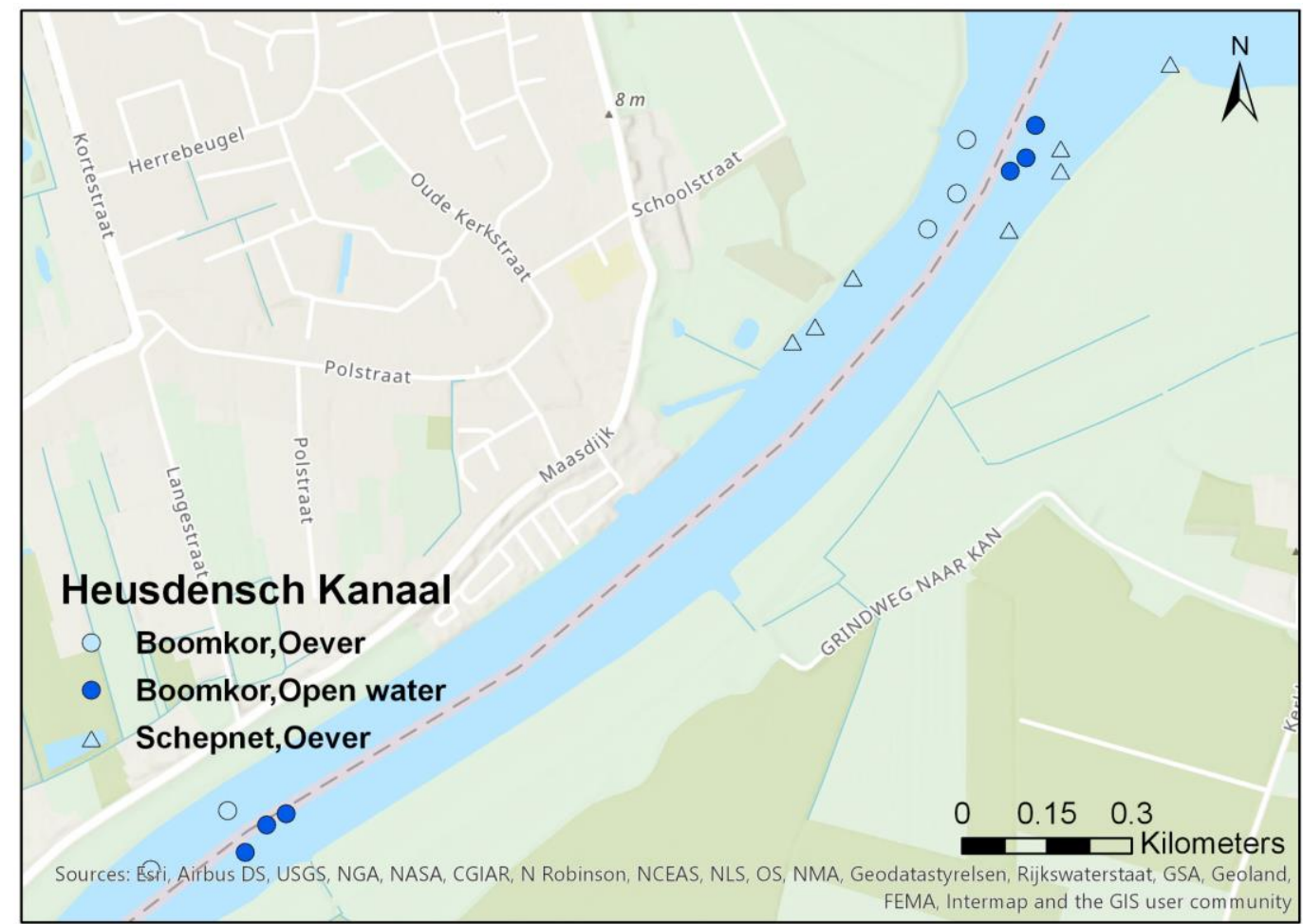

Figuur 2.92 Bemonsteringslocaties van de actieve monitoring in het Heusdensch Kanaal van 20102019 per tuig per habitat.

\subsubsection{Heusdensch Kanaal hoofdstroom (open water en oeverzone)}

Het Heusdensch Kanaal wordt sinds 2010 ieder jaar in het najaar met de boomkor en het elektroschepnet bemonsterd. In de periode 2010-2011 werd dit gebied in november bemonsterd, vanaf 2012 alleen in oktober.

De tien meest algemene soorten in het Heusdensch Kanaal voor de gehele periode 2010-2019 zijn zwartbekgrondel, Kesslers grondel, pos, snoek, kolblei, brasem, winde, blankvoorn, baars en snoekbaars. Deze omvatten meer dan $99 \%$ van het totale gemiddelde aantal en biomassa voor zowel de vangsten met de boomkor als het schepnet (Bijlage 34). Ten opzichte van de voorgaande rapportage (van Rijssel et al. 2019a) behoort de Kesslers grondel tot de top tien meest algemene soorten in plaats van de aal.

In het open water en langs de oever (boomkor) is baars de dominante soort zowel qua aantal, qua biomassa behoren snoekbaars, brasem en blankvoorn ook tot de dominante soorten (Figuur 2.93 boven). Verder worden er af en toe relatief grote hoeveelheden brasem, blankvoorn en snoekbaars gevangen. Pos werd in 2010 nog redelijk veel gevangen maar daarna nauwelijks nog. De vangsten van alle soorten lijken de laatste drie jaar weer iets toe te nemen na een afname in de jaren daarvoor. De zwartbekgrondel wordt ook sinds 2013 regelmatig gevangen maar niet in hele grote hoeveelheden, op 2019 na.

Langs de oever (schepnet) is de zwartbekgrondel sinds 2014 de dominante soort (Figuur 2.93 onder). Ook worden baars en aal (overige soorten) nog regelmatig gevangen alhoewel de vangsten sterk fluctueren. De biomassa van overige soorten in 2010 bestond voornamelijk uit karper. Ook hier is zowel qua aantal als qua biomassa weer toename van blankvoorn te zien in 2019.

De lengte-frequentieverdelingen per soort, per tuig voor de hoofdstroom en de zijwateren gecombineerd over alle jaren van de monitoring van de Getijden Maas, Afgedamde Maas en het Heusdensch Kanaal gecombineerd zijn hier te vinden:

https://wmropendata.wur.nl/site/zoetwatervis/64/waterlichaam/ 
Heusdensch kanaal hoofdstroom open water
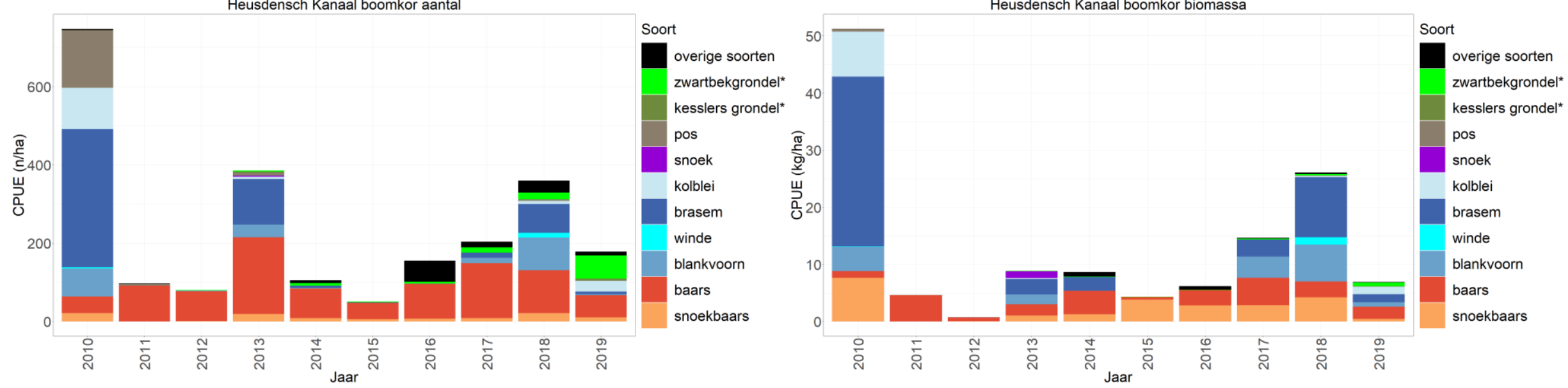

Heusdensch kanaal hoofdstroom oever
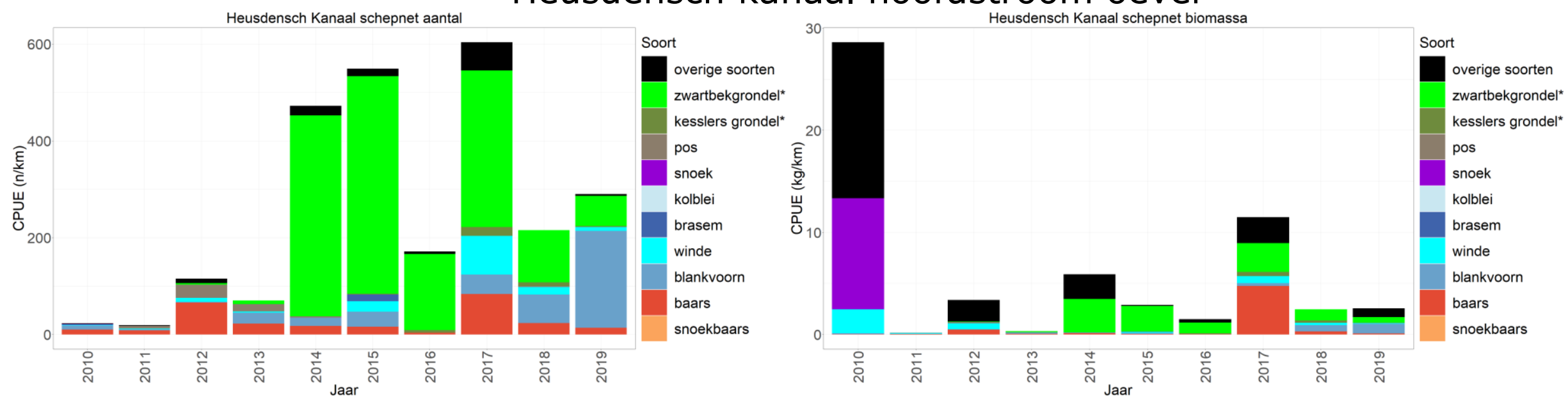

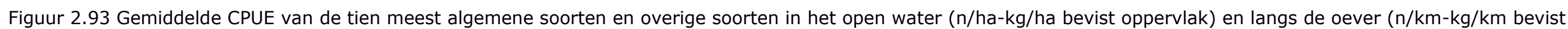
oppervlak) gevangen met een boomkor en elektroschepnet in de hoofdstroom van het Heusdensch kanaal tijdens de actieve monitoring van $2010-2019, *=$ exoot. 


\subsubsection{Chinese wolhandkrab}

De Chinese wolhandkrab wordt sinds 2018 gevangen in de hoofdstroom van het Heusdensch Kanaal met de hoogste aantallen in 2019 (Figuur 2.94).

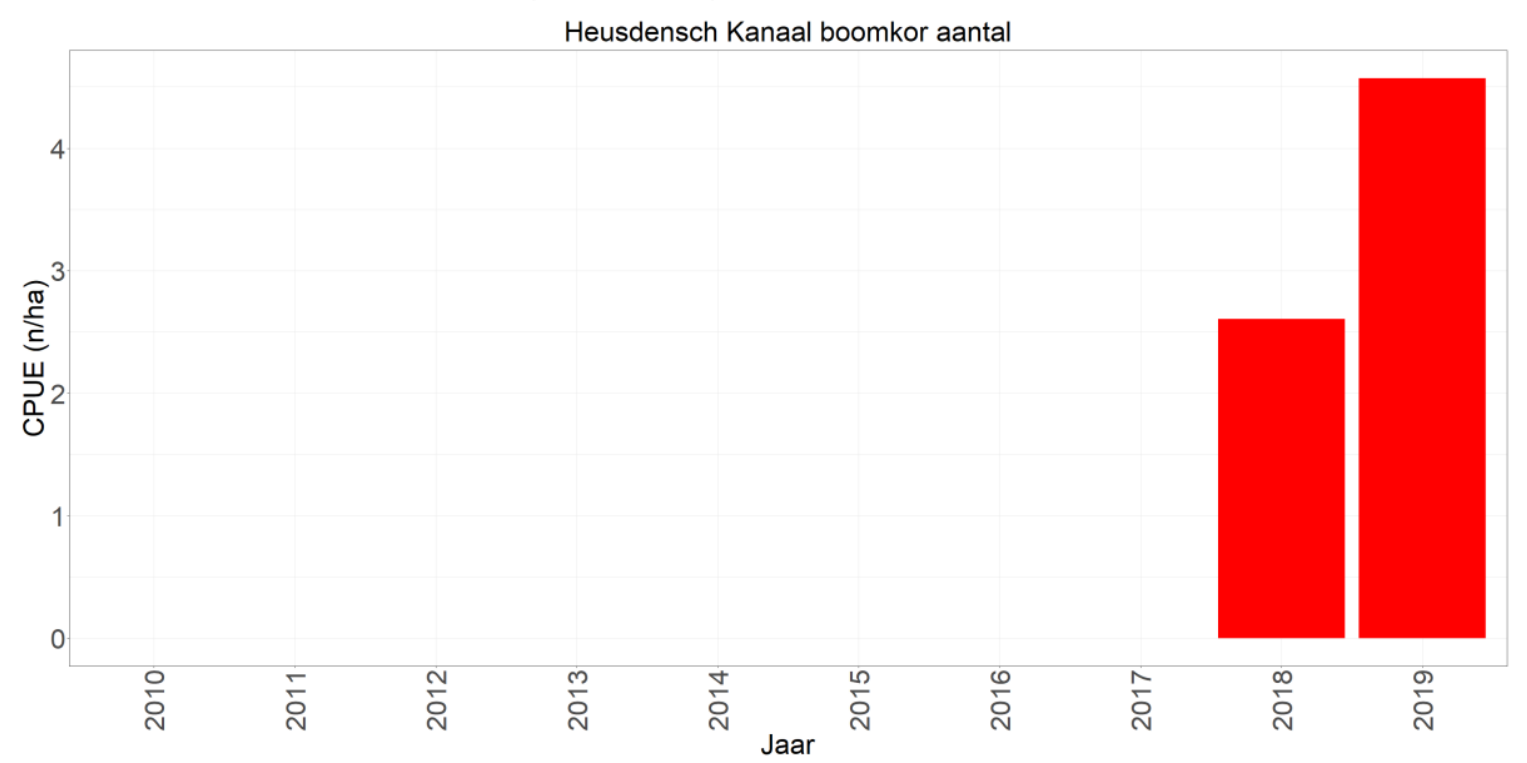

Figuur 2.94 Gemiddelde CPUE (n/ha bevist oppervlak) per jaar van de Chinese wolhandkrab in de hoofdstroom van het open water van het Heusdensch Kanaal gevangen met de boomkor.

\subsubsection{Aalvangsten}

Voor de aanlandingen van aal voor KRW-lichaam Heusdensch Kanaal zijn de gegevens van de "Benedenrivieren en Haringvliet i.o." gebruikt (Bijlage 2) en deze zijn weer gegeven in Figuur 2.80. 


\subsection{Noordwaard (Brabantse Biesbosch)}

De bemonsteringslocaties over de periode 2016-2019 zijn weergegeven in Figuur 2.95.

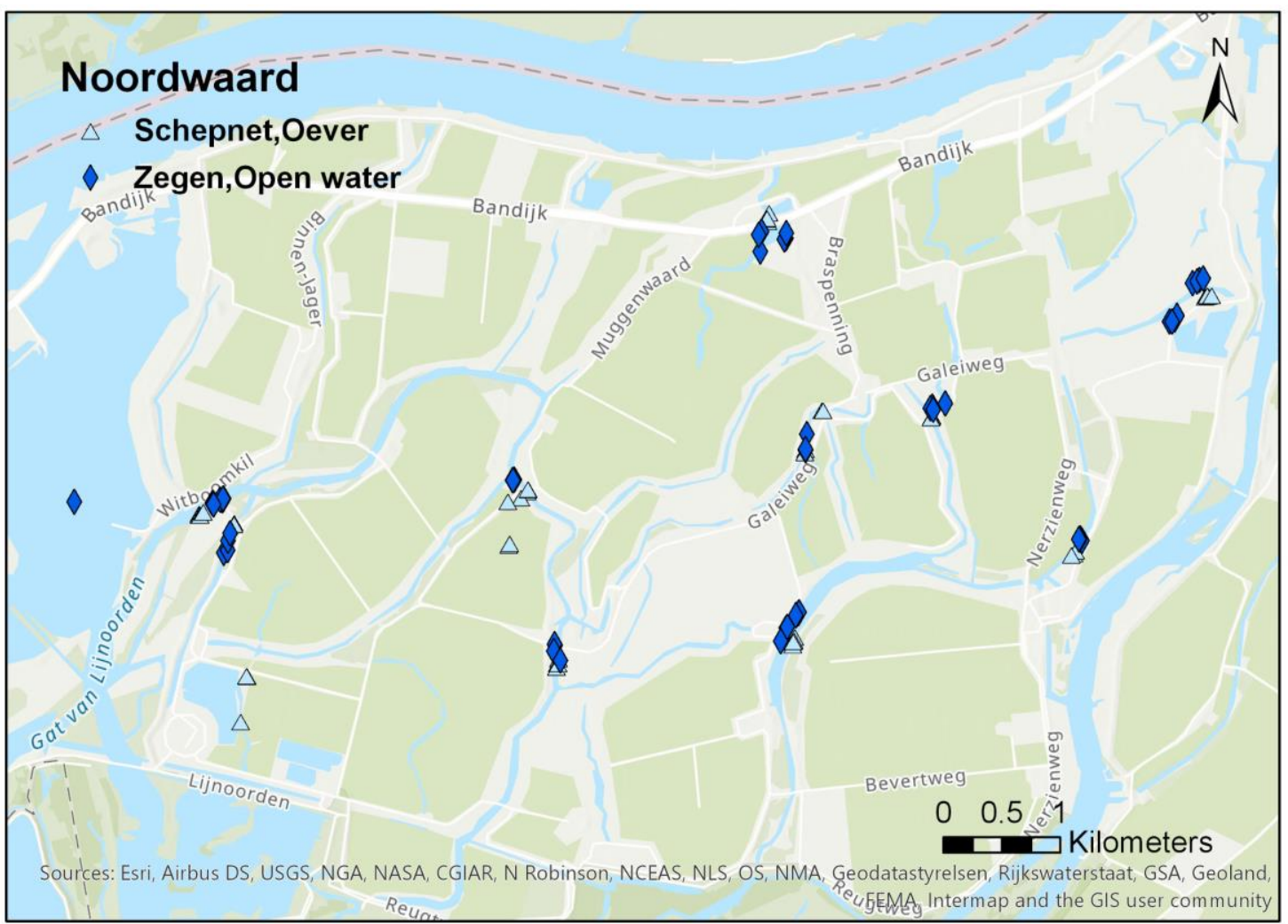

Figuur 2.95 Bemonsteringslocaties van de actieve monitoring in de Noordwaard van 2016-2019 per tuig per habitat.

\subsubsection{Noordwaard (oeverzone)}

De Noordwaard wordt sinds 2016 ieder jaar in het najaar met het elektroschepnet en de zegen bemonsterd. In 2016 werd in augustus en september bemonsterd, in 2017 in augustus, in 2018 in oktober en in 2019 weer in augustus.

De tien meest algemene soorten in de Noordwaard voor de gehele periode 2016-2019 zijn zwartbekgrondel, roofblei, snoek, rietvoorn, karper, winde, blankvoorn, bittervoorn, baars en aal. Deze omvatten meer dan $92 \%$ van het totale gemiddelde aantal en biomassa voor de vangsten met het schepnet (Bijlage 35). Ten opzichte van de voorgaande rapportage (van Rijssel et al. 2019a) valt de roofblei in de top tien meest algemene soorten in plaats van het vetje. Dit komt doordat dit jaar de vangsten van de zegen ook worden meegenomen in de rapportage, terwijl in de voorgaande rapportage alleen de schepnetvangsten zijn besproken. De Chinese wolhandkrab is niet met het schepnet of de zegen in de Noordwaard gevangen.

Langs de oever (zegen) zijn blankvoorn en baars de dominante soorten, daarnaast wordt er relatief veel brasem en rietvoorn gevangen (Figuur 2.96, boven). Het valt op dat het vetje nauwelijks met de zegen wordt gevangen, wat er toe heeft bijgedragen dat deze soort niet tot de top tien meest algemene soorten behoort.

Langs de oever (schepnet) zijn baars, blankvoorn, bittervoorn en het vetje (valt onder overige soorten) de dominante soorten qua aantal (Figuur 2.96, onder). De laatste twee zijn soorten die in geen van de andere bemonsterde KRW-lichamen in de top tien algemene soorten voorgekomen. Dit komt waarschijnlijk door het afwijkende habitat (polders) ten opzichte van de overige KRW-lichamen (rivieren en meren). Verder wordt de rietvoorn ook regelmatig gevangen, net als de zwartbekgrondel. Qua biomassa zijn de snoek en karper dominant (Figuur 2.96, onder). Aangezien dit gebied nog maar vier jaar bemonsterd wordt is het lastig om iets over trends in soorten te concluderen. Wel zien we een afname in aantallen van het vetje (valt onder overige soorten). Serpeling, snoekbaars en pos zijn 
voor het eerst gevangen met het schepnet in 2019, deze soorten werden al wel eerder gevangen met de zegen.

De lengte-frequentieverdelingen per soort, per tuig over alle jaren van de monitoring van dit KRWlichaam zijn hier te vinden: https://wmropendata.wur.nl/site/zoetwatervis/35/waterlichaam/

\subsubsection{Aalvangsten}

Voor de aanlandingen van aal voor KRW-lichaam Noordwaard zijn de gegevens van de

"Benedenrivieren en Haringvliet i.o." gebruikt (Bijlage 2) en deze zijn weer gegeven in Figuur 2.80. 


\section{Noordwaard oever}

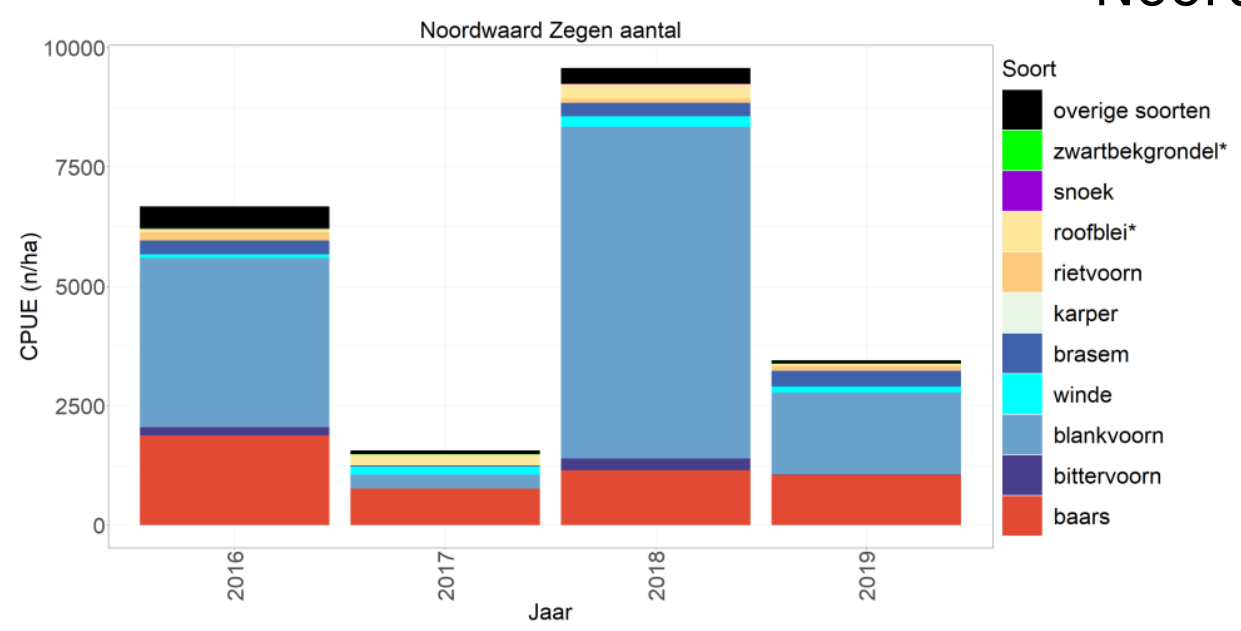

Noordwaard schepnet aantal

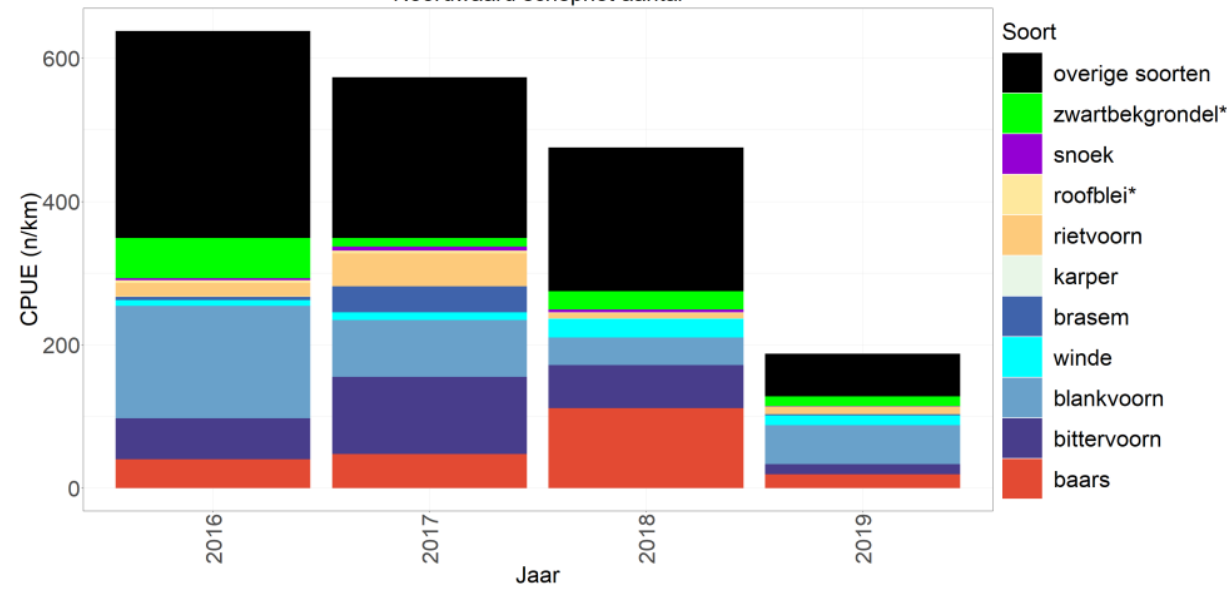

\section{Noordwaard Zegen biomassa}

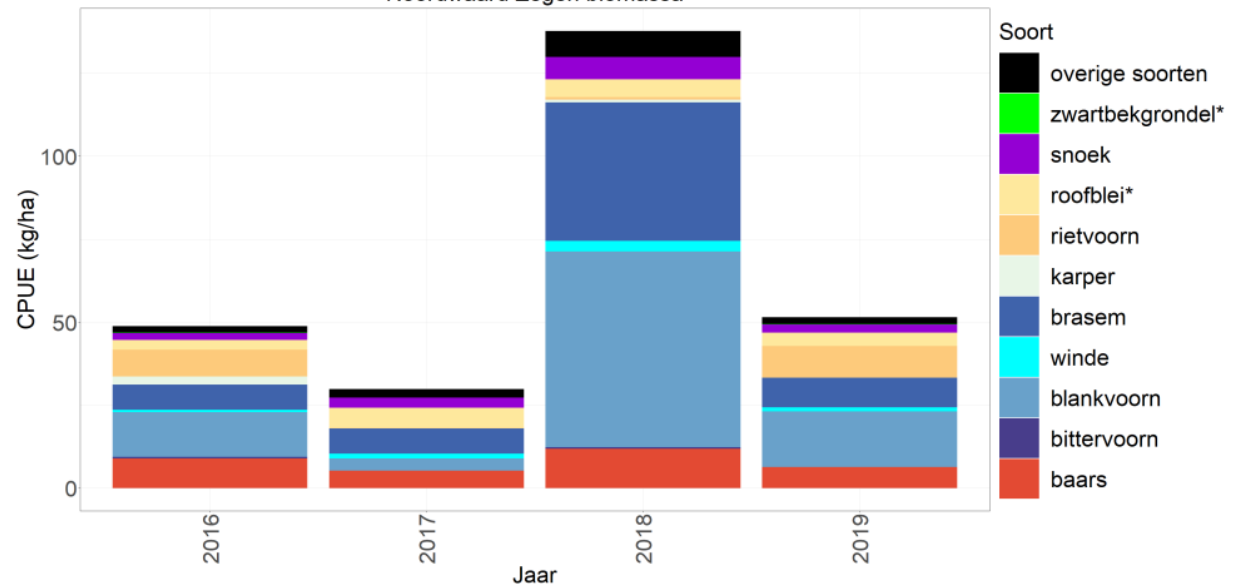

Noordwaard schepnet biomassa

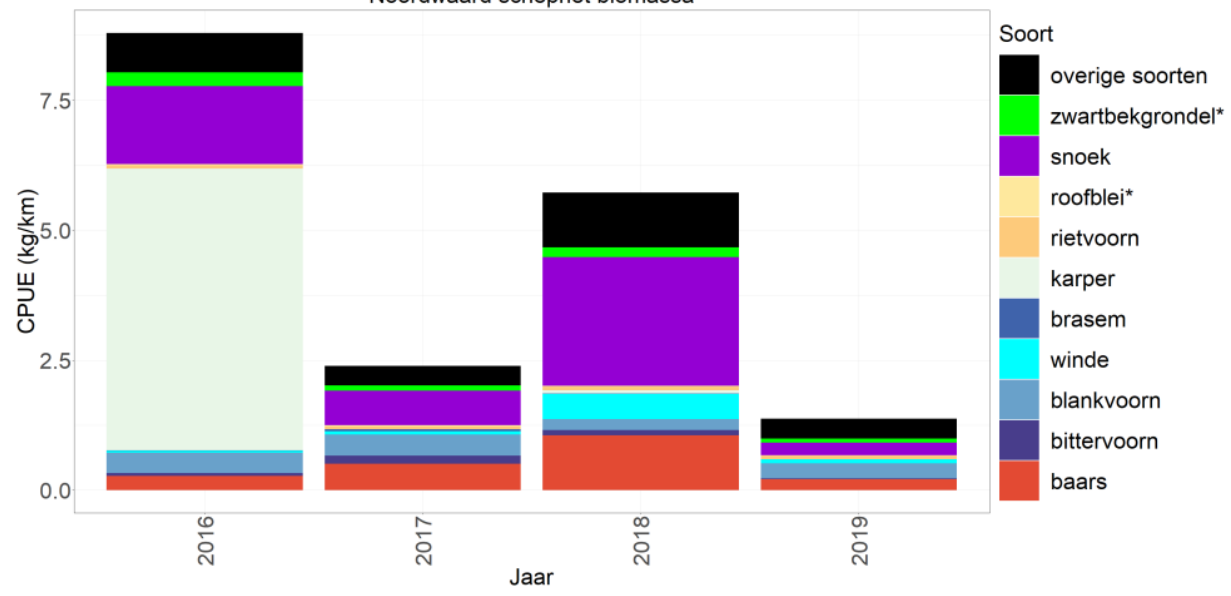

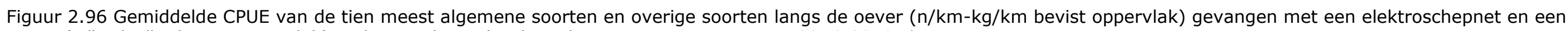
zegen ( $\mathrm{n} / \mathrm{ha}-\mathrm{kg} / \mathrm{ha}$ bevist oppervlak) in de Noordwaard tijdens de actieve monitoring van 2016-2019, * = exoot. 


\subsection{Nieuwe Merwede (Dordtse Biesbosch)}

De bemonsteringslocaties over de periode 1997-2019 zijn weergegeven in Figuur 2.97.

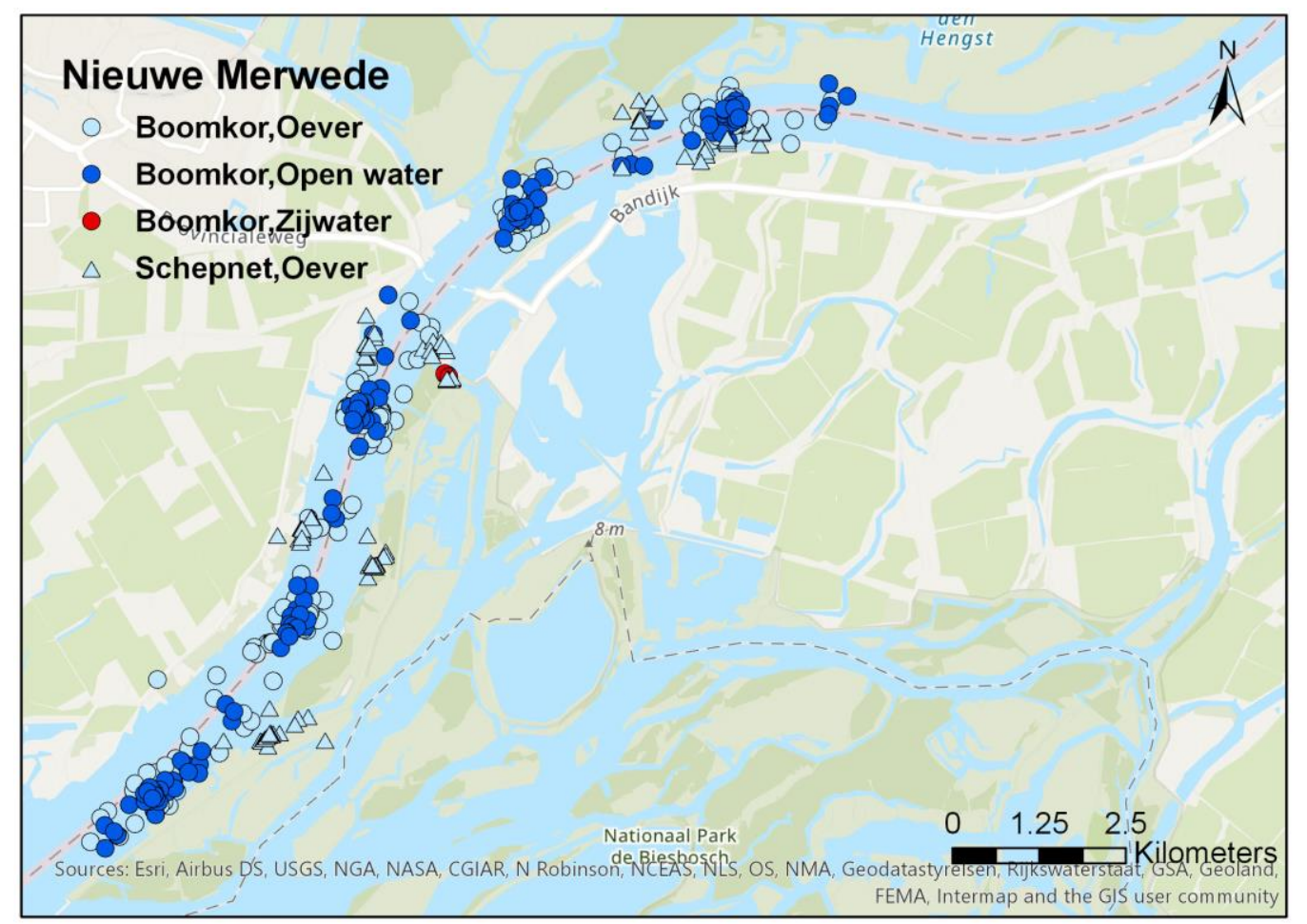

Figuur 2.97 Bemonsteringslocaties van de actieve monitoring in de Nieuwe Merwede van 1997-2019 per tuig per habitat.

\subsubsection{Nieuwe Merwede hoofdstroom (open water en oeverzone)}

De Nieuwe Merwede wordt sinds 1997 ieder jaar in het najaar met de boomkor en het elektroschepnet bemonsterd. Ieder jaar is de bemonstering in oktober uitgevoerd, behalve in 1999, toen werd deze in november uitgevoerd en in 2007 in zowel oktober als november.

De tien meest algemene soorten in de hoofdstroom van de Nieuwe Merwede voor de gehele periode 1997-2019 zijn zwartbekgrondel, Pontische stroomgrondel, kolblei, brasem, bot, winde, blankvoorn, baars, snoekbaars en aal. Deze omvatten meer dan 93\% van het totale gemiddelde aantal en biomassa voor zowel de vangsten met de boomkor als het schepnet (Bijlage 36). De biomassa van overige soorten bestaat voornamelijk uit karper.

In het open water en langs de oever (boomkor) zijn blankvoorn, brasem en snoekbaars de dominante soorten, zowel qua aantal als qua biomassa (Figuur 2.98 boven). De laatste tien jaar zijn de hoeveelheden van blankvoorn en brasem sterker gaan fluctueren. Snoekbaars vertoont relatief stabiele vangsten door de jaren heen. Kolblei werd voorheen ook regelmatig gevangen, maar de laatste jaren nauwelijks nog. Bot is ook een soort die in sommige jaren veel wordt gevangen. Sinds 2009/2010 worden de invasieve zwartbekgrondel en Pontische stroomgrondel regelmatig gevangen, alhoewel dit de laatste drie jaar weer wat minder lijkt te zijn.

Langs de oever (schepnet) zijn blankvoorn en baars qua aantal de dominante soorten (Figuur 2.98 onder). Ook worden er relatief veel windes en vanaf 2009 zwartbekgrondels en Pontische stroomgrondels gevangen. Qua biomassa zien we dat aal en winde voornamelijk de dominante soorten zijn in de vangsten, waarbij aal de laatste jaren (wel in afnemende mate) relatief veel wordt gevangen en de winde wat minder. De biomassa van overige soorten bestaat voornamelijk uit karper.

De lengte-frequentieverdelingen per soort, per tuig voor de hoofdstroom en de zijwateren gecombineerd over alle jaren van de monitoring van dit KRW-lichaam zijn hier te vinden: https://wmropendata.wur.nl/site/zoetwatervis/36/waterlichaam/ 

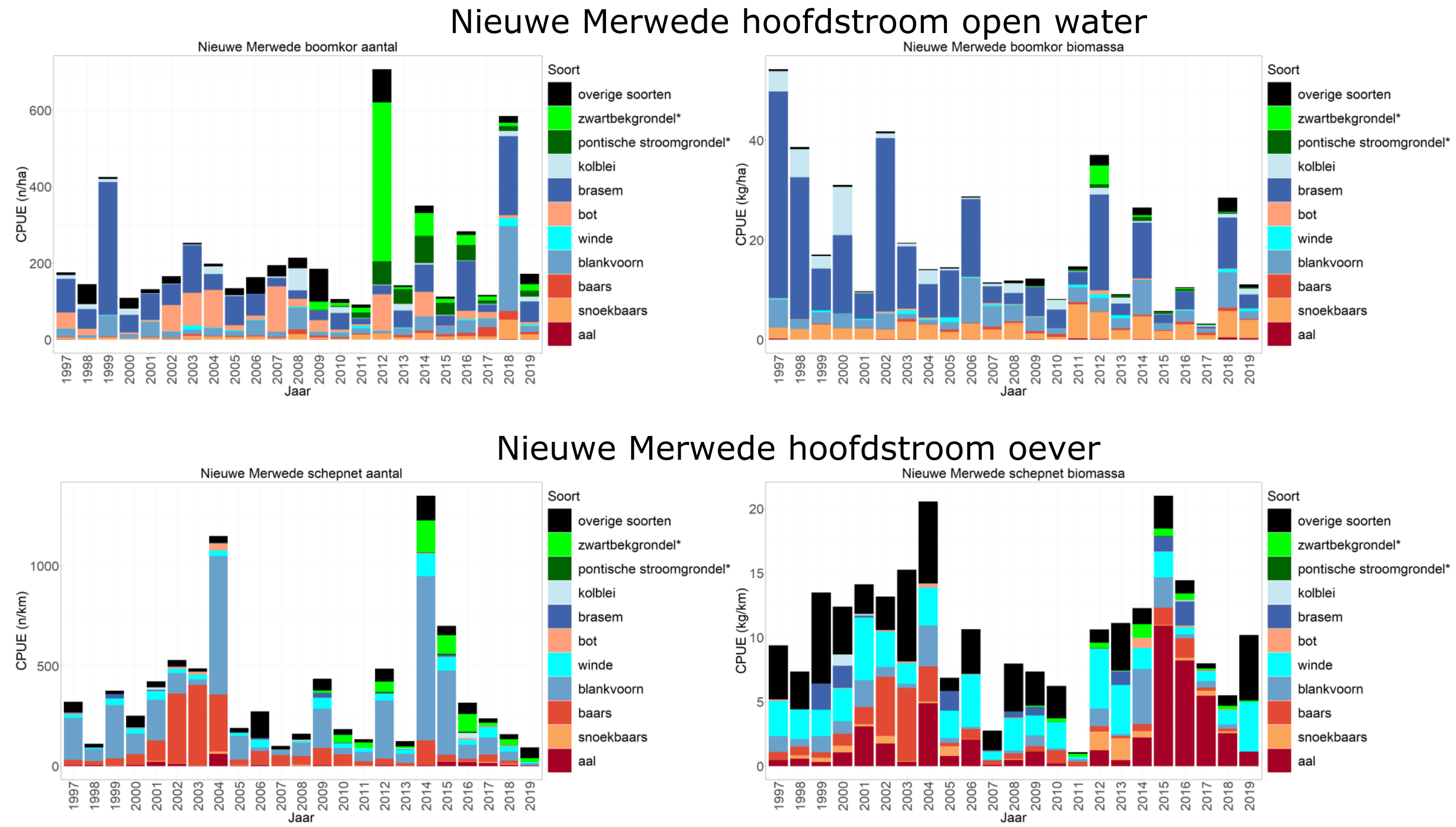

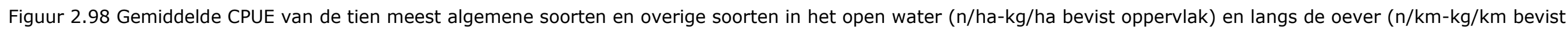
oppervlak) gevangen met een boomkor en elektroschepnet in de hoofdstroom van de Nieuwe Merwede tijdens de actieve monitoring van $1997-2019, *=$ exoot. 


\subsubsection{Chinese wolhandkrab}

De Chinese wolhandkrab wordt met enige regelmaat gevangen in de hoofdstroom van de Nieuwe Merwede. De aantallen fluctueren rondom een laag gemiddelde, met meerdere jaren zonder vangsten. In 2019 werden relatief hoge aantallen wolhandkrabben gevangen (Figuur 2.99).

Nieuwe Merwede boomkor aantal

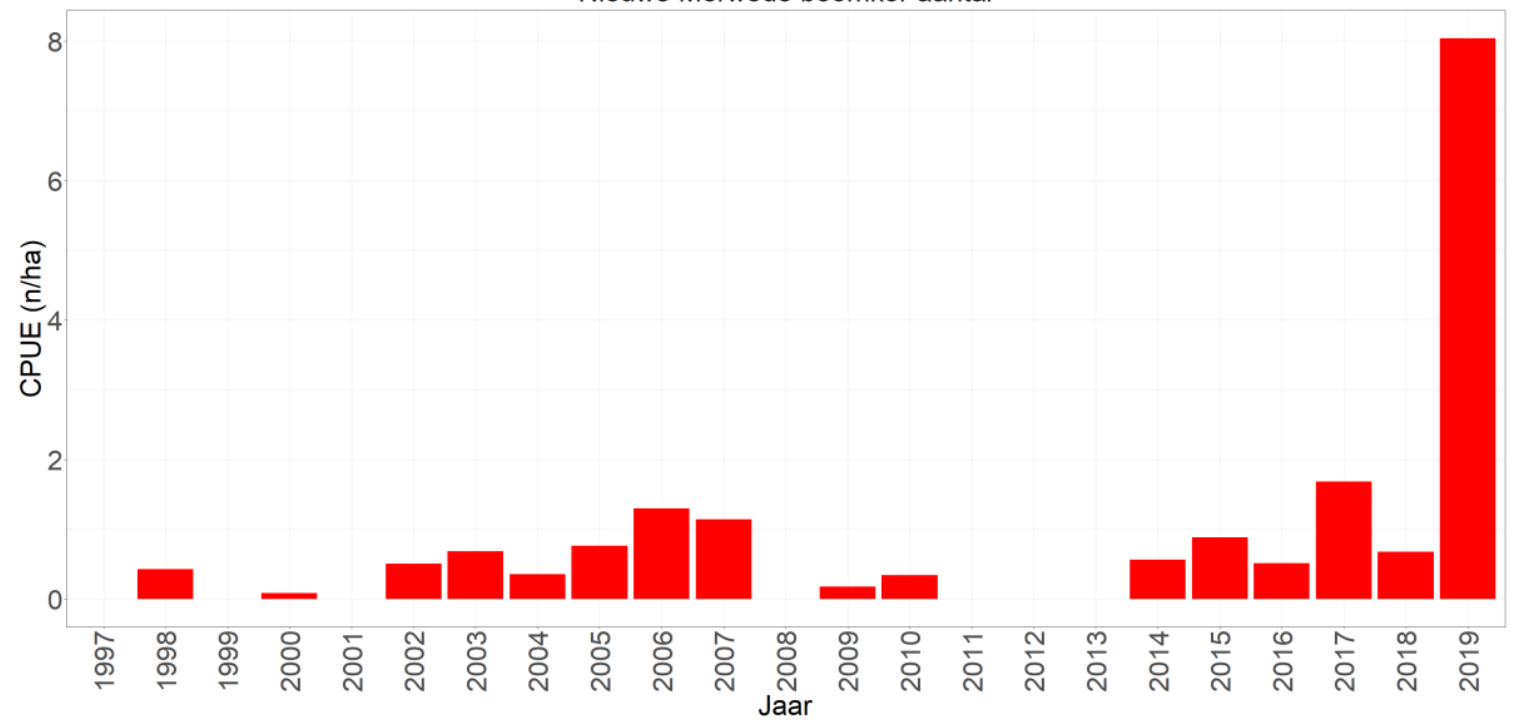

Figuur 2.99 Gemiddelde CPUE (n/ha bevist oppervlak) per jaar van de Chinese wolhandkrab in de hoofdstroom van het open water van de Nieuwe Merwede gevangen met de boomkor.

\subsubsection{Nieuwe Merwede zijwateren}

Langs de Nieuwe Merwede is een zijkanaal bemonsterd met de boomkor in het open water.

De tien meest algemene soorten in het zijwater van de Nieuwe Merwede voor de gehele periode 20072019 zijn zwartbekgrondel, Pontische stroomgrondel, pos, snoek, roofblei, brasem, winde, blankvoorn, baars en snoekbaars. Deze omvatten meer dan $97 \%$ van het totale gemiddelde aantal en biomassa voor zowel de vangsten met de boomkor als het schepnet (Bijlage 37). Qua aantallen en biomassa lijkt de dichtheid van vis in de zijwateren hoger te zijn dan in de hoofdstroom.

Opvallend is dat kolblei en bot ontbreken in de top tien van de zijwateren, terwijl deze wel tot de top tien behoren in het open water en bij de oever van de hoofdstroom van de Nieuwe Merwede. Hun plaats in de top tien is ingenomen door pos en roofblei.

Net als in het open water van de hoofdstroom zijn brasem en blankvoorn de dominante soorten in de boomkorvangsten, zowel qua aantal als qua biomassa. In de zijwateren komt baars daar ook nog bij (Figuur 2.100). De vangsten van alle soorten fluctueren sterk van jaar tot jaar, met ook hier weerhoge vangsten van blankvoorn in 2019. Wat opvalt is dat er relatief weinig invasieve grondelsoorten worden gevangen. 


\section{Nieuwe Merwede zijwateren open water}

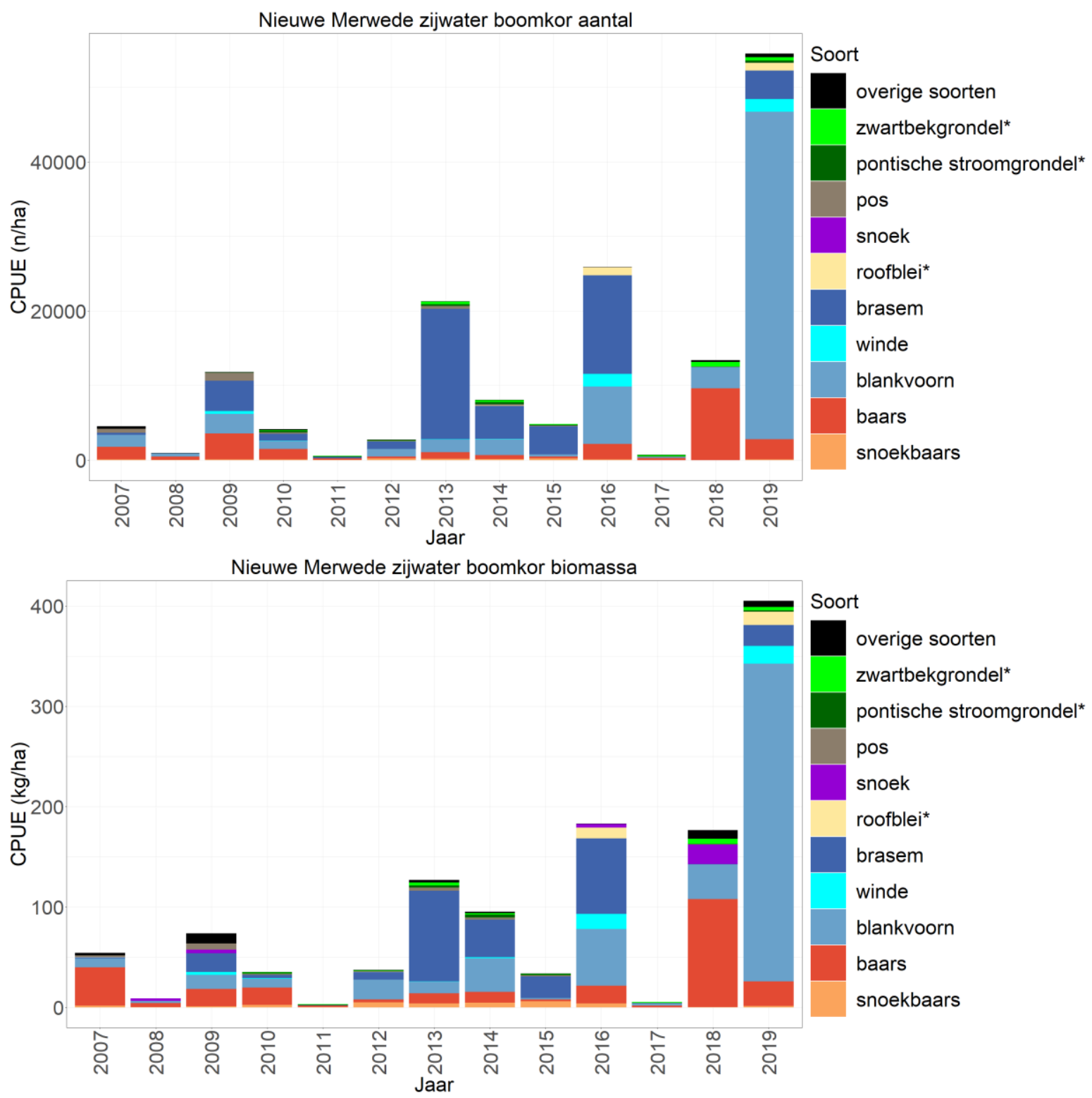

Figuur 2.100 Gemiddelde CPUE van de tien meest algemene soorten en overige soorten in het open water ( $\mathrm{n} / \mathrm{ha}-\mathrm{kg} / \mathrm{ha}$ bevist oppervlak) gevangen met een boomkor in de zijwateren van de Nieuwe Merwede tijdens de actieve monitoring van 2007-2019, * = exoot. 


\subsubsection{Chinese wolhandkrab}

De Chinese wolhandkrab wordt sinds 2007 in enkele jaren in grote hoeveelheden gevangen in de zijwateren van de Nieuwe Merwede. In de andere jaren worden er geen wolhandkrabben gevangen (Figuur 2.99).

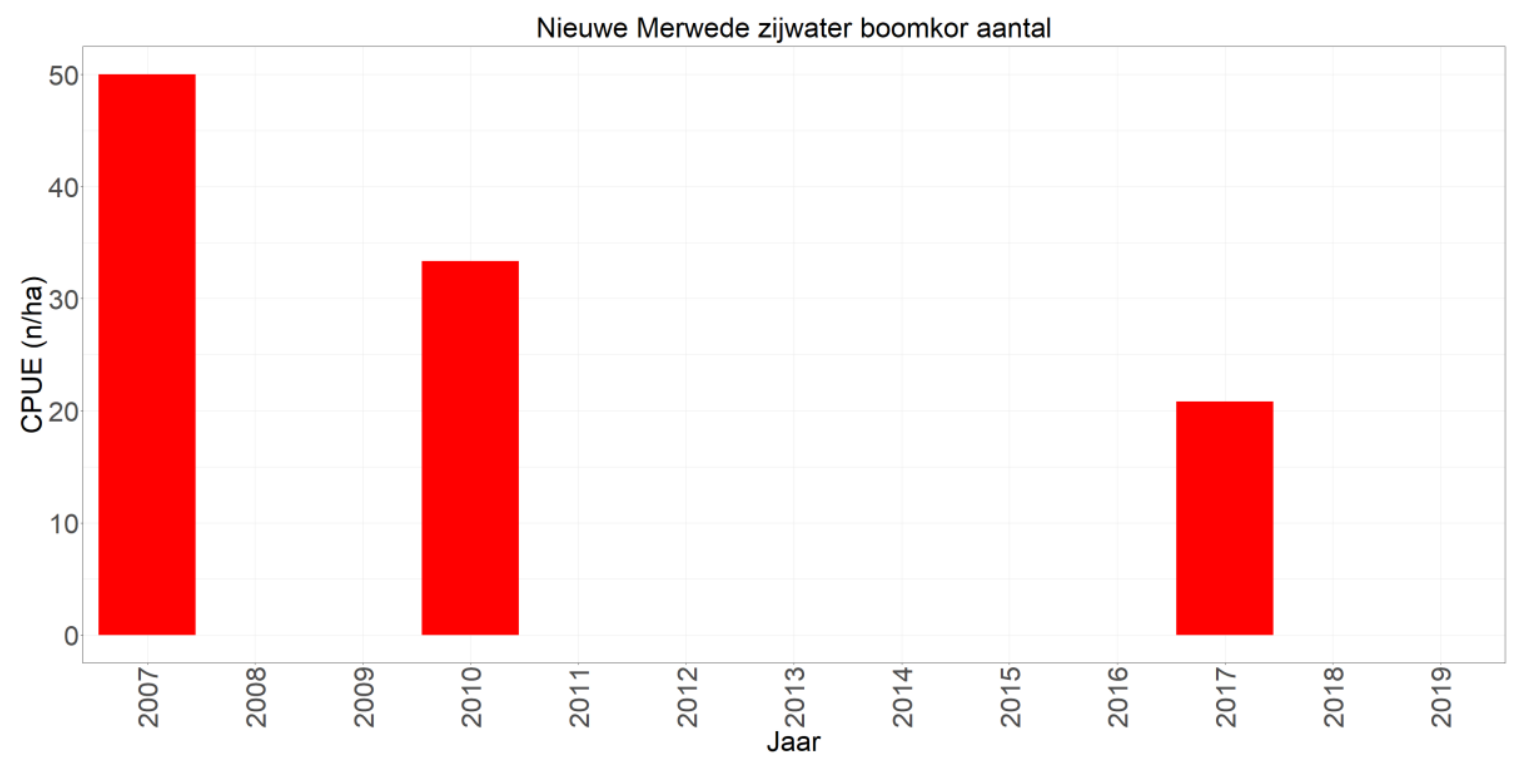

Figuur 2.101 Gemiddelde CPUE (n/ha bevist oppervlak) per jaar van de Chinese wolhandkrab in de zijwateren van de Nieuwe Merwede gevangen met de boomkor.

\subsubsection{Aalvangsten}

Voor de aanlandingen van aal voor KRW-lichaam Nieuwe Merwede zijn de gegevens van de "Benedenrivieren en Haringvliet i.o." gebruikt (Bijlage 2) en deze zijn weer gegeven in Figuur 2.80. 


\subsection{Hollands(ch)e IJssel}

De bemonsteringslocaties over de periode 2016-2019 zijn weergegeven in Figuur 2.102.

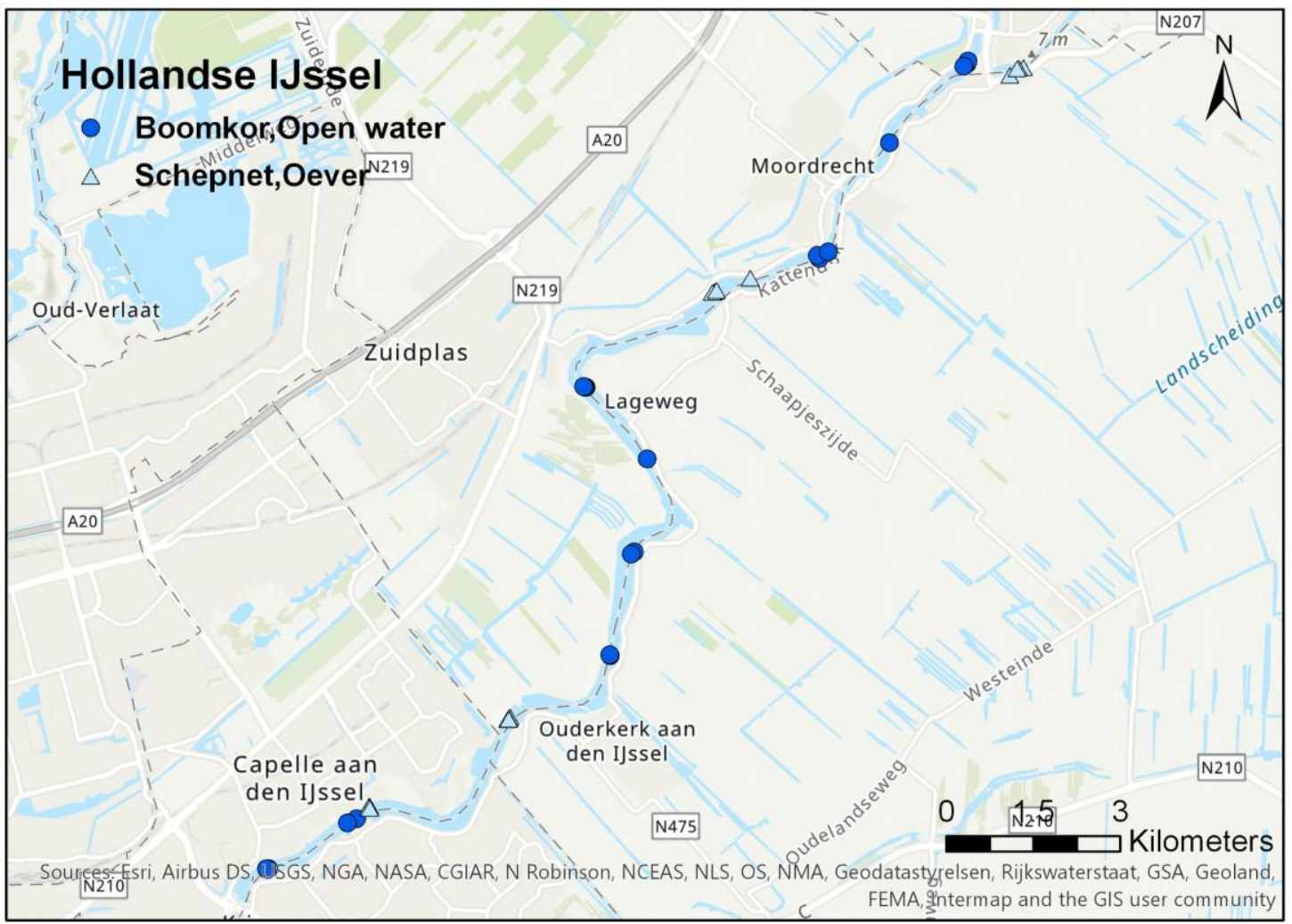

Figuur 2.102 Bemonsteringslocaties van de actieve monitoring in de Hollandse IJssel van 2016-2019 per tuig per habitat.

\subsubsection{Hollandse IJssel hoofdstroom (open water en oeverzone)}

De Hollandse IJssel wordt sinds 2016 ieder jaar in het najaar (oktober) met de boomkor en het elektroschepnet bemonsterd.

De tien meest algemene soorten in de hoofdstroom van de Hollandse IJssel voor de gehele periode 2016-2019 zijn zwartbekgrondel, kolblei, rietvoorn, brasem, bot, winde, blankvoorn, baars, snoekbaars en aal. Deze omvatten meer dan $97 \%$ van het totale gemiddelde aantal en biomassa voor de vangsten met het schepnet (Bijlage 38). Ten opzichte van de voorgaande rapportage (van Rijssel et al. 2019a) behoort de rietvoorn tot de top tien meest algemene soorten in plaats van de driedoornige stekelbaars.

In het open water (boomkor) zijn brasem, bot, snoekbaars en aal zowel qua aantal als qua biomassa de dominante soorten in de boomkorvangsten (Figuur 2.103 boven). Ook worden rietvoorn en de invasieve zwartbekgrondel regelmatig gevangen. Aangezien dit gebied nog maar vier jaar bemonsterd wordt, is het lastig om iets over trends in soorten te kunnen concluderen. Wel zien we dat brasem en kolblei de laatste twee jaren wat hogere vangsten laten zien, waar het tegenovergestelde juist het geval lijkt te zijn in andere KRW-lichamen. In 2019 zijn de winde en de witvinriviergrondel voor het eerst gevangen met de boomkor, de winde werd al eerder gevangen met het schepnet.

Langs de oever (schepnet) zijn aal, winde, zwartbekgrondel en de driedoornige stekelbaars (valt onder overige soorten) qua aantal de dominante soort (Figuur 2.103 onder). Ook hier is het lastig om iets over trends in soorten door de tijd heen te kunnen concluderen. In 2019 vallen de relatief hoge vangsten van aal, rietvoorn en zwartbekgrondel op. In 2019 is de sneep voor het eerst gevangen in de Hollandsche IJssel.

De lengte-frequentieverdelingen per soort, per tuig over alle jaren van de monitoring van dit KRWlichaam zijn hier te vinden: https://wmropendata.wur.nl/site/zoetwatervis/70/waterlichaam/ 


\section{Hollandse IJssel hoofdstroom open water}
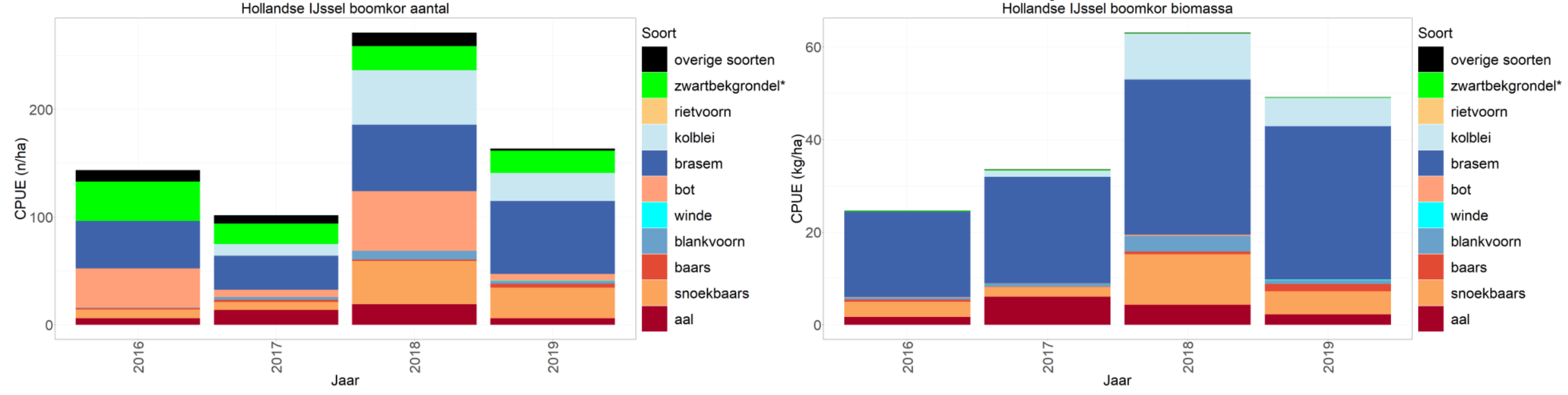

Hollandse IJssel hoofdstroom oever

Hollandse IJssel schepnet aantal
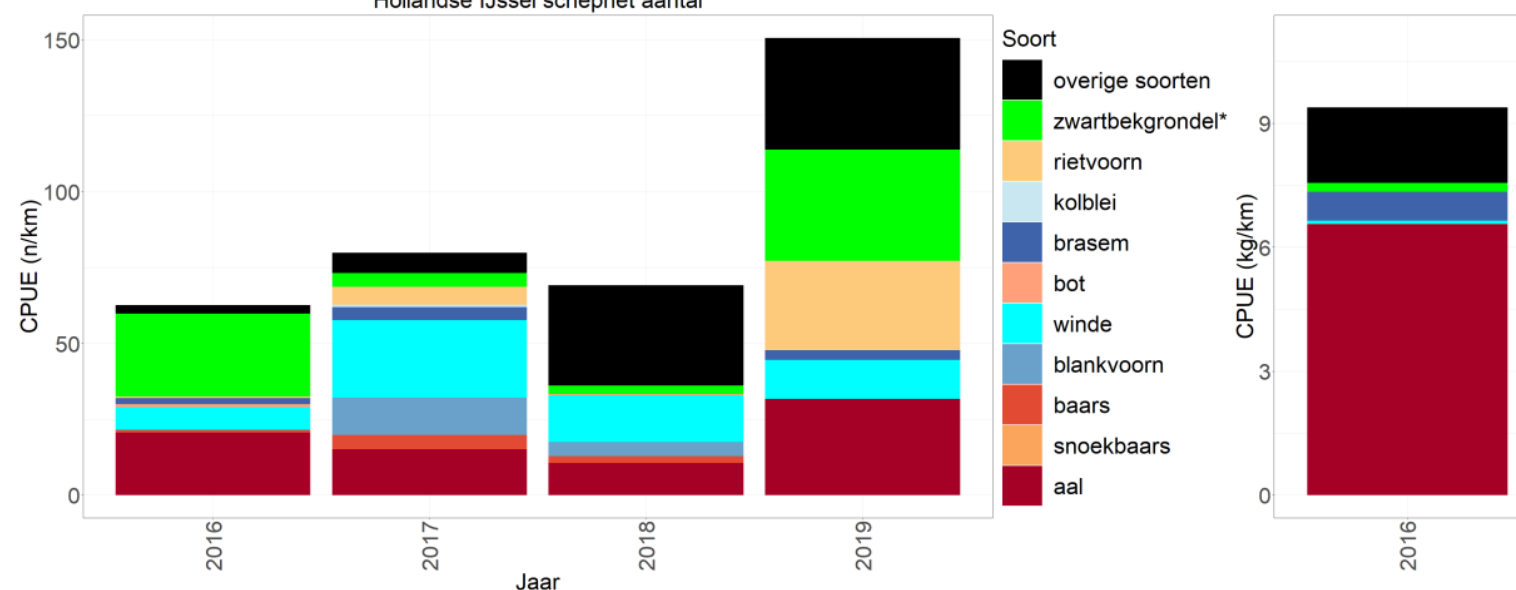

Hollandse IJssel schepnet biomassa

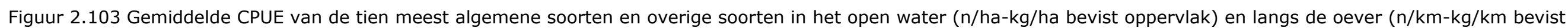
oppervlak) gevangen met een boomkor en elektroschepnet in de hoofdstroom van de Hollandse IJssel tijdens de actieve monitoring van $2016-2019, *=$ exoot. 


\subsubsection{Chinese wolhandkrab}

De Chinese wolhandkrab wordt sinds 2016 regelmatig gevangen in de Hollandse IJssel met de hoogste aantallen in 2019 (Figuur 2.104).

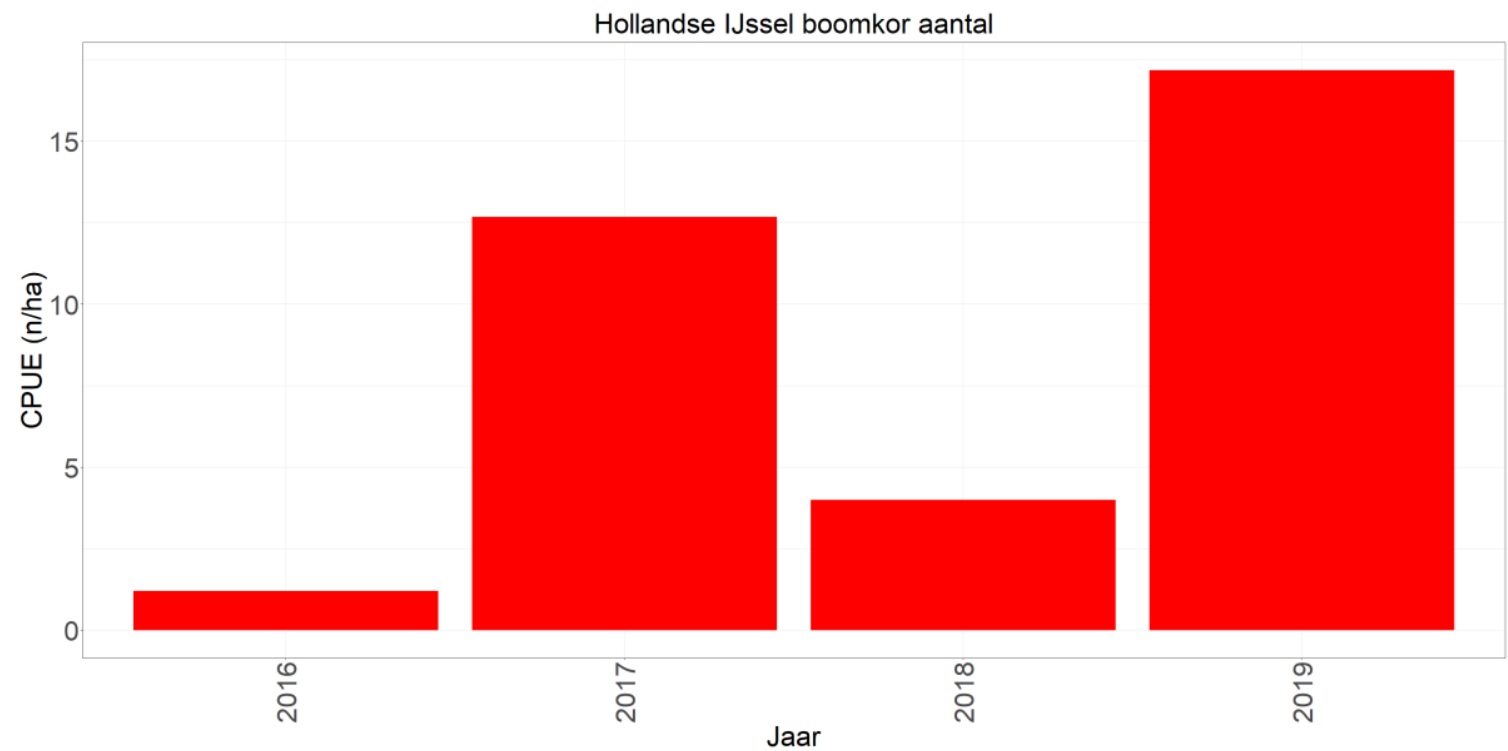

Figuur 2.104 Gemiddelde CPUE (n/ha bevist oppervlak) per jaar van de Chinese wolhandkrab in de hoofdstroom van het open water van de Hollandse IJssel gevangen met de boomkor.

\subsubsection{Aalvangsten}

Voor de aanlandingen van aal voor KRW-lichaam Hollandse IJssel zijn de gegevens van de "Benedenrivieren en Haringvliet i.o." gebruikt (Bijlage 2) en deze zijn weer gegeven in Figuur 2.80. 


\subsection{Oude Maas}

De bemonsteringslocaties over de periode 1997-2019 zijn weergegeven in Figuur 2.105.

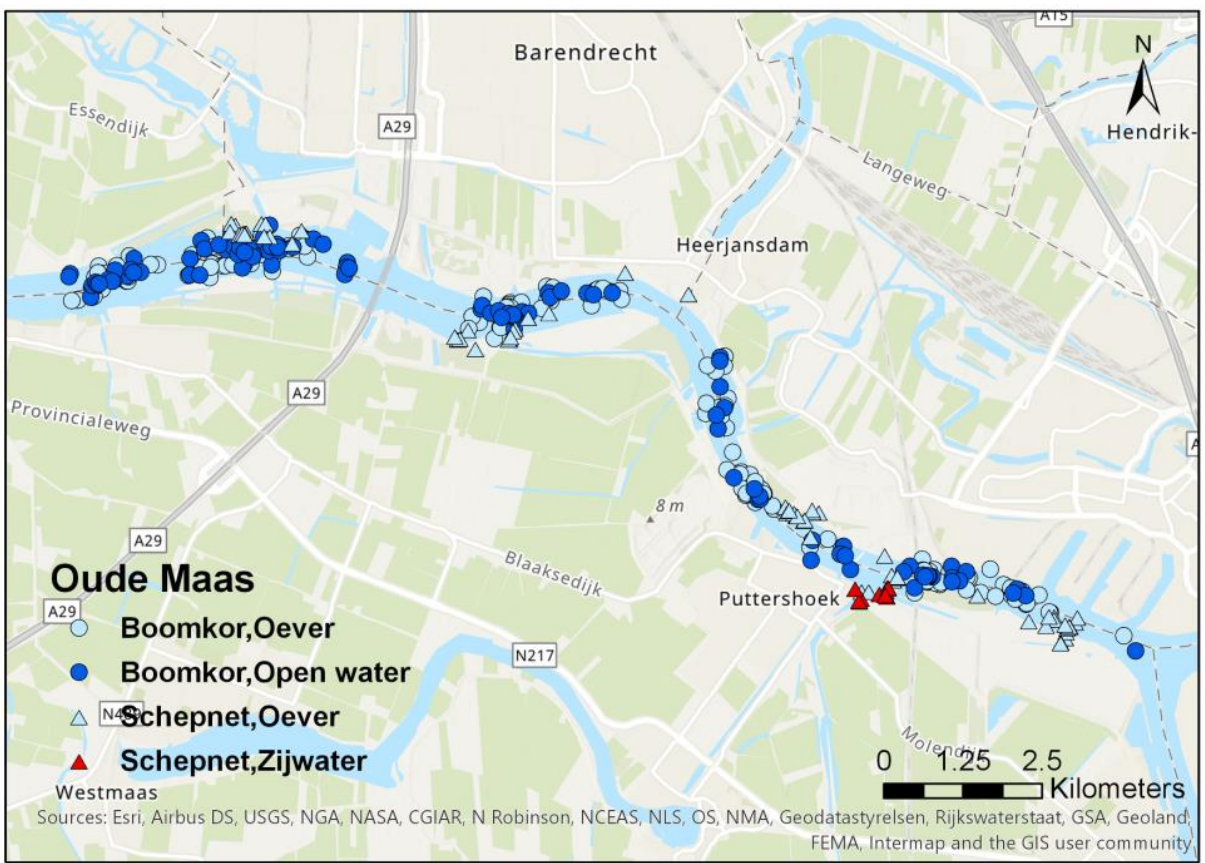

Figuur 2.105 Bemonsteringslocaties van de actieve monitoring in de Oude Maas van 1997-2019 per tuig per habitat.

\subsubsection{Oude Maas hoofdstroom (open water en oeverzone)}

De Oude Maas wordt sinds 1997 ieder jaar in het najaar met de boomkor en het elektroschepnet bemonsterd. De bemonstering is altijd in oktober uitgevoerd, behalve in 1999, toen werd deze in november uitgevoerd.

De tien meest algemene soorten in de hoofdstroom van de Oude Maas voor de gehele periode 19972019 zijn zwartbekgrondel, kolblei, brasem, bot, winde, blankvoorn, baars, snoekbaars, alver en aal. Deze omvatten meer dan $95 \%$ van het totale gemiddelde aantal en biomassa voor zowel de vangsten met de boomkor als het schepnet (Bijlage 39). De biomassa van overige soorten bestaat voornamelijk uit karper.

In het open water en langs de oever zijn brasem, kolblei, aal en bot de dominante soorten, zowel qua aantal als qua biomassa (Figuur 2.106 boven). Sinds 2007 worden er ook veel zwartbekgrondels gevangen en vanaf dit moment lijken de vangsten van bot lager te liggen. Pas sinds 2018 zien we weer wat hogere vangsten van bot, na een aantal jaren van relatief lage zwartbekgrondelvangsten. Brasem lijkt de laatste tien jaar te zijn afgenomen, maar wordt de laatste twee jaar weer meer gevangen. In de andere KRW-lichamen gaat een afname van brasem vaak gepaard met een afname van kolblei. Dit lijkt hier niet het geval: de kolblei wordt de laatste jaren zelfs wat meer gevangen met de hoogste vangsten in 2019. Aal wordt ook regelmatig gevangen, met fluctuerende hoeveelheden. In 2019 is haring/sprot voor het eerst in de Oude Maas gevangen, wellicht is dit een effect van het op een kier zetten van de Haringvlietsluis.

Langs de oever (schepnet) is alver qua aantal de dominante soort; de Oude Maas is het enige KRWlichaam waarbij dit het geval is (Figuur 2.106 onder). Ook worden er relatief veel windes en vanaf 2008 zwartbekgrondels gevangen. Qua biomassa zien we dat aal en winde voornamelijk de dominante soorten zijn in de vangsten, met wat hogere vangsten van aal in de laatste jaren (op $2018 \mathrm{na}$ ). Voorheen leek brasem ook tot de dominante soorten te horen. De biomassa van overige soorten bestaat voornamelijk uit karper.

De lengte-frequentieverdelingen per soort, per tuig voor de hoofdstroom en de zijwateren gecombineerd over alle jaren van de monitoring van de Getijden Lek en de Oude Maas gecombineerd zijn hier te vinden: https://wmropendata.wur.nl/site/zoetwatervis/66/waterlichaam/ 


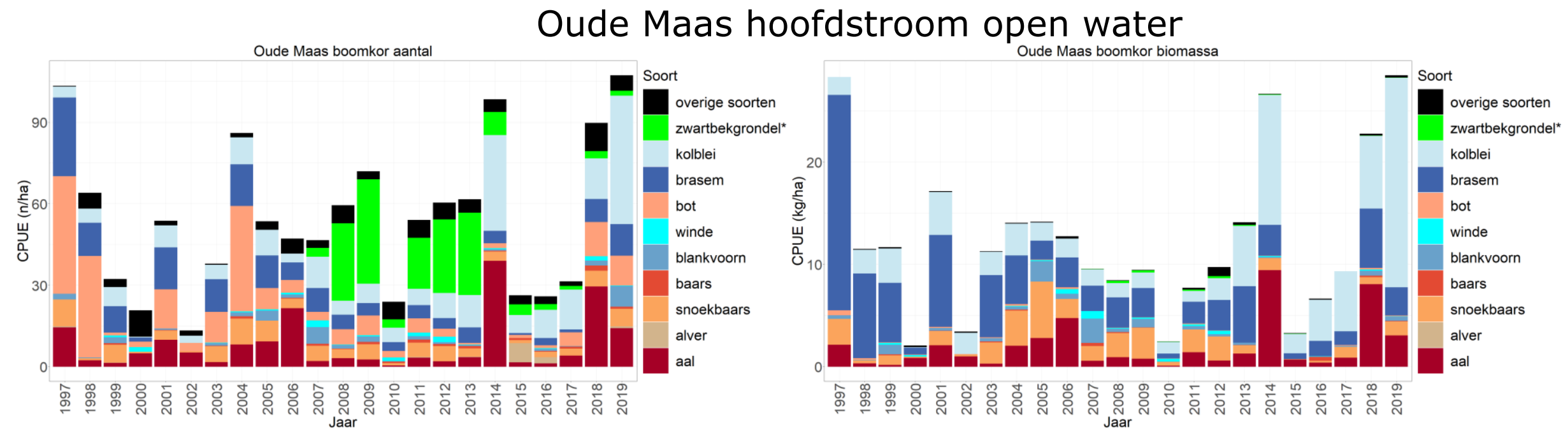

Oude Maas hoofdstroom oever

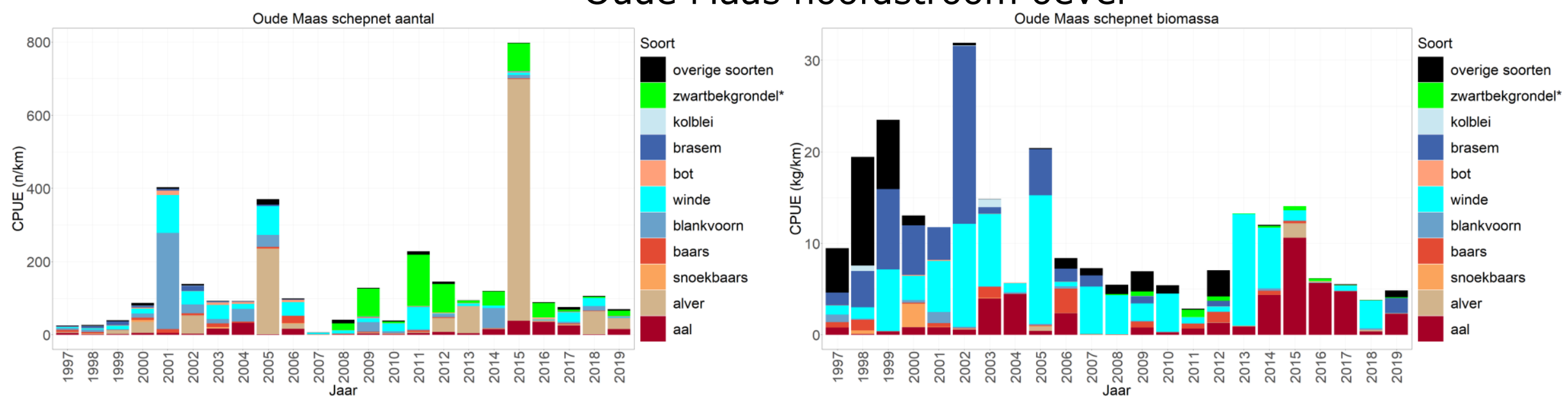

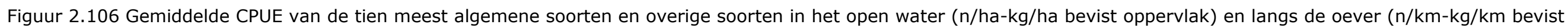
oppervlak) gevangen met een boomkor en elektroschepnet in de hoofdstroom van de Oude Maas tijdens de actieve monitoring van $1997-2019, *=$ exoot. 


\subsubsection{Chinese wolhandkrab}

De Chinese wolhandkrab wordt met enige regelmaat gevangen in de hoofdstroom van de Oude Maas. Wat opvalt is de relatief zeer hoge piek in 2006, en de jaren zonder vangsten in 2012 en 2013. Ook in 2018 werden er relatief hoge aantallen wolhandkrabben gevangen (Figuur 2.107).

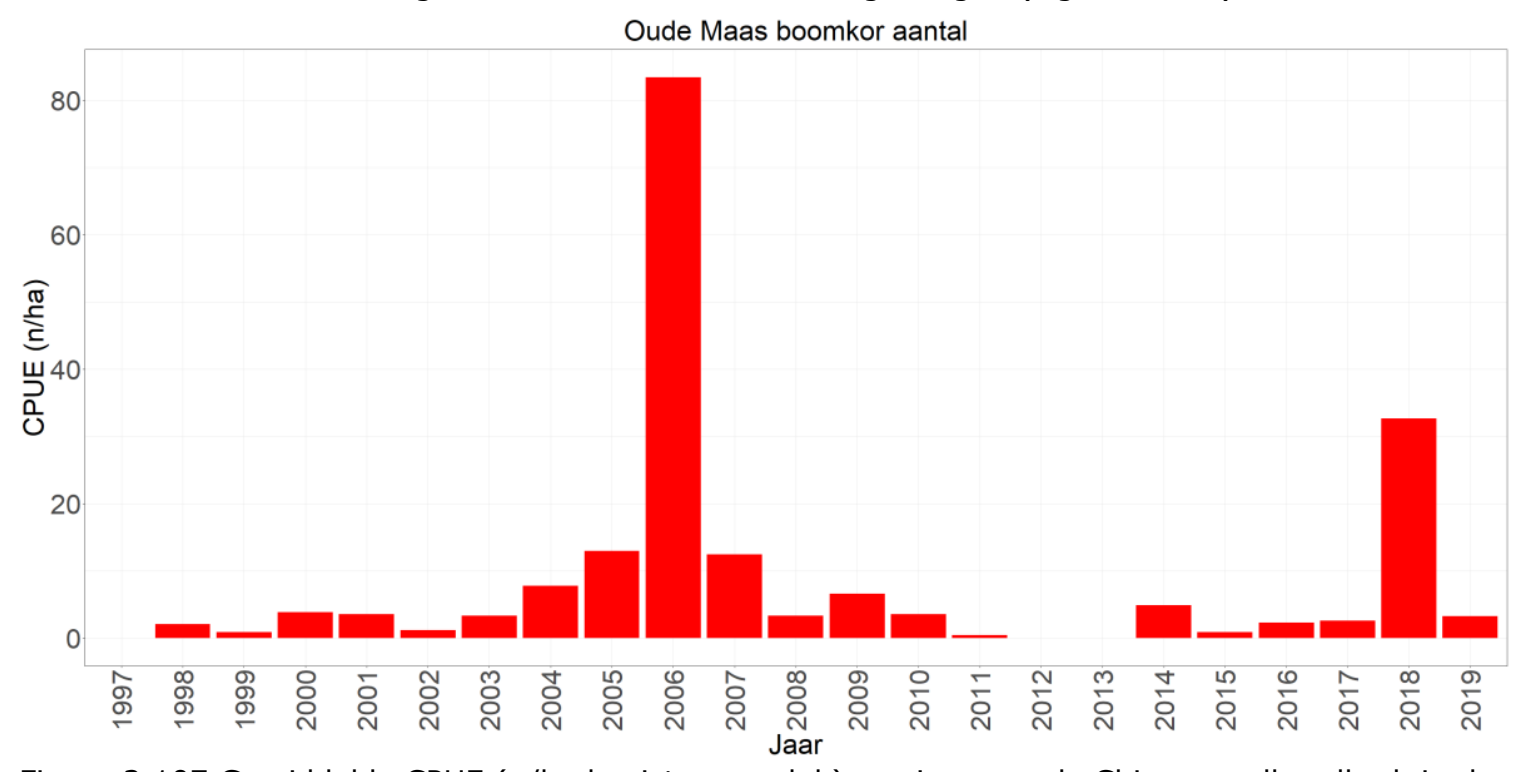

Figuur 2.107 Gemiddelde CPUE (n/ha bevist oppervlak) per jaar van de Chinese wolhandkrab in de hoofdstroom van het open water van de Oude Maas gevangen met de boomkor.

\subsubsection{Oude Maas zijwateren}

Langs de Oude Maas zijn een zijkanaal en een inham bemonsterd, met het schepnet langs de oever.

De tien meest algemene soorten in de zijwateren van de Oude Maas voor de gehele periode 20022019 zijn zwartbekgrondel, snoek, roofblei, brasem, bot, winde, blankvoorn, baars, snoekbaars en aal. Deze omvatten meer dan 95\% van het totale gemiddelde aantal en de biomassa voor de vangsten met het schepnet (Bijlage 39). Ten opzichte van de voorgaande rapportage (van Rijssel et al. 2019a) behoort de dunlipharder tot de meest algemene soorten in plaats van de roofblei. Qua aantallen en biomassa lijkt de dichtheid van vis tussen de hoofd- en zijwateren ongeveer gelijk te zijn.

Opvallend is dat kolblei en alver ontbreken in de top tien van de zijwateren, terwijl deze wel tot de top tien behoren in het open water en bij de oever van de hoofdstroom van de Oude Maas. Hun plaats in de top tien is ingenomen door snoek en dunlipharder.

Blankvoorn en winde zijn qua aantal en biomassa de dominante soorten (Figuur 2.108). Sinds 2009 wordt de zwartbekgrondel ook regelmatig gevangen en behoort deze tot de dominante soorten in sommige jaren. De vangsten van alle soorten fluctueren sterk qua aantal en biomassa. Erg opvallend zijn de hoge biomassavangsten van de dunlipharder in 2018 en 2019, dit heeft er ook voor gezorgd dat deze soort tot de top tien meest algemene soorten behoort.

De Chinese wolhandkrab is alleen in 2014 in lage aantallen gevangen met het schepnet in de zijwateren van de Oude Maas. 


\section{Oude Maas zijwateren oever}
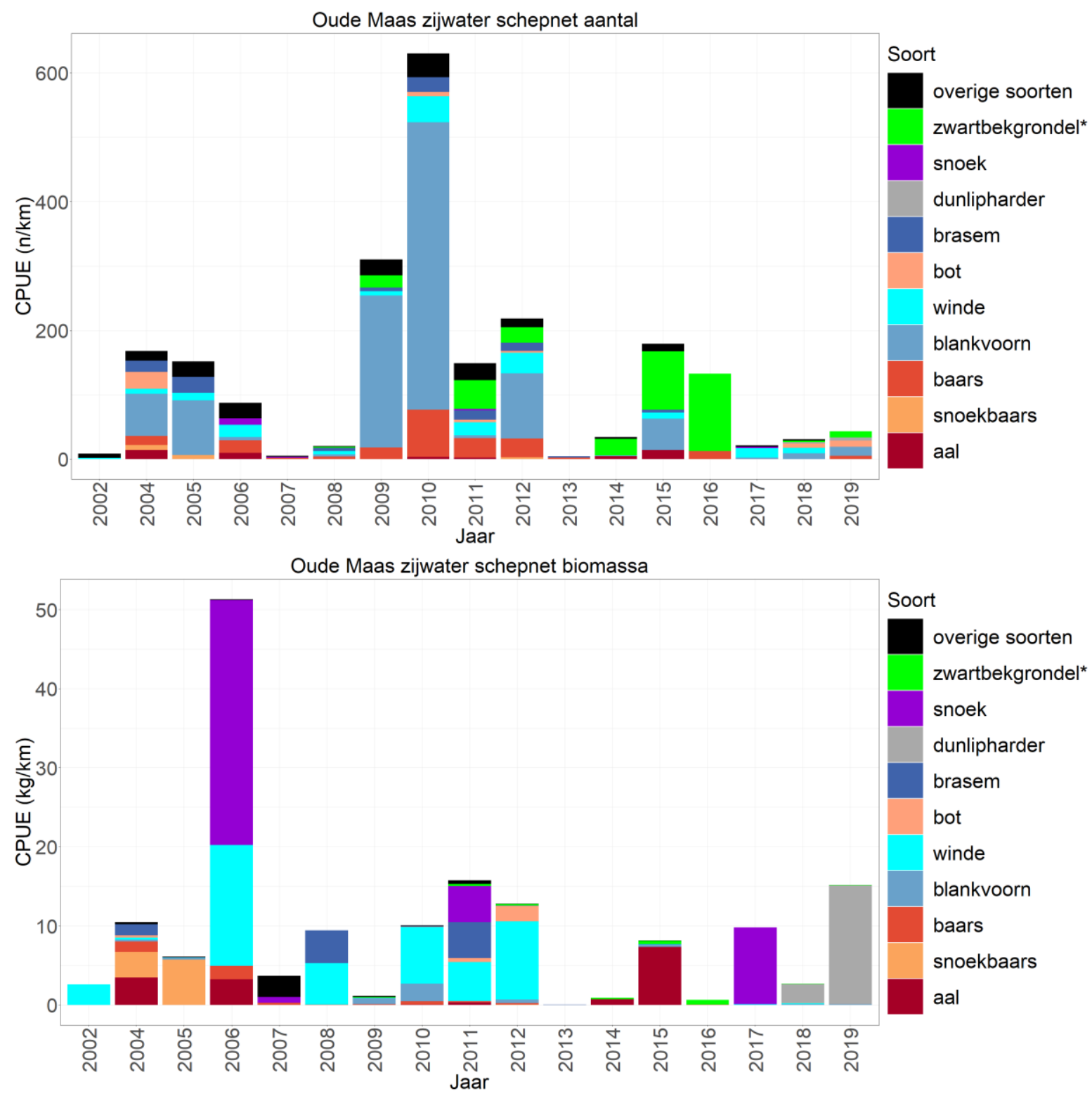

Figuur 2.108 Gemiddelde CPUE van de tien meest algemene soorten en overige soorten langs de oever $(\mathrm{n} / \mathrm{km}-\mathrm{kg} / \mathrm{km}$ bevist oppervlak) gevangen met een elektroschepnet in zijwateren van de Oude Maas tijdens de actieve monitoring van 2002-2019, * exoot.

\subsubsection{Aalvangsten}

Voor de aanlandingen van aal voor KRW-lichaam Oude Maas zijn de gegevens van de

"Benedenrivieren en Haringvliet i.o." gebruikt (Bijlage 2) en deze zijn weer gegeven in Figuur 2.80. 


\subsection{Hollandsch Diep (Haringvliet-Oost)}

De bemonsteringslocaties over de periode 1997-2019 zijn weergegeven in Figuur 2.109.

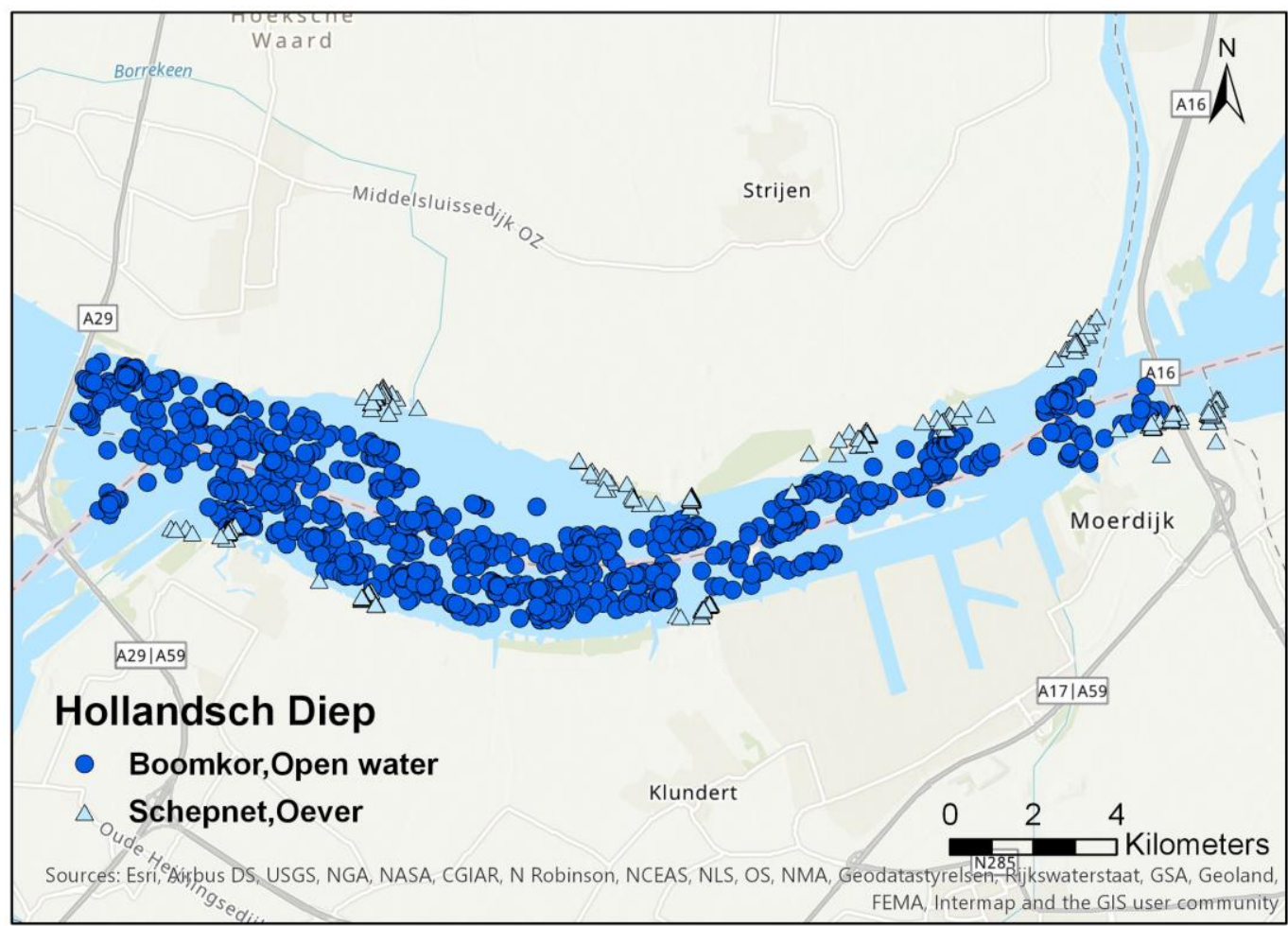

Figuur 2.109 Bemonsteringslocaties van de actieve monitoring in de Hollandsch Diep van 1997-2019 per tuig per habitat.

\subsubsection{Hollandsch Diep hoofdstroom (open water en oeverzone)}

Het Hollandsch Diep wordt sinds 1997 ieder jaar in het najaar met de boomkor en het elektroschepnet bemonsterd. De meeste jaren is de bemonstering in oktober uitgevoerd, behalve in de jaren 1998, 2002-2004, 2008-2009, 2014-2015 en 2019, toen werd deze in zowel september als oktober uitgevoerd. Het Hollandsch Diep is in 2011 ook in het voorjaar bemonsterd, deze data is uit de trendanalyse gelaten voor een betere vergelijkbaarheid tussen de jaren.

De tien meest algemene soorten in de hoofdstroom van het Hollandsch Diep voor de gehele periode 1997-2019 zijn zwartbekgrondel, kolblei, karper, brasem, bot, winde, blankvoorn, baars, snoekbaars en aal. Deze omvatten meer dan $97 \%$ van het totale gemiddelde aantal en biomassa voor zowel de vangsten met de boomkor als het schepnet (Bijlage 41).

In het open water (boomkor) zijn brasem, blankvoorn, snoekbaars en baars de dominante soorten, zowel qua aantal als qua biomassa (Figuur 2.110 boven). Deze soorten lijken allemaal relatief stabiel, op de brasem na. Deze lijkt met name sinds 2011 steeds meer af te nemen, hoewel er vanaf 2016 weer een opleving lijkt te zijn. Sinds 2009 wordt de zwartbekgrondel ook regelmatig gevangen, met een noemenswaardige toename in 2019. Verder vallen de hoge vangsten van aal en baars in 2019 op.

Langs de oever (schepnet) is blankvoorn qua aantal de dominante soort (Figuur 2.110 onder). Blankvoorn wordt, na een ogenschijnlijke toename in aantallen tot 2015, de laatste vier jaar echter weinig gevangen. Vanaf 2009 worden er veel zwartbekgrondels gevangen hoewel de aantallen de laatste drie jaren ook weer lager zijn. Hierbij moet wel vermeld worden dat de totale vangsten de afgelopen jaren lager zijn. Qua biomassa zien we dat aal, winde en brasem voornamelijk de dominante soorten zijn in de vangsten, hoewel brasemvangsten wel wat zijn afgenomen de afgelopen jaren. Dit is opvallend, gezien de toename van brasem de laatste jaren in de hoofdstroom. Verder wordt de winde qua biomassa de laatste jaren ook minder gevangen (op 2018 na), terwijl aal weer wat meer wordt gevangen.

De lengte-frequentieverdelingen per soort, per tuig over alle jaren van de monitoring van dit KRWlichaam zijn hier te vinden: https://wmropendata.wur.nl/site/zoetwatervis/39/waterlichaam/ 

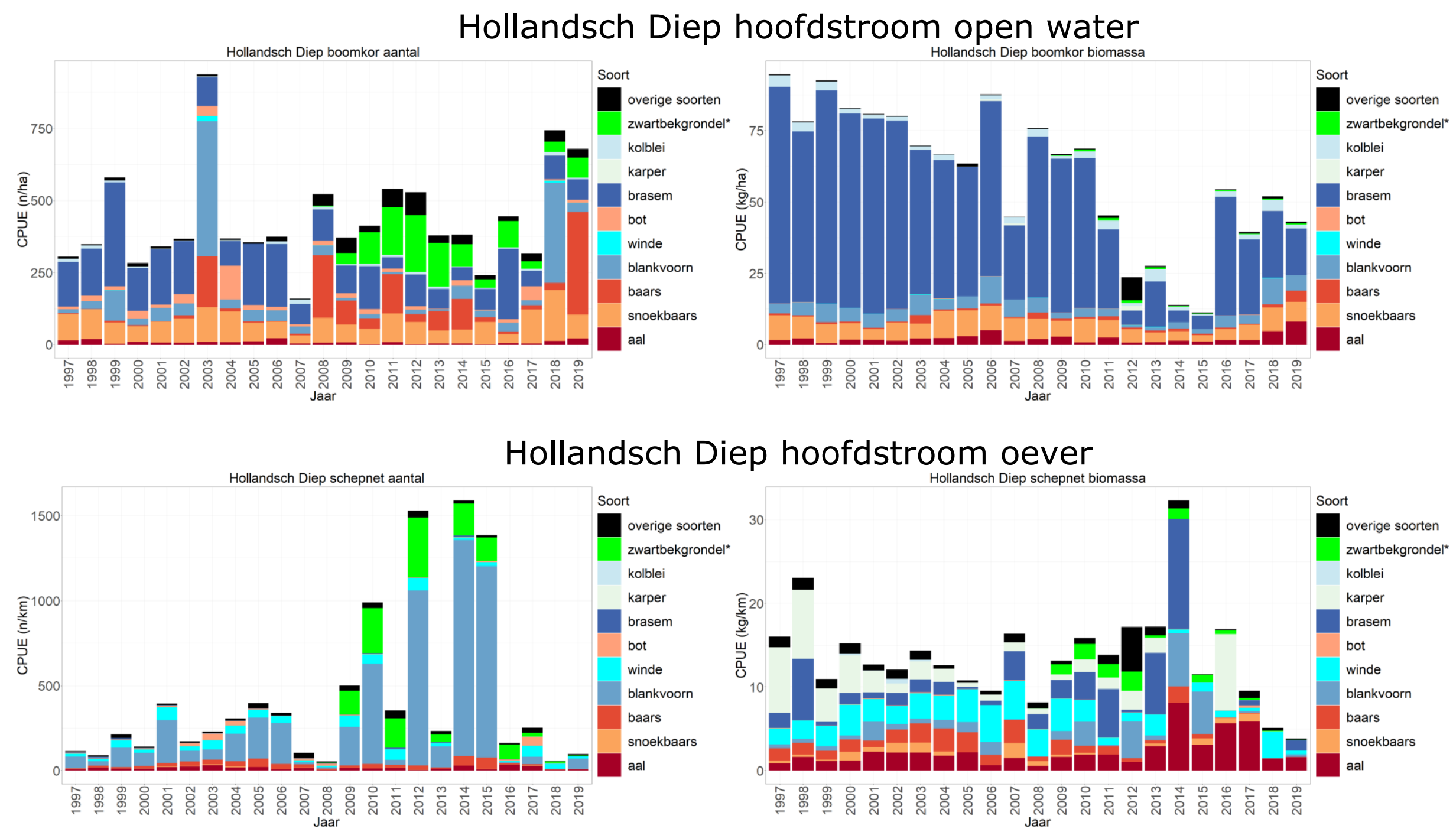

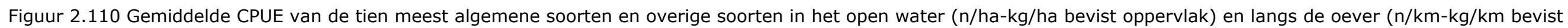
oppervlak) gevangen met een boomkor en elektroschepnet in de hoofdstroom van het Hollandsch Diep tijdens de actieve monitoring van $1997-2019, *=$ exoot. 


\subsubsection{Chinese wolhandkrab}

De Chinese wolhandkrab wordt al sinds 1997 regelmatig gevangen in de hoofdstroom van het Hollandsch Diep. In 2008-2015 zien we een dip in de vangsten met geen vangsten in 2012-2013, maar deze wordt gevolgd door hoge vangsten in 2016-2019. (Figuur 2.111).

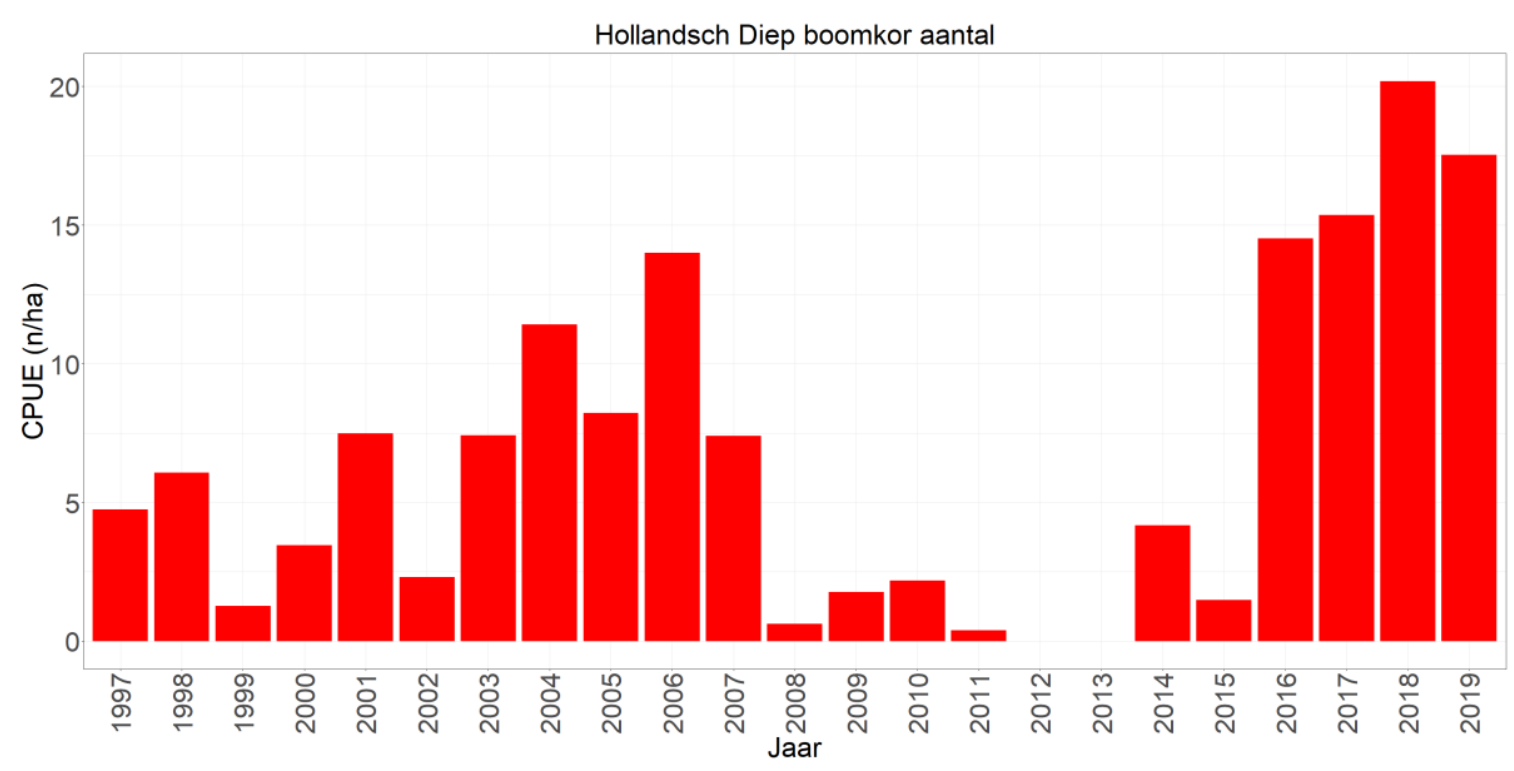

Figuur 2.111 Gemiddelde CPUE (n/ha bevist oppervlak) per jaar van de Chinese wolhandkrab in de hoofdstroom van het open water van het Hollandsch Diep gevangen met de boomkor.

\subsubsection{Aalvangsten}

Voor de aanlandingen van aal voor KRW-lichaam Hollandsch Diep zijn de gegevens van de "Benedenrivieren en Haringvliet i.o." gebruikt (Bijlage 2) en deze zijn weer gegeven in Figuur 2.80. 


\subsection{Haringvliet-West}

De bemonsteringslocaties over de periode 2002-2019 zijn weergegeven in Figuur 2.112.

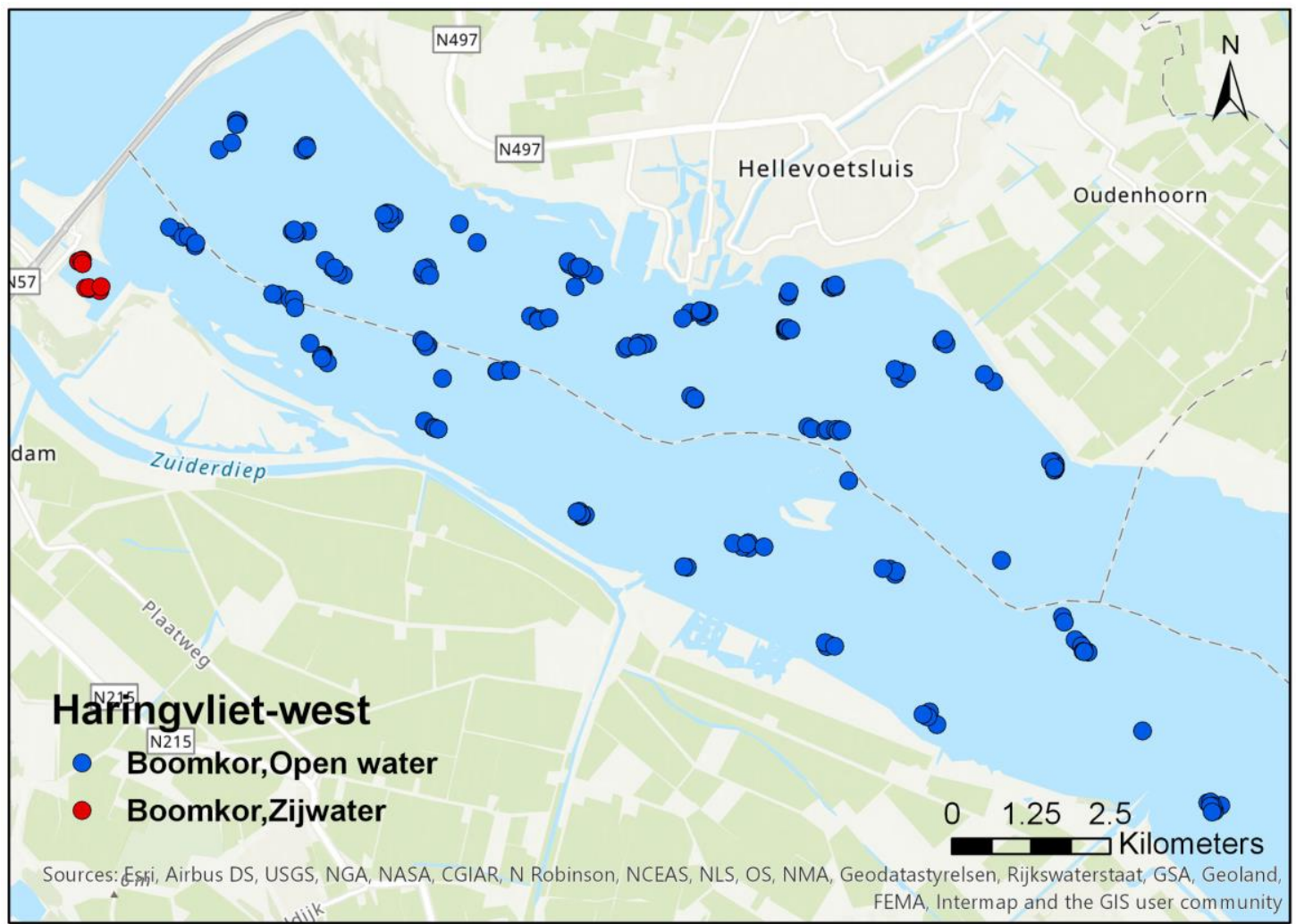

Figuur 2.112 Bemonsteringslocaties van de actieve monitoring in de Haringvliet-West van 2011-2019 per tuig per habitat.

\subsubsection{Haringvliet-West hoofdstroom (open water)}

Aangezien het Haringvliet-West pas vanaf 2011 consistent met de boomkor is bemonsterd zijn alleen bemonsteringsgegevens vanaf dit jaar geselecteerd. Daardoor vervallen alle bemonsteringspunten langs de oever met het schepnet, en de "zijwateren" met de boomkor boven het eiland Tiengemeten. Het Haringvliet-West wordt ieder jaar in het najaar en in het voorjaar bemonsterd. Om een beeld te krijgen van de veranderingen per cohort is besloten om bemonsteringen van het najaar te combineren met de bemonstering van het daaropvolgende voorjaar. Zo worden bijvoorbeeld vangsten uit het najaar van 2012 en het voorjaar van 2013 samengevoegd, en als 2013 in de figuur weergegeven. De voorjaarsbemonstering heeft in 2011 niet plaats gevonden, die van 2012 vond plaats in juni, in 20132015 vond deze plaats in april, in 2016 was er geen bemonstering in het voorjaar en vanaf 2017 vindt deze plaats in februari. De najaarsbemonstering vond in 2011-2013 plaats in november en vanaf 2014 in oktober met uitzondering van 2015 (geen najaarsbemonstering) en 2016 (zowel oktober als november). In 2019 is het Haringvliet-West op 11 en 12 februari en op 28 en 29 oktober bemonsterd. De vangsten van 12 februari nabij de Haringvlietdam vielen volgens ATKB wat tegen, wat mogelijk met het kieren te maken zou kunnen hebben aangezien op 12 februari de kier van de Haringvlietsluis voor de tweede keer sinds de officiële opening in 2018 werd geopend. Het viel ATKB ook op dat er in meerdere trekken dode vissen werd aangetroffen (reeds in staat van ontbinding). Dit kan mogelijk het gevolg zijn van de intrek van zout water. Op 10 oktober is er namelijk veel zout water ingelaten naar het Haringvliet, en zijn er ook diepe putten in het westelijk deel van het Haringvliet met zout water gevuld ten behoeve van een proef om het gedrag van zout (water) te onderzoeken.

De tien meest algemene soorten in de hoofdstroom van het Haringvliet-West voor de gehele periode 2011-2019 zijn zwartbekgrondel, pos, spiering, kolblei, brasem, bot, blankvoorn, baars, snoekbaars en aal. Deze omvatten meer dan 99\% van het totale gemiddelde aantal en biomassa voor de vangsten met de boomkor (Bijlage 42). Ten opzichte van de voorgaande rapportage (van Rijssel et al. 2019a) behoort de kolblei tot de top tien meest algemene soorten in plaats van de snoek. 
In het open water (boomkor) zijn pos, baars en snoekbaars de dominante soorten, zowel qua aantal als qua biomassa (Figuur 2.113 boven). Qua biomassa is de aal ook een belangrijke soort. Zowel voor aal als voor baars, brasem en snoekbaars zien we de laatste jaren een toename in de biomassa van de vangsten. Ook worden er weer wat grotere hoeveelheden blankvoorn gevangen in 2018 en 2019. De hoeveelheden van pos fluctueren sterk van jaar tot jaar. De zwartbekgrondel wordt sinds het begin van de monitoring in 2011 regelmatig gevangen. De vangsten van het najaar van 2019 zijn weergegeven als zijnde die van 2020 en zijn nog niet volledig (de vangsten van het voorjaar van 2020 moeten hier nog bij komen) en worden vanwege die reden alleen getoond en niet besproken.

In 2019 zijn maar liefst acht soorten gevangen in de hoofdstroom die voorheen niet zijn gevangen (grondel sp., vijfdradige meun, wijting, koolvis, steenbolk, tong, kleine zeenaald en roofblei). Zeven van deze acht soorten zijn mariene soorten en dit lijkt dan ook een direct effect van het kieren te zijn.

De lengte-frequentieverdelingen per soort, per tuig voor de hoofdstroom en de zijwateren gecombineerd over alle jaren van de monitoring van dit KRW-lichaam zijn hier te vinden: https://wmropendata.wur.nl/site/zoetwatervis/39/waterlichaam/ 

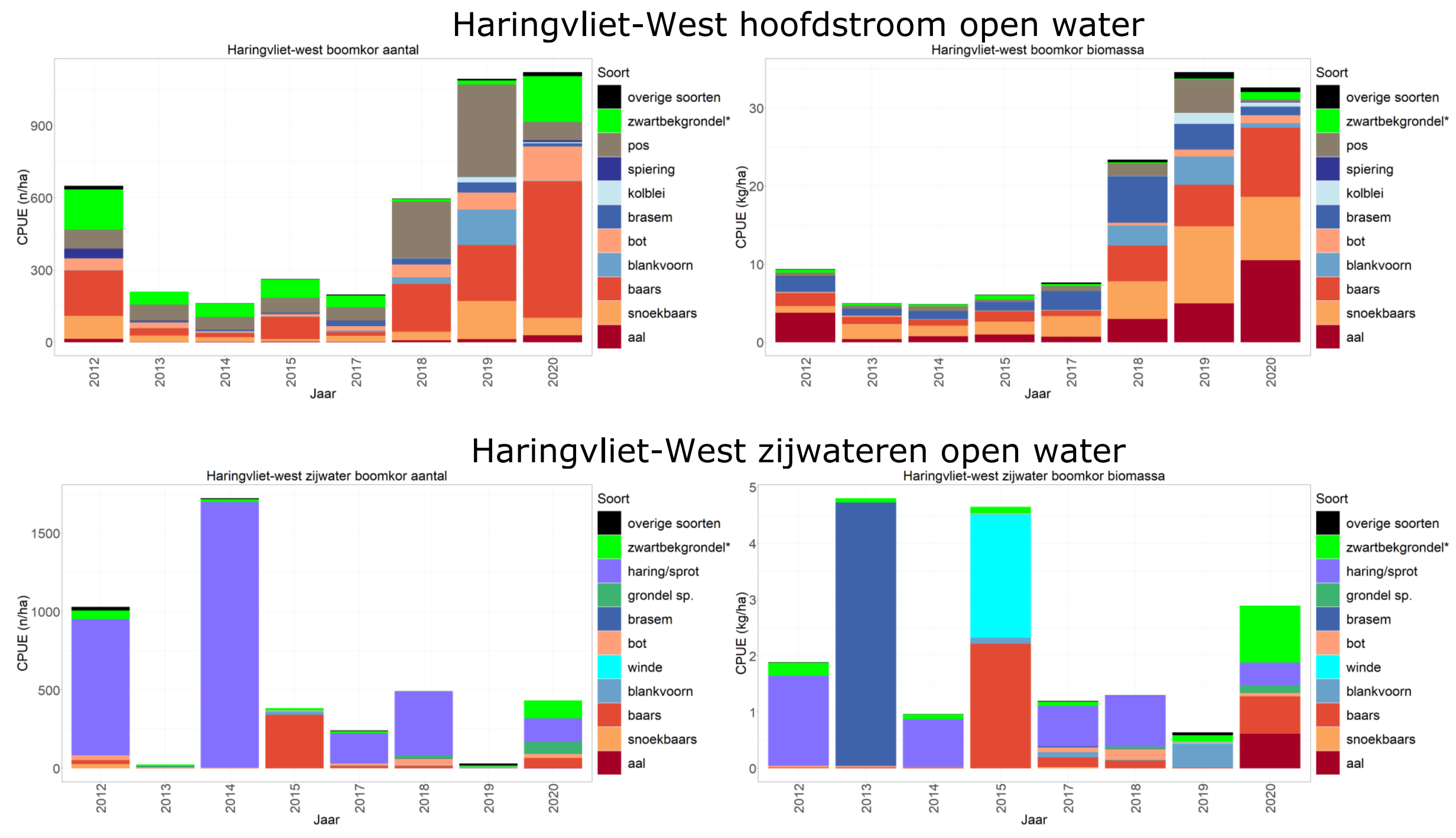

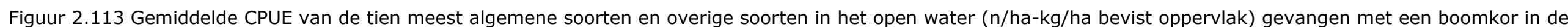

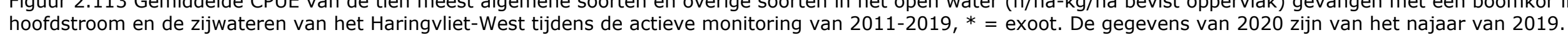




\subsubsection{Chinese wolhandkrab}

De Chinese wolhandkrab wordt sinds 2011 regelmatig gevangen in de hoofdstroom van het Haringvliet-West (met uitzondering van 2013 en 2014 net als in het Hollandsch Diep). Vanaf 2015 nemen de gevangen aantallen gestaag toe met hoge vangsten in 2019 (Figuur 2.114).

Haringvliet-west boomkor aantal

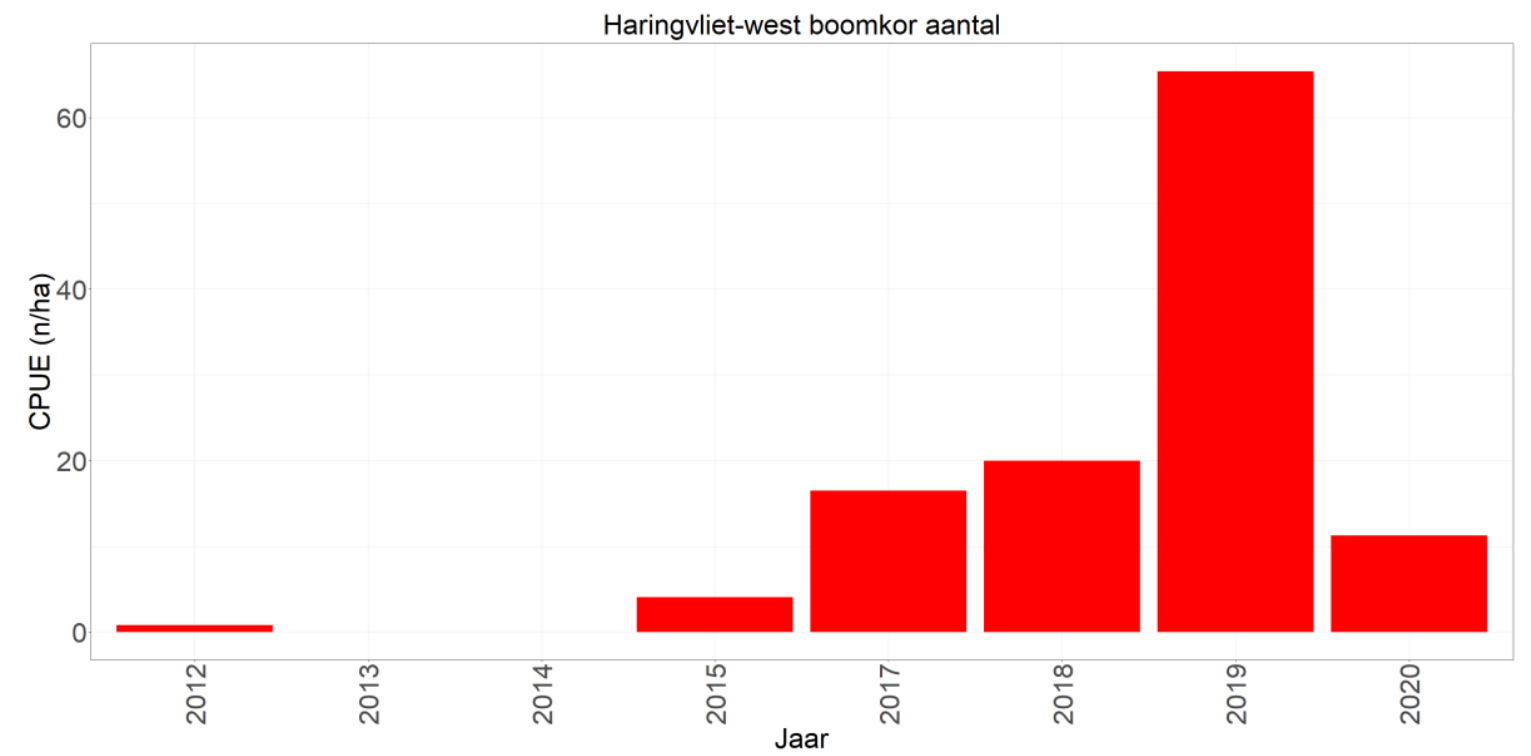

Figuur 2.114 Gemiddelde CPUE (n/ha bevist oppervlak) per jaar van de Chinese wolhandkrab in de hoofdstroom van het open water van het Haringvliet-West gevangen met de boomkor. De gegevens van 2020 zijn van het najaar van 2019. 


\subsubsection{Haringvliet-West zijwater}

Het enige zijwater dat bemonsterd wordt met een boomkor is de binnenhaven in Stellendam.

De tien meest algemene soorten in het zijwater van het Haringvliet-West voor de gehele periode 2011-2019 zijn zwartbekgrondel, spiering, haring/sprot, grondel sp., brasem, bot, winde, blankvoorn, baars en snoekbaars. Deze omvatten meer dan $99 \%$ van het totale gemiddelde aantal en biomassa voor de vangsten met de boomkor (Bijlage 43). Aangezien haring en sprot lastig uit elkaar te houden zijn deze tijdens de bemonstering samengevoegd. De zandgrondels (o.a. Pomatoschistus lozanoi, $P$. minutus, $P$. microps) zijn ook moeilijk van elkaar te onderscheiden en worden daarom onder grondel sp. geschaard.

Opvallend is dat pos en kolblei ontbreken in de top tien van de zijwateren, terwijl deze wel tot de top tien behoren van de hoofdstroom van het Haringvliet-West. Hun plaats in de top tien is ingenomen door de zoutwatersoorten haring/sprot en de grondel sp. Dit heeft voornamelijk met de ligging van de haven te maken; deze ligt vlakbij de Haringvlietsluizen waardoor het water ook een brak karakter heeft.

Haring/sprot zijn qua aantal de dominante soorten in de boomkorvangsten (Figuur 2.113 onder). Qua biomassa valt baars hier ook nog onder. De vangsten fluctueren sterk van jaar tot jaar en er is geen duidelijke trend voor de soorten te onderscheiden. De vangsten van 2019 zijn de laagste tot nu toe, wel zijn de aal en driedoornige stekelbaars voor het eerst in dit zijwater gevangen.

De vangsten van het najaar van 2019 zijn weergegeven als zijnde die van 2020 en zijn nog niet volledig (de vangsten van het voorjaar van 2020 moeten hier nog bij komen) en worden vanwege die reden alleen getoond en niet besproken.

\subsubsection{Chinese wolhandkrab}

De Chinese wolhandkrab wordt sinds 2015 regelmatig gevangen in het zijwater van het HaringvlietWest. Vanaf 2015 nemen, net als in de hoofdstroom, de gevangen aantallen gestaag toe met een hoge vangsten in 2019 (Figuur 2.115).

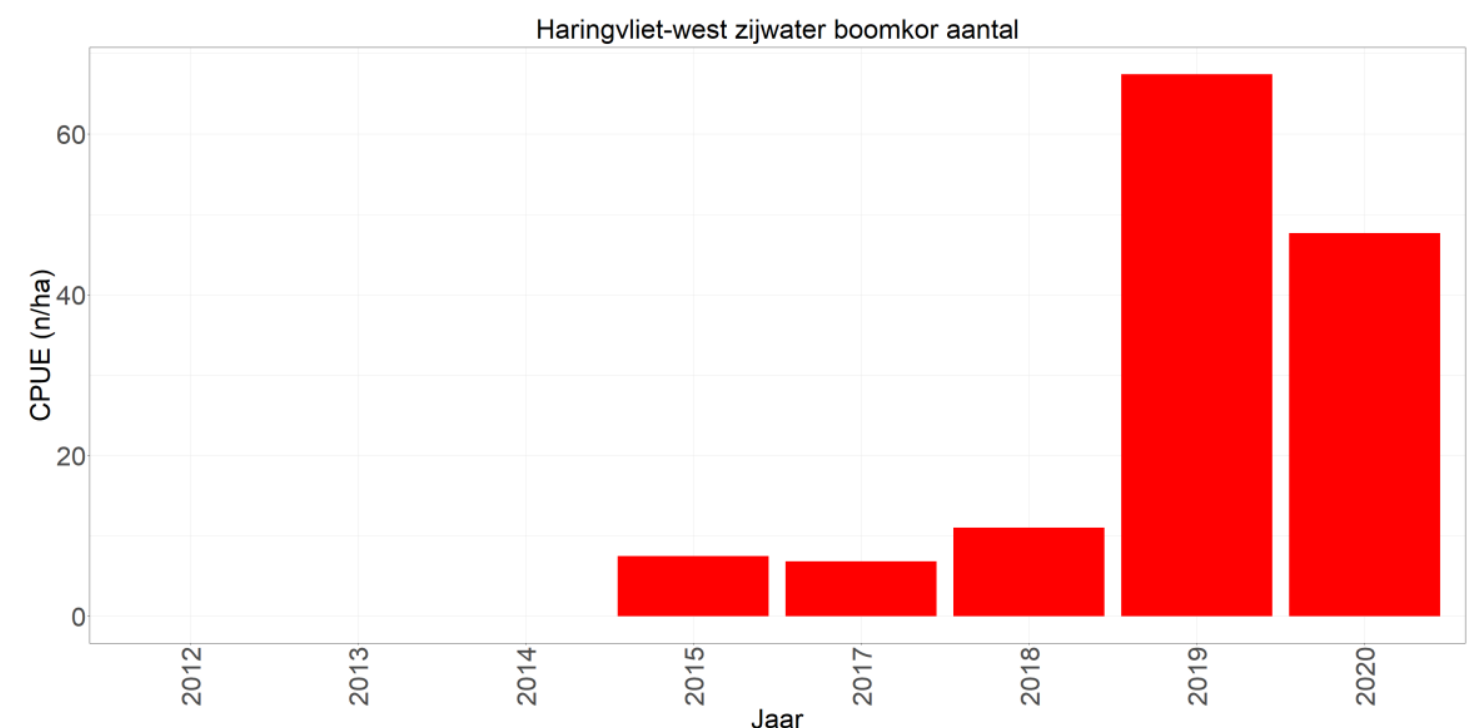

Figuur 2.115 Gemiddelde CPUE (n/ha bevist oppervlak) per jaar van de Chinese wolhandkrab in de hoofdstroom van het open water van het Haringvliet-West gevangen met de boomkor.

\subsubsection{Aalvangsten}

Voor de aanlandingen van aal voor KRW-lichaam Haringvliet-West zijn de gegevens van de "Benedenrivieren en Haringvliet i.o." gebruikt (Bijlage 2) en deze zijn weer gegeven in Figuur 2.80. 


\subsection{Volkerak}

De bemonsteringslocaties over de periode 2008-2019 zijn weergegeven in Figuur 2.116.

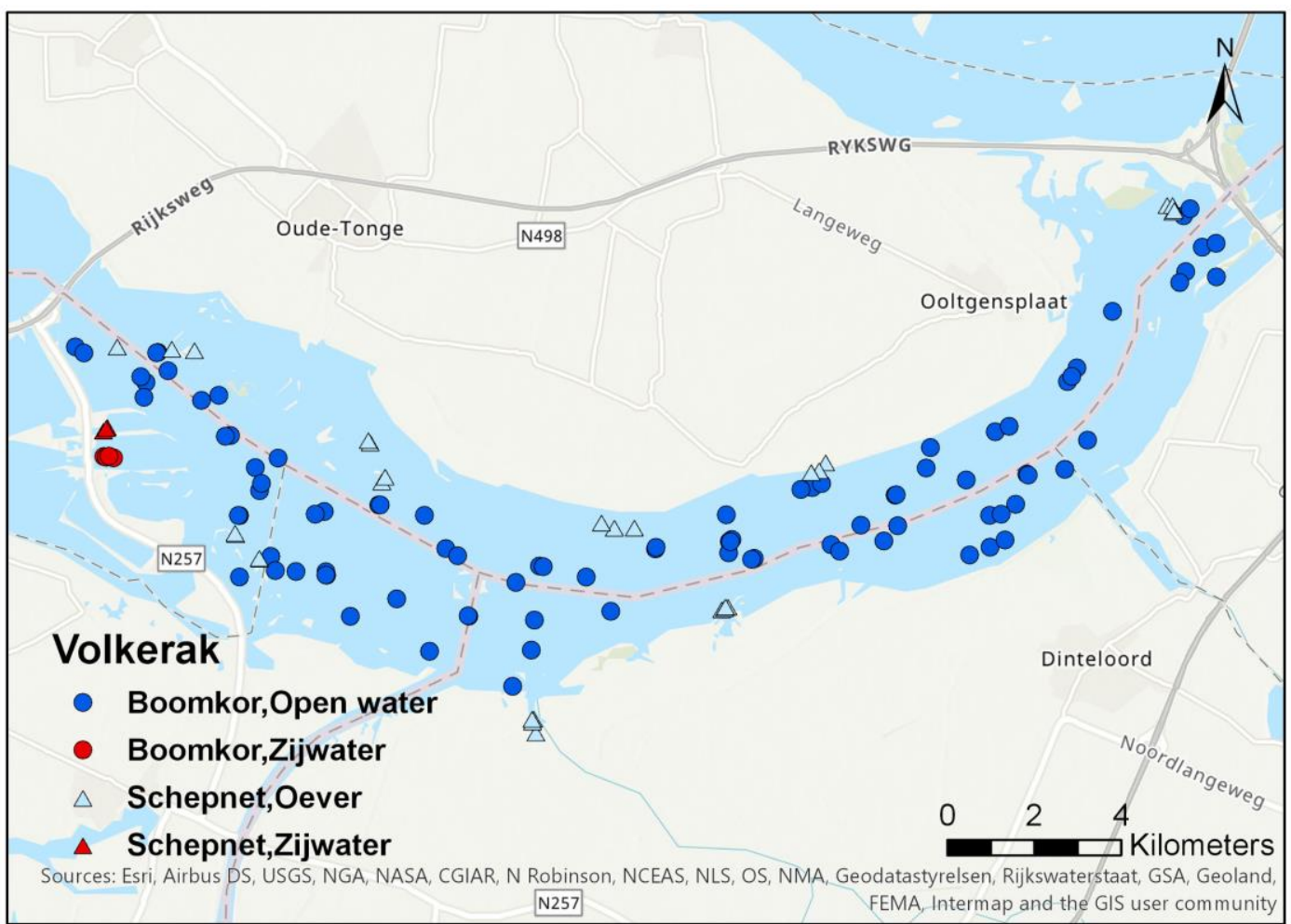

Figuur 2.116 Bemonsteringslocaties van de actieve monitoring in de Volkerak van 2008-2019 per tuig per habitat.

\subsubsection{Volkerak hoofdstroom (open water en oeverzone)}

Het Volkerak wordt sinds 2010 om de drie jaar in het najaar met de boomkor en het elektroschepnet bemonsterd. In 2008 is het Volkerak in maart bemonsterd, in 2010 in september, in 2013 in september en oktober en vanaf 2016 in november. De data van 2008 wordt wel in grafieken weergegeven maar het verschil in bemonsteringsperiode moet bij de interpretatie van de grafieken in acht worden genomen. Daarnaast is er in 2019 's avonds/'s nachts met de boomkor bemonsterd in plaats van overdag zoals in de voorgaande jaren, dit zou mogelijk de grote toename van aantallen en biomassa in de boomkor vangsten kunnen verklaren en dit maakt de vergelijking met de voorgaande jaren niet onvermengd (Figuur 2.117).

De tien meest algemene soorten in de hoofdstroom van het Volkerak voor de gehele periode 20082019 zijn zwartbekgrondel, snoek, karper, brasem, bot, winde, blankvoorn, baars, snoekbaars en aal. Deze omvatten meer dan $99 \%$ van het totale gemiddelde aantal en biomassa voor zowel de vangsten met de boomkor als het schepnet (Bijlage 46). Ten opzichte van de voorgaande rapportage (van Rijssel et al. 2019a) is pos vervangen door snoek in de top tien meest algemene soorten.

In het open water (boomkor) is baars de dominante soort zowel qua aantal als qua biomassa (Figuur 2.117 boven). Deze lijkt ook met de jaren sterk toe te nemen. Verder wordt snoekbaars regelmatig gevangen, net als de zwartbekgrondel (sinds 2010) met hoge vangsten in 2019. In 2019 is de sneep voor het eerst gevangen in het Volkerak.

Langs de oever (schepnet) zijn aal en zwartbekgrondel de dominante soorten (net als in het Zoommeer, Figuur 2.117 onder). De vangsten van alle soorten fluctueren sterk tussen de jaren, waardoor een trend per soort lastig te onderscheiden is.

De lengte-frequentieverdelingen per soort, per tuig voor de hoofdstroom en de zijwateren gecombineerd over alle jaren van de monitoring van dit KRW-lichaam zijn hier te vinden: https://wmropendata.wur.nl/site/zoetwatervis/67/waterlichaam/ 

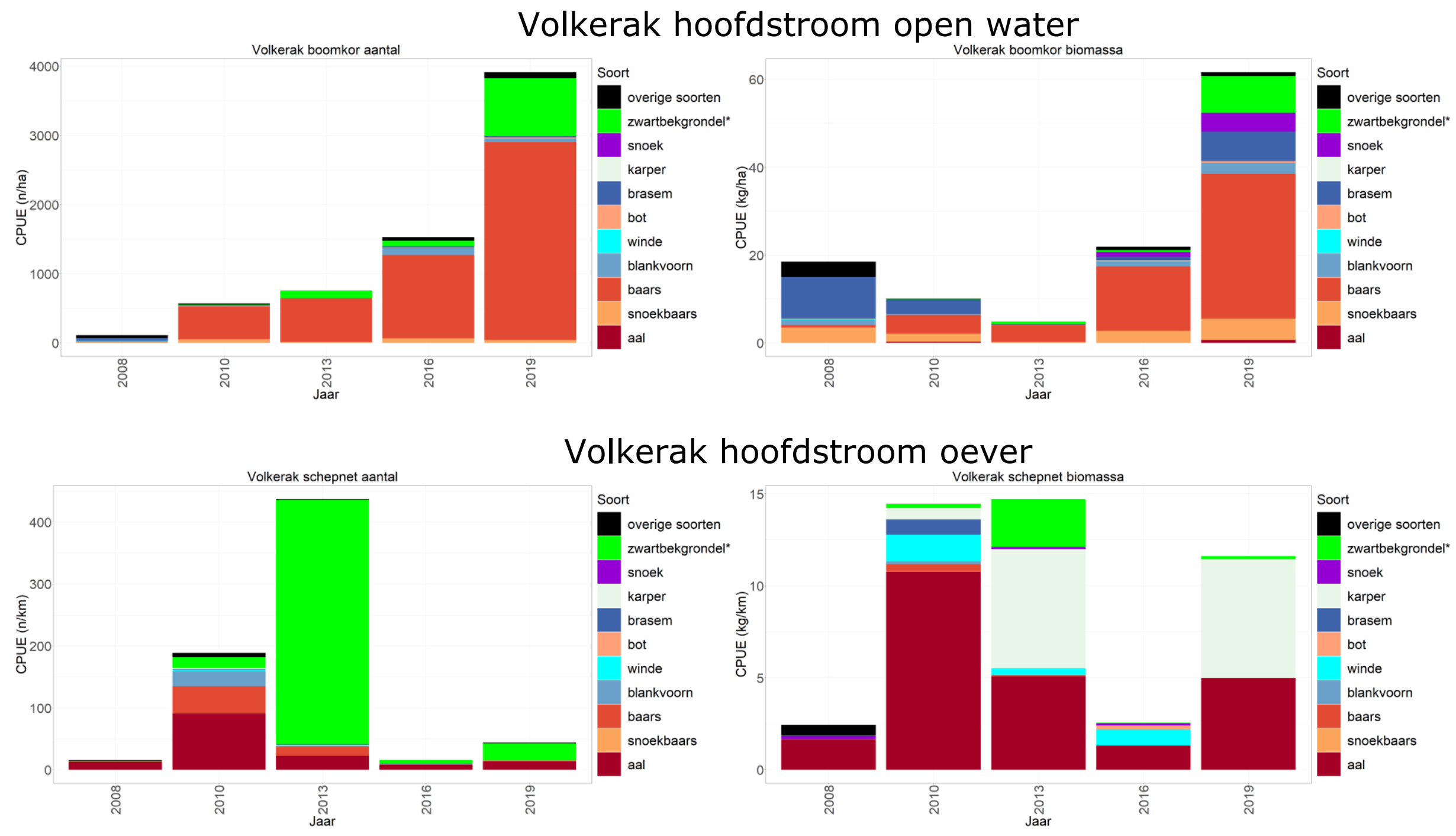

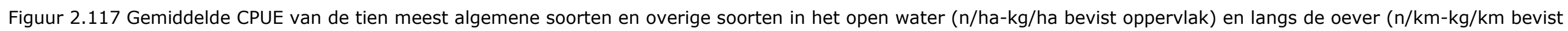
oppervlak) gevangen met een boomkor en elektroschepnet in de hoofdstroom van het Volkerak tijdens de actieve monitoring van $2008-2016, *=$ exoot. 


\subsubsection{Chinese wolhandkrab}

De Chinese wolhandkrab wordt sinds 2008 met enige regelmaat regelmatig gevangen in de hoofdstroom van het Volkerak (met uitzondering van 2013). In 2019 zijn de hoogste aantallen gevangen (Figuur 2.118).

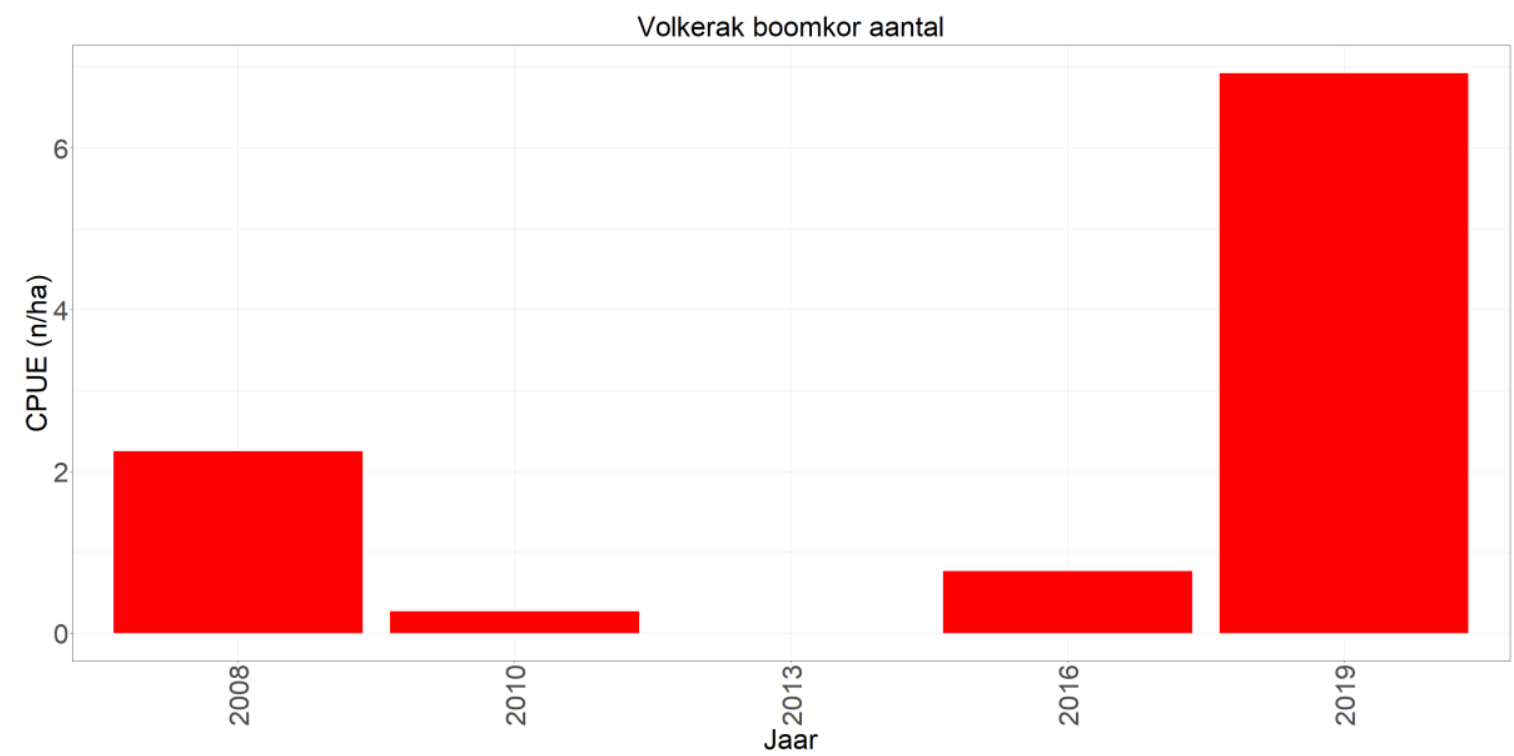

Figuur 2.118 Gemiddelde CPUE ( $\mathrm{n} / \mathrm{ha}$ bevist oppervlak) per jaar van de Chinese wolhandkrab in de hoofdstroom van het open water van het Volkerak gevangen met de boomkor. 


\subsubsection{Volkerak zijwater}

Het zijwater dat bemonsterd is met zowel de boomkor als het schepnet betreft het sluizencomplex Krammersluizen.

De tien meest algemene soorten in het zijwater van het Volkerak voor de gehele periode 2008-2016 zijn zwartbekgrondel, roofblei, rivierdonderpad, haring/sprot, bot, winde, blankvoorn, snoekbaars, baars, en aal. Deze omvatten meer dan $99 \%$ van het totale gemiddelde aantal en biomassa voor zowel de vangsten met de boomkor als het schepnet (Bijlage 47). Ten opzichte van de voorgaande rapportage (van Rijssel et al. 2019a) behoren de roofblei en de snoekbaars tot de tien meest algemene soorten in plaats van pos en snoek, ook hier zou het effect van de avondbemonstering een rol in gespeeld kunnen hebben.

Opvallend is dat karper en brasem ontbreken in de top tien van de zijwateren, terwijl deze wel tot de top tien behoren in het open water van de hoofdstroom van het Volkerak. Hun plaats in de top tien is ingenomen door de rivierdonderpad en de zoutwatersoorten haring/sprot. Het vangen van de zoutwatersoorten heeft voornamelijk met de ligging van de zijwateren te maken; vlakbij de Krammersluizen die aansluiten op de Oosterschelde.

Net als in het open water van de hoofdstroom is baars de dominante soort in de boomkorvangsten, zowel qua aantal als qua biomassa (Figuur 2.119 boven). Andere soorten die regelmatig gevangen worden zijn bot en haring/sprot. In 2019 zijn hogere vangsten van bot, haring/sprot, zwartbekgrondel en met name snoekbaars te zien. Deze laatste is voor het eerst gevangen in dit zijwater.

Langs de oever (schepnet) zijn, net als in de hoofdstroom, aal en zwartbekgrondel de dominante soorten (Figuur 2.119 onder). De vangsten per soort fluctueren sterk van jaar op jaar. In 2010 werd er nog relatief veel blankvoorn, winde en baars gevangen, maar in latere jaren nauwelijks nog. 

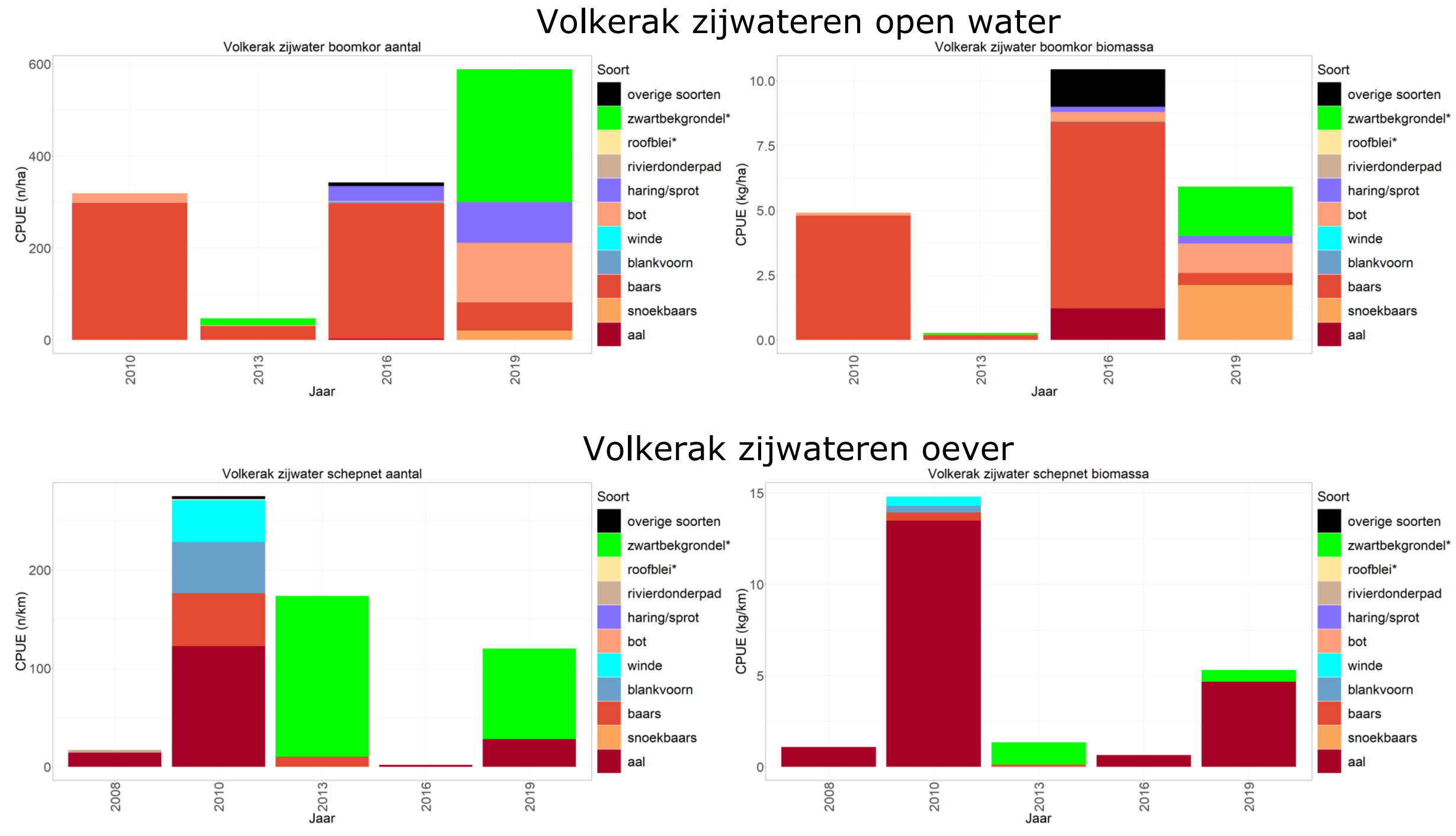

Figuur 2.119 Gemiddelde CPUE van de tien meest algemene soorten en overige soorten in het open water ( $\mathrm{n} / \mathrm{ha}-\mathrm{kg} / \mathrm{ha}$ bevist oppervlak) en langs de oever ( $\mathrm{n} / \mathrm{km}-\mathrm{kg} / \mathrm{km}$ bevist oppervlak) gevangen met een boomkor en elektroschepnet in de zijwateren van het Volkerak tijdens de actieve monitoring van 2008-2019, * = exoot. 


\subsubsection{Chinese wolhandkrab}

De Chinese wolhandkrab wordt sinds 2016 gevangen in de zijwateren van het Volkerak. In 2019 zijn vrij hoge aantallen gevangen (Figuur 2.120).

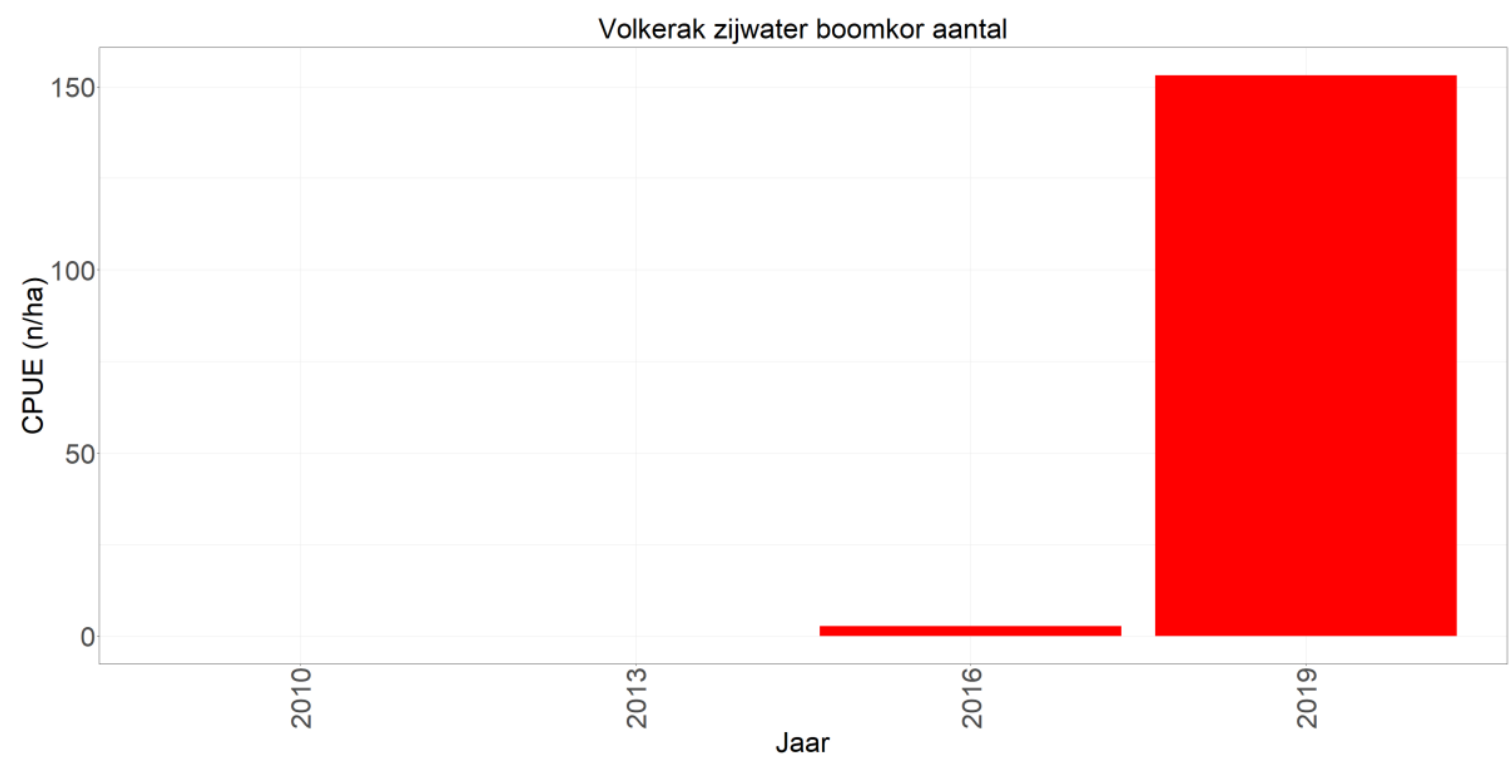

Figuur 2.120 Gemiddelde CPUE (n/ha bevist oppervlak) per jaar van de Chinese wolhandkrab in de zijwateren van het Volkerak gevangen met de boomkor.

\subsubsection{Aalvangsten}

Voor de aanlandingen van aal voor KRW-lichaam Zoommeer zijn de gegevens van het "Volkerak \& Zoommeer" gebruikt (Bijlage 2) en deze zijn weergegeven in Figuur 2.125. 


\subsection{Zoommeer (Zoommeer, Eendracht)}

De bemonsteringslocaties over de periode 2016-2019 zijn weergegeven in Figuur 2.121.

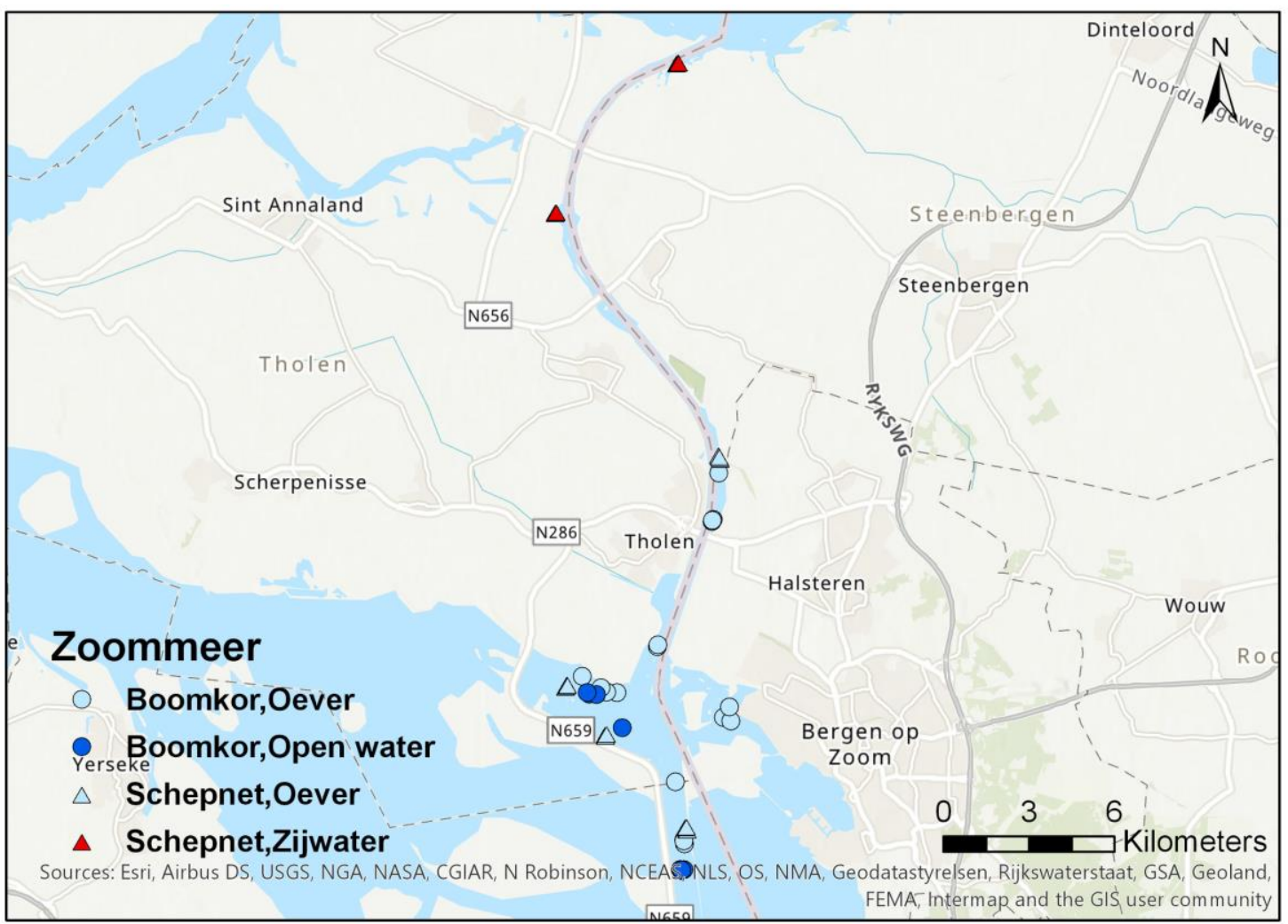

Figuur 2.121 Bemonsteringslocaties van de actieve monitoring in de Zoommeer van 2016-2019 per tuig per habitat.

\subsubsection{Zoommeer hoofdstroom (open water en oeverzone)}

Het Zoommeer wordt sinds 2016 ieder jaar in het najaar (november) met de boomkor en het elektroschepnet bemonsterd.

De tien meest algemene soorten in de hoofdstroom van het Zoommeer voor de gehele periode 20162019 zijn zwartbekgrondel, pos, spiering, snoek, brasem, bot, blankvoorn, baars, snoekbaars en aal. Deze omvatten meer dan $99 \%$ van het totale gemiddelde aantal en biomassa voor zowel de vangsten met de boomkor als het schepnet (Bijlage 44).

In het open water en langs de oever (boomkor) is baars de dominante soort, zowel qua aantal als qua biomassa (Figuur 2.122 boven). In 2016 werd ook nog relatief veel brasem gevangen. Aangezien dit gebied nog maar vier jaar bemonsterd wordt is het lastig om iets over trends in soorten te kunnen concluderen. Wel is te zien dat ieder jaar minder baars wordt gevangen. Ook valt op dat de invasieve zwartbekgrondel niet heel veel wordt gevangen in vergelijking met andere bemonsterde KRWlichamen, alhoewel ook hier hogere vangsten van deze soort te zien zijn in 2019. In 2019 is de marmergrondel voor het eerst in de hoofdstroom van het Zoommeer gevangen, deze soort werd al wel eerder in de zijwateren gevangen.

Langs de oever (schepnet) zijn maar vijf verschillende soorten gevangen, waarbij aal en de invasieve zwartbekgrondel de dominante soorten zijn (Figuur 2.122 onder).

De lengte-frequentieverdelingen per soort, per tuig voor de hoofdstroom en de zijwateren gecombineerd over alle jaren van de monitoring van dit KRW-lichaam zijn hier te vinden: https://wmropendata.wur.nl/site/zoetwatervis/69/waterlichaam/ 


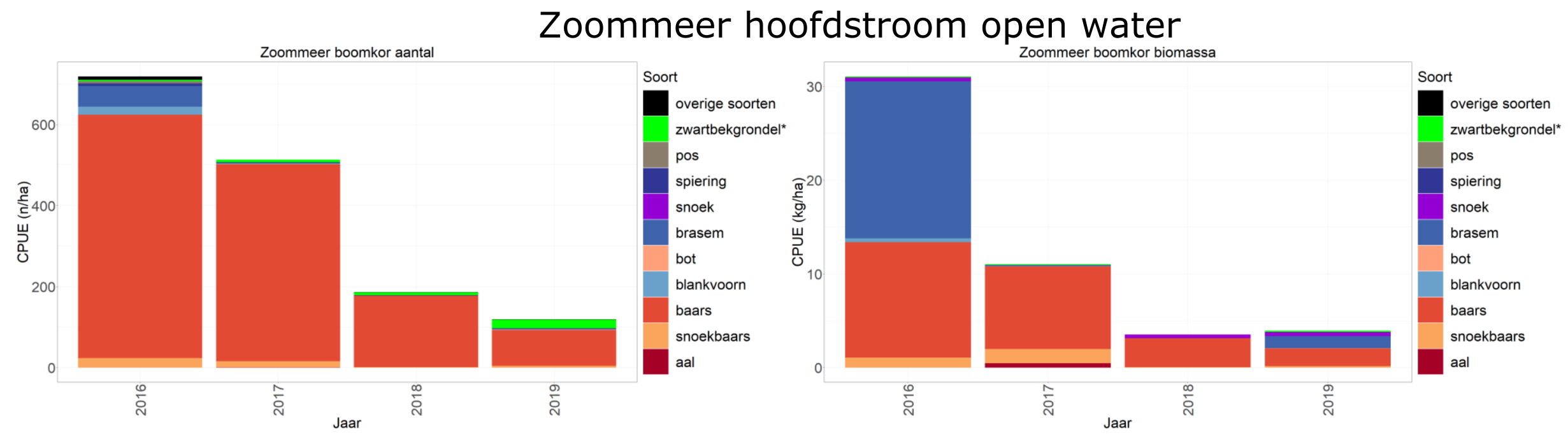

\section{Zoommeer hoofdstroom oever}
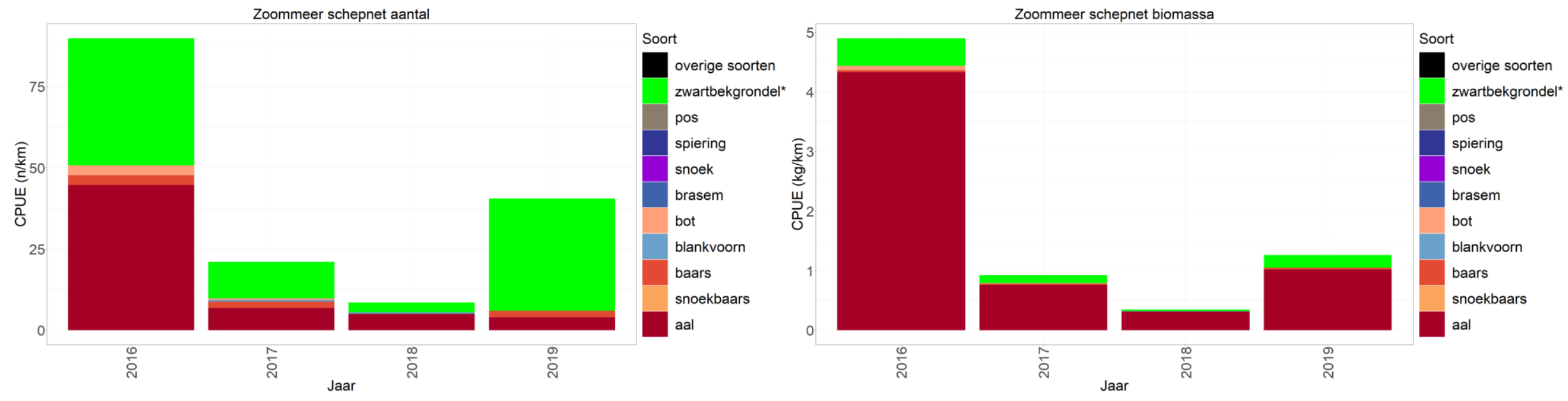

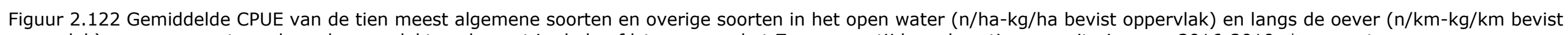
oppervlak) gevangen met een boomkor en elektroschepnet in de hoofdstroom van het Zoommeer tijdens de actieve monitoring van $2016-2019, *=$ exoot. 


\subsubsection{Chinese wolhandkrab}

De Chinese wolhandkrab wordt sinds 2017 een enkele keer gevangen in de hoofdstroom van het open water in het Zoommeer met de hoogste vangsten in 2019 (Figuur 2.123).

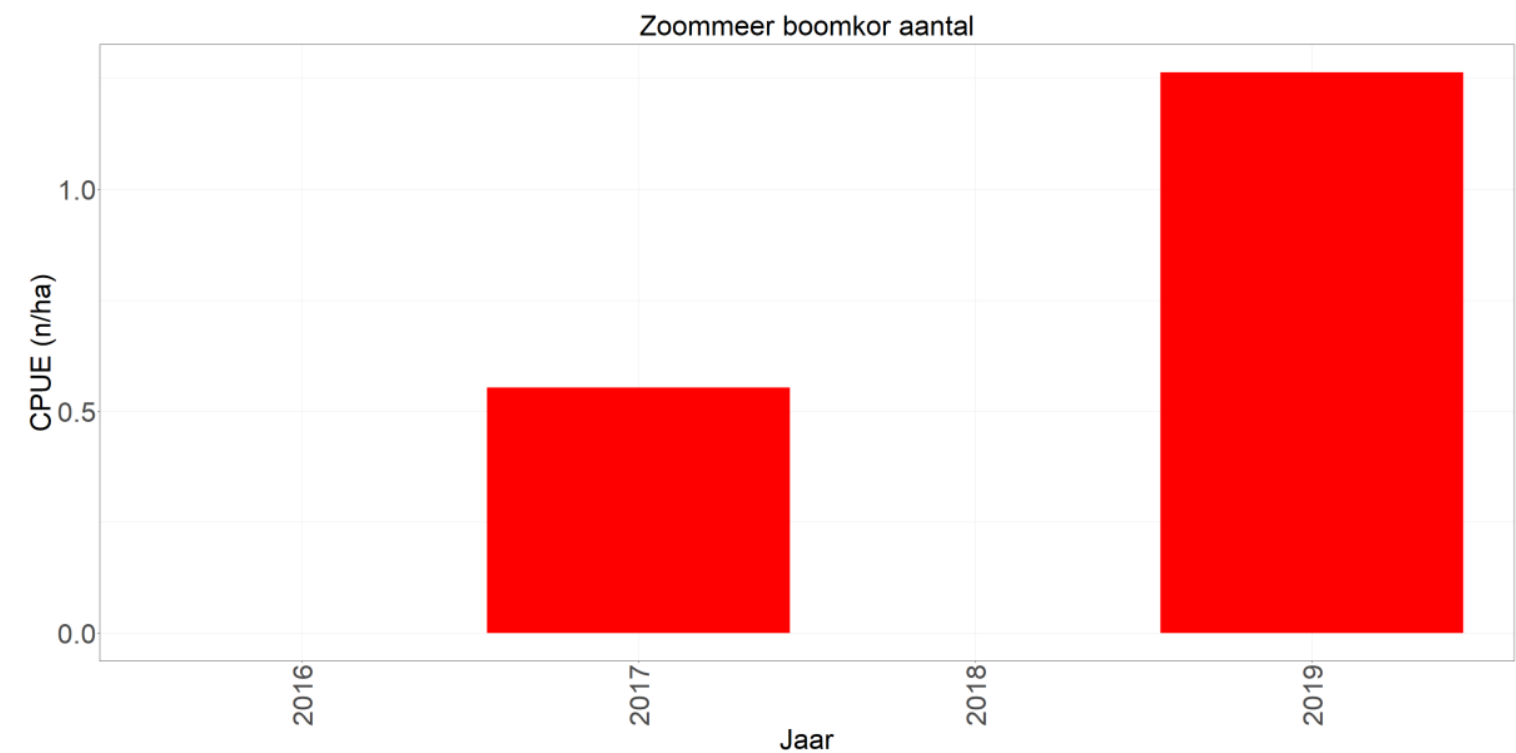

Figuur 2.123 Gemiddelde CPUE (n/ha bevist oppervlak) per jaar van de Chinese wolhandkrab in de hoofdstroom van het open water van het Zoommeer gevangen met de boomkor. 


\subsubsection{Zoommeer zijwateren}

Langs het Zoommeer zijn twee zijkanalen bemonsterd met het schepnet langs de oever.

De zes gevangen soorten in de zijwateren van het Zoommeer voor de gehele periode 2016-2019 zijn zwartbekgrondel, marmergrondel, winde, roofblei, baars en aal. Deze omvatten $100 \%$ van het totale gemiddelde aantal en biomassa voor de vangsten met het schepnet (Bijlage 45). De Chinese wolhandkrab is niet met het schepnet gevangen in de zijwateren van het Zoommeer.

Net als langs de oever in de hoofdstroom zijn er maar weinig soorten (zes) gevangen. Wat opvallend is dat drie van deze soorten niet tot de algemene soorten behoren in de hoofdstroom; marmergrondel, roofblei (beide exoten) en de winde. Waarschijnlijk komt dit door de afwijkende locaties van de zijwaterbemonsteringen (Figuur 2.121). Verder lijkt de vangst niet erg verschillend van de oevervangsten met het schepnet in de hoofdstroom met aal en zwartbekgrondel als dominante soorten, waarbij er een afname van aal lijkt te zijn (Figuur 2.124 onder). Winde wordt ook relatief veel gevangen in de zijwateren. In 2016 zien we dat er veel zwartbekgrondels zijn gevangen langs de oever in de hoofdstroom, terwijl dit voor de zijwateren pas in 2017 het geval is.

\section{Zoommeer zijwateren oever}

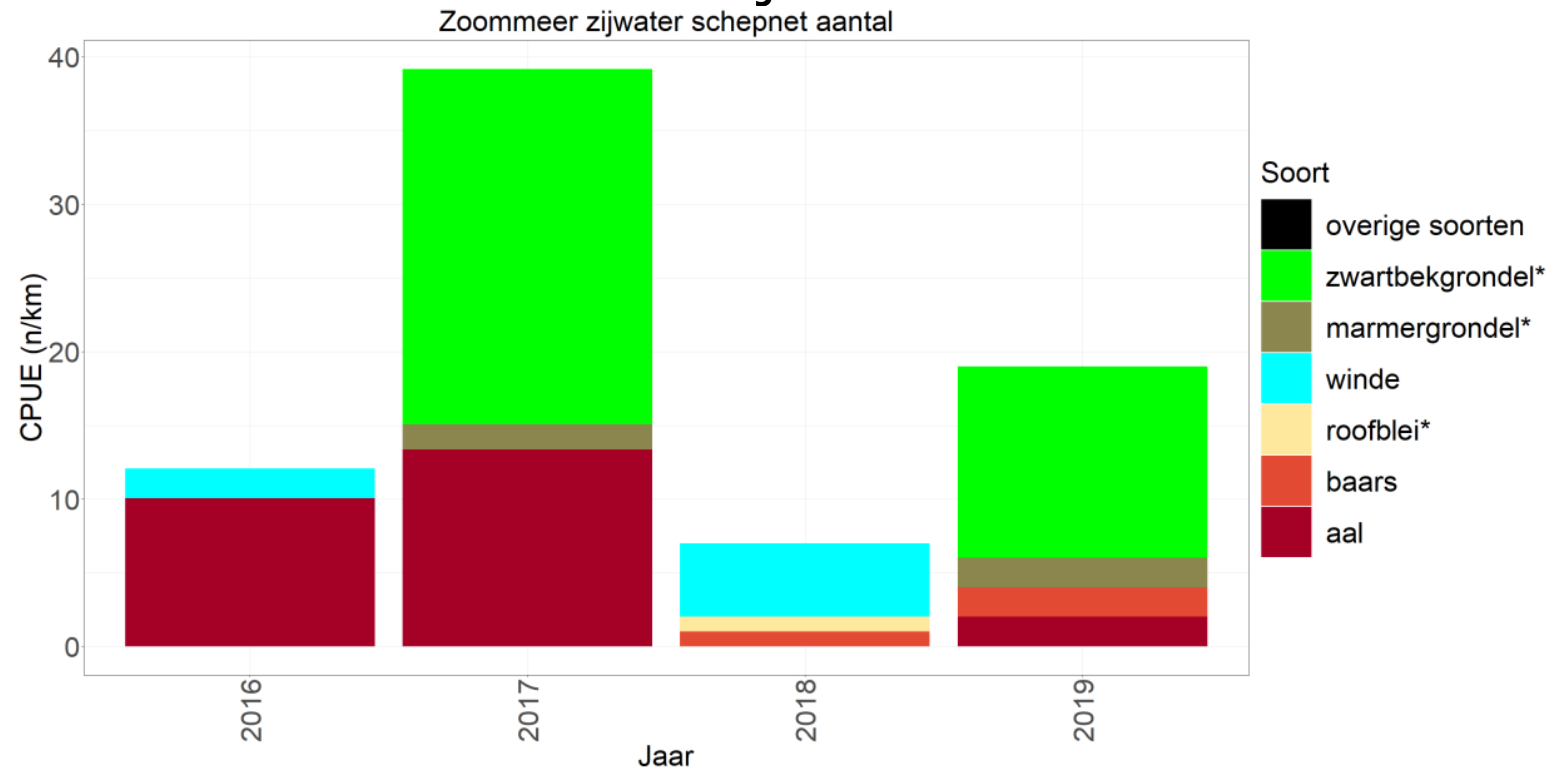

Zoommeer zijwater schepnet biomassa

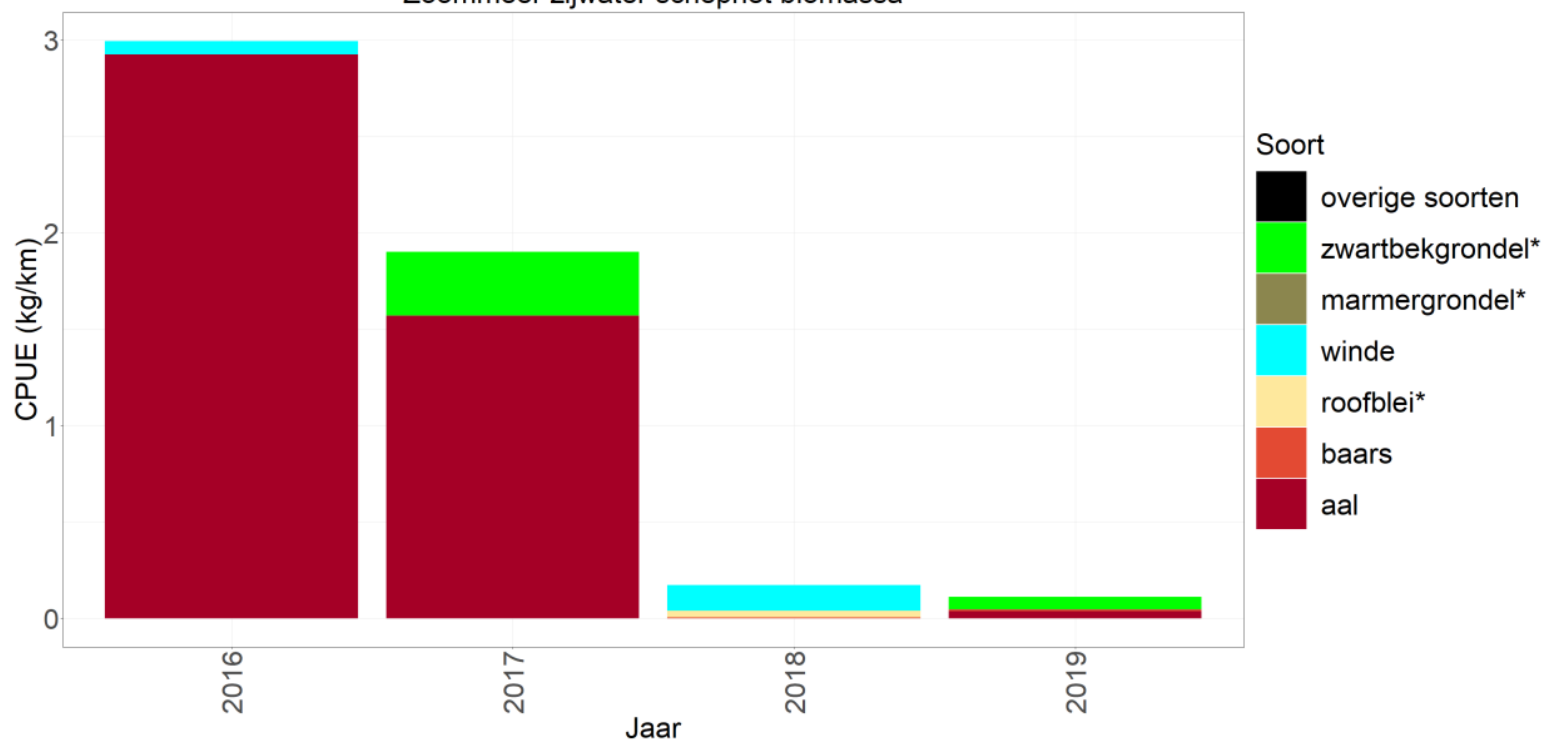

Figuur 2.124 Gemiddelde CPUE van de zes gevangen soorten langs de oever (n/km-kg/km bevist oppervlak) gevangen met een elektroschepnet in de zijwateren van het Zoommeer tijdens de actieve monitoring van 2016-2019, * = exoot. 


\subsubsection{Aalvangsten}

Voor de aanlandingen van KRW-lichamen Volkerak en Zoommeer zijn de gegevens van het "Volkerak \& Zoommeer" gebruikt (Bijlage 2). Na 2010 is een grote afname van de aanlandingen te zien als gevolg van het verbod op aalvisserij in de grote rivieren en een deel van het Krammer-Volkerak in verband met te hoge dioxine- en PCB-gehaltes in aal. Dit betekent dat de aanlandingen van het Volkerak \& Zoommeer vanaf 2011 voornamelijk gebaseerd zijn op het Zoommeer en op een deel van het Volkerak. Na de daling na 2010 lijken de aanlandingen tot en met 2017 enigszins stabiel waarbij de meeste alen met schietfuiken worden gevangen. In 2018 en 2019 is er een toename van de aanlandingen voornamelijk door een toename van aangelande aal door middel van hokfuiken (Figuur 2.125). Sinds 2014 is te zien dat de inspanning van schietfuiken is toegenomen terwijl de vangsten ongeveer gelijk blijven (Figuur 2.126).

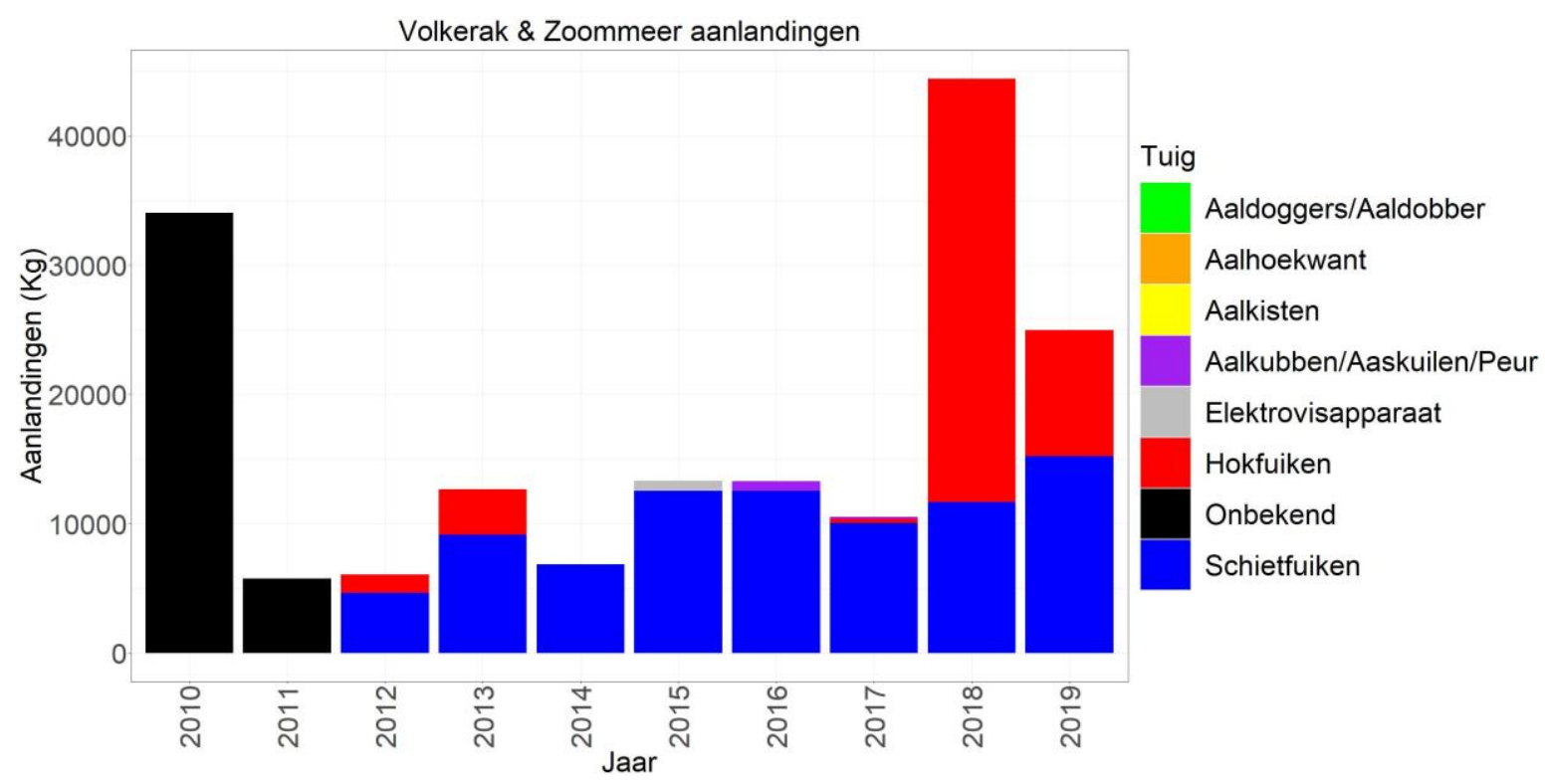

Figuur 2.125 Aanlandingen $(\mathrm{kg})$ van de beroepsvisserij per tuig in het Volkerak \& Zoommeer (Volkerak en Zoommeer). Sinds 2012 zijn aalvissers verplicht de inspanning van het vistuig op te geven aan het ministerie van LNV.

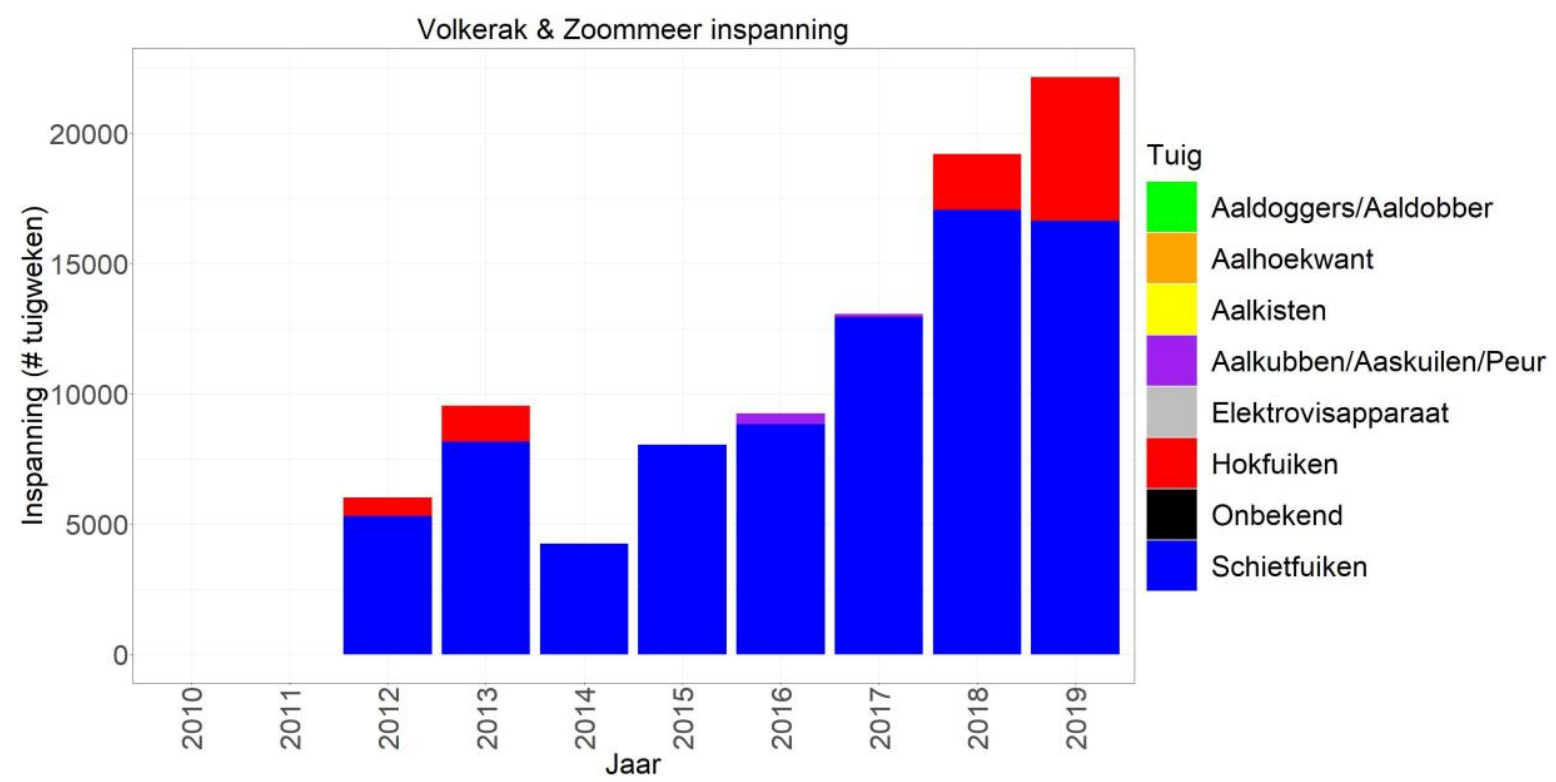

Figuur 2.126 Inspanning (aantal tuigweken) van de beroepsvisserij per tuig in het Volkerak \& Zoommeer. 


\subsection{Veerse Meer}

De bemonsteringslocaties over de periode 2016-2019 zijn weergegeven in Figuur 2.127.

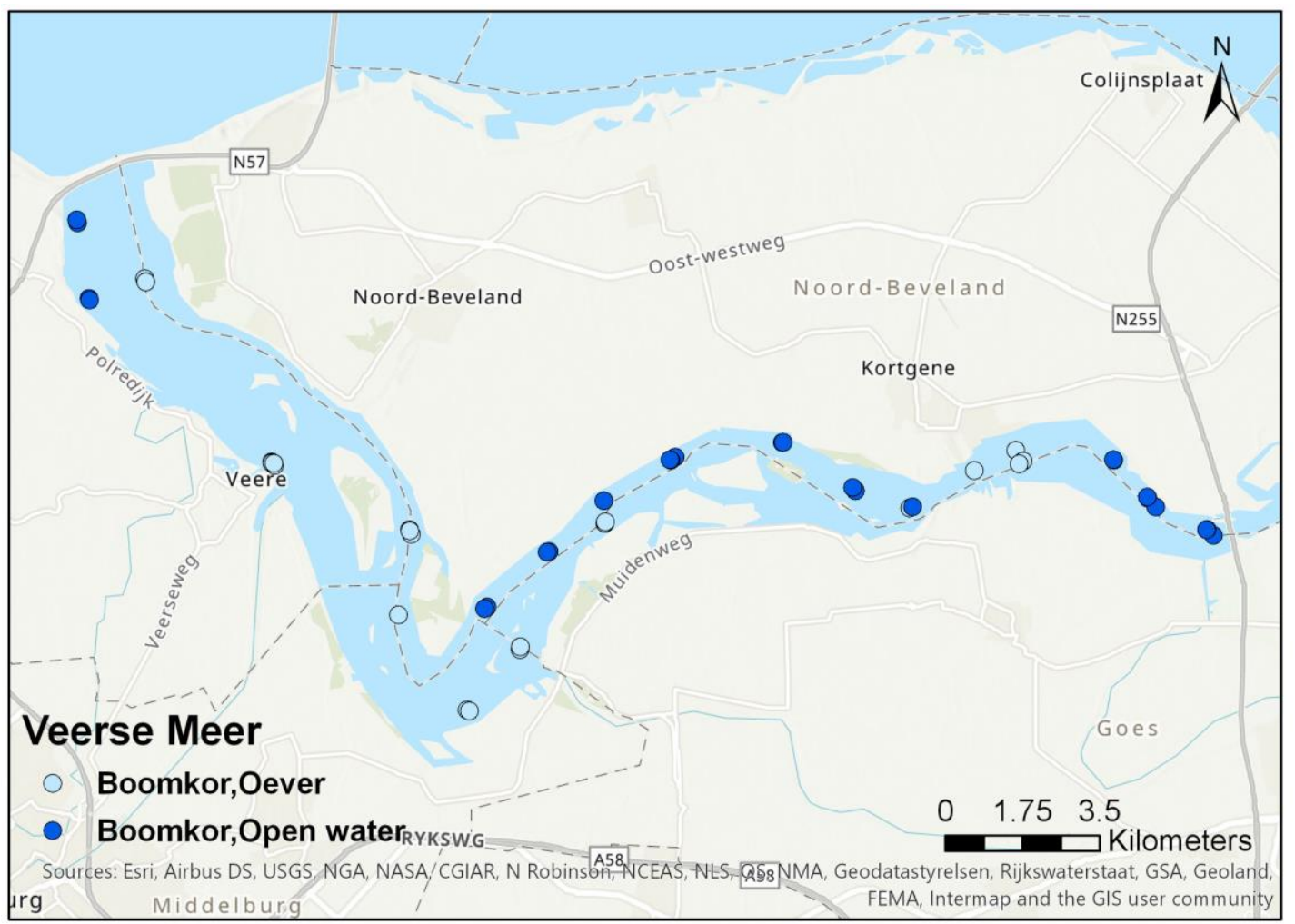

Figuur 2.127 Bemonsteringslocaties van de actieve monitoring in de Veerse Meer van 2016-2019 per tuig per habitat.

\subsubsection{Veerse Meer hoofdstroom (open water en oeverzone)}

Het Veerse Meer wordt sinds 2016 ieder jaar in het najaar (november) met de boomkor bemonsterd. Vijf ondiepe stations worden bevist met een aangepaste boomkor. De dimensies van de aangepaste boomkor zijn hetzelfde als die van de originele boomkor. Het verschil is dat er een lichtere rollenpees en een wekkerketting is gemonteerd. Tevens zijn er extra slijtlappen onder het net aangebracht ter bescherming tegen de oesters die aanwezig zijn op de ondiepere trajecten. In 2019 viel het ATKB op dat de aangetroffen zwarte grondels in zeer slechte staat waren; mager met een witachtige gloed en aangetaste vinnen/staarten.

De tien meest algemene soorten in de hoofdstroom van het Veerse Meer voor de gehele periode 20162019 zijn: zwarte grondel, tarbot, schol, koornaarvis sp. ${ }^{1}$, grote zeenaald, haring/sprot, grondel sp. ${ }^{1}$, brakwatergrondel, bot en aal. Deze omvatten meer dan $96 \%$ van het totale gemiddelde aantal en biomassa voor de vangsten met de boomkor (Bijlage 48). Ten opzichte van de voorgaande rapportage (van Rijssel et al. 2019a) behoort de grote zeenaald tot de tien meest algemene soorten in plaats van de griet. De Chinese wolhandkrab is niet in het Veerse Meer gevangen.

In het (zoute) open water en langs de oever (boomkor) is grondel sp. de dominante soort, zowel qua aantal als qua biomassa (Figuur 2.128). Aangezien dit gebied nog maar vier jaar bemonsterd wordt is het lastig om iets over trends in soorten te kunnen concluderen. Wat wel opvalt is dat bot en aal de enige soorten zijn in de top tien die ook in het zoete water kunnen voorkomen (diadrome soorten). Daarnaast is de toename van de koornaarvis sp. in 2019 opvallend en zijn de schar en de zeedonderpad voor het eerst in het Veerse Meer gevangen.

De lengte-frequentieverdelingen per soort, per tuig over alle jaren van de monitoring van dit KRWlichaam zijn hier te vinden: https://wmropendata.wur.nl/site/zoetwatervis/54/waterlichaam/

\footnotetext{
${ }^{1}$ Aangezien koornaarvis- en zandgrondelsoorten nauwelijks van elkaar te onderscheiden zijn worden ze in dit rapport bij de FGRA monitoring geschaard onder grondel sp. en koornaarvis sp.
} 


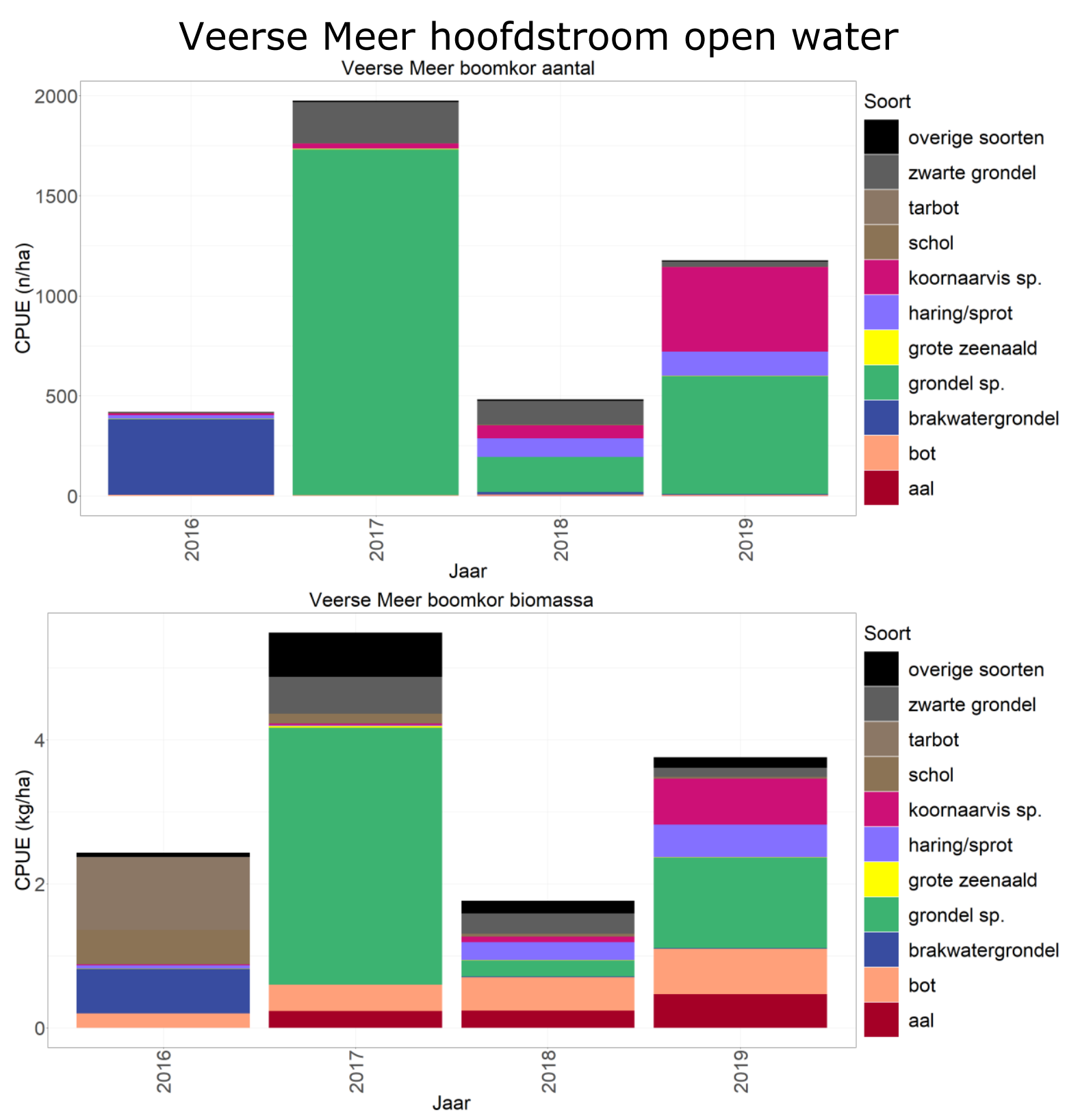

Figuur 2.128 Gemiddelde CPUE van de tien meest algemene soorten en overige soorten in het open water ( $\mathrm{n} / \mathrm{ha}-\mathrm{kg} / \mathrm{ha}$ bevist oppervlak) gevangen met een boomkor in de hoofdstroom van het Veerse Meer tijdens de actieve monitoring van 2016-2019. 


\subsubsection{Aalvangsten}

Voor de aanlandingen van KRW-lichaam Veerse Meer zijn de gegevens van het "Veerse Meer" gebruikt (Bijlage 2). Aal wordt voornamelijk met schietfuiken gevangen en de aanlandingen nemen af tot en met 2016, vanaf 2017 is er weer een toename in aanlandingen van aal, gevangen met zowel schietfuiken als hokfuiken. Dit terwijl de inspanning vanaf 2016 ongeveer gelijk blijft na een afname tussen 2012-2016 (Figuur 2.129, Figuur 2.130).

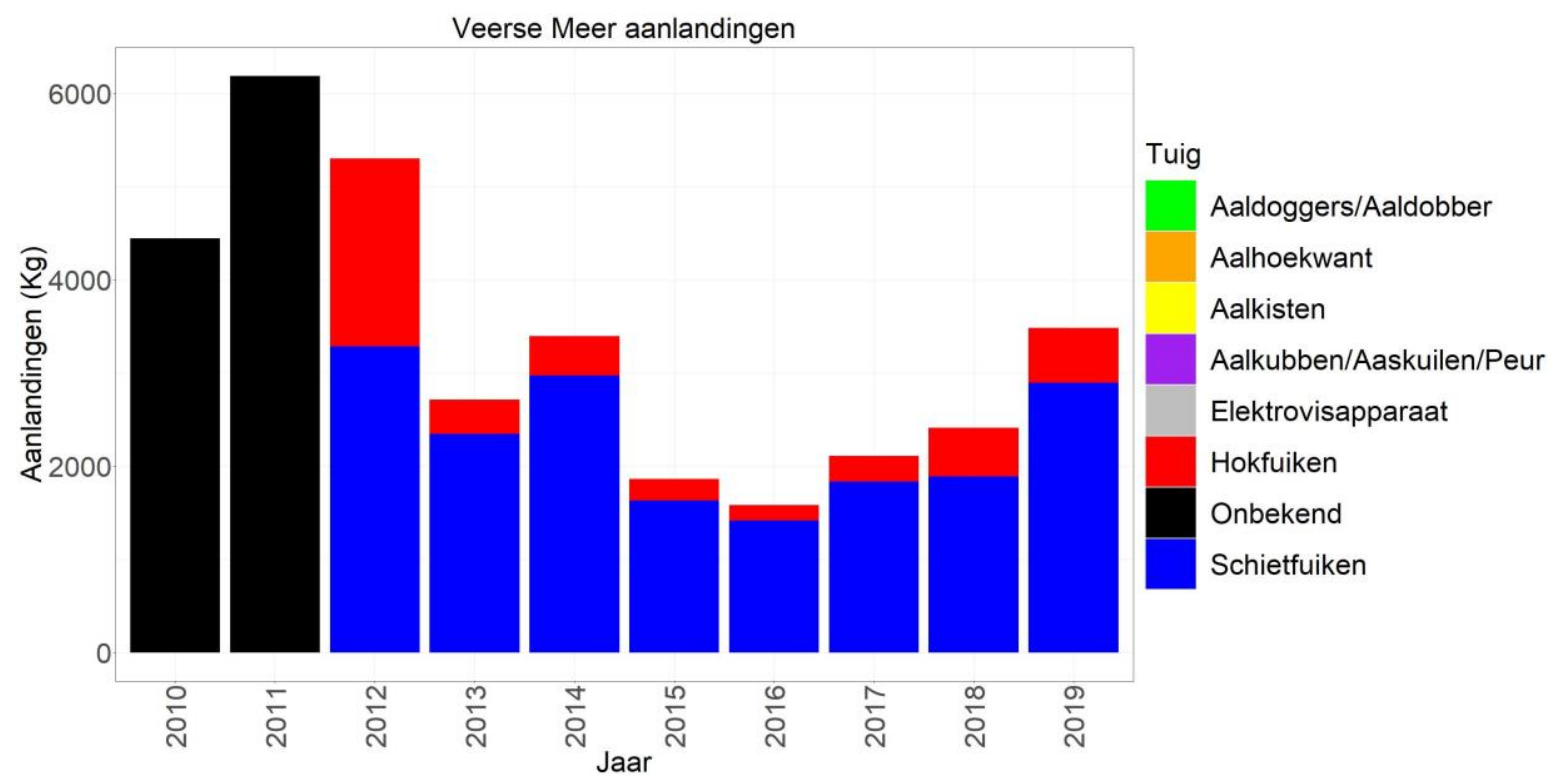

Figuur 2.129 Aanlandingen $(\mathrm{kg})$ van de beroepsvisserij per tuig in het Veerse Meer. Sinds 2012 zijn aalvissers verplicht de inspanning van het vistuig op te geven aan het ministerie van LNV.

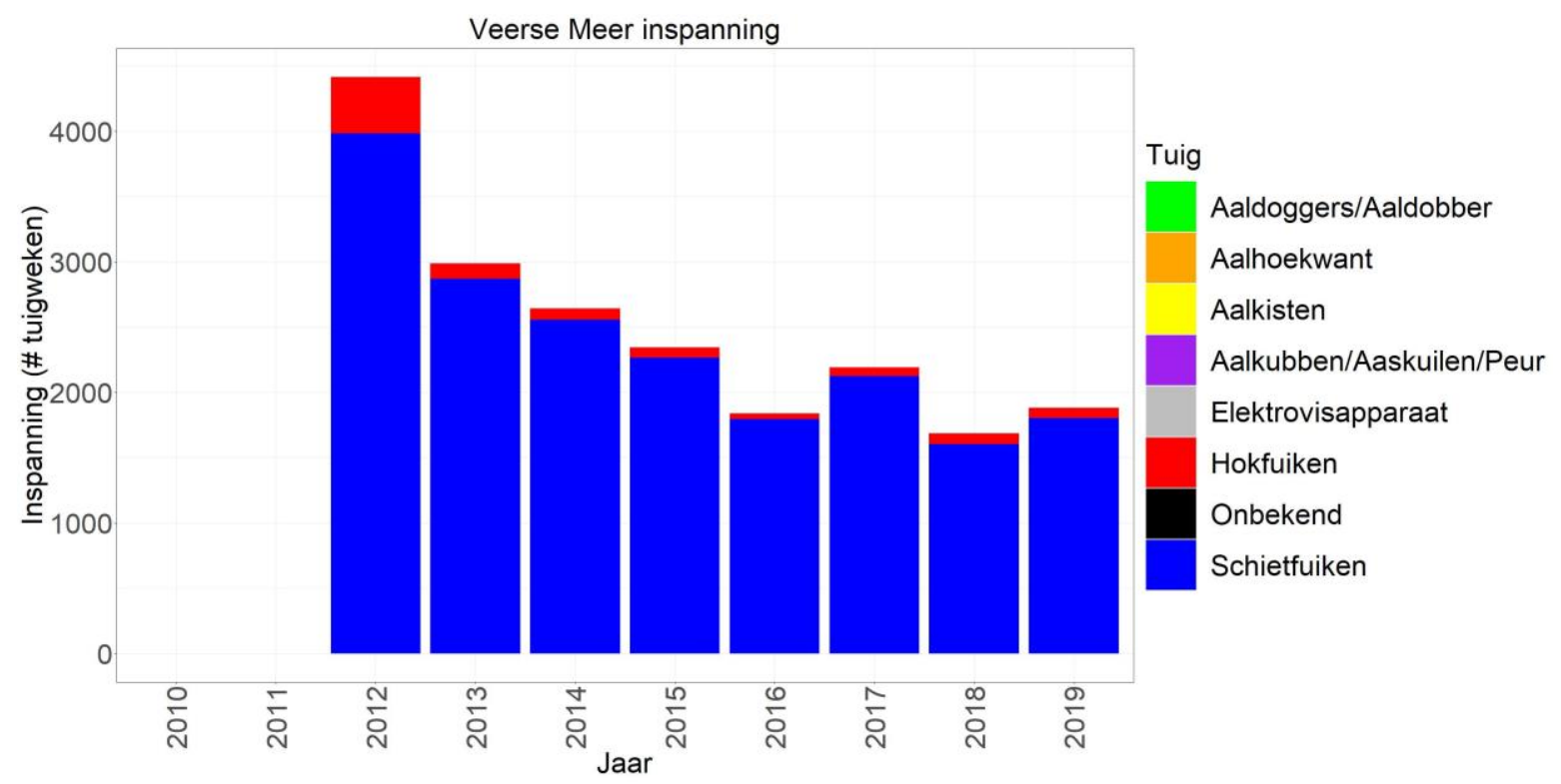

Figuur 2.130 Inspanning (aantal tuigweken) van de beroepsvisserij per tuig in het Veerse Meer. 


\subsection{Grevelingen(meer)}

De bemonsteringslocaties over de periode 2008-2019 zijn weergegeven in Figuur 2.131.

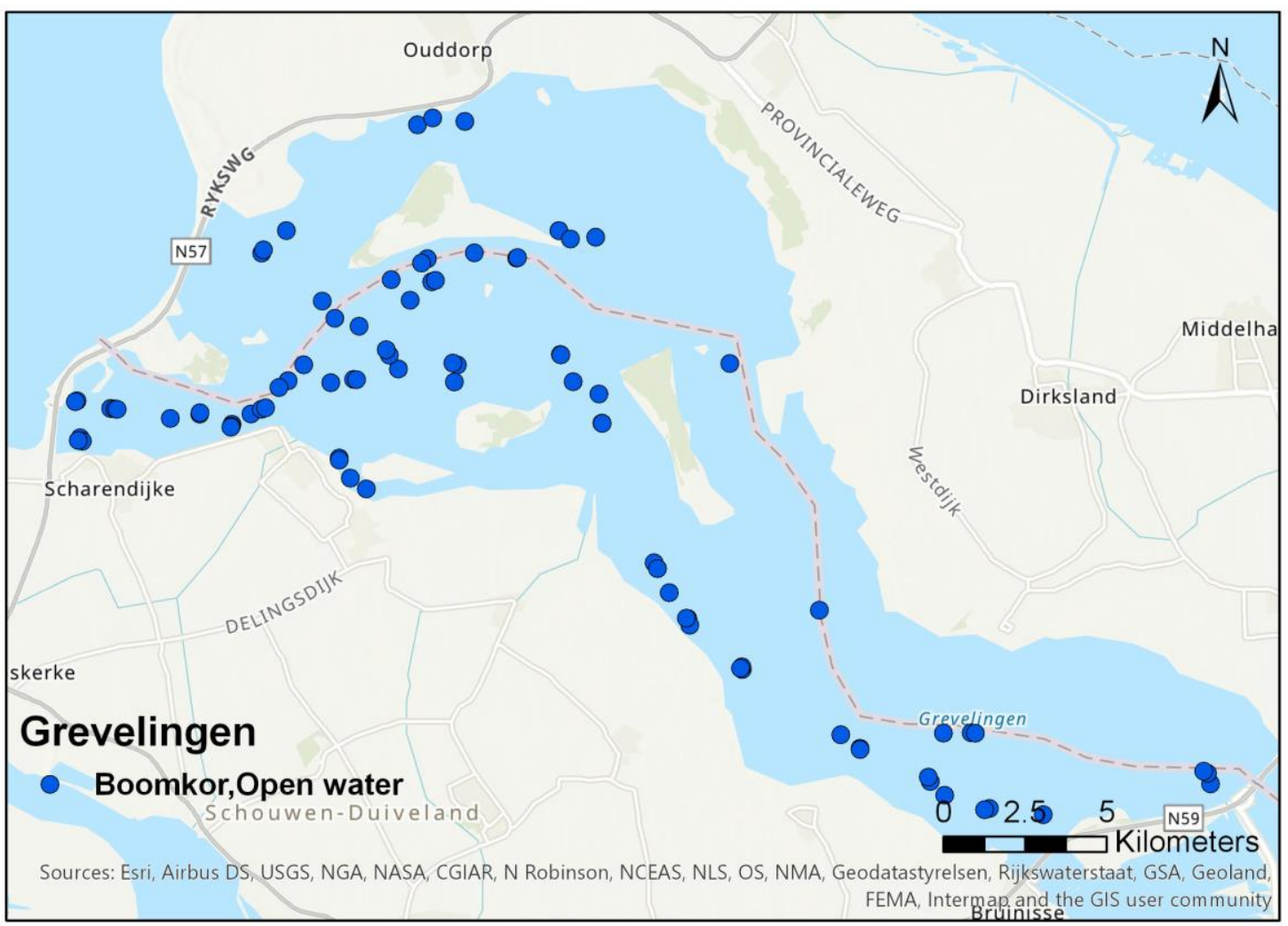

Figuur 2.131 Bemonsteringslocaties van de actieve monitoring in de Grevelingen van 2008-2019 per tuig per habitat.

\subsubsection{Grevelingenmeer hoofdstroom (open water)}

Het Grevelingenmeer wordt sinds 2008 om de twee tot vier jaar in het voorjaar met de boomkor bemonsterd. In 2008 is het Grevelingenmeer in maart bemonsterd, in 2011 en 2013 in april en vanaf 2017 in februari.

De tien meest algemene soorten in de hoofdstroom van het Grevelingenmeer voor de gehele periode 2008-2019 zijn zwarte grondel, zeebaars, tong, tarbot, schol, schar, koornaarvis sp., haring/sprot, grondel sp., griet en driedoornige stekelbaars. Deze omvatten meer dan $93 \%$ van het totale gemiddelde aantal en biomassa voor de vangsten met de boomkor (Bijlage 49). Ten opzichte van de voorgaande rapportage (van Rijssel et al. 2019a) behoren de zeebaars en de driedoornige stekelbaars tot de tien meest algemene soorten in plaats van schar en de brakwatergrondel. De Chinese wolhandkrab is niet in het Grevelingenmeer gevangen.

In het (zoute) open water (boomkor) zijn grondel sp., haring/sprot de dominante soorten (Figuur 2.132). In eerdere jaren waren dit voornamelijk platvissoorten zoals tarbot, schol, griet en tong. Ook hier fluctueren de vangsten sterk van jaar tot jaar. Wat opvalt is dat de platvissoorten sinds 2008 steeds minder worden gevangen. Door het afgesloten karakter van het Grevelingenmeer komen diadrome soorten niet in de top tien algemene soorten voor. Wat opvalt is zijn de hoge vangsten van zowel haring/sprot als koornaarvis sp. in 2019. Dit zien we ook terug in het Veerse Meer en voor haring/sprot ook in het Haringvliet. In 2019 is de goudharder voor het eerst gevangen in het Grevelingenmeer.

De lengte-frequentieverdelingen per soort, per tuig over alle jaren van de monitoring van dit KRWlichaam zijn hier te vinden: https://wmropendata.wur.nl/site/zoetwatervis/38/waterlichaam/ 


\section{Grevelingen hoofdstroom open water}

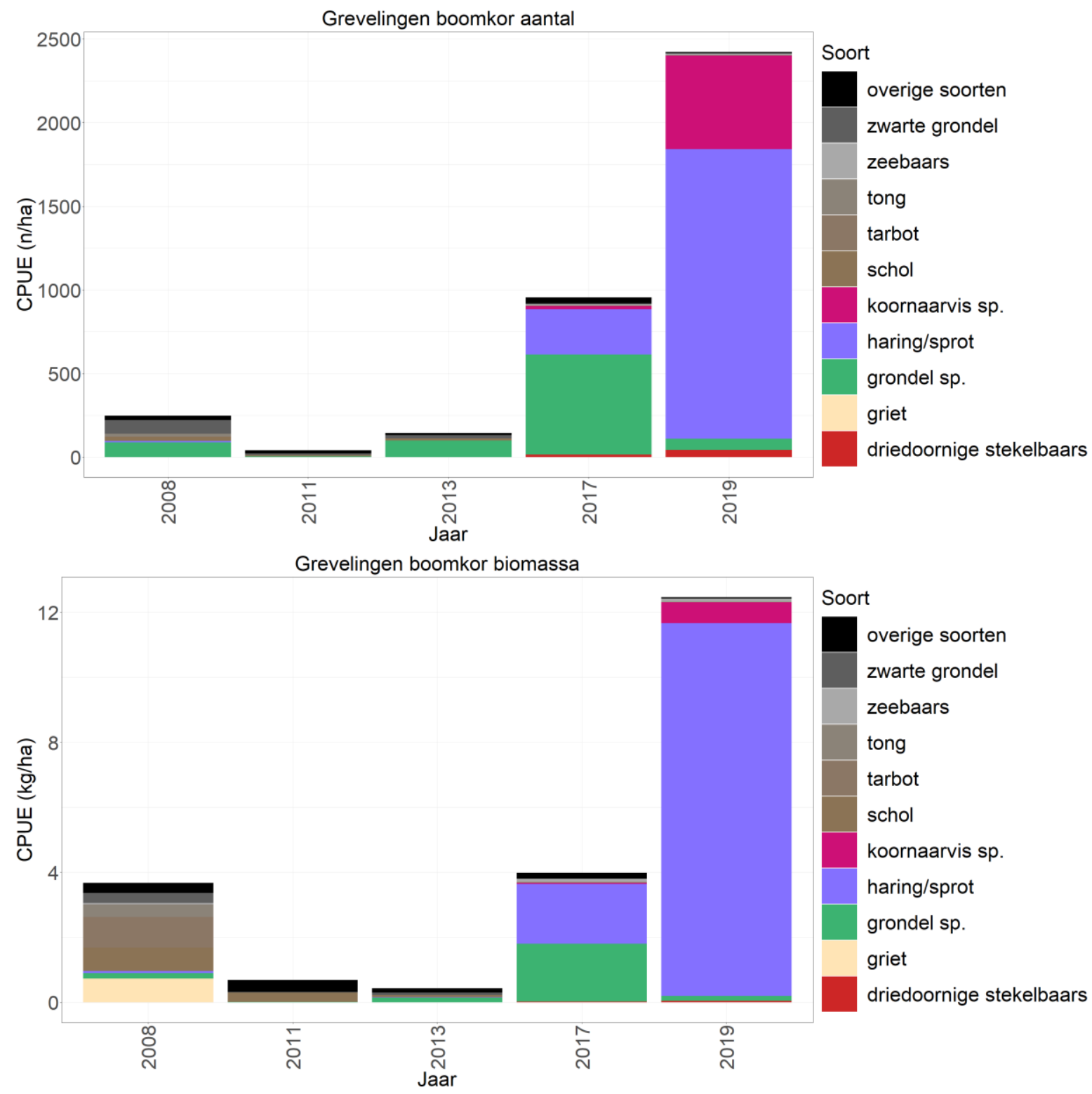

Figuur 2.132 Gemiddelde CPUE van de tien meest algemene soorten en overige soorten in het open water ( $\mathrm{n} / \mathrm{ha}-\mathrm{kg} / \mathrm{ha}$ bevist oppervlak) gevangen met een boomkor in de hoofdstroom van het Grevelingenmeer tijdens de actieve monitoring van 2008-2019. 


\subsubsection{Aalvangsten}

Voor de aanlandingen van KRW-lichaam Grevelingenmeer zijn de gegevens van het "Grevelingenmeer" gebruikt (Bijlage 2). Ook in dit KRW-lichaam is een afname van het aantal aanlandingen sinds 2010 te zien, alleen kan deze afname niet toegeschreven worden aan het verbod op aalvisserij in de grote rivieren, aangezien het Grevelingenmeer niet onder dit verbod valt. In 2014 is weer een flinke afname van het aantal aanlandingen te zien. De meeste aal wordt met schietfuiken gevangen (Figuur 2.133). Deze afname zou wellicht te maken kunnen hebben met een afname van aal in het Grevelingenmeer. De lage aanlandingen van 2015/2016 kunnen deels verklaard worden door de lagere inspanning evenals de toenames in 2017/2018 deels te verklaren zijn door toegenomen inspanningen (Figuur 2.134).

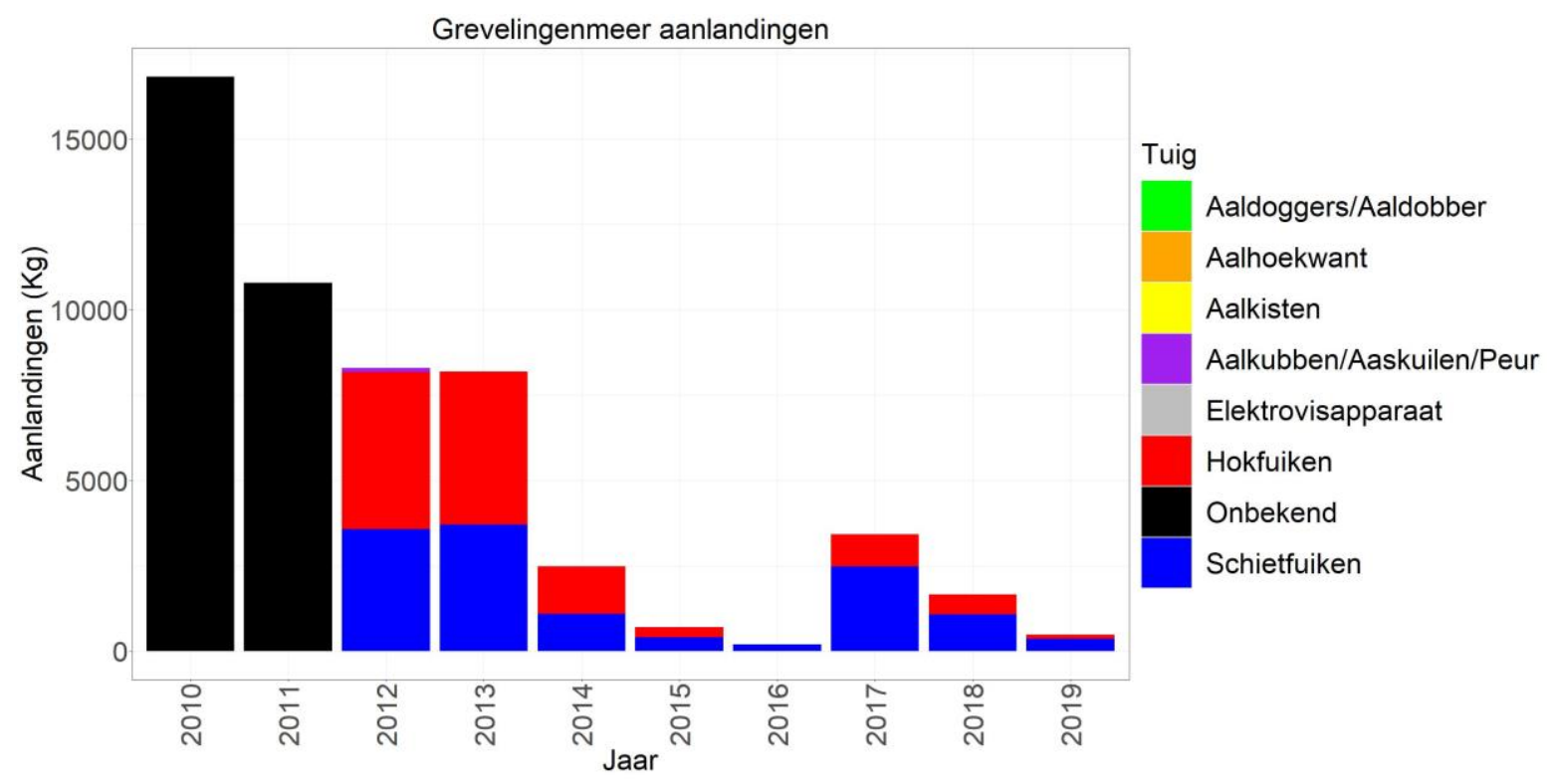

Figuur 2.133 Aanlandingen (kg) van de beroepsvisserij per tuig in het Grevelingenmeer. Sinds 2012 zijn aalvissers verplicht de inspanning van het vistuig op te geven aan het ministerie van LNV.

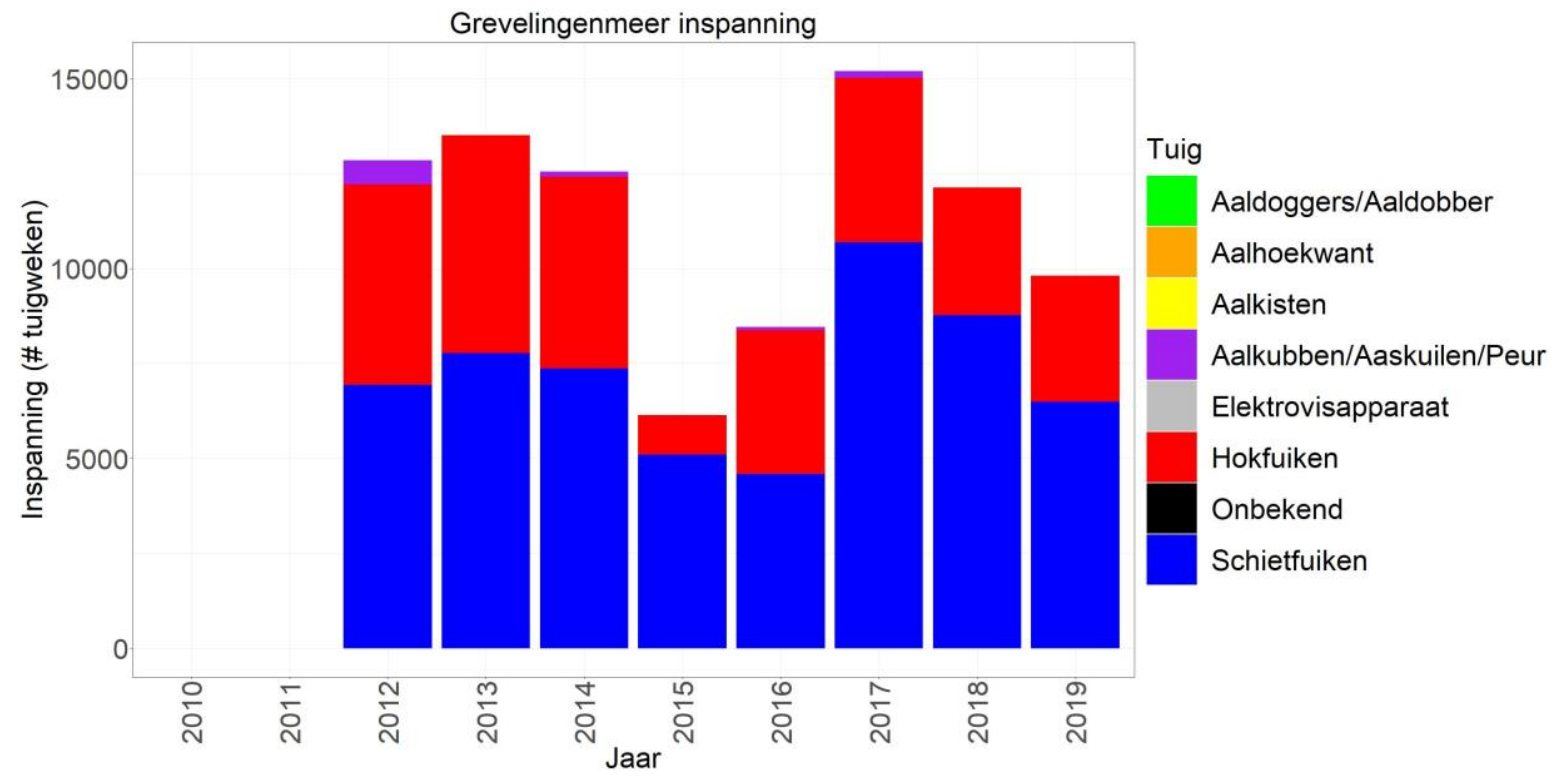

Figuur 2.134 Inspanning (aantal tuigweken) van de beroepsvisserij per tuig in het Grevelingenmeer. 


\subsection{Nieuwe Waterweg}

De bemonsteringslocaties over de periode 2011-2019 zijn weergegeven in Figuur 2.135.

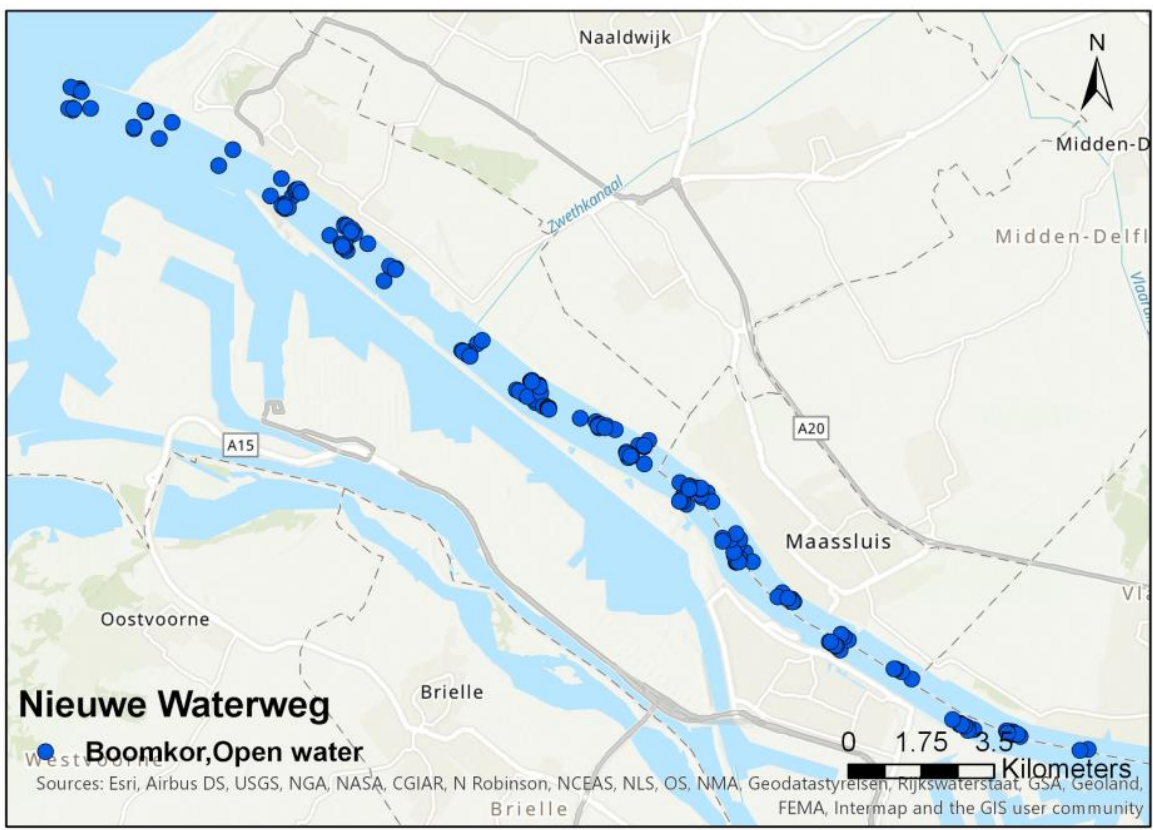

Figuur 2.135 Bemonsteringslocaties van de actieve monitoring in de Nieuwe Waterweg van 2011-2019 per tuig per habitat.

\subsubsection{Nieuwe Waterweg hoofdstroom (open water)}

De Nieuwe Waterweg wordt sinds 2011 ieder jaar in het najaar en het voorjaar bemonsterd. Om een beeld te krijgen van de veranderingen per cohort is besloten om bemonsteringen van het najaar te combineren met de bemonstering van het daaropvolgende voorjaar. Zo worden bijvoorbeeld vangsten uit het najaar van 2012 en het voorjaar van 2013 samengevoegd, en als 2013 in de figuur weergegeven. De voorjaarsbemonstering heeft in 2011 niet plaats gevonden, die van 2012 vond plaats in juni, in 2013-2015 vond deze plaats in april, in 2016 was er geen bemonstering in het voorjaar en vanaf 2017 vindt deze plaats in februari. De najaarsbemonstering vond in 2011 plaats in december, van 2012-2017 in november met uitzondering van 2015 (geen najaarsbemonstering), in 2018 oktober en november en in 2019 in november.

De tien meest algemene soorten in de hoofdstroom van de Nieuwe Waterweg voor de gehele periode 2011-2019 zijn zeedonderpad, wijting, tong, steenbolk, spiering, schol, schar, kabeljauw, grondel sp. en bot. Deze omvatten meer dan $92 \%$ van het totale gemiddelde aantal en biomassa voor de vangsten met de boomkor (Bijlage 50). Dit relatief lage percentage is ook een indicatie dat er veel verschillende soorten worden gevangen in de Nieuwe Waterweg.

In het (zoute) open water (boomkor) zijn grondel sp., schol, schar, bot, wijting en steenbolk de dominante soorten zowel qua aantal als qua biomassa (Figuur 2.136). De vangsten lijken door de jaren heen qua aantal en biomassa redelijk stabiel. Dit lijkt ook te gelden voor de individuele soorten, alhoewel er sterke fluctuaties van jaar tot jaar zijn. Door de open verbinding met de Noordzee komen hier soorten in de top tien voor die nergens anders in de bemonsterde KRW-lichamen voorkomen (zoals de zeedonderpad, steenbolk, kabeljauw). In 2019 is baars voor het eerst in de Nieuwe Waterweg gevangen. De vangsten van het najaar van 2019 zijn weergegeven als zijnde die van 2020 en zijn nog niet volledig (de vangsten van het voorjaar van 2020 moeten hier nog bij komen) en worden om die reden alleen getoond en niet besproken.

De lengte-frequentieverdelingen per soort, per tuig over alle jaren van de monitoring van dit KRWlichaam zijn hier te vinden: https://wmropendata.wur.nl/site/zoetwatervis/48/waterlichaam/ 


\section{Nieuwe Waterweg hoofdstroom open water}

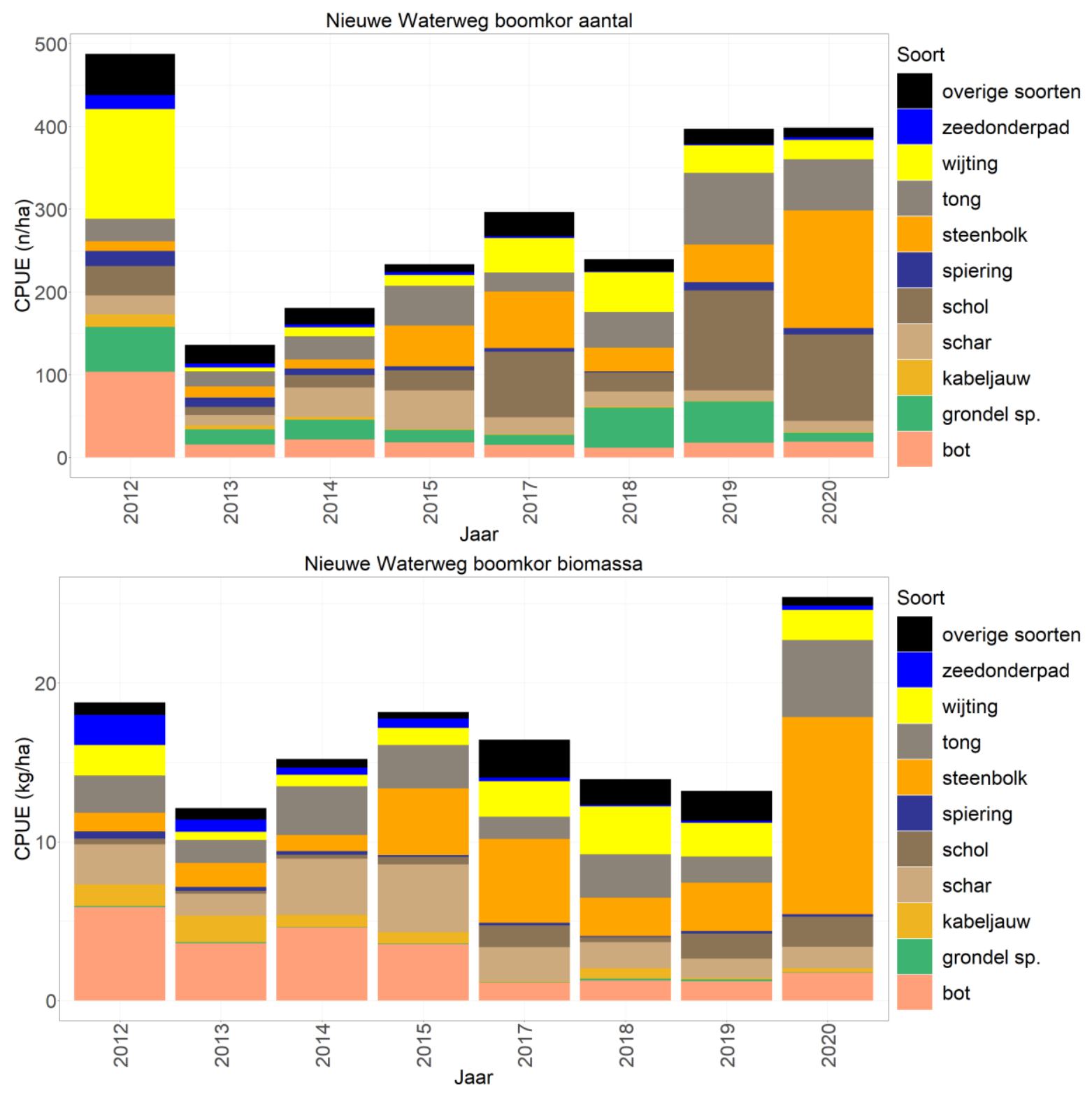

Figuur 2.136 Gemiddelde CPUE van de tien meest algemene soorten en overige soorten in het open water ( $\mathrm{n} / \mathrm{ha}-\mathrm{kg} / \mathrm{ha}$ bevist oppervlak) gevangen met een boomkor in de hoofdstroom van de Nieuwe Waterweg tijdens de actieve monitoring van 2011-2019. De gegevens weergegeven als zijnde van 2020 zijn van het najaar van 2019. 


\subsubsection{Chinese wolhandkrab}

De Chinese wolhandkrab wordt sinds 2011 regelmatig in behoorlijke aantallen gevangen in de hoofdstroom van de Nieuwe Waterweg, alhoewel er ook jaren zijn wanneer er totaal geen wolhandkrabben worden gevangen. Er lijkt geen duidelijke trend te zijn door de jaren heen (Figuur 2.137).

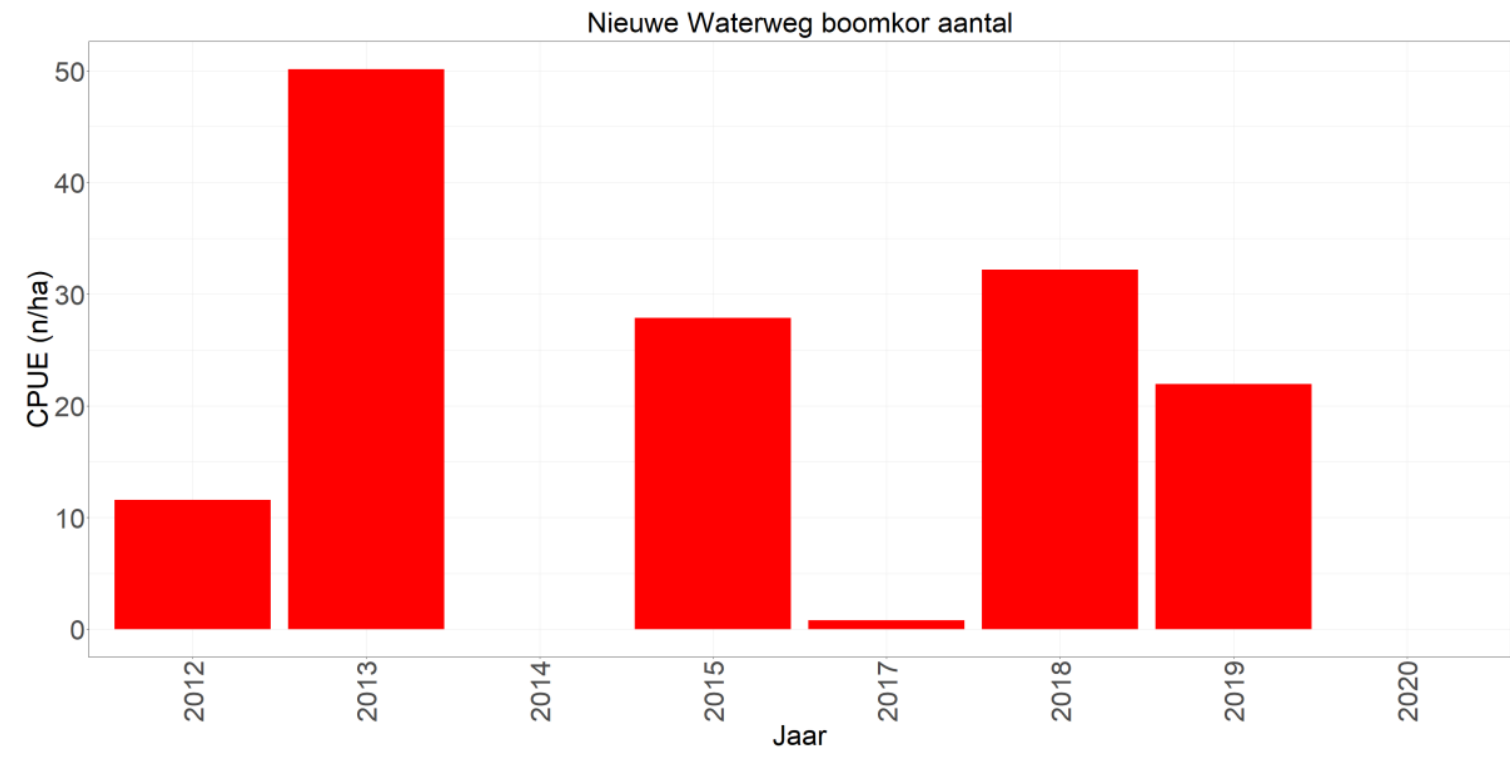

Figuur 2.137 Gemiddelde CPUE (n/ha bevist oppervlak) per jaar van de Chinese wolhandkrab in de hoofdstroom van het open water van de Nieuwe Waterweg gevangen met de boomkor. De gegevens van 2020 zijn van het najaar van 2019.

\subsubsection{Aalvangsten}

Voor de aanlandingen van KRW-lichaam Nieuwe Waterweg zijn de gegevens van de "Nieuwe Waterweg" gebruikt (Bijlage 2). In 2011 is het verbod op aalvisserij in de grote rivieren in verband met te hoge dioxine- en PCB-gehaltes in aal ingegaan waardoor er alleen aanlandingen uit 2010 zijn. In dit jaar is er 5.315 kilo aan aal aangeland (Bijlage 2). 


\subsection{Noordzeekanaal}

De bemonsteringslocaties over de periode 2008-2019 zijn weergegeven in Figuur 2.138.

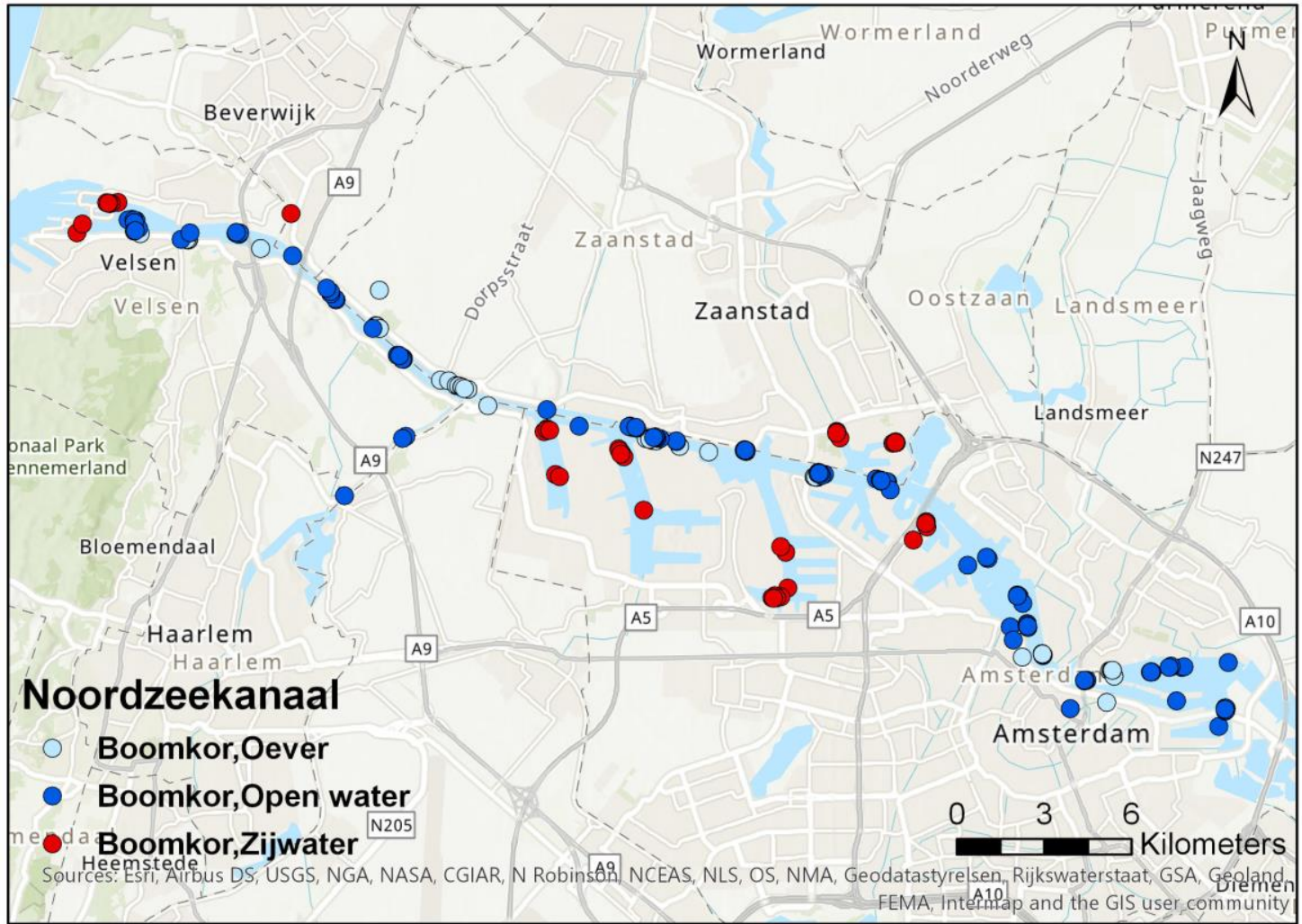

Figuur 2.138 Bemonsteringslocaties van de actieve monitoring in de Noordzeekanaal van 2008-2019 per tuig per habitat.

\subsubsection{Noordzeekanaal hoofdstroom (open water en oeverzone)}

Het Noordzeekanaal wordt sinds 2016 ieder jaar in het najaar (november) en het voorjaar (februari) bemonsterd. Om een beeld te krijgen van de veranderingen per cohort is besloten om bemonsteringen van het najaar te combineren met de bemonstering van het daaropvolgende voorjaar. Zo worden bijvoorbeeld vangsten uit het najaar van 2016 en het voorjaar van 2017 samengevoegd, en als 2017 in de figuur weergegeven. In 2008, 2011 en 2014 hebben er ook bemonsteringen plaatsgevonden in november. Deze bemonsteringen worden wel in de grafieken weergegeven maar het verschil in bemonsteringsperiode moet bij de interpretatie van de grafieken in acht worden genomen. Er heeft geen bemonstering plaatsgevonden in het najaar van 2019.

De tien meest algemene soorten in de hoofdstroom van het Noordzeekanaal voor de gehele periode 2008-2019 zijn zeebaars, tong, kolblei, haring/sprot, grondel sp., brasem, bot, baars, snoekbaars en aal. Deze omvatten meer dan $85 \%$ van het totale gemiddelde aantal en biomassa voor de vangsten met de boomkor (Bijlage 51). Dit is het laagste percentage van alle bemonsterde KRW-lichamen een ook hier zien we dat dit een goede indicatie is voor een hoge soortendiversiteit in de vangsten (Bijlage 51). Ten opzichte van de voorgaande rapportage (van Rijssel et al. 2019a) behoort de zeebaars tot de tien meest algemene soorten in plaats van de blankvoorn.

In het open water en langs de oever (boomkor) zijn brasem, kolblei, snoekbaars, bot, grondel sp. en tong zowel qua aantal als qua biomassa de dominante soorten (Figuur 2.139 boven). Door de verbinding via de sluizen met de Noordzee is een deel van het Noordzeekanaal gevuld met zout/brak water waardoor er een mengeling is van zoet- en zoutwatervissoorten. Net als bij de Nieuwe Waterweg is te zien dat de vangsten per soort over het algemeen relatief stabiel door de jaren heen lijken te zijn met sterke fluctuaties van jaar op jaar. Wat opvalt is dat brasem en kolblei hier niet sterk afnemen, wat in veel stroomopwaartse KRW-lichamen wel het geval is. Verder lijkt het erop dat bot met de jaren wat toeneemt en dat grondel sp. en haring/sprot met de jaren afnemen.

De lengte-frequentieverdelingen per soort, per tuig voor de hoofdstroom en de zijwateren gecombineerd over alle jaren van de monitoring van dit KRW-lichaam zijn hier te vinden: https://wmropendata.wur.nl/site/zoetwatervis/49/waterlichaam/ 

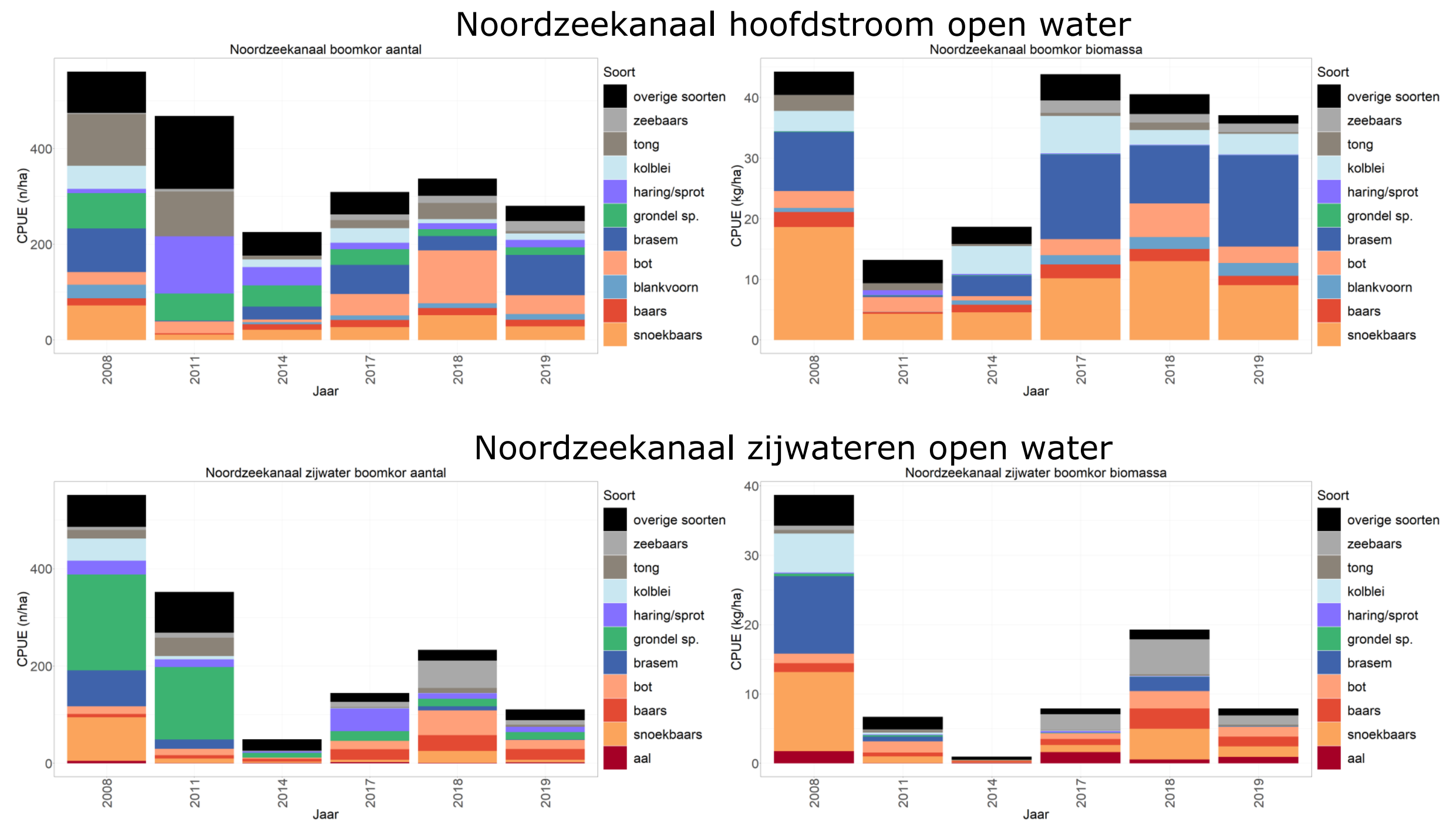

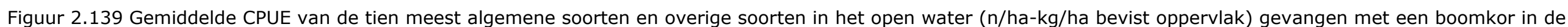
hoofdstroom en de zijwateren van het Noordzeekanaal tijdens de actieve monitoring van 2008-2019. 


\subsubsection{Chinese wolhandkrab}

De Chinese wolhandkrab wordt sinds 2014 regelmatig gevangen in de hoofdstroom van het Noordzeekanaal (Figuur 2.140).

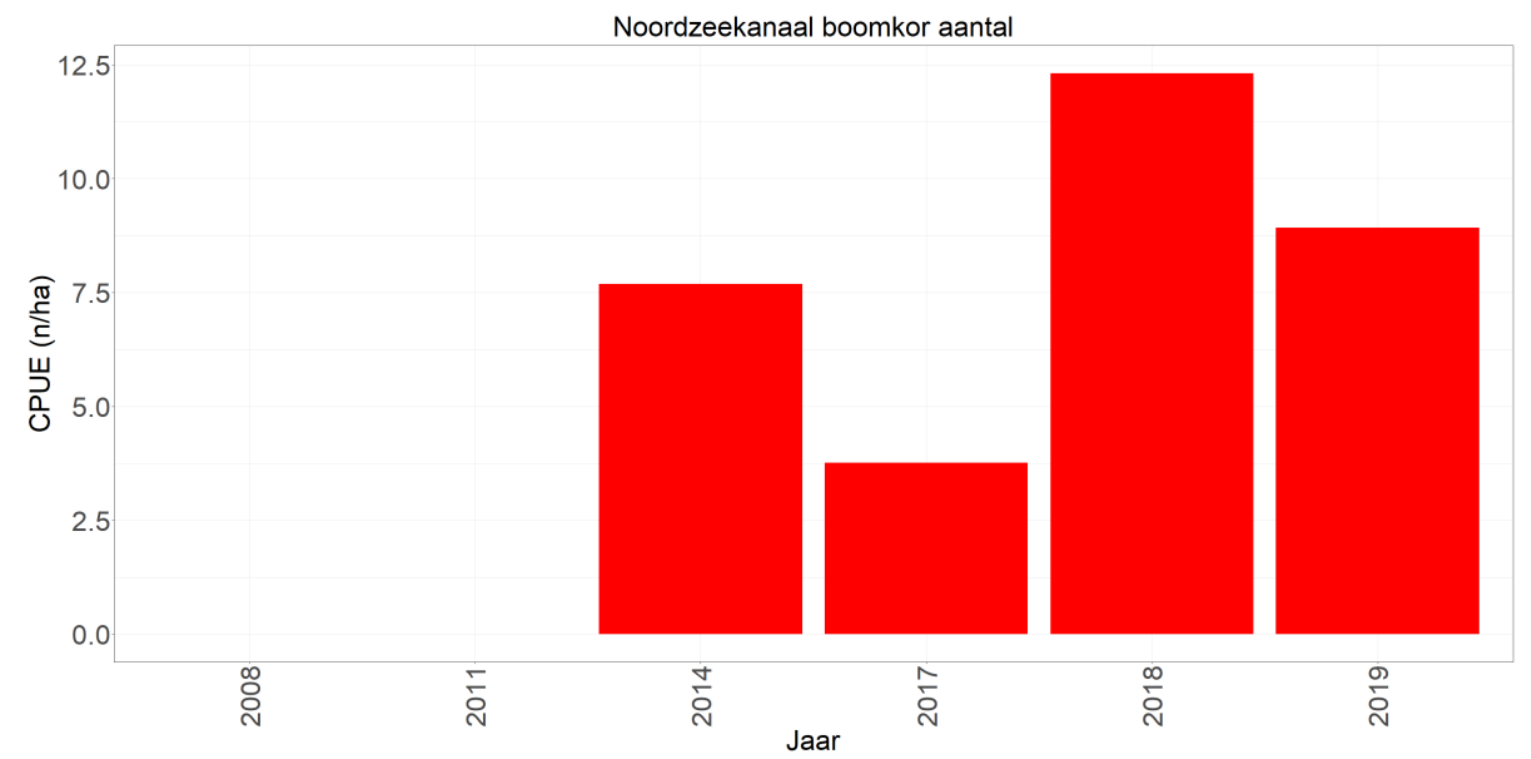

Figuur 2.140 Gemiddelde CPUE (n/ha bevist oppervlak) per jaar van de Chinese wolhandkrab in de hoofdstroom van het open water van het Noordzeekanaal gevangen met de boomkor.

\subsubsection{Noordzeekanaal zijwateren}

Langs het Noordzeekanaal zijn twee zijkanalen, vijf havens en een sluizencomplex bemonsterd met de boomkor in het open water.

De tien meest algemene soorten in deze zijwateren voor de gehele periode 2008-2019 zijn zeebaars, tong, kolblei, haring/sprot, grondel sp., brasem, bot, baars, snoekbaars en aal. Deze omvatten meer dan $88 \%$ van het totale gemiddelde aantal en biomassa voor de vangsten met de boomkor (Bijlage 52).

Net als in het open water van de hoofdstroom zijn brasem, kolblei, snoekbaars, bot en grondel sp. de dominante soorten in de boomkorvangsten, zowel qua aantal als qua biomassa (Figuur 2.139 onder). Tong wordt wat minder in de zijwateren gevangen dan in de hoofdstroom en vooral de laatste drie jaar wordt er meer zeebaars gevangen. Wellicht is dit een effect van de diverse maatregelen die zijn getroffen ter bescherming van de zeebaars, zoals vangstrestricties voor zowel beroeps- als sportvissers. Verder lijkt er een afname van grondel sp. te zijn, die inzet tussen 2011 en 2014. In tegenstelling tot in de hoofdstroom worden brasem en kolblei met de jaren minder vaak gevangen. 


\subsubsection{Chinese wolhandkrab}

Net als in de hoofdstroom wordt de Chinese wolhandkrab sinds 2014 regelmatig gevangen in de zijwateren van het Noordzeekanaal al zij het wel in lagere aantallen dan in de hoofdstroom. De aantallen fluctueren sterk door de jaren heen (Figuur 2.141).

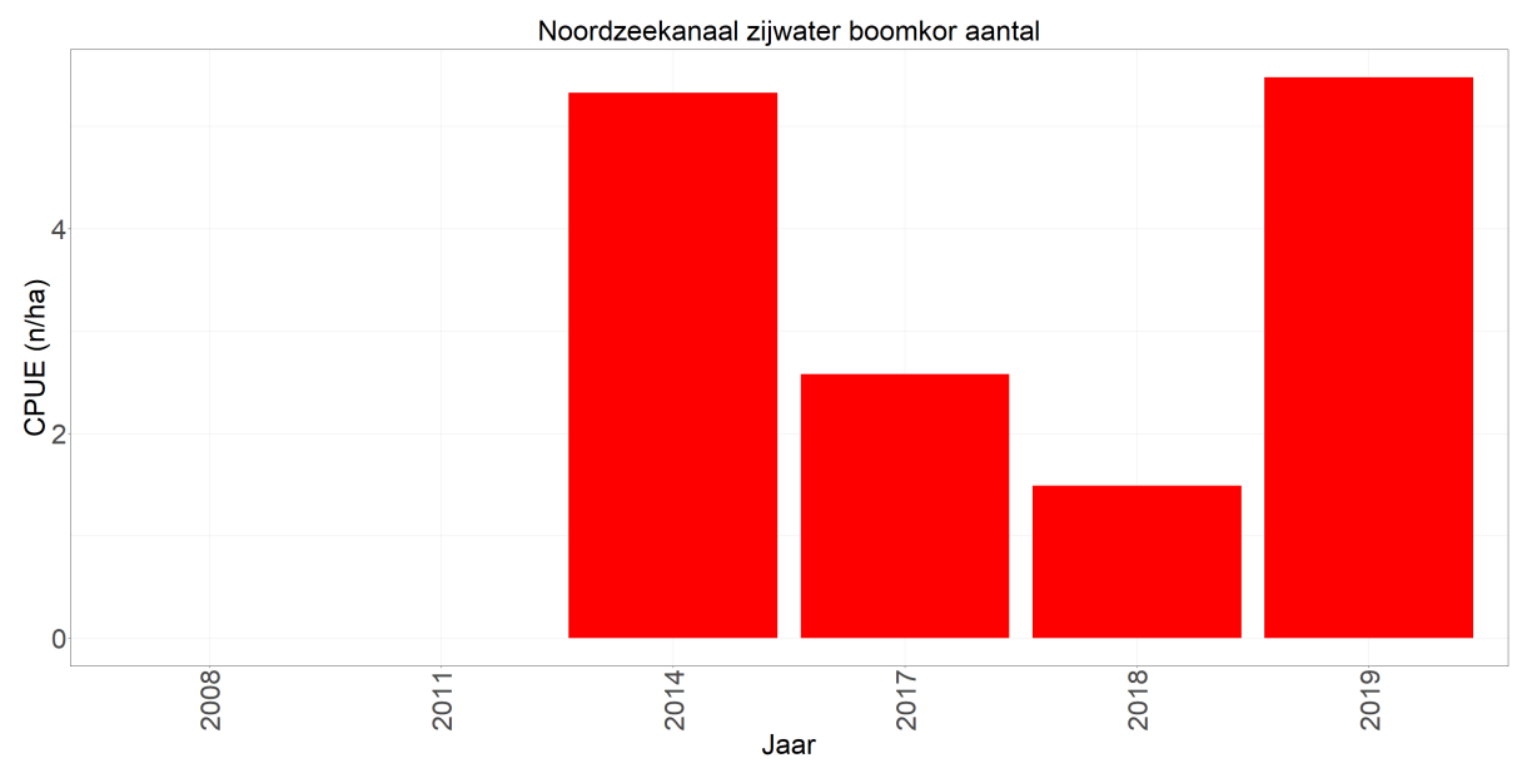

Figuur 2.141 Gemiddelde CPUE (n/ha bevist oppervlak) per jaar van de Chinese wolhandkrab in de zijwateren van het Noordzeekanaal gevangen met de boomkor. 


\subsubsection{Aalvangsten}

Voor de aanlandingen van KRW-lichaam Noordzeekanaal zijn de gegevens van het "Noordzeekanaal" gebruikt (Bijlage 2). Na 2010 is een grote afname van de aanlandingen te zien als gevolg van het verbod op aalvisserij in de grote rivieren en het grootste deel van het Noordzeekanaal in verband met te hoge dioxine- en PCB-gehaltes in aal. Zijkanaal B van het Noordzeekanaal is uitgesloten van het verbod. Hier mag nog wel op aal worden gevist. De Staat heeft hier een huurovereenkomst met een beroepsvisser. Dit betekent dat de aanlandingen van het Noordzeekanaal vanaf 2011 alleen op zijkanaal B gebaseerd zijn. De aanlandingen zijn vanaf 2011 relatief stabiel, en aal wordt in alle jaren vrijwel alleen met hokfuiken gevangen (op 2014 na, Figuur 2.142, Figuur 2.143).

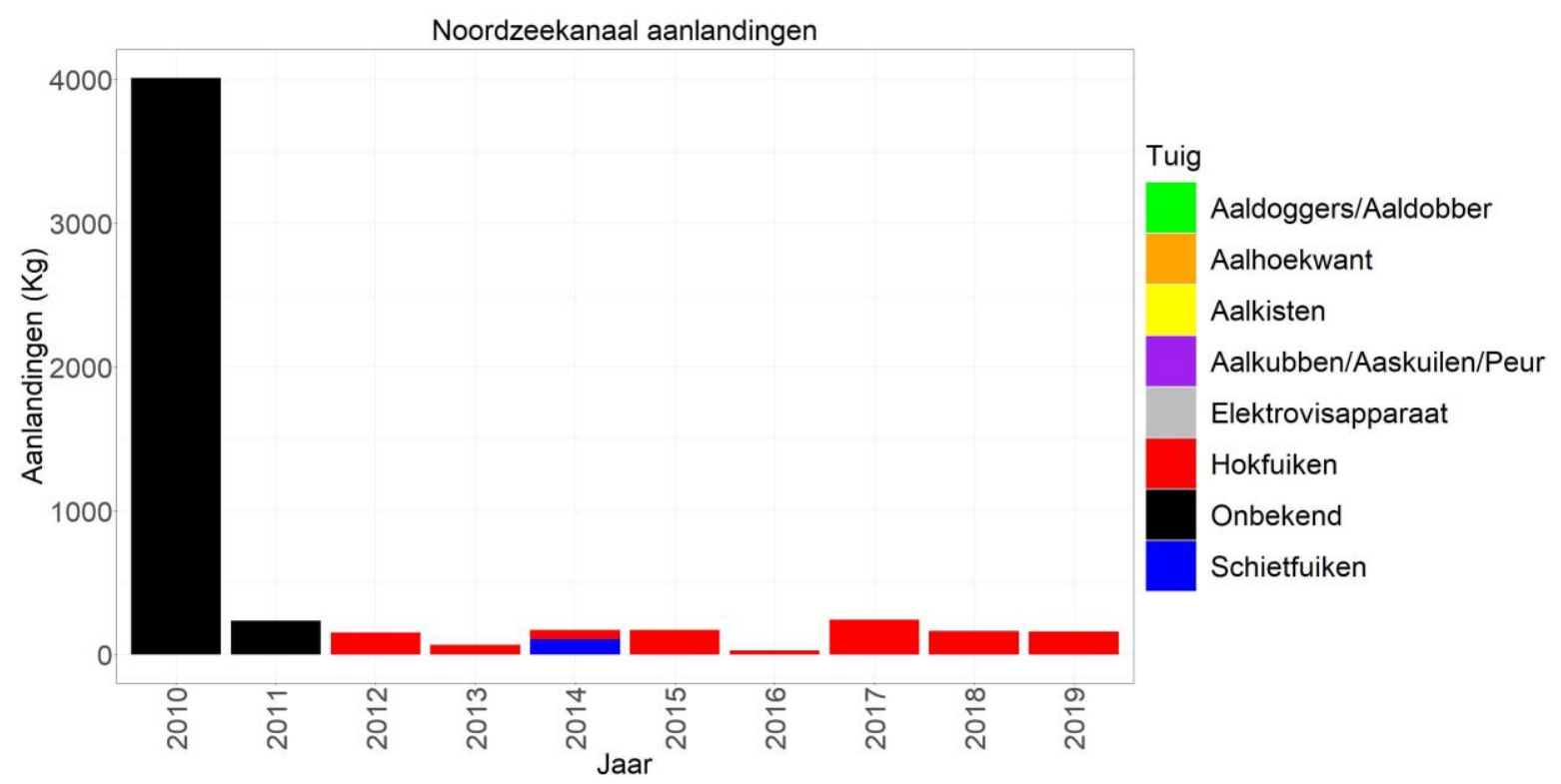

Figuur 2.142 Aanlandingen (kg) van de beroepsvisserij per tuig in het Noordzeekanaal. Sinds 2012 zijn aalvissers verplicht de inspanning van het vistuig op te geven aan het ministerie van LNV.

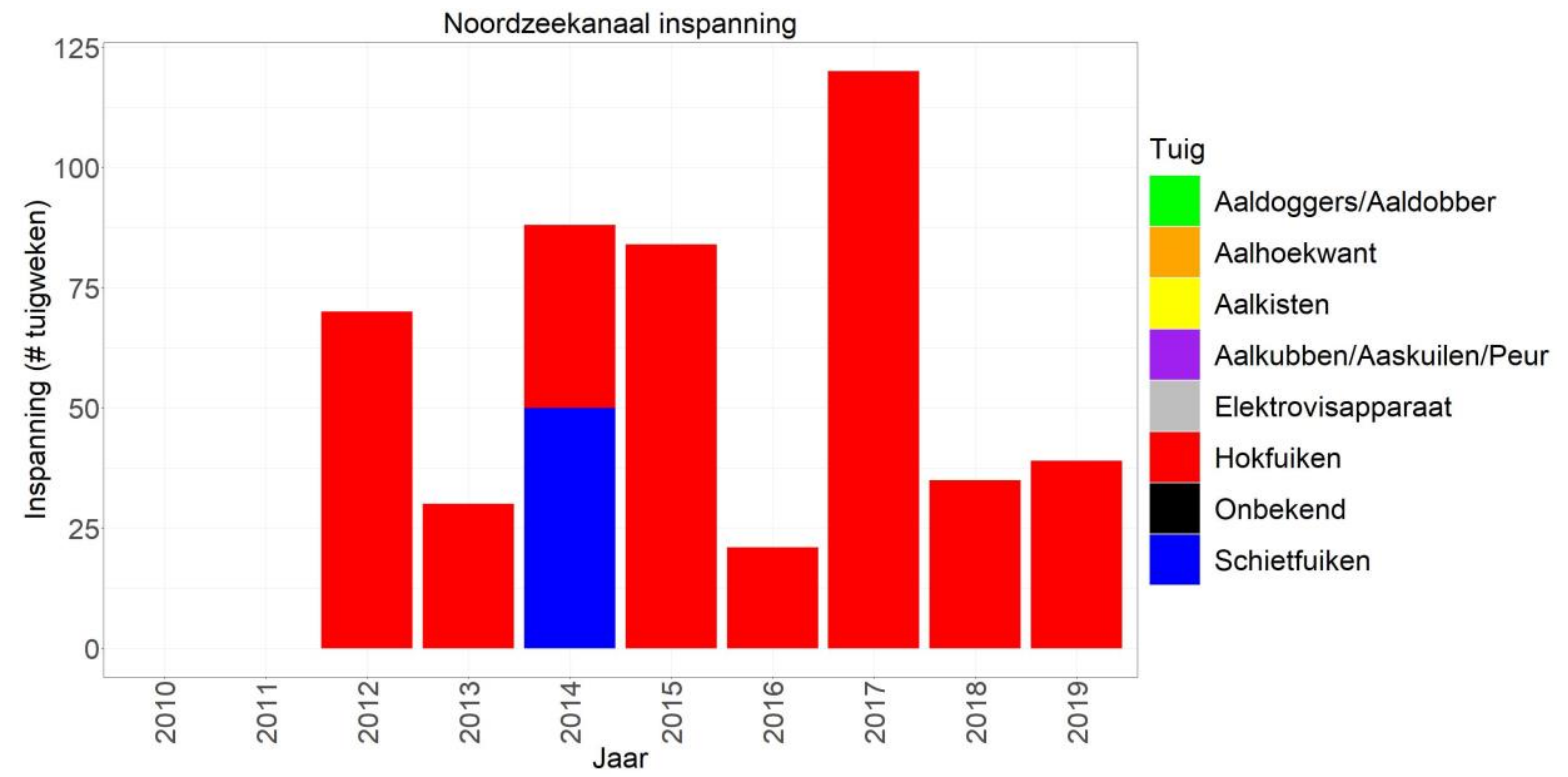

Figuur 2.143 Inspanning (aantal tuigweken) van de beroepsvisserij per tuig in het Noordzeekanaal. 


\subsection{Oosterschelde}

De bemonsteringslocaties over de periode 1970-2019 zijn weergegeven in Figuur 2.144.

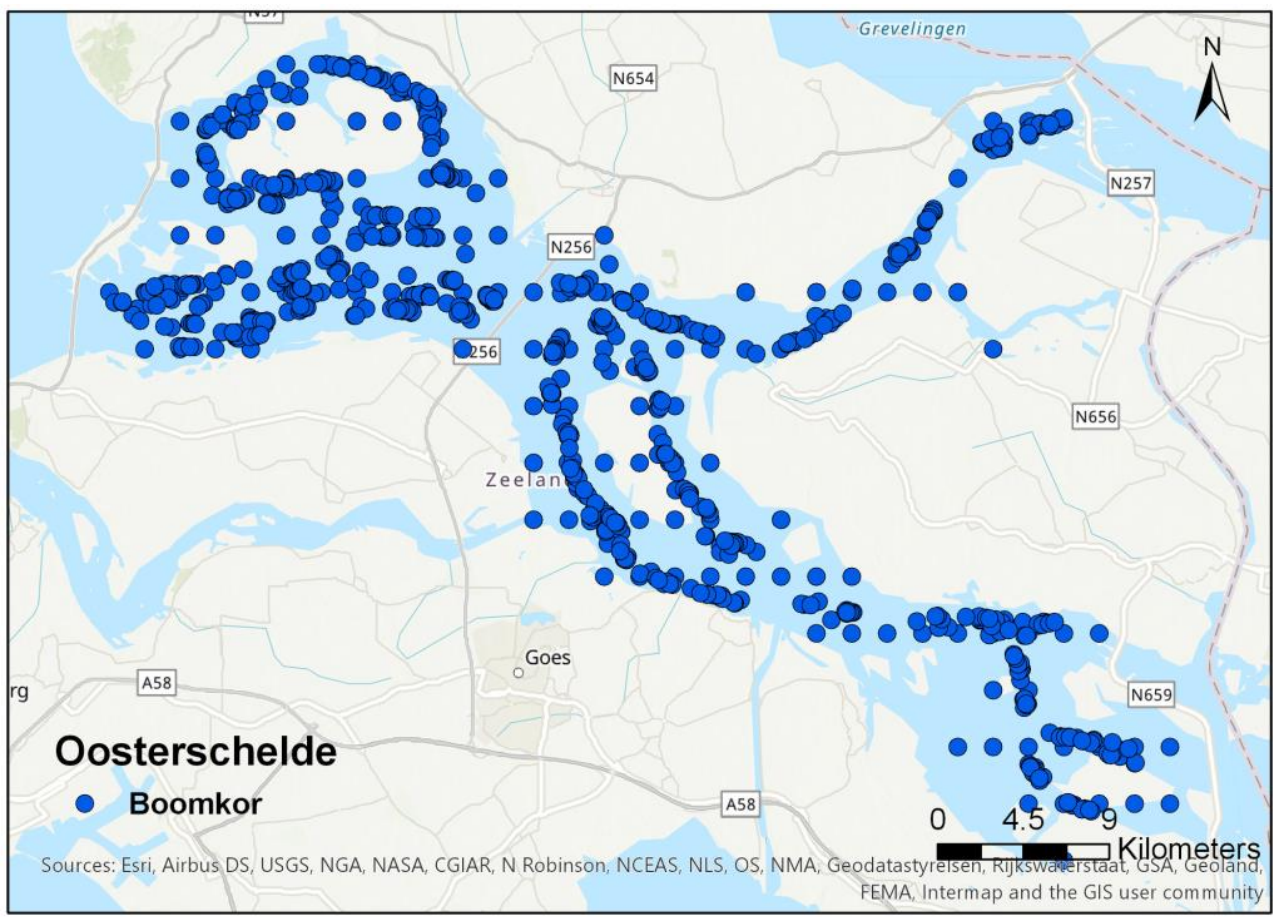

Figuur 2.144 Bemonsteringslocaties van de DFS in de Oosterschelde in de periode 1970-2019 per tuig.

De Oosterschelde wordt sinds 1970 ieder jaar in het najaar met de boomkor bemonsterd. Van 19701987 in september en/of oktober, en vanaf 1988 in september. Aangezien een deel van de bemonsteringen in de eerdere jaren buiten de Oosterschelde heeft plaatsgevonden, maar in de Voordelta, is er een selectie gemaakt van bemonsteringen die alleen in het water van de Oosterschelde liggen. Ook enkele bemonsteringen waarvan de coördinaten abusievelijk op het land liggen zijn van de analyse uitgesloten. Deze selectie heeft geen effect gehad op de selectie van de tien meest voorkomende soorten en lijkt maar een geringe invloed te hebben op de trends.

De tien meest algemene soorten in de Oosterschelde voor de gehele periode 1970-2019 zijn: zeedonderpad, wijting, tong, steenbolk, schol, schar, puitaal, haring, grondels en bot. Deze omvatten meer dan 94\% van het totale gemiddelde aantal en biomassa voor de vangsten met de boomkor (Bijlage 53). Soorten die niet in alle jaren tot op soort zijn gedetermineerd zijn samengevoegd. Dit geldt voor zandspieringen, koornaarvissen, grondels en voor zeenaalden die niet met zekerheid als grote zeenaald zijn gedetermineerd. De Chinese wolhandkrab is alleen in 2018 drie keer met de boomkor in de Oosterschelde gevangen.

Grondels en schol zijn de dominante soorten in de boomkorvangsten, zowel qua aantal als qua biomassa (Figuur 2.145). Wat direct opvalt is het hoge aantal en biomassa van schol in 1988. Verder laten sommige soorten ondanks wat fluctuaties een relatief stabiele trend zien terwijl andere soorten een afname laten zien sinds het einde van de jaren 80 (schol, schar, tong). Daarnaast is er sinds 2006 over de gehele linie minder vis gevangen dan voorheen. Eén van de oorzaken is de achteruitgang van standaard kinderkamersoorten (bv. schol, schar, tong, bot) en het kleiner worden van soorten als schol en schar (Mulder et al. 2020). Vergelijkbare afnemende trends vanaf midden jaren 1980 zijn waarneembaar in de Waddenzee, en langs de Noordzee-, Wadden en Voordeltakust (Tulp 2015). Het feit dat een soortgelijke trend waarneembaar is in deze gebieden, die een vergelijkbare kinderkamer functie hebben als de Oosterschelde, wijst er mogelijk op dat niet alleen lokale factoren (bijvoorbeeld voedselaanbod) de oorzaak kunnen zijn van de afname van visbiomassa en dichtheden, maar dat ook andere factoren zoals de stijging van de watertemperatuur door klimaatverandering mogelijk invloed kunnen hebben (Teal et al. 2012; Tulp 2015).

Net als in het Veerse Meer, Grevelingenmeer en het Haringvliet is er een toename van haring te zien in 2019 (t.o.v. de voorgaande twee jaren). In 2019 is de witte koolvis voor het eerst in de Oosterschelde gevangen. 


\section{Oosterschelde open water}
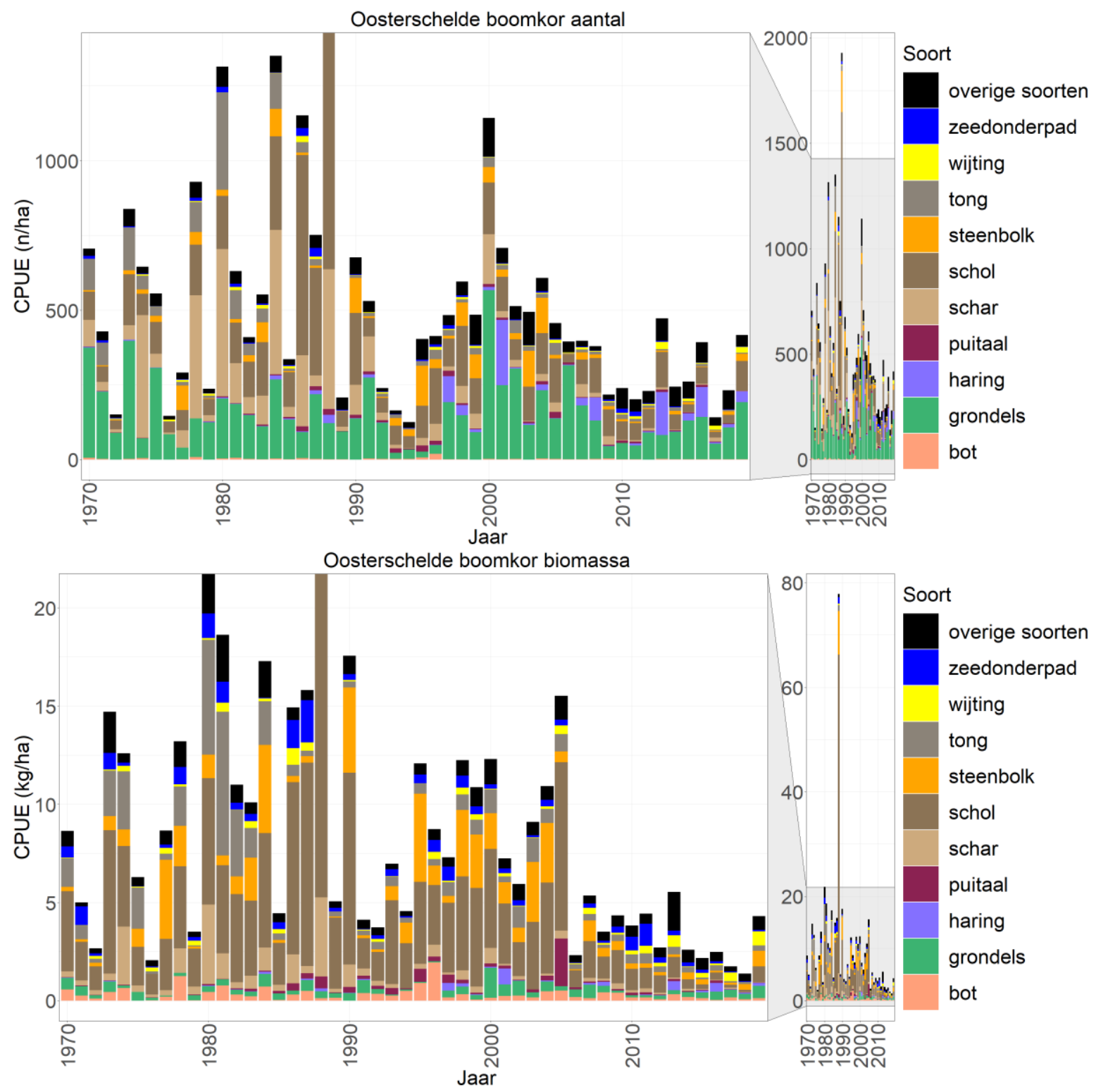

Figuur 2.145 Gemiddelde CPUE van de tien meest algemene soorten en overige soorten in het open water gevangen met een boomkor ( $\mathrm{n} / \mathrm{ha}-\mathrm{kg} / \mathrm{ha})$ in de Oosterschelde tijdens de monitoring van 19702019. 


\subsubsection{Aalvangsten}

Voor de aanlandingen van KRW-lichaam Oosterschelde zijn de gegevens van de "Oosterschelde" gebruikt (Bijlage 2). De aanlandingen fluctueren sterk en worden soms gedomineerd door vangsten met hokfuiken en soms door vangsten met schietfuiken (Figuur 2.146). Wat opvalt is de relatief hoge inspanningen met aalkubben/aalkuilen/peur, maar ook de hoge opbrengst van hokfuiken en schietfuiken met een relatief lage inspanning in 2017 en 2018 (Figuur 2.147).

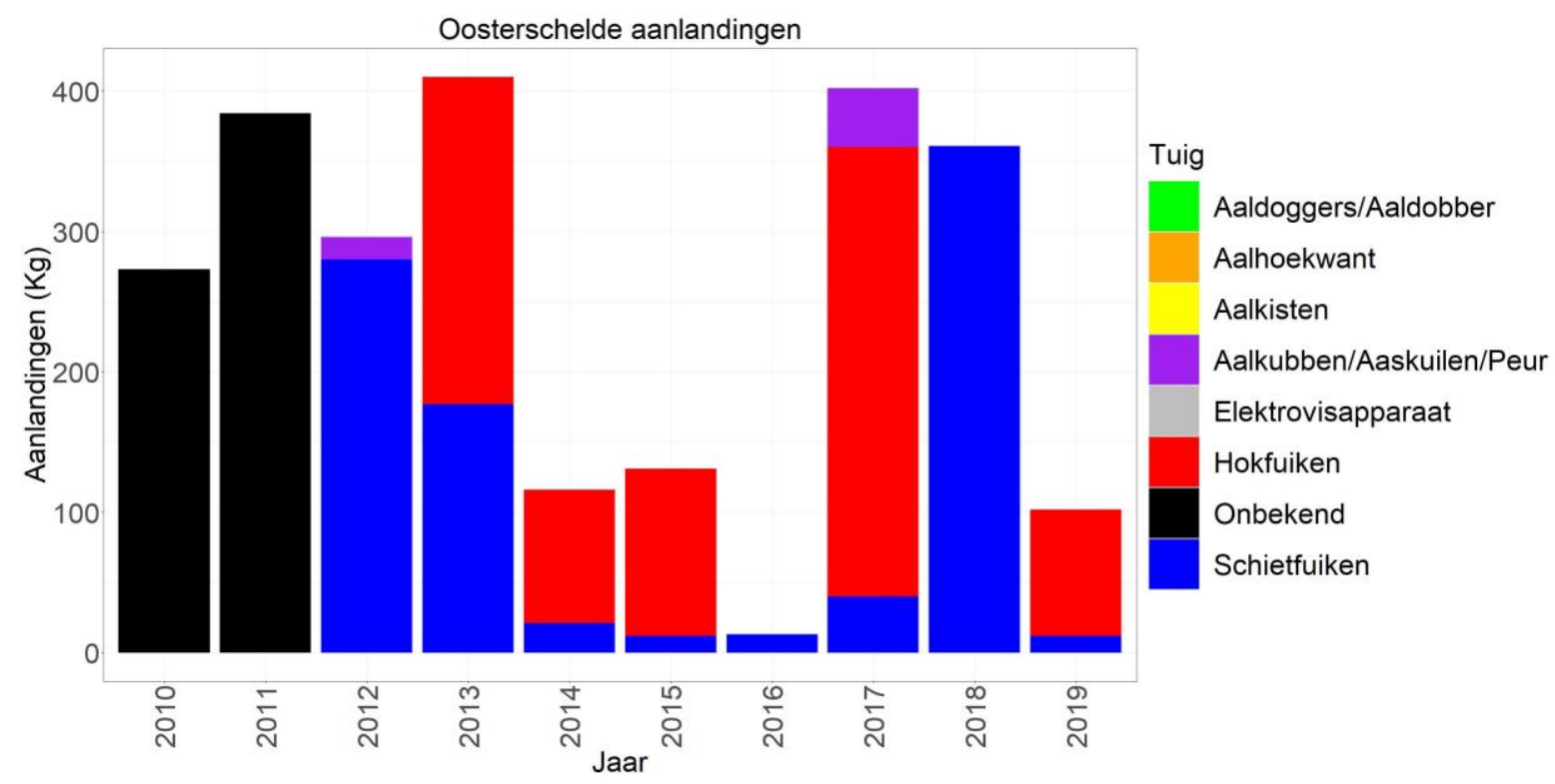

Figuur 2.146 Aanlandingen $(\mathrm{kg})$ van de beroepsvisserij per tuig in de Oosterschelde. Sinds 2012 zijn aalvissers verplicht de inspanning van het vistuig op te geven aan het ministerie van LNV.

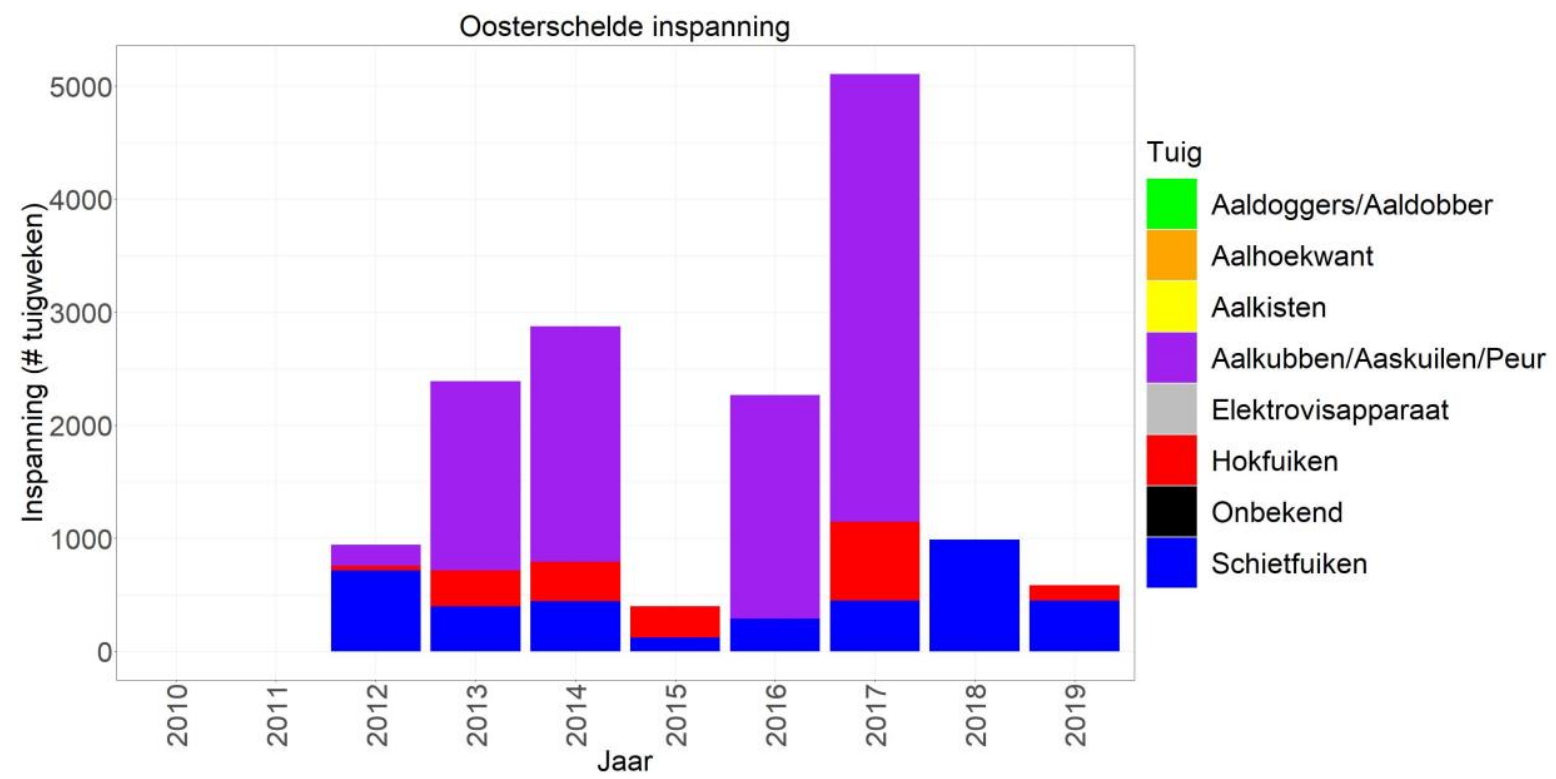

Figuur 2.147 Inspanning (aantal tuigweken) van de beroepsvisserij per tuig in de Oosterschelde. 


\subsection{Westerschelde}

\subsubsection{Ankerkuil}

De bemonsteringslocaties met de ankerkuil over de periode 2008-2019 zijn weergegeven in Figuur 2.148 .

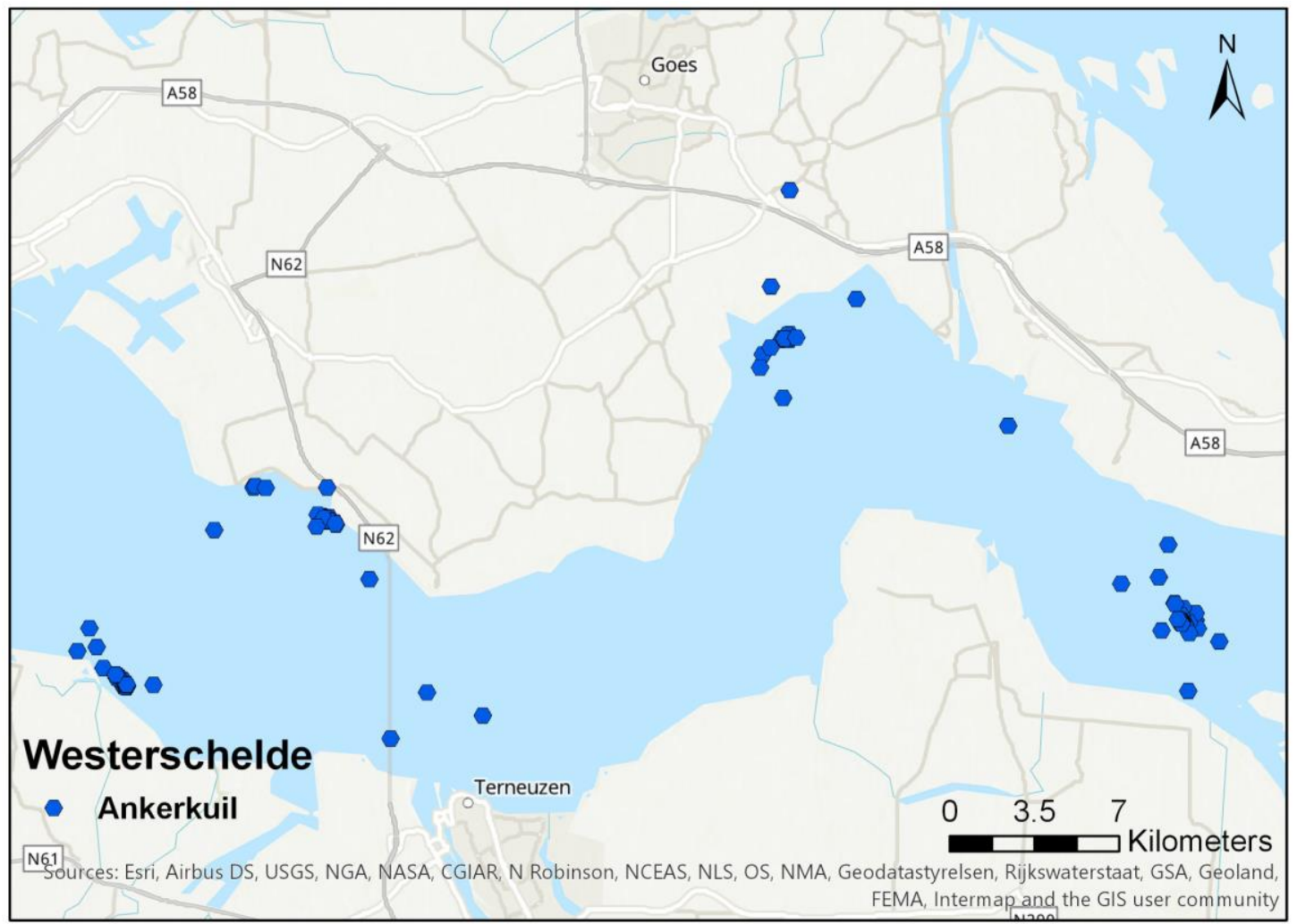

Figuur 2.148 Bemonsteringslocaties van de ankerkuil bemonstering in de Westerschelde in de periode 2008-2019 per tuig.

De Westerschelde wordt sinds 2007 ieder jaar in het najaar (meestal september) en het voorjaar (meestal mei) met de ankerkuil bemonsterd. Om een beeld te krijgen van de veranderingen per cohort is besloten om bemonsteringen van het najaar te combineren met de bemonstering van het daaropvolgende voorjaar. Zo worden bijvoorbeeld vangsten uit het najaar van 2007 en het voorjaar van 2008 samengevoegd, en als 2008 in de figuur weergegeven.

De aantallen/biomassa per trek zijn omgerekend naar aantallen per $80 \mathrm{~m}^{2}$ passagevlak per visuur. Dat is ook de standaardwaarde die gebruikt wordt ten behoeve van rapportage voor de Kaderrichtlijn Water. De hoeveelheid passerend water wordt berekend door aan de hand van de gemiddelde nethoogte (waterdiepte) en de netbreedte ( 8 meter) het passage vlak te berekenen en daarnaast nog met een standaard stroommeter de horizontale waterpassage te bepalen. Hierdoor kan het totaal gepasseerde volume water worden berekend (De Boois \& Couperus 2019).

In de periode 2007-2011 werden er maar twee van de vier stations bemonsterd (nabij de Schaar van Valkenisse/Plaat van Walsoorden en het vaarwater bij de Paulinapolder). Vanaf 2012 zijn er vier locaties bemonsterd (naast bovengenoemde, Brouwersplaat/Middelgat en het Gaatje bij Borssele). In 2010 is er niet bemonsterd.

De tien meest algemene soorten in de Westerschelde voor de gehele periode 2008-2019 zijn:

zeebaars, kleine zandspiering, wijting, sprot, spiering, pelsers, kleine zeenaald, haring, grondels indet. en clupeidae. Deze omvatten meer dan $99 \%$ van het totale gemiddelde aantal en biomassa voor de vangsten met de ankerkuil (Bijlage 54). Soorten die niet in alle jaren tot op de soort zijn gedetermineerd zijn samengevoegd. Dit geldt voor zandspiering, koornaarvissen, grondels en voor zeenaalden die niet met zekerheid als grote zeenaald zijn gedetermineerd. Met 'clupeidae' worden kleine haring/sprotachtigen bedoeld, die nog net in het larvale stadium zaten of al wel uit het larvale stadium waren maar te klein waren om aan boord tot op de soort te kunnen worden gedetermineerd. 
In het open water zijn de clupeidae en haring de dominante soorten in de ankerkuilvangsten, zowel qua aantal als qua biomassa (Figuur 2.149). Wat direct opvalt is het enorm hoge aantal en biomassa van de clupeidae en haring in 2008. De laatste jaren lijkt er een toename te zijn van soorten zoals sprot. Pelser is de enige soort die niet in andere top-tien-lijstjes van algemene soorten in de bemonsterde KRW-lichamen voorkomen. In 2019 zijn de zwartbekgrondel, Noorse zandspiering en zonnevis voor het eerst met ankerkuil in de Westerschelde gevangen. De vangsten van het najaar van 2019 zijn weergegeven als zijnde die van 2020 en zijn nog niet volledig (de vangsten van het voorjaar van 2020 moeten hier nog bij komen) en worden om die reden alleen getoond en niet besproken. 


\section{Westerschelde open water}

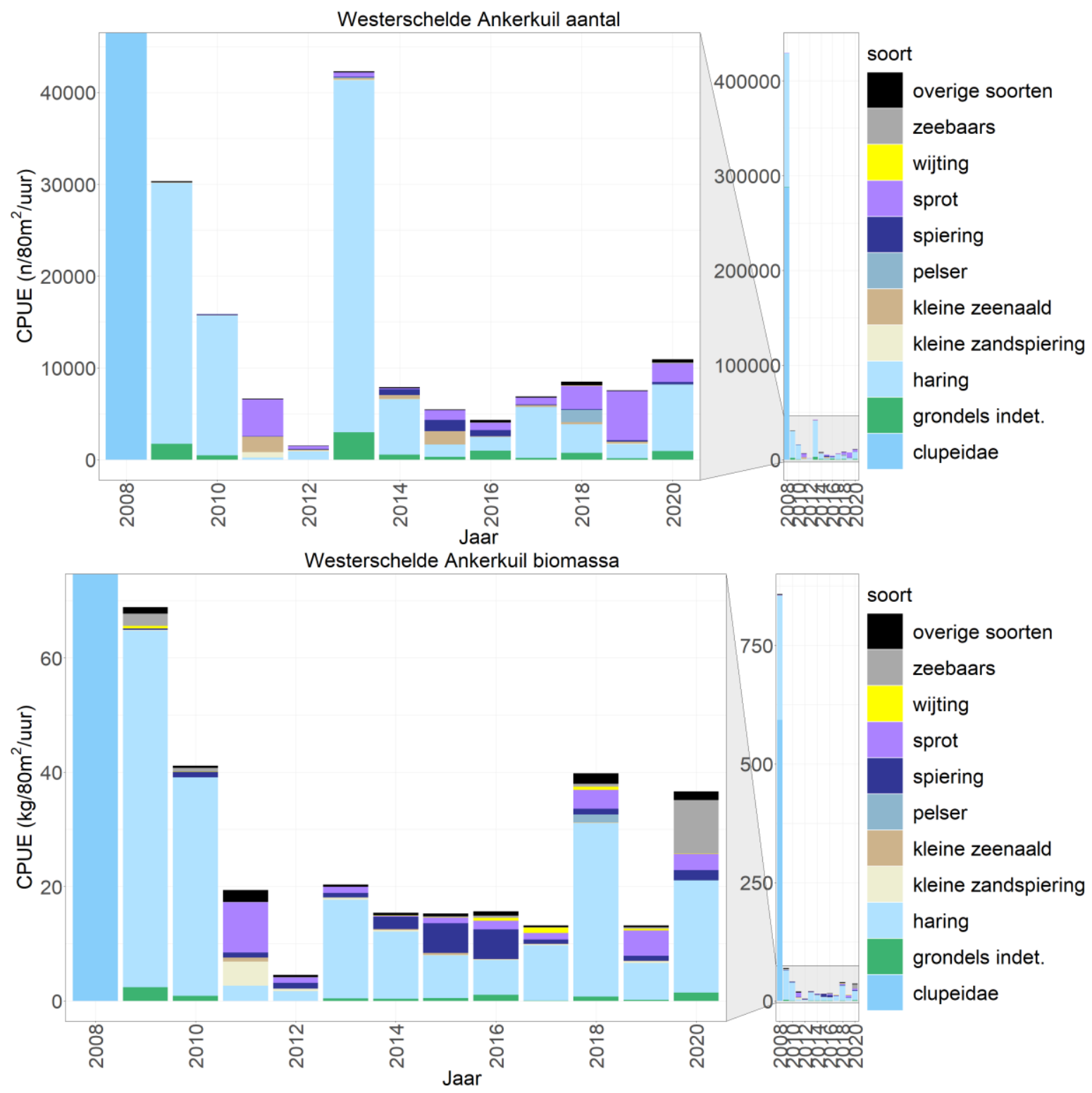

Figuur 2.149 Gemiddelde CPUE van de tien meest algemene soorten en overige soorten in het open water gevangen met een ankerkuil (n/80 $\mathrm{m}^{2} / \mathrm{uur}-\mathrm{kg} / 80 \mathrm{~m}^{2} / \mathrm{uur}$ ) in de Westerschelde tijdens de monitoring van 2008-2019. In 2010 is er niet bemonsterd, de gegevens die hier gepresenteerd zijn als zijnde 2010 komen uit het najaar van 2009 en het voorjaar van 2011, die van 2020 zijn van het najaar van 2019 en zijn daardoor niet direct vergelijkbaar met andere jaren. 


\subsubsection{DFS}

De bemonsteringslocaties met de boomkor over de periode 1970-2019 zijn weergegeven in Figuur 2.150 .

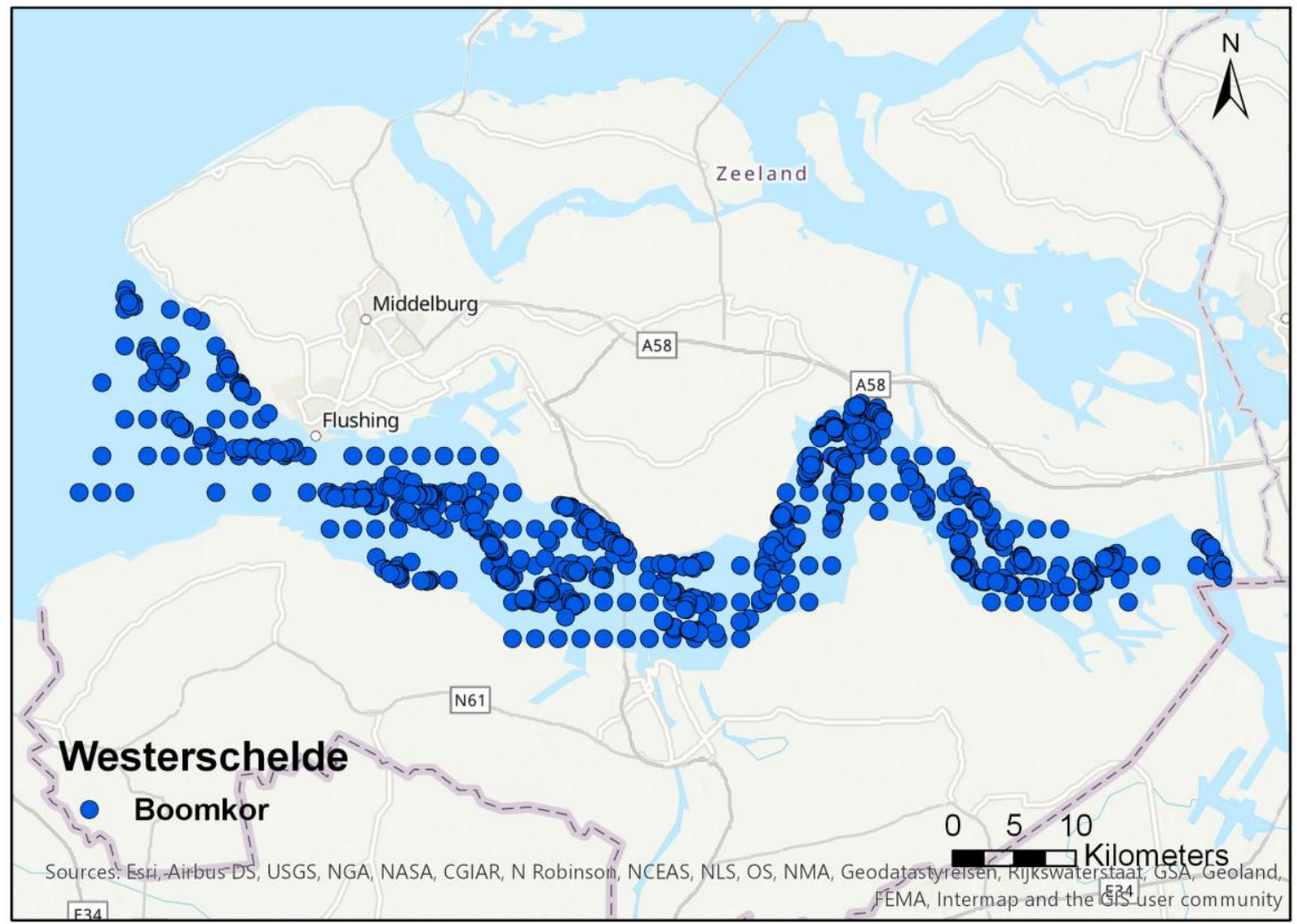

Figuur 2.150 Bemonsteringslocaties met de boomkor in de Westerschelde in de periode 1970-2019 per tuig.

De Westerschelde wordt sinds 1970 ieder najaar bemonsterd met de boomkor. Van 1970-1989 in september en/of oktober en vanaf 1990 in september (in 2000 en 2015 deels ook in augustus). Net als in de Oosterschelde is er een selectie gemaakt van bemonsteringen die alleen in het water van de Westerschelde liggen, hierdoor zijn sommige bemonsteringen waarvan de coördinaten abusievelijk op het land liggen ook van de analyse uitgesloten. Deze selectie heeft geen effect gehad op de selectie van de tien meest voorkomende soorten en lijkt maar een geringe invloed te hebben op de trends.

De tien meest algemene soorten in de Westerschelde voor de gehele periode 1970-2019 zijn: zeebaars, tong, steenbolk, sprot, spiering, schol, schar, haring, grondels en bot. Deze omvatten meer dan $90 \%$ van het totale gemiddelde aantal en biomassa voor de vangsten met de boomkor (Bijlage 55). Soorten die niet in alle jaren tot op de soort zijn gedetermineerd zijn samengevoegd. Dit geldt voor zandspieringen, koornaarvissen, grondels en voor zeenaalden die niet met zekerheid als grote zeenaald zijn gedetermineerd.

Net als in de Oosterschelde zijn grondels de dominante soort qua aantal (Figuur 2.151). Voor biomassa zijn dat bot en schol. Over het algemeen vertonen de meeste soorten een stabiele trend. Wat opvalt is dat er sinds 2000 consistent veel haring wordt gevangen en dit geldt voor bot vanaf 2007. Steenbolk lijkt sinds 2008 veel minder vaak te worden gevangen dan voorheen. Zeebaars lijkt de laatste jaren weer relatief goed gevangen te worden. In tegenstelling tot de Oosterschelde wordt er gemiddeld niet minder vis in totaal gevangen dan voorheen. 


\section{Westerschelde open water}

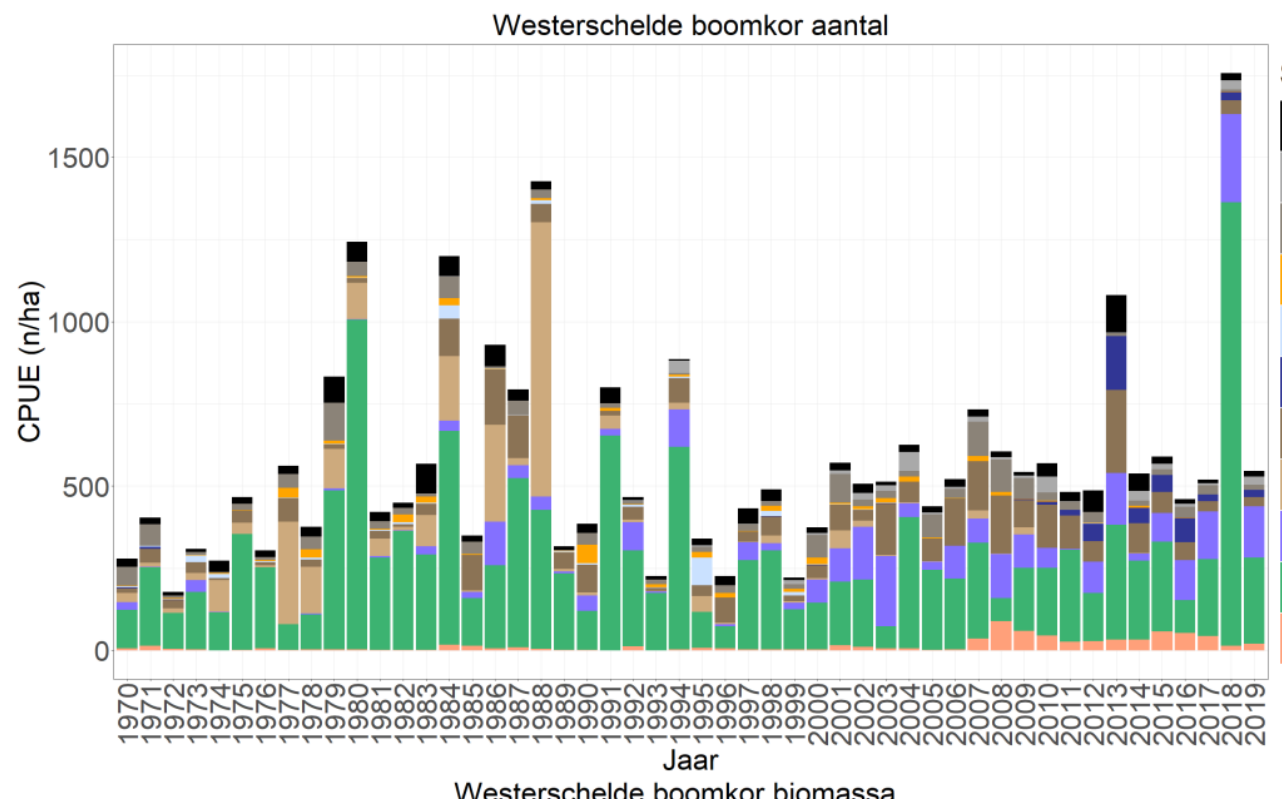

Soort

zeebaars

tong

steenbolk

sprot

spiering

schol

schar

haring

grondels

bot

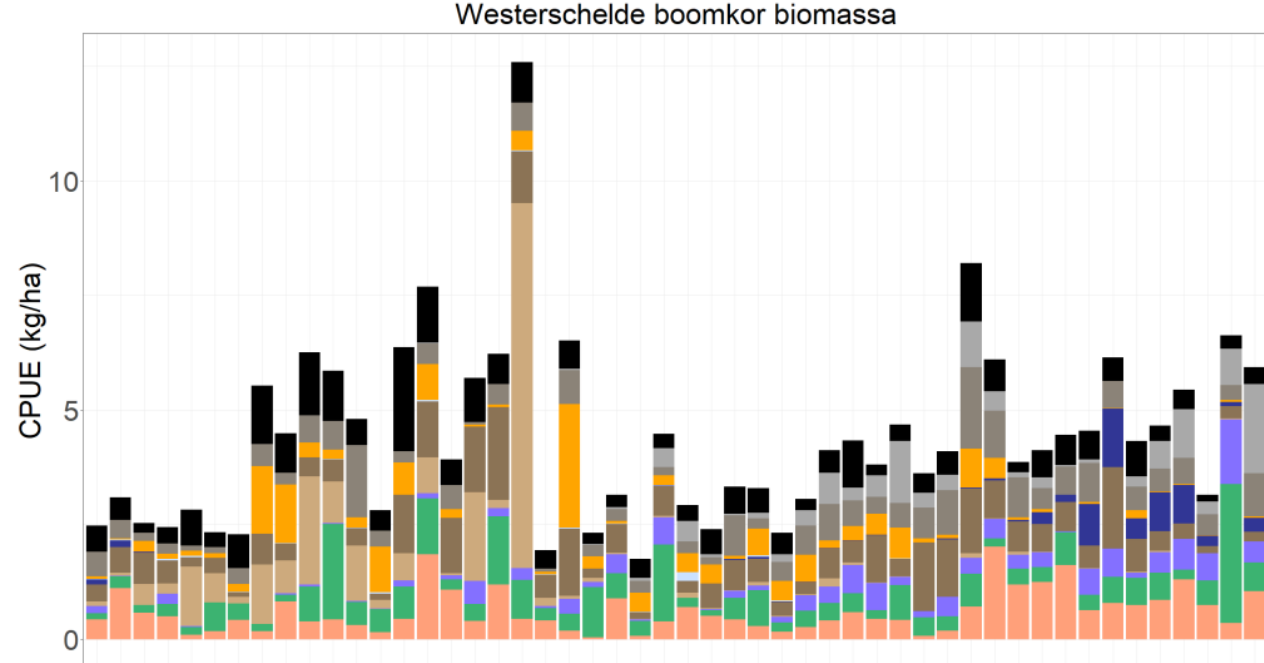

Soort

overige soorten

zeebaars

tong

steenbolk

sprot

spiering

schol

schar

haring

grondels

bot

0-NMthen Do-

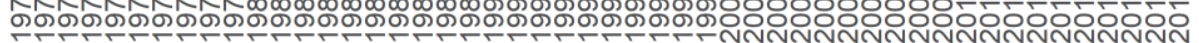

Jaar

Figuur 2.151 Gemiddelde CPUE van de tien meest algemene soorten en overige soorten in het open water gevangen met een boomkor ( $\mathrm{n} / \mathrm{ha}-\mathrm{kg} / \mathrm{ha})$ in de Westerschelde tijdens de DFS-monitoring van 1970-2019. 


\subsubsection{Chinese wolhandkrab}

De Chinese wolhandkrab wordt met de ankerkuil sinds 2015 een enkele keer gevangen in het open water van de Westerschelde. De ankerkuil is geen geschikt tuig om deze soort te vangen, aangezien de ankerkuil de bodem niet altijd zal raken en het een passief tuig is wat maar enkele uren gebruikt wordt en dus voornamelijk vissen vangt die met het tij mee bewegen (Figuur 2.152).

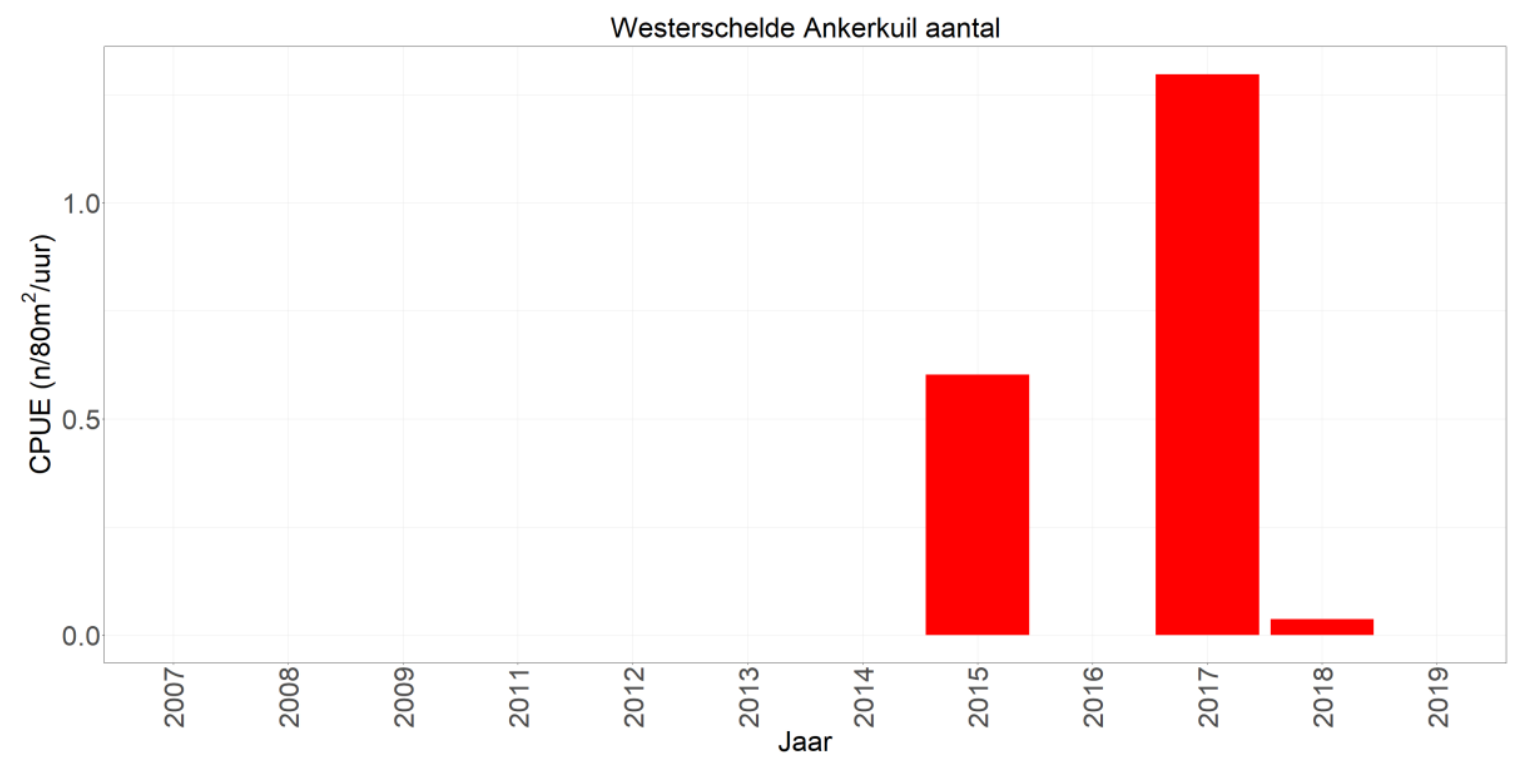

Figuur 2.152 Gemiddelde CPUE (n/80m²/uur) per jaar van de Chinese wolhandkrab in de Westerschelde gevangen met de ankerkuil.

De Chinese wolhandkrab wordt sinds 2002 regelmatig met de boomkor tijdens de DFS gevangen (Figuur 2.153). De aantallen lijken redelijk stabiel met een piek in 2015 en 2016 . Opvallend genoeg zijn dat jaren waarin de aantallen in de grote rivieren vaak erg laag waren.

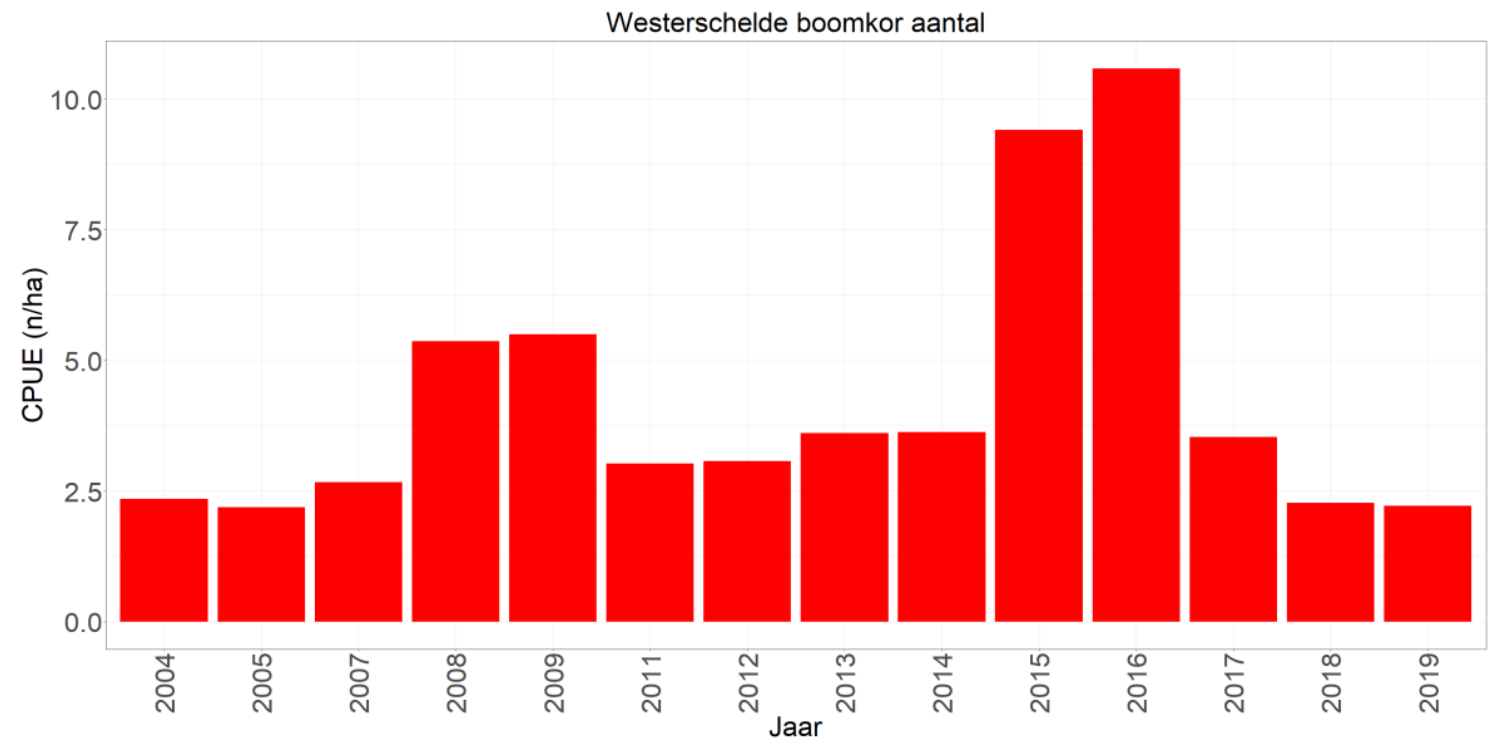

Figuur 2.153 Gemiddelde CPUE (n/ha bevist oppervlak) per jaar van de Chinese wolhandkrab in de Westerschelde gevangen met de boomkor.

\subsubsection{Aalvangsten}

Voor de aanlandingen van KRW-lichaam Westerschelde zijn de gegevens van de "Westerschelde" gebruikt (Bijlage 2). Er is vanuit de Westerschelde vanaf 2010 geen aal aangeland. 


\subsection{Eems-estuarium}

De bemonsteringslocaties over de periode 2007-2019 zijn weergegeven in Figuur 2.154.

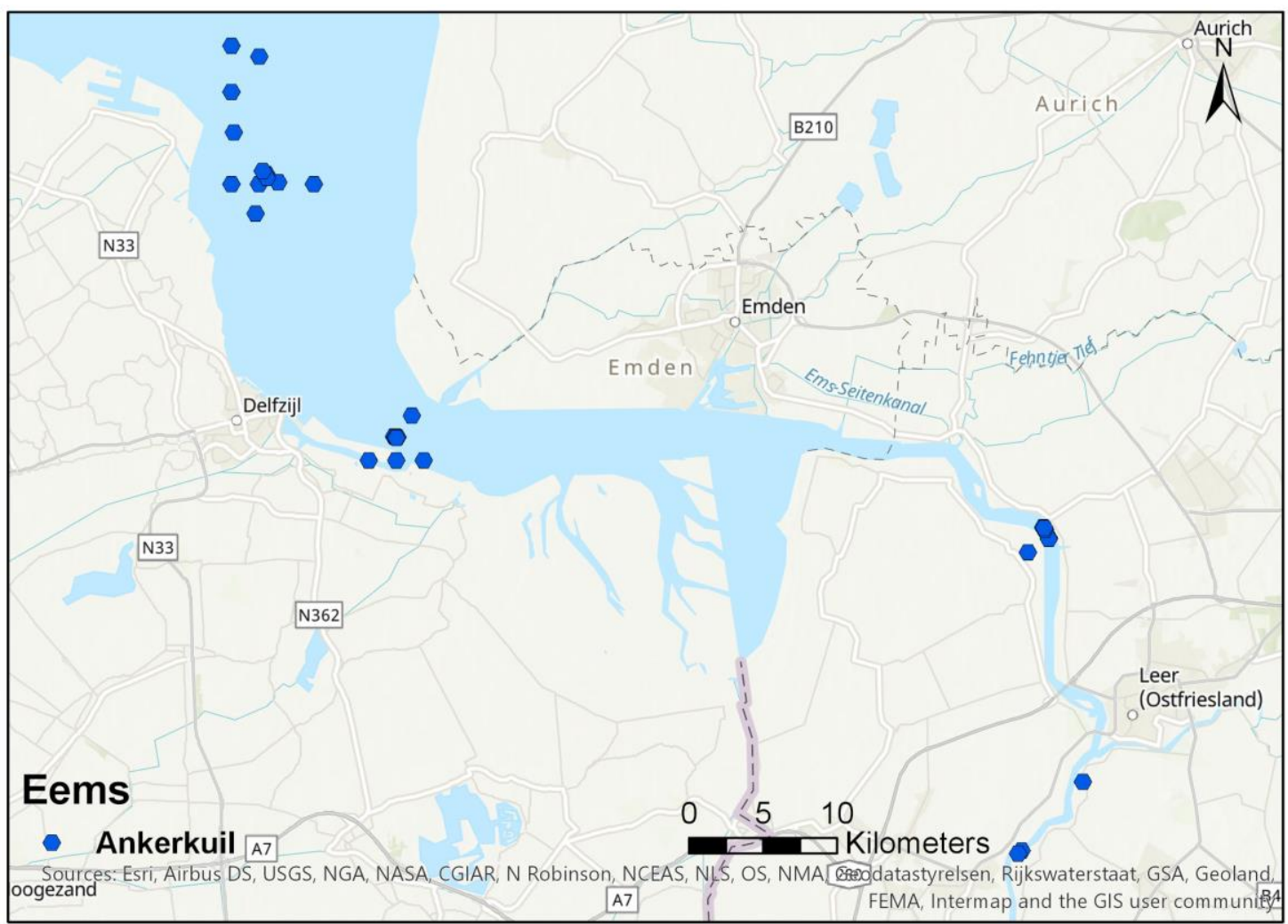

Figuur 2.154 Bemonsteringslocaties van de actieve monitoring in het Eems-estuarium in de periode 2007-2019 per tuig.

Net als de Westerschelde wordt het Eems-estuarium sinds 2007 ieder jaar in het voorjaar (mei) en het najaar (september) met de ankerkuil bemonsterd (zie Westerschelde, 2.31, voor verklaring eenheid ankerkuil). Om een beeld te krijgen van de veranderingen per cohort is ook hier besloten om bemonsteringen van het najaar te combineren met de bemonstering van het daaropvolgende voorjaar. Zo worden bijvoorbeeld vangsten uit het najaar van 2007 en het voorjaar van 2008 samengevoegd, en als 2008 in de figuur weergegeven. De data uit 2011 is met een ander tuig bemonsterd dan de andere jaren en kan daardoor wat afwijken. In 2012 en 2016 zijn er extra bemonsteringen stroomopwaarts, voorbij Leer (Ostfriesland), uitgevoerd, deze bemonsteringen zijn voor de analyse uit de dataset verwijderd.

De tien meest algemene soorten in het Eems-estuarium voor de gehele periode 2007-2019 zijn: wijting, sprot, spiering, kleine zeenaald, haring, dikkopje, fint, brakwatergrondel, bot en ansjovis. Deze omvatten meer dan 95\% van het totale gemiddelde aantal en biomassa voor de vangsten met de ankerkuil (Bijlage 56). Ten opzichte van de voorgaande rapportage (van Rijssel et al. 2019a) behoort de ansjovis tot de tien meest algemene soorten in plaats van de slakdolf. De Chinese wolhandkrab is niet met de ankerkuil in het Eems-estuarium gevangen.

De haring is de dominante soort in de ankerkuilvangsten, zowel qua aantal als qua biomassa (Figuur 2.155). Wat opvalt is de gestage toename van haring in de tijd met 2019 als hoogtepunt, iets wat we ook in andere waterlichamen zien. Andere soorten die regelmatig gevangen worden zijn wijting, grondels, spiering en brakwatergrondel. Ansjovis en fint zijn de enige soorten die niet in andere top tien lijstjes van algemene soorten in de bemonsterde KRW-lichamen voorkomen. De meeste soorten lijken relatief stabiel, met af en toe fluctuaties van jaar tot jaar. Er lijkt een lichte toename van het dikkopje (grondelsoort) te zien in de laatste jaren. Ook is de ansjovis de laatste twee jaar toegenomen, wellicht is dit een effect van toenemende reproductie van ansjovis in de Duitse bocht (voor het eerst sinds 50 jaar in de late 2000s, Heesen et al. 2015) en op overige plekken in het oostelijk deel van de Waddenzee. De noordelijke uitbreiding van het leef- en paaigebied van ansjovis zou een effect van klimaatverandering kunnen zijn volgens Kopetsch \& Scholle (2020). 


\section{Eems-estuarium open water}
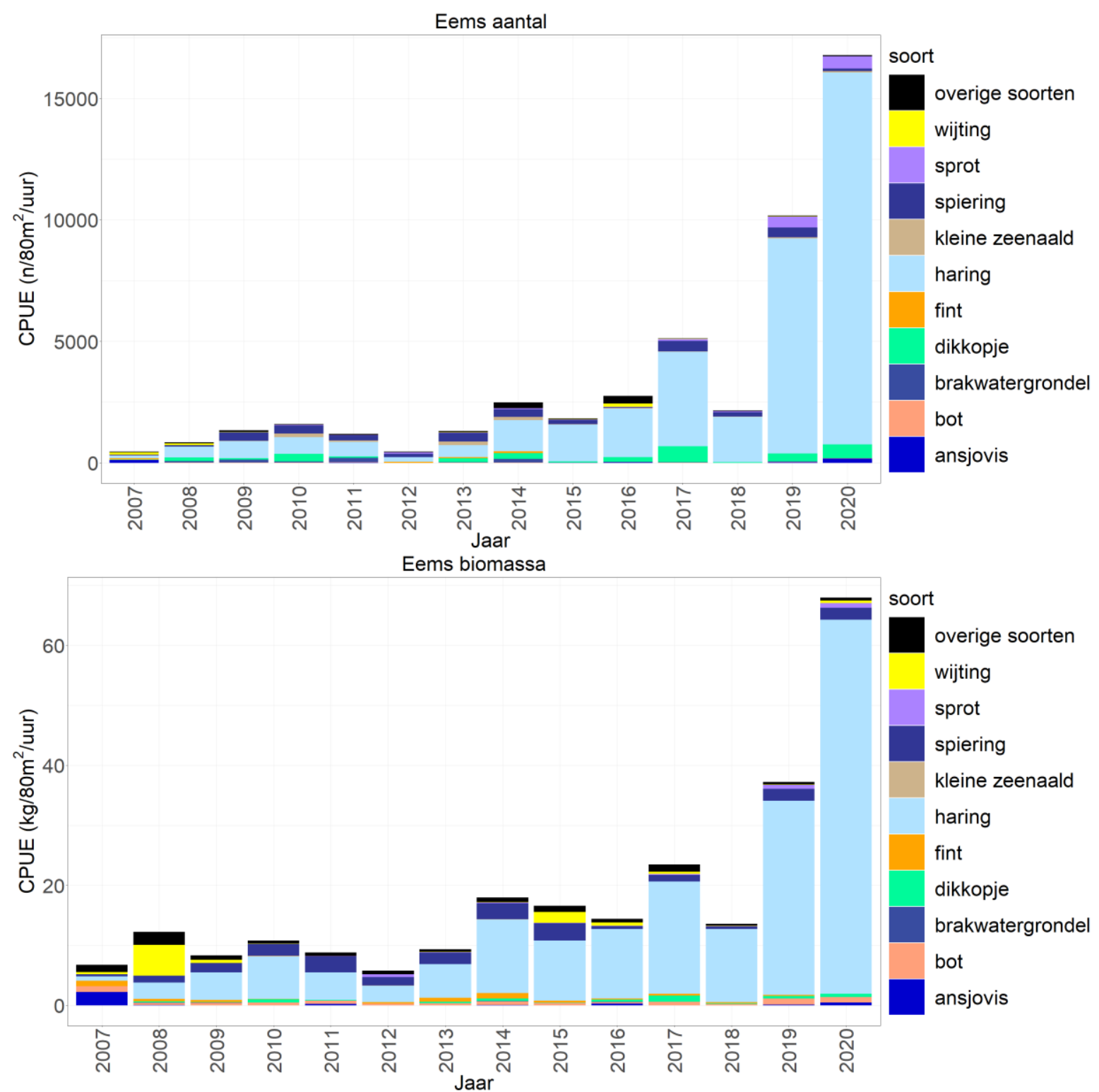

Figuur 2.155 Gemiddelde CPUE van de tien meest algemene soorten en overige soorten in het open water gevangen met een ankerkuil ( $\mathrm{n} / 80 \mathrm{~m}^{2} / \mathrm{uur}-\mathrm{kg} / 80 \mathrm{~m}^{2} / \mathrm{uur}$ ) in het Eems-estuarium tijdens de monitoring van 2007-2019. Data uit 2011 is met een ander tuig verzameld dan de overige jaren (de breedte van de kuil was $10 \mathrm{~m}$ in plaats van $13 \mathrm{~m}$ ). De gegevens van 2007 zijn alleen van het voorjaar van 2007, die van 2020 zijn van het najaar van 2019 en zijn daardoor niet direct vergelijkbaar met andere jaren. 


\subsubsection{Aalvangsten}

Voor de aanlandingen van KRW-lichaam Eems zijn de gegevens van de "Eems" gebruikt (Bijlage 2). Op relatief hoge vangsten met zowel hokfuiken als schietfuiken in 2012 na wordt er nauwelijks tot geen aal vanuit het Eems-estuarium aangeland (Figuur 2.156, Figuur 2.157).

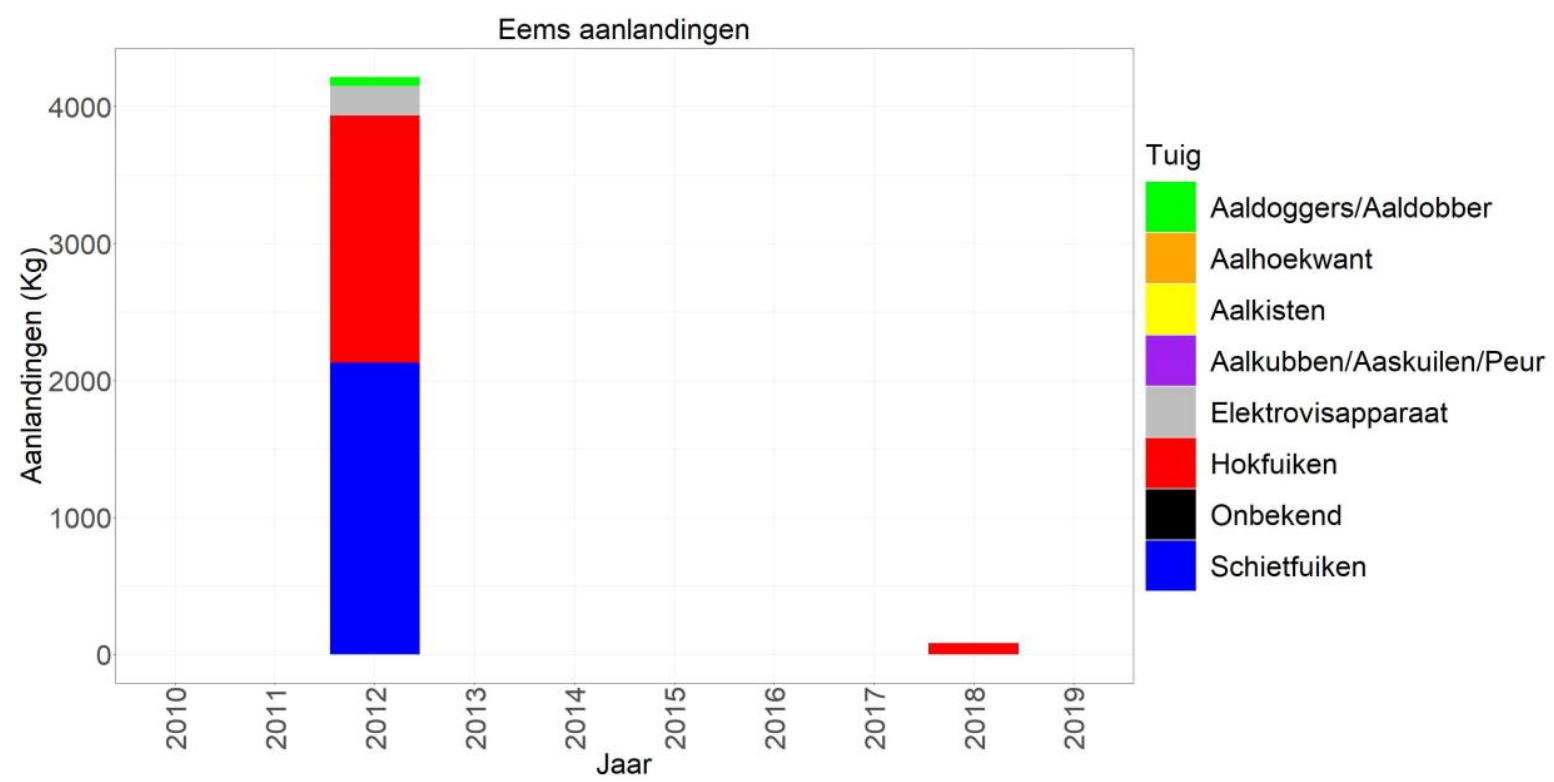

Figuur 2.156 Aanlandingen $(\mathrm{kg})$ van de beroepsvisserij per tuig in het Eems-estuarium. Sinds 2012 zijn aalvissers verplicht de inspanning van het vistuig op te geven aan het ministerie van LNV.

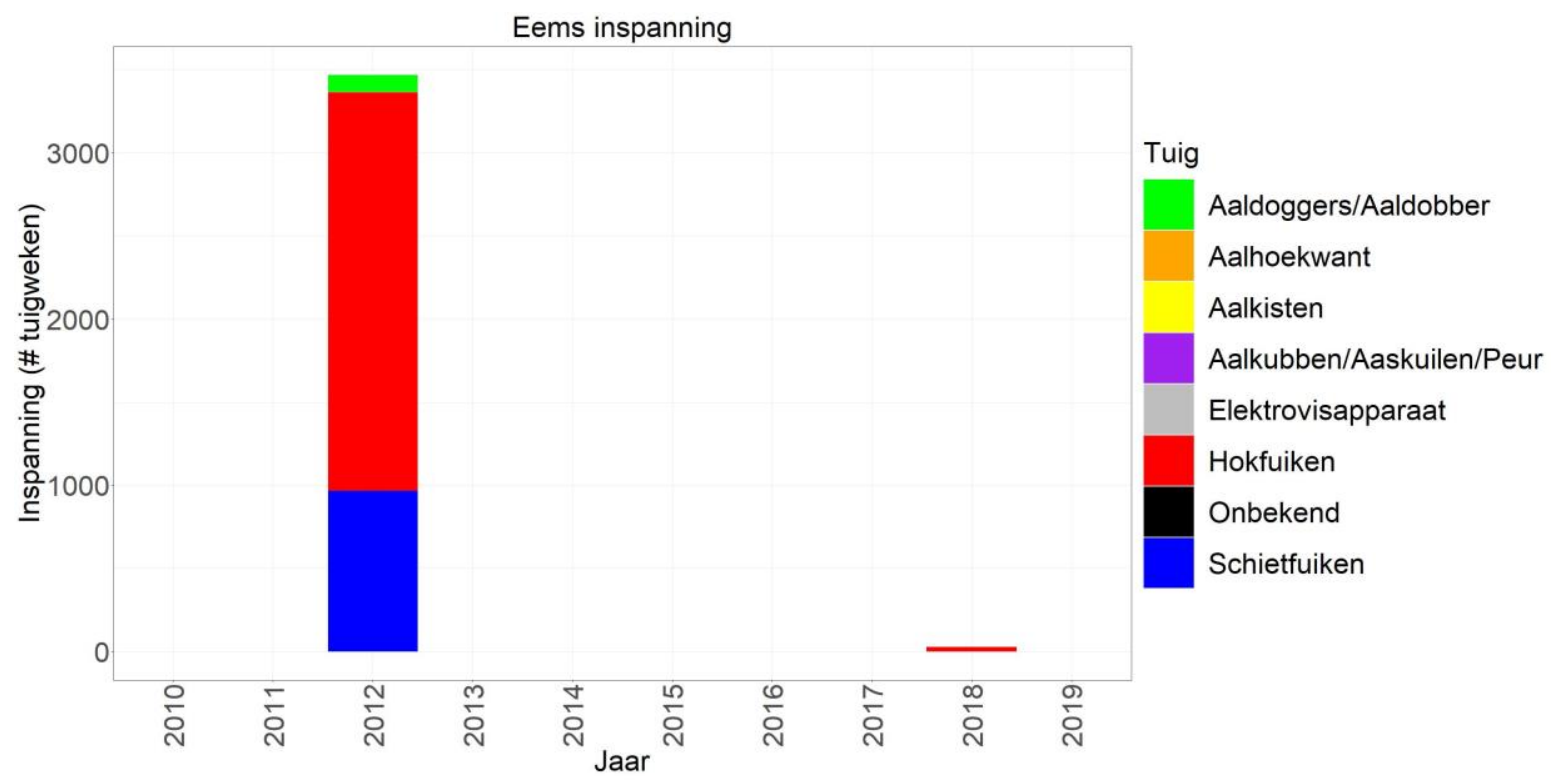

Figuur 2.157 Inspanning (aantal tuigweken) van de beroepsvisserij per tuig in het Eems-estuarium. 


\subsection{Vergelijking tussen overgangswateren}

In de overgangswateren is de soortensamenstelling vanwege het brakke en zoute water beduidend anders dan in de zoete Rijkswateren. Om een beeld te krijgen welke soorten er voornamelijk in de (zoute) overgangswateren voorkomen en hoe dit verschilt per KRW-lichaam is er een vergelijking gemaakt. Echter kunnen vangsten met verschillende tuigen niet met elkaar vergeleken worden. Daarom worden de overgangswateren die met de ankerkuil en de boomkor (DFS) bemonsterd worden met elkaar vergeleken, en de wateren die alleen met de boomkor bemonsterd worden (en binnen de actieve monitoring vallen).

Oosterschelde, Westerschelde, Eems-estuarium (bemonsterd met ankerkuil en/of boomkor) De totalen van de gevangen soorten in aantallen en biomassa zijn vergelijkbaar tussen de Oosterschelde, Westerschelde en het Eems-estuarium. In de ankerkuilbemonstering is haring zowel qua aantal als qua biomassa de meest dominante soort in de Westerschelde en het Eems-estuarium. In de Westerschelde lijkt haring een afnemende trend te vertonen op een piek in 2018 na, terwijl haring in het Eems-estuarium juist lijkt toe te nemen. Sprot en grondels worden in beide wateren ook relatief veel gevangen. Daarnaast komen wijting, spiering en de kleine zeenaald ook in de top tien van beide wateren voor. In de Westerschelde komen zandspiering, zeebaars en pelser ook in de top tien voor terwijl deze in de top tien van het Eems-estuarium ontbreken. In plaats daarvan komen fint en bot en ansjovis in de top tien van het Eems-estuarium voor.

Bij de bemonstering met de boomkor (DFS) zien we dat vangstsamenstelling grotendeels gelijk is voor de Ooster- en Westerschelde. Beide worden qua aantallen gedomineerd door grondels, qua biomassa lijkt de schol en belangrijke soort voor de Oosterschelde en bot voor de Westerschelde, vooral in de laatste 10 jaar. Verder komen in beide wateren tong, steenbolk, schar, haring dusdanig vaak voor dat ze in beide wateren tot de top tien meest algemene soorten behoren. Grote verschillen zijn dat in de Westerschelde spiering en zeebaars tot de top tien behoren en een belangrijk onderdeel van de biomassa vormen terwijl in de Oosterschelde wijting en in het recente verleden ook zeedonderpad en puitaal een belangrijk onderdeel van de biomassa vormden.

\section{Nieuwe waterweg, Noordzeekanaal (bemonsterd boomkor)}

Zowel de Nieuwe Waterweg als het Noordzeekanaal staan in directe verbinding met de zee. De grootste verschillen zijn dat de Nieuwe waterweg een water is dat al eeuwenlang van nature bestaat terwijl de afgraving van het Noordzeekanaal in 1876 is afgerond en met sluizen begrensd wordt terwijl de Nieuwe Waterweg een volledig vrije doorgang biedt. De bemonsteringspunten van de Nieuwe Waterweg reiken iets verder landinwaarts dan Maassluis terwijl die van het Noordzeekanaal vanaf de kust tot aan Amsterdam lopen. De verschillen tussen de wateren en de bemonsteringspunten zorgen ervoor dat de soortensamenstelling van de Nieuwe waterweg en het Noordzeekanaal sterk verschilt. In het Noordzeekanaal komen, naast zoutwatersoorten ook relatief veel zoetwatersoorten in de top tien meest algemene soorten voor (snoekbaars, baars, blankvoorn, brasem, kolblei, aal). De zoutwatersoorten in de top tien van het Noordzeekanaal (tong, bot, grondels) komen, op de haring/sprot na, ook in de top tien van de Nieuwe Waterweg voor. Qua totalen in biomassa en aantal lijkt er meer in het Noordzeekanaal gevangen te worden dan in de Nieuwe Waterweg. In de Nieuwe Waterweg komen geen zoetwatersoorten in de top tien voor, naast de drie bovengenoemde zoutwatersoorten vinden we wijting, spiering, schar, schol, kabeljauw, steenbolk en zeedonderpad in de top tien. Van deze zeven soorten komt alleen kabeljauw niet voor in de top tien van de Eems en de Ooster- en Westerschelde.

\section{Grevelingenmeer (bemonsterd met de boomkor)}

Het Grevelingenmeer is een voormalige zeearm van de Noordzee die sinds 1971 van de zee afgesloten is door de bouw van de Brouwersdam. Het meer wordt sinds 2008 elke drie jaar bemonsterd. Net als in de Eems en de Ooster-/Westerschelde (en deels ook het Noordzeekanaal) zijn de haring/sprot en de grondels zowel qua aantallen als qua biomassa de dominante soorten. Vooral de grondels zijn erg dominant, alhoewel dit qua biomassa niet altijd het geval is geweest. In 2008 werden er voornamelijk veel platvissoorten gevangen wat nu niet meer het geval is. In een uitgebreide analyse van de historische en huidige visstand van het Grevelingenmeer bleek dat het sluisbeleid erg bepalend lijkt te zijn geweest voor de visstand in het Grevelingenmeer (Tangelder et al. 2019). De platvissenpopulatie 
lijkt erg sterk afhankelijk te zijn van de intrek van larven in het voorjaar, aangezien de platvissen zich niet voortplanten in het Grevelingenmeer. Wellicht dat de verandering in vangstsamenstelling ook te maken heeft met de veranderingen die afgelopen decennia in het Grevelingenmeer hebben plaatsgevonden i.v.m. de afsluiting ervan (zoals toename zuurstofloze gebieden). Voornamelijk in de zomerperiode is het diepere gedeelte van het meer zuurstofloos. Pelagische soorten (haring/sprot) en soorten die veel in het ondiepe deel van het meer voorkomen, zoals grondels, (de Graaf, 1979, Tangelder et al. 2019) zullen minder last hebben van deze zuurstofloze laag en daardoor mogelijk succesvol(ler) zijn (dan andere soorten). 


\subsection{Discussie en conclusies}

In de voorgaande paragrafen zijn er per KRW-lichaam de trends van de meest algemene vissoorten beschreven. Alhoewel ieder KRW-lichaam apart is geanalyseerd, zijn er vergelijkbare patronen in trends te zien, die in meerdere KRW-lichamen voorkomen en wellicht dus ook een gemeenschappelijk oorzaak hebben. Hieronder worden deze patronen in de visstand in de Rijkswateren van Nederland bediscussieerd.

\section{Afname cypriniden en andere benthische soorten}

In veel waterlichamen is te zien dat er in de periode 2009-2012 een sterke afname is van de cypriniden (brasem, kolblei, blankvoorn). Aan de andere kant zijn er ook enkele KRW-lichamen die een lichte toename van deze soorten vertonen. De redenen voor zowel de toe- als afname zijn nog onduidelijk. Aangezien de afname van deze cypriniden meerdere KRW-lichamen betreft en veelal in dezelfde periodes plaatsvindt is het waarschijnlijk dat er een gemeenschappelijke oorzaak is voor de afname. Op dit moment kunnen we alleen speculeren over mogelijke oorzaken.

Eén van deze mogelijke oorzaken zou een gebrek aan voedsel kunnen zijn. Zowel het IJsselmeer als de grote rivieren vertonen een afname van nutriënten in de periode 1990-2010 (van Puijenbroek et al. 2014). Bij een afname van nutriënten neemt de groei van autotrofe organismen zoals planten, algen en organismen vaak ook af. Daarnaast kan er ook een verschuiving zijn in het voorkomen van autotrofe organismen door de afname van nutriënten, waarbij bepaalde soorten afnemen en andere juist toenemen. Een afname in groei of een verschuiving van het voorkomen van autotrofe organismen kan een groot effect hebben op zoöplankton en bodemfauna en daardoor op vissoorten die op deze organismen foerageren. Het is mogelijk dat het bovenstaande ervoor gezorgd heeft dat bovengenoemde cypriniden zo sterk zijn afgenomen de laatste jaren. Daarnaast zou er ook door de afname van nutriënten en chlorofyl-a (RIVM 2017) competitie tussen cypriniden en baarsachtigen zijn ontstaan waarbij de baarzen in het voordeel zouden kunnen zijn (zie hoofdstuk 6.29).

Een andere mogelijkheid zou kunnen zijn dat de toename van invasieve soorten (bijvoorbeeld de zwartbekgrondel) rond die periode (2010-2012) voor een afname gezorgd heeft. In veel KRWlichamen is er een toename van invasieve grondelsoorten, waarbij er vaak direct een afname te zien is van andere bentische soorten zoals de pos of de rivierdonderpad. Van Kessel et al. (2013, 2014, 2016) hebben aan de hand van experimenten en observaties (vangstgegevens) onderzoek gedaan om te kijken of de opkomst van de invasieve grondels de reden is geweest voor de afname van de rivierdonderpad en het bermpje, wat inderdaad in veel gevallen zo leek te zijn (zie hoofdstuk 2.8.1). Dit zou onder andere kunnen komen door competitie voor schuil- en ei-afzetplaatsen en/of voedsel, territoriaal gedrag en/of predatie van eieren. Competitie voor schuil- en ei-afzetplaatsen wordt door van Kessel et al. (2013) als zeer aannemelijk beschouwd, vanwege de zeer hoge dichtheid van zwartbekgrondels die binnen een jaar bereikt kan worden, wat duidt op een snelle reproductie en mogelijk ook snelle lichaamsgroei. Het is nog onduidelijk of de toename van de invasieve grondels ook tot competitie (voor voedsel, habitat) heeft geleid met andere bentische soorten zoals de cypriniden. In de KRW-lichamen zien we dat voornamelijk de zwartbekgrondel in de periode 2009-2012 toeneemt, en met name langs de oevers. Het zou goed mogelijk kunnen zijn dat de cypriniden, die paaien in ondiepe gedeeltes en hun eieren afzetten op waterplanten of meer vaste substraten als stenen en beschoeiingen langs de oevers, moeten concurreren met de zwartbekgrondel. Hoewel de predatie van eieren door de zwartbekgrondel mogelijk een goede verklaring zou zijn voor de afname van inheemse soorten, blijkt er uit een studie in Tsjechië dat zowel de zwartbekgrondel als de marmergrondel nauwelijks viseieren of larven opnemen in hun dieet (Vasek et al. 2014). Aan de andere kant bleek uit twee recente studies (Verstijnen et al. 2019, Juza et al. 2018) dat het dieet van de zwartbekgrondel in de Biesboschspaarbekkens grotendeels uit vlokreeften (32-59\%) maar ook voor 9-15\% uit vislarven bestaat. Het is onduidelijk om welke soorten vislarven dit gaat en of zulke percentages een (groot) effect hebben op vispopulaties. Het zou interessant zijn het dieet van de zwartbekgrondel in andere KRW-lichamen te onderzoeken gedurende verschillende seizoenen.

Een derde oorzaak zou de visserij kunnen zijn. Alhoewel de fuikenvisserij op aal op de grote rivieren sinds 2011 gesloten is vanwege te hoge dioxinegehaltes in aal, mag de visserij op schubvissoorten 
met staandwant en zegen op de rivieren nog plaatsvinden. Het is mogelijk dat door de sluiting van de fuikenvisserij meerdere vissers zijn overgestapt naar de staandwant- en/of zegenvisserij, en de intensiteit hiervan dus is toegenomen. Dit zou een afname van cypriniden-soorten ook kunnen verklaren, hoewel hier tot nog toe geen directe aanwijzingen voor zijn. Daarnaast lijkt het aantal vissers dat met staandwant/zegen op de rivieren vist gering te zijn (van Rijssel et al. 2019b) desalniettemin kan een gering aantal vissers grote hoeveelheden vis vangen. Een voorbeeld hiervan is de zegenvisserij op het IJsselmeer waarbij een gering aantal vissers in zeven dagen verspreid over de winter vele tientallen tonnen vis (brasem) kan vangen (Tien et al. 2020). Aangezien er op het IJssel/Markermeer jaarlijks honderden tonnen cypriniden wordt gevangen is een effect van de visserij in deze KRW-lichamen ook niet uit te sluiten.

Een vierde oorzaak van een afname van rheofiele soorten zoals barbeel is wellicht te vinden in het dichtslibben van verschillende nevengeulen langs de grote rivieren (zie 3.2.3). Deze nevengeulen kunnen als kraamkamer dienen en door het dichtslibben neemt de stroming sterk af wat voor een afname van stroomminnende soort geleid kan hebben (Stoffers et al. 2020)

\section{Toe- en afnames andere soorten}

Alhoewel het er in 2017 en 2018 op leek dat de zwartbekgrondel wellicht op zijn retour was, werd deze invasieve exoot in 2019 in veel KRW-lichamen weer meer gevangen en domineerde in sommige wateren zowel de aantallen als de biomassa. Aal werd in de meeste wateren in 2019 weer wat minder gevangen dan in de jaren ervoor, in slechts een klein aantal wateren was er sprake van een toename (zowel in aantal als biomassa). De aanlandingen van aal lijken in voor aalvisserij belangrijke KRWlichamen te zijn toegenomen (bijv. IJsselmeer, Markermeer, Randmeren), terwijl er in deze wateren geen duidelijk stijging van aal blijkt uit de verschillende monitoringen.

De monitoring van wolhandkrabben wordt voor het eerst besproken in deze rapportage. Over het algemeen lijkt er de laatste paar jaar een toename van het aantal wolhandkrabben te zijn met 2019 vaak als hoogtepunt, vooral in de benedenrivieren, ondanks dat een aantal vissers actief op deze soort vist. In het IJsselmeer lijkt er daarentegen de laatste paar jaren een afname van wolhandkrabben te zijn. In dit KRW-lichaam wordt ook actief op wolhandkrabben gevist.

\section{Aanbevelingen}

Dit rapport geeft een overzicht van de visstand per KRW-lichaam, waarbij de trends van de meest algemene soorten in kaart wordt gebracht. De oorzaken van de toe/-afnames van deze soorten zijn echter vaak nog onduidelijk, waardoor de trends soms moeilijk te duiden zijn en slechts speculatieve suggesties gedaan kunnen worden. Een aantal van deze suggesties zou onderzocht kunnen worden, zoals het dieet van de meerval in de Grensmaas om te bepalen of deze mede verantwoordelijk is voor de afname van barbeel. Zo is het ook aan te bevelen om het dieet van de invasieve grondels tijdens het broedseizoen te bestuderen, om te bepalen of deze daadwerkelijk (veel) visseneitjes eten wat een mogelijke verklaring is voor de achteruitgang van de cypriniden. Verder zou een uitgebreide analyse van het effect van omgevingsvariabelen (zoals temperatuur, waterstand, waterafvoer) op de vangsten en visstand per KRW-lichaam inzicht kunnen geven in de hoge jaar op jaar variatie van de vangsten in sommige KRW-lichamen.

\section{Conclusies}

Concluderend zien we dat de visstand in veel KRW-lichamen de afgelopen jaren achteruit is gegaan, waarbij cypriniden en inheemse bodemsoorten als pos en rivierdonderpad vaak sterk afnemen.

Daarnaast zien we ook achteruitgang in andere soorten zoals de spiering, barbeel en het bermpje. Aan de andere kant zien we een sterke toename van invasieve exotische soorten (bijvoorbeeld zwartbekgrondel en Pontische stroomgrondel) maar ook van bijvoorbeeld de inheemse Europese meerval. Schubvissoorten zoals baars en snoekbaars, maar ook aal lijken de laatste jaren in meerdere KRW-lichamen toe te nemen. De toename van aal zou wellicht direct in verband kunnen staan met maatregelen genomen vanuit het aalbeheerplan (o.a. gesloten aalvisserij op de grote rivieren sinds 2011, gesloten aalvisserij tijdens de migratiemaanden sinds 2009, verbeterde migratiemogelijkheden) in combinatie met een hogere glasaalintrek in 2013 en 2014. In sommige KRW-lichamen lijken deze toe- en afnames van soorten met elkaar gecorreleerd, en is er mogelijk een causaal verband. Verder onderzoek zou moeten uitwijzen of dit inderdaad zo is. Voor sommige KRW-lichamen ontbreekt nog een langjarige monitoringsreeks waardoor er nog geen conclusies voor deze wateren getrokken kunnen worden. 


\section{$3 \quad$ Landelijke trends Habitatrichtlijnsoorten}

\section{$3.1 \quad$ Inleiding}

\subsubsection{Vereisten rapportage Habitatrichtlijn}

Binnen de Europese Habitatrichtlijn (HR) zijn veertien vissoorten aangewezen (Tabel 3.1) waarvan de status elke zes jaar aan de Europese Commissie moet worden gerapporteerd via een zogenaamde HR artikel-17 rapportage (EEA, 2017²). Hierin wordt op basis van een aantal vooraf gestelde criteria de staat van instandhouding van de soort bepaald. Eén van die criteria is een beoordeling van de trend in de landelijke bestandsgrootte over de laatste 12 jaar (data: 2008-2019). Hierbij wordt alleen gevraagd om de beoordeling van de richting van de verandering ('stable / increasing / decreasing / uncertain / unknown'). Een kwantificering van de verandering is optioneel en Nederland heeft ervoor gekozen om die niet uit te voeren. De kwalitatieve beoordeling hoort, waar mogelijk, te gebeuren met een statistische analyse. Als een statistische analyse niet mogelijk is, dan zal in een later stadium met expert judgement een beoordeling gedaan worden van de staat van instandhouding, op basis van alle criteria (EEA, 2017).

Dit hoofdstuk bevat per HR-soort een kort overzicht van de ecologie, gevolgd door de recente ontwikkelingen van een soort, een beoordeling van de trend in landelijk vangstsucces in de laatste 12 jaar en tot besluit de historische ontwikkelingen.

\subsubsection{Dataselectie}

Voor een deel van de HR-soorten wordt de landelijke trend geanalyseerd met de gegevens die verzameld zijn in monitoringsprogramma's op de Rijkswateren; namelijk voor barbeel, elft, fint, Noordzeehouting, rivierprik, zeeprik en zalm. Van de overige soorten worden de Europese en de Atlantische steur in Nederland als uitgestorven beschouwd en lijkt de grote marene niet van oorsprong in Nederland voor te komen. Voor bittervoorn, grote en kleine modderkruiper, beekprik en rivierdonderpad wordt de landelijke trend berekend door andere partijen, met gegevens die daarvoor geschikter zijn dan de monitoringprogramma's op de Rijkswateren.

Voor de analyse (zie Bijlage 57 voor details) worden eerst de meest geschikte monitoringsprogramma's per soort geselecteerd. De belangrijkste selectiecriteria hierbij zijn dat (a) het gebruikte bemonsteringstuig van een survey geschikt is om die soort te vangen en (b) het bemonsterde habitat relevant is voor de soort.

(a) Voor de diadrome soorten (elft, fint, Noordzeehouting, rivierprik, zeeprik en zalm) zijn de gegevens van monitoringsprogramma's met passieve vistuigen (diadrome vissurvey, vangstregistratie aalvissers en zalmsteeksurvey) het meest geschikt; trekkende vis brengt weinig tijd door op een specifieke locatie. De trefkans is veel hoger met een passief vistuig dat lange tijd in het water aanwezig is dan met een actief vistuig waarmee kortdurend wordt gemonsterd. Voor de nietdiadrome soort barbeel worden de gegevens uit monitoringsprogramma's met actieve vistuigen het meest geschikt geacht.

(b) Vervolgens wordt voor de afzonderlijke soorten een selectie van de locaties gemaakt waar een soort mogelijk zou kunnen voorkomen. Voor de diadrome soorten wordt ook geselecteerd op de maanden waarin de soort migreert. Omdat de monitoringsinspanning meestal niet evenwichtig over de maanden, jaren en/of locaties verdeeld is, worden vervolgens aannames gedaan voor missende maanden/jaren (deze worden expliciet besproken per soort). Daarna wordt een landelijke trend in vangstsucces (aantal per fuiketmaal of $\mathrm{km}$ ) berekend.

\footnotetext{
${ }^{2}$ https://cdr.eionet.europa.eu/nl/eu/art17/envxuhrwa/NL_species_reports-20190819.xml/manage_document
} 
Tabel 3.1 Vissoorten die zijn aangewezen binnen de Europese Habitatrichtlijn (HR) en de HR-Bijlagen waarin ze zijn opgenomen. Soorten in de laatste kolom (en met vetgedrukte Nederlandse naam) worden in de HR Artikel-17 rapportage, en hier, geanalyseerd met de gegevens verzameld in de monitoringsprogramma's op de Rijkswateren.

\begin{tabular}{|c|c|c|c|c|c|}
\hline Nederlandse naam & Wetenschappelijke naam & $\begin{array}{l}\text { HR } \\
\text { Bijlage } \\
\text { II }\end{array}$ & $\begin{array}{l}\text { HR } \\
\text { Bijlage } \\
\text { IV }\end{array}$ & $\begin{array}{l}\text { HR } \\
\text { Bijlage } \\
\text { V }\end{array}$ & $\begin{array}{l}\text { Trendanalyse } \\
\text { met gegevens } \\
\text { Rijkswateren }\end{array}$ \\
\hline barbeel & Barbus barbus & - & - & $\mathrm{x}$ & \multirow[t]{3}{*}{$\mathrm{x}$} \\
\hline beekprik & Lempetra planeri & $x$ & - & - & \\
\hline bittervoorn & Rhodeus amarus & $x$ & - & - & \\
\hline elft & Alosa alosa & $x$ & - & $x$ & $x$ \\
\hline fint & Alosa fallax & $x$ & - & $x$ & \multirow[t]{3}{*}{$x$} \\
\hline grote marene & Coregonus lavaretus & - & - & $x$ & \\
\hline grote modderkruiper & Misgurnus fossilis & $x$ & - & - & \\
\hline Noordzeehouting & Coregonus oxyrhynchus & $x$ & $x$ & - & \multirow[t]{3}{*}{$\mathrm{X}$} \\
\hline kleine modderkruiper & Cobitis taenia & $x$ & - & - & \\
\hline rivierdonderpad & Cottus perifretum & $x$ & - & - & \\
\hline rivierprik & Lampetra fluviatilis & $x$ & - & $x$ & \multirow[t]{2}{*}{$\mathrm{X}$} \\
\hline Europese steur & Acipenser sturio & $x$ & $x$ & - & \\
\hline zalm & Salmo salar & $x$ & - & $x$ & $x$ \\
\hline zeeprik & Petromyzon marinus & $x$ & - & - & $x$ \\
\hline
\end{tabular}

\subsubsection{Trendanalyse}

De focus in de trendberekeningen van de landelijke bestandsgrootte ligt op de afgelopen 12 jaar. De opwerking en interpretatie is identiek aan die van de HR-artikel-17 rapportage in 2019. Hiervan is een uitgebreide beschrijving opgenomen in Bijlage 57.

Voor de statistische bepaling van de landelijke trend wordt door het Centraal Bureau voor de Statistiek (CBS) het software programma Trendspotter (Soldaat et al. 2007) gebruikt. Met deze methodiek kan worden vastgesteld of over de afgelopen 12 jaar de soort significant toe- of afneemt. Aangezien deze analyse door het CBS eens in de zes jaar zal worden uitgevoerd (laatste keer in 2017), zal in de voorliggende rapportage geen nieuwe statistische analyse worden getoond. De laatste statistische trendanalyse zal worden besproken (2006-2017) en de eerstvolgende analyse zal in 2023 plaats vinden. De trend met data van na 2017 zal in dit rapport dus niet statistisch onderzocht, maar wel besproken worden.

\subsubsection{Expert judgement}

Voor vijf van de zeven soorten (Noordzeehouting, zeeprik, rivierprik, fint en elft) is geen continue tijdreeks van 2008-2019 te genereren. Er zijn alleen twee tijdreeksen beschikbaar van twee verschillende surveys (registratie vangsten aalvissers en diadrome vissurvey), waarbij geen overlap in de tijd is geweest (minimaal twee jaar zonder survey). Het is onbekend hoe de vangstefficiënties van de twee surveys zich tot elkaar verhouden, omdat de bemonsterde weken, de exacte locatie en het gebruikte tuig verschillen in de twee surveys. Er kan dus voor deze soorten alleen met expert judgement een inschatting van de trend over de laatste 12 jaar gemaakt worden. Voor zalm, elft en barbeel zijn wel tijdreeksen van 2008-2019 te genereren. 


\subsection{Barbeel}

\subsubsection{Ecologie}

De barbeel (Barbus barbus, Figuur 3.1) is een karperachtige riviervis, die voorkomt in de middenloop van rivieren. De soort houdt van matig tot snelstromend zuurstofrijk water met een schone bodem van zand, kiezels en keien. Deze bodemvis is omnivoor (alleseter) en zoekt zijn voedsel tussen stenen en zand in de schemer en nacht. Hij komt voor in middelgrote tot grote rivieren, kan 70-100 cm lang worden en ca. 15-25 jaar oud. Volwassen exemplaren migreren in de zomer naar stroomopwaarts gelegen paaigebieden om zich voort te planten (Wijmans, 2007). Zenderonderzoek in de Maas en Rijn laat zien dat de meeste barbelen over relatief kleine afstanden migreren $(<10 \mathrm{~km}$ ) (De Leeuw \& Winter, 2008). De paaitijd is van mei tot begin juli. Paaien vindt alleen plaats in ondiepe gebieden met kiezelondergrond. Mannetjes zijn geslachtsrijp bij $15 \mathrm{~cm}$ en een leeftijd van 2-4 jaar; vrouwtjes bij 20-35 cm en 3-8 jaar. De juvenielen verblijven vaak in de relatief ondiepe kiezelbanken van de rivier, op dezelfde locaties als waar ze geboren zijn. Naarmate ze groter worden, gebruiken ze ook diepere delen (tot enkele meters diep). Meer soortinformatie is te vinden in het Kennisdocument Barbeel (Wijmans, 2007).

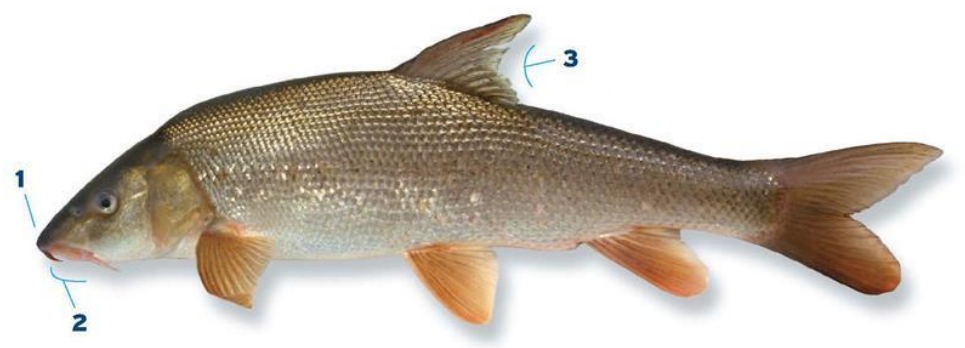

Figuur 3.1. Barbeel met onderscheidende kenmerken (bron: Sportvisserij Nederland, meer informatie: http://www.sportvisserijnederland.nl/vis-water/vissoorten/vissengids.html)

\subsubsection{Historische ontwikkeling}

De barbeel was eind $19^{e}$ eeuw tot de jaren 40 van de vorige eeuw het talrijkst in de Limburgse Maas en kwam in mindere mate ook voor in Rijn, Waal en Gelderse IJssel. Door ingrepen in de rivieren (normalisaties, stuwen, waterverontreiniging) is de barbeelstand na de Tweede Wereldoorlog sterk afgenomen. Tot het begin van de jaren 90 van de vorige eeuw kwam de soort alleen nog voor in de Limburgse Grensmaas en het stroomgebied van de Roer. Sinds die tijd wordt de barbeel ook weer op onregelmatige basis aangetroffen in andere stromende wateren dan in de Grensmaas. Wijmans (2007) spreekt over een comeback van de soort aan het einde van de $20^{\text {ste }}$ eeuw (Wijmans, 2007 en referenties daarin), waarbij de verbeterde waterkwaliteit wellicht een belangrijke rol heeft gespeeld.

\subsubsection{Huidige ontwikkeling en trend}

Er is momenteel geen informatie beschikbaar over de staat van instandhouding van de barbeel.

Zelfstandige populaties (populaties die niet afhankelijk zijn van andere wateren) komen alleen voor in de midden-regionen van rivieren met overwegend kiezelbodem; van de bemonsterde Rijkswateren kent daarom alleen de Grensmaas relatief hoge dichtheden. De soort komt in de benedenstroomse delen van de Maas en Rijn meer onregelmatig voor (Bovenloop Waal, Bovenloop Gelderse IJssel en Benedenloop Nederrijn), waarschijnlijk als uitvloeisel vanuit meer bovenstrooms voorkomende bronpopulaties. Recentelijk zijn er wel juveniele barbelen in de Waal en IJssel waargenomen (L. Nagelkerke, pers. comm.) wat op mogelijke paai in deze wateren duidt. Desondanks is de landelijke trend gebaseerd op het vangstsucces van de actieve monitoring met het elektroschepnet in de hoofdstroom van de Grensmaas. Barbeel toont een vrij stabiel vangstsucces tot een piek qua aantallen in 2011, gevolgd door een afname tot in 2019 (Figuur 3.2). Tot 2015 vond de bemonstering in mei plaats (door RAVON) en sinds 2015 in april (door ATKB), en deze verandering heeft mogelijk invloed gehad op het absolute vangstsucces in 2015-2019 ten opzichte van de periode ervoor. De afname in het vangstsucces is echter 
ook zichtbaar binnen 2015-2019. Wat echter ook opvalt is dat er sinds 2015 ook geen (mogelijk) geslachtsrijpe barbelen worden gevangen, maar slechts juvenielen. (Figuur 3.2. Gemiddelde vangstsucces (aantal per $\mathrm{km}$ ) van barbeel per jaar met lengteverdeling, zoals gevangen met het elektroschepnet in de actieve monitoring in de Grensmaas.). Het is nog onduidelijk of dit (alleen) door de verandering van periode en uitvoerder komt, alhoewel het niet vangen van barbelen in de hoofdstroom in 2019 suggereert eerder een bijna algehele verdwijning van barbeel uit de Grensmaas (er zijn in 2019 nog wel acht barbelen in het zijwater van de Grensmaas gevangen).

De trend is statistisch onderzocht met Trendspotter door het CBS: over 2006-2017 vindt een statistisch significante afname in vangstsucces plaats ${ }^{3}$ (Tien et al. 2019).

Opvallend is dat in de gebieden Bovenloop Waal (H2.11) en Bovenloop Gelderse IJssel (H2.6), net als in de Grensmaas, ook vanaf 2011 een duidelijke afname is te zien van de barbelen. Dit duidt erop dat de afnames wellicht een gemeenschappelijke oorzaak hebben waarbij lokale factoren minder van belang zijn. In een recente studie vonden Stoffers et al. (2020) dat zijwateren zoals de gecreëerde nevengeulen van de Waal en Nederrijn, die als kraamkamer dienen voor veel vissoorten, in de afgelopen jaren langzaamaan zijn dichtgeslibd. Dit heeft ervoor gezorgd er in deze nevengeulen geen permanente doorstroming van water mogelijk is, cruciaal voor rheofiele soorten zoals barbeel wat ook een van de soorten was die als eerste en het meeste afnam als gevolg van het dichtslibben van deze nevengeulen. Het is waarschijnlijk dat deze ontwikkeling ook plaats heeft gevonden in (delen van) de Grensmaas wat in combinatie met verminderde afvoer en het gedeeltelijk droogvallen van de Grensmaas in de afgelopen jaren er voor gezorgd kan hebben dat de barbeel in deze rivier drastisch is afgenomen.

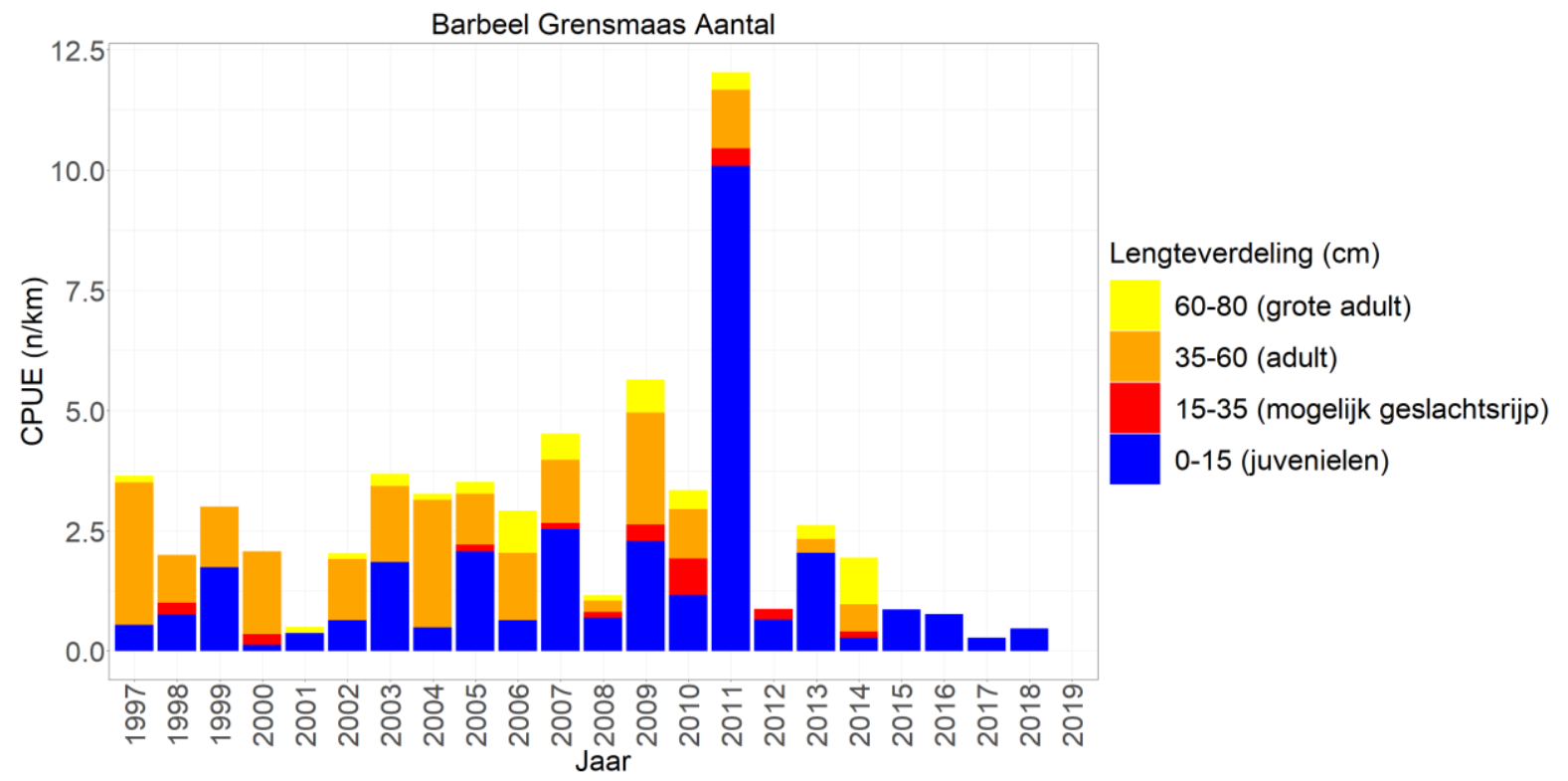

Figuur 3.2. Gemiddelde vangstsucces (aantal per $\mathrm{km}$ ) van barbeel per jaar met lengteverdeling, zoals gevangen met het elektroschepnet in de actieve monitoring in de Grensmaas.

\footnotetext{
${ }^{3}$ Over de gehele periode (1997-2019) is sprake van een matige afname.
} 


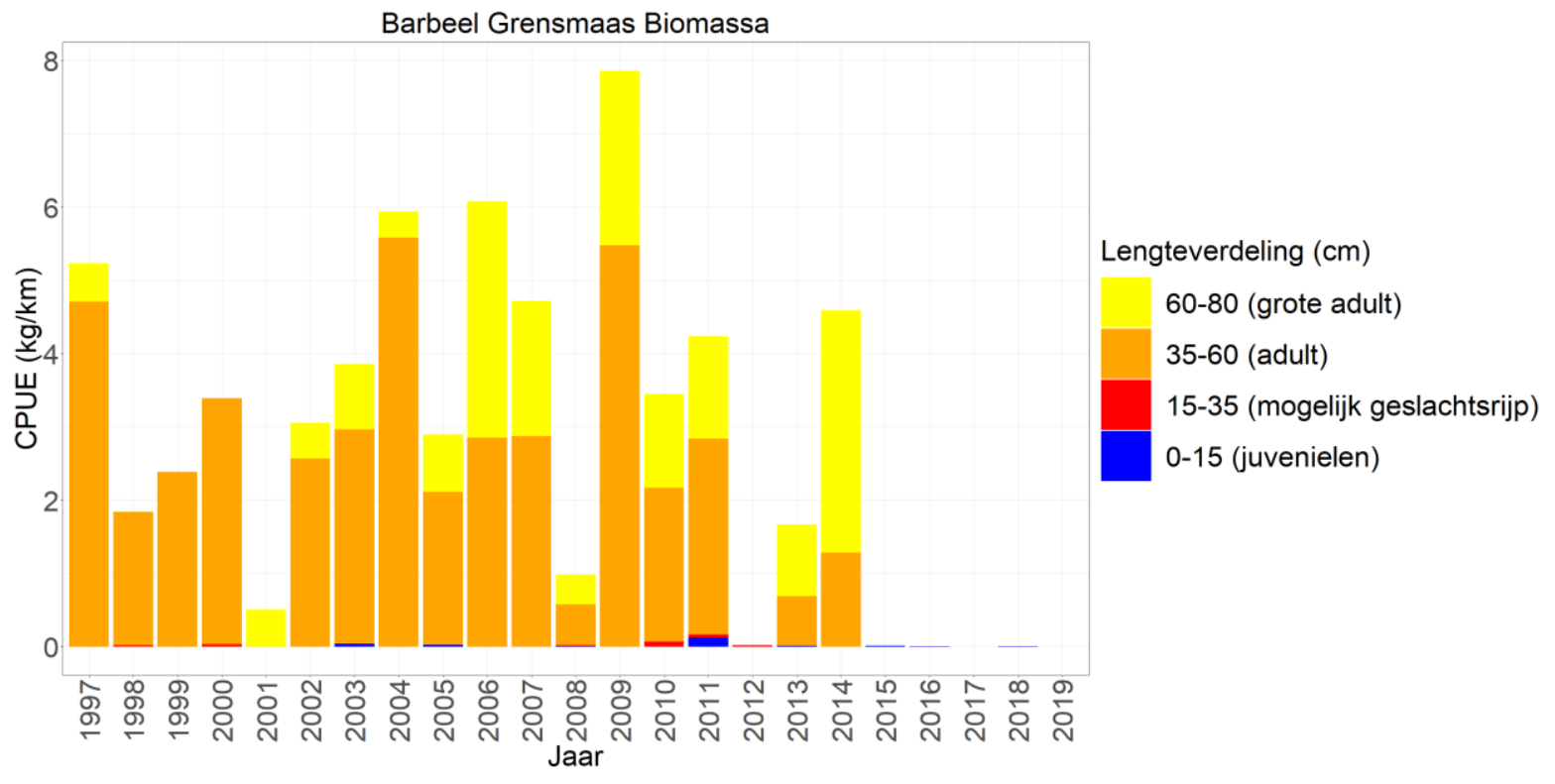

Figuur 3.3. Gemiddelde vangstsucces ( $\mathrm{kg}$ per $\mathrm{km}$ ) van barbeel per jaar met lengteverdeling, zoals gevangen met het elektroschepnet in de actieve monitoring in de Grensmaas. 


\subsection{Elft}

\subsubsection{Ecologie}

De elft (Alosa alosa, Figuur 3.4) is een anadrome vis die zijn voornaamste groei realiseert in zout water en in de paaitijd (mei-juni) de rivier optrekt. Elften paaien op grindbedden bovenstrooms in de rivier in Duitsland en België. Eieren worden afgezet op grindbanken en larven en jonge vissen migreren geleidelijk de rivier af en groeien op in zoetwatergetijdengebieden. Wanneer de vis ongeveer 12 centimeter is, trekt hij naar zee. Jonge vissen kunnen één tot twee jaar in de rivier blijven voordat ze naar zee trekken. Wanneer de elft ongeveer $50 \mathrm{~cm}$ is, trekt hij weer stroomopwaarts om te paaien. Volwassen dieren paaien meer dan één keer (LNV, 2008).

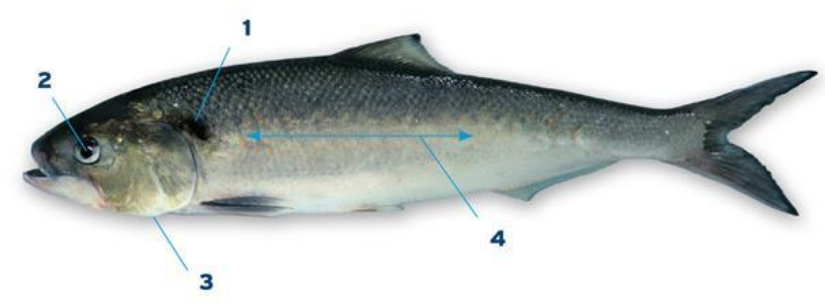

Figuur 3.4. Elft met onderscheidende kenmerken (bron: Sportvisserij Nederland, meer informatie: http://www.sportvisserijnederland.nl/vis-water/vissoorten/vissengids.html)

\subsubsection{Historische ontwikkeling}

De elft is een steeds zeldzamere vis geworden in Nederland door de effectieve visserij aan het einde van de $19^{\mathrm{e}}$ en begin van de $20^{\mathrm{e}}$ eeuw, en door verstuwing van de grote rivieren, oeververharding en grindwinning waardoor paaiplaatsen verdwenen. In de periode 1880-1890 werden in Nederland in de Rijndelta jaarlijks tenminste 150.000-275.000 kilogram elft gevangen. De vangsten namen vervolgens sterk af en rond 1928 is de vangst naar nul kilo gedaald (De Groot, 2002). Paaiplaatsen lagen onder andere stroomopwaarts in de Rijn en zijrivieren. Na 1990 wordt nog melding gemaakt van een klein aantal optrekkende elften en mogelijke paaiplaatsen tussen Mannheim en Gambsheim (Kloppmann et al. 2003). Sinds de start van een herintroductieprogramma in de Duitse Rijn (Scharbert \& Beeck 2010) trekken jaarlijks minimaal enkele tientallen volwassen elften op via de vispassage in de Rijn bij Iffezheim in Duitsland. De elft heeft voor zover bekend nooit gepaaid in Nederland (Patberg et al., 2005, LNV 2008).

\subsubsection{Huidige ontwikkeling en trend}

De staat van instandhouding (2007) van de elft is 'zeer ongunstig' (Profieldocument Elft: LNV, 2008).

De elft wordt vrijwel nooit in de monitoringprogramma's in de Rijkswateren aangetroffen (op een enkele keer in de zalmsteken na). Elft is in de jaren veertig van de $20^{\mathrm{e}}$ eeuw al uitgestorven als paaipopulatie in de Maas en Rijn, en in de fuik van het NIOZ bij Texel is de elft sinds 1960 niet aangetroffen ${ }^{4}$. In 2010 is een herintroductieprogramma in de Duitse Rijn gestart (Scharbert \& Beeck 2010) waarbij jonge elft is uitgezet in de Duitse Rijn. Als deze uitzettingen succesvol zijn kunnen er enkele jaren later voor het eerst volwassen terugkerende elften in het gehele stroomgebied van de Rijn verschijnen. In Nederland is er

\footnotetext{
${ }^{4}$ www.waddenzeevismonitor. $\mathrm{nl}$
} 
geen data van elften beschikbaar maar in de vistrap in de Rijn bij Iffezheim wordt wel gemonitord en zijn er sinds enkele jaren wel hogere aantallen elft aangetroffen ${ }^{5}$, maar dit kan ook veroorzaakt worden door verbeteringen aan de doorlaatbaarheid van de vistrap in 2013 (Figuur 3.5). De huidige aantallen liggen dus nog onder het detectieniveau van de Nederlandse monitoringprogramma's. In 2019 is echter door de ankerkuilvisserij in de oevergeul van de Waal bij Dreumel 's nachts elft gevangen (Collas et al in prep.).

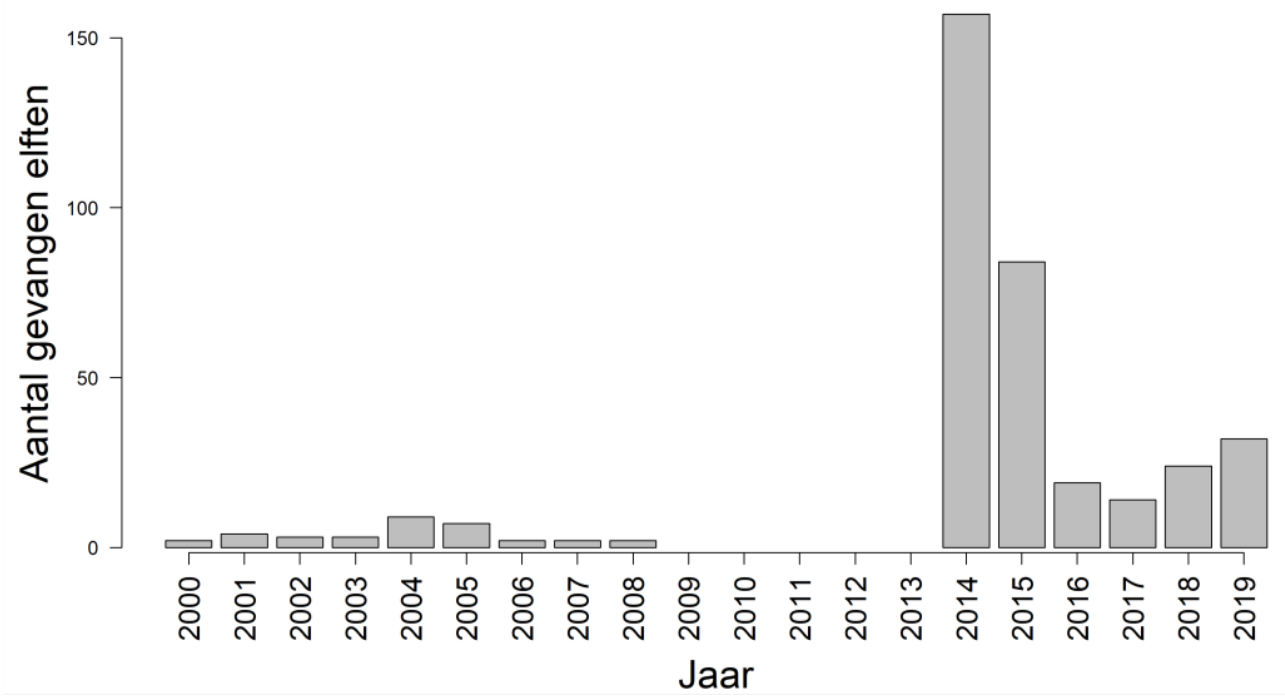

Figuur 3.5 Aantal gevangen elften per jaar bij de vistrap in de Rijn bij Iffezheim. Data is afkomstig van https://www.wfbw.de/aktuelles/kontrollstationen/. Tussen 2009 en 2013 was de vistrap wegens verbouwing gesloten waardoor er in die jaren geen vissen zijn geregistreerd.

Voor de landelijke trend van elft wordt gebruik gemaakt van de monitoringsfuiken op de vijf belangrijke in- en uittreklocaties; Haringvliet, Kornwerderzand, Nieuwe Waterweg, Maas (in het zuiden) en de Rijn (in het oosten). Op geen van deze locaties is in de migratiemaanden (april-juni) elft gevangen, in zowel de vangstregistratie aalvissers (1994-2013) als de diadrome vissurvey (2014-2019, zie Figuur 3.6).

Mocht elft in de toekomst weer in hogere aantallen terugkeren in Nederland, dan zal dit in de bestaande monitoring gedetecteerd moeten kunnen worden.

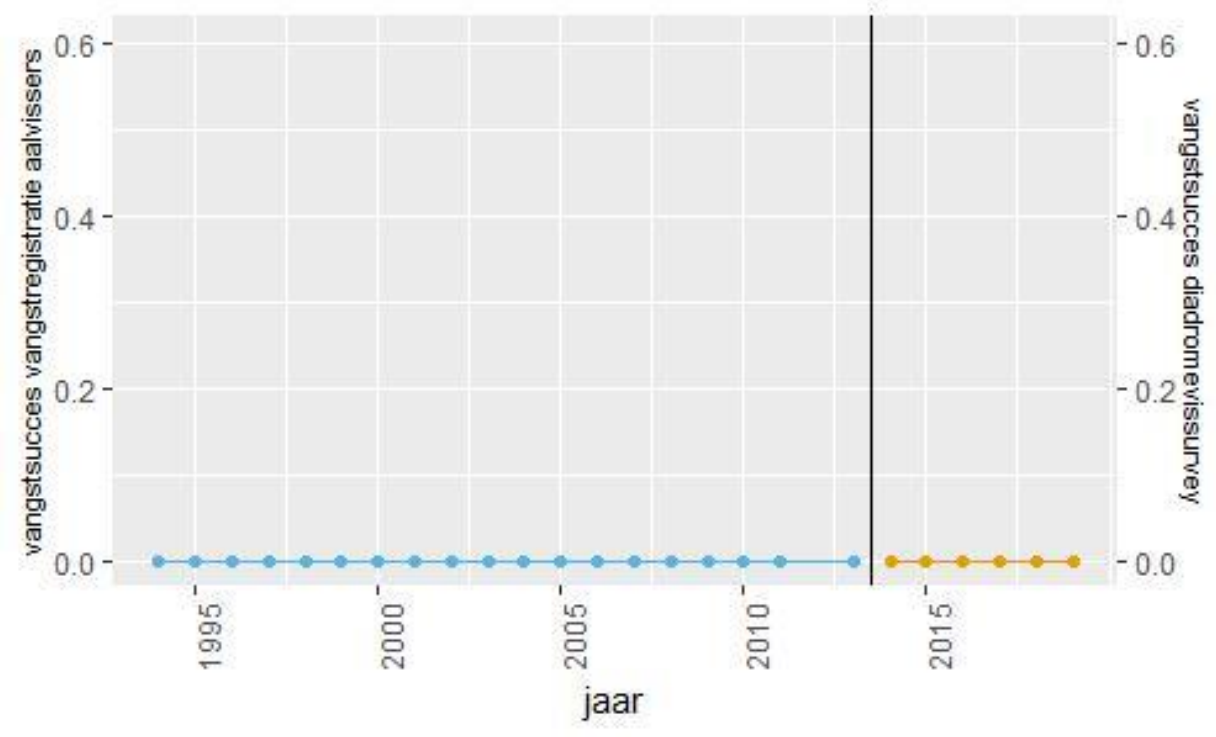

Figuur 3.6. Het gemiddelde vangstsucces (aantal per fuiketmaal) per jaar van elft in de vangstregistratie aalvissers (blauw) en in de diadrome vissurvey (oranje), zoals geschat over in- en uittrekplekken (Haringvliet, Kornwerderzand, Nieuwe Waterweg) en doortrekgebieden (Rijn (oost), Maas (zuid)). De verticale lijn geeft de scheiding tussen de twee verschillende monitoringen weer.

\footnotetext{
${ }^{5}$ https://www.wfbw.de/fileadmin/user_upload/WFBW-Files/Jahresberichte_Iffezheim-Gambsheim/Iffezheim_20002017.pdf
} 


\subsection{Fint}

\subsubsection{Ecologie}

De fint (Alosa fallax, Figuur 3.7) is net als de elft een anadrome vis die voornamelijk in zout water verblijft en om te paaien het zoete water intrekt (april - juni). De fint trekt de rivier echter veel minder ver op dan elft. Finten kunnen meerdere jaren paaien en doen dit op locaties dichtbij zee, waar getij nog merkbaar is. Eieren bewegen met de getijdestromingen mee in estuaria zoals de Westerschelde en het Eems-estuarium. Opgroeigebieden bevinden zich in open estuaria. Na een jaar verspreiden de jonge finten zich meer langs zeekusten (Patberg et al., 2005).

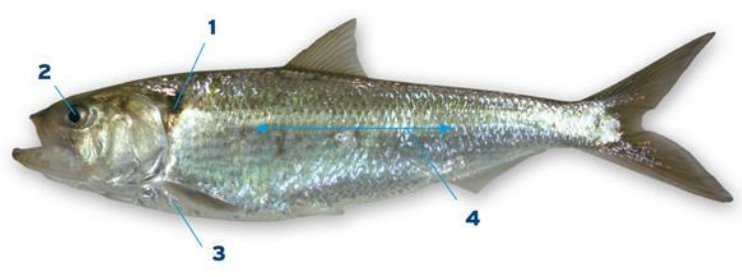

Figuur 3.7. Fint met onderscheidende kenmerken (bron: Sportvisserij Nederland, meer informatie: http://www.sportvisserijnederland.nl/vis-water/vissoorten/vissengids.html)

\subsubsection{Historische ontwikkeling}

In de $16^{\mathrm{e}}$ en $17^{\mathrm{e}}$ eeuw werd intensief op fint gevist. Ook tussen 1920 en 1950 bestond een intensieve visserij op fint, waarbij vangsten terugliepen van een miljoen kilogram in 1938 tot tienduizenden kilogram in de jaren 50. Tot in 1970 was de fint vooral in de benedenrivieren nog redelijk algemeen. Na afsluiting van het Haringvliet is de paaipopulatie in Nederland verdwenen. Sinds 1994 komen in sommige jaren gedurende het groeiseizoen weer grotere aantallen finten voor langs de Nederlandse kust (De Groot, 2002, LNV, 2008). Deze exemplaren moeten afkomstig zijn uit buitenlandse bronpopulaties, maar welke is niet bekend. Grote populaties komen nog voor in de Elbe (Magrath \& Thiel, 2013) en ook in de Schelde is de fint weer als paaipopulatie teruggekeerd in de afgelopen decennia (Breine et al., 2020a, b).

\subsubsection{Huidige ontwikkeling en trend}

De staat van instandhouding (2007) van de fint is 'zeer ongunstig' (LNV, 2008).

Voor de landelijke trend van fint wordt gebruik gemaakt van de monitoringsfuiken op de drie relevante intreklocaties; Haringvliet, Kornwerderzand en Nieuwe Waterweg. Bij het Haringvliet en Kornwerderzand worden in de paaimigratiemaanden (april-juni) alleen zeer lage aantallen fint gevangen (minder dan 0,05 fint per fuiketmaal), in zowel de vangstregistratie aalvissers (1994-2010) als de diadromevissurvey (2014-2019). Bij de Nieuwe Waterweg was dit ook het geval tot en met 2006, maar sindsdien wordt fint in sommige jaren in hogere aantallen gevangen (meer dan één per fuiketmaal), in zowel de vangstregistratie aalvissers als de diadromevissurvey. Over de drie locaties heen, geeft dit een trend van een laag en stabiel vangstsucces tot en met 2006, gevolgd door een hoger maar zeer variabel vangstsucces tussen 2007-2019 (Figuur 3.8). Omdat het vangstsucces in de twee surveys niet direct vergelijkbaar is en de jaar-op-jaar variatie groot is, is geen statistisch betrouwbare trend over de laatste 12 jaar (2008-2019) te bepalen. Wel lijkt het erop dat vanaf 2006 de aantallen intrekkende fint tijdens de paaimigratie in Nederland in sommige jaren duidelijk hoger zijn dan de jaren ervoor. Dit blijkt ook uit de verschillende hoeveelheden (bij)gevangen fint in overige monitoringen en de garnalenvisserij (Glorius et al. 2015, van Rijssel et al. 2019b). De gegevens van de diadromevissurvey betreffen alleen adulte 
finten $>27 \mathrm{~cm}$ waarbij de grootste gevangen fint $56 \mathrm{~cm}$ was. Bij de vangstregistratie van de aalvissers is geen lengte opgemeten.

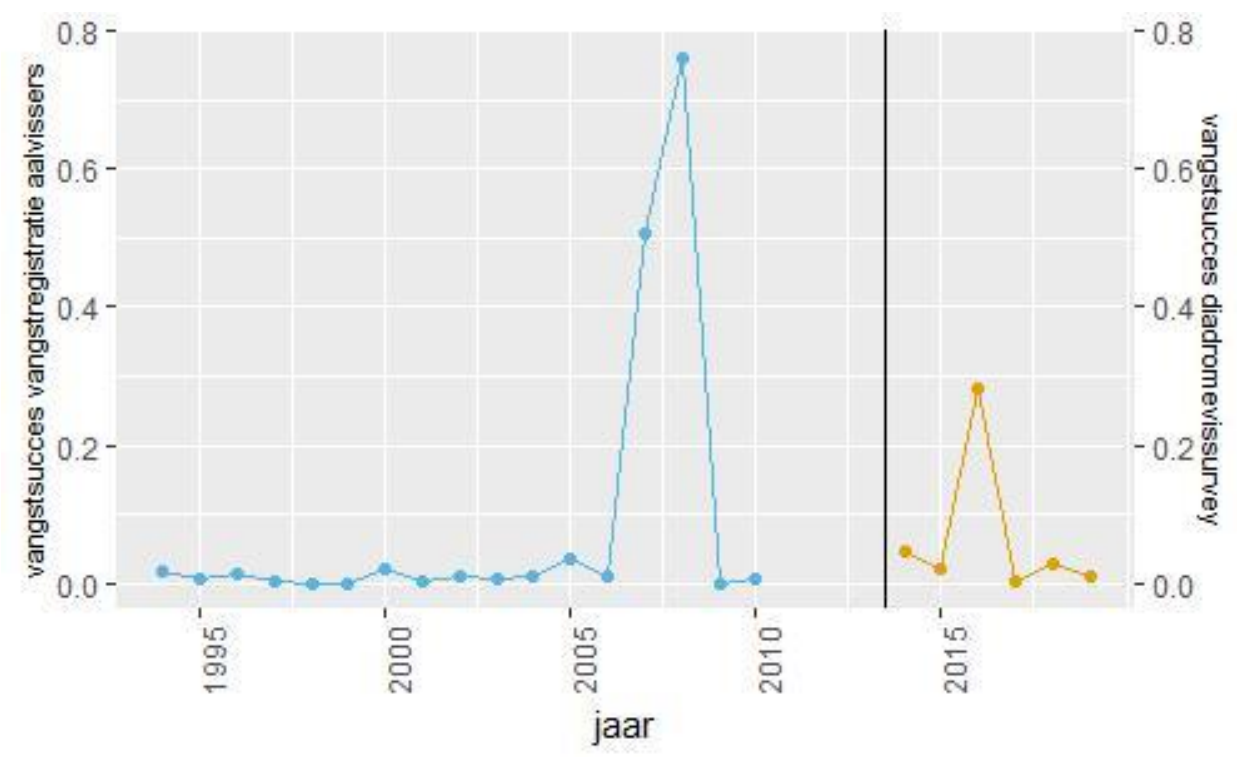

Figuur 3.8. Het gemiddelde vangstsucces (aantal per fuiketmaal) per jaar van fint in de vangstregistratie aalvissers (blauw) en in de diadrome vissurvey (oranje), zoals geschat over drie intrekplekken van fint (Haringvliet, Kornwerderzand en Nieuwe Waterweg). De verticale lijn geeft de scheiding tussen de twee verschillende monitoringen weer. 


\subsection{Noordzeehouting}

\subsubsection{Ecologie}

De Noordzeehouting (Coregonus oxyrinchus, Figuur 3.9) is een anadrome vis, die in de winter (oktoberdecember) bij een leeftijd van circa 2-3 jaar vanuit de Waddenzee migreert naar de lager gelegen delen van de rivieren om daar te paaien. Noordzeehouting kan tot tien jaar oud worden en meerdere keren paaien. Eieren worden in zoet water vrij in de waterkolom afgezet waarna de eieren zich vasthechten aan substraat (doorgaans grind of stenen, soms waterplanten). Vanaf een lengte van 3-4 cm kunnen de juvenielen zout water tolereren (Borcherding et al., 2008). Over paaiplaatsen van de in Nederland voorkomende Noordzeehouting is weinig bekend. In het IJsselmeer en Markermeer komt een (stand)populatie die jaarrond in het zoete water blijft.

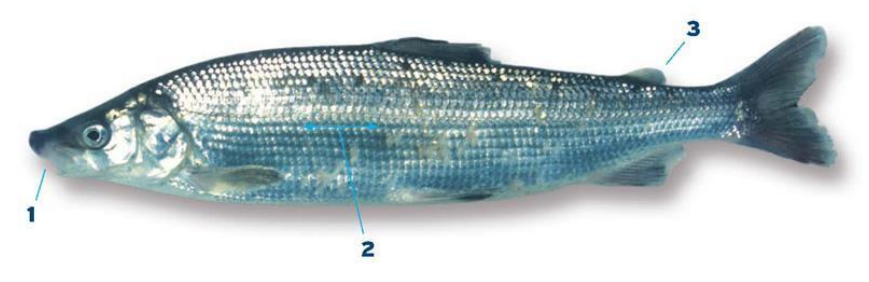

Figuur 3.9. Houting met onderscheidende kenmerken (bron: Sportvisserij Nederland, meer informatie: http://www.sportvisserijnederland.nl/vis-water/vissoorten/vissengids.html)

\subsubsection{Historische ontwikkeling}

In vroegere eeuwen was de Noordzeehouting een vrij algemene vis in het Nederlandse rivierengebied, zuidwestelijke delta en de Zuiderzee (minder in de Waddenzee). Tot in de eerste decennia van de $20^{\circ}$ eeuw vond er visserij op Noordzeehouting plaats in de Nederrijn, waarbij circa 15 ton per jaar werd gevangen (Poulsen et al. 2012). Sinds 1940 is de Noordzeehouting verdwenen uit de Rijn en is deze populatie als uitgestorven beschouwd. Tussen 1992 en 2006 vond in de Duitse Rijn net over de Nederlandse grens een herintroductieprogramma met jonge Noordzeehouting vanuit het Deense Waddengebied plaats (Borcherding et al. 2006). De toename van Noordzeehouting in het IJsselmeer tot en met 2009 houdt zeer waarschijnlijk verband met dat herintroductieprogramma. Wat de oorzaak van de afname sinds 2011 is, is vooralsnog onbekend.

\subsubsection{Huidige ontwikkeling en trend}

Voor de Noordzeehouting zijn nog geen instandhoudingsdoelen vastgesteld, omdat bij de invoering van de Habitatrichtlijn de soort in Nederland was verdwenen en als uitgestorven werd beschouwd.

In Duitsland (in de Rijn en Lippe nabij de Nederlandse grens) werden in 1992-2006 jaarlijks 10- tot 100duizenden Noordzeehoutingen uitgezet. Dit programma is succesvol gebleken; de overgrote meerderheid van Noordzeehouting in het IJsselmeer is tegenwoordig afkomstig uit natuurlijke paaibestanden (Borcherding et al., 2010). Ook uit chemisch merkonderzoek blijkt dat er een natuurlijk reproducerende populatie in het stroomgebied van de IJssel is (De Leeuw et al., 2005; Borcherding et al., 2008; Borcherding et al., 2014). Er is debat over de taxonomische status van houting, zie een overzicht hiervan in Winter (2017).

Omdat de primaire migratiemaanden voor Noordzeehouting (november-december, Borcherding et al. 2014) niet overeenkomen met de consistent bemonsterde maanden in de vismonitoringsprogramma's 
met passieve vistuigen, is het niet mogelijk om trends voor Noordzeehouting tijdens de paaitrek te onderzoeken. De gegevens die verzameld zijn buiten de paaitrek (het groeiseizoen) kunnen wel gebruikt worden. Een substantieel deel van de houting die in Nederland voorkomt voltooit zijn levenscyclus in zoet water en is dus niet diadroom. Een deel benut wel zoutere habitats tijdens een deel van zijn leven (diadrome individuen, Borcherding et al. 2008). Hoe de verhouding tussen diadrome en niet-diadrome individuen ligt is onbekend. Wel is duidelijk dat de dispersie van Noordzeehouting langs kustgebieden zeer beperkt is, dat in het Nederlandse deel van het Rijn-stroomgebied (inclusief de mondingen aan zeezijde) een Rijn-eigen populatie houting bestaat en dat er geen menging is met buitenlandse populaties. De Noordzeehoutingvangsten buiten het migratieseizoen zijn dus ook een goede weerspiegeling van de populatietrend van de Noordzeehoutingpopulatie in het Nederlandse Rijnstroomgebied.

Noordzeehouting wordt bij Haringvliet, Nieuwe Waterweg, Maas en Rijn in stabiele en zeer lage aantallen aangetroffen (minder dan 0,02 houting per fuiketmaal). Alleen bij Kornwerderzand wordt Noordzeehouting in hogere aantallen aangetroffen, met een hoogtepunt van 0,5 houting per fuiketmaal in 2009. De landelijke trend (gemiddeld over de vijf locaties) wordt dan ook gedomineerd door de trend bij Kornwerderzand: sinds 1996 wordt houting aangetroffen waarna het vangstsucces in de monitoringen vrij consistent toeneemt met als hoogtepunt 2009 (Figuur 3.10). Daarna nemen de vangsten in de vangstregistratie aalvissers weer scherp en consistent af. De reden hiervoor is onbekend. Ook in de diadromevissurvey (vanaf 2016) wordt Noordzeehouting gevangen. Omdat het vangstsucces in de twee surveys niet direct vergelijkbaar is, is de trend sinds 2013 niet met zekerheid te bepalen. Alsnog lijkt er, gezien de vrij stabiele trend in beide surveys, geen sprake te zijn van een toename in aantallen maar eerder van een consistente afname na 2013. Samengevat is de hoeveelheid Noordzeehouting, na een initiële sterke toename vanaf 2000, vanaf 2010 weer sterk afgenomen. De trend sinds 2013 is onzeker maar lijkt negatief te blijven. Noordzeehouting wordt in de staandwantmonitoring, de openwatermonitoring en door vissers op het IJsselmeer echter nog regelmatig gevangen (van Rijssel et al. 2019b). De gegevens van de diadromevissurvey betreffen houtingen tussen de $15-48 \mathrm{~cm}$, bij de vangstregistratie van de aalvissers is geen lengte opgemeten (Figuur 3.11).

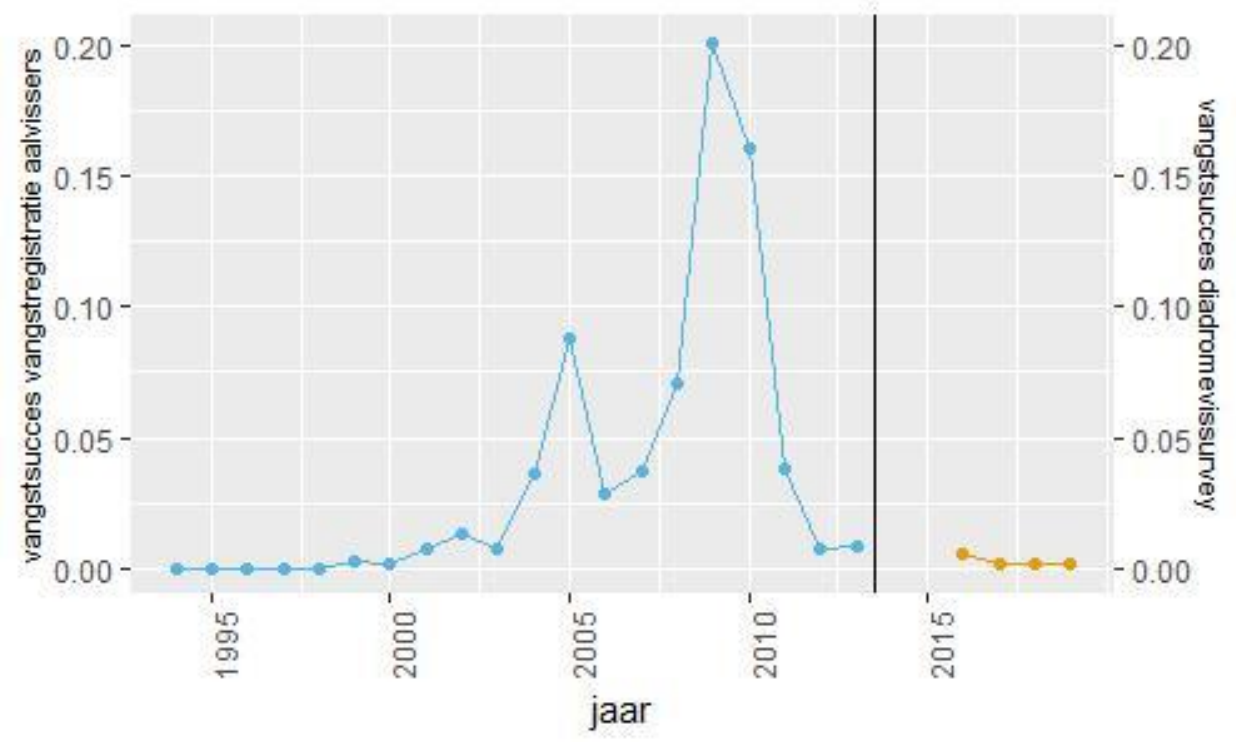

Figuur 3.10. Het gemiddelde vangstsucces (aantal per fuiketmaal) per jaar van Noordzeehouting in de vangstregistratie aalvissers (blauw) en in de diadrome vissurvey (oranje), zoals geschat op vijf potentieel belangrijke opgroeiplekken van Noordzeehouting (Haringvliet, Kornwerderzand, Nieuwe Waterweg, Rijn (oost), Maas (zuid)). De verticale lijn geeft de scheiding tussen de twee verschillende monitoringen weer. 


\section{Noordzeehouting landelijk LF}

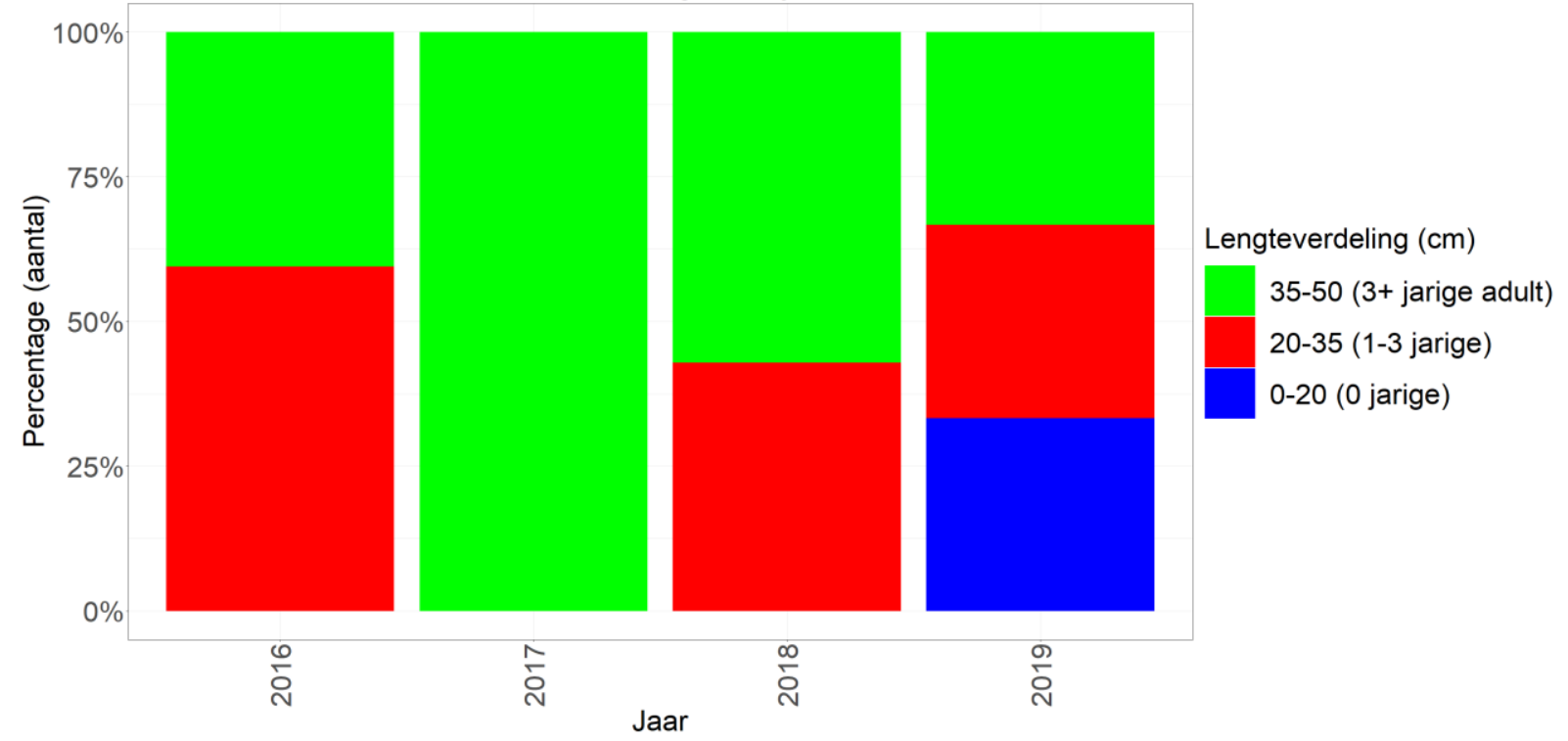

Figuur 3.11 Procentuele lengteverdeling van Noordzeehouting in de diadrome vissurvey. 


\subsection{Rivierprik}

\subsubsection{Ecologie}

De rivierprik (Lampetra fluviatilis, Figuur 3.12) is een rondbeksoort die eerst enkele jaren als ingegraven larve in stromend zoet water leeft en dan naar de kustzone en estuaria trekt om als parasiet van vissen te leven. In het najaar en winter trekken volwassen exemplaren weer de rivieren op om in het vroege voorjaar te gaan paaien. Na de voortplanting in het voorjaar sterven de prikken. Larven (ammocoeten) leven drie tot vijf jaar in de rivierbodem, waarna ze bij een lengte van 12-13 cm metamorfoseren en naar zee trekken, waar ze in twee tot drie jaar verder doorgroeien tot 35-45 cm (Maitland 2003). De soort komt wijdverspreid in Nederland voor (Patberg et al., 2005; De Leeuw et al., 2005). Er zijn echter nog maar een beperkt aantal plaatsen bekend waar paai bewezen is: in zijbeken van de Maas, de Rijn, de IJssel en de Waal en in het stroomgebied van de Drentse Aa (De Leeuw et al., 2005; Winter \& Griffioen 2007; Kranenbarg et al., 2012; Winter et al., 2013; Spikmans et al., 2016; de Bruin et al., 2018).

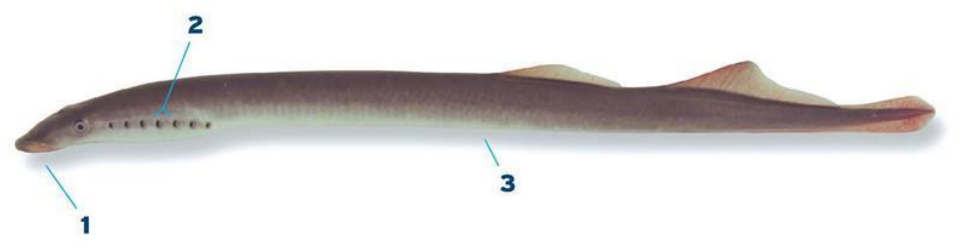

Figuur 3.12 Rivierprik met onderscheidende kenmerken (bron: Sportvisserij Nederland, meer informatie: http://www.sportvisserijnederland.nl/vis-water/vissoorten/vissengids.html)

\subsubsection{Historische ontwikkeling}

Rivierprik kwam vroeger in grote aantallen voor. Ze werden gevangen als aas voor met name de kabeljauwvisserij. Door aanleg van stuwen en door vervuiling zijn de aantallen sterk afgenomen gedurende de $20^{\mathrm{e}}$ eeuw. De soort wordt in de wintermaanden veelvuldig waargenomen in de Maas- en Rijntakken, het IJsselmeergebied en het Noordzeekanaal en lijkt in aantal te zijn toegenomen aan het einde van de $20^{\mathrm{e}}$ eeuw. De kwaliteit van de data is echter gering en deze historische ontwikkelingen zijn gebaseerd op vaak anekdotische waarnemingen of vangsten binnen kortlopende projecten (Bijlsma et al. 2019).

\subsubsection{Huidige ontwikkeling en trend}

De staat van instandhouding (2007) van de rivierprik is 'matig ongunstig' (LNV, 2008).

Volwassen rivierprik migreert in oktober-december (soms tot in januari), waarbij met name de maanden november en december belangrijk zijn en meegenomen moeten worden in het bepalen van de landelijke trend. De locaties van de vangstregistratie aalvissers zijn echter geen van alle in december consistent bemonsterd. Alleen de tijdreeks van de diadrome vissurvey is daarom geschikt om bestandsontwikkelingen van rivierprik te volgen. Hierbij kunnen alleen de locaties en jaren waarin ook december is bemonsterd worden meegenomen: Haringvliet en Kornwerderzand (Afsluitdijk). Aangezien beide locaties belangrijk zijn voor de intrek van rivierprik, worden de jaren waarin beide locaties in december zijn bemonsterd getoond. Aangezien deze jaren waarin gemonitord is per locatie van elkaar verschillen, worden de locaties apart getoond (Figuur 3.13). Er is te weinig informatie om een statistisch betrouwbare trendanalyse te doen, maar ook om op basis van expert judgement een trend te bespreken. Zodra gegevens over meerdere jaren beschikbaar zijn, kan de trend voor rivierprik per locatie bekeken worden. De gegevens van de diadromevissurvey betreffen alleen adulte rivierprikken ( $>26 \mathrm{~cm}$ en $<46$ $\mathrm{cm})$. 
De landelijke trend over de afgelopen 12 jaar is niet te bepalen. Wanneer we naar de bemonsteringen per locatie kijken (waarbij er niet geselecteerd is op een gemeenschappelijke december-bemonstering of dezelfde fuiklocaties door de tijd heen), is te zien dat de rivierprik op alle locaties afneemt of niet tot nauwelijks gevangen wordt (Figuur 3.14). Hierbij moet wel vermeld worden dat (1) de Rijn alleen in oktober en november bemonsterd wordt en dat deze niet in 2012, 2016 en 2018 bemonsterd is, (2) de Nieuwe Waterweg alleen in oktober en november bemonsterd wordt (in 2014 deels ook december), (3) de Maas alleen in oktober en november bemonsterd wordt (in 2012 deels ook december) en dat deze in 2017 en 2018 niet bemonsterd is, (4) het Haringvliet alleen in oktober en november bemonsterd is, op 2012, 2014 en 2016 na, toen is er ook in december bemonsterd en in 2018 is er helemaal niet in het Haringvliet bemonsterd en (5) bij Kornwerderzand bijna ieder jaar in oktober, november en december bemonsterd is. In 2013 is er alleen kort in oktober bemonsterd en in 2015 alleen in december, in 2018 is er niet in december bemonsterd. Daarnaast is er in 2012 en 2013 bij Kornwerderzand op andere locaties bemonsterd dan in de daaropvolgende monitoringsjaren.

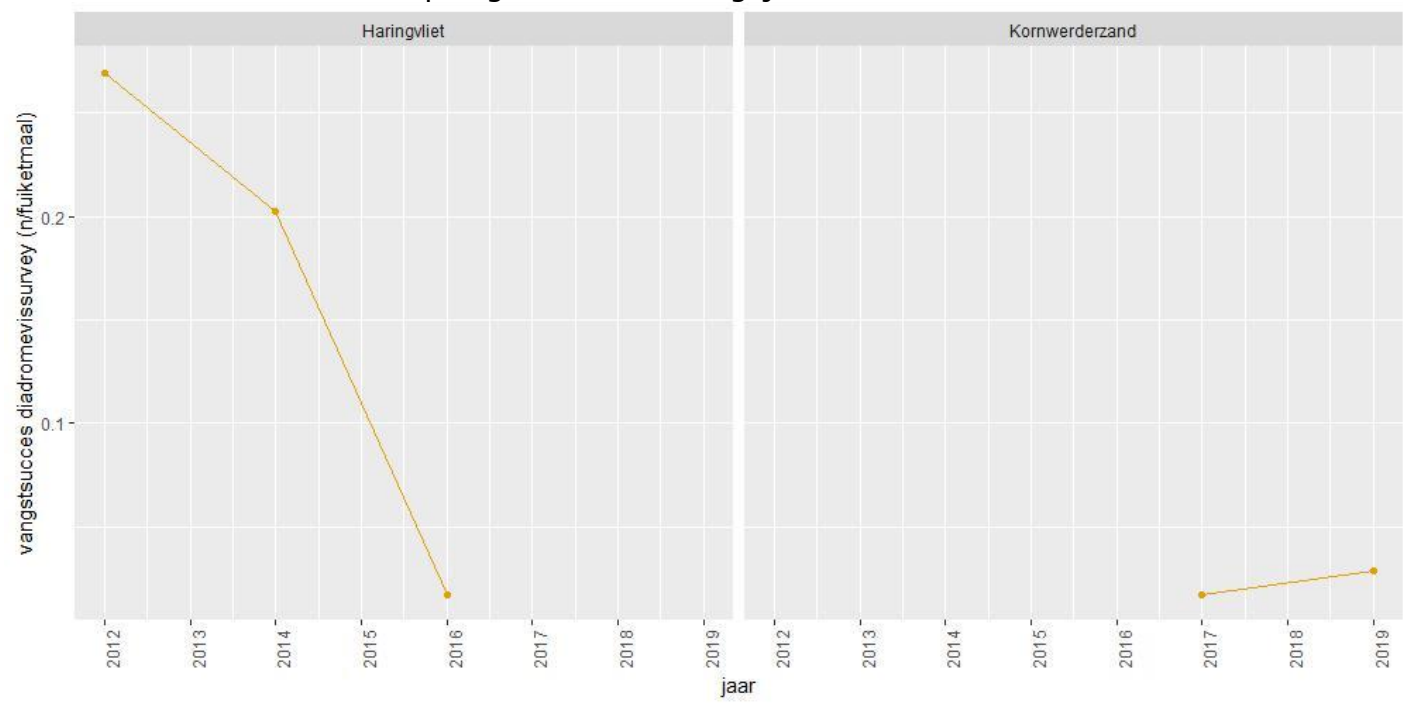

Figuur 3.13 Het gemiddelde vangstsucces (aantal per fuiketmaal) van rivierprik per jaar in de diadromevissurvey, bij Haringvliet en Kornwerderzand, gevangen in de maanden oktober, november en december.
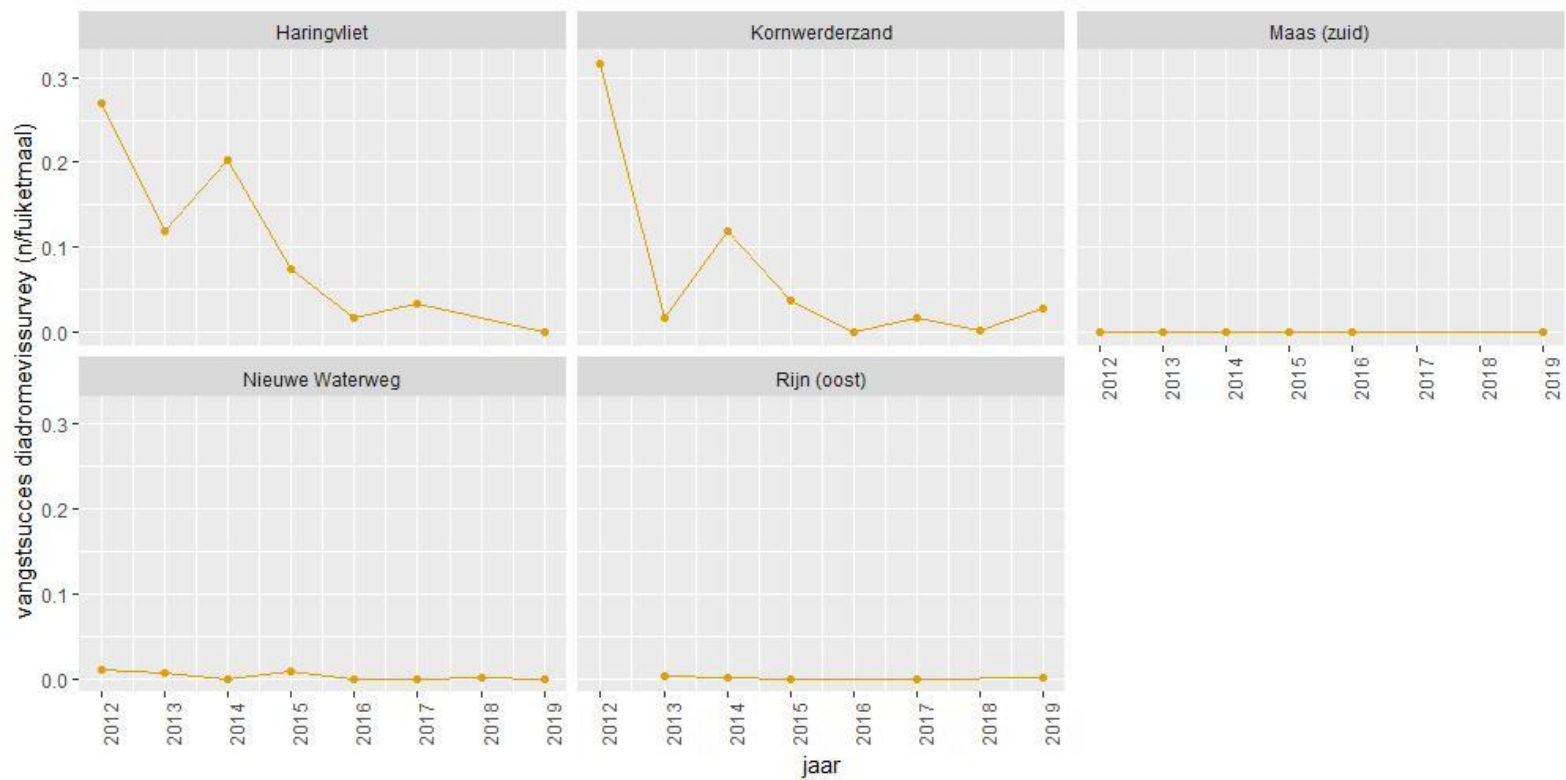

Figuur 3.14 Het gemiddelde vangstsucces (aantal per fuiketmaal) van rivierprik per locatie per jaar in de diadromevissurvey gevangen in de maanden oktober, november en/of december. 


\subsection{Zeeprik}

\subsubsection{Ecologie}

De zeeprik (Petromyzon marinus, Figuur 3.15) is een rondbeksoort die in de periode februari tot juni ver landinwaarts de rivieren optrekt om te paaien in ondiep snel stromend water met grindbodems.

Paaigebieden in Nederland lijken niet tot nauwelijks voor te komen, hoewel de zeeprik vermoedelijk wel in het Nederlandse deel van de Roer paait (van Kessel et al. 2009). Na het paaien sterven de zeeprikken. De larven graven zich vier tot zes jaar in de zand- of modderbodem in stromende wateren in en metamorfoseren daarna bij een lengte van $15-20 \mathrm{~cm}$ tot zeeprikken met ogen en een zuigbek. In het winterhalfjaar trekken ze naar zee waar ze als parasiet op grote vissen en ook zeezoogdieren leven, totdat ze na twee tot vier jaar bij lengtes van 60-100 cm weer naar rivieren trekken om te paaien (Patberg et al., 2005). Zeeprikken vertonen in tegenstelling tot veel andere diadrome soorten geen homing (terugkeer) naar hun geboorterivier. In plaats daarvan oriënteren ze zich op feromonen die de ingegraven larven uitscheiden (Bergstedt \& Seelye, 1995).

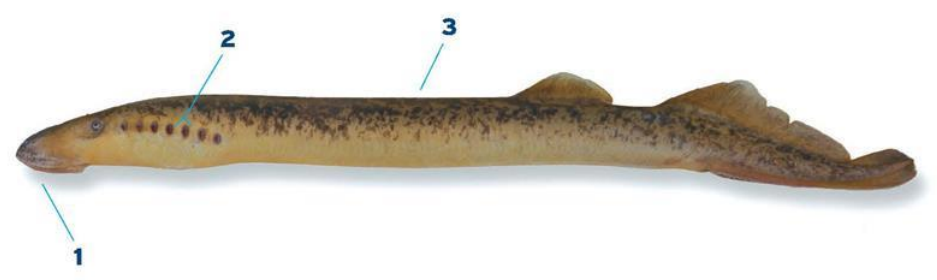

Figuur 3.15 Zeeprik met onderscheidende kenmerken (bron: Sportvisserij Nederland, meer informatie: http://www.sportvisserijnederland.nl/vis-water/vissoorten/vissengids.html)

\subsubsection{Historische ontwikkeling}

Zeeprik kwam in het verleden vrij algemeen voor in de Nederlandse rivieren. Door de aanleg van stuwen en verslechtering van waterkwaliteit kon een aantal paaigebieden niet meer bereikt worden, waarna er waarschijnlijk een dieptepunt in de aantallen ontstond in de periode 1970-1985 (van den Brink et al., 1990). Daarna zijn, waarschijnlijk door onder andere de sterk verbeterde waterkwaliteit en vismigratievoorzieningen bij barrières, de aantallen weer toegenomen, hoewel pas sinds 1994 monitoringsgegevens beschikbaar zijn.

\subsubsection{Huidige ontwikkeling en trend}

De staat van instandhouding (2007) van de zeeprik is 'matig ongunstig' (LNV, 2008).

Volwassen zeeprik migreert in april-juni. Alle vijf in- en uittreklocaties van de diadromevissurvey (Den Oever, Kornwerderzand, Haringvliet, Noordzeekanaal, Nieuwe Waterweg) zijn relevant voor zeeprik en worden in ieder geval in mei bemonsterd in zowel de vangstregistratie aalvissers als de diadromevissurvey. De landelijke trend wordt berekend over deze vijf locaties. Hierbij wordt zeeprik regelmatig in redelijke aantallen (meer dan 0,05 zeeprik per fuiketmaal) aangetroffen bij het Haringvliet en in nog hogere aantallen bij Kornwerderzand (Figuur 3.18). Op de andere locaties worden veel lagere aantallen gevangen. Het vangstsucces bij Haringvliet is vrij stabiel over de jaren heen, maar bij Kornwerderzand is een duidelijke trend te zien. Deze trend bepaalt in belangrijke mate de geschatte landelijke trend (Figuur 3.16): een toename tot en met 2003 gevolgd door een afname tot en met 2010. Tussen 2011-2015 is door gebrek aan gegevens (monitoring vond niet meer plaats) geen landelijke trend te schatten. Wel is voor de locatie Kornwerderzand duidelijk dat de afnemende trend sinds 2003 doorzet tot en met 2012 (Figuur 3.18). In de diadromevissurvey in 2016-2019 wordt zeeprik ook weer aangetroffen met fluctuerende vangsten, de reeks is nog te kort om een trendinschatting te maken. Voor 
Haringvliet is de afname van zeeprikken al sinds 2014 in de diadromevissurvey te zien (Figuur 3.18). Samengevat lijkt zeeprik tussen 2006-2012 dus af te nemen. Ook tussen 2014 en 2017 lijkt zeeprik af te nemen, maar deze trend is zeer onzeker. Er worden voornamelijk adulte zeeprikken gevangen die naar binnenlandse wateren terugkeren om te paaien, alhoewel er in 2016 en 2018 ook een aantal kleinere zeeprikken zijn gevangen $(19,28$ en $31 \mathrm{~cm}$ ) waarvan gedacht wordt dat ze naar zee aan het migreren waren (Figuur 3.17).

De landelijke trend in 2008-2019 is dus niet statistisch te analyseren, maar lijkt op basis van expert judgement af te nemen.

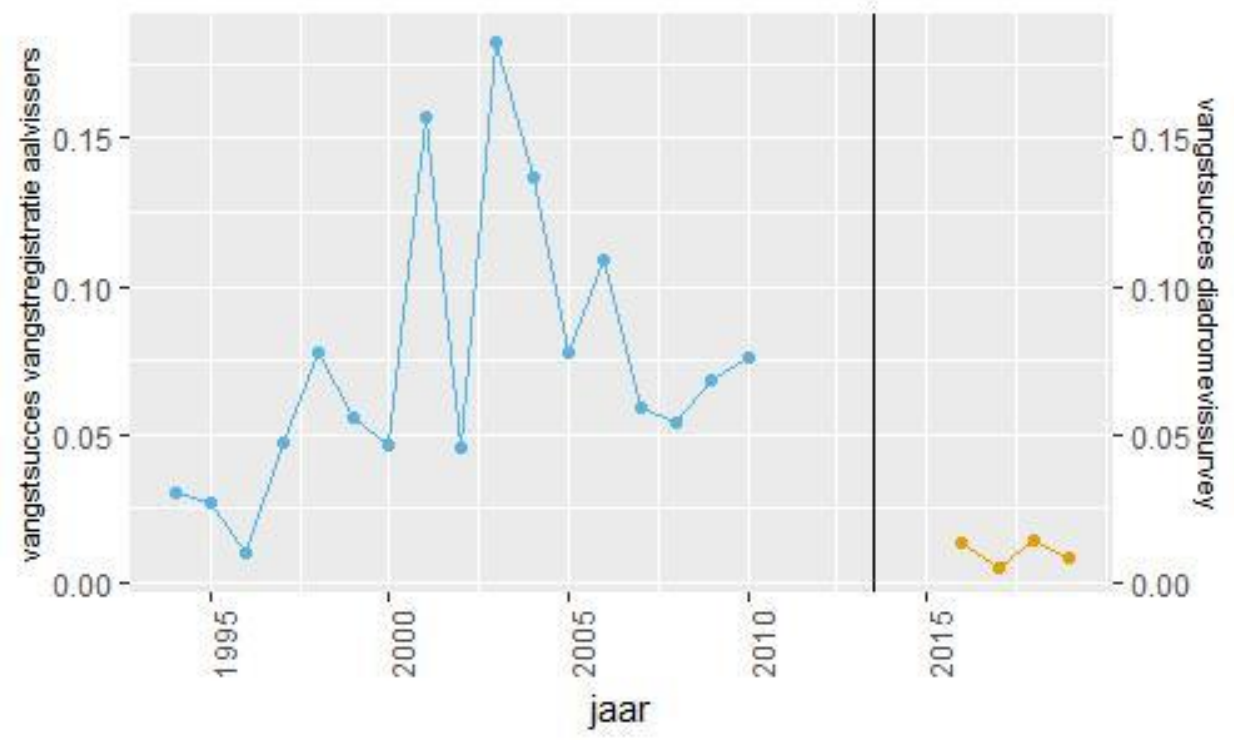

Figuur 3.16. Het gemiddelde vangstsucces (aantal per fuiketmaal) van zeeprik per jaar in de vangstregistratie aalvissers (blauw) en in de diadrome vissurvey (oranje), zoals geschat over in- en uittrekplekken Haringvliet, Kornwerderzand, Nieuwe Waterweg alsmede Rijn (oost), Maas (zuid)). De verticale lijn geeft de scheiding tussen de twee verschillende monitoringen weer.

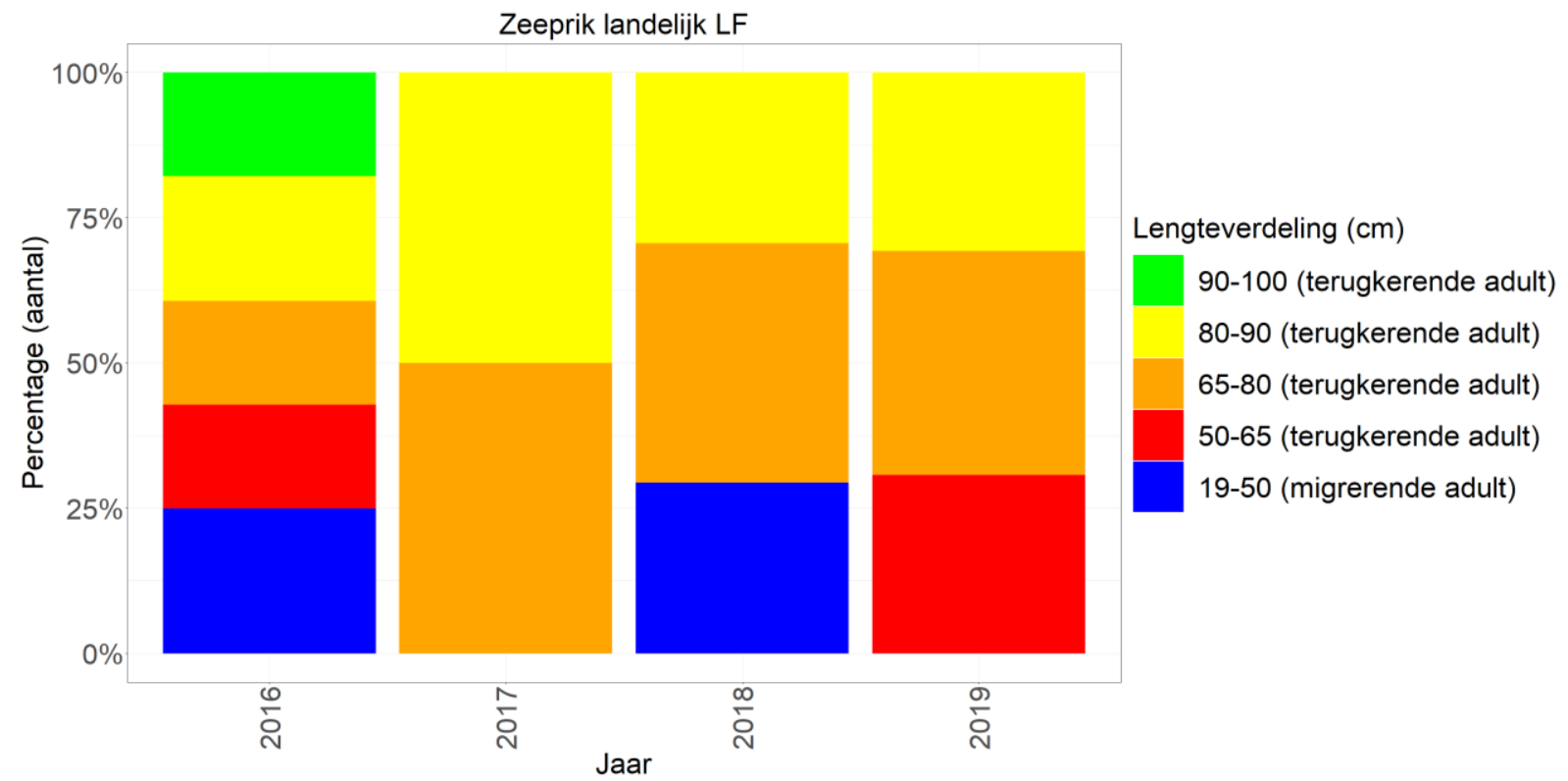

Figuur 3.17 Procentuele lengteverdeling van zeeprik in de diadrome vissurvey. 

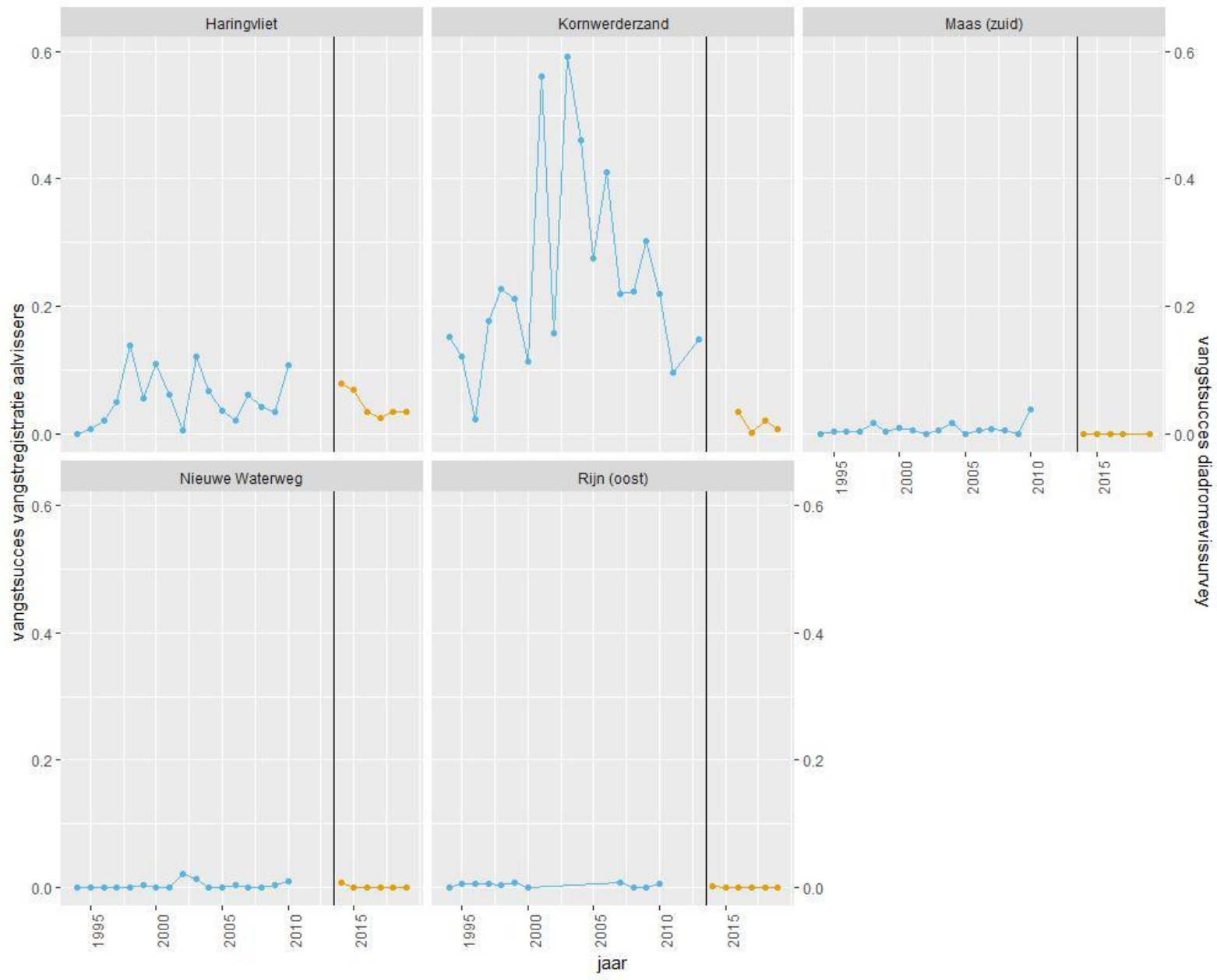

Figuur 3.18. De trend van zeeprik per locatie wat betreft het vangstsucces (aantal per fuiketmaal) per jaar in de vangstregistratie aalvissers (blauw) en in de diadrome vissurvey (oranje), zoals gevangen bij vijf in- en uittrekplekken (Haringvliet, Kornwerderzand, Nieuwe Waterweg, Rijn (oost), Maas (zuid)). De verticale lijn geeft de scheiding tussen de twee verschillende monitoringen weer. 


\subsection{Zalm}

\subsubsection{Ecologie}

De zalm (Salmo salar, Figuur 3.19) realiseert het grootste deel van zijn groei op zee en paait in zoet water. De soort gebruikt Nederland als doortrekgebied naar de paaigebieden over de grens in snelstromende bovenlopen van de rivieren Maas en Rijn met kiezelbodems. De jonge zalm groeit hier één tot twee jaar op en vertrekt dan na een aantal gedaantewisselingen naar zee als 'smolt' $(10-20 \mathrm{~cm})$. Op zee leggen zalmen duizenden kilometers af naar de oceanische voedselgebieden rondom Faröer en zelfs tot aan Groenland, waar ze uitgroeien tot 60-150 cm. Na één of meerdere jaren op zee keren ze terug naar hun geboorterivier om te paaien (Bijlsma et al. 2019). Migratie van paairijpe zalm naar bovenstroomse paaigronden vindt gedurende het hele jaar plaats met een zwaartepunt in de voorzomer en het najaar (Winter \& de Leeuw et al., 2007; Hop en Vriese 2018). Volwassen dieren paaien over het algemeen eenmalig (> $90 \%$ in de Rijnpopulatie) en sterven daarna (LNV, 2008).

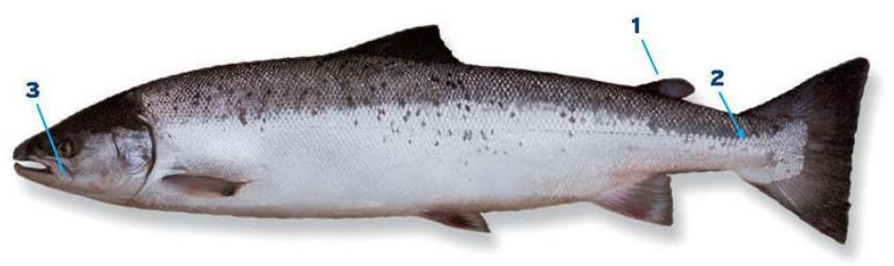

Figuur 3.19. Zalm met onderscheidende kenmerken (bron: Sportvisserij Nederland, meer informatie: http://www.sportvisserijnederland.nl/vis-water/vissoorten/vissengids.html)

\subsubsection{Historische ontwikkeling}

Vroeger werden verschillende populaties, zogenaamde 'rassen' (rivier-eigen deelpopulaties), zalmen onderscheiden waaronder de Rijnzalmen en de Maaszalmen, die Nederland als doortrekgebied gebruikten. De Rijnpopulatie was één van de grootste van Europa en is al sinds de late middeleeuwen in aantal achteruitgegaan (Lenders et al., 2016). Tussen 1885 en 1940 liepen de commerciële vangsten nog verder terug van ca 120.000 vissen per jaar naar enkele exemplaren. De "Maas en Rijn-populaties" worden sinds het midden van de twintigste eeuw als uitgestorven beschouwd (LNV, 2008; Bijlsma et al. 2019).

Trends in populatiegrootte van zalm zijn zeer vermoedelijk sterk beïnvloed door bovenstroomse uitzetprogramma's in de Rijn en Maas: sinds de jaren tachtig van de $20^{\circ}$ eeuw worden zalmen in verschillende stadia en van verschillende herkomst uitgezet in het Rijn-stroomgebied en later gebeurde dat ook op kleinere schaal in de Maas. Deze uitzettingen duren tot op heden voort. De sterftepercentages over de periode van wegtrekkende smolts tot terugkerende volwassen zalmen zijn momenteel te hoog om een zichzelf in stand houdende populatie te vormen (Bijlsma et al. 2019). Het voorkomen van zalm in het Rijn- en Maas stroomgebied is daarmee nog afhankelijk van uitzettingen en daarmee zal ook de trend mede bepaald worden door trends in uitzettingen. Om de zalm als een zichzelf in stand houdende populatie te laten terugkeren zijn aanvullende maatregelen noodzakelijk in zowel zoete als zoute watersystemen (Schneider, 2011; Bijlsma et al. 2019). Er zijn nog veel obstakels die migratie bemoeilijken, er vindt nog een te hoge visserijsterfte plaats op zee en tijdens de trek, en de habitatkwaliteit van paai- en opgroeigebieden is op veel plaatsen nog te gering (Schneider, 2011).

\subsubsection{Huidige ontwikkeling en trend}

De staat van instandhouding (2007) van de zalm is 'zeer ongunstig' (LNV, 2008). 
Voor de monitoring van zalm (en zeeforel) is een specifiek passief monitoringsprogramma; de zalmsteeksurvey. Van de locaties in dit programma wordt voor de landelijke trend over de laatste 12 jaar de Waal als meest representatieve gezien, omdat het overgrote deel van de trekkende zalmen in Nederland via de Waal gaat (Hop en Vriese, 2018) en omdat er bij de andere meetpunten trendbreuken in de reeksen zijn, waardoor deze niet goed bruikbaar zijn voor lange-termijn ontwikkelingen in 20082019.

De trend is statistisch onderzocht met Trendspotter: over 2006-2017 vindt een sterke statistisch significante afname in vangstsucces plaats (Tien et al. 2019). In 1997-2002 nam het vangstsucces toe, gevolgd door een vrij stabiele fase (2003-2009) en een sterke afname vanaf 2010 (Figuur 3.20). Deze trend komt overeen met de trend stroomopwaarts in de belangrijkste paaizijrivier in Duitsland, bij Sieg (ongepubliceerde gegevens van de 'Rheinischer Fischereiverband von 1880 e.V.'). In 2019 is het vangstsucces iets gestegen ten opzichte van 2017 en 2018 maar nog steeds erg laag (Figuur 3.20, Figuur 3.21). Er worden voornamelijk terugkerende adulten gevangen ( $>50 \mathrm{~cm}$ ). Tot 2014 werden ook zalmen $<50 \mathrm{~cm}$ gevangen, dit zouden zalmen kunnen zijn die hun weg naar open zee niet kunnen vinden of te "jong" al de rivieren op trekken. Dit zouden wellicht ook zee- /beekforellen kunnen zijn die abusievelijk als zalm gedetermineerd zijn.

Om een beeld te krijgen van de zalmen die niet de Rijn maar de Maas optrekken zijn ook de gegevens van de zalmvangsten in de Maas bij Lith in een grafiek weergegeven (Figuur 3.22, Figuur 3.23). Deze gegevens worden jaarlijks sinds 1994 in mei-juli en oktober-november verzameld, en vanaf 2014 om het jaar. Net als bij de landelijke trend (van de Waal) is er na het jaar 2000 een sterke afname te zien die niet lijkt te herstellen. Waar bij de trend van de Waal nog een licht herstel lijkt op te treden in de jaren voor 2010 is dit niet het geval voor de zalm in de Maas. Net als in de Waal worden voornamelijk terugkerende adulten gevangen $(>50 \mathrm{~cm}$ ) en tot 2014 werden er ook zalmen $<50 \mathrm{~cm}$ gevangen.

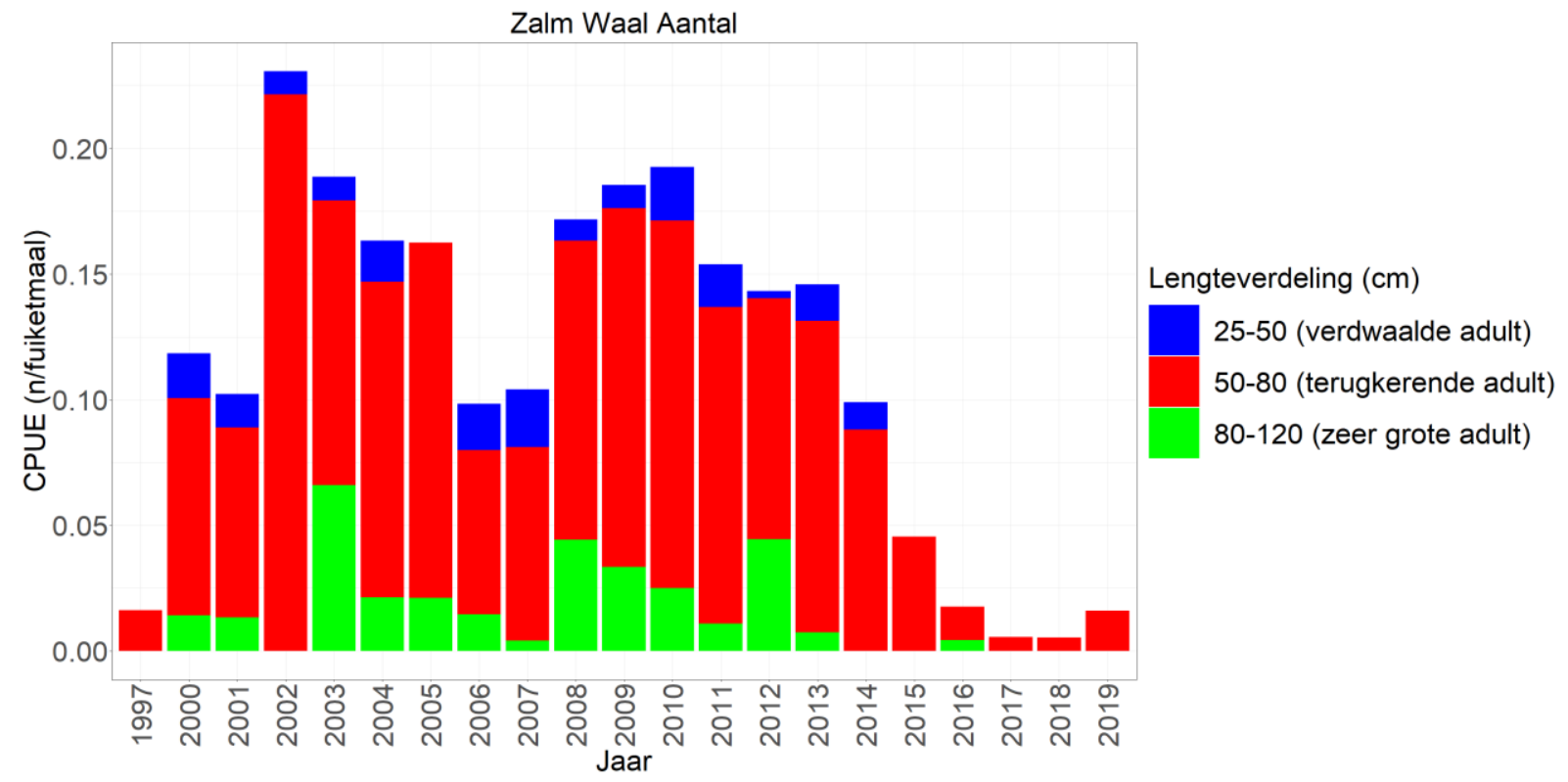

Figuur 3.20. Gemiddelde vangstsucces (aantal per fuiketmaal) van zalm per jaar met lengteverdeling, zoals gevangen in de zalmsteeksurvey in de Waal. 


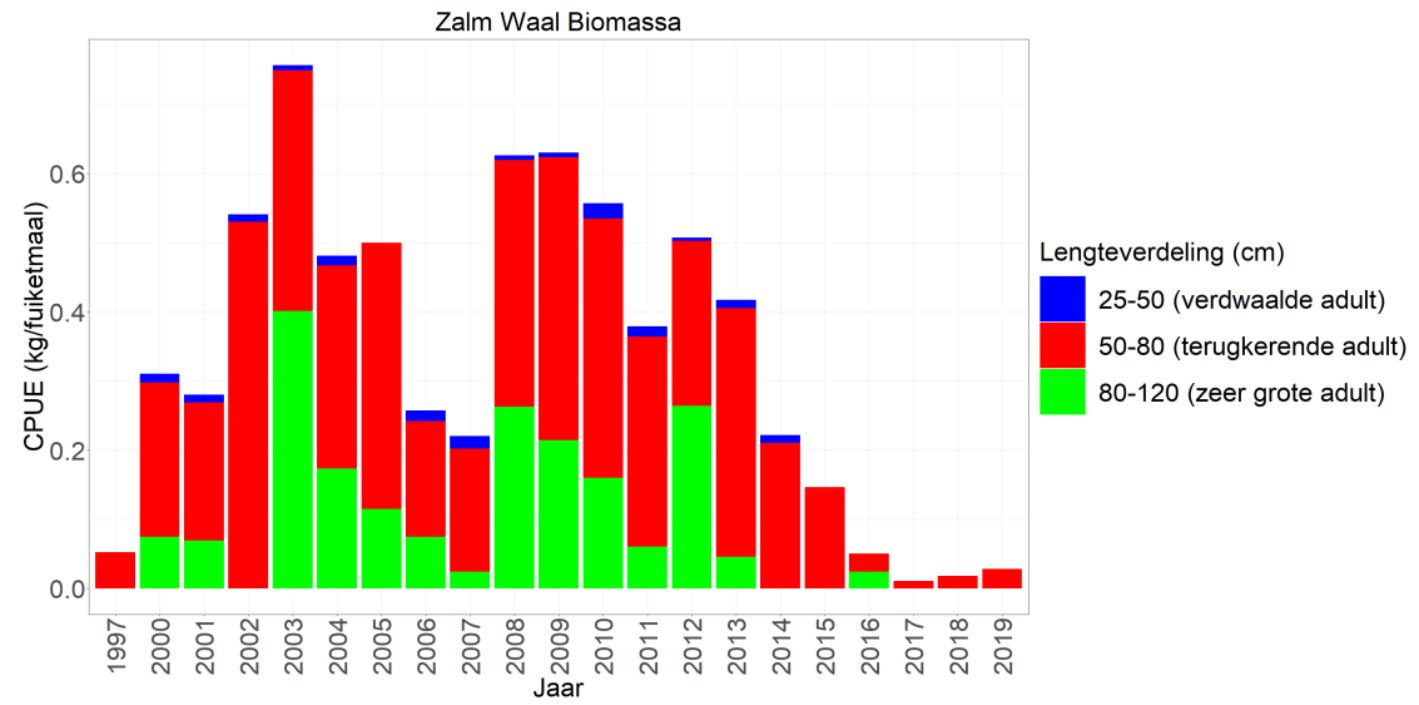

Figuur 3.21. Gemiddelde vangstsucces (kilogram per fuiketmaal) van zalm per jaar met lengteverdeling, zoals gevangen in de zalmsteeksurvey in de Waal.

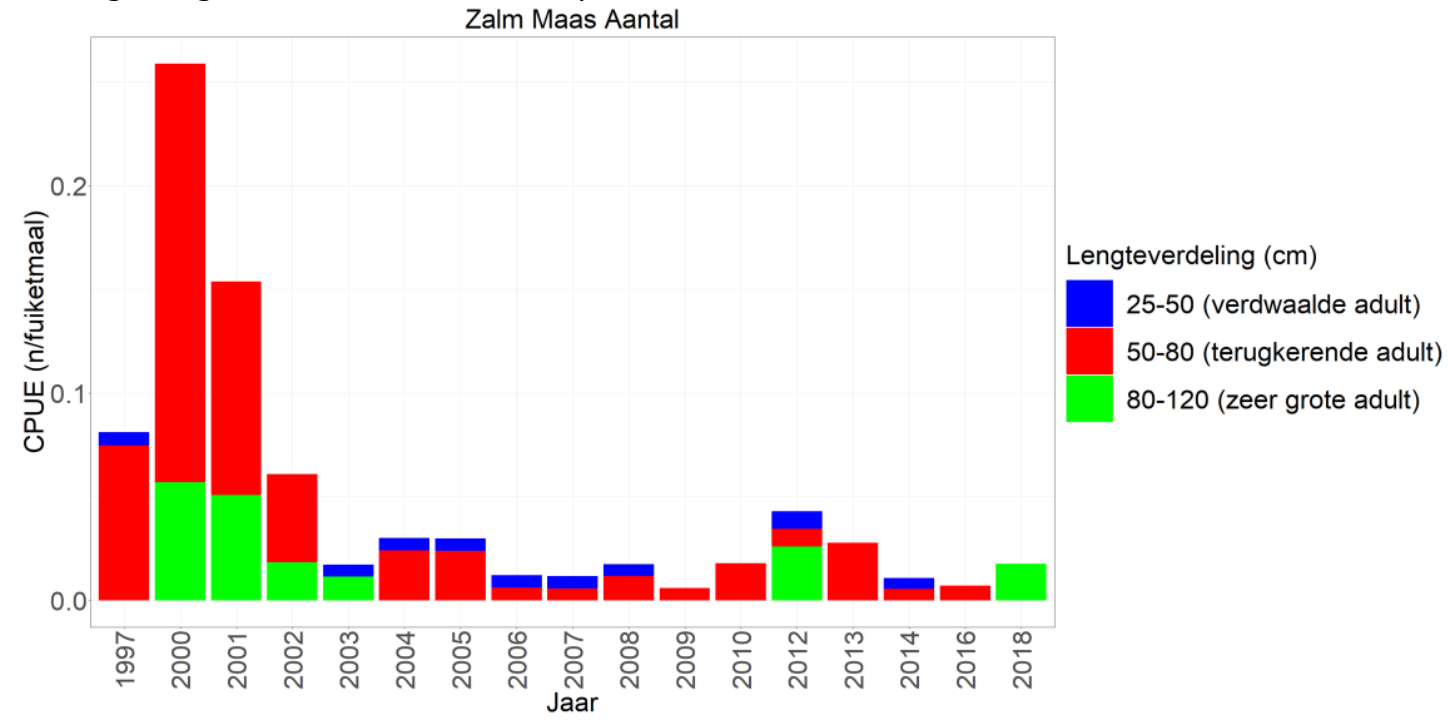

Figuur 3.22. Gemiddelde vangstsucces (aantal per fuiketmaal) van zalm per jaar met lengteverdeling, zoals gevangen in de zalmsteeksurvey in de Maas (Lith).

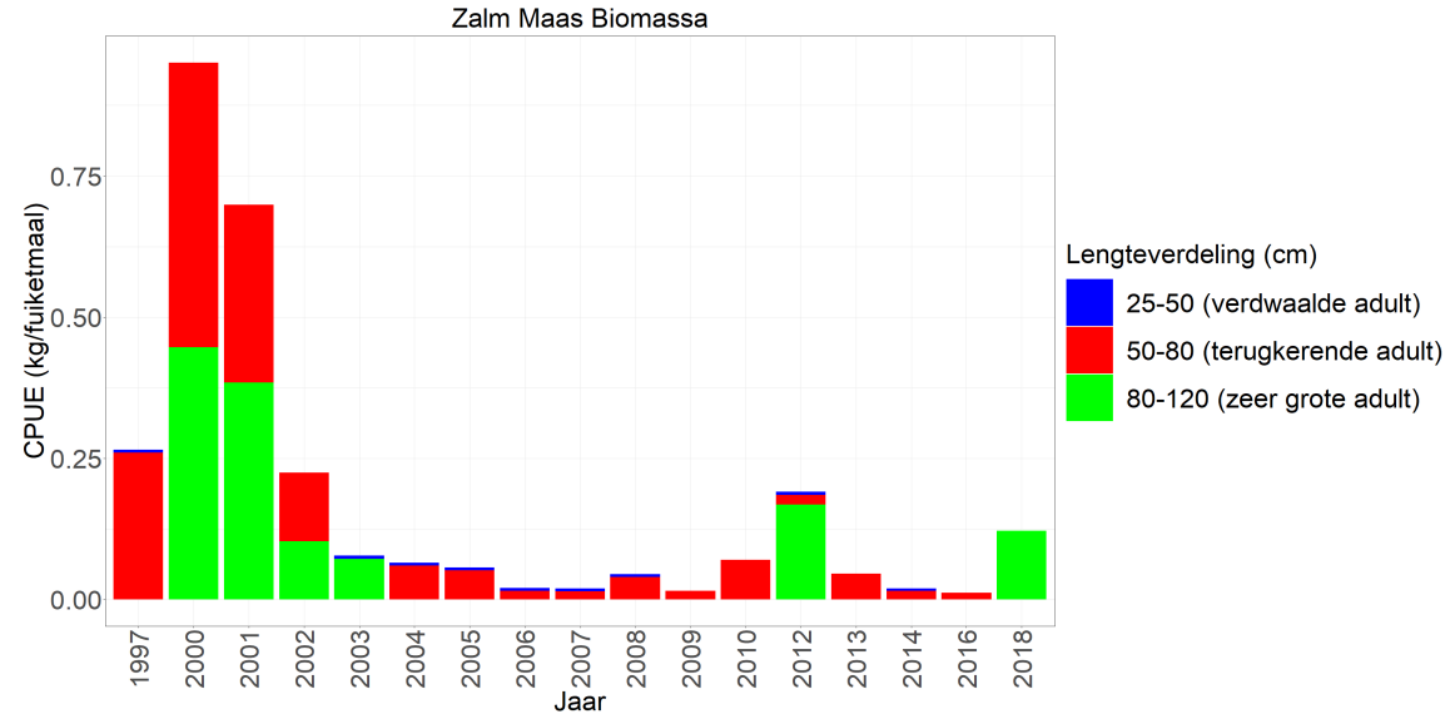

Figuur 3.23. Gemiddelde vangstsucces (kilogram per fuiketmaal) van zalm per jaar met lengteverdeling, zoals gevangen in de zalmsteeksurvey in de Maas (Lith). 


\subsection{Discussie en conclusies}

De twee HR-soorten waarvan de trend in vangstsucces statistisch onderzocht kon worden, barbeel en zalm, laten allebei een afname over de periode 2006-2017 zien. Binnen deze 12 jaar is barbeel vanaf 2007 vrij stabiel (op één uitschieter na) tot in 2011 maar neemt daarna af. Zalm gevangen in de Waal is vanaf 2007 vrij stabiel tot in 2010 en neemt daarna af. In de Maas neemt zalm sinds het begin van de monitoring af. Barbeel wordt nauwelijks nog gevangen op de Grensmaas, waar deze eerst juist voornamelijk voorkwam. Ook Noordzeehouting en zeeprik lijken af te nemen gedurende grofweg de laatste tien jaren, alhoewel voor deze soorten geen consistente tijdreeks over de hele periode beschikbaar is. Noordzeehouting neemt sterk toe tot in 2009 en neemt daarna af (in ieder geval tot in 2012 en waarschijnlijk ook daarna). Zeeprik neemt vanaf 2003 al af, in ieder geval tot in 2010 en waarschijnlijk tot in 2019. Alle vier de soorten lijken dus afgenomen in de periode 2008-2019.

De afname in het vangstsucces van drie van de vier soorten begint rond dezelfde tijd (2010-2014); zalm (Waal), barbeel, Noordzeehouting. Zeeprik en zalm op de Maas nemen al langer af. Het is dus voor in ieder geval zalm (Waal), barbeel en Noordzeehouting mogelijk dat de oorzaak voor afname (deels) dezelfde is. Aangezien de tijdreeksen van deze drie soorten afkomstig zijn van verschillende locaties (Grensmaas voor barbeel, Waal voor zalm, en vijf andere locaties voor Noordzeehouting) is enkel een locatie-specifieke oorzaak niet voordehandliggend. Het lijkt logischer dat hierbij veranderingen op een grotere ruimtelijke schaal een rol spelen, zoals veranderingen van menselijke activiteiten, (bijvoorbeeld verschillende vormen van recreatieve of beroepsvisserij en stroperij), of natuurlijke sterfte (zoals ziektes of predatie door vogels of roofvissen). Wellicht speelt de verminderde water afvoer, langere periodes van (extreme) droogte in combinatie met het dichtslibben van nevengeulen (Stoffers et al. 2020) hier ook een (grote) rol.

Voor rivierprik en fint zijn de beschikbare tijdreeksen nog te kort (respectievelijk twee/drie en vijf jaar) om uitspraken te doen over trends. Voor rivierprik zijn alleen monitoringsprogramma's geschikt waarin in minimaal de paaimaanden november en december bemonsterd worden op dezelfde fuiklocaties; dit geldt momenteel alleen voor de diadromevissurvey in het Haringvliet vanaf 2012 en in het IJsselmeer bij Kornwerderzand vanaf 2017. Het wordt daarom ook sterk aanbevolen om de uitvoering van de diadromevissurvey in december voort te blijven zetten.

Voor fint geldt daarnaast dat de jaar-op-jaar variatie binnen de vier beschikbare monitoringsjaren erg groot is. Wel lijkt het vangstsucces van fint sinds 2006 hoger te zijn dan ervoor (vanaf 1994).

De bestandsgrootte van elft is zo klein, dat deze onder het detectieniveau van de Nederlandse monitoringprogramma's ligt. Wel is vanuit vangsten in Duitsland bekend (Figuur 3.5) dat elft voorkomt in de Nederlandse wateren: de trend is dus onzeker, met een zeer lage bestandsgrootte. Mocht elft in de toekomst significant toenemen, dan zou dit binnen de monitoring waargenomen moeten kunnen worden. 


\section{Evaluatie Natura 2000-gebieden}

\subsection{Inleiding en methode}

Om beheerplannen van Natura 2000-gebieden te kunnen evalueren met betrekking tot de status van de beschermde vissoorten (Habitatrichtlijn Annex II soorten), worden in dit hoofdstuk de instandhoudingsdoelstellingen voor vissoorten in vijf Rijkswateren geëvalueerd.

Elk Natura 2000-gebied in Nederland kent een aanwijzingsbesluit en een (concept)beheerplan waarin staat welke instandhoudingsdoelstellingen en maatregelen voor de relevante habitattypen en soorten zijn vastgesteld. Aan het einde van de beheerplanperiode (na 6 jaar), en eventueel al halverwege (na 3 jaar), moet een beheerplan geëvalueerd worden om vast te stellen in hoeverre de gestelde instandhoudingsdoelstellingen zijn gehaald. In dit rapport wordt gekeken naar de Habitatrichtlijn (HR)vissoorten zeeprik, rivierprik en fint in de Natura 2000-gebieden Waddenzee, Noordzeekustzone en de Deltawateren (Haringvliet, Hollandsch Diep, Oude Maas, Veerse Meer, Grevelingen, Oosterschelde en Westerschelde \& Saeftinghe). Voor de wateren van het Haringvliet en het Hollandsch Diep worden de zalm en elft ook getoetst. Voor het Haringvliet worden ook de rivierdonderpad en bittervoorn getoetst, alhoewel er voor de bittervoorn geen geschikte monitoring plaats vindt in het habitat waar deze voorkomt en er daardoor dus geen geschikte data aanwezig is. De overige wateren van de Deltawateren (Oude Maas, Veerse Meer, Grevelingen en Oosterschelde) worden niet op vissoorten getoetst aangezien er geen vissoorten als habitatsoorten staan aangegeven in de beheerplannen van deze wateren.

Een instandhoudingsdoelstelling is opgebouwd uit 3 aspecten die getoetst moeten worden: Omvang leefgebied, Kwaliteit leefgebied en Populatie. In dit rapport wordt alleen gekeken naar het aspect Populatie. Het referentiejaar voor de instandhoudingsdoelstelling voor de populatie is het jaar van aanwijzing van het Natura 2000-gebied (2009 voor de Waddenzee, Noordzeekustzone en Westerschelde, 2013 voor het Hollandsch Diep en 2015 voor het Haringvliet). Bij een verbeterdoelstelling moet vastgesteld worden of de populatie t.o.v. het referentiejaar is toegenomen. Bij een behoudsdoelstelling moet de populatie ten minste even groot zijn gebleven.

De toegepaste methodiek is in overleg met RWS opgesteld (Bos et al., 2020). Uit de datasets van alle uitgevoerde bemonsteringen en informatie over HR-vissoorten, zowel in zoete als in zoute wateren, zijn per HR-vissoort per Natura 2000-gebied geschikte datasets geselecteerd. Deze selectie is gebaseerd op tien verschillende aspecten. Voorbeelden hiervan zijn: valt de monitoring binnen het Natura 2000gebied? Valt de monitoring samen met de trekperiode in het geval van migrerende soorten? Is het vistuig en/of het bemonsterde habitat geschikt? Wat is de rol van het Natura 2000 gebied voor de desbetreffende vissoorten? Voor verdere details zie (Bos et al., 2020).

De Waddenzee is een gebied waar de HR-vissoorten fint, zeeprik en rivierprik het hele jaar door foerageren. Dit gebied zal ook als corridor fungeren voor soorten die naar het IJsselmeer en andere binnenwateren migreren. Fint gebruikt de Waddenzee ook om op te groeien. Er vinden verscheidene monitoringen plaats op en langs de Waddenzee.

De actieve monitoring die met behulp van een boomkor plaatsvindt is de demersal fish survey (DFS). Doordat de vangkans van migrerende soorten met een actief tuig zeer gering is, wordt er voor dit gebied geen dataselectie m.b.t. de trekperiode toegepast, waardoor gevangen individuen ook foeragerende vissen kunnen zijn. Rivierprik en met name fint zouden aan de hand van dit tuig gevangen kunnen worden, deze monitoring is echter niet geschikt om zeeprik te monitoren.

Naast de DFS vinden er bij de sluizen van de afsluitdijk twee fuikenmonitoringen plaats. De diadrome vismonitoring zoete Rijkswateren (FDIA) en de diadrome vismonitoring Kornwerderzand (DIADROOM). 
De FDIA monitoring vindt zowel bij de sluizen van Den Oever als bij de sluizen van Kornwerderzand aan de IJsselmeerzijde plaats (naast negen overige locaties in de Nederlandse binnenwateren). De DIADROOM-monitoring vindt alleen bij de sluizen van Kornwerderzand plaats aan de Waddenzeezijde. Beide monitoringen zijn met name geschikt voor binnentrekkende zeeprik en rivierprik die op zoek zijn naar paaiplaatsen in de (Europese) binnenwateren. De DIADROOM-monitoring aan de Waddenzeezijde is ook geschikt voor het monitoren van fint. Aangezien de volwassen individuen die tijdens de trekperiode hier gevangen worden waarschijnlijk deelnemen aan de paaitrek, wordt er voor deze datasets wel een selectie gemaakt voor de trekperiode per soort. Daarnaast wordt er ook onderscheid gemaakt in de volwassenen en juvenielen, zodat de paaipopulatie en dieren die in het gebied opgroeien/foerageren apart beoordeeld kunnen worden.

De vierde monitoring die we kunnen gebruiken voor de Waddenzee is de fuik van het Koninklijk Nederlands Instituut voor Onderzoek der Zee (NIOZ) op Texel. Sinds 1959 is het NIOZ begonnen met een vismonitoring waarbij verschillende locaties met verschillende tuigen zijn bemonsterd. Vanaf 1974 wordt alleen nog de zogenaamde 'komfuik' bij de Stuifdijk, op de kop van Texel in het Marsdiep gebruikt. Deze vismonitoring start jaarlijks vanaf maart of april en de fuik blijft in het water tot oktober. Van deze data zijn alleen jaarlijks gevangen aantallen beschikbaar waardoor een (uitgebreide) trendanalyse (zoals voor de andere gegevens wordt uitgevoerd) voor deze data niet mogelijk is. Deze gegevens zullen gepresenteerd worden en zullen ter ondersteuning van de conclusies gebruikt worden.

De Noordzeekustzone is met name een foerageergebied voor populaties van rivierprik, zeeprik en fint. Voor fint wordt dit gebied ook gebruikt om op te groeien. Dit gebied fungeert in mindere mate dan de Waddenzee ook als corridor voor deze soorten. De DFS vindt ook in de Noordzeekustzone plaats, en ook hier wordt er geen dataselectie m.b.t. de trekperiode toegepast en is de monitoring met name interessant voor fint en ook rivierprik. Voor dit gebied worden ook de gegevens van de DIADROOMmonitoring bij de sluizen bij Kornwerderzand en de NIOZ-fuik bij Texel gebruikt aangezien deze monitoringen ook informatie verschaffen over populaties in de Noordzeekustzone.

Het Haringvliet is een gebied dat door de HR-soorten elft, fint, rivierprik, zeeprik en zalm voornamelijk als corridor wordt gebruikt. Voor elft en fint zou dit gebied deels ook als opgroeigebied kunnen fungeren terwijl voor de rivierprik en de fint het Haringvliet ook als foerageergebied kan fungeren. De rivierdonderpad is een HR-soort die zijn gehele levenscyclus in dit gebied volbrengt. De FDIA-monitoring vindt ook op verschillende locaties in het Haringvliet plaats en wordt gebruikt om populaties van elft, fint, rivierprik, zeeprik en zalm te toetsen. Daarnaast wordt voor de zalm ook de gegevens van de zalmsteken monitoring op de Waal gebruikt aangezien het grootste gedeelte van de zalm populatie via de Waal door Nederland trekt (Hop en Vriese 2018). Van deze groep zalmen trekt ook weer het merendeel door het Haringvliet en de Haringvlietsluizen (Vriese 2018, van Rijssel et al. 2019b) waardoor de zalmstekenmonitoring op de Waal ook deels representatief zal zijn voor het Haringvliet. Voor zowel de fint van de FDIA-monitoring als voor de zalm in de zalmstekenmonitoring is onderscheid gemaakt tussen volwassen en juveniele individuen. Voor de rivierdonderpad zijn de gegevens van de actieve monitoring op de grote rivieren gebruikt om de populatietrend te toetsen.

Het Hollandsch Diep verschilt niet veel van het Haringvliet qua HR-soorten en monitoring. Elft, fint, rivierprik, zeeprik en zalm gebruiken dit gebied voornamelijk als corridor, waarbij elft en fint het gebied mogelijk als opgroeigebied kan gebruiken en de rivierprik het mogelijk als foerageergebied gebruikt. Voor het Hollandsch Diep worden de FDIA-monitoring gegevens van het Haringvliet gebruikt (in het Hollandsch Diep zelf staan geen fuiken) voor deze soorten. Voor de zalm worden tevens de gegevens van de zalmsteken gebruikt om dezelfde redenen als voor het Haringvliet. De rivierdonderpad geldt niet als habitatsoort voor het Hollandsch Diep.

De Westerschelde \& Saeftinghe is een gebied dat door de HR-soorten fint, rivierprik en zeeprik wordt gebruikt om te foerageren en tevens als corridor fungeert. Voor fint is de Westerschelde ook een opgroeigebied. Dit gebied wordt sinds 2007 ieder voor- en najaar bemonsterd met de ankerkuil. Ook voor deze gegevens wordt er voor fint onderscheid gemaakt tussen volwassen en juveniele individuen. 
Veel datasets bevatten een groot percentage nulwaarnemingen (geen vis gevangen). Hierdoor is de gemiddelde vangst per monster klein. Wanneer er wel voldoende aantallen vissen gevangen zijn, wordt de trend statistisch getoetst m.b.v. logistische regressie (GLM) op basis van aantallen. Als toepassing van GLM op aantallen niet tot een significante trend leidt, dan is vervolgens getoetst met GLM op de kans op aan/afwezigheid van een vissoort in een gebied. Als er veel nulwaarnemingen zijn, dan is er direct getoetst m.b.v. GLM op basis van de kans op aan/afwezigheid van een vissoort in een gebied. In een groot deel van de soort-gebiedscombinaties is door beperkte data deze laatste de gebruikte methode.

Het doelbereik is bepaald door de statistische uitkomst van de trendanalyse te vergelijken met de instandhoudingsdoelstelling voor een bepaalde HR-vissoort in een Natura 2000-gebied. Als het doel bijvoorbeeld 'uitbreiding populatie' is, dan is het doel bereikt wanneer aangetoond kan worden dat de populatie een positieve trend vertoont die statistisch significant is met $P<0.05$. Dit zegt echter nog weinig over de mate van uitbreiding van de populatie. Wanneer de trend onzeker is kan niet met zekerheid worden gesteld of de doelen wel of niet zijn behaald.

De uiteindelijke evaluatie van de instandhoudingsdoelstelling voor een soort in een gebied zal niet alleen gebaseerd moeten worden op de uitkomst van de statistische analyse van de data, maar dient ook in de juiste context geplaatst te worden door middel van expert-kennis. Daarom worden, ter ondersteuning, alle monitoringsresultaten sinds de start van de monitoring tevens geplot, zodat de statistische resultaten visueel in perspectief geplaatst kunnen worden. Deze reeks gaat vaak veel verder terug dan het jaar van het aanwijzingsbesluit.

\subsection{Ecologie Habitatrichtlijn soorten}

De ecologie van de habitatrichtlijn soorten is voor zeeprik, rivierprik, fint, elft en zalm te lezen in Hoofdstuk 3, de ecologie van de rivierdonderpad is hieronder beschreven.

\subsubsection{Rivierdonderpad}

\subsubsection{Ecologie}

De rivierdonderpad (Cottus perifretum, Figuur 4.1) is een kleine rheofiele vissoort die vooral in heldere, kleinere stromende wateren met een zandige of stenige bodem voorkomt. Hier is deze vissoort vooral te vinden in het zuurstofrijke water van stroomversnellingen. Ook in stilstaande wateren komt de rivierdonderpad voor, vooral in de met basaltblokken of puin beschermde oeverzone van grote meren en plassen. De paaitijd valt in maart en april, als het water 10 tot $12{ }^{\circ} \mathrm{C}$ is. De rivierdonderpad wordt niet groter dan $15 \mathrm{~cm}$. In het eerste jaar bereikt hij een lengte van 4 tot $5 \mathrm{~cm}$, in het tweede jaar wordt de rivierdonderpad geslachtsrijp.

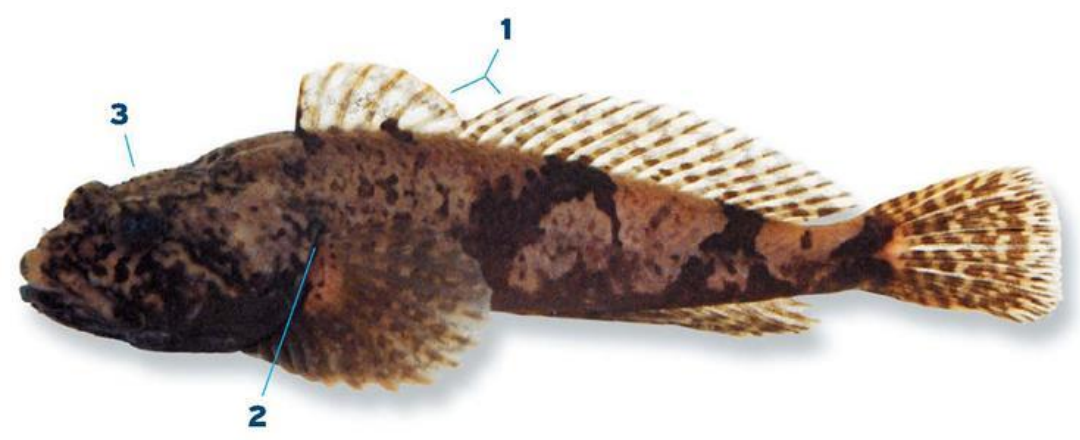

Figuur 4.1. Rivierdonderpad met onderscheidende kenmerken (bron: Sportvisserij Nederland, meer informatie: http://www.sportvisserijnederland.nl/vis-water/vissoorten/vissengids.html) 


\subsubsection{Historische ontwikkeling}

Onderzoek heeft uitgewezen dat de (zoetwater)donderpad in Nederland kan worden onderverdeeld in twee soorten, namelijk Cottus rhenanus ('beekdonderpad') en Cottus perifretum ('rivierdonderpad') (Freyhof et al., 2005). Cottus gobio, zoals de Nederlandse donderpad tot voor kort werd genoemd, komt in ons land niet voor. Donderpadpopulaties welke momenteel onder de naam Cottus gobio worden geschaard hebben een oostelijker verspreidingsgebied in midden Europa en Scandinavië. Bij onderzoek aan Natura 2000 gebieden, aangewezen (mede) voor de donderpad bleek dat het in bijna alle gevallen om de rivierdonderpad Cottus perifretum gaat. Alleen in het Geuldal en in het Roerdal net over de grens in België komt ook de beekdonderpad Cottus rhenanus voor (Crombaghs et al. 2007). Het geslacht Cottus komt in bijna heel Europa voor, tot ver in Rusland. Redeke (1941) schrijft dat de (rivier)donderpad tussen 1900 en 1940 verspreid in Nederland voor kwam in beken, rivieren, meren en 'oude slootjes' in Friesland. De rivierdonderpad C. perifretum kwam al in 1893 voor in Zuid-Holland, terwijl de beekdonderpad C. rhenanus al in 1919 in de Geul rondzwom.

De Nie (1996) beschrijft meldingen waaruit blijkt dat de donderpad op verschillende plaatsen in de periode daarna achteruitging (Zuid-Hollandse boezemwateren) dan wel geheel uitstierf door beeknormalisaties (Gelderse vallei) en watervervuiling (drie Zuid-Limburgse beken). Crombaghs et al. (2007) achten het waarschijnlijk dat beide soorten leden onder de slechte waterkwaliteit in de jaren '60'70, met name ook vanwege de gevoeligheid van donderpadden voor zware metalen.

De ontwikkeling van de donderpad vertoonde in de laatste decennia een gevarieerd beeld. Zowel in het IJsselmeer als op de rivieren nam de vangstfrequentie van donderpadden in de jaren ' 80 toe. In de grote rivieren werd de donderpad bovengemiddeld frequent aangetroffen (de Nie, 1996). Ook in Friesland en Noord- en Zuid-Hollandse wateren werd de donderpad op veel plaatsen aangetroffen. Het is nu inmiddels duidelijk dat dit $C$. perifretum betreft: een hybride vorm tussen de $C$. rhenanus en de 'pure' vorm van $C$. perifretum, welke voorkomt in Noordwest Frankrijk, het westelijk deel van België en Engeland (Freyhof et al., 2005, Nolte \& Sheets, 2005, Nolte et al., 2005). Lokaal in Limburg, Noord-Brabant en Overijssel was er eind 20 e eeuw daarentegen juist sprake van een afname van het voorkomen van de donderpad. Deze afname betrof in een aantal gevallen zeker de donderpad die nu te boek staat als 'beekdonderpad' C. rhenanus, maar het is niet uit te sluiten dat het plaatselijk ook de rivierdonderpad $C$. perifretum betrof.

De rivierdonderpad komt op veel meer plaatsen voor dan de beekdonderpad, zoals de Zeeuwse delta en de randmeren. Samenvattend kan gesteld worden dat zowel $C$. perifretum als $C$. rhenanus al lang in Nederland aanwezig zijn. Midden vorige eeuw zijn beide soorten sterk achteruitgegaan, hoogstwaarschijnlijk vanwege een verslechtering van de waterkwaliteit. Door de verbetering van de waterkwaliteit en het intensieve gebruik van stortsteen heeft vooral de rivierdonderpad $C$. perifretum een sterke opmars gemaakt stroomopwaarts. Maar ook de beekdonderpad is weer toegenomen. In de periode 2000-2008 heeft de beekdonderpad zich vanuit de zijbeken van de Geul weer naar de Geul zelf uitgebreid, terwijl ook in de zijbeken zelf de verspreiding toenam. De laatste tien jaar is er juist weer een sterke afname van de rivierdonderpad door heel Nederland te zien, wat hoogstwaarschijnlijk te maken heeft met de opkomst van de invasieve grondels (Tien et al. 2019). Van Kessel et al. (2016) hebben bijvoorbeeld al aangetoond dat de afname van rivierdonderpadden in de Maas zeer waarschijnlijk komt door predatie en competitie voor schuilplaatsen en voedsel met de invasieve zwartbekgrondel. 


\subsection{Waddenzee}

De Waddenzee is in 2009 aangewezen als Natura 2000-gebied. De vissoorten die in het beheerplan van de Waddenzee zijn opgenomen zijn zeeprik, rivierprik en fint. De doelstelling voor alle drie de soorten is uitbreiding van de populatie. De Waddenzee fungeert voor deze soorten als foerageer- en doortrekgebied voor de paaitrek, voor fint is de Waddenzee ook een opgroeigebied. De monitoringprogramma's die hier plaatsvinden zijn de Demersal Fish Survey (DFS) met de boomkor, FDIA (Kornwerderzand, Den Oever aan de IJsselmeerzijde), DIADROOM (Kornwerderzand aan de Waddenzeezijde) met fuiken en de NIOZfuik op Texel. Voor de dataset van de DFS is geen selectie op trekperiode of lengte toegepast aangezien deze monitoring plaatsvindt in het foerageergebied van de geselecteerde HR-vissoorten. Daarnaast is de vangkans voor deze soorten met een actief tuig erg gering. Voor de datasets van de FDIA en DIADROOM monitoring, waarbij de fuiken dichtbij de sluizen van Kornwerderzand en Den Over staan, zijn alleen de data uit de trekperiode geselecteerd conform Tabel 4.1. Voor fint is bovendien onderscheid gemaakt tussen volwassen individuen $(>30 \mathrm{~cm}$ ) en juveniele individuen, zodat kan worden gekeken of het om individuen gaat die dit gebied als doortrekgebied gebruiken of om te paaien. Voor zeeprik en rivierprik was het niet mogelijk om de individuen op te splitsen in volwassenen en juvenielen omdat met het gebruikte vistuig alleen volwassen individuen worden gevangen (kleine prikken zwemmen door mazen van de fuik heen).

De gegevens van de DIADROOM-monitoring en de NIOZ-fuik zijn zowel voor de Waddenzee als de Noordzeekustzone gebruikt om de gebieden te toetsen, aangezien ze voor beide gebieden een indicatie van de populatie trends geven.

Tabel 4.1 Trekperiode trekvis.

\begin{tabular}{ll} 
Soort & Maanden in ciffers \\
Fint & gehele voorjaarsperiode $(1 ; 2 ; 3 ; 4 ; 5 ; 6)$ \\
\hline Rivierprik & $10 ; 11 ; 12$ \\
\hline Zeeprik & $3 ; 4 ; 5 ; 6$ \\
\hline
\end{tabular}

\subsubsection{Zeeprik}

\section{Onderzoeksvraag}

Wat is de trend van zeeprik in de Waddenzee voor de periode 2009-2019?

\section{Databeschikbaarheid}

\section{DFS}

Data zijn beschikbaar vanaf 1970. De DFS gegevens worden niet gebruikt om de zeeprik te toetsen aangezien deze monitoring hiervoor niet geschikt is. Zeeprik is ook sinds 2000 niet meer gevangen in de DFS in de Waddenzee.

\section{FDIA}

Voor de zeeprik zijn data uit de jaren 2014-2019 beschikbaar (Figuur 4.2) van twee locaties (Kornwerderzand en Den Oever, beide aan de IJsselmeerzijde), bemonsterd in de maanden maart, april, mei en juni. In 2014 is alleen de locatie Den Oever bemonsterd en in 2015 zijn geen van beide locatie bemonsterd. Aangezien beide locaties vergelijkbare trends vertonen zijn deze samengevoegd voor de trendanalyse. 


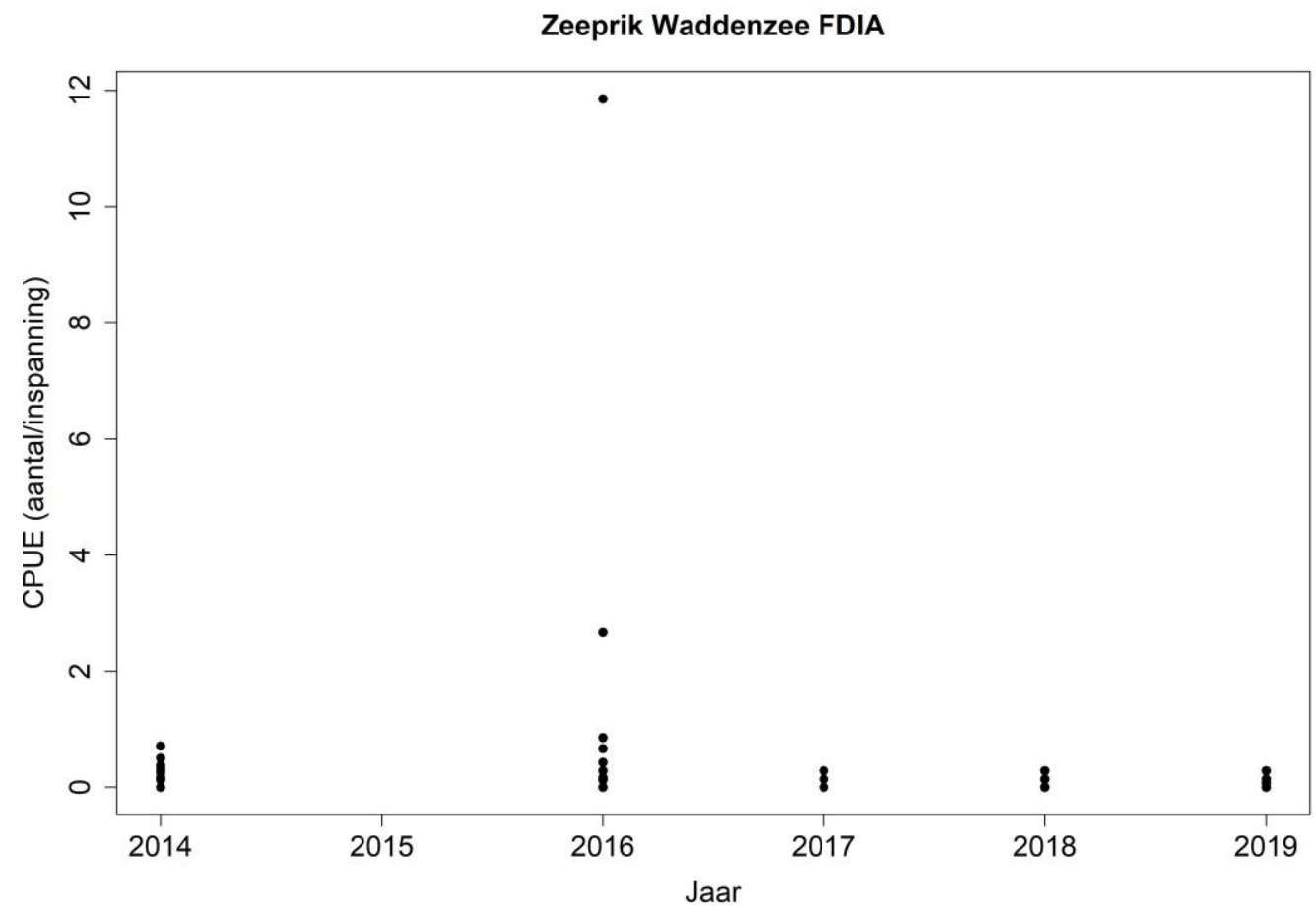

Figuur 4.2. Vangst per eenheid inspanning (CPUE) per bemonstering per jaar voor zeeprik in de fuiken bij Kornwerderzand en Den Oever (IJsselmeerzijde).

\section{Analyse}

Omdat de zeeprik in de periode 2014-2019 in voldoende aantallen gevangen is met de fuiken, is een statistische analyse met GLM o.b.v. aantallen uitgevoerd. In deze periode is een significante $(P<0.001)$ afname van zeeprik in de Waddenzee opgetreden (Figuur 4.3). De trend heeft een jaareffect van 0,60 wat betekent dat zeeprik gemiddeld ieder jaar met $40 \%$ is afgenomen.

\section{Zeeprik Waddenzee FDIA}

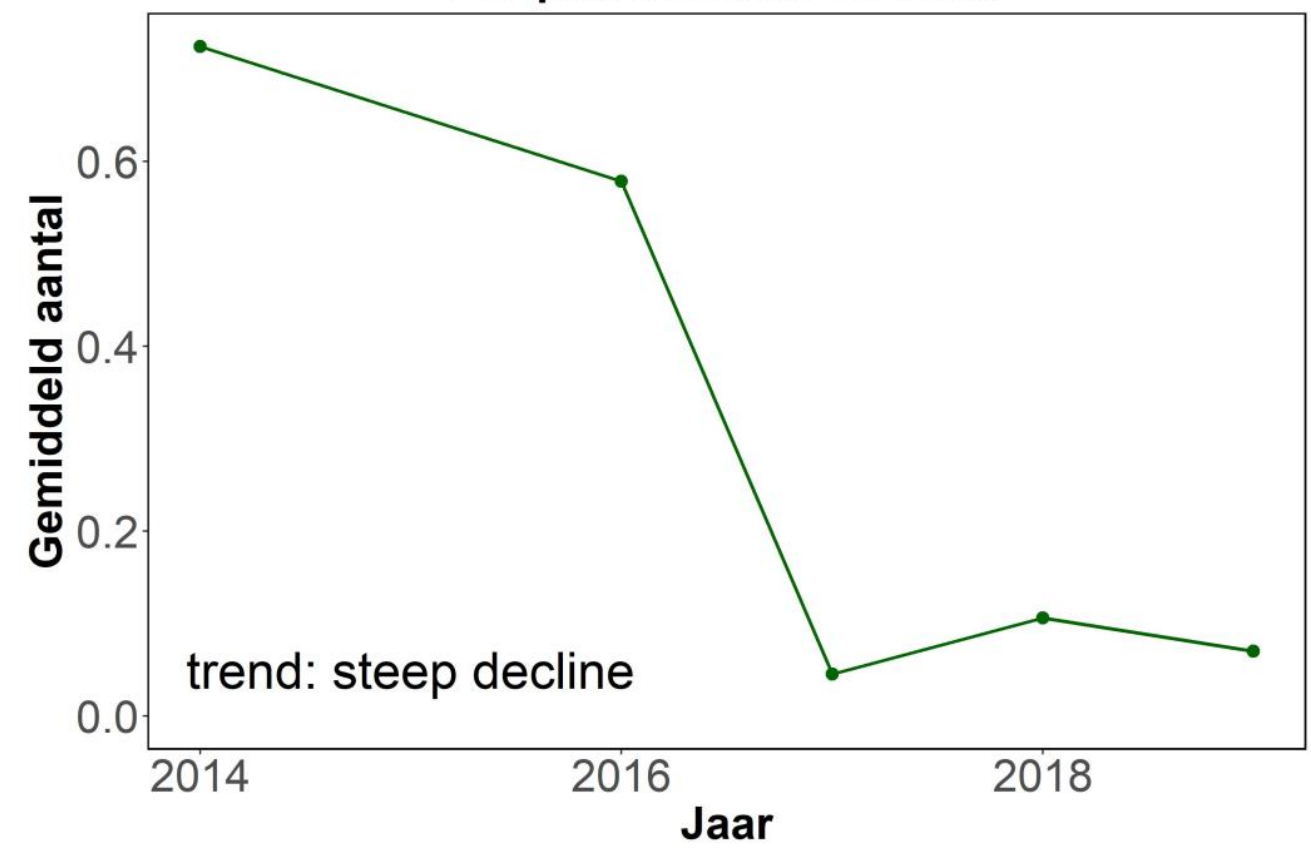

Figuur 4.3. Gemiddeld aantal gevangen zeeprikken in fuiken bij Kornwerderzand en Den Oever (IJsselmeerzijde) gecorrigeerd voor inspanning. 


\section{DIADROOM}

Voor de zeeprik zijn data uit de jaren 2000-2019 beschikbaar (Figuur 4.4) van zeven fuiken op één locatie (Kornwerderzand, Waddenzeezijde), bemonsterd in de maanden maart, april, mei en juni. In 2000 is maar één van de zeven fuiken bemonsterd. Pas sinds 2008 vindt de monitoring ook in maart plaats met uitzondering van de jaren 2010, 2012 en 2013. Alleen in 2000 en 2002 is er niet gemonitord in maand april. Alhoewel het missen van de maanden maart en april belangrijke factoren zouden kunnen zijn voor de trendanalyse, was er geen grote invloed op de trendanalyse zichtbaar.

\section{Zeeprik Waddenzee-Noordzeekustzone DIADROOM}

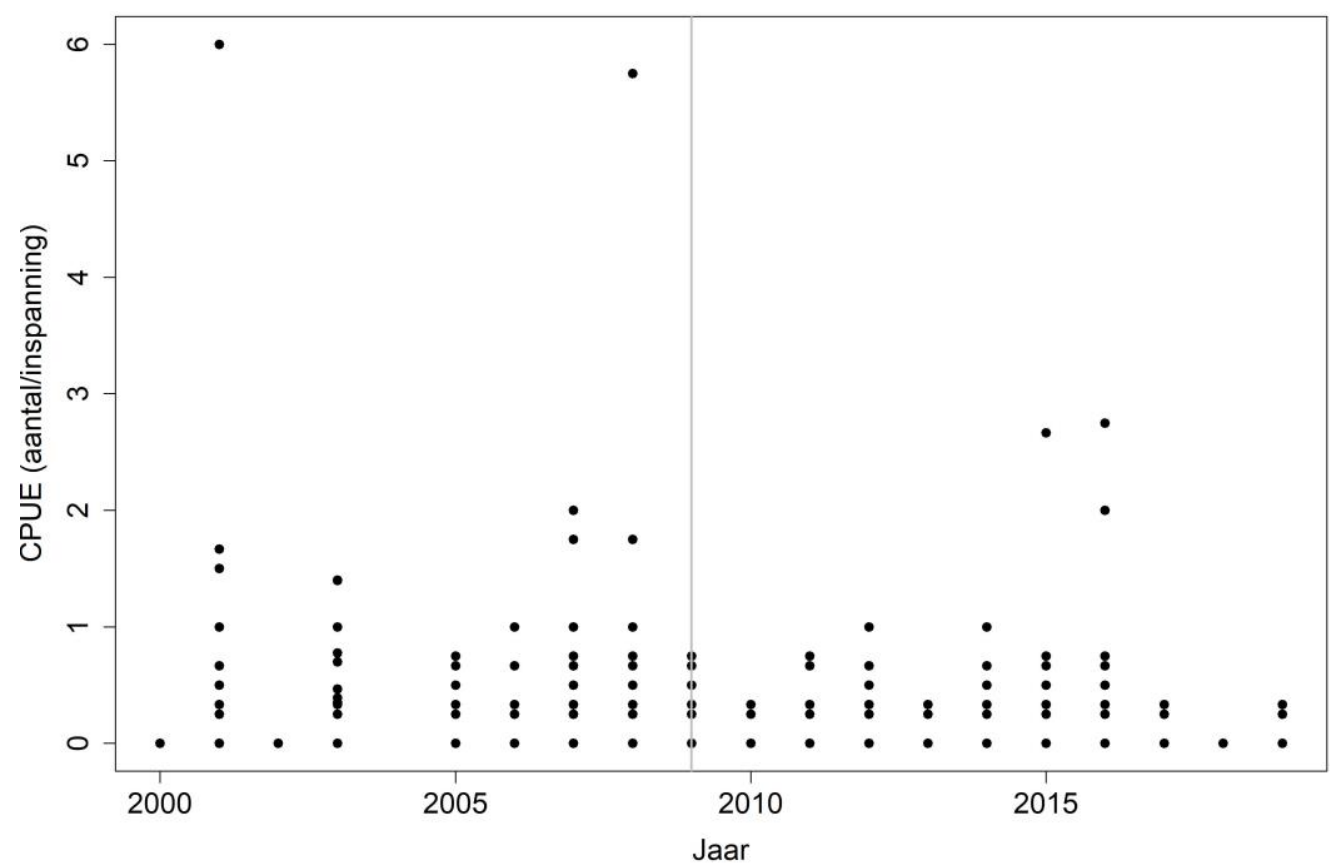

Figuur 4.4. Vangst per eenheid inspanning (CPUE) per bemonstering per jaar voor zeeprik in de fuiken bij Kornwerderzand (Waddenzeezijde). De grijze lijn geeft het jaar van aanwijzing weer van het Natura 2000-gebied.

\section{Analyse}

Omdat de zeeprik in de periode 2009-2019 in voldoende aantallen gevangen is met de fuiken, is een statistische analyse met GLM o.b.v. aantallen uitgevoerd. In deze periode is geen significante $(P=0.19)$ toe- of afname van zeeprik in de Waddenzee/Noordzeekustzone opgetreden (Figuur 4.5). Vanwege de onzekere trend is er ook een analyse op aan-/afwezigheid uitgevoerd waarbij de trend een significant $(P=0.009)$ jaareffect heeft van 0.48 wat betekent dat de vangkans ieder jaar met $52 \%$ afneemt (Figuur 4.6). 


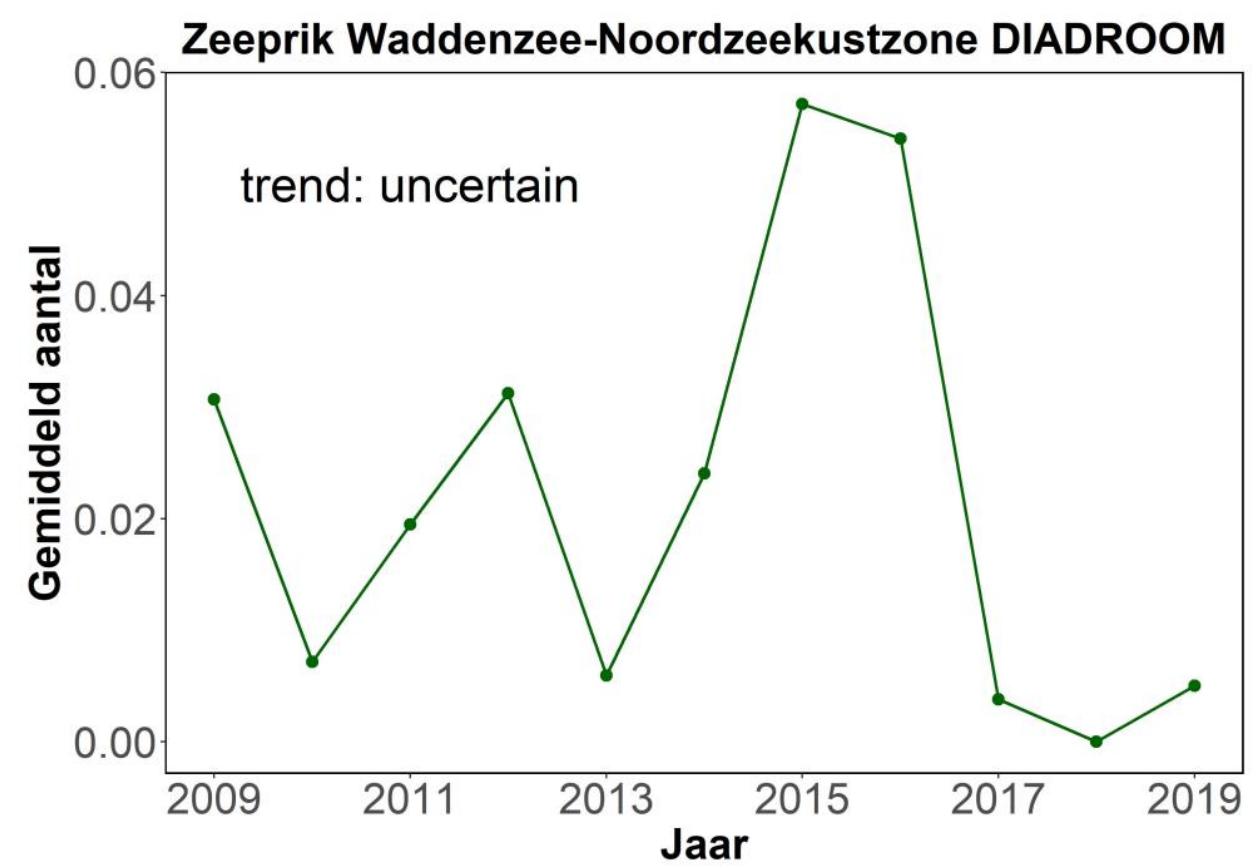

Figuur 4.5. Gemiddeld aantal gevangen zeeprikken in fuiken bij Kornwerderzand (Waddenzeezijde) gecorrigeerd voor inspanning vanaf het jaar dat de Waddenzee en de Noordzeekustzone zijn aangewezen als Natura 2000-gebied.

\section{Zeeprik Waddenzee-Noordzeekustzone DIADROOM}

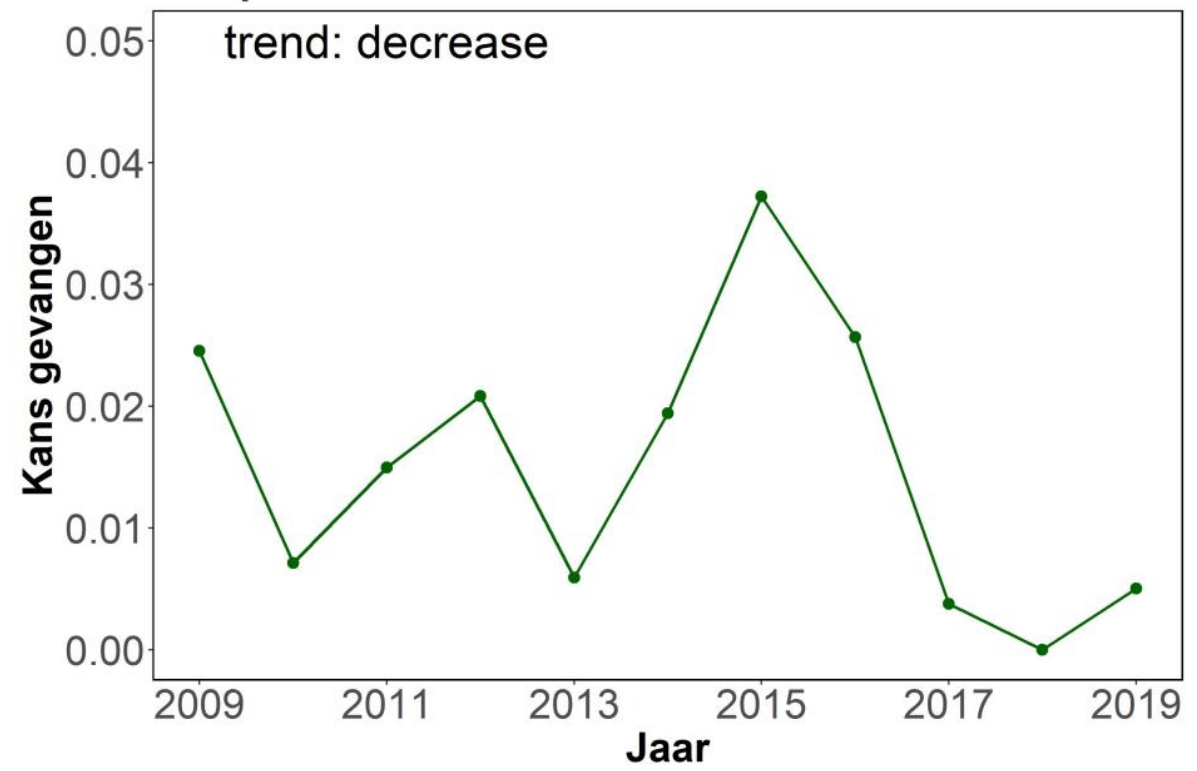

Figuur 4.6 Kans op het vangen van zeeprik in fuiken bij Kornwerderzand (Waddenzeezijde) gecorrigeerd voor inspanning vanaf het jaar dat de Waddenzee en de Noordzeekustzone zijn aangewezen als Natura 2000-gebied.

\section{NIOZ-Fuik}

Voor de zeeprik zijn data uit de jaren 1960-2019 beschikbaar (Figuur 4.7) van één "komfuik" in het Marsdiep op Texel bemonsterd in de maanden maart-oktober. Alleen de opgewerkte gegevens (aantal per jaar) zijn ter beschikking gesteld aan WMR waardoor we geen correctie voor inspanning kunnen doen. 


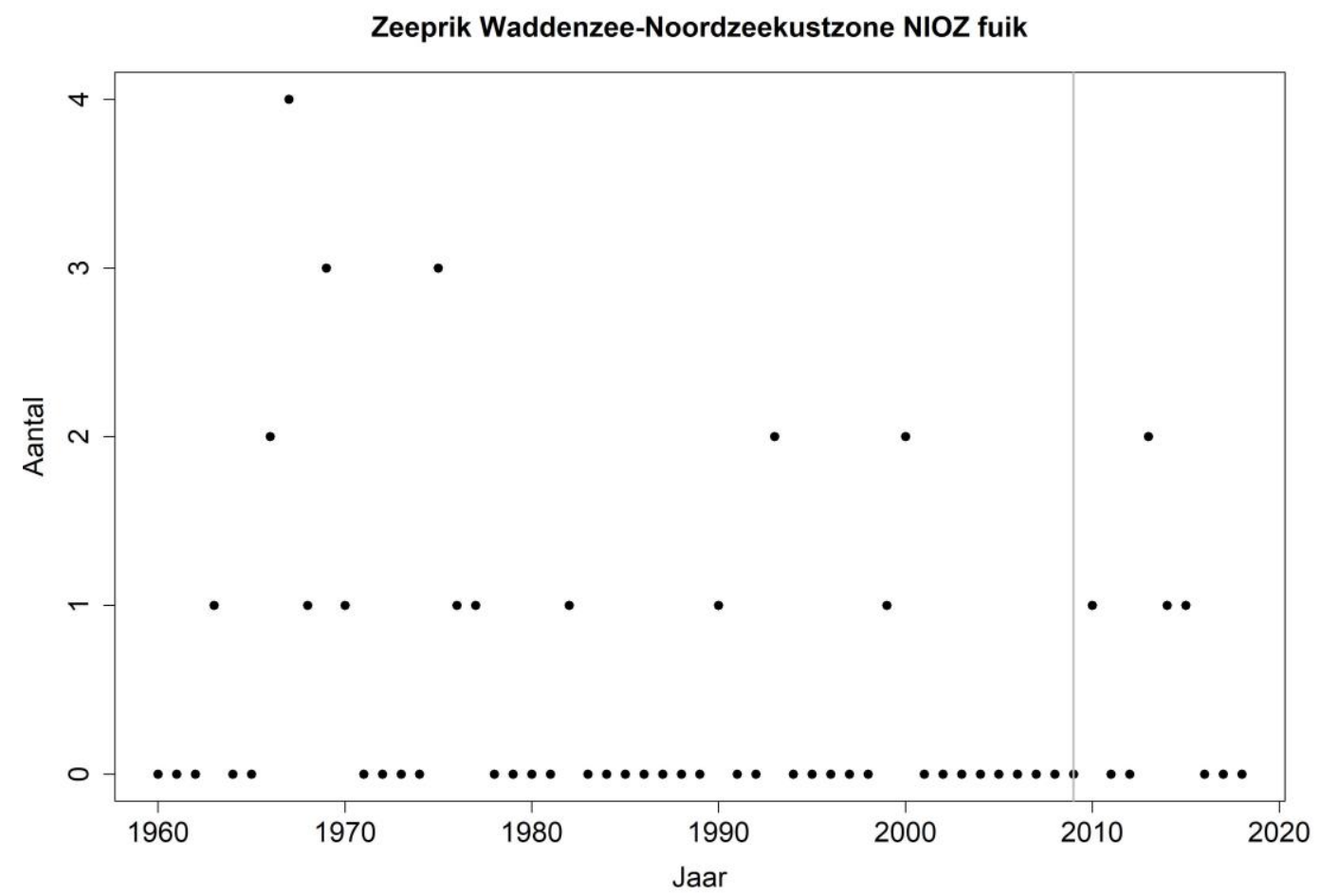

Figuur 4.7 Aantal per jaar voor zeeprik in de NIOZ-fuik op Texel. De grijze lijn geeft het jaar van aanwijzing weer van het Natura 2000-gebied.

\section{Analyse}

Omdat de zeeprik in de periode 2009-2019 maar een enkele keer is gevangen met de NIOZ-fuik, is een statistische analyse met GLM o.b.v. aan-/afwezigheid uitgevoerd. In deze periode is geen significante $(P=0.66)$ toe- of afname van zeeprik in de Waddenzee/Noordzeekustzone opgetreden (Figuur 4.8).

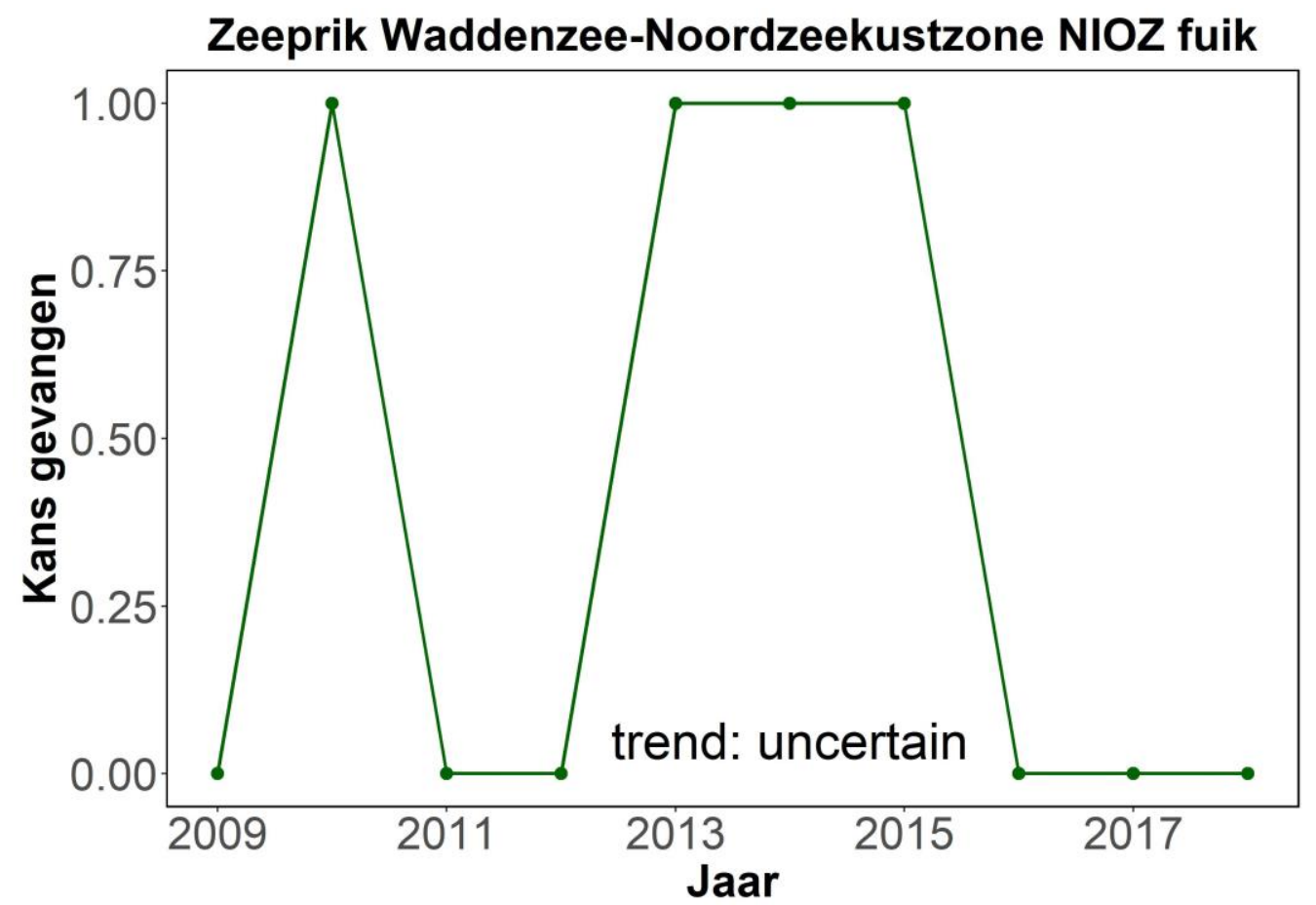

Figuur 4.8 Kans op het vangen van zeeprik in de NIOZ fuik gecorrigeerd voor inspanning vanaf het jaar dat de Waddenzee en de Noordzeekustzone zijn aangewezen als Natura 2000-gebied. 


\section{Conclusie}

In de Waddenzee neemt de zeeprik (sterk) af of is de trend onzeker. Het is onduidelijk wat hier aan ten grondslag ligt. De verwachting is dat de soort in de toekomst mogelijk zal toenemen zodra de Vismigratierivier is geïmplementeerd.

\subsubsection{Rivierprik}

Onderzoeksvraag.

Wat is de trend van rivierprik in de Waddenzee voor de periode 2009-2019?

\section{Databeschikbaarheid}

DFS

Data zijn beschikbaar vanaf 1970. Rivierprik is in de periode sinds de gebiedsaanwijzing in twee jaren gevangen in de DFS in de Waddenzee (Figuur 4.9). Hierdoor lenen deze gegevens zich niet voor een trendanalyse.

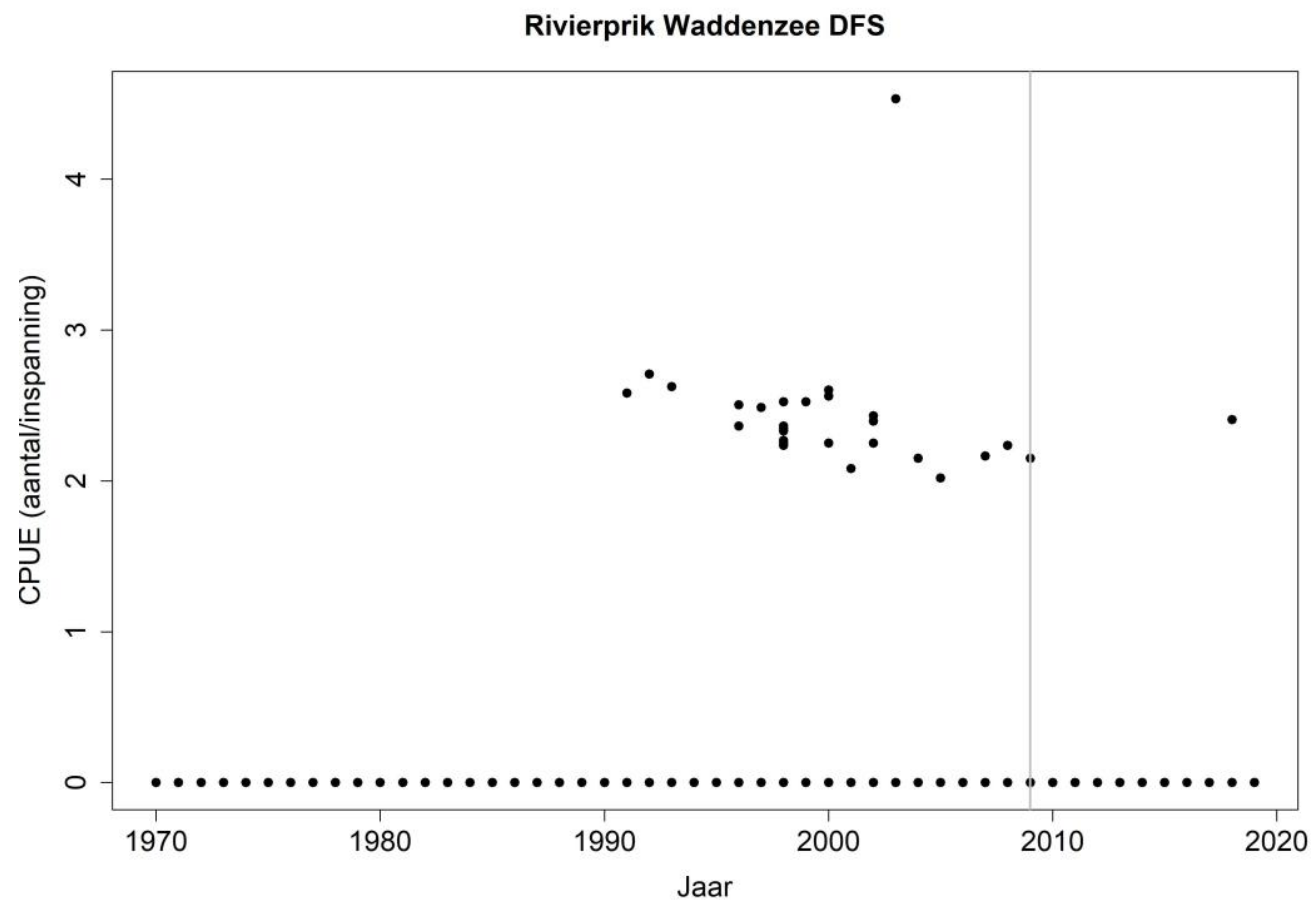

Figuur 4.9. Aantal per hectare ( $\mathrm{n} / \mathrm{ha}$ ) per bemonstering per jaar voor rivierprik in de boomkor in de Waddenzee. De grijze lijn geeft het jaar van aanwijzing weer van het Natura 2000-gebied.

\section{FDIA}

Voor de rivierprik zijn data uit de jaren 2012-2019 beschikbaar (Figuur 4.10) van twee locaties (Kornwerderzand en Den Oever, beide aan de IJsselmeerzijde), bemonsterd in de maanden september, oktober, november, december. In 2014 en 2015 is alleen de locatie Kornwerderzand bemonsterd. Aangezien beide locaties vergelijkbare trends vertonen zijn deze samengevoegd voor de trendanalyse. 


\section{Rivierprik Waddenzee FDIA}

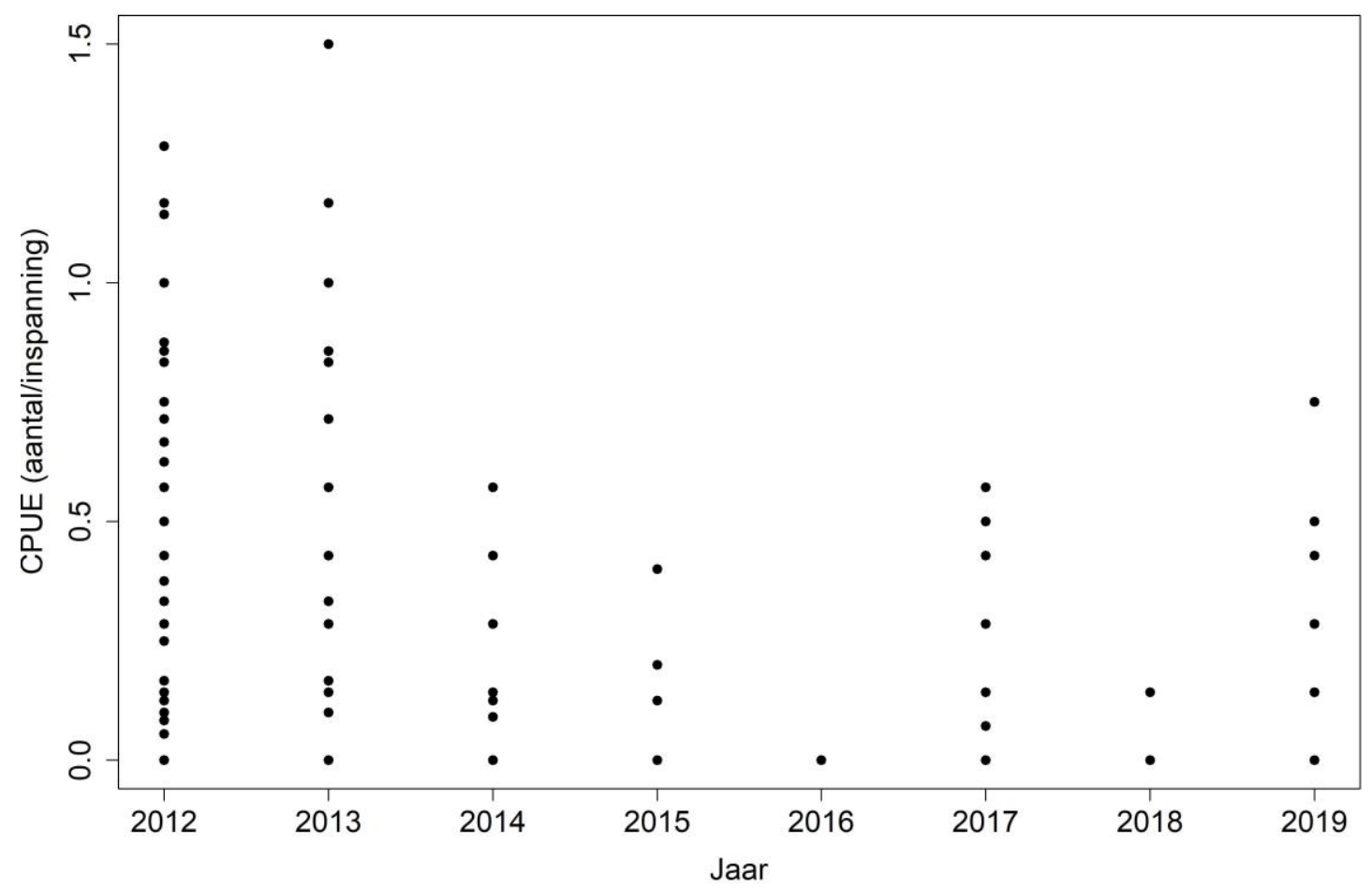

Figuur 4.10. Vangst per eenheid inspanning (CPUE) per bemonstering per jaar voor rivierprik in de fuiken bij Kornwerderzand en Den Oever (IJsselmeerzijde).

\section{Analyse}

Omdat de rivierprik in de periode 2012-2019 in voldoende aantallen is gevangen met de fuiken, is een statistische analyse met GLM o.b.v. aantallen uitgevoerd. In deze periode is een significante $(P<0.001)$ afname van rivierprik in de Waddenzee opgetreden (Figuur 4.11). De trend heeft een jaareffect van 0,58 wat betekent dat rivierprik gemiddeld ieder jaar met $42 \%$ is afgenomen. Hierbij moet wel vermeld worden dat de locatie bij Kornwerderzand niet ieder jaar in oktober, november en december bemonsterd is. In 2013 is er alleen kort in oktober bemonsterd en in 2015 alleen in december, in 2014 en 2016 alleen in oktober en november en maar een keer in begin december, en in 2018 is er niet in december bemonsterd. Daarnaast is er in 2012 en 2013 bij Kornwerderzand en in 2012 bij Den Oever op andere locaties bemonsterd dan in de daaropvolgende monitoringsjaren. Dit heeft uiteraard grote invloed op de trend. Wanneer er een strengere selectie op de data toegepast zou worden waarbij alleen dezelfde fuikenlocaties meegenomen worden en de jaren waarin in de maanden oktober, november en december bemonsterd zijn worden meegenomen, zou de trend van Kornwerderzand zoals gepresenteerd in Figuur 3.13 van toepassing zijn en is er nog niet genoeg data voor een trendanalyse of expert judgement. 


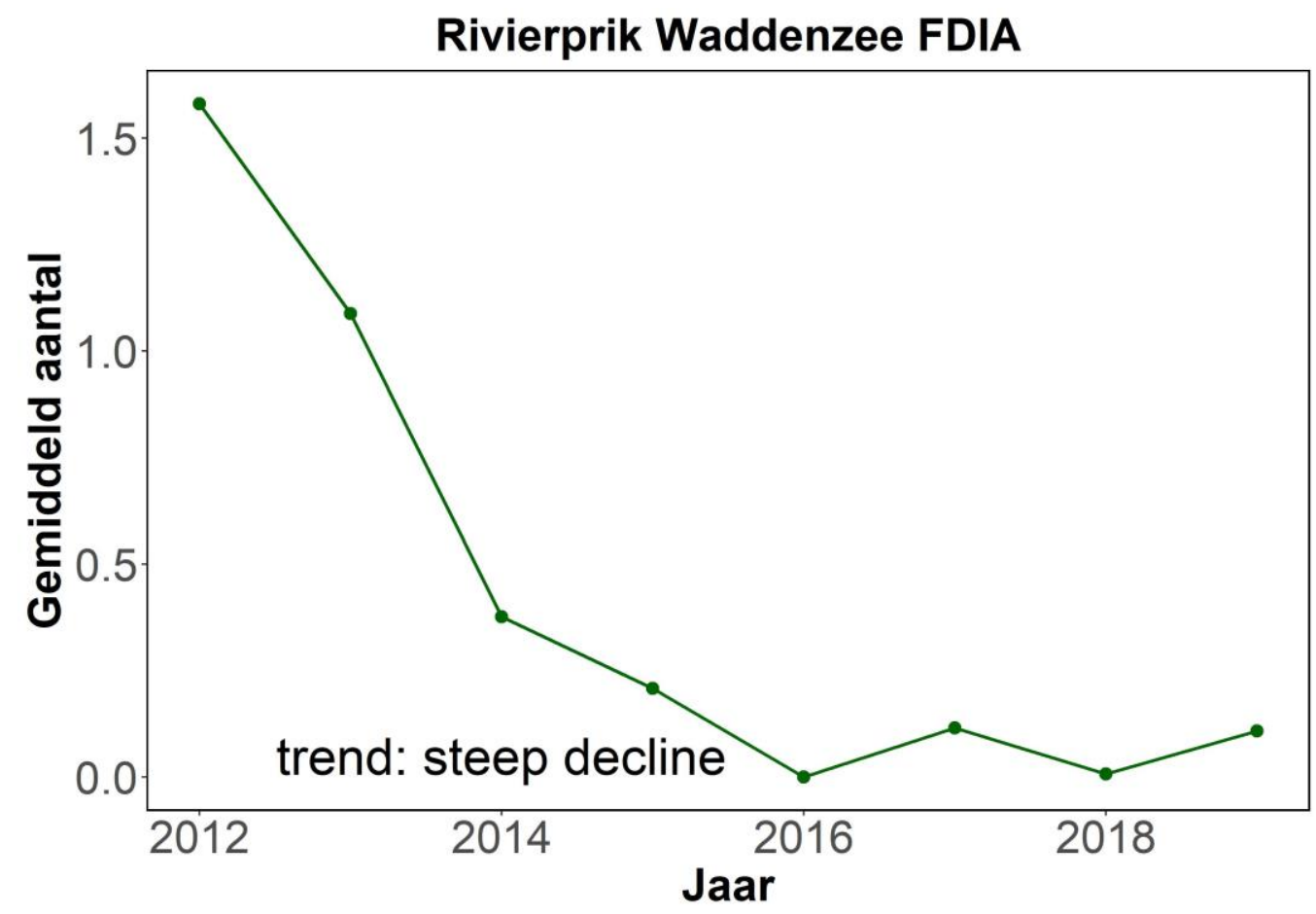

Figuur 4.11. Gemiddeld aantal gevangen rivierprikken in fuiken in de Waddenzee gecorrigeerd voor inspanning.

\section{DIADROOM}

Voor de rivierprik zijn data uit de jaren 2000-2019 beschikbaar (Figuur 4.12) van zeven fuiken op één locatie (Kornwerderzand, Waddenzeezijde), bemonsterd in de september, oktober, november en vanaf 2014 ook een enkele dag in december (op 2015 en 2018 na). In 2000 zijn maar vier van de zeven fuiken bemonsterd. In 2013 is er meerdere keren (12x) in december bemonsterd. Alhoewel de maand december over het algemeen een zeer effectieve maand is om rivierprik te bemonsteren lijkt het effect hiervan in 2013 te ontbreken.

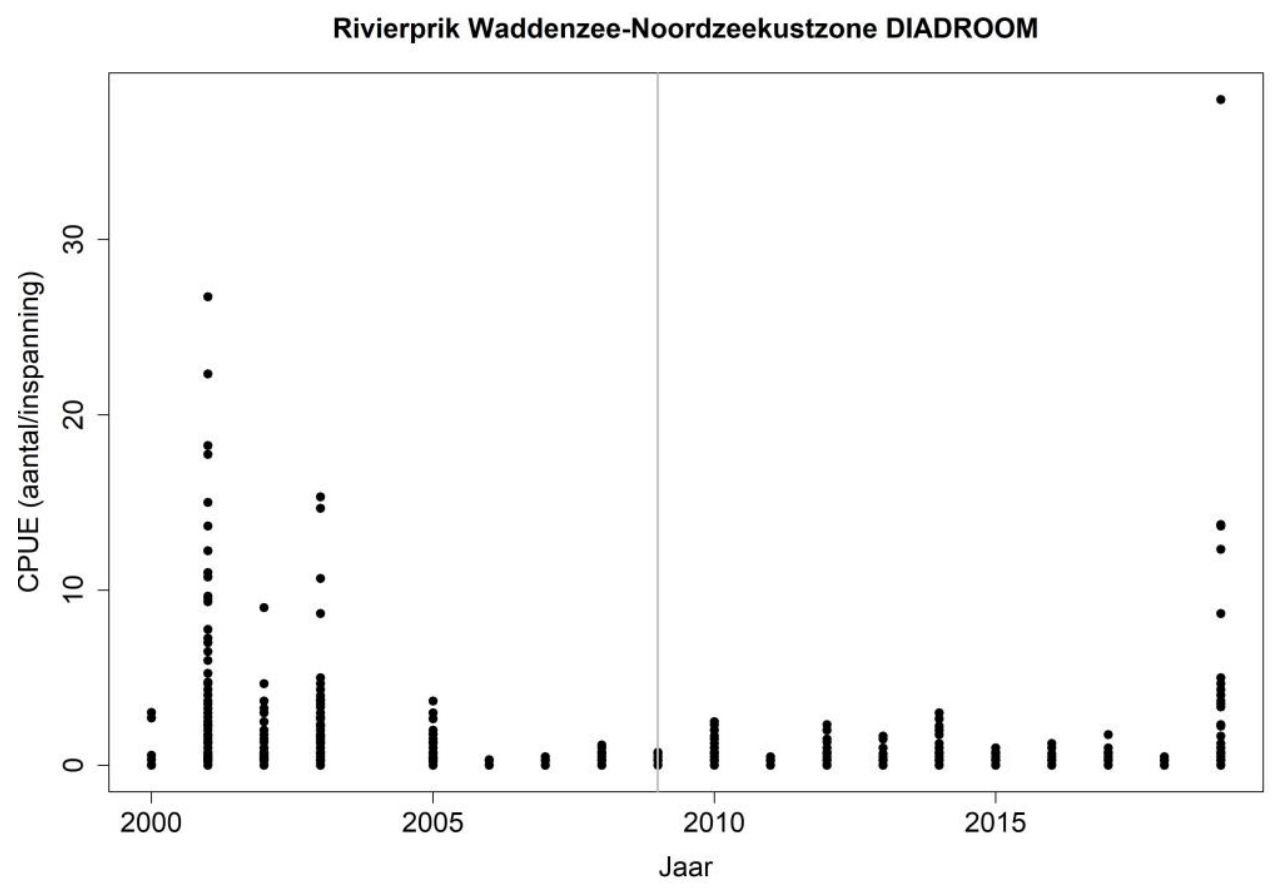

Figuur 4.12. Vangst per eenheid inspanning (CPUE) per bemonstering per jaar voor rivierprik in de fuiken bij Kornwerderzand (Waddenzeezijde). De grijze lijn geeft het jaar van aanwijzing weer van het Natura 2000-gebied. 
Analyse

Omdat de rivierprik in de periode 2009-2019 in voldoende aantallen gevangen is met de fuiken, is een statistische analyse met GLM o.b.v. aantallen uitgevoerd. In deze periode is een significante $(P<0.001)$ sterke toename van rivierprik in de Waddenzee/Noordzeekustzone opgetreden (Figuur 4.13). De trend heeft een jaareffect van 1,18 wat betekent dat rivierprik gemiddeld ieder jaar met $18 \%$ is toegenomen. Deze toename wordt echter alleen door het goede vangstjaar van 2019 veroorzaakt. Wanneer er over een langere periode getoetst zou worden zou er geen sterke toename zijn. Vanwege de grote invloed van het laatste vangstjaar is er ook een analyse op aan-/afwezigheid uitgevoerd waarbij de trend geen significant $(P=0.50)$ jaareffect heeft (Figuur 4.14).

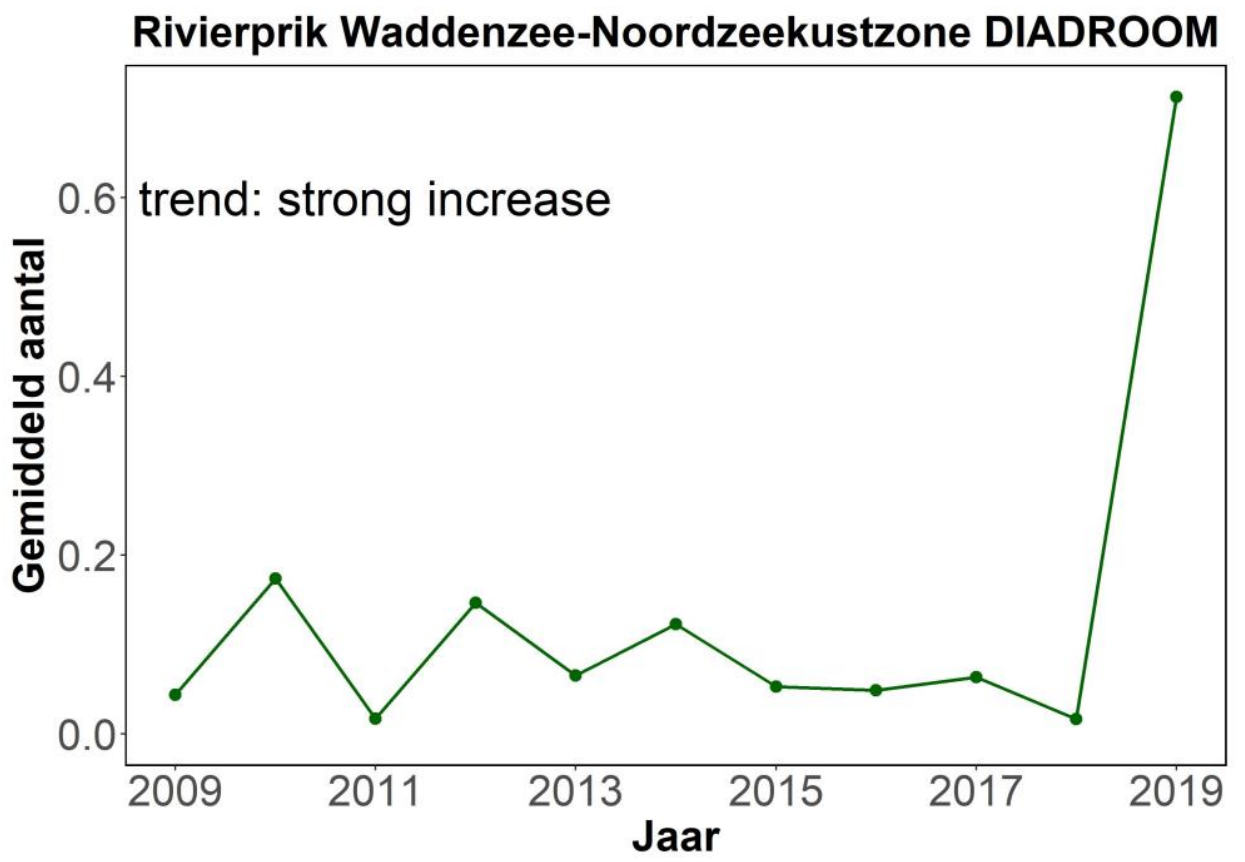

Figuur 4.13. Gemiddeld aantal gevangen zeeprikken in fuiken bij Kornwerderzand (Waddenzeezijde) gecorrigeerd voor inspanning vanaf het jaar dat de Waddenzee en de Noordzeekustzone zijn aangewezen als Natura 2000-gebied.

\section{Rivierprik Waddenzee-Noordzeekustzone DIADROOM}

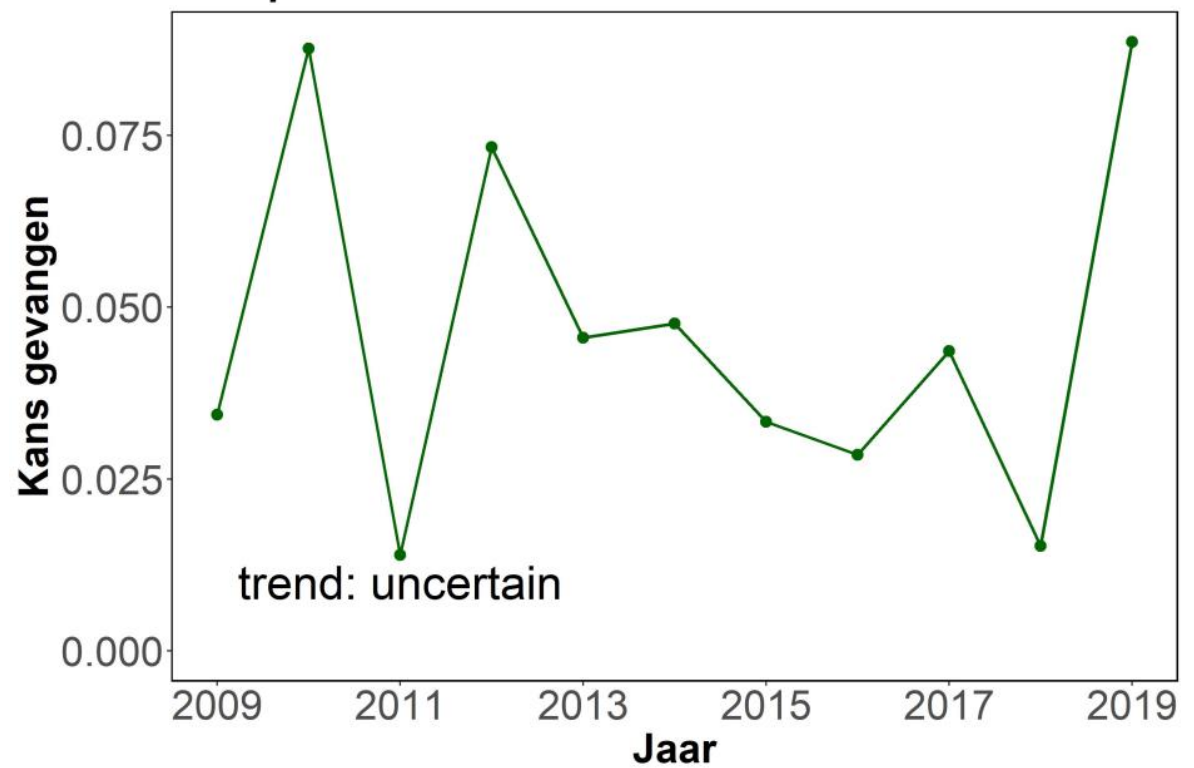

Figuur 4.14 Kans op het vangen van rivierprik in fuiken bij Kornwerderzand (Waddenzeezijde) gecorrigeerd voor inspanning vanaf het jaar dat de Waddenzee en de Noordzeekustzone zijn aangewezen als Natura 2000-gebied. 


\section{NIOZ-Fuik}

Voor de rivierprik zijn data uit de jaren 1960-2019 beschikbaar (Figuur 4.15) van één "komfuik" in het Marsdiep op Texel bemonsterd in de maanden maart-oktober. Na 1999 is er geen rivierprik in deze fuik gevangen waardoor er geen analyse is uitgevoerd vanaf het moment van aanwijzing van het Natura 2000-gebied.

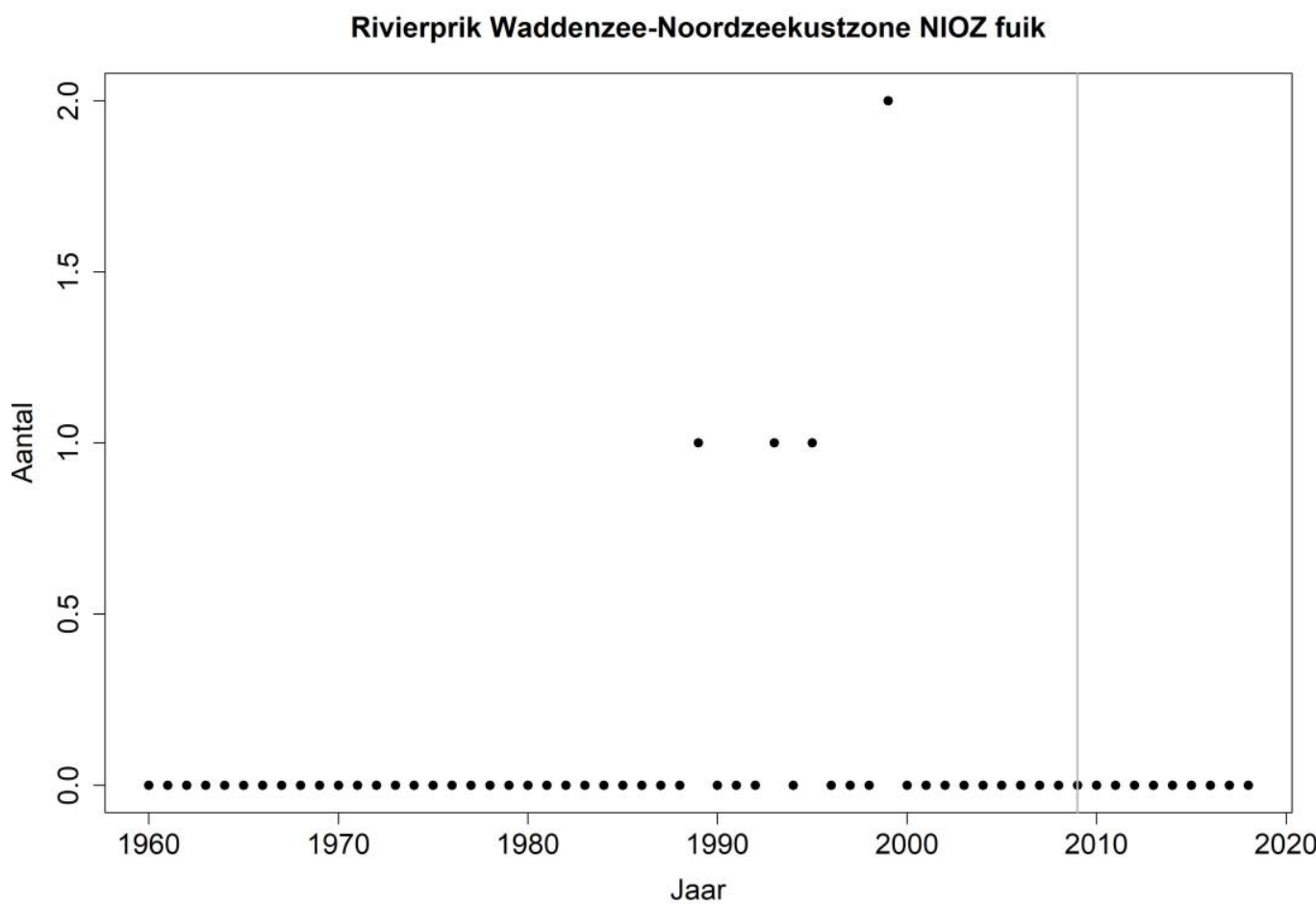

Figuur 4.15 Aantal per jaar voor rivierprik in de NIOZ-fuik op Texel. De grijze lijn geeft het jaar van aanwijzing weer van het Natura 2000-gebied.

\section{Conclusie}

In de Waddenzee neemt de rivierprik sinds 2009 sterk af, is de trend onzeker of neemt deze sterk toe afhankelijk van de gebruikte monitoring en dataselectie. Deze ogenschijnlijke toename in de DIADROOMmonitoring wordt alleen bepaald door hoge vangsten in 2019. Wanneer er naar de data vanaf 2000 wordt gekeken, lijkt er echter sprake te zijn van een afname (niet getoetst). Over het algemeen lijkt de rivierprik dus af te nemen in de Waddenzee wanneer de hoge vangsten van 2019 in de DIADROOM monitoring een enkele uitschieter blijkt te zijn. De verwachting is dat de soort in de toekomst mogelijk zal toenemen zodra de Vismigratierivier is voltooid. 


\subsubsection{Fint}

\section{Onderzoeksvraag.}

Wat is de trend van fint in de Waddenzee voor de periode 2009-2019?

\section{Databeschikbaarheid}

\section{DFS}

Data zijn beschikbaar vanaf 1970-2019 bemonsterd in de maanden augustus, september, oktober met de boomkor (Figuur 4.16).

\section{Fint Waddenzee DFS}

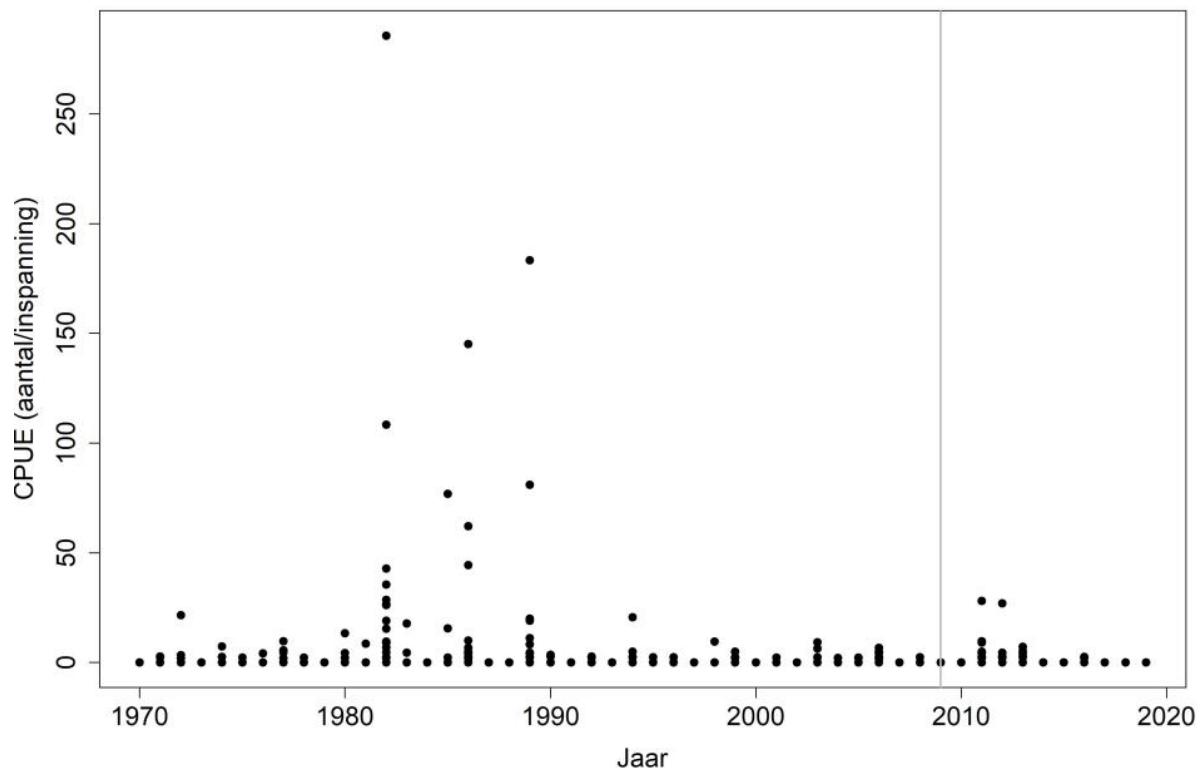

Figuur 4.16 Aantal per hectare (n/ha) per bemonstering per jaar voor fint in de boomkor in de Waddenzee. De grijze lijn geeft het jaar van aanwijzing weer van het Natura 2000-gebied.

\section{Analyse}

Omdat de fint in de periode 2009-2019 in voldoende aantallen gevangen is met de boomkor, is een statistische analyse met GLM o.b.v. aantallen uitgevoerd. In deze periode is een significante $(P=0.02)$ afname van fint in de Waddenzee opgetreden (Figuur 4.17). De trend heeft een jaareffect van 0,79 wat betekent dat fint gemiddeld ieder jaar met $21 \%$ is afgenomen. De statistische analyse op aan/afwezigheid geeft ook een significante $(P=0.01)$ afname aan (niet weergegeven). 
Fint Waddenzee DFS

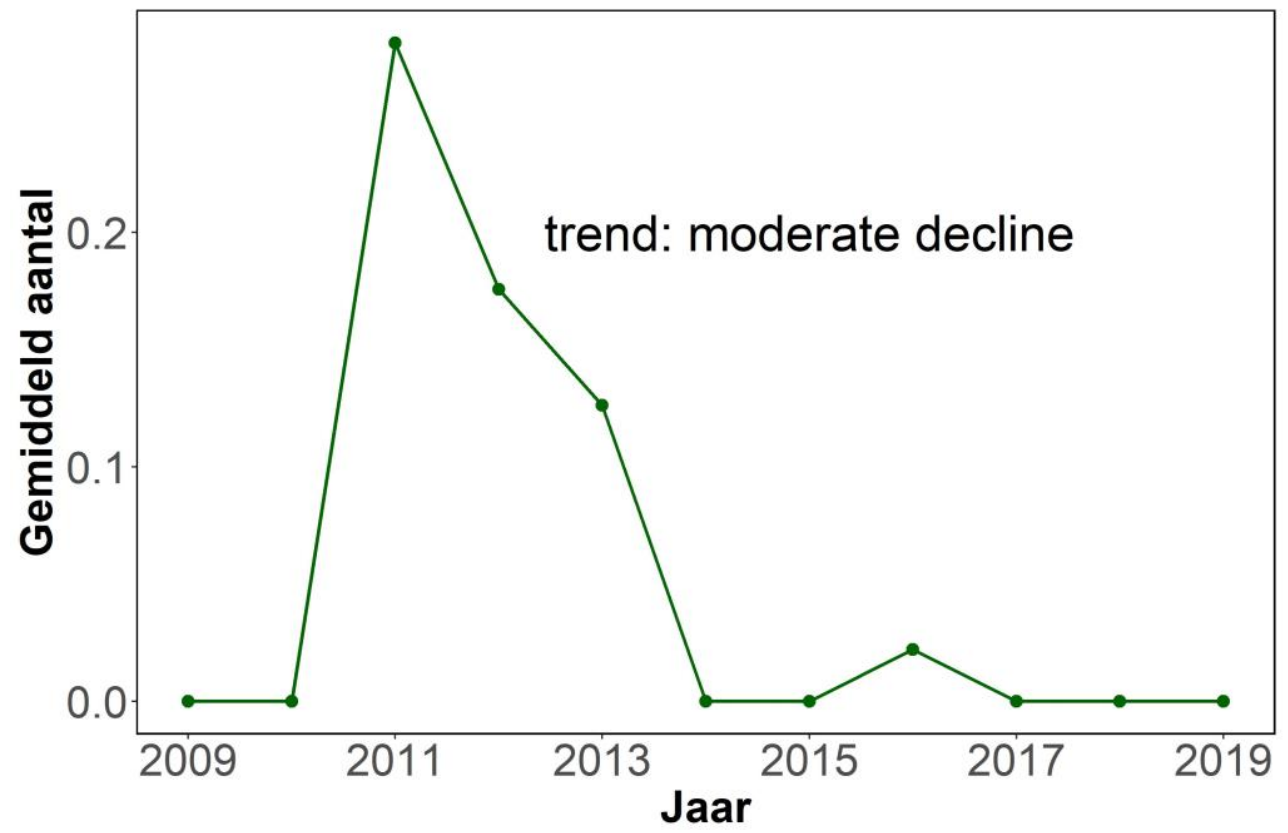

Figuur 4.17 Gemiddeld aantal finten gevangen per jaar in de boomkor in de Waddenzee gecorrigeerd voor inspanning vanaf het jaar dat de Waddenzee is aangewezen als Natura 2000-gebied.

\section{DIADROOM}

Voor de fint zijn data uit de jaren 2000-2019 beschikbaar van zeven fuiken op één locatie (Kornwerderzand, Waddenzeezijde), bemonsterd in de maanden maart, april, mei en juni. In 2000 is maar één van de zeven fuiken bemonsterd. Pas sinds 2008 vindt de monitoring ook in maart plaats met uitzondering van de jaren 2010, 2012 en 2013. Alleen in 2000 en 2002 is er niet gemonitord in maand april. Alhoewel het missen van de maanden maart en april belangrijke factoren zouden kunnen zijn voor de trendanalyse, was er geen grote invloed op de trendanalyse zichtbaar. Voor de trendanalyse van de adulten zijn volwassen finten $(>30 \mathrm{~cm}$ ) geselecteerd, en voor de trendanalyses van de juvenielen zijn individuen $<30 \mathrm{~cm}$ geselecteerd (Figuur 4.18, Figuur 4.19). 
Fint adult Waddenzee-Noordzeekustzone DIADROOM

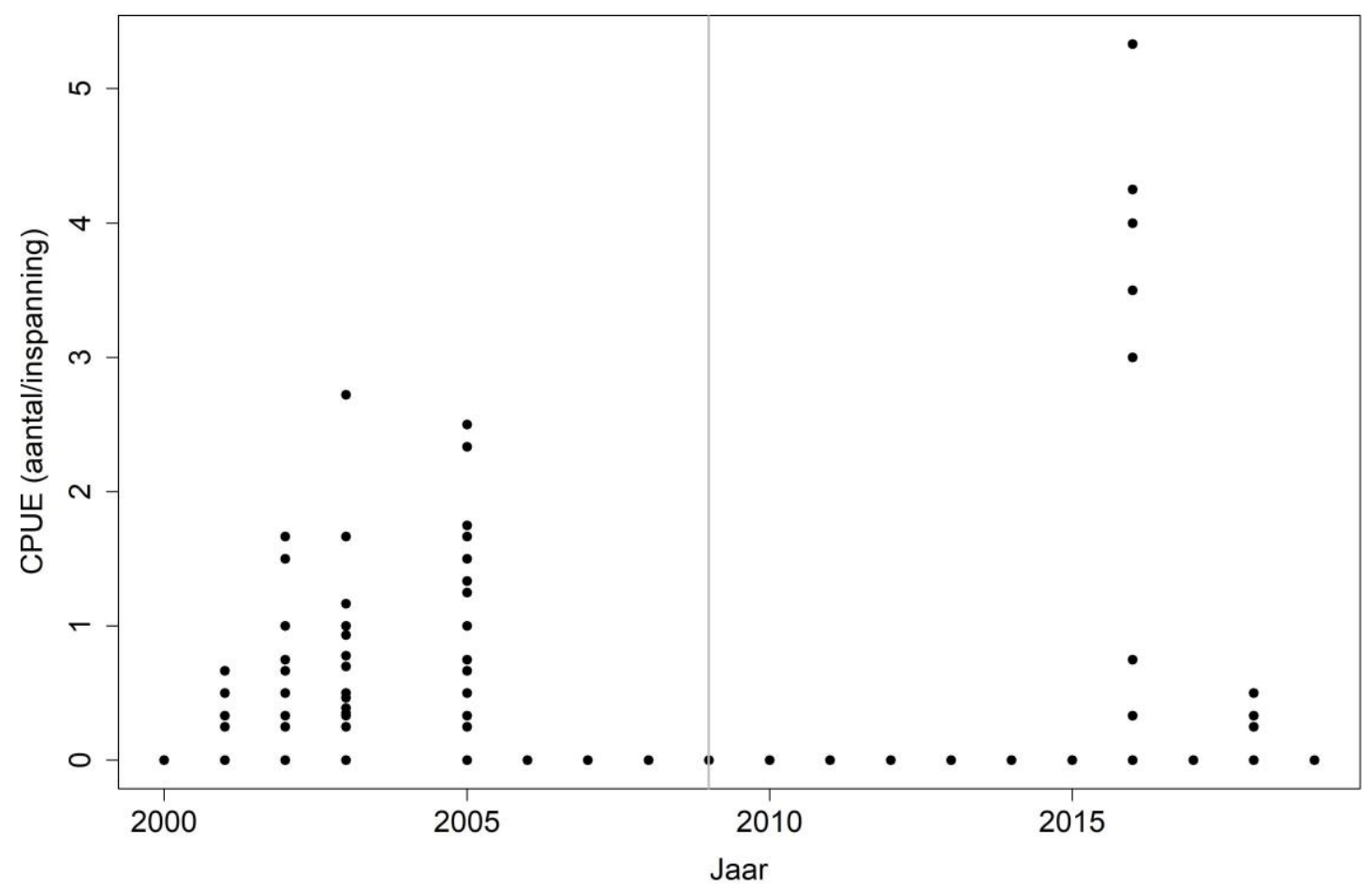

Figuur 4.18. Vangst per eenheid inspanning (CPUE) per bemonstering per jaar voor adulte fint in fuiken in de Waddenzee/Noordzeekustzone. De grijze lijn geeft het jaar van aanwijzing weer van het Natura 2000-gebied.

Fint juveniel Waddenzee-Noordzeekustzone DIADROOM

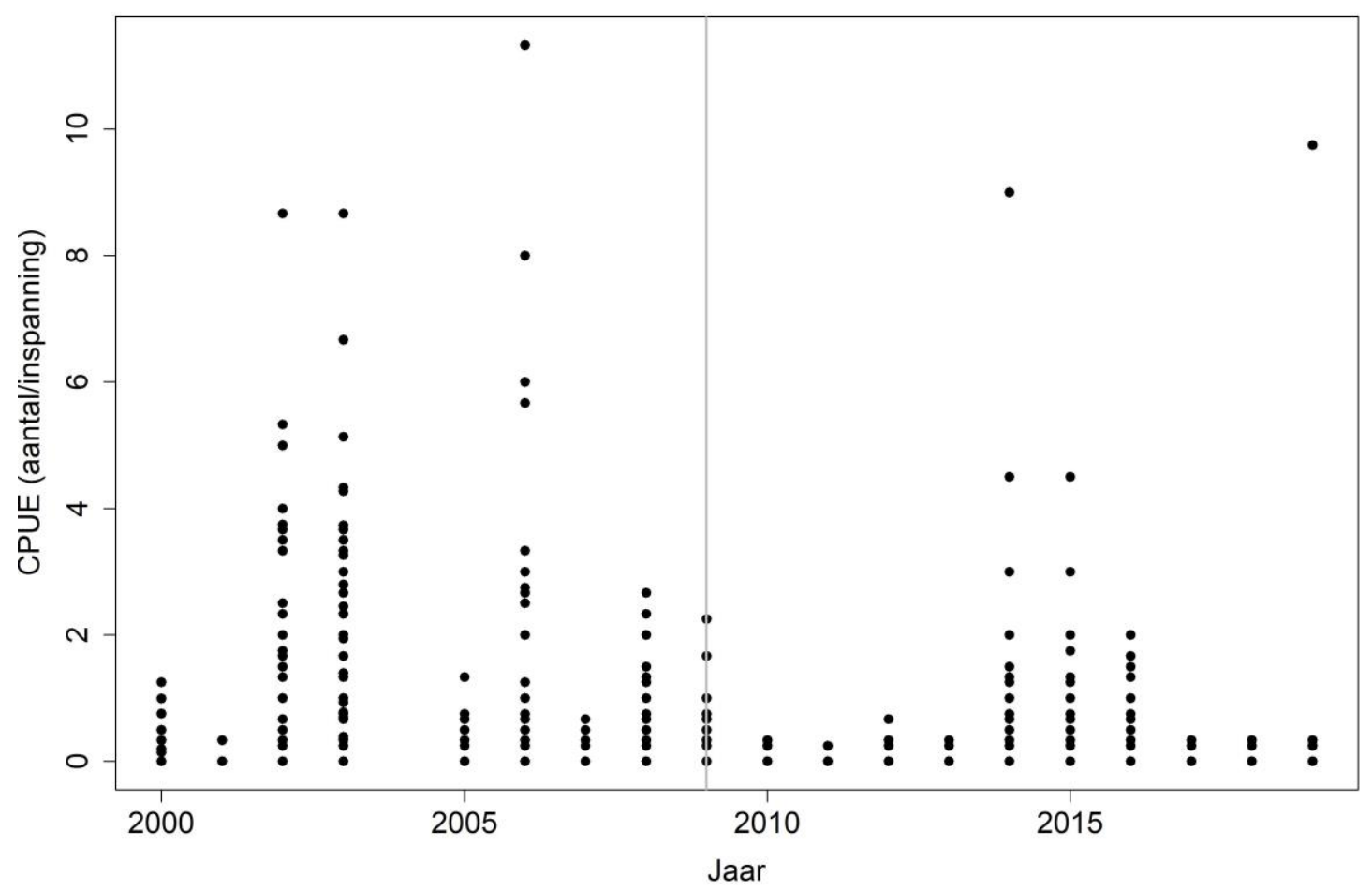

Figuur 4.19 Vangst per eenheid inspanning (CPUE) per bemonstering per jaar voor juveniele fint in fuiken in de Waddenzee/Noordzeekustzone. De grijze lijn geeft het jaar van aanwijzing weer van het Natura 2000-gebied. 
Aangezien de adulte finten maar in twee jaren (2016 en 2018) zijn gevangen met de fuiken in de periode 2009-2019, is een statistische analyse met GLM o.b.v. aan-afwezigheid uitgevoerd. In deze periode is een significante $(P=0.01)$ toename van adulte fint in de Waddenzee/Noordzeekustzone opgetreden (Figuur 4.20). De trend van de adulte fint heeft een jaareffect van 0.57 en wat betekent dat de kans op het vangen van adulte fint gemiddeld ieder jaar met respectievelijk $43 \%$ is toegenomen. De analyse op basis van aantallen geeft een niet significante, onzekere trend weer (niet weer gegeven).

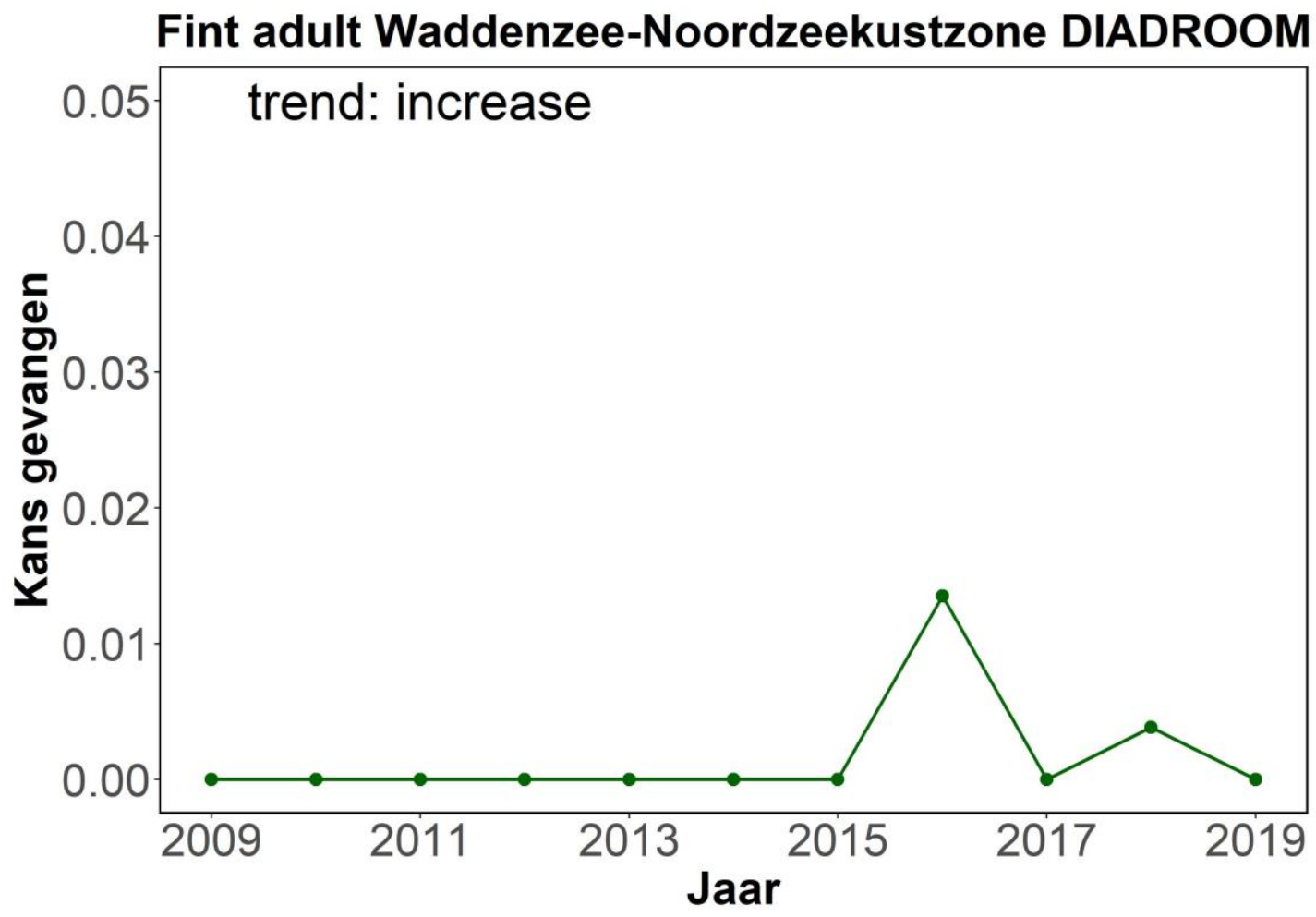

Figuur 4.20 Kans op het vangen van adulte fint in fuiken bij Kornwerderzand (Waddenzeezijde) gecorrigeerd voor inspanning vanaf het jaar dat de Waddenzee en de Noordzeekustzone zijn aangewezen als Natura 2000-gebied.

Omdat juveniele fint in de periode 2009-2019 in voldoende aantallen gevangen is met de fuiken, is een statistische analyse met GLM o.b.v. aantallen uitgevoerd. In deze periode is geen significante $(P=0.78)$ toe-/afname van juveniele fint in de Waddenzee/Noordzeekustzone opgetreden (Figuur 4.21). De analyse op aan-/afwezigheid geeft een significante $(P=0.01)$ afname aan (niet weergegeven). Ook wanneer er naar de gegevens van een langere periode wordt gekeken is er een duidelijke afname zichtbaar (niet getoetst). 


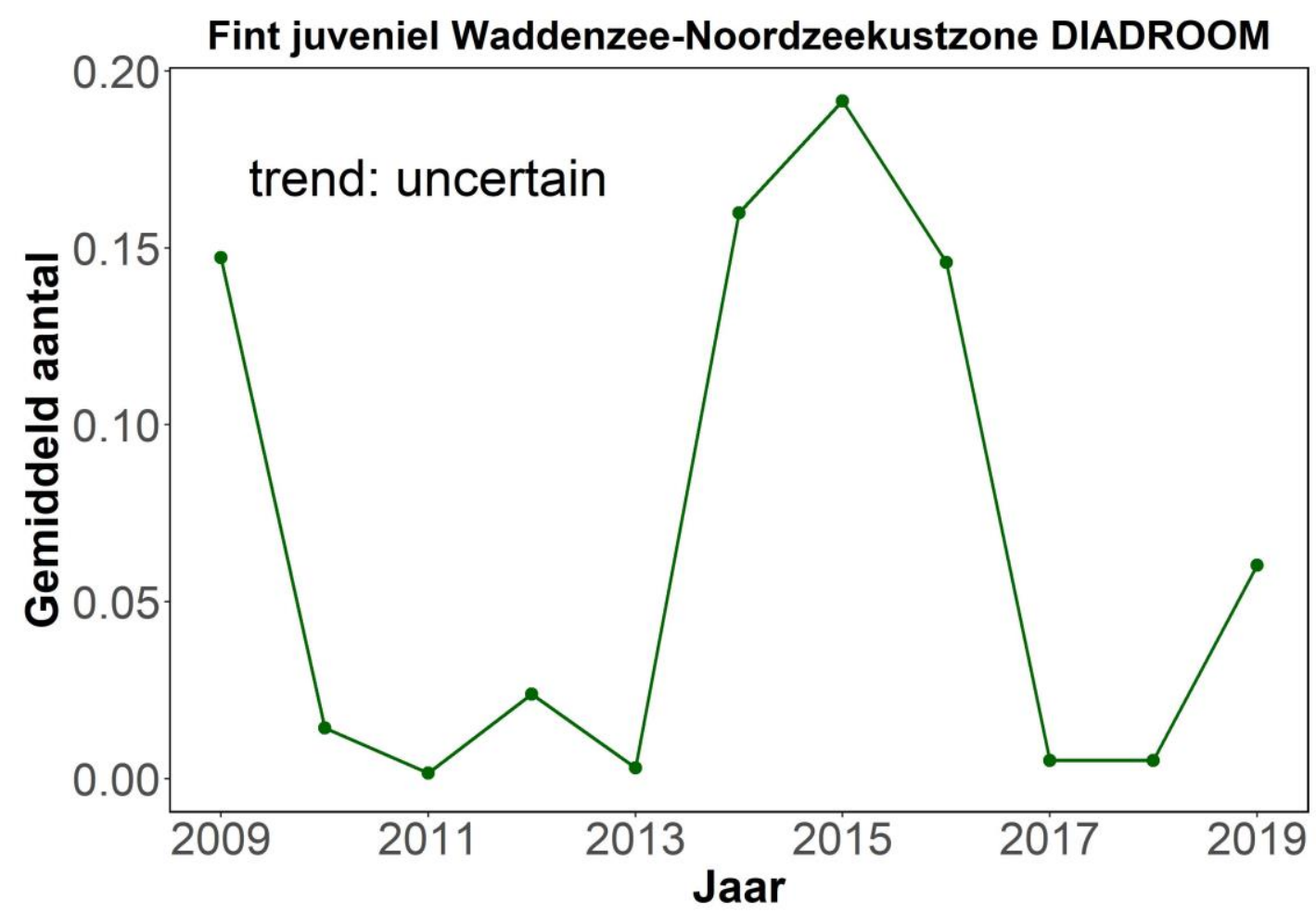

Figuur 4.21 Gemiddeld aantal juveniele finten gevangen per jaar in fuiken bij Kornwerderzand (Waddenzeezijde) gecorrigeerd voor inspanning vanaf het jaar dat de Waddenzee en de Noordzeekustzone zijn aangewezen als Natura 2000-gebied.

\section{NIOZ-Fuik}

Voor de fint zijn data uit de jaren 1960-2019 beschikbaar (Figuur 4.22) van één "komfuik" in het Marsdiep op Texel bemonsterd in de maanden maart-oktober. Alleen de opgewerkte gegevens (aantal per jaar) zijn ter beschikking gesteld aan WMR waardoor we geen correctie voor inspanning kunnen

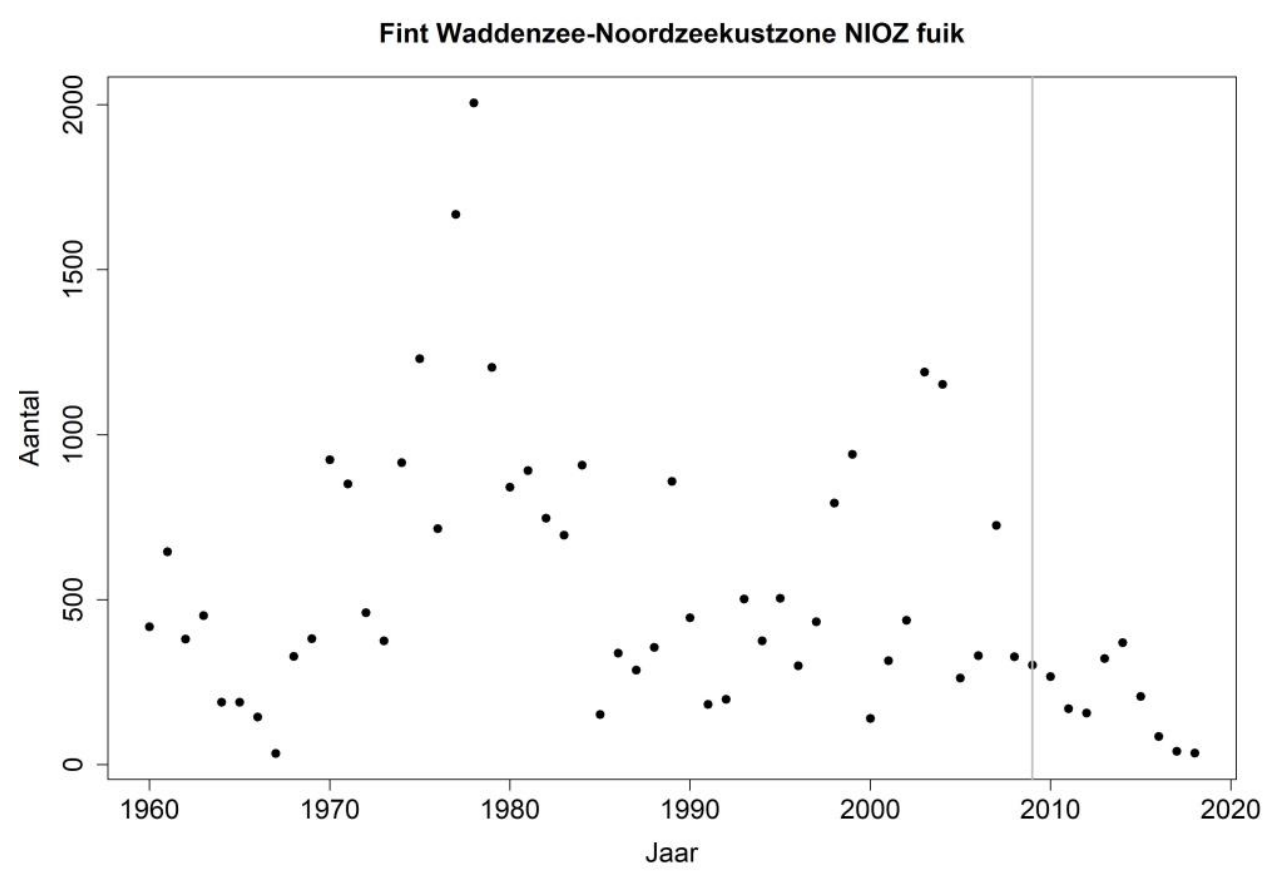

doen.

Figuur 4.22 Aantal per jaar voor fint in de NIOZ-fuik op Texel. De grijze lijn geeft het jaar van aanwijzing weer van het Natura 2000-gebied. 
Analyse

Omdat de fint in de periode 2009-2019 in voldoende aantallen is gevangen met de NIOZ-fuik, is een statistische analyse met GLM o.b.v. aantallen uitgevoerd. In deze periode is geen significante $(P=0.07)$ toe- of afname van fint in de Waddenzee/Noordzeekustzone opgetreden (Figuur 4.8). Alhoewel de zichtbare afname van fint niet significant lijkt te zijn is de non-significantie hoogstwaarschijnlijk een effect van het gebruik van opgewerkte, in plaats van, ruwe data. Ook wanneer er naar gegevens van een langere periode wordt gekeken is een duidelijke afname zichtbaar.

\section{Fint Waddenzee-Noordzeekustzone NIOZ fuik}

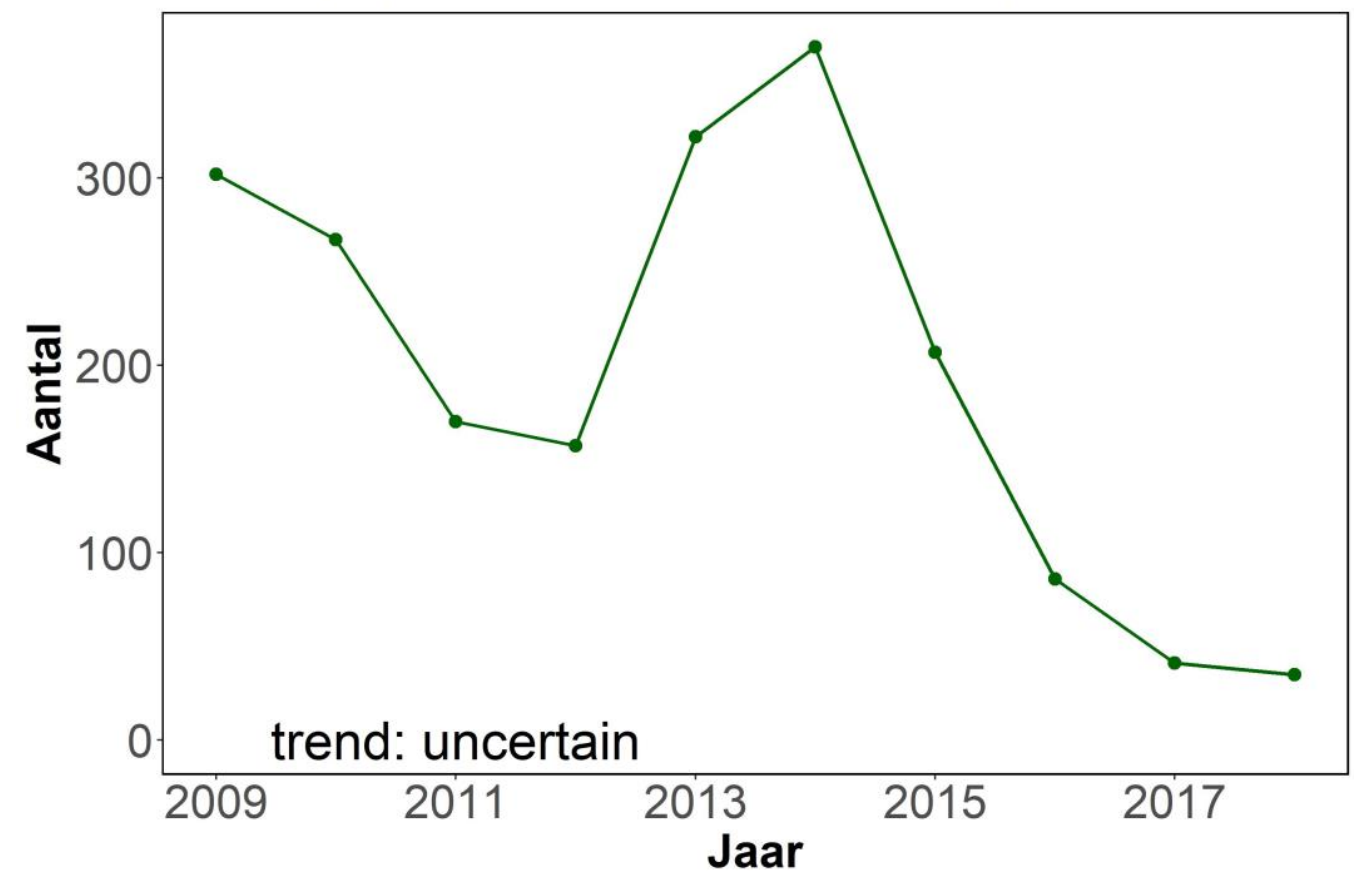

Figuur 4.23 Aantal finten gevangen per jaar in de NIOZ-fuik vanaf het jaar dat de Waddenzee en de Noordzeekustzone zijn aangewezen als Natura 2000-gebied.

\section{Conclusie}

In de Waddenzee neemt de fint sinds 2009 af, is de trend onzeker of neemt deze toe afhankelijk van de gebruikte monitoring en levensfase. De toenemende trend van de vangkans op adulte finten in de DIADROOM-monitoring geeft aan dat er in theorie iets meer finten dan voorheen de mogelijkheid hebben om het IJsselmeer of andere rivieren op te zwemmen om te paaien, alhoewel het waarschijnlijk is dat deze dieren in Nederland niet succesvol kunnen en zullen paaien wanneer ze het IJsselmeer op zwemmen. Voor de juveniele finten in de DIADROOMmonitoring en de finten in de DFSmonitoring (waar ook voornamelijk juveniele finten in worden gevangen) en de NIOZ-fuik is de trend onzeker of is er een afname. Wanneer naar de gegevens van een langere periode wordt gekeken is er een afname te zien. Al met al lijkt de trend van fint dus onzeker of af te nemen. Alhoewel er met de komst van de Vismigratierivier betere migratiemogelijkheden zullen komen, wordt geen toename van de soort verwacht. Dit heeft te maken met de verwachting dat er nauwelijks nieuwe aanwas door paai in de Nederlandse rivieren en het IJsselmeer zal komen door een gebrek aan geschikt opgroeigebied (natuurlijk estuarium).

\subsubsection{Conclusies per soort Waddenzee}

\begin{tabular}{lllll} 
Natura 2000 gebied & Soort & Instandhoudings-doelstelling populatie & Classificatie populatietrend & Evaluatie doelbereik \\
Waddenzee & Zeeprik & $>$ & Afname & Doel niet behaald \\
\hline Waddenzee & Rivierprik & $>$ & Onzeker/Afname & Doel niet behaald \\
\hline Waddenzee & Fint & $>$ & Onzeker/Afname & Doel niet behaald
\end{tabular}




\subsection{Noordzeekustzone}

De Noordzeekustzone is in 2009 aangewezen als Natura 2000-gebied. De vissoorten die in het beheerplan van de Noordzeekustzone zijn opgenomen zijn zeeprik, rivierprik en fint. De doelstelling voor alle drie de soorten is uitbreiding van de populatie. De Noordzeekustzone fungeert voor deze soorten als foerageergebied en gedeeltelijk ook als doortrekgebied voor de paaitrek, voor fint is de Noordzeekustzone ook een opgroeigebied. De monitoringprogramma's die hier plaatsvinden zijn de Demersal Fish Survey (DFS) met de boomkor, DIADROOM (Kornwerderzand aan de Waddenzeezijde) met fuiken en de NIOZ-fuik op Texel. Voor de dataset van de DFS is geen selectie op trekperiode of lengte toegepast aangezien deze monitoring plaatsvindt in het foerageergebied van de geselecteerde HRvissoorten. Daarnaast is de vangkans voor deze soorten met een actief tuig erg gering. Voor de dataset van de DIADROOM monitoring, waarbij de fuiken dichtbij de sluizen staan, zijn alleen de data uit de trekperiode geselecteerd conform Tabel 4.1. Voor fint is bovendien onderscheid gemaakt tussen volwassen individuen $(>30 \mathrm{~cm}$ ) en juveniele individuen, zodat kan worden gekeken of het om individuen gaat die dit gebied als doortrekgebied gebruiken om te paaien of om juvenielen die het gebied gebruiken om op te groeien. Van zeeprik en rivierprik worden alleen volwassen individuen gevangen (kleine prikken zwemmen door mazen van de fuik heen).

De gegevens van de DIADROOM-monitoring en de NIOZ-fuik zijn zowel voor de Waddenzee als de Noordzeekustzone gebruikt om de gebieden te toetsen aangezien ze voor beide gebieden een indicatie van de populatietrends geven. 


\subsubsection{Zeeprik}

\section{Onderzoeksvraag}

Wat is de trend van zeeprik in de Noordzeekustzone voor de periode 2009-2019?

\section{Databeschikbaarheid}

\section{DFS}

Data zijn beschikbaar vanaf 1970. De DFS gegevens worden niet gebruikt om de zeeprik te toetsen aangezien deze monitoring hiervoor niet geschikt is. Zeeprik is ook sinds 1999 niet meer gevangen in de DFS in de Noordzeekustzone.

\section{DIADROOM}

Voor de zeeprik in de DIADROOM monitoring verwijzen we naar paragraaf 4.3.1

\section{NIOZ-Fuik}

Voor de zeeprik in de NIOZ-fuik verwijzen we naar paragraaf 4.3.1

\section{Conclusie}

In de Noordzeekustzone is de trend voor zeeprik onzeker (DIADROOM monitoring en NIOZ-fuik) of neemt deze af (DIADROOM monitoring). Het is onduidelijk wat hier aan ten grondslag ligt. De verwachting is dat de soort in de toekomst mogelijk zal toenemen zodra de Vismigratierivier is voltooid.

\subsubsection{Rivierprik}

\section{Onderzoeksvraag.}

Wat is de trend van rivierprik in de Noordzeekustzone voor de periode 2009-2019?

\section{Databeschikbaarheid}

\section{DFS}

Data zijn beschikbaar vanaf 197-2019 bemonsterd in de maanden augustus, september, oktober met de boomkor in de Noordzeekustzone (Figuur 4.24).

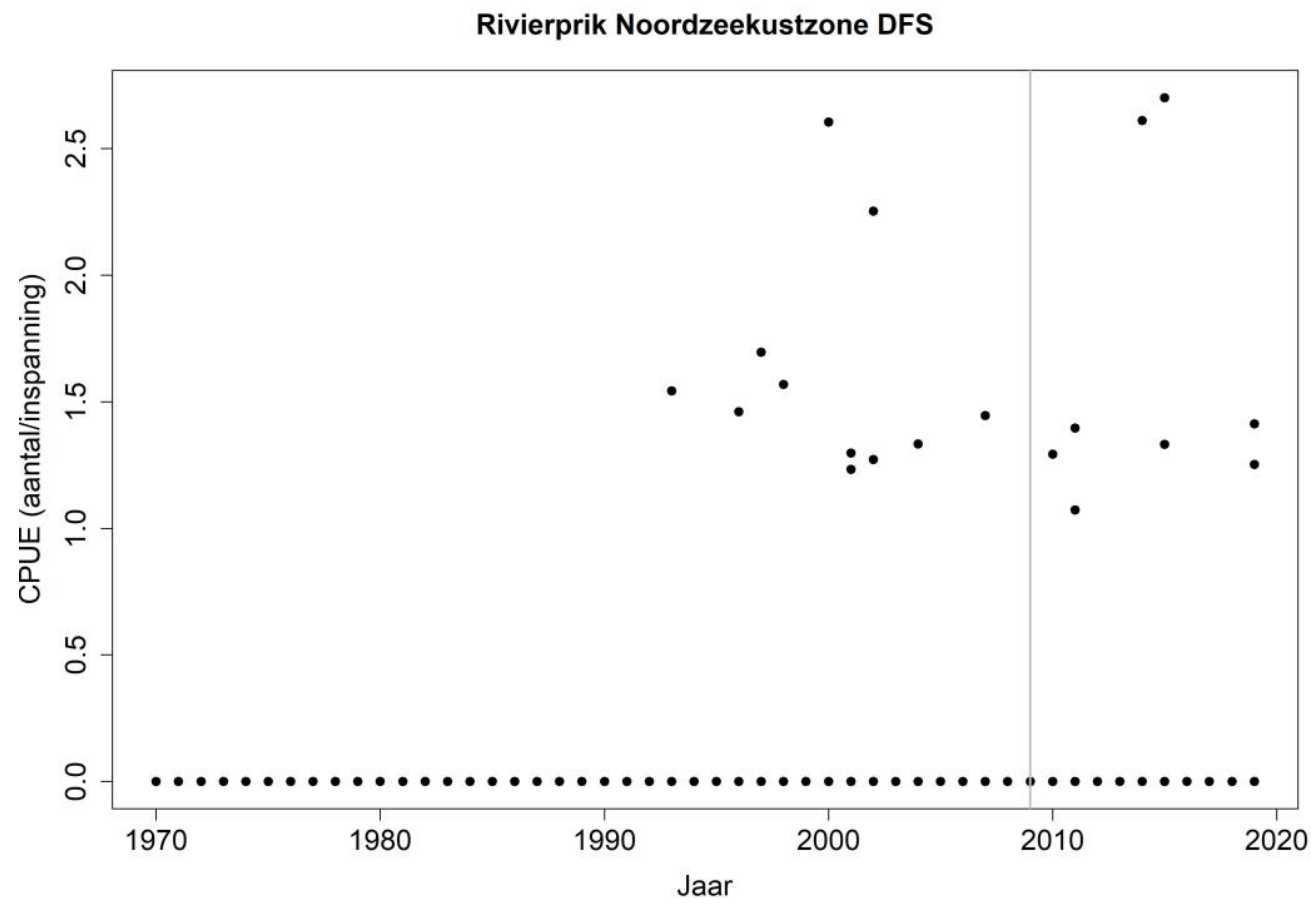

Figuur 4.24 Aantal per hectare (n/ha) per bemonstering per jaar voor rivierprik in de boomkor in de Noordzeekustzone. De grijze lijn geeft het jaar van aanwijzing weer van het Natura 2000-gebied. 


\section{Analyse}

Omdat er relatief veel nulvangsten van de rivierprik zijn in de periode 2009-2019, is een statistische analyse met GLM o.b.v. aan-/afwezigheid uitgevoerd. In deze periode is geen significante $(P=0.82)$ toe/afname van rivierprik in de Noordzeekustzone opgetreden (Figuur 4.25). De statistische analyse gebaseerd op aantallen geeft ook een onzekere trend aan ( $P=0.79$, niet weergegeven).

\section{Rivierprik Noordzeekustzone DFS}

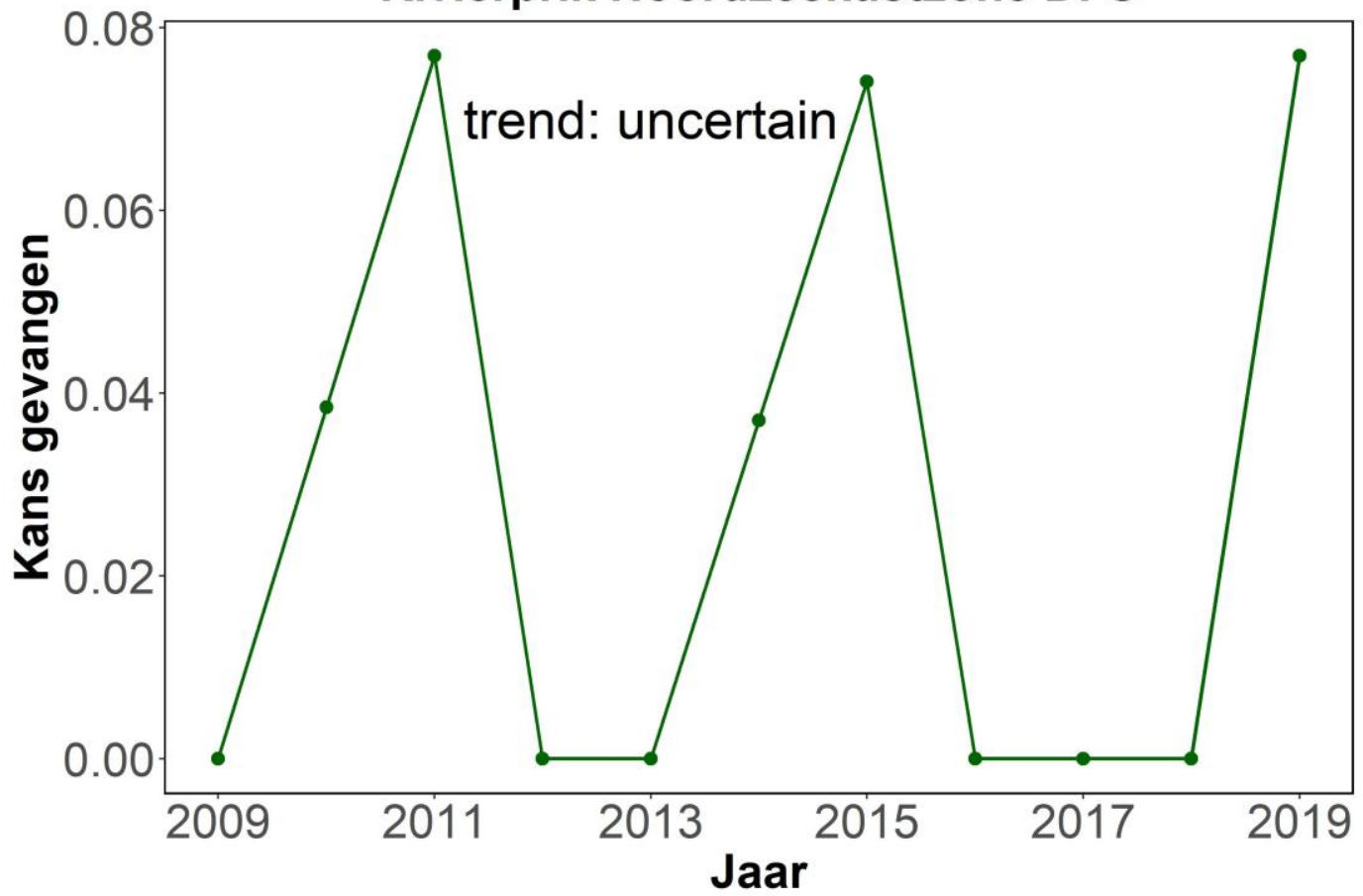

Figuur 4.25 Kans op het vangen van rivierprik in de boomkor gecorrigeerd voor inspanning vanaf het jaar dat de Noordzeekustzone is aangewezen als Natura 2000-gebied.

\section{DIADROOM}

Voor de rivierprik in de DIADROOM monitoring verwijzen we naar paragraaf 4.3 .2

\section{NIOZ-Fuik}

Voor de rivierprik in de NIOZ-fuik verwijzen we naar paragraaf 4.3.2

\section{Conclusie}

In de Noordzeekustzone is de trend voor rivierprik sinds 2009 onzeker (DFS) of nemen de aantallen sterk toe (DIADROOM). Deze ogenschijnlijke toename in de DIADROOM monitoring wordt voornamelijk bepaald door hoge vangsten in 2019. Wanneer er naar de data vanaf 2000 wordt gekeken, lijkt er echter sprake te zijn van een afname (niet getoetst). Over het algemeen lijkt de trend van de rivierprik dus onzeker. De verwachting is dat de soort in de toekomst mogelijk zal toenemen zodra de Vismigratierivier is voltooid. 


\subsubsection{Fint}

\section{Onderzoeksvraag}

Wat is de trend van fint in de Noordzeekustzone voor de periode 2009-2019?

\section{Databeschikbaarheid}

\section{DFS}

Data zijn beschikbaar vanaf 1970-2019 bemonsterd in de maanden augustus, september, oktober met de boomkor (Figuur 4.26).

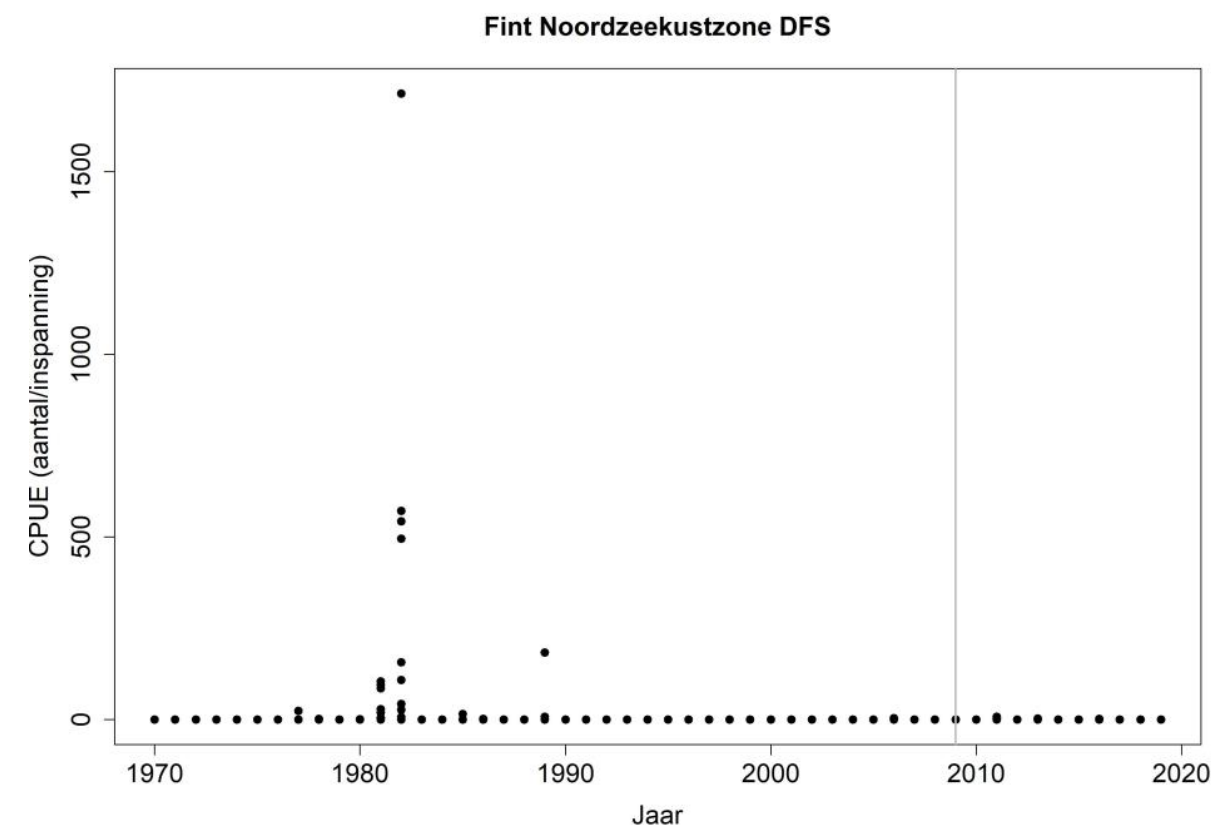

Figuur 4.26 Aantal per hectare ( $n / h a)$ per bemonstering per jaar voor fint in de boomkor in de Noordzeekustzone. De grijze lijn geeft het jaar van aanwijzing weer van het Natura 2000-gebied.

\section{Analyse}

Omdat er voor fint in de periode 2009-2019 relatief veel nulvangsten zijn gedaan met de boomkor, is een statistische analyse met GLM o.b.v. aan-/afwezigheid uitgevoerd. In deze periode is geen significante $(P=0.15)$ toe-/afname van fint in de Noordzeekustzone opgetreden (Figuur 4.27). De statistische analyse gebaseerd op aantallen geeft ook een onzekere trend aan $(P=0.05)$, niet weergegeven). 


\section{Fint Noordzeekustzone DFS}

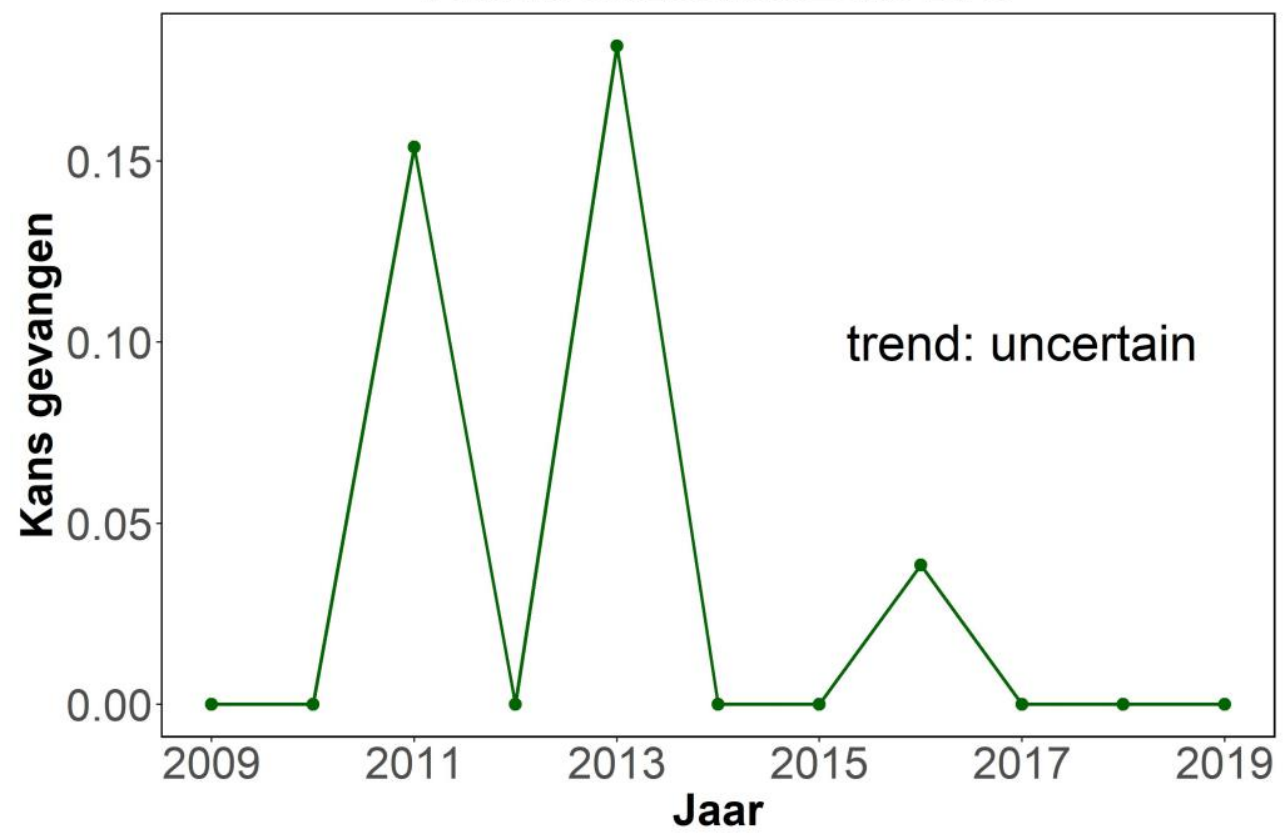

Figuur 4.27 Kans op het vangen van fint in de boomkor in de Noordzeekustzone gecorrigeerd voor inspanning vanaf het jaar dat de Noordzeekustzone is aangewezen als Natura 2000-gebied.

\section{DIADROOM}

Voor de fint in de DIADROOM monitoring verwijzen we naar paragraaf 4.3.3

\section{NIOZ-Fuik}

Voor de fint in de NIOZ-fuik verwijzen we naar paragraaf 4.3.3

\section{Conclusie}

In de Noordzeekustzone neemt de fint sinds 2009 af, is de trend onzeker of neemt deze toe afhankelijk van de gebruikte monitoring en levensfase. De toenemende trend van de vangkans op adulte finten in de DIADROOM monitoring geeft aan dat er in theorie iets meer finten dan voorheen de mogelijkheid hebben om het IJsselmeer of andere rivieren op te zwemmen om te paaien, alhoewel het waarschijnlijk is dat deze dieren in Nederland niet succesvol kunnen en zullen paaien wanneer ze het IJsselmeer op zwemmen. Voor de juveniele finten in de DIADROOM-monitoring en de finten in de DFS-monitoring (waar ook voornamelijk juveniele finten in worden gevangen) en de NIOZ-fuik is de trend onzeker of lijkt de trend af te nemen. Wanneer op langere termijn naar de gegevens wordt gekeken is er een afname te zien. Al met al lijkt de trend van fint dus onzeker of af te nemen. Alhoewel er met de komst van de Vismigratierivier betere migratiemogelijkheden zullen komen, wordt geen toename van de soort verwacht. Dit heeft te maken met de verwachting dat er nauwelijks nieuwe aanwas door paai in de Nederlandse rivieren en het IJsselmeer zal komen door een gebrek aan geschikt opgroeigebied (natuurlijk estuarium).

\subsubsection{Conclusies per soort Noordzeekustzone}

\begin{tabular}{lllll} 
Natura 2000 gebied & Soort & $\begin{array}{c}\text { Instandhoudings- } \\
\text { doelstelling populatie }\end{array}$ & Classificatie populatietrend & Evaluatie doelbereik \\
Noordzeekustzone & Zeeprik & $>$ & Onzeker/Afname & Doel niet behaald \\
\hline Noordzeekustzone & Rivierprik & $>$ & Onzeker & Doel mogelijk niet behaald \\
\hline Noordzeekustzone & Fint & $>$ & Onzeker/Afname & Doel niet behaald \\
\hline
\end{tabular}




\subsection{Hollandsch Diep}

Het Hollandsch Diep is in 2013 aangewezen als Natura 2000-gebied. De vissoorten die in het beheerplan van het Hollandsch Diep zijn opgenomen zijn zeeprik, rivierprik, fint, elft en zalm. De doelstelling voor alle vijf de soorten is uitbreiding van de populatie. Het Hollandsch Diep fungeert voor deze soorten als doortrekgebied voor de paaitrek, voor fint en elft zou het Hollandsch Diep ook een opgroeigebied kunnen zijn en een mogelijk foerageergebied voor rivierprik. Het monitoringprogramma dat hier plaatsvindt is de actieve monitoring van de rivieren (FGRA). Aangezien dit geen geschikte monitoring voor deze migrerende soorten is zijn de FDIA-monitoring gegevens van het Haringvliet gebruikt voor de toetsing. Daarnaast worden voor de zalm ook de gegevens van de zalmstekenmonitoring op de Waal gebruikt (zie paragraaf 3.8.3). Voor de datasets van de FDIA en de FGRZ (zalmsteken) monitoring, zijn alleen de data uit de trekperiode geselecteerd conform Tabel 4.2. Voor fint (en elft) is bovendien onderscheid gemaakt tussen volwassen individuen ( $>30$ en $>45 \mathrm{~cm}$ respectievelijk) en juveniele individuen, zodat kan worden gekeken of het om individuen gaat die dit gebied als doortrekgebied gebruiken om te paaien. Voor zeeprik en rivierprik was het niet mogelijk om de individuen op te splitsen in volwassenen en juvenielen omdat alleen volwassen individuen zijn gevangen (kleine prikken zwemmen door mazen van de fuik heen). Voor zalm in de FGRZ-monitoring is ook onderscheid gemaakt tussen vrijwel zekere "terugkeerders" en "verdwaalde" of fout geïdentificeerde zalmen door een selectie te maken van zalmen boven en onder de $50 \mathrm{~cm}$ lengte.

De gegevens van de FDIA- en FGRZ-monitoring zijn zowel voor het Hollandsch Diep als het Haringvliet gebruikt om de gebieden te toetsen aangezien ze voor beide gebieden een indicatie van de populatietrends geven. De trendanalyse voor het Haringvliet verschilt alleen in het jaar van aanwijzing (2015) ten opzichte van de trendanalyse voor het Hollandsch Diep (2013), wat voor verschillende beoordelingen zou kunnen zorgen.

Tabel 4.2. Trekperiode trekvis.

\begin{tabular}{ll} 
Elft & Maanden in cijfers \\
\hline Fint & gehele voorjaarsperiode $(1 ; 2 ; 3 ; 4 ; 5 ; 6)$ \\
\hline Rivierprik & gehele voorjaarsperiode $(1 ; 2 ; 3 ; 4 ; 5 ; 6)$ \\
\hline Zeeprik & $10 ; 11 ; 12$ \\
\hline Zalm & $3 ; 4 ; 5 ; 6$ \\
\hline
\end{tabular}

\subsubsection{Zeeprik}

Onderzoeksvraag

Wat is de trend van zeeprik in het Hollandsch Diep voor de periode 2013-2019?

\section{Databeschikbaarheid}

\section{FDIA}

Voor de zeeprik zijn data uit de jaren 2014-2019 beschikbaar (Figuur 4.28) van zeven stations bemonsterd in de maanden maart, april, en mei in het Haringvliet. 


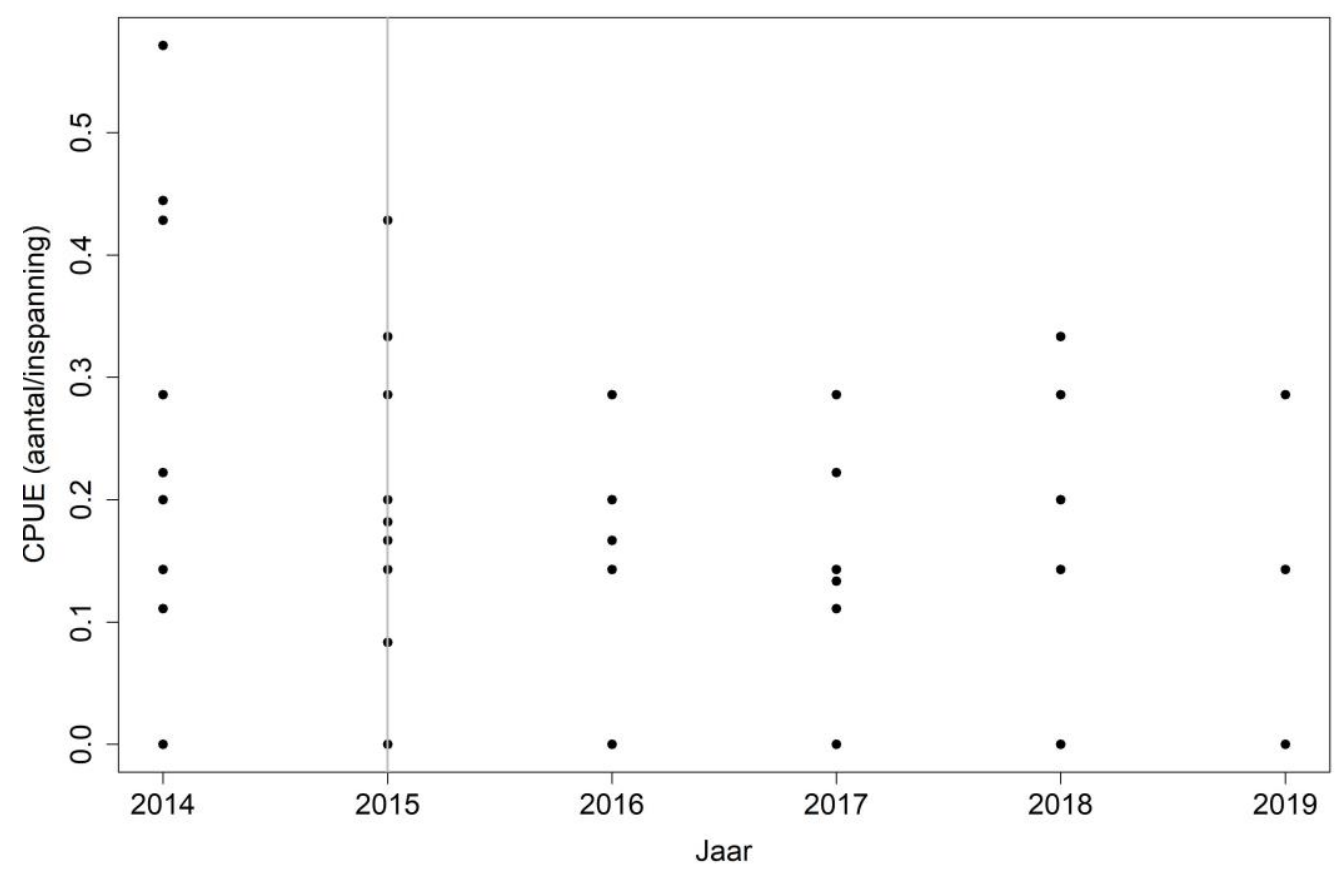

Figuur 4.28 Vangst per eenheid inspanning (CPUE) per bemonstering per jaar voor zeeprik in de fuiken in het Haringvliet. De grijze lijn geeft het jaar van aanwijzing weer van het Natura 2000-gebied Haringvliet (het jaar van aanwijzing van het Hollandsch Diep was in 2013).

\section{Analyse}

Omdat de zeeprik in de periode 2014-2019 in voldoende aantallen gevangen is met de fuiken, is een statistische analyse met GLM o.b.v. aantallen uitgevoerd. In deze periode is een significante $(P<0.001)$ afname van zeeprik in het Hollandsch Diep opgetreden (Figuur 4.29). De trend heeft een jaareffect van 0.66 wat betekent dat zeeprik gemiddeld ieder jaar met $34 \%$ is afgenomen.

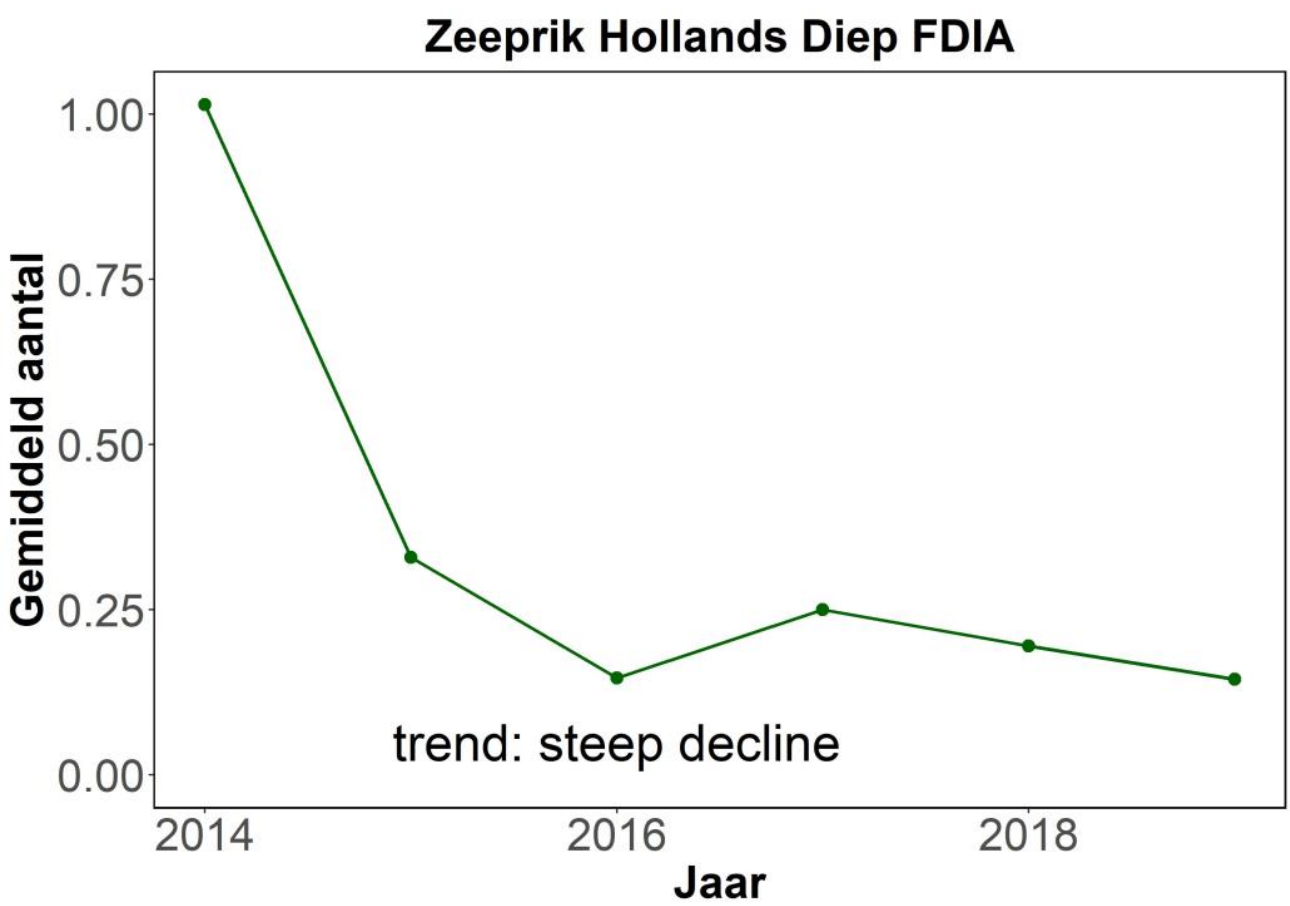

Figuur 4.29. Gemiddeld aantal gevangen zeeprikken in fuiken in het Haringvliet gecorrigeerd voor inspanning. 


\section{Conclusie}

In het Hollandsch Diep neemt de zeeprik sterk af. Het is onduidelijk wat hier aan ten grondslag ligt. De verwachting is dat de soort in de toekomst toeneemt omdat er nu betere migratiemogelijkheden zijn, als gevolg van de uitvoering van het Kierbesluit.

\subsubsection{Rivierprik}

\section{Onderzoeksvraag}

Wat is de trend van rivierprik in het Hollandsch Diep voor de periode 2013-2019?

\section{Databeschikbaarheid}

\section{FDIA}

Voor de rivierprik zijn data uit de jaren 2012-2019 beschikbaar (Figuur 4.30) van 7 stations bemonsterd in de maanden oktober, november, en om het jaar in december (2012, 2014, 2016). In 2018 zijn de locaties niet bemonsterd in de herfst.

\section{Rivierprik Hollands Diep FDIA}

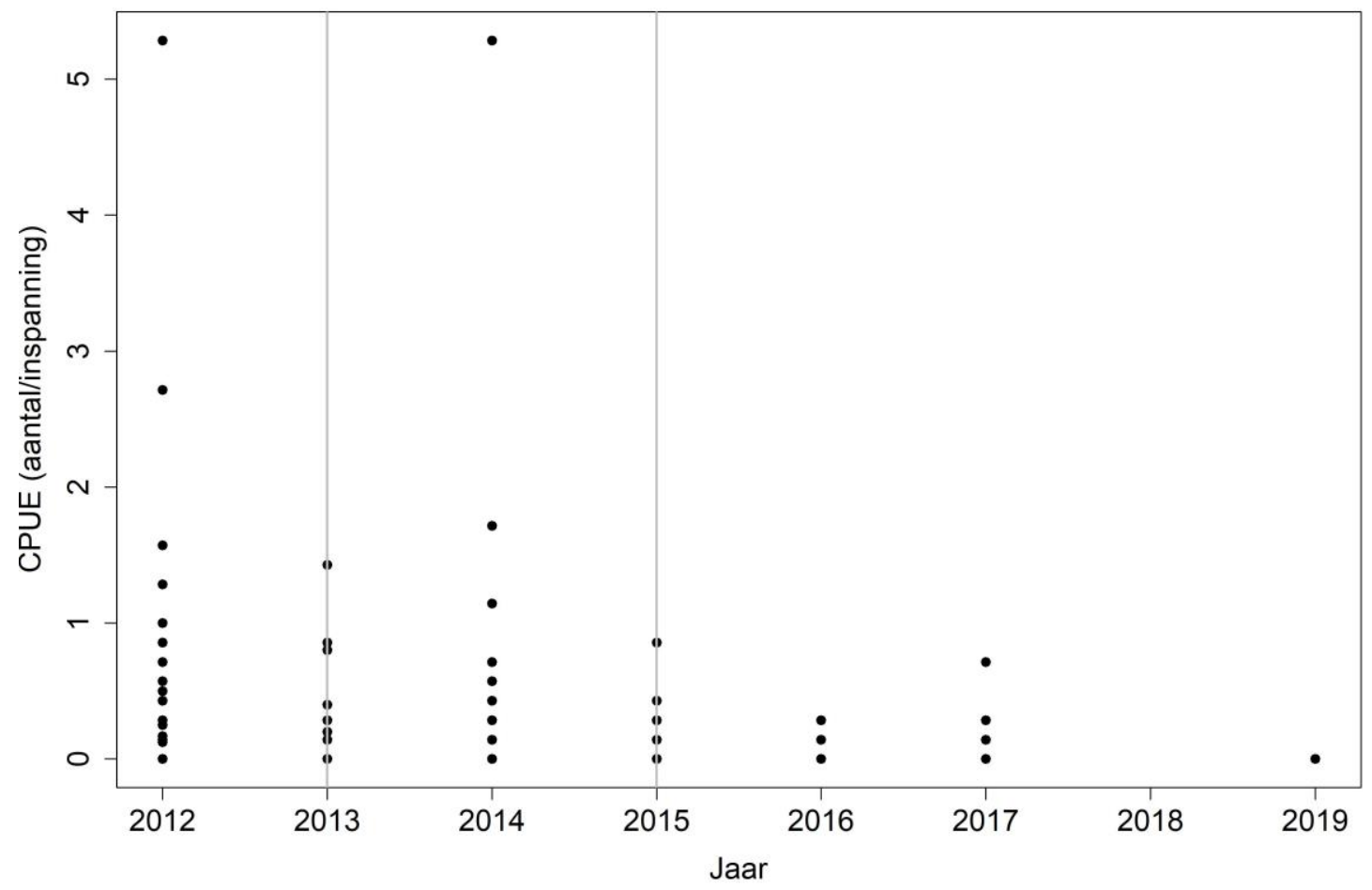

Figuur 4.30. Vangst per eenheid inspanning (CPUE) per bemonstering per jaar voor rivierprik in de fuiken van het Haringvliet. De grijze lijnen geven het jaar van aanwijzing weer van de Natura 2000-gebieden Hollandsch Diep (2013) en Haringvliet (2015).

\section{Analyse}

Omdat de rivierprik in de periode 2012-2019 in voldoende aantallen is gevangen met de fuiken, is een statistische analyse met GLM o.b.v. aantallen uitgevoerd. In deze periode is een significante $(P<0.001)$ sterke afname van rivierprik in het Hollandsch Diep opgetreden (Figuur 4.31). De trend heeft een jaareffect van 0.59 wat betekent dat rivierprik gemiddeld ieder jaar met $41 \%$ is afgenomen. Hierbij moet wel vermeld worden dat de locatie in het Haringvliet alleen in de jaren 2012, 2014 en 2016 in oktober, november en december bemonsterd is. In de overige maanden is alleen in oktober en november bemonsterd, m.u.v. 2018 waarin in zijn geheel niet bemonsterd is op het Haringvliet. Dit heeft uiteraard grote invloed op de trend. Wanneer er een strengere selectie op de data toegepast zou worden waarbij alleen de jaren waarin in de maanden oktober, november en december bemonsterd zijn worden 
meegenomen, zou de trend van het Haringvliet zoals gepresenteerd in Figuur 3.13 van toepassing zijn. Ook aan de hand van de strengere dataselectie lijkt echter een afnemende trend zichtbaar.

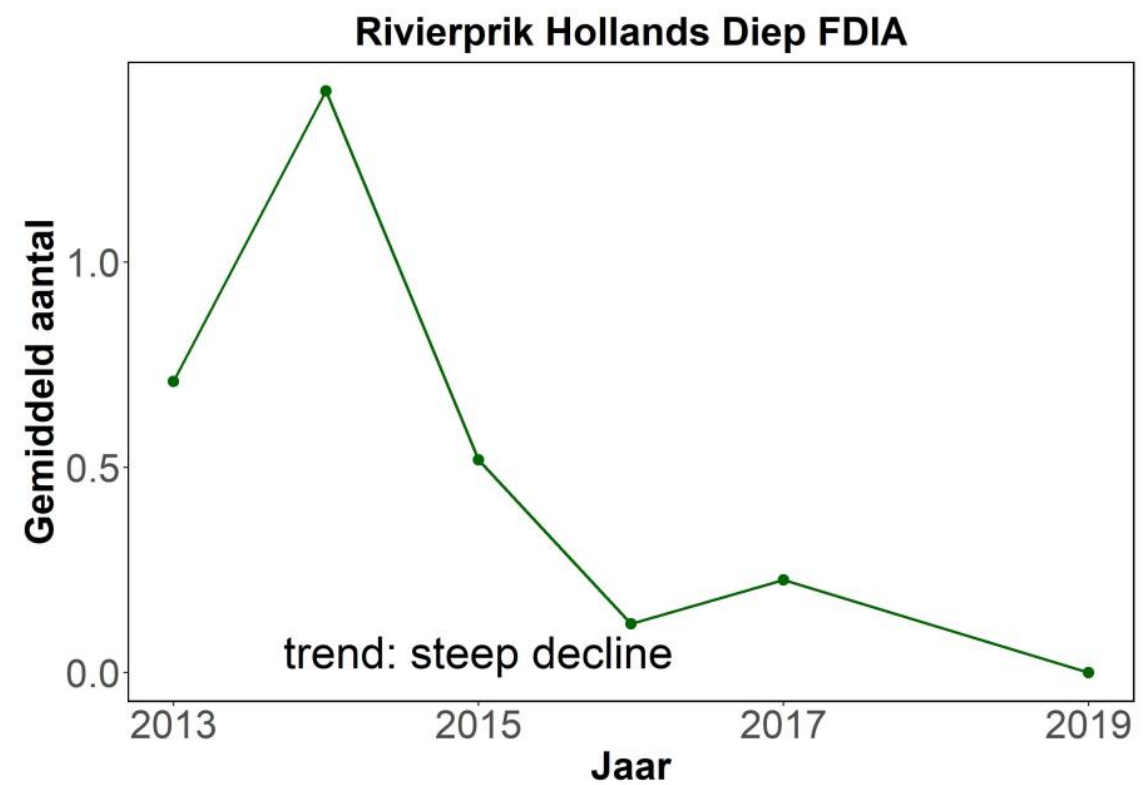

Figuur 4.31. Gemiddeld aantal gevangen rivierprikken in fuiken in de Hollandsch Diep gecorrigeerd voor inspanning vanaf het jaar dat het Hollandsch Diep is aangewezen als Natura 2000-gebied.

\section{Conclusie}

In het Hollandsch Diep neemt de rivierprik sterk af. Het is onduidelijk wat hier aan ten grondslag ligt. De verwachting is dat de soort in de toekomst toeneemt omdat er nu betere migratiemogelijkheden zijn, als gevolg van de uitvoering van het Kierbesluit. 


\subsubsection{Fint}

\section{Onderzoeksvraag}

Wat is de trend van fint in het Hollandsch Diep voor de periode 2013-2019?

\section{Databeschikbaarheid}

\section{FDIA}

$$
\text { Jaar }
$$

Figuur 4.32) van zeven stations bemonsterd in de maanden maart, april, en mei in het Haringvliet.

Fint Hollands Diep FDIA

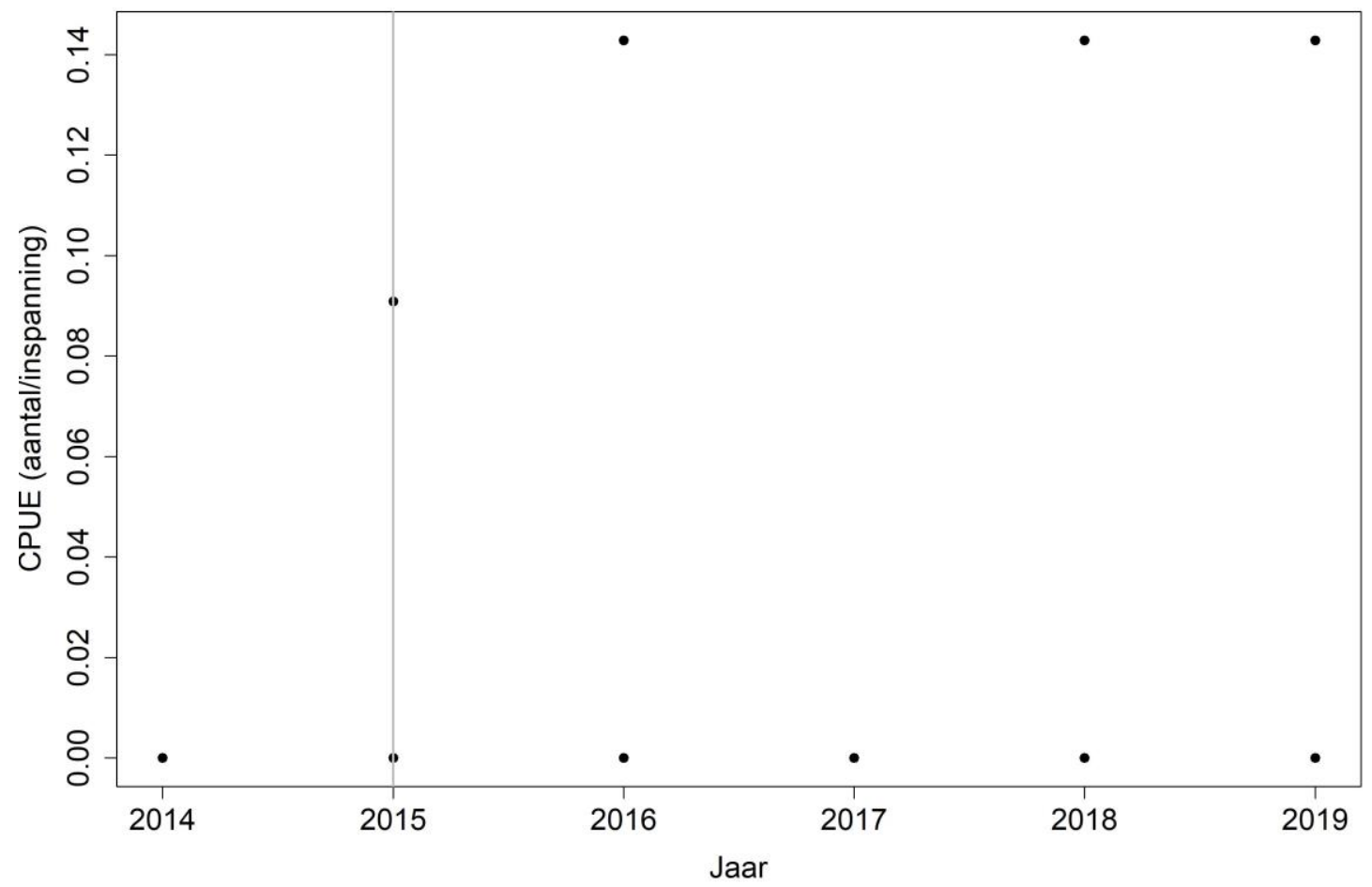

Figuur 4.32. Vangst per eenheid inspanning (CPUE) per bemonstering per jaar voor fint in fuiken van het Haringvliet. De grijze lijn geeft het jaar van aanwijzing weer van het Natura 2000-gebied Haringvliet (het jaar van aanwijzing van het Hollandsch Diep was in 2013).

\section{Analyse}

Er zijn alleen maar volwassen finten $(>30 \mathrm{~cm}$ ) gevangen in de fuiken. Aangezien er relatief veel nulvangsten waren in de periode 2014-2019, is een statistische analyse met GLM o.b.v. aan-/afwezigheid uitgevoerd. In deze periode is geen significante $(P=0.07)$ toe-/afname van adulte fint in het Hollandsch Diep opgetreden (Figuur 4.33). De trend van de adulte fint is stabiel ondanks de relatief hoge vangsten in 2018. De analyse op basis van aantallen geeft een niet significante, onzekere trend weer (niet weer gegeven). 
Fint Hollands Diep FDIA

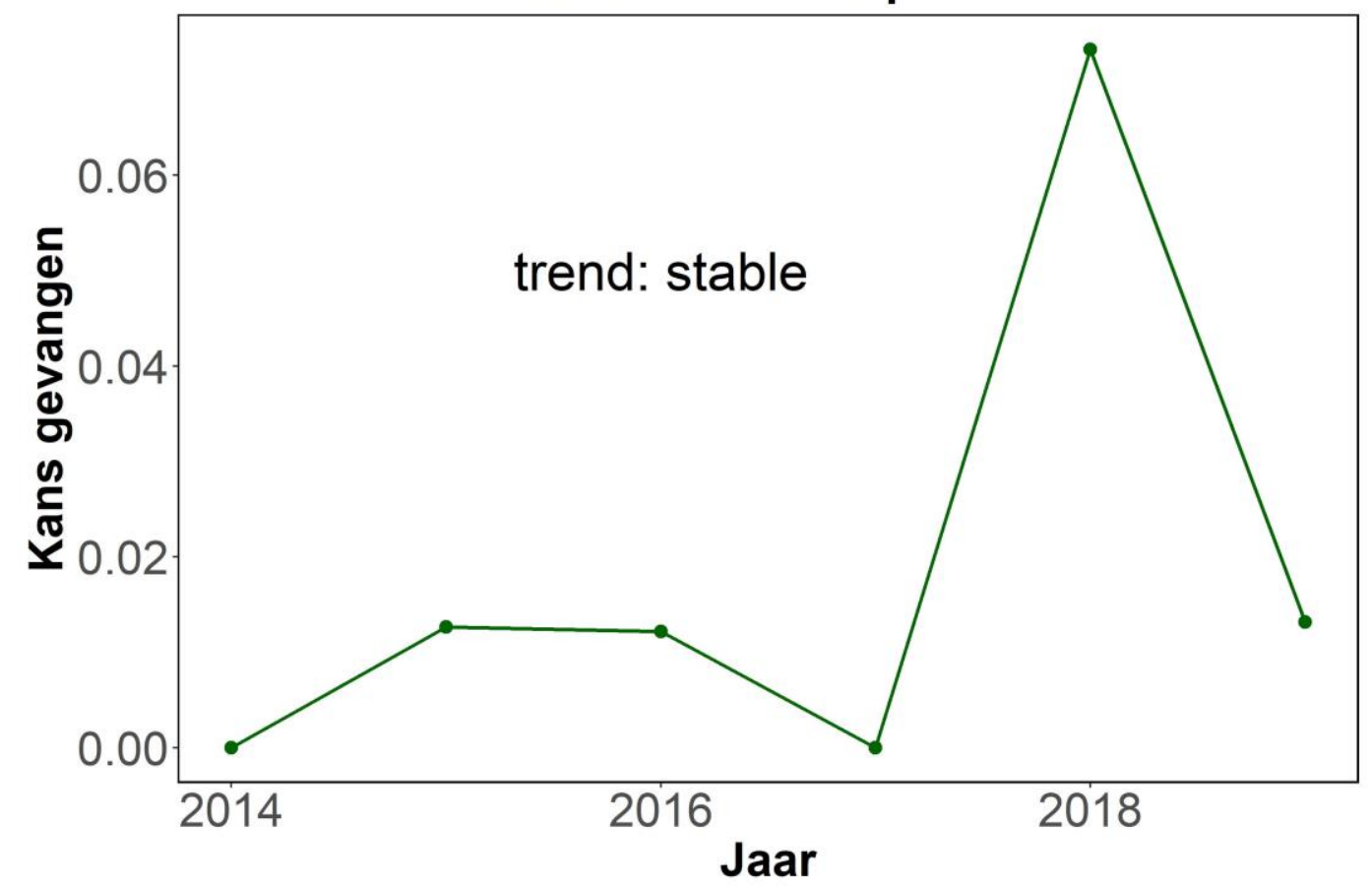

Figuur 4.33 Kans op het vangen van adulte fint in de fuiken van het Haringvliet gecorrigeerd voor inspanning.

\section{Conclusie}

In het Hollandsch Diep is de trend van fint sinds 2014 stabiel. Alhoewel er nu betere migratiemogelijkheden zijn als gevolg van de uitvoering van het Kierbesluit, wordt geen toename van de soort verwacht. Dit heeft te maken met de verwachting dat er nauwelijks nieuwe aanwas door paai in de Nederlandse rivieren zal komen door een gebrek aan geschikt opgroeigebied (natuurlijk estuarium).

\subsubsection{Elft}

\section{Onderzoeksvraag}

Wat is de trend van elft in het Hollandsch Diep voor de periode 2013-2019?

\section{Databeschikbaarheid}

\section{FDIA}

Voor de elft zijn data uit de jaren 2014-2019 beschikbaar van zeven stations bemonsterd in de maanden maart, april, en mei in het Haringvliet. Er is sinds het begin van de monitoring geen elft in het voorjaar gevangen.

\section{Conclusie}

De trend van de elft in het Haringvliet is onzeker bij gebrek aan data. De monitoring is onvoldoende om een dermate schaarse soort als elft te kunnen beoordelen. Mogelijk kan elft alleen op basis van stroomgebied (landelijke trend) worden beoordeeld, en niet op afzonderlijk Natura-2000-gebied, tenzij een aanzienlijk grotere, en nog meer op trekvis gerichte, monitoringsinspanning wordt gerealiseerd.

\subsubsection{Zalm}

\section{Onderzoeksvraag}

Wat is de trend van zalm in het Hollandsch Diep voor de periode 2013-2019? 


\section{Databeschikbaarheid}

\section{FDIA}

Voor de zalm zijn data uit de jaren 2012-2019 beschikbaar (Figuur 4.34) van zeven stations bemonsterd in de maanden mei, september, oktober en november in het Haringvliet. In 2018 is alleen in mei bemonsterd.

\section{Zalm Hollands Diep FDIA}

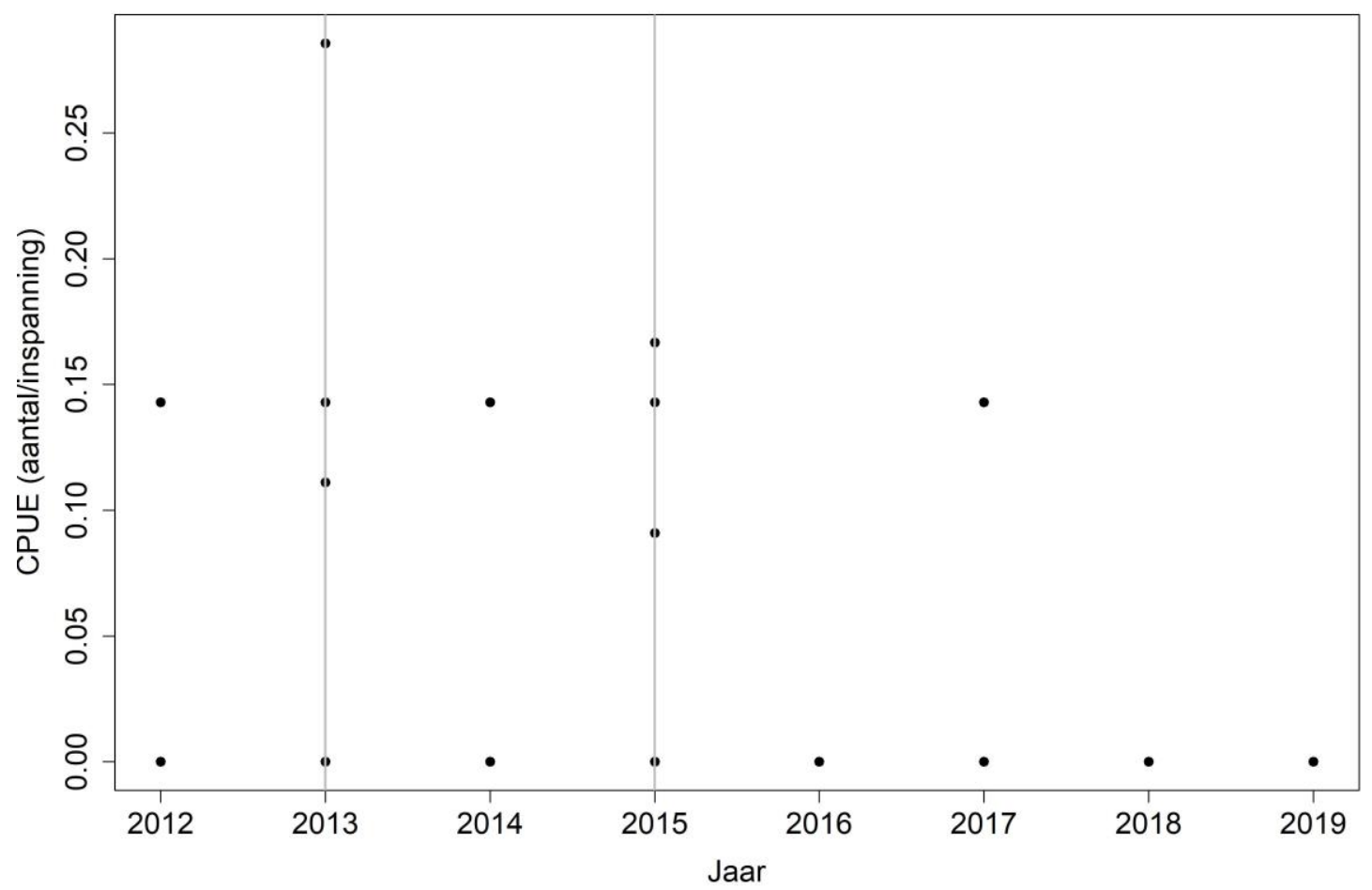

Figuur 4.34 Vangst per eenheid inspanning (CPUE) per bemonstering per jaar voor zalm in fuiken van het Haringvliet. De grijze lijnen geven het jaar van aanwijzing weer van de Natura 2000 -gebieden Hollandsch Diep (2013) en Haringvliet (2015).

\section{Analyse}

Aangezien er relatief veel nulvangsten waren in de periode 2013-2019, is een statistische analyse met GLM o.b.v. aan-/afwezigheid uitgevoerd. In deze periode is een significante $(P=0.009)$ sterke afname van zalm in het Hollandsch Diep opgetreden (Figuur 4.35). De analyse op basis van aantallen geeft een significante $(P=0.002)$ sterke afname weer (niet weergegeven). 


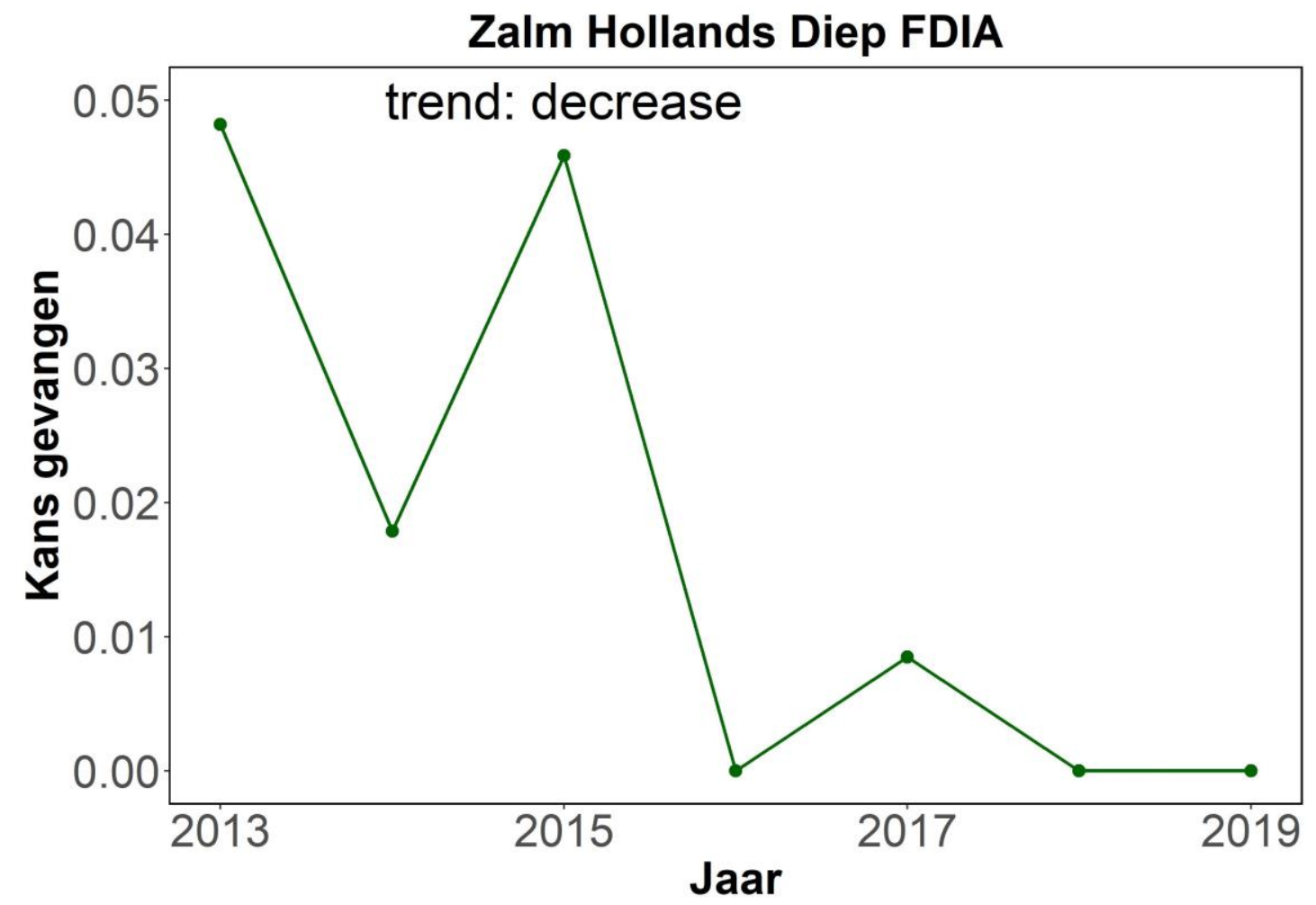

Figuur 4.35 Kans op het vangen van zalm in de fuiken van het Haringvliet gecorrigeerd voor inspanning vanaf het jaar dat het Hollandsch Diep is aangewezen als Natura 2000-gebied.

\section{FGRZ}

Voor de zalm zijn data uit de jaren 1994-2019 beschikbaar (Figuur 4.36) in de maanden mei-december in de Waal. De maanden augustus, september en december zijn maar een enkele keer bemonsterd en zijn daarom toch meegenomen in de data analyse (ondanks dat ze officieel buiten de migratiemaanden vallen). Er is pas vanaf 2010 ook in de maand mei bemonsterd en vanaf 2014 ontbreekt de maand juli. 


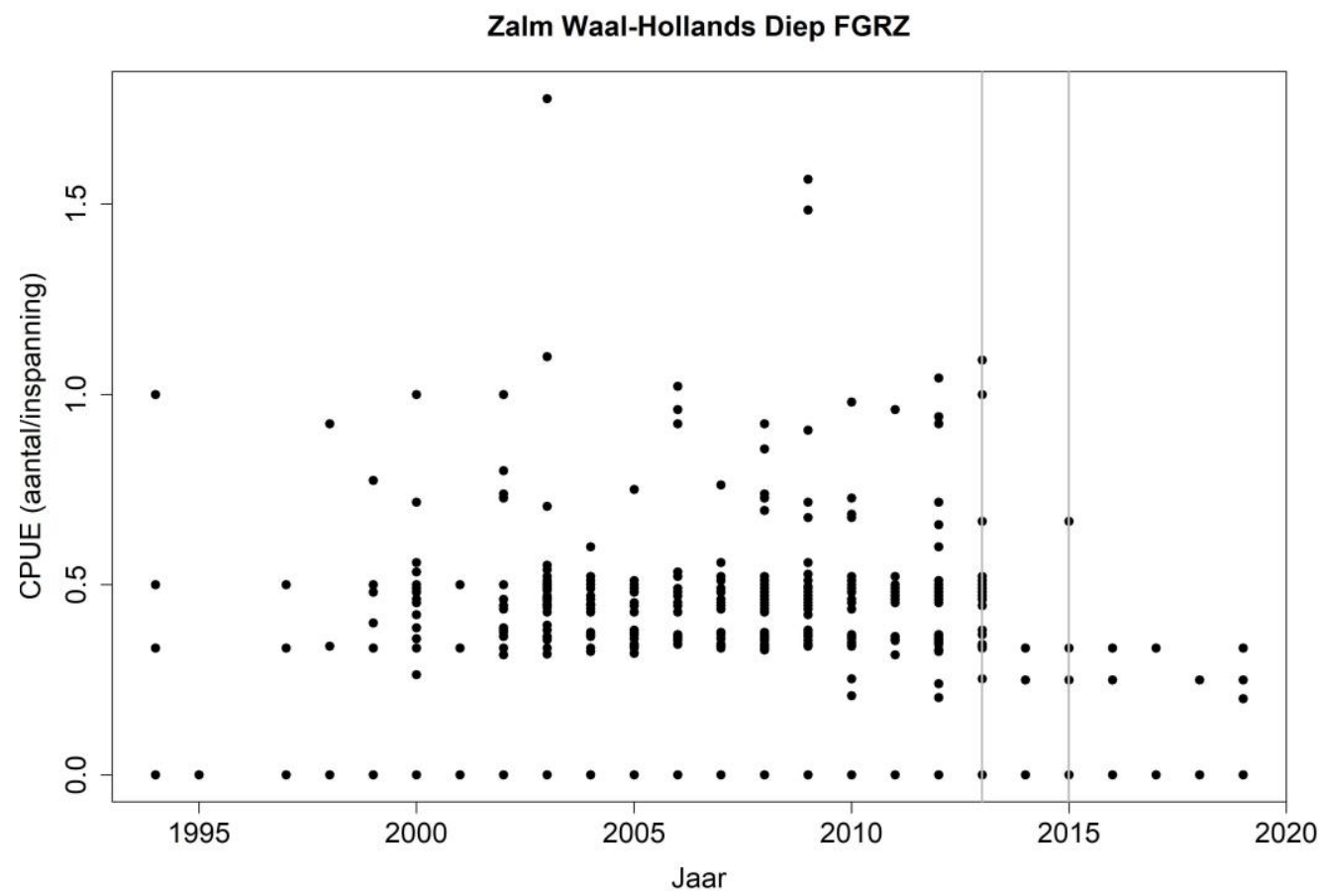

Figuur 4.36 Vangst per eenheid inspanning (CPUE) per bemonstering per jaar voor zalm in zalmsteken van de Waal. De grijze lijnen geven het jaar van aanwijzing weer van de Natura 2000-gebieden Hollandsch Diep (2013) en Haringvliet (2015).

\section{Analyse}

Het overgrote deel van de zalmen heeft een lengte van boven de $50 \mathrm{~cm}$ en dit zijn vrijwel zeker "terugkeerders". Daarom is alle data (dus alle lengtes) voor de analyse hier samengenomen. Aangezien er voldoende aantallen vissen gevangen zijn in de periode 2013-2019, is een statistische analyse met GLM o.b.v. aantallen uitgevoerd. In deze periode is een significante $(P<0.001)$ sterke afname van zalm in het Hollandsch Diep opgetreden (Figuur 4.37).

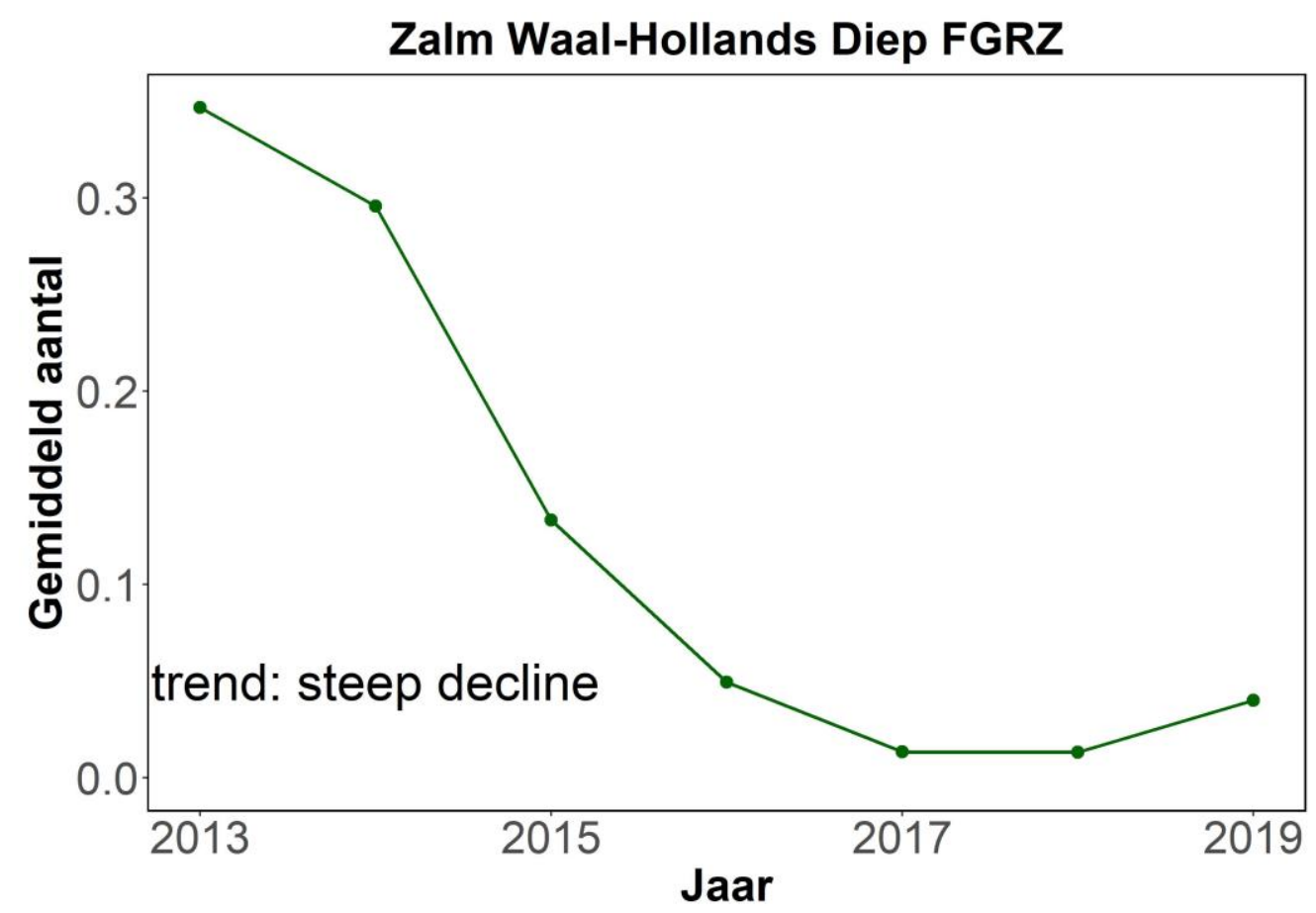


Figuur 4.37 Gemiddeld aantal gevangen in de zalmsteken van de Waal gecorrigeerd voor inspanning vanaf het jaar dat het Hollandsch Diep is aangewezen als Natura 2000-gebied.

Conclusie

In het Hollandsch Diep is de zalm sinds 2013 sterk afgenomen. Het is onduidelijk wat hier aan ten grondslag ligt. Wanneer de Haringvlietdam een belemmering heeft gevormd is de verwachting is dat de soort in de toekomst toeneemt omdat er nu betere migratiemogelijkheden zijn, als gevolg van de uitvoering van het Kierbesluit.

\subsubsection{Conclusies per soort Hollandsch Diep}

\begin{tabular}{llllll} 
Natura 2000 gebied & Soort & Instandhoudings-doelstelling populatie & Classificatie populatietrend & Evaluatie doelbereik \\
Hollandsch Diep & Zeeprik & $>$ & Afname & Doel niet behaald \\
\hline Hollandsch Diep & Rivierprik & $>$ & Afname & Doel niet behaald \\
\hline Hollandsch Diep & Fint & $>$ & Stabiel & Doel niet behaald \\
\hline Hollandsch Diep & Elft & $>$ & Onzeker & Onduidelijk \\
\hline Hollandsch Diep & Zalm & $>$ & Afname & Doel niet behaald
\end{tabular}




\subsection{Haringvliet}

Het Haringvliet is in 2015 aangewezen als Natura 2000-gebied. De vissoorten die in het beheerplan van het Haringvliet zijn opgenomen zijn zeeprik, rivierprik, fint, elft, zalm, rivierdonderpad en bittervoorn. De doelstelling voor de eerste vijf (trekvis)soorten is uitbreiding van de populatie, voor de rivierdonderpad en de bittervoorn is de doelstelling behoud van de populatie. Het Haringvliet fungeert voor de trekvissoorten als doortrekgebied voor de paaitrek, voor fint en elft zou het Haringvliet ook een opgroeigebied kunnen zijn en een mogelijk foerageergebied voor rivierprik. De rivierdonderpad migreert niet en spendeert zijn gehele levenscyclus in één gebied. Aangezien er geen geschikte monitoring plaats vindt om de populatietrends van bittervoorn vast te stellen is deze soort buiten beschouwing gelaten. De monitoringprogramma's die in het Haringvliet plaatsvinden zijn de actieve monitoring van de rivieren (FGRA) en de FDIA monitoring. De FGRA kan alleen voor rivierdonderpad gebruikt worden aangezien dit de enige habitatsoort is die zijn gehele levenscyclus in één gebied voltooit en daardoor een (veel) hogere vangkans heeft met actieve monitoring dan de trekvissoorten. Voor de zalm worden ook de gegevens van de zalmstekenmonitoring op de Waal gebruikt (zie paragraaf 3.8.3). Voor de datasets van de FDIAen de FGRZ(zalmsteken)-monitoring, zijn alleen de data uit de trekperiode geselecteerd conform Tabel 4.2. Voor fint (en elft) is bovendien onderscheid gemaakt tussen volwassen individuen ( $>30$ en $>45 \mathrm{~cm}$ respectievelijk) en juveniele individuen, zodat kan worden gekeken of het om individuen gaat die dit gebied als doortrekgebied gebruiken om te paaien. Voor zeeprik en rivierprik was het niet mogelijk om de individuen op te splitsen in volwassenen en juvenielen omdat alleen volwassen individuen zijn gevangen (kleine prikken zwemmen door mazen van de fuik heen). Voor zalm in de FGRZ monitoring is ook onderscheid gemaakt tussen vrijwel zekere "terugkeerders" en "verdwaalde" of fout geïdentificeerde zalmen door een selectie te maken van zalmen boven en onder de $50 \mathrm{~cm}$ lengte.

De gegevens van de FDIA- en FGRZ-monitoring zijn zowel voor het Hollandsch Diep als het Haringvliet gebruikt om de gebieden te toetsen aangezien ze voor beide gebieden een indicatie van de populatietrends geven. De trendanalyse voor het Haringvliet verschilt alleen in het jaar van aanwijzing (2015) ten opzichte van de trendanalyse voor het Hollandsch Diep (2013) wat voor verschillende beoordelingen zou kunnen zorgen.

\subsubsection{Zeeprik}

Onderzoeksvraag

Wat is de trend van zeeprik in het Haringvliet voor de periode 2015-2019?

\section{Databeschikbaarheid}

\section{FDIA}

Voor de zeeprik zijn data uit de jaren 2014-2019 beschikbaar (Figuur 4.28) van zeven stations in het Haringvliet, bemonsterd in de maanden maart, april, en mei. 
Analyse

Omdat de zeeprik in de periode 2015-2019 in voldoende aantallen gevangen is met de fuiken, is een statistische analyse met GLM o.b.v. aantallen uitgevoerd. In deze periode is geen significante $(P=0.10)$ toe-/afname van zeeprik in het Haringvliet opgetreden (Figuur 4.38). De analyse op basis van aan/afwezigheid geeft ook een onzekere trend ( $P=0.13$, niet weergegeven).

\section{Zeeprik Haringvliet FDIA}

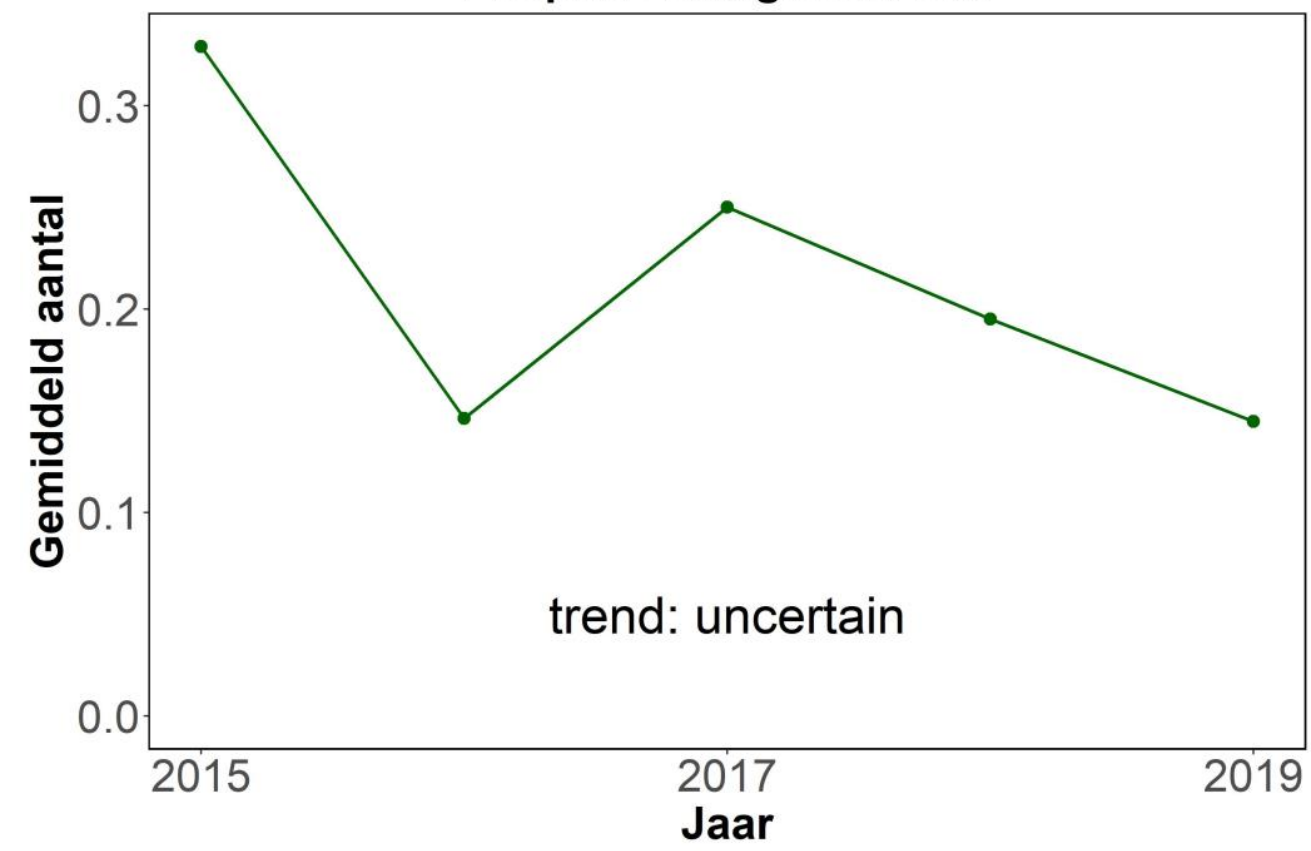

Figuur 4.38 Gemiddeld aantal gevangen zeeprikken in fuiken in het Haringvliet gecorrigeerd voor inspanning.

\section{Conclusie}

In het Haringvliet is de trend van zeeprik onzeker. Dat deze trend onzeker is en niet sterk afneemt zoals in het Hollandsch Diep heeft te maken met het jaar van aanstelling van het Haringvliet (2015), wat twee jaar later is dan het Hollandsch Diep (2013). De verwachting is dat de soort in de toekomst toeneemt omdat er nu betere migratiemogelijkheden zijn, als gevolg van de uitvoering van het Kierbesluit.

\subsubsection{Rivierprik}

Onderzoeksvraag

Wat is de trend van rivierprik in het Haringvliet voor de periode 2015-2019?

\section{Databeschikbaarheid}

\section{FDIA}

Voor de rivierprik zijn data uit de jaren 2012-2019 beschikbaar (Figuur 4.30) van 7 stations bemonsterd in de maanden oktober, november, en om het jaar in december (2012, 2014, 2016). In 2018 zijn de locaties niet bemonsterd in de herfst en de winter.

\section{Analyse}

Omdat de rivierprik in de periode 2012-2019 in voldoende aantallen is gevangen met de fuiken, is een statistische analyse met GLM o.b.v. aantallen uitgevoerd. In deze periode is een significante $(P=0.003)$ afname van rivierprik in de Haringvliet opgetreden (Figuur 4.39). Ondanks deze significante afname wordt de trend echter als onzeker beschouwd vanwege de hoge standaardfout. De analyse op basis van aan-/afwezigheid geeft ook een afname van rivierprik aan $(P<0.001$, niet weergegeven). 


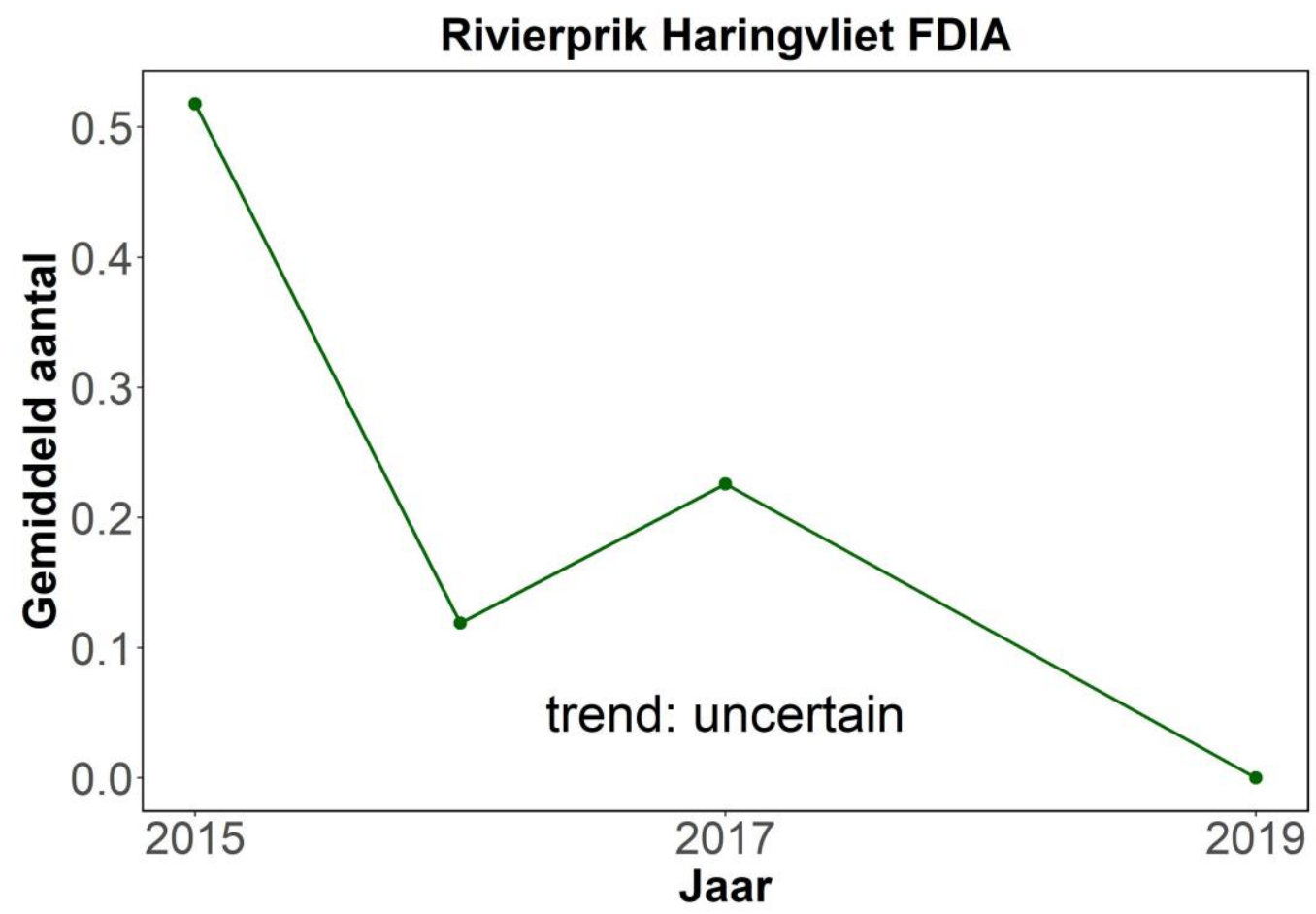

Figuur 4.39. Gemiddeld aantal gevangen rivierprikken in fuiken in de Haringvliet gecorrigeerd voor inspanning vanaf het jaar dat het Haringvliet is aangewezen als Natura 2000-gebied.

\section{Conclusie}

In het Haringvliet is de trend van rivierprik onzeker/neemt af. Dat deze trend onzeker is en niet sterk afneemt zoals in het Hollandsch Diep heeft te maken met het jaar van aanstelling van het Haringvliet (2015), wat twee jaar later is dan het Hollandsch Diep (2013). De verwachting is dat de soort in de toekomst toeneemt omdat er nu betere migratiemogelijkheden zijn, als gevolg van de uitvoering van het Kierbesluit. 


\subsubsection{Fint}

\section{Onderzoeksvraag}

Wat is de trend van fint in het Haringvliet voor de periode 2015-2019?

\section{Databeschikbaarheid}

\section{FDIA}

$$
\text { Jaar }
$$

Figuur 4.32) van zeven stations bemonsterd in de maanden maart, april, en mei in het Haringvliet.

\section{Analyse}

Er zijn alleen maar volwassen finten $(>30 \mathrm{~cm}$ ) gevangen in de fuiken. Aangezien er relatief veel nulvangsten waren in de periode 2015-2019, is een statistische analyse met GLM o.b.v. aan-/afwezigheid uitgevoerd. In deze periode is geen significante $(P=0.21)$ toe-/afname van adulte fint in het Haringvliet opgetreden (Figuur 4.40). De analyse op basis van aantallen geeft een niet significante, onzekere trend weer $(P=0.19$, niet weer gegeven).

\section{Fint Haringvliet FDIA}

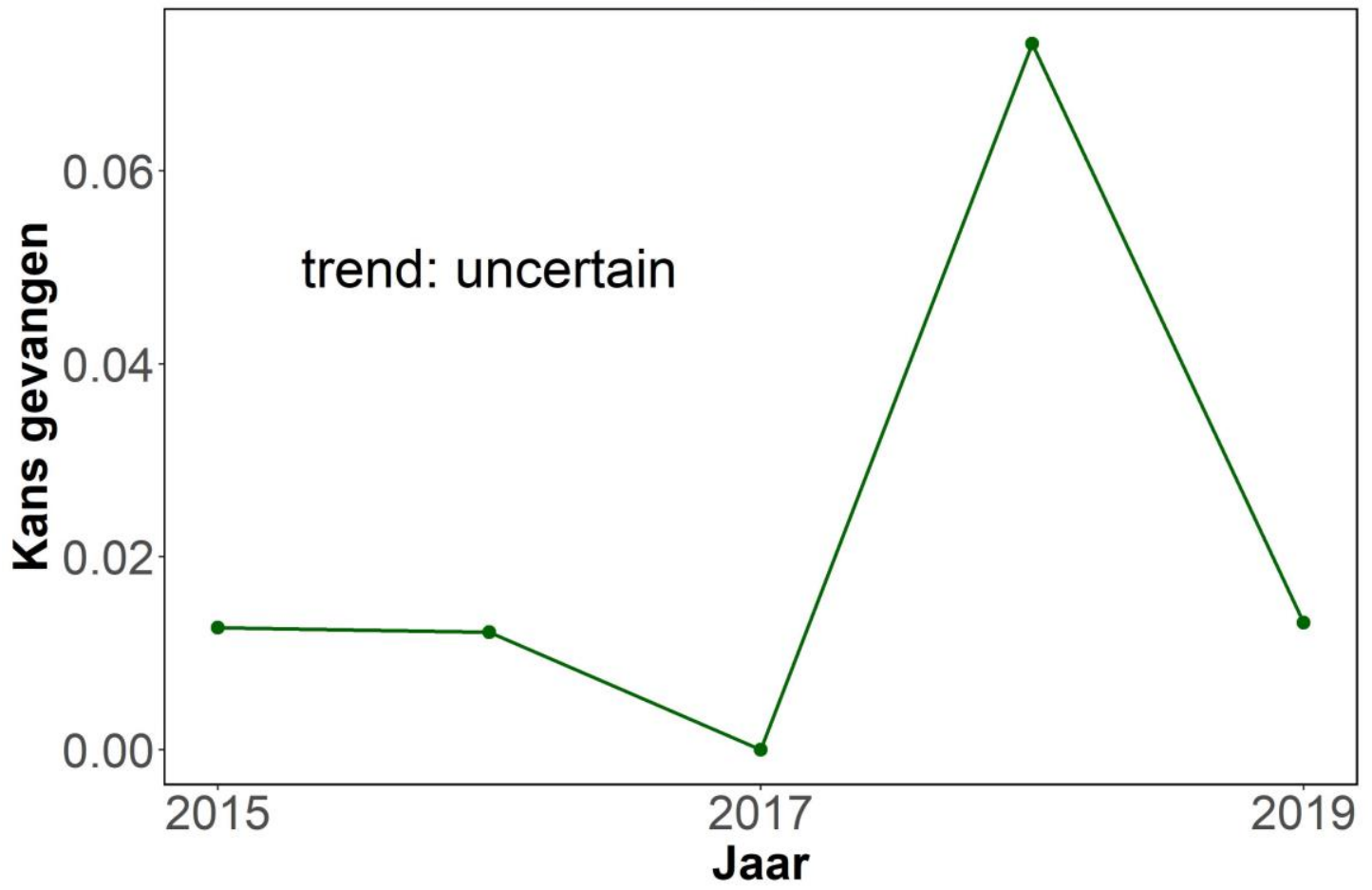

Figuur 4.40 Kans op het vangen van adulte fint in de fuiken van het Haringvliet gecorrigeerd voor inspanning.

\section{Conclusie}

In het Haringvliet is de trend van fint sinds 2015 onzeker. Wanneer de data vanaf 2014 worden getoetst net zoals voor het Hollandsch Diep is de trend stabiel. Alhoewel er nu betere migratiemogelijkheden zijn als gevolg van de uitvoering van het Kierbesluit, wordt geen toename van de soort verwacht. Dit heeft te maken met de verwachting dat er nauwelijks nieuwe aanwas door paai in de Nederlandse rivieren zal komen door een gebrek aan geschikt opgroeigebied (natuurlijk estuarium). 


\subsubsection{Elft}

Onderzoeksvraag

Wat is de trend van elft in het Haringvliet voor de periode 2015-2019?

\section{Databeschikbaarheid}

\section{FDIA}

Voor de elft zijn data uit de jaren 2015-2019 beschikbaar van zeven stations bemonsterd in de maanden maart, april, en mei in het Haringvliet. $\mathrm{Er}$ is sinds het begin van de monitoring geen elft in het voorjaar gevangen.

\section{Conclusie}

De trend van de elft in het Haringvliet is onzeker bij gebrek aan data. De monitoring is onvoldoende om een dermate schaarse soort als elft te kunnen beoordelen. Mogelijk kan elft alleen op basis van stroomgebied (landelijke trend) worden beoordeeld, en niet op afzonderlijk Natura-2000-gebied, tenzij een aanzienlijk grotere, en nog meer op trekvis gerichte, monitoringsinspanning wordt gerealiseerd.

\subsubsection{Zalm}

\section{Onderzoeksvraag}

Wat is de trend van zalm in het Haringvliet voor de periode 2015-2019?

\section{Databeschikbaarheid}

\section{FDIA}

Voor de zalm zijn data uit de jaren 2012-2019 beschikbaar (Figuur 4.34) van zeven stations bemonsterd in de maanden mei, september, oktober en november in het Haringvliet. In 2018 is er alleen in mei bemonsterd.

\section{Analyse}

Aangezien er relatief veel nulvangsten waren in de periode 2015-2019, is een statistische analyse met GLM o.b.v. aan-/afwezigheid uitgevoerd. In deze periode is een significante $(P=0.04)$ sterke afname van zalm in het Haringvliet opgetreden (Figuur 4.41). De analyse op basis van aantallen geeft een significante $(P=0.04)$ sterke afname weer (niet weer gegeven).

\section{Zalm Haringvliet FDIA}

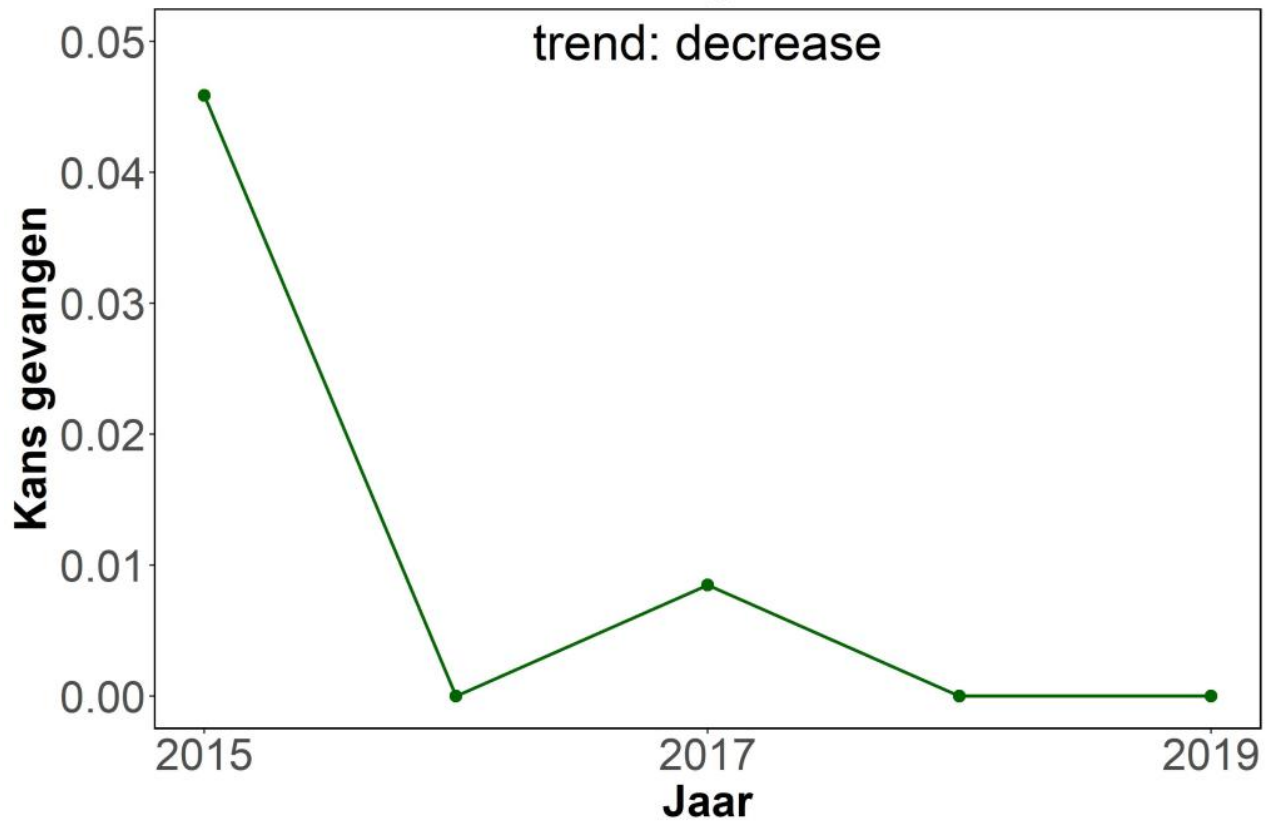

Figuur 4.41 Kans op het vangen van zalm in de fuiken van het Haringvliet gecorrigeerd voor inspanning vanaf het jaar dat het Haringvliet is aangewezen als Natura 2000-gebied. 


\section{FGRZ}

Voor de zalm zijn data uit de jaren 1994-2019 beschikbaar in de maanden mei-december in de Waal (Figuur 4.36). De maanden augustus, september en december zijn maar een enkele keer bemonsterd en zijn daarom toch meegenomen in de data analyse (ondanks dat ze officieel buiten de migratiemaanden vallen). Er is pas vanaf 2010 ook in de maand mei bemonsterd en vanaf 2014 ontbreekt de maand juli.

\section{Analyse}

Het overgrote deel van de zalmen heeft een lengte van boven de $50 \mathrm{~cm}$ en dit zijn vrijwel zeker "terugkeerders". Daarom is alle data voor de analyse hier is samen genomen. Aangezien er voldoende aantallen vissen gevangen zijn in de periode 2015-2019, is een statistische analyse met GLM o.b.v. aantallen uitgevoerd. In deze periode is een significante $(P=0.02)$ afname van zalm in het Haringvliet opgetreden (Figuur 4.42). Ondanks deze afname wordt de trend als onzeker beschouwd vanwege de hoge standaardfout. De analyse op basis van aan-/afwezigheid geeft ook een afname van zalm aan $(P=0.02$, niet weergegeven).

\section{Zalm Waal-Haringvliet FGRZ}

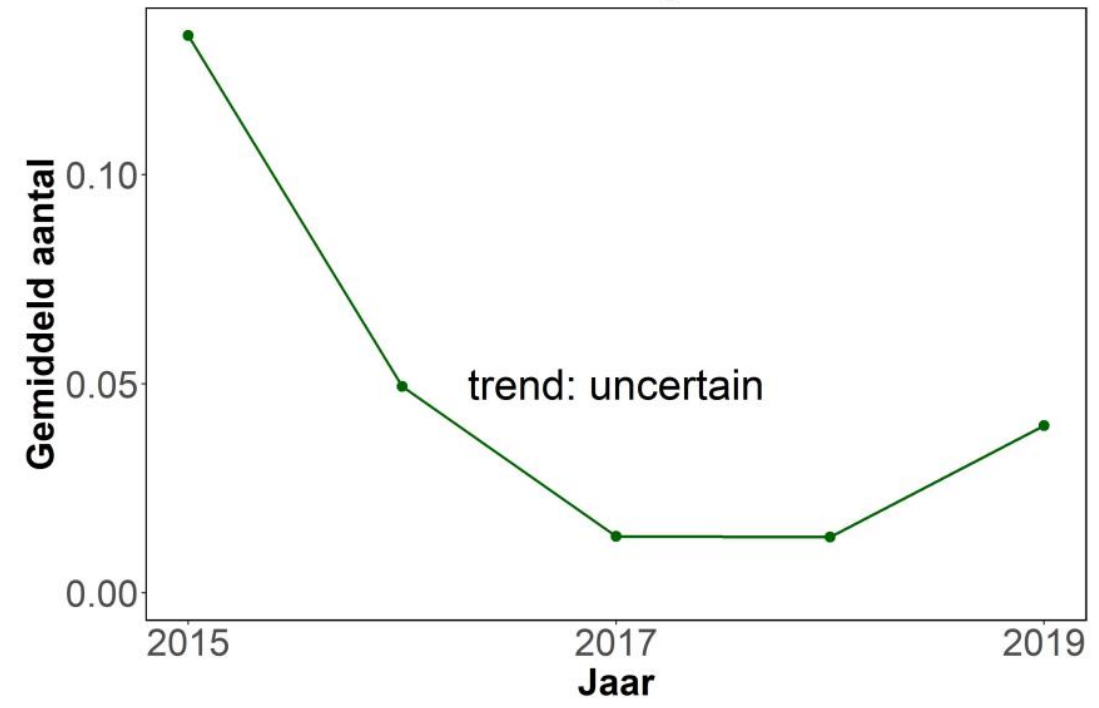

Figuur 4.42 Gemiddeld aantal gevangen in de zalmsteken van de Waal gecorrigeerd voor inspanning vanaf het jaar dat het Haringvliet is aangewezen als Natura 2000-gebied.

\section{Conclusie}

In het Haringvliet is de zalm sinds 2015 afgenomen of is de trend onzeker. Dat de trend van de FRGZ monitoring onzeker is en niet sterk afneemt zoals in het Hollandsch Diep heeft te maken met het jaar van aanstelling van het Haringvliet (2015) wat twee jaar later is dan het Hollandsch Diep (2013). Het is onduidelijk wat de oorzaak van deze afname is. Wanneer de Haringvlietdam een belemmering heeft gevormd is de verwachting is dat de soort in de toekomst toeneemt omdat er nu betere migratiemogelijkheden zijn, als gevolg van de uitvoering van het Kierbesluit.

\subsubsection{Rivierdonderpad}

Onderzoeksvraag

Wat is de trend van rivierdonderpad in het Haringvliet voor de periode 2015-2019?

\section{Databeschikbaarheid}

\section{FGRA}

Voor de rivierdonderpad zijn data uit de jaren 2011-2019 beschikbaar met de boomkor (Figuur 4.43). Het Haringvliet wordt bemonsterd in het voorjaar en het najaar. In 2011 en 2016 is alleen in het najaar bemonsterd (oktober-november), in 2012 is vrij laat in het voorjaar bemonsterd (juni), in 2013 en 2014 is in april en oktober/november bemonsterd, in 2015 alleen in april en vanaf 2017 in februari en oktober. 


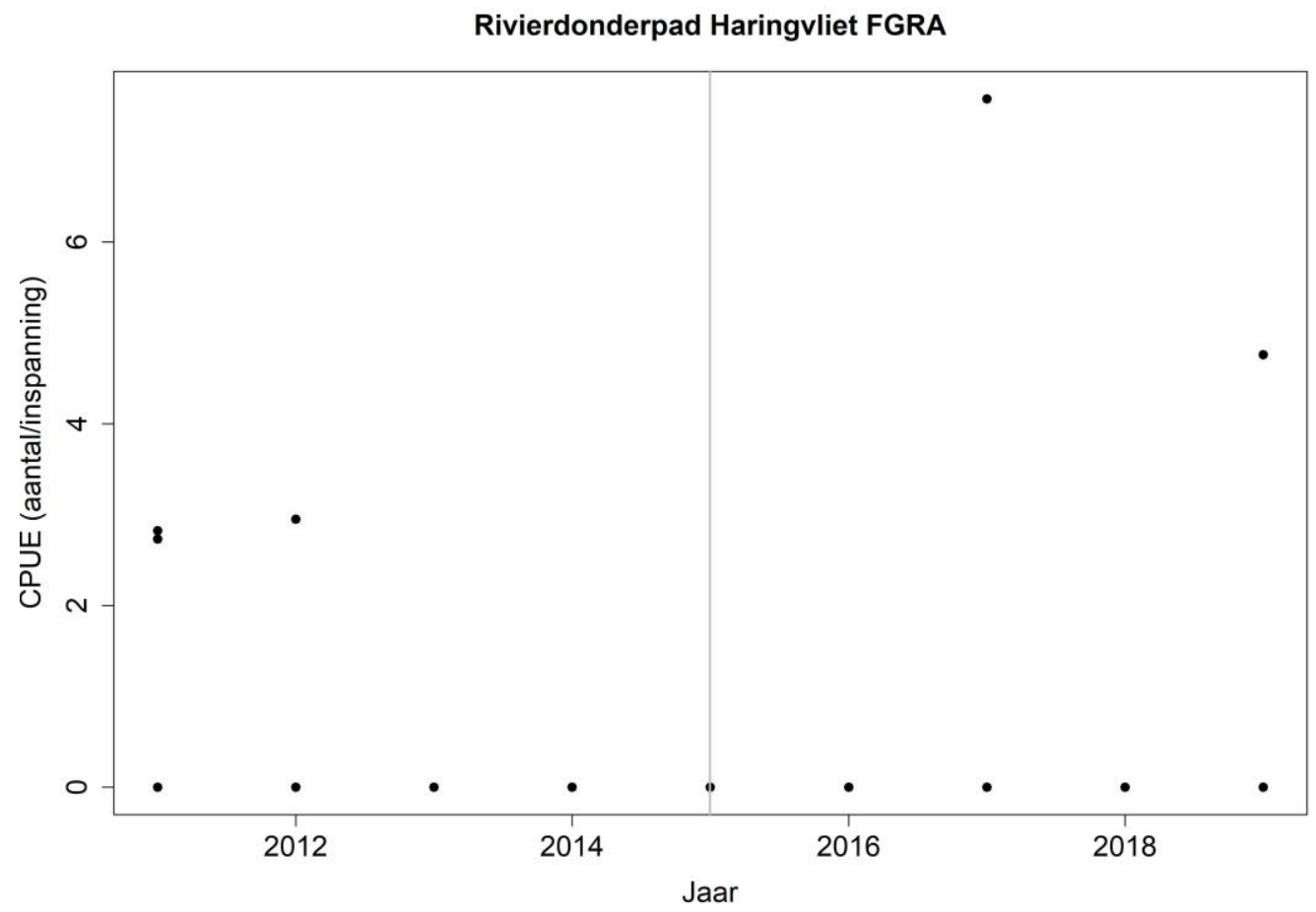

Figuur 4.43 Vangst per eenheid inspanning (CPUE) per bemonstering per jaar voor rivierdonderpad in de boomkor in het Haringvliet. De grijze lijn geeft het jaar van aanwijzing weer van het Natura 2000-gebied Haringvliet.

\section{Analyse}

Aangezien er relatief veel nulvangsten waren in de periode $2015-2019$, is een statistische analyse met GLM o.b.v. aan-/afwezigheid uitgevoerd. In deze periode is geen significante ( $P=0.51)$ toe-/afname van de rivierdonderpad in het Haringvliet opgetreden Figuur 4.44). De analyse op basis van aantallen geeft een niet significante $(P=0.64)$, onzekere trend weer (niet weer gegeven).

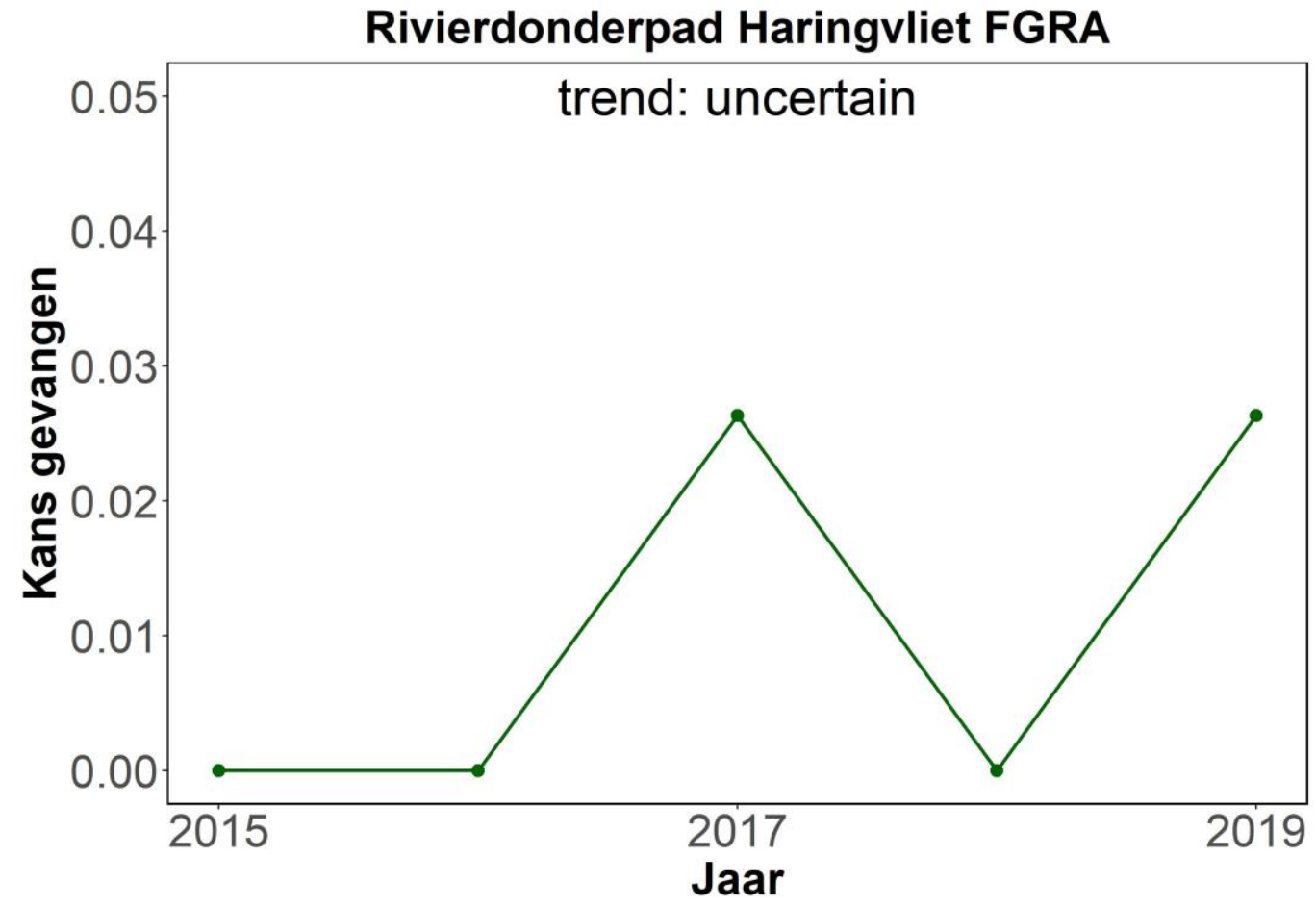

Figuur 4.44. Kans op het vangen van rivierdonderpad in de boomkor in het Haringvliet gecorrigeerd voor inspanning. 


\section{Conclusie}

De trend van de rivierdonderpad op het Haringvliet is onzeker. De instandhoudings-doelstelling is 'behoud' en aangezien daarvoor een toenemende of minstens een stabiele trend nodig is, is deze niet gehaald.

\subsubsection{Conclusies per soort Haringvliet}

\begin{tabular}{llllll} 
Natura 2000 gebied & Soort & Instandhoudings-doelstelling & Classificatie populatietrend & Evaluatie doelbereik \\
Haringvliet & Zeeprik & $>$ & Afname/Onzeker & Doel niet behaald \\
\hline Haringvliet & Rivierprik & $>$ & Afname/Onzeker & Doel niet behaald \\
\hline Haringvliet & Fint & $>$ & Onzeker/Stabiel & Doel niet behaald \\
\hline Haringvliet & Elft & $>$ & Onzeker & Onduidelijk \\
\hline Haringvliet & Zalm & $>$ & Afname/Onzeker & Doel niet behaald \\
\hline Haringvliet & Rivierdonderpad & $=$ & Onzeker & Doel niet behaald \\
\hline Haringvliet & Bittervoorn & $=$ & n.v.t. & n.v.t.
\end{tabular}




\subsection{Westerschelde \& Saefthinghe}

De Westerschelde \& Saeftinghe (hierna Westerschelde) is in 2009 aangewezen als Natura 2000-gebied. De vissoorten die in het beheerplan van de Westerschelde zijn opgenomen zijn zeeprik, rivierprik en fint. De doelstelling voor alle drie de soorten is uitbreiding van de populatie. De Westerschelde fungeert voor deze soorten als foerageer- en doortrekgebied voor de paaitrek, voor fint is de Westerschelde ook een opgroeigebied. Het monitoringprogramma dat hier plaatsvindt is de Westerschelde Ankerkuil Survey (WAV). Voor deze monitoring is geen selectie op trekperiode of lengte toegepast, aangezien deze monitoring plaatsvindt in o.a. het foerageergebied van de geselecteerde HR-vissoorten. Daarnaast is de vangkans voor deze soorten met een passief tuig dat maar twee keer in het jaar (voorjaar en najaar) wordt ingezet, erg gering.

\subsubsection{Zeeprik}

\section{Onderzoeksvraag}

Wat is de trend van zeeprik in de Westerschelde voor de periode 2009-2019?

\section{Databeschikbaarheid}

\section{WAV}

Data zijn beschikbaar vanaf 2007 (Figuur 4.45). Tot 2011 werden er twee locaties bemonsterd (het vaarwater bij de Paulinapolder en Schaar van Valkenisse/Plaat van Walsoorden), vanaf 2012 zijn daar twee locaties bij gekomen (Brouwersplaat/Middelgat en het Gaatje bij Borssele). In 2010 is er niet bemonsterd. Er wordt altijd in het voorjaar (meestal mei) en het najaar (meestal september) bemonsterd. Zeeprik is sinds 2008 niet meer gevangen in de WAV monitoring in de Westerschelde.

\section{Zeeprik Westerschelde WAV}

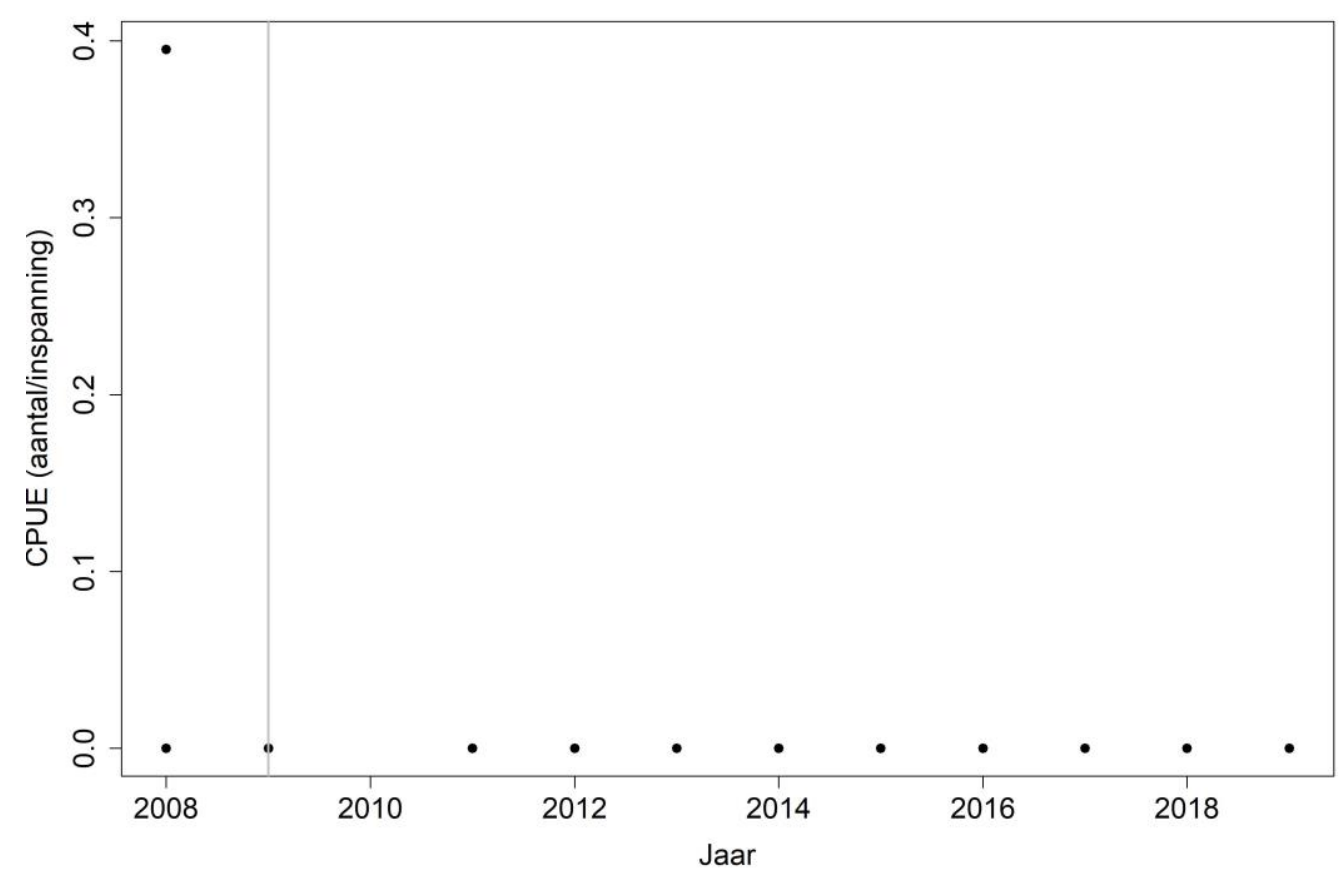

Figuur 4.45 Vangst per eenheid inspanning (CPUE) per bemonstering per jaar voor zeeprik in de ankerkuil in de Westerschelde. De grijze lijn geeft het jaar van aanwijzing weer van het Natura 2000gebied Westerschelde \& Saeftinghe.

\section{Conclusie}

In de Westerschelde wordt zeeprik sinds 2008 niet meer gevangen waardoor de trend onzeker is. 


\subsubsection{Rivierprik}

\section{Onderzoeksvraag}

Wat is de trend van rivierprik in de Westerschelde voor de periode 2009-2019?

\section{Databeschikbaarheid}

\section{WAV}

Data zijn beschikbaar vanaf 2007 (Figuur 4.45). Tot 2011 werden er twee locaties bemonsterd (het vaarwater bij de Paulinapolder en Schaar van Valkenisse/Plaat van Walsoorden), vanaf 2012 zijn daar twee locaties bij gekomen (Brouwersplaat/Middelgat en het Gaatje bij Borssele). In 2010 is er niet bemonsterd. Er wordt altijd in het voorjaar (meestal mei) en het najaar (meestal september) bemonsterd.

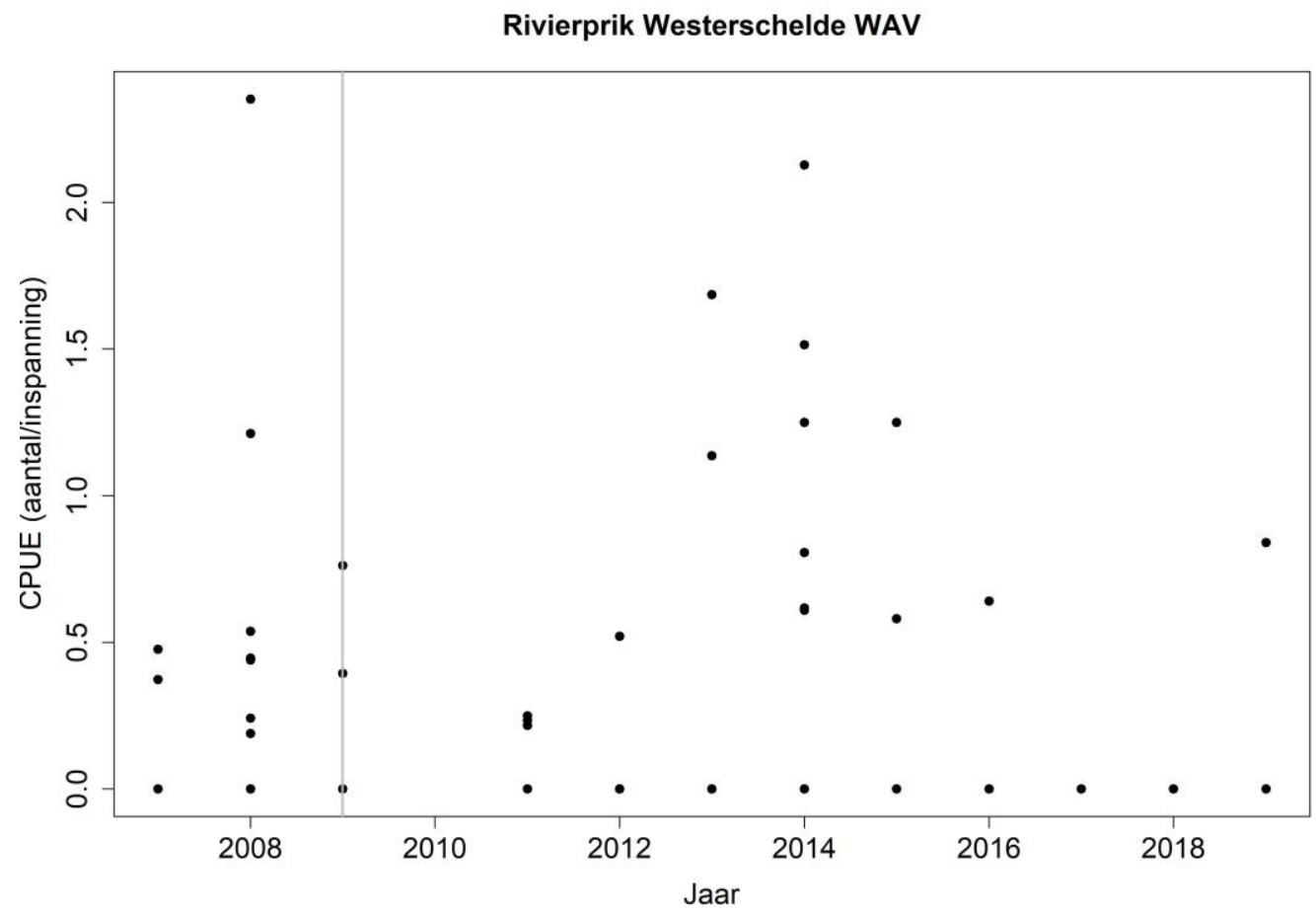

Figuur 4.46. Vangst per eenheid inspanning (CPUE) per bemonstering per jaar voor rivierprik in de ankerkuil in de Westerschelde. De grijze lijn geeft het jaar van aanwijzing weer van het Natura 2000gebied Westerschelde \& Saeftinghe.

\section{Analyse}

Omdat de rivierprik in de periode 2009-2019 in voldoende aantallen is gevangen met de ankerkuil, is een statistische analyse met GLM o.b.v. aantallen uitgevoerd. In deze periode is geen significante $(P=0.13)$ toe-/afname van rivierprik in de Westerschelde opgetreden (Figuur 4.47). De analyse op basis van aan/afwezigheid geeft een stabiele trend aan (niet weergegeven). 


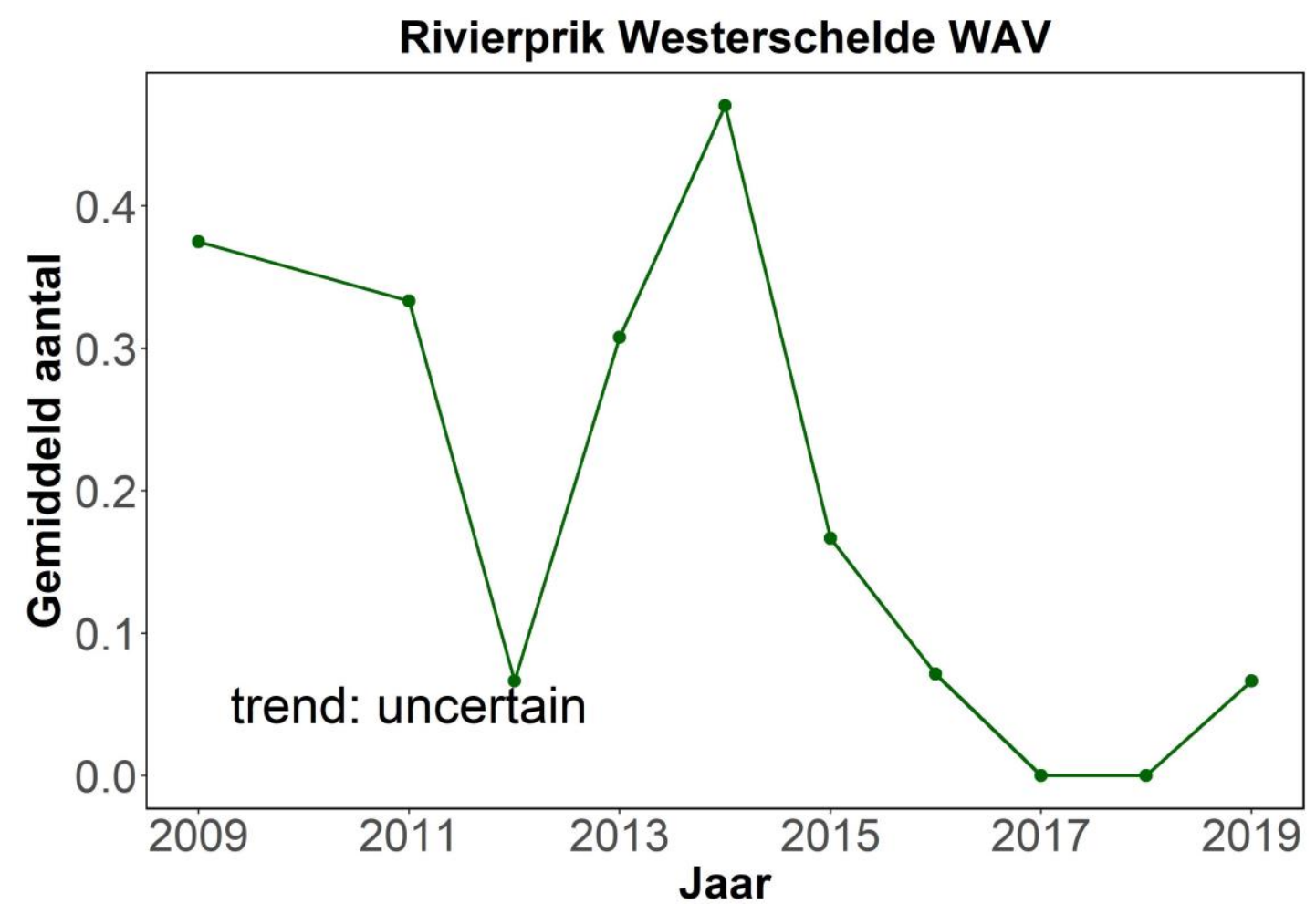

Figuur 4.47 Gemiddeld aantal gevangen rivierprikken in de ankerkuil in de Westerschelde gecorrigeerd voor inspanning.

\section{Conclusie}

In de Westerschelde is de trend voor rivierprik onzeker. Er lijkt sinds 2014 een afname te zijn van rivierprik (Figuur 4.47) net zoals er een afname is voor rivierprik in het Hollandsch Diep en het Haringvliet vanaf die periode.

\subsubsection{Fint}

Onderzoeksvraag

Wat is de trend van fint in de Westerschelde voor de periode 2009-2019?

\section{Databeschikbaarheid}

\section{WAV}

Data zijn beschikbaar vanaf 2008 (Figuur 4.48). Tot 2011 werden er twee locaties bemonsterd (het vaarwater bij de Paulinapolder en Schaar van Valkenisse/Plaat van Walsoorden), vanaf 2012 zijn daar twee locaties bij gekomen (Brouwersplaat/Middelgat en het Gaatje bij Borssele). In 2010 is er niet bemonsterd. Er wordt altijd in het voorjaar (meestal mei) en het najaar (meestal september) bemonsterd. 
Fint Westerschelde WAV

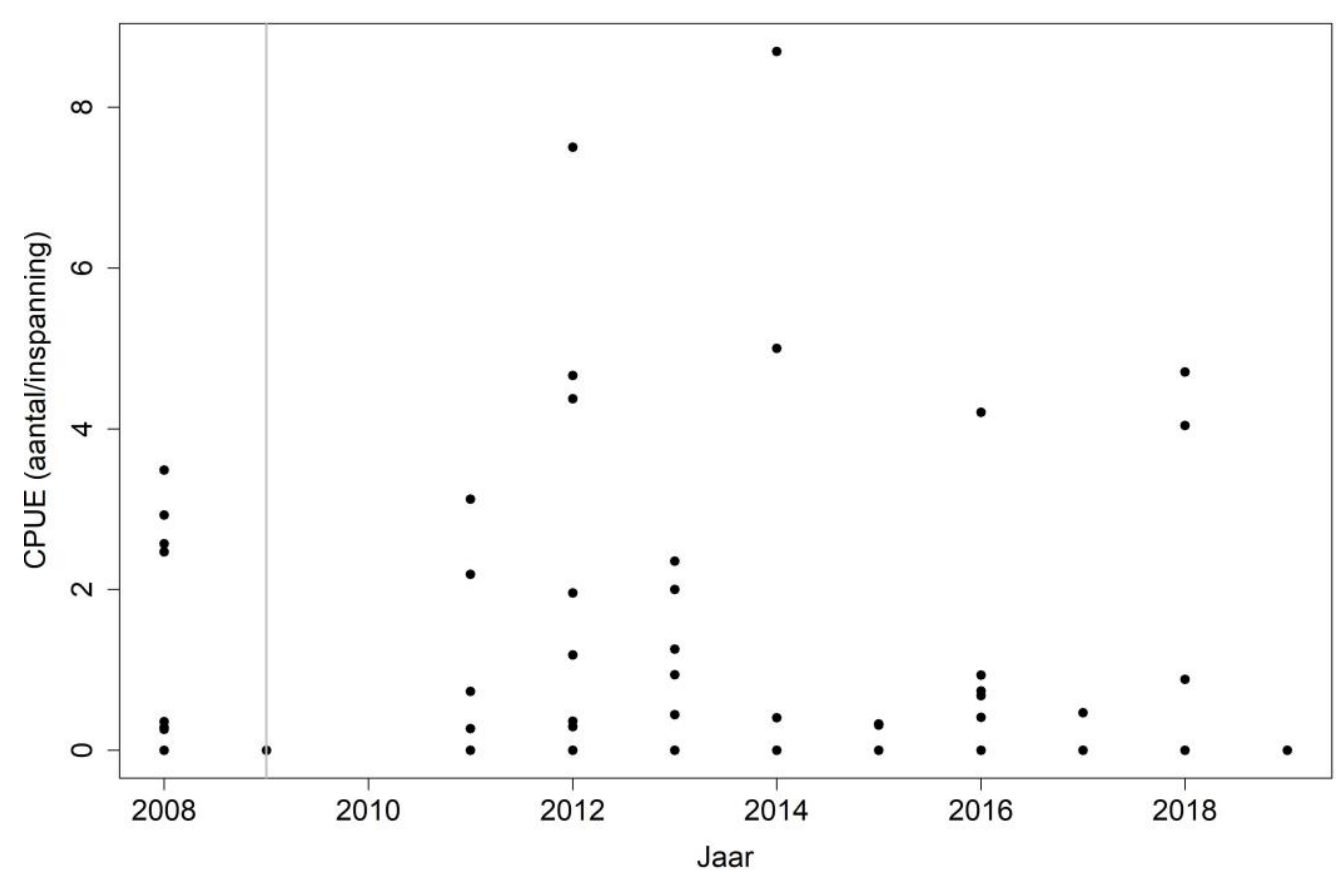

Figuur 4.48 Vangst per eenheid inspanning (CPUE) per bemonstering per jaar voor fint in de ankerkuil in de Westerschelde. De grijze lijn geeft het jaar van aanwijzing weer van het Natura 2000-gebied Westerschelde \& Saeftinghe.

\section{Analyse}

Omdat de fint in de periode 2009-2019 in voldoende aantallen gevangen is met de ankerkuil, is een statistische analyse met GLM o.b.v. aantallen uitgevoerd. In deze periode is geen significante $(P=0.24)$ toe-/afname van fint in de Westerschelde opgetreden (Figuur 4.49). De statistische analyse op aan/afwezigheid geeft ook een onzekere trend aan $(P=0.54$, niet weergegeven). Deze aantallen worden voornamelijk gedomineerd door juveniele finten, alleen in 2015, 2016 en 2018 werden er respectievelijk 1,5 en 1 adulte finten $(>30 \mathrm{~cm})$ gevangen. 
Fint Westerschelde WAV

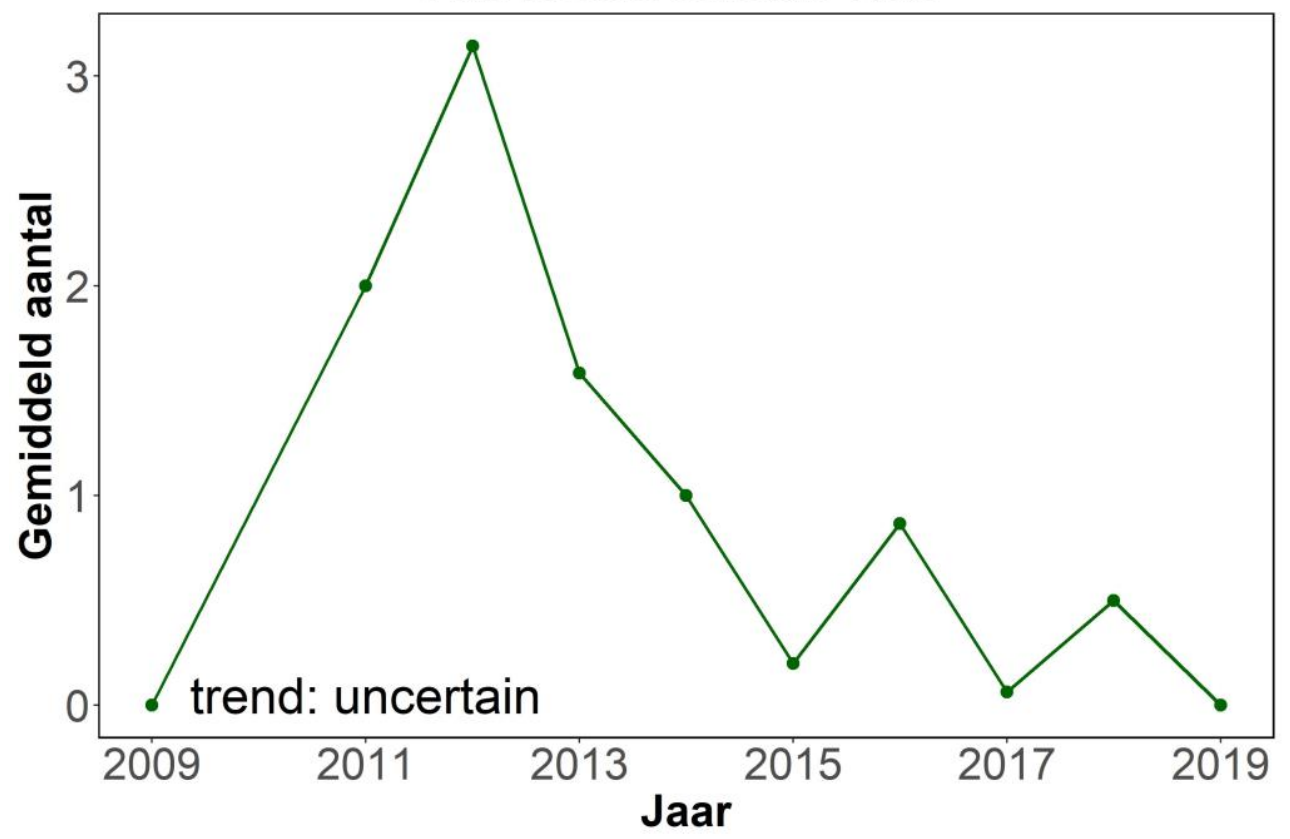

Figuur 4.49 Gemiddeld aantal finten gevangen per jaar in de boomkor in de Westerschelde gecorrigeerd voor inspanning vanaf het jaar dat de Westerschelde is aangewezen als Natura 2000-gebied.

\section{Conclusie}

De trend voor fint in de Westerschelde is onzeker. In de Zeeschelde in België wordt sinds 2007 de fint ook bemonsterd met de ankerkuil en met fuiken (Breine et al. 2020a, b). Deze auteurs concludeerden ook dat de aantallen finten sterk variëren van jaar tot jaar (zowel adulten als juvenielen). In sommige jaren (o.a. 2017, 2018 en 2019) is er sprake van succesvolle rekrutering door paai in de Schelde (Breine et al. 2020a, b). In 2016 werden er met de ankerkuil in de Westerschelde de meeste adulte finten gevangen, 5 individuen. In ditzelfde jaar werd ook een relatief hoge biomassa van fint in de Schelde gevangen (Breine et al. 2020a, b) wat er op kan duiden dat de gevangen finten in de Westerschelde inderdaad bezig waren met de paaitrek richting de rivier de Schelde.

\subsubsection{Conclusies per soort Westerschelde}

\begin{tabular}{lllll} 
Natura 2000 gebied & Soort & Instandhoudings-doelstelling populatie & Classificatie populatietrend & Evaluatie doelbereik \\
Westerschelde & Zeeprik & $>$ & Onzeker & Doel niet behaald \\
\hline Westerschelde & Rivierprik & $>$ & Onzeker & Doel niet behaald \\
\hline Westerschelde & Fint & $>$ & Onzeker & Doel niet behaald
\end{tabular}




\section{Ecologische kwaliteitsratio's}

\section{$5.1 \quad$ Inleiding}

De Kaderrichtlijn Water (KRW) beoogt onder meer de bescherming en verbetering van aquatische ecosystemen en duurzaam gebruik van water te bewerkstelligen (STOWA, 2018). Het doel van de KRW is een 'goede toestand' te bereiken voor alle wateren. Voor deze beoordeling wordt aan de hand van Ecologische Kwaliteit Ratio's (EKR) de staat van de Nederlandse wateren vergeleken met de staat van een vergelijkbaar type water waar menselijke invloeden niet of in zeer beperkte mate aanwezig zijn (geweest). Deze laatste situatie geldt als een referentie die is gelijkgesteld aan een 'zeer goede toestand' van het water. De meeste waterlichamen in Nederland zijn niet meer natuurlijk, maar zijn in de loop der tijd sterk veranderd of zelfs kunstmatig aangelegd.

Voor natuurlijke watertypen ligt de norm bij de (ondergrens van de) kwaliteitsklasse Goede Ecologische Toestand (GET). Aangezien watertypen in meerdere regio's voor kunnen komen, zijn de doelstellingen voor natuurlijke wateren landelijk opgesteld met referentieniveau (ZGET) en doel (GET).

Omdat de wateren in Nederland veelal kunstmatig of sterk veranderd zijn, is voor deze niet-natuurlijke wateren een Maximaal Ecologisch Potentieel (MEP) gesteld. Dit is het hoogste niveau waar het Goed Ecologisch Potentieel (GEP) een afgeleide van is (Figuur 5.5.1; zie STOWA, 2018 voor verdere achtergrondinformatie). Ecologische Toestand is ingedeeld in vijf klassen, Ecologisch Potentieel heeft vier klassen, waarvan 'GEP en hoger' het hoogste niveau is. De doelscore (GEP) verschilt per waterlichaam en wordt vastgesteld door de beheerder.

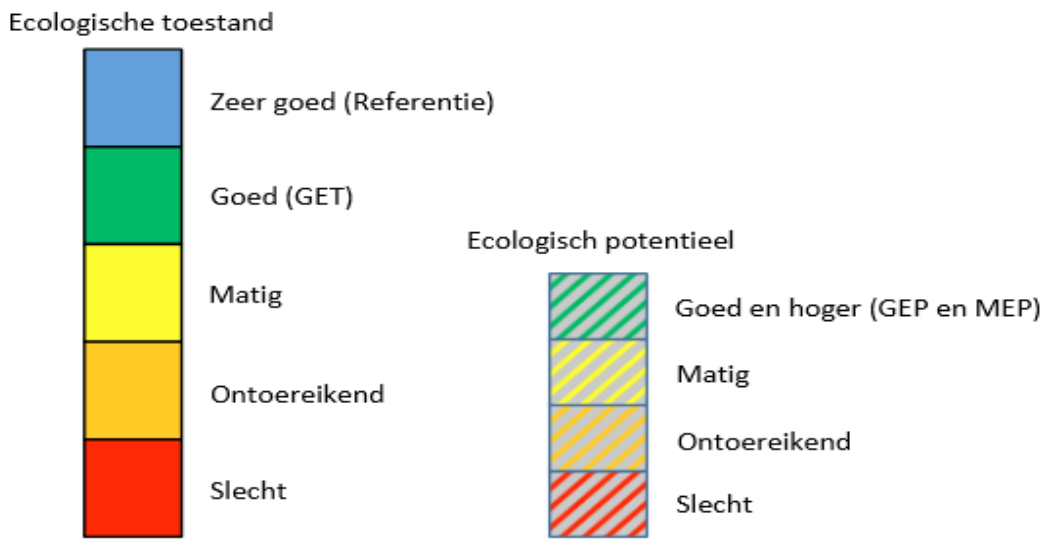

Figuur 5.5.1. De vijf klassen van de maatlat van natuurlijke watertypen (links) en de vier klassen van de maatlat van sterk veranderde en kunstmatige wateren (rechts) met bijbehorende kleurcodering (STOWA 2018).

Het vaststellen van een referentie voor de Nederlandse wateren is lastig, omdat daarvoor uitgegaan moet worden van dat er helemaal geen, of alleen in zeer geringe mate, menselijke invloeden zijn. Aangezien Nederlandse wateren sinds 1000 A.D. steeds meer onder controle van de mens zijn komen te staan, is dat een bijna onmogelijke opgave. Het was daarom noodzakelijk om een kwantificering van de referenties te baseren op een combinatie van historische gegevens, beschrijvingen van onverstoorde situatie in binnen- en buitenland, modeluitkomsten en kennis van experts (STOWA, 2018). 
In dit hoofdstuk staan de EKR-beoordelingen voor waterlichamen in de Rijkswateren (rivieren (R) en meren (M) en overgangswateren (O2), op basis van gegevens van visbemonsteringen gedurende 20062019. Berekeningen van EKR-scores zijn voor het tweede jaar op rij uitgevoerd met het programma Aquokit (versie 3.6, normgroep: 'KRW-maatlatten-2018 - Vis' onder normkader BKMW2009:21). De resultaten worden weergegeven als EKR-scores per waterlichaam voor de verschillende jaren. Indien in een waterlichaam een visbemonstering is uitgevoerd, kan een EKR-score berekend worden voor het jaar waarin bemonsterd is. Voor waterlichamen die niet in het bemonsteringsprogramma zijn opgenomen, moeten de EKR-scores worden overgenomen van andere waterlichamen om tot een beoordeling te komen. Deze waterlichamen hebben wel een eigen vastgesteld GEP-doel. De hiervoor benodigde projectieregels zijn ingebouwd in Aquokit. 


\subsection{Watertypen en waterlichamen}

Waterlichamen en watertypen zijn als volgt gedefinieerd:

- Waterlichaam. Een onderscheiden oppervlaktewater van aanzienlijke omvang, zoals een meer, een waterbekken, een stroom, een rivier, een kanaal, een deel van een stroom, rivier of kanaal, een overgangswater of een strook kustwater.

- Watertype. Elk waterlichaam heeft karakteristieke abiotische kenmerken. Deze kenmerken worden gebruikt om een waterlichaam te typeren. Belangrijke criteria hierbij zijn zoutgehalte, stroming, alkaliniteit (buffering), gemiddelde diepte, breedte of oppervlakte en bodemaard (Bijkerk, 2010).

De rijkswateren zijn onderverdeeld in diverse waterlichamen. De rijkswateren bevatten 50 waterlichamen waarvan 19 meren (M), 16 rivieren (R), 9 kustwateren (K) en 6 overgangswateren (O).

In de rijkswateren worden de volgende watertypen onderscheiden:

- Meren (M6, M7b, M14, M20, M21a, M21b, M30 en M32).

- Rivieren (R7, R8 en R16)

- Overgangswateren (O2a en O2b)

- Kustwateren (K1, K2 en K3)

Vis is geen biologisch kwaliteitselement voor kustwateren ( $K, 0 . a$. Waddenzee) en wordt daar derhalve niet beoordeeld middels de EKR-scores voor de KRW. Kustwateren worden om die reden verder buiten beschouwing gelaten in deze rapportage. 


\subsection{Opzet deelmaatlatten en berekening EKR-score}

De Nederlandse wateren worden beoordeeld aan de hand van maatlatten. Maatlatten zijn een maat om de toestand van een water uit te drukken. Er wordt gebruikt gemaakt van 'KRW-maatlatten-2018 - Vis'. De maatlat 'vis' bestaat uit twee of drie deelmaatlatten. De twee deelmaatlatten abundantie (a) en soortsamenstelling (b) vormen voor de meeste watertypen samen de beoordeling (EKR-score). Deze twee deelmaatlatten worden per watertype weer verder onderverdeeld in specifieke 'sub-deelmaatlatten' (indicatoren in Aquokit) die kenmerkend zijn voor het type water. Deze sub-deelmaatlatten zijn gekozen ter indicatie van de mate van (antropogene) druk op het waterlichaam. Voor sommige watertypen geldt nog een derde deelmaatlat: leeftijdsopbouw (c). Voor de berekening van EKR-scores krijgt elke deelmaatlat een wegingsfactor.

Voor alle deelmaatlatten wordt een afzonderlijke EKR-score berekend tussen de 0 en 1 . Elke deelmaatlat levert een relatieve bijdrage aan de totale EKR-score. Een gedetailleerde beschrijving van de deelmaatlatten per watertype is te vinden in Van der Molen et al. (2016). Een EKR-score ligt altijd tussen de 0 en 1 en geeft een relatieve score weer. Hoe lager de score, hoe minder goed een waterlichaam wordt beoordeeld ten opzichte van de bijbehorende referentie/het doel.

\section{Deelmaatlat 'abundantie'}

Abundantie is het relatieve aandeel van een selectie van vissoorten en deze deelmaatlat is per watertype specifiek. Bij de grote riviertypen zijn de indicatoren gebaseerd op de aantal percentages van inheemse rheofiele (stroomminnende) en limnofiele (met een voorkeur voor binnenwater) soorten. Voor meren worden vier indicatoren berekend: 1) het relatieve aandeel biomassa brasem, 2) baars en blankvoorn als percentage van alle eurytope vis, 3) plantminnende vis en 4) zuurstoftolerante vis. Voor M21b (IJsselmeer) is nog de indicator biomassa bot toegevoegd. Voor een gedetailleerde beschrijving van deze deelmaatlat per watertype zie Van der Molen et al. (2016) en STOWA (2018).

\section{Deelmaatlat 'soortsamenstelling'}

De soortsamenstelling wordt uitgedrukt als het voorkomen van vissoorten per watertype. Voor brakke en zoute meren, voor rivieren en voor overgangswateren is de lijst uitgesplitst naar ecologische gilden, waarbij voor grote rivieren ook nog een type-specifieke selectie is gemaakt. Hierin wordt het aantal inheemse rheofiele, diadrome en limnofiele soorten vastgesteld (STOWA, 2018, Bijlage 11, Tabel D1). Voor M21b (IJsselmeer) wordt ook nog de indicator aantal diadrome soorten uit fuikvangsten toegevoegd.

\section{Deelmaatlat 'leeftijdsopbouw'}

Ter indicatie van het effect van visserij is bij de waterlichamen M21a en M21b een extra maatlat voor snoekbaars toegevoegd. Bij de 'KRW-maatlatten-2012 - Vis', welke bij de EKR berekeningen in 2019 gebruikt is, bestond deze ook voor M14 en M20. Bij de 'KRW-maatlatten-2018 - Vis' is deze echter verwijderd voor deze waterlichamen. De maatlat voor snoekbaars geeft een beeld van de verhouding ondermaatse en maatse snoekbaars. Wanneer de (naar biomassa gewogen) gemiddelde lengte kleiner is dan $42 \mathrm{~cm}$, dan wordt de totale EKR-score verminderd met 0,2 (maximale aftrek). Bij 37-42 cm is er 0,15 aftrek, bij 42-50 cm 0,1 aftrek, bij 50-59 cm 0,05 aftrek en vanaf $59 \mathrm{~cm}$ of minder dan 50 gevangen exemplaren groter dan $15 \mathrm{~cm}$ vindt geen aftrek plaats. Waarden op de grens worden gekoppeld aan de laagste correctie (Van der Molen et al., 2016). 


\subsection{EKR-score berekening}

De totale EKR-score per waterlichaam wordt voor meren $(M)$, rivieren $(R)$ en overgangswateren $(02 b$, bemonsterd met boomkor) als volgt berekend (Zie STOWA 2018 voor alle details):

\section{Meren (M7b, M14, M20, M21)}

$\mathrm{EKR}=\Sigma$ (wegingsfactor $*$ score deelmaatlat) - aftrek score leeftijdsopbouw snoekbaars (max 0.2 EKR)

Meren (M30, M32)

$\mathrm{EKR}=\Sigma$ (wegingsfactor $*$ score deelmaatlat)

Grote rivieren ( $R 7, \mathbf{R 8}, \mathbf{R} 16)$

EKR $=(($ deelmaatlatten soortsamenstelling / 3) $+($ abundantie / 2)) / 2

Overgangswateren (O2b)

EKR $=(($ deelmaatlatten soortsamenstelling / 5) $+($ abundantie / 7) $) / 2$

Voorbeeld: Een rivier heeft twee deelmaatlatten: voor de abundantie, bestaande uit twee indicatoren en Voorbeeld: Een rivier heeft vijf deelmaatlatten: twee voor de abundantie en drie voor de soortsamenstelling, bestaande uit drie indicatoren. Om tot een totaalscore te komen, wordt elke individuele deelmaatlat vermenigvuldigd met een vastgestelde wegingsfactor (zie STOWA, 2018). Voor de rivieren zijn de wegingsfactoren gelijk binnen de deelmaatlatten soortsamenstelling en abundantie. De som van alle 'gewogen' deelscores vormt de uiteindelijke EKR-score. De opbouw van de EKR-score per gewogen deelmaatlat levert een eindbeoordeling voor natuurlijke wateren op die opgedeeld is in vijf categorieën met een range van slecht $(0-0,2)$ tot zeer goed $(0,8-1,0)$. Voor kunstmatige wateren is de opdeling naar vier categorieën van slecht tot goed en hoger.

\section{EKR-score natuurlijke watertype / waterlichamen}

$0.0-0.2$ = slecht

$0.2-0.4=$ ontoereikend

$0.6-0.8=$ goed $($ GET: goede ecologische toestand)

$0.8-1.0$ = zeer goed (ZGET: zeer goede ecologische toestand)

\section{EKR-score kunstmatige watertype / waterlichamen}

$1.0-0.25=$ slecht

$0.25-0.5=$ ontoereikend

$0.75-1.0=$ goed en hoger (GEP: goed ecologische potentieel) 


\subsection{Selectie gegevens}

Om tot een juiste beoordeling van de vispopulatie te komen, worden de waterlichamen gemonitord. Grofweg zijn de monitoringsprogramma's onderverdeeld in een actieve monitoring (met actieve tuigen) en een passieve monitoring (met passieve tuigen). In Deel II van dit rapport (Van Keeken et al., 2020) wordt uitgebreider ingegaan op alle monitoringsprogramma's. De actieve monitoring wordt gebruikt voor de inschatting van het voorkomen van vissen (aantallen per soort), ofwel de abundantie. De actieve monitoring bestaat uit vangsten met de boomkor, stort- en wonderkuil (M14), ankerkuil (O2a) in het open water en met het elektroschepnet en zegen bij de oevers. Bij de actieve bemonstering van de rivieren wordt gerekend met winterhalfjaren ${ }^{6}$.

Per waterlichaam wordt, indien relevant, een verdeelsleutel toegepast tussen de oever en het open water naar rato hectare, waarbij het open water het grootste deel uitmaakt (Bijlage 57). Enkel voor de Grensmaas, waar alleen met elektroschepnet gevist wordt, wordt hiervan afgeweken en wordt met $100 \%$ oeveroppervlakte gerekend. Zijwateren worden voor de EKR-analyse niet als apart waterdeel meegenomen, maar trekken uitgevoerd in zijwateren worden ingedeeld naar 'open' of 'oever' aan de hand van het gebruikte vistuig. Deze verdeelsleutel is in het verleden opgesteld en wordt jaarlijks gelijk gehouden. De berekening van oeveroppervlakte is volgens RWS niet altijd juist. De verdeelsleutel tussen open water, oever en eventueel zijwater zou om deze reden een update moeten krijgen.

Naast gegevens van de actieve monitoring worden ook gegevens van de passieve monitoring gebruikt bij het berekenen van EKR-scores. De passieve monitoring wordt aanvullend op de actieve monitoring gebruikt voor de deelmaatlat 'soortsamenstelling' (aanwezigheid of afwezigheid van soorten) en voor M21b voor soortenrijkdom diadrome vissen. De passieve monitoring heeft immers een grotere kans op vangst van soorten die slechts periodiek of in kleinere aantallen voorkomen in het water, zoals bijvoorbeeld diadrome vissen. Het passieve monitoringsprogramma 'vangstregistratie aalvissers' is echter in veel waterlichamen weggevallen door dioxineproblemen (nu gesloten gebieden). Om die reden is in 2012 een aanvullende diadrome vismonitoring met fuiken gestart waarbij op enkele locaties (IJsselmeer Den Oever en Kornwerderzand, Bovenrijn, Maas bij Belfeld, Nieuwe Waterweg, Haringvliet en Noordzeekanaal) in het voor- en najaar bemonsterd wordt. In 2015 en 2018 zijn aanvullend op deze reguliere diadrome vismonitoring gegevens verzameld voor de deelmaatlat soortsamenstelling (Tabel 5.1) door bemonstering van vier aanvullende locaties. Dit betroffen de IJssel nabij Deventer, Lek nabij Hagestein, Waal nabij Varik/Hurwenen en Maas nabij Lith. Bij de passieve bemonstering wordt uitgegaan van kalenderjaar en niet van winterhalfjaar.

Sinds 2019 kunnen (met terugwerkende kracht) de passieve monitoringsgegevens ingelezen worden door Aquokit. Niet in alle jaren en niet in alle gebieden wordt met fuiken gemonitord. Om die reden worden soms gegevens geëxtrapoleerd van jaren en gebieden waarin wel een bemonstering heeft plaatsgevonden. In Tabel 5.1 wordt de herkomst van de gegevens weergegeven met vijf kleuren. Deze tabel is opgenomen in de functionaliteit van Aquokit.

- Zwart: EKR-scores berekend met gegevens van werkelijk bemonsterde jaren in het gebied.

- Geel: jaren die niet bemonsterd zijn in een gebied, maar bemonstering heeft wel in andere jaren plaatsgevonden. Dit is bijvoorbeeld het geval in gebieden die driejaarlijks bemonsterd worden. Gegevens van 2019 en 2020 worden geleend van 2018.

- Groen: gebieden die niet bemonsterd zijn, maar die gegevens van een ander gebied lenen. In het desbetreffende jaar is in het gebied waarvan geleend wordt wel gemonitord en zijn gegevens van dat jaar wel beschikbaar.

- Blauw: gebieden die niet bemonsterd zijn, maar die gegevens van een ander gebied lenen. In het desbetreffende jaar is in het gebied waarvan geleend wordt niet gemonitord en zijn

\footnotetext{
${ }^{6}$ Een winterhalfjaar houdt in dat er voor een beoordeling van bijvoorbeeld het jaar 2018, geput wordt uit vangstgegevens van het najaar van 2017 en het voorjaar van 2018.
} 
gegevens van dat jaar daarom niet beschikbaar. Geleend wordt van een eerder jaar (2019 en 2020 lenen van 2018).

- Wit: gebieden die niet bemonsterd zijn en geen gegevens lenen van een ander gebied.

Tabel 5.1 Overzicht van de gebruikte fuikgegevens en schema of welke wijze de gegevens gebruikt worden in de berekening van de EKR-scores. Voor uitleg van de kleuren in de tabel zie tekst boven de tabel.

\begin{tabular}{|c|c|c|c|c|c|c|c|c|c|c|}
\hline Waterlichaamnaam & Code & type & fuikdata & Leent fuiken & 2015 & 2016 & 2017 & 2018 & 2019 & 2020 \\
\hline Bedijkte Maas & NL91BM & R7 & Belfeld & NL91ZM & & & & & & \\
\hline Zandmaas & NL91ZM & R7 & Belfeld & & & & & & & \\
\hline Nederrijn, Lek & NL93_7 & R7 & Hagestein & & & & & & & \\
\hline Boven Rijn, Waal & NL93_8 & R7 & Waal & & & & & & & \\
\hline Boven Rijn, Waal & NL93_8 & R7 & Rijn (Lobith) & & & & & & & \\
\hline IJssel & NL93_IJSSEL & R7 & Ijssel & & & & & & & \\
\hline Haringvliet oost & NL94_1 & R8 & Haringvliet & & & & & & & \\
\hline Dordtse Biesbosch & NL94_2 & R8 & Waal & NL93_8 & & & & & & \\
\hline Oude Maas & NL94_4 & R8 & Hagestein & NL93_7 & & & & & & \\
\hline Beneden Maas & NL94_5 & R8 & Lith & & & & & & & \\
\hline Brabantse Biesbosch & NL94_10 & R8 & Lith & NL94_5 & & & & & & \\
\hline Grensmaas & NL91GM & R16 & Belfeld & NL91ZM & & & & & & \\
\hline
\end{tabular}

Opmerkingen bij de fuikenmonitoringsgegevens.

- Wegens het uitsluiten van een visser op de Maas in 2017 en het Haringvliet in 2018 zijn deze gebieden niet continu gemonitord. In 2019 zijn deze gebieden weer bemonsterd.

- Wegens de lage waterstand in het najaar van 2018 zijn de Rijn (jaarlijks bemonsterd) en de IJssel (eens in de drie jaar bemonsterd) in het najaar van 2018 niet bemonsterd tijdens de passieve fuikenmonitoring. Voor de Rijn worden enkel gegevens van het voorjaar gebruikt voor 2018. De IJssel is in het najaar van 2019 bemonsterd en gegevens van voorjaar 2018 en najaar 2019 worden samengevoegd als één monitoringsjaar.

- $\quad$ De Hollandse IJssel (NL94_7) wordt niet met fuiken bemonsterd en leent ook niet van ander waterlichaam.

Diverse waterlichamen worden niet bemonsterd. Deze waterlichamen worden wel beoordeeld, maar 'lenen' hun EKR-beoordeling van toegewezen andere waterlichamen. Dit betekent dat deze waterlichamen één op één de EKR-score overnemen, ook wanneer het type water verschilt tussen de wateren. De waterlichamen hebben wel een eigen GEP-waarde gekregen, waardoor het uiteindelijke beoordelingsresultaat wel kan verschillen. 


\subsection{Aquokit}

In 2020 zijn de EKR-scores berekend met het programma Aquokit. In 2020 konden, naast de actieve bemonsteringsdata, ook fuikgegevens ingelezen worden en is zijn een aantal wateren de fuikgegevens volgens het schema in Tabel 5.1 meegenomen in de beoordeling.

Najaarsgegevens van het Zoommeer (M20) en het Veerse Meer (M32) zijn niet gecorrigeerd voor berekening van een winterhalfjaar. Voor de actieve monitoring op de rivieren wordt uitgegaan van een winterhalfjaar, waarbij gegevens van het najaar bij het voorjaar van het jaar genomen worden. De gegevens van het najaar krijgen het jaartal van het volgende voorjaar. Tot en met 2019 werden echter ook de najaarsgegevens van het Zoommeer (M20) en het Veerse Meer (M32) hiervoor gecorrigeerd. In Aquokit is tot op heden echter de aanpassing voor winterhalfjaar alleen doorgevoerd voor $\mathrm{R}$ wateren, waardoor de gegevens van het Zoommeer en het Veerse Meer dit jaar deze correctie niet krijgen. De gegevens zijn daardoor echter in lijn met andere najaarsgegevens van meren M14 en M21, welke ook in het najaar bemonsterd worden en ook niet gecorrigeerd worden voor een winterhalfjaar. De gegevens van beide meren bemonsterd in het najaar van 2016-2019 houden deze jaren ook in de Aquokit dataset en worden dus in tegenstelling tot voorgaande jaren niet aangepast naar 2017-2020.

In 2020 zijn toetsingen voor de overgangswateren opgenomen. Daarbij wordt onderscheid gemaakt tussen $\mathrm{O} 2 \mathrm{a}$, waarbij bemonsterd is met een ankerkuil en $\mathrm{O} 2 \mathrm{~b}$, waarbij bemonsterd is met een boomkor. Voor O2b zijn toetsingen in Aquokit ingebouwd en uitgevoerd. Voor O2a zijn de berekeningen ook in Aquokit ingevoerd, maar deze wijken momenteel nog af van controleberekeningen in Excel. Om die reden worden de gegevens van O2a wateren (Eems-estuarium en Westerschelde) nog niet gepresenteerd. 


\subsection{EKR-beoordeling per waterlichaam}

De EKR-beoordelingen van de bemonsterde en de niet-bemonsterde waterlichamen zijn weergegeven in Tabel 5.2. In Tabel 5.3 is voor een aantal rivieren de EKR-beoordeling inclusief fuikgegevens weergegeven. De EKR-waarden krijgen (na afronding op twee decimalen) een beoordeling (Zie Hoofdstuk 5.4 voor kleurcodering). Tevens is het GEP-doel per gebied weergegeven.

Tabel 5.2. EKR-score per waterlichaam voor meren, rivieren en overgangswateren zonder fuikgegevens. Uitzonderingen zijn M21b (IJsselmeer), waarbij fuikgegevens gebruikt zijn om de indicator diadrome vis mee te bepalen en O2b (Noordzeekanaal, Nieuwe waterweg en Haringvliet).

\begin{tabular}{|c|c|c|c|c|c|c|c|c|c|c|c|}
\hline Waterlichaam code & Waterlichaam naam & Type & Leent EKR van & GEP & 2006 & 2007 & 2008 & 2009 & 2010 & 2011 & 2012 \\
\hline NL81_2 & Eems-Dollard & O2a & & \begin{tabular}{|r|}
0.42 \\
\end{tabular} & & & & & & & \\
\hline NL86_ 5 & Amsterdam-Rijnkanaal Betuwepand & M7b & NL93_7 & 0.10 & & & & & & & \\
\hline NL86_ 6 & Amsterdam-Rijnkanaal Noordpand & M7b & NL93_7 & 0.10 & & & & & & & \\
\hline NL87_1 & Noordzeekanaal* $^{*}$ & $\mathrm{O} 2 \mathrm{~b}$ & & 0.43 & & & & & & & \\
\hline NL89_ANTWKNPD & Antwerps kanaalpand & M30 & NL89_volkerak & 0.10 & & & & & & & \\
\hline NL89_GREVLEMR & Grevelingenmeer & M32 & & 0.60 & & & 0.40 & & & 0.39 & \\
\hline NL89_KANTNZGT & kanaal Terneuzen Gent & M30 & NL89_westsde & 0.10 & & & & & & & \\
\hline NL89_SPUIKNL & Bathse Spuikanaal & M7a & NL89_volkerak & 0.10 & & & & & & & \\
\hline NL89_VEERSMR & Veerse meer & M32 & & 0.45 & & & & & & & \\
\hline NL89_VOLKERAK & Volkerak & M20 & & 0.25 & & & 0.15 & & & 0.23 & \\
\hline NL89_WESTSDE_OWL & Westerschelde & O2a & & 0.37 & & & & & & & \\
\hline NL89_ZOOMMEDT & Zoommeer, Eendracht & M20 & & 0.09 & & & & & & & \\
\hline NL90_1 & Midden Limburgse en Noord-Brabantse kanalen & M6 & NL91ZM & 0.10 & & & 0.06 & 0.13 & 0.17 & 0.20 & 0.13 \\
\hline NL91BM & Bedijkte Maas & R7 & & 0.35 & & & 0.17 & 0.20 & 0.19 & 0.18 & 0.16 \\
\hline NL91BOM & Bovenmaas & R7 & NL91GM & 0.35 & & & & & & & \\
\hline NL91GM & Grensmaas & R16 & & 0.45 & 0.39 & 0.43 & 0.35 & 0.48 & 0.53 & 0.44 & 0.44 \\
\hline NL91JK & Julianakanaal & M7 & NL91ZM & 0.10 & & 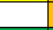 & 0.06 & 0.13 & 0.17 & 0.20 & 0.13 \\
\hline NL91MWK & Maas-Waalkanaal & M7 & NL93_8 & 0.10 & 0.07 & 0.15 & 0.15 & 0.07 & 0.18 & 0.15 & 0.12 \\
\hline NL91ZM & Zandmaas & R7 & & 0.25 & & & 0.06 & 0.13 & 0.17 & 0.20 & 0.13 \\
\hline NL92_IJSSELMEER & IJsselmeer & M21b & & 0.52 & & & & & & & \\
\hline NL92_KETELMEEER_VOSSEMEER & Ketelmeer, Vossemeer & M14 & & 0.25 & & & 0.20 & & & 0.23 & \\
\hline NL92_MARKERMEER & Markermeer & M21a & & 0.60 & & & & & & & \\
\hline NL92_RANDMEREN_OOST & Randmeren-Oost & M14 & & 0.40 & & 0.39 & & & 0.26 & & \\
\hline NL92_RANDMEREN_ZUID & Randmeren-Zuid & M14 & & 0.30 & & & & 0.27 & & & 0.38 \\
\hline NL92_ZWARTEMEER & Zwartemeer & M14 & & 0.40 & & & 0.28 & & & 0.38 & \\
\hline NL93_7 & Nederrijn, Lek & R7 & & 0.17 & 0.17 & 0.11 & 0.09 & 0.06 & 0.07 & 0.14 & 0.14 \\
\hline NL93_8 & Boven Rijn, Waal & R7 & & 0.25 & 0.07 & 0.15 & 0.15 & 0.07 & 0.18 & 0.15 & 0.12 \\
\hline NL93_IJSSELL & IJssel & R7 & & 0.25 & 0.10 & 0.13 & 0.17 & 0.12 & 0.22 & 0.22 & 0.22 \\
\hline NL93_TWENTHEKANALEN & Twenthekanalen ${ }^{* *}$ & M7b & & 0.10 & & & & & & & \\
\hline NL94_1 & Haringvliet oost & R8 & & 0.19 & & 0.10 & 0.13 & 0.09 & 0.10 & 0.06 & 0.13 \\
\hline NL94_2 2 & Dordtse Biesbosch & R8 & & 0.22 & & 0.27 & 0.16 & 0.15 & 0.18 & 0.13 & 0.16 \\
\hline NL94_3 3 & Boven en Beneden Merwede & R8 & NL94_4 & 0.19 & & 0.11 & 0.20 & 0.19 & 0.15 & 0.19 & 0.19 \\
\hline NL94_4 & Oude Maas & R8 & & 0.19 & & 0.11 & 0.20 & 0.19 & 0.15 & 0.19 & 0.19 \\
\hline NL94_5 & Beneden Maas & R8 & & 0.20 & & 0.15 & 0.12 & 0.09 & 0.14 & 0.17 & 0.09 \\
\hline NL94_6 6 & Bergsche Maas & R8 & NL94_5 & 0.10 & & 0.15 & 0.12 & 0.09 & 0.14 & 0.17 & 0.09 \\
\hline NL94_7 & Hollandsche IJssel & R8 & & 0.19 & & & & & & & \\
\hline NL94_8 & Nieuwe Maas & $02 \mathrm{~b}$ & & 0.50 & & & & & & & \\
\hline NL94_9 & Nieuwe Waterweg & $02 \mathrm{~b}$ & & 0.50 & & & & & & & \\
\hline NL94_10 & Brabantse Biesbosch & R8 & & 0.29 & & & & & & & \\
\hline NL94_11 & Haringvliet west & $02 b$ & & 0.45 & & & & & & & \\
\hline
\end{tabular}


Tabel 5.2. Vervolg

\begin{tabular}{|c|c|c|c|c|c|c|c|c|c|c|c|}
\hline Waterlichaam code & Waterlichaam naam & Type & Leent EKR van & GEP & 2013 & 2014 & 2015 & 2016 & 2017 & 2018 & 2019 \\
\hline NL81_2 & Eems-Dollard & O2a & & \begin{tabular}{|l|}
0.42 \\
\end{tabular} & & & & & & & \\
\hline NL86_5 & Amsterdam-Rijnkanaal Betuwepand & M7b & NL93_7 & 0.10 & & & & & & & \\
\hline NL86_6 & Amsterdam-Rijnkanaal Noordpand & M7b & NL93_7 & 0.10 & & & & & & & \\
\hline NL87_1 & Noordzeekanaal* & $\mathrm{O} 2 \mathrm{~b}$ & & 0.43 & & & & 0.36 & 0.43 & 0.42 & 0.40 \\
\hline NL89_ANTWKNPD & Antwerps kanaalpand & M30 & NL89_volkerak & 0.10 & & & & & & & \\
\hline NL89_GREVLEMR & Grevelingenmeer & M32 & & 0.60 & 0.44 & & & & 0.45 & & 0.36 \\
\hline NL89_KANTNZGT & kanaal Terneuzen Gent & M30 & NL89_westsde & 0.10 & & & & & & & \\
\hline NL89_SPUIKNL & Bathse Spuikanaal & M7a & NL89_volkerak & 0.10 & & & & & & & \\
\hline NL89_VEERSMR & Veerse meer & M32 & & 0.45 & & & & 0.43 & 0.52 & 0.57 & 0.60 \\
\hline NL89_VOLKERAK & Volkerak & M20 & & 0.25 & & 0.40 & & & 0.65 & 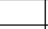 & \\
\hline NL89_WESTSDE_OWL & Westerschelde & O2a & & 0.37 & & & & & & & \\
\hline NL89_ZOOMMEDT & Zoommeer, Eendracht & M20 & & 0.09 & & & & 0.23 & 0.48 & 0.75 & 0.44 \\
\hline NL90_1 & Midden Limburgse en Noord-Brabantse kanalen & M6 & NL91ZM & 0.10 & & & 0.08 & & & 0.21 & 0.15 \\
\hline NL91BM & Bedijkte Maas & R7 & & 0.35 & & & 0.17 & & 0.16 & 0.21 & 0.20 \\
\hline NL91BOM & Bovenmaas & R7 & NL91GM & 0.35 & & & & & & & \\
\hline NL91GM & Grensmaas & R16 & & 0.45 & 0.43 & 0.47 & 0.25 & 0.43 & 0.16 & 0.32 & 0.31 \\
\hline NL91JK & Julianakanaal & M7 & NL91ZM & 0.10 & & 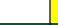 & 0.08 & 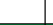 & 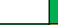 & 0.21 & 0.15 \\
\hline NL91MWK & Maas-Waalkanaal & M7 & NL93_8 & 0.10 & 0.11 & 0.14 & 0.11 & 0.13 & 0.14 & 0.07 & 0.08 \\
\hline NL91ZM & Zandmaas & R7 & & 0.25 & & & 0.08 & & & 0.21 & 0.15 \\
\hline NL92_IJSSELMEER & IJsselmeer & M21b & & 0.52 & 0.26 & 0.30 & 0.60 & 0.38 & 0.36 & 0.52 & 0.58 \\
\hline NL92_KETELMEER_VOSSEMEER & Ketelmeer, Vossemeer & M14 & & 0.25 & & 0.24 & & 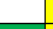 & 0.20 & & \\
\hline NL92_MARKERMEER & Markermeer & M21a & & 0.60 & 0.54 & 0.47 & 0.53 & 0.79 & 0.54 & 0.54 & 0.56 \\
\hline NL92_RANDMEREN_OOST & Randmeren-Oost & M14 & & 0.40 & 0.40 & & & 0.34 & & & 0.37 \\
\hline NL92_RANDMEREN_ZUID & Randmeren-Zuid & M14 & & 0.30 & & & 0.32 & & & 0.22 & 0.27 \\
\hline NL92_ZWARTEMEER & Zwartemeer & M14 & & 0.40 & & 0.41 & & & 0.37 & & \\
\hline NL93_7 & Nederrijn, Lek & R7 & & 0.17 & 0.20 & 0.06 & 0.08 & 0.15 & 0.16 & 0.08 & 0.13 \\
\hline NL93_8 & Boven Rijn, Waal & R7 & & 0.25 & 0.11 & 0.14 & 0.11 & 0.13 & 0.14 & 0.07 & 0.08 \\
\hline NL93_IJSSEL & IJssel & R7 & & 0.25 & 0.24 & 0.20 & 0.14 & 0.13 & 0.16 & 0.14 & 0.12 \\
\hline NL93_TWENTHEKANALEN & Twenthekanalen ${ }^{* *}$ & M7b & & 0.10 & & & & & & & \\
\hline NL94_1 & Haringvliet oost & R8 & & 0.19 & 0.13 & 0.06 & 0.05 & 0.13 & 0.05 & 0.10 & 0.10 \\
\hline NL94_2 2 & Dordtse Biesbosch & R8 & & 0.22 & 0.14 & 0.16 & 0.17 & 0.18 & 0.17 & 0.14 & 0.12 \\
\hline NL94_3 & Boven en Beneden Merwede & R8 & NL94_4 & 0.19 & 0.15 & 0.20 & 0.07 & 0.25 & 0.08 & 0.15 & 0.16 \\
\hline NL94_4 & Oude Maas & R8 & & 0.19 & 0.15 & 0.20 & 0.07 & 0.25 & 0.08 & 0.15 & 0.16 \\
\hline NL94_5 & Beneden Maas & R8 & & 0.20 & 0.22 & 0.15 & \begin{tabular}{l|l}
0.09 \\
\end{tabular} & 0.15 & 0.07 & 0.10 & 0.16 \\
\hline NL94_6 & Bergsche Maas & R8 & NL94_5 & 0.10 & 0.22 & 0.15 & 0.09 & 0.15 & 0.07 & 0.10 & 0.16 \\
\hline NL94_7 & Hollandsche IJssel & R8 & & 0.19 & & & & & 0.10 & 0.14 & 0.06 \\
\hline NL94_8 & Nieuwe Maas & $02 \mathrm{~b}$ & & 0.50 & & & & & & & \\
\hline NL94_9 & Nieuwe Waterweg & $02 \mathrm{~b}$ & & 0.50 & & & 0.38 & 0.44 & 0.42 & 0.50 & 0.43 \\
\hline NL94_10 & Brabantse Biesbosch & R8 & & 0.29 & & 0.07 & & & 0.40 & 0.42 & 0.41 \\
\hline NL94_11 & Haringvliet west & $02 \mathrm{~b}$ & & 0.45 & & & 0.23 & 0.27 & 0.27 & 0.25 & 0.35 \\
\hline
\end{tabular}


Tabel 5.3 EKR-score per waterlichaam voor rivieren, bepaald inclusief fuikgegevens.

\begin{tabular}{|c|c|c|c|c|c|c|c|c|}
\hline Waterlichaam code & Waterlichaam naam & Type & Leent fuiken van & 2015 & 2016 & 2017 & 2018 & 2019 \\
\hline NL91BM & Bedijkte Maas & R7 & NL91ZM & 0.17 & & 0.26 & 0.28 & 0.30 \\
\hline NL91ZM & Zandmaas & R7 & & 0.15 & & & 0.34 & 0.21 \\
\hline NL93_7 & Nederrijn, Lek & R7 & & 0.31 & 0.38 & 0.36 & 0.28 & 0.29 \\
\hline NL93_8 & Boven Rijn, Waal & R7 & & 0.24 & 0.33 & 0.24 & 0.17 & 0.18 \\
\hline NL93_IJSSEL & IJssel & R7 & & 0.28 & 0.26 & 0.23 & 0.18 & 0.19 \\
\hline NL94_1 & Haringvliet oost & R8 & & 0.22 & 0.19 & 0.15 & 0.17 & 0.16 \\
\hline NL94_2 & Dordtse Biesbosch & R8 & NL93_8 & 0.20 & 0.18 & 0.20 & 0.18 & 0.16 \\
\hline NL94 4 & Oude Maas & R8 & & 0.31 & 0.48 & 0.31 & 0.32 & 0.33 \\
\hline NL94_5 & Beneden Maas & R8 & & 0.19 & 0.22 & 0.17 & 0.20 & 0.19 \\
\hline NL94_10 & Brabantse Biesbosch & R8 & NL94_5 & & & 0.47 & 0.45 & 0.44 \\
\hline NL91GM & Grensmaas & R16 & NL91ZM & 0.28 & 0.47 & 0.26 & 0.35 & 0.34 \\
\hline
\end{tabular}




\subsection{Uitwerking van EKR-score en toelichting}

Een verklaring voor variatie in EKR-scores tussen jaren of een EKR-score lager dan GEP is veelal complex. Vaak wordt een lage EKR-score veroorzaakt door lage scores van meerdere deelmaatlatten en dit kan per jaar variëren door bijvoorbeeld aan- of afwezigheid van soorten in de vangst van dat jaar. De gegevens in onderstaande figuren staan als tabellen in Bijlage 58. Duiding van scores in een specifiek waterlichaam heeft beperkingen:

(1) De maatlatten zijn ontwikkeld voor watertypen, niet voor specifieke (KRW-) waterlichamen. De EKR 's houden daarom geen rekening met gebiedsspeciefieke hydromorfologische eigenschappen, zoals het voorkomen van bepaalde habitats die van invloed zijn op de scores.

(2) de maatlatten zijn niet afgestemd op de monitoring. De maatlatten veronderstellen een bepaalde visstand in een bepaald water, maar in grotere wateren zijn de monitoringsopties beperkt en sluiten in de meeste gevallen niet aan op de veronderstelde potentiele visstand. Daardoor zegt een EKR vaak meer over de mogelijkheid of onmogelijkheid om een bepaald type monitoring uit te voeren dan over de werkelijke ecologische toestand van een waterlichaam.

(3) natuurlijke variatie door variatie in waterstanden, toegankelijkheid van bepaalde habitats, het niet meenemen van uiterwaardwateren (terwijl maatlatten deels gebaseerd zijn op veronderstelde visfauna in uiterwaardwateren.

(4) de rol van exoten wordt niet meegenomen. Exoten nemen een groeiend deel van de visgemeenschappen in de grote rivieren en IJsselmeergebied, met name Ponto-Kaspische grondels. Ongeacht de waterkwaliteit of overige ecologische toestand (goed functionerend habitats) kunnen EKR's meer of minder sterk afwijken door de aan- of afwezigheid van exoten.

(5) Deelmaatlatten kunnen sterk worden gedomineerd door de aanwezigheid van een of enkele soorten. Het aandeel rheofielen wordt in veel gevallen zeer sterk gedomineerd door de hoeveelheid winde. Daardoor is de EKR vrijwel ongevoelig voor andere, wellicht meer indicatieve reofiele soorten als sneep, serpeling, barbeel, riviergrondel e.d.

Duiding van de scores vereist feitelijk in eerste instantie een grondige analyse van voorgestelde maatlat, mate van matching van monitoringsmethodiek, potentiele bemonsteringsvariatie en afwijkingen, soortspecifieke veranderingen die deelmaatlatten beïnvloeden, voordat een duiding in termen van ecologische kwaliteit kan worden gedaan. 


\subsubsection{M14 deelscores}

De deelmaatlatscores van de vier M14 wateren (ondiepe (matige grote) gebufferde plassen, Figuur 5.2ad) worden met name bepaald door variatie in massafractie baars en blankvoorn en massafractie brasem en karper. De massafractie plantminnende soorten komt enkel voor de Randmeren Oost en het Zwarte Meer in 2017 boven een score van 0.1 uit. De scores van de massafractie zuurstoftolerante soorten staat voor veel jaren op 0 en komt indien er wel een score is niet boven de 0.03 uit.

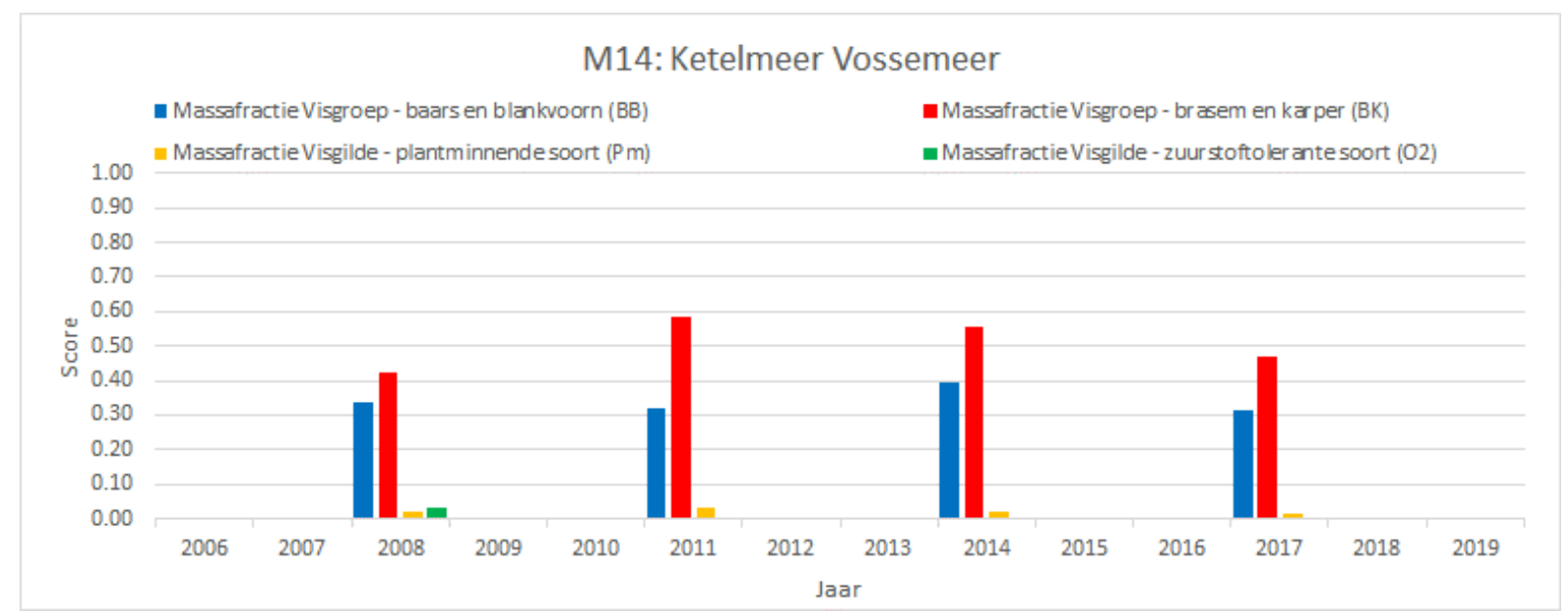

Figuur 5.2a. M14, Ketelmeer Vossemeer: deelscore per indicator per jaar.

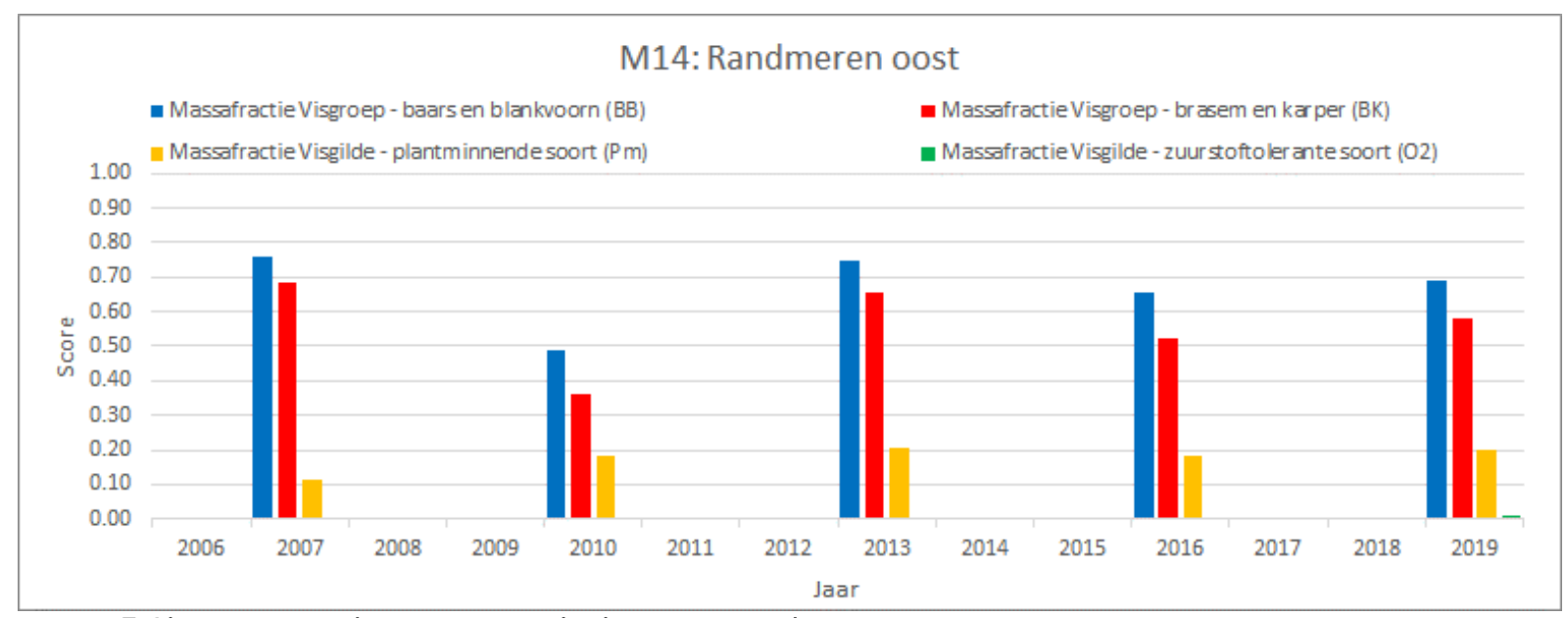

Figuur 5.2b. M14, Randmeren oost: deelscore per indicator per jaar. 


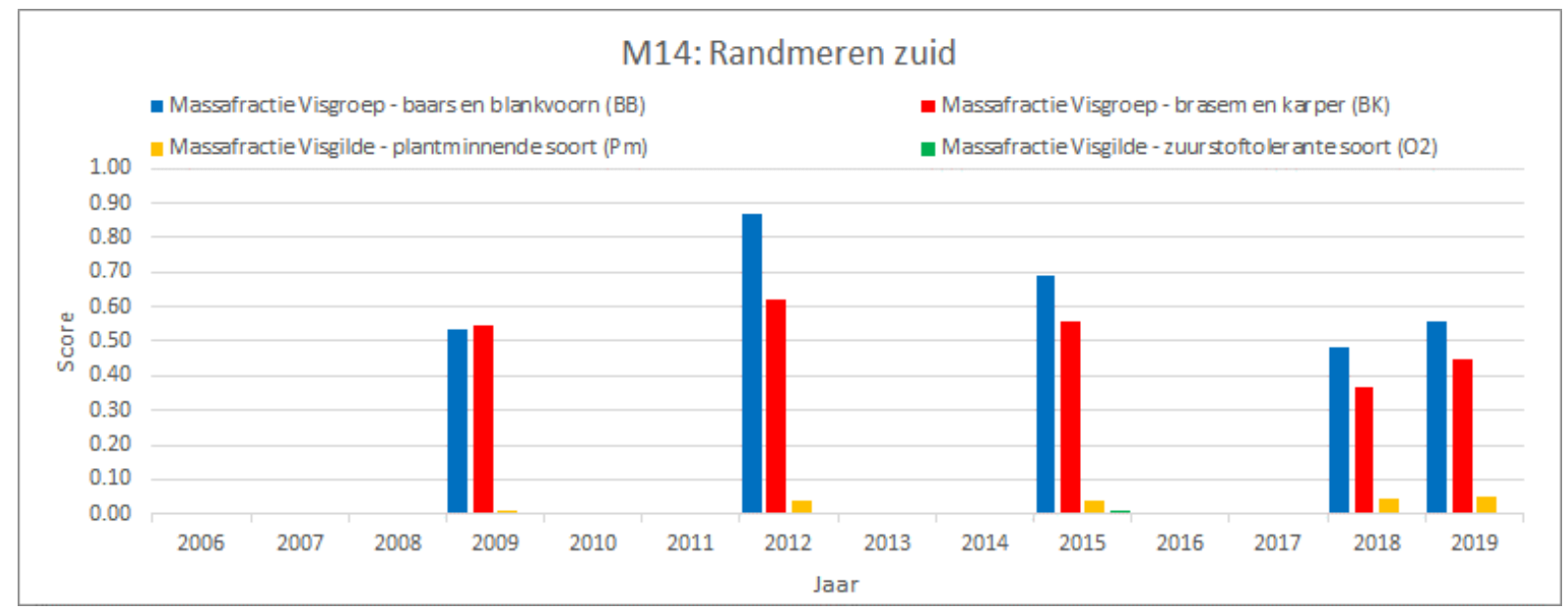

Figuur 5.2c. M14, Randmeren zuid: deelscore per indicator per jaar.

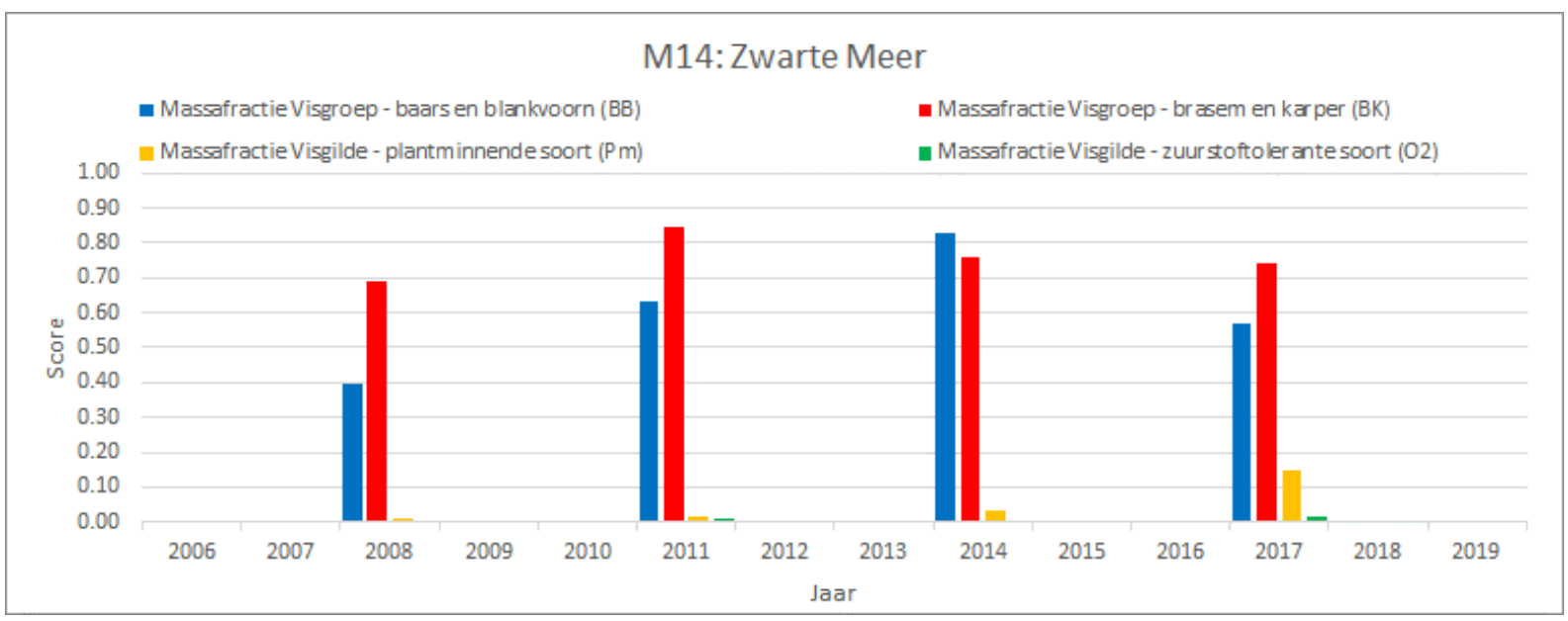

Figuur 5.2d. M14, Zwarte Meer: deelscore per indicator per jaar. 


\subsubsection{M20 deelscores}

Voor de M20 wateren (matig grote diepe gebufferde meren, Figuur 5.3a-b) wordt de variatie in score bepaald door de massafracties baars en blankvoorn, brasem en karper en plantminnende soorten. De indicator massafractie plantminnende soorten had in drie van de vier jaren een indicatorscore groter dan 0.10 voor het Zoommeer, terwijl voor het Volkerak enkel in 2017 een aanzienlijk deel plantminnende soorten meetelden in de maatlatscore. Het Zoommeer had in 2019 in vergelijking tot de twee voorgaande jaren een lagere score van baars en blankvoorn en brasem en karper, waardoor de EKR score in 2019 lager was dan de twee voorgaande jaren. De deelscores van de massafractie zuurstoftolerante soorten staat voor alle jaren op 0.

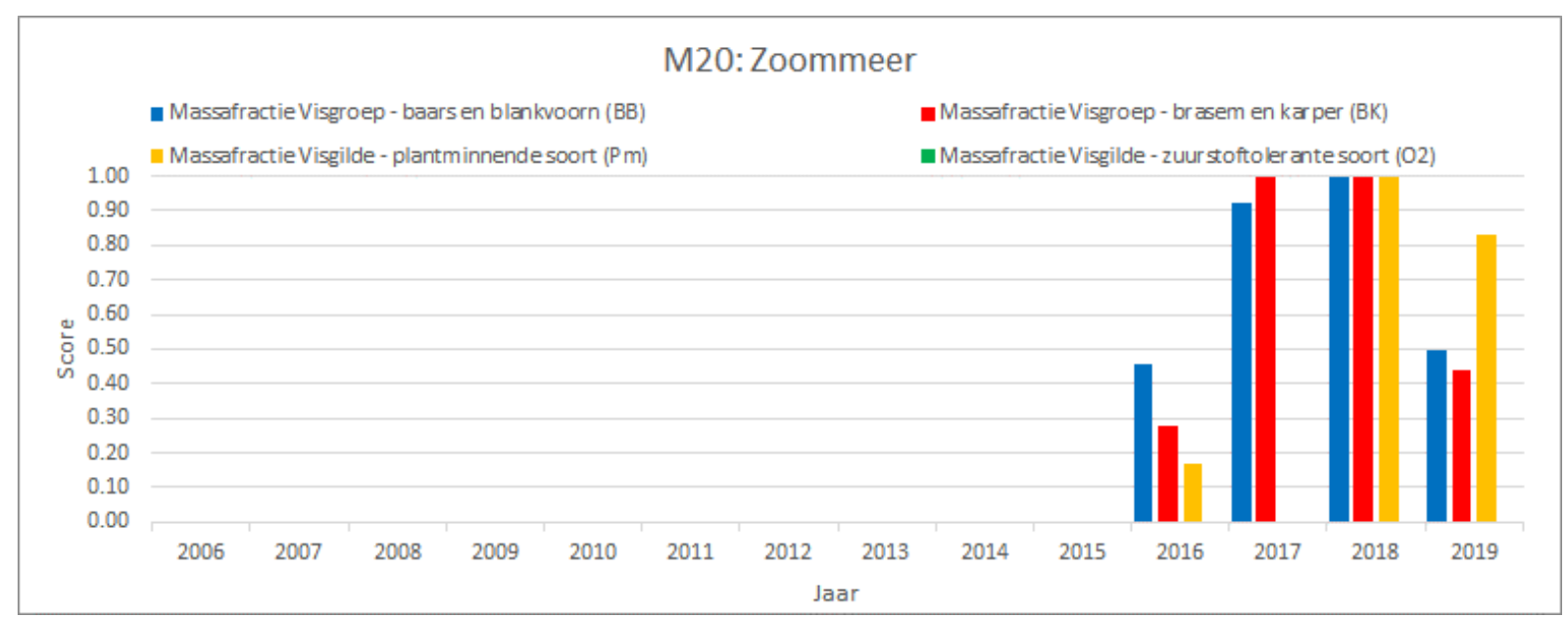

Figuur 5.3a. M20, Zoommeer: deelscore per indicator per jaar.

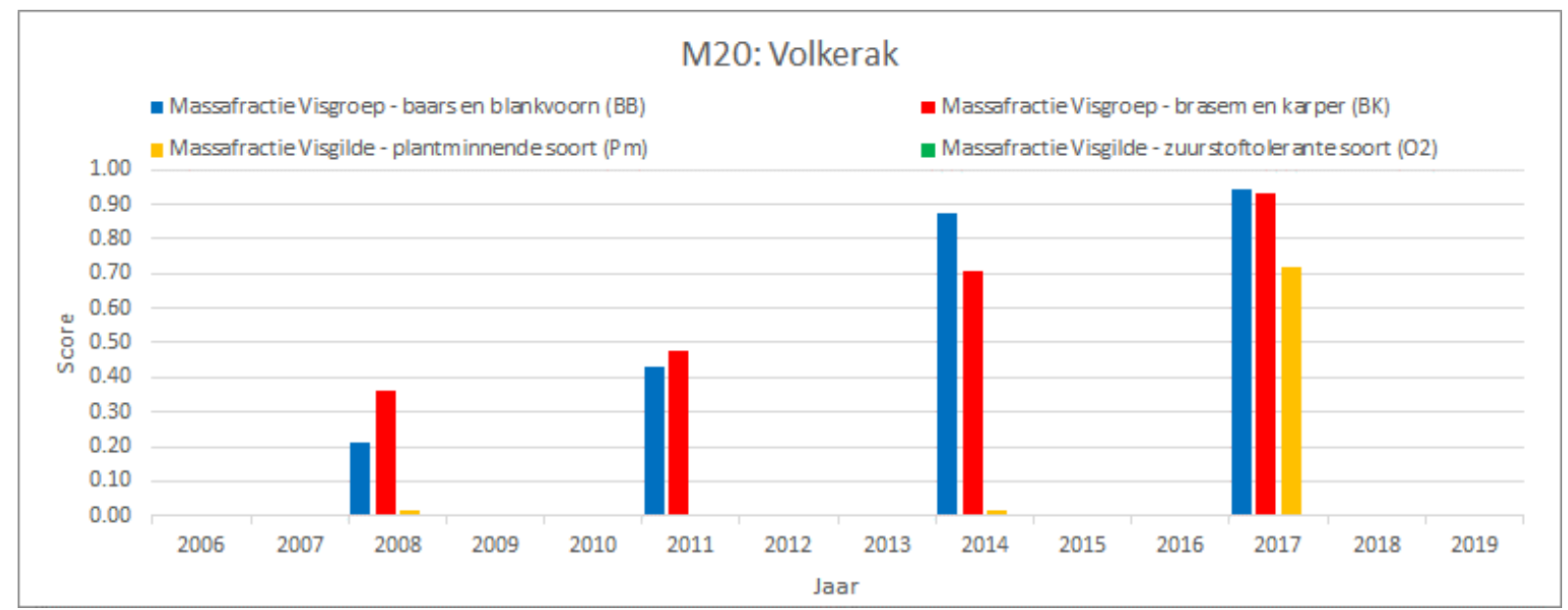

Figuur 5.3b. M20, Volkerak: deelscore per indicator per jaar. 


\subsubsection{M21 deelscores}

De variatie in EKR score van M21a (grote diepe gebufferde meren, Figuur 5.4a) Markermeer werd met name bepaald door de hoogte van de massafractie baars en blankvoorn, de massafractie brasem en karper (veelal hoog, in vier jaren waarde 1 door weinig totale vangsten) en de correctiefactor voor snoekbaars. Doordat de weging van bemonstering in de oever erg laag is in vergelijking met het open water, valt de biomassa van plantminnende soorten, welke met name in de oeverzone voorkomen, weg ten opzichte van vissen gevangen in het open water en zijn de deelscores voor deze indicator erg laag. De deelscores van de massafractie zuurstoftolerante soorten (in dit gebied is dit zeelt) staat voor alle jaren op 0. De soort wordt sporadisch in de oever gevangen maar de biomassa is erg klein.

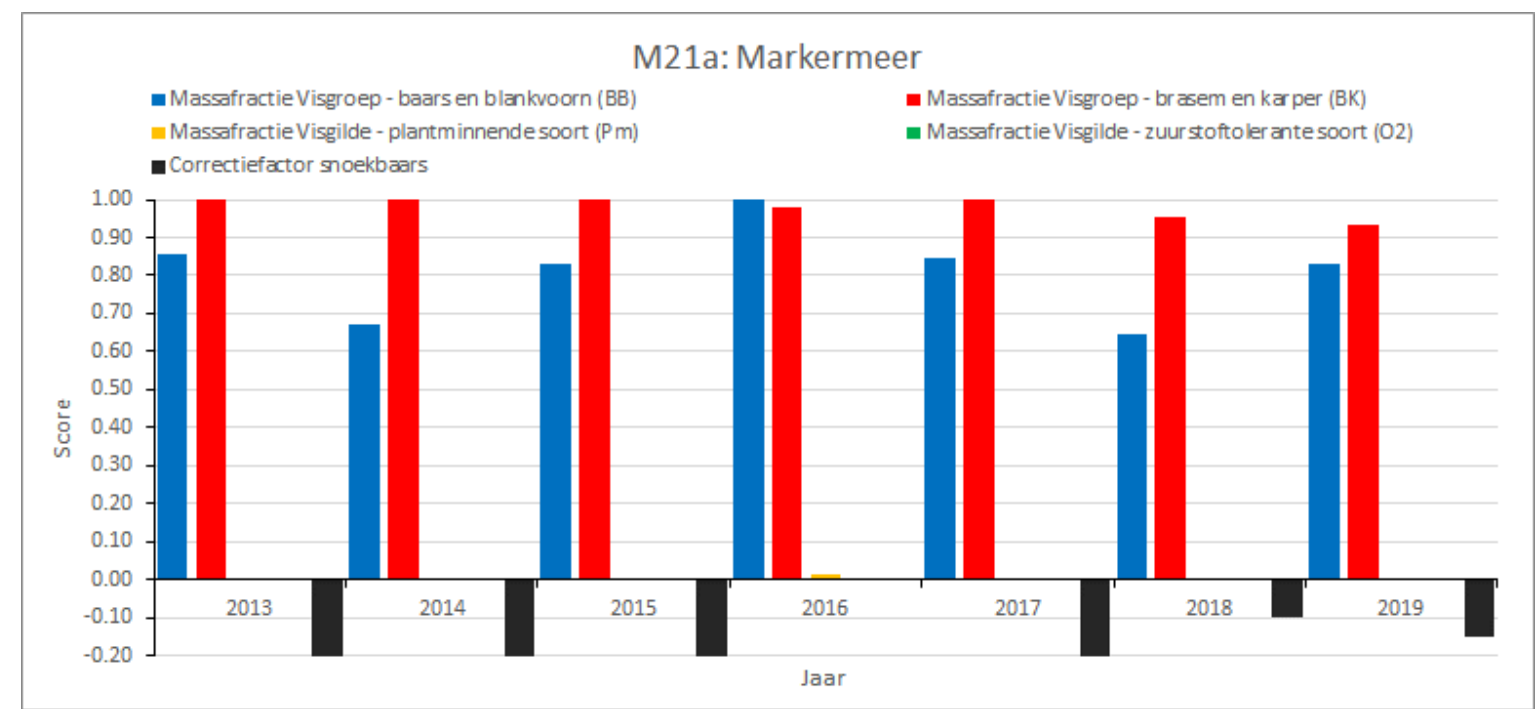

Figuur 5.4a. M21a, Markermeer: deelscore per indicator per jaar.

De variatie in EKR score van M21b (grote diepe gebufferde meren, Figuur 5.4b) IJsselmeer wordt bepaald door een viertal indicatoren. De drie andere indicatoren hebben uiterst beperkt tot geen invloed op de variatie in EKR score, te weten massafractie brasem en karper (altijd score 1, weinig vangsten van deze soorten), massafractie plantminnende soorten (tussen 0-0.01) en massafractie zuurstoftolerante soorten (altijd 0 ). De indicatoren soortenrijkdom diadrome vissen rivieren en biomassa bot zijn sinds dit jaar opgenomen in de EKR scoreberekening. 


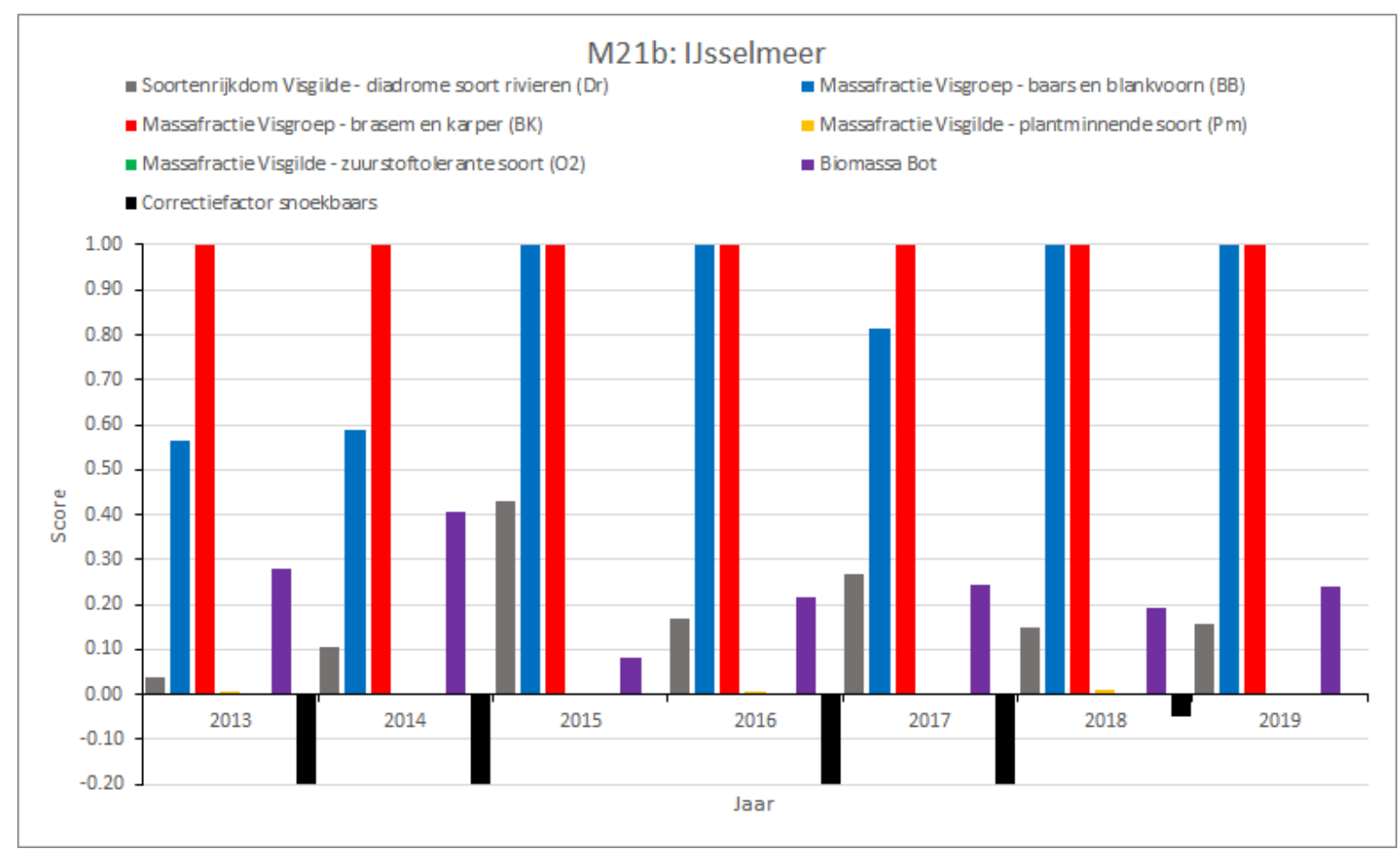

Figuur 5.4b. M21b, IJsselmeer: deelscore per indicator per jaar. 


\subsubsection{M32 deelscores}

Bij M32 wateren (brakke tot zoute meren, Figuur 5.5a-b) zijn er in totaal acht indicatoren, waarbij indicatoren met estuariene en mariene soorten de hoogste scores hebben. Variatie in de EKR score tussen jaren wordt bepaald door variatie in meerdere indicatoren. In het Veerse meer heeft ook massafractie diadrome soorten zoute wateren een aandeel met scores van 1 in drie van de vier jaren.

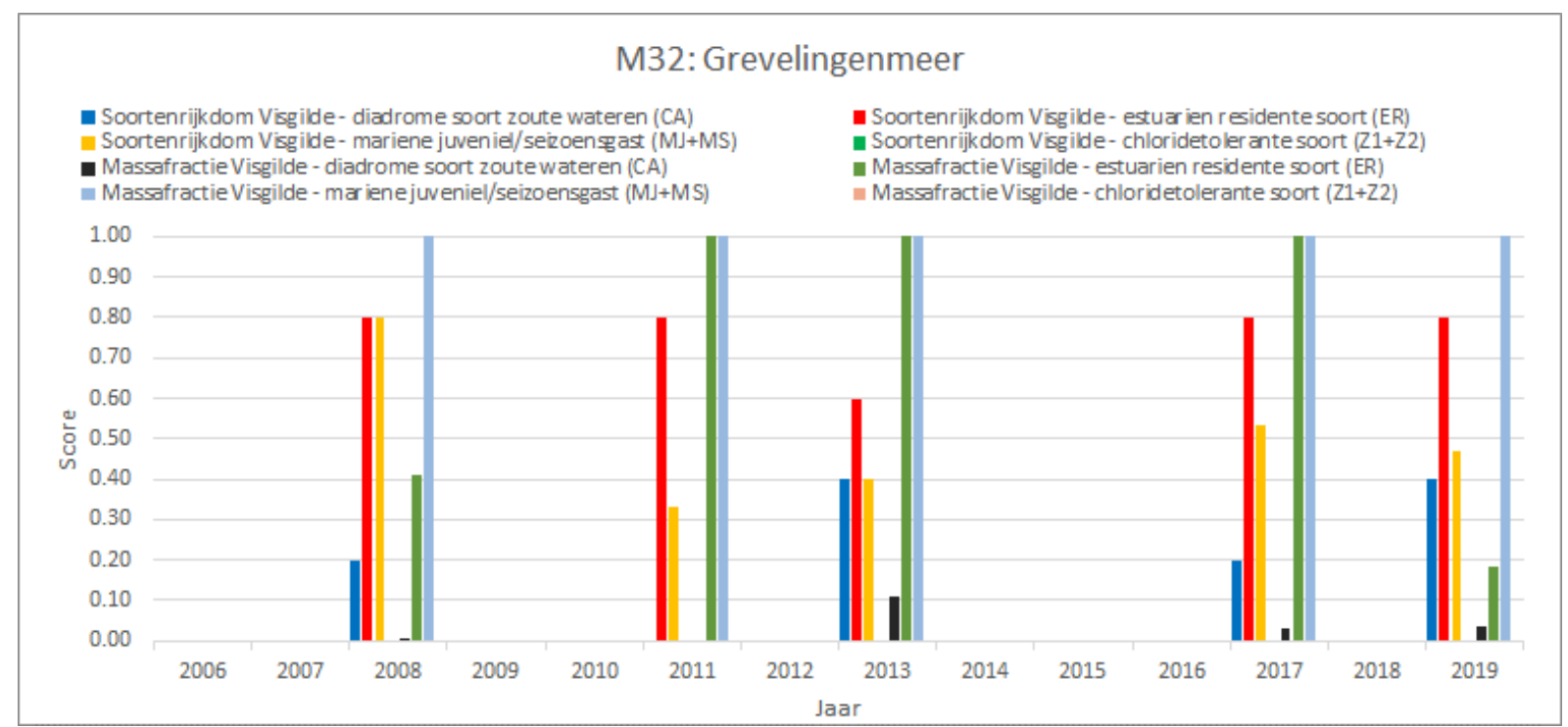

Figuur 5.5a. M32, Grevelingen: deelscore per indicator per jaar.

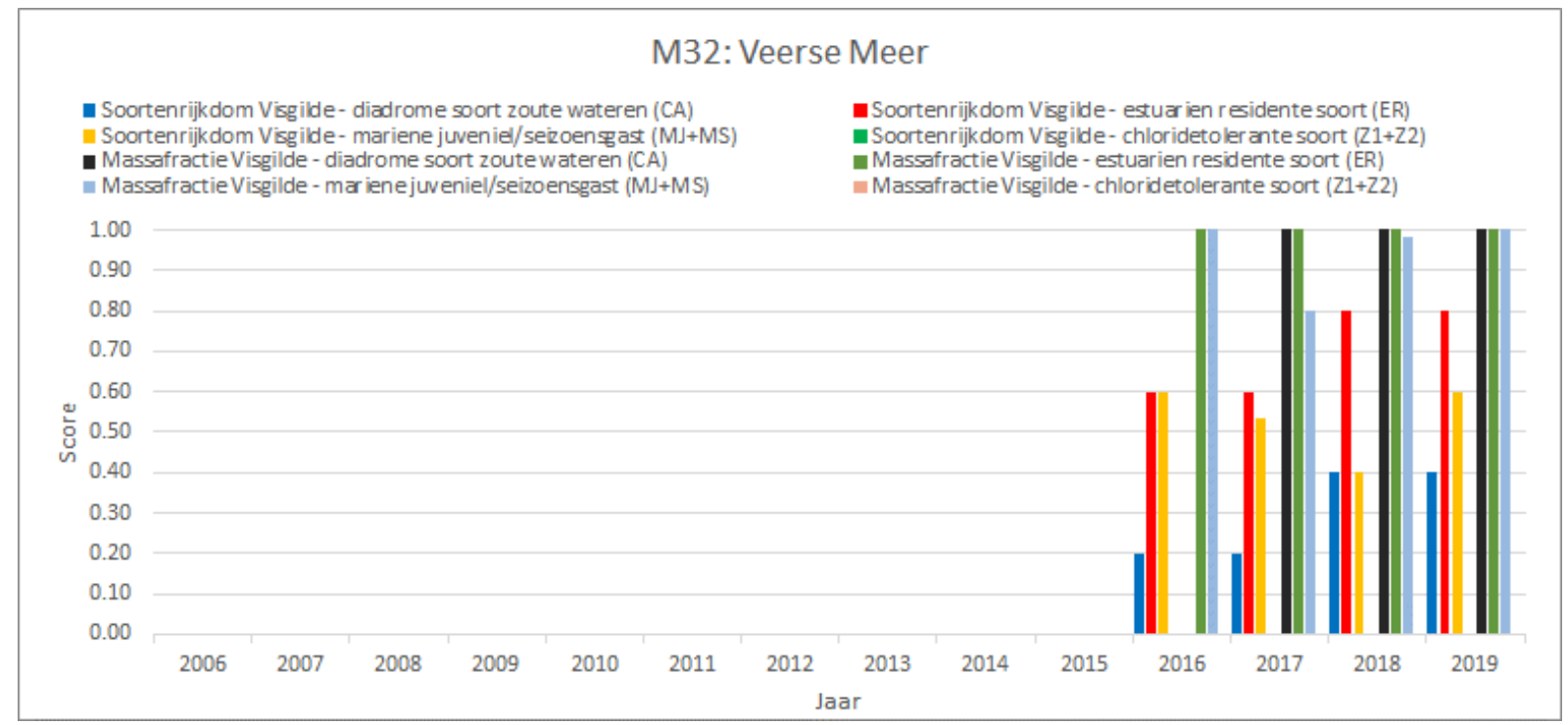

Figuur 5.5b. M32, Veerse Meer: deelscore per indicator per jaar. 


\subsection{5. $R 7$ deelscores}

Bij R7 wateren (langzaam stromende rivier op zand/klei, Figuur 5.6a-e) hebben de indicatoren soortenrijkdom diadrome en limnofiele soorten de hoogste deelscore. De andere drie indicatoren komen veelal niet, of net, boven een deelscore van 0.1 uit. Met name voor diadrome soorten bestaat variatie in score tussen 0.1 en 0.3 , wat komt door het vangen van 0-2 soorten (score 0.1 ) of 3-4 soorten (score 0.3) (Figuur 5.7). Bij rheofiele vissen zijn tot negen soorten gevangen over alle gebieden en jaren, waardoor de score door deze indicator nooit boven de 0.1 uitgekomen is. Vanaf 10 soorten neemt de score toe (Zie STOWA 2018, Tabel 15.4A). Figuur 5.8a-e tonen de verschillen in indicatorscores van soortenrijkdom tussen een toetsing met fuikgegevens en een toetsing zonder fuikgegevens per waterlichaam. Opname van fuikgegevens gaf voor de Bedijkte Maas en Zandmaas in sommige jaren een verhoging van de indicatorscore voor soortenrijkdom limnofiele soorten en voor de Bedijkte Maas in twee jaar ook een verhoging van de indicator rheofiele soorten. Voor de overige drie R7 waterlichamen was in sommige jaren naast eerder genoemde twee indicatoren ook een verhoging te zien voor soortenrijkdom diadrome vissoorten.

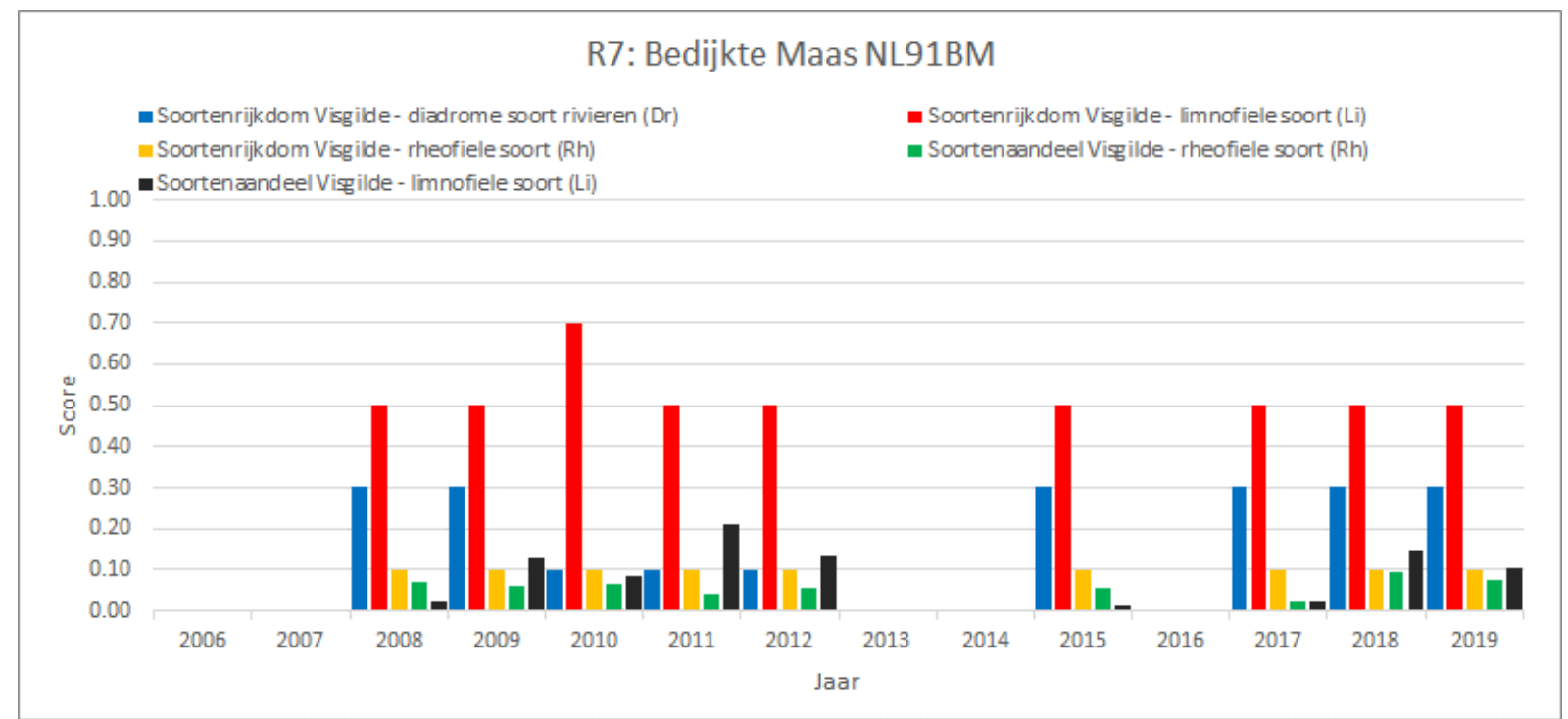

Figuur 5.6a. R7, Bedijkte Maas: deelscore per indicator per jaar.

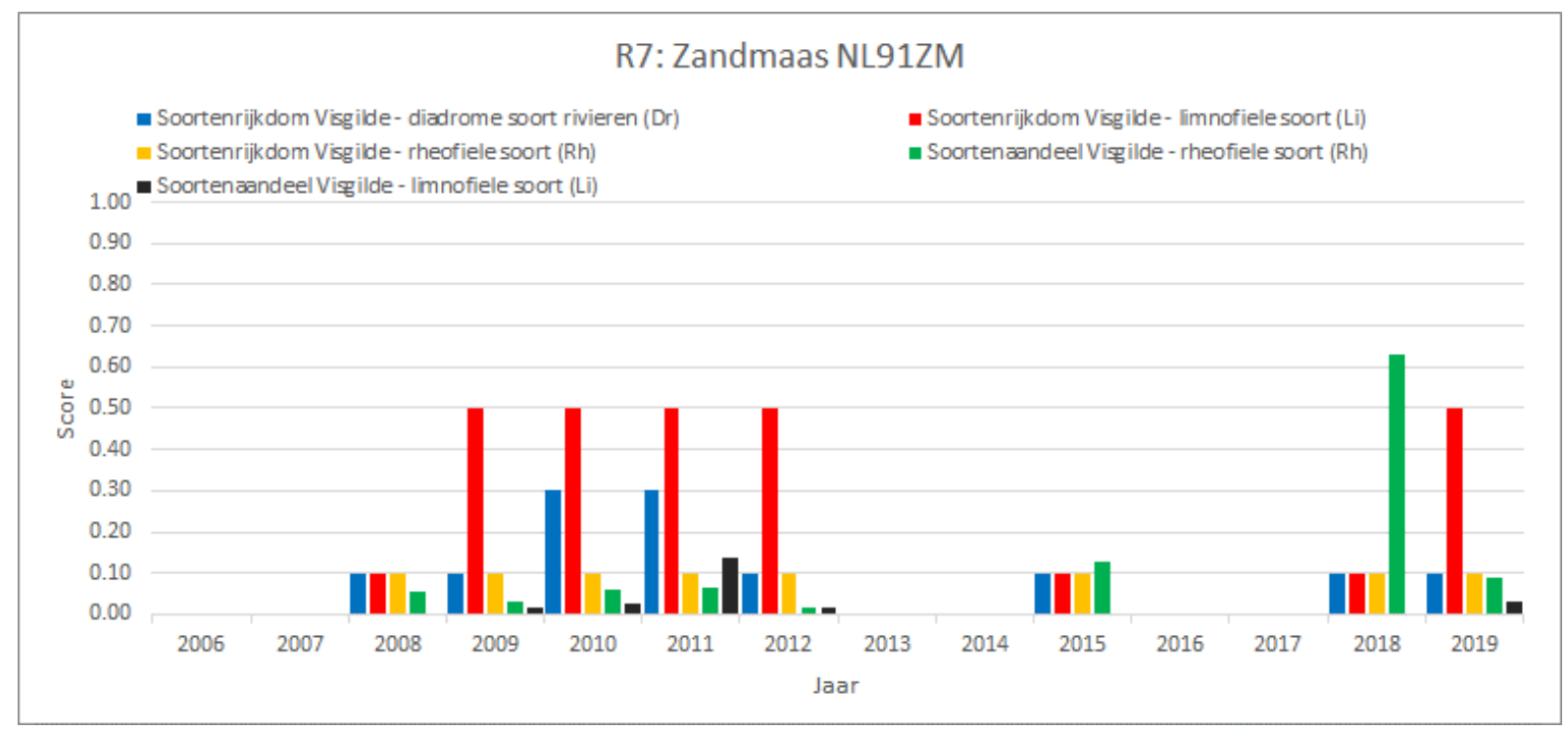

Figuur 5.6b. R7, Zandmaas: deelscore per indicator per jaar. 


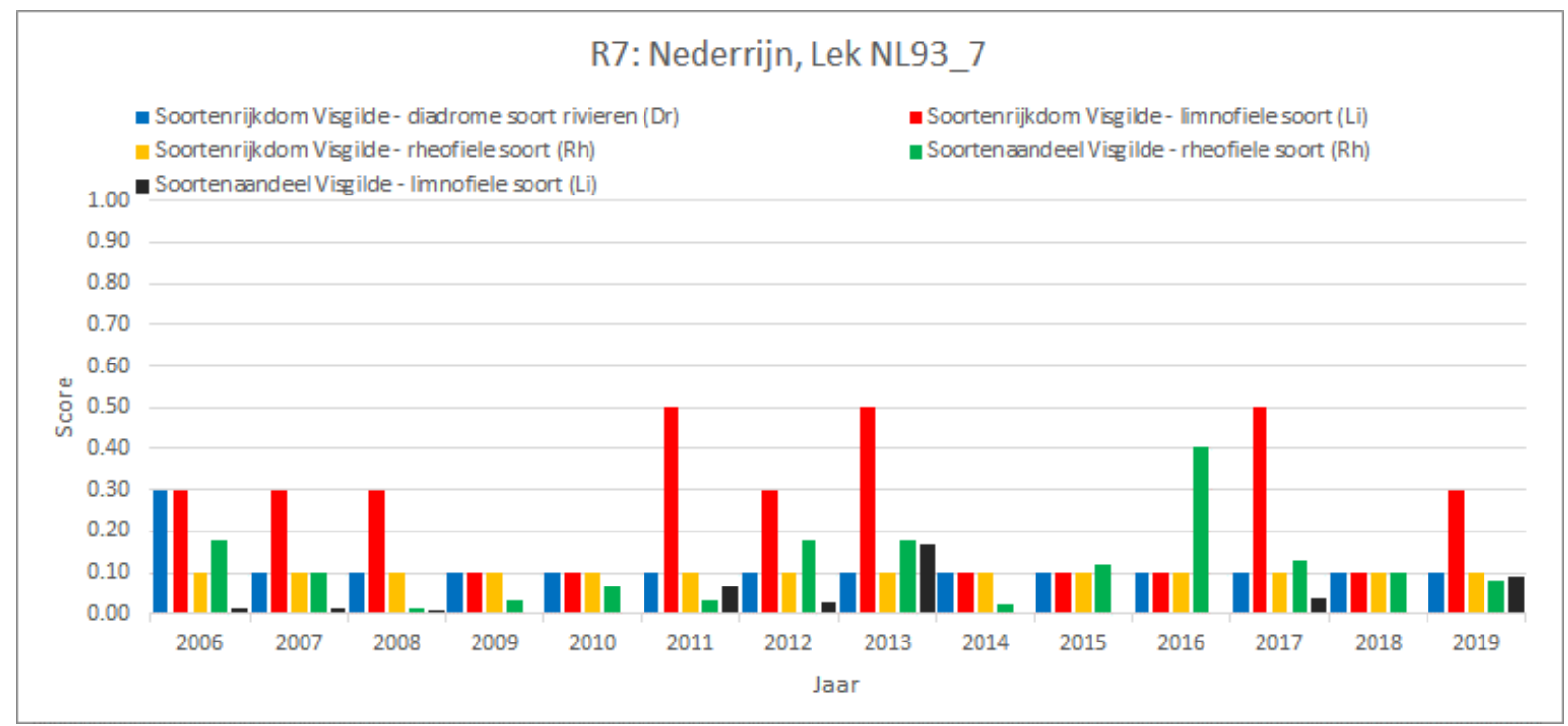

Figuur 5.6c. R7, Nederrijn, Lek: deelscore per indicator per jaar.

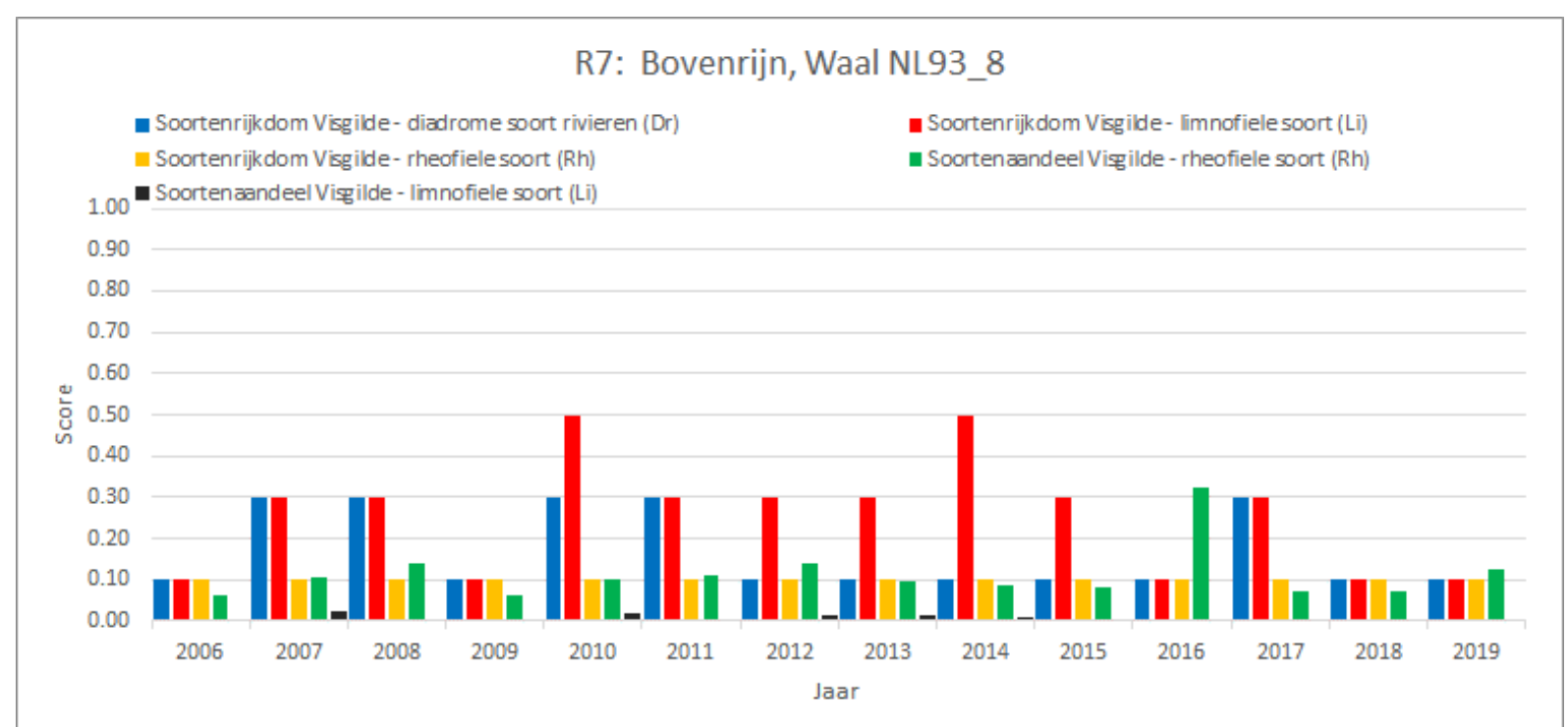

Figuur 5.6d. R7, Bovenrijn, Waal: deelscore per indicator per jaar.

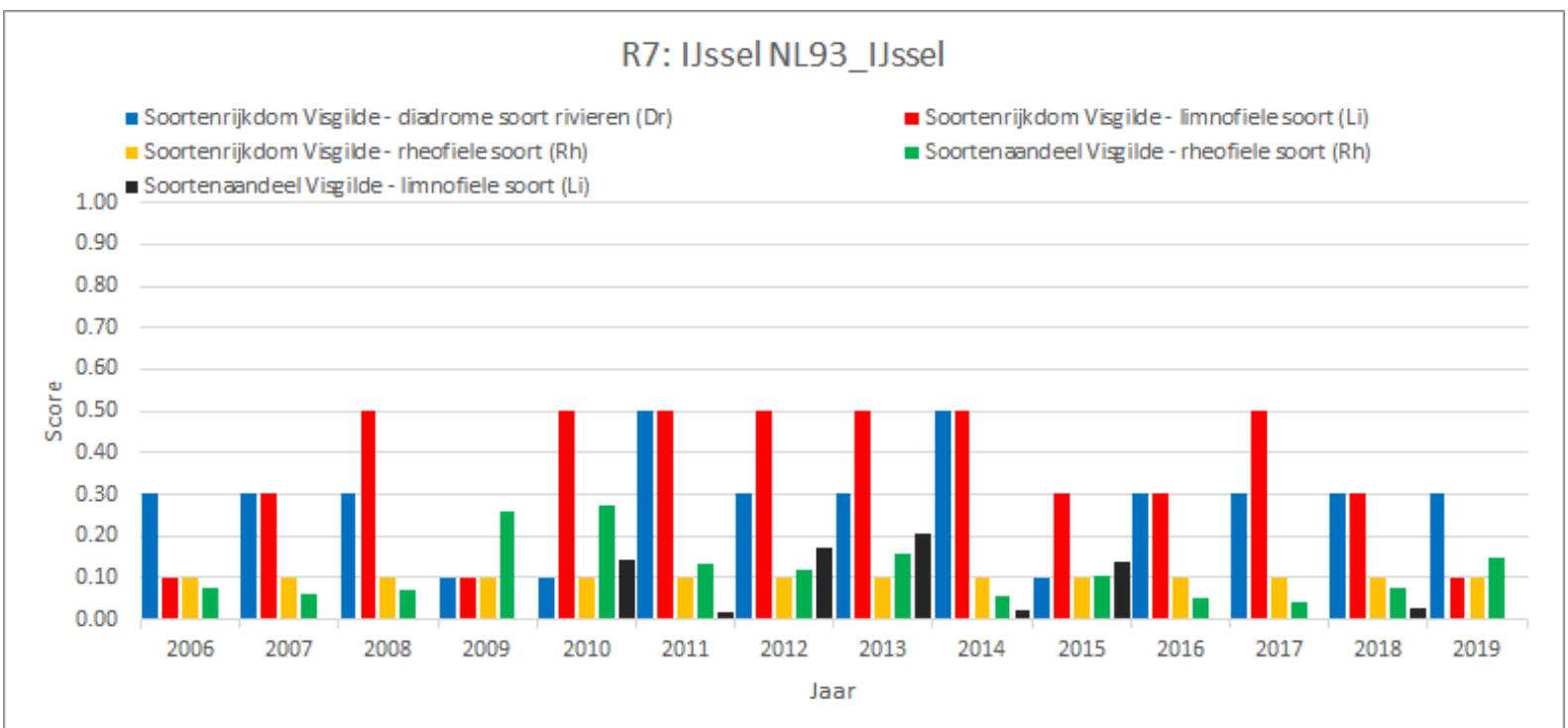

Figuur 5.6e. R7, IJssel: deelscore per indicator per jaar. 

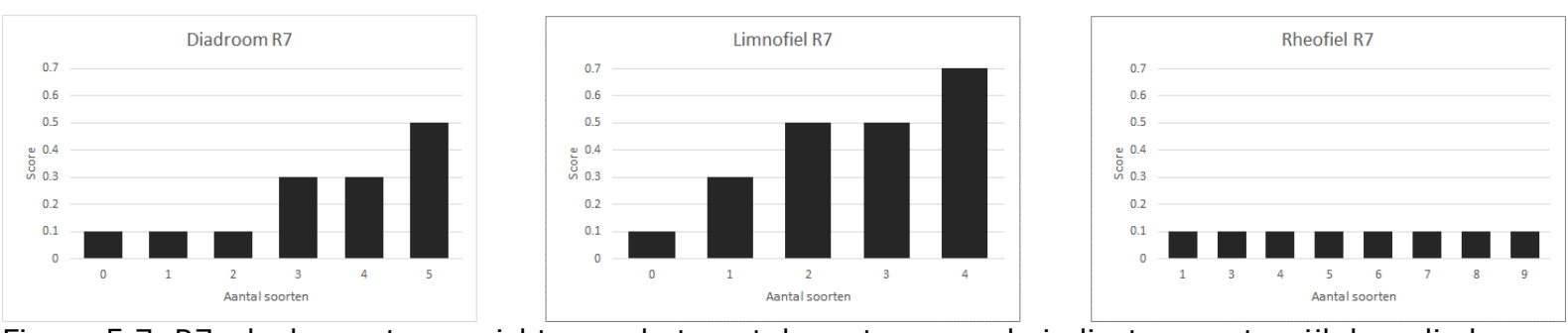

Figuur 5.7. R7: deelscore ten opzichte van het aantal soorten voor de indicator soortenrijkdom diadroom, limnofiel en rheofiel, waargenomen scores over alle gebieden en jaren van R7 samen.

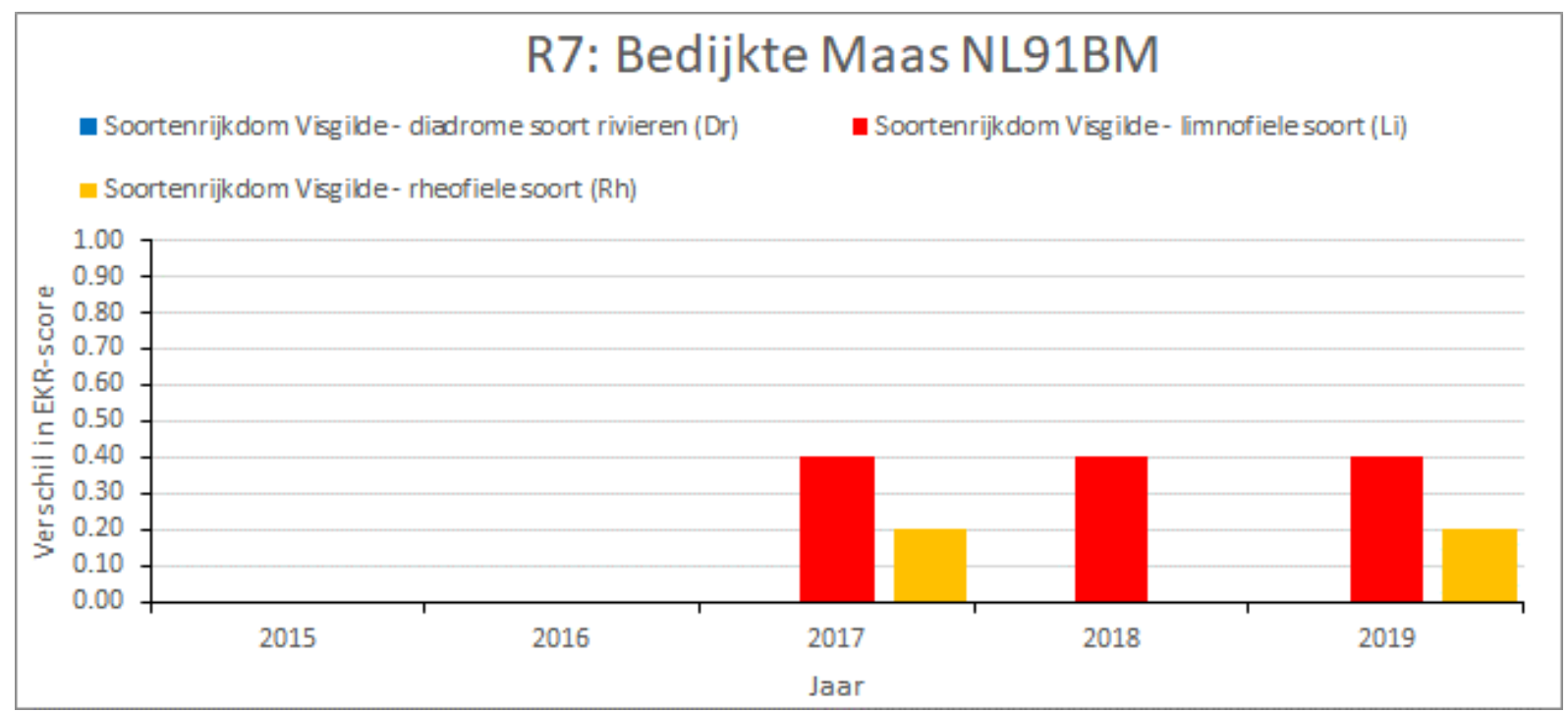

Figuur 5.8a. R7, Bedijkte Maas: verschil in score per indicator soortenrijkdom, berekend met fuiken ten opzichte van zonder fuiken per jaar.

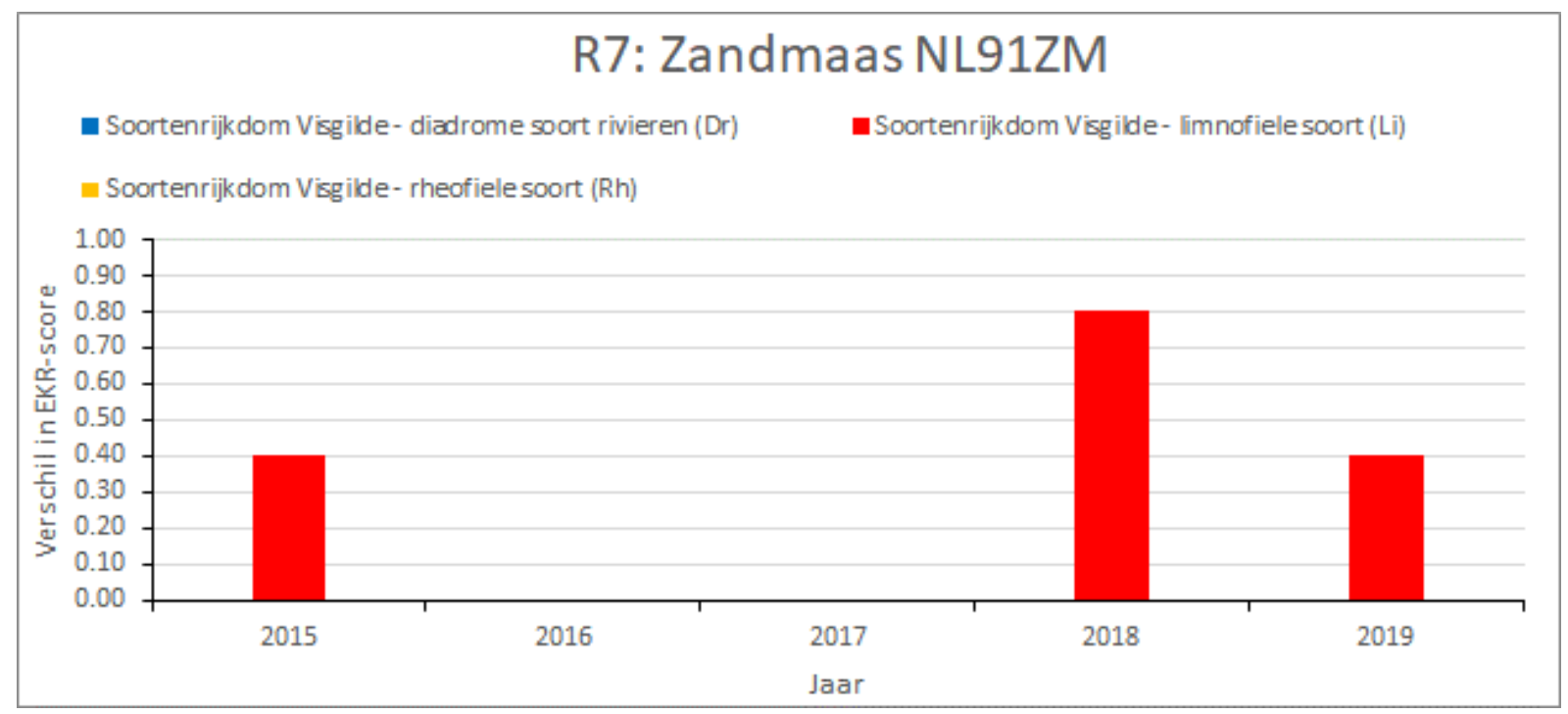

Figuur 5.8b. R7, Zandmaas: verschil in score per indicator soortenrijkdom, berekend met fuiken ten opzichte van zonder fuiken per jaar. 


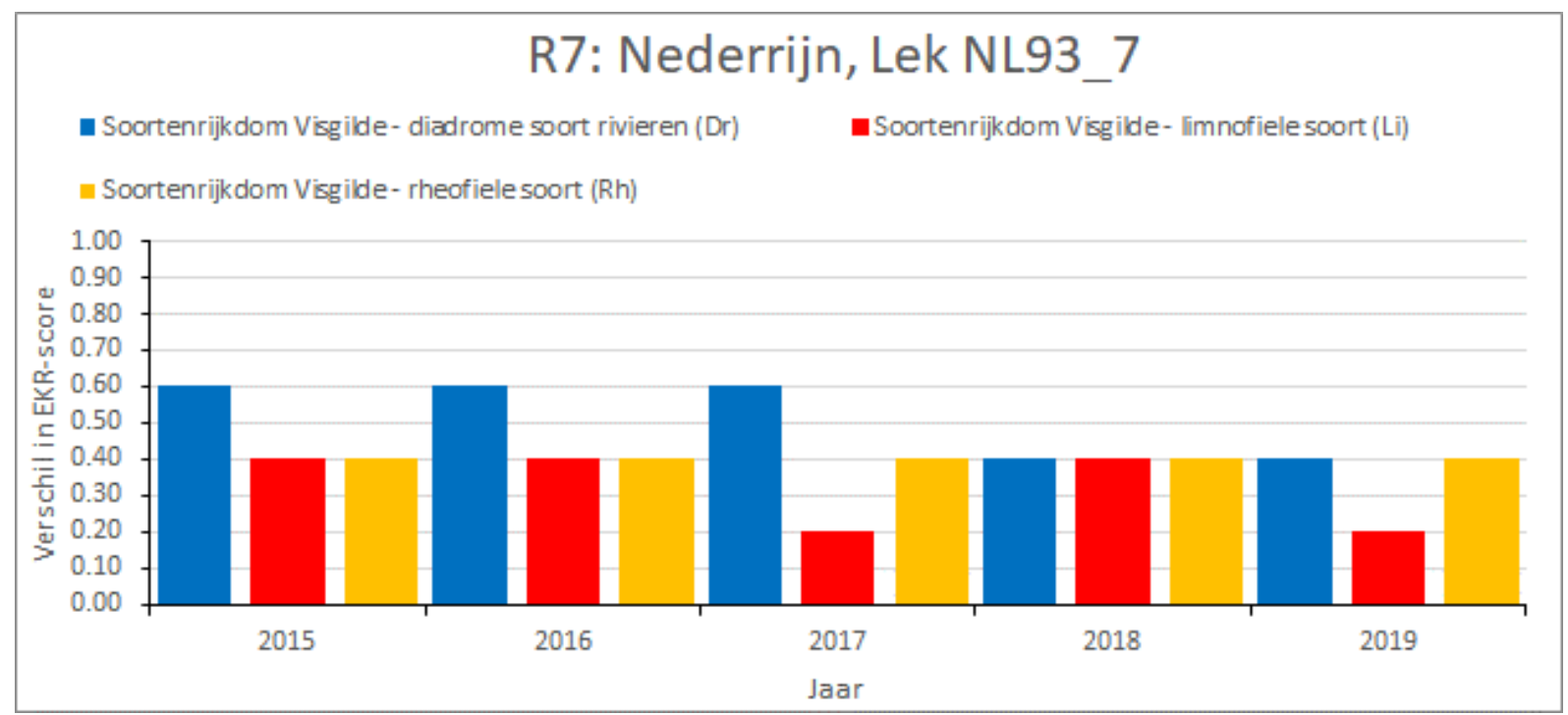

Figuur 5.8c. R7, Nederrijn, Lek: verschil in score per indicator soortenrijkdom, berekend met fuiken ten opzichte van zonder fuiken per jaar.

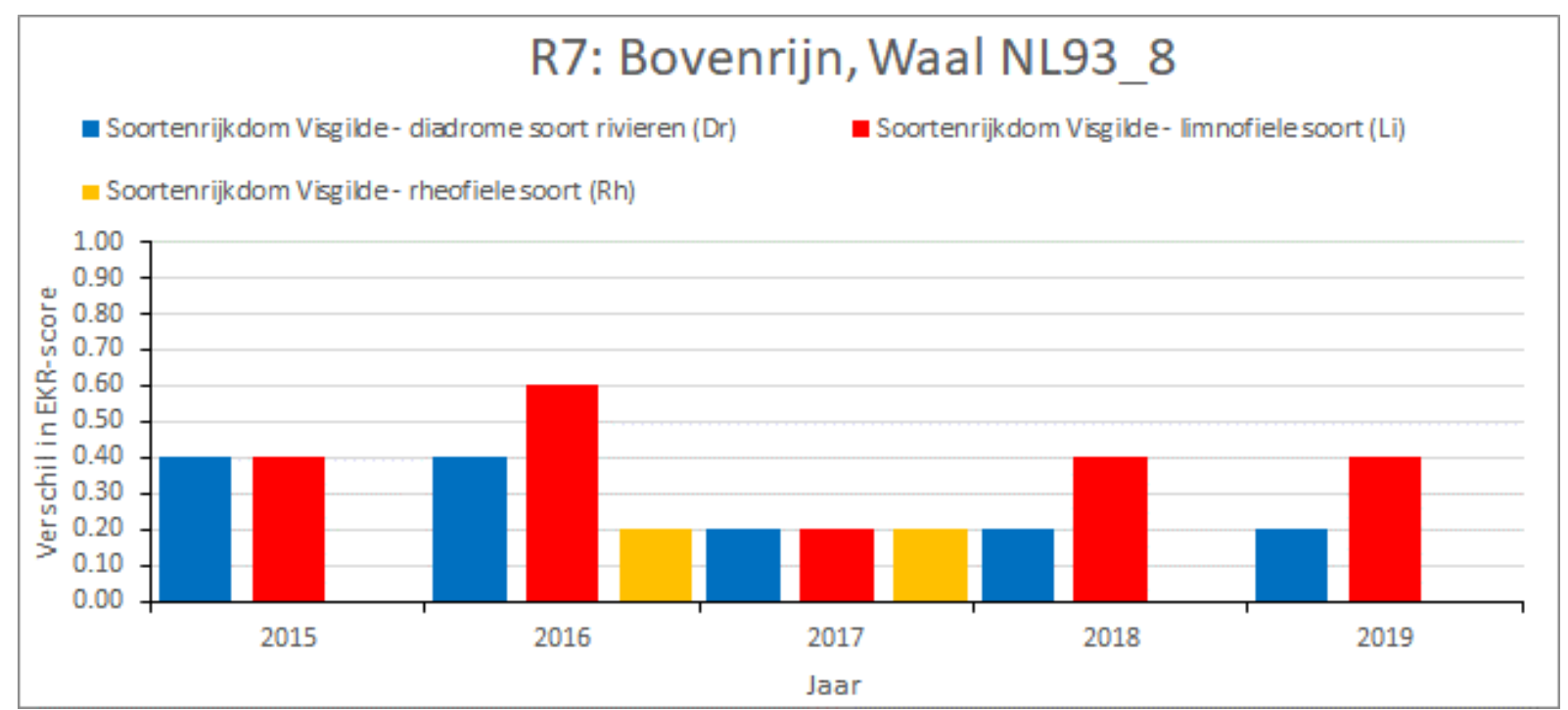

Figuur 5.8d. R7, Bovenrijn, Waal: verschil in score per indicator soortenrijkdom, berekend met fuiken ten opzichte van zonder fuiken per jaar.

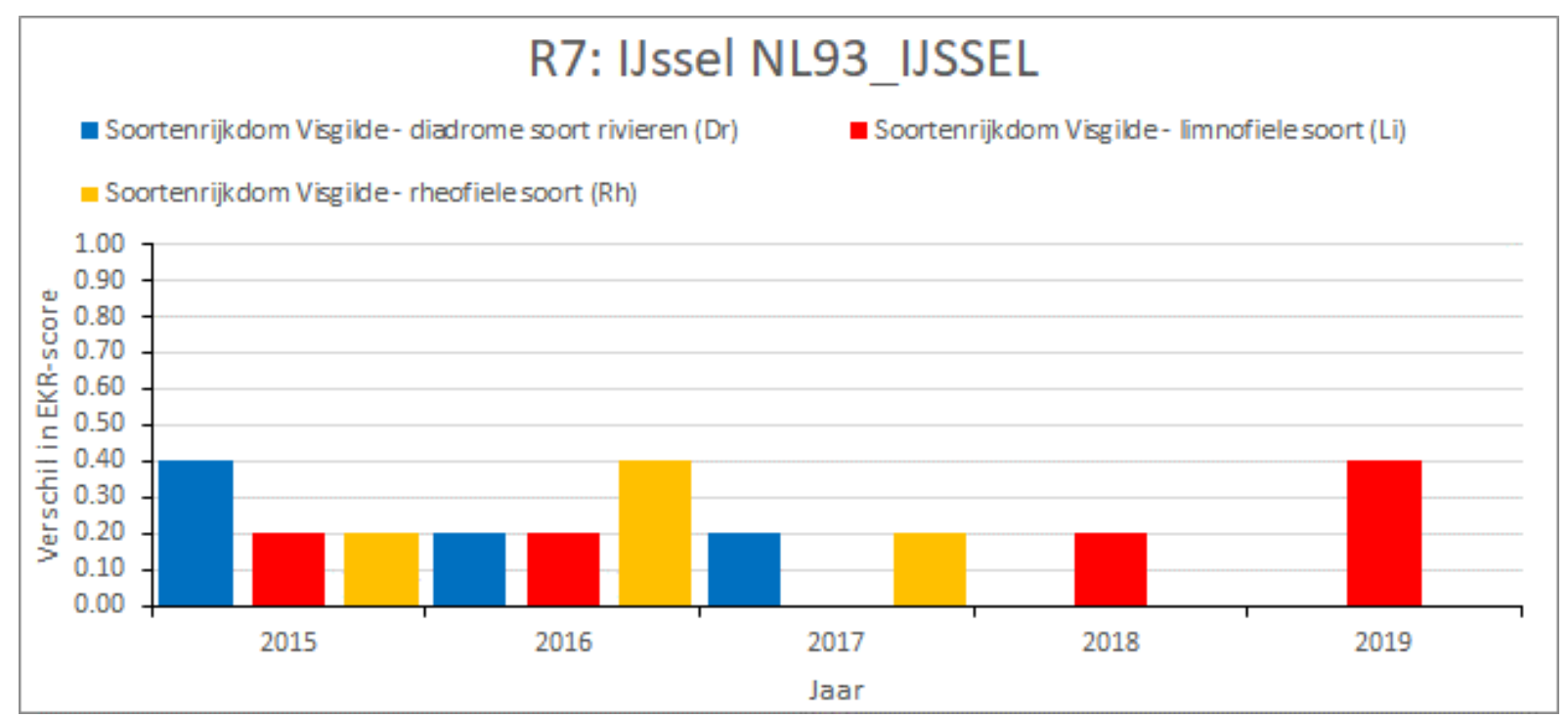

Figuur 5.8e. R7, IJssel: verschil in score per indicator soortenrijkdom, berekend met fuiken ten opzichte van zonder fuiken per jaar. 


\subsection{6. $R 8$ deelscores}

Bij R8 (zoet getijdenwater op zand/klei, Figuur 5.9a-f) bestaat de variatie in EKR scores met name door variatie in het aantal gevangen limnofiele soorten, waarbij er verschil zit tussen het vangen van geen (score 0.1), één (0.3) en twee tot drie soorten (0.5) (Figuur 5.10) en het soortenaandeel rheofiele soorten. Bij rheofiele vissen zijn tot acht soorten gevangen over alle gebieden en jaren, waardoor de score door deze indicator nooit boven de 0.1 uitgekomen is (Zie STOWA 2018, Tabel 16.4A). Voor de Biesbosch wordt gevist met een zegen en niet in een hoofdstroom met een boomkor, waarbij het soortenaandeel limnofiele soorten in dit waterlichaam hoger is in vergelijking met de andere waterlichamen. Figuur 5.11a-e tonen de verschillen in indicator scores van soortenrijkdom tussen een toetsing met fuikgegevens en een toetsing zonder fuikgegevens per waterlichaam. Opname van fuikgegevens gaf per waterlichaam en jaar verhoging in minstens één indicator. Bij de Oude Maas (NL94_4) was bijvoorbeeld een verhoging te zien voor alle indicatoren voor alle jaren, terwijl bij de Brabantsche Biesbosch (NL94_10) dit enkel was voor soortenrijkdom diadrome soorten. De bemonstering wordt hier echter uitgevoerd met een zegen in plaats van boomkor, waarbij de gevangen visgemeenschap ook anders is.

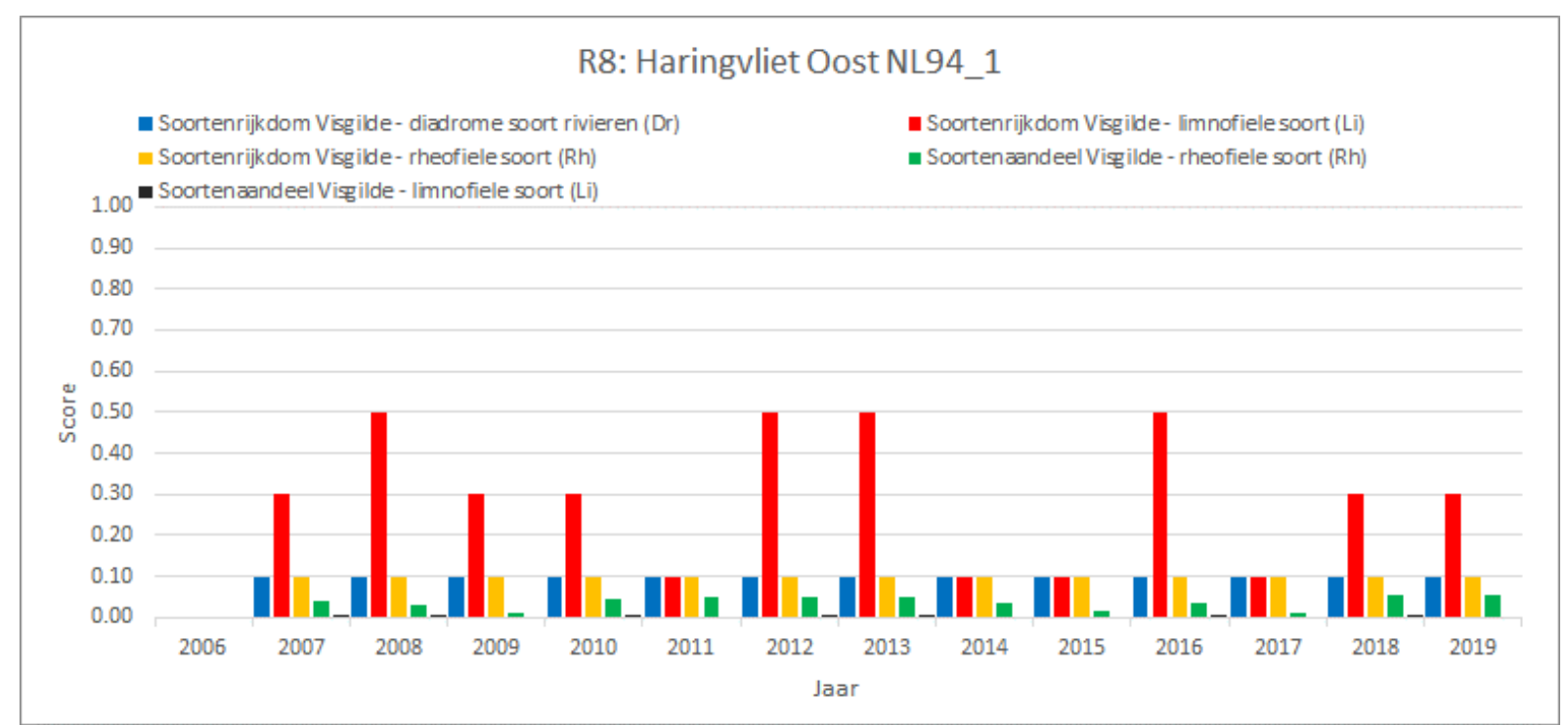

Figuur 5.9a. R8, Haringvliet oost: deelscore per indicator per jaar.

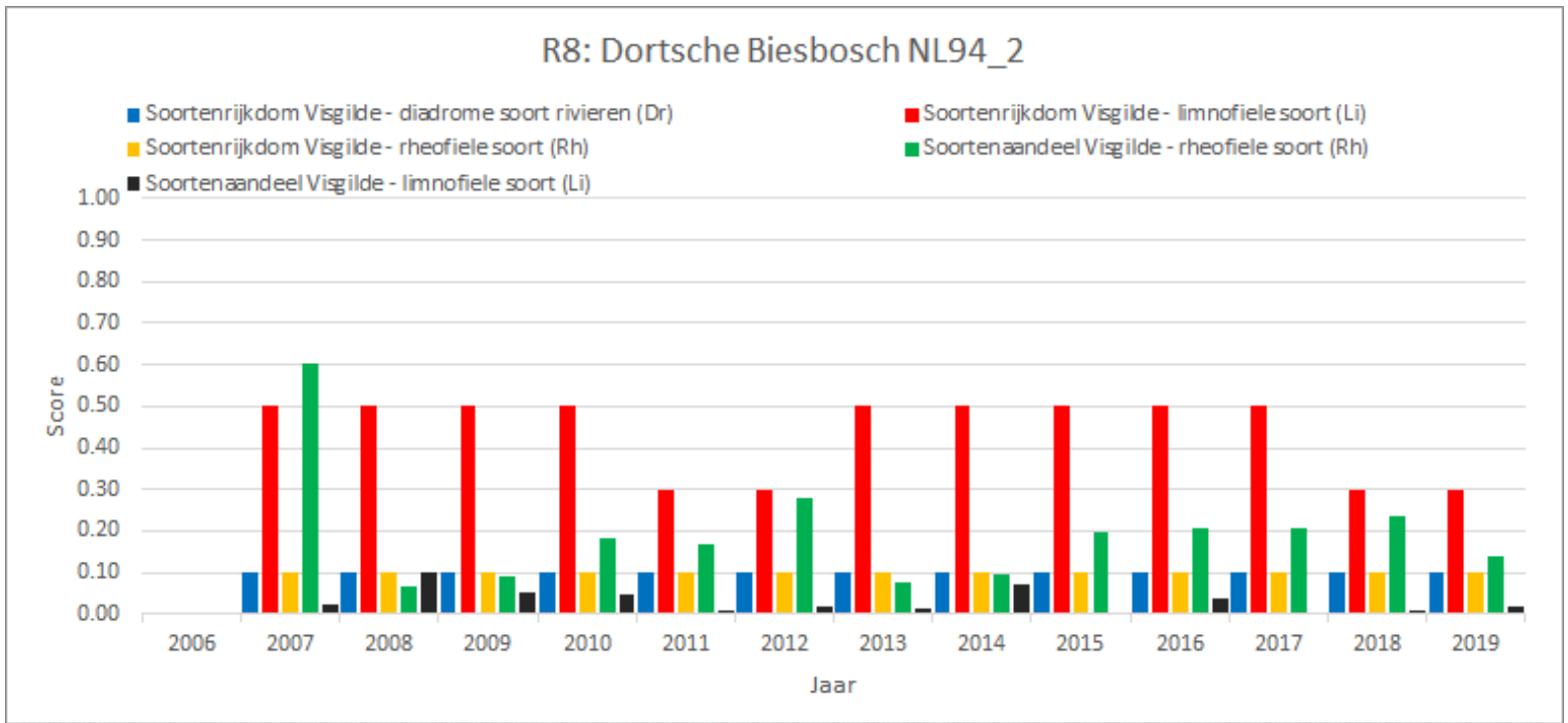

Figuur 5.9b. R8, Dortsche Biesbosch: deelscore per indicator per jaar. 


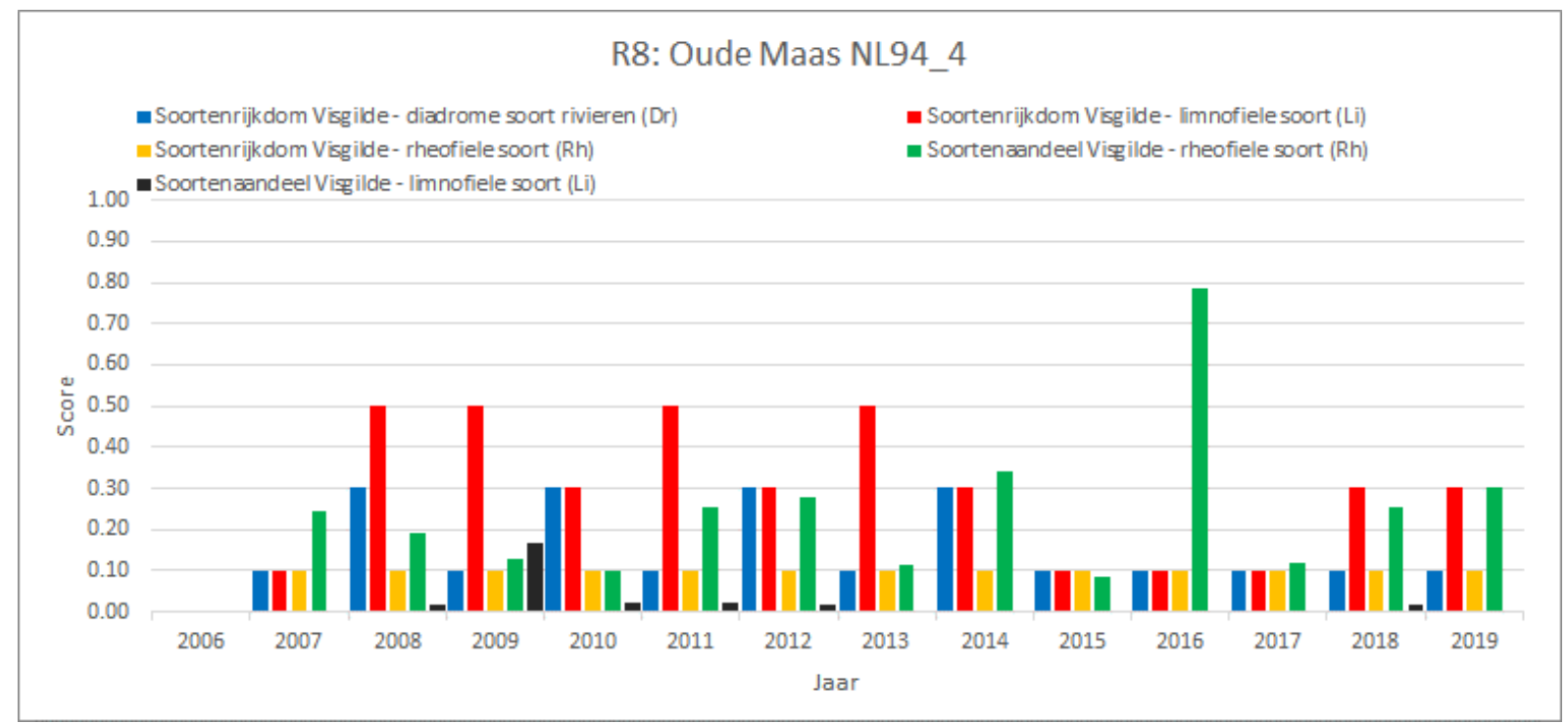

Figuur 5.9c. R8, Oude Maas: deelscore per indicator per jaar.

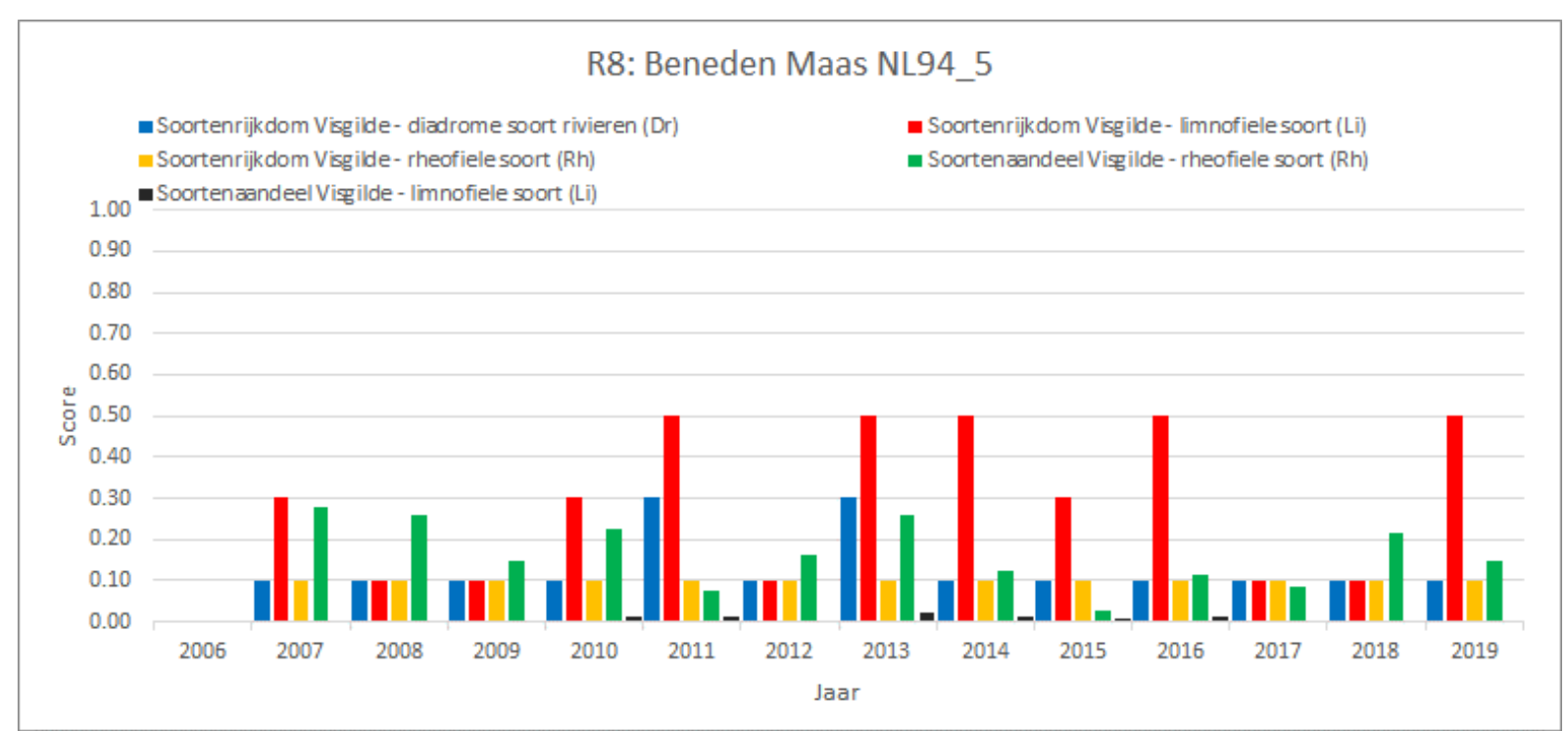

Figuur 5.9d. R8, Beneden Maas: deelscore per indicator per jaar.

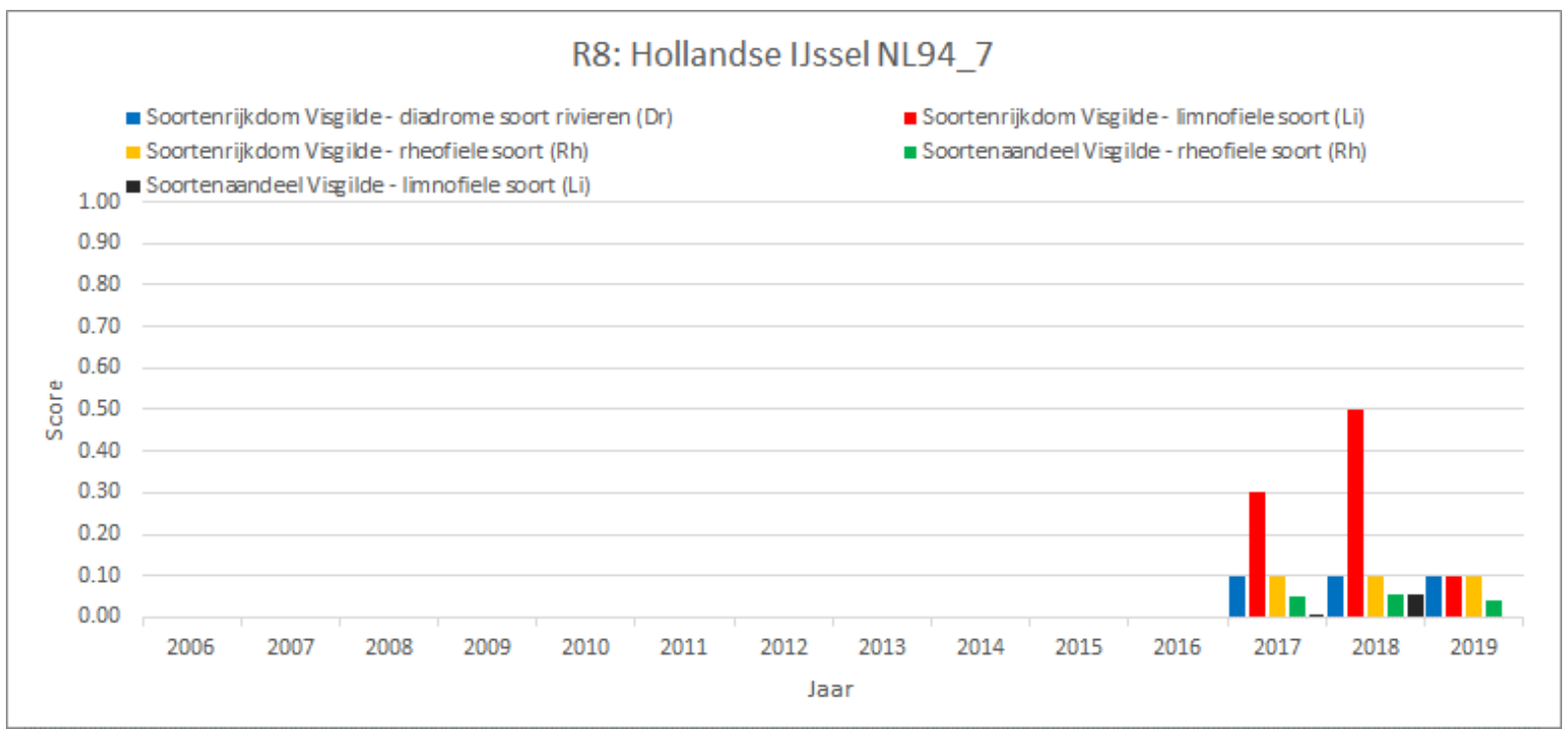

Figuur 5.9e. R8, Hollandse IJssel: deelscore per indicator per jaar. 
R8: Brabantse Biesbosch NL94_10

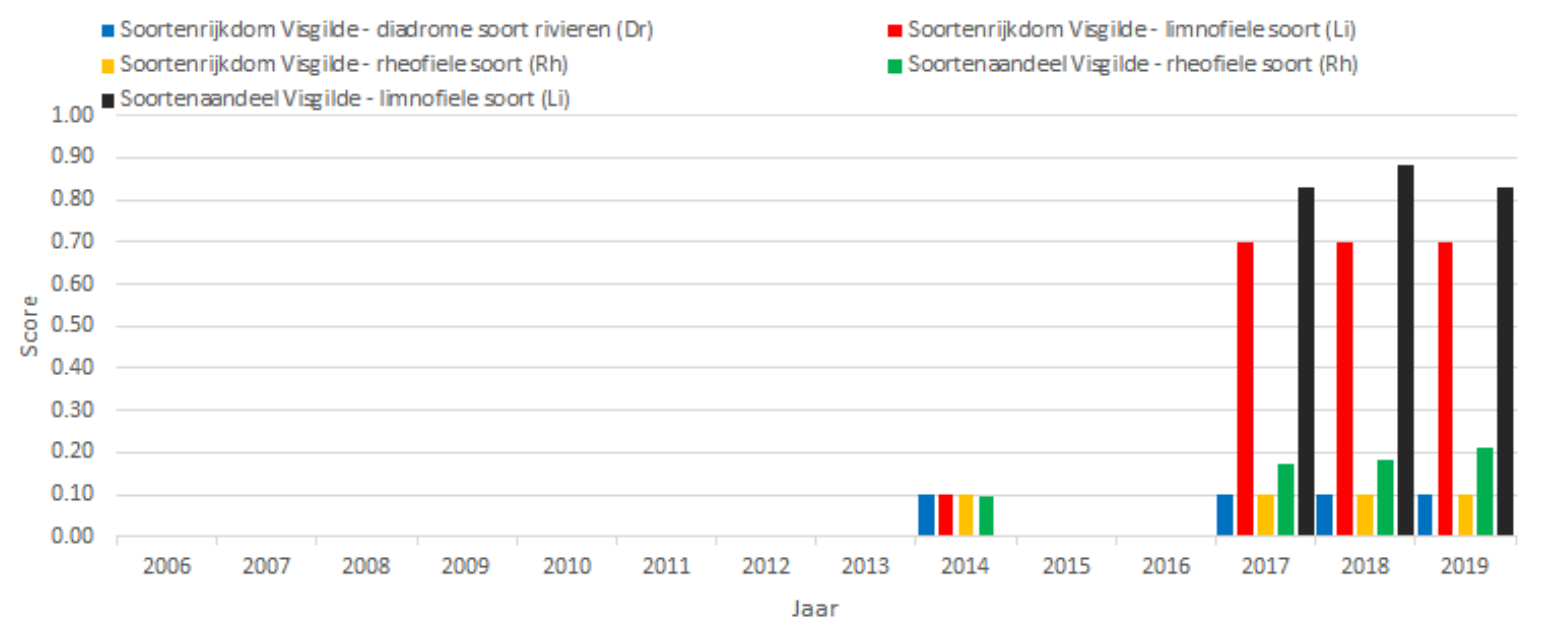

Figuur 5.9f. R8, Brabantsche Biesbosch: deelscore per indicator per jaar.
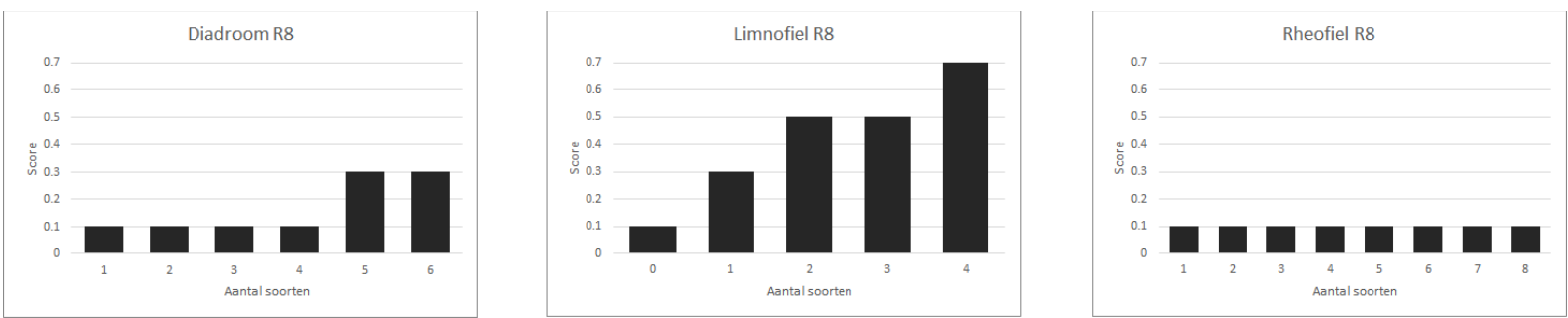

Figuur 5.10. R8: deelscore ten opzichte van het aantal soorten voor de indicator soortenrijkdom diadroom, limnofiel en rheofiel, waargenomen scores over alle gebieden en jaren van R8 samen.

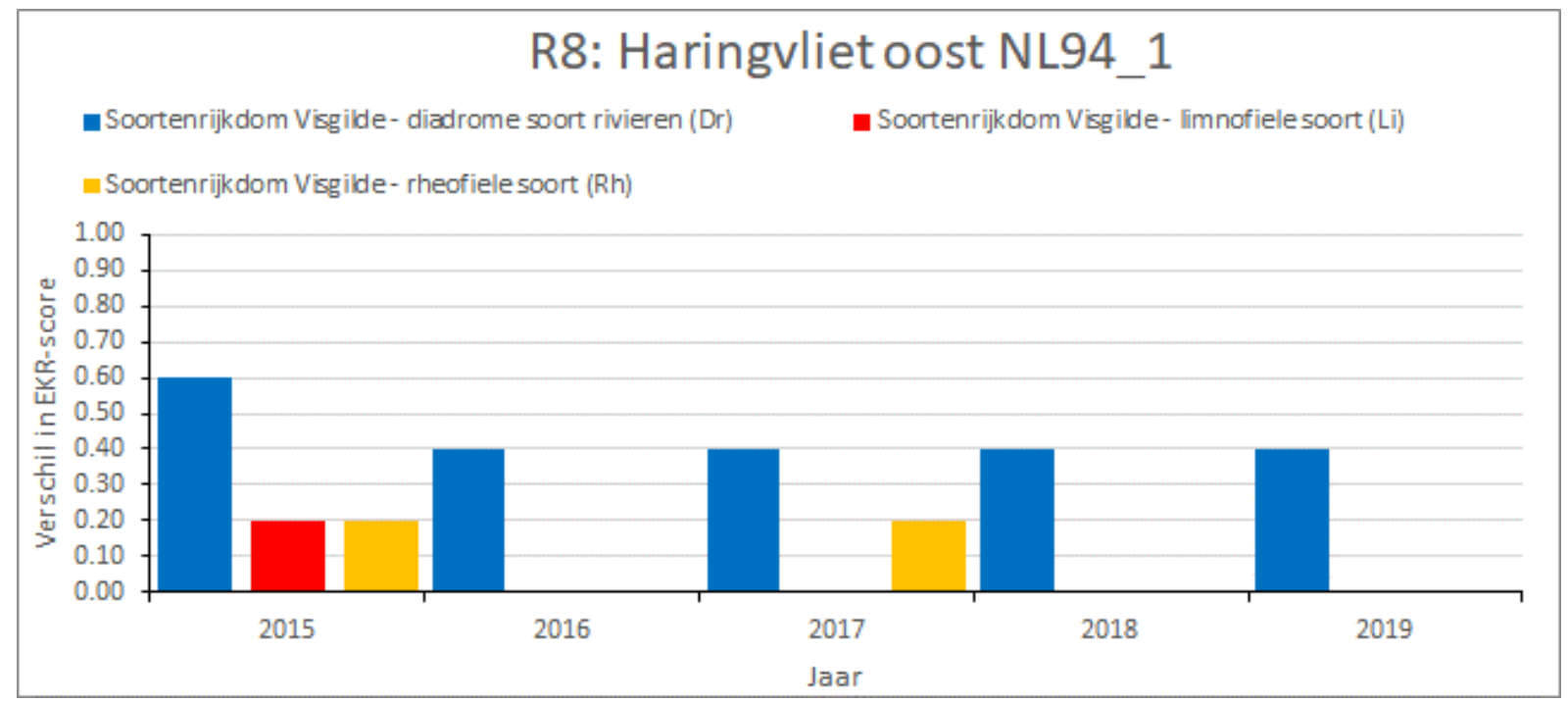

Figuur 5.11a. R8, Haringvliet oost: verschil in score per indicator soortenrijkdom, berekend met fuiken ten opzichte van zonder fuiken per jaar. 


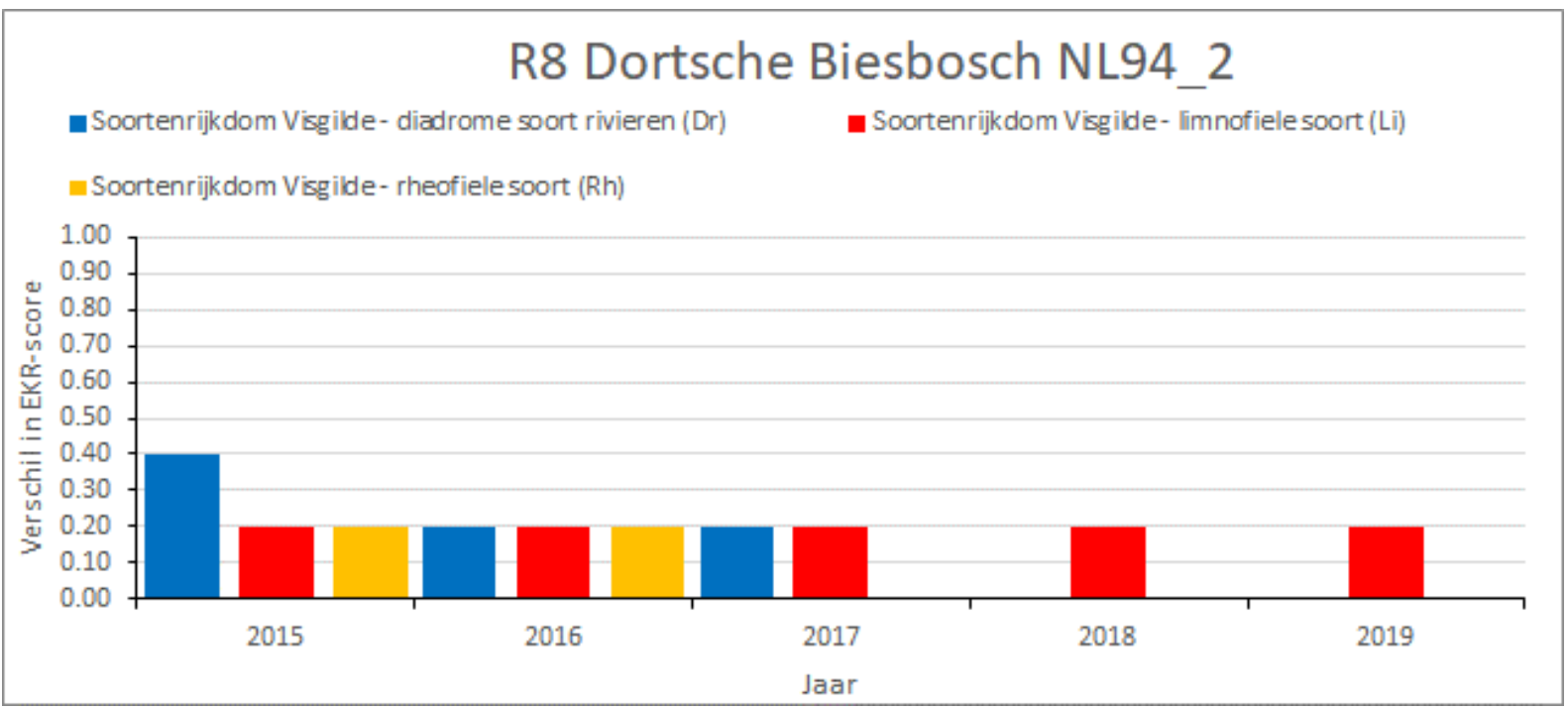

Figuur 5.11b. R8, Dortsche Biesbosch: verschil in score per indicator soortenrijkdom, berekend met fuiken ten opzichte van zonder fuiken per jaar.

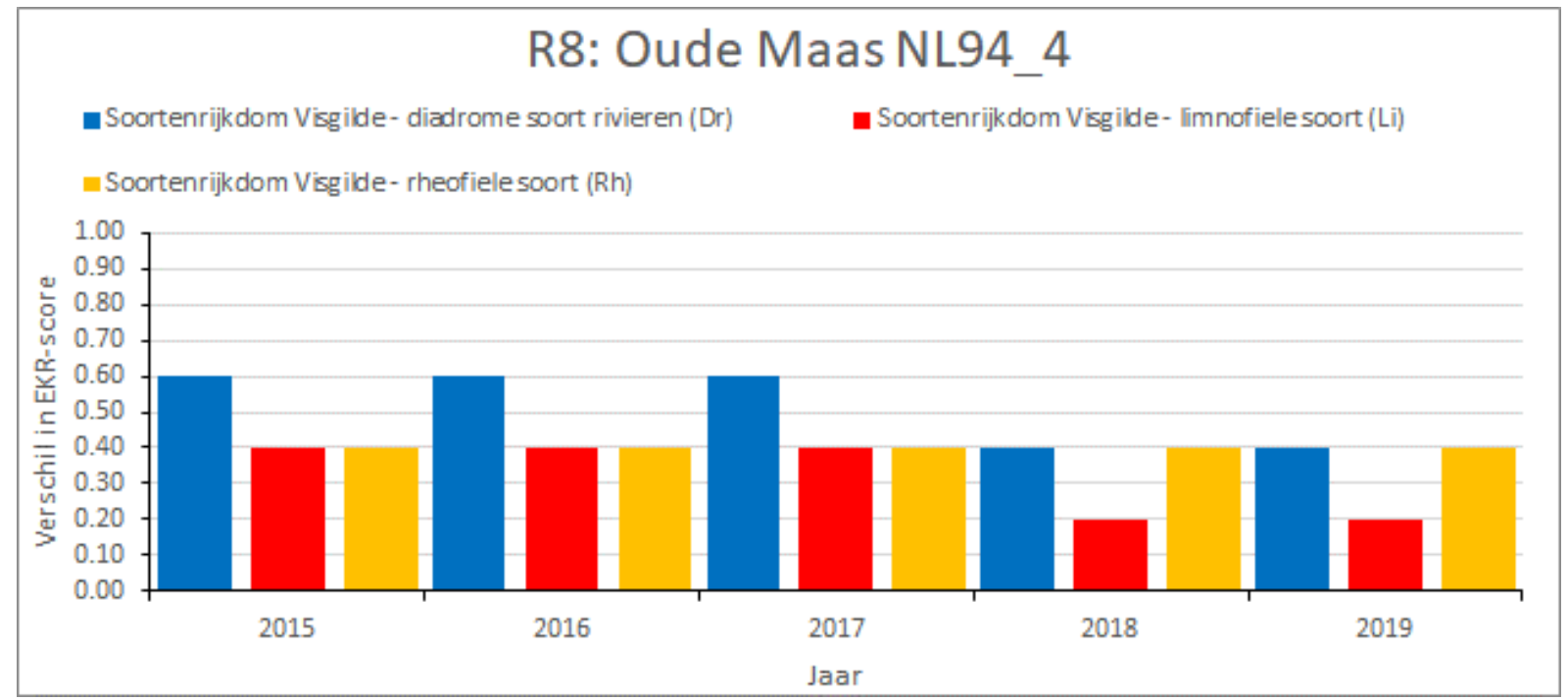

Figuur 5.11c. R8, Oude Maas: verschil in score per indicator soortenrijkdom, berekend met fuiken ten opzichte van zonder fuiken per jaar.

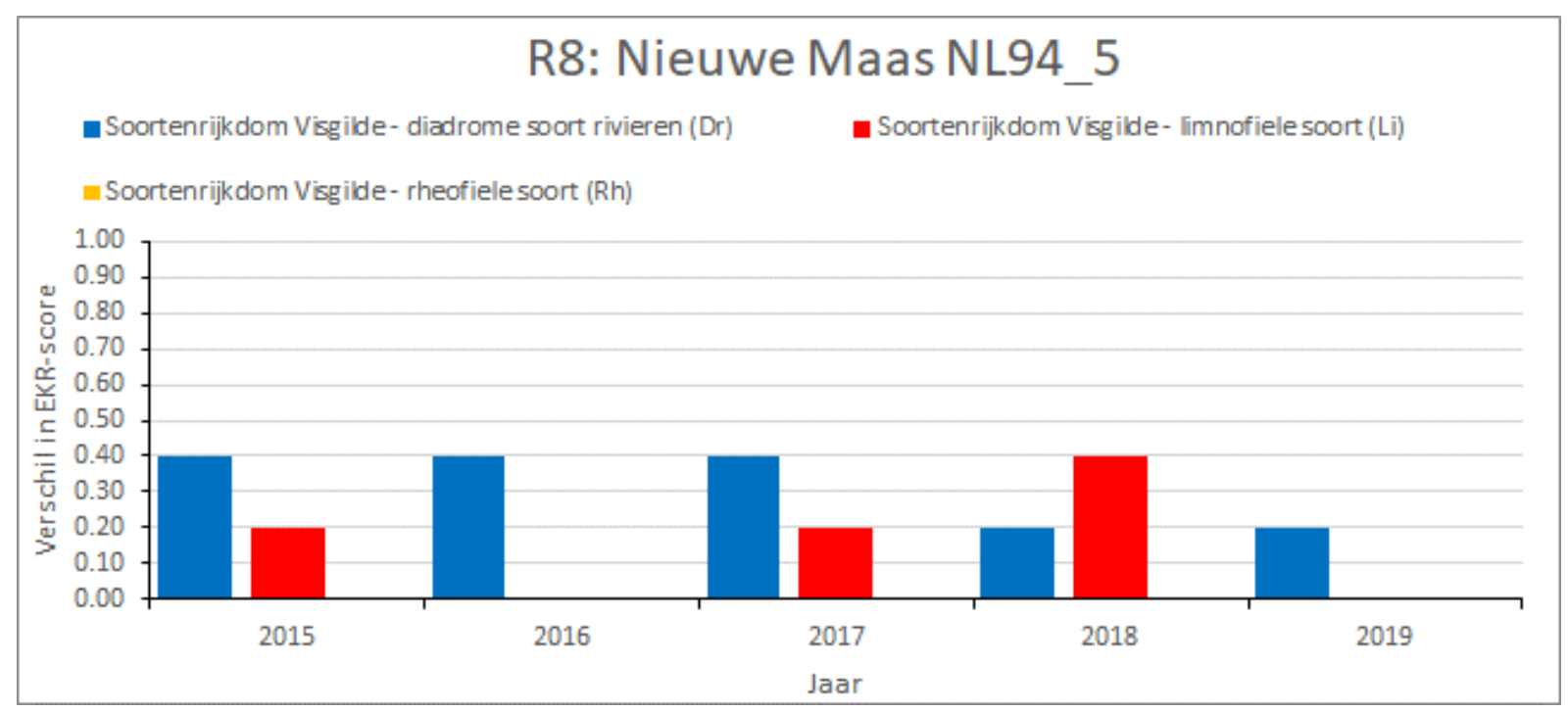

Figuur 5.11d. R8, Beneden Maas: verschil in score per indicator soortenrijkdom, berekend met fuiken ten opzichte van zonder fuiken per jaar. 


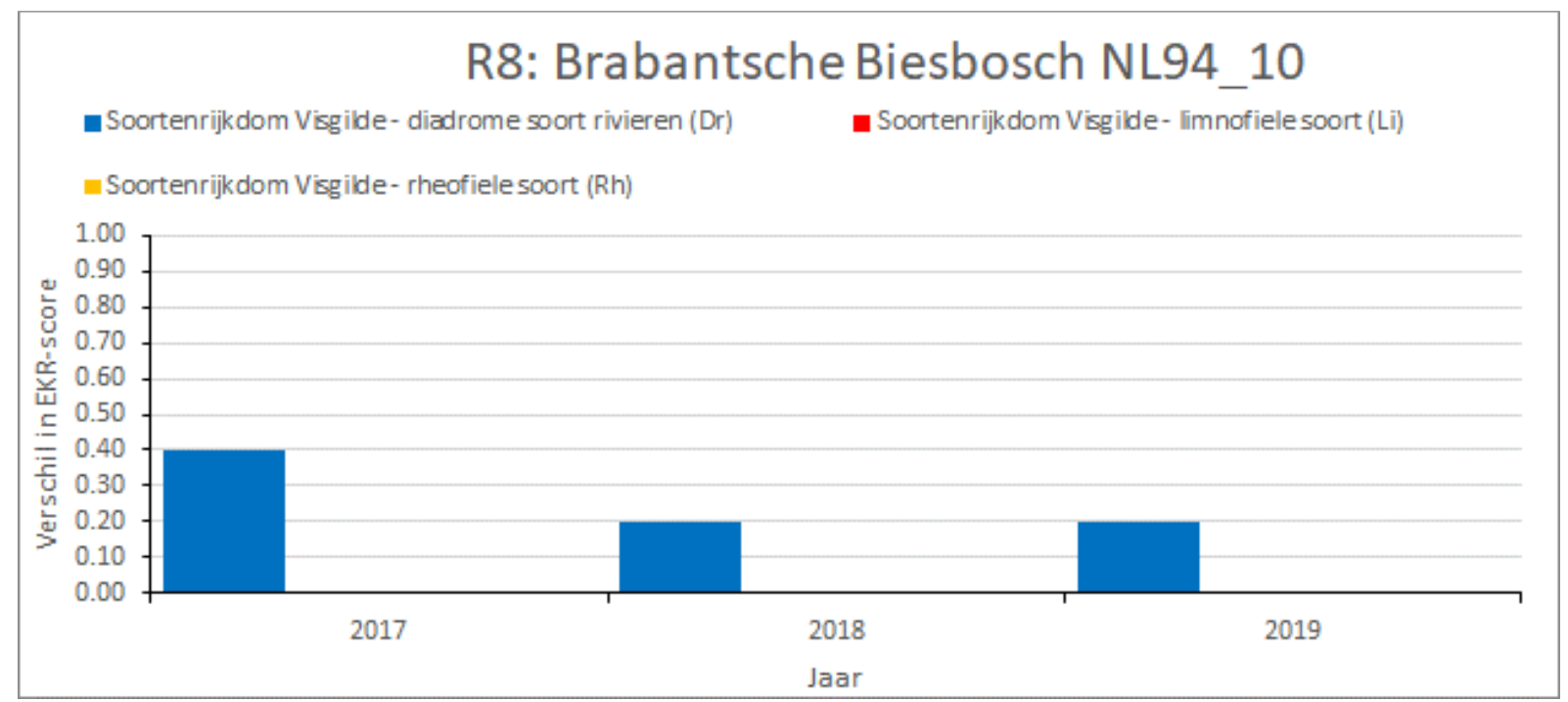

Figuur 5.11e. R8, Brabantsche Biesbosch: verschil in score per indicator soortenrijkdom, berekend met fuiken ten opzichte van zonder fuiken per jaar. 


\subsubsection{R16 deelscores}

Bij R16 (snel stromende rivier op zandbodem of grind, Figuur 5.12) de Grensmaas is in vergelijking met R7 en R8 het soortenaandeel rheofiele soorten, maar ook limnofiele soorten hoger. Daarbij bestaat wel jaarlijkse variatie in de hoogte van de deelscores, welke de uiteindelijke EKR score bepalen. Bij rheofiele vissen zijn tot 13 soorten gevangen over alle jaren, waardoor de score door deze indicator nooit boven de 0.1 (Figuur 5.13) uitgekomen is (Zie STOA 2018, Tabel 21.4A). Variatie in de EKR score tussen jaren wordt bepaald door variatie in meerdere indicatoren. Figuur 5.14 toont de verschillen in indicator scores van soortenrijkdom tussen een toetsing met fuikgegevens en een toetsing zonder fuikgegevens. Opname van fuikgegevens (Figuur 5.14) geeft een verhoging van de indicator soortenrijkdom rheofiele soorten in 2015 en limnofiele soorten in 2016-2019.

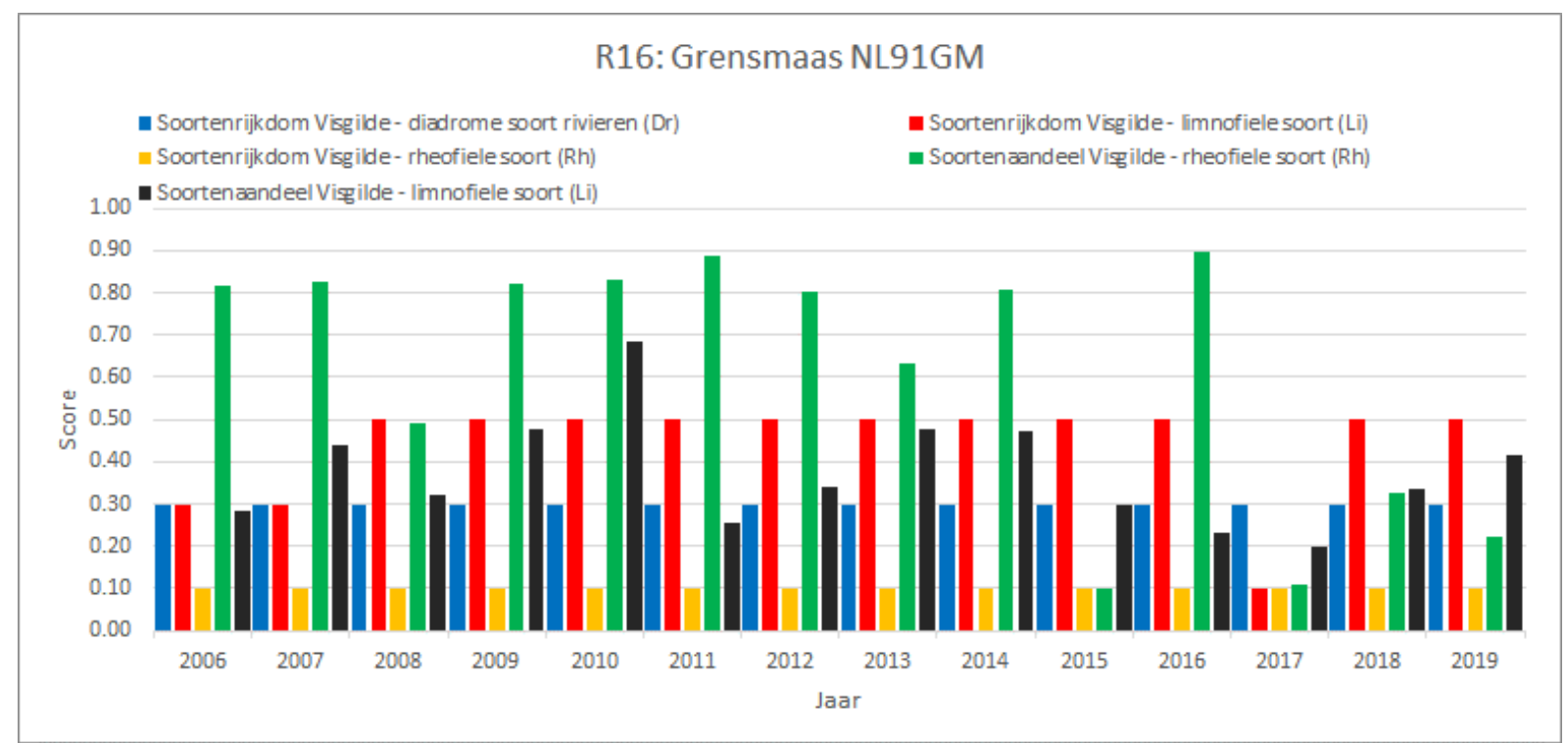

Figuur 5.12. R16, Grensmaas: deelscore per indicator per jaar.
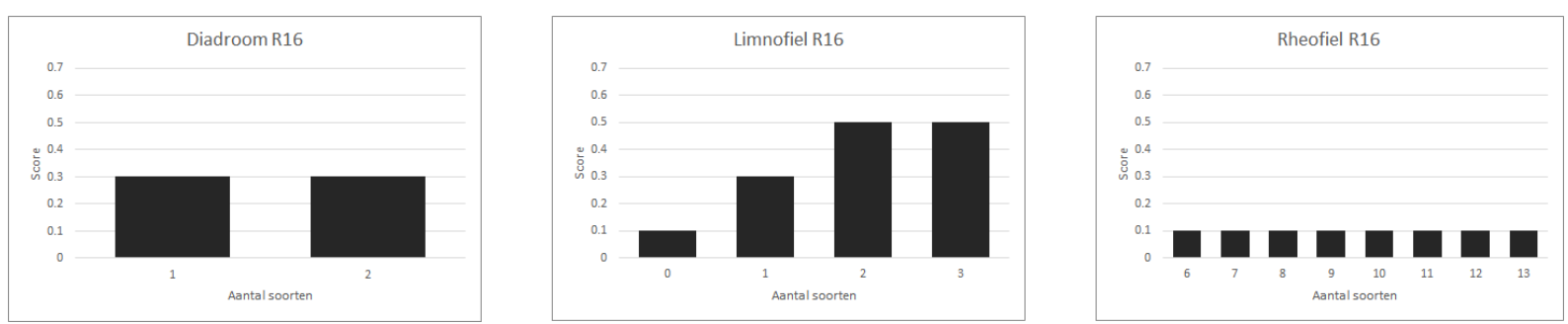

Figuur 5.13. R16: deelscore ten opzichte van het aantal soorten voor de indicator soortenrijkdom diadroom, limnofiel en rheofiel, waargenomen scores over alle jaren van R16 samen. 


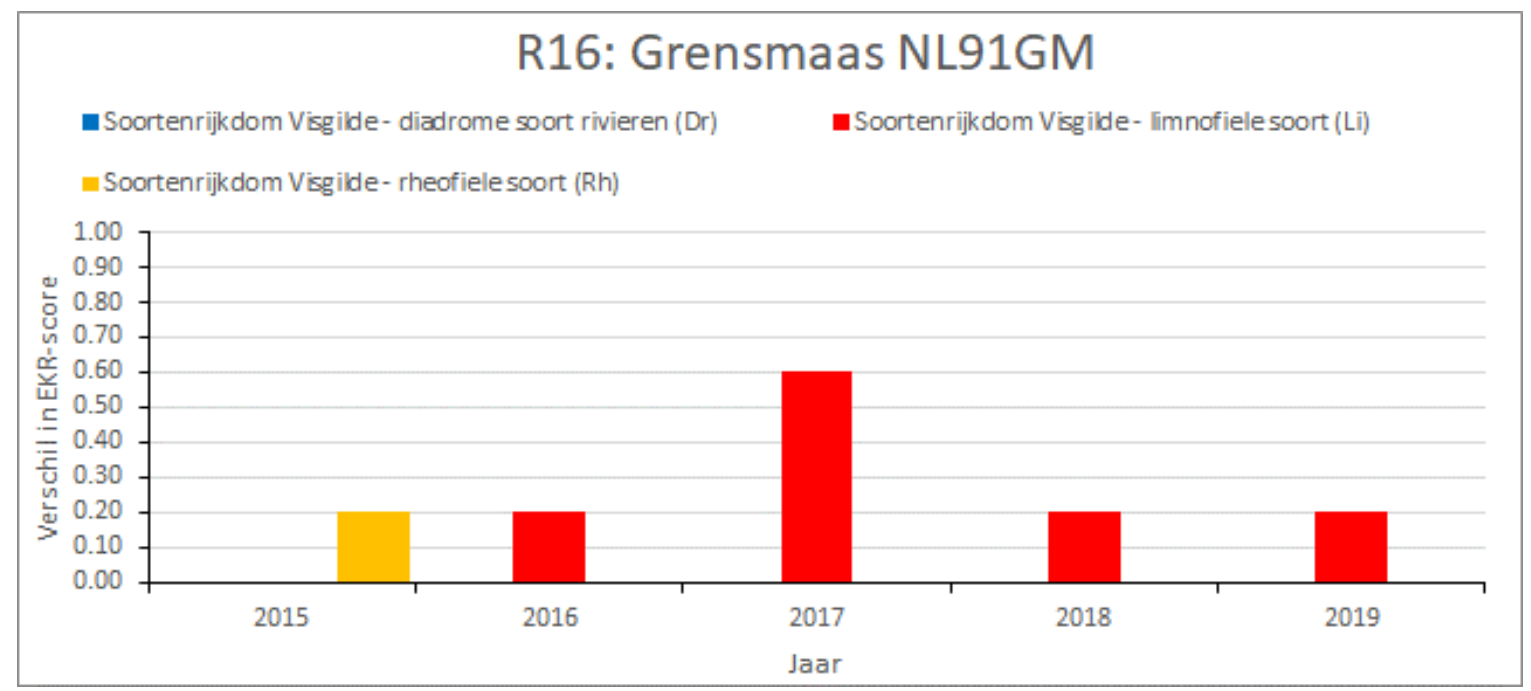

Figuur 5.14. R16, Grensmaas: verschil in score per indicator soortenrijkdom, berekend met fuiken ten opzichte van zonder fuiken per jaar. 


\subsubsection{O2b deelscores}

De variatie per jaar in O2b (overgangswateren bemonsterd met boomkor) EKR scores, welke berekend wordt inclusief fuikgegevens, komt door jaarlijkse variatie van een veelvoud van indicatoren (Figuur 5.15a-c). Voor O2a (overgangswateren bemonsterd met ankerkuil) worden deelmaatlatscores nog niet gepresenteerd, omdat de berekeningen in Aquokit afwijken van controleberekeningen in Excel.

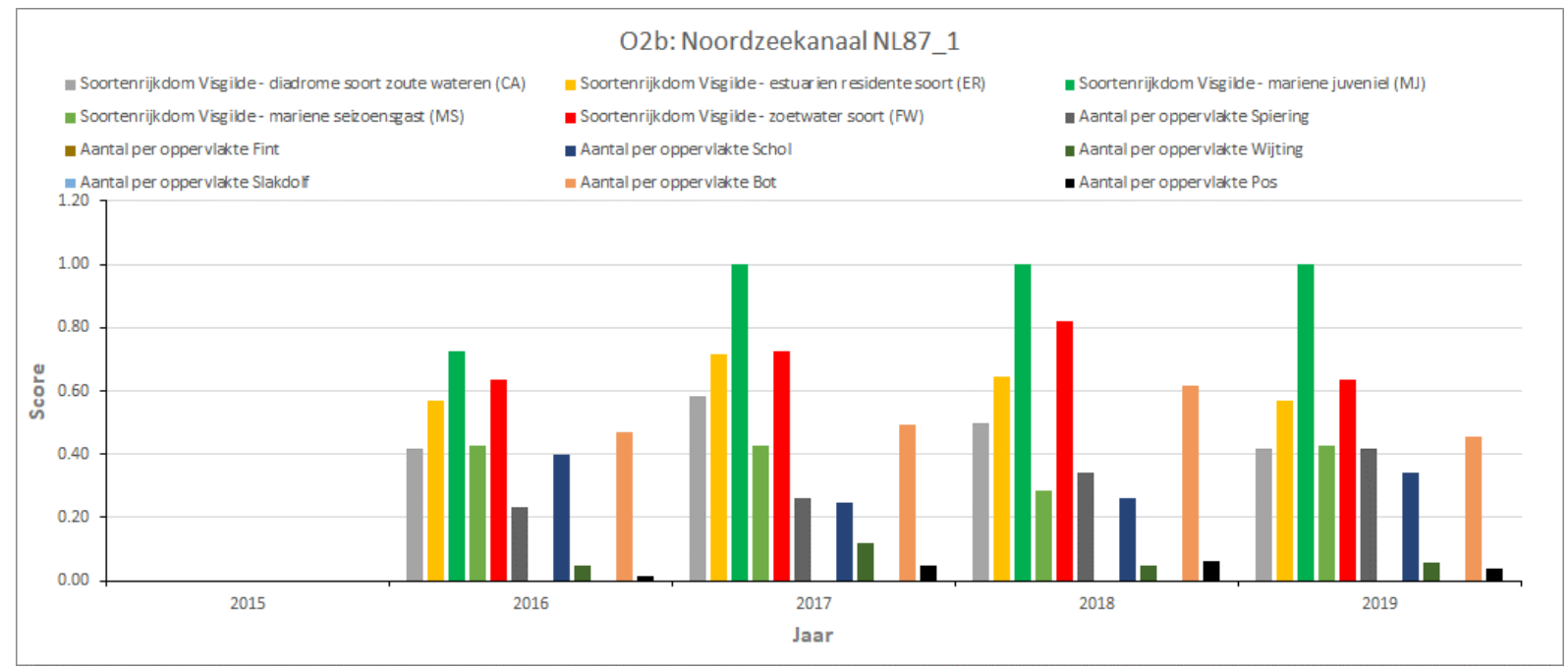

Figuur 5.15a. O2b, Noordzeekanaal: deelscore per indicator per jaar.

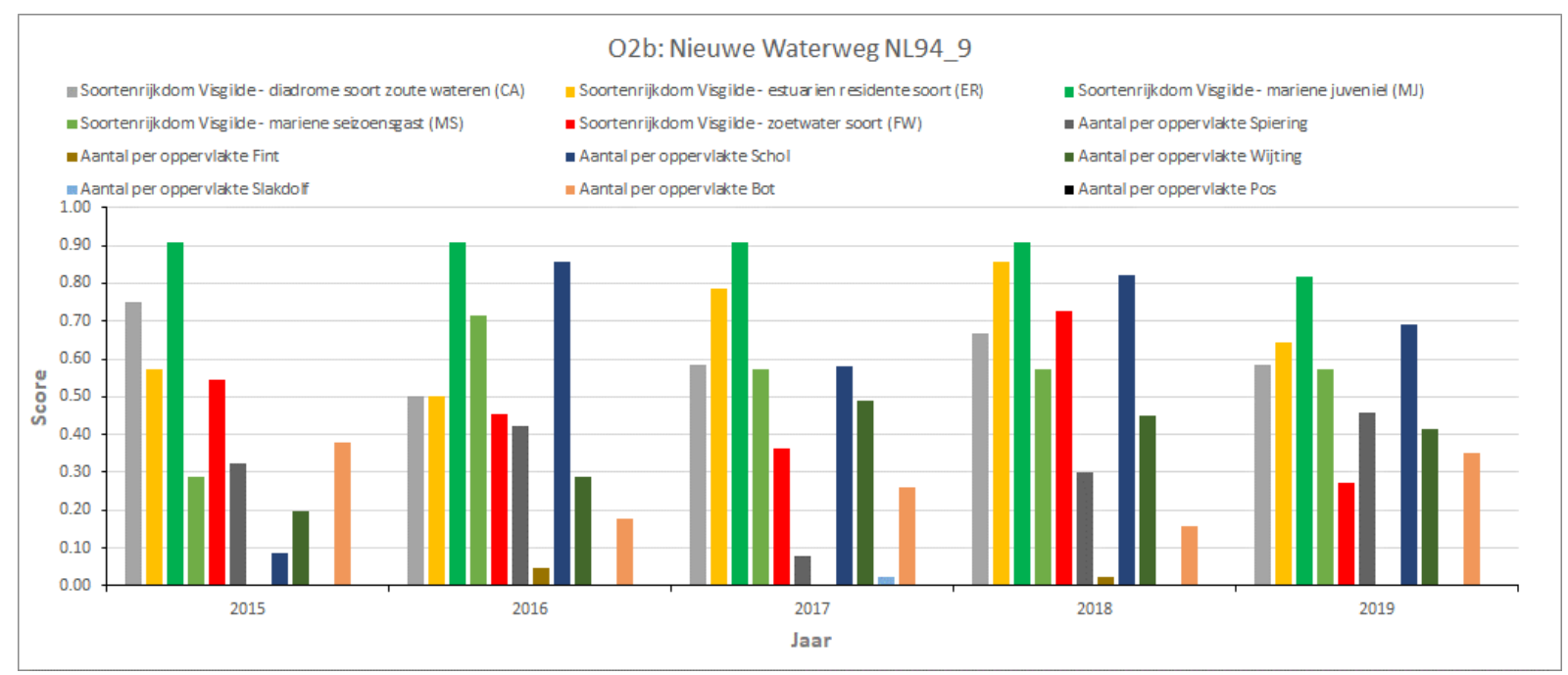

Figuur 5.15b. O2b, Nieuwe Waterweg: deelscore per indicator per jaar. 


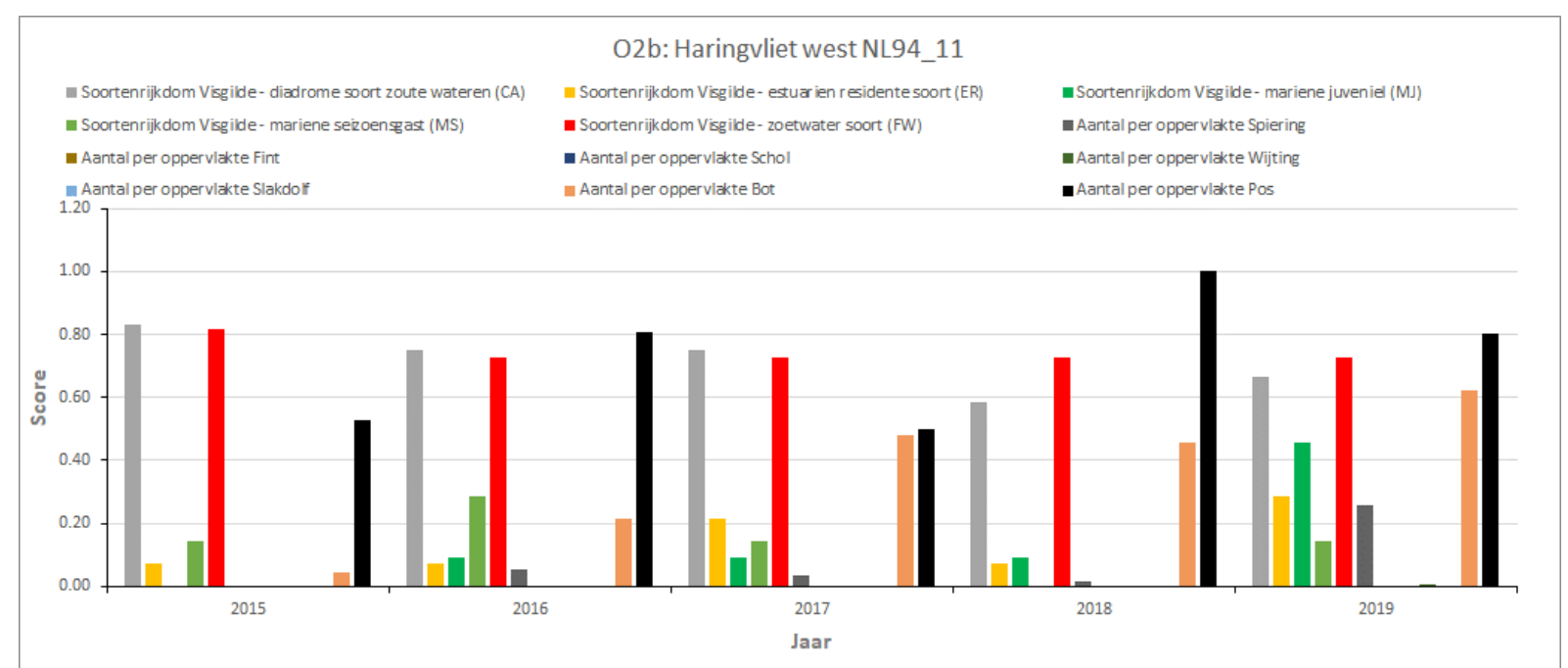

Figuur 5.15c. O2b, Haringvliet west: deelscore per indicator per jaar. 


\section{Trends in blankvoorn}

\section{$6.1 \quad$ Inleiding}

Onderstaande informatie is deels een samenvatting van het Kennisdocument blankvoorn (de Laak, 2010).

In Nederland is de blankvoorn (Rutilus rutilus) een van de meest voorkomende vissoorten in allerlei watertypen. De blankvoorn kan ook goed overleven onder minder geschikte omstandigheden, zoals een slechte zuurstofhuishouding of verontreiniging van het water. In Nederland worden in de winter grote scholen aangetroffen in havens langs het IJsselmeer, de Randmeren en de benedenrivieren. De blankvoorn komt ook algemeen voor in kleine stilstaande watersystemen, zoals polders, maar ontbreekt in snelstromende beekjes. De blankvoorn zwemt meestal in scholen, welke bestaan uit vissen van dezelfde jaarklasse. De groepen houden zich vaak op in de oeverzone (litoraal) bij waterplanten, maar ook wel op diepere delen in het open water. In het voorjaar verplaatsen de scholen met volwassen vissen zich naar de paaiplaatsen, welke zich in de oeverzone bevinden. De paai vindt in ondiepe watergedeelten plaats, in de periode begin april tot eind mei. De eieren worden over het algemeen afgezet op water- en oeverplanten, maar ook stenen of takken kunnen als paaisubstraat dienen. In stromend water vindt de afzet van eieren hoofdzakelijk op stenen plaats, maar verder komen ook overhangende vegetatie, flab en ander uitstekend materiaal in aanmerking als paaisubstraat. De blankvoorneieren en larven kunnen niet tegen brak water. Blankvoorns die leven in brakwaterzones keren dan ook terug naar de rivier om in het zoete water te paaien (volwassen blankvoorns kunnen tegen zoutgehaltes tot circa $5-6 \%$; dit is licht tot matig brak water (Rask, 1989)). Meestal wordt ieder jaar op dezelfde plaatsen gepaaid. Na de paai blijven blankvoorns in scholen bij elkaar, en in de periode oktober-november concentreert blankvoorn zich in grote scholen langs de oevers. De blankvoorn leeft in zijn eerste levensjaar voornamelijk in het ondiepe litoraal. Oudere blankvoorns komen meer voor in dieper water tot 15 meter, maar afhankelijk van de voedselsituatie, ontwijkgedrag ten opzichte van predatoren, tijdstip van de dag enz., komen zij ook wel in ondieper water voor (Persson 1983a,b).

De voedselsamenstelling van de blankvoorn verschilt per cohort vissen, per seizoen en op basis van de beschikbaarheid van het voedsel. Zoöplankton (watervlooien) kan een belangrijk deel van het voedsel vormen, vooral bij nuljarigen, maar ook bij oudere blankvoorn kan zoöplankton een groot deel va het dieet uitmaken. Bij een lage beschikbaarheid aan dierlijk voedsel schakelen volwassen vissen eenvoudig over op algen, planten en detritus. Blankvoorns beschikken over keeltanden waardoor slakken, mosselen en dood organisch materiaal ook vaak (een groot) deel van het voedselpakket uit kunnen maken van vooral grotere blankvoorns.

In de zomer is de blankvoorn voornamelijk overdag actief. In de herfst en winter wordt in de litorale zone het foerageergedrag deels verlegd naar de schemer en nacht, als reactie op een verhoogd predatierisico op het open water overdag en veranderingen in de voedselbeschikbaarheid door verandering in de lichtcondities (Hautala, 2008). In de jaren 60 en 70 van de 20e eeuw raakten veel wateren in Europa geëutrofieerd. Dit had tot gevolg dat onder andere de zichtdiepte afnam (het water werd minder helder). Verschillende auteurs beschrijven dat de blankvoornpopulatie toenam bij eutrofiëring (Goldspink, 1971; Kottelat \& Freyhof, 2007). Vaak resulteerde dit wel in groei-belemmerde ("gestunte") populaties (welke kunnen ontstaan door langzame groei van individuen, als gevolg van intraspecifieke competitie door (te) hoge blankvoorndichtheden). 


\subsubsection{Migratie}

Er is veel onderzoek verricht naar de dag-/nachtmigratie van de blankvoorn. De migratie kan verschillen tussen diverse watersystemen (diepe zandwinplassen/meren en ondiepe meren, polder, rivieren) en is afhankelijk van de hoeveelheid beschikbare beschutting (e.g. veel hout, waterplanten, oevervegetatie). In het algemeen kan gesteld worden dat de kleine blankvoorn (tot 2 jaar) zich het liefst ophoudt in ondiepe litorale zones met beschutting in de vorm van waterplanten, hout of ingroeiende oevervegetatie. Naarmate de visjes ouder worden, trekken zij 's nachts naar het open water om daar op plankton te foerageren. De grotere blankvoorns houden zich overdag het liefst op in diepere waterlagen van het open water. In de schemer en nacht trekken zij naar de ondiepere waterlagen van het open water en naar de ondiepe delen van de oever om te foerageren (Lucas \& Baras, 2001).

In het voorjaar trekken de blankvoorns naar de paaiplaatsen. In grote meren zijn dat vaak ondiepe delen met waterplanten. In rivieren voorkomende blankvoorn vertoont de meeste trekverschijnselen, vaak naar zijwateren (dit kunnen zijrivieren zijn, maar ook meestromende nevengeulen) om daar in de stromingsluwe delen te paaien. De juveniele vissen verblijven daar tot een leeftijd van 2 jaar, alvorens ze zich weer naar de rivier verplaatsen (Molls, 1999). Zijrivieren, kribvakken, beken en nevengeulen leveren zo een (potentiële) bijdrage aan de visstand op grotere rivieren, zoals de Maas (Pollux et al., 2006), mits er goede verbindingen zijn. Tijdens de migratie vormen blankvoorns grote groepen (Couch, 1867; OVB, 1988). De blankvoorn lijkt ook homing gedrag te vertonen, waarbij deze terugkeert naar de geboorteplaats om te paaien. In diverse experimenten is aangetoond dat in ieder geval een deel van de blankvoornpopulatie dit homing gedrag laat zien, alhoewel de mate van homing in deze experimenten nooit bepaald is (Goldspink, 1977). In Noorwegen werden in een meer circa 19.000 paairijpe vissen gemerkt op vijf paaiplaatsen. Na een jaar kwam ongeveer 13\% terug op dezelfde paaiplaats. Dit is een minimumschatting; met name vrouwtjes hebben door de merkmethode een verhoogde sterfte gehad. Ongeveer $14 \%$ van de paaiers werd op een andere paaiplaats gevangen (L'Abee-Lund \& Vøllestad, 1985). In België werd vastgesteld dat blankvoorns in een sterk verstuwde rivier maar 800 meter zwommen naar een paaiplaats. Indien er vrije migratie mogelijk was, werden afstanden van 8 tot 12 kilometer afgelegd naar de paaiplaatsen. De migratie kan dus sterk beperkt worden door migratiebarrières (Geeraerts et al., 2006).

\subsubsection{Bedreigingen}

\subsubsection{Parasieten en ziektes}

De blankvoorn kent vele parasieten en ziektes. De cumulatieve sterfte in de periode november tot april door deze ziekten en parasieten in Duitsland werd geschat op 20\% (Knopf et al., 2007). De wintersterfte van éénzomerige vis wordt bepaald door de conditiefactor (en deze wordt indirect weer bepaald door de temperatuur, die eventueel een voedseltekort veroorzaakt) en de infectiedruk (Knopf et al., 2007). In een onderzoek van Rückert et al. (2006) in het Kielkanaal (Noord-Duitsland) en een nabijgelegen afgesloten water, bleek dat in brasem en blankvoorn in totaal 30 soorten parasieten werden aangetroffen. Daarnaast kent de blankvoorn schimmelinfecties (zoals furunculose) en diverse bacteriëleof virusziekten. De lintworm Ligula intestinalis is de meest bekende parasiet onder de blankvoorn. Uitbraken van deze parasiet kunnen leiden tot sterftepercentages van wel $80 \%$. De uitbraak wordt meestal voorafgegaan door hoge dichtheden van vissen met een lage groeisnelheid, de zogenaamde "gestunte" populaties, die ontstaan in bijvoorbeeld geëutrofieerde wateren. Deze grote hoeveelheden kleine vis trekken visetende vogels aan (meeuwen, aalscholvers, reigers, futen), die als tussengastheer van de lintworm fungeren. De uitbraak van de ziekte en de daaraan gekoppelde sterfte leidt daarna tot een verbeterde groeisnelheid en een lagere infectiedruk (Kennedy et al., 2001).

\subsubsection{Predatoren}

De blankvoorn wordt door o.a. de vissoorten aal, fint, snoek, snoekbaars, kwabaal, forel, meerval (Froese \& Pauly, 2009) en baars (Eklöv \& Persson 1995) gegeten. Visbroed, larven en juvenielen worden ook gegeten door kreeften, de larven van bepaalde waterinsecten (libellen, glazenwassers) en 
waterkevers. Daarnaast wordt de blankvoorn gegeten door alle visetende vogels, zoals de aalscholver, reigers, futen, zaagbekken, meeuwen, sterns (bijv. visdiefjes) en de visarend.

\subsubsection{Interspecifieke competitie}

In onder andere Zweden zijn uitgebreide studies verricht naar de concurrentie tussen blankvoorn en baars. Bekend is het werk van bijvoorbeeld Persson (1983a,b), maar ook Lessmark (1983) heeft hier uitgebreid onderzoek naar gedaan. Daarnaast is meer recentelijk onderzoek gedaan naar interspecifieke competitie tussen blankvoorn, baars en de kleine marene (vergelijkbaar met spiering in de Nederlandse waterlichamen, Beier 2016). Uit deze onderzoeken blijkt dat er verschillende mechanismen zijn die een rol spelen in de concurrentie tussen de soorten. De mechanismen die concurrentie veroorzaken, verschillen tussen eutrofe en minder eutrofe systemen, diepe en ondiepe wateren, en systemen met en zonder specialistische zoöplanktivoren. De blankvoorn benut voedsel dat ook voor een bepaalde jaarklasse baars belangrijk is (zoöplankton). Hierdoor moet deze jaarklasse baars ander voedsel benutten (bijvoorbeeld bodemfauna), wat juist weer belangrijk is voor de bovenliggende jaarklasse baarzen. Hierdoor kan binnen de baarspopulatie intraspecifieke competitie om voedsel ontstaan, waardoor de baarspopulatie afneemt en mogelijk zelfs in een ander deelhabitat (tussen de waterplanten) zijn voedsel moet zoeken. Ook qua foerageertechniek is de blankvoorn mogelijk in het voordeel (Beier 2017). Een baars is een jager en pakt grote individuele prooien, die soms snel zwemmen. De blankvoorn is een soort die liever kleinere prooien pakt, die niet zo snel bewegen. De blankvoorn kan zo een populatie watervlooien (zoöplankton) begrazen, waardoor de gemiddelde lengte van de watervlooien klein blijft en er dus geen voldoende groot voedsel voor de baars overblijft in simpele watersystemen als in Noord-Zweden. De aanwezigheid van een zoöplankton specialist zoals de kleine marene in Zweden of spiering in Nederland kan er voor zorgen dat blankvoorn de pelagische zone minder gebruikt en daardoor ook een lagere totale biomassa van de soort veroorzaakt (Beier 2016). De aanwezigheid van zo een specialist kan er ook voor zorgen dat de predatie mogelijkheden van baars toenemen, zowel direct als een alternatieve prooi als indirect door veranderingen ontstaan door verschillend habitat gebruik. De concurrentie met blankvoorn kan dus grote impact hebben op de populatieopbouw en het verspreidingspatroon van baars.

\subsubsection{Invasieve exoten}

Invasieve exoten zoals de Ponto-Kaspische grondels kunnen een bedreiging voor blankvoorn vormen door predatie en interspecifieke competitie.

Het is goed mogelijk dat de blankvoorn die in ondiepe gedeeltes paait, en zijn eieren afzet op waterplanten of meer vaste substraten als stenen en beschoeiingen langs de oevers, moet concurreren met de invasieve zwartbekgrondel welke in veel KRW-lichamen sinds 2012 is toegenomen (zie hoofdstuk 2 en van Rijssel et al. 2019a). Hoewel de predatie van eieren door de zwartbekgrondel mogelijk een goede verklaring is voor de afname van blankvoorn, blijkt er uit een studie in Tsjechië dat zowel de zwartbekgrondel als de marmergrondel nauwelijks viseieren of larven opnemen in hun dieet (Vasek et al. 2014). Aan de andere kant bleek uit twee recente studies (Verstijnen et al. 2019, Juza et al. 2018) dat het dieet van de zwartbekgrondel in de Biesboschspaarbekkens grotendeels uit vlokreeften (32-59\%) maar ook voor $9-15 \%$ uit vislarven bestaat. Het is onduidelijk om welke soorten vislarven dit gaat en of dergelijke percentages een (groot) effect kunnen hebben op blankvoornpopulaties. Het zou interessant zijn het dieet van de zwartbekgrondel in andere KRW-lichamen te onderzoeken gedurende verschillende seizoenen.

Competitie voor schuil- en eiafzetplaatsen en/of voedsel en territoriaal gedrag van de invasieve grondels zouden ook van invloed kunnen zijn op de blankvoornpopulaties. Competitie voor schuil- en eiafzetplaatsen wordt door van Kessel et al. (2013) als zeer aannemelijk beschouwd voor de afname van benthische soorten zoals het bermpje. 


\subsubsection{Klimaat-/ habitatverandering}

Veranderingen in het habitat door bijvoorbeeld klimaatverandering kunnen invloed hebben op blankvoornpopulaties. De waarden van hogere temperaturen, lage zuurstofconcentraties en een hoge zuurgraad lijken echter extreem te moeten zijn voordat er een (groot) direct effect is op blankvoornpopulaties (zie onder). Hierbij moet wel vermeld worden dat over indirecte (grote) effecten nog weinig bekend is.

De blankvoorn komt in grote delen van Europa voor in zowel relatief koude $\left(2^{\circ} \mathrm{C}\right)$ als warme wateren $\left(30^{\circ} \mathrm{C}\right)$ (Froese \& Pauly, 2009). Embryo's hebben een goede ontwikkeling bij temperaturen van 11,5 $20^{\circ} \mathrm{C}$. Bij temperaturen boven de $20^{\circ} \mathrm{C}$ neemt het aantal eieren dat uitkomt af en er is een toename in het aantal abnormaliteiten van larven bij temperaturen boven de $16^{\circ} \mathrm{C}$ (Alabaster en Lloyd, 1982). In Nederland start de paai bij een temperatuur van $14{ }^{\circ} \mathrm{C}$ (Goldspink, 1971).

Blankvoorn heeft een hoge tolerantie voor lage zuurstofgehaltes. Zuurstofgehaltes lager dan $1 \mathrm{mg} \mathrm{O} / \mathrm{l}$ bij $24^{\circ} \mathrm{C}$ worden echter vermeden, en er treedt sterfte op bij een zuurstofconcentratie van $0,82 \mathrm{mg} / \mathrm{l} \mathrm{bij}$ $30^{\circ} \mathrm{C}$ (Alabaster en Robertson, 1961). Zuurstofgehaltes van 5-6 mg/l lijken te worden geprefereerd.

Bij een lagere $\mathrm{pH}$ heeft de baars een competitief voordeel ten opzichte van de blankvoorn (Persson, 1982). In een verzuurd meer herstelde de baarspopulatie zich sneller dan de blankvoornpopulatie in een periode dat de $\mathrm{pH}$ waarde omhoog werd gebracht door bekalking. Dit is een indicatie dat baars beter tegen een lagere $\mathrm{pH}$ waarde kan dan blankvoorn, hoewel ook aspecten als competitie het herstel van de blankvoornpopulatie kunnen verhinderen (Tammi et al., 2004). Bij een pH-waarde lager dan 5,5 vindt geen reproductie plaats (Svärdson, 1976). Adulte blankvoorns vermijden een pH-waarde lager dan 5,6, en de levensvatbaarheid van eieren daalt als de pH-waarde lager dan 5,5 is (Alabaster en Lloyd, 1982). Binnen de bandbreedte van 5,6-10,5 lijkt blankvoorn geen voorkeur te hebben (Alabaster en Lloyd, 1982). De meeste KRW-lichamen in Nederland hebben een pH waarde van 7-8 en komen dus niet in de buurt van waardes van 5,5 en lager.

\subsubsection{Beroepsvisserij}

In Nederland wordt (en werd) blankvoorn beroepsmatig gevangen met fuiken, staandwant en zegens. Vroeger werd blankvoorn in Nederland nog wel gegeten, maar de vangsten van blankvoorn door de beroepsvisserij zijn sinds enkele tientallen jaren gericht op het leveren van pootvis en consumptievis voor andere landen. Veel op het IJsselmeer gevangen blankvoorn wordt gedroogd en naar Rusland geëxporteerd (Buijs 2009). Door de fuikvisserij op aal op het IJsselmeer werden jaarlijks vele duizenden juveniele blankvoorns bijgevangen, waarvan een aanzienlijk deel de vangst niet overleefde (Deerenberg \& van Willigen, 2004). Er wordt in Nederland geen centrale registratie van de blankvoornvangsten bijgehouden door de beroepsvisserij (behalve het IJsselmeer).

\subsubsection{Waterkrachtcentrales en koelwaterinlaten}

Voor de bouw van waterkrachtcentrales (WKC's) is de bouw van een stuw noodzakelijk om de turbines van de WKC geleidelijk, en ook in perioden van droogtes, van water te voorzien. Hierdoor verliest de rivier zowel bovenstrooms als benedenstrooms veel van haar natuurlijke dynamiek en diversiteit. Daarnaast raken veel vissen beschadigd in de turbines van de WKC. De mate van beschadiging hangt af van het type turbine, het verval (hoogte) door de turbine, het toerental van de turbine en de grootte van de vis. Bij de WKC Linne in de Maas zijn uitgebreide proeven gedaan om de schade aan vis als gevolg van passage door de turbines te bepalen. De schade bij blankvoorn door de horizontale Kaplanturbine is bij verschillende debieten in het voor- en najaar vastgesteld. De schade in het voorjaar was het geringst: $2,8 \%$ directe sterfte in de klasse $10-20 \mathrm{~cm}$ en $3,8 \%$ sterfte bij de klasse $>20 \mathrm{~cm}$. In het najaar waren de schadepercentages respectievelijk 2,9 en $10,8 \%$. Het betreft directe sterfte door doorsnijdingen en ernstig letsel dat direct de dood tot gevolg heeft (Bakker \& Gerritsen, 1992). Aan de uitgestelde sterfte (sterfte na een bepaalde tijd, door bijvoorbeeld inwendige bloedingen of beschadigingen aan de slijmhuid) is in dit onderzoek geen aandacht besteed. Evenmin is gekeken naar de effecten van schade door roofvissen en vogels, die op beschadigde maar ook gezonde vissen jagen, waarbij deze laatste in de 
wateruitlaat de oriëntatie verliezen en een gemakkelijke prooi zijn. Meerdere WKC's in een rivier op korte afstand van elkaar kunnen sterke negatieve effecten hebben op de totale populatie. In het algemeen kan gesteld worden dat de sterfte in één WKC afhankelijk is van: (1) het verval; (2) het toerental van de turbine; (3) het type turbine (Francis, vijzel of Kaplan zijn bekende typen); (4) de vissoort en (5) de lengte van de vissen (in het algemeen geldt: hoe langer de vis, hoe meer schade).

Bij polders wordt het water naar hoger gelegen boezemwateren gepompt via gemalen. Door STOWA is er onderzoek verricht naar de schade aan vis bij diverse typen gemalen in Nederland (STOWA 2012). Hieruit bleek dat er voornamelijk veel juveniele $(<15 \mathrm{~cm}$ ) cypriniden (waar blankvoorn onder valt) de gemalen passeren. Bij slechts vier van de 26 gemalen werden meer dan 100 cypriniden $>15 \mathrm{~cm}$ gevangen. De sterftepercentages bij deze laatste groep variëren per gemaal en per schroef tussen de 0 en $90 \%$. Voor de groep cypriniden $<15 \mathrm{~cm}$ (qua de grootste groep die het gemaal passeert) liggen de sterfte percentages tussen de 0 en $80 \%$, met de meeste percentages onder de $25 \%$. Percentages van vissen met lichte verwondingen varieerden bij de cypriniden $>15 \mathrm{~cm}$ van 0 tot $100 \%$ en die van zware verwondingen van 0 tot $85 \%$. Voor cypriniden $<15 \mathrm{~cm}$ lagen de percentages van vissen met lichte verwondingen tussen de 0 en $10 \%$ en de percentages van vissen met zware verwondingen tussen de 0 en $80 \%$. Dus vooral de percentages van vissen met lichte verwondingen liggen hoger voor grotere cypriniden dan voor kleinere cypriniden. Verder lijkt er ook nog een aanzienlijk effect te zijn van uitgestelde sterfte bij cypriniden $<15 \mathrm{~cm}$, met percentages variërend tussen 0 en $100 \%$. Bij cypriniden $>15 \mathrm{~cm}$ waren deze percentages opvallend genoeg $0 \%$, hoewel dit maar bij drie gemalen getest is. Voor de meeste gemalen geldt dan wel weer dat de directe vissterfte hoger is bij grotere cypriniden dan bij kleinere.

In het drinkwaterspaarbekken de Gijster (in de Biesbosch) wordt water uit de Maas ingelaten voor de bereiding van drinkwater. Door middel van driftnetten werden tussen 8 mei en 18 juni 1996 meer dan 12.000 vislarven gevangen. Omgerekend naar het aantal kubieke meters water wat in die periode werd ingelaten, betekent dit dat er in deze periode 45,3 miljoen vislarven (snoekbaars $36 \%$, baars $12 \%$, brasem $28 \%$, blankvoorn $24 \%$ ) in dit spaarbekken zijn terechtgekomen (Ketelaars, 1998). Zolang niet al het water uit een rivier door de drinkwaterbekkens gaat, hoeft de inzuiging van vissen geen probleem op populatieniveau te vormen. 


\subsection{Blankvoorn trends per KRW-lichaam}

Uit voorgaande rapportages is gebleken dat er sinds 2010-2012 een sterke achteruitgang is van de cypriniden (brasem, kolblei, blankvoorn) in de Rijkswateren (e.g. van Rijssel et al. 2019a). Om meer inzicht in deze achteruitgang te krijgen wordt er in dit hoofdstuk naar de trends van blankvoorn per KRW-lichaam gekeken. Daarnaast wordt er ook per KRW-lichaam naar de lengte-frequentieverdelingen van blankvoorn door de jaren heen gekeken, om te zien of de afname voornamelijk in bepaalde jaarklassen (cohorts) voorkomt. Hiervoor zijn dezelfde gegevens gebruikt als in hoofdstuk 2 .

In dit hoofdstuk zal per KRW-lichaam de trend van blankvoorn getoond en besproken worden. Hierbij zullen ook de lengte-frequentie verdelingen worden gebruikt, om patronen van cohorts duidelijker te maken. Voor sommige waterlichamen waarin zowel in het voorjaar als in het najaar wordt bemonsterd de gegevens van het najaar van 2019 weergegeven als die van 2020 (net als in hoofdstuk 2) en bevatten dus nog niet de gegevens van het voorjaar van 2020 en worden daarom dus alleen getoond en niet besproken.

De toekenning van de leeftijd en het levensstadium in de grafieken zijn gebaseerd op de marktbemonstering (monitoring waarbij de vangsten van vissers worden bemonsterd) van blankvoorn op het IJssel-/Markermeer. Hierbij wordt de geslachtsrijpheid van blankvoorn bepaald aan de hand van de gonaden, en de leeftijd aan de hand van seizoens-/jaarringen die gevormd worden in de otolieten (gehoorsteentjes). Aan de hand van de lengte-leeftijdsleutel en de schattingen van het paaibestand (Tien \& Van der Hammen 2019) is de leeftijd en het levensstadium gekoppeld aan de lengtes van de vissen. Deze leeftijdsindeling is vrij grof en kan afwijken van de werkelijke leeftijdsindeling en is daarom puur ter indicatie hoe de vangsten zijn samengesteld. Aangezien we voor de overige KRW-waterlichamen geen leeftijd en geslachtsrijpheid gegevens hebben, zijn voor deze KRW-lichamen de leeftijden en levensstadia ook op bovenstaande gegevens gebaseerd. Dit betekent wel dat voor deze KRW-lichamen de werkelijke leeftijden en levensstadia van blankvoorn kunnen afwijken. 


\subsection{IJsselmeer}

\subsubsection{Open water}

Sinds het begin van de monitoringsreeks vanaf 1989 lijken de blankvoornvangsten met zowel de boomkor als de elektrokor af te nemen (Figuur 6.1), tot een opleving van 2003-2008 die voornamelijk uit juvenielen bestaat. Hierna zet de afname verder door, met fluctuaties tussen de jaren. Wat opvalt aan deze afname is dat er in de jaren '90 van de vorige eeuw meer oudere (en dus grotere) exemplaren werden gevangen en dat voornamelijk de afname in aantallen van deze oudere exemplaren zorgt voor de neerwaartse trend. Dit is ook te zien in de afname in biomassa; waar deze voorheen grotendeels bestond uit oudere exemplaren bestaat de biomassa de laatste paar jaar soms wel voor $50 \%$ uit juvenielen. De opleving van 2003-2008 is ook terug te zien in de aanlandingen van blankvoorn gevangen op het IJssel/Markermeer (Figuur 2.10). In de jaren 2017 en 2018 werd er in het open water van het IJssel/Markermeer relatief veel grote blankvoorn gevangen in vergelijking met de jaren daarvoor, terwijl de aanwas van 0-jarige vis in 2017 zeer laag was (Tien \& van der Hammen 2019). In 2019 is het relatieve aandeel grote blankvoorn weer lager terwijl het aandeel juvenielen weer hoger ligt.

\subsubsection{Oever}

Sinds het begin van de oeverbemonstering in 2007 lijken de aantallen en biomassa van blankvoorn relatief stabiel, waarbij de aantallen zowel langs de stenen en rietoevers (schepnet) als langs de zandoevers (zegen) gedomineerd worden door juvenielen (Figuur 6.2). De biomassa werd tot 2012 grotendeels bepaald door de oudere exemplaren, maar vanaf 2012 zijn de het ook de juvenielen die de biomassa bepalen. In 2016-2018 namen de vangsten langs alle oevers toe, maar in 2019 waren de vangsten overal weer zeer laag. 


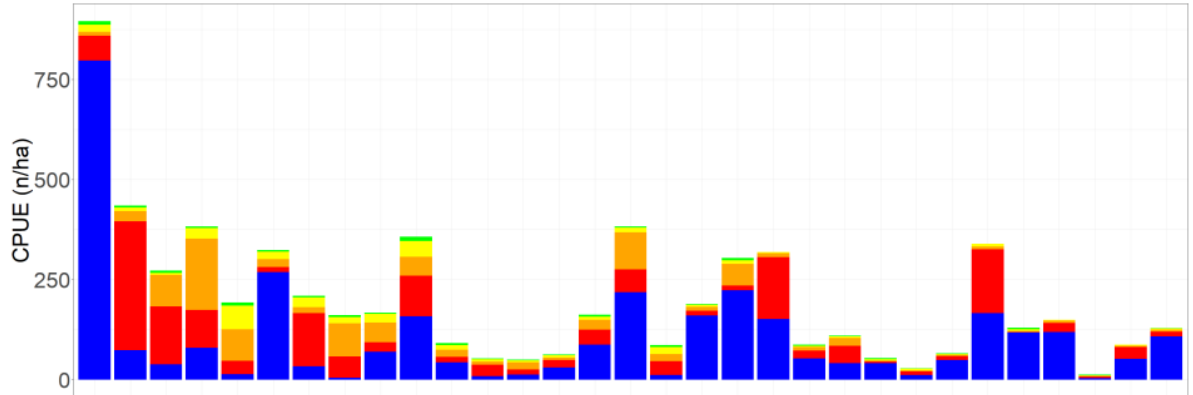

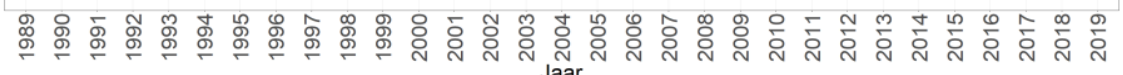
25-40 (4+-jarigen)

10-15 (1-jarigen mogelijk geslachtsrijp)

0-10 (0-jarigen)

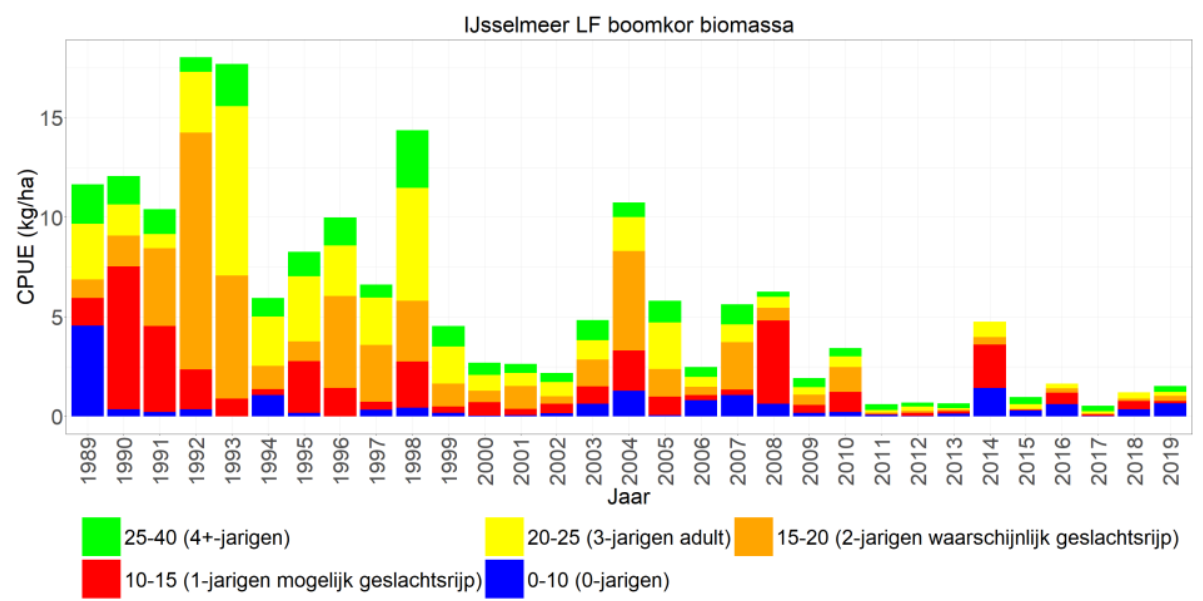

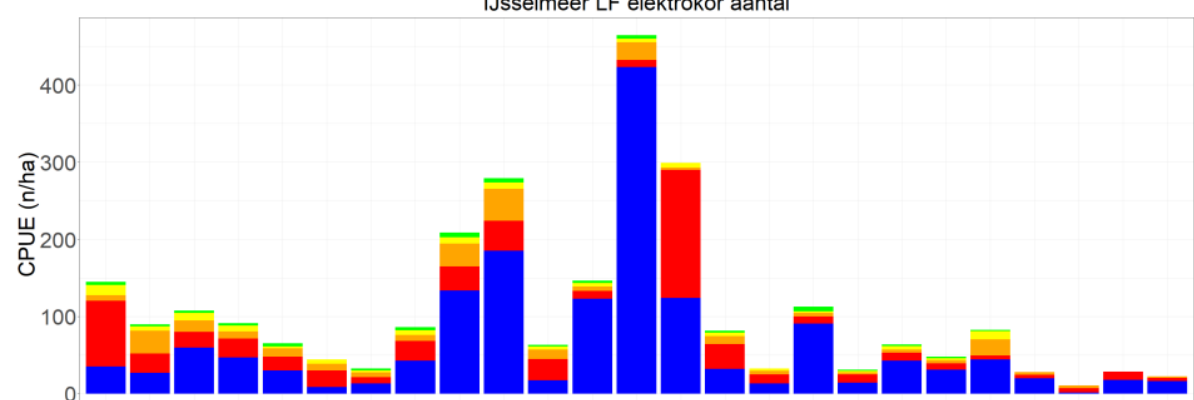

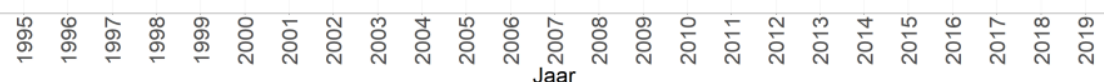

25-40 (4+-jarigen)

(3-jarigen adult) $\quad$ 15-20 (2-jarigen waarschijnlijk geslachtsrijp)

10-15 (1-jarigen mogelijk geslachtsrijp) $\square$ 0-10 (0-jarigen)

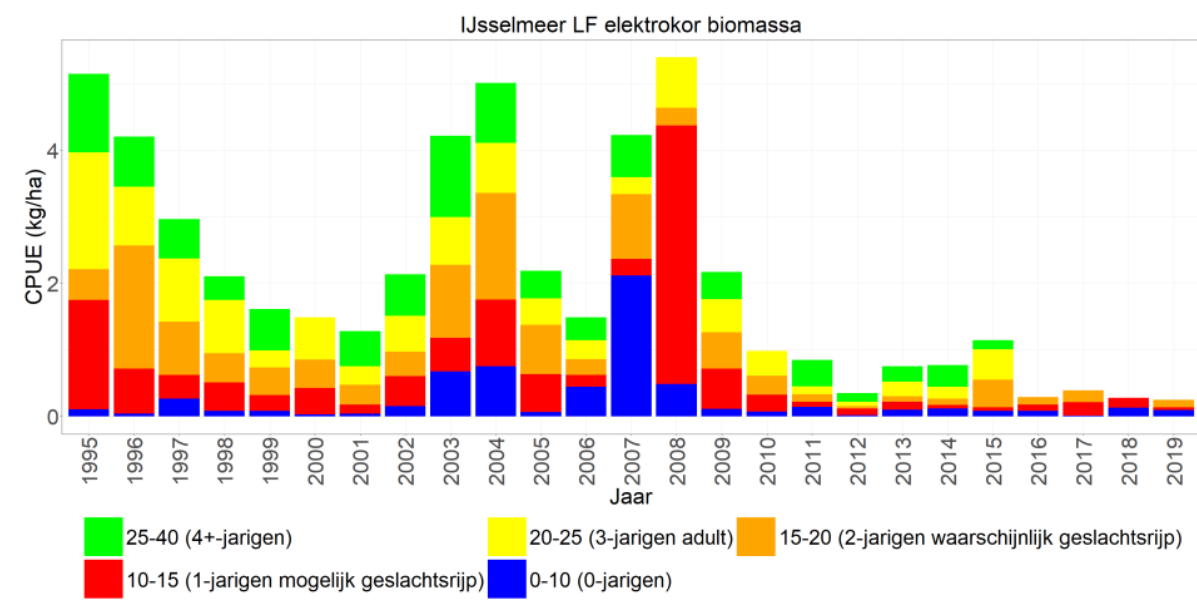

Figuur 6.1 Gemiddelde CPUE ( $\mathrm{n} / \mathrm{ha}$ en $\mathrm{kg} / \mathrm{ha}$ bevist oppervlak) per jaar met lengteverdeling ( $\mathrm{cm}$ ) van blankvoorn gevangen met de boomkor en de elektrokor in het open water van het IJsselmeer. 

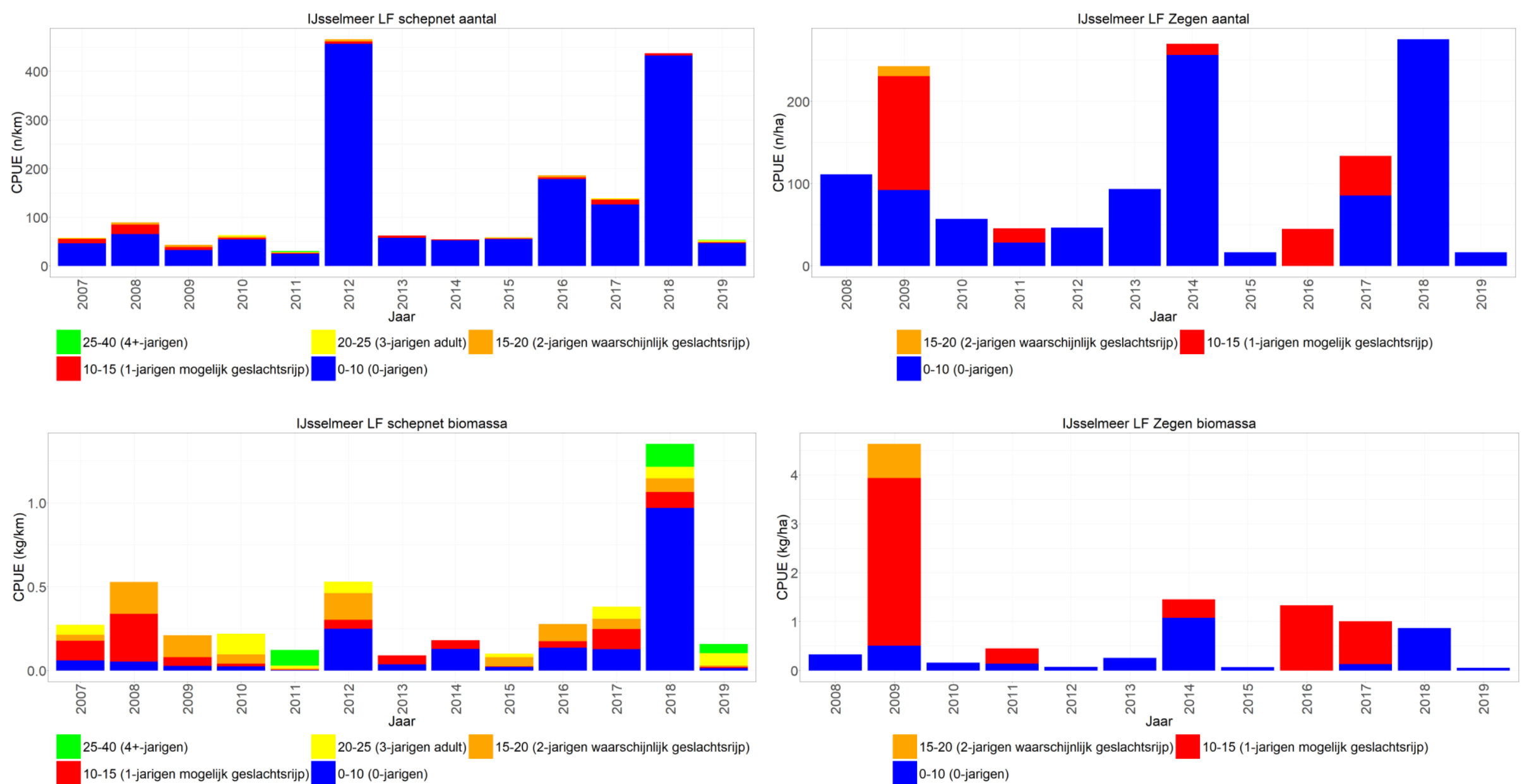

Figuur 6.2 Gemiddelde CPUE ( $\mathrm{n} / \mathrm{km}-\mathrm{n} / \mathrm{ha}$ en $\mathrm{kg} / \mathrm{km}-\mathrm{kg} /$ ha bevist oppervlak) per jaar met lengteverdeling ( $\mathrm{cm}$ ) van blankvoorn gevangen met het schepnet en de zegen langs oevers met riet en steen (schepnet) en de zandoevers (zegen) van het IJsselmeer. 


\subsection{Markermeer}

\subsubsection{Open water}

Net als op het IJsselmeer lijkt de blankvoorn sinds het begin van de monitoringsreeks vanaf 1989 af te nemen, met name qua aantallen en in minder mate qua biomassa. De afname lijkt wel minder sterk te zijn dan op het IJsselmeer (Figuur 6.3). Ook in het Markermeer is een opleving van blankvoorn te zien, hier van 2004-2011 (in het IJsselmeer was dit van 2003-2009). Hierna zet de afname door, hoewel er de laatste drie jaar een toename lijkt te zijn (in het IJsselmeer is dit in de laatste twee jaar ook het geval). Wat opvalt, is dat in tegenstelling tot het IJsselmeer, de aantallen regelmatig gedomineerd worden door 1-2 jarige blankvoorn, een fenomeen wat in het IJsselmeer voor het laatst in de jaren ' 90 van de vorige eeuw plaats vond. Wat ook opvalt is dat de biomassa gedomineerd wordt door grotere exemplaren en dat het aandeel juvenielen met de tijd lijkt af te nemen (in plaats van een toename van het aandeel juvenielen zoals we zien op het IJsselmeer). Met name in de laatste drie jaar is er een sterke toename van oudere en grotere individuen, zowel met de boomkor als de elektrokor. Deze toename is ook terug te zien in de aanlandingen van het IJssel-/Markermeer (Figuur 2.10) en kan verschillende en/of een combinatie van oorzaken hebben. Zo was er in 2014 een zeer sterke jaarklasse van blankvoorn (in het IJsselmeer) die mogelijk verantwoordelijk is voor de toename van de aantallen en biomassa in 20172019. Een andere mogelijkheid is dat het aangepaste visserijbeheer vanaf visseizoen 2014/2015 effect heeft, waarbij de volgende maatregelen zijn getroffen; (a) de visserij met staande netten ('staandwantvisserij') is beperkt tot $15 \%$ van de beschikbare inzet (in merkjes) per visser, veruit de meest blankvoorn (95-98\%) wordt met het staandwant gevangen (Tien et al. 2020), (b) zegenvisserij op het open water is beperkt tot 7 dagen per jaar per vergunning en het aan elkaar knopen van zegennetten is niet meer toegestaan, (c) zegenvisserij in de havens is niet meer toegestaan (de havenvisserij is met name gericht op blankvoorn die de havens als refugia in de winter gebruikt en ter plekke in zeer hoge dichtheden voorkomt (PO Visplan 2013)), en (d) vissen met grote fuik met ruif op blankvoorn in de (voor aalvisserij) gesloten periode is niet meer toegestaan (Tien et al. 2020). De recente toename van blankvoorn op het Markermeer zou mogelijk ook een effect kunnen zijn van de aanleg van de Markerwadden. Op dit moment wordt onderzocht of blankvoorn de Markerwadden (massaal) als paaigebied gebruikt. De eerste voorlopige resultaten laten zien dat er in het voorjaar met het larvennet voornamelijk blankvoornlarven worden gevangen en dat in het najaar met de zegen relatief veel blankvoorn in de geulen en haven wordt gevangen. Daarnaast bleek ook dat blankvoorn veel voorkomt op locaties tussen de eilanden van de Markerwadden die in verbinding staan met het open water (de Leeuw \& van Emmerik, 2020). Alhoewel de blankvoorn dus veel in en rondom de Markerwadden voorkomt, betekent dit uiteraard nog niet per sé dat de Markerwadden een positief effect op de blankvoornpopulatie hebben gehad.

Bovenstaande speculaties over de oorzaken van toe- of afnames van blankvoorn in het Markermeer kunnen ook gedeeltelijk van toepassing zijn op het IJsselmeer.

\subsubsection{Oever}

In tegenstelling tot de aantallen en biomassa van blankvoorn langs de stenen en rietoevers van het IJsselmeer lijken deze langs stenen, riet- en vooroevers in het Markermeer af te nemen sinds het begin van de oeverbemonstering (schepnet, Figuur 6.4). Ook hier worden de aantallen bepaald door de juvenielen en de biomassa met name door oudere individuen. Net als op het IJsselmeer werd de biomassa t/m 2012 grotendeels bepaald door de oudere exemplaren blankvoorn maar vanaf 2012 zijn het ook de juvenielen die de biomassa bepalen. In de laatste vier jaar lijkt er geen toename te zijn langs de oevers, zoals op het IJsselmeer. De biomassa wordt wel weer grotendeels bepaald door de oudere individuen. Bij de zandoevers (zegen) worden vrijwel alleen maar juvenielen gevangen met sterk wisselende vangsten van jaar tot jaar. 

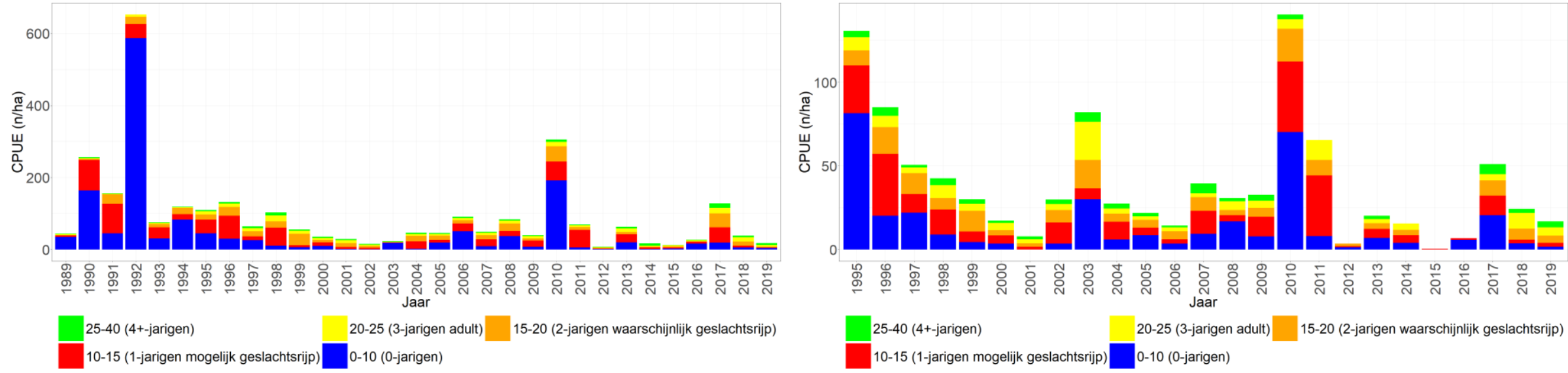
25-40 (4+-jarigen)
(3-jarigen adult) $\quad$ 15-20 (2-jarigen waarschijnlijk geslachtsrijp)
10-15 (1-jarigen mogelijk geslachtsrijp) $\quad$ 0-10 (0-jarigen)

oomkor biomass
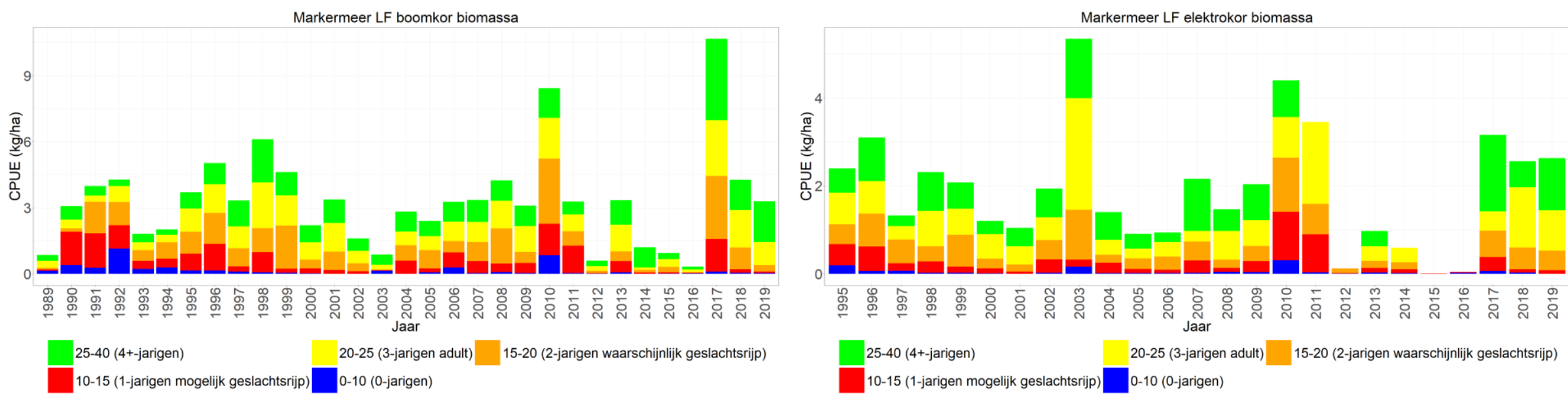

Figuur 6.3 Gemiddelde CPUE ( $\mathrm{n} / \mathrm{ha}$ en $\mathrm{kg} / \mathrm{ha}$ bevist oppervlak) per jaar met lengteverdeling (cm) van blankvoorn gevangen met de boomkor en de elektrokor in het open water van het Markermeer. 

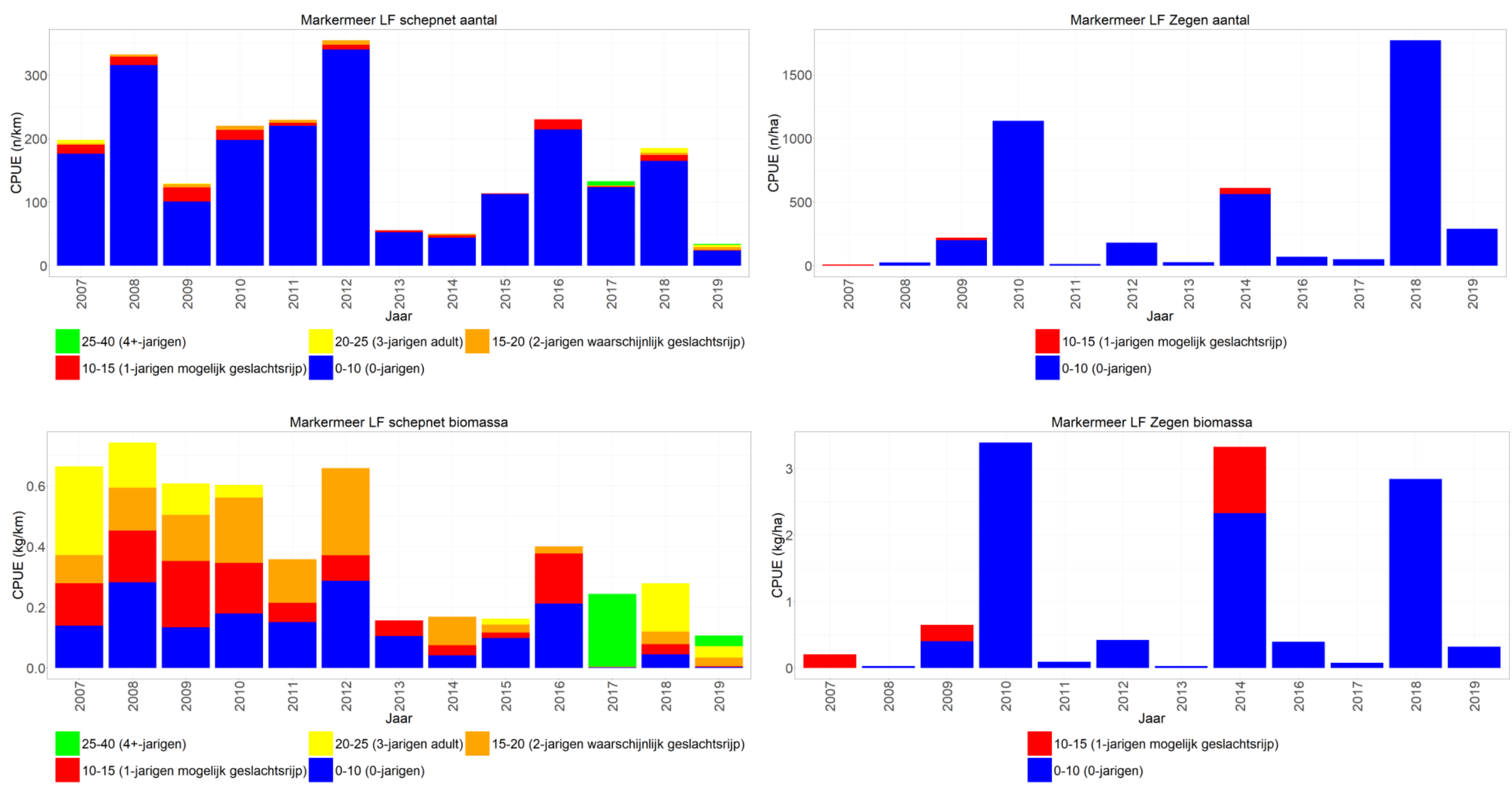

Figuur 6.4 Gemiddelde CPUE ( $\mathrm{n} / \mathrm{km}-\mathrm{n} / \mathrm{ha}$ en $\mathrm{kg} / \mathrm{km}-\mathrm{kg} / \mathrm{ha}$ bevistoppervlak) per jaar met lengteverdeling ( $\mathrm{cm}$ ) van blankvoorn gevangen met het schepnet en de zegen langs oevers met riet en steen en vooroevers (schepnet) en de zandoevers (zegen) van het Markermeer. 


\subsection{Randmeren-Oost}

\subsubsection{Open water}

Blankvoorn wordt relatief veel gevangen in de Randmeren-Oost, zowel met de stortkuil als met de wonderkuil (Figuur 6.5). De vangsten fluctueren sterk per monitoringsjaar, en er zijn geen duidelijke trends zichtbaar. De aantallen worden gedomineerd door nuljarigen terwijl de biomassa voornamelijk door meerjarigen bepaald wordt (met ook nog wel een groot aandeel voor de nuljarigen). In tegenstelling tot veel andere wateren lijkt er in dit KRW-lichaam geen afname van oudere individuen te zijn, in ieder geval niet sinds 2007. Wat opvalt is dat, hoewel de stortkuil al relatief veel blankvoorn vangt, de wonderkuil nog grotere hoeveelheden (nuljarige) blankvoorn vangt.

\subsubsection{Oever}

Sinds 2013 worden de oevers van de Randmeren-Oost met het schepnet bemonsterd (figuur xx). De reeks is nog te kort om iets over een toe- of afname door de tijd heen te concluderen. De aantallen worden door nuljarigen gedomineerd, terwijl de biomassa voornamelijk wordt gedomineerd door meerjarigen. Wat opvalt is het relatief hoge aantal nuljarigen in 2019. 

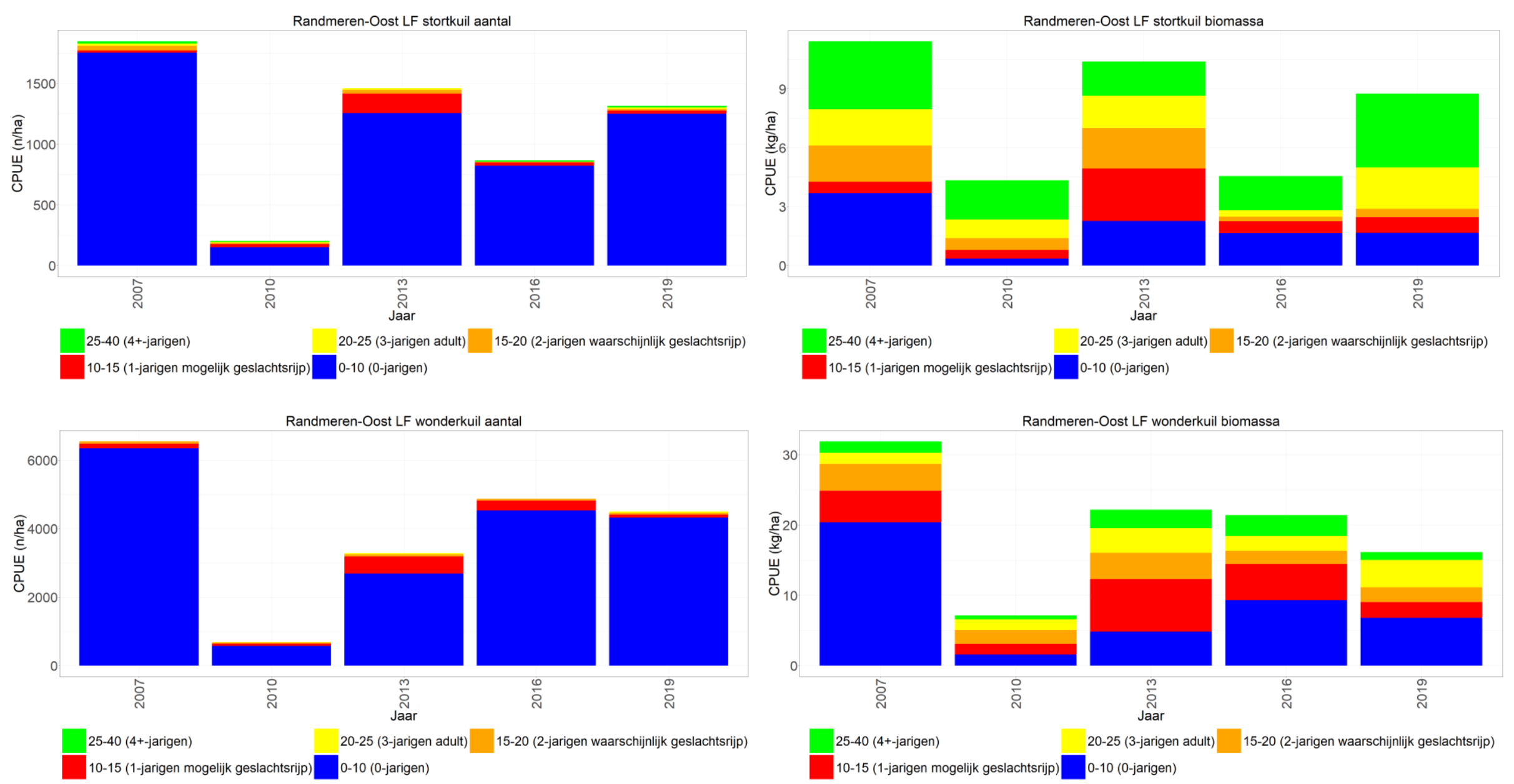

Figuur 6.5 Gemiddelde CPUE (n/km-n/ha en kg/km-kg/ha bevistoppervlak) per jaar met lengteverdeling (cm) van blankvoorn gevangen met de stortkuil en wonderkuil in het open water van de Randmeren-Oost. 


\section{Randmeren-Oost LF schepnet aantal}

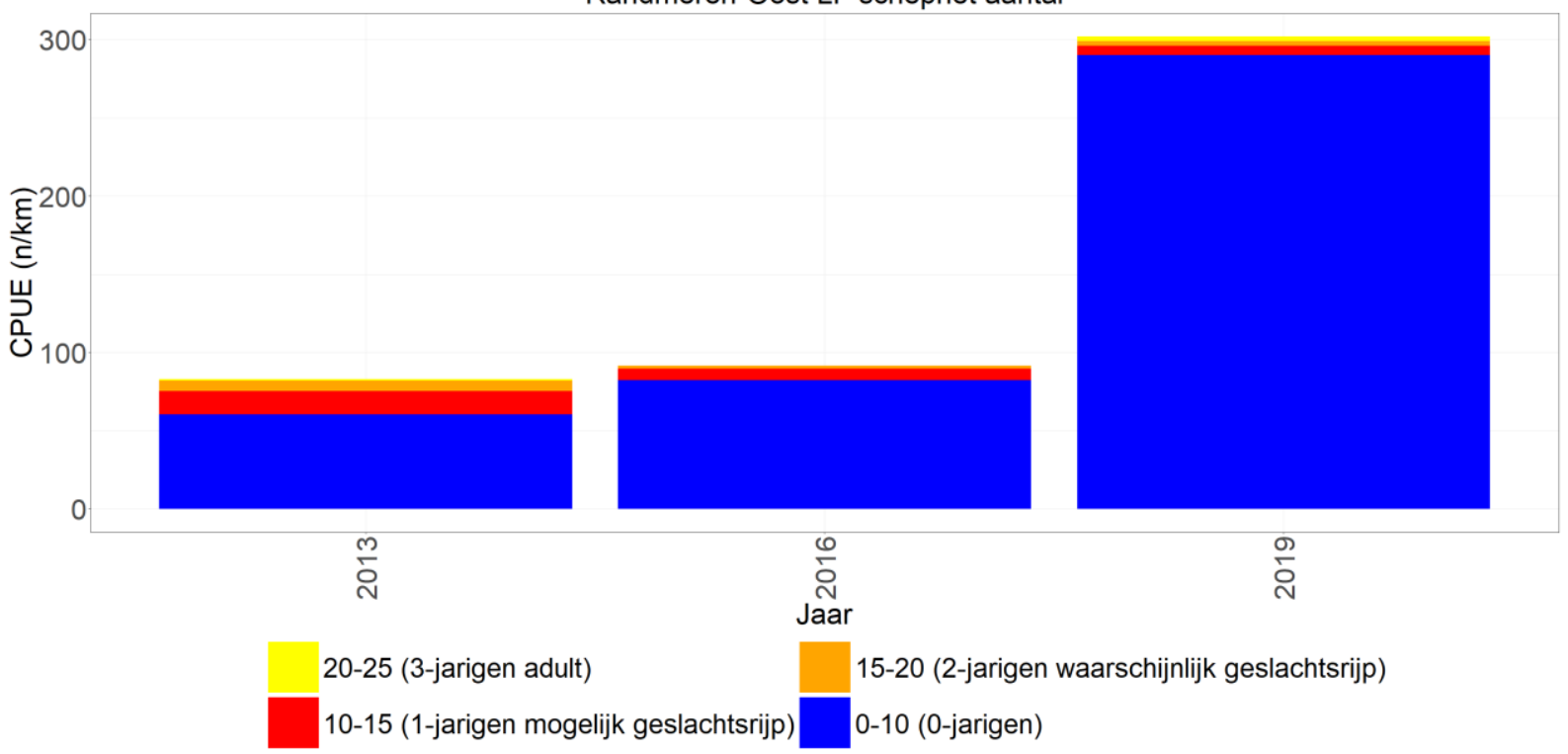

Randmeren-Oost LF schepnet biomassa

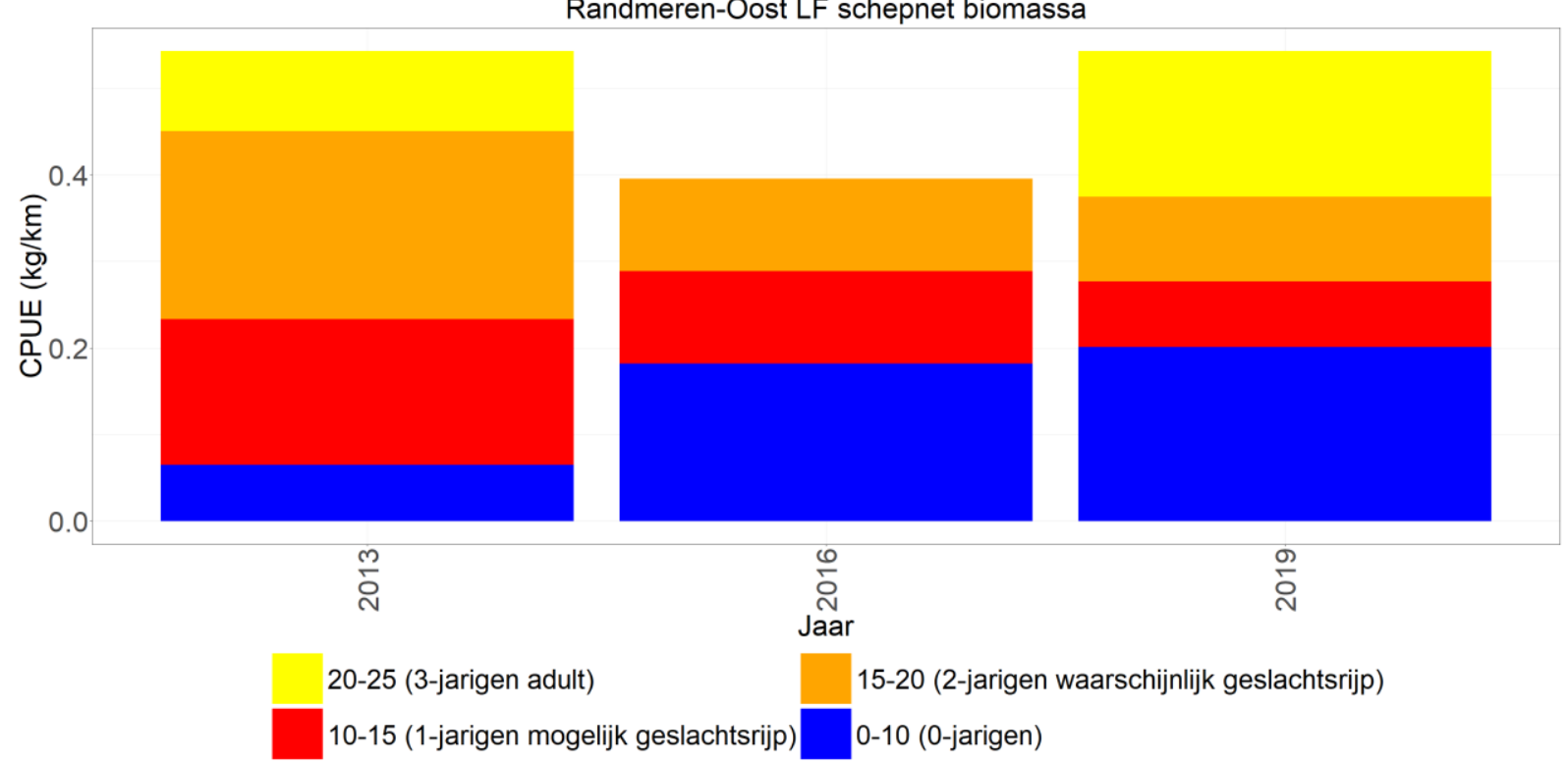

Figuur 6.6 Gemiddelde CPUE ( $\mathrm{n} / \mathrm{km}$ en $\mathrm{kg} / \mathrm{km}$ bevistoppervlak) per jaar met lengteverdeling ( $\mathrm{cm}$ ) van blankvoorn gevangen met elektroschepnet langs de oevers van de Randmeren-Oost. 


\subsection{Randmeren-Zuid}

\subsubsection{Open water}

Net als in de Randmeren-Oost wordt blankvoorn met de stortkuil relatief veel gevangen in de Randmeren-Zuid (Figuur 6.5). De vangsten fluctueren sterk per monitoringsjaar, en er zijn geen duidelijke trends zichtbaar. De aantallen worden gedomineerd door nuljarigen en de biomassa voornamelijk door meerjarigen, alhoewel nuljarigen nog een relatief groot aandeel in biomassa hebben (behalve in de jaren 2009 en 2018). In tegenstelling tot veel andere wateren lijkt er ook in dit KRWlichaam geen afname van oudere individuen te zijn, alhoewel de monitoring pas sinds 2009 loopt.

\subsubsection{Oever}

Sinds 2012 worden de oevers van de Randmeren-Zuid met het schepnet bemonsterd. De vangsten fluctueren sterk met zeer lage aantallen en biomassa in 2018 (dit geldt ook voor de stortkuilvangsten). De aantallen en biomassa worden beide door nuljarigen gedomineerd. Wat opvalt is het relatief hoge aantal nuljarigen in 2019, net als in de Randmeren-Oost. 

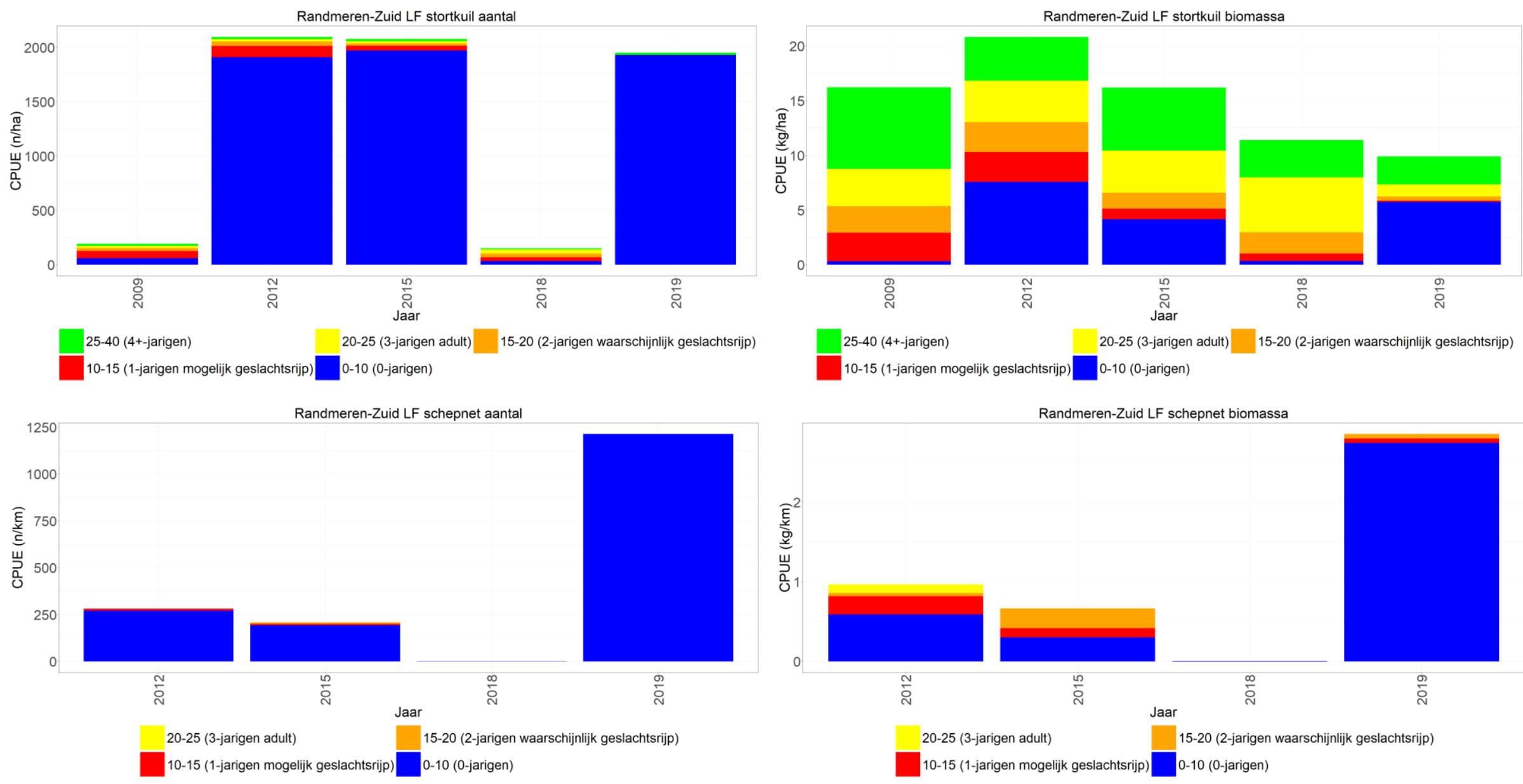

Figuur 6.7 Gemiddelde CPUE (n/ha-n/km bevistoppervlak), lengteklasse verdeling in percentages en gemiddelde CPUE (kg/ha-kg/km bevistoppervlak) per jaar van blankvoorn gevangen met de stortkuil in het open water en met het elektroschepnet langs de oevers van de Randmeren-Zuid. 


\subsection{Benedenloop Gelderse IJssel}

\subsubsection{Hoofdstroom (open water)}

Blankvoorn laat vanaf 2003 lagere boomkorvangsten zien in zowel aantal als biomassa en alleen in sommige jaren zijn nog wat pieken zien. Vanaf 2014 lijken de vangsten weer wat toe te nemen, hoewel ze de laatste twee jaar weer lager zijn. De lengteverdeling lijkt door de tijd heen vrij stabiel te zijn zonder grote veranderingen met relatief veel oudere vis die zowel de aantallen als de biomassa domineren (Figuur 6.8, links).

\subsubsection{Hoofdstroom (oever)}

Langs de oevers (schepnet) zien we, net als in de hoofdstroom, een vergelijkbare afname vanaf 2004 en een lichte toename vanaf 2014. De vangsten bestaan voornamelijk uit nuljarige vis alhoewel tot 2003 relatief veel oudere vis de biomassa domineerde, sindsdien domineert de nuljarige vis vaak ook de biomassa (Figuur 6.8, rechts).

\subsubsection{Zijwateren (open water)}

Net als in de hoofdstroom lijken de vangsten vanaf 2002 gemiddeld gezien lager dan daarvoor, zowel qua aantal als qua biomassa. Ondanks dat er in sommige jaren wel oplevingen zijn, lijkt de populatie zich niet te herstellen. In tegenstelling tot de hoofdstroom bestaan de aantallen voornamelijk uit nuljarigen, terwijl de biomassa net als in de hoofdstroom wordt gedomineerd door oudere vissen. Wellicht dat de bemonsterde zijwateren als kraamkamer functioneren en er daarom meer juvenielen gevangen worden (Figuur 6.9, links).

\subsubsection{Zijwateren (oever)}

Langs de oever vallen de hoge aantallen en biomassa gevangen in 2005 direct op. Na deze piek zijn de gevangen aantallen en biomassa zeer laag en zien we ook geen oplevingen meer in recentere jaren. De vangsten bestaan hier zowel qua aantal als biomassa voornamelijk uit nuljarigen. In 2018 is er met het schepnet nauwelijks vis en dus ook geen blankvoorn gevangen in de zijwateren waarschijnlijk vanwege de zeer lage watertemperatuur (Figuur 6.9, rechts). 

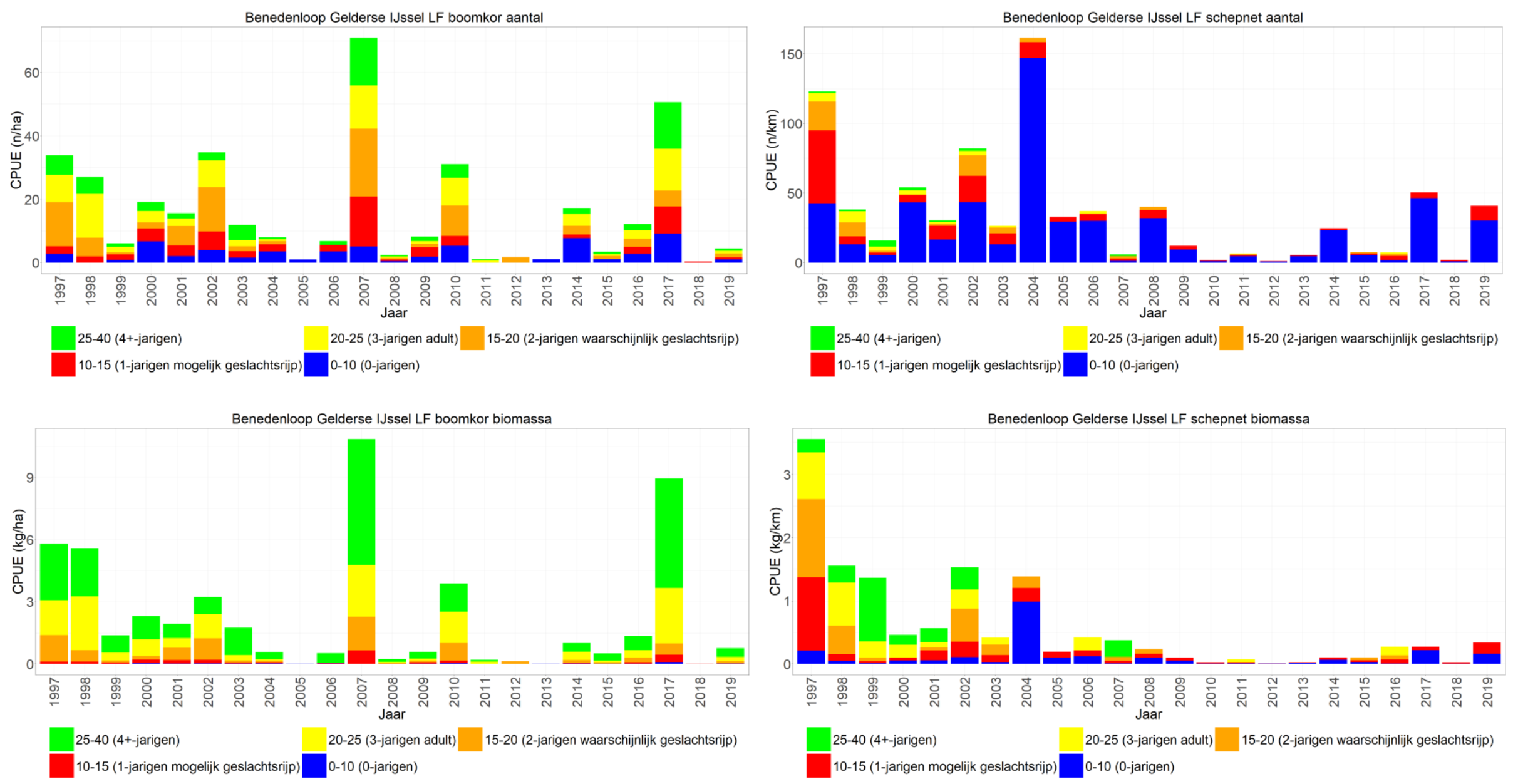

Figuur 6.8 Gemiddelde CPUE ( $\mathrm{n} / \mathrm{km}-\mathrm{n} / \mathrm{ha}$ en $\mathrm{kg} / \mathrm{km}-\mathrm{kg} / \mathrm{ha}$ bevistoppervlak) per jaar met lengteverdeling ( $\mathrm{cm}$ ) van blankvoorn gevangen met de boomkor in het open water en met het elektroschepnet langs de oevers van de Benedenloop Gelderse IJssel. 

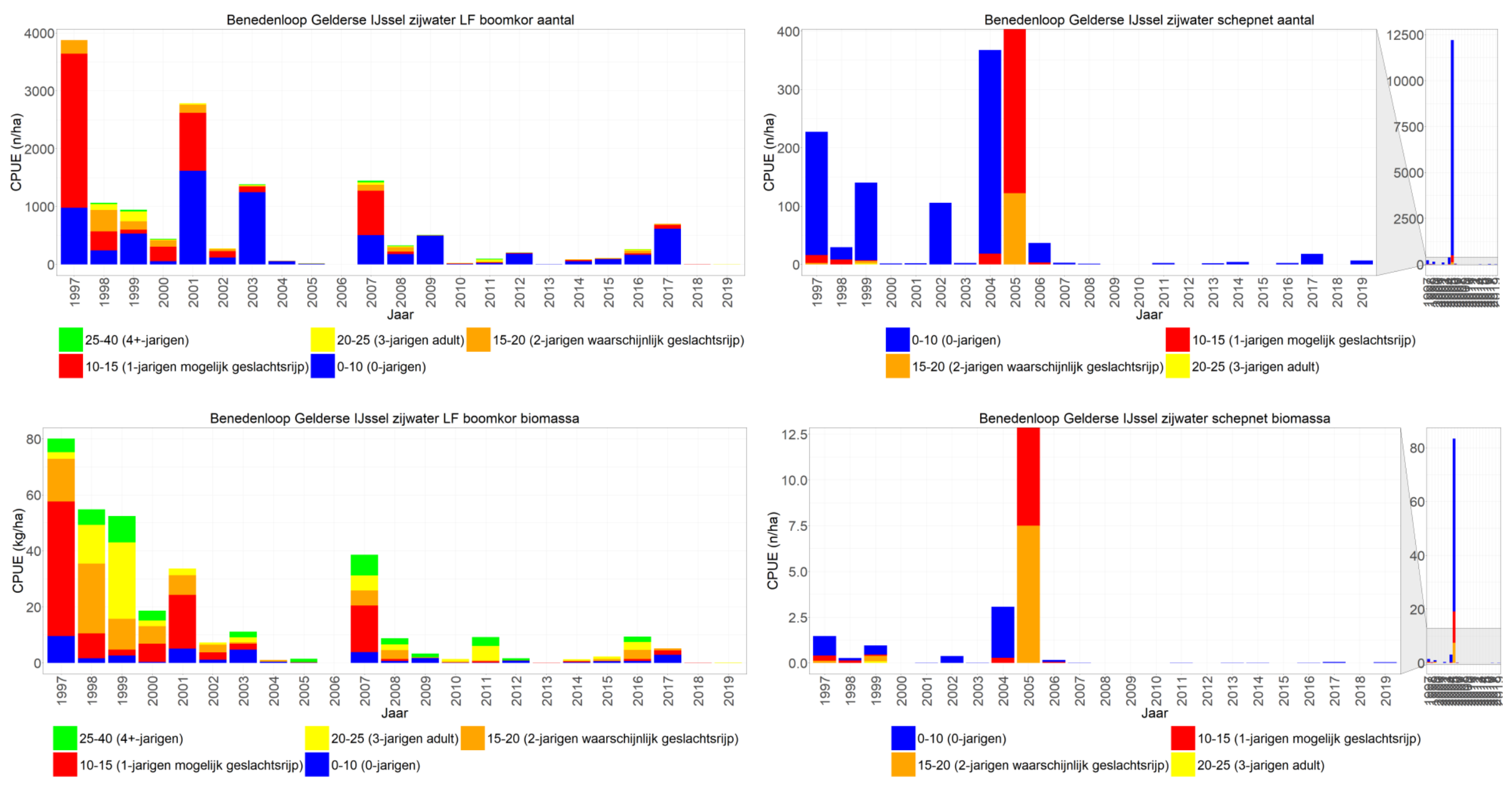

Figuur 6.9 Gemiddelde CPUE (n/km-n/ha en kg/km-kg/ha bevistoppervlak) per jaar met lengteverdeling (cm) van blankvoorn gevangen met de boomkor (links) in de zijwateren en met het elektroschepnet (rechts) langs de oevers van de Benedenloop Gelderse IJssel. 


\subsection{Bovenloop Gelderse IJssel}

\subsubsection{Hoofdstroom (open water)}

Door de tijd heen lijken zowel de aantallen als de biomassa van blankvoorn in de hoofdstroom relatief stabiel, alhoewel er de laatste twee jaar zeer weinig is gevangen. Net als in de Benedenloop Gelderse IJssel bestaan zowel de aantallen maar voornamelijk de biomassa uit oudere vissen (Figuur 6.10, links).

\subsubsection{Hoofdstroom (oever)}

Langs de oever lijkt er sinds het begin van de monitoring tot 2004 een toename te zijn, voornamelijk veroorzaakt door een toename in oudere individuen. Deze oudere individuen worden vanaf 2005 veel minder gevangen, wat voor een sterke afname zorgt in aantal en biomassa. Sindsdien lijken de aantallen en biomassa relatief stabiel (Figuur 6.10, rechts).

\subsubsection{Zijwateren (open water)}

Net als in de zijwateren van de Benedenloop Gelderse IJssel bestaan de vangsten qua aantal voornamelijk uit nuljarigen en bestaat de biomassa voornamelijk uit oudere individuen. Verder zien we in de laatste tien jaar lagere aantallen en biomassa dan in de jaren daarvoor, op de pieken in 2017 en 2018 na (Figuur 6.11, links).

\subsubsection{Zijwateren (oever)}

Langs de oever in de zijwateren is net als in de hoofdstroom te zien dat er vanaf 2005 nauwelijks nog oudere individuen gevangen worden, wat voor een afname in biomassa maar ook aantallen zorgt (Figuur 6.11 , rechts). 

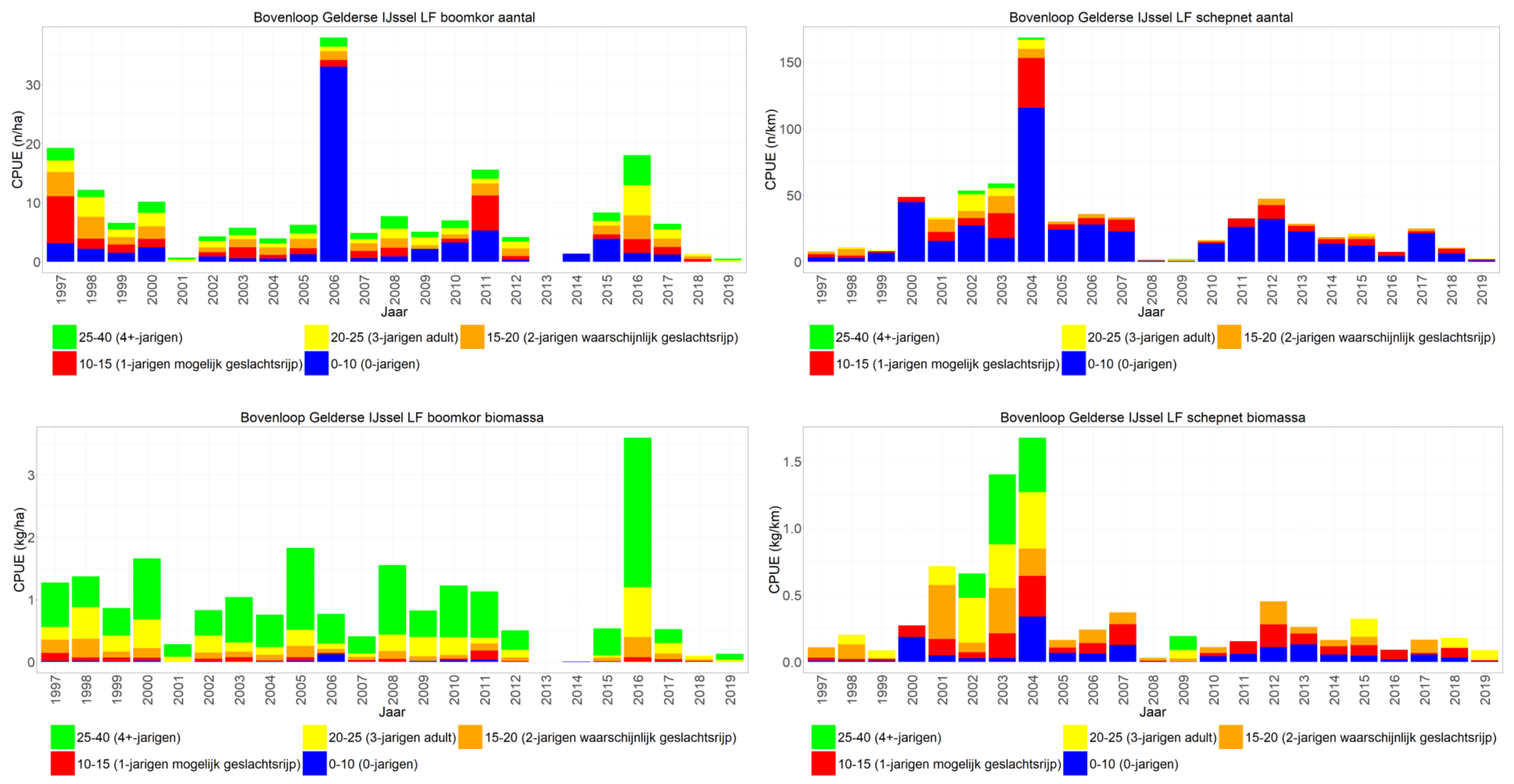

Figuur 6.10 Gemiddelde CPUE ( $\mathrm{n} / \mathrm{km}-\mathrm{n} / \mathrm{ha}$ en $\mathrm{kg} / \mathrm{km}-\mathrm{kg} / \mathrm{ha}$ bevistoppervlak) per jaar met lengteverdeling (cm) van blankvoorn gevangen met de boomkor in het open water en met het elektroschepnet langs de oevers van de Bovenloop Gelderse IJssel. 

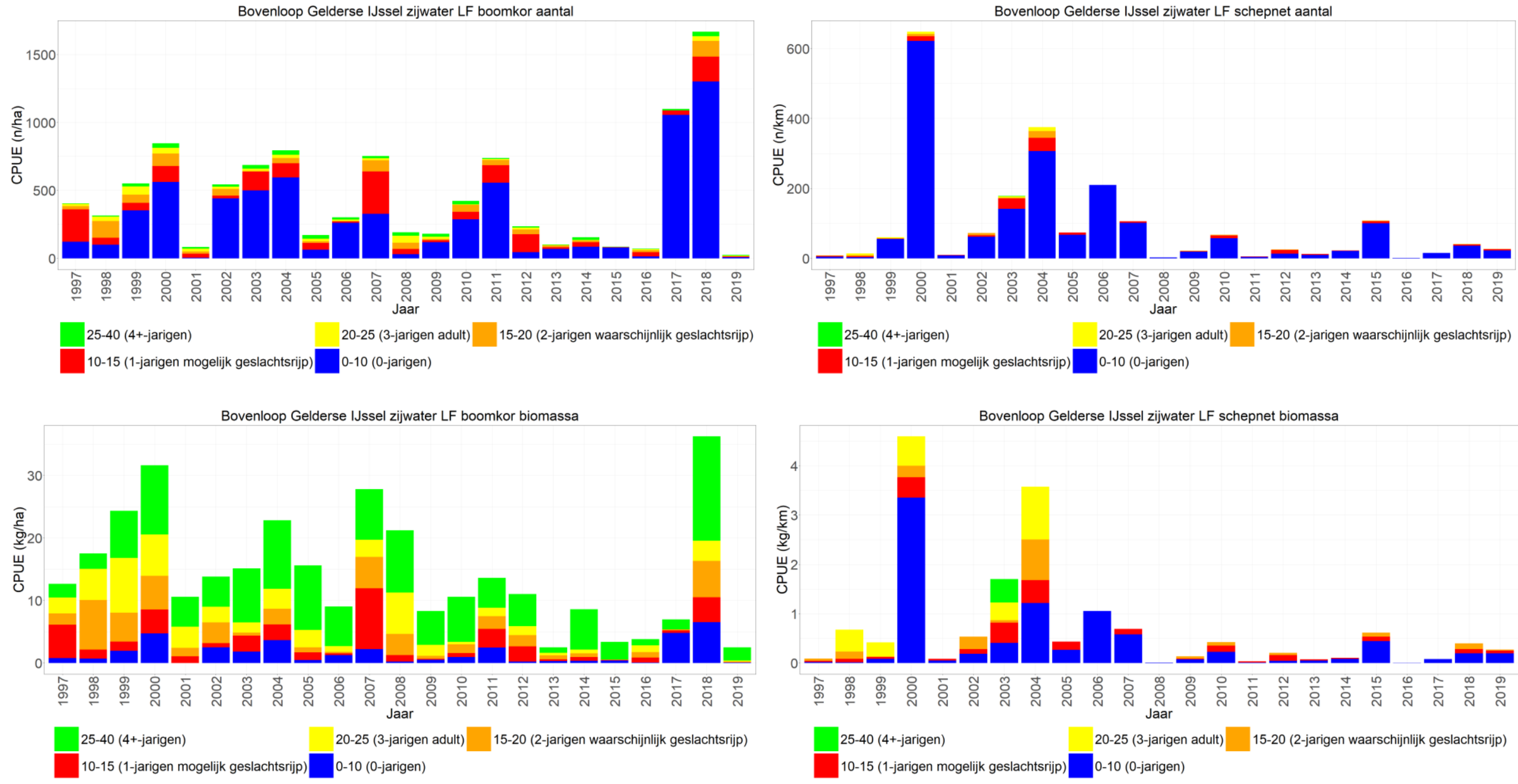

Figuur 6.11 Gemiddelde CPUE ( $\mathrm{n} / \mathrm{km}-\mathrm{n} / \mathrm{ha}$ en $\mathrm{kg} / \mathrm{km}-\mathrm{kg} / \mathrm{ha}$ bevistoppervlak) per jaar met lengteverdeling ( $\mathrm{cm}$ ) van blankvoorn gevangen met de boomkor in de zijwateren en met het elektroschepnet langs de oevers van de Bovenloop Gelderse IJssel. 


\subsection{Rijn}

\subsubsection{Hoofdstroom (open water)}

Sinds het begin van de monitoring leek blankvoorn toe te nemen in de hoofdstroom van de Rijn. Sinds 2011 zijn zowel qua aantallen als qua biomassa de vangsten echter laag, met pieken in 2017 en 2019. Ook hier lijkt de afname voornamelijk voort te komen uit de afnamen van oudere individuen die tot 2011 de vangsten zowel qua aantallen als biomassa domineerde (Figuur 6.12, links).

\subsubsection{Hoofdstroom (oever)}

Langs de oever lijken de aantallen en biomassa meer te fluctueren en is er geen duidelijke toe- of afname zichtbaar door de tijd heen. Wel valt op dat vanaf 2009 de biomassa niet meer door meerjarige maar door nuljarige vis wordt gedomineerd (Figuur 6.12).

\subsubsection{Zijwateren (open water)}

In de zijwateren van de Rijn is ook vanaf 2011 een afname van voornamelijk aantallen te zien. Deze afname is niet echt terug te zien in de biomassa, welk voornamelijk gedomineerd wordt door meerjarige blankvoorn terwijl de aantallen voornamelijk gedomineerd (werden) door juvenielen (Figuur 6.13, links).

\subsubsection{Zijwateren (oever)}

Blankvoorn wordt vrij weinig langs de oever van de zijwateren van de Rijn gevangen, getuige de ontbrekende jaren in Figuur 6.13 (rechts). Er lijkt geen duidelijke trend in de vangsten te zitten, behalve dat er tot 2005 ieder jaar nog blankvoorn werd gevangen, daarna vele jaren niet. 

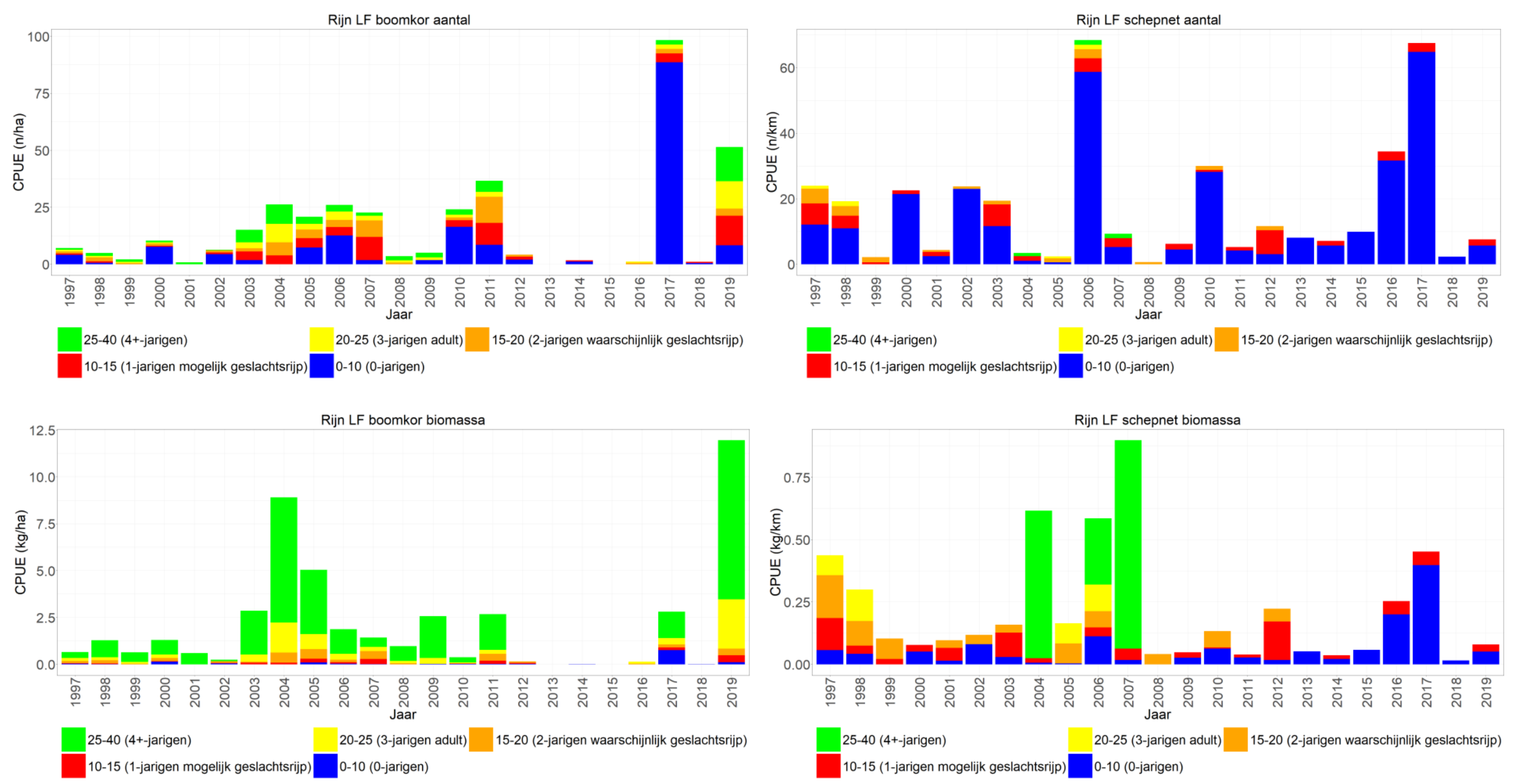

Figuur 6.12 Gemiddelde CPUE ( $\mathrm{n} / \mathrm{km}-\mathrm{n} / \mathrm{ha}$ en $\mathrm{kg} / \mathrm{km}-\mathrm{kg} / \mathrm{ha}$ bevistoppervlak) per jaar met lengteverdeling $(\mathrm{cm})$ van blankvoorn gevangen met de boomkor in het open water en met het elektroschepnet langs de oevers van de Rijn. 
Rijn zijwater LF boomkor aantal

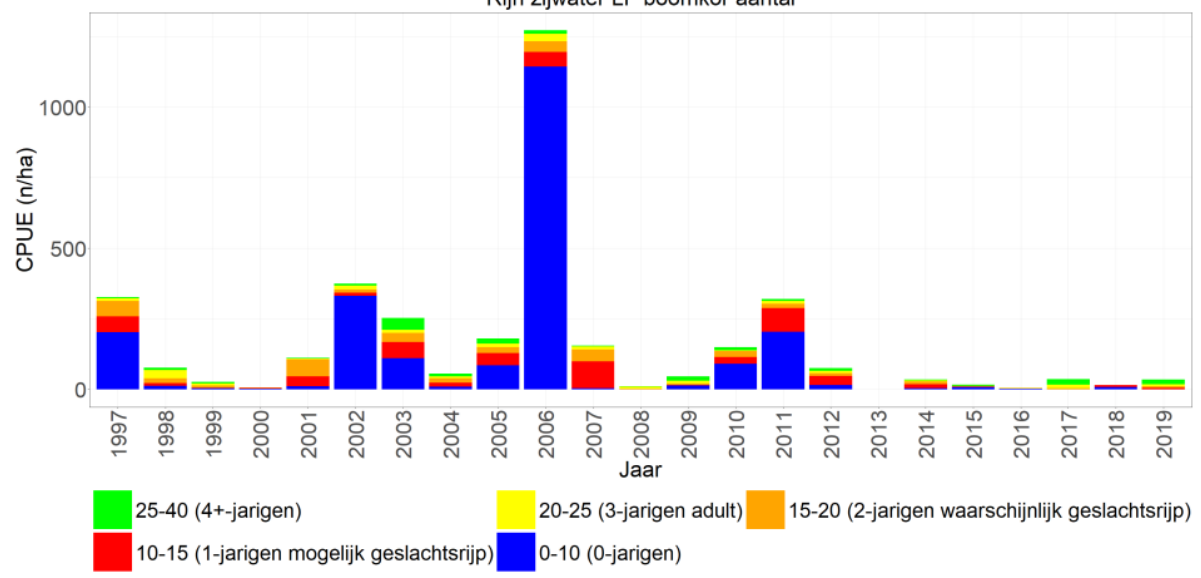

Rijn zijwater LF boomkor biomassa

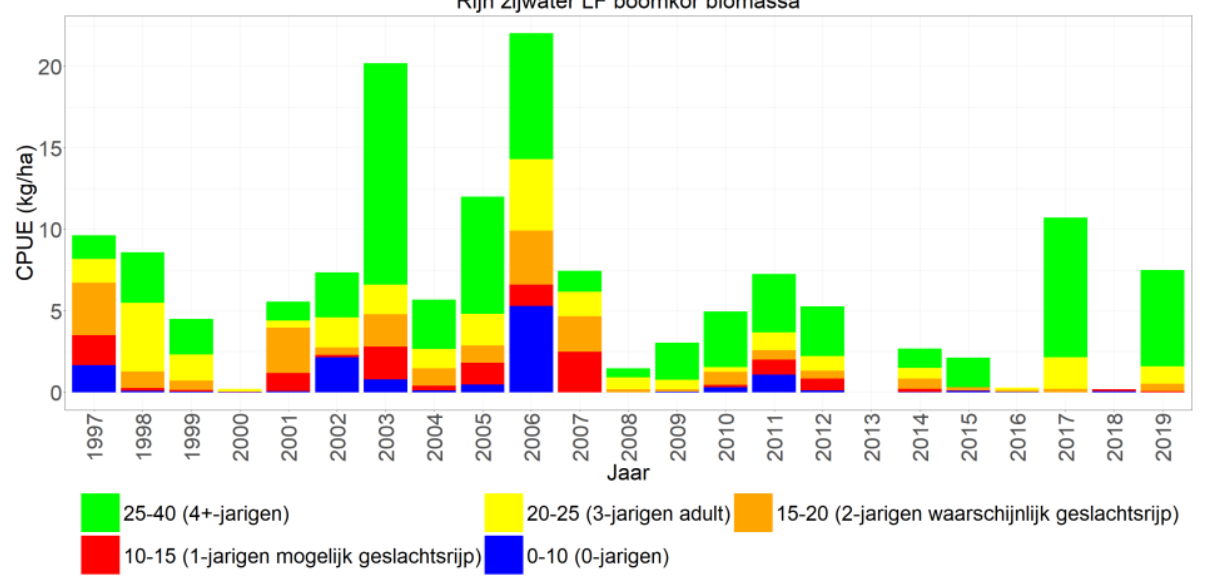

Rijn zijwater LF schepnet aantal

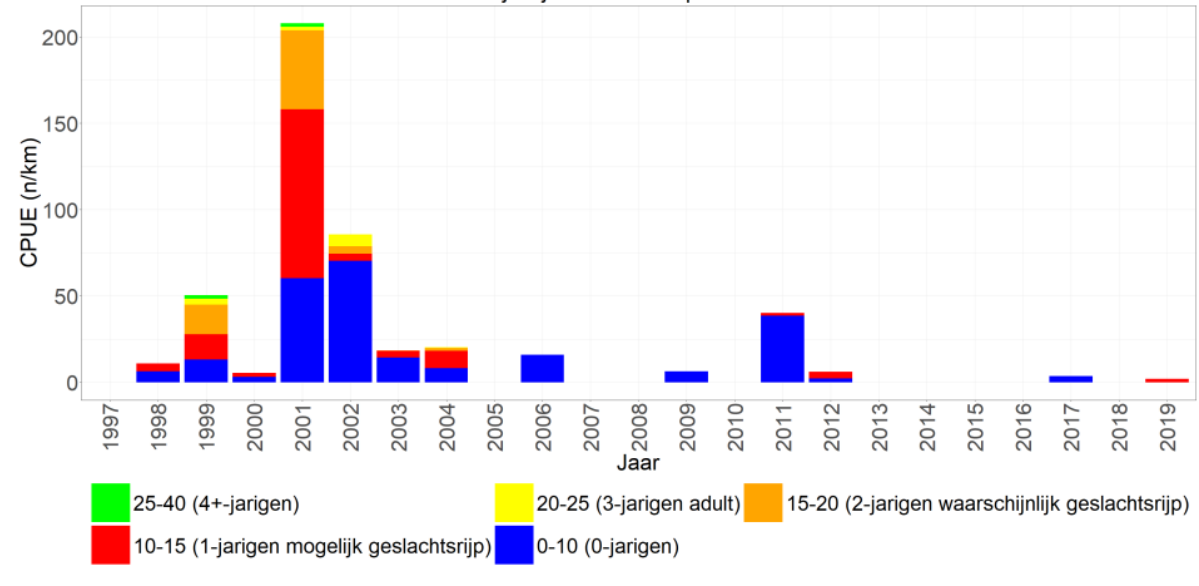

Rijn zijwater LF schepnet biomassa

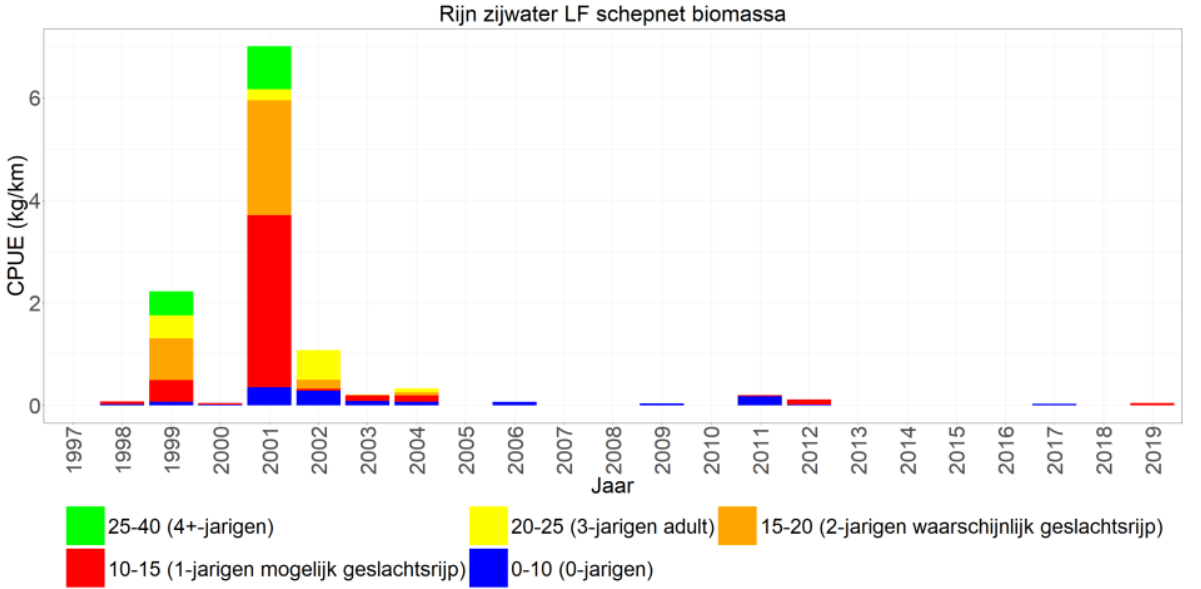

Figuur 6.13 Gemiddelde CPUE ( $\mathrm{n} / \mathrm{km}-\mathrm{n} / \mathrm{ha}$ en $\mathrm{kg} / \mathrm{km}-\mathrm{kg} / \mathrm{ha}$ bevistoppervlak) per jaar met lengteverdeling ( $\mathrm{cm}$ ) van blankvoorn gevangen met de boomkor in de zijwateren en met het elektroschepnet langs de oevers van de Rijn. 


\subsection{Grensmaas}

\subsubsection{Hoofdstroom}

In de Grensmaas zijn de aantallen en biomassa van blankvoorn sinds 2004 afgenomen maar lijkt er vanaf 2014 weer een lichte opleving te zijn. Zowel de aantallen als de biomassa bestaan voornamelijk uit nuljarigen, alhoewel de biomassa aan het begin en in de laatste jaren van de monitoring door volwassen dieren wordt gedomineerd (Figuur 6.14, links).

\subsubsection{Zijwateren}

In de zijwateren zien we vanaf 2010 een toename van blankvoorn, voornamelijk door een toename in meerjarige individuen, maar ook het aantal nuljarigen lijkt toe te nemen (Figuur 6.14, rechts). 

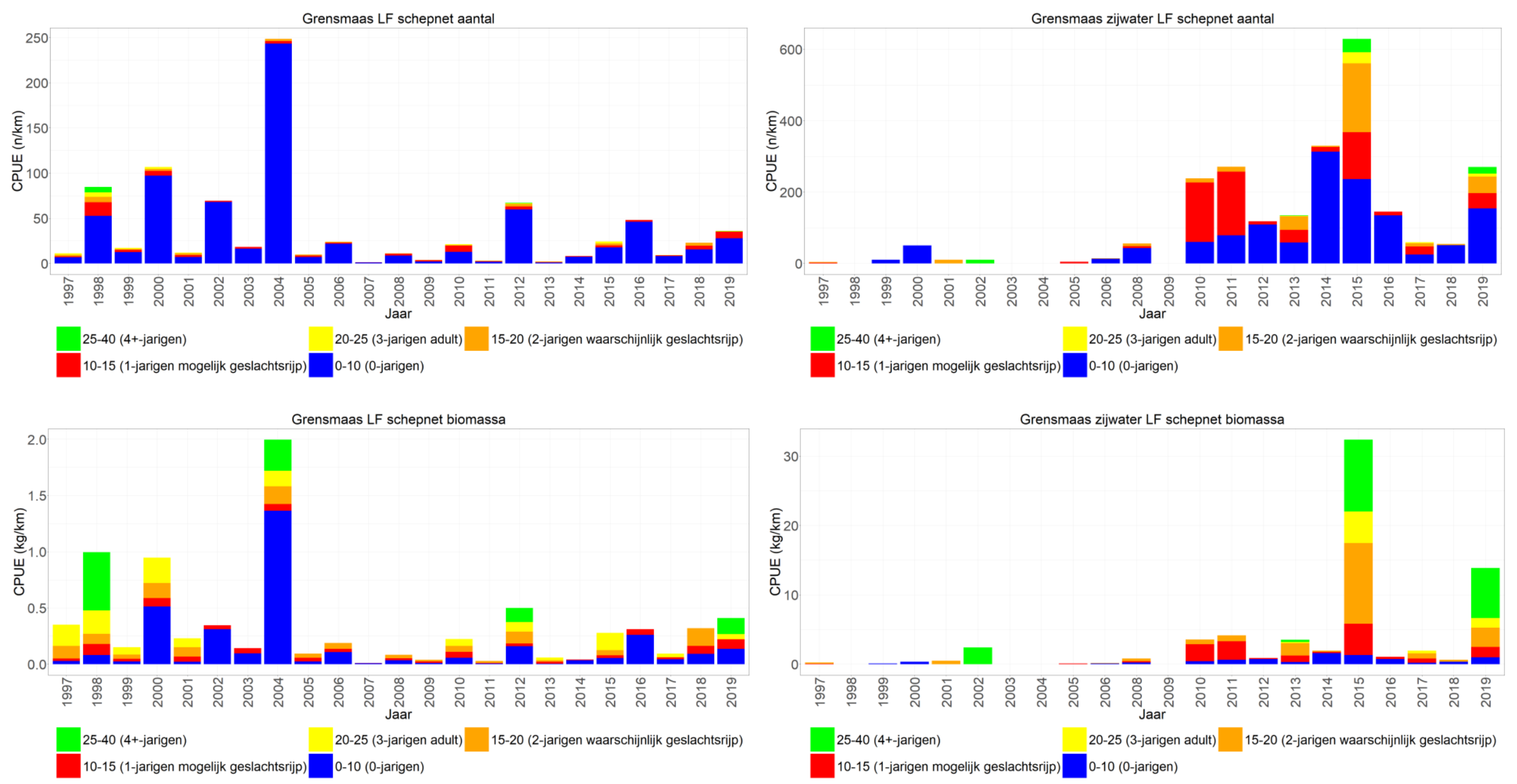

Figuur 6.14 Gemiddelde CPUE ( $\mathrm{n} / \mathrm{km}-\mathrm{kg} / \mathrm{km}$ bevistoppervlak) per jaar met lengteverdeling ( $\mathrm{cm}$ ) van blankvoorn gevangen met het elektroschepnet in het open water en de zijwateren van de Grensmaas. 


\subsection{Zandmaas}

\subsubsection{Hoofdstroom (open water)}

Blankvoorn laat zowel qua aantal als qua biomassa geen duidelijke toe- of afname zien sinds het begin van de monitoring in de hoofdstroom. De biomassa wordt gedomineerd door meerjarige individuen terwijl de aantallen soms door nuljarigen en soms door meerjarigen worden gedomineerd (Figuur 6.15, links).

\subsubsection{Hoofdstroom (oever)}

Langs de oever lijken de vangsten ook relatief stabiel, voornamelijk bestaande uit nuljarigen. Wat opvalt zijn de relatief hoge aantallen en biomassa van meerjarige blankvoorn in 2008 (Figuur 6.15, rechts).

\subsubsection{Zijwateren (open water)}

De zijwateren laten veel hogere aantallen blankvoorn zien dan de hoofdstroom en ook hier lijken de vangsten relatief stabiel door de tijd heen, met wat hogere vangsten in 2019. De aantallen worden gedomineerd door nuljarigen en de biomassa door meerjarige blankvoorn (Figuur 6.16, links).

\subsubsection{Zijwateren (oever)}

Langs de oevers van de zijwateren lijken de blankvoorn vangsten ook relatief stabiel en bestaan ze voornamelijk uit nul- en 1 jarige blankvoorn. De aantallen en biomassa van de 1 -jarige blankvoorn lijken toe te nemen met de jaren (Figuur 6.16, rechts). 

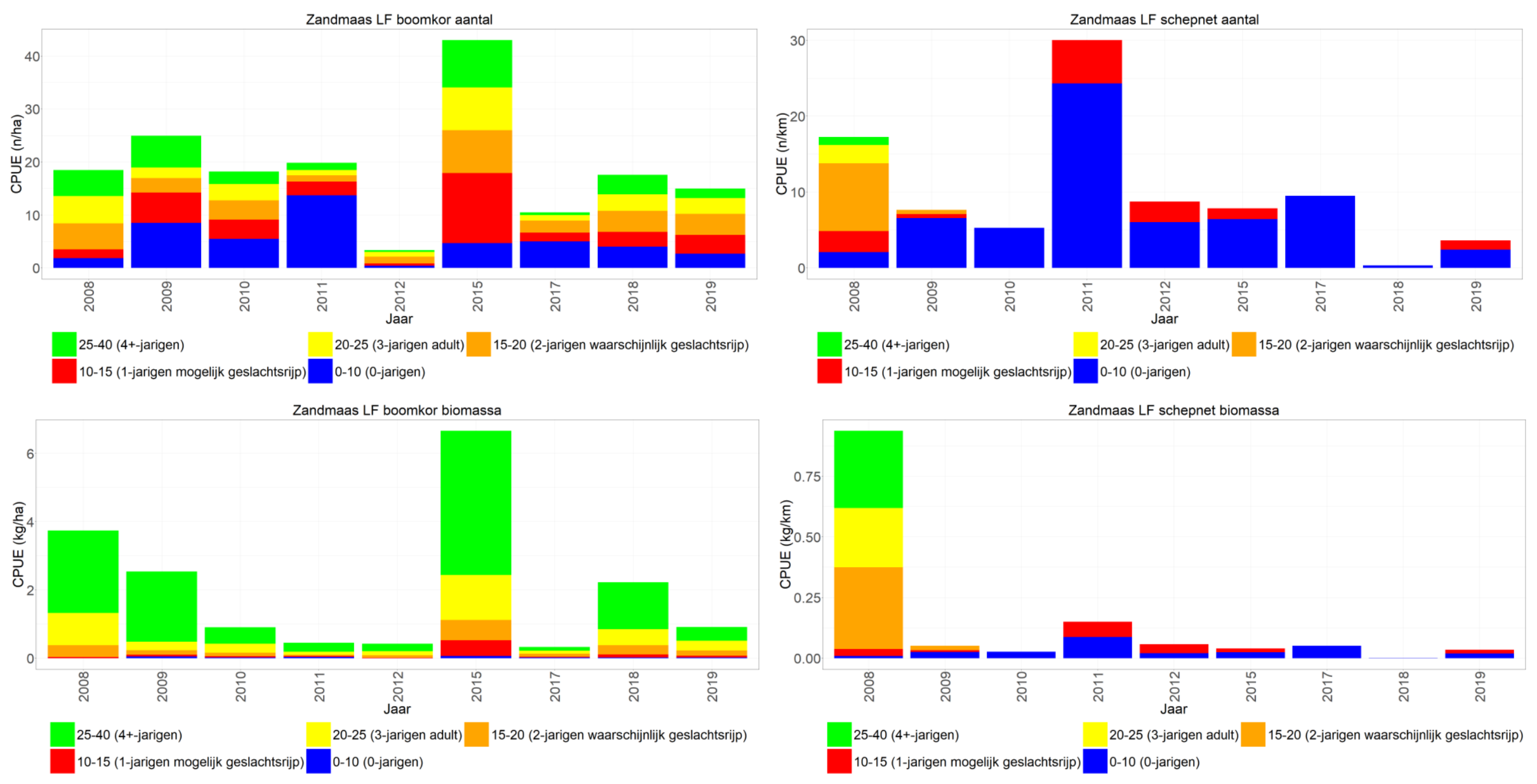

Figuur 6.15 Gemiddelde CPUE ( $\mathrm{n} / \mathrm{km}-\mathrm{n} / \mathrm{ha}$ en $\mathrm{kg} / \mathrm{km}-\mathrm{kg} / \mathrm{ha}$ bevistoppervlak) per jaar met lengteverdeling $(\mathrm{cm})$ van blankvoorn gevangen met de boomkor in het open water en met het elektroschepnet langs de oevers van de Zandmaas. 

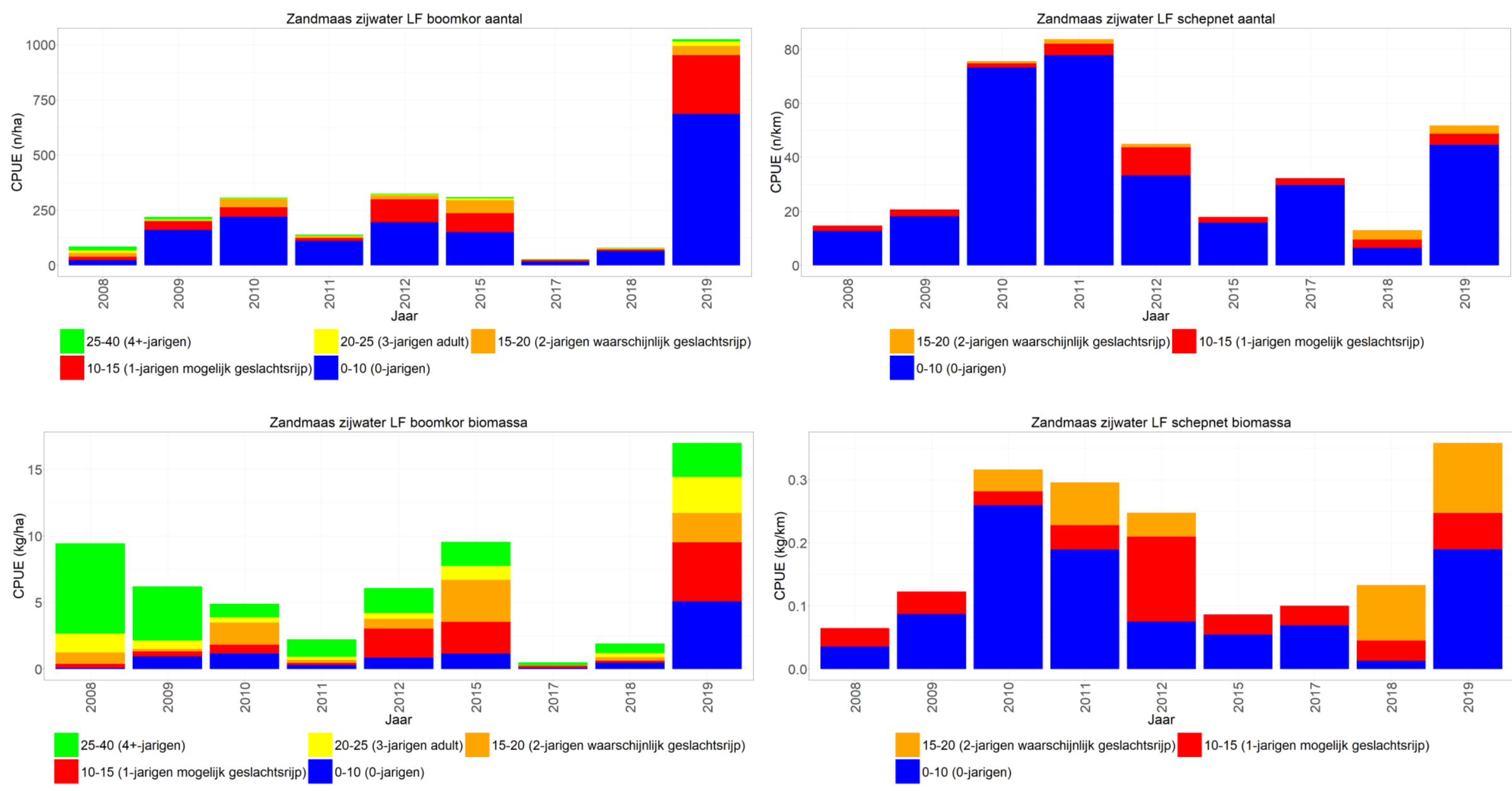

Figuur 6.16 Gemiddelde CPUE ( $\mathrm{n} / \mathrm{km}-\mathrm{n} / \mathrm{ha}$ en $\mathrm{kg} / \mathrm{km}-\mathrm{kg} / \mathrm{ha}$ bevistoppervlak) per jaar met lengteverdeling ( $\mathrm{cm}$ ) van blankvoorn gevangen met de boomkor in de zijwateren en met het elektroschepnet langs de oevers van de Zandmaas. 


\subsection{Bovenloop Nederrijn}

\subsubsection{Hoofdstroom (open water)}

In de Bovenloop Nederrijn zijn twee momenten van afname zichtbaar in de hoofdstroom. Vanaf 2003 zijn de aantallen gedaald voornamelijk door een daling van het aantal nuljarigen. Vanaf 2012 lijken er zowel minder nuljarige als meerjarige blankvoorn gevangen te worden, alhoewel er in de periode 2015-2017 een kleine opleving lijkt te zijn (Figuur 6.17, links).

\subsubsection{Hoofdstroom (oever)}

Langs de oever zien we sinds 2008 ook een sterke daling, met twee pieken in 2017 en 2018. Wat opvalt is dat de biomassa sinds 2004 voornamelijk uit nuljarige bestaat in plaats van meerjarige blankvoorn zoals in de jaren daarvoor (Figuur 6.17, rechts).

\subsubsection{Zijwateren (open water)}

In de zijwateren lijken de aantallen en biomassa sinds het begin van de monitoring grofweg op te lopen tot 2005 en sindsdien daalt het de aantallen en biomassa van blankvoorn naar niveaus vergelijkbaar met het begin van de monitoring. De daling is zowel in de nuljarige als in de meerjarige blankvoorn te zien (Figuur 6.18, links).

\subsubsection{Zijwateren (oever)}

Net als in de oevers van de hoofdstroom worden er voornamelijk juvenielen gevangen en is er sinds 2008 een daling ingezet, alhoewel er hier voor nuljarige blankvoorn herstel lijkt te zijn vanaf 2017. Oudere blankvoorn wordt minder langs de oevers van de zijwateren gevangen dan langs de oevers van de hoofdstroom (Figuur 6.18, rechts). 

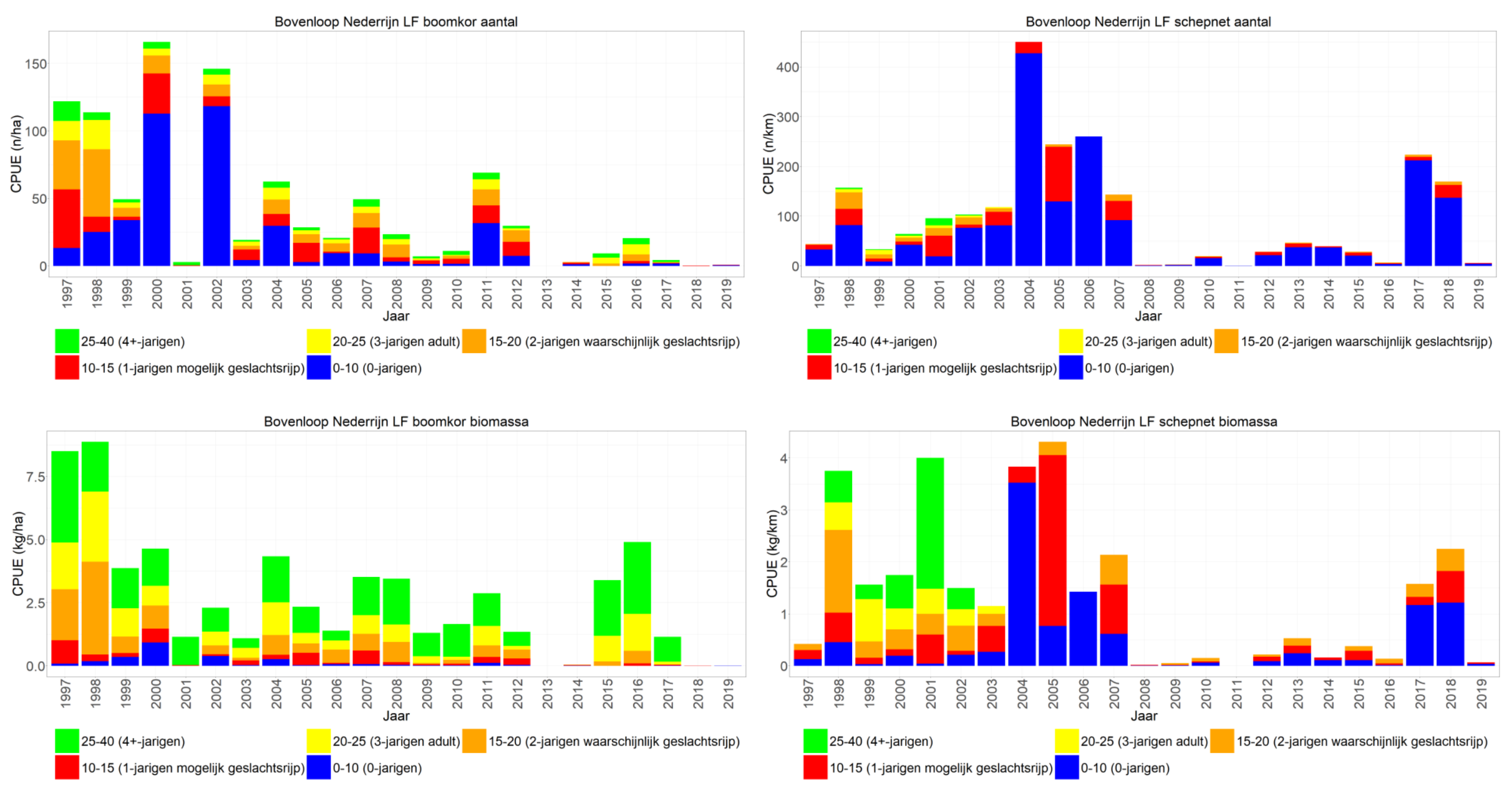

Figuur 6.17 Gemiddelde CPUE ( $\mathrm{n} / \mathrm{km}-\mathrm{n} / \mathrm{ha}$ en $\mathrm{kg} / \mathrm{km}-\mathrm{kg} / \mathrm{ha}$ bevistoppervlak) per jaar met lengteverdeling ( $\mathrm{cm}$ ) van blankvoorn gevangen met de boomkor in het open water en met het elektroschepnet langs de oevers van de Bovenloop Nederrijn. 

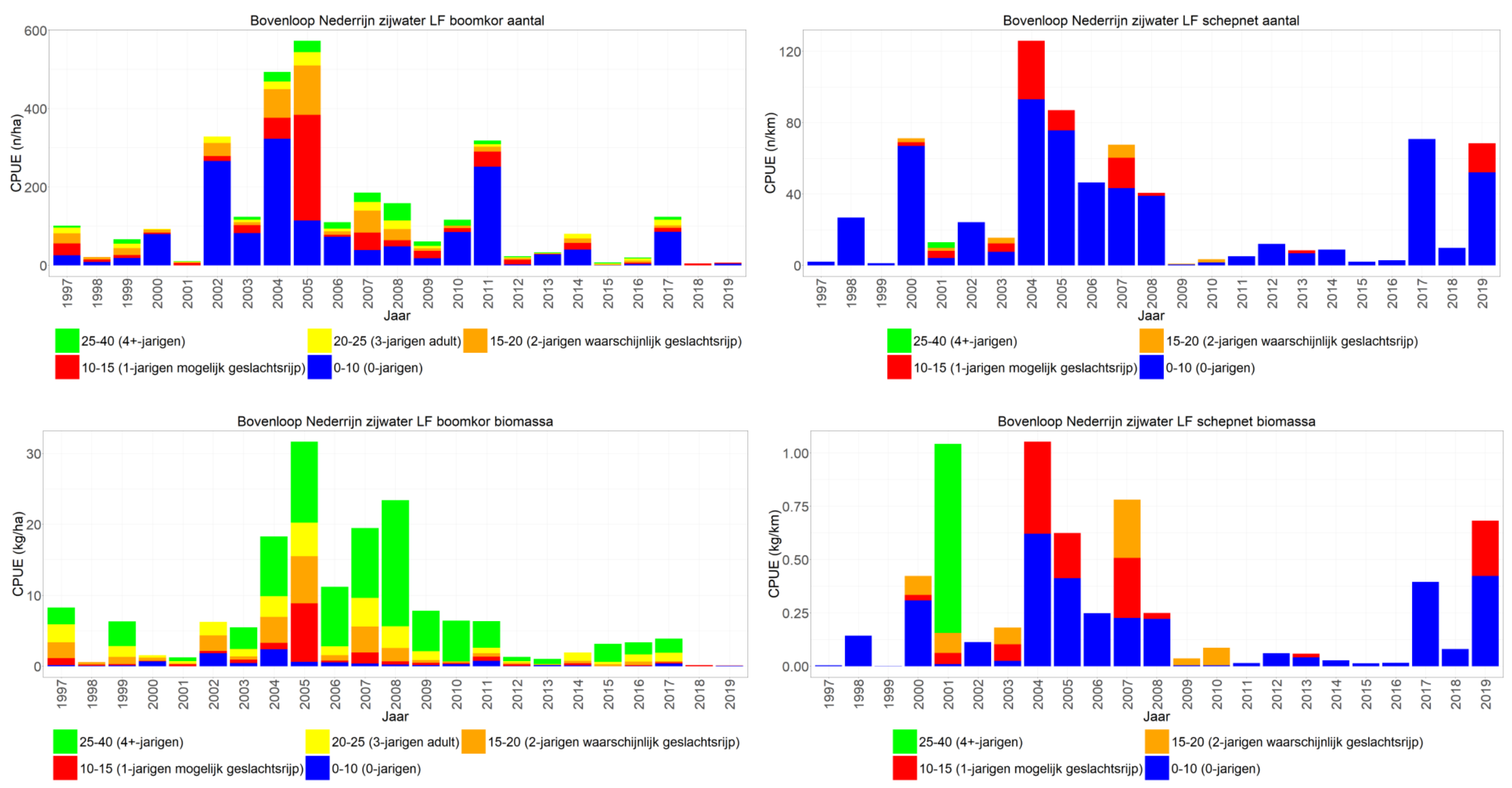

Figuur 6.18 Gemiddelde CPUE ( $\mathrm{n} / \mathrm{km}-\mathrm{n} / \mathrm{ha}$ en $\mathrm{kg} / \mathrm{km}-\mathrm{kg} / \mathrm{ha}$ bevistoppervlak) per jaar met lengteverdeling ( $\mathrm{cm}$ ) van blankvoorn gevangen met de boomkor in de zijwateren en met het elektroschepnet langs de oevers van de Bovenloop Nederrijn. 


\subsection{Bovenloop Waal}

\subsubsection{Hoofdstroom (open water)}

Blankvoorn laat sinds het begin van de monitoring een relatief stabiele trend zien tot 2012 waarna zowel de aantallen als de biomassa afnemen. Ook in dit water lijkt dit voornamelijk door een afname van meerjarige blankvoorn te komen. In de periode 2016-2018 lijkt er een kleine opleving te zijn (Figuur 6.19 , links).

\subsubsection{Hoofdstroom (oever)}

Langs de oevers is vanaf 2005 ook een afname te zien met name door de afname van meerjarige blankvoorn. Ook hier lijkt er een opleving in de periode 2015-2019 te zijn, maar er worden in deze periode nog geen oudere individuen gevangen zoals in de periode voor 2005 (Figuur 6.19, rechts).

\subsubsection{Zijwateren (open water)}

De vangsten van de zijwateren lijken relatief stabiel te zijn zowel qua aantal als qua biomassa met een uitschieter qua aantallen in 2010. Er lijkt de laatste jaren zelf een lichte toename te zijn waarbij er wat meer oudere individuen worden gevangen (Figuur 6.20, links).

\subsubsection{Zijwateren (oever)}

Langs de oevers van de zijwateren zien wel we een afname van met name de biomassa vanaf 2005, welke voornamelijk veroorzaakt wordt door een afname van meerjarige blankvoorn (Figuur 6.20, rechts). 

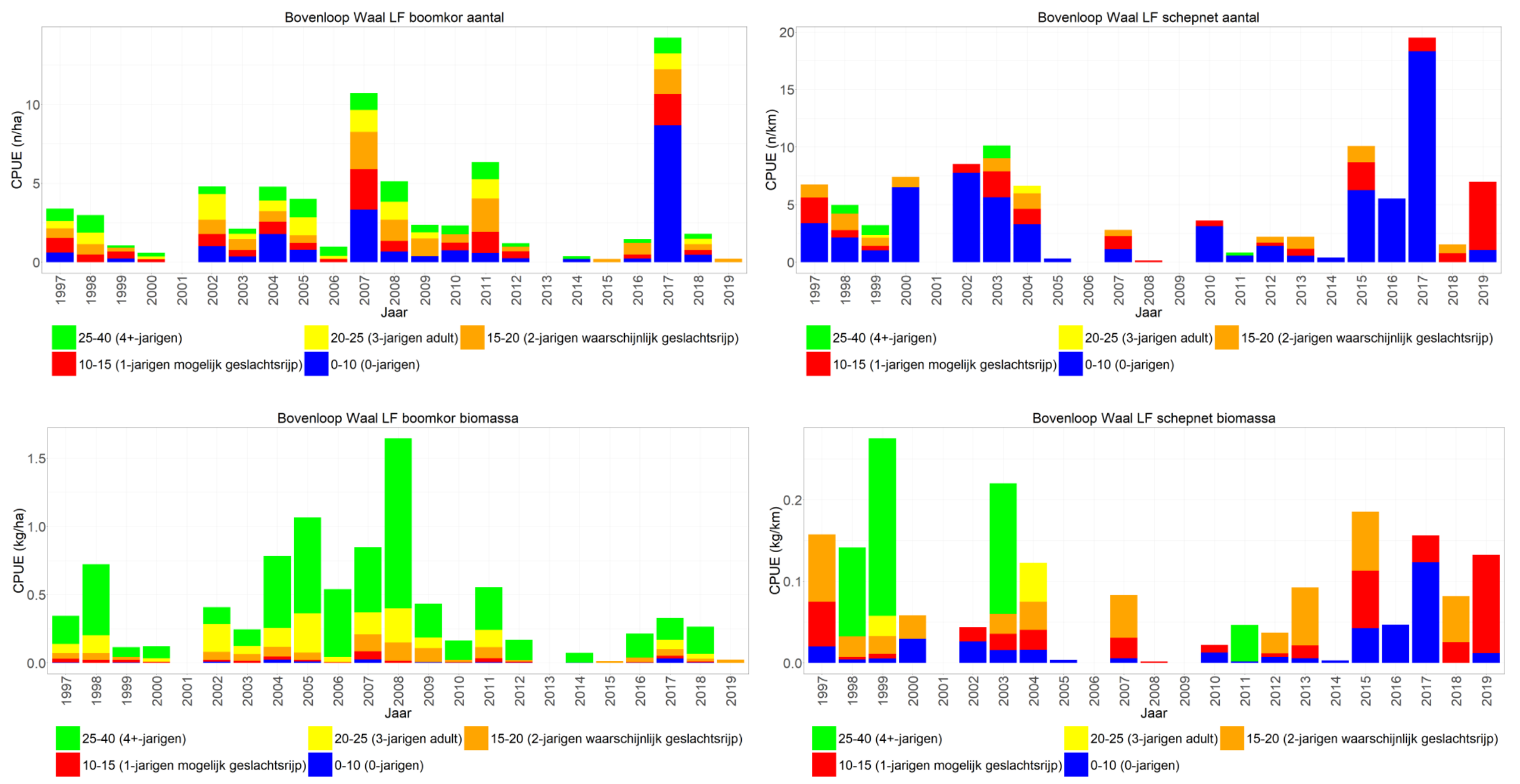

Figuur 6.19 Gemiddelde CPUE ( $\mathrm{n} / \mathrm{km}-\mathrm{n} / \mathrm{ha}$ en $\mathrm{kg} / \mathrm{km}-\mathrm{kg} / \mathrm{ha}$ bevistoppervlak) per jaar met lengteverdeling ( $\mathrm{cm}$ ) van blankvoorn gevangen met de boomkor in het open water en met het elektroschepnet langs de oevers van de Bovenloop Waal. 

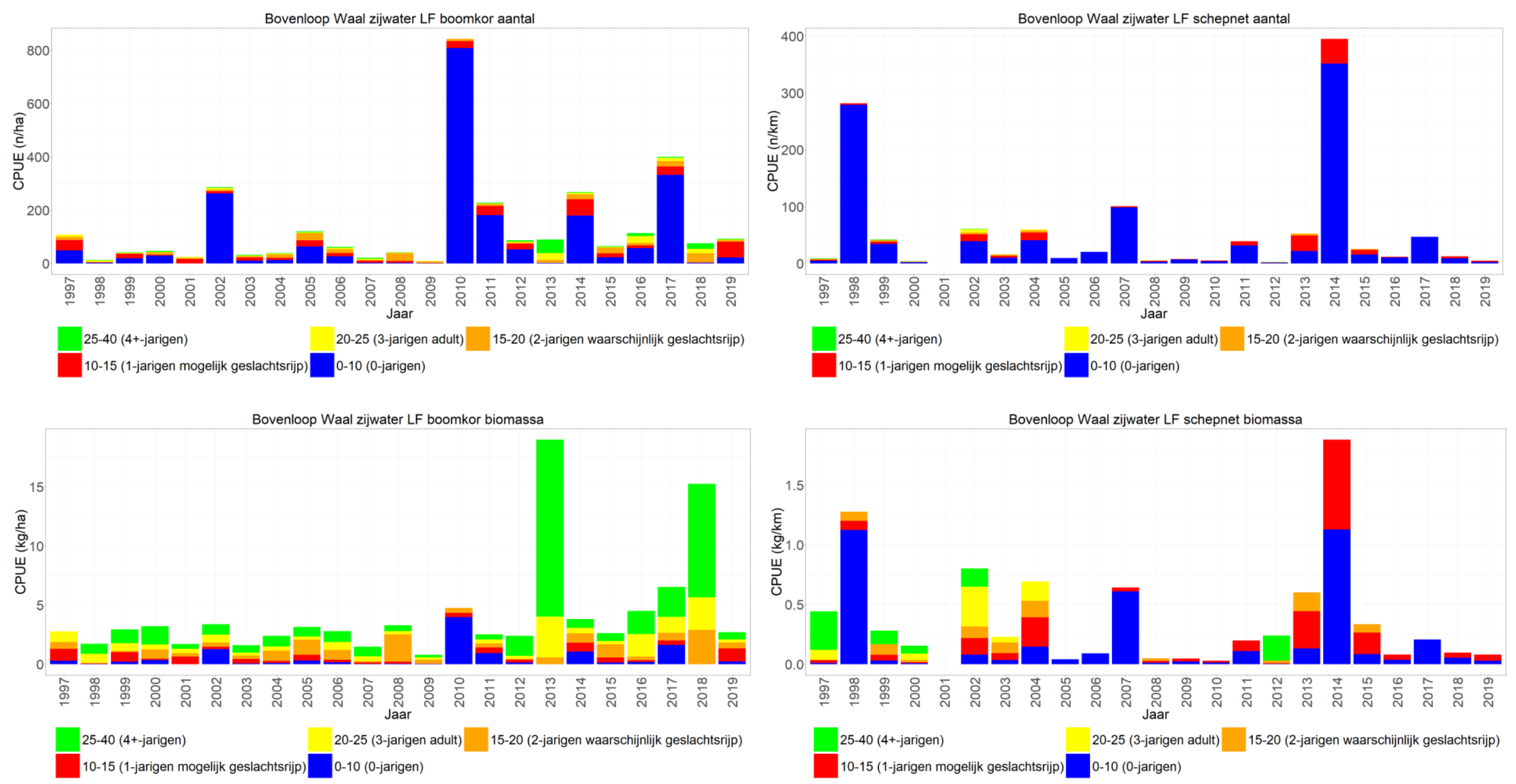

Figuur 6.20 Gemiddelde CPUE (n/km-n/ha en kg/km-kg/ha bevistoppervlak) per jaar met lengteverdeling ( $\mathrm{cm}$ ) van blankvoorn gevangen met de boomkor in de zijwateren en met het elektroschepnet langs de oevers van de Bovenloop Waal. 


\subsection{Benedenloop Nederrijn}

\subsubsection{Hoofdstroom (open water)}

In de Benedenloop Nederrijn wordt relatief weinig blankvoorn gevangen in de hoofdstroom en zijn de vangsten erg wisselvallig. Soms bestaat de vangst volledig uit nuljarigen $(2014,2018)$ en soms grotendeels uit meerjarige individuen (2019). Er is dan ook geen duidelijke trend waarneembaar alhoewel er de laatste twee jaar zeer weinig blankvoorn is gevangen (Figuur 6.21, links).

\subsubsection{Hoofdstroom (oever)}

Langs de oevers is ook geen duidelijke trend waarneembaar en bestaan de vangsten voornamelijk uit nuljarigen (Figuur 6.21, rechts).

\subsubsection{Zijwateren (open water)}

In de zijwateren wordt er meer blankvoorn gevangen dan in de hoofdstroom. Wat opvalt is dat zowel de aantallen als de biomassa voornamelijk bestaan uit meerjarige blankvoorn, zeker de laatste twee jaar. Ook in de zijwateren zijn de vangsten sterk wisselvallig en is er nauwelijks een trend te onderscheiden (Figuur 6.22, links).

\subsubsection{Zijwateren (oever)}

Langs de oevers worden voornamelijk juvenielen gevangen met elektrisch schepnet. Ook hier is er door de wisselvalligheid van de vangstengeen trend te onderscheiden (Figuur 6.22, rechts). 

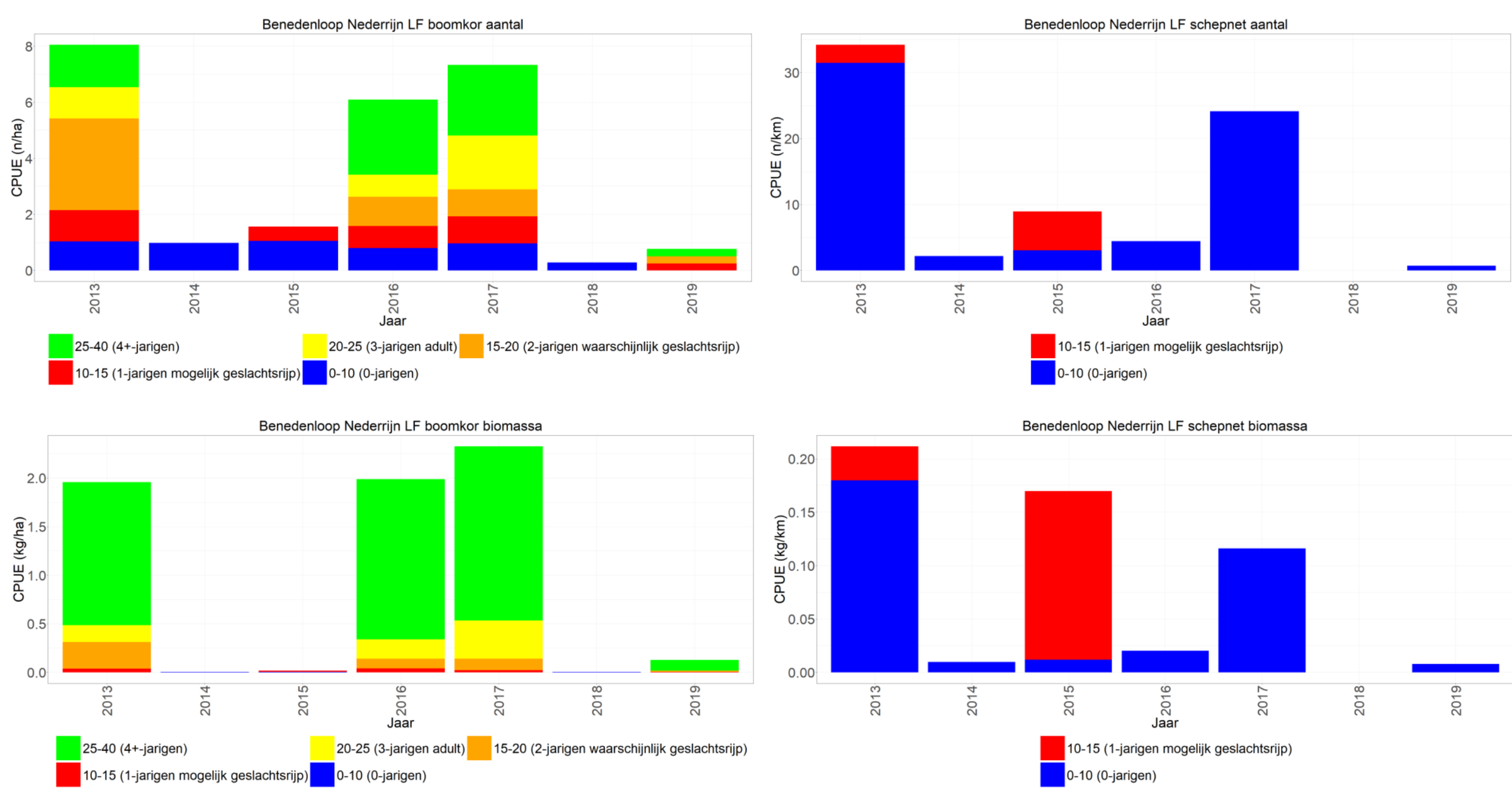

Figuur 6.21 Gemiddelde CPUE (n/km-n/ha en kg/km-kg/ha bevistoppervlak) per jaar met lengteverdeling (cm) van blankvoorn gevangen met de boomkor in het open water en met het elektroschepnet langs de oevers van de Benedenloop Nederrijn. 

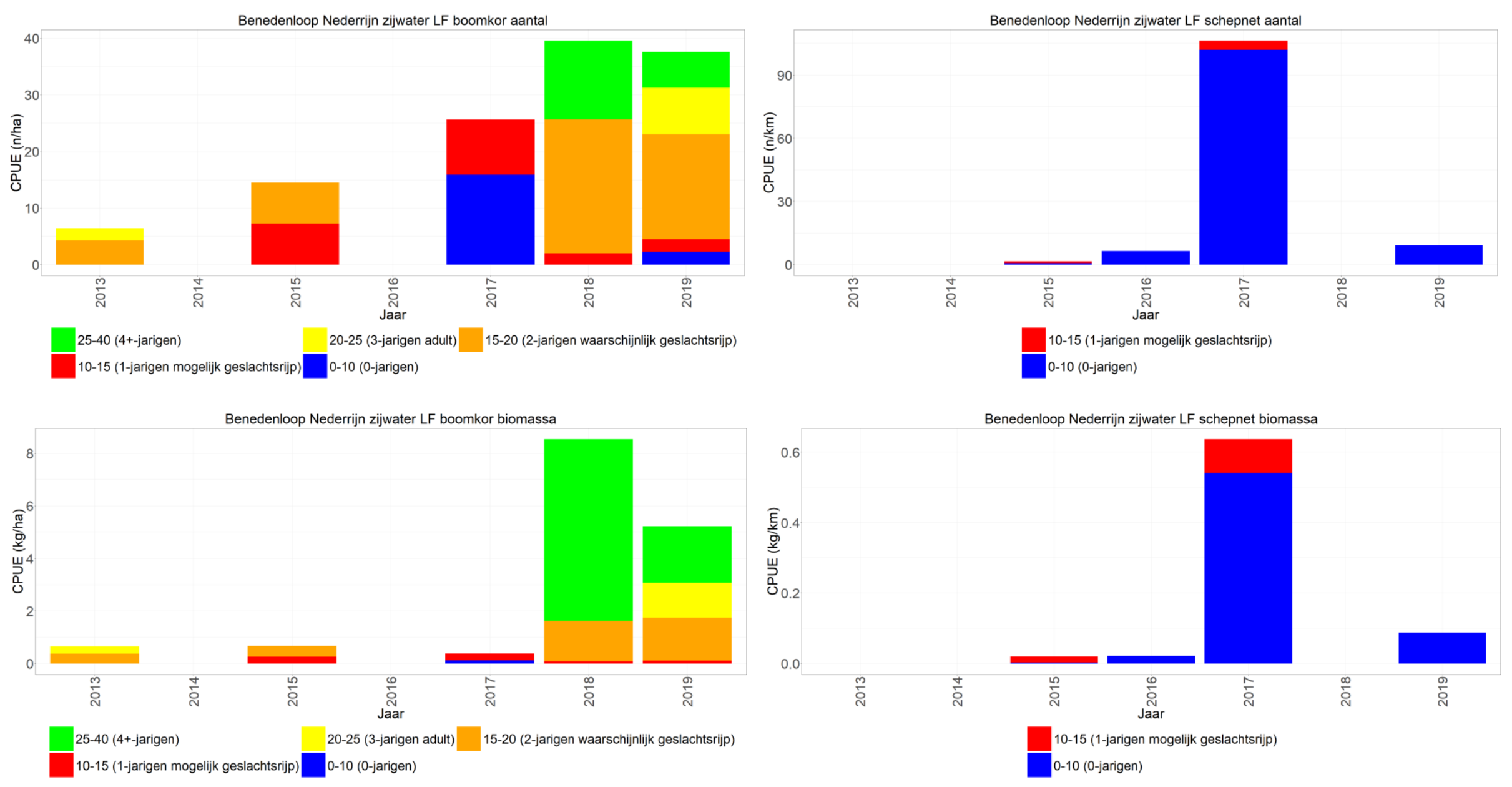

Figuur 6.22 Gemiddelde CPUE (n/km-n/ha en kg/km-kg/ha bevistoppervlak) per jaar met lengteverdeling (cm) van blankvoorn gevangen met de boomkor in de zijwateren en met het elektroschepnet langs de oevers van de Benedenloop Nederrijn. 


\subsection{Benedenloop Waal}

\subsubsection{Hoofdstroom (open water)}

Blankvoorn in de hoofdstroom van de Benedenloop Waal fluctueert en lijkt relatief stabiel qua aantal en biomassa door de tijd heen. De lage hoeveelheden in 2019 zouden kunnen komen doordat er in dat jaar vanwege verhoogde waterstand veel trajecten zijn verplaatst, verkort of zelfs vervallen waardoor dit jaar niet geheel representatief is. De blankvoorn vangsten bestaan voornamelijk uit meerjarige individuen (Figuur 6.23, links).

\subsubsection{Hoofdstroom (oever)}

De vangsten langs de oever lijken ook relatief stabiel waarbij de vangsten voornamelijk uit nuljarige blankvoorn bestaan (Figuur 6.23, rechts).

\subsubsection{Zijwateren (open water)}

In de zijwateren zien we een vergelijkbaar beeld als in de hoofdstroom; blankvoorn is relatief stabiel waarbij de biomassa voornamelijk uit meerjarige individuen bestaat. De aantallen bestaan hier echter voor een groter deel uit nuljarigen dan in de hoofdstroom. Daarnaast zijn de gevangen hoeveelheden ook groter in de zijwateren dan in de hoofdstroom (Figuur 6.24, links).

\subsubsection{Zijwateren (oever)}

Langs de oever van de zijwateren wordt voornamelijk nuljarige blankvoorn gevangen waarbij de vangsten een relatief stabiel beeld geven. 2018 en 2019 laten relatief lage vangsten zien, maar er wordt getwijfeld aan de representativiteit van de vangsten met het schepnet in deze jaren vanwege de hoge waterstand (Figuur 6.24, rechts). 

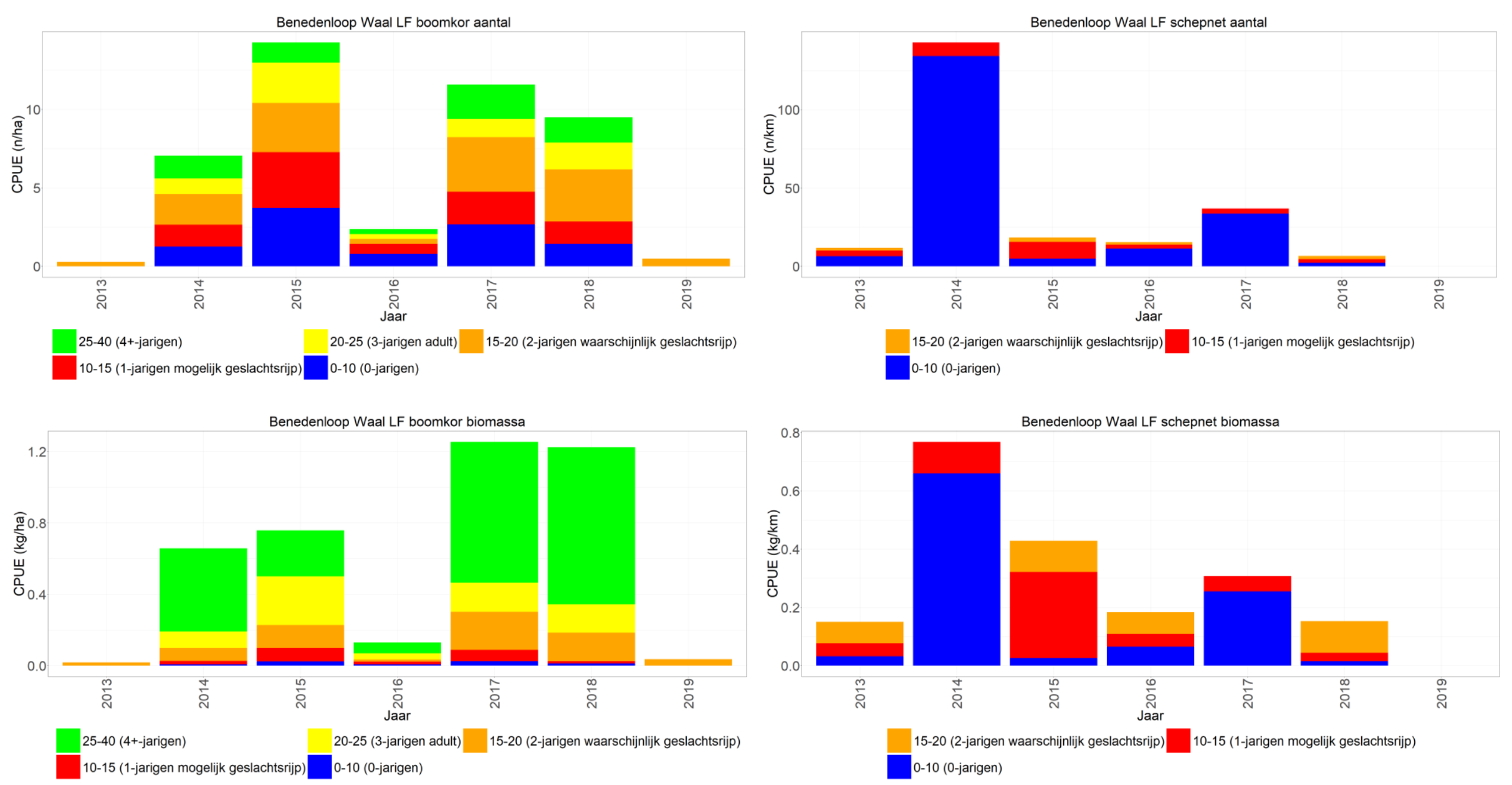

Figuur 6.23 Gemiddelde CPUE ( $\mathrm{n} / \mathrm{km}-\mathrm{n} / \mathrm{ha}$ en $\mathrm{kg} / \mathrm{km}-\mathrm{kg} / \mathrm{ha}$ bevist oppervlak) per jaar met lengteverdeling ( $\mathrm{cm}$ ) van blankvoorn gevangen met de boomkor in het open water en met het elektroschepnet langs de oevers van de Benedenloop Waal. 

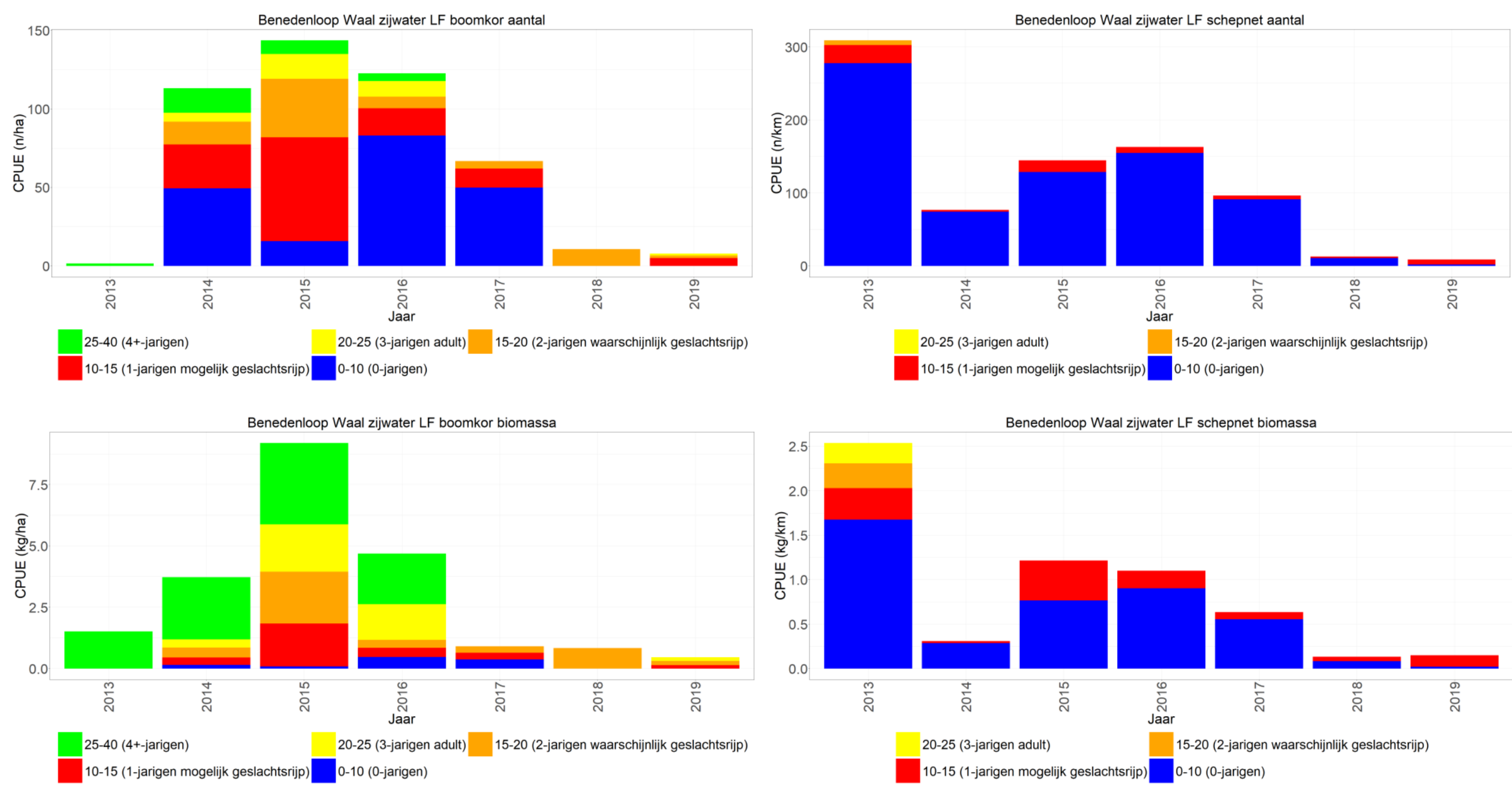

Figuur 6.24 Gemiddelde CPUE (n/km-n/ha en kg/km-kg/ha bevistoppervlak) per jaar met lengteverdeling ( $\mathrm{cm}$ ) van blankvoorn gevangen met de boomkor in de zijwateren en met het elektroschepnet langs de oevers van de Benedenloop Waal. 


\subsection{Getijden Lek}

\subsubsection{Hoofdstroom (open water)}

In de periode 1997-2001 zijn de blankvoornvangsten relatief laag maar nemen deze toe in de periode 2002-2010. Vanaf 2011 is er weer een afname en zijn de aantallen en biomassa vergelijkbaar met de periode 1997-2001. De toe- en afnames worden voornamelijk veroorzaakt door fluctuaties in de hoeveelheden meerjarige blankvoorn, waar de vangsten in de meeste jaren voornamelijk uit bestaan (Figuur 6.25, links).

\subsubsection{Hoofdstroom (oever)}

Langs de oevers is ook een afname in aantallen en biomassa zichtbaar vanaf 2003, hierbij zijn het zowel de nuljarige als de meerjarige blankvoorn die afnemen. Vanaf 2011 is de afname voornamelijk vanwege een afname van meerjarige blankvoorn (Figuur 6.25, rechts).

\subsubsection{Zijwateren (open water)}

In de zijwateren worden grotere hoeveelheden blankvoorn gevangen dan in de hoofdstroom. De afname die zichtbaar is in de hoofdstroom lijkt niet zichtbaar in de zijwateren waarbij. Hier lijken, ondanks sterke jaarlijkse fluctuaties, de vangsten relatief stabiel. De aantallen bestaan voornamelijk uit nuljarigen terwijl de biomassa wordt gedomineerd door de meerjarige blankvoorn (Figuur 6.26, links).

\subsubsection{Zijwateren (oever)}

Langs de oever is wel een afname zichtbaar vanaf 2005 die voornamelijk wordt veroorzaakt door de afname van meerjarige blankvoorn (Figuur 6.26, rechts). 

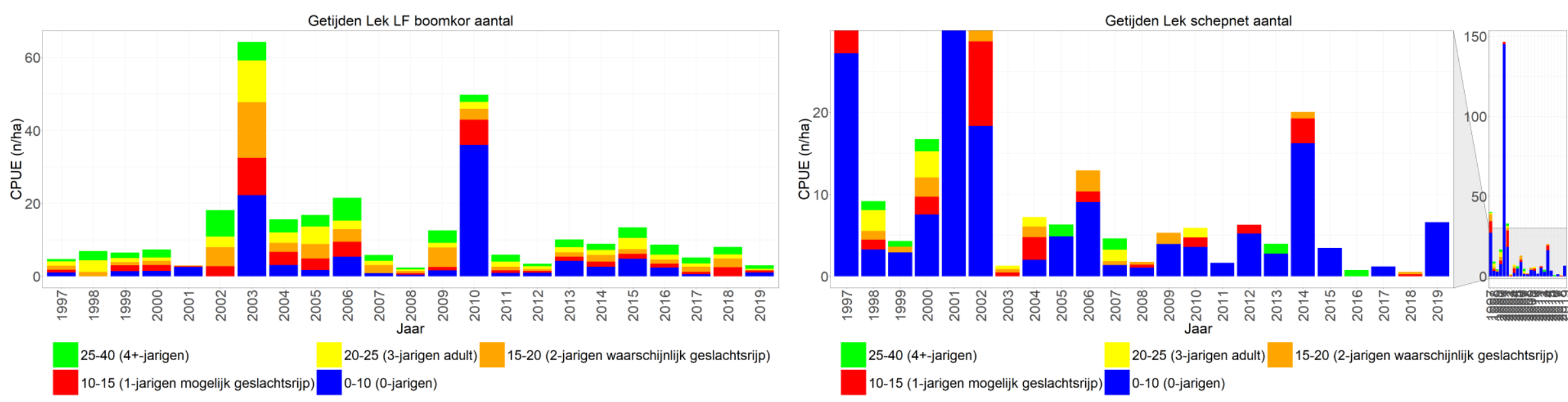

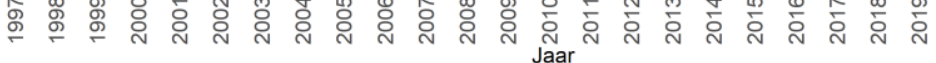

$\cos$

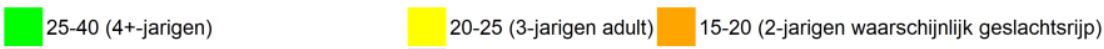

10-15 (1-jarigen mogelijk geslachtsrijp) $\quad$ 0-10 (0-jarigen)
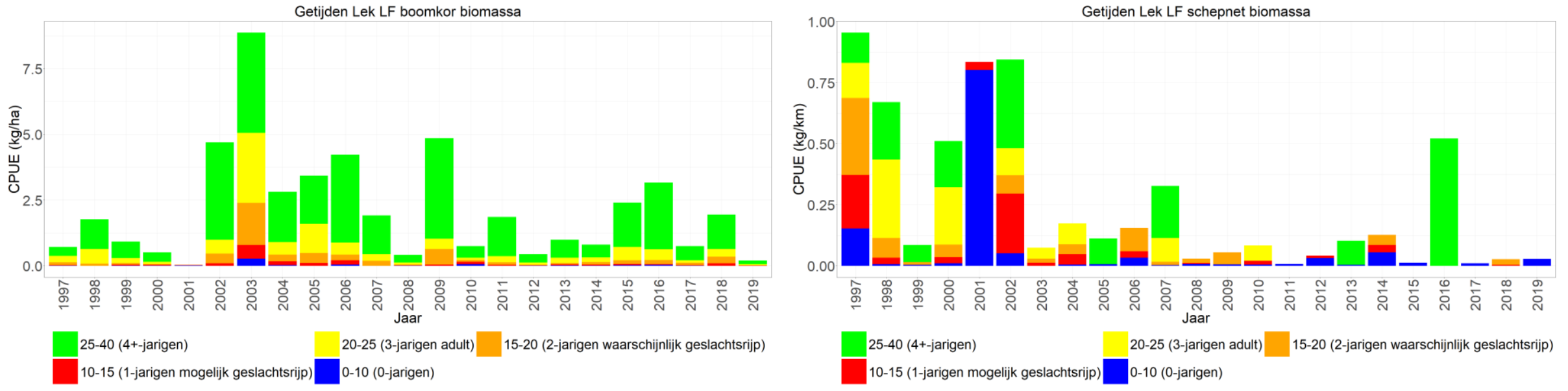

Figuur 6.25 Gemiddelde CPUE ( $\mathrm{n} / \mathrm{km}-\mathrm{n} / \mathrm{ha}$ en $\mathrm{kg} / \mathrm{km}-\mathrm{kg} / \mathrm{ha}$ bevistoppervlak) per jaar met lengteverdeling ( $\mathrm{cm}$ ) van blankvoorn gevangen met de boomkor in het open water en met het elektroschepnet langs de oevers van de Getijden Lek. 

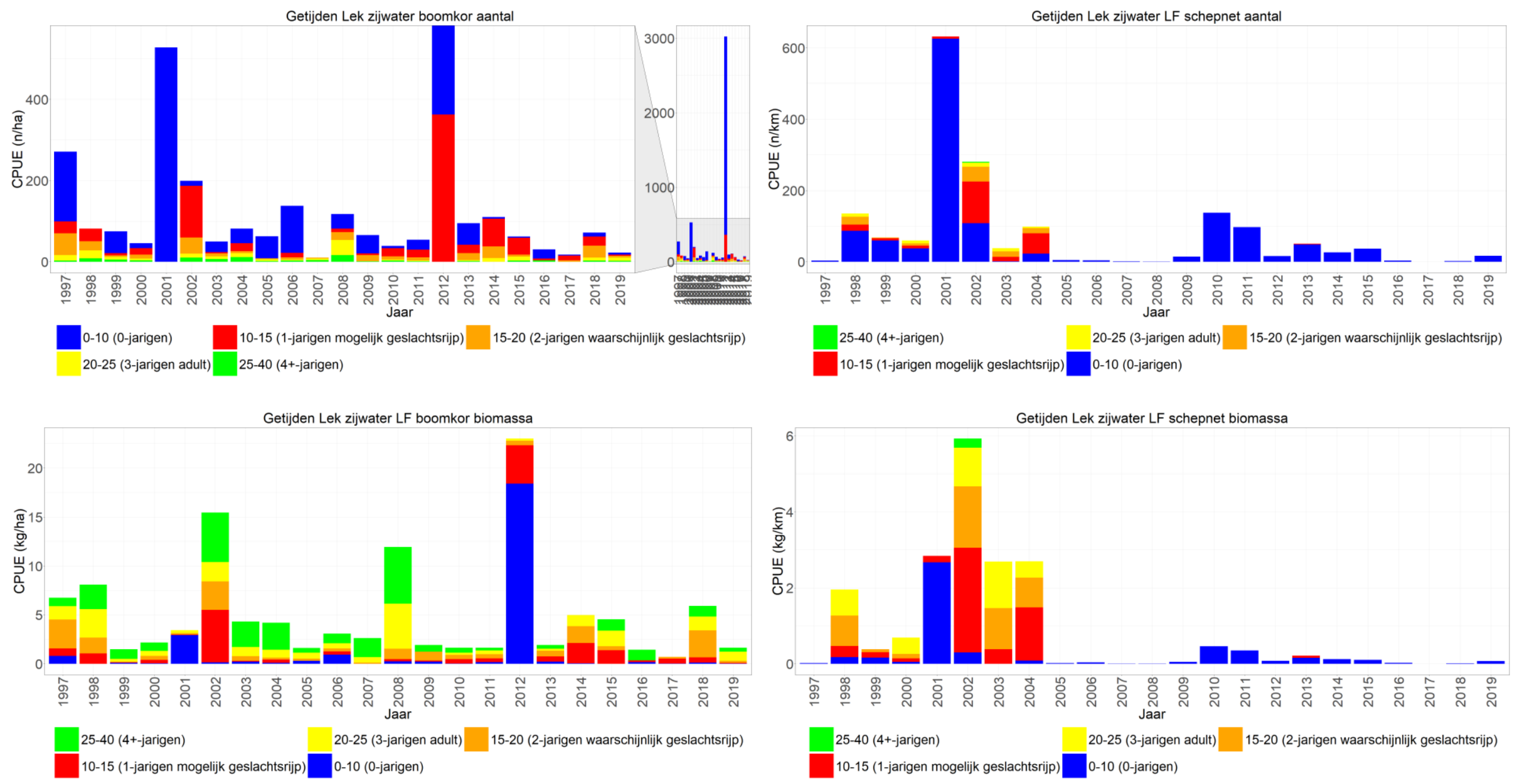

Figuur 6.26 Gemiddelde CPUE ( $\mathrm{n} / \mathrm{km}-\mathrm{n} / \mathrm{ha}$ en $\mathrm{kg} / \mathrm{km}-\mathrm{kg} / \mathrm{ha}$ bevistoppervlak) per jaar met lengteverdeling ( $\mathrm{cm}$ ) van blankvoorn gevangen met de boomkor in de zijwateren en met het elektroschepnet langs de oevers van de Getijden Lek. 


\subsection{Getijden Maas}

\subsubsection{Hoofdstroom (open water)}

Blankvoorn fluctueert sterk in de hoofdstroom van de Getijden Maas en er zijn verschillende periodes van enkele jaren waarin er relatief veel blankvoorn wordt gevangen gevolgd door perioden waarin er relatief weinig wordt gevangen. Vanaf 2009 lijken de aantallen relatief lager te blijven. Wat opvalt is dat, in de jaren wanneer de biomassa voor een groot deel uit oudere individuen bestaat (zoals 2006 en 2008), er ook veel nuljarige worden gevangen, wat een indicatie zou kunnen zijn dat deze oudere individuen van belang zijn voor het paaibestand (Figuur 6.27, links).

\subsubsection{Hoofdstroom (oever)}

Langs de oevers worden vrijwel alleen maar nuljarigen gevangen, behalve in de eerste drie jaar van de monitoring. De vangsten van de oevers fluctueren ook sterk en er is geen duidelijke trend zichtbaar, behalve dat er van 2016-2018 nauwelijks blankvoorn wordt (Figuur 6.27, rechts).

\subsubsection{Zijwateren (open water)}

Ook in de zijwateren zijn vangsten van blankvoorn wisselvallig en vanaf 2009 lijkt er een afname te zijn waarna de vangsten op twee jaren na laag blijven. Deze afname lijkt zowel door een afname in de nuljarige als in de meerjarige blankvoorn veroorzaakt te worden. De aantallen worden gedomineerd door nuljarigen en de biomassa in sommige jaren ook (Figuur 6.28, links).

\subsubsection{Zijwateren (oever)}

Net als in de hoofdstroom werd er in de eerste drie jaar van de monitoring van de oevers nog relatief veel meerjarige blankvoorn gevangen die de biomassa domineerde, sindsdien bestaan de vangsten voornamelijk uit nuljarigen. In 2004 valt op dat er extreem veel nuljarigen zijn gevangen en in 2019 werd er ook relatief veel blankvoorn gevangen. Net als in het open water van de zijwateren lijken de vangsten na 2009 gemiddeld lager (Figuur 6.28, rechts). 
Getijden Maas LF boomkor aantal

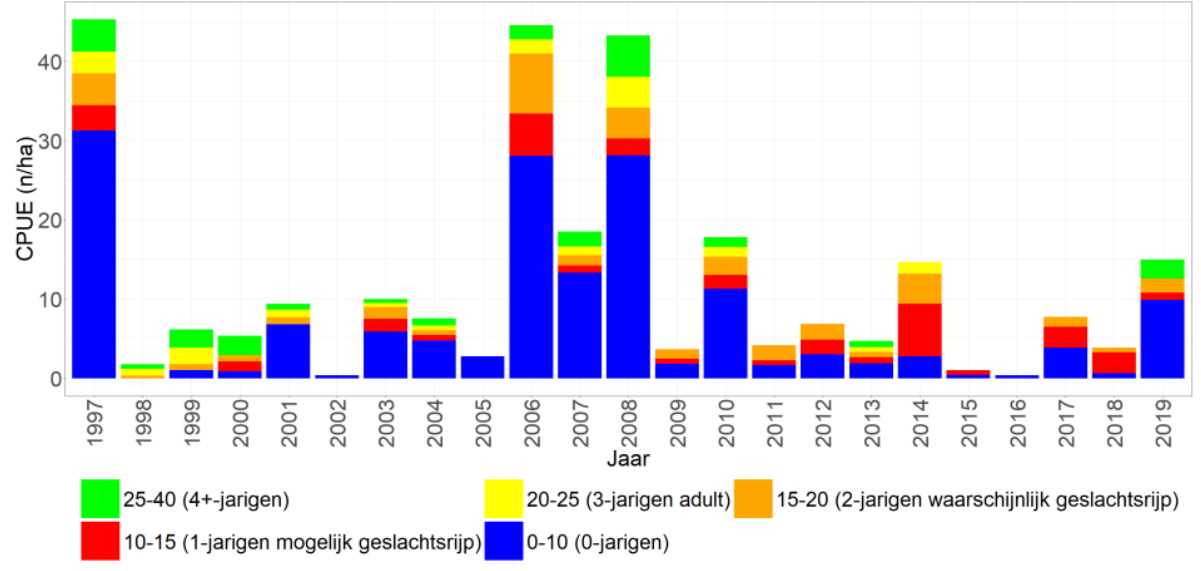

Getijden Maas LF boomkor biomassa

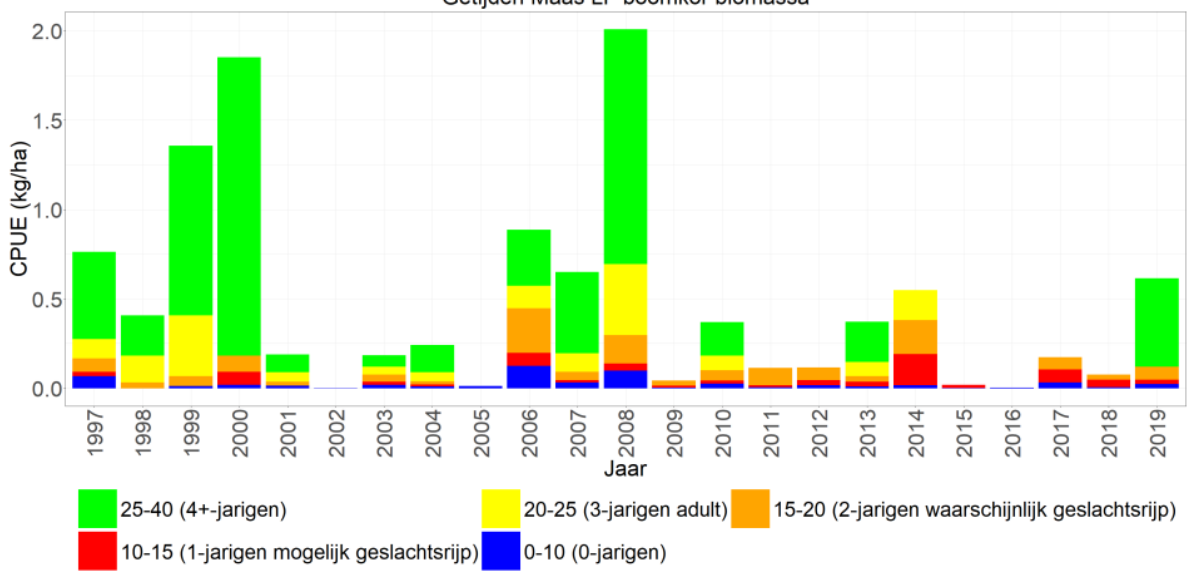

Getijden Maas LF schepnet aanta
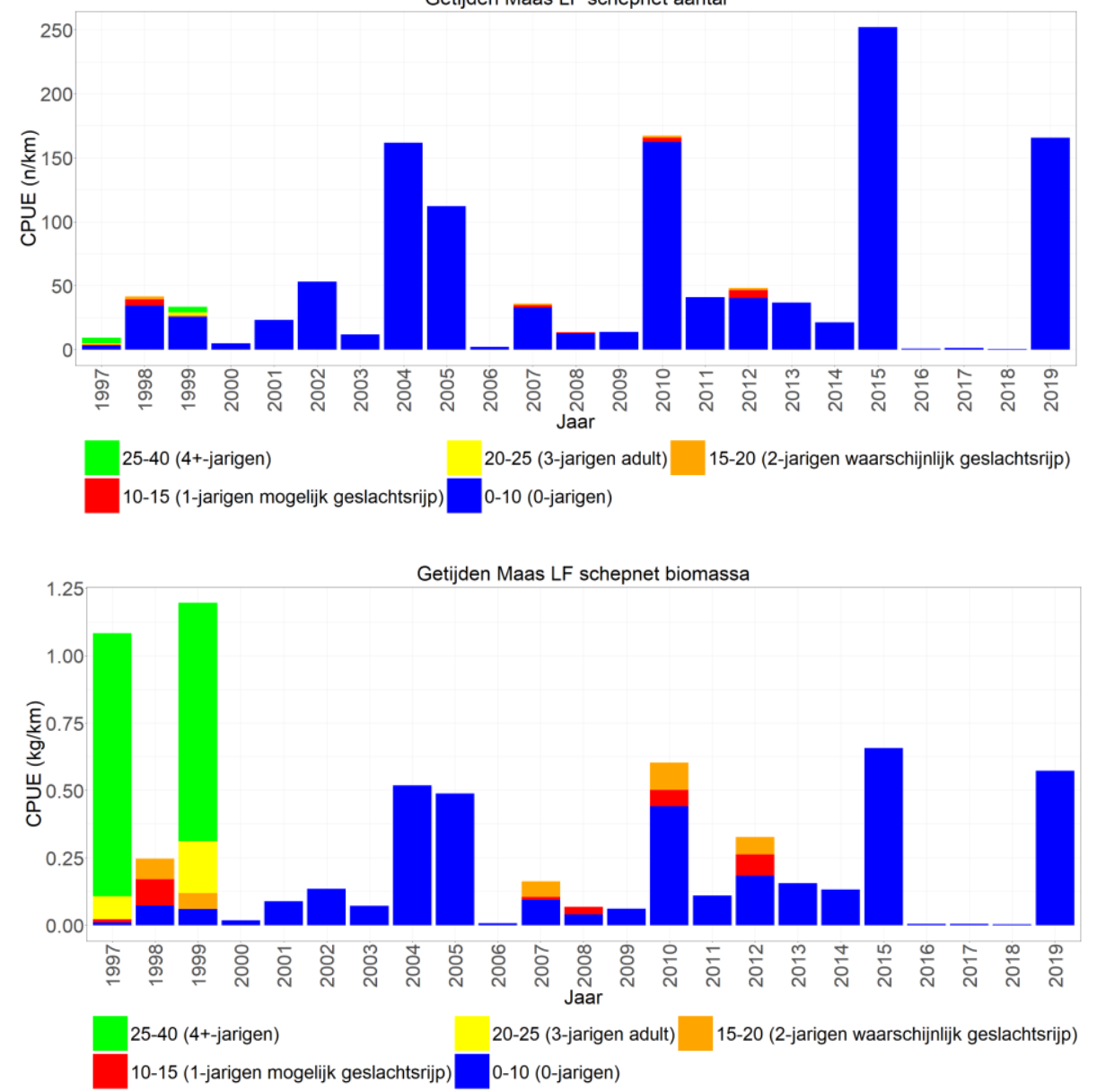

Figuur 6.27 Gemiddelde CPUE (n/km-n/ha en kg/km-kg/ha bevistoppervlak) per jaar met lengteverdeling ( $\mathrm{cm}$ ) van blankvoorn gevangen met de boomkor in het open water en met het elektroschepnet langs de oevers van de Getijden Maas. 

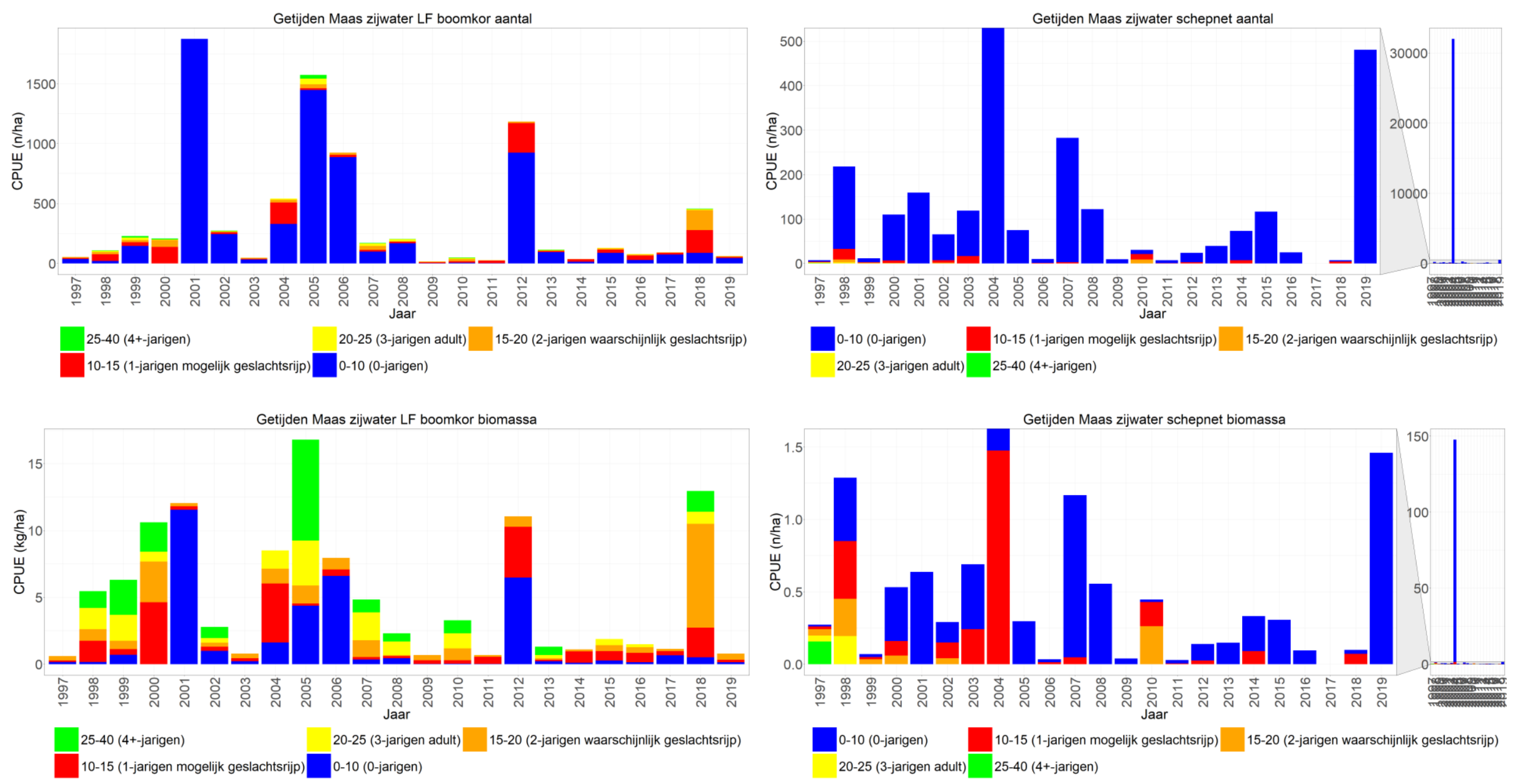

Figuur 6.28 Gemiddelde CPUE (n/km-n/ha en kg/km-kg/ha bevistoppervlak) per jaar met lengteverdeling ( $\mathrm{cm}$ ) van blankvoorn gevangen met de boomkor in de zijwateren en met het elektroschepnet langs de oevers van de Getijden Maas. 


\subsection{Afgedamde Maas}

\subsubsection{Hoofdstroom (open water)}

De vangsten in de hoofdstroom van de Afgedamde Maas zijn wisselvallig en er is geen duidelijk trend zichtbaar. Wat opvalt is dat de piek van aantallen in het begin van de monitoring voornamelijk uit meerjarige blankvoorn bestaat (Figuur 6.29, links).

\subsubsection{Hoofdstroom (oever)}

Voor de blankvoornvangsten langs de oever zien we eenzelfde wisselvallig beeld waarbij er geen duidelijke trend zichtbaar is en er voornamelijk juvenielen worden gevangen. In 2019 is tot nog toe de meeste blankvoorn gevangen (Figuur 6.29, rechts).

\subsubsection{Zijwateren (open water)}

Net als in veel andere KRW-lichamen wordt er in de zijwateren van de Afgedamde Maas meer blankvoorn gevangen dan in de hoofdstroom. Wat opvalt is dat zowel de aantallen als de biomassa voornamelijk bestaan uit 1- \& 2-jarige blankvoorn waar deze in andere KRW-lichamen vaak uit nuljarige blankvoorn bestaan. In 2018 en 2019 worden zeer hoge aantallen en biomassa's gevangen (Figuur 6.30, links).

\subsubsection{Zijwateren (oever)}

Langs de oevers worden er voornamelijk nuljarigen gevangen en zijn de vangsten wisselvallig (Figuur 6.30 , rechts). 

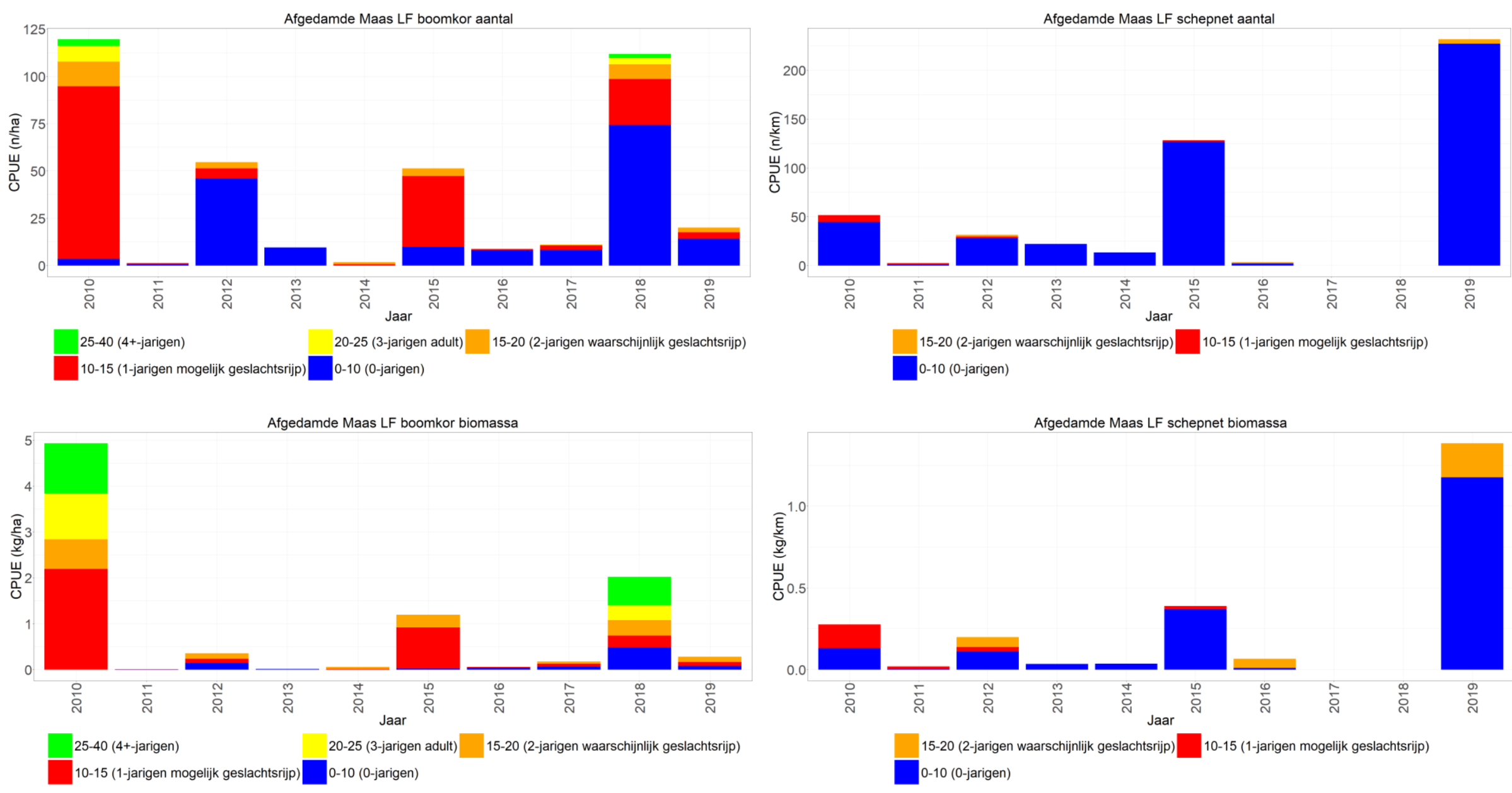

Figuur 6.29 Gemiddelde CPUE ( $\mathrm{n} / \mathrm{km}-\mathrm{n} / \mathrm{ha}$ en $\mathrm{kg} / \mathrm{km}-\mathrm{kg} / \mathrm{ha}$ bevistoppervlak) per jaar met lengteverdeling ( $\mathrm{cm}$ ) van blankvoorn gevangen met de boomkor in het open water en met het elektroschepnet langs de oevers van de Afgedamde Maas. 

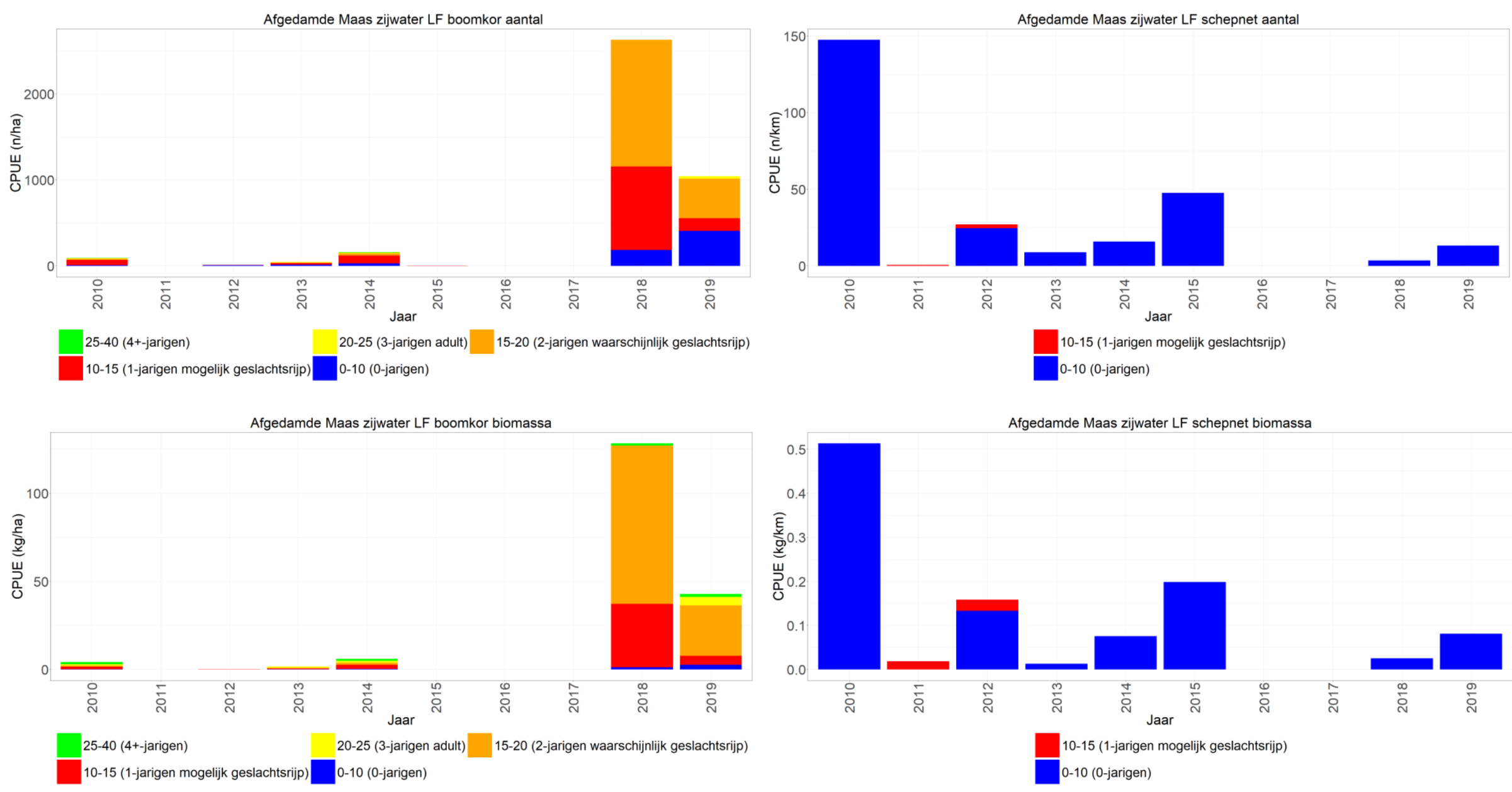

Figuur 6.30 Gemiddelde CPUE ( $\mathrm{n} / \mathrm{km}-\mathrm{n} / \mathrm{ha}$ en $\mathrm{kg} / \mathrm{km}-\mathrm{kg} / \mathrm{ha}$ bevistoppervlak) per jaar met lengteverdeling ( $\mathrm{cm}$ ) van blankvoorn gevangen met de boomkor in de zijwateren en met het elektroschepnet langs de oevers van de Afgedamde Maas. 


\subsection{Heusdensch Kanaal}

\subsubsection{Hoofdstroom}

Wat direct opvalt is dat de aantallen gedomineerd worden door meerjarige blankvoorn terwijl dit in andere KRW-lichamen veelal nuljarige blankvoorn betreft. De vangsten zijn wisselvallig en er is geen duidelijke trend te zien (Figuur 6.31), links.

\subsubsection{Oever}

Langs de oevers van het Heusdensch Kanaal worden voornamelijk nuljarigen met het schepnet gevangen. Sinds 2014 lijken zowel de aantallen als de biomassa van blankvoorn gestaag toe te nemen (Figuur 6.31, rechts). 

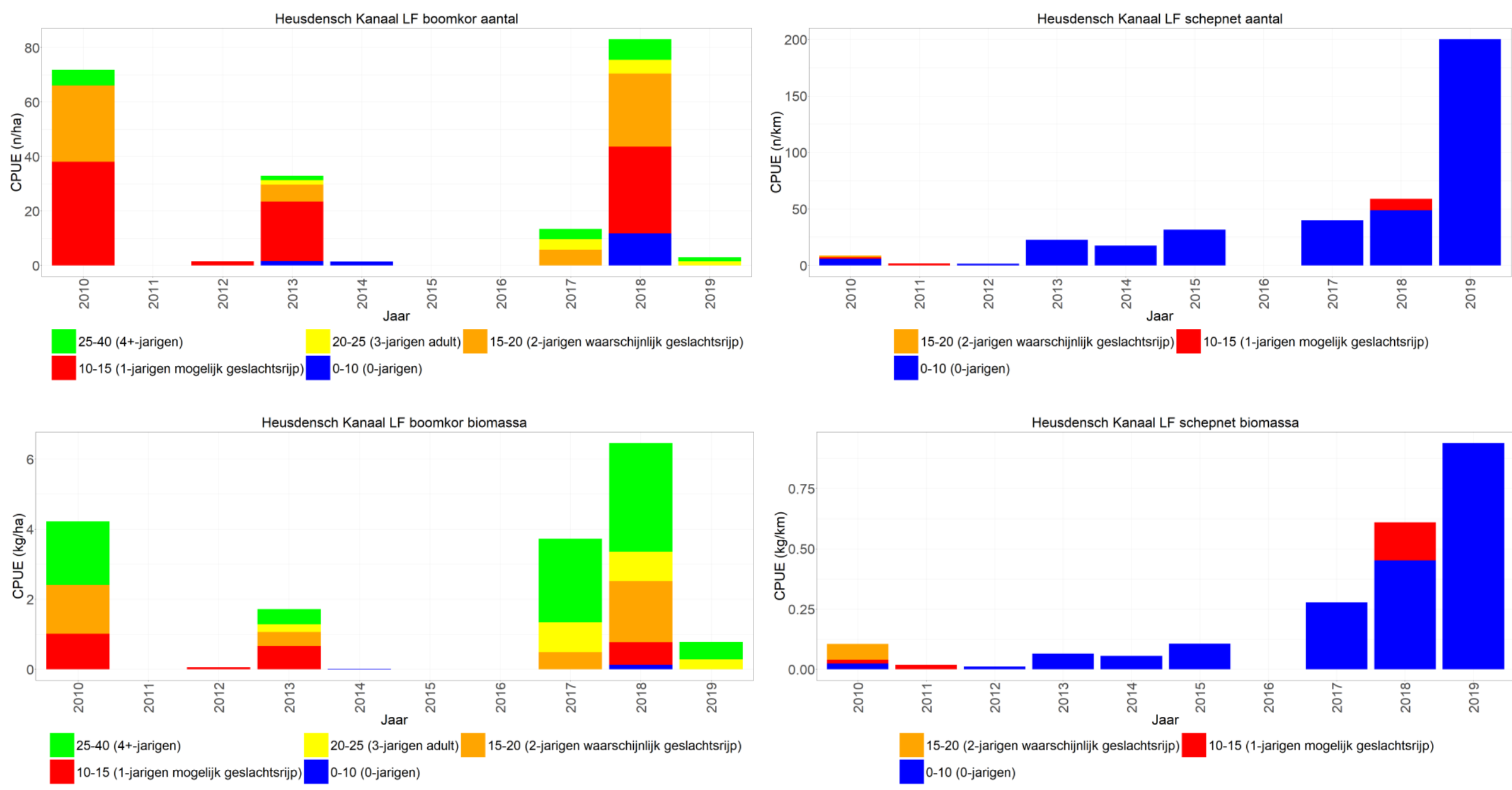

Figuur 6.31 Gemiddelde CPUE (n/km-n/ha en $\mathrm{kg} / \mathrm{km}-\mathrm{kg} / \mathrm{ha}$ bevistoppervlak) per jaar met lengteverdeling ( $\mathrm{cm}$ ) van blankvoorn gevangen met de boomkor in het open water en met het elektroschepnet langs de oevers van de Heusdensch Kanaal. 


\subsection{Noordwaard}

\subsubsection{Oever schepnet}

De Noordwaard wordt sinds 2016 bemonsterd, en er wordt langs de oevers met het schepnet voornamelijk nuljarige en 1-jarige blankvoorn gevangen. De vangsten lijken relatief stabiel door de tijd heen en het valt op dat de biomassa in 2019 mede wordt bepaald door meerjarige blankvoorn in plaats van voornamelijk nul- en 1-jarige blankvoorn (Figuur 6.32, links).

\subsubsection{Oever zegen}

De oevers worden ook met een zegen bemonsterd. Hier zien we ook dat er voornamelijk nul- en 1-jarige blankvoorn wordt gevangen en dat de vangsten per jaar wisselvallig zijn. Ook hier zien we dat de biomassa in 2018 en 2019 grotendeels uit zowel nul- en 1-jarige blankvoorn als meerjarige blankvoorn bestaat (Figuur 6.32, rechts). 

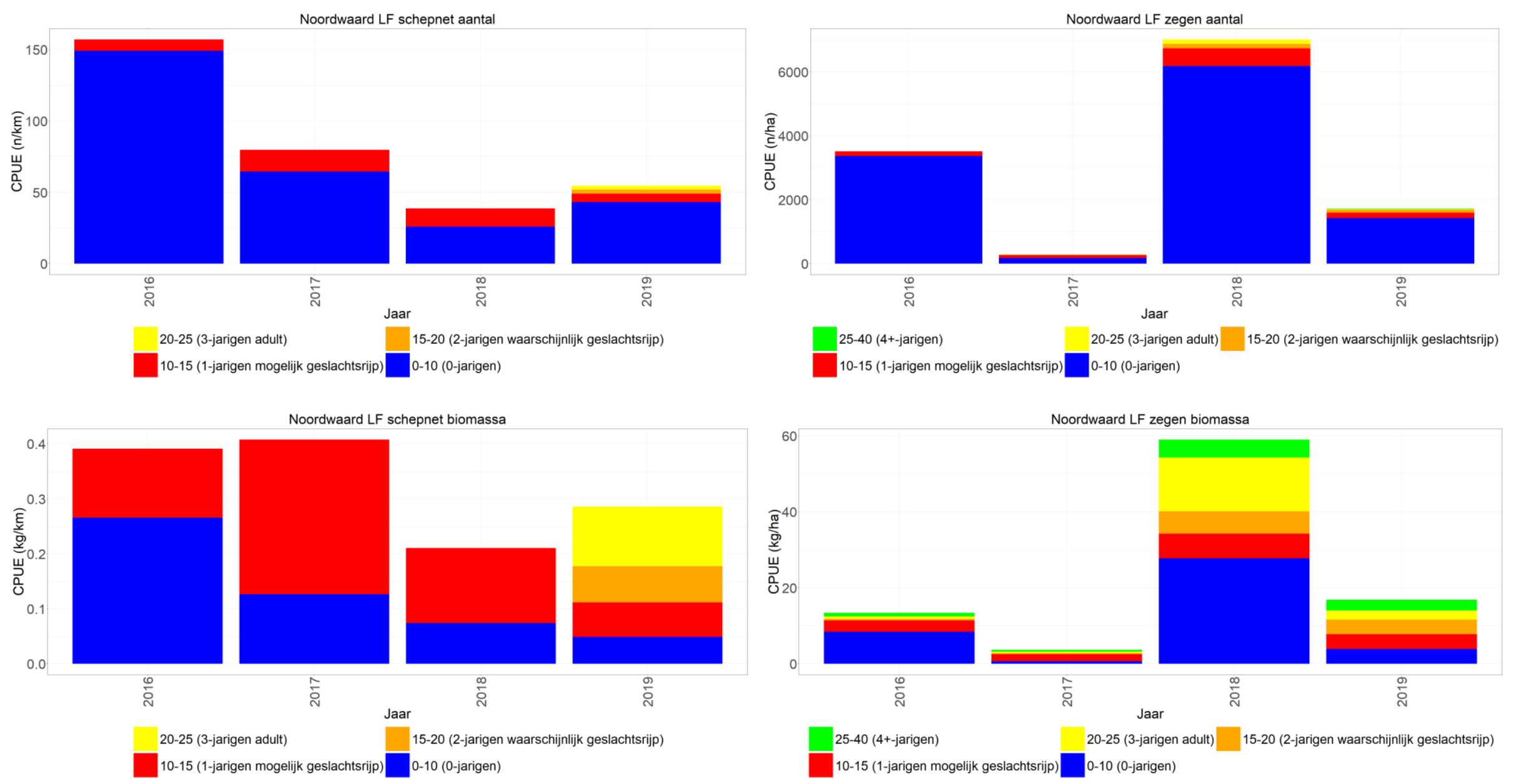

Figuur 6.32 Gemiddelde CPUE ( $\mathrm{n} / \mathrm{km}-\mathrm{n} / \mathrm{ha}$ en $\mathrm{kg} / \mathrm{km}-\mathrm{kg} / \mathrm{ha}$ bevistoppervlak) per jaar met lengteverdeling (cm) van blankvoorn gevangen met het elektroschepnet en de zegen langs de oevers van de Noordwaard. 


\subsection{Nieuwe Merwede}

\subsubsection{Hoofdstroom (open water)}

Blankvoorn in de hoofdstroom van de Nieuwe Merwede laat zowel qua aantal als qua biomassa een stabiel beeld zien. Vanaf 2006 lijkt er een toename te zijn geweest van voornamelijk oudere individuen, welke de laatste paar jaar weer iets af lijken te nemen. De aantallen bestaan voor een relatief groot deel uit meerjarige individuen; deze domineren ook de biomassa. In 2018 is er een piek in aantallen en biomassa door hoge vangsten van nul- en 1-jarige blankvoorn (Figuur 6.33, links).

\subsubsection{Hoofdstroom (oever)}

Langs de oevers wordt voornamelijk nuljarige blankvoorn gevangen, hoewel een groot deel van de biomassa tot 2005 nog bestond uit meerjarige blankvoorn. Door het wegvallen van de meerjarige blankvoorn lijkt de blankvoornbiomassa af te nemen en deze lijkt zich niet te herstellen op wat piekjaren in 2014 en 2015 na (Figuur 6.33, rechts).

\subsubsection{Zijwateren (open water)}

De zijwateren geven een relatief stabiel beeld van blankvoorn door de tijd heen waarbij met de boomkor voornamelijk nuljarigen worden gevangen. Wat opvalt is de enorme piek in aantallen en ook biomassa van nuljarige blankvoorn in 2019 (Figuur 6.34). Deze werden voornamelijk bij de Spieringsluis gevangen die de Nieuwe Merwede met de Brabantsche Biesbosch verbindt. 

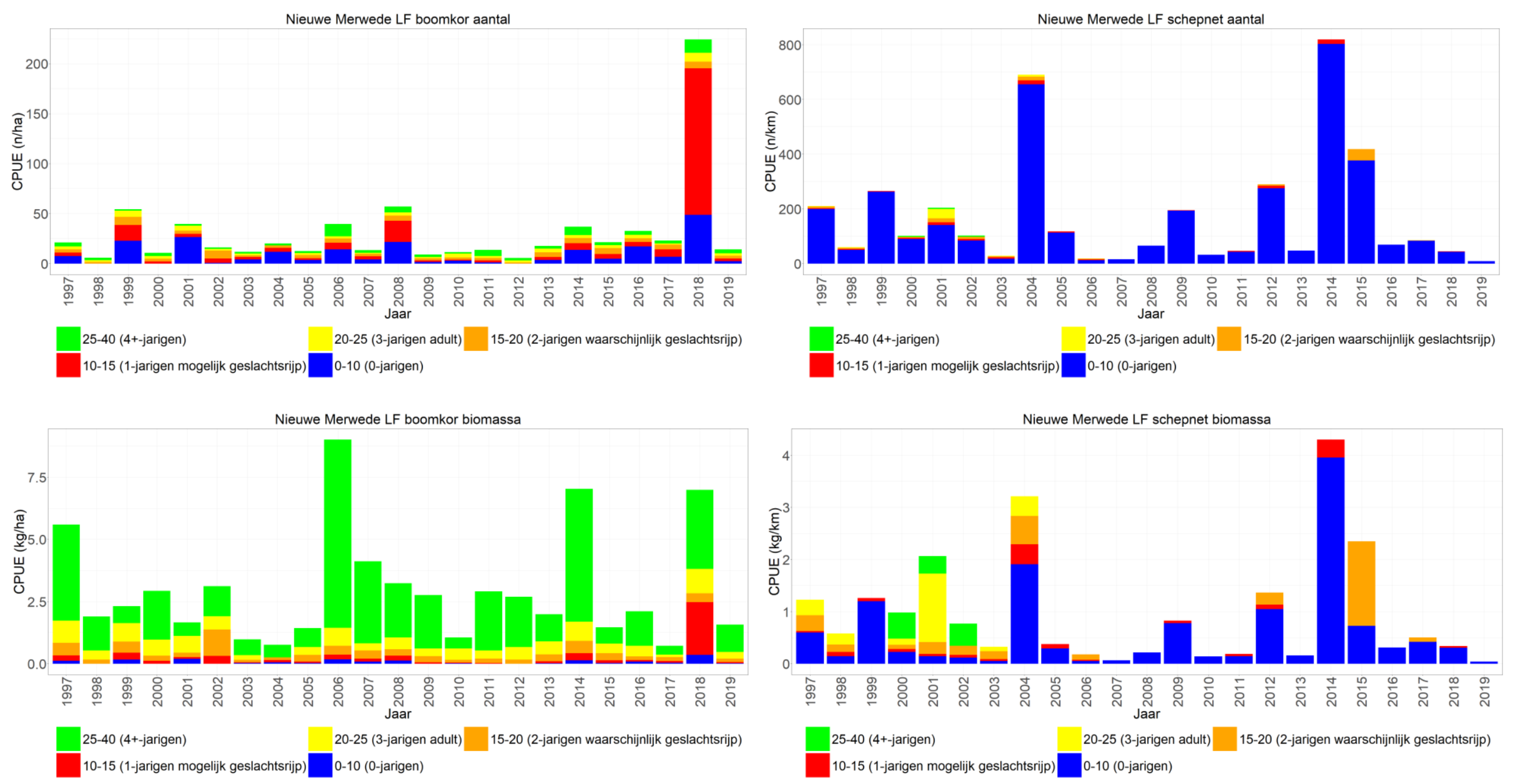

Figuur 6.33 Gemiddelde CPUE ( $\mathrm{n} / \mathrm{km}-\mathrm{n} / \mathrm{ha}$ en $\mathrm{kg} / \mathrm{km}-\mathrm{kg} / \mathrm{ha}$ bevistoppervlak) per jaar met lengteverdeling ( $\mathrm{cm}$ ) van blankvoorn gevangen met de boomkor in het open water en met het elektroschepnet langs de oevers van de Nieuwe Merwede. 

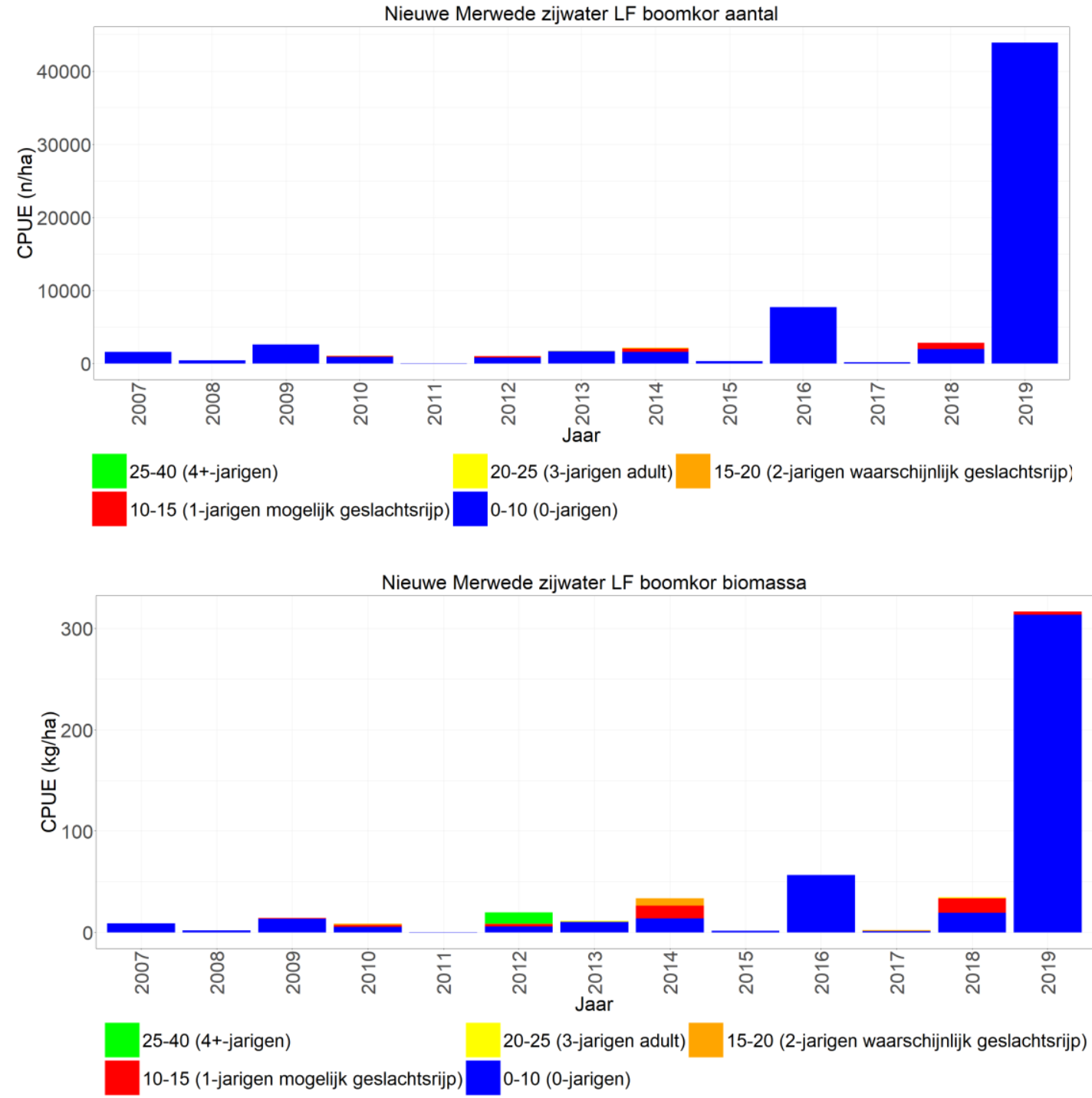

Figuur 6.34 Gemiddelde CPUE (n/ha-kg/ha bevistoppervlak) per jaar met lengteverdeling (cm) van blankvoorn gevangen met de boomkor in de zijwateren van de Nieuwe Merwede.

\subsection{Hollandse IJssel}

\subsubsection{Hoofdstroom}

Sinds 2016 wordt de hoofdstroom van de Hollandsche IJssel bemonsterd waarbij er relatief weinig blankvoorn wordt gevangen. Wat opvalt is dat zowel de aantallen als de biomassa gedomineerd worden door meerjarige blankvoorn. Er lijkt nog geen duidelijke trend in de vangsten door de tijd heen te zijn (Figuur 6.35, links).

\subsubsection{Oever}

Langs de oevers van de Hollande IJssel wordt ook weinig en voornamelijk nuljarige blankvoorn gevangen, tot nog toe zijn deze alleen in 2017 en 2018 gevangen (Figuur 6.35, rechts). 

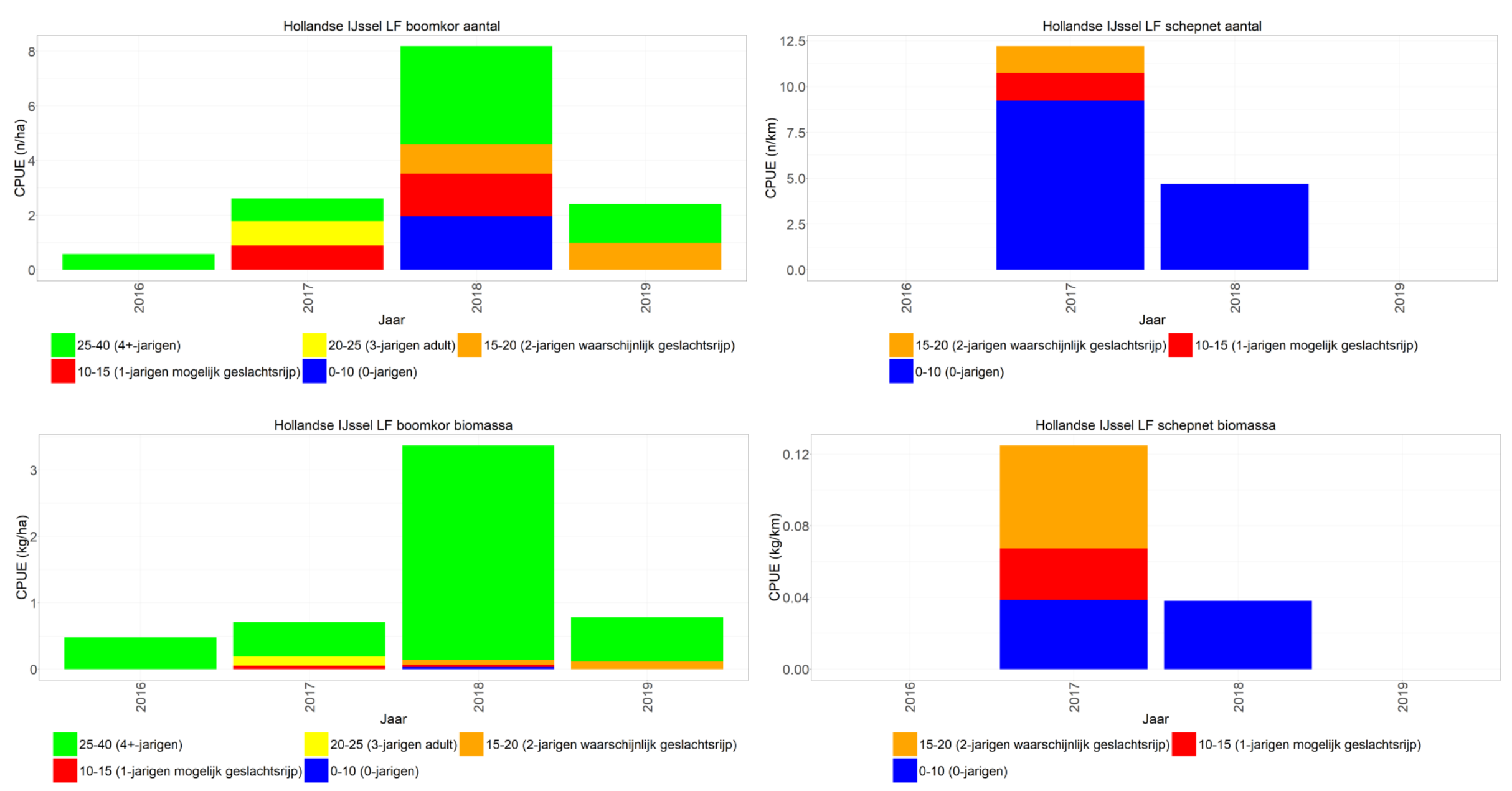

Figuur 6.35 Gemiddelde CPUE ( $\mathrm{n} / \mathrm{km}-\mathrm{n} / \mathrm{ha}$ en $\mathrm{kg} / \mathrm{km}-\mathrm{kg} / \mathrm{ha}$ bevistoppervlak) per jaar met lengteverdeling ( $\mathrm{cm}$ ) van blankvoorn gevangen met de boomkor in het open water en met het elektroschepnet langs de oevers van de Hollandse IJssel. 


\subsection{Oude Maas}

\subsubsection{Hoofdstroom (open water)}

In de hoofdstroom van de Oude Maas wordt relatief weinig blankvoorn gevangen en worden zowel de aantallen als de biomassa gedomineerd door meerjarige blankvoorn. Vanaf 2009 lijkt er een afname te zijn die voornamelijk veroorzaakt wordt door een afname van nuljarige en meerjarige blankvoorn. In 2018 lijkt er een herstel van 0-jarige blankvoorn op te treden met hoge vangsten in 2019 (Figuur 6.36, links).

\subsubsection{Hoofdstroom (oever)}

Net als in sommige andere KRW-lichamen is te zien dat de biomassa langs de oevers in de eerste jaren van de monitoring nog gedomineerd wordt door meerjarige vis maar dat deze binnen nagenoeg verdwijnen. De vangsten blijven erg wisselvallig door de jaren heen en bestaan voornamelijk uit nuljarige blankvoorn (Figuur 6.36, rechts).

\subsubsection{Zijwateren (oever)}

Nuljarige blankvoorn wordt in de zijwateren meer (met het elektrisch schepnet) gevangen dan in de hoofdstroom, iets wat we in meerdere KRW-lichamen zien. De vangsten bestaan hoofdzakelijk uit nuljarige blankvoorn en vanwege de hoge wisselvalligheid van de vangsten is er geen trend waarneembaar (Figuur 6.37). 
Oude Maas LF boomkor aantal
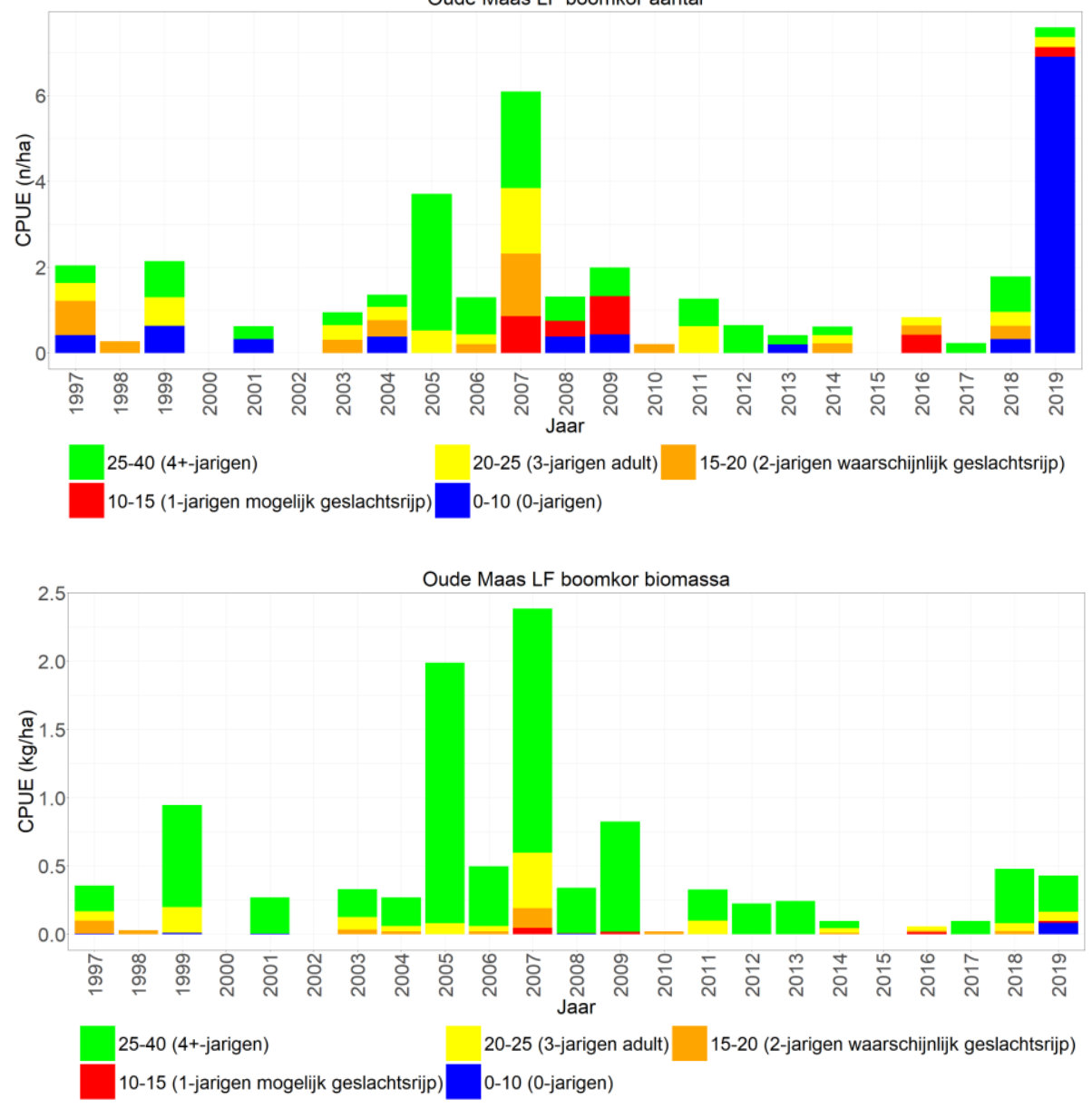

Oude Maas LF schepnet aantal
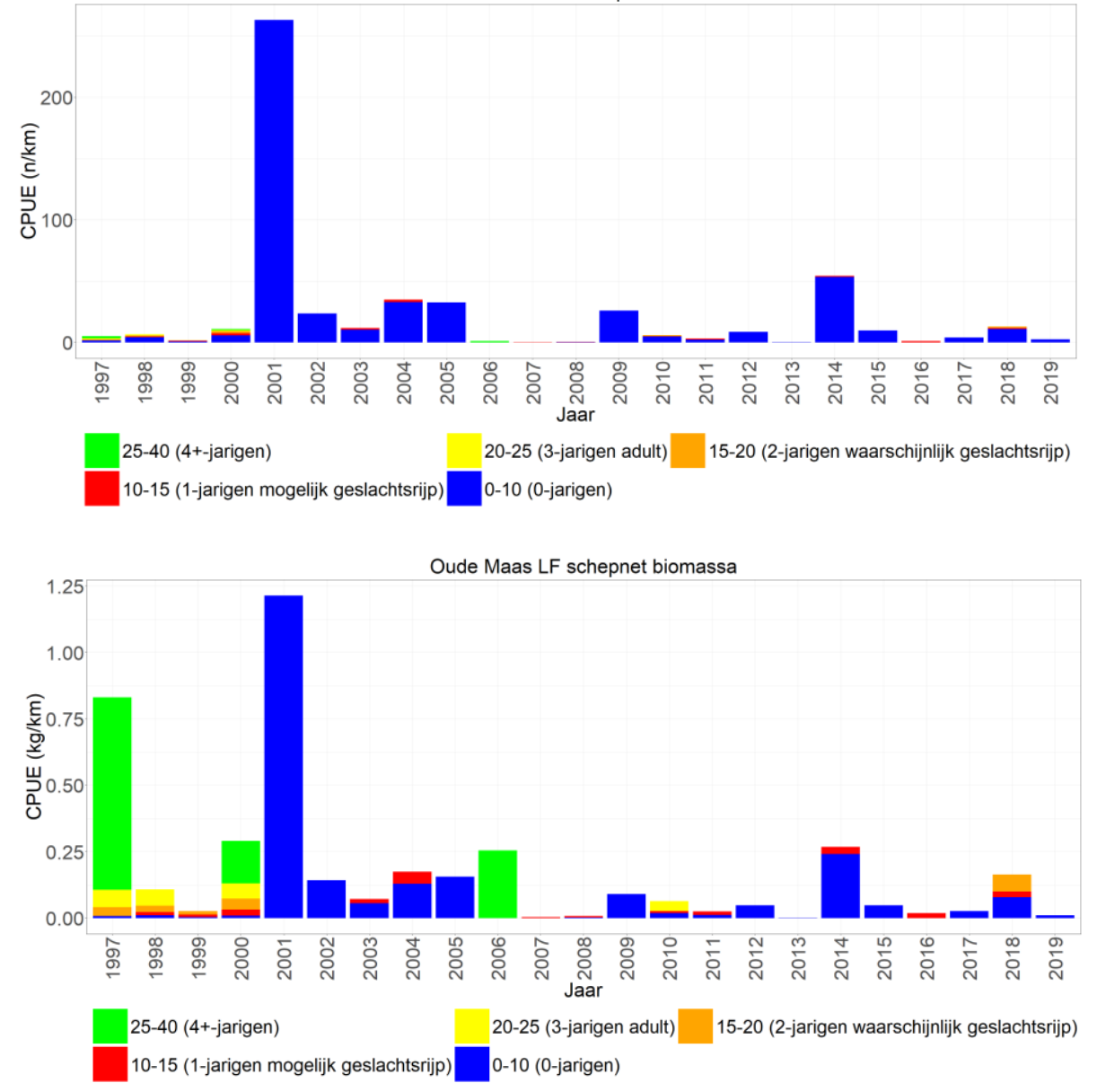

Figuur 6.36 Gemiddelde CPUE ( $\mathrm{n} / \mathrm{km}-\mathrm{n} / \mathrm{ha}$ en $\mathrm{kg} / \mathrm{km}-\mathrm{kg} / \mathrm{ha}$ bevistoppervlak) per jaar met lengteverdeling ( $\mathrm{cm}$ ) van blankvoorn gevangen met de boomkor in het open water en met het elektroschepnet langs de oevers van de Oude Maas. 

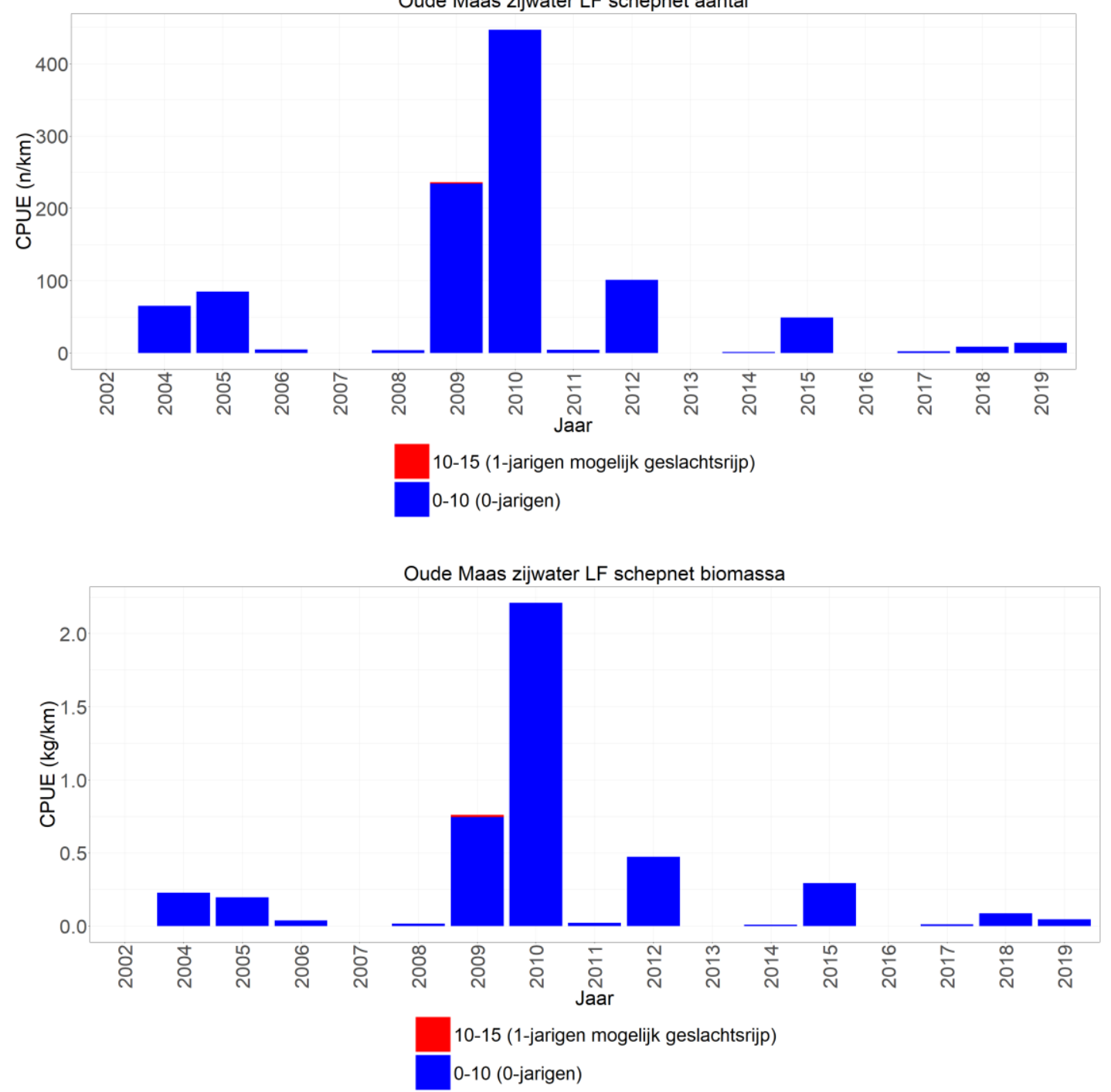

Figuur 6.37 Gemiddelde CPUE ( $/ \mathrm{km}-\mathrm{kg} / \mathrm{km}$ bevistoppervlak) per jaar met lengteverdeling $(\mathrm{cm})$ van blankvoorn gevangen met het elektroschepnet in de zijwateren van de Oude Maas. 


\subsection{Hollandsch Diep}

\subsubsection{Hoofdstroom}

Blankvoorn in de hoofdstroom van het Hollandsch Diep laat een relatief stabiel beeld zien, zowel qua aantallen als qua biomassa. Desondanks zijn de vangsten hier na 2009 gemiddeld lager dan ervoor. Deze afname is in alle leeftijdsklassen zichtbaar en vanaf 2015 lijkt deze zich ook weer in alle leeftijdsklassen te herstellen met een piek in 2018, voornamelijk door hoge vangsten van nul- en 1-jarigen. De aantallen worden voornamelijk gedomineerd door nuljarigen en de biomassa door meerjarige blankvoorn (Figuur 6.38 , links).

\subsubsection{Oever}

Net als in sommige andere KRW-lichamen werd biomassa langs de oevers in het begin van de monitoring nog gedomineerd door meerjarige blankvoorn en sinds 2005 neemt de nuljarige blankvoorn deze rol over. Dit resulteert in sterke fluctuaties van de zowel de biomassa als de aantallen (Figuur 6.38, rechts). 

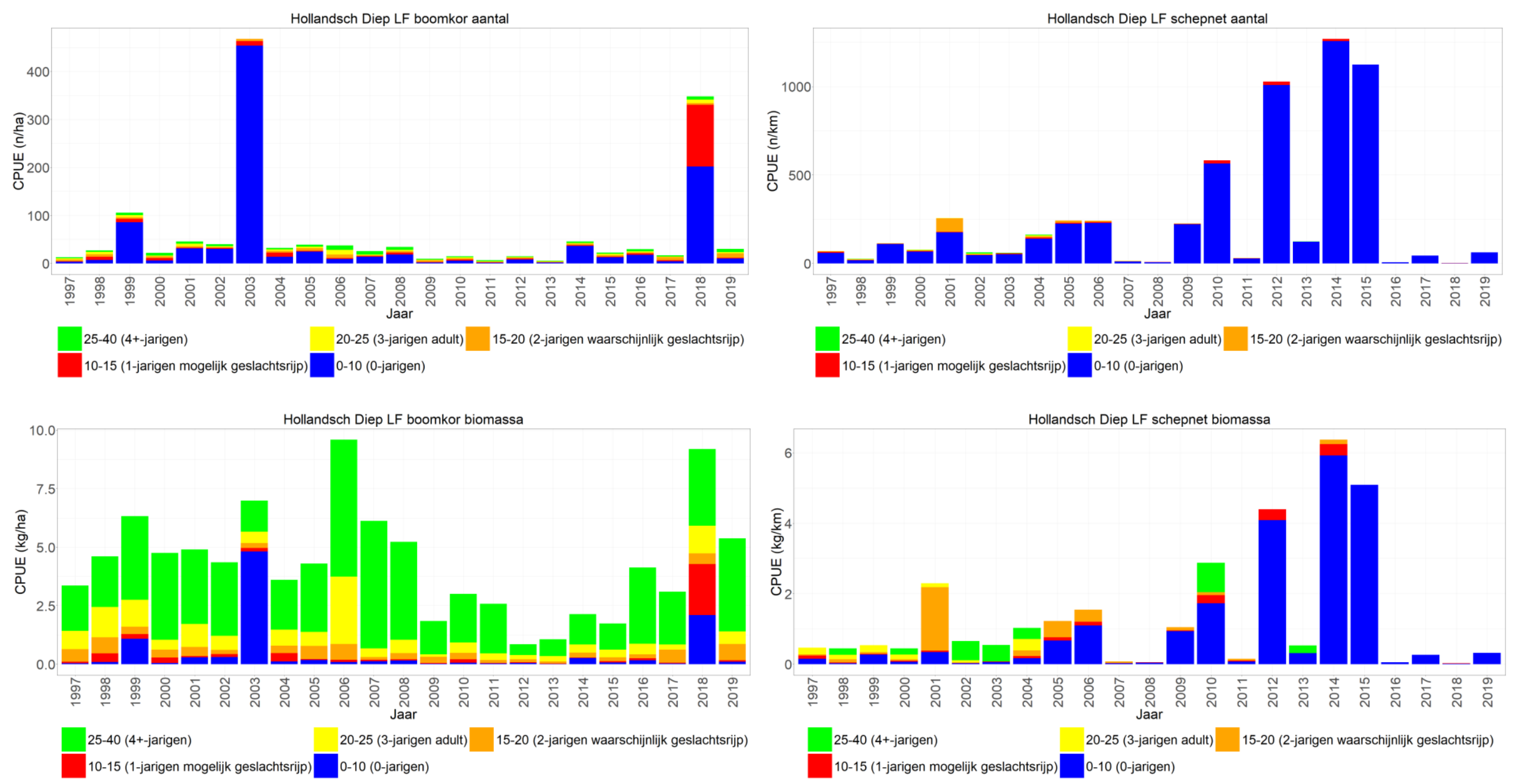

Figuur 6.38 Gemiddelde CPUE ( $\mathrm{n} / \mathrm{km}-\mathrm{n} / \mathrm{ha}$ en $\mathrm{kg} / \mathrm{km}-\mathrm{kg} / \mathrm{ha}$ bevistoppervlak) per jaar met lengteverdeling ( $\mathrm{cm}$ ) van blankvoorn gevangen met de boomkor in het open water en met het elektroschepnet langs de oevers van de Hollandsch Diep. 


\subsection{Haringvliet-West}

\subsubsection{Hoofdstroom (open water)}

In de hoofdstroom van het Haringvliet-West werd tot voor kort relatief weinig blankvoorn gevangen. Sinds 2018 lijken de vangsten qua aantal en qua biomassa toe te nemen en bestaan deze voornamelijk uit meerjarige blankvoorn (Figuur 6.39, links).

\subsubsection{Zijwater (open water)}

In het zijwater (jachthaven van Stellendam) wordt er sinds 2015 voornamelijk nul- en 1-jarige blankvoorn gevangen welke wel weer lijkt af te nemen met de jaren. In 2019 bestond de vangst voornamelijk uit meerjarige blankvoorn (Figuur 6.39, rechts). 

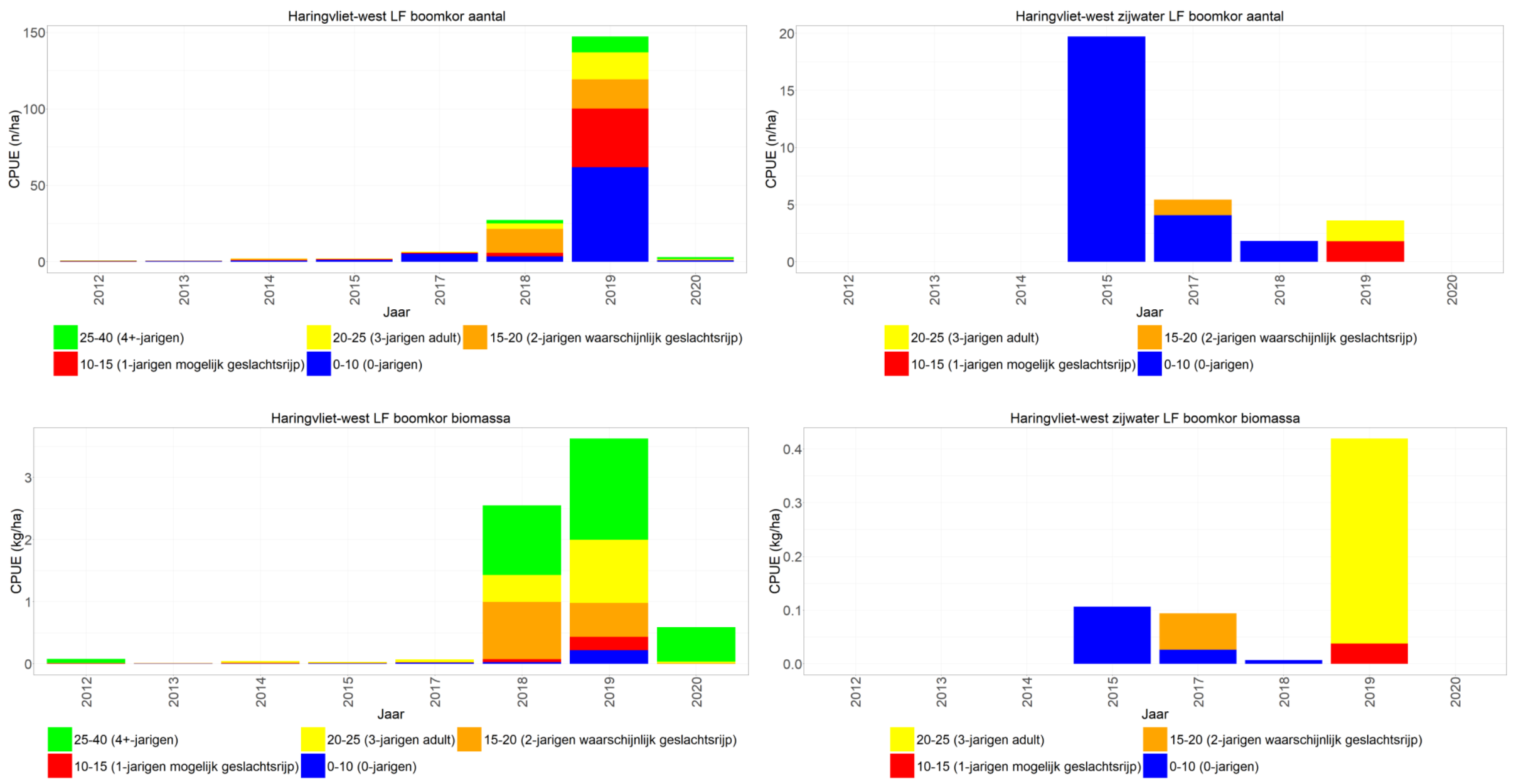

Figuur 6.39 Gemiddelde CPUE ( $\mathrm{n} / \mathrm{ha}$-kg/ha bevistoppervlak) per jaar met lengteverdeling ( $\mathrm{cm}$ ) van blankvoorn gevangen met de boomkor in het open water en in de zijwateren van het Haringvliet-West. 


\subsection{Volkerak}

\subsubsection{Hoofdstroom (open water)}

In het Volkerak worden de aantallen gedomineerd door nuljarige en de biomassa door meerjarige blankvoorn. De vangsten zijn wisselvallig en er lijkt geen duidelijke trend te zijn, alhoewel er de laatste twee monitoringsjaren relatief veel nuljarige blankvoorn is gevangen (Figuur 6.40, links).

\subsubsection{Hoofdstroom (oever)}

Langs de oevers wordt er relatief weinig blankvoorn gevangen en bestaan de vangsten voornamelijk uit nuljarige blankvoorn(Figuur 6.40, rechts).

\subsubsection{Zijwater (open water)}

In het zijwater (sluizencomplex) van het Volkerak is met de boomkor alleen in 2016 en met het schepnet alleen in 2010 blankvoorn gevangen waarbij de vangst voornamelijk uit nuljarigen bestond (

Figuur 6.41). 

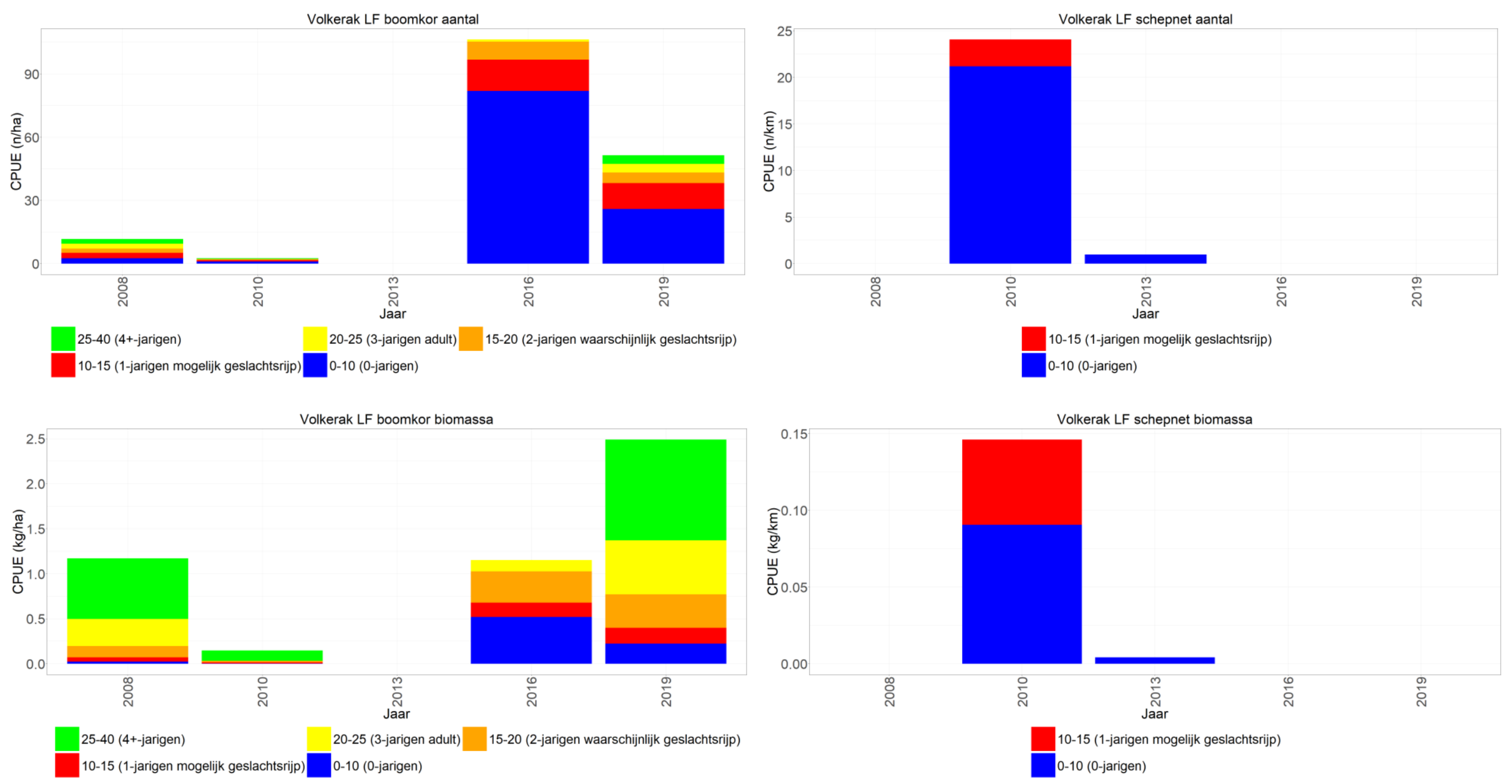

Figuur 6.40 Gemiddelde CPUE ( $\mathrm{n} / \mathrm{km}-\mathrm{n} / \mathrm{ha}$ en $\mathrm{kg} / \mathrm{km}-\mathrm{kg} / \mathrm{ha}$ bevistoppervlak) per jaar met lengteverdeling ( $\mathrm{cm}$ ) van blankvoorn gevangen met de boomkor in het open water en met het elektroschepnet langs de oevers van de Volkerak. 
Volkerak zijwater LF boomkor aantal
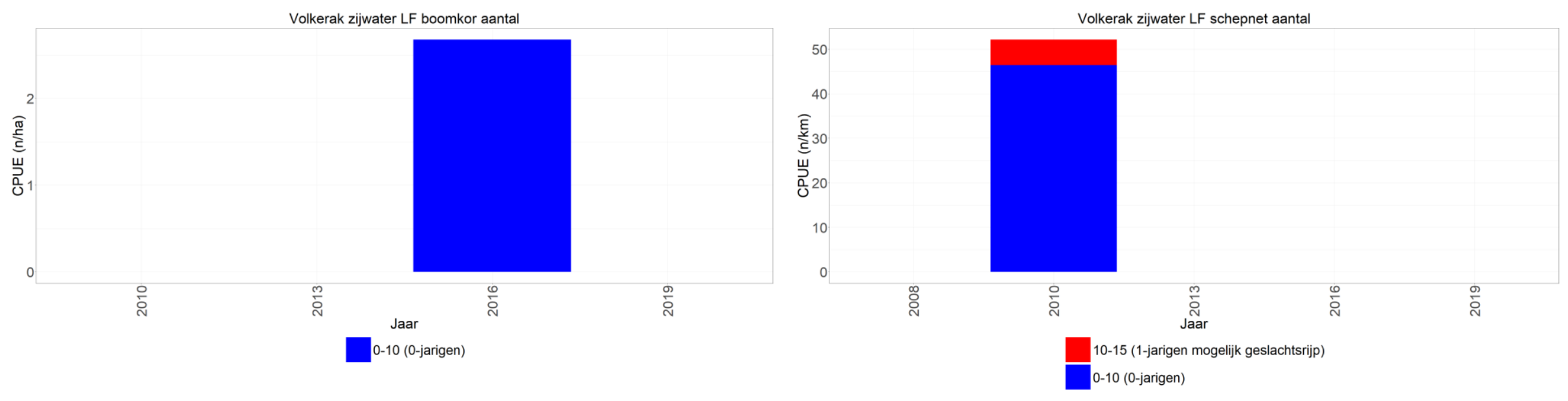

Volkerak zijwater LF boomkor biomassa

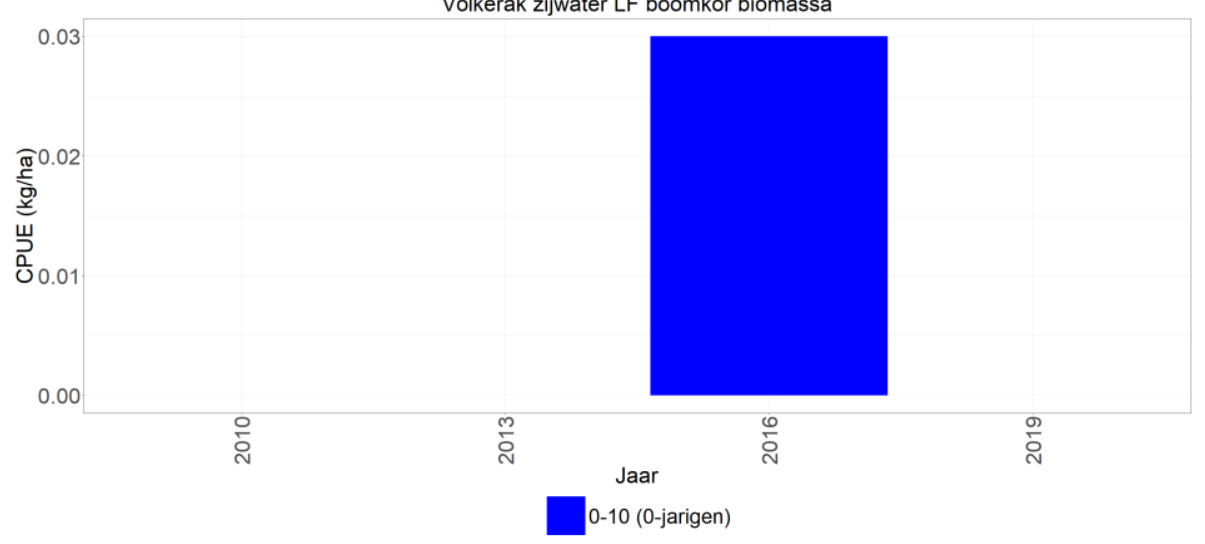

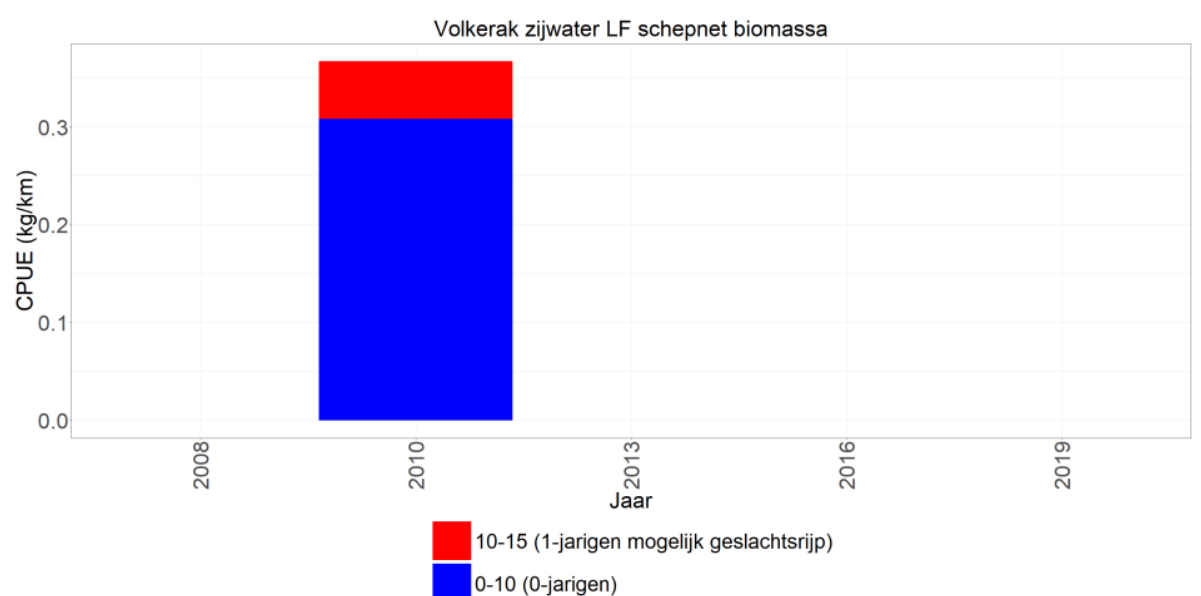

Figuur 6.41 Gemiddelde CPUE ( $\mathrm{n} / \mathrm{km}-\mathrm{n} / \mathrm{ha}$ en $\mathrm{kg} / \mathrm{km}-\mathrm{kg} / \mathrm{ha}$ bevist oppervlak) per jaar met lengteverdeling ( $\mathrm{cm}$ ) van blankvoorn gevangen met de boomkor in de zijwateren en met het elektroschepnet langs de oevers van de Volkerak. 


\subsection{Zoommeer}

\subsubsection{Hoofdstroom en oever}

In het Zoommeer wordt sinds het begin van de monitoring in 2016 relatief weinig blankvoorn gevangen en voornamelijk nul- en 1-jarige blankvoorn. Vanwege de korte reeks en de lage vangsten is er geen duidelijke trend zichtbaar (Figuur 6.42). In de zijwateren is geen blankvoorn gevangen. 

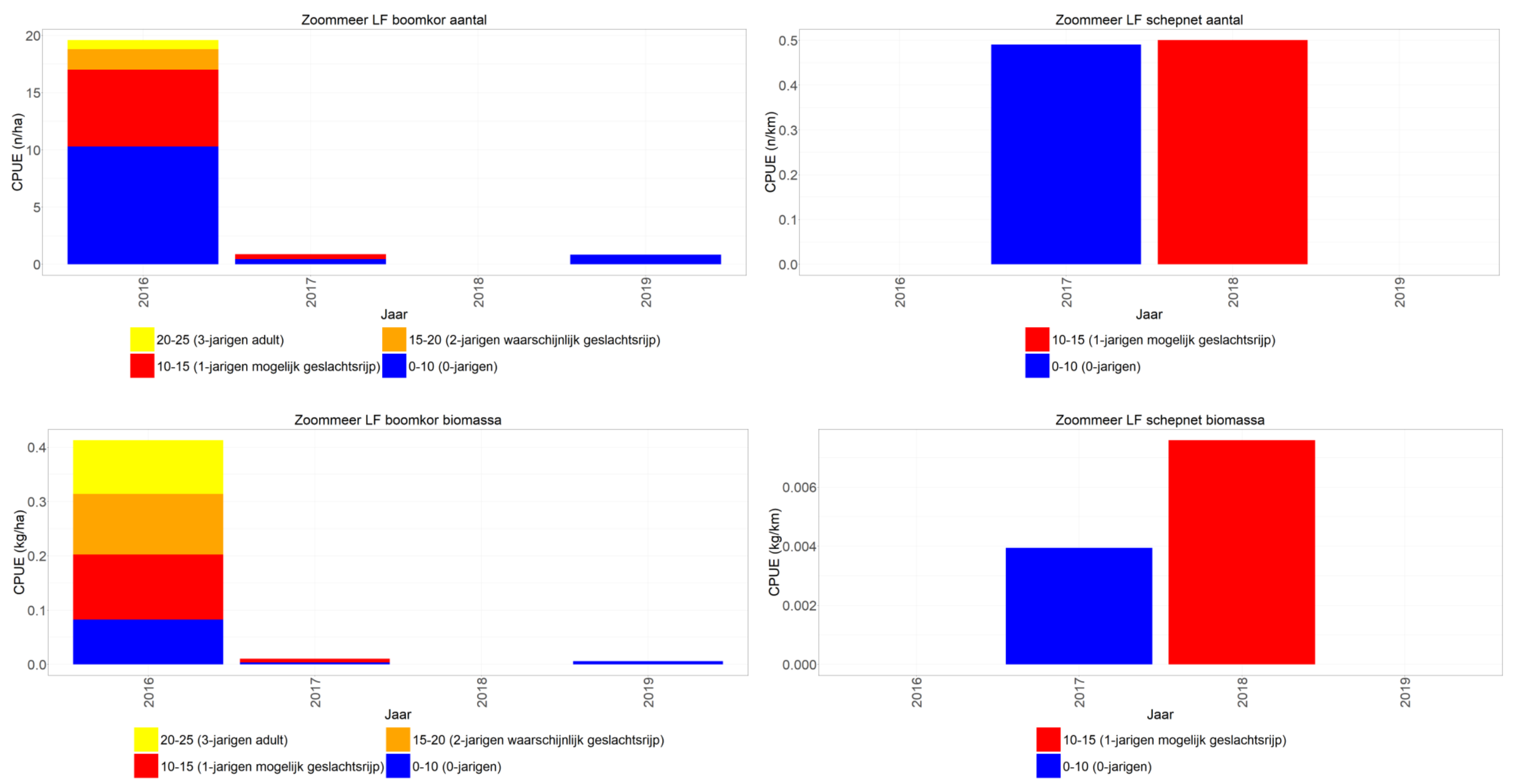

Figuur 6.42 Gemiddelde CPUE ( $\mathrm{n} / \mathrm{km}-\mathrm{n} / \mathrm{ha}$ en $\mathrm{kg} / \mathrm{km}-\mathrm{kg} / \mathrm{ha}$ bevistoppervlak) per jaar met lengteverdeling ( $\mathrm{cm}$ ) van blankvoorn gevangen met de boomkor in het open water en met het elektroschepnet langs de oevers van de Zoommeer. 


\subsection{Noordzeekanaal}

\subsubsection{Hoofdstroom (open water)}

In de hoofdstroom van het Noordzeekanaal lijken de aantallen en de biomassa van blankvoorn sinds 2014 toe te nemen en worden deze beiden gedomineerd door meerjarige blankvoorn. Uitzondering hierop is 2008 wanneer de aantallen nog door nuljarige blankvoorn gedomineerd werden (Figuur 6.43, links). Het is bekend dat blankvoornlarven en -eieren niet goed bestand zijn tegen brak water, dit zou het lage voorkomen van nuljarige blankvoorn in het relatief zilte water van het Noordzeekanaal kunnen verklaren.

\subsubsection{Zijwateren (open water)}

In de zijwateren bestaan de vangsten ook voornamelijk uit meerjarige blankvoorn, in tegenstelling tot veel andere KRW-lichamen waarbij de zijwateren voornamelijk door nuljarige blankvoorn gedomineerd worden. In de zijwateren lijkt er in tegenstelling tot de hoofdstroom een afname van blankvoorn te zijn (Figuur 6.43, rechts). 

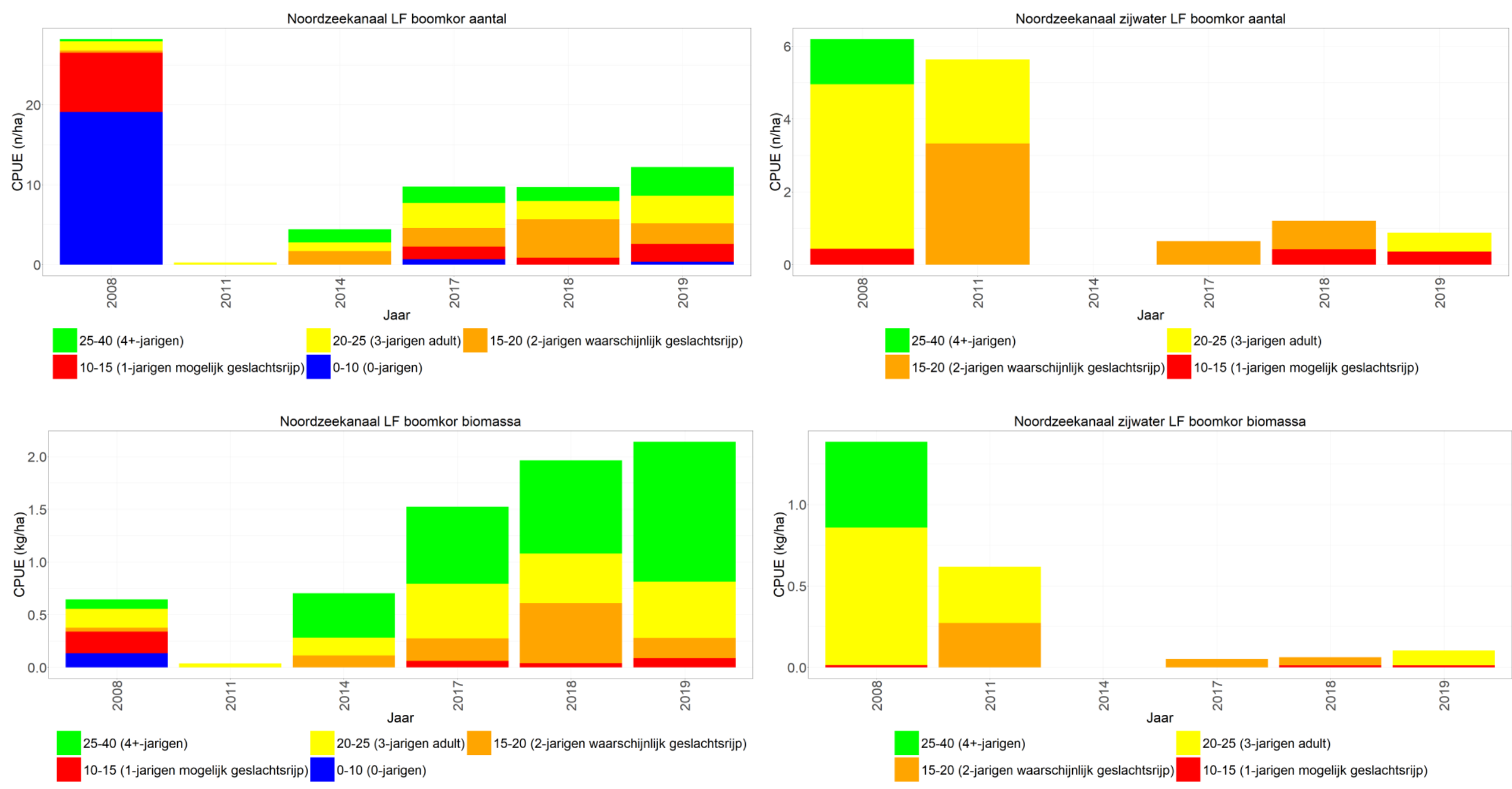

Figuur 6.43 Gemiddelde CPUE ( $\mathrm{n} / \mathrm{ha}-\mathrm{kg} / \mathrm{ha}$ bevistoppervlak) per jaar met lengteverdeling ( $\mathrm{cm}$ ) van blankvoorn gevangen met de boomkor in het open water en in de zijwateren van het Noordzeekanaal. 


\subsection{Discussie}

In veel KRW-lichamen is er sinds het begin van de monitoring een afname van blankvoorn zichtbaar waarbij er één of soms twee periodes zijn waarin deze afname hoofdzakelijk plaatsvindt (Tabel 6.1). De eerste periode is tussen 2002 en 2005 de tweede periode is tussen 2009 en 2012. De afnames bestaan in de meeste KRW-lichamen uit een afname van meerjarige individuen, waarbij in sommige gevallen de totale aantallen en biomassa van blankvoorn zich wel gedeeltelijk lijken te herstellen, maar waarbij de oudere individuen niet meer worden gevangen.

Tabel 6.1 Overzicht van kwalitatief bepaalde trends in blankvoorn per KRW-lichaam sinds het begin van de monitoringen (niet gebaseerd op analyses). Trends zijn kwalitatief ingedeeld door naar toe/afnames in de monitoringen sinds het begin van de monitoring te kijken. Op dezelfde wijze zijn de leeftijdscategorieën toegewezen aan toe-/afnames door de tijd heen.

\begin{tabular}{|c|c|c|c|}
\hline KRW-lichaam & Trend (kwalitatief) & $\begin{array}{l}\text { Gestandaardiseerde } \\
\text { monitoring sinds }\end{array}$ & $\begin{array}{l}\text { Leeftijdscategorie } \\
\text { toe-/afname }\end{array}$ \\
\hline IJsselmeer & Sterke afname & 1989 & Meerjarig \\
\hline Markermeer & Afname & 1989 & Nuljarig + meerjarig \\
\hline Randmeren-Oost & Wisselvallig/stabiel & 2007 & Nuljarig + meerjarig \\
\hline Randmeren-Zuid & Wisselvallig/stabiel & 2009 & Nuljarig + meerjarig \\
\hline $\begin{array}{l}\text { Benedenloop Gelderse } \\
\text { IJssel }\end{array}$ & Afname & 1997 & Meerjarig \\
\hline Bovenloop Gelderse IJsse & Afname/stabiel & 1997 & Meerjarig \\
\hline Rijn & Afname & 1997 & Meerjarig \\
\hline Grensmaas & Afname & 1997 & Nuljarig + meerjarig \\
\hline Zandmaas & Stabiel & 2013 & Nuljarig + meerjarig \\
\hline Bovenloop Nederrijn & Sterke afname & 1997 & Nuljarig + meerjarig \\
\hline Bovenloop Waal & Afname & 1997 & Nuljarig + meerjarig \\
\hline Benedenloop Nederrijn & Wisselvallig & 2013 & Meerjarig \\
\hline Benedenloop Waal & Wisselvallig & 2013 & Meerjarig \\
\hline Getijden Lek & Wisselvallig & 1997 & Meerjarig \\
\hline Getijden Maas & Afname & 1997 & Nuljarig + meerjarig \\
\hline Afgedamde Maas & Wisselvallig & 2010 & Nuljarig \\
\hline Heusdensch Kanaal & Wisselvallig & 2010 & Meerjarig \\
\hline Noordwaard & Stabiel & 2016 & Nuljarig \\
\hline Nieuwe Merwede & Herstellende na afname & 1997 & Nuljarig + meerjarig \\
\hline Hollandse IJssel & Stabiel & 2016 & Meerjarig \\
\hline Oude Maas & Afname & 1997 & Nuljarig + meerjarig \\
\hline Hollandsch Diep & Herstellende na afname & 1997 & Meerjarig \\
\hline Haringvliet-West & Stabiel/lichte toename & 2012 & Meerjarig \\
\hline Zoommeer & Wisselvallig & 2016 & Nuljarig \\
\hline Volkerak & Wisselvallig & 2008 & Meerjarig \\
\hline Noordzeekanaal & Herstellende na afname & 2008 & Meerjarig \\
\hline
\end{tabular}

Wat opvalt is dat de KRW-lichamen waarbij de eerste tekenen van herstel zichtbaar lijken voornamelijk in de benedenrivieren liggen (Haringvliet-West, Hollandsch Diep, Nieuwe Merwede). Bij deze gebieden moet wel in acht worden genomen dat het om hogere vangsten in de afgelopen 2-4 jaar gaat (korte tijdspanne) wat simpelweg ook het effect van goede jaarklassen kan zijn. Het is dus niet met zekerheid te zeggen dat er daadwerkelijk herstel ingezet is. Het is nog onduidelijk waardoor dit "contrast" met andere KRW-lichamen, waarbij er een afname van blankvoorn lijkt te zijn, wordt veroorzaakt. Ook zien 
we in het Noordzeekanaal een toename van met name oudere blankvoorn. Dit zou wellicht in verband kunnen staan met de lichte toename die de laatste drie jaar te zien is in het Markermeer.

Voornamelijk bij de monitoringen die nog niet zo lang lopen (vanaf 2010-2016) en die niet jaarlijks worden uitgevoerd is het beeld dat blankvoorn geeft vaak sterk wisselvallig of stabiel. Dit komt voornamelijk door de korte tijdreeks of de langere tijdsintervallen tussen bemonsteringsjaren waardoor een duidelijke trend (nog) niet zichtbaar is. Daarnaast achten we de mogelijkheid groot dat deze wisselvalligheid voortkomt uit een afname van blankvoorn voordat de monitoringen van start zijn gegaan.

De aantallen van de blankvoorn worden meestal gedomineerd door nuljarige blankvoorn terwijl de biomassa meestal gedomineerd wordt door meerjarige blankvoorn, wat vanzelfsprekend in de lijn der verwachting ligt. In een aantal KRW-lichamen zien we dat deze verdeling anders ligt, wat in veel gevallen toe te schrijven is aan de karakteristieke eigenschappen van het waterlichaam (b.v. relatief brak water waar alleen meerjarige blankvoorn tegen bestand is zoals in het Noordzeekanaal) of het relatief weinig voorkomen van de blankvoorn in deze wateren waardoor de leeftijdsverdeling van de vangsten niet per se representatief is voor de populatie (bv Hollandse IJssel).

Om een overzicht te krijgen in welke KRW-lichamen recentelijk relatief veel blankvoorn gevangen wordt, is er een aantal overzichtskaarten gecreëerd. Deze geven de gemiddelde biomassa blankvoorn van de afgelopen 6 jaar in de hoofdstroom (boomkor) en langs de oever (elektroschepnet) weer, voor zowel nuljarige als meerjarige blankvoorn (Figuur 6.44). Voor de randmeren is de stortkuil in plaats van de wonderkuil geselecteerd aangezien hier meer data beschikbaar van was dan van de wonderkuil. Alhoewel de vangsten van zowel de boomkor als de stortkuil beide zijn omgerekend naar kg/ha kunnen deze waarden vanwege het verschil in vangtuig niet direct met elkaar vergeleken worden. Daarnaast kunnen verschillende gebieden ook verschillende vangstefficiënties hebben doordat sommige type rivieren (bv. rivieren met kribben) moeilijker te bemonsteren zijn dan anderen waardoor de verschillende CPUE's soms meer een indicatie zijn van de vangbaarheid dan van de dichtheid van blankvoorn in een gebied.

Wat opvalt is dat biomassa van zowel nuljarige als meerjarige blankvoorn in de hoofstroom van de Randmeren relatief hoog is. Hoewel een directe vergelijking met de andere KRW-lichamen hier niet toepasbaar is, is dit wel een indicatie dat de blankvoorn het de laatste zes jaar relatief goed doet in de Randmeren, wat ook te zien is in paragrafen 2.4 en 2.5 waaruit blijkt dat blankvoorn een relatief groot deel van de vangsten beslaat. Daarnaast valt op dat de biomassa van nuljarige blankvoorn in het open water en langs de oevers van het IJsselmeer relatief hoog is t.o.v. van het Markermeer terwijl de biomassa van meerjarige blankvoorn weer hoger is in het open water van het Markermeer t.o.v. van het IJsselmeer in het open water. Een ander KRW-lichaam dat opvalt is het Hollandsch Diep waarin zowel in de hoofdstroom als langs de oevers relatief veel nuljarige en meerjarige blankvoorn voorkomt t.o.v. de andere KRW-lichamen. Andere KRW-lichamen vallen juist op door de relatief lage biomassa van blankvoorn. Zo komt blankvoorn nauwelijks voor in de (zoute) overgangswateren en alleen meerjarige blankvoorn in het Noordzeekanaal. Zowel nuljarige als meerjarige blankvoorn lijken relatief weinig voor te komen in de bovenlopen van de rivieren verder stroomopwaarts (Figuur 6.44). De Getijden Maas valt op vanwege het volledig ontbreken van meerjarige blankvoorn langs de oevers. Meerjarige blankvoorn komt het meeste voor langs de oevers van het IJssel- en Markermeer en langs de oevers van de Dordtse Biesbosch (Nieuwe Merwede). 

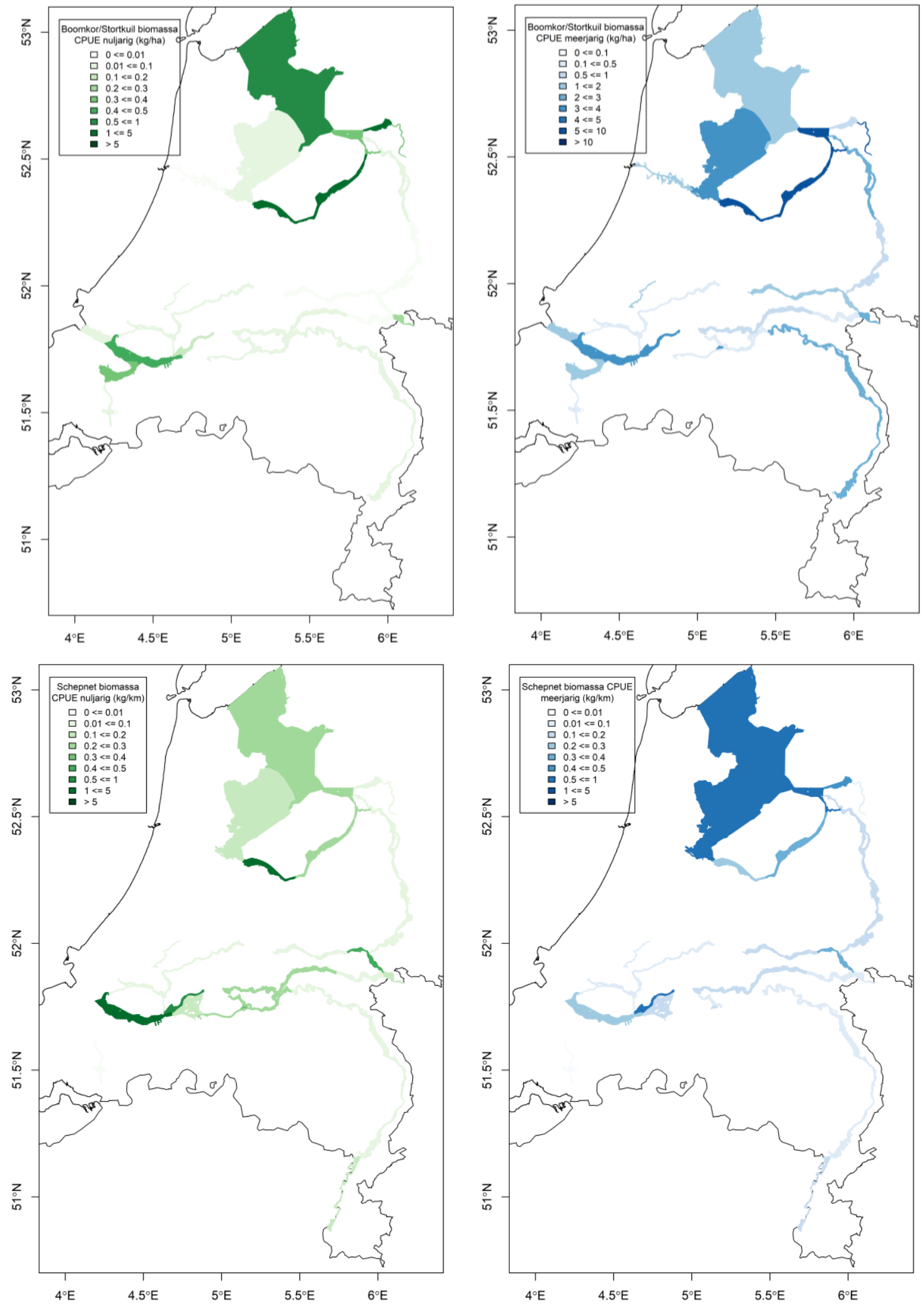

Figuur 6.44 Gemiddelde cpue (kg/ha-kg/km) van de biomassa van nuljarige (groen) en meerjarige (blauw) blankvoorn in de periode 2013-2019 per KRW-lichaam gevangen in de hoofdstroom met de boomkor of de stortkuil (boven) of langs de oever met het elektroschepnet (onder). NB de waarden van de randmeren kunnen niet direct met de andere KRW-lichamen vergeleken worden i.v.m. het verschil in vangtuig, daarnaast hebben de verschillende kaarten verschillende legenda's en zijn de zijwateren niet in deze kaarten meegenomen. Daarnaast kunnen verschillende gebieden ook verschillende vangstefficiënties hebben doordat sommige type rivieren (rivieren met kribben) moeilijker te bemonsteren zijn dan anderen. 
Aan het begin van dit hoofdstuk is een aantal bedreigingen voor de blankvoorn aangekaart welke allemaal van invloed geweest kunnen zijn op hierboven beschreven afnames. Het afnemen van voornamelijk meerjarige en dus paairijpe blankvoorn kan vooralsnog niet specifiek worden toegewezen aan één oorzaak, en mogelijke oorzaken die hieronder worden genoemd zijn voornamelijk speculaties. Twee waarschijnlijke mechanismen zijn (1) dat er onder de juveniele blankvoorn zoveel sterfte is dat veel van hen het volwassen/paairijpe stadium niet bereiken, of (2) dat meerjarige blankvoorn meer wordt blootgesteld aan bepaalde bedreigingen (bijv. door visserij of gemalen) dan juveniele blankvoorn en de sterfte voornamelijk onder adulten plaatsvindt. Uiteraard kan ook een combinatie van beide mechanismen de oorzaak van de afnames zijn.

In het geval van (1) zou dit kunnen komen door een gebrek aan voedsel. Zowel het IJsselmeer als de grote rivieren vertoonden een afname van nutriënten in de periode 1990-2010 (van Puijenbroek et al. 2014) en voor die tijd zelfs een zeer sterke afname (Noordhuis et al. 2014). Bij een afname van nutriënten neemt de groei van autotrofe organismen zoals planten en algen vaak ook af. Daarnaast kan er ook een verschuiving zijn in het voorkomen van autotrofe organismen door de afname van nutriënten, waarbij bepaalde soorten afnemen en andere juist toenemen. Een afname in groei of een verschuiving van het voorkomen van autotrofe organismen kan een groot effect hebben op zoöplankton en bodemfauna en daardoor op blankvoorn die op deze organismen foerageren. De Leeuw \& van Donk (2020b) hebben onlangs een aantal hypotheses voor de afnames van vis in het IJsselmeergebied opgesteld waarbij ze de gebrekkige nutriëntenstromen door onnatuurlijke oeverzones, waardoor het doorgroeien naar oudere jaarklassen sterk beperkt is, als één van de twee voornaamste hypotheses naar voren brengen.

In het Belgische en Franse gedeelte van de Maas zijn er verschillende onderzoeken geweest die aan de hand van modellen geprobeerd hebben de oorzaak van de achteruitgang van blankvoorn en andere cypriniden te achterhalen (Otjacques et al. 2015, 2016, Latli et al. 2017, Latli et al. 2019). In deze gedeeltes van de Maas is er een $85 \%$ afname van zoo- en fytoplankton waargenomen in 15 jaar welke voornamelijk wordt toegedicht aan de toename van de invasieve Aziatische korfmossels (Corbicula spp., Pigneur et al. 2014). In het Belgische gedeelte van de Maas, wat sterk gekanaliseerd is, wordt de afname van fytoplankton als voornaamste oorzaak gezien voor de $85 \%$ afname van blankvoorn sinds de jaren '90 (Otjacques et al. 2015, 2016). Daarentegen is het blankvoornbestand in het Franse gedeelte van de Maas, wat veel minder gereguleerd is, vrijwel constant gebleven. Latli et al. (2019) testten daarom de hypothese dat de homogenisatie van het habitat (door te kanaliseren) zou zorgen voor een afname van voedselbeschikbaarheid en zowel intra- als interspecifieke competitie zou bevorderen, met name tussen nuljarige vissen. Uit hun onderzoek aan de hand van stabiele isotopen bleek in situaties met lage zoöplanktonbiomassa's, dat de meeste nuljarige vis afhankelijk is van benthische voedselbronnen i.p.v. plankton. Daarbij kwam dat in het Belgische, meer gereguleerde deel van de Maas intraspecifieke competitie tussen jaarklassen van cypriniden ervoor zorgde dat nuljarige cypriniden zich meer specialiseerden en ervoor zorgden dat sommige individuen minder energierijk voedsel zoals waterplanten aten. In het minder gekanaliseerde, Franse gedeelte van de Maas voedden de nuljarigen zich met een breed scala aan energierijk voedsel (bijv. macro-invertebraten), wat impliceert dat de diversiteit van het habitat intra- en interspecifieke competitie vermindert. In tegenstelling tot de nuljarige cypriniden, vonden Latli et al. (2019) dat nuljarige baars in het gekanaliseerde Belgische gedeelte van de Maas, een lage diversiteit aan prooisoorten at (macro-invertebraten en nuljarige vis). Doordat deze baarsjes minder niche-overlap vertoonden dan de cypriniden leken ze minder beïnvloed te worden door interspecifieke competitie. Daar komt bij dat baarsjes eerder uit het ei komen en sneller groeien dan cypriniden waardoor ze eerder al vislarven en grote macro-invertebraten kunnen eten dan andere nuljarige taxa (Pinder 2001, Persson \& Hansson 1999) en dus een competitief voordeel hebben over cypriniden.

In de Nederlandse wateren is een soortgelijk scenario mogelijk voor blankvoorn als in de Belgische en Franse Maas. In de Nederlandse rivieren is sinds 1990 de concentratie chlorofyl-a in de KRW-lichamen ook sterk afgenomen (RIVM 2017). Alhoewel de Aziatische korfmossel (Corbicula spp.) ook in de Nederlandse wateren voorkomt, lijken de Ponto-Kaspische quaggamossel (Dreissena rostriformis 
bugensis) en de driehoeksmossel (Dreissena polymorpha) een grotere verspreiding en hogere dichtheden te hebben (Matthews et al. 2014, NDFF \& ANEMOON 2020). Net als de Aziatische korfmossel kunnen deze Dreissenidae (quaggamossel en/of de driehoeksmossel) een grote impact hebben op het ecosysteem door het uitfilteren van fytoplankton. In een meta-analyse vonden Higgins \& Vander Zanden (2010) dat er bij wateren waarbij Dreissenidae zich hadden gevestigd, een afname van $35-78 \%$ in zoöplankton en een afname van 40-70\% van fytoplankton werd waargenomen, waarbij het effect op rivieren het grootst was. De toename van deze mossels in de Nederlandse wateren kan dus net als in de Belgische en Franse Maas van invloed zijn geweest op Nederlandse blankvoornpopulatie. Dit effect zou dan het grootste moeten zijn op nuljarige blankvoorn aangezien deze meer afhankelijk is van zoöplankton dan volwassen blankvoorn. Volwassen blankvoorn is zelfs een efficiënte predator van driehoeksmossel (Nagelkerke \& Sibbing 1996) die deze in tijde van voedselschaarste opneemt in zijn dieet (Lammens et al. 1987). Naast een afname van fytoplankton, zien we in veel KRW-lichamen de laatste paar jaar ook een toename van baars. Deze toename lijkt overeen te komen met het competitieve voordeel dat baars kan hebben heeft over cypriniden doordat baarslarven vroeger uit het ei komen en sneller groeien dan cypriniden wat er voor kan zorgen dat baars minder hinder ondervindt van de afname van fyto- en zoöplankton dan cypriniden zoals blankvoorn ondanks dat baars in het eerste jaar bijna volledig afhankelijk is van zoöplankton (Craig, 1987). Aan de andere kant lijkt de blankvoorn betere foerageerder van zoöplankton te zijn dan baars (Beier, 2016). Daarnaast kan blankvoorn, wanneer er competitie voor voedsel ontstaat met agressievere soorten zoals de invasieve PontoKaspische grondels, mogelijk het onderspit delven. Uit een studie in een Tsjechische rivier blijkt dat zowel nuljarige baars als blankvoorn niche-overlap hebben met invasieve Ponto-Kaspische grondels wat tot voedselcompetitie kan leiden bij voedselschaarste (Janac et al. 2016). Aangezien de afname van fosfaten en fytoplankton in de Nederlandse rivieren voor een voedselschaarste gezorgd kunnen hebben, is competitie tussen deze soorten niet uit te sluiten. In het IJssel- en Markermeer is er naar maaginhouden van de zwartbekgrondel gekeken die zijn verzameld tijdens de open-waterbemonstering in oktober/november 2016 (Schilder 2017). Hieruit bleek dat het dieet van de zwartbekgrondel in deze periode voornamelijk uit mollusken bestond (34-54\%) waaronder ook driehoeks- en quaggamosselen, vervolgens voornamelijk uit ongedefinieerd organisch materiaal (25-41\%), en daarna uit macroinvertebraten (10-16\%). Afhankelijk van de grootte van de zwartbekgrondel maakte zoöplankton (1$13 \%$ ) en vis (inclusief eieren, $0.02-19 \%$ ) maar een relatief klein deel uit van het dieet. Het dieet van blankvoorn in het IJsselmeer is voor het laatst in 1994 onderzocht (Dekker en Schaap 1995). In augustus 1994 bestond het voedsel van 629 blankvoorns gemiddeld uit gelijke hoeveelheden driehoeksmosselen, algen en waterplanten, zoöplankton en slakken. Daarnaast zijn er in november van dat jaar nog eens ca. 50 maaginhouden van blankvoorns onderzocht. Hierbij waren 19 blankvoorns (13$17 \mathrm{~cm}$ ) met gevulde magen waarvan er 16 uitsluitend met slakken, 3 uitsluitend met driehoeksmosselen waren gevuld. In augustus bestonden de maaginhouden in deze leeftijdscategorie voor meer dan $90 \%$ uit algen en de overige $10 \%$ uit zoöplankton en slakken. Dat betekent dat het voedsel van de blankvoorn tussen augustus en november vrijwel geheel anders kan zijn. Vooral in de periode oktober/november lijkt het erop dat de grootste vorm van (een mogelijke) competitie tussen blankvoorn en de zwartbekgrondel om mollusken draait en dat dit voornamelijk geldt voor adulte blankvoorn en minder voor nuljarige blankvoorn. Ook hier geldt dat competitie als oorzaak voornamelijk speculatief is totdat hier voldoende onderzoek naar gedaan is.

Afname van oudere individuen (2) zou op het IJssel-/Markermeer ook veroorzaakt kunnen zijn door de visserij, aangezien deze zich voornamelijk richt op de oudere individuen ondanks dat blankvoorn is opgenomen in de Visserijwet zonder minimummaat waardoor ook kleinere blankvoorn aangeland mag worden. Afname door visserij kan daarnaast ook betrekking hebben op juveniele blankvoorn door middel van de duizenden juveniele blankvoorn die in de fuikenvisserij werden bijgevangen (Deerenberg \& van Willigen, 2004). Op de rivieren wordt er ook op blankvoorn gevist. Het is onduidelijk hoeveel vissers nog actief op blankvoorn vissen op de grote rivieren; een aantal vissers lijkt zich alleen in de wintermaanden te richten op pootvis zoals blankvoorn (van Rijssel et al. 2019b). De visserijdruk op blankvoorn in het IJssel-/Markermeer zou sinds het visserijseizoen 2014/2015 deels afgenomen moeten zijn vanwege de visserijbeheer-maatregelen (zie 6.4.1). 
In de inleiding van dit hoofdstuk zijn parasieten ook als mogelijke bedreiging voor blankvoorn genoemd. Alhoewel we hier geen recente gegevens over hebben blijkt uit gegevens van blankvoorn verzameld tijdens de open-water-bemonstering op het IJssel- en Markermeer dat het percentage geïnfecteerde blankvoorns met de lintworm Ligula intestinalis in de jaren ' 90 nooit boven de $5 \%$ is geweest. Het aantal onderzochte blankvoorns varieerde van 83-200 per jaar in de periode 1993-2001. Er zijn geen gegevens met betrekking tot parasieten in blankvoorn van na deze periode verzameld hoewel er sinds 2016 wel een marktbemonstering van blankvoorn wordt uitgevoerd door WMR op het IJssel-/Markermeer. Bij deze bemonstering worden geen parasieten geregistreerd.

Zowel vogel- als vispredatie zouden ook een rol kunnen spelen in afnames van blankvoorn. In het IJsselmeergebied komen verschillende vogels voor die prederen op blankvoorn zoals de aalscholver, reigers, fuut, zaagbekken, meeuwen, en sterns. Van deze soorten zijn met name de duikende predatoren; aalscholver, grote zaagbek en fuut belangrijke predatoren die de grootste hoeveelheid vis qua biomassa tot zich nemen (De Leeuw \& Van Donk 2020a). De predatoren die aan de oppervlakte jagen zoals de zwarte stern, meeuwen en de visdief zijn nemen maar een relatief klein deel voor hun rekening. De visconsumptie van de duikende predatoren is in 2002 toegenomen en lijkt sindsdien relatief stabiel (De Leeuw \& Van Donk 2020a).

Aalscholvers zijn zeer opportunistische foerageerders en eten in principe wat het meeste voorkomt in de wateren. In 1982 is er een verschuiving naar spiering, pos en baars (Voslamber 1988) die in die periode meer dan de helft van de biomassa van het IJsselmeer vormde (Klinge et al. 1998). Blankvoorn werd in beide periodes ook wel gegeten maar maakte qua aantallen geen groot deel uit van het dieet van de aalscholver (3-4\%) en qua biomassa was dit (12-16\%). In het begin van jaren '90 worden pos, spiering en baars nog steeds veel gegeten door aalscholvers in het IJsselmeergebied (incl. Markermeer) maar daar is blankvoorn bij gekomen. Spiering, pos en baars werden in die periode voornamelijk in het Markermeer gevangen, terwijl blankvoorn vooral van het IJsselmeer afkomstig was (van Dam et al. 1995; Klinge et al. 2008). Deze vier soorten domineerden de biomassa en helemaal de aantallen in deze periode in het IJsselmeer (Figuur 2.3). In de jaren die daarop volgen 1996-2000 (van Rijn \& van Eerden 2001) en 2005/2006 (Klinge et al. 2008, van Eerden \& van Rijn 2007) wordt pos een nog belangrijker voedsel item voor de aalscholver in het IJsselmeergebied (op basis van gewicht), gevolgd door baars en blankvoorn terwijl spiering een steeds kleiner aandeel in het dieet krijgt. Dit komt overeen met de sterke toename van pos en sterke afname van spiering in die periode in het IJsselmeer (Figuur 2.3). In de periode 2009-2013 bestaat meer dan de helft van het dieet van de aalscholvers rond het IJsselmeer uit pos (gebaseerd op aantallen), weer een hoger deel (30\%) uit spiering en slechts $5 \%$ uit blankvoorn (Deerenberg et al. 2013). Ook in deze periode komt het dieet van de aalscholver overeen met het veelvuldig voorkomen van pos en een kleine opleving van spiering in het IJsselmeer (Figuur 2.3). De meest recente schatting van aalscholver predatie in het IJsselmeergebied komt van de Leeuw \& van Donk (2020) waarbij geschat wordt dat $12-44 \%$ van het dieet van de aalscholver uit blankvoorn bestaat, voor futen zijn is dit $2 \%$ en voor de grote zaagbek $13-27 \%$.

Uit bovenstaande blijkt wel dat de aalscholver inderdaad foerageert op wat er voor handen is rondom het IJsselmeer. Hierdoor kan dus ook de aalscholver bijgedragen hebben aan de afname van blankvoorn, maar zal deze predator, naarmate het blankvoornbestand meer afnam, een steeds kleinere rol gespeeld hebben aangezien andere vissoorten de rol van blankvoorn in het dieet van de aalscholver overgenomen zullen hebben. Daarnaast treedt mogelijk een effect van 'landscape of fear' op (De Leeuw \& Van Donk, 2020b). Het steeds frequenter voorkomen van perioden met helder water heeft een sterk effect op het anti-predatorgedrag van vis: vis zoekt een veilig heenkomen in dieper water (geulen, zandwinputten), troebeler water (indien mogelijk), tussen waterplanten (in de zomer), of in havens. Versterkt door toegenomen mogelijkheden voor broeden (aalscholvers) en overwinteren (aalscholvers en futen) is het aantal aanwezige vogels per jaar toegenomen in het IJsselmeer (De Leeuw \& Van Donk, 2020b). Door toegenomen helderheid is het vangstsucces van deze vogels zeer waarschijnlijk ook toegenomen. Dat betekent dat het predatierisico voor kleine vis toegenomen moet zijn, wat het antipredatorgedrag van vis 
aanzienlijk versterkt kan hebben. Het gaat daarbij niet alleen om hoe groot de kans is dat jonge vis een prooi wordt (hogere sterfte) maar ook het indirecte effect dat vis zich terugtrekt naar de relatief wat veiliger gebieden. Dat betekent dat een steeds groter areaal van het IJsselmeer ongeschikt wordt voor jonge vis en die jonge vis op een aanzienlijk kleiner areaal moet zien te overleven. De beperkte, relatief veilige arealen waar vis zich dan terugtrekt in dit zogenaamde 'landscape of fear' (Zanette \& Clinchy, 2019) kan bovendien extra vogels en roofvissen aantrekken waardoor de sterfte verder toeneemt.

Van de mogelijke vispredatoren komen snoekbaars en baars het meeste voor in het IJsselmeer. Schilder (2017) heeft maaginhouden van deze twee soorten onderzocht in de periode oktober-december 2016. Uit dit onderzoek bleek dat voornamelijk grotere baars (>25 cm) blankvoorn at, waarbij blankvoorn $13 \%$ van het dieet besloeg in het IJsselmeer. Voor snoekbaars gold hetzelfde als voor baars dat voornamelijk alleen grotere snoekbaars (>40 cm) blankvoorn at waarbij blankvoorn 19\% van het dieet besloeg in het IJsselmeer, en net als bij baars, $0 \%$ in het Markermeer. Dit houdt in dat grotere exemplaren van baars en snoekbaars zouden kunnen bijgedragen hebben aan de afname van blankvoorn in het IJsselmeer alhoewel deze bijdrage steeds meer afgenomen zal zijn aangezien het aandeel grote baarzen en snoekbaarzen de laatste decennia sterk is afgenomen in het IJsselmeer (Tien et al. 2020).

Ondanks de afname van blankvoorn in de meeste KRW-lichamen zien we in veel van deze gebieden ook weer hogere vangsten van blankvoorn in 2019. Deze beslaan meestal alle leeftijdscategorieën. Of deze hogere vangsten de eerste tekenen zijn van daadwerkelijke oplevingen van de populatie of enkel het effect van sterke jaarklassen zal de toekomst moeten uitwijzen. 


\section{$7 \quad$ Kwaliteitsborging}

Wageningen Marine Research beschikt over een ISO 9001:2015 gecertificeerd kwaliteitsmanagementsysteem. Dit certificaat is geldig tot 15 december 2021. De organisatie is gecertificeerd sinds 27 februari 2001. De certificering is uitgevoerd door DNV GL.

De gegevens van de verschillende monitoringen zijn opgenomen in de WMR database FRISBE. Voordat de gegevens in de database worden geïmporteerd, wordt eerst een aantal standaard controles uitgevoerd en worden de gegevens waar nodig aangepast.

Jaarlijks vindt een identificatieworkshop zoetwatervis plaats, voor medewerkers van WMR en ingehuurde beroepsvissers en andere externen. Hierover wordt jaarlijks gerapporteerd (van Keeken, 2018). 


\section{Literatuur}

- $\quad$ Alabaster JS, Lloyd R, 1982. Water quality criteria for freshwater fish. Sec. ed. Food and Agriculture Organization of the United Nations. Butterworth Scientific pp. 361.

- Alabaster JS, Robertson KG, 1961. The effect of diurnal changes in temperature, dissolved oxygen and illumination on the behaviour of roach (Rutilus rutilus (L.)), bream (Abramis brama (L.)) and perch (Perca fluviatilis (L.)). Animal behaviour IX 3-4 p. 187-192.

- Bakker HD, Gerritsen JJ, 1992. Schade aan vis als gevolg van passage door de waterkrachtcentrale in de Maas bij Linne, Deel II: Schubvis. KEMA, Arnhem, 17 augustus 1992, rapport 98263-MOB 92- 3701.

- $\quad$ Bergstedt RA en Seelye JG, 1995. Evidence for a lack of homing by sea lamprey. Transactions of the American Fisheries Society, 124: 235-239

- Bijkerk, RR, 2010. Handboek Hydrobiologie. Belangrijke criteria hierbij zijn zoutgehalte (met als maat het chloridegehalte), stroming, alkaliniteit (buffering), gemiddelde diepte, breedte of oppervlakte en bodemaard. STOWA, Amersfoort.

- Bijlsma, R.J., Agrillo, E., Attore, F., Boitani, L., Brunner, A., Evan, P., Foppen, R., Gubbay, S., Janssen, J.A.M., van Kleunen, A., Langhout, W., Pacifici, M., Ramirez, I. Rondinini, C., van Roomen, M. Siepel, H., van Swaaij, C.A.M., Winter, H.V. 2019. Defining and applying the concept of Favourable Reference Values for species and habitats under the EU Birds and Habitats Directives. ISSN 1566-7197. WER Report 2929.

- $\quad$ Borcherding J, Scharbert A \& Urbatzka R. 2006. Timing of downstream migration and food uptake of juvenile North Sea houting stocked in the Lower Rhine and the Lippe (Germany). Journal of Fish Biology 68, 1271-1286.

- $\quad$ Borcherding J, Pickhardt C, Winter HV en Becker JS, 2008. Migration history of North Sea houting (Coregonus oxyrinchus L.) caught in Lake IJsselmeer (The Netherlands) inferred from scale transects of Sr-88: Ca-44 ratios. Aquatic Sciences 70:1, 47-56

- $\quad$ Borcherding J, Heynen M, Jäger-Kleinicke T, Winter HV en Eckman R, 2010. Re-establishment of the North Sea houting in the River Rhine. Fisheries Management and Ecology 17: 291-293.

- $\quad$ Borcherding J, Breukelaar AW, Winter HV en König U, 2014. Spawning migration and larval drift of anadromous North Sea houting (Coregonus oxyrinchus) in the River IJssel, the Netherlands. Ecology of Freshwater Fish 23: 161-170.

- $\quad$ Bos OG, Winter HW, van Keeken O, van Rijssel JC, Soldaat L. 2020. Naar een beoordelingssystematiek voor evaluatie van instandhoudingsdoelstellingen voor vissen in Natura 2000-gebieden in zoete en zoute rijkswateren. Wageningen Marine Research rapport C005/20.

- Brabrand $\AA$, 2001. Piscivory in larval perch (Perca fluviatilis): mechanisms structuring larval roach (Rutilus rutilus) cohorts. Ecology of Freshwater Fish 10(2) 97-104.

- $\quad$ Breine J, Pauwels IS, Verhelst PJ, Vandamme L, Baeyens R, Reubens J en Coeck J, 2017. Successful external acoustic tagging of twaite shad Alosa fallax (Lacépède 1803). Fisheries Research 191: 36-40.

- Breine J, Galle L, Lambeens I, Maes Y, Terrie T, Van Thuyne G, 2020a. Monitoring van de visgemeenschap in het Zeeschelde-estuarium: ankerkuilcampagnes 2019. Rapporten van het Instituut voor Natuur- en Bosonderzoek 2020 (4). INBO, Brussel.

- $\quad$ Breine J, Galle L, Lambeens I, Maes Y, Terrie T, Van Thuyne G, 2020b. Opvolgen van het visbestand in het Zeeschelde-estuarium: Viscampagnes 2019. Rapporten van het Instituut voor Natuur- en Bosonderzoek 2020 (6). INBO, Brussel.

- $\quad$ Buijs GJ, 2009. Vechten om de witvis. Visionair 11, 17-20.

- Carol J, Benejam L, Benito J, Garcia-Berthou E, 2009. Growth and diet of European catfish S. glanis in early and late invasion stages. Fundamental and Applied Limnology, 174:317-328. 
- Chotkowski MA, Marsden JE, 1999. Round goby and mottled sculpin predation on lake trout eggs and fry: field predictions from laboratory experiments. J Great Lakes Res 25:26-35.

- Cohen, A.N., \& J.T. Carlton, 1997. Transoceanic transport mechanisns: Introduction of the Chinese mitten crab, Eriocheir sinensis, to California. Pacific Science 51(1): 1-11.

- Copp GH, Kováč V, Zweimüller I, Dias A, Nascimento M, Balážová M, 2008. Preliminary study of dietary interactions between invading Ponto-Caspian gobies and some native fish species in the River Danube near Bratislava (Slovakia) Aquatic Invasions 3:193-200.

- Copp HG et al, 2009. Voracious invader or benign feline? A review of the environmental biology of European catfish Silurus glanis in its native and introduced ranges. Fish. Fish. 10, 252-282.

- Corkum LD, Sapota MR, Skora KE, 2004. The round goby, Neogobius melanostomus, a fish invader on both sides of the Atlantic Ocean, Biol. Invasions, 173-181.

- $\quad$ Couch J, 1867. A history of the Fishes of the British Islands. Vol IV. Hansebooks, London.

- Craig J, 1987. The biology of perch and related fishes. Portland,OR: Timber Press.

- Crombaghs B, Dorenbosch M, R Gubbels R, Kranenbarg J, 2007. Nederlandse Rivierdonderpad uit de Habitatrichtlijn bestaat uit twee soorten. De Levende Natuur 108 (6):pp. 248-251.

- De Boer H, 1972. De voedselbiologie van de Aalscholver. Rapport Zoölogisch Lab. Rijksuniversiteit Groningen,Rijksinstituut voor Natuurbeheer, Leersum.

- De Boois IJ, Couperus AC, 2019. Ankerkuilbemonstering in de Westerschelde Resultaten 2019 en Meerjarenoverzichten. Wageningen Marine Research report C104/19.

- De Bruin A, Kranenbarg J en Spikmans F, 2018. Onderzoek rivierprik Oude Grift. RAVON, Nijmegen. Rapportnummer 2017.144.

- De Graaf UH, 1979. Enkele kleine vissoorten in de ondiepe delen van het Grevelingenmeer: een schatting van hun aantal, biomassa en productie. Delta Instituut voor Hydrobiologisch Onderzoek.

- De Graaf M, De Boois IJ, Bos OG, Griffioen AB, Van Keeken O, Tien NSH en De Vries P, 2016. Toestand vis en visserij in de Zoete Rijkswateren: 2015. Deel I: Trends. Wageningen Marine Research Report C114/16.

- De Groot SJ, 2002. A review of the past and present status of anadromous fish species in the Netherlands: is restocking the Rhine feasible? Hydrobiologia 478 (1-3): 205-218.

- De Laak GAJ, 2010. Kennisdocument blankvoorn, Rutilus rutilus (Linnaeus, 1758). Kennisdocument 32. Sportvisserij Nederland, Bilthoven.

- De Leeuw JJ, Tulp I, de Boois IJ, van Willigen J en Westerink HJ, 2005. Zeldzame vissen in het IJsselmeergebied. Jaarrapport 2005. IMARES rapport C024/07.

- De Leeuw JJ, Winter HV, 2008. Migration of rheophilic fish in the large lowland rivers Meuse and Rhine, the Netherlands. Fisheries Management and Ecology 15: 409-415.

- $\quad$ De Leeuw JJ, van Emmerik W, 2020. Vis rond de Marker Wadden. Visionair 54, 18-21.

- De Leeuw JJ, van Donk SC, 2020a. Voedselreservering voor visetende vogels in het IJsselmeer en Markermeer. Wageningen Marine Research rapport C030/20.

- De Leeuw JJ, van Donk SC, 2020b. Hypotheses voor afname van de visstand in het IJsselmeer. Wageningen Marine Research rapport C051/20a.

- De Nie HW, 1996. Atlas van de Nederlandse zoetwatervissen. Media Publishing, Doetinchem.

- Deerenberg C, van Willigen JA. 2004. Bijvangst in schietfuiken op het IJsselmeer in relatie tot aantal kelen en aantal stadagen. RIVO rapport C005/04.

- Deerenberg, C, Rozemeijer MJC, van de Wolfshaar, K.E. \& van Rijn, S. Onderbouwing Herijking en Harmonisatie spieringprotocol - benodigde kennis, beschikbare kennis en kennislacunes. IMARES rapport (niet gepubliceerd).

- $\quad$ Dekker W, Schaap L, 1995. Het voedsel van blankvoorn en bot in het IJsselmeer in augustus 1994. DLO-Rijksinstituut voor Vissserijonderzoek, RIVO rapport nummer C035/1995.

- $\quad$ Dorenbosch M, van Kessel N, Kranenenbarg J, Spikmans F, Verberk WCEP, Leuven RSEW, 2011. Nevengeulen in uiterwaarden als kraamkamer voor riviervissen. Bosschap, bedrijfschap voor bos en natuur Rapport nr. 2011/OBN143-RI.

- $\quad$ EEA, 2017. Reference portal for reporting under Article 17 of the Habitats Directive. http://cdr.eionet.europa.eu/help/habitats_art17 
- Eklöv P, Persson L, 1995. Species-specific antipredator capacities and prey refuges: interactions between piscivorous perch (Perca fluviatilis) and juvenile perch and roach (Rutilus rutilus).

Behavioral Ecology and Sociobiology, 37(3), 169-178.

- Fladung $E, 2000$. Untersuchungen zur bestandsregulierung und verwertung der Chinesischen Wollhandkrabbe (Eriocheir sinensis). Schriften des Instituts für Binnenfischerei e.V. PotsdamSacrow Band 5. Institut für Binnenfischerei, Jägershof.

- French JRP, Jude DJ, 2001. Diets and diet overlap of nonindigenous gobies and small native fishes co-habitating the St. Clair River, Michigan. J. Great Lakes Res. 27:300-311.

- Freyhof J, Kottelat M, Nolte A, 2005. Taxonomic diversity of european Cottus with description of eight new species (Teleostei: Cottidae). Ichthyological Exploration of Freshwaters 16(2): 107172.

- Froese R, Pauly D (Eds), 2009. FishBase. World Wide Web electronic publication. www.fishbase.org, version (05/2009).

- Geeraerts CM, Ovidio M, Verbiest H, Buysse D, Coeck J, Belpaire C, Philippart JC 2006. De trekpatronen van blankvoorn (Rutilus rutilus L.) in gefragmenteerde rivieren in België. Congres Watersysteemkennis 2006 - 2007. Instituut voor Natuur- en Bosonderzoek.

- Glorius S, Craeymeersch J, Van der Hammen T, Rippen A, Cuperus J, Van der Weide B, Steenbergen J \& Tulp I (2015) Effecten van garnalenvisserij in Natura 2000 gebieden. IMARES Rapport C013/15.

- Goldspink CR, 1971. Fish production studies in Tjeukemeer, The Netherlands. NIOO CL Nederlands Instituut voor Oecologisch Onderzoek, Centrum voor Limnologie, 1971.

- Goldspink CR, 1977. The return of marked roach (Rutilus rutilus L.) to spawning grounds in Tjeukemeer, The Netherlands. Journal of Fish Biology, 11(6), 599-603.

- Griffioen $A B$ en Winter HV, 2014. Merk-terugvangst experiment rivierprik (Lampetra fluviatilis) bij Kornwerderzand. IMARES-report C044/14.

- Hautala A, 2008. Autumnal shift from diurnal to nocturnal peaking feeding activity of Rutilus rutilus in boreal lake littoral zones. Journal of Fish Biology 73(6), 1407-1418.

- Heesen H, Daan N, Ellis J, 2015. Fish atlas oft he Celtic Sea, North Sea, and Baltic Sea, based on international reaserch-vessel surveys. Wageningen Academic Publishers, Wageningen, pp 572.

- Hempel M, 2017. Ecological niche of invasive round goby Neogobius melanostomus (Pallas, 1814 ) in the Kiel Canal and adjacent section of the Elbe River. Doctor of Philosophy, Universität Hamburg.

- Hop J, Vriese FT, 2018. Analyse detectiegegevens salmoniden 2011-2016. ATKB rapport 20170122/rap01.

- ICES, 2020. Working Group on Beam Trawl Surveys (WGBEAM). ICES Scientific Reports. 2:48. $86 \mathrm{pp}$.

- Janáč M, Valová Z, Roche K, Jurajda P, 2016. No effect of round goby Neogobius melanostomus colonisation on young-of-the-year fish density or microhabitat use. Biological Invasions, $18(8)$, 2333-2347.

- Jude DJ, Janssen J, Crawford G, 1995. Ecology, distribution, and impact of the newly introduced round tubenose gobies on the biota of the St. Clair \& Detroit Rivers. In The Lake Huron Ecosystem: Ecology, Fisheries and Management, eds. M. Munawar, T.A. Edsall, and J.H. Leach, pp. 447-460. Amsterdam, The Netherlands: SPB Academic Publishing.

- Jůza T, Blabolil P, Baran, R, Bartoň D, Čech M, Draštík V, .. Kubečka J 2018. Collapse of the native ruffe (Gymnocephalus cernua) population in the Biesbosch lakes (the Netherlands) owing to round goby (Neogobius melanostomus) invasion. Biological Invasions, 20(6), 1523-1535.

- Kamps LF, 1937. De Chineesche Wolhandkrab in Nederland. Proefschrift. Drukkerij "De Marne", Leens.

- Kennedy CR, Shears C, Shears A, 2001. Long-term dynamics of Ligula intestinalis and roach Rutilus rutilus: a study of three epizootic cycles over thirty-one years. Parasitology 123(3) 257269.

- Klinge M, Buijse AD, Cazemier WG, Lammens EHRR, Prins KH, 1998. Biologische monitoring zoete rijkswateren. Vis in de zoete rijkswateren 1992-1996. Report 98.017 
- $\quad$ Klinge M, 2008. Bureaustudie: invloed aalscholvers IJsselmeer en Markermeer op visstand en beroepsvisserij. Witteveen + Bos, Deventer.

- Kloppmann M, Zeiler M, Stelzenmüller V, Ehrich S, Zauke GP en Böttcher U. 2003. Zur Ausweisung von Natura 2000-Schutzgebieten in der AWZ von Nord- und Ostsee unter Berücksichtigung der FFH-Lebensraumtypen und -Fischarten.

- Knopf K, Krieger A, Hölker F, 2007. Parasite community and mortality of overwintering young-ofthe-year roach (Rutilus rutilus). Journal of Parasitology 93(5):985-991.

- Kopetsch D \& Scholle J, 2020. Stow net fishery Ems 2019 : fish fauna study within the framework of water status monitoring in accordance with the WFD; Bioconsult Bremen.

- Kottelat, M \& J. Freyhof, 2007. Handbook of European freshwater fishes. Kottelat, Cormol and Freyhof, Berlin, Germany.

- Kranenbarg J, Spikmans F, Thissen JBM, de Bruin A en Herder HE, 2012. Rivierprikken in de Kendel. Natuurhistorisch Maandblad 101(12): 254-261.

- L'Abee-Lund JH, Vøllestad LA, 1985. Homing precision of roach Rutilus rutilus in Lake Årungen, Norway. Environmental Biology of Fishes 13(3), 235-239.

- Lammens EHRR, Geursen J, McGillavry PJ, 1986. Diet shifts, feeding efficiency and coexistence of bream (Abramis brama), roach (Rutilus rutilus) and white bream (Blicca bjoerkna) in hypertrophic lakes. In: Lammens, EHRR: Interactions between fishes and the structure of fish communities in Dutch shallow, eutrophic lakes. Doctoral thesis, University of Wageningen, 5064.

- $\quad$ Latli A, Descy JP, Mondy CP, Floury M, Viroux L, Otjacques W, Marescaux J, Depiereux E, Ovidio $M$, Usseglio-Polatera $P$, Kestemont $P, 2017$. Long-term trends in trait structure of riverine communities facing predation risk increase and trophic resource decline. Ecological applications, 27(8), 2458-2474.

- Latli A, Michel LN, Lepoint G, Kestemont P, 2019. River habitat homogenisation enhances trophic competition and promotes individual specialisation among young of the year fish. Freshwater Biology 64:520-531.

- Lenders HJR, Chamuleau TPM, Hendriks AJ, Lauwerier RCGM, Leuven RSEW en Verberk WCEP, 2016. Historical rise of waterpower initiated the collapse of salmon stocks. Scientific Reports 6: 29269.

- Lessmark O, 1983. Competition between perch Perca fluviatilus and roach Rutilus rutilus in south Swedish lakes. Institute of Limnology. University of Lund, Sweden.

- $\quad$ LNV, 2008. Profieldocument Elft. Website = https://www.synbiosys.alterra.nl/natura2000/gebiedendatabase.aspx?subj=profielen

- Lucas \& Baras, 2001. Migration of freshwater fish. Blackwell Scientific Publications.

- Maitland PS, 2003. Ecology of the River, Brook and Sea Lamprey. Conserving Natura 2000 Rivers Ecology Series No. 5. English Nature, Peterborough.

- Matthews J, Van der Velde G, De Vaate AB, Collas FP, Koopman KR, Leuven RS, 2014. Rapid range expansion of the invasive quagga mussel in relation to zebra mussel presence in The Netherlands and Western Europe. Biological Invasions, 16(1), 23-42.

- Molls F, 1999. New insights into the migration and habitat use by bream and white bream in the floodplain of the River Rhine. Journal of Fish Biology 55(6), 1187-1200.

- Mombaerts M, Verreycken H, Volckaert FA, Huyse T, 2014. The invasive round goby Neogobius melanostomus and tubenose goby Proterorhinus semilunaris: two introduction routes into Belgium. Aquatic Invasions, 9(3).

- $\quad$ Mulder IM, Tulp I, Ysebaert T, 2020. Ontwikkelingen van bodemgebonden vis en epibenthos in de Oosterschelde in de periode 1970-2018. Wageningen Marine Research report C024/20.

- $\quad$ Nagelkerke LAJ, Sibbing FA, 1996. Efficiency of feeding on zebra mussel (Dreissena polymorpha) by common bream (Abramis brama), white bream (Blicca bjoerkna), and roach (Rutilus rutilus): the effects of morphology and behaviour. Can J Fish Aquat Sci 53:2847-2861.

- $\quad$ NDDF \& ANEMOON 2020. Verspreidingsatlas samengesteld door Nationale Databank voor Flora en Fauna en Stichting Anemoon: www.verspreidingsatlas.nl 
- Niemeijer, B. \& Wullink, J. 2019. Reisverslag MWTL Rivieren voorjaar 2019. ATKB report nr: 20180615/not05

- $\quad$ Noble RAA, Cowx IG, Goffaux D, Kestemont P, 2007. Assessing the health of European rivers using functional ecological guilds of fish communities: standardising species classification and approaches to metric selection. Fisheries Management and Ecology, 14(6), 381-392.

- Nolte AW, Sheets HD, 2005. Shape based assignment tests suggest transgressive phenotypes in natural sculpin hybrids (Teleostei, Scorpaeniformes, Cottidae). Frontiers in zoology, 2(1), 11.

- $\quad$ Nolte AW, Freyhof J, Stemshorn KC, Tautz D, 2005. An invasive lineage of sculpins, Cottus sp.(Pisces, Teleostei) in the Rhine with new habitat adaptations has originated from hybridization between old phylogeographic groups. Proceedings of the Royal Society B: Biological Sciences, 272(1579), 2379-2387.

- Otjacques W, De Laender F, Kestemont P, 2016. Discerning the causes of a decline in a common European fish, the roach (Rutilus rutilus L.): A modelling approach. Ecological Modelling, 322, 92-100.

- Otjacques W, Latli A, Bernard B, Ovidio M, Depiereux E, Kestemont P, 2015. Recent decline of roach Rutilus rutilus stock in a large river ecosystem in relation with its population dynamics. Fundamental and Applied Limnology, 187, 13.

- OVB, 1988. Cursus Vissoorten, deel 1. Organisatie ter Verbetering van de Binnenvisserij (OVB), Nieuwegein.

- $\quad$ Panning A., 1939. The Chinese mitten crab. Smithsonian Ann. Rep. 1938: 361-375.

- $\quad$ Patberg W, de Leeuw JJ en Winter HV, 2005. Verspreiding van rivierprik, zeeprik, fint en elft in Nederland na 1970. Nederlands Instituut voor Visserij Onderzoek (RIVO) Rapport nr. C004/05.

- Persson L, 1983a. Effects of intra- and interspecific competition on dynamics and size structure of a perch Perca fluviatilis and a roach Rutilus rutilus population. Oikos. vol. 41. 1983. p. 126132.

- $\quad$ Persson L, 1983b. Food consumption and the significance of detritus and algae to intraspecific competition in roach Rutilus rutilus in a shallow eutrophic lake. Oikos. vol. 41. 1983. p. 118-125

- Persson A, Hansson, LA, 1999. Diet shift in fish following competitive release. Canadian Journal of Fisheries and Aquatic Sciences, 56, 70-78.

- Pigneur LM, Falisse E, Roland K, Everbecq E, Deliège JF, Smitz JS, Van Doninck K, Descy JP, 2014. Impact of invasive Asian clams, Corbicula spp., on a large river ecosystem. Freshw Biol, 59: 573-583.

- $\quad$ Pinder AC, 2001. Keys to larval and juvenile stages of coarse fishes from fresh waters in the British Isles. In: D. W. Sutcliffe (Ed.),. UK: Freshwater Biological Association.

- PO IJsselmeer 2013. Visplan IJsselmeer en Markermeer-IJmeer 2013. VBC IJsselmeer i.o./ Deel PO IJsselmeer/beroepsvisserij.

- Pollux BJA, Korosi A, Verberk WCEP, Pollux PMJ, van der Velde G, 2006. Reproduction, Growth, and Migration of Fishes in a Regulated Lowland Tributary: Potential Recruitment to the River Meuse. Hydrobiologia 565(1) 105-120.

- Poos M, Dextrase AJ, Schwalb AN, Ackerman JD, 2010. Secondary invasion of the round goby into high diversity Great Lakes tributaries and species at risk hotspots: potential new concerns for endangered freshwater species. Biol Invasions 12:1269-1284.

- Poulsen SB, Jensen LF, Schulz C, Deacon M, Meyer KE, Jäger-Kleinicke T, Schwarten H, Svendsen JC. 2012. Ontogenetic differentiation of swimming performance and behaviour in relation to habitat availability in the endangered North Sea houting (Coregonus oxyrinchus). Aquatic Living Resources, 25(3), 241-249.

- Rask M, 1989. A note on the diet of roach Rutilus rutilus L., and other cyprinids at Tvärminne, Northern Baltic Sea. Aqua Fenn. 19 (1) p. 19- 27.

- $\quad$ Redeke, HC, 1941. De fauna van Nederland X (Pisces). Sijthoff's, Leiden.

- $\quad$ RIVM, 2017. Waterkwaliteit in Nederland; toestand (2012-2015) en trend (1992-2015) Addendum bij rapport 2016-0076. RIVM Rapport 2017-0008. 
- $\quad$ Scharbert A en Beeck P, 2010. The reintroduction of the allis shad (Alosa alosa) to the Rhine system. LANUV-Fachbericht 28. North Rhine-Westphalia State Agency for Nature, Environment and Consumer Protection.

- Schneider J, 2011. Review of reintroduction of Atlantic salmon (Salmo salar) in tributaries of the Rhine River in the German Federal States of Rhineland-Palatinate and Hesse J. Appl. Ichthyol. 27 (Suppl. 3), 24-32.

- $\quad$ Schilder K 2017. The invasive Neogobius melanostomus (round goby) in the foodweb of lake IJsselmeer and lake Markermeer. MSc-rapport, University of Amsterdam \& Wageningen University \& Research.

- Soes, D. M., van Horssen, P. W., Bouma, S., \& Collombon, M. T. 2007. Chinese wolhandkrab: een literatuurstudie naar ecologie en effecten. Bureau Waardenburg.

- $\quad$ Soldaat L, Visser H, van Roomen M en van Strien A, 2007. Smoothing and trend detection in waterbird monitoring data using structural time-series analysis and the Kalman filter. J. of Ornithology 148, suppl. 2: 351-357 DOI 10.1007/s10336-007-0176.

- $\quad$ Spikmans F, de Bruin A en Kranenbarg J, 2016. Verkennende studie naar voorkomen larven rivier- en zeeprik in de Maas. Stichting RAVON rapport 2015.032, Nijmegen.

- $\quad$ Stoffers T, Collas FPL, Buijse AD, Geerling GW, Jans LH, Van Kessel N, Verreth JAJ, Nagelkerke LAJ. 2020. 30 years of large river restoration: How long do restored floodplain channels remain suitable for targeted rheophilic fishes in the lower river Rhine?. Science of The Total Environment, 142931.

- $\quad$ STOWA 2012. Gemalen of vermalen worden? Onderzoek naar de visvriendelijkheid van 26 opvoerwerktuigen. STOWA rapport 2012-04.

- STOWA 2018. Referenties en maatlatten voor natuurlijke watertypen voor de kaderrichtlijn water 2021-2027. STOWA rapport 2018-49.

- Svärdson G, 1976. Interspecific Population Dominance in Fish Communities of Scandinavian Lakes. Rep. Inst. Freshwat. Res. Drottningholm 55 p. 144-171.

- Syväranta J et al, 2010. Dietary breadth and trophic position of introduced European catfish Silurus glanis in the River Tarn (Garonne River basin), southwest France. Aquat. Biol. 8, 137144.

- Tammi J, Rask M, Vuorenmaa J, Lappalainen A, Vesala S, 2004. Population responses of perch (Perca fluviatilis) and roach (Rutilus rutilus) to recovery from acidification in small Finnish lakes. Hydrobiologia 528(1-3) 107-122.

- Tangelder M, Ysebaert T, Wijsman J, Janssen J, Mulder I, Nolte A, Stolte W, van Rooijen N, van den Boogaart L, Arts F, Hoekstein M, Sluijter M, van der Jagt H \& Kaardinaal E 2019. Ecologisch onderzoek Getij Grevelingen: Onderzoek naar de historische ontwikkeling van het watersysteem en inschatting van de autonome ontwikkeling vergeleken met getijscenario's en effecten op Natura 2000-soorten en habitats bij gedempt getij. Wageningen Marine Research rapport C089/19.

- Teal, L.R., van Hal, R., van Kooten, T., Ruardij, P. \& Rijnsdorp, A.D. 2012. Bio-energetics underpins the spatial response of North Sea plaice (Pleuronectes platessa L.) and sole (Solea solea L.) to climate change. Global Change Biology, 18, 3291-3305.

- $\quad$ Tien NSH, Griffioen AB, van Keeken OA, van Rijssel JC, de Leeuw JJ, 2019. Vismonitoring Zoete Rijkswateren en Overgangswateren $\mathrm{t} / \mathrm{m}$ 2017. Deel 1: Toestand en trends. Wageningen Marine Research rapport C084/18A.

- $\quad$ Tien NSH, Van der Hammen T, 2019. Bestandsoverzicht van snoekbaars, blankvoorn en brasem in het IJssel-/Markermeer. Wageningen Marine Research rapport C023/19.

- $\quad$ Tien NSH, Mosqueira Sanchez I, Brunel T, van der Hammen T, Molla Gazi K, van Donk S, Foekema E, de Leeuw JJ, 2020. Bestandsoverzicht van snoekbaars, baars, blankvoorn en brasem en de evaluatie van potentiële oogstregels voor snoekbaars en baars. Wageningen Marine Research rapport C041/20.

- Tulp, I. 2015. Analyse visgegevens DFS (Demersal Fish Survey) ten behoeve van de compensatiemonitoring Maasvlakte 2. Wageningen Marine Research, rapport C080/15. 
- Van Dam C, Buijse AD, Dekker W, van Eerden MR, Klein Breteler JGP, Veldkamp R, 1995. Aalscholvers en beroepsvisserij in het IJsselmeer, het Markermeer en Noordwest-Overijssel. Rapport IKC Natuurbeheer nr. 19, Wageningen.

- Van de Wolfshaar KE, Griffioen AB, Winter HV, Tien NSH, Gerla D, van Keeken O en van der Hammen T, 2018. Evaluation of the Dutch Eel Management Plan 2018: Status of the eel population in 2005-2016. CVO rapport: 18.009.

- Van den Brink F, van der Velde G en Cazemier WG, 1990. The faunistic composition of the freshwater section of the river Rhine in The Netherlands: present state and changes since 1900. Limnologie aktuell Vol 1, 191-216.

- Van der Hammen T, 2019. Recreational fisheries in the Netherlands: Analyses of the 2017 screening survey and the 2016-2017 logbook survey. Wageningen Marine Research, CVO rapport 18.025 .

- Van der Molen, DTR, Pot R, Evers CRM, van Herpen FCJ en Nieuwerburgh LLJ. 2016. Referenties en maatlatten voor natuurlijke watertypen voor de Kader Richtlijn Water 2015-2021, Stichting Toegepast Onderzoek Waterbeheer rapportnummer 2012-31.

- Van der Winden J, Dirksen S, Poot M, 2018. Visdieven in het IJsselmeergebied. Aantalsontwikkeling, kolonisatie eilanden en broedsucces. Rapport 2018-02, Jan van der Winden Ecology, Utrecht.

- Van Dobben WH, 1952. The food of the Cormorant in the Netherlands. Ardea, 40: 1-63.

- Van Eerden MR, van Rijn S, 2007. Aalscholvers, vis en visserij in het IJsselmeergebied 'Zwart schaap of indicator in het dynamisch drieluik?' Visionair 1 (3): 30-33.

- Van Keeken OA, de Bruijn PJA, Griffioen AB, van Os-Koomen E, Wiegerinck JAM, 2020. Vismonitoring Zoete Rijkswateren en Overgangswateren t/m 2019: Deel II, Toegepaste methoden. Wageningen Marine Research rapport C047/20.

- Van Keeken OA, 2018. Species identification workshop winter 2017-2019, fresh water fish. WMR report 18.003.

- Van Kessel, N, Dorenbosch M, Crombaghs B, Gubbels R, 2009. Indicaties voor voortplanting van de Zeeprik in Nederland. Natuurhistorisch Maandblad 98:32-37.

- Van Kessel N, Dorenbosch M, De Boer MRM, Leuven R, Van der Velde G, 2011. Competition for shelter between four invasive gobiids and two native benthic fish species. Curr Zool 57:844-851

- Van Kessel N, Kranenbarg J, Dorenbosch M, de Bruin A, Nagelkerke LAJ, van der Velde G, Leuven RSEW, 2013. Mitigatie van effecten van uitheemse grondels: kansen voor natuurvriendelijke oevers en uitgekiende kunstwerken. Radboud University Nijmegen, Report Environmental Science 436, pp 1-88.

- Van Kessel N, Dorenbosch M, Kranenbarg J, van der Velde G, Leuven RSEW, 2014. Invasieve grondels in de grote rivieren en hun effect op de beschermde rivierdonderpad. De Levende Natuur 115: 122-128

- Van Kessel N, Dorenbosch M, Kranenbarg J, van der Velde G, Leuven RSEW, 2016. Invasive Ponto-Caspian gobies rapidly reduce the abundance of protected native bullhead. - Aquatic Invasions 11 (2): 179-188.

- Van Rijn SHM, Van Eerden MR, 2002. Aalscholvers in het IJsselmeergebied: concurrent of graadmeter. RIZA rapport 2001.058.

- Van Rijssel JC, van der Hammen T, 2020. Report on the eel stock, fishery and other impacts, in The Netherlands. ICES, WGEEL 2020.

- Van Rijssel JC, van Keeken OA, de Leeuw JJ, 2019a. Vismonitoring Zoete Rijkswateren en Overgangswateren t/m 2018. Wageningen Marine Research rapport C109/19.

- Van Rijssel JC, van Puijenbroek M, Schilder K, Winter E, 2019b. Impact van verschillende visserijvormen op trekvissen. Wageningen Marine Research rapport C046/19.

- Vanderploeg HA et al, 2002. Dispersal and emerging ecological impacts of Ponto-Caspian species in the Laurentian Great Lakes. Can J Fish Aquat Sci 59:1209-1228.

- Vašek M, Všetičková L, Roche K, Jurajda P, 2014. Diet of two invading gobiid species (Proterorhinus semilunaris and Neogobius melanostomus) during the breeding and hatching 
season: no field evidence of extensive predation on fish eggs and fry. Limnologica-Ecology and Management of Inland Waters, 46, 31-36.

- Veldhuizen T \& Stanish S, 1999. Overview of the Life History, Distribution, Abundance and impacts of the Chinese mitten crab, Eriocheir sinensis. California Department of Water Resources, Environmental Services Office.

- Verstijnen Y, Lucassen E, Smolders F, \& Wagenvoort A, 2019. De invloed van de invasieve Quaggamossel en Zwartbekgrondel op het voedselweb in de Biesboschspaarbekkens. H2O online, Augustus 2019.

- Voslamber B, 1988. Visplaatskeuze, foerageerwijze en voedselkeuze van aalscholvers phalacrocorax carbo in het ijsselmeergebied in 1982. Flevobericht nr. 286.

- Vriese, F.T., 2018. Concept artikel Smolt migration on the river Rhine 2006-2016. ATKB rapport 20170120/Rap.01

- Wijmans PADM, 2007. Kennisdocument barbeel, barbus barbus (Linnaeus, 1758). Kennisdocument 14. Sportvisserij Nederland.

- Wilkoń-Michalska J, 1967. Spawning migration of roach (Rutilus Rutilus L.) in lake Śniardwy. Ser. H 90:517-538.

- Winter HV en de Leeuw JJ, 2007. Zender-experiment met zalm en zeeforel in de Lek/Nederrijn bij Hagestein gedurende 2005-2006. IMARES Report C053.07.

- Winter HV en Griffioen AB, 2007. Verspreiding van rivierprik-larven in het Drentsche Aa stroomgebied. IMARES, IJmuiden.

- Winter HV, 2009. Voorkomen en gedrag van trekvissen nabij kunstwerken en consequenties voor de vangkans met vistuigen. Imares-rapport C076/09.

- Winter HV, Griffioen AB, van Keeken OA en Schollema PP, 2013. Telemetry study on migration of river lamprey and silver eel in the Hunze and Aa catchment basin. IMARES report C012/13.

- Winter HV, 2017. Taxonomische status van houting in Nederlandse wateren. WUR rapport C115/17.

- Zanette LY, Clinchy M. 2019. Ecology of fear. Current Biology 29, R301-R316. 


\section{Verantwoording}

Rapport C105/20

Projectnummer: 4316100124, 4316100125 en 4311218014

Dit rapport is met grote zorgvuldigheid tot stand gekomen. De wetenschappelijke kwaliteit is intern getoetst door een collega-onderzoeker en het verantwoordelijk lid van het managementteam van Wageningen Marine Research

Akkoord:

Jip Vrooman

Onderzoeker/ecoloog

Handtekening:

Datum:

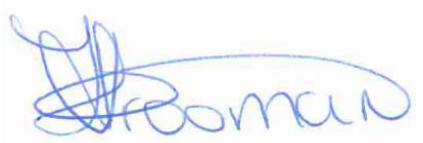

1 december 2020

Akkoord:

Drs. J. Asjes

MT lid Integratie

Handtekening:

Datum:

1 december 2020 


\section{Bijlage 1 Ecologische gildes}

Soort

\begin{tabular}{|r|l|} 
Soort & Invasieve soo \\
\hline Blauwneus & \\
\hline Donaubrasem & \\
\hline Kesslers grondel & \\
\hline Marmergrondel & \\
\hline Pontische stroomgrondel & \\
\hline Witvinriviergrondel & \\
\hline Zwartbekgrondel & \\
\hline Aal & \\
\hline Brasem & \\
\hline Guropese meerval & \\
\hline Giebel & \\
\hline Hybride cyprinide & \\
\hline Karper & \\
\hline Kleine modderkruiper &
\end{tabular}

Kleine modderkruiper Kolblei Kwabaal

Snoekbaars

$\begin{array}{r}\hline \text { Snoek } \\ \hline \\ \hline \text { Blank }\end{array}$

Driedoornige stekelbaars

Graskarper

$\begin{array}{r}\hline \text { Snoek } \\ \hline \text { Spiering } \\ \hline \text { Goudvis } \\ \text { Bot } \\ \hline \text { Zeelt } \\ \hline \text { Amerikanons }\end{array}$

$\begin{array}{r}\hline \text { Graskarper } \\ \hline \text { Snoek } \\ \hline \text { Goudvis } \\ \hline \text { Bot } \\ \hline \text { Zeelt } \\ \hline \text { Amerikaanse }\end{array}$

$\begin{array}{r}\hline \text { Snoek } \\ \hline \text { Spiering } \\ \hline \text { Goudvis } \\ \hline \text { Bot } \\ \hline \text { Zeelt } \\ \hline \text { Amerikanse }\end{array}$

$\begin{array}{r}\hline \text { Snoek } \\ \hline \text { Spiering } \\ \hline \text { Goudvis } \\ \text { Bot } \\ \hline \text { Zeelt } \\ \hline \text { Amerikanons }\end{array}$

$\begin{array}{r}\hline \text { Snoek } \\ \hline \text { Spiering } \\ \hline \text { Goudvis } \\ \text { Bot } \\ \hline \text { Zeelt }\end{array}$ Pos Alver

Baars

Amerikaanse hondsvis
Blauwband

Zonnebaars

Kleine marene

Bittervoorn

Noordzeehouting

Rietvoorn

Tiendoornige stekelbaars

Vetje

Barbeel

Beekprik

Bermpje

Rivierdonderpad

Riviergrondel

Rivierprik

Sneep

Steur

Zeeprik

Roofblei

Elft

Elrits

Fint

Gestippelde alver

Kopvoorn

Serpeling

Vlagzalm

Winde

Zalm

Zeeforel
Invasieve soort Ecologische gilde Eurytoop

Eurytoop

Eurytoop

Eurytoop

Eurytoop

Eurytoop

Eurytoop

Eurytoop

Eurytoop

Eurytoop

Eurytoop

Eurytoop

Eurytoop

Eurytoop

Eurytoop

Eurytoop

Eurytoop

Eurytoop

Eurytoop

Eurytoop

Eurytoop

Eurytoop

Eurytoop

Eurytoop

Eurytoop

Limnofiel

Limnofiel

Limnofiel

Limnofiel

Limnofiel

Limnofiel

Limnofiel

Limnofiel

Limnofiel

Limnofiel

Limnofiel

Limnofiel

Rheofiel

Rheofiel

Rheofiel

Rheofiel

Rheofiel

Rheofiel

Rheofiel

Rheofiel

Rheofiel

Rheofiel

Rheofiel

Rheofiel

Rheofiel

Rheofiel

Rheofiel

Rheofiel

Rheofiel

Rheofiel

Rheofiel

Rheofiel

Voorkeur in waterkolom
Bentisch

Bentisch

Bentisch

Bentisch

Bentisch

Bentisch

Bentisch

Bentisch

Bentisch

Bentisch

Bentisch

Bentisch

Bentisch

Bentisch

Bentisch

Bentisch

Bentisch

Pelagisch

Pelagisch

Pelagisch

Pelagisch

Pelagisch

Pelagisch

Pelagisch

Bentisch

Bentisch

Bentisch

Pelagisch

Pelagisch

Pelagisch

Pelagisch

Pelagisch

Pelagisch

Pelagisch

Pelagisch

Pelagisch

Bentisch

Bentisch

Bentisch

Bentisch

Bentisch

Bentisch

Bentisch

Bentisch

Bentisch

Pelagisch

Pelagisch

Pelagisch

Pelagisch

Pelagisch

Pelagisch

Pelagisch

Pelagisch

Pelagisch

Pelagisch

Pelagisch 


\begin{tabular}{|c|c|c|c|}
\hline Soort & Invasieve soort & Ecologische gilde & Voorkeur in waterkolom \\
\hline Adderzeenaald & & Marien & Bentisch \\
\hline Blonde grondel & & Marien & Bentisch \\
\hline Brakwatergrondel & & Marien & Bentisch \\
\hline Dikkopje & & Marien & Bentisch \\
\hline Driedradige meun & & Marien & Bentisch \\
\hline Dwergbolk & & Marien & Bentisch \\
\hline Dwergtong & & Marien & Bentisch \\
\hline Gehoornde slijmvis & & Marien & Bentisch \\
\hline Glasgrondel & & Marien & Bentisch \\
\hline Grauwe poon & & Marien & Bentisch \\
\hline Griet & & Marien & Bentisch \\
\hline Groene zeedonderpad & & Marien & Bentisch \\
\hline Grote zeenaald & & Marien & Bentisch \\
\hline Harnasmannetje & & Marien & Bentisch \\
\hline Kabeljauw & & Marien & Bentisch \\
\hline Kleine pieterman & & Marien & Bentisch \\
\hline Kleine zeenaald & & Marien & Bentisch \\
\hline Knorrepos & & Marien & Bentisch \\
\hline Lozano's grondel & & Marien & Bentisch \\
\hline Naakte grondel & & Marien & Bentisch \\
\hline Pitvis & & Marien & Bentisch \\
\hline Puitaal & & Marien & Bentisch \\
\hline Rasterpitvis & & Marien & Bentisch \\
\hline Rode poon & & Marien & Bentisch \\
\hline Schar & & Marien & Bentisch \\
\hline Schol & & Marien & Bentisch \\
\hline Schurftvis & & Marien & Bentisch \\
\hline Slakdolf & & Marien & Bentisch \\
\hline Steenbolk & & Marien & Bentisch \\
\hline Tarbot & & Marien & Bentisch \\
\hline Tong & & Marien & Bentisch \\
\hline Tongschar & & Marien & Bentisch \\
\hline Vijfdradige meun & & Marien & Bentisch \\
\hline Vorskwab & & Marien & Bentisch \\
\hline Wijting & & Marien & Bentisch \\
\hline Witte koolvis & & Marien & Bentisch \\
\hline Zandspiering & & Marien & Bentisch \\
\hline Zeedonderpad & & Marien & Bentisch \\
\hline Zwarte grondel & & Marien & Bentisch \\
\hline Zwarte koolvis & & Marien & Bentisch \\
\hline Ansjovis & & Marien & Pelagisch \\
\hline Botervis & & Marien & Pelagisch \\
\hline Diklipharder & & Marien & Pelagisch \\
\hline Dunlipharder & & Marien & Pelagisch \\
\hline Goudharder & & Marien & Pelagisch \\
\hline Haring & & Marien & Pelagisch \\
\hline Horsmakreel & & Marien & Pelagisch \\
\hline Kleine koornaarvis & & Marien & Pelagisch \\
\hline Koornaarvis & & Marien & Pelagisch \\
\hline Sprot & & Marien & Pelagisch \\
\hline Zeebaars & & Marien & Pelagisch \\
\hline
\end{tabular}




\section{Bijlage 2 Totaal aangelande jaarlijkse vangsten beroepsvissers per gebied in kilo's (bron:LNV)}

\begin{tabular}{|c|c|c|c|c|c|c|c|c|c|c|}
\hline Gebied & 2010 & 2011 & 2012 & 2013 & 2014 & 2015 & 2016 & 2017 & 2018 & 2019 \\
\hline Alblasserwaard & 453 & 267 & 429 & 227 & 181 & 578 & 715 & 767 & 898 & 417 \\
\hline Amstel Gooi en Vecht & 1413 & 2795 & 3138 & 2769 & 2728 & 4768 & 2943 & 3500 & 4365 & 4159 \\
\hline Brabantse Delta & 6359 & 4695 & 5828 & 4780 & 5544 & 3588 & 1640 & 3755 & 1152 & 820 \\
\hline Eems & 0 & 0 & 4214 & 0 & 0 & 0 & 0 & 0 & 83 & 0 \\
\hline Fryslan & 36975 & 37089 & 35356 & 34972 & 34025 & 34057 & 29829 & 34910 & 30612 & 32930 \\
\hline Grevelingenmeer & 16824 & 10784 & 8288 & 8190 & 2480 & 698 & 187 & 3422 & 1655 & 475 \\
\hline Hoekse Waard & 844 & 0 & 0 & 0 & 0 & 115 & 53 & 0 & 0 & 0 \\
\hline Hollands Noorderkwartier & 32232 & 39108 & 30581 & 26434 & 27850 & 25549 & 22027 & 24392 & 22627 & 25462 \\
\hline Hunze en Aa's & 3437 & 7900 & 3125 & 7084 & 4482 & 4225 & 3609 & 3670 & 4130 & 2180 \\
\hline IJssel Plus & 27015 & 12866 & 12088 & 8225 & 9363 & 7175 & 5333 & 7437 & 3986 & 3476 \\
\hline IJsselmeer en Markermeer i.o. & 116613 & 178535 & 168280 & 144124 & 163832 & 140544 & 174284 & 264489 & 281138 & 327674 \\
\hline Lauwersmeer & 3730 & 6294 & 9866 & 14001 & 12514 & 4138 & 7536 & 7886 & 8719 & 7590 \\
\hline Noorderzijlvest & 4189 & 4420 & 6049 & 5031 & 5843 & 4158 & 7443 & 6020 & 6447 & 5181 \\
\hline Noordzeekanaal & 4010 & 235 & 152 & 66 & 170 & 170 & 29 & 242 & 164 & 161 \\
\hline Oosterschelde & 273 & 384 & 296 & 410 & 116 & 131 & 13 & 402 & 361 & 102 \\
\hline Oosterschelde ten westen vd waterkering & 0 & 0 & 0 & 0 & 0 & 0 & 0 & 0 & 167 & 0 \\
\hline Rijn en IJssel & 31 & 23 & 2 & 30 & 31 & 0 & 0 & 0 & 6 & 0 \\
\hline Rijnland & 11236 & 10959 & 16112 & 14209 & 11504 & 12017 & 11781 & 12446 & 11237 & 8995 \\
\hline Rivierenland & 459 & 2185 & 792 & 783 & 962 & 671 & 1009 & 951 & 1155 & 494 \\
\hline Roer en Overmaas & 0 & 0 & 0 & 0 & 0 & 11 & 0 & 0 & 35 & 0 \\
\hline Schieland en Krimpenerwaard & 577 & 906 & 575 & 345 & 188 & 900 & 38 & 491 & 61 & 0 \\
\hline Stichtse Rijnlanden & 2707 & 5328 & 2950 & 2144 & 1964 & 2152 & 2238 & 2339 & 3002 & 1712 \\
\hline Twentekanaal & 139 & 693 & 844 & 325 & 730 & 294 & 393 & 130 & 351 & 0 \\
\hline Veerse Meer & 4441 & 6185 & 5300 & 2716 & 3394 & 1863 & 1581 & 2111 & 2409 & 3483 \\
\hline Veluwe & 0 & 0 & 0 & 0 & 0 & 0 & 380 & 0 & 4600 & 3778 \\
\hline Veluwe Randmeren & 8802 & 12212 & 11017 & 13084 & 10788 & 14144 & 7471 & 8594 & 10065 & 11361 \\
\hline Volkerak-Zoommeer & 34050 & 5745 & 6062 & 12676 & 6846 & 13322 & 13302 & 10535 & 44410 & 24946 \\
\hline Waal Plus & 8213 & 0 & 0 & 0 & 10 & 0 & 0 & 0 & 6 & 34 \\
\hline Waddenzee & 20 & 0 & 0 & 0 & 0 & 0 & 0 & 0 & 60 & 0 \\
\hline Zandmaas (incl. Limburgse kanalen) & 8229 & 5 & 1164 & 1269 & 144 & 0 & 254 & 296 & 747 & 0 \\
\hline Zeegat van Goeree & 101 & 201 & 2196 & 1962 & 963 & 1951 & 3539 & 1085 & 1408 & 1086 \\
\hline Zeeuwse Eilanden & 2135 & 2179 & 2388 & 2094 & 1372 & 1016 & 1179 & 2162 & 3323 & 2928 \\
\hline Zuidelijke Randmeren & 4235 & 1248 & 4395 & 2100 & 1903 & 2926 & 1465 & 4353 & 4451 & 7146 \\
\hline Zuiderzeeland & 2211 & 3813 & 2932 & 1893 & 3324 & 3761 & 1711 & 3183 & 1889 & 1927 \\
\hline Aa en Maas (incl. Brabantse kanalen) & 584 & 0 & 0 & 0 & 0 & 0 & 0 & 12 & 0 & 0 \\
\hline Goeree Overflakkee & 1512 & 1074 & 1030 & 409 & 117 & 50 & 396 & 197 & 0 & 190 \\
\hline Grensmaas & 190 & 0 & 0 & 0 & 0 & 0 & 0 & 89 & 0 & 0 \\
\hline IJsselmonde & 30 & 0 & 325 & 0 & 170 & 0 & 428 & 0 & 0 & 0 \\
\hline Reest en Wieden & 1679 & 3099 & 2561 & 2119 & 2453 & 2335 & 597 & 810 & 0 & 954 \\
\hline Voorne en Putten & 1502 & 2653 & 0 & 751 & 123 & 757 & 0 & 81 & 0 & 0 \\
\hline Amsterdam-Rijnkanaal & 3440 & 1958 & 885 & 367 & 482 & 87 & 0 & 0 & 0 & 0 \\
\hline Benedenrivieren en Haringvliet i.o. & 69327 & 84 & 0 & 0 & 0 & 150 & 0 & 0 & 0 & 0 \\
\hline Delfland & 0 & 0 & 0 & 0 & 492 & 656 & 0 & 0 & 0 & 0 \\
\hline Groot Salland & 94 & 257 & 0 & 0 & 52 & 0 & 0 & 0 & 0 & 0 \\
\hline Peel en Maasvallei & 0 & 0 & 0 & 0 & 0 & 1 & 0 & 0 & 0 & 0 \\
\hline Zeeuws-Vlaanderen & 657 & 274 & 574 & 0 & 0 & 11 & 0 & 0 & 0 & 0 \\
\hline Delftland & 0 & 352 & 0 & 0 & 0 & 0 & 0 & 0 & 0 & 0 \\
\hline Dommel & 0 & 1 & 0 & 0 & 0 & 0 & 0 & 0 & 0 & 0 \\
\hline Maasmond & 33 & 0 & 0 & 0 & 0 & 0 & 0 & 0 & 0 & 0 \\
\hline Nederrijn Plus i.o. & 15342 & 0 & 0 & 0 & 0 & 0 & 0 & 0 & 0 & 0 \\
\hline Nieuwe waterweg & 5315 & 0 & 0 & 0 & 0 & 0 & 0 & 0 & 0 & 0 \\
\hline Regge en Dinkel & 40 & 0 & 0 & 0 & 0 & 0 & 0 & 0 & 0 & 0 \\
\hline Velt en Vecht & 420 & 295 & 0 & 0 & 0 & 0 & 0 & 0 & 0 & 0 \\
\hline Totaal & 442118 & 367101 & 349794 & 315589 & 317140 & 288969 & 303403 & 410757 & 455719 & 479661 \\
\hline
\end{tabular}




\section{Bijlage 3 IJsselmeer open water}

Tabel 1. Soortensamenstelling in percentages op basis van aantal in boomkorvangsten in het IJsselmeer per 5-jarige periode. De groepering geeft de ecologische indeling aan de hand van Noble et al. (2007) aan. Het cumulatief percentage geeft aan hoeveel de soorten over de gehele periode (1989-2019) voorkomen op basis van de gesommeerde CPUE op basis van het aantal. Nul-percentages zijn naar beneden afgeronde waarden, $*$ = exoot.

\begin{tabular}{|c|c|c|c|c|c|c|c|c|}
\hline Soort & Groepering & $\begin{array}{l}\text { Cumulatief } \\
\text { percentage }\end{array}$ & $\begin{array}{r}1989- \\
1994\end{array}$ & $\begin{array}{r}1995- \\
1999\end{array}$ & $\begin{array}{r}2000- \\
2004\end{array}$ & $\begin{array}{r}2005- \\
2009\end{array}$ & $\begin{array}{r}2010- \\
2014\end{array}$ & $\begin{array}{r}2015- \\
2019\end{array}$ \\
\hline pos & Eurytoop (Bentisch) & 40.32 & 14 & 33.82 & 59.67 & 62.99 & 72.26 & 15.09 \\
\hline spiering & Eurytoop (Pelagisch) & 75.24 & 57.45 & 38.5 & 22.47 & 21.25 & 13.9 & 29.66 \\
\hline baars & Eurytoop (Pelagisch) & 95.36 & 23.22 & 22.56 & 15.82 & 12.4 & 10.39 & 44.15 \\
\hline blankvoorn & Eurytoop (Pelagisch) & 97.89 & 4.27 & 2.55 & 1.12 & 2.52 & 1.11 & 1.67 \\
\hline brasem & Eurytoop (Bentisch) & 98.53 & 0.76 & 1.87 & 0.46 & 0.34 & 0.21 & 0.26 \\
\hline snoekbaars & Eurytoop (Bentisch) & 99.04 & 0.26 & 0.58 & 0.4 & 0.45 & 0.7 & 1.3 \\
\hline zwartbekgrondel* & Eurytoop (Bentisch) & 99.39 & - & - & - & - & 0.06 & 4.04 \\
\hline pontische stroomgrondel* & Eurytoop (Bentisch) & 99.7 & - & - & - & - & 0.09 & 3.47 \\
\hline driedoornige stekelbaars & Eurytoop (Pelagisch) & 99.92 & 0.01 & 0.02 & 0.01 & 0.02 & 1.13 & 0.1 \\
\hline bot & Limnofiel (Bentisch) & 99.95 & 0.03 & 0.04 & 0.03 & 0.01 & 0.03 & 0.08 \\
\hline rivierdonderpad & Rheofiel (Bentisch) & 99.98 & 0.01 & 0.06 & 0.01 & 0.01 & 0.08 & 0 \\
\hline haring/sprot & Marien (Pelagisch) & 99.99 & 0 & - & 0 & 0 & 0 & 0.13 \\
\hline winde & Rheofiel (Pelagisch) & 99.99 & 0 & 0 & 0.01 & 0.01 & 0.01 & 0 \\
\hline noordzeehouting & Limnofiel (Pelagisch) & 100 & - & - & - & 0 & 0 & 0.02 \\
\hline karper & Eurytoop (Bentisch) & 100 & 0 & 0 & 0 & 0 & 0 & 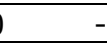 \\
\hline kesslers grondel* & Eurytoop (Bentisch) & 100 & - & - & - & - & 0 & 0 \\
\hline giebel & Eurytoop (Bentisch) & 100 & - & 0 & - & 0 & 0 & 0 \\
\hline marmergrondel* & Eurytoop (Bentisch) & 100 & - & - & - & - & 0 & - \\
\hline grondel sp. & Marien (Bentisch) & 100 & - & - & - & 0 & 0 & 0 \\
\hline hybride cyprinide & Eurytoop (Bentisch) & 100 & 0 & 0 & 0 & - & - & - \\
\hline kolblei & Eurytoop (Bentisch) & 100 & 0 & 0 & 0 & - & - & 0 \\
\hline alver & Eurytoop (Pelagisch) & 100 & - & - & 0 & 0 & - & 0 \\
\hline dunlipharder & Marien (Pelagisch) & 100 & - & - & - & - & - & 0 \\
\hline riviergrondel & Rheofiel (Bentisch) & 100 & - & - & 0 & - & 0 & - \\
\hline rivierprik & Rheofiel (Bentisch) & 100 & 0 & - & 0 & - & 0 & - \\
\hline serpeling & Rheofiel (Pelagisch) & 100 & 0 & - & - & - & - & - \\
\hline atlantische forel & Rheofiel (Pelagisch) & 100 & - & 0 & - & - & - & \\
\hline snoek & Eurytoop (Pelagisch) & 100 & 0 & - & - & - & 0 & \\
\hline sneep & Rheofiel (Bentisch) & 100 & 0 & - & 0 & - & - & - \\
\hline diklipharder & Marien (Pelagisch) & 100 & - & - & - & 0 & - & \\
\hline kleine modderkruiper & Eurytoop (Bentisch) & 100 & - & 0 & - & - & - & 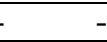 \\
\hline
\end{tabular}


Tabel 2. Soortensamenstelling in percentages op basis van biomassa in boomkorvangsten in het IJsselmeer per 5-jarige periode. De groepering geeft de ecologische indeling aan de hand van Noble et al. (2007) aan. Het cumulatief percentage geeft aan hoeveel de soorten over de gehele periode (19892019) voorkomen op basis van de gesommeerde CPUE op basis van de biomassa. Nul-percentages zijn naar beneden afgeronde waarden, $*=$ exoot.

\begin{tabular}{|c|c|c|c|c|c|c|c|c|}
\hline Soort & Groepering & $\begin{array}{l}\text { Cumulatief } \\
\text { percentage }\end{array}$ & $\begin{array}{r}1989- \\
1994 \\
\end{array}$ & $\begin{array}{r}1995- \\
1999 \\
\end{array}$ & $\begin{array}{r}2000- \\
2004 \\
\end{array}$ & $\begin{array}{r}2005- \\
2009 \\
\end{array}$ & $\begin{array}{r}2010- \\
2014 \\
\end{array}$ & $\begin{array}{r}2015- \\
2019 \\
\end{array}$ \\
\hline pos & Eurytoop (Bentisch) & 35.41 & 13.06 & 24.95 & 51.49 & 53.1 & 69.62 & 21.13 \\
\hline baars & Eurytoop (Pelagisch) & 58.48 & 24.26 & 22.13 & 18.63 & 18.14 & 16.51 & 48.58 \\
\hline spiering & Eurytoop (Pelagisch) & 78.07 & 37.84 & 11.25 & 10.92 & 12.66 & 7.45 & 11.13 \\
\hline brasem & Eurytoop (Bentisch) & 89.04 & 11.95 & 28.57 & 11.91 & 5.37 & 0.52 & 0.77 \\
\hline blankvoorn & Eurytoop (Pelagisch) & 95.86 & 10.88 & 9.15 & 3.56 & 6.93 & 2.36 & 2.08 \\
\hline snoekbaars & Eurytoop (Bentisch) & 98.61 & 1.59 & 3.37 & 3.11 & 3.57 & 2.74 & 4.75 \\
\hline pontische stroomgrondel* & Eurytoop (Bentisch) & 99.09 & - & - & - & - & 0.1 & 5.65 \\
\hline zwartbekgrondel* & Eurytoop (Bentisch) & 99.49 & - & - & - & - & 0.06 & 4.89 \\
\hline bot & Limnofiel (Bentisch) & 99.86 & 0.41 & 0.54 & 0.34 & 0.13 & 0.37 & 0.2 \\
\hline noordzeehouting & Limnofiel (Pelagisch) & 99.93 & - & - & - & 0.02 & 0.05 & 0.74 \\
\hline driedoornige stekelbaars & Eurytoop (Pelagisch) & 99.96 & 0 & 0 & 0 & 0 & 0.15 & 0.01 \\
\hline winde & Rheofiel (Pelagisch) & 99.97 & 0 & 0 & 0.03 & 0.06 & 0.02 & 0 \\
\hline rivierdonderpad & Rheofiel (Bentisch) & 99.98 & 0 & 0.02 & 0.01 & 0 & 0.03 & 0 \\
\hline karper & Eurytoop (Bentisch) & 99.99 & 0 & 0.01 & 0 & 0 & 0.01 & - \\
\hline hybride cyprinide & Eurytoop (Bentisch) & 99.99 & 0.01 & 0 & 0 & - & - & \\
\hline haring/sprot & Marien (Pelagisch) & 99.99 & - & - & 0 & 0 & 0 & 0.03 \\
\hline kolblei & Eurytoop (Bentisch) & 99.99 & 0 & 0 & 0 & - & - & 0.01 \\
\hline atlantische forel & Rheofiel (Pelagisch) & 100 & - & 0.01 & - & - & - & \\
\hline kesslers grondel* & Eurytoop (Bentisch) & 100 & - & - & - & - & 0 & 0.01 \\
\hline giebel & Eurytoop (Bentisch) & 100 & - & 0 & - & 0 & 0 & 0.01 \\
\hline snoek & Eurytoop (Pelagisch) & 100 & 0 & - & - & - & 0 & \\
\hline rivierprik & Rheofiel (Bentisch) & 100 & 0 & - & 0 & - & 0 & \\
\hline alver & Eurytoop (Pelagisch) & 100 & - & - & 0 & 0 & - & 0 \\
\hline sneep & Rheofiel (Bentisch) & 100 & 0 & - & 0 & - & - & - \\
\hline marmergrondel* & Eurytoop (Bentisch) & 100 & - & - & - & - & 0 & - \\
\hline grondel sp. & Marien (Bentisch) & 100 & - & - & - & 0 & 0 & 0 \\
\hline serpeling & Rheofiel (Pelagisch) & 100 & 0 & - & - & - & - & \\
\hline diklipharder & Marien (Pelagisch) & 100 & - & - & - & 0 & - & \\
\hline $\begin{array}{l}\text { riviergrondel } \\
\end{array}$ & Rheofiel (Bentisch) & 100 & - & - & 0 & - & 0 & - \\
\hline kleine modderkruiper & Eurytoop (Bentisch) & 100 & - & 0 & - & - & - & - \\
\hline dunlipharder & Marien (Pelagisch) & 100 & - & - & - & - & - & 0 \\
\hline
\end{tabular}


Tabel 3. Soortensamenstelling in percentages op basis van aantal in elektrokorvangsten in het IJsselmeer per 5-jarige periode. De groepering geeft de ecologische indeling aan de hand van Noble et al. (2007) aan. Het cumulatief percentage geeft aan hoeveel de soorten over de gehele periode (19952019) voorkomen op basis van de gesommeerde CPUE op basis van het aantal. Nul-percentages zijn naar beneden afgeronde waarden, $*=$ exoot.

\begin{tabular}{|c|c|c|c|c|c|c|c|}
\hline Soort & Groepering & $\begin{array}{l}\text { Cumulatief } \\
\text { percentage }\end{array}$ & $\begin{array}{r}1995- \\
1999 \\
\end{array}$ & $\begin{array}{r}2000- \\
2004 \\
\end{array}$ & $\begin{array}{r}2005- \\
2009 \\
\end{array}$ & $\begin{array}{r}2010- \\
2014 \\
\end{array}$ & $\begin{array}{r}2015- \\
2019 \\
\end{array}$ \\
\hline pos & Eurytoop (Bentisch) & 54.22 & 37.15 & 58.85 & 68.65 & 61.79 & 17.72 \\
\hline baars & Eurytoop (Pelagisch) & 76.49 & 21.55 & 28.34 & 19.03 & 11.33 & 34.06 \\
\hline spiering & Eurytoop (Pelagisch) & 93.61 & 34.52 & 9.4 & 10.23 & 19.97 & 25.69 \\
\hline aal & Eurytoop (Bentisch) & 95.95 & 4.17 & 1.88 & 0.17 & 0.24 & 0.66 \\
\hline blankvoorn & Eurytoop (Pelagisch) & 96.92 & 1.03 & 0.71 & 1.47 & 0.69 & 0.89 \\
\hline zwartbekgrondel* & Eurytoop (Bentisch) & 97.75 & - & - & - & 0.52 & 10.66 \\
\hline pontische stroomgrondel* & Eurytoop (Bentisch) & 98.51 & - & - & - & 1.34 & 7.85 \\
\hline bot & Limnofiel (Bentisch) & 98.87 & 0.69 & 0.27 & 0.13 & 0.26 & 1.06 \\
\hline snoekbaars & Eurytoop (Bentisch) & 99.24 & 0.3 & 0.34 & 0.16 & 0.52 & 1.1 \\
\hline driedoornige stekelbaars & Eurytoop (Pelagisch) & 99.6 & 0.02 & 0 & 0.01 & 2.26 & 0.09 \\
\hline rivierdonderpad & Rheofiel (Bentisch) & 99.79 & 0.12 & 0.08 & 0.05 & 0.81 & 0.04 \\
\hline brasem & Eurytoop (Bentisch) & 99.97 & 0.46 & 0.11 & 0.1 & 0.16 & 0.15 \\
\hline marmergrondel* & Eurytoop (Bentisch) & 99.98 & - & - & - & 0.05 & 0 \\
\hline winde & Rheofiel (Pelagisch) & 99.99 & 0 & 0.01 & 0 & 0.01 & 0 \\
\hline haring/sprot & Marien (Pelagisch) & 99.99 & - & - & 0 & 0.01 & 0.02 \\
\hline kesslers grondel* & Eurytoop (Bentisch) & 99.99 & - & - & - & 0.02 & 0.01 \\
\hline noordzeehouting & Limnofiel (Pelagisch) & 100 & - & - & 0 & 0 & 0.01 \\
\hline karper & Eurytoop (Bentisch) & 100 & 0 & 0 & 0 & 0 & \\
\hline kleine modderkruiper & Eurytoop (Bentisch) & 100 & - & 0 & 0 & 0 & 0 \\
\hline riviergrondel & Rheofiel (Bentisch) & 100 & 0 & 0 & 0 & 0 & - \\
\hline giebel & Eurytoop (Bentisch) & 100 & 0 & - & 0 & 0 & \\
\hline kolblei & Eurytoop (Bentisch) & 100 & 0 & 0 & - & - & - \\
\hline alver & Eurytoop (Pelagisch) & 100 & - & 0 & - & - & 0 \\
\hline brakwatergrondel & Marien (Bentisch) & 100 & - & - & 0 & 0 & - \\
\hline rivierprik & Rheofiel (Bentisch) & 100 & 0 & 0 & - & - & - \\
\hline blauwneus* & Eurytoop (Bentisch) & 100 & - & - & - & - & 0 \\
\hline diklipharder & Marien (Pelagisch) & 100 & - & - & 0 & - & \\
\hline grondel sp. & Marien (Bentisch) & 100 & - & - & 0 & - & \\
\hline
\end{tabular}


Tabel 4. Soortensamenstelling in percentages op basis van biomassa in elektrokorvangsten in het IJsselmeer per 5-jarige periode. De groepering geeft de ecologische indeling aan de hand van Noble et al. (2007) aan. Het cumulatief percentage geeft aan hoeveel de soorten over de gehele periode (19952019) voorkomen op basis van de gesommeerde CPUE op basis van de biomassa. Nul-percentages zijn naar beneden afgeronde waarden, $*=$ exoot.

\begin{tabular}{|c|c|c|c|c|c|c|c|}
\hline Soort & Groepering & $\begin{array}{l}\text { Cumulatief } \\
\text { percentage }\end{array}$ & $\begin{array}{r}1995- \\
1999 \\
\end{array}$ & $\begin{array}{r}2000- \\
2004 \\
\end{array}$ & $\begin{array}{r}2005- \\
2009 \\
\end{array}$ & $\begin{array}{r}2010- \\
2014 \\
\end{array}$ & $\begin{array}{r}2015- \\
2019 \\
\end{array}$ \\
\hline pos & Eurytoop (Bentisch) & 50.91 & 39.43 & 52.98 & 63.42 & 68.27 & 23.9 \\
\hline baars & Eurytoop (Pelagisch) & 76.2 & 26.14 & 29.9 & 24.31 & 16.21 & 30.54 \\
\hline aal & Eurytoop (Bentisch) & 83.48 & 9.48 & 5.81 & 1.32 & 2.15 & 5.86 \\
\hline spiering & Eurytoop (Pelagisch) & 88.18 & 7.19 & 2.21 & 3.89 & 6.19 & 8.95 \\
\hline brasem & Eurytoop (Bentisch) & 91.29 & 7.2 & 3.88 & 1.42 & 0.21 & 0.29 \\
\hline bot & Limnofiel (Bentisch) & 93.61 & 4.95 & 1.73 & 0.94 & 1.95 & 2.87 \\
\hline blankvoorn & Eurytoop (Pelagisch) & 95.93 & 3.75 & 1.85 & 3.25 & 1.15 & 1.21 \\
\hline snoekbaars & Eurytoop (Bentisch) & 97.6 & 1.76 & 1.57 & 1.39 & 1.44 & 3.39 \\
\hline pontische stroomgrondel* & Eurytoop (Bentisch) & 98.75 & - & - & - & 1.25 & 11.18 \\
\hline zwartbekgrondel* & Eurytoop (Bentisch) & 99.78 & - & - & - & 0.47 & 11.12 \\
\hline rivierdonderpad & Rheofiel (Bentisch) & 99.85 & 0.05 & 0.04 & 0.02 & 0.28 & 0.01 \\
\hline noordzeehouting & Limnofiel (Pelagisch) & 99.91 & - & - & 0 & 0.05 & 0.58 \\
\hline driedoornige stekelbaars & Eurytoop (Pelagisch) & 99.95 & 0 & 0 & 0 & 0.27 & 0.01 \\
\hline kesslers grondel* & Eurytoop (Bentisch) & 99.96 & - & - & - & 0.05 & 0.04 \\
\hline karper & Eurytoop (Bentisch) & 99.97 & 0.02 & 0 & 0.02 & 0.02 & \\
\hline winde & Rheofiel (Pelagisch) & 99.98 & 0 & 0.02 & 0.01 & 0.01 & 0.01 \\
\hline blauwneus* & Eurytoop (Bentisch) & 99.99 & - & - & - & - & 0.05 \\
\hline kolblei & Eurytoop (Bentisch) & 99.99 & 0.01 & 0 & - & - & \\
\hline marmergrondel* & Eurytoop (Bentisch) & 99.99 & - & - & - & 0.02 & 0 \\
\hline haring/sprot & Marien (Pelagisch) & 100 & - & - & 0 & 0.01 & 0 \\
\hline giebel & Eurytoop (Bentisch) & 100 & 0 & - & 0 & 0.01 & \\
\hline rivierprik & Rheofiel (Bentisch) & 100 & 0 & 0 & - & - & - \\
\hline alver & Eurytoop (Pelagisch) & 100 & - & 0 & - & - & 0 \\
\hline riviergrondel & Rheofiel (Bentisch) & 100 & 0 & 0 & 0 & 0 & - \\
\hline kleine modderkruiper & Eurytoop (Bentisch) & 100 & - & 0 & 0 & 0 & 0 \\
\hline diklipharder & Marien (Pelagisch) & 100 & - & - & 0 & - & \\
\hline grondel sp. & Marien (Bentisch) & 100 & - & - & 0 & - & \\
\hline brakwatergrondel & Marien (Bentisch) & 100 & - & - & 0 & 0 & \\
\hline
\end{tabular}




\section{Bijlage 4 IJsselmeer oever}

Tabel 1. Soortensamenstelling in percentages op basis van aantal in elektroschepnetvangsten bij oevers met stenen en riet in het IJsselmeer per 5-jarige periode. De groepering geeft de ecologische indeling aan de hand van Noble et al. (2007) aan. Het cumulatief percentage geeft aan hoeveel de soorten over de gehele periode (2007-2019) voorkomen op basis van de gesommeerde CPUE op basis van het aantal. Nul-percentages zijn naar beneden afgeronde waarden, $*=$ exoot.

\begin{tabular}{|c|c|c|c|c|c|}
\hline Soort & Groepering & Cumulatief percentage & $2007-2009$ & $2010-2014$ & $2015-2019$ \\
\hline zwartbekgrondel* & Eurytoop (Bentisch) & 38.14 & - & 6 & 53.47 \\
\hline blankvoorn & Eurytoop (Pelagisch) & 70.86 & 30.31 & 48.59 & 28.1 \\
\hline baars & Eurytoop (Pelagisch) & 80.34 & 36.71 & 14.79 & 4.04 \\
\hline aal & Eurytoop (Bentisch) & 87.67 & 12.74 & 8.55 & 6.2 \\
\hline winde & Rheofiel (Pelagisch) & 93.69 & 11.13 & 5.82 & 5.37 \\
\hline brasem & Eurytoop (Bentisch) & 96.24 & 3.33 & 7.86 & 0.79 \\
\hline pontische stroomgrondel* & Eurytoop (Bentisch) & 96.94 & - & 2.64 & 0.18 \\
\hline bot & Limnofiel (Bentisch) & 97.45 & 1.55 & 0.33 & 0.42 \\
\hline kesslers grondel* & Eurytoop (Bentisch) & 97.87 & - & 0.03 & 0.61 \\
\hline spiering & Eurytoop (Pelagisch) & 98.17 & 0.3 & 1.21 & 0 \\
\hline rivierdonderpad & Rheofiel (Bentisch) & 98.41 & 0.71 & 0.77 & 0.01 \\
\hline marmergrondel* & Eurytoop (Bentisch) & 98.57 & - & 0.69 & 0.02 \\
\hline rietvoorn & Limnofiel (Pelagisch) & 98.72 & 0.14 & 0.26 & 0.12 \\
\hline zeebaars & Marien (Pelagisch) & 98.86 & 0.73 & 0.12 & 0.07 \\
\hline snoekbaars & Eurytoop (Bentisch) & 98.98 & 0.53 & 0.1 & 0.07 \\
\hline bittervoorn & Limnofiel (Pelagisch) & 99.1 & - & 0.2 & 0.11 \\
\hline roofblei* & Rheofiel (Pelagisch) & 99.21 & 0.16 & 0.12 & 0.11 \\
\hline snoek & Eurytoop (Pelagisch) & 99.3 & 0.2 & 0.2 & 0.05 \\
\hline driedoornige stekelbaars & Eurytoop (Pelagisch) & 99.39 & 0.16 & 0.28 & 0.02 \\
\hline giebel & Eurytoop (Bentisch) & 99.48 & 0.03 & 0.06 & 0.11 \\
\hline grondels indet. & Marien (Bentisch) & 99.57 & - & 0.4 & \\
\hline kleine modderkruiper & Eurytoop (Bentisch) & 99.65 & 0.11 & 0.27 & 0.02 \\
\hline karper & Eurytoop (Bentisch) & 99.73 & 0.22 & 0.07 & 0.07 \\
\hline brakwatergrondel & Marien (Bentisch) & 99.8 & 0.01 & 0.33 & \\
\hline alver & Eurytoop (Pelagisch) & 99.87 & 0.49 & 0.04 & 0.01 \\
\hline pos & Eurytoop (Bentisch) & 99.93 & 0.2 & 0.14 & 0.01 \\
\hline kolblei & Eurytoop (Bentisch) & 99.96 & 0.06 & 0.09 & 0.02 \\
\hline zeelt & Limnofiel (Bentisch) & 99.98 & 0.05 & 0.03 & 0.01 \\
\hline witvinriviergrondel* & Eurytoop (Bentisch) & 99.99 & 0.08 & - & \\
\hline sneep & Rheofiel (Bentisch) & 99.99 & 0.02 & - & 0.01 \\
\hline hybride cyprinide & Eurytoop (Bentisch) & 100 & 0.04 & - & \\
\hline tiendoornige stekelbaars & Limnofiel (Pelagisch) & 100 & 0.01 & 0.01 & \\
\hline
\end{tabular}


Tabel 2. Soortensamenstelling in percentages op basis van biomassa in elektroschepnetvangsten bij oevers met stenen en riet in het IJsselmeer per 5-jarige periode. De groepering geeft de ecologische indeling aan de hand van Noble et al. (2007) aan. Het cumulatief percentage geeft aan hoeveel de soorten over de gehele periode (2007-2019) voorkomen op basis van de gesommeerde CPUE op basis van de biomassa. Nul-percentages zijn naar beneden afgeronde waarden, $*=$ exoot.

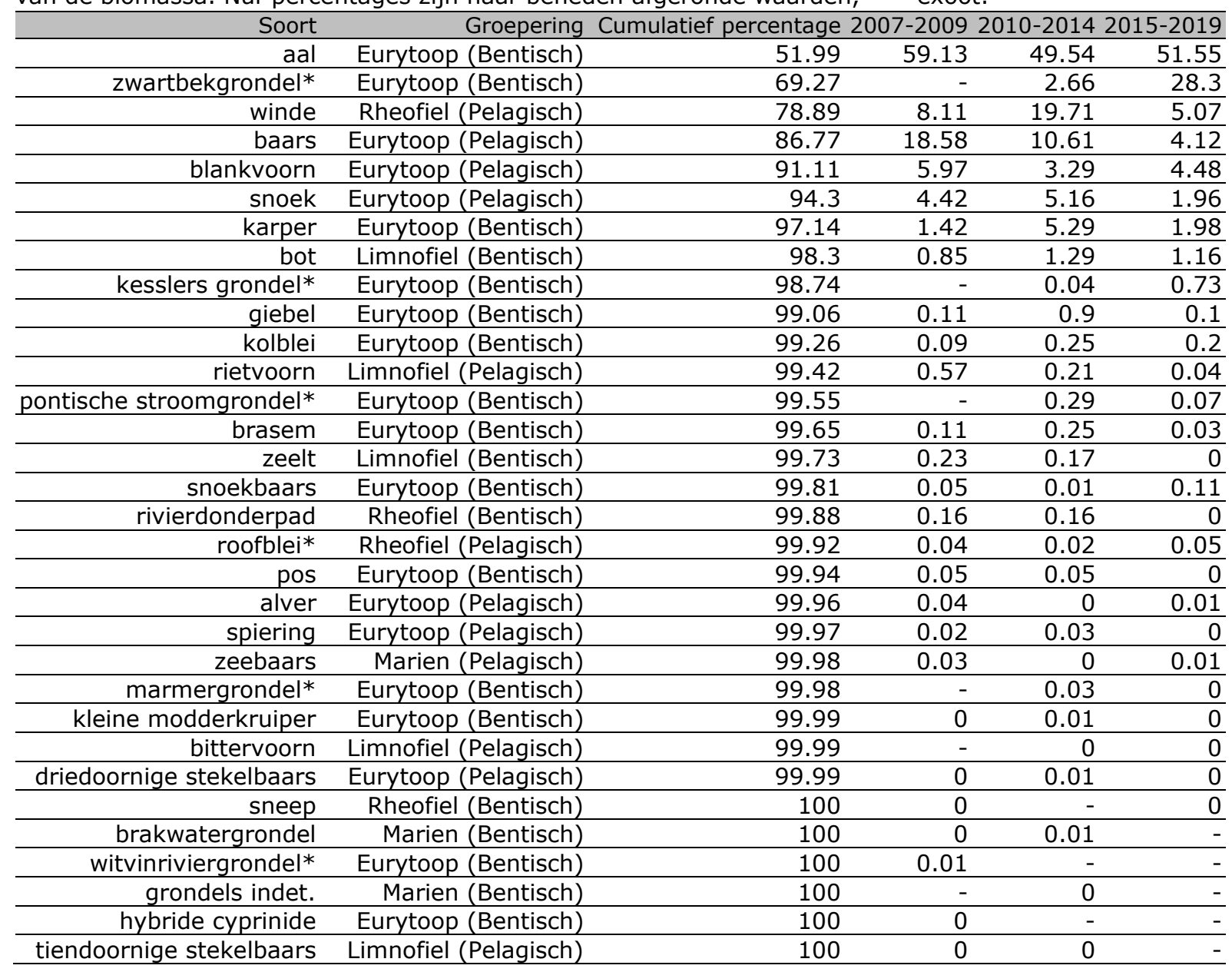


Tabel 3. Soortensamenstelling in percentages op basis van aantal in zegenvangsten bij zandoevers in het IJsselmeer per 5-jarige periode. De groepering geeft de ecologische indeling aan de hand van Noble et al. (2007) aan. Het cumulatief percentage geeft aan hoeveel de soorten over de gehele periode (20072019) voorkomen op basis van de gesommeerde CPUE op basis van het aantal. Nul-percentages zijn naar beneden afgeronde waarden, $*=$ exoot.

\begin{tabular}{|c|c|c|c|c|c|}
\hline Soort & Groepering & Cumulatief percentage & $2007-2009$ & $2010-2014$ & $+2015-2019$ \\
\hline winde & Rheofiel (Pelagisch) & 47.94 & 47.41 & 35.89 & 55.23 \\
\hline baars & Eurytoop (Pelagisch) & 71.53 & 25.84 & 28.74 & 19.05 \\
\hline blankvoorn & Eurytoop (Pelagisch) & 86.86 & 14.59 & 22.55 & 11.71 \\
\hline pontische stroomgrondel* & Eurytoop (Bentisch) & 89.96 & - & - & 7.05 \\
\hline roofblei* & Rheofiel (Pelagisch) & 92.07 & 2.94 & 4.32 & 0.27 \\
\hline pos & Eurytoop (Bentisch) & 93.67 & 3.94 & 1.2 & 0.17 \\
\hline snoekbaars & Eurytoop (Bentisch) & 95.02 & 0.71 & 0.77 & 2.15 \\
\hline brasem & Eurytoop (Bentisch) & 96.02 & 0.7 & 1.1 & 1.16 \\
\hline alver & Eurytoop (Pelagisch) & 96.97 & 1.53 & 0.58 & 0.74 \\
\hline zwartbekgrondel* & Eurytoop (Bentisch) & 97.82 & - & 0.58 & 1.61 \\
\hline driedoornige stekelbaars & Eurytoop (Pelagisch) & 98.56 & 0.47 & 2.11 & 0.14 \\
\hline karper & Eurytoop (Bentisch) & 99.16 & 1.41 & 0.67 & \\
\hline rietvoorn & Limnofiel (Pelagisch) & 99.38 & - & - & 0.5 \\
\hline bot & Limnofiel (Bentisch) & 99.58 & 0.24 & 0.24 & 0.14 \\
\hline zeebaars & Marien (Pelagisch) & 99.76 & 0.12 & 0.58 & \\
\hline vetje & Limnofiel (Pelagisch) & 99.83 & - & 0.29 & \\
\hline aal & Eurytoop (Bentisch) & 99.89 & - & 0.1 & 0.08 \\
\hline kolblei & Eurytoop (Bentisch) & 99.95 & 0.12 & 0.1 & \\
\hline noordzeehouting & Limnofiel (Pelagisch) & 100 & - & 0.19 & \\
\hline
\end{tabular}

Tabel 4. Soortensamenstelling in percentages op basis van biomassa in zegenvangsten bij zandoevers in het IJsselmeer per 5-jarige periode. De groepering geeft de ecologische indeling aan de hand van Noble et al. (2007) aan. Het cumulatief percentage geeft aan hoeveel de soorten over de gehele periode (20072019) voorkomen op basis van de gesommeerde CPUE op basis van de biomassa. Nul-percentages zijn naar beneden afgeronde waarden, $*$ = exoot.

\begin{tabular}{|c|c|c|c|c|c|}
\hline Soort & Groepering & Cumulatief percentage & 2007-2009 & $2010-2014$ & $2015-2019$ \\
\hline winde & Rheofiel (Pelagisch) & 53.31 & 44.22 & 70.48 & 44.44 \\
\hline baars & Eurytoop (Pelagisch) & 76.35 & 27.49 & 14.24 & 27.82 \\
\hline blankvoorn & Eurytoop (Pelagisch) & 88.29 & 18.17 & 7.61 & 9.89 \\
\hline pontische stroomgrondel* & Eurytoop (Bentisch) & 91.96 & - & - & 11.69 \\
\hline roofblei* & Rheofiel (Pelagisch) & 94.28 & 2.68 & 3.7 & 0.4 \\
\hline snoekbaars & Eurytoop (Bentisch) & 95.72 & 0.44 & 0.32 & 3.76 \\
\hline alver & Eurytoop (Pelagisch) & 96.92 & 2.79 & 0.35 & 0.4 \\
\hline karper & Eurytoop (Bentisch) & 97.78 & 2.04 & 0.47 & - \\
\hline pos & Eurytoop (Bentisch) & 98.5 & 1.53 & 0.45 & 0.15 \\
\hline zwartbekgrondel* & Eurytoop (Bentisch) & 98.81 & - & 0.23 & 0.72 \\
\hline kolblei & Eurytoop (Bentisch) & 99.08 & 0.14 & 0.67 & - \\
\hline bot & Limnofiel (Bentisch) & 99.33 & 0.32 & 0.14 & 0.29 \\
\hline aal & Eurytoop (Bentisch) & 99.56 & - & 0.49 & 0.18 \\
\hline brasem & Eurytoop (Bentisch) & 99.72 & 0.13 & 0.12 & 0.23 \\
\hline noordzeehouting & Limnofiel (Pelagisch) & 99.84 & - & 0.36 & - \\
\hline zeebaars & Marien (Pelagisch) & 99.93 & 0.04 & 0.21 & - \\
\hline vetje & Limnofiel (Pelagisch) & 99.96 & - & 0.1 & - \\
\hline driedoornige stekelbaars & Eurytoop (Pelagisch) & 99.99 & 0.02 & 0.06 & 0.01 \\
\hline rietvoorn & Limnofiel (Pelagisch) & 100 & - & - & 0.02 \\
\hline
\end{tabular}




\section{Bijlage 5 Markermeer open water}

Tabel 1. Soortensamenstelling in percentages op basis van aantal boomkorvangsten in het Markermeer per 5-jarige periode. De groepering geeft de ecologische indeling aan de hand van Noble et al. (2007) aan. Het cumulatief percentage geeft aan hoeveel de soorten over de gehele periode (1989-2019) voorkomen op basis van de gesommeerde CPUE op basis van het aantal. Nul-percentages zijn naar beneden afgeronde waarden, $*=$ exoot.

\begin{tabular}{|c|c|c|c|c|c|c|c|c|}
\hline Soort & Groepering & $\begin{array}{l}\text { Cumulatief } \\
\text { percentage }\end{array}$ & $\begin{array}{r}1989- \\
1994\end{array}$ & $\begin{array}{r}1995- \\
1999\end{array}$ & $\begin{array}{r}2000- \\
2004\end{array}$ & $\begin{array}{r}2005- \\
2009\end{array}$ & $\begin{array}{r}2010- \\
2014\end{array}$ & $\begin{array}{r}2015- \\
2019\end{array}$ \\
\hline pos & Eurytoop (Bentisch) & 43.8 & 35.81 & 46.1 & 70.91 & 58.16 & 28.78 & 30.16 \\
\hline spiering & Eurytoop (Pelagisch) & 82.34 & 46.6 & 34.75 & 20.25 & 31.11 & 50.26 & 41.15 \\
\hline baars & Eurytoop (Pelagisch) & 94.86 & 13.77 & 16.02 & 6.69 & 5.61 & 6.82 & 21.82 \\
\hline blankvoorn & Eurytoop (Pelagisch) & 97.13 & 3.3 & 1.85 & 0.77 & 2.93 & 2.19 & 1.86 \\
\hline driedoornige stekelbaars & Eurytoop (Pelagisch) & 98.03 & 0.08 & 0.12 & 0.01 & 0.04 & 6.46 & 0.4 \\
\hline zwartbekgrondel* & Eurytoop (Bentisch) & 98.89 & - & - & - & - & 4.53 & 2.66 \\
\hline snoekbaars & Eurytoop (Bentisch) & 99.57 & 0.15 & 0.71 & 1.04 & 1.7 & 0.4 & 1.21 \\
\hline brasem & Eurytoop (Bentisch) & 99.82 & 0.19 & 0.28 & 0.25 & 0.3 & 0.25 & 0.28 \\
\hline rivierdonderpad & Rheofiel (Bentisch) & 99.92 & 0.1 & 0.18 & 0.05 & 0.03 & 0.22 & - \\
\hline pontische stroomgrondel* & Eurytoop (Bentisch) & 99.97 & - & - & - & - & 0.03 & 0.39 \\
\hline alver & Eurytoop (Pelagisch) & 100 & - & 0 & 0.02 & 0.1 & 0.05 & 0.05 \\
\hline winde & Rheofiel (Pelagisch) & 100 & 0 & 0 & 0 & 0.01 & 0.01 & - \\
\hline kesslers grondel* & Eurytoop (Bentisch) & 100 & - & - & - & - & - & 0.01 \\
\hline marmergrondel* & Eurytoop (Bentisch) & 100 & - & - & - & - & 0 & - \\
\hline hybride cyprinide & Eurytoop (Bentisch) & 100 & 0 & 0 & - & - & - & - \\
\hline giebel & Eurytoop (Bentisch) & 100 & - & - & - & - & 0 & - \\
\hline karper & Eurytoop (Bentisch) & 100 & - & - & - & 0 & 0 & - \\
\hline diklipharder & Marien (Pelagisch) & 100 & - & - & - & 0 & - & \\
\hline bot & Limnofiel (Bentisch) & 100 & - & - & 0 & - & - & - \\
\hline
\end{tabular}

Tabel 2. Soortensamenstelling in percentages op basis van biomassa in boomkorvangsten in het Markermeer per 5-jarige periode. De groepering geeft de ecologische indeling aan de hand van Noble et al. (2007) aan. Het cumulatief percentage geeft aan hoeveel de soorten over de gehele periode (19892019) voorkomen op basis van de gesommeerde CPUE op basis van de biomassa. Nul-percentages zijn naar beneden afgeronde waarden, $*=$ exoot.

\begin{tabular}{|c|c|c|c|c|c|c|c|c|}
\hline Soort & Groepering & $\begin{array}{l}\text { Cumulatief } \\
\text { percentage }\end{array}$ & $\begin{array}{r}1989- \\
1994 \\
\end{array}$ & $\begin{array}{r}1995- \\
1999 \\
\end{array}$ & $\begin{array}{r}2000- \\
2004 \\
\end{array}$ & $\begin{array}{r}2005- \\
2009 \\
\end{array}$ & $\begin{array}{r}2010- \\
2014 \\
\end{array}$ & $\begin{array}{r}2015- \\
2019 \\
\end{array}$ \\
\hline pos & Eurytoop (Bentisch) & 43.11 & 38.21 & 39.19 & 63.49 & 49.41 & 38.4 & 26.24 \\
\hline baars & Eurytoop (Pelagisch) & 62.95 & 22.98 & 22.25 & 11.56 & 13.09 & 19.61 & 29 \\
\hline spiering & Eurytoop (Pelagisch) & 76.23 & 23.16 & 15.16 & 5.9 & 7.87 & 17.23 & 6.34 \\
\hline blankvoorn & Eurytoop (Pelagisch) & 87.45 & 8.16 & 12.12 & 6.6 & 14.53 & 13.2 & 16.72 \\
\hline snoekbaars & Eurytoop (Bentisch) & 93.96 & 1.19 & 4.6 & 8.87 & 11.17 & 2.86 & 14.03 \\
\hline brasem & Eurytoop (Bentisch) & 98.62 & 6.21 & 6.57 & 3.51 & 3.7 & 1.48 & 4.16 \\
\hline zwartbekgrondel* & Eurytoop (Bentisch) & 99.71 & - & - & - & - & 6.26 & 2.79 \\
\hline driedoornige stekelbaars & Eurytoop (Pelagisch) & 99.82 & 0.03 & 0.02 & 0 & 0.01 & 0.76 & 0.04 \\
\hline pontische stroomgrondel* & Eurytoop (Bentisch) & 99.9 & - & - & - & - & 0.03 & 0.57 \\
\hline alver & Eurytoop (Pelagisch) & 99.94 & - & 0.01 & 0.03 & 0.15 & 0.09 & 0.08 \\
\hline rivierdonderpad & Rheofiel (Bentisch) & 99.98 & 0.06 & 0.08 & 0.02 & 0.01 & 0.06 & - \\
\hline winde & Rheofiel (Pelagisch) & 99.99 & 0 & 0 & 0 & 0.06 & 0.02 & - \\
\hline kesslers grondel* & Eurytoop (Bentisch) & 100 & - & - & - & - & - & 0.02 \\
\hline bot & Limnofiel (Bentisch) & 100 & - & - & 0.01 & - & - & - \\
\hline hybride cyprinide & Eurytoop (Bentisch) & 100 & 0.01 & 0 & - & - & - & - \\
\hline karper & Eurytoop (Bentisch) & 100 & - & - & - & 0.01 & 0 & - \\
\hline diklipharder & Marien (Pelagisch) & 100 & - & - & - & 0 & - & - \\
\hline marmergrondel* & Eurytoop (Bentisch) & 100 & - & - & - & - & 0 & - \\
\hline giebel & Eurytoop (Bentisch) & 100 & - & - & - & - & 0 & - \\
\hline
\end{tabular}


Tabel 3. Soortensamenstelling in percentages op basis van aantal in elektrokorvangsten in het Markermeer per 5-jarige periode. De groepering geeft de ecologische indeling aan de hand van Noble et al. (2007) aan. Het cumulatief percentage geeft aan hoeveel de soorten over de gehele periode (19952019) voorkomen op basis van de gesommeerde CPUE op basis van het aantal. Nul-percentages zijn naar beneden afgeronde waarden, $*=$ exoot.

\begin{tabular}{|c|c|c|c|c|c|c|c|}
\hline Soort & Groepering & $\begin{array}{l}\text { Cumulatief } \\
\text { percentage }\end{array}$ & $\begin{array}{r}1995- \\
1999\end{array}$ & $\begin{array}{r}2000- \\
2004\end{array}$ & $\begin{array}{r}2005- \\
2009\end{array}$ & $\begin{array}{r}2010- \\
2014\end{array}$ & $\begin{array}{r}2015- \\
2019\end{array}$ \\
\hline pos & Eurytoop (Bentisch) & 47.97 & 49.09 & 50.27 & 55.2 & 40.29 & 48.5 \\
\hline spiering & Eurytoop (Pelagisch) & 83.92 & 37.3 & 41.11 & 36.88 & 34.37 & 20.87 \\
\hline baars & Eurytoop (Pelagisch) & 92.33 & 10.88 & 7.05 & 4.66 & 5.02 & 14.87 \\
\hline zwartbekgrondel* & Eurytoop (Bentisch) & 96.53 & - & - & - & 16.4 & 10.08 \\
\hline blankvoorn & Eurytoop (Pelagisch) & 97.61 & 1.28 & 0.63 & 1.49 & 1.2 & 1.04 \\
\hline aal & Eurytoop (Bentisch) & 98.58 & 0.87 & 0.51 & 0.16 & 0.05 & 0.25 \\
\hline driedoornige stekelbaars & Eurytoop (Pelagisch) & 99.02 & 0.07 & 0.01 & 0.03 & 1.92 & 0.35 \\
\hline snoekbaars & Eurytoop (Bentisch) & 99.45 & 0.17 & 0.24 & 1.31 & 0.42 & 1.01 \\
\hline pontische stroomgrondel* & Eurytoop (Bentisch) & 99.71 & - & - & - & 0.03 & 2.68 \\
\hline rivierdonderpad & Rheofiel (Bentisch) & 99.85 & 0.24 & 0.09 & 0.08 & 0.12 & \\
\hline brasem & Eurytoop (Bentisch) & 99.97 & 0.1 & 0.09 & 0.15 & 0.13 & 0.24 \\
\hline alver & Eurytoop (Pelagisch) & 99.98 & 0 & 0 & 0.04 & 0.02 & 0.03 \\
\hline kesslers grondel* & Eurytoop (Bentisch) & 99.99 & - & - & - & - & 0.04 \\
\hline soort onbekend & Overige & 99.99 & - & - & - & - & 0.04 \\
\hline marmergrondel* & Eurytoop (Bentisch) & 100 & - & - & - & 0.02 & \\
\hline winde & Rheofiel (Pelagisch) & 100 & - & 0 & - & 0 & \\
\hline bot & Limnofiel (Bentisch) & 100 & - & 0 & 0.01 & 0 & \\
\hline dunlipharder & Marien (Pelagisch) & 100 & - & - & - & 0 & 0 \\
\hline giebel & Eurytoop (Bentisch) & 100 & - & 0 & - & - & \\
\hline
\end{tabular}

Tabel 4. Soortensamenstelling in percentages op basis van biomassa in elektrokorvangsten in het Markermeer per 5-jarige periode. De groepering geeft de ecologische indeling aan de hand van Noble et al. (2007) aan. Het cumulatief percentage geeft aan hoeveel de soorten over de gehele periode (19952019) voorkomen op basis van de gesommeerde CPUE op basis van de biomassa. Nul-percentages zijn naar beneden afgeronde waarden, $*=$ exoot.

\begin{tabular}{|c|c|c|c|c|c|c|c|}
\hline Soort & Groepering & $\begin{array}{l}\text { Cumulatief } \\
\text { percentage }\end{array}$ & $\begin{array}{r}1995- \\
1999 \\
\end{array}$ & $\begin{array}{r}2000- \\
2004 \\
\end{array}$ & $\begin{array}{r}2005- \\
2009\end{array}$ & $\begin{array}{r}2010- \\
2014\end{array}$ & $\begin{array}{r}2015- \\
2019\end{array}$ \\
\hline pos & Eurytoop (Bentisch) & 52.41 & 54.29 & 60.45 & 56.93 & 51.01 & 40 \\
\hline baars & Eurytoop (Pelagisch) & 68.57 & 19.43 & 15.23 & 13.94 & 13.86 & 19.7 \\
\hline spiering & Eurytoop (Pelagisch) & 78.02 & 11.88 & 10.44 & 7.48 & 10.23 & 3.53 \\
\hline blankvoorn & Eurytoop (Pelagisch) & 85.47 & 6.95 & 7.08 & 10.12 & 6.15 & 11.02 \\
\hline aal & Eurytoop (Bentisch) & 90.94 & 4.69 & 3.33 & 1.88 & 1.07 & 3.71 \\
\hline zwartbekgrondel* & Eurytoop (Bentisch) & 94.86 & - & - & - & 13.4 & 8.9 \\
\hline snoekbaars & Eurytoop (Bentisch) & 98.24 & 0.97 & 2.13 & 7.99 & 3.42 & 8.34 \\
\hline brasem & Eurytoop (Bentisch) & 99.46 & 1.61 & 1.24 & 1.58 & 0.46 & 1.55 \\
\hline pontische stroomgrondel* & Eurytoop (Bentisch) & 99.81 & - & - & - & 0.05 & 2.97 \\
\hline rivierdonderpad & Rheofiel (Bentisch) & 99.87 & 0.15 & 0.05 & 0.03 & 0.04 & \\
\hline driedoornige stekelbaars & Eurytoop (Pelagisch) & 99.94 & 0.02 & 0 & 0 & 0.24 & 0.04 \\
\hline alver & Eurytoop (Pelagisch) & 99.96 & 0.01 & 0.01 & 0.04 & 0.04 & 0.05 \\
\hline kesslers grondel* & Eurytoop (Bentisch) & 99.98 & - & - & - & - & 0.17 \\
\hline winde & Rheofiel (Pelagisch) & 99.99 & - & 0.03 & - & 0.03 & - \\
\hline bot & Limnofiel (Bentisch) & 100 & - & 0.02 & 0.02 & 0 & - \\
\hline marmergrondel* & Eurytoop (Bentisch) & 100 & - & - & - & 0 & - \\
\hline soort onbekend & Overige & 100 & - & - & - & - & 0 \\
\hline giebel & Eurytoop (Bentisch) & 100 & - & 0 & - & - & - \\
\hline dunlipharder & Marien (Bentisch) & 100 & - & - & - & 0 & 0 \\
\hline
\end{tabular}




\section{Bijlage 6 Markermeer oever}

Tabel 1. Soortensamenstelling in percentages op basis van aantal in elektroschepnetvangsten bij oevers met stenen, riet en vooroevers in het Markermeer per 5-jarige periode. De groepering geeft de ecologische indeling aan de hand van Noble et al. (2007) aan. Het cumulatief percentage geeft aan hoeveel de soorten over de gehele periode (2007-2019) voorkomen op basis van de gesommeerde CPUE op basis van het aantal. Nul-percentages zijn naar beneden afgeronde waarden, * = exoot.

\begin{tabular}{|c|c|c|c|c|c|}
\hline Soort & Groepering & Cumulatief percentage & $2007-2009$ & $2010-2014$ & $2015-2019$ \\
\hline blankvoorn & Eurytoop (Pelagisch) & 50.04 & 66.37 & 46.88 & 45.1 \\
\hline zwartbekgrondel* & Eurytoop (Bentisch) & 77.15 & - & 28.5 & 38.93 \\
\hline baars & Eurytoop (Pelagisch) & 86.71 & 20.09 & 8.72 & 5.27 \\
\hline winde & Rheofiel (Pelagisch) & 90.41 & 5.38 & 4.78 & 1.85 \\
\hline aal & Eurytoop (Bentisch) & 92.27 & 2.6 & 1.8 & 1.57 \\
\hline rietvoorn & Limnofiel (Pelagisch) & 93.67 & 0.44 & 2.96 & 0.38 \\
\hline brasem & Eurytoop (Bentisch) & 94.45 & 0.66 & 1.53 & 0.15 \\
\hline driedoornige stekelbaars & Eurytoop (Pelagisch) & 95.14 & 0.12 & 0.49 & 1.15 \\
\hline pos & Eurytoop (Bentisch) & 95.81 & 2.01 & 0.49 & 0.19 \\
\hline pontische stroomgrondel* & Eurytoop (Bentisch) & 96.4 & - & - & 1.42 \\
\hline kleine modderkruiper & Eurytoop (Bentisch) & 96.9 & 0.07 & 0.47 & 0.75 \\
\hline bittervoorn & Limnofiel (Pelagisch) & 97.41 & 0.18 & 1.08 & 0.12 \\
\hline alver & Eurytoop (Pelagisch) & 97.87 & 0.95 & 0.34 & 0.35 \\
\hline kesslers grondel* & Eurytoop (Bentisch) & 98.29 & - & 0.05 & 0.96 \\
\hline kolblei & Eurytoop (Bentisch) & 98.69 & 0.24 & 0.76 & 0.13 \\
\hline marmergrondel* & Eurytoop (Bentisch) & 99.06 & - & 0.11 & 0.81 \\
\hline snoekbaars & Eurytoop (Bentisch) & 99.26 & 0.17 & 0.34 & 0.08 \\
\hline rivierdonderpad & Rheofiel (Bentisch) & 99.4 & 0.21 & 0.24 & 0 \\
\hline tiendoornige stekelbaars & Limnofiel (Pelagisch) & 99.53 & - & 0.01 & 0.31 \\
\hline snoek & Eurytoop (Pelagisch) & 99.65 & 0.09 & 0.1 & 0.14 \\
\hline bot & Limnofiel (Bentisch) & 99.71 & 0.23 & 0.02 & 0.01 \\
\hline giebel & Eurytoop (Bentisch) & 99.77 & - & - & 0.15 \\
\hline roofblei* & Rheofiel (Pelagisch) & 99.83 & 0.12 & 0 & 0.08 \\
\hline zeelt & Limnofiel (Bentisch) & 99.88 & - & 0.09 & 0.03 \\
\hline vetje & Limnofiel (Pelagisch) & 99.93 & 0.01 & 0.11 & \\
\hline karper & Eurytoop (Bentisch) & 99.97 & 0.04 & 0.05 & 0.03 \\
\hline riviergrondel & Rheofiel (Bentisch) & 99.99 & - & 0.03 & 0.02 \\
\hline spiering & Eurytoop (Pelagisch) & 99.99 & 0 & 0.02 & \\
\hline hybride cyprinide & Eurytoop (Bentisch) & 100 & - & 0.01 & \\
\hline
\end{tabular}


Tabel 2. Soortensamenstelling in percentages op basis van biomassa in elektroschepnetvangsten bij oevers met stenen, riet en vooroevers in het Markermeer per 5-jarige periode. De groepering geeft de ecologische indeling aan de hand van Noble et al. (2007) aan. Het cumulatief percentage geeft aan hoeveel de soorten over de gehele periode (2007-2019) voorkomen op basis van de gesommeerde CPUE op basis van de biomassa. Nul-percentages zijn naar beneden afgeronde waarden, * =xoot.

\begin{tabular}{|c|c|c|c|c|c|}
\hline Soort & Groepering & Cumulatief percentage & 7-2009 & $0-2014$ & $5-2019$ \\
\hline aal & Eurytoop (Bentisch) & 21.4 & 18.77 & 26.06 & 19.08 \\
\hline zwartbekgrondel* & Eurytoop (Bentisch) & 37.18 & - & 21.01 & 22.55 \\
\hline snoek & Eurytoop (Pelagisch) & 51.86 & 18.59 & 7.76 & 18.14 \\
\hline karper & Eurytoop (Bentisch) & 63.32 & 12.96 & 3.01 & 18.07 \\
\hline winde & Rheofiel (Pelagisch) & 74.04 & 18.09 & 13.95 & 2.39 \\
\hline baars & Eurytoop (Pelagisch) & 84.09 & 12.04 & 11.26 & 7.49 \\
\hline blankvoorn & Eurytoop (Pelagisch) & 93.47 & 12.44 & 9.48 & 7.05 \\
\hline rietvoorn & Limnofiel (Pelagisch) & 95.14 & 1.02 & 3.31 & 0.66 \\
\hline brasem & Eurytoop (Bentisch) & 96.47 & 2.66 & 1.71 & 0.01 \\
\hline kesslers grondel* & Eurytoop (Bentisch) & 97.1 & - & 0.09 & 1.58 \\
\hline snoekbaars & Eurytoop (Bentisch) & 97.67 & 1.82 & 0.16 & 0.02 \\
\hline kolblei & Eurytoop (Bentisch) & 98.17 & 0.49 & 0.83 & 0.2 \\
\hline bot & Limnofiel (Bentisch) & 98.65 & 0.42 & 0.47 & 0.54 \\
\hline giebel & Eurytoop (Bentisch) & 99 & - & - & 0.93 \\
\hline pontische stroomgrondel* & Eurytoop (Bentisch) & 99.27 & - & - & 0.7 \\
\hline alver & Eurytoop (Pelagisch) & 99.46 & 0.28 & 0.2 & 0.1 \\
\hline pos & Eurytoop (Bentisch) & 99.62 & 0.32 & 0.19 & 0.04 \\
\hline kleine modderkruiper & Eurytoop (Bentisch) & 99.73 & 0.01 & 0.08 & 0.2 \\
\hline zeelt & Limnofiel (Bentisch) & 99.82 & - & 0.19 & 0.08 \\
\hline roofblei* & Rheofiel (Pelagisch) & 99.86 & 0.05 & 0 & 0.05 \\
\hline bittervoorn & Limnofiel (Pelagisch) & 99.89 & 0.01 & 0.07 & 0.01 \\
\hline rivierdonderpad & Rheofiel (Bentisch) & 99.92 & 0.04 & 0.06 & 0 \\
\hline riviergrondel & Rheofiel (Bentisch) & 99.95 & - & 0.05 & 0.01 \\
\hline marmergrondel* & Eurytoop (Bentisch) & 99.97 & - & 0.01 & 0.05 \\
\hline driedoornige stekelbaars & Eurytoop (Pelagisch) & 99.98 & 0 & 0.01 & 0.02 \\
\hline hybride cyprinide & Eurytoop (Bentisch) & 99.99 & - & 0.02 & - \\
\hline vetje & Limnofiel (Pelagisch) & 100 & 0 & 0.02 & - \\
\hline tiendoornige stekelbaars & Limnofiel (Pelagisch) & 100 & - & 0 & 0.01 \\
\hline spiering & Eurytoop (Pelagisch) & 100 & 0 & 0 & - \\
\hline
\end{tabular}


Tabel 3. Soortensamenstelling in percentages op basis van aantal in zegenvangsten bij zandoevers in het Markermeer per 5-jarige periode. De groepering geeft de ecologische indeling aan de hand van Noble et al. (2007) aan. Het cumulatief percentage geeft aan hoeveel de soorten over de gehele periode (20072019) voorkomen op basis van de gesommeerde CPUE op basis van het aantal. Nul-percentages zijn naar beneden afgeronde waarden, $*=$ exoot.

\begin{tabular}{|c|c|c|c|c|c|}
\hline Soort & Groepering & Cumulatief percentage & $2007-2009$ & $2010-2014$ & $2015-2019$ \\
\hline brasem & Eurytoop (Bentisch) & 32.06 & 17.47 & 43.74 & 11.75 \\
\hline blankvoorn & Eurytoop (Pelagisch) & 57.55 & 22.27 & 20.14 & 38.81 \\
\hline pos & Eurytoop (Bentisch) & 76.22 & 30.13 & 22.94 & 4.39 \\
\hline baars & Eurytoop (Pelagisch) & 85.05 & 15.72 & 2.16 & 21.01 \\
\hline zwartbekgrondel* & Eurytoop (Bentisch) & 89.95 & - & 1.5 & 14.54 \\
\hline winde & Rheofiel (Pelagisch) & 93.26 & 10.48 & 1.37 & 4.75 \\
\hline alver & Eurytoop (Pelagisch) & 95.84 & 1.75 & 3.64 & 0.53 \\
\hline snoekbaars & Eurytoop (Bentisch) & 97.48 & 0.87 & 1.98 & 1.19 \\
\hline kolblei & Eurytoop (Bentisch) & 98.65 & - & 1.66 & 0.53 \\
\hline pontische stroomgrondel* & Eurytoop (Bentisch) & 98.99 & - & - & 1.25 \\
\hline driedoornige stekelbaars & Eurytoop (Pelagisch) & 99.3 & - & 0.5 & \\
\hline roofblei* & Rheofiel (Pelagisch) & 99.56 & 0.44 & 0.18 & 0.36 \\
\hline giebel & Eurytoop (Bentisch) & 99.66 & - & - & 0.36 \\
\hline kesslers grondel* & Eurytoop (Bentisch) & 99.76 & - & - & 0.36 \\
\hline spiering & Eurytoop (Pelagisch) & 99.85 & - & 0.16 & \\
\hline hybride cyprinide & Eurytoop (Bentisch) & 99.95 & 0.44 & - & \\
\hline rietvoorn & Limnofiel (Pelagisch) & 100 & - & - & 0.18 \\
\hline
\end{tabular}

Tabel 4. Soortensamenstelling in percentages op basis van biomassa in zegenvangsten bij zandoevers in het Markermeer per 5-jarige periode. De groepering geeft de ecologische indeling aan de hand van Noble et al. (2007) aan. Het cumulatief percentage geeft aan hoeveel de soorten over de gehele periode (20072019) voorkomen op basis van de gesommeerde CPUE op basis van de biomassa. Nul-percentages zijn naar beneden afgeronde waarden, $*$ = exoot.

\begin{tabular}{|c|c|c|c|c|c|}
\hline Soort & Groepering & Cumulatief percentage & 2007-2009 & $2010-2014$ & $2015-2019$ \\
\hline brasem & Eurytoop (Bentisch) & 28.1 & 13.22 & 42.26 & 3.98 \\
\hline winde & Rheofiel (Pelagisch) & 49.22 & 36.79 & 13.89 & 30.33 \\
\hline baars & Eurytoop (Pelagisch) & 67.81 & 22.01 & 9.83 & 35.76 \\
\hline blankvoorn & Eurytoop (Pelagisch) & 80.2 & 13.83 & 12.8 & 10.96 \\
\hline pos & Eurytoop (Bentisch) & 88.25 & 10.96 & 10.73 & 1.29 \\
\hline zwartbekgrondel* & Eurytoop (Bentisch) & 91.26 & - & 1.16 & 8.05 \\
\hline alver & Eurytoop (Pelagisch) & 93.78 & 0.2 & 3.85 & 0.62 \\
\hline kolblei & Eurytoop (Bentisch) & 96.3 & - & 2.99 & 2.48 \\
\hline snoekbaars & Eurytoop (Bentisch) & 97.93 & 2.1 & 1.91 & 0.86 \\
\hline rietvoorn & Limnofiel (Pelagisch) & 98.92 & - & - & 3.45 \\
\hline roofblei* & Rheofiel (Pelagisch) & 99.46 & 0.5 & 0.46 & 0.73 \\
\hline pontische stroomgrondel* & Eurytoop (Bentisch) & 99.66 & - & - & 0.68 \\
\hline giebel & Eurytoop (Bentisch) & 99.83 & - & - & 0.61 \\
\hline kesslers grondel* & Eurytoop (Bentisch) & 99.89 & - & - & 0.2 \\
\hline driedoornige stekelbaars & Eurytoop (Pelagisch) & 99.95 & - & 0.1 & - \\
\hline hybride cyprinide & Eurytoop (Bentisch) & 99.99 & 0.39 & - & - \\
\hline spiering & Eurytoop (Pelagisch) & 100 & - & 0.02 & - \\
\hline
\end{tabular}




\section{Bijlage 7 Randmeren-Oost}

Tabel 1. Soortensamenstelling in percentages op basis van aantal in stortkuilvangsten van de Randmeren-Oost per 5-jarige periode. De groepering geeft de ecologische indeling aan de hand van Noble et al. (2007) aan. Het cumulatief percentage geeft aan hoeveel de soorten over de gehele periode voorkomen op basis van de gesommeerde CPUE op basis van het aantal. Nul-percentages zijn naar beneden afgeronde waarden, * exoot.

\begin{tabular}{|c|c|c|c|c|}
\hline Groepering & Cumulatief percentage & $2005-2009$ & $2010-2014$ & 2015-2019 \\
\hline baars Eurytoop (Pelagisch) & 40.31 & 22.57 & 43.8 & 46.15 \\
\hline pos Eurytoop (Bentisch) & 69.16 & 40.67 & 36.43 & 13.29 \\
\hline blankvoorn Eurytoop (Pelagisch) & 85.73 & 28.12 & 11.38 & 16.2 \\
\hline brasem Eurytoop (Bentisch) & 93.33 & 2.67 & 7.48 & 10.5 \\
\hline zwartbekgrondel* Eurytoop (Bentisch) & 96.31 & - & 0 & 8.16 \\
\hline kolblei Eurytoop (Bentisch) & 98.12 & 4.47 & 0.06 & 2.38 \\
\hline snoekbaars Eurytoop (Bentisch) & 98.82 & 0.84 & 0.61 & 0.74 \\
\hline pontische stroomgrondel* Eurytoop (Bentisch) & 99.48 & - & - & 1.79 \\
\hline driedoornige stekelbaars Eurytoop (Pelagisch) & 99.58 & 0.4 & - & 0.05 \\
\hline alver Eurytoop (Pelagisch) & 99.65 & - & 0.01 & 0.18 \\
\hline marmergrondel* Eurytoop (Bentisch) & 99.72 & - & 0.02 & 0.16 \\
\hline snoek Eurytoop (Pelagisch) & 99.78 & 0.02 & 0.07 & 0.08 \\
\hline kesslers grondel* Eurytoop (Bentisch) & 99.83 & - & - & 0.12 \\
\hline karper Eurytoop (Bentisch) & 99.86 & 0.06 & 0.04 & 0.02 \\
\hline giebel Eurytoop (Bentisch) & 99.9 & 0.08 & 0.01 & 0.04 \\
\hline kleine modderkruiper Eurytoop (Bentisch) & 99.93 & 0.06 & 0.03 & 0.01 \\
\hline hybride cyprinide Eurytoop (Bentisch) & 99.95 & - & 0 & 0.05 \\
\hline aal Eurytoop (Bentisch) & 99.96 & 0.01 & 0.02 & 0.02 \\
\hline spiering Eurytoop (Pelagisch) & 99.97 & 0.01 & 0.02 & 0 \\
\hline noordzeehouting Limnofiel (Pelagisch) & 99.98 & - & 0 & 0.02 \\
\hline tiendoornige stekelbaars Limnofiel (Pelagisch) & 99.99 & - & - & 0.02 \\
\hline zeelt Limnofiel (Bentisch) & 99.99 & - & - & 0.01 \\
\hline roofblei* Rheofiel (Pelagisch) & 99.99 & 0.01 & 0 & 0 \\
\hline rietvoorn Limnofiel (Pelagisch) & 100 & 0.01 & 0 & 0 \\
\hline rivierdonderpad Rheofiel (Bentisch) & 100 & 0.01 & - & \\
\hline winde Rheofiel (Pelagisch) & 100 & - & 0 & 0 \\
\hline
\end{tabular}


Tabel 2. Soortensamenstelling in percentages op basis van biomassa in stortkuilvangsten van de RandmerenOost per 5-jarige periode. De groepering geeft de ecologische indeling aan de hand van Noble et al. (2007) aan. Het cumulatief percentage geeft aan hoeveel de soorten over de gehele periode voorkomen op basis van de gesommeerde CPUE op basis van de biomassa. Nul-percentages zijn naar beneden afgeronde waarden, $*=$ exoot.

\begin{tabular}{|c|c|c|c|c|c|}
\hline Soort & Groepering & Cumulatief percentage & $2005-2009$ & $2010-2014$ & $2015-2019$ \\
\hline brasem & Eurytoop (Bentisch) & 37.44 & 33.24 & 44.96 & 32.93 \\
\hline baars & Eurytoop (Pelagisch) & 55.49 & 15.26 & 14.43 & 23.35 \\
\hline blankvoorn & Eurytoop (Pelagisch) & 70.07 & 18.34 & 14.73 & 11.99 \\
\hline pos & Eurytoop (Bentisch) & 82.6 & 21.25 & 13.23 & 6.18 \\
\hline snoek & Eurytoop (Pelagisch) & 87.6 & 1.85 & 6.12 & 5.97 \\
\hline snoekbaars & Eurytoop (Bentisch) & 91.36 & 4.53 & 3.45 & 3.56 \\
\hline zwartbekgrondel* & Eurytoop (Bentisch) & 94.53 & - & 0 & 8.29 \\
\hline kolblei & Eurytoop (Bentisch) & 96.94 & 4.11 & 1.51 & 2.17 \\
\hline pontische stroomgrondel* & Eurytoop (Bentisch) & 97.54 & - & - & 1.56 \\
\hline karper & Eurytoop (Bentisch) & 98.13 & 0.54 & 0.49 & 0.71 \\
\hline aal & Eurytoop (Bentisch) & 98.7 & 0.48 & 0.67 & 0.54 \\
\hline noordzeehouting & Limnofiel (Pelagisch) & 99.06 & - & 0.01 & 0.93 \\
\hline roofblei* & Rheofiel (Pelagisch) & 99.4 & 0 & 0.08 & 0.83 \\
\hline winde & Rheofiel (Pelagisch) & 99.58 & - & 0.1 & 0.37 \\
\hline kesslers grondel* & Eurytoop (Bentisch) & 99.69 & - & - & 0.3 \\
\hline hybride cyprinide & Eurytoop (Bentisch) & 99.79 & - & 0.1 & 0.17 \\
\hline giebel & Eurytoop (Bentisch) & 99.86 & 0.13 & 0.04 & 0.07 \\
\hline rietvoorn & Limnofiel (Pelagisch) & 99.92 & 0.21 & 0 & 0 \\
\hline alver & Eurytoop (Pelagisch) & 99.96 & - & 0.04 & 0.07 \\
\hline kleine modderkruiper & Eurytoop (Bentisch) & 99.98 & 0.02 & 0.02 & 0 \\
\hline marmergrondel* & Eurytoop (Bentisch) & 99.99 & - & 0.01 & 0.02 \\
\hline driedoornige stekelbaars & Eurytoop (Pelagisch) & 99.99 & 0.02 & - & 0 \\
\hline spiering & Eurytoop (Pelagisch) & 100 & 0 & 0.01 & 0 \\
\hline zeelt & Limnofiel (Bentisch) & 100 & - & - & 0.01 \\
\hline rivierdonderpad & Rheofiel (Bentisch) & 100 & 0 & - & \\
\hline tiendoornige stekelbaars & Limnofiel (Pelagisch) & 100 & - & - & 0 \\
\hline
\end{tabular}


Tabel 3. Soortensamenstelling in percentages op basis van aantal in schepnetvangsten van de Randmeren-Oost per 5-jarige periode. De groepering geeft de ecologische indeling aan de hand van Noble et al. (2007) aan. Het cumulatief percentage geeft aan hoeveel de soorten over de gehele periode voorkomen op basis van de gesommeerde CPUE op basis van het aantal. Nul-percentages zijn naar beneden afgeronde waarden, * = exoot.

\begin{tabular}{|c|c|c|c|c|}
\hline Soort & Groepering & Cumulatief percentage & $0-2014$ & $5-2019$ \\
\hline blankvoorn & Eurytoop (Pelagisch) & 29.14 & 31.72 & 28.64 \\
\hline baars & Eurytoop (Pelagisch) & 49.09 & 46.66 & 14.86 \\
\hline brasem & Eurytoop (Bentisch) & 63.24 & 1.23 & 16.61 \\
\hline rietvoorn & Limnofiel (Pelagisch) & 74.72 & 3.73 & 12.96 \\
\hline zwartbekgrondel* & Eurytoop (Bentisch) & 86.07 & 0.03 & 13.51 \\
\hline bittervoorn & Limnofiel (Pelagisch) & 89.3 & 0.44 & 3.76 \\
\hline aal & Eurytoop (Bentisch) & 91.85 & 3.19 & 2.44 \\
\hline kolblei & Eurytoop (Bentisch) & 93.97 & 2.93 & 1.96 \\
\hline snoek & Eurytoop (Pelagisch) & 95.99 & 4.44 & 1.56 \\
\hline winde & Rheofiel (Pelagisch) & 97.04 & 2.85 & 0.71 \\
\hline marmergrondel* & Eurytoop (Bentisch) & 97.81 & 0.23 & 0.87 \\
\hline vetje & Limnofiel (Pelagisch) & 98.56 & - & 0.89 \\
\hline driedoornige stekelbaars & Eurytoop (Pelagisch) & 98.83 & 0.3 & 0.26 \\
\hline rivierdonderpad & Rheofiel (Bentisch) & 99.05 & 1.13 & 0.05 \\
\hline pontische stroomgrondel* & Eurytoop (Bentisch) & 99.27 & 0.07 & 0.25 \\
\hline zeelt & Limnofiel (Bentisch) & 99.43 & 0.04 & 0.17 \\
\hline kleine modderkruiper & Eurytoop (Bentisch) & 99.56 & 0.17 & 0.12 \\
\hline alver & Eurytoop (Pelagisch) & 99.68 & - & 0.15 \\
\hline karper & Eurytoop (Bentisch) & 99.79 & 0.17 & 0.09 \\
\hline pos & Eurytoop (Bentisch) & 99.86 & 0.42 & 0.01 \\
\hline tiendoornige stekelbaars & Limnofiel (Pelagisch) & 99.9 & 0.09 & 0.03 \\
\hline roofblei* & Rheofiel (Pelagisch) & 99.94 & - & 0.04 \\
\hline hybride cyprinide & Eurytoop (Bentisch) & 99.97 & 0.04 & 0.03 \\
\hline giebel & Eurytoop (Bentisch) & 99.99 & 0.12 & \\
\hline kesslers grondel* & Eurytoop (Bentisch) & 100 & - & 0.01 \\
\hline
\end{tabular}

Tabel 4. Soortensamenstelling in percentages op basis van biomassa in schepnetvangsten van de RandmerenOost per 5-jarige periode. De groepering geeft de ecologische indeling aan de hand van Noble et al. (2007) aan. Het cumulatief percentage geeft aan hoeveel de soorten over de gehele periode voorkomen op basis van de gesommeerde CPUE op basis van de biomassa. Nul-percentages zijn naar beneden afgeronde waarden, $*=$ exoot.

\begin{tabular}{|c|c|c|c|c|}
\hline Soort & Groepering & Cumulatief percentage & $2010-2014$ & 2015-2019 \\
\hline snoek & Eurytoop (Pelagisch) & 34.43 & 51.09 & 24.91 \\
\hline karper & Eurytoop (Bentisch) & 55.36 & 24.82 & 18.69 \\
\hline aal & Eurytoop (Bentisch) & 71.2 & 5.4 & 21.81 \\
\hline baars & Eurytoop (Pelagisch) & 79.13 & 9.6 & 6.98 \\
\hline zwartbekgrondel* & Eurytoop (Bentisch) & 85.15 & 0 & 9.46 \\
\hline blankvoorn & Eurytoop (Pelagisch) & 90.3 & 5.19 & 5.13 \\
\hline winde & Rheofiel (Pelagisch) & 92.76 & 1.74 & 2.87 \\
\hline brasem & Eurytoop (Bentisch) & 94.73 & 0.03 & 3.08 \\
\hline kolblei & Eurytoop (Bentisch) & 96.53 & 0.07 & 2.79 \\
\hline rietvoorn & Limnofiel (Pelagisch) & 98.15 & 0.45 & 2.28 \\
\hline zeelt & Limnofiel (Bentisch) & 99.25 & 0.83 & 1.26 \\
\hline giebel & Eurytoop (Bentisch) & 99.45 & 0.54 & \\
\hline bittervoorn & Limnofiel (Pelagisch) & 99.63 & 0.01 & 0.29 \\
\hline alver & Eurytoop (Pelagisch) & 99.69 & - & 0.09 \\
\hline pos & Eurytoop (Bentisch) & 99.74 & 0.11 & 0.01 \\
\hline marmergrondel* & Eurytoop (Bentisch) & 99.78 & 0.01 & 0.07 \\
\hline pontische stroomgrondel* & Eurytoop (Bentisch) & 99.83 & 0 & 0.07 \\
\hline rivierdonderpad & Rheofiel (Bentisch) & 99.87 & 0.09 & 0.01 \\
\hline hybride cyprinide & Eurytoop (Bentisch) & 99.91 & 0 & 0.07 \\
\hline vetje & Limnofiel (Pelagisch) & 99.94 & - & 0.04 \\
\hline $\begin{array}{r}\text { roofblei* } \\
\end{array}$ & Rheofiel (Pelagisch) & 99.96 & - & 0.04 \\
\hline kleine modderkruiper & Eurytoop (Bentisch) & 99.98 & 0.01 & 0.03 \\
\hline kesslers grondel* & Eurytoop (Bentisch) & 100 & - & 0.02 \\
\hline driedoornige stekelbaars & Eurytoop (Pelagisch) & 100 & 0 & 0 \\
\hline tiendoornige stekelbaars & Limnofiel (Pelagisch) & 100 & 0 & 0 \\
\hline
\end{tabular}


Tabel 5. Soortensamenstelling in percentages op basis van aantal in wonderkuilvangsten van de RandmerenOost per 5-jarige periode. De groepering geeft de ecologische indeling aan de hand van Noble et al. (2007) aan. Het cumulatief percentage geeft aan hoeveel de soorten over de gehele periode voorkomen op basis van de gesommeerde CPUE op basis van het aantal. Nul-percentages zijn naar beneden afgeronde waarden, * = exoot.

\begin{tabular}{|c|c|c|c|c|c|}
\hline Soort & Groepering & Cumulatief percentage & 2005-2009 & $2010-2014$ & 2015-2019 \\
\hline blankvoorn & Eurytoop (Pelagisch) & 49.45 & 57.55 & 37.77 & 51.03 \\
\hline baars & Eurytoop (Pelagisch) & 79.67 & 20.91 & 43.23 & 28.62 \\
\hline pos & Eurytoop (Bentisch) & 86.37 & 15.1 & 7.47 & 1.26 \\
\hline brasem & Eurytoop (Bentisch) & 91.25 & 1.06 & 4.67 & 7.28 \\
\hline kolblei & Eurytoop (Bentisch) & 93.71 & 0.35 & 0.49 & 4.81 \\
\hline driedoornige stekelbaars & Eurytoop (Pelagisch) & 95.78 & 1.82 & 3.46 & 1.46 \\
\hline snoekbaars & Eurytoop (Bentisch) & 96.73 & 1.09 & 0.85 & 0.92 \\
\hline zwartbekgrondel* & Eurytoop (Bentisch) & 97.48 & - & - & 1.6 \\
\hline tiendoornige stekelbaars & Limnofiel (Pelagisch) & 98.07 & 0.48 & 0.96 & 0.45 \\
\hline karper & Eurytoop (Bentisch) & 98.39 & 0.48 & 0.06 & 0.36 \\
\hline pontische stroomgrondel* & Eurytoop (Bentisch) & 98.68 & - & 0 & 0.63 \\
\hline marmergrondel* & Eurytoop (Bentisch) & 98.9 & - & 0.18 & 0.37 \\
\hline kleine modderkruiper & Eurytoop (Bentisch) & 99.1 & 0.4 & 0.21 & 0.08 \\
\hline zeelt & Limnofiel (Bentisch) & 99.27 & 0.05 & 0 & 0.34 \\
\hline alver & Eurytoop (Pelagisch) & 99.44 & 0.02 & 0.1 & 0.29 \\
\hline giebel & Eurytoop (Bentisch) & 99.57 & 0.43 & 0.04 & 0.01 \\
\hline rietvoorn & Limnofiel (Pelagisch) & 99.71 & 0.15 & 0.23 & 0.07 \\
\hline snoek & Eurytoop (Pelagisch) & 99.8 & 0.02 & 0.11 & 0.12 \\
\hline hybride cyprinide & Eurytoop (Bentisch) & 99.87 & 0 & 0.02 & 0.15 \\
\hline winde & Rheofiel (Pelagisch) & 99.92 & 0.03 & 0.07 & 0.06 \\
\hline rivierdonderpad & Rheofiel (Bentisch) & 99.95 & 0.03 & 0.07 & 0 \\
\hline kesslers grondel* & Eurytoop (Bentisch) & 99.98 & - & 0.01 & 0.05 \\
\hline aal & Eurytoop (Bentisch) & 99.99 & 0.01 & 0.01 & 0.02 \\
\hline bermpje & Rheofiel (Bentisch) & 100 & 0.02 & - & \\
\hline roofblei* & Rheofiel (Pelagisch) & 100 & 0 & 0 & 0 \\
\hline noordzeehouting & Limnofiel (Pelagisch) & 100 & - & - & 0 \\
\hline vetje & Limnofiel (Pelagisch) & 100 & - & - & 0 \\
\hline
\end{tabular}


Tabel 6. Soortensamenstelling in percentages op basis van biomassa in wonderkuilvangsten van de Randmeren-Oost per 5-jarige periode. De groepering geeft de ecologische indeling aan de hand van Noble et al. (2007) aan. Het cumulatief percentage geeft aan hoeveel de soorten over de gehele periode voorkomen op basis van de gesommeerde CPUE op basis van de biomassa. Nul-percentages zijn naar beneden afgeronde waarden, $*=$ exoot.

\begin{tabular}{|c|c|c|c|c|c|}
\hline Soort & Groepering & Cumulatief percentage & 2005-2009 & 2010-2014 & 2015-2019 \\
\hline blankvoorn & Eurytoop (Pelagisch) & 38.11 & 44.53 & 43.82 & 31.38 \\
\hline baars & Eurytoop (Pelagisch) & 58.98 & 27.38 & 17.05 & 19.14 \\
\hline brasem & Eurytoop (Bentisch) & 77.97 & 2.76 & 21.32 & 27.1 \\
\hline pos & Eurytoop (Bentisch) & 83.1 & 13.34 & 4.39 & 0.8 \\
\hline snoek & Eurytoop (Pelagisch) & 87.6 & 2.53 & 5.16 & 5.28 \\
\hline kolblei & Eurytoop (Bentisch) & 92.05 & 1.55 & 3.06 & 6.87 \\
\hline snoekbaars & Eurytoop (Bentisch) & 94.5 & 3.92 & 1.81 & 1.95 \\
\hline karper & Eurytoop (Bentisch) & 95.58 & 0.93 & 0.18 & 1.63 \\
\hline rietvoorn & Limnofiel (Pelagisch) & 96.5 & 1.17 & 1.41 & 0.52 \\
\hline zwartbekgrondel* & Eurytoop (Bentisch) & 97.33 & - & - & 1.75 \\
\hline aal & Eurytoop (Bentisch) & 97.97 & 0.88 & 0.3 & 0.67 \\
\hline winde & Rheofiel (Pelagisch) & 98.41 & 0.25 & 0.72 & 0.41 \\
\hline hybride cyprinide & Eurytoop (Bentisch) & 98.83 & 0.01 & 0.13 & 0.82 \\
\hline alver & Eurytoop (Pelagisch) & 99.13 & 0.01 & 0.19 & 0.53 \\
\hline pontische stroomgrondel* & Eurytoop (Bentisch) & 99.35 & - & 0 & 0.45 \\
\hline driedoornige stekelbaars & Eurytoop (Pelagisch) & 99.45 & 0.19 & 0.13 & 0.05 \\
\hline kesslers grondel* & Eurytoop (Bentisch) & 99.56 & - & 0.02 & 0.22 \\
\hline roofblei* & Rheofiel (Pelagisch) & 99.67 & 0.03 & 0.05 & 0.17 \\
\hline kleine modderkruiper & Eurytoop (Bentisch) & 99.76 & 0.21 & 0.07 & 0.03 \\
\hline giebel & Eurytoop (Bentisch) & 99.84 & 0.22 & 0.03 & 0.02 \\
\hline zeelt & Limnofiel (Bentisch) & 99.89 & 0.03 & 0.04 & 0.08 \\
\hline marmergrondel* & Eurytoop (Bentisch) & 99.94 & - & 0.04 & 0.08 \\
\hline tiendoornige stekelbaars & Limnofiel (Pelagisch) & 99.98 & 0.06 & 0.05 & 0.03 \\
\hline noordzeehouting & Limnofiel (Pelagisch) & 99.99 & - & - & 0.02 \\
\hline rivierdonderpad & Rheofiel (Bentisch) & 100 & 0.01 & 0.02 & 0 \\
\hline bermpje & Rheofiel (Bentisch) & 100 & 0.01 & - & - \\
\hline vetje & Limnofiel (Pelagisch) & 100 & - & - & 0 \\
\hline
\end{tabular}




\section{Bijlage 8 Randmeren-Zuid}

Tabel 1. Soortensamenstelling in percentages op basis van aantal in stortkuilvangsten van de Randmeren-Zuid per 5-jarige periode. De groepering geeft de ecologische indeling aan de hand van Noble et al. (2007) aan. Het cumulatief percentage geeft aan hoeveel de soorten over de gehele periode voorkomen op basis van de gesommeerde CPUE op basis van het aantal. Nul-percentages zijn naar beneden afgeronde waarden, $*=$ exoot.

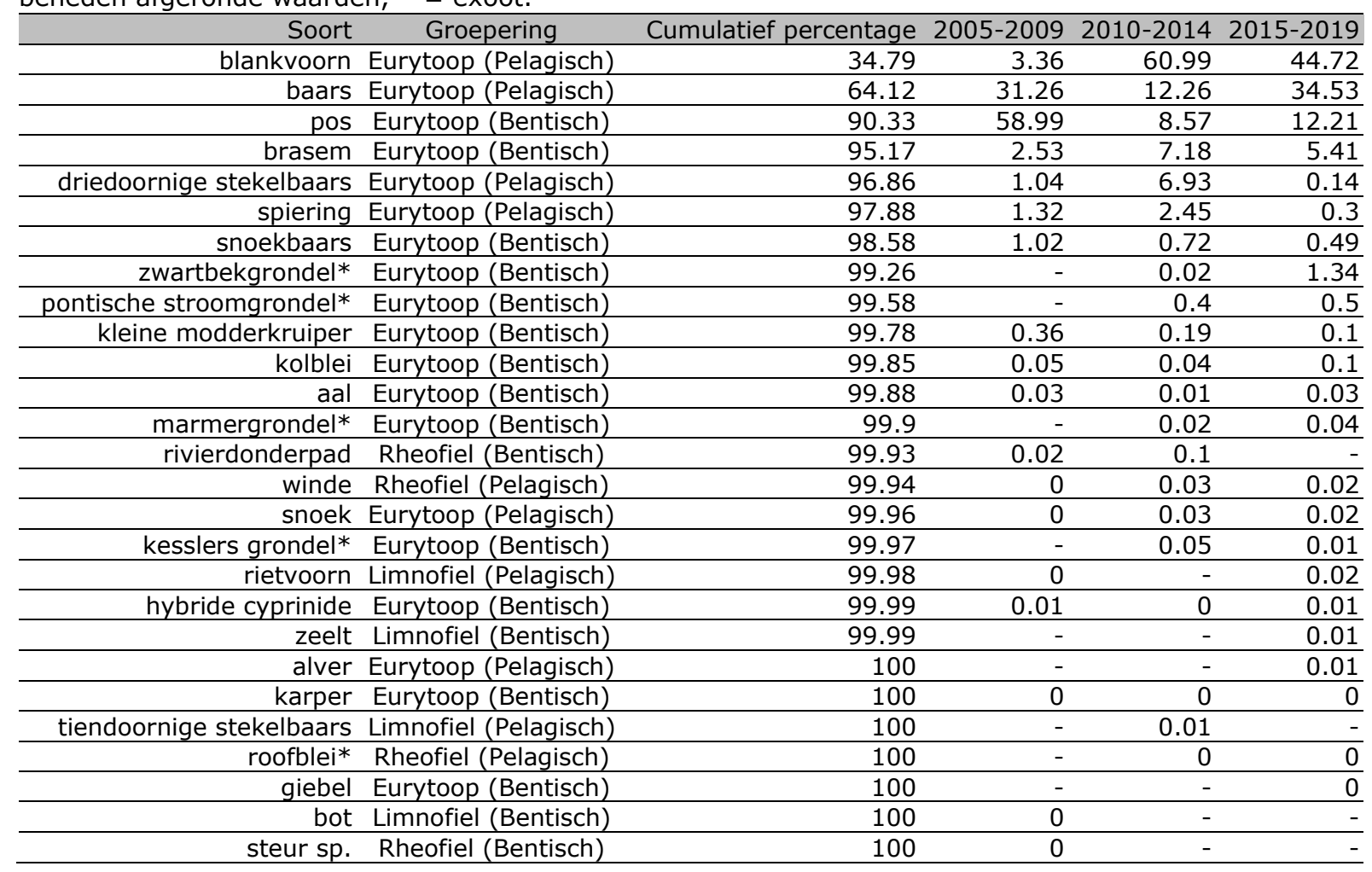


Tabel 2. Soortensamenstelling in percentages op basis van biomassa in stortkuilvangsten van de RandmerenZuid per 5-jarige periode. De groepering geeft de ecologische indeling aan de hand van Noble et al. (2007) aan. Het cumulatief percentage geeft aan hoeveel de soorten over de gehele periode voorkomen op basis van de gesommeerde CPUE op basis van de biomassa. Nul-percentages zijn naar beneden afgeronde waarden, $*=$ exoot.

\begin{tabular}{|c|c|c|c|c|c|}
\hline Soort & Groepering & Cumulatief percentage & 2005-2009 & $2010-2014$ & 2015-2019 \\
\hline brasem & Eurytoop (Bentisch) & 40.62 & 39.28 & 29.21 & 45.9 \\
\hline blankvoorn & Eurytoop (Pelagisch) & 65.98 & 16.34 & 43.63 & 25.48 \\
\hline baars & Eurytoop (Pelagisch) & 77.35 & 12.5 & 12.34 & 10.14 \\
\hline snoekbaars & Eurytoop (Bentisch) & 87.82 & 12.97 & 6.67 & 9.97 \\
\hline pos & Eurytoop (Bentisch) & 96.01 & 16.55 & 3.08 & 3.68 \\
\hline snoek & Eurytoop (Pelagisch) & 96.98 & 0.24 & 1.07 & 1.48 \\
\hline kolblei & Eurytoop (Bentisch) & 97.79 & 0.54 & 0.91 & 0.97 \\
\hline aal & Eurytoop (Bentisch) & 98.37 & 0.59 & 0.35 & 0.66 \\
\hline karper & Eurytoop (Bentisch) & 98.75 & 0.26 & 1.08 & 0.22 \\
\hline zwartbekgrondel* & Eurytoop (Bentisch) & 99.1 & - & 0.06 & 0.73 \\
\hline pontische stroomgrondel* & Eurytoop (Bentisch) & 99.25 & - & 0.27 & 0.21 \\
\hline spiering & Eurytoop (Pelagisch) & 99.39 & 0.21 & 0.31 & 0.03 \\
\hline roofblei* & Rheofiel (Pelagisch) & 99.51 & - & 0 & 0.26 \\
\hline winde & Rheofiel (Pelagisch) & 99.63 & 0.04 & 0.37 & 0.07 \\
\hline driedoornige stekelbaars & Eurytoop (Pelagisch) & 99.72 & 0.05 & 0.43 & 0 \\
\hline steur sp. & Rheofiel (Bentisch) & 99.81 & 0.26 & - & \\
\hline hybride cyprinide & Eurytoop (Bentisch) & 99.9 & 0.07 & 0.06 & 0.11 \\
\hline kleine modderkruiper & Eurytoop (Bentisch) & 99.94 & 0.07 & 0.05 & 0.02 \\
\hline rietvoorn & Limnofiel (Pelagisch) & 99.96 & 0.02 & - & 0.03 \\
\hline kesslers grondel* & Eurytoop (Bentisch) & 99.98 & - & 0.08 & 0.01 \\
\hline zeelt & Limnofiel (Bentisch) & 99.99 & - & - & 0.01 \\
\hline rivierdonderpad & Rheofiel (Bentisch) & 99.99 & 0 & 0.02 & \\
\hline bot & Limnofiel (Bentisch) & 99.99 & 0.01 & - & \\
\hline marmergrondel* & Eurytoop (Bentisch) & 100 & - & 0 & 0 \\
\hline alver & Eurytoop (Pelagisch) & 100 & - & - & 0.01 \\
\hline giebel & Eurytoop (Bentisch) & 100 & - & - & 0 \\
\hline tiendoornige stekelbaars & Limnofiel (Pelagisch) & 100 & - & 0 & \\
\hline
\end{tabular}


Tabel 3. Soortensamenstelling in percentages op basis van aantal in schepnetvangsten van de Randmeren-Zuid per 5 -jarige periode. De groepering geeft de ecologische indeling aan de hand van Noble et al. (2007) aan. Het cumulatief percentage geeft aan hoeveel de soorten over de gehele periode voorkomen op basis van de gesommeerde CPUE op basis van het aantal. Nul-percentages zijn naar beneden afgeronde waarden, * = exoot.

\begin{tabular}{rrrrr}
\hline Soort & Groepering & Cumulatief percentage & $2010-2014$ & $2015-2019$ \\
\hline zwartbekgrondel* & Eurytoop (Bentisch) & 35.79 & 1.17 & 38.81 \\
\hline baars & Eurytoop (Pelagisch) & 67.22 & 23.55 & 32.12 \\
\hline blankvoorn & Eurytoop (Pelagisch) & 94.97 & 57.62 & 25.15 \\
\hline rietvoorn & Limnofiel (Pelagisch) & 96.11 & 2.32 & 1.03 \\
\hline aal & Eurytoop (Bentisch) & 97.19 & 1.37 & 1.05 \\
\hline kolblei & Eurytoop (Bentisch) & 97.9 & 0.42 & 0.74 \\
\hline winde & Rheofiel (Pelagisch) & 98.44 & 2.31 & 0.38 \\
\hline marmergrondel* & Eurytoop (Bentisch) & 98.91 & 3.54 & 0.2 \\
\hline snoek & Eurytoop (Pelagisch) & 99.09 & 0.92 & 0.12 \\
\hline brasem & Eurytoop (Bentisch) & 99.26 & 0.92 & 0.11 \\
\hline Rheofiel (Bentisch) & 99.43 & 1.94 & 0.01 \\
\hline pivierdonderpad & Eurytoop (Bentisch) & 99.57 & 0.73 & 0.09 \\
\hline pos & Eurytoop (Bentisch) & 99.65 & 0.91 & 0.02 \\
\hline kleine modderkruiper & 99.72 & 0.76 & 0.01 \\
\hline karper & Eurytoop (Bentisch) & 99.78 & 0.34 & 0.03 \\
\hline driedoornige stekelbaars & Eurytoop (Pelagisch) & 99.83 & 0.63 & - \\
\hline Liendoornige stekelbaars & Limnofiel (Pelagisch) & 99.88 & 0.13 & 0.04 \\
\hline zeelt & Limnofiel (Bentisch) & 99.92 & 0.03 & 0.05 \\
\hline snoekbaars & Eurytoop (Bentisch) & 99.94 & 0.05 & 0.01 \\
\hline bittervoorn & Limnofiel (Pelagisch) & 99.95 & 0.16 & 0 \\
\hline pontische stroomgrondel* & Eurytoop (Bentisch) & 99.97 & - & 0.02 \\
\hline hybride cyprinide & Eurytoop (Bentisch) & 99.98 & - & 0.01 \\
\hline kesslers grondel* & Eurytoop (Bentisch) & 99.99 & 0.11 & - \\
\hline riviergrondel & Rheofiel (Bentisch) & 100 & 0.03 & 0.01 \\
\hline roofblei* & Rheofiel (Pelagisch) & 100 & 0.03 & - \\
\hline giebel & Eurytoop (Bentisch) & 100 & 0.03 & - \\
\hline goudvis* & Limnofiel (Bentisch) & &
\end{tabular}

Tabel 4. Soortensamenstelling in percentages op basis van biomassa in schepnetvangsten van de RandmerenZuid per 5-jarige periode. De groepering geeft de ecologische indeling aan de hand van Noble et al. (2007) aan. Het cumulatief percentage geeft aan hoeveel de soorten over de gehele periode voorkomen op basis van de gesommeerde CPUE op basis van de biomassa. Nul-percentages zijn naar beneden afgeronde waarden, $*^{*}=$ exoot.

\begin{tabular}{|c|c|c|c|c|}
\hline Soort & Groepering & Cumulatief percentage & $2010-2014$ & $2015-2019$ \\
\hline zwartbekgrondel* & Eurytoop (Bentisch) & 34.13 & 1.83 & 38.56 \\
\hline baars & Eurytoop (Pelagisch) & 50.13 & 20.21 & 15.43 \\
\hline aal & Eurytoop (Bentisch) & 63.19 & 6.9 & 13.9 \\
\hline snoek & Eurytoop (Pelagisch) & 73.45 & 24.91 & 8.25 \\
\hline blankvoorn & Eurytoop (Pelagisch) & 81.74 & 14.83 & 7.39 \\
\hline karper & Eurytoop (Bentisch) & 89.19 & 1.71 & 8.24 \\
\hline winde & Rheofiel (Pelagisch) & 96.49 & 10.66 & 6.84 \\
\hline rietvoorn & Limnofiel (Pelagisch) & 97.77 & 8.27 & 0.32 \\
\hline goudvis* & Limnofiel (Bentisch) & 98.46 & 5.73 & \\
\hline snoekbaars & Eurytoop (Bentisch) & 99.11 & 0.02 & 0.74 \\
\hline zeelt & Limnofiel (Bentisch) & 99.5 & 3.1 & 0.02 \\
\hline kolblei & Eurytoop (Bentisch) & 99.63 & 0.04 & 0.14 \\
\hline marmergrondel* & Eurytoop (Bentisch) & 99.72 & 0.5 & 0.03 \\
\hline pos & Eurytoop (Bentisch) & 99.81 & 0.37 & 0.05 \\
\hline rivierdonderpad & Rheofiel (Bentisch) & 99.87 & 0.51 & 0 \\
\hline brasem & Eurytoop (Bentisch) & 99.92 & 0.12 & 0.04 \\
\hline kleine modderkruiper & Eurytoop (Bentisch) & 99.95 & 0.14 & 0.01 \\
\hline kesslers grondel* & Eurytoop (Bentisch) & 99.97 & - & 0.03 \\
\hline roofblei* & Rheofiel (Pelagisch) & 99.98 & 0.02 & 0.01 \\
\hline hybride cyprinide & Eurytoop (Bentisch) & 99.98 & - & 0.01 \\
\hline driedoornige stekelbaars & Eurytoop (Pelagisch) & 99.99 & 0.02 & 0 \\
\hline tiendoornige stekelbaars & Limnofiel (Pelagisch) & 99.99 & 0.03 & \\
\hline riviergrondel & Rheofiel (Bentisch) & 99.99 & 0.03 & \\
\hline pontische stroomgrondel* & Eurytoop (Bentisch) & 100 & 0.01 & 0 \\
\hline giebel & Eurytoop (Bentisch) & 100 & 0.02 & \\
\hline bittervoorn & Limnofiel (Pelagisch) & 100 & 0 & 0 \\
\hline
\end{tabular}




\section{Bijlage 9 Figuren 1992-1996}

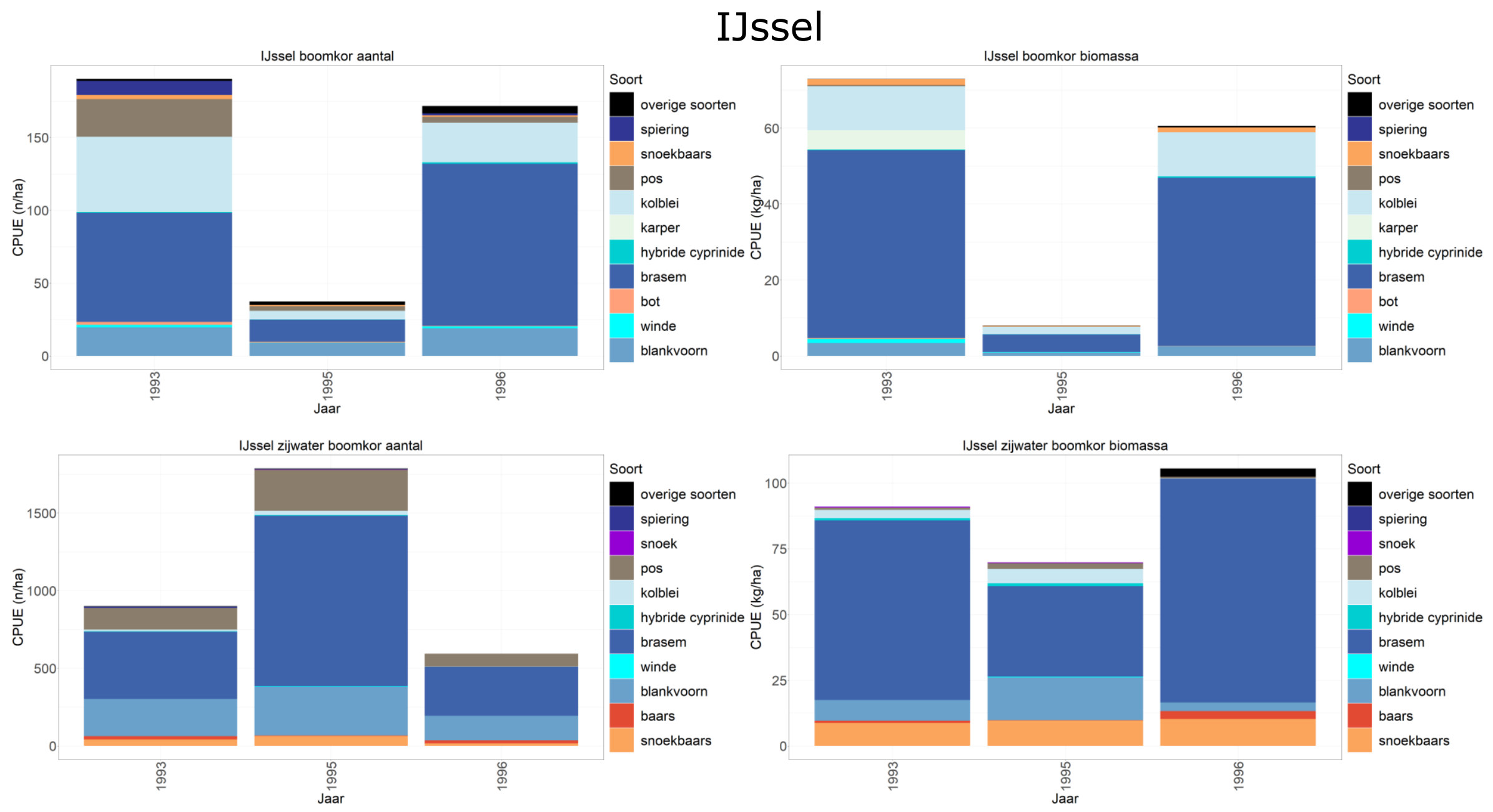

Figuur 7.1 Gemiddelde CPUE van de tien meest algemene soorten en overige soorten in het open water, langs de oever en in het zijwater (n/ha-kg/ha bevist oppervlak) gevangen met een boomkor in de hoofdstroom van de IJssel tijdens de actieve monitoring van 1992-1996. De IJssel omvat de gehele rivier de Gelderse IJssel en het Pannerdens Kanaal in 1993 en 1995, gegevens uit 1996 omvatten alleen de Bovenloop Gelderse IJssel. 


\section{Overijsselse Vecht}

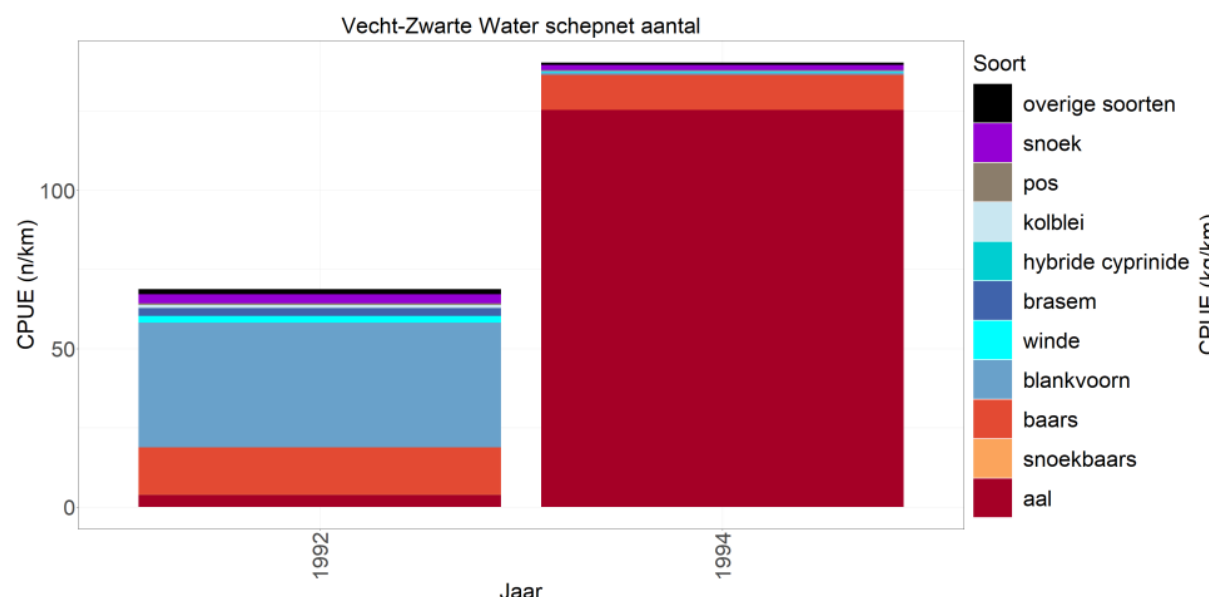

Vecht-Zwarte Water Wonderkuil aantal

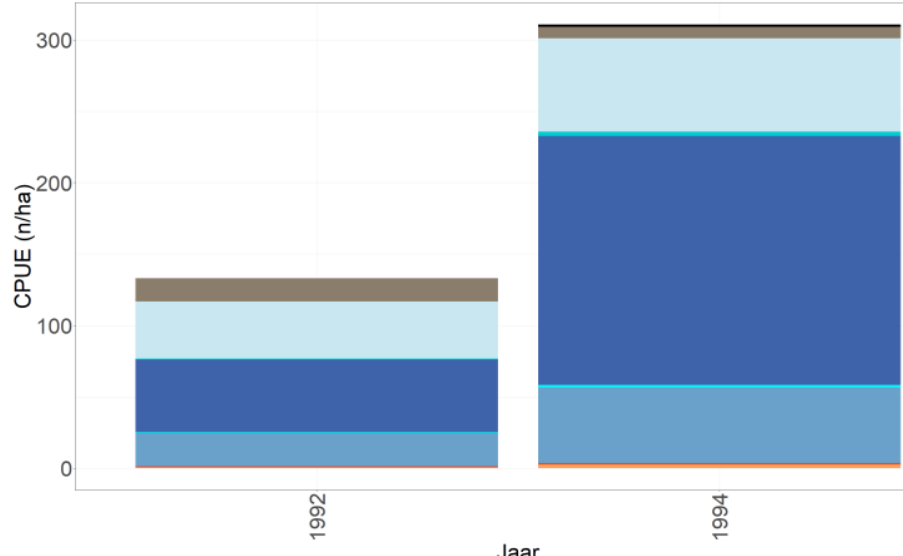

Soort

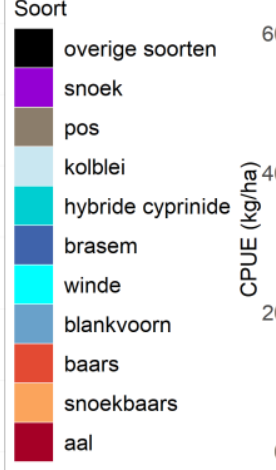

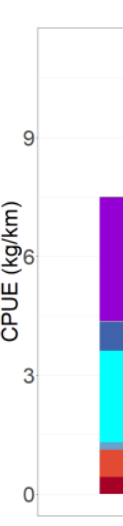

0

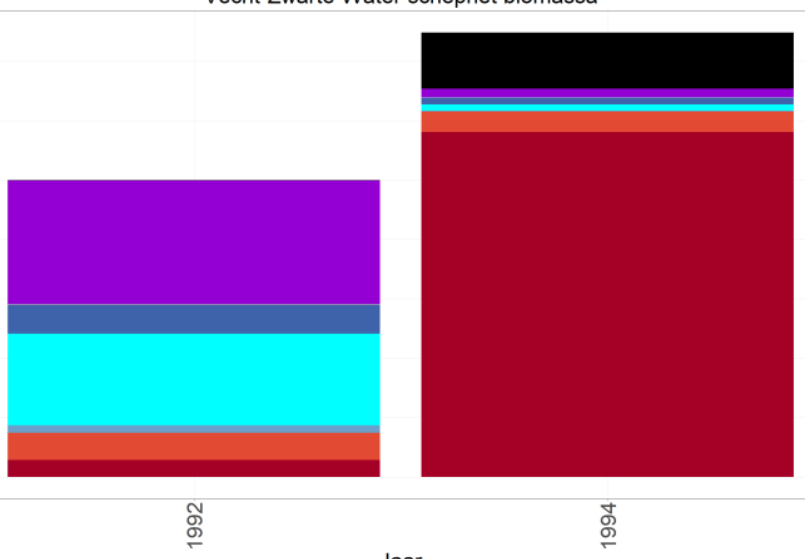

Jar

Vecht-Zwarte Water Wonderkuil biomassa

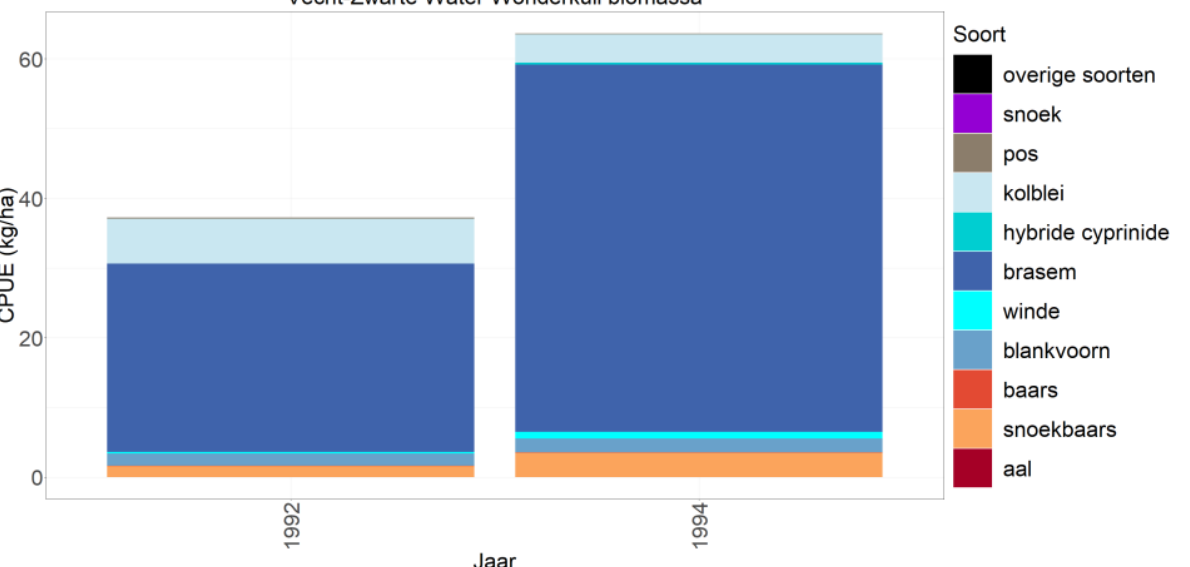

Figuur 7.2 Gemiddelde CPUE van de tien meest algemene soorten en overige soorten langs de oever gevangen met een schepnet ( $\mathrm{n} / \mathrm{km}-\mathrm{kg} / \mathrm{km}$ bevist oppervlak) en een wonderkuil ( $\mathrm{n} / \mathrm{ha}-\mathrm{kg} / \mathrm{ha}$ bevist oppervlak) van de Overijsselse Vecht tijdens de actieve monitoring van 1992-1996. De Overijsselse Vecht omvat de gehele rivier de Vecht inclusief het Zwarte Water. 


\section{Zwarte Meer}
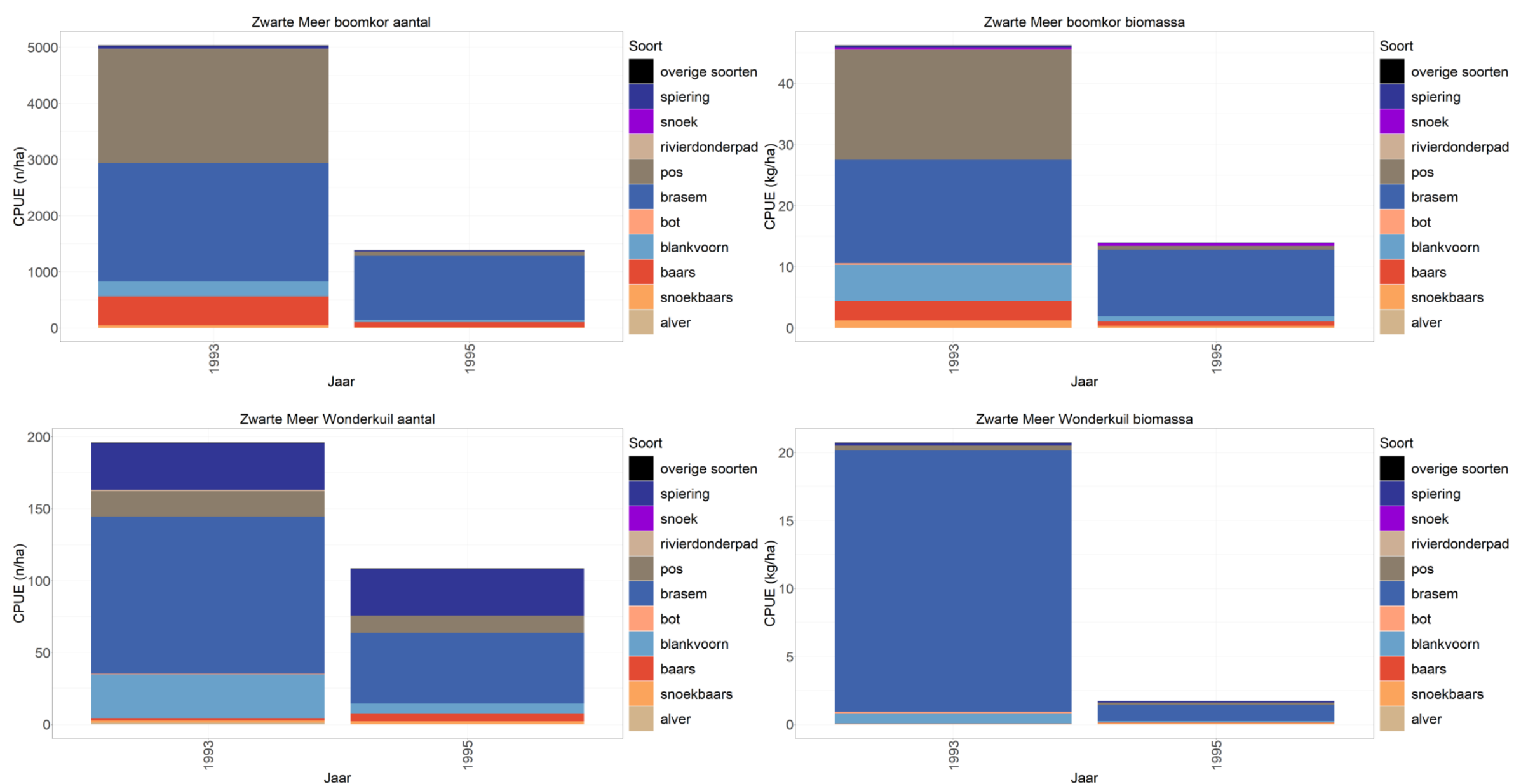

Figuur 7.3 Gemiddelde CPUE van de tien meest algemene soorten en overige soorten langs de oever gevangen met een schepnet ( $\mathrm{n} / \mathrm{km}-\mathrm{kg} / \mathrm{km}$ bevist oppervlak) en een wonderkuil ( $\mathrm{n} / \mathrm{ha}-\mathrm{kg} / \mathrm{ha}$ bevist oppervlak) van het Zwarte Meer tijdens de actieve monitoring van 1992-1996. 


\section{Ketelmeer}
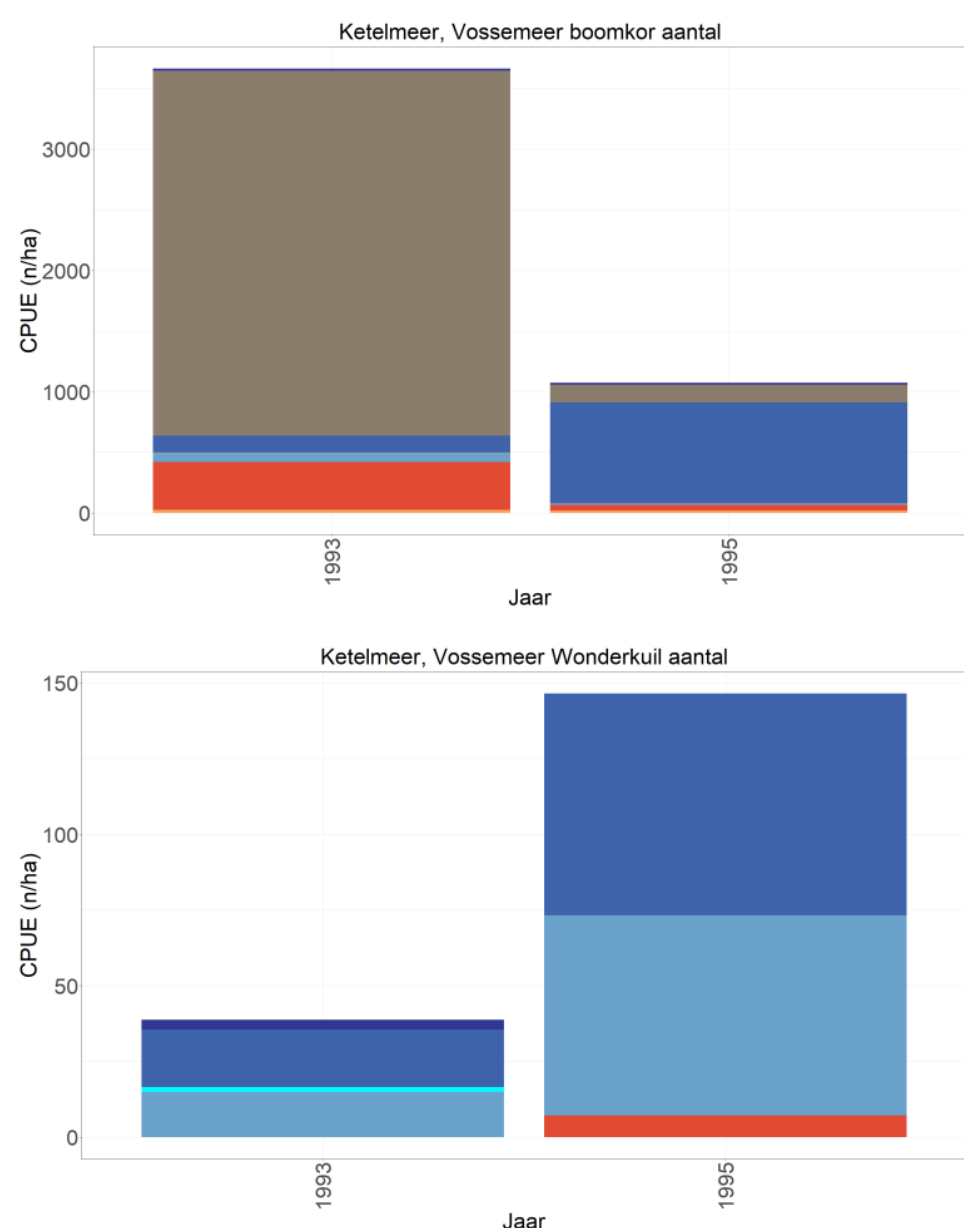
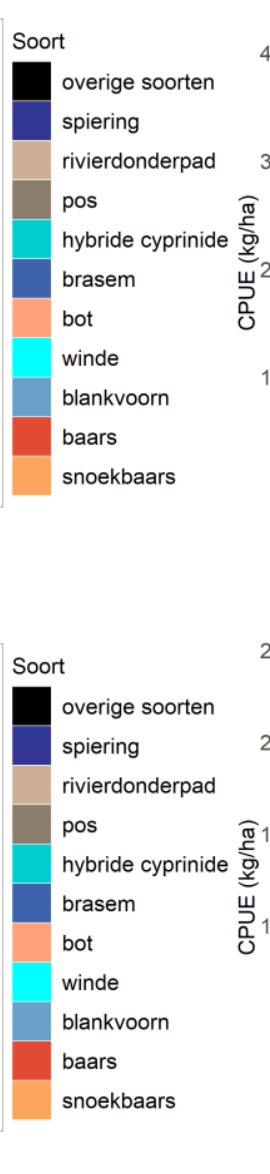

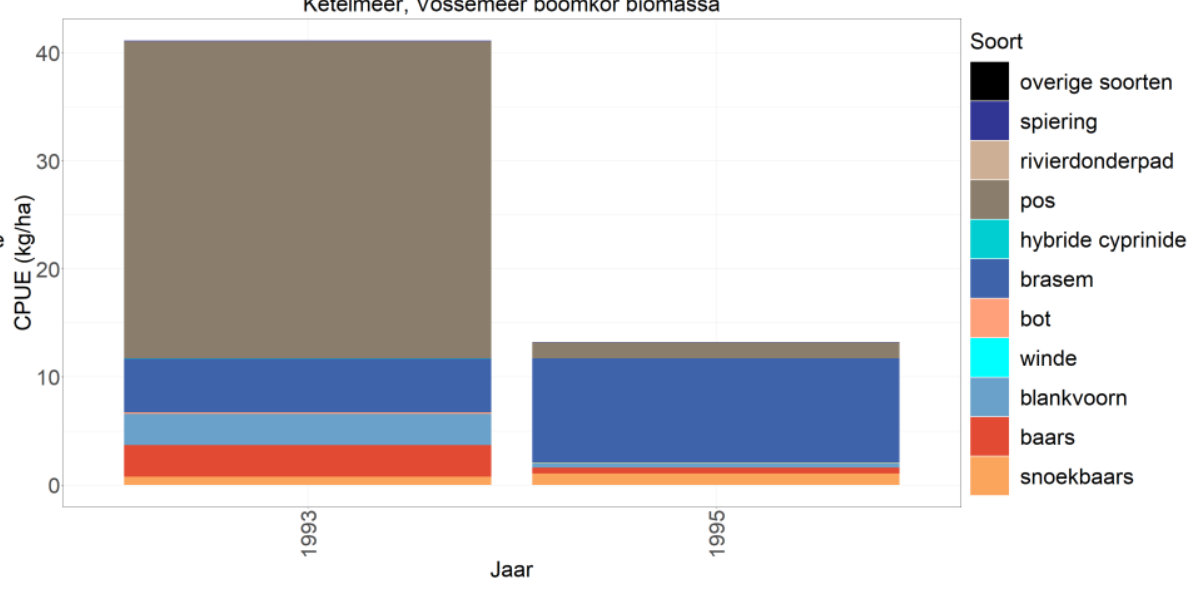

Ketelmeer, Vossemeer boomkor biomassa

Jaa

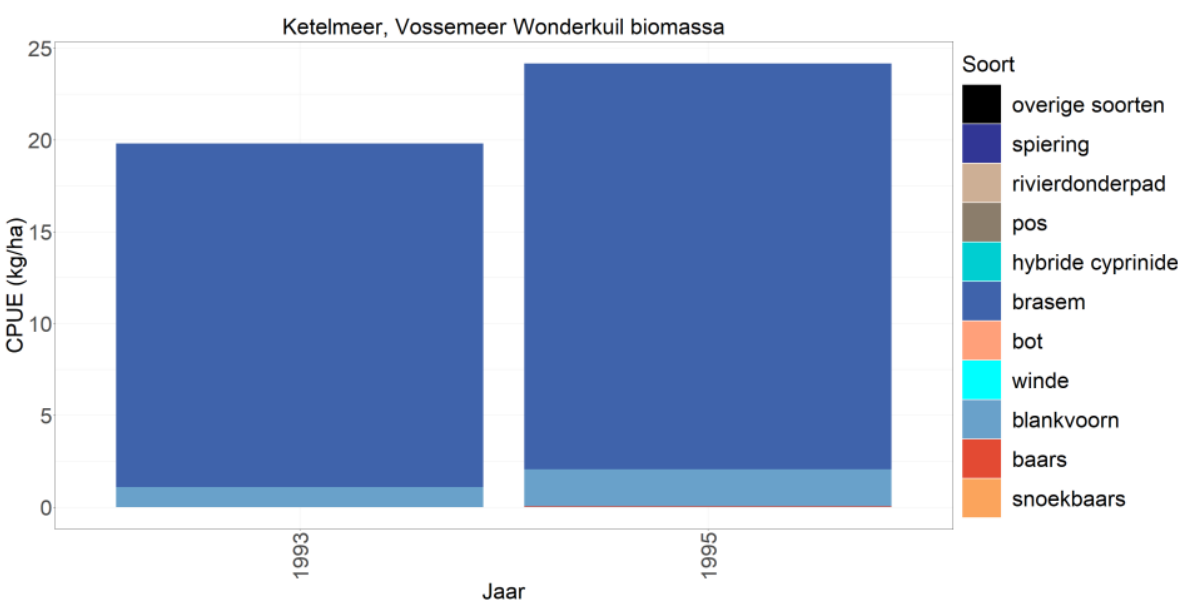

Figuur 7.4 Gemiddelde CPUE van de tien meest algemene soorten en overige soorten in het open water en langs de oever gevangen met een boomkor en een wonderkuil ( $\mathrm{n} / \mathrm{ha}-\mathrm{kg} / \mathrm{ha}$ bevist oppervlak) van het Ketelmeer tijdens de actieve monitoring van 1992-1996. Het Vossemeer is in deze periode niet bemonsterd. 


\section{Randmeren-Oost}
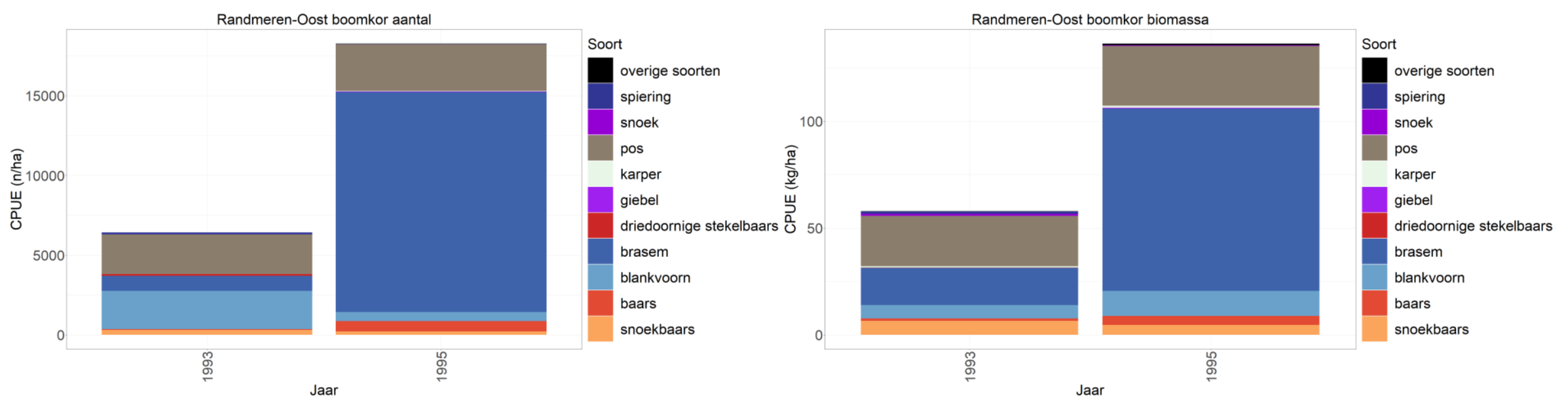

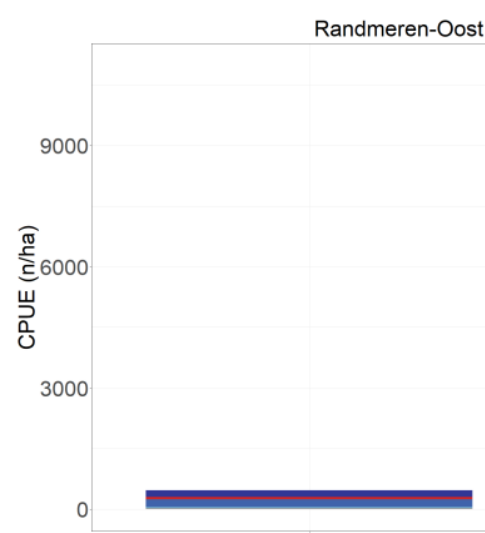

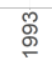

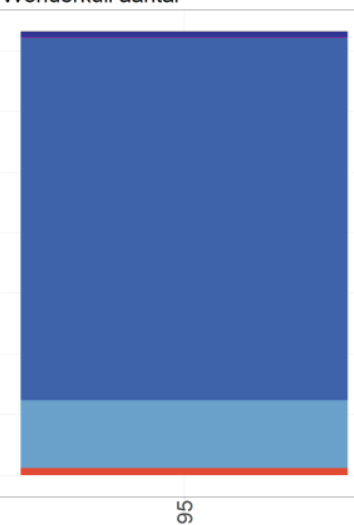

Jaar
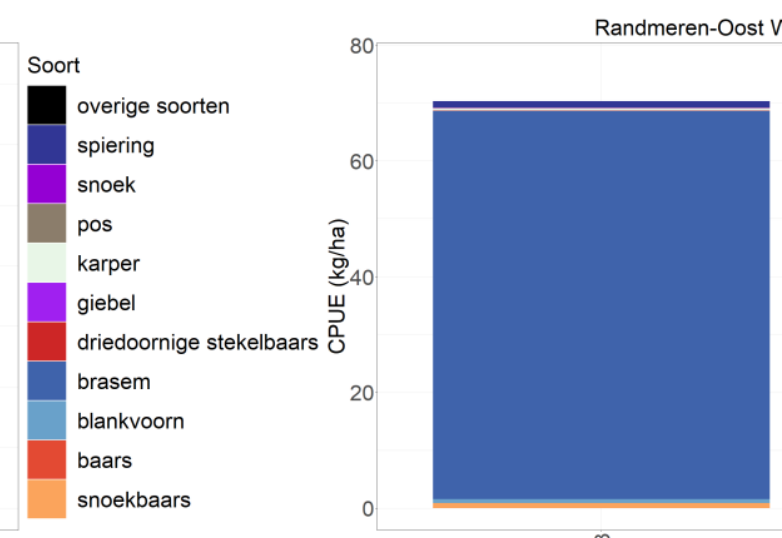

$\stackrel{g}{9}$

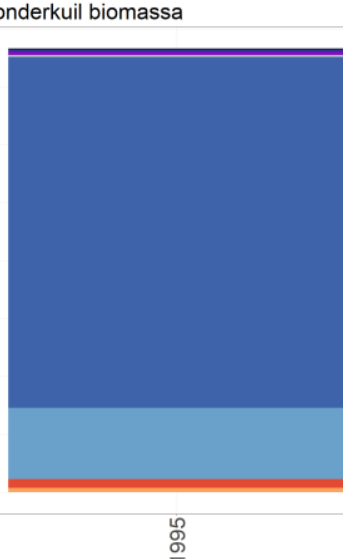

Jaa

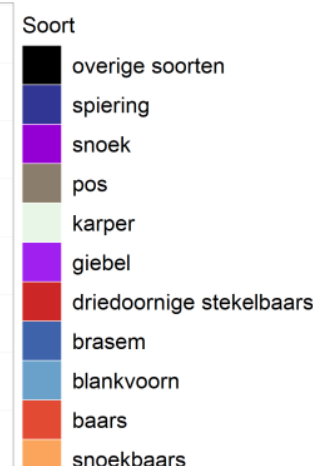

snoekbaars

Figuur 7.5 Gemiddelde CPUE van de tien meest algemene soorten en overige soorten in het open water en langs de oever gevangen met een boomkor en een wonderkuil (n/ha-kg/ha bevist oppervlak) van de Randmeren-Oost tijdens de actieve monitoring van 1992-1996. Het Drontermeer is alleen met een boomkor bemonsterd, het Veluwemeer, Wolderwijd en het Nuldernauw zijn met zowel de boomkor als de wonderkuil bemonsterd. 


\section{Randmeren-Zuid}
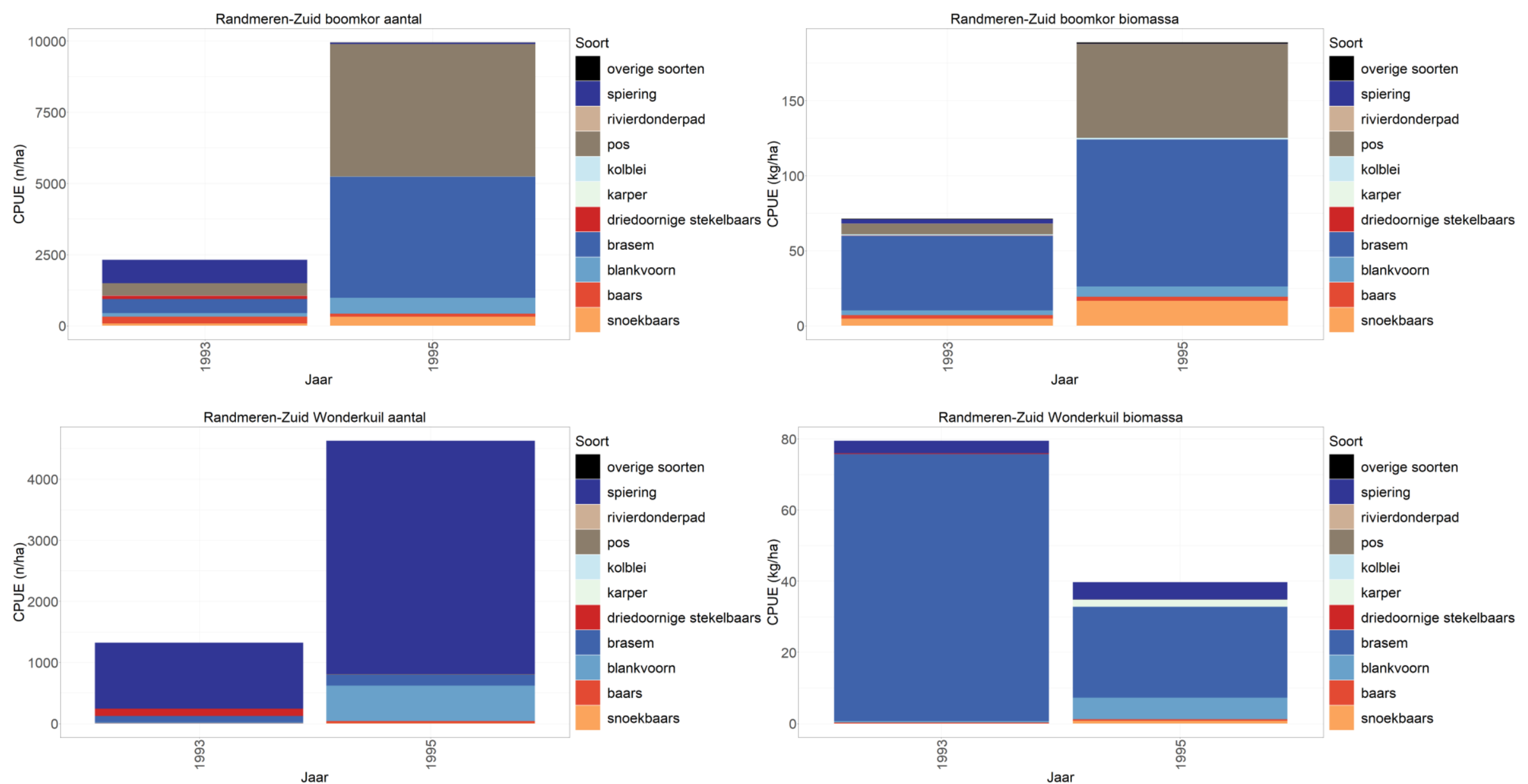

Figuur 7.6 Gemiddelde CPUE van de tien meest algemene soorten en overige soorten in het open water en langs de oever gevangen met een boomkor en een wonderkuil (n/ha-kg/ha bevist oppervlak) van de Randmeren-Zuid tijdens de actieve monitoring van 1992-1996. Het Nijkerkernauw is alleen met een boomkor bemonsterd, het Eemmeer en het Gooimeer zijn met zowel de boomkor als de wonderkuil bemonsterd. 


\section{Noordzeekanaal}
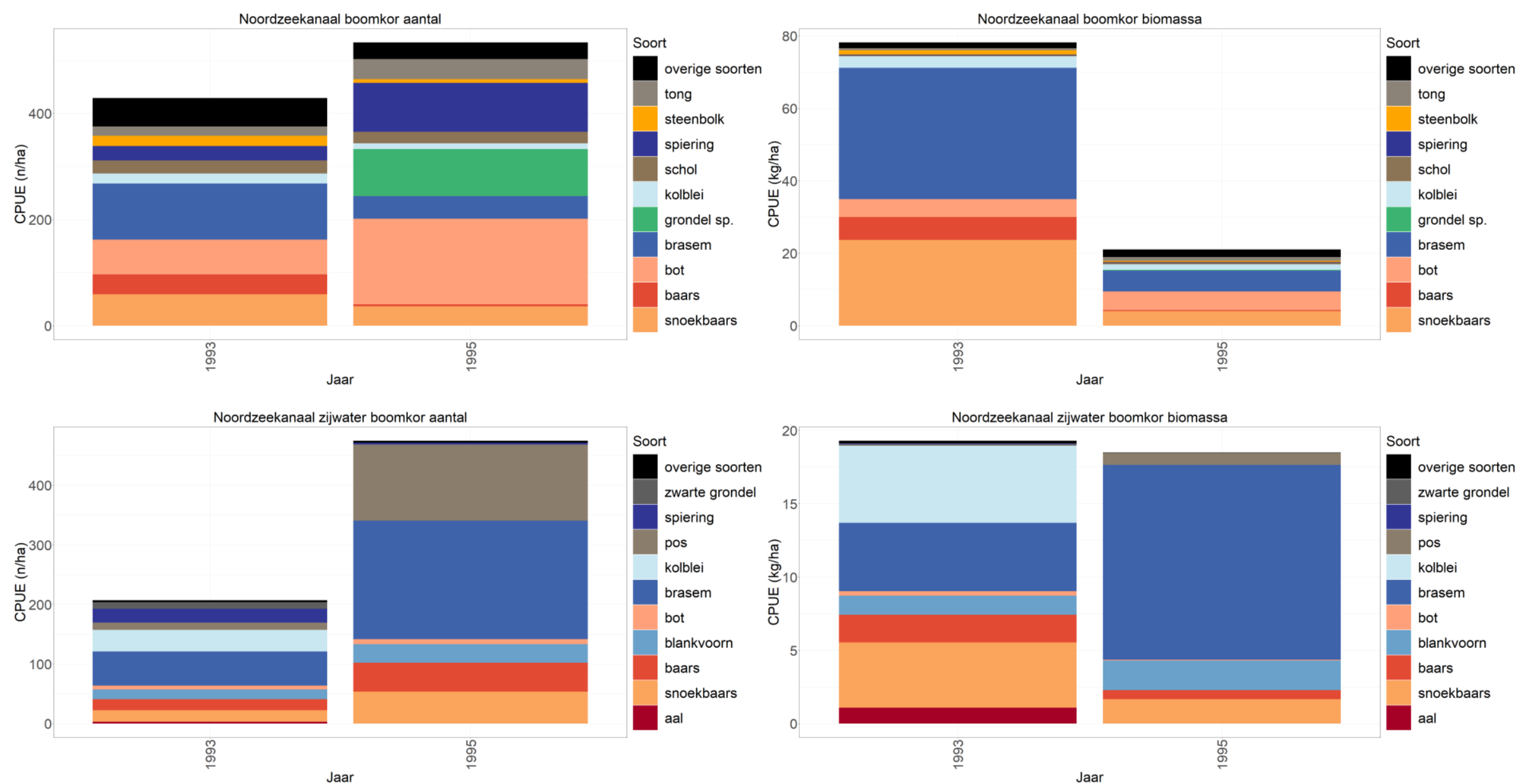

Figuur 7.7 Gemiddelde CPUE van de tien meest algemene soorten en overige soorten in het open water, langs de oever en in het zijwater ( $\mathrm{n} / \mathrm{ha}$-kg/ha bevist oppervlak) gevangen met een boomkor in het Noordzeekanaal tijdens de actieve monitoring van 1992-1996. Het Noordzeekanaal omvat, net als in de gegevens van na 1997, ook het IJmeer. 


\section{Grensmaas}

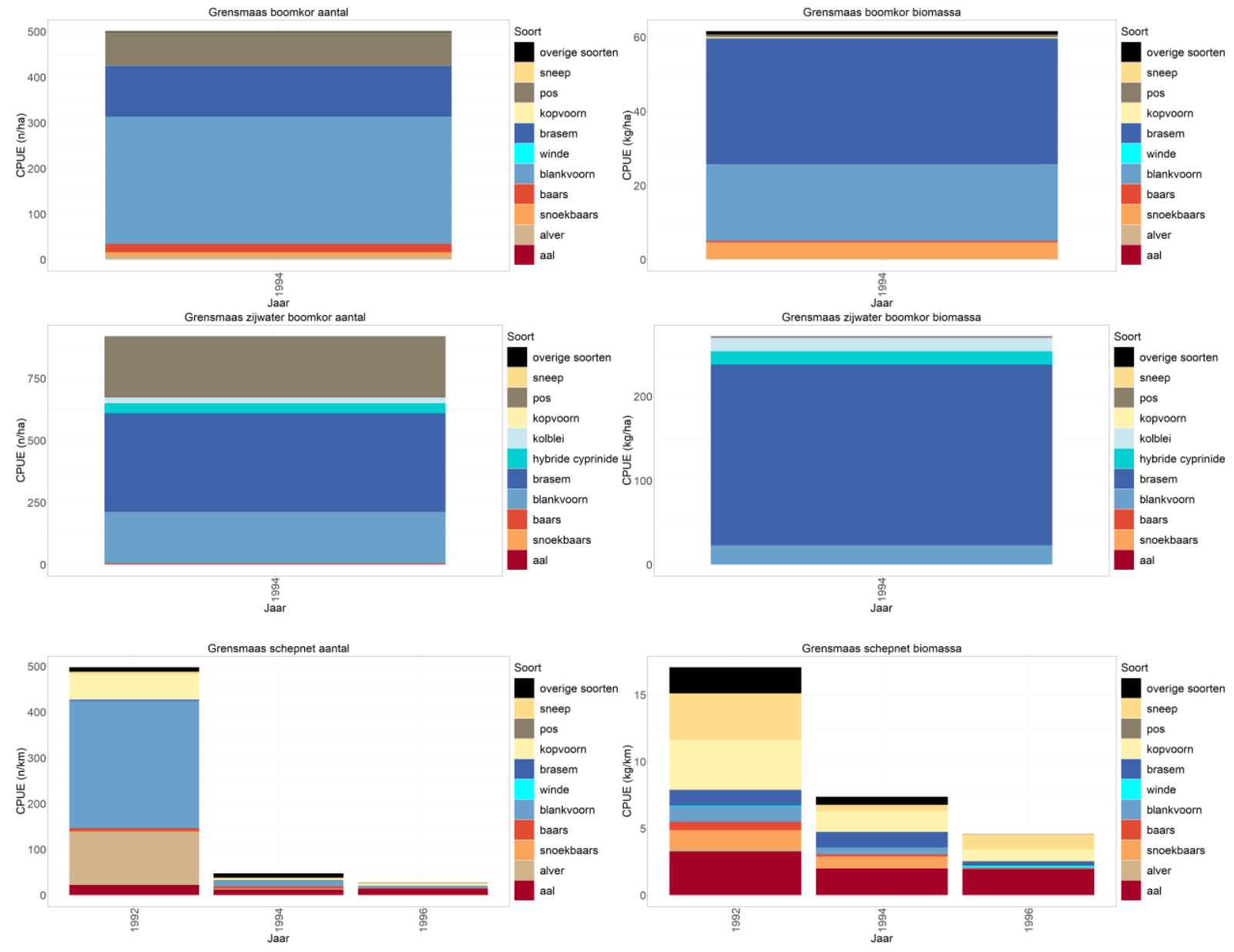

Figuur 7.8 Gemiddelde CPUE van de tien meest algemene soorten en overige soorten in het open water, langs de oever en in het zijwater ( $\mathrm{n} / \mathrm{ha}-\mathrm{kg} / \mathrm{ha}$ bevist oppervlak) gevangen met een boomkor en langs de oever gevangen met het schepnet $(\mathrm{n} / \mathrm{km}-\mathrm{kg} / \mathrm{km}$ bevist oppervlak) in de Grensmaas tijdens de actieve monitoring van 1992-1996. Er is alleen in 1994 met de boomkor bemonsterd. 


\section{Beneden Maas}
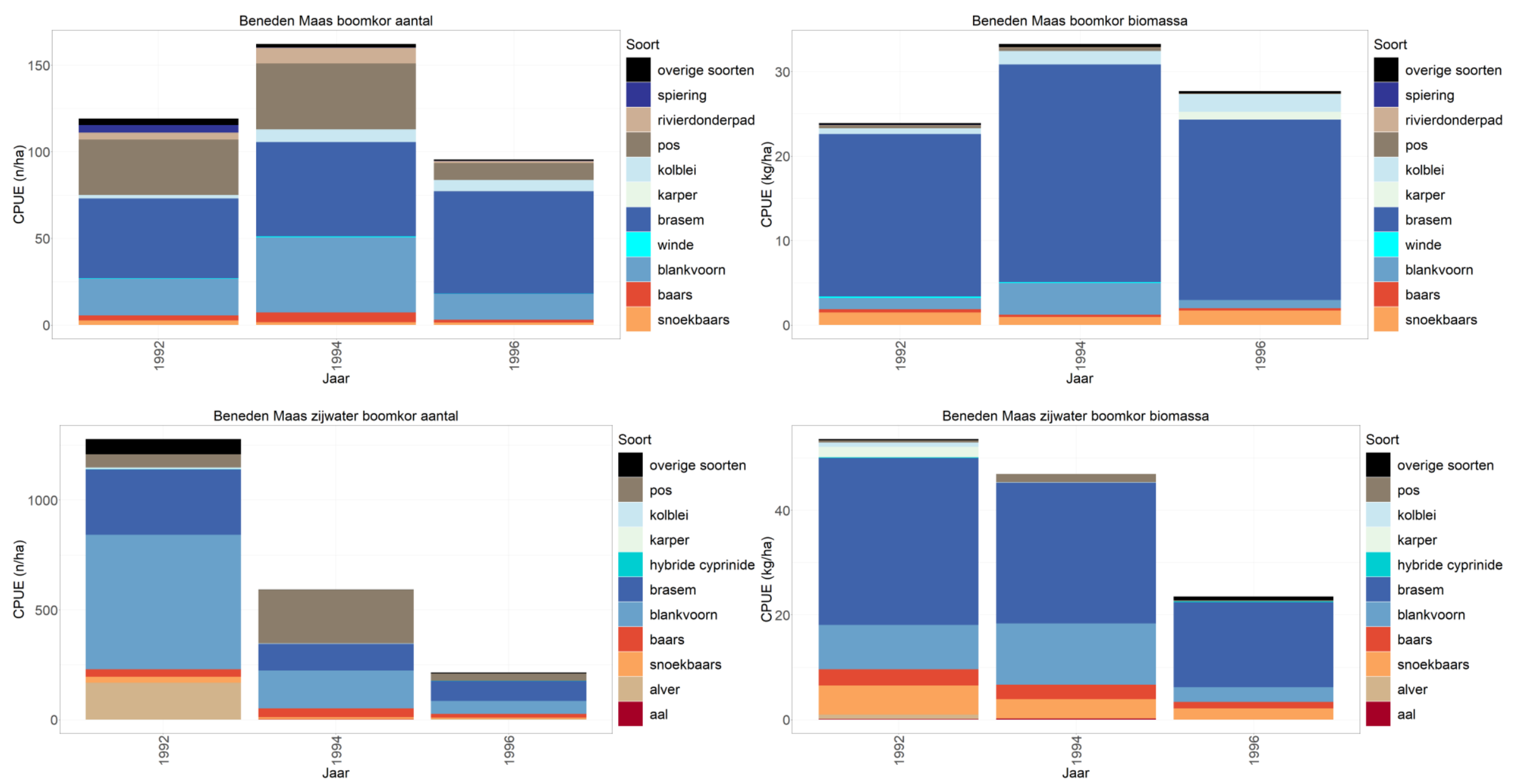

Figuur 7.9 Gemiddelde CPUE van de tien meest algemene soorten en overige soorten in het open water, langs de oever en in het zijwater (n/ha-kg/ha bevist oppervlak) gevangen met een boomkor in de Beneden Maas tijdens de actieve monitoring van 1992-1996. De Beneden Maas omvat de Zandmaas en de Getijden Maas. 


\section{Oude Maas}
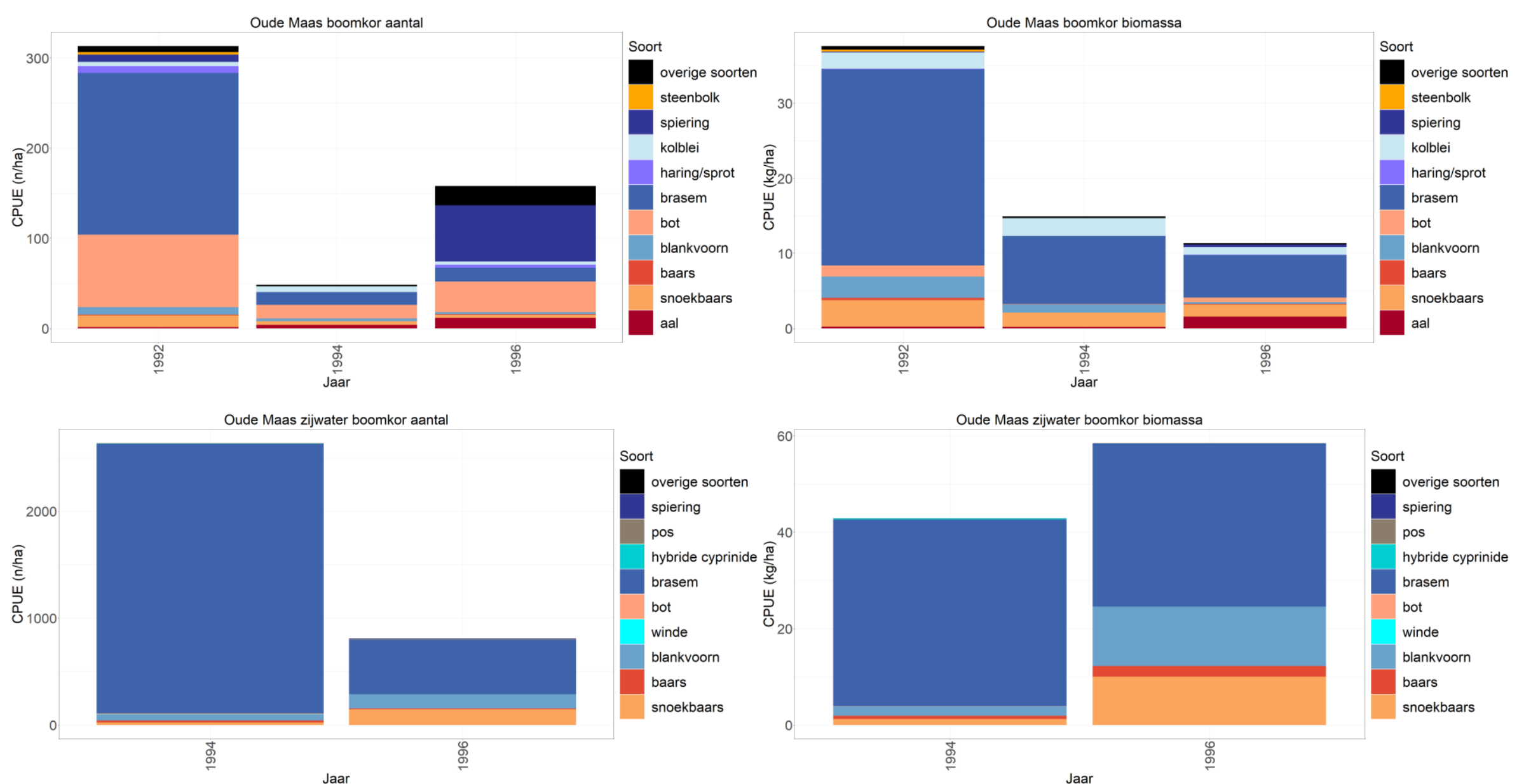

Figuur 7.10 Gemiddelde CPUE van de tien meest algemene soorten en overige soorten in het open water, langs de oever en in het zijwater (n/ha-kg/ha bevist oppervlak) gevangen met een boomkor in de Oude Maas tijdens de actieve monitoring van 1992-1996. De Oude Maas omvat de rivier de Oude Maas, de Dordtsche Kil en het Spui. 


\section{Nieuwe Maas}
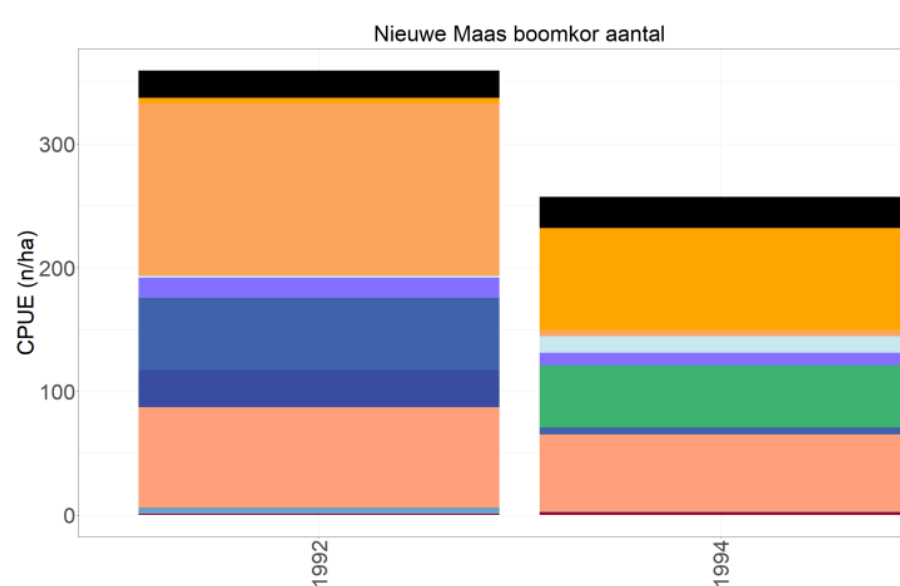

Jaar

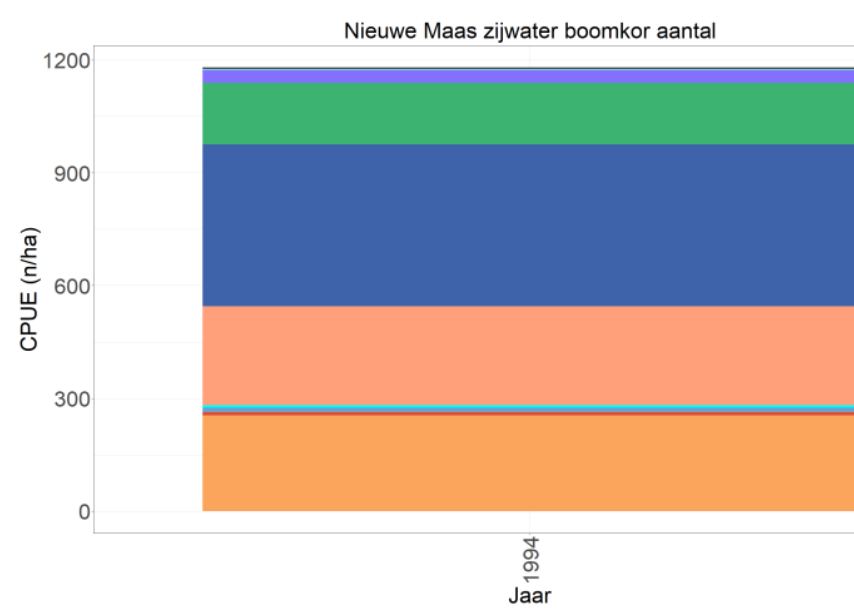

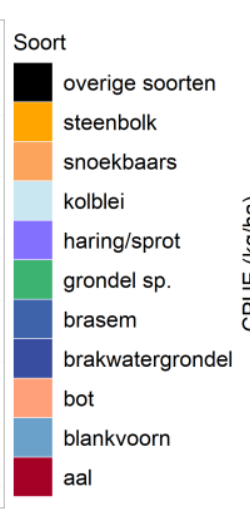

Soort

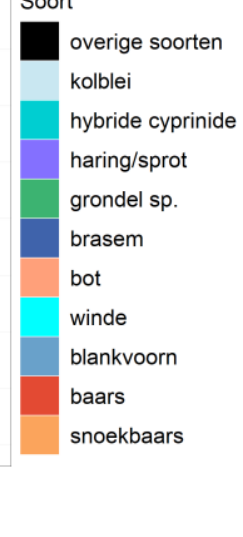

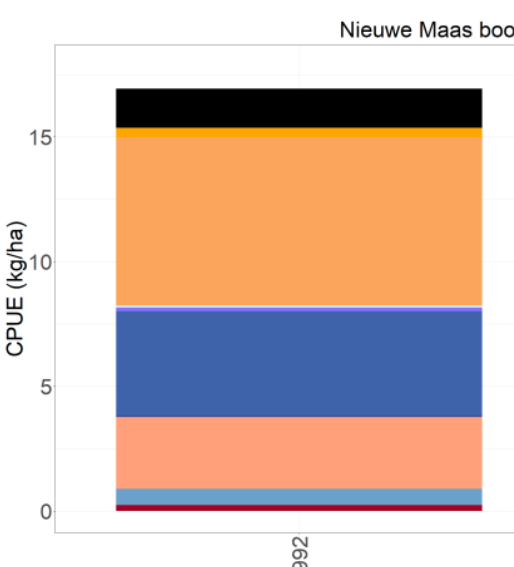

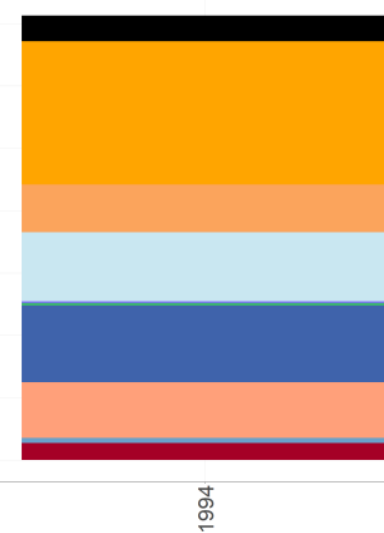

Jaar

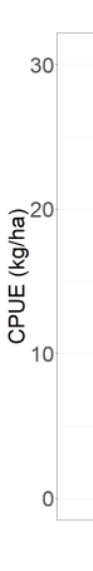

Soort

overige soorten steenbolk snoekbaars kolblei

haring/sprot grondel sp.

brasem

brakwatergrondel bot blankvoorn

Figuur 7.11 Gemiddelde CPUE van de tien meest algemene soorten en overige soorten in het open water, langs de oever en in het zijwater ( $\mathrm{n} / \mathrm{ha}-\mathrm{kg} / \mathrm{ha}$ bevist oppervlak) gevangen met een boomkor in de Nieuwe Maas tijdens de actieve monitoring van 1992-1996. De Oude Maas omvat de rivier de Nieuwe Maas en de Nieuwe Waterweg. 


\section{Nederrijn \& Lek}
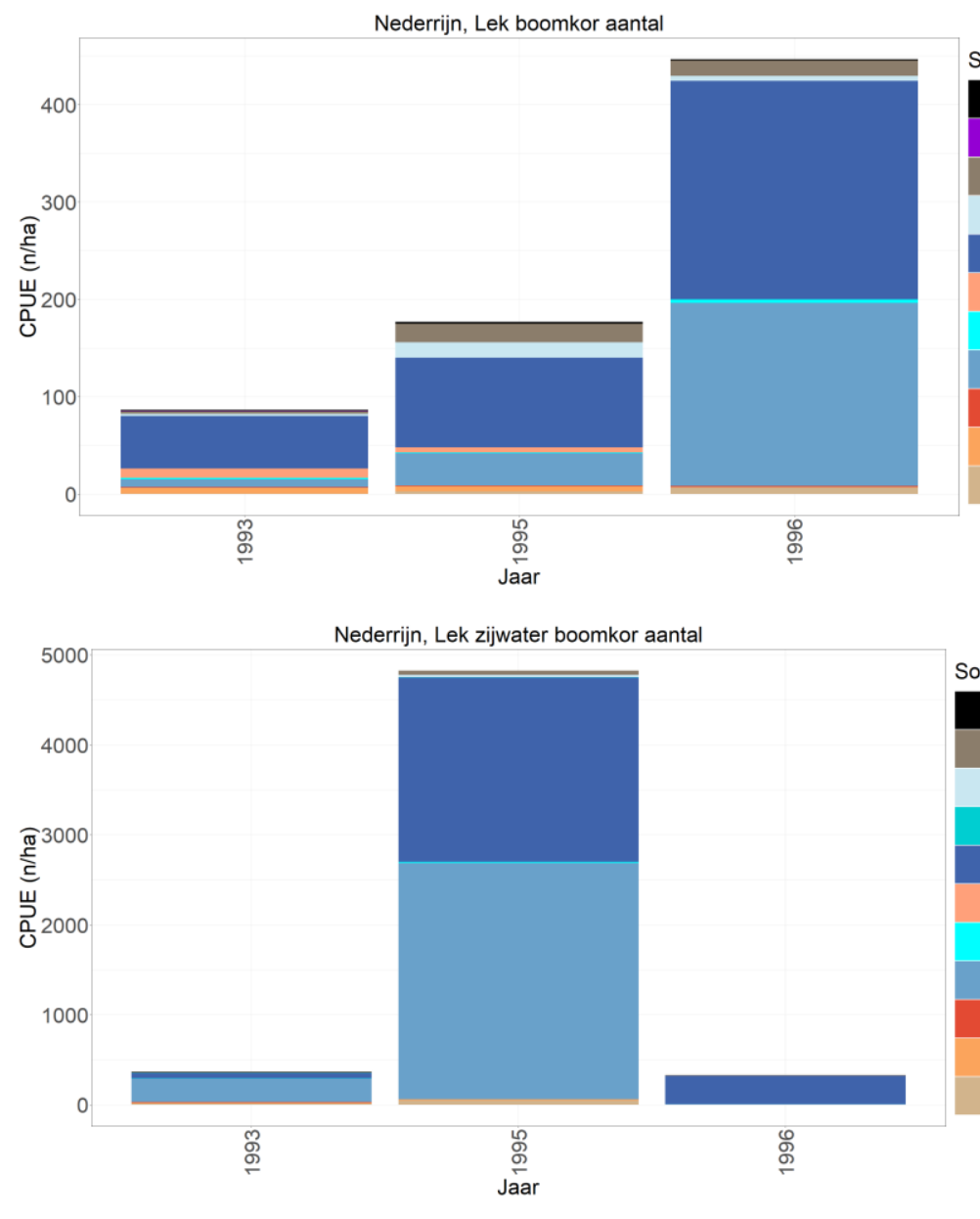
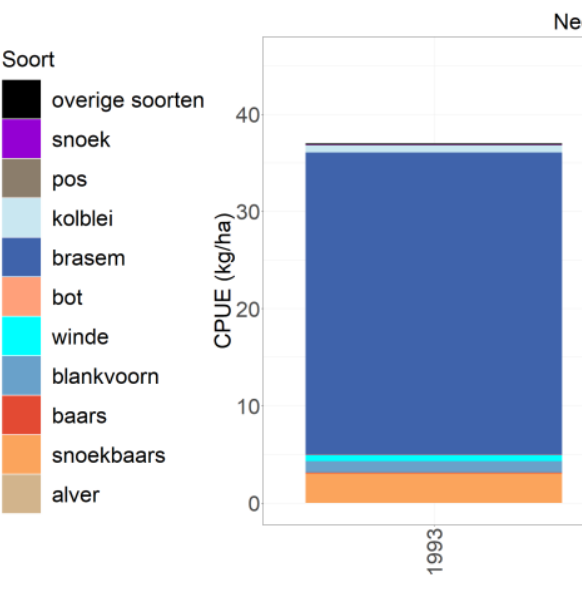

derrijn, Lek boomkor biomass
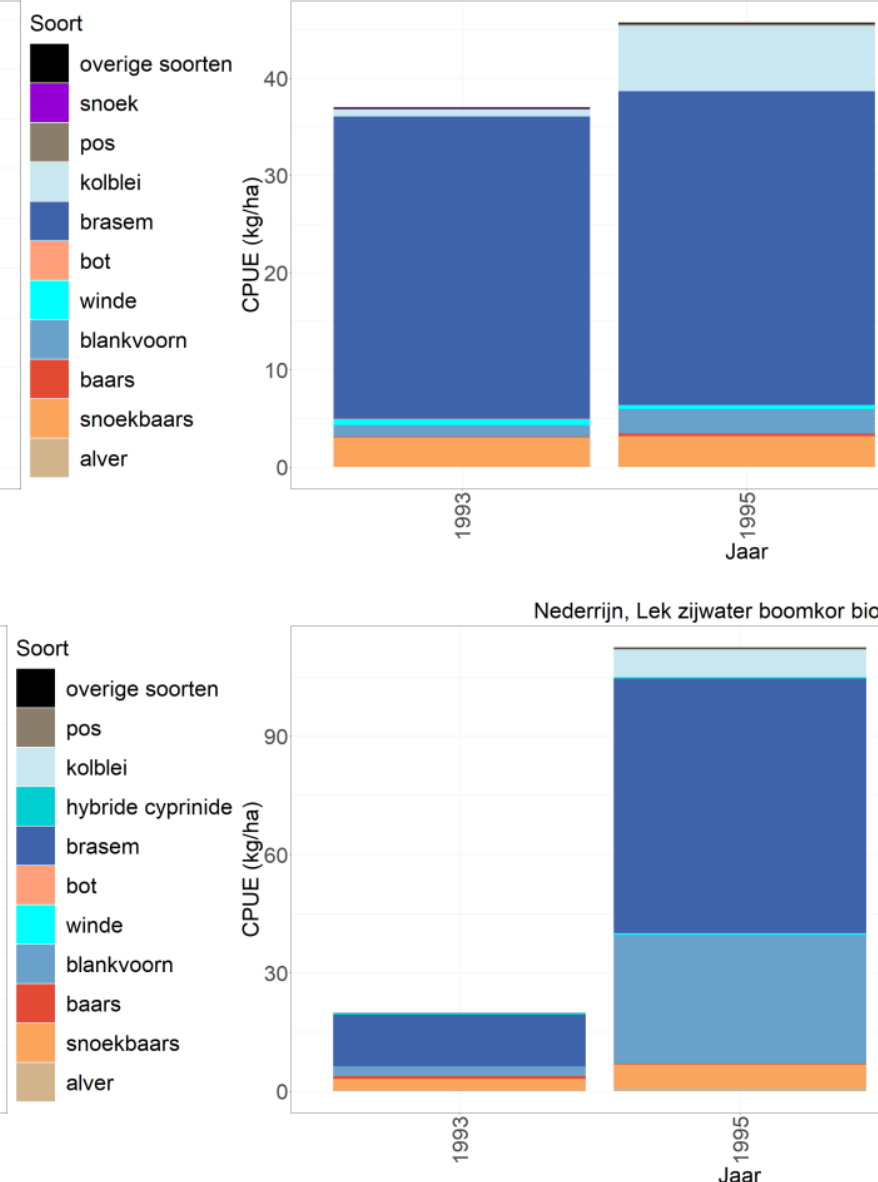
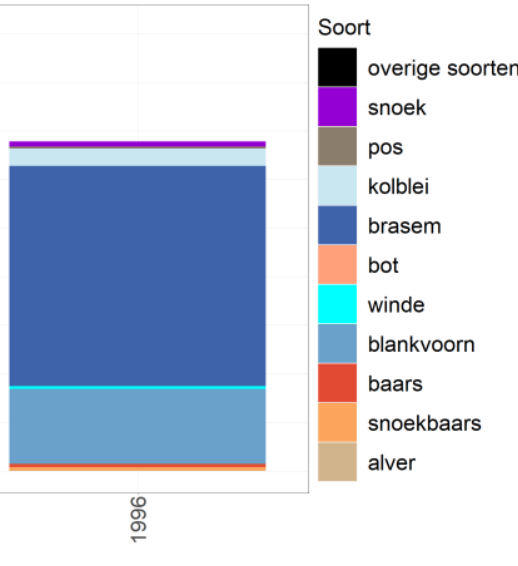

Nederrijn, Lek zijwater boomkor biomassa

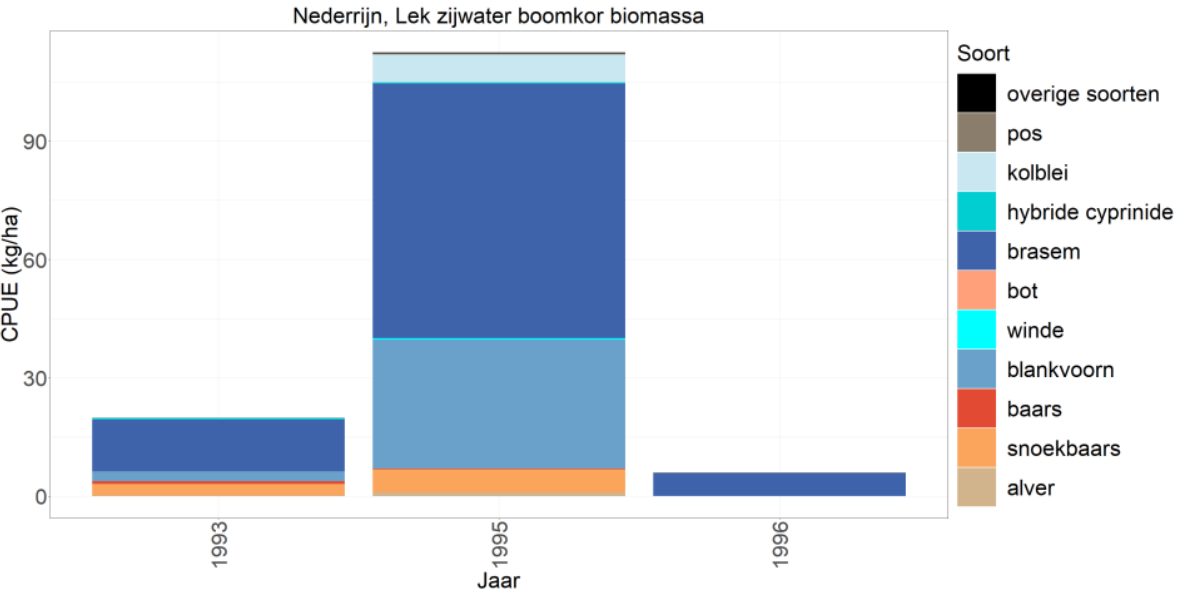

Figuur 7.12 Gemiddelde CPUE van de tien meest algemene soorten en overige soorten in het open water, langs de oever en in het zijwater ( $\mathrm{n} / \mathrm{ha}-\mathrm{kg} / \mathrm{ha}$ bevist oppervlak) gevangen met een boomkor in de Nederrijn \& Lek tijdens de actieve monitoring van 1992-1996. De Nederrijn \& Lek omvat de rivier de Nederrijn en de Getijden Lek en de rivier de Lek in 1993 en 1995, gegevens uit 1996 omvatten alleen de Bovenloop Nederrijn. 


\section{Rijn}
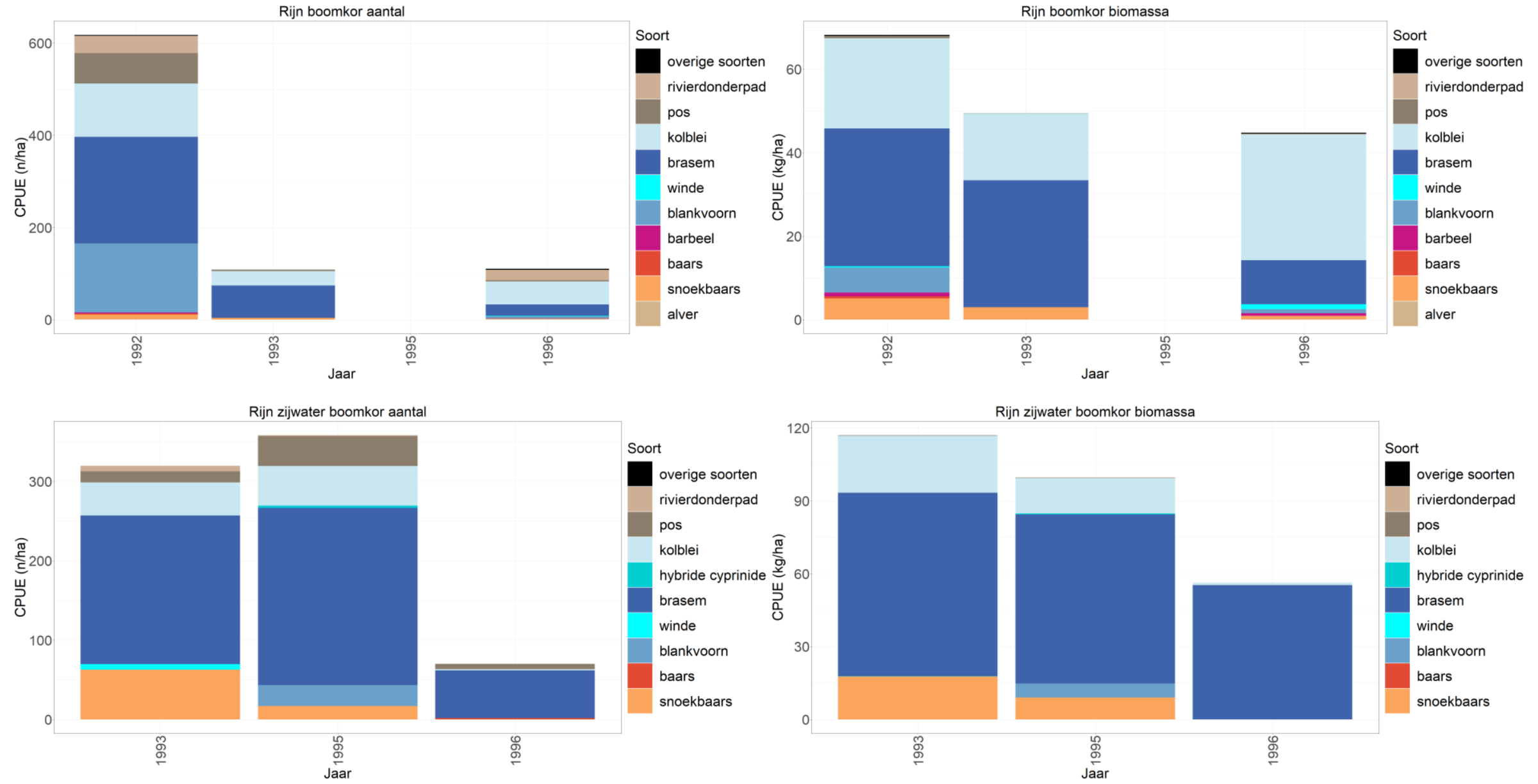

Figuur 7.13 Gemiddelde CPUE van de tien meest algemene soorten en overige soorten in het open water, langs de oever en in het zijwater (n/ha-kg/ha bevist oppervlak) gevangen met een boomkor in de Rijn tijdens de actieve monitoring van 1992-1996. De gegevens van de Rijn uit 1992 zijn afkomstig van de Rijn in Duitsland en in 1995 zijn alleen de zijwateren van de Rijn bemonsterd. 


\section{Waal}
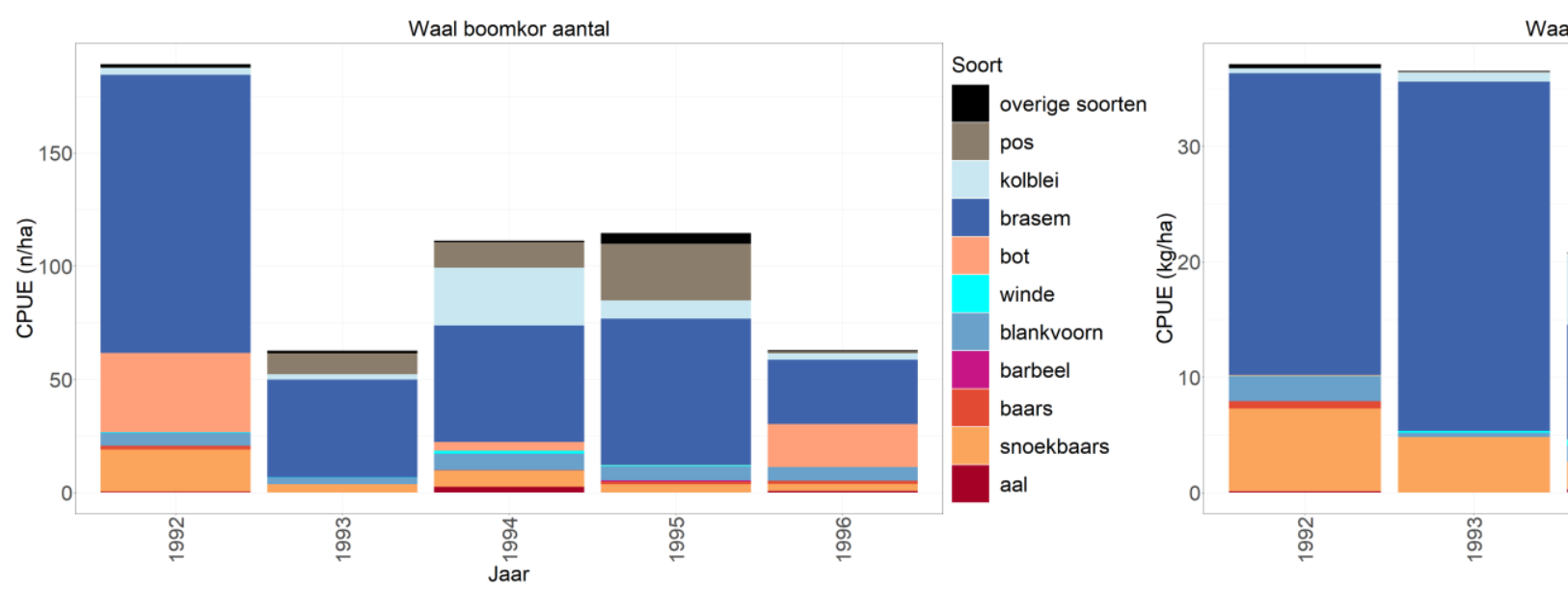

al boomkor biomassa
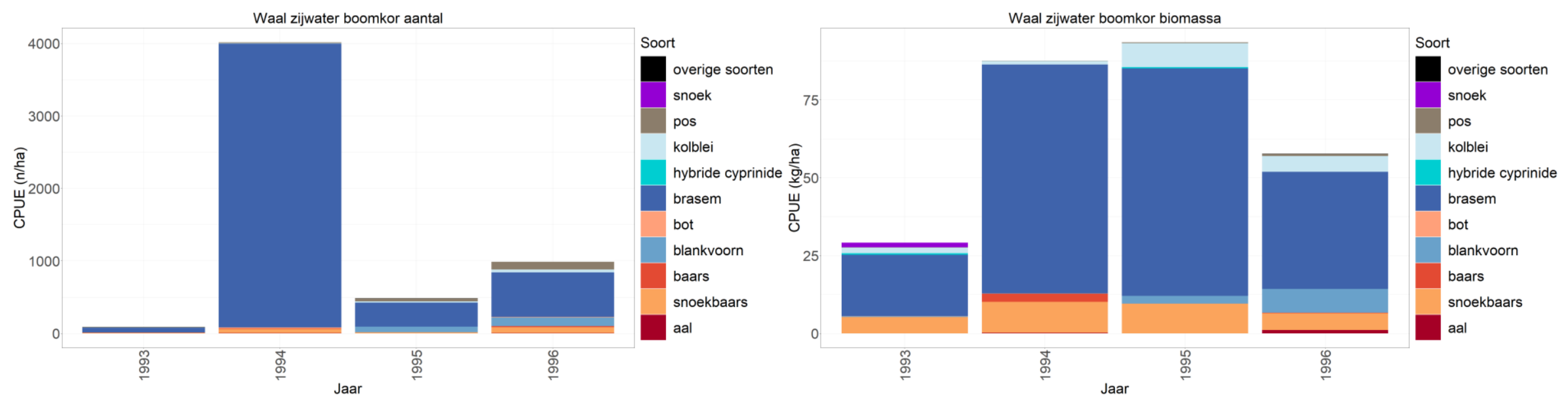

Figuur 7.14 Gemiddelde CPUE van de tien meest algemene soorten en overige soorten in het open water, langs de oever en in het zijwater (n/ha-kg/ha bevist oppervlak) gevangen met een boomkor in de Waal tijdens de actieve monitoring van 1992-1996. De Waal omvat de rivier de Waal, de boven Merwede en de beneden Merwede voor gegevens in 1993 en 1995, de Waal omvat alleen de Boven en Beneden Merwede in 1992 en 1994 , en in 1996 omvat de Waal alleen de Bovenloop Waal. In 1992 zijn de zijwateren niet bemonsterd. 


\section{Dordtsche Biesbosch}

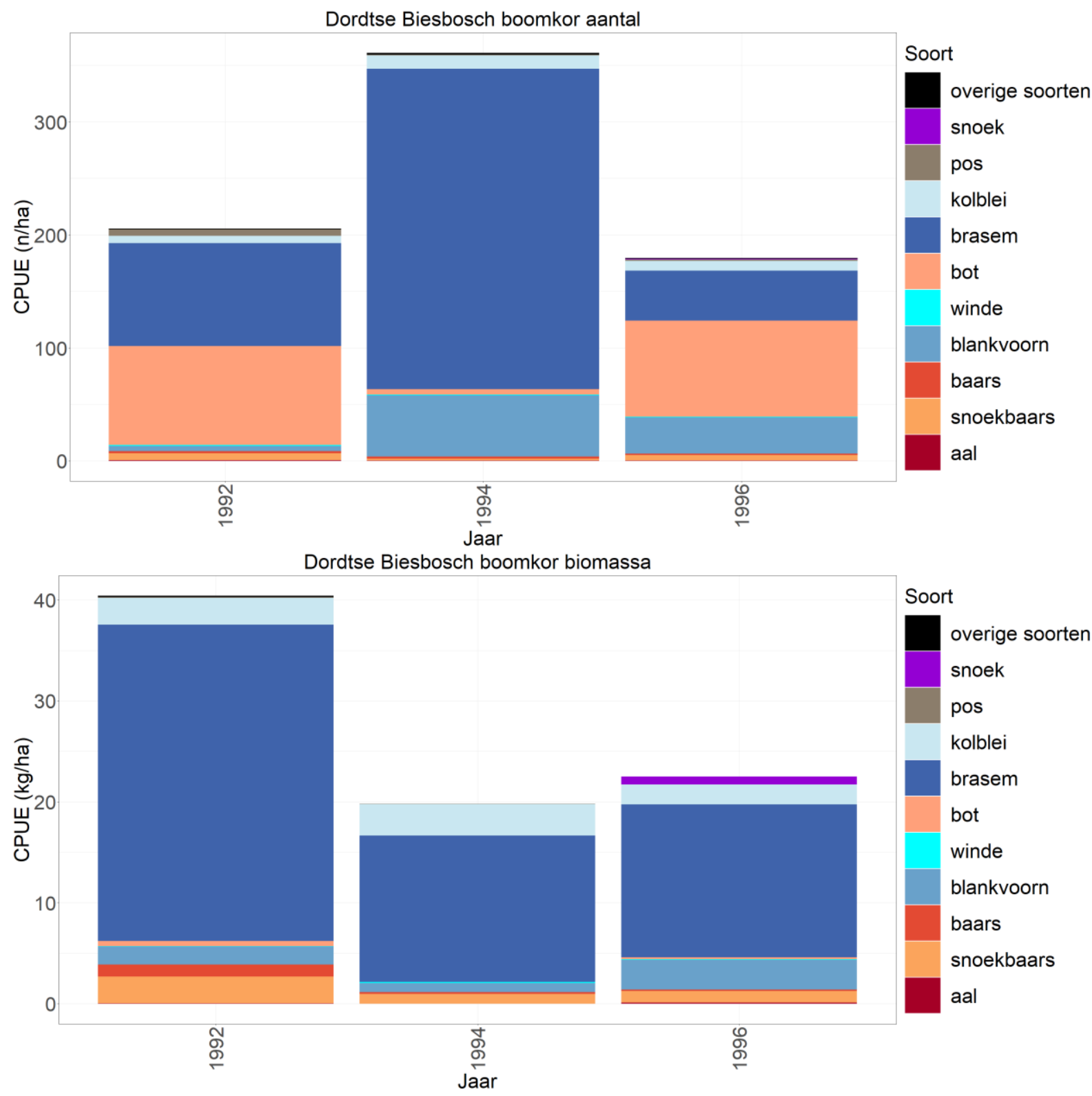

Figuur 7.15 Gemiddelde CPUE van de tien meest algemene soorten en overige soorten in het open water en langs de oever ( $\mathrm{n} / \mathrm{ha}-\mathrm{kg} / \mathrm{ha}$ bevist oppervlak) gevangen met een boomkor in de Dordtsche Biesbosch tijdens de actieve monitoring van 1992-1996. De Dordtsche Biesbosch omvat de rivier de Nieuwe Merwede. 


\section{Brabantse Biesbosch}

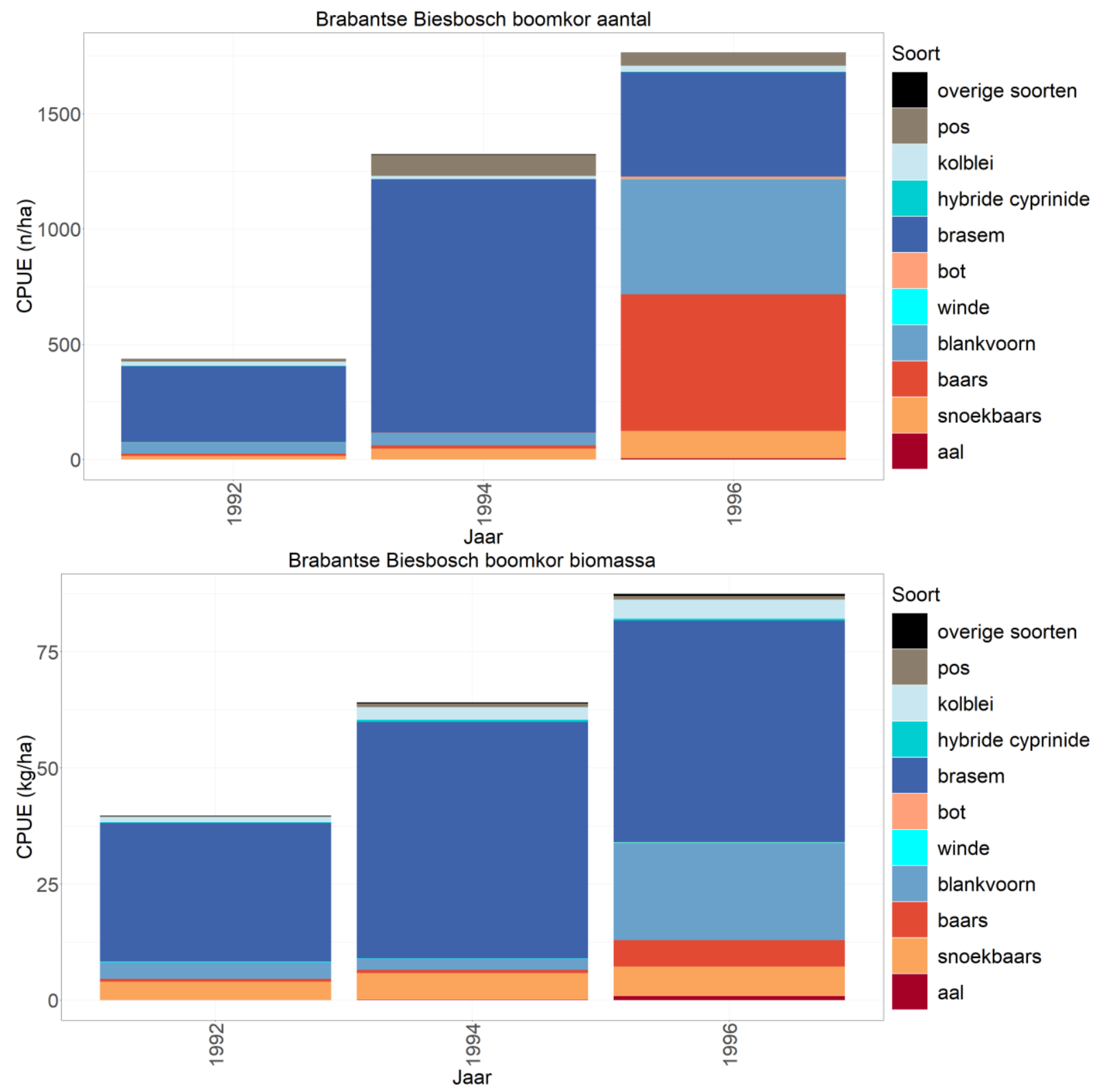

Figuur 7.16 Gemiddelde CPUE van de tien meest algemene soorten en overige soorten in het open water en langs de oever ( $\mathrm{n} / \mathrm{ha}-\mathrm{kg} / \mathrm{ha}$ bevist oppervlak) gevangen met een boomkor in de Brabantse Biesbosch tijdens de actieve monitoring van 1992-1996. De Brabantse Biesbosch omvat de Biesbosch en de Amer in en 1992 en 1994 en alleen de Biesbosch in 1996. 


\section{Haringvliet-oost}

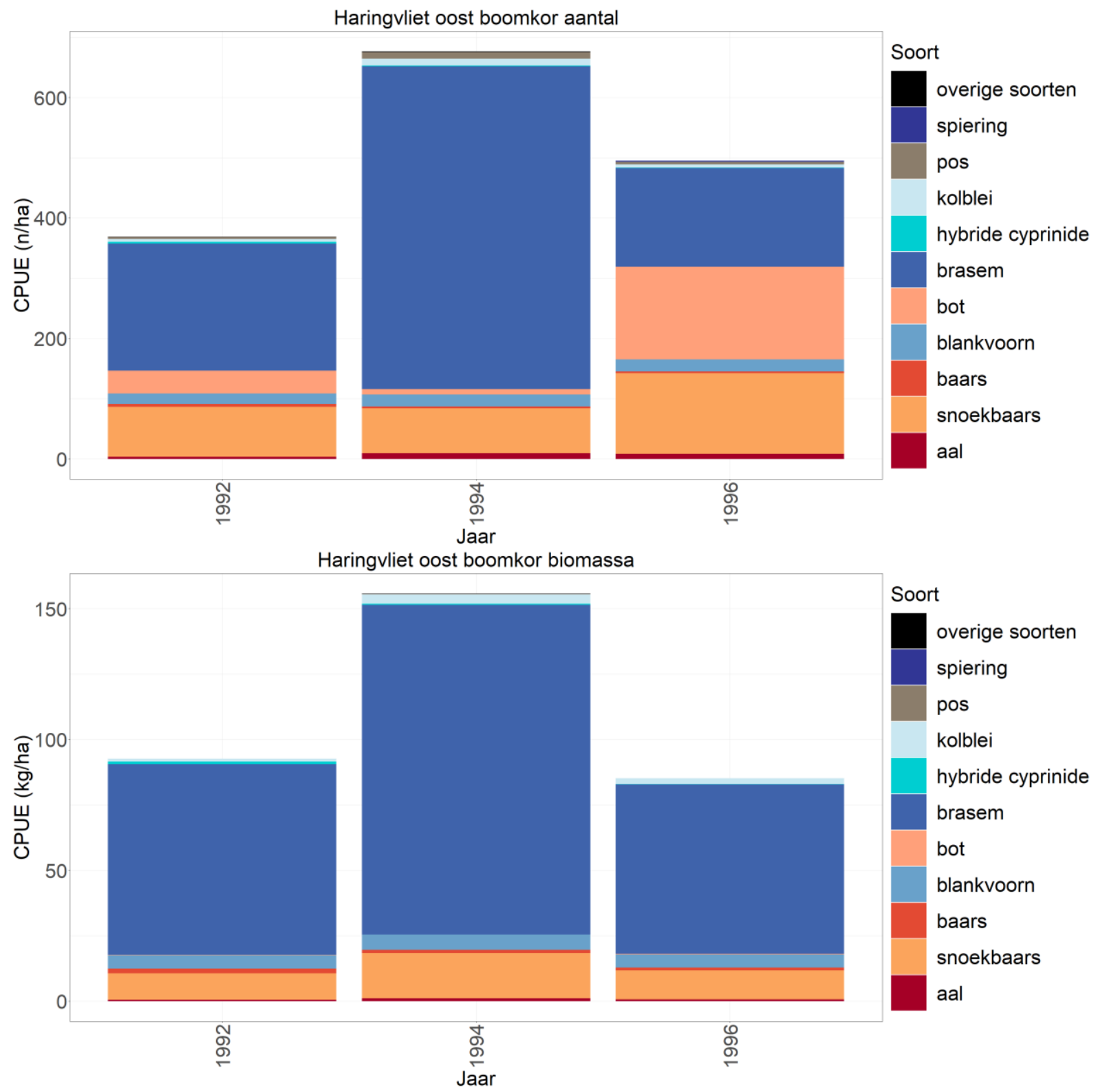

Figuur 7.17 Gemiddelde CPUE van de tien meest algemene soorten en overige soorten in het open water en langs de oever ( $\mathrm{n} / \mathrm{ha}-\mathrm{kg} / \mathrm{ha}$ bevist oppervlak) gevangen met een boomkor in het Haringvliet-oost tijdens de actieve monitoring van 1992-1996. Het Haringvliet-oost omvat het Hollandsch Diep. 


\section{Haringvliet-west}

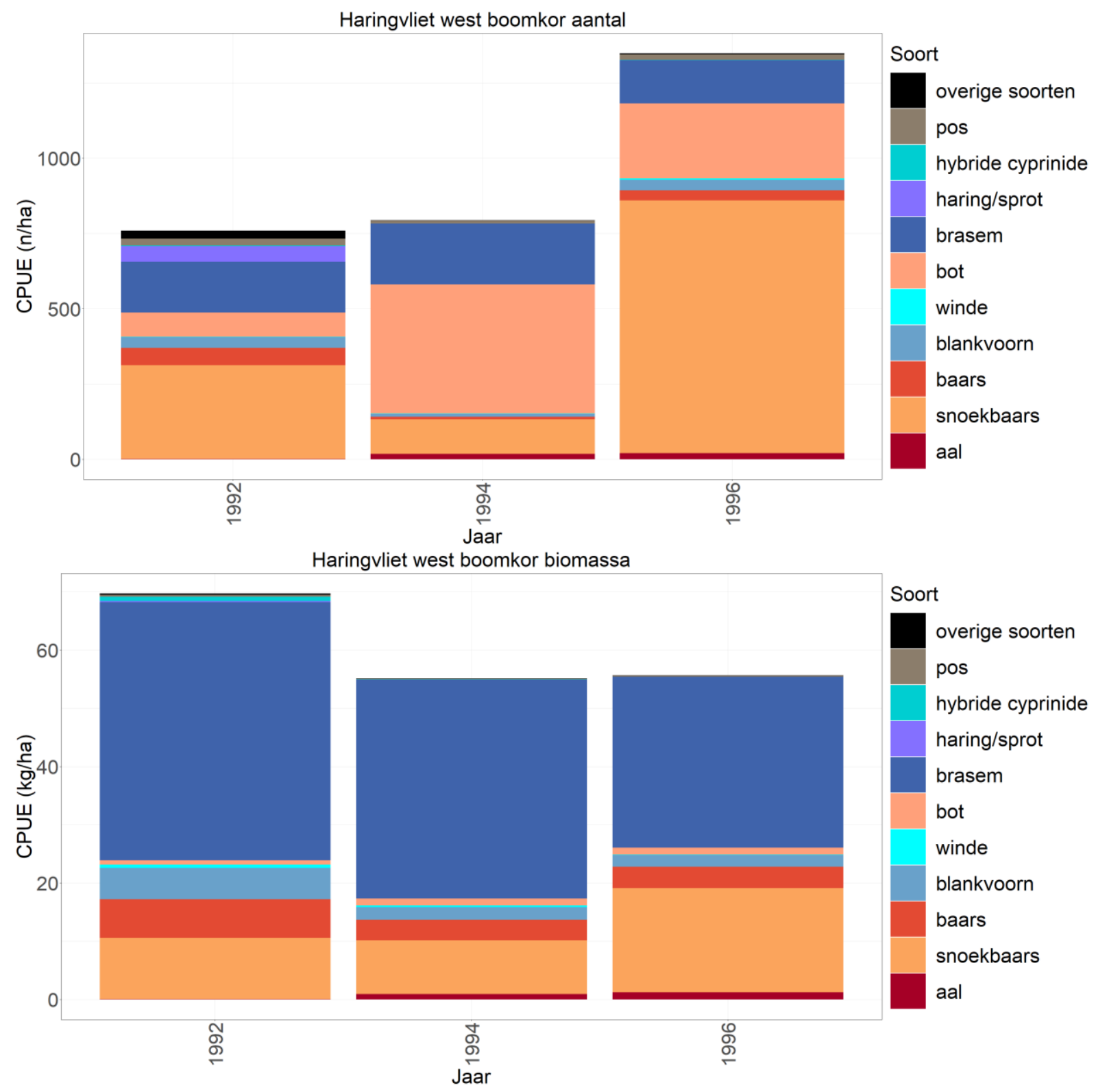

Figuur 7.18 Gemiddelde CPUE van de tien meest algemene soorten en overige soorten in het open water en langs de oever ( $\mathrm{n} / \mathrm{ha}-\mathrm{kg} / \mathrm{ha}$ bevist oppervlak) gevangen met een boomkor in het Haringvliet-west tijdens de actieve monitoring van 1992-1996. 


\section{Volkerak}
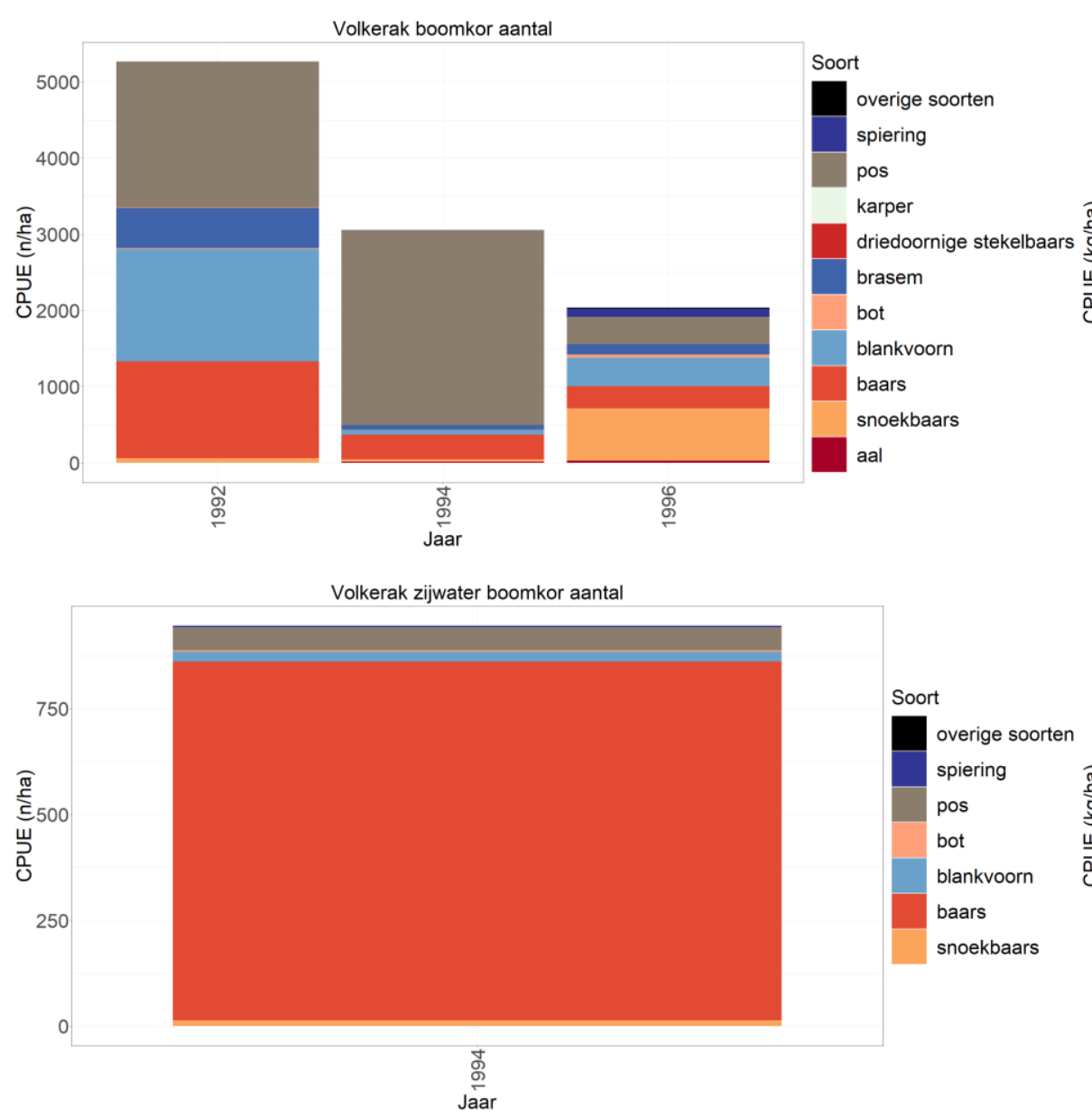

Volkerak boomkor biomassa

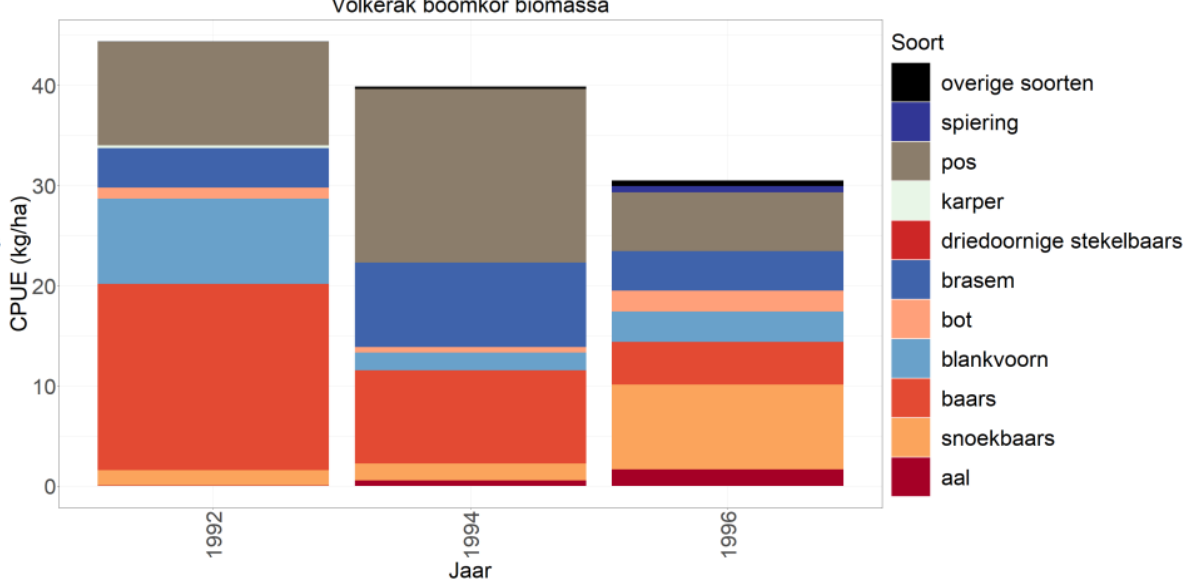

Volkerak zijwater boomkor biomassa

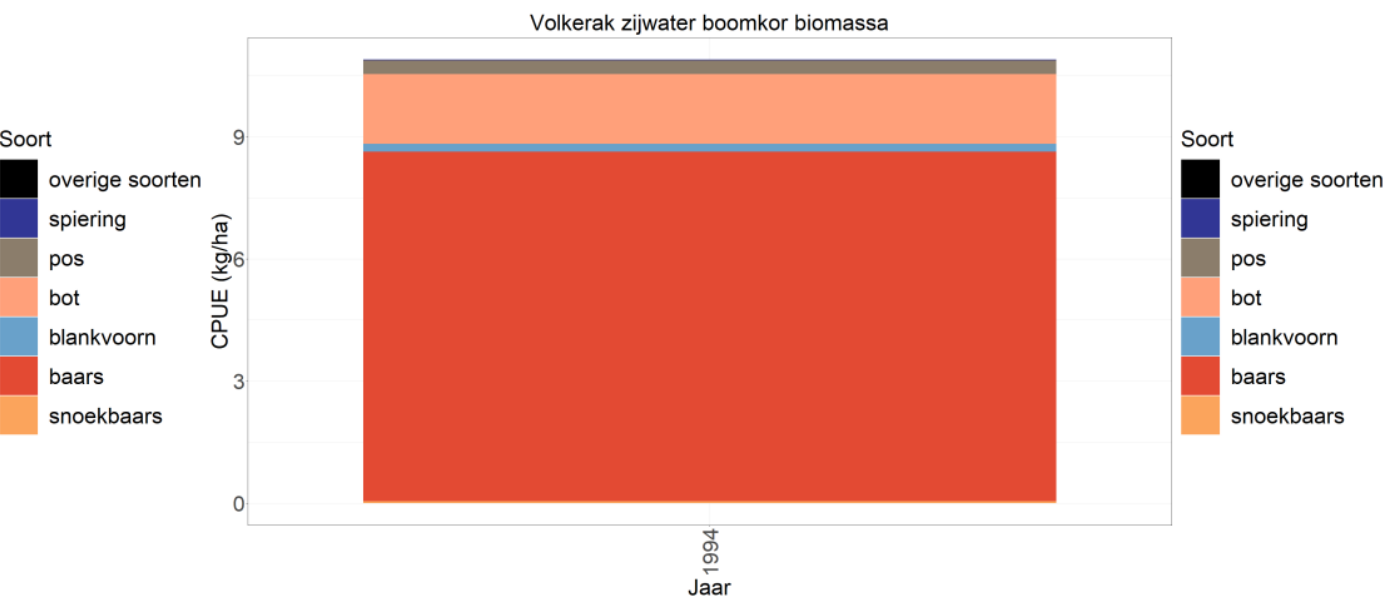

Figuur 7.19 Gemiddelde CPUE van de tien meest algemene soorten en overige soorten in het open water en in het zijwater ( $\mathrm{n} / \mathrm{ha-kg/ha} \mathrm{bevist} \mathrm{oppervlak)}$ gevangen met een boomkor in het Volkerak tijdens de actieve monitoring van 1992-1996. De vluchthaven bij de Dintel is het zijwater dat in 1994 met een enkele trek is bemonsterd. 


\section{Zoommeer}

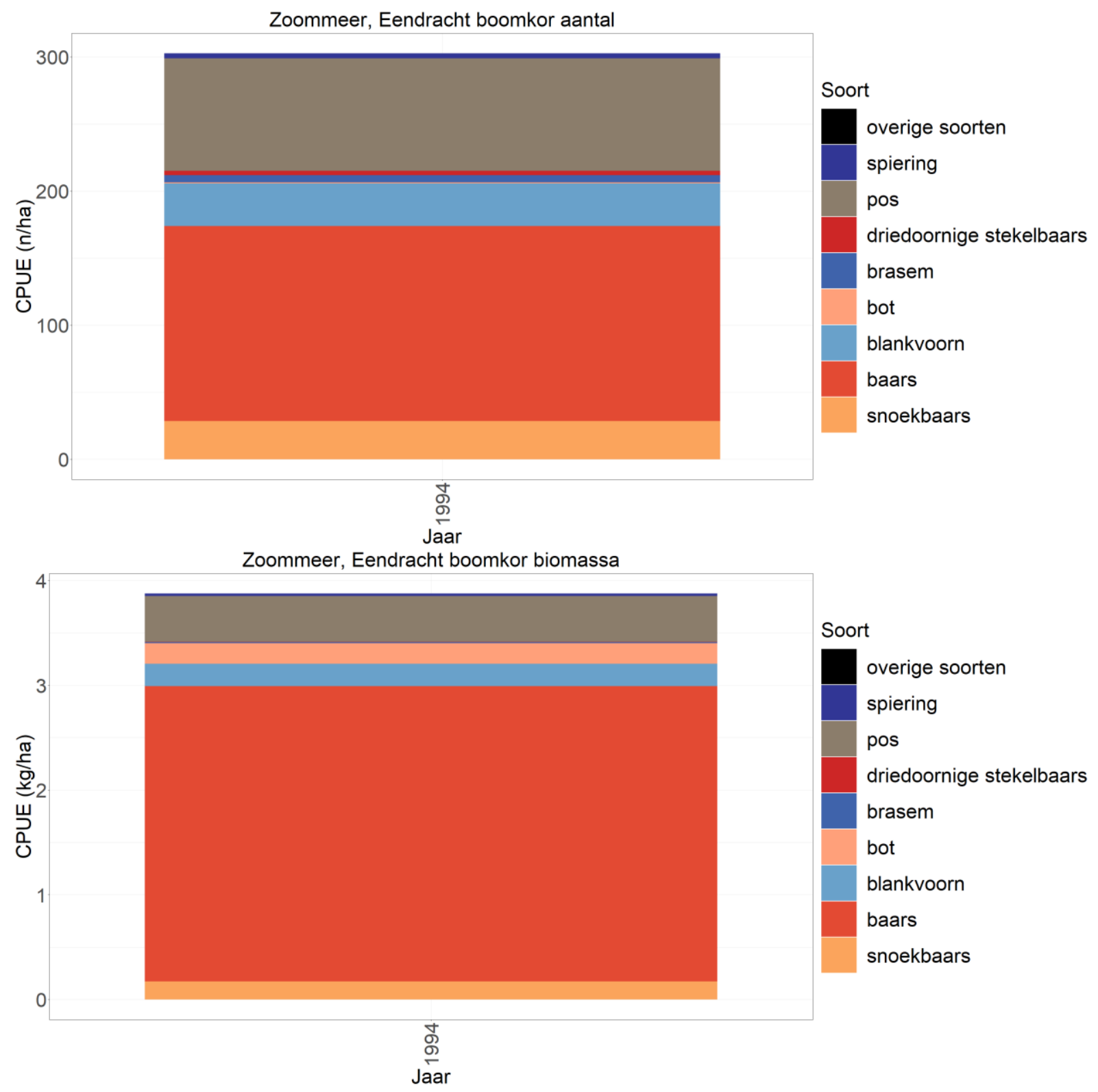

Figuur 7.20 Gemiddelde CPUE van de tien meest algemene soorten en overige soorten in het open water ( $\mathrm{n} / \mathrm{ha}-\mathrm{kg} / \mathrm{ha}$ bevist oppervlak) gevangen met een boomkor in het Zoommeer tijdens de actieve monitoring van 1992-1996. Het Zoommeer is alleen in 1994 bemonsterd, exclusief het Schelde Rijnlandkanaal, welke wel in de huidige bemonstering wordt meegenomen. 


\section{Amsterdam-Rijnkanaal}

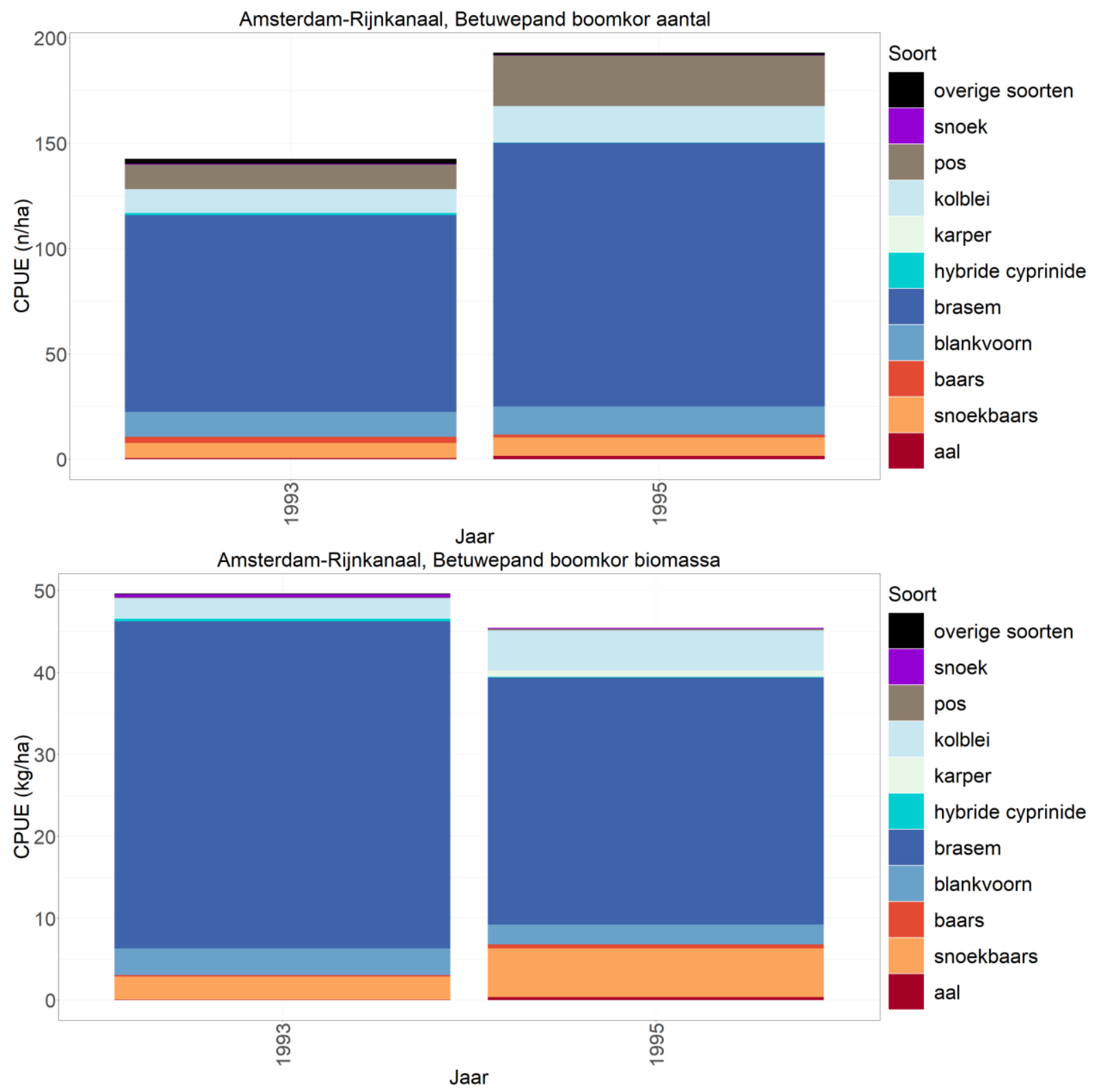

Figuur 7.21 Gemiddelde CPUE van de tien meest algemene soorten en overige soorten in het open water en langs de oever ( $\mathrm{n} / \mathrm{ha}-\mathrm{kg} / \mathrm{ha}$ bevist oppervlak) gevangen met een boomkor in het AmsterdamRijnkanaal tijdens de actieve monitoring van 1992-1996. 


\section{Bijlage 10 Benedenloop Gelderse IJssel hoofdstroom}

Tabel 1. Soortensamenstelling in percentages op basis van aantal in boomkorvangsten in de hoofdstroom van de Benedenloop Gelderse IJssel per 5-jarige periode. De groepering geeft de ecologische indeling aan de hand van Noble et al. (2007) aan. Het cumulatief percentage geeft aan hoeveel de soorten over de gehele periode voorkomen op basis van de gesommeerde CPUE op basis van het aantal. Nulpercentages zijn naar beneden afgeronde waarden, * = exoot.

\begin{tabular}{|c|c|c|c|c|c|c|c|}
\hline Soort & Groepering & $\begin{array}{l}\text { Cumulatief } \\
\text { percentage }\end{array}$ & $\begin{array}{r}1997- \\
1999\end{array}$ & $\begin{array}{r}2000- \\
2004\end{array}$ & $\begin{array}{r}2005- \\
2009\end{array}$ & $\begin{array}{r}2010- \\
2014\end{array}$ & $\begin{array}{r}2015- \\
2019\end{array}$ \\
\hline spiering & Eurytoop (Pelagisch) & 90.6 & 96.8 & 64.08 & 37.09 & 36.84 & 71.7 \\
\hline pos & Eurytoop (Bentisch) & 94.95 & 1.89 & 20.97 & 30.19 & 15.22 & 4.61 \\
\hline brasem & Eurytoop (Bentisch) & 97.11 & 0.47 & 6.52 & 14.07 & 10.76 & 12.39 \\
\hline blankvoorn & Eurytoop (Pelagisch) & 97.97 & 0.19 & 3.1 & 6.75 & 14.14 & 2.53 \\
\hline kolblei & Eurytoop (Bentisch) & 98.76 & 0.36 & 2.45 & 5.16 & 3.21 & 2.2 \\
\hline snoekbaars & Eurytoop (Bentisch) & 99.17 & 0.08 & 0.61 & 1.1 & 0.94 & 4.11 \\
\hline riviergrondel & Rheofiel (Bentisch) & 99.31 & 0.03 & 0.81 & 1.93 & 0.09 & 0.04 \\
\hline rivierdonderpad & Rheofiel (Bentisch) & 99.43 & 0.05 & 0.15 & 0.51 & 6.17 & \\
\hline bot & Limnofiel (Bentisch) & 99.54 & 0.06 & 0.55 & 0.19 & 0.92 & 0.06 \\
\hline baars & Eurytoop (Pelagisch) & 99.64 & 0.04 & 0.04 & 1.29 & 0.2 & 0.42 \\
\hline winde & Rheofiel (Pelagisch) & 99.72 & 0.01 & 0.34 & 0.64 & 1.51 & 0.36 \\
\hline zwartbekgrondel* & Eurytoop (Bentisch) & 99.77 & - & - & - & 2.33 & 0.47 \\
\hline alver & Eurytoop (Pelagisch) & 99.82 & - & 0.22 & 0.38 & 1.22 & 0.12 \\
\hline witvinriviergrondel* & Eurytoop (Bentisch) & 99.86 & - & - & 0.23 & 2.93 & 0.11 \\
\hline pontische stroomgrondel* & Eurytoop (Bentisch) & 99.89 & - & - & - & 1.12 & 0.28 \\
\hline driedoornige stekelbaars & Eurytoop (Pelagisch) & 99.91 & 0.01 & 0.01 & 0.05 & 0.27 & 0.08 \\
\hline sneep & Rheofiel (Bentisch) & 99.92 & - & 0.02 & 0.06 & 0.45 & 0.16 \\
\hline hybride cyprinide & Eurytoop (Bentisch) & 99.94 & 0.02 & 0.03 & 0.03 & - & 0.01 \\
\hline barbeel & Rheofiel (Bentisch) & 99.95 & 0.01 & 0.01 & 0.07 & 0.11 & 0.01 \\
\hline aal & Eurytoop (Bentisch) & 99.96 & 0 & 0.07 & 0.03 & 0.11 & 0.01 \\
\hline donaubrasem* & Eurytoop (Bentisch) & 99.97 & - & - & - & - & 0.12 \\
\hline kesslers grondel* & Eurytoop (Bentisch) & 99.97 & - & - & - & 0.45 & 0.02 \\
\hline noordzeehouting & Limnofiel (Pelagisch) & 99.98 & - & - & 0.03 & 0.19 & 0.05 \\
\hline marmergrondel* & Eurytoop (Bentisch) & 99.98 & - & - & - & 0.21 & 0.05 \\
\hline roofblei* & Rheofiel (Pelagisch) & 99.99 & 0 & - & - & 0.1 & 0.05 \\
\hline kleine modderkruiper & Eurytoop (Bentisch) & 99.99 & - & - & 0.03 & 0.21 & \\
\hline snoek & Eurytoop (Pelagisch) & 99.99 & - & - & 0.03 & - & 0.02 \\
\hline noordzeehouting/grote marene & Limnofiel (Pelagisch) & 99.99 & - & - & 0.05 & - & - \\
\hline tiendoornige stekelbaars & Limnofiel (Pelagisch) & 99.99 & - & - & 0.02 & 0.09 & - \\
\hline karper & Eurytoop (Bentisch) & 100 & - & - & 0.05 & - & - \\
\hline rivierprik & Rheofiel (Bentisch) & 100 & - & - & 0.03 & - & - \\
\hline giebel & Eurytoop (Bentisch) & 100 & - & 0.01 & - & - & - \\
\hline zeeprik & Rheofiel (Bentisch) & 100 & - & - & - & 0.1 & \\
\hline kleine marene* & Limnofiel (Pelagisch) & 100 & - & - & - & - & 0.01 \\
\hline bittervoorn & Limnofiel (Pelagisch) & 100 & - & - & - & 0.1 & \\
\hline
\end{tabular}


Tabel 2. Soortensamenstelling in percentages op basis van biomassa in boomkorvangsten in de hoofdstroom van de Benedenloop Gelderse IJssel per 5-jarige periode. De groepering geeft de ecologische indeling aan de hand van Noble et al. (2007) aan. Het cumulatief percentage geeft aan hoeveel de soorten over de gehele periode voorkomen op basis van de gesommeerde CPUE op basis van de biomassa. Nul-percentages zijn naar beneden afgeronde waarden, $*=$ exoot.

\begin{tabular}{|c|c|c|c|c|c|c|c|}
\hline Soort & Groepering & $\begin{array}{l}\text { Cumulatief } \\
\text { percentage }\end{array}$ & $\begin{array}{r}1997- \\
1999 \\
\end{array}$ & $\begin{array}{r}2000- \\
2004 \\
\end{array}$ & $\begin{array}{r}2005- \\
2009 \\
\end{array}$ & $\begin{array}{r}2010- \\
2014 \\
\end{array}$ & $\begin{array}{r}2015- \\
2019 \\
\end{array}$ \\
\hline brasem & Eurytoop (Bentisch) & 61.94 & 48.08 & 73.21 & 79.81 & 67.27 & 46.49 \\
\hline spiering & Eurytoop (Pelagisch) & 72.5 & 26.88 & 3.77 & 1.01 & 1.23 & 6.8 \\
\hline snoekbaars & Eurytoop (Bentisch) & 83.02 & 7.09 & 8.61 & 6.15 & 8.7 & 25.16 \\
\hline kolblei & Eurytoop (Bentisch) & 89.2 & 9.34 & 4.51 & 3.8 & 3.13 & 6.98 \\
\hline blankvoorn & Eurytoop (Pelagisch) & 94.17 & 4.02 & 5.32 & 4.4 & 7.9 & 6.04 \\
\hline winde & Rheofiel (Pelagisch) & 95.73 & 0.15 & 1.18 & 1.65 & 6.6 & 2.41 \\
\hline pos & Eurytoop (Bentisch) & 97.21 & 1.91 & 2.25 & 1.15 & 0.67 & 0.77 \\
\hline hybride cyprinide & Eurytoop (Bentisch) & 97.68 & 1.43 & 0.09 & 0 & - & 0.02 \\
\hline karper & Eurytoop (Bentisch) & 98.09 & - & - & 1.55 & - & \\
\hline bot & Limnofiel (Bentisch) & 98.48 & 0.71 & 0.66 & 0.08 & 0.44 & 0.07 \\
\hline snoek & Eurytoop (Pelagisch) & 98.85 & - & - & 0.01 & - & 1.99 \\
\hline barbeel & Rheofiel (Bentisch) & 99.21 & 0.1 & 0 & 0.09 & 2.03 & 0.99 \\
\hline baars & Eurytoop (Pelagisch) & 99.38 & 0.19 & 0.04 & 0.1 & 0.01 & 0.42 \\
\hline noordzeehouting & Limnofiel (Pelagisch) & 99.55 & - & - & 0.03 & 0.94 & 0.54 \\
\hline roofblei* & Rheofiel (Pelagisch) & 99.7 & 0.03 & - & - & 0.08 & 0.74 \\
\hline donaubrasem* & Eurytoop (Bentisch) & 99.76 & - & - & - & - & 0.31 \\
\hline aal & Eurytoop (Bentisch) & 99.8 & 0.02 & 0.15 & 0.04 & 0.03 & 0 \\
\hline riviergrondel & Rheofiel (Bentisch) & 99.84 & 0.02 & 0.11 & 0.05 & 0 & 0 \\
\hline zeeprik & Rheofiel (Bentisch) & 99.87 & - & - & - & 0.5 & \\
\hline alver & Eurytoop (Pelagisch) & 99.9 & - & 0.07 & 0.03 & 0.09 & 0.02 \\
\hline sneep & Rheofiel (Bentisch) & 99.93 & - & 0 & 0.01 & 0.04 & 0.13 \\
\hline rivierdonderpad & Rheofiel (Bentisch) & 99.95 & 0.03 & 0.01 & 0.01 & 0.09 & \\
\hline zwartbekgrondel* & Eurytoop (Bentisch) & 99.97 & - & - & - & 0.05 & 0.05 \\
\hline pontische stroomgrondel* & Eurytoop (Bentisch) & 99.98 & - & - & - & 0.04 & 0.03 \\
\hline witvinriviergrondel* & Eurytoop (Bentisch) & 99.98 & - & - & 0.01 & 0.08 & 0.01 \\
\hline kesslers grondel* & Eurytoop (Bentisch) & 99.99 & - & - & - & 0.06 & 0.01 \\
\hline noordzeehouting/grote marene & Limnofiel (Pelagisch) & 99.99 & - & - & 0.02 & - & \\
\hline kleine marene* & Limnofiel (Pelagisch) & 99.99 & - & - & - & - & 0.01 \\
\hline giebel & Eurytoop (Bentisch) & 100 & - & 0.01 & - & - & \\
\hline driedoornige stekelbaars & Eurytoop (Pelagisch) & 100 & 0 & 0 & 0 & 0 & $\underline{0}$ \\
\hline kleine modderkruiper & Eurytoop (Bentisch) & 100 & - & - & 0 & 0.01 & \\
\hline marmergrondel* & Eurytoop (Bentisch) & 100 & - & - & - & 0 & 0 \\
\hline rivierprik & Rheofiel (Bentisch) & 100 & - & - & 0 & - & \\
\hline bittervoorn & Limnofiel (Pelagisch) & 100 & - & - & - & 0 & \\
\hline tiendoornige stekelbaars & Limnofiel (Pelagisch) & 100 & - & - & 0 & 0 & \\
\hline
\end{tabular}


Tabel 3. Soortensamenstelling in percentages op basis van aantal in schepnetvangsten in de hoofdstroom van de Benedenloop Gelderse IJssel per 5-jarige periode. De groepering geeft de ecologische indeling aan de hand van Noble et al. (2007) aan. Het cumulatief percentage geeft aan hoeveel de soorten over de gehele periode voorkomen op basis van de gesommeerde CPUE op basis van het aantal. Nul-percentages zijn naar beneden afgeronde waarden, $*=$ exoot.

\begin{tabular}{|c|c|c|c|c|c|c|c|}
\hline Soort & Groepering & $\begin{array}{l}\text { Cumulatief } \\
\text { percentage }\end{array}$ & $\begin{array}{r}1997- \\
1999\end{array}$ & $\begin{array}{r}2000- \\
2004\end{array}$ & $\begin{array}{r}2005- \\
2009\end{array}$ & $\begin{array}{r}2010- \\
2014\end{array}$ & $\begin{array}{r}2015- \\
2019 \\
\end{array}$ \\
\hline spiering & Eurytoop (Pelagisch) & 52.8 & 76.42 & 44.08 & 0.13 & 0.43 & 7.6 \\
\hline blankvoorn & Eurytoop (Pelagisch) & 78.48 & 14.21 & 30.59 & 60.17 & 40.55 & 40.36 \\
\hline winde & Rheofiel (Pelagisch) & 82.66 & 1.77 & 5.29 & 8.98 & 7.29 & 8.69 \\
\hline baars & Eurytoop (Pelagisch) & 86.28 & 1.76 & 3.61 & 9.51 & 9.77 & 9.23 \\
\hline pos & Eurytoop (Bentisch) & 89.8 & 0.77 & 6.74 & 5.23 & 4.72 & 0.78 \\
\hline brasem & Eurytoop (Bentisch) & 91.76 & 1.31 & 2.75 & 1.69 & 3.45 & 1.21 \\
\hline aal & Eurytoop (Bentisch) & 93.69 & 0.62 & 1.42 & 5.74 & 6.8 & 8.99 \\
\hline kolblei & Eurytoop (Bentisch) & 95.22 & 1.31 & 2.02 & 0.13 & - & 1.7 \\
\hline alver & Eurytoop (Pelagisch) & 96.45 & 0.67 & 0.86 & 2.66 & 1.23 & 6.08 \\
\hline zwartbekgrondel* & Eurytoop (Bentisch) & 97.01 & - & - & - & 5.88 & 6.08 \\
\hline snoekbaars & Eurytoop (Bentisch) & 97.54 & 0.33 & 0.57 & 0.97 & - & 1.61 \\
\hline snoek & Eurytoop (Pelagisch) & 98 & 0.28 & 0.45 & 0.15 & 1.55 & 1.59 \\
\hline driedoornige stekelbaars & Eurytoop (Pelagisch) & 98.42 & 0.33 & 0.14 & 0.35 & 3.74 & 1.54 \\
\hline karper & Eurytoop (Bentisch) & 98.68 & - & 0.43 & 1.29 & 0.61 & \\
\hline roofblei* & Rheofiel (Pelagisch) & 98.85 & 0.03 & 0.25 & 0.55 & - & 0.29 \\
\hline bittervoorn & Limnofiel (Pelagisch) & 98.99 & 0.02 & 0.04 & - & 4.3 & 0.29 \\
\hline pontische stroomgrondel* & Eurytoop (Bentisch) & 99.14 & - & - & - & 1.97 & 1.43 \\
\hline rietvoorn & Limnofiel (Pelagisch) & 99.26 & 0.02 & 0.28 & - & - & \\
\hline sneep & Rheofiel (Bentisch) & 99.36 & 0.02 & 0.03 & 0.72 & - & 0.52 \\
\hline kesslers grondel* & Eurytoop (Bentisch) & 99.44 & - & - & - & 3.62 & \\
\hline serpeling & Rheofiel (Pelagisch) & 99.52 & - & 0.14 & 0.32 & 0.37 & \\
\hline kopvoorn & Rheofiel (Pelagisch) & 99.6 & - & 0.12 & - & 1.1 & \\
\hline bot & Limnofiel (Bentisch) & 99.66 & 0.01 & 0.03 & 0.59 & 0.64 & \\
\hline marmergrondel* & Eurytoop (Bentisch) & 99.72 & - & - & - & 1.28 & 0.41 \\
\hline kleine modderkruiper & Eurytoop (Bentisch) & 99.78 & - & - & - & 0.34 & 0.69 \\
\hline hybride cyprinide & Eurytoop (Bentisch) & 99.83 & 0.02 & 0.03 & 0.15 & - & 0.29 \\
\hline barbeel & Rheofiel (Bentisch) & 99.86 & - & 0.07 & - & 0.36 & \\
\hline zeelt & Limnofiel (Bentisch) & 99.89 & 0.04 & 0.03 & - & - & \\
\hline tiendoornige stekelbaars & Limnofiel (Pelagisch) & 99.92 & 0.02 & - & - & - & 0.32 \\
\hline riviergrondel & Rheofiel (Bentisch) & 99.95 & 0.02 & - & 0.25 & - & \\
\hline giebel & Eurytoop (Bentisch) & 99.97 & - & 0.03 & 0.25 & - & \\
\hline blauwband* & Limnofiel (Pelagisch) & 99.99 & - & - & - & - & 0.3 \\
\hline witvinriviergrondel & Eurytoop (Bentisch) & 100 & - & - & 0.17 & - & \\
\hline
\end{tabular}


Tabel 4. Soortensamenstelling in percentages op basis van biomassa in schepnetvangsten in de hoofdstroom van de Benedenloop Gelderse IJssel per 5-jarige periode. De groepering geeft de ecologische indeling aan de hand van Noble et al. (2007) aan. Het cumulatief percentage geeft aan hoeveel de soorten over de gehele periode voorkomen op basis van de gesommeerde CPUE op basis van de biomassa. Nul-percentages zijn naar beneden afgeronde waarden, $*=$ exoot.

\begin{tabular}{|c|c|c|c|c|c|c|c|}
\hline Soort & Groepering & $\begin{array}{l}\text { Cumulatief } \\
\text { percentage }\end{array}$ & $\begin{array}{r}1997- \\
1999\end{array}$ & $\begin{array}{r}2000- \\
2004 \\
\end{array}$ & $\begin{array}{r}2005- \\
2009 \\
\end{array}$ & $\begin{array}{r}2010- \\
2014 \\
\end{array}$ & $\begin{array}{r}2015- \\
2019 \\
\end{array}$ \\
\hline karper & Eurytoop (Bentisch) & 31.52 & - & 40.29 & 75.51 & 32.28 & \\
\hline brasem & Eurytoop (Bentisch) & 52.38 & 37.14 & 19.14 & 3.07 & 27.09 & 7.79 \\
\hline snoek & Eurytoop (Pelagisch) & 70.12 & 23.17 & 15.92 & 0.17 & 2.21 & 55.86 \\
\hline winde & Rheofiel (Pelagisch) & 78.34 & 10.61 & 5.01 & 7.2 & 27.77 & 2.84 \\
\hline blankvoorn & Eurytoop (Pelagisch) & 85.8 & 14.88 & 6.12 & 3.56 & 1.33 & 4.9 \\
\hline aal & Eurytoop (Bentisch) & 91.81 & 2.63 & 3.98 & 8.2 & 5.58 & 23.2 \\
\hline kolblei & Eurytoop (Bentisch) & 94.62 & 3.37 & 4.24 & 0.01 & - & 0.98 \\
\hline spiering & Eurytoop (Pelagisch) & 96.86 & 5.44 & 1.92 & 0 & 0.01 & 0.41 \\
\hline baars & Eurytoop (Pelagisch) & 97.93 & 0.84 & 0.98 & 1.32 & 0.56 & 2.14 \\
\hline snoekbaars & Eurytoop (Bentisch) & 98.83 & 1.03 & 1.27 & 0.33 & - & 0.34 \\
\hline pos & Eurytoop (Bentisch) & 99.27 & 0.2 & 0.77 & 0.17 & 0.2 & 0.1 \\
\hline zeelt & Limnofiel (Bentisch) & 99.39 & 0.5 & 0 & - & - & \\
\hline bot & Limnofiel (Bentisch) & 99.51 & 0.01 & 0.07 & 0.17 & 0.85 & \\
\hline alver & Eurytoop (Pelagisch) & 99.61 & 0.09 & 0.04 & 0.16 & 0.05 & 0.4 \\
\hline zwartbekgrondel* & Eurytoop (Bentisch) & 99.69 & - & - & - & 0.25 & 0.65 \\
\hline rietvoorn & Limnofiel (Pelagisch) & 99.75 & 0.02 & 0.13 & - & - & \\
\hline kopvoorn & Rheofiel (Pelagisch) & 99.81 & - & 0.01 & - & 0.74 & \\
\hline kesslers grondel* & Eurytoop (Bentisch) & 99.85 & - & - & - & 0.57 & \\
\hline serpeling & Rheofiel (Pelagisch) & 99.89 & - & 0.02 & 0.02 & 0.37 & \\
\hline roofblei* & Rheofiel (Pelagisch) & 99.92 & 0.01 & 0.05 & 0.03 & - & 0.03 \\
\hline pontische stroomgrondel* & Eurytoop (Bentisch) & 99.94 & - & - & - & 0.05 & 0.19 \\
\hline barbeel & Rheofiel (Bentisch) & 99.95 & - & 0.02 & - & 0.04 & \\
\hline sneep & Rheofiel (Bentisch) & 99.97 & 0 & 0 & 0.05 & - & 0.06 \\
\hline driedoornige stekelbaars & Eurytoop (Pelagisch) & 99.98 & 0.02 & 0 & 0 & 0.01 & 0.04 \\
\hline hybride cyprinide & Eurytoop (Bentisch) & 99.98 & 0.02 & 0 & 0 & - & 0.03 \\
\hline giebel & Eurytoop (Bentisch) & 99.99 & - & $\overline{0}$ & 0.02 & - & \\
\hline bittervoorn & Limnofiel (Pelagisch) & 99.99 & 0 & 0 & - & 0.03 & 0.01 \\
\hline marmergrondel* & Eurytoop (Bentisch) & 99.99 & - & - & - & 0.01 & 0.02 \\
\hline kleine modderkruiper & Eurytoop (Bentisch) & 100 & - & - & - & 0.01 & 0.02 \\
\hline witvinriviergrondel* & Eurytoop (Bentisch) & 100 & - & - & 0.01 & - & \\
\hline riviergrondel & Rheofiel (Bentisch) & 100 & 0 & - & 0.01 & - & \\
\hline blauwband* & Limnofiel (Pelagisch) & 100 & - & - & - & - & 0 \\
\hline tiendoornige stekelbaars & Limnofiel (Pelagisch) & 100 & 0 & - & - & - & 0 \\
\hline
\end{tabular}




\section{Bijlage 11 Benedenloop Gelderse IJssel zijwateren}

Tabel 1. Soortensamenstelling in percentages op basis van aantal in boomkorvangsten in de zijwateren van de Benedenloop Gelderse IJssel per 5-jarige periode. De groepering geeft de ecologische indeling aan de hand van Noble et al. (2007) aan. Het cumulatief percentage geeft aan hoeveel de soorten over de gehele periode voorkomen op basis van de gesommeerde CPUE op basis van het aantal. Nulpercentages zijn naar beneden afgeronde waarden, $*=$ exoot.

\begin{tabular}{|c|c|c|c|c|c|c|c|}
\hline Soort & Groepering & $\begin{array}{l}\text { Cumulatief } \\
\text { percentage }\end{array}$ & $\begin{array}{r}1997- \\
1999\end{array}$ & $\begin{array}{r}2000- \\
2004\end{array}$ & $\begin{array}{r}2005- \\
2009\end{array}$ & $\begin{array}{r}2010- \\
2014\end{array}$ & $\begin{array}{r}2015- \\
2019\end{array}$ \\
\hline spiering & Eurytoop (Pelagisch) & 41.38 & 85.98 & 11.08 & 2.6 & 13.59 & 57.51 \\
\hline pos & Eurytoop (Bentisch) & 81.78 & 2.4 & 57.38 & 85.95 & 56.24 & 6.75 \\
\hline brasem & Eurytoop (Bentisch) & 90.34 & 3.93 & 18.91 & 5.5 & 14.35 & 7.42 \\
\hline blankvoorn & Eurytoop (Pelagisch) & 97.4 & 6.51 & 9.01 & 4.52 & 7.39 & 16.2 \\
\hline snoekbaars & Eurytoop (Bentisch) & 98.21 & 0.18 & 1.91 & 0.2 & 1.01 & 4.13 \\
\hline baars & Eurytoop (Pelagisch) & 98.83 & 0.18 & 0.62 & 0.26 & 2.97 & 4.78 \\
\hline kolblei & Eurytoop (Bentisch) & 99.35 & 0.74 & 0.1 & 0.56 & 0.71 & 0.38 \\
\hline winde & Rheofiel (Pelagisch) & 99.66 & 0.04 & 0.85 & 0.2 & 0.62 & 0.29 \\
\hline zwartbekgrondel* & Eurytoop (Bentisch) & 99.76 & - & - & - & 0.78 & 1.46 \\
\hline alver & Eurytoop (Pelagisch) & 99.82 & 0 & 0 & 0.09 & 0.7 & 0.36 \\
\hline marmergrondel* & Eurytoop (Bentisch) & 99.86 & - & - & - & 1.02 & 0.04 \\
\hline hybride cyprinide & Eurytoop (Bentisch) & 99.9 & 0.01 & 0 & 0.08 & 0.12 & 0.06 \\
\hline roofblei* & Rheofiel (Pelagisch) & 99.93 & - & 0.11 & 0.01 & 0.03 & 0.02 \\
\hline driedoornige stekelbaars & Eurytoop (Pelagisch) & 99.95 & 0.02 & - & - & 0.12 & 0.06 \\
\hline pontische stroomgrondel* & Eurytoop (Bentisch) & 99.96 & - & - & - & 0.14 & 0.17 \\
\hline snoek & Eurytoop (Pelagisch) & 99.97 & - & 0 & 0 & 0.07 & 0.11 \\
\hline kesslers grondel* & Eurytoop (Bentisch) & 99.97 & - & - & - & 0.07 & 0.09 \\
\hline sneep & Rheofiel (Bentisch) & 99.98 & - & 0.01 & - & - & 0.09 \\
\hline bot & Limnofiel (Bentisch) & 99.99 & 0 & 0.01 & - & 0.03 & - \\
\hline zeelt & Limnofiel (Bentisch) & 99.99 & - & - & - & 0.07 & 0.04 \\
\hline riviergrondel & Rheofiel (Bentisch) & 99.99 & 0.01 & - & - & - & - \\
\hline aal & Eurytoop (Bentisch) & 100 & 0 & 0.01 & - & - & - \\
\hline atlantische forel & Rheofiel (Pelagisch) & 100 & - & - & 0.01 & - & - \\
\hline karper & Eurytoop (Bentisch) & 100 & - & - & 0 & - & - \\
\hline giebel & Eurytoop (Bentisch) & 100 & - & - & - & - & 0.02 \\
\hline
\end{tabular}


Tabel 2. Soortensamenstelling in percentages op basis van biomassa in boomkorvangsten in de zijwateren van de Benedenloop Gelderse IJssel per 5-jarige periode. De groepering geeft de ecologische indeling aan de hand van Noble et al. (2007) aan. Het cumulatief percentage geeft aan hoeveel de soorten over de gehele periode voorkomen op basis van de gesommeerde CPUE op basis van de biomassa. Nul-percentages zijn naar beneden afgeronde waarden, $*=$ exoot.

\begin{tabular}{|c|c|c|c|c|c|c|c|}
\hline Soort & Groepering & $\begin{array}{l}\text { Cumulatief } \\
\text { percentage }\end{array}$ & $\begin{array}{r}1997- \\
1999 \\
\end{array}$ & $\begin{array}{r}2000- \\
2004 \\
\end{array}$ & $\begin{array}{r}2005- \\
2009 \\
\end{array}$ & $\begin{array}{r}2010- \\
2014 \\
\end{array}$ & $\begin{array}{r}2015- \\
2019 \\
\end{array}$ \\
\hline pos & Eurytoop (Bentisch) & 28.53 & 2.74 & 41.28 & 58.95 & 21.52 & 4.82 \\
\hline brasem & Eurytoop (Bentisch) & 55.6 & 29.49 & 29.76 & 16.74 & 49.77 & 20.16 \\
\hline blankvoorn & Eurytoop (Pelagisch) & 72.43 & 26.53 & 12.42 & 10.86 & 12.68 & 14.17 \\
\hline spiering & Eurytoop (Pelagisch) & 83.86 & 26.49 & 2.99 & 1.71 & 3.53 & 14.87 \\
\hline snoekbaars & Eurytoop (Bentisch) & 91.47 & 3.92 & 9.99 & 4.64 & 5.48 & 25.11 \\
\hline kolblei & Eurytoop (Bentisch) & 96.11 & 9.31 & 0.89 & 2.82 & 2.05 & 5.87 \\
\hline snoek & Eurytoop (Pelagisch) & 97.06 & - & 0.44 & 1.28 & 1.31 & 5.03 \\
\hline baars & Eurytoop (Pelagisch) & 97.85 & 0.65 & 0.68 & 0.23 & 0.91 & 3.23 \\
\hline winde & Rheofiel (Pelagisch) & 98.6 & 0.41 & 1.09 & 0.9 & 0.86 & 0.46 \\
\hline zeelt & Limnofiel (Bentisch) & 99 & - & - & - & 0.01 & 4.8 \\
\hline atlantische forel & Rheofiel (Pelagisch) & 99.26 & - & - & 1.03 & - & \\
\hline karper & Eurytoop (Bentisch) & 99.43 & - & - & 0.68 & - & \\
\hline hybride cyprinide & Eurytoop (Bentisch) & 99.56 & 0.26 & 0.06 & 0.07 & 0.2 & 0.04 \\
\hline bot & Limnofiel (Bentisch) & 99.66 & 0.04 & 0.1 & - & 0.83 & \\
\hline $\begin{array}{l}\text { roofblei* } \\
\end{array}$ & Rheofiel (Pelagisch) & 99.73 & - & 0.24 & 0.01 & 0.02 & 0.02 \\
\hline zwartbekgrondel* & Eurytoop (Bentisch) & 99.8 & - & - & - & 0.21 & 0.59 \\
\hline aal & Eurytoop (Bentisch) & 99.86 & 0.15 & 0.04 & - & - & \\
\hline alver & Eurytoop (Pelagisch) & 99.91 & 0 & 0.01 & 0.06 & 0.4 & 0.1 \\
\hline giebel & Eurytoop (Bentisch) & 99.96 & - & - & - & - & 0.56 \\
\hline kesslers grondel* & Eurytoop (Bentisch) & 99.97 & - & - & - & 0.12 & 0.05 \\
\hline sneep & Rheofiel (Bentisch) & 99.98 & - & 0.02 & - & - & 0.04 \\
\hline pontische stroomgrondel* & Eurytoop (Bentisch) & 99.99 & - & - & - & 0.04 & 0.06 \\
\hline marmergrondel* & Eurytoop (Bentisch) & 100 & - & - & - & 0.05 & 0 \\
\hline driedoornige stekelbaars & Eurytoop (Pelagisch) & 100 & 0 & - & - & 0.01 & 0.01 \\
\hline riviergrondel & Rheofiel (Bentisch) & 100 & 0.01 & - & - & - & \\
\hline
\end{tabular}


Tabel 3. Soortensamenstelling in percentages op basis van aantal in schepnetvangsten in de zijwateren van de Benedenloop Gelderse IJssel per 5-jarige periode. De groepering geeft de ecologische indeling aan de hand van Noble et al. (2007) aan. Het cumulatief percentage geeft aan hoeveel de soorten over de gehele periode voorkomen op basis van de gesommeerde CPUE op basis van het aantal. Nulpercentages zijn naar beneden afgeronde waarden, * = exoot.

\begin{tabular}{|c|c|c|c|c|c|c|c|}
\hline Soort & Groepering & $\begin{array}{l}\text { Cumulatief } \\
\text { percentage }\end{array}$ & $\begin{array}{r}1997- \\
1999\end{array}$ & $\begin{array}{r}2000- \\
2004\end{array}$ & $\begin{array}{r}2005- \\
2009\end{array}$ & $\begin{array}{r}2010- \\
2014\end{array}$ & $\begin{array}{r}2015- \\
2019\end{array}$ \\
\hline blankvoorn & Eurytoop (Pelagisch) & 76.38 & 44.97 & 70.44 & 79.55 & 12.47 & 13.34 \\
\hline brasem & Eurytoop (Bentisch) & 89.67 & 1.83 & 1.5 & 14.69 & 1.74 & \\
\hline winde & Rheofiel (Pelagisch) & 93.42 & 2.82 & 4.71 & 3.25 & 0.91 & 43.94 \\
\hline spiering & Eurytoop (Pelagisch) & 95 & 28.14 & 3.44 & - & 1.33 & - \\
\hline baars & Eurytoop (Pelagisch) & 96.46 & 15.67 & 9.31 & 0.15 & 17.24 & 7.74 \\
\hline alver & Eurytoop (Pelagisch) & 97.44 & 2.04 & 2.39 & 0.86 & 2.97 & 0.4 \\
\hline kolblei & Eurytoop (Bentisch) & 97.94 & - & - & 0.56 & - & - \\
\hline roofblei* & Rheofiel (Pelagisch) & 98.43 & 0.55 & 3.77 & 0.28 & - & 5 \\
\hline pos & Eurytoop (Bentisch) & 98.75 & 0.88 & - & 0.3 & 1.97 & - \\
\hline aal & Eurytoop (Bentisch) & 98.93 & 1.15 & 0.98 & 0.07 & 5.26 & - \\
\hline sneep & Rheofiel (Bentisch) & 99.1 & - & 0.18 & 0.19 & - & - \\
\hline snoek & Eurytoop (Pelagisch) & 99.27 & 0.63 & 0.91 & 0.03 & 3.48 & 5.02 \\
\hline pontische stroomgrondel* & Eurytoop (Bentisch) & 99.4 & - & - & - & 5.49 & 9.79 \\
\hline zwartbekgrondel* & Eurytoop (Bentisch) & 99.52 & - & - & - & 8.92 & 6.67 \\
\hline driedoornige stekelbaars & Eurytoop (Pelagisch) & 99.6 & 0.46 & 0.15 & 0.04 & - & 1.47 \\
\hline marmergrondel* & Eurytoop (Bentisch) & 99.67 & - & - & - & 17.24 & - \\
\hline rietvoorn & Limnofiel (Pelagisch) & 99.72 & 0.18 & 1.03 & - & - & - \\
\hline snoekbaars & Eurytoop (Bentisch) & 99.76 & 0.28 & - & 0.02 & 4.08 & - \\
\hline bittervoorn & Limnofiel (Pelagisch) & 99.81 & - & - & - & 10.79 & 0.37 \\
\hline bot & Limnofiel (Bentisch) & 99.85 & - & - & - & 0.91 & 3.34 \\
\hline karper & Eurytoop (Bentisch) & 99.89 & - & 1.03 & - & - & - \\
\hline kesslers grondel* & Eurytoop (Bentisch) & 99.92 & - & - & - & 1.49 & 1.45 \\
\hline hybride cyprinide & Eurytoop (Bentisch) & 99.94 & - & - & 0.02 & - & \\
\hline kleine modderkruiper & Eurytoop (Bentisch) & 99.95 & - & - & - & - & 1.45 \\
\hline zeelt & Limnofiel (Bentisch) & 99.97 & - & - & - & 3.71 & \\
\hline rivierdonderpad & Rheofiel (Bentisch) & 99.98 & 0.08 & - & 0.01 & - & - \\
\hline riviergrondel & Rheofiel (Bentisch) & 99.98 & 0.17 & - & - & - & - \\
\hline tiendoornige stekelbaars & Limnofiel (Pelagisch) & 99.99 & 0.16 & - & - & - & - \\
\hline giebel & Eurytoop (Bentisch) & 100 & - & 0.17 & - & - & \\
\hline
\end{tabular}


Tabel 4. Soortensamenstelling in percentages op basis van biomassa in schepnetvangsten in de zijwateren van de Benedenloop Gelderse IJssel per 5-jarige periode. De groepering geeft de ecologische indeling aan de hand van Noble et al. (2007) aan. Het cumulatief percentage geeft aan hoeveel de soorten over de gehele periode voorkomen op basis van de gesommeerde CPUE op basis van de biomassa. Nul-percentages zijn naar beneden afgeronde waarden, $*=$ exoot.

\begin{tabular}{|c|c|c|c|c|c|c|c|}
\hline Soort & Groepering & $\begin{array}{l}\text { Cumulatief } \\
\text { percentage }\end{array}$ & $\begin{array}{r}1997- \\
1999\end{array}$ & $\begin{array}{r}2000- \\
2004\end{array}$ & $\begin{array}{r}2005- \\
2009\end{array}$ & $\begin{array}{r}2010- \\
2014\end{array}$ & $\begin{array}{r}2015- \\
2019\end{array}$ \\
\hline blankvoorn & Eurytoop (Pelagisch) & 51.28 & 23.79 & 20.1 & 61.52 & 1.16 & 1.28 \\
\hline brasem & Eurytoop (Bentisch) & 71.98 & 0.4 & 48.15 & 20.56 & 0.11 & \\
\hline snoek & Eurytoop (Pelagisch) & 81.94 & 45.1 & 9.4 & 2.14 & 65.45 & 74.18 \\
\hline winde & Rheofiel (Pelagisch) & 86.22 & 3.19 & 2.41 & 4.28 & 2.4 & 9.95 \\
\hline snoekbaars & Eurytoop (Bentisch) & 90.49 & 0.74 & - & 5.36 & 5.33 & - \\
\hline aal & Eurytoop (Bentisch) & 92.98 & 9.63 & 6.15 & 1.4 & 13.12 & \\
\hline baars & Eurytoop (Pelagisch) & 94.77 & 9.92 & 5.62 & 0.61 & 3.39 & 1.59 \\
\hline alver & Eurytoop (Pelagisch) & 96.2 & 0.42 & 0.13 & 1.78 & 0.32 & 0.04 \\
\hline kolblei & Eurytoop (Bentisch) & 97.48 & - & - & 1.65 & - & \\
\hline roofblei* & Rheofiel (Pelagisch) & 97.94 & 0.26 & 1.44 & 0.31 & - & 1.2 \\
\hline bot & Limnofiel (Bentisch) & 98.34 & - & - & - & 4.66 & 7 \\
\hline karper & Eurytoop (Bentisch) & 98.73 & - & 4.03 & - & - & - \\
\hline spiering & Eurytoop (Pelagisch) & 99.11 & 5.33 & 0.26 & - & 0.1 & \\
\hline rietvoorn & Limnofiel (Pelagisch) & 99.36 & 0.68 & 2.15 & - & - & \\
\hline pos & Eurytoop (Bentisch) & 99.56 & 0.33 & - & 0.22 & 0.18 & \\
\hline sneep & Rheofiel (Bentisch) & 99.69 & - & 0.04 & 0.16 & - & - \\
\hline zwartbekgrondel* & Eurytoop (Bentisch) & 99.8 & - & - & - & 1.48 & 1.87 \\
\hline pontische stroomgrondel* & Eurytoop (Bentisch) & 99.88 & - & - & - & 0.49 & 1.53 \\
\hline kesslers grondel* & Eurytoop (Bentisch) & 99.94 & - & - & - & 0.28 & 1.25 \\
\hline zeelt & Limnofiel (Bentisch) & 99.95 & - & - & - & 0.81 & \\
\hline driedoornige stekelbaars & Eurytoop (Pelagisch) & 99.96 & 0.06 & 0.01 & 0.01 & - & 0.04 \\
\hline giebel & Eurytoop (Bentisch) & 99.97 & - & 0.1 & - & - & \\
\hline riviergrondel & Rheofiel (Bentisch) & 99.98 & 0.14 & - & - & - & \\
\hline marmergrondel* & Eurytoop (Bentisch) & 99.99 & - & - & - & 0.44 & \\
\hline bittervoorn & Limnofiel (Pelagisch) & 99.99 & - & - & - & 0.27 & 0.02 \\
\hline hybride cyprinide & Eurytoop (Bentisch) & 100 & - & - & 0 & - & \\
\hline kleine modderkruiper & Eurytoop (Bentisch) & 100 & - & - & - & - & 0.04 \\
\hline rivierdonderpad & Rheofiel (Bentisch) & 100 & 0.01 & - & 0 & - & \\
\hline tiendoornige stekelbaars & Limnofiel (Pelagisch) & 100 & 0.01 & - & - & - & \\
\hline
\end{tabular}




\section{Bijlage 12 Bovenloop Gelderse IJssel hoofdstroom}

Tabel 1. Soortensamenstelling in percentages op basis van aantal in boomkorvangsten in de hoofdstroom van de Bovenloop Gelderse IJssel per 5-jarige periode. De groepering geeft de ecologische indeling aan de hand van Noble et al. (2007) aan. Het cumulatief percentage geeft aan hoeveel de soorten over de gehele periode voorkomen op basis van de gesommeerde CPUE op basis van het aantal. Nul-percentages zijn naar beneden afgeronde waarden, $*=$ exoot.

\begin{tabular}{|c|c|c|c|c|c|c|c|}
\hline Soort & Groepering & $\begin{array}{l}\text { Cumulatief } \\
\text { percentage }\end{array}$ & $\begin{array}{r}1997- \\
1999\end{array}$ & $\begin{array}{r}2000- \\
2004\end{array}$ & $\begin{array}{r}2005- \\
2009\end{array}$ & $\begin{array}{r}2010- \\
2014\end{array}$ & $\begin{array}{r}2015- \\
2019\end{array}$ \\
\hline kolblei & Eurytoop (Bentisch) & 28.12 & 47.33 & 38.65 & 21.96 & 4.59 & 9.83 \\
\hline brasem & Eurytoop (Bentisch) & 49.78 & 19.56 & 19.93 & 25.68 & 16.96 & 11.34 \\
\hline blankvoorn & Eurytoop (Pelagisch) & 68.73 & 20.45 & 15.94 & 14.8 & 28.78 & 42.29 \\
\hline pos & Eurytoop (Bentisch) & 76.82 & 1.59 & 1.92 & 16.49 & 1.01 & 0.97 \\
\hline winde & Rheofiel (Pelagisch) & 83.57 & 0.86 & 6.57 & 5.04 & 21.65 & 15.07 \\
\hline riviergrondel & Rheofiel (Bentisch) & 87.15 & 5.98 & 6.07 & 2.35 & - & 1.93 \\
\hline witvinriviergrondel* & Eurytoop (Bentisch) & 90.39 & - & - & 5.88 & 5.34 & 1.96 \\
\hline barbeel & Rheofiel (Bentisch) & 93.35 & 0.42 & 3.76 & 3.19 & 6.17 & 0.96 \\
\hline bot & Limnofiel (Bentisch) & 94.47 & 1.64 & 1.26 & 0.86 & 1.34 & 0.33 \\
\hline snoekbaars & Eurytoop (Bentisch) & 95.53 & 0.53 & 1.83 & 0.87 & 0.75 & 2.26 \\
\hline rivierdonderpad & Rheofiel (Bentisch) & 96.35 & 0.32 & 1.47 & 1.06 & - & \\
\hline alver & Eurytoop (Pelagisch) & 97.03 & 0.31 & 0.15 & 0.37 & 3.12 & 1.88 \\
\hline baars & Eurytoop (Pelagisch) & 97.64 & 0.11 & 0.61 & 0.65 & 1.25 & 0.95 \\
\hline sneep & Rheofiel (Bentisch) & 98.11 & 0.09 & 0.17 & 0.07 & 1.63 & 4.52 \\
\hline zwartbekgrondel* & Eurytoop (Bentisch) & 98.54 & - & - & - & 3.17 & 1.91 \\
\hline pontische stroomgrondel* & Eurytoop (Bentisch) & 98.83 & - & - & - & 2.04 & 1.62 \\
\hline hybride cyprinide & Eurytoop (Bentisch) & 99.07 & 0.38 & 0.5 & 0.12 & - & \\
\hline aal & Eurytoop (Bentisch) & 99.22 & 0.17 & 0.07 & 0.21 & - & 0.32 \\
\hline rivierprik & Rheofiel (Bentisch) & 99.38 & 0.08 & 0.5 & 0.04 & 0.15 & \\
\hline roofblei* & Rheofiel (Pelagisch) & 99.53 & 0.1 & 0.14 & 0.13 & 0.14 & 0.66 \\
\hline spiering & Eurytoop (Pelagisch) & 99.67 & 0.08 & 0.36 & 0.04 & 0.15 & 0.32 \\
\hline kesslers grondel* & Eurytoop (Bentisch) & 99.73 & - & - & - & 0.6 & \\
\hline europese meerval & Eurytoop (Bentisch) & 99.78 & - & - & 0.04 & 0.15 & 0.31 \\
\hline donaubrasem* & Eurytoop (Bentisch) & 99.82 & - & - & 0.07 & 0.15 & \\
\hline serpeling & Rheofiel (Pelagisch) & 99.86 & - & 0.05 & - & 0.15 & 0.29 \\
\hline snoek & Eurytoop (Pelagisch) & 99.89 & - & - & 0.04 & - & 0.28 \\
\hline marmergrondel* & Eurytoop (Bentisch) & 99.91 & - & - & 0.04 & - & \\
\hline kopvoorn & Rheofiel (Pelagisch) & 99.93 & - & - & - & 0.15 & \\
\hline karper & Eurytoop (Bentisch) & 99.94 & - & - & - & 0.15 & \\
\hline noordzeehouting & Limnofiel (Pelagisch) & 99.96 & - & - & - & 0.14 & \\
\hline bittervoorn & Limnofiel (Pelagisch) & 99.97 & - & - & - & 0.14 & \\
\hline driedoornige stekelbaars & Eurytoop (Pelagisch) & 99.99 & - & - & - & 0.13 & \\
\hline atlantische forel & Rheofiel (Pelagisch) & 100 & - & 0.06 & - & - & \\
\hline
\end{tabular}


Tabel 2. Soortensamenstelling in percentages op basis van biomassa in boomkorvangsten in de hoofdstroom van de Bovenloop Gelderse IJssel per 5-jarige periode. De groepering geeft de ecologische indeling aan de hand van Noble et al. (2007) aan. Het cumulatief percentage geeft aan hoeveel de soorten over de gehele periode voorkomen op basis van de gesommeerde CPUE op basis van de biomassa. Nul-percentages zijn naar beneden afgeronde waarden, * = exoot.

\begin{tabular}{|c|c|c|c|c|c|c|c|}
\hline Soort & Groepering & $\begin{array}{l}\text { Cumulatief } \\
\text { percentage }\end{array}$ & $\begin{array}{r}1997- \\
1999\end{array}$ & $\begin{array}{r}2000- \\
2004\end{array}$ & $\begin{array}{r}2005- \\
2009\end{array}$ & $\begin{array}{r}2010- \\
2014\end{array}$ & $\begin{array}{r}2015- \\
2019\end{array}$ \\
\hline brasem & Eurytoop (Bentisch) & 47.38 & 46.98 & 36.15 & 57.65 & 34.45 & 33.71 \\
\hline kolblei & Eurytoop (Bentisch) & 70.11 & 42.99 & 35.1 & 19.37 & 5.17 & 8.29 \\
\hline winde & Rheofiel (Pelagisch) & 84.58 & 1.08 & 11.98 & 10.45 & 36.62 & 28.8 \\
\hline barbeel & Rheofiel (Bentisch) & 91.73 & 0.09 & 7.33 & 7.07 & 12.79 & 5.99 \\
\hline blankvoorn & Eurytoop (Pelagisch) & 95.85 & 6.49 & 5.37 & 2.3 & 4.05 & 12.53 \\
\hline snoekbaars & Eurytoop (Bentisch) & 97.5 & 0.57 & 2.58 & 1.37 & 1.43 & 3.96 \\
\hline karper & Eurytoop (Bentisch) & 98 & - & - & - & 3.23 & \\
\hline roofblei* & Rheofiel (Pelagisch) & 98.35 & 0.05 & 0.09 & 0.59 & 0.17 & 0.3 \\
\hline bot & Limnofiel (Bentisch) & 98.68 & 1.08 & 0.36 & 0.13 & 0.42 & 0.14 \\
\hline hybride cyprinide & Eurytoop (Bentisch) & 98.91 & 0.27 & 0.66 & 0.13 & - & \\
\hline europese meerval & Eurytoop (Bentisch) & 99.14 & - & - & 0.01 & 0.61 & 3.04 \\
\hline snoek & Eurytoop (Pelagisch) & 99.33 & - & - & 0.2 & - & 2.14 \\
\hline pos & Eurytoop (Bentisch) & 99.48 & 0.06 & 0.03 & 0.28 & 0.02 & 0.01 \\
\hline aal & Eurytoop (Bentisch) & 99.57 & 0.06 & 0.04 & 0.15 & - & 0.23 \\
\hline witvinriviergrondel* & Eurytoop (Bentisch) & 99.65 & - & - & 0.12 & 0.11 & 0.03 \\
\hline riviergrondel & Rheofiel (Bentisch) & 99.73 & 0.2 & 0.15 & 0.04 & - & 0.04 \\
\hline noordzeehouting & Limnofiel (Pelagisch) & 99.79 & - & - & - & 0.41 & - \\
\hline sneep & Rheofiel (Bentisch) & 99.84 & 0 & 0.01 & 0.01 & 0.13 & 0.61 \\
\hline baars & Eurytoop (Pelagisch) & 99.88 & 0 & 0.05 & 0.04 & 0.03 & 0.05 \\
\hline donaubrasem* & Eurytoop (Bentisch) & 99.91 & - & - & 0.05 & 0.07 & \\
\hline alver & Eurytoop (Pelagisch) & 99.94 & 0.02 & 0.01 & 0.02 & 0.07 & 0.08 \\
\hline rivierprik & Rheofiel (Bentisch) & 99.96 & 0.02 & 0.06 & 0 & 0.01 & - \\
\hline kopvoorn & Rheofiel (Pelagisch) & 99.97 & - & - & - & 0.12 & - \\
\hline rivierdonderpad & Rheofiel (Bentisch) & 99.98 & 0.01 & 0.01 & 0.01 & - & - \\
\hline pontische stroomgrondel* & Eurytoop (Bentisch) & 99.99 & - & - & - & 0.03 & 0.02 \\
\hline zwartbekgrondel* & Eurytoop (Bentisch) & 99.99 & - & - & - & 0.03 & 0.02 \\
\hline kesslers grondel* & Eurytoop (Bentisch) & 100 & - & - & - & 0.02 & - \\
\hline spiering & Eurytoop (Pelagisch) & 100 & 0 & 0 & 0 & 0.01 & 0 \\
\hline serpeling & Rheofiel (Pelagisch) & 100 & - & 0 & - & 0 & 0.01 \\
\hline atlantische forel & Rheofiel (Pelagisch) & 100 & - & 0 & - & - & \\
\hline marmergrondel* & Eurytoop (Bentisch) & 100 & - & - & 0 & - & - \\
\hline driedoornige stekelbaars & Eurytoop (Pelagisch) & 100 & - & - & - & 0 & - \\
\hline bittervoorn & Limnofiel (Pelagisch) & 100 & - & - & - & 0 & - \\
\hline
\end{tabular}


Tabel 3. Soortensamenstelling in percentages op basis van aantal in schepnetvangsten in de hoofdstroom van de Bovenloop Gelderse IJssel per 5-jarige periode. De groepering geeft de ecologische indeling aan de hand van Noble et al. (2007) aan. Het cumulatief percentage geeft aan hoeveel de soorten over de gehele periode voorkomen op basis van de gesommeerde CPUE op basis van het aantal. Nul-percentages zijn naar beneden afgeronde waarden, $*=$ exoot.

\begin{tabular}{|c|c|c|c|c|c|c|c|}
\hline Soort & Groepering & $\begin{array}{l}\text { Cumulatief } \\
\text { percentage }\end{array}$ & $\begin{array}{r}1997- \\
1999 \\
\end{array}$ & $\begin{array}{r}2000- \\
2004 \\
\end{array}$ & $\begin{array}{r}2005- \\
2009 \\
\end{array}$ & $\begin{array}{r}2010- \\
2014 \\
\end{array}$ & $\begin{array}{r}2015- \\
2019 \\
\end{array}$ \\
\hline blankvoorn & Eurytoop (Pelagisch) & 52.23 & 34.14 & 71.22 & 70.98 & 23.33 & 56.04 \\
\hline zwartbekgrondel* & Eurytoop (Bentisch) & 71.48 & - & - & - & 57.69 & 5.68 \\
\hline winde & Rheofiel (Pelagisch) & 79.01 & 5.99 & 5.71 & 18.22 & 6.17 & 19.58 \\
\hline aal & Eurytoop (Bentisch) & 85.29 & 41.6 & 6.45 & 0.47 & 0.51 & 3.14 \\
\hline alver & Eurytoop (Pelagisch) & 88.95 & 9.62 & 3.96 & 2.41 & 1.93 & 6.88 \\
\hline baars & Eurytoop (Pelagisch) & 91.78 & 2.53 & 4.12 & 2.56 & 1.23 & 1.83 \\
\hline kesslers grondel* & Eurytoop (Bentisch) & 93.83 & - & - & - & 6.16 & 0.48 \\
\hline pos & Eurytoop (Bentisch) & 95.61 & 0.86 & 3.56 & 0.29 & 0.04 & \\
\hline brasem & Eurytoop (Bentisch) & 96.51 & 1.11 & 1.08 & 2.5 & 0.25 & 0.29 \\
\hline kolblei & Eurytoop (Bentisch) & 97.25 & 0.58 & 1.45 & - & 0.04 & - \\
\hline kopvoorn & Rheofiel (Pelagisch) & 97.76 & 1.05 & 0.34 & 0.61 & 0.61 & 0.5 \\
\hline serpeling & Rheofiel (Pelagisch) & 98.15 & - & 0.6 & 0.34 & 0.15 & 0.76 \\
\hline sneep & Rheofiel (Bentisch) & 98.49 & 0.3 & 0.08 & 0.71 & 0.52 & 1.15 \\
\hline roofblei* & Rheofiel (Pelagisch) & 98.75 & 0.45 & 0.18 & 0.35 & 0.3 & 0.3 \\
\hline snoek & Eurytoop (Pelagisch) & 98.92 & - & 0.2 & 0.09 & 0.03 & 1.35 \\
\hline driedoornige stekelbaars & Eurytoop (Pelagisch) & 99.08 & 0.45 & 0.14 & - & 0.04 & 1.26 \\
\hline snoekbaars & Eurytoop (Bentisch) & 99.23 & 0.21 & 0.25 & - & 0.02 & 0.24 \\
\hline barbeel & Rheofiel (Bentisch) & 99.36 & 0.55 & 0.19 & - & - & - \\
\hline marmergrondel* & Eurytoop (Bentisch) & 99.46 & - & - & - & 0.3 & - \\
\hline bittervoorn & Limnofiel (Pelagisch) & 99.54 & - & - & - & 0.26 & - \\
\hline rietvoorn & Limnofiel (Pelagisch) & 99.62 & - & 0.09 & - & 0.1 & - \\
\hline vetje & Limnofiel (Pelagisch) & 99.69 & - & - & - & 0.22 & - \\
\hline rivierdonderpad & Rheofiel (Bentisch) & 99.76 & - & 0.1 & 0.17 & - & - \\
\hline rivierprik & Rheofiel (Bentisch) & 99.8 & - & 0.09 & - & - & - \\
\hline hybride cyprinide & Eurytoop (Bentisch) & 99.84 & 0.3 & - & 0.24 & - & \\
\hline pontische stroomgrondel* & Eurytoop (Bentisch) & 99.88 & - & - & - & 0.06 & 0.5 \\
\hline bot & Limnofiel (Bentisch) & 99.92 & 0.25 & 0.03 & - & - & - \\
\hline riviergrondel & Rheofiel (Bentisch) & 99.95 & - & 0.07 & - & - & - \\
\hline spiering & Eurytoop (Pelagisch) & 99.97 & - & 0.04 & - & - & \\
\hline bermpje & Rheofiel (Bentisch) & 99.99 & - & 0.03 & - & - & \\
\hline zonnebaars* & Limnofiel (Pelagisch) & 100 & - & - & - & 0.03 & - \\
\hline karper & Eurytoop (Bentisch) & 100 & - & - & 0.05 & - & - \\
\hline
\end{tabular}


Tabel 4. Soortensamenstelling in percentages op basis van biomassa in schepnetvangsten in de hoofdstroom van de Bovenloop Gelderse IJssel per 5-jarige periode. De groepering geeft de ecologische indeling aan de hand van Noble et al. (2007) aan. Het cumulatief percentage geeft aan hoeveel de soorten over de gehele periode voorkomen op basis van de gesommeerde CPUE op basis van de biomassa. Nul-percentages zijn naar beneden afgeronde waarden, $*=$ exoot.

\begin{tabular}{|c|c|c|c|c|c|c|c|}
\hline Soort & Groepering & $\begin{array}{l}\text { Cumulatief } \\
\text { percentage }\end{array}$ & $\begin{array}{r}1997- \\
1999 \\
\end{array}$ & $\begin{array}{r}2000- \\
2004 \\
\end{array}$ & $\begin{array}{r}2005- \\
2009 \\
\end{array}$ & $\begin{array}{r}2010- \\
2014 \\
\end{array}$ & $\begin{array}{r}2015- \\
2019 \\
\end{array}$ \\
\hline aal & Eurytoop (Bentisch) & 28.46 & 57.6 & 31.72 & 2.99 & 9.13 & 25.78 \\
\hline winde & Rheofiel (Pelagisch) & 49.73 & 18.42 & 10.92 & 56 & 30.38 & 19.26 \\
\hline blankvoorn & Eurytoop (Pelagisch) & 64.44 & 6.47 & 20.07 & 10.56 & 12.08 & 7.4 \\
\hline brasem & Eurytoop (Bentisch) & 74.89 & 9.28 & 8.47 & 28.37 & 7.03 & 0.01 \\
\hline snoek & Eurytoop (Pelagisch) & 84.09 & - & 8.91 & 0.03 & 8.32 & 42.47 \\
\hline snoekbaars & Eurytoop (Bentisch) & 87.99 & 5.49 & 5.49 & - & 0.08 & 3.16 \\
\hline kolblei & Eurytoop (Bentisch) & 91.49 & 0.22 & 6.8 & - & 0.01 & \\
\hline zwartbekgrondel* & Eurytoop (Bentisch) & 94.04 & - & - & - & 21.7 & 0.6 \\
\hline kopvoorn & Rheofiel (Pelagisch) & 95.22 & 0.17 & 1.86 & 1.29 & 0.15 & 0.07 \\
\hline baars & Eurytoop (Pelagisch) & 96.35 & 0.24 & 1.82 & 0.36 & 0.84 & 0.16 \\
\hline kesslers grondel* & Eurytoop (Bentisch) & 97.34 & - & - & - & 8.36 & 0.32 \\
\hline roofblei* & Rheofiel (Pelagisch) & 98.03 & 0.07 & 1.27 & 0.03 & 0.21 & 0.01 \\
\hline alver & Eurytoop (Pelagisch) & 98.67 & 1.17 & 0.53 & 0.13 & 1.12 & 0.56 \\
\hline rietvoorn & Limnofiel (Pelagisch) & 99.19 & - & 1.03 & - & 0.01 & \\
\hline pos & Eurytoop (Bentisch) & 99.5 & 0.05 & 0.55 & 0.1 & 0.01 & \\
\hline bot & Limnofiel (Bentisch) & 99.7 & 0.69 & 0.21 & - & - & \\
\hline serpeling & Rheofiel (Pelagisch) & 99.79 & - & 0.11 & 0.06 & 0.1 & 0.06 \\
\hline sneep & Rheofiel (Bentisch) & 99.86 & 0.02 & 0.04 & 0.06 & 0.32 & 0.1 \\
\hline rivierprik & Rheofiel (Bentisch) & 99.91 & - & 0.1 & - & - & \\
\hline barbeel & Rheofiel (Bentisch) & 99.95 & 0.04 & 0.05 & - & - & - \\
\hline rivierdonderpad & Rheofiel (Bentisch) & 99.96 & - & 0.02 & 0.01 & - & - \\
\hline hybride cyprinide & Eurytoop (Bentisch) & 99.97 & 0.06 & - & 0 & - & \\
\hline riviergrondel & Rheofiel (Bentisch) & 99.97 & - & 0.02 & - & - & \\
\hline pontische stroomgrondel* & Eurytoop (Bentisch) & 99.98 & - & - & - & 0.05 & 0.01 \\
\hline driedoornige stekelbaars & Eurytoop (Pelagisch) & 99.98 & 0.01 & 0 & - & 0 & 0.02 \\
\hline zonnebaars* & Limnofiel (Pelagisch) & 99.99 & - & - & - & 0.03 & \\
\hline marmergrondel* & Eurytoop (Bentisch) & 99.99 & - & - & - & 0.03 & \\
\hline bittervoorn & Limnofiel (Pelagisch) & 100 & - & - & - & 0.03 & \\
\hline bermpje & Rheofiel (Bentisch) & 100 & - & 0 & - & - & \\
\hline vetje & Limnofiel (Pelagisch) & 100 & - & - & - & 0.01 & \\
\hline karper & Eurytoop (Bentisch) & 100 & - & - & 0.01 & - & \\
\hline spiering & Eurytoop (Pelagisch) & 100 & - & 0 & - & - & \\
\hline
\end{tabular}




\section{Bijlage 13 Bovenloop Gelderse IJssel zijwateren}

Tabel 1. Soortensamenstelling in percentages op basis van aantal in boomkorvangsten in de zijwateren van de Bovenloop Gelderse IJssel per 5-jarige periode. De groepering geeft de ecologische indeling aan de hand van Noble et al. (2007) aan. Het cumulatief percentage geeft aan hoeveel de soorten over de gehele periode voorkomen op basis van de gesommeerde CPUE op basis van het aantal. Nul-percentages zijn naar beneden afgeronde waarden, $*=$ exoot.

\begin{tabular}{|c|c|c|c|c|c|c|c|}
\hline Soort & Groepering & $\begin{array}{l}\text { Cumulatief } \\
\text { percentage }\end{array}$ & $\begin{array}{r}1997- \\
1999\end{array}$ & $\begin{array}{r}2000- \\
2004\end{array}$ & $\begin{array}{r}2005- \\
2009\end{array}$ & $\begin{array}{r}2010- \\
2014\end{array}$ & $\begin{array}{r}2015- \\
2019\end{array}$ \\
\hline brasem & Eurytoop (Bentisch) & 49.46 & 55.41 & 60.92 & 47.94 & 39.46 & 16.26 \\
\hline blankvoorn & Eurytoop (Pelagisch) & 79.33 & 23.27 & 21.92 & 27.09 & 38.1 & 60.36 \\
\hline pos & Eurytoop (Bentisch) & 89.38 & 5.76 & 10.35 & 17.05 & 10.73 & 2.71 \\
\hline baars & Eurytoop (Pelagisch) & 93.59 & 1.84 & 1.11 & 3.06 & 7.04 & 16.53 \\
\hline kolblei & Eurytoop (Bentisch) & 97.64 & 10.59 & 4.34 & 3.27 & 0.73 & 0.41 \\
\hline snoekbaars & Eurytoop (Bentisch) & 98.5 & 1.71 & 0.72 & 0.84 & 0.65 & 0.55 \\
\hline pontische stroomgrondel* & Eurytoop (Bentisch) & 98.84 & - & - & - & 1.6 & 0.6 \\
\hline winde & Rheofiel (Pelagisch) & 99.13 & 0.02 & 0.1 & 0.1 & 0.74 & 0.95 \\
\hline hybride cyprinide & Eurytoop (Bentisch) & 99.38 & 0.83 & 0.19 & 0.24 & 0.03 & \\
\hline zwartbekgrondel* & Eurytoop (Bentisch) & 99.53 & - & - & - & 0.32 & 0.92 \\
\hline spiering & Eurytoop (Pelagisch) & 99.67 & 0.35 & 0.2 & 0.02 & - & \\
\hline alver & Eurytoop (Pelagisch) & 99.74 & 0.16 & 0.03 & 0.07 & 0.1 & 0.06 \\
\hline marmergrondel* & Eurytoop (Bentisch) & 99.8 & - & - & 0.13 & 0.11 & 0.21 \\
\hline sneep & Rheofiel (Bentisch) & 99.84 & - & - & - & 0.1 & 0.17 \\
\hline roofblei* & Rheofiel (Pelagisch) & 99.87 & - & 0.02 & 0.01 & 0.09 & 0.05 \\
\hline riviergrondel & Rheofiel (Bentisch) & 99.89 & 0.02 & 0.04 & 0.03 & - & - \\
\hline snoek & Eurytoop (Pelagisch) & 99.91 & 0.02 & 0.02 & 0.03 & 0.03 & \\
\hline kesslers grondel* & Eurytoop (Bentisch) & 99.93 & - & - & - & 0.05 & 0.09 \\
\hline bittervoorn & Limnofiel (Pelagisch) & 99.95 & - & - & - & 0.05 & 0.09 \\
\hline bot & Limnofiel (Bentisch) & 99.96 & - & - & - & 0.06 & \\
\hline aal & Eurytoop (Bentisch) & 99.97 & - & 0 & 0.05 & - & \\
\hline kleine modderkruiper & Eurytoop (Bentisch) & 99.98 & - & 0.01 & 0.02 & - & \\
\hline witvinriviergrondel* & Eurytoop (Bentisch) & 99.98 & - & - & 0.03 & - & \\
\hline rivierdonderpad & Rheofiel (Bentisch) & 99.99 & - & 0.01 & - & - & \\
\hline serpeling & Rheofiel (Pelagisch) & 99.99 & - & - & - & - & 0.03 \\
\hline atlantische forel & Rheofiel (Pelagisch) & 100 & - & - & 0.02 & - & \\
\hline zeelt & Limnofiel (Bentisch) & 100 & - & - & - & 0.02 & \\
\hline giebel & Eurytoop (Bentisch) & 100 & 0.01 & - & - & - & \\
\hline
\end{tabular}


Tabel 2. Soortensamenstelling in percentages op basis van biomassa in boomkorvangsten in de zijwateren van de Bovenloop Gelderse IJssel per 5-jarige periode. De groepering geeft de ecologische indeling aan de hand van Noble et al. (2007) aan. Het cumulatief percentage geeft aan hoeveel de soorten over de gehele periode voorkomen op basis van de gesommeerde CPUE op basis van de biomassa. Nul-percentages zijn naar beneden afgeronde waarden, $*=$ exoot.

\begin{tabular}{|c|c|c|c|c|c|c|c|}
\hline Soort & Groepering & $\begin{array}{l}\text { Cumulatief } \\
\text { percentage }\end{array}$ & $\begin{array}{r}1997- \\
1999\end{array}$ & $\begin{array}{r}2000- \\
2004\end{array}$ & $\begin{array}{r}2005- \\
2009\end{array}$ & $\begin{array}{r}2010- \\
2014\end{array}$ & $\begin{array}{r}2015- \\
2019\end{array}$ \\
\hline brasem & Eurytoop (Bentisch) & 57.03 & 58.49 & 56.85 & 50.09 & 63.85 & 54.23 \\
\hline blankvoorn & Eurytoop (Pelagisch) & 74.33 & 10.91 & 15.37 & 23.68 & 20.3 & 27.43 \\
\hline kolblei & Eurytoop (Bentisch) & 89.07 & 18.18 & 19.04 & 15.91 & 5.38 & 0.44 \\
\hline snoekbaars & Eurytoop (Bentisch) & 96.19 & 10.29 & 5.71 & 4.93 & 5.42 & 10.88 \\
\hline baars & Eurytoop (Pelagisch) & 97.48 & 0.35 & 0.54 & 1.39 & 2.22 & 5.81 \\
\hline pos & Eurytoop (Bentisch) & 98.55 & 0.41 & 1.18 & 1.75 & 1.43 & 0.53 \\
\hline hybride cyprinide & Eurytoop (Bentisch) & 99.18 & 1.06 & 0.76 & 0.51 & 0.05 & \\
\hline snoek & Eurytoop (Pelagisch) & 99.53 & 0.27 & 0.43 & 0.76 & 0.08 & \\
\hline winde & Rheofiel (Pelagisch) & 99.74 & 0 & 0.04 & 0.45 & 0.58 & 0.29 \\
\hline aal & Eurytoop (Bentisch) & 99.82 & - & 0.03 & 0.47 & - & \\
\hline pontische stroomgrondel* & Eurytoop (Bentisch) & 99.88 & - & - & - & 0.29 & 0.16 \\
\hline bot & Limnofiel (Bentisch) & 99.92 & - & - & - & 0.24 & \\
\hline zwartbekgrondel* & Eurytoop (Bentisch) & 99.93 & - & - & - & 0.05 & 0.1 \\
\hline alver & Eurytoop (Pelagisch) & 99.95 & 0.01 & 0.01 & 0.01 & 0.03 & 0.03 \\
\hline roofblei* & Rheofiel (Pelagisch) & 99.96 & - & 0.03 & 0 & 0.02 & 0.01 \\
\hline spiering & Eurytoop (Pelagisch) & 99.97 & 0.02 & 0.02 & 0 & - & \\
\hline sneep & Rheofiel (Bentisch) & 99.98 & - & - & - & 0.02 & 0.05 \\
\hline riviergrondel & Rheofiel (Bentisch) & 99.99 & 0 & 0.01 & 0.01 & - & \\
\hline kesslers grondel* & Eurytoop (Bentisch) & 99.99 & - & - & - & 0.02 & 0.03 \\
\hline atlantische forel & Rheofiel (Pelagisch) & 99.99 & - & - & 0.02 & - & \\
\hline marmergrondel* & Eurytoop (Bentisch) & 100 & - & - & 0.01 & 0 & 0.01 \\
\hline rivierdonderpad & Rheofiel (Bentisch) & 100 & - & 0 & - & - & \\
\hline giebel & Eurytoop (Bentisch) & 100 & 0 & - & - & - & \\
\hline witvinriviergrondel* & Eurytoop (Bentisch) & 100 & - & - & 0 & - & \\
\hline kleine modderkruiper & Eurytoop (Bentisch) & 100 & - & 0 & 0 & - & \\
\hline bittervoorn & Limnofiel (Pelagisch) & 100 & - & - & - & 0 & 0 \\
\hline serpeling & Rheofiel (Pelagisch) & 100 & - & - & - & - & 0.01 \\
\hline zeelt & Limnofiel (Bentisch) & 100 & - & - & - & 0 & \\
\hline
\end{tabular}


Tabel 3. Soortensamenstelling in percentages op basis van aantal in schepnetvangsten in de zijwateren van de Bovenloop Gelderse IJssel per 5-jarige periode. De groepering geeft de ecologische indeling aan de hand van Noble et al. (2007) aan. Het cumulatief percentage geeft aan hoeveel de soorten over de gehele periode voorkomen op basis van de gesommeerde CPUE op basis van het aantal. Nul-percentages zijn naar beneden afgeronde waarden, $*=$ exoot.

\begin{tabular}{|c|c|c|c|c|c|c|c|}
\hline Soort & Groepering & $\begin{array}{l}\text { Cumulatief } \\
\text { percentage }\end{array}$ & $\begin{array}{r}1997- \\
1999 \\
\end{array}$ & $\begin{array}{r}2000- \\
2004 \\
\end{array}$ & $\begin{array}{r}2005- \\
2009 \\
\end{array}$ & $\begin{array}{r}2010- \\
2014 \\
\end{array}$ & $\begin{array}{r}2015- \\
2019 \\
\end{array}$ \\
\hline blankvoorn & Eurytoop (Pelagisch) & 72.68 & 45.04 & 78.97 & 75.29 & 43.53 & 67.01 \\
\hline baars & Eurytoop (Pelagisch) & 81.89 & 21.95 & 8.16 & 7.73 & 12.8 & 9.23 \\
\hline pos & Eurytoop (Bentisch) & 86.11 & 5.84 & 4.62 & 6.42 & 1.18 & 1.01 \\
\hline winde & Rheofiel (Pelagisch) & 90.29 & 2.01 & 2.93 & 3.91 & 8.03 & 13.14 \\
\hline aal & Eurytoop (Bentisch) & 93.11 & 19.65 & 2.58 & 2.61 & 0.28 & 0.62 \\
\hline zwartbekgrondel* & Eurytoop (Bentisch) & 94.82 & - & - & - & 15.11 & 0.14 \\
\hline alver & Eurytoop (Pelagisch) & 95.58 & 2.65 & 0.09 & 0.89 & 3.79 & 1.58 \\
\hline snoekbaars & Eurytoop (Bentisch) & 96.11 & - & 0.51 & 1.18 & 0.29 & 0.55 \\
\hline kolblei & Eurytoop (Bentisch) & 96.64 & 1.72 & 0.64 & - & - & 0.29 \\
\hline kesslers grondel* & Eurytoop (Bentisch) & 97.06 & - & - & - & 3.74 & \\
\hline brasem & Eurytoop (Bentisch) & 97.41 & 0.29 & 0.24 & 0.62 & 0.86 & 0.42 \\
\hline roofblei* & Rheofiel (Pelagisch) & 97.74 & 0.29 & 0.27 & 0.13 & 0.78 & 0.5 \\
\hline marmergrondel* & Eurytoop (Bentisch) & 98.06 & - & - & 0.17 & 2.47 & 0.37 \\
\hline snoek & Eurytoop (Pelagisch) & 98.37 & 0.54 & 0.07 & 0.3 & 0.99 & 1.63 \\
\hline kopvoorn & Rheofiel (Pelagisch) & 98.66 & - & 0.31 & - & 0.35 & 0.56 \\
\hline bittervoorn & Limnofiel (Pelagisch) & 98.84 & - & - & 0.32 & 1.21 & 0.16 \\
\hline vetje & Limnofiel (Pelagisch) & 99 & - & - & 0.05 & 1.42 & \\
\hline serpeling & Rheofiel (Pelagisch) & 99.16 & - & 0.11 & - & 0.31 & 0.84 \\
\hline riviergrondel & Rheofiel (Bentisch) & 99.32 & - & 0.19 & - & 0.14 & \\
\hline rietvoorn & Limnofiel (Pelagisch) & 99.44 & - & 0.13 & 0.13 & 0.16 & \\
\hline zeelt & Limnofiel (Bentisch) & 99.55 & - & 0.08 & - & 0.34 & 0.32 \\
\hline pontische stroomgrondel* & Eurytoop (Bentisch) & 99.66 & - & - & - & 0.97 & \\
\hline driedoornige stekelbaars & Eurytoop (Pelagisch) & 99.74 & - & - & 0.26 & 0.42 & 0.16 \\
\hline kleine modderkruiper & Eurytoop (Bentisch) & 99.79 & - & - & - & 0.27 & 0.35 \\
\hline rivierdonderpad & Rheofiel (Bentisch) & 99.83 & - & 0.04 & - & 0.06 & \\
\hline tiendoornige stekelbaars & Limnofiel (Pelagisch) & 99.86 & - & 0.02 & - & 0.08 & 0.24 \\
\hline bot & Limnofiel (Bentisch) & 99.89 & - & - & - & 0.15 & 0.22 \\
\hline karper & Eurytoop (Bentisch) & 99.92 & - & - & - & 0.14 & 0.19 \\
\hline sneep & Rheofiel (Bentisch) & 99.95 & - & - & - & 0.15 & 0.16 \\
\hline hybride cyprinide & Eurytoop (Bentisch) & 99.97 & - & 0.03 & - & - & 0.13 \\
\hline rivierprik & Rheofiel (Bentisch) & 99.99 & - & 0.02 & - & - & \\
\hline bermpje & Rheofiel (Bentisch) & 100 & - & - & - & - & 0.19 \\
\hline
\end{tabular}


Tabel 4. Soortensamenstelling in percentages op basis van biomassa in schepnetvangsten in de zijwateren van de Bovenloop Gelderse IJssel per 5-jarige periode. De groepering geeft de ecologische indeling aan de hand van Noble et al. (2007) aan. Het cumulatief percentage geeft aan hoeveel de soorten over de gehele periode voorkomen op basis van de gesommeerde CPUE op basis van de biomassa. Nul-percentages zijn naar beneden afgeronde waarden, * = exoot.

\begin{tabular}{|c|c|c|c|c|c|c|c|}
\hline Soort & Groepering & $\begin{array}{l}\text { Cumulatief } \\
\text { percentage }\end{array}$ & $\begin{array}{r}1997- \\
1999\end{array}$ & $\begin{array}{r}2000- \\
2004\end{array}$ & $\begin{array}{r}2005- \\
2009\end{array}$ & $\begin{array}{r}2010- \\
2014\end{array}$ & $\begin{array}{r}2015- \\
2019\end{array}$ \\
\hline snoek & Eurytoop (Pelagisch) & 26.89 & 1 & 16.09 & 25.68 & 56.13 & 64.7 \\
\hline snoekbaars & Eurytoop (Bentisch) & 53.26 & - & 30.4 & 35.21 & 5.78 & 18.95 \\
\hline blankvoorn & Eurytoop (Pelagisch) & 68.32 & 23.47 & 20.53 & 5.62 & 8.09 & 6.67 \\
\hline aal & Eurytoop (Bentisch) & 82.7 & 53.36 & 18.61 & 7.53 & 2.22 & 2.78 \\
\hline winde & Rheofiel (Pelagisch) & 87.94 & 0.4 & 4.7 & 9.77 & 5.53 & 1.94 \\
\hline brasem & Eurytoop (Bentisch) & 92.9 & 0.01 & 2.86 & 14.36 & 6.91 & 0.03 \\
\hline baars & Eurytoop (Pelagisch) & 97.32 & 16.71 & 4.42 & 1.26 & 6.96 & 3.32 \\
\hline pos & Eurytoop (Bentisch) & 98.08 & 1.26 & 1.03 & 0.51 & 0.27 & 0.1 \\
\hline rietvoorn & Limnofiel (Pelagisch) & 98.52 & - & 0.76 & 0 & 0.04 & - \\
\hline zwartbekgrondel* & Eurytoop (Bentisch) & 98.82 & - & - & - & 2.96 & 0.02 \\
\hline kesslers grondel* & Eurytoop (Bentisch) & 99.12 & - & - & - & 2.92 & \\
\hline kolblei & Eurytoop (Bentisch) & 99.4 & 3.56 & 0.24 & - & - & 0.1 \\
\hline bot & Limnofiel (Bentisch) & 99.5 & - & - & - & 0.39 & 0.53 \\
\hline alver & Eurytoop (Pelagisch) & 99.58 & 0.2 & 0.05 & 0.04 & 0.35 & 0.09 \\
\hline zeelt & Limnofiel (Bentisch) & 99.67 & - & 0.01 & - & 0.68 & 0.07 \\
\hline roofblei* & Rheofiel (Pelagisch) & 99.75 & 0.03 & 0.09 & 0.01 & 0.19 & 0.08 \\
\hline kopvoorn & Rheofiel (Pelagisch) & 99.82 & - & 0.09 & - & 0.04 & 0.11 \\
\hline karper & Eurytoop (Bentisch) & 99.85 & - & - & - & 0.02 & 0.31 \\
\hline riviergrondel & Rheofiel (Bentisch) & 99.89 & - & 0.05 & - & 0.05 & - \\
\hline serpeling & Rheofiel (Pelagisch) & 99.92 & - & 0.01 & - & 0.09 & 0.11 \\
\hline hybride cyprinide & Eurytoop (Bentisch) & 99.94 & - & 0.03 & - & - & 0.01 \\
\hline pontische stroomgrondel* & Eurytoop (Bentisch) & 99.95 & - & - & - & 0.16 & \\
\hline marmergrondel* & Eurytoop (Bentisch) & 99.96 & - & - & 0.01 & 0.1 & 0.01 \\
\hline rivierdonderpad & Rheofiel (Bentisch) & 99.97 & - & 0.01 & - & 0 & - \\
\hline sneep & Rheofiel (Bentisch) & 99.98 & - & - & - & 0.03 & 0.04 \\
\hline kleine modderkruiper & Eurytoop (Bentisch) & 99.98 & - & - & - & 0.02 & 0.03 \\
\hline bittervoorn & Limnofiel (Pelagisch) & 99.99 & - & - & 0 & 0.04 & 0 \\
\hline rivierprik & Rheofiel (Bentisch) & 99.99 & - & 0.01 & - & - & - \\
\hline vetje & Limnofiel (Pelagisch) & 99.99 & - & - & 0 & 0.03 & - \\
\hline bermpje & Rheofiel (Bentisch) & 100 & - & - & - & - & 0.02 \\
\hline driedoornige stekelbaars & Eurytoop (Pelagisch) & 100 & - & - & 0 & 0.01 & 0 \\
\hline tiendoornige stekelbaars & Limnofiel (Pelagisch) & 100 & - & 0 & - & 0 & 0.01 \\
\hline
\end{tabular}




\section{Bijlage 14 Rijn hoofdstroom}

Tabel 1. Soortensamenstelling in percentages op basis van aantal in boomkorvangsten in de hoofdstroom van de Rijn per 5-jarige periode. De groepering geeft de ecologische indeling aan de hand van Noble et al. (2007) aan. Het cumulatief percentage geeft aan hoeveel de soorten over de gehele periode voorkomen op basis van de gesommeerde CPUE op basis van het aantal. Nul-percentages zijn naar beneden afgeronde waarden, $*$ = exoot.

\begin{tabular}{|c|c|c|c|c|c|c|c|}
\hline Soort & Groepering & $\begin{array}{l}\text { Cumulatief } \\
\text { percentage }\end{array}$ & $\begin{array}{r}1997- \\
1999\end{array}$ & $\begin{array}{r}2000- \\
2004\end{array}$ & $\begin{array}{r}2005- \\
2009\end{array}$ & $\begin{array}{r}2010- \\
2014\end{array}$ & $\begin{array}{r}2015- \\
2019\end{array}$ \\
\hline brasem & Eurytoop (Bentisch) & 43.15 & 30.02 & 51.44 & 44.94 & 35.86 & 54.69 \\
\hline kolblei & Eurytoop (Bentisch) & 63.51 & 53.71 & 17.26 & 9.75 & 5.76 & 0.11 \\
\hline blankvoorn & Eurytoop (Pelagisch) & 82.33 & 4.43 & 17.37 & 18.92 & 33.7 & 33.11 \\
\hline pos & Eurytoop (Bentisch) & 86.07 & 1.94 & 2.48 & 9.45 & 1.86 & 0.12 \\
\hline snoekbaars & Eurytoop (Bentisch) & 88.91 & 2.89 & 3.23 & 3.37 & 2.61 & 1.31 \\
\hline riviergrondel & Rheofiel (Bentisch) & 90.73 & 3.01 & 1.76 & 2.62 & - & \\
\hline winde & Rheofiel (Pelagisch) & 92.32 & 0.05 & 2.33 & 1.37 & 2.74 & 2.36 \\
\hline witvinriviergrondel* & Eurytoop (Bentisch) & 93.9 & - & - & 4.59 & 2.86 & 0.4 \\
\hline zwartbekgrondel* & Eurytoop (Bentisch) & 95.2 & - & - & - & 5.75 & 4.3 \\
\hline barbeel & Rheofiel (Bentisch) & 96.04 & 0.36 & 0.73 & 1.04 & 2.22 & 0.35 \\
\hline baars & Eurytoop (Pelagisch) & 96.74 & - & 0.94 & 0.44 & 1.89 & 0.95 \\
\hline $\begin{array}{ll}\text { rivierprik } \\
\end{array}$ & Rheofiel (Bentisch) & 97.33 & 1.06 & 0.9 & 0.31 & 0.31 & \\
\hline pontische stroomgrondel* & Eurytoop (Bentisch) & 97.78 & - & - & 0.13 & 2.47 & 0.84 \\
\hline hybride cyprinide & Eurytoop (Bentisch) & 98.19 & 0.75 & 0.59 & 0.28 & - & 0.13 \\
\hline alver & Eurytoop (Pelagisch) & 98.59 & 1 & 0.12 & 0.25 & 0.47 & \\
\hline marmergrondel* & Eurytoop (Bentisch) & 98.86 & - & - & 1.02 & 0.14 & \\
\hline bot & Limnofiel (Bentisch) & 99.12 & 0.23 & 0.25 & 0.55 & - & \\
\hline donaubrasem* & Eurytoop (Bentisch) & 99.35 & - & 0.12 & 0.49 & 0.32 & 0.24 \\
\hline roofblei* & Rheofiel (Pelagisch) & 99.54 & 0.05 & 0.31 & 0.14 & 0.15 & 0.35 \\
\hline kesslers grondel* & Eurytoop (Bentisch) & 99.7 & - & - & 0.08 & 0.74 & 0.35 \\
\hline sneep & Rheofiel (Bentisch) & 99.83 & 0.07 & - & 0.14 & 0.15 & 0.39 \\
\hline rivierdonderpad & Rheofiel (Bentisch) & 99.9 & 0.2 & 0.1 & - & - & \\
\hline aal & Eurytoop (Bentisch) & 99.95 & 0.13 & - & 0.06 & - & \\
\hline giebel & Eurytoop (Bentisch) & 99.97 & 0.09 & - & - & - & \\
\hline blauwneus* & Eurytoop (Bentisch) & 99.99 & - & - & 0.07 & - & \\
\hline snoek & Eurytoop (Pelagisch) & 100 & - & 0.06 & - & - & \\
\hline
\end{tabular}


Tabel 2. Soortensamenstelling in percentages op basis van biomassa in boomkorvangsten in de hoofdstroom van de Rijn per 5-jarige periode. De groepering geeft de ecologische indeling aan de hand van Noble et al. (2007) aan. Het cumulatief percentage geeft aan hoeveel de soorten over de gehele periode voorkomen op basis van de gesommeerde CPUE op basis van de biomassa. Nul-percentages zijn naar beneden afgeronde waarden, $*=$ exoot.

\begin{tabular}{|c|c|c|c|c|c|c|c|}
\hline Soort & Groepering & $\begin{array}{l}\text { Cumulatief } \\
\text { percentage }\end{array}$ & $\begin{array}{r}1997- \\
1999 \\
\end{array}$ & $\begin{array}{r}2000- \\
2004 \\
\end{array}$ & $\begin{array}{r}2005- \\
2009 \\
\end{array}$ & $\begin{array}{r}2010- \\
2014 \\
\end{array}$ & $\begin{array}{r}2015- \\
2019 \\
\end{array}$ \\
\hline brasem & Eurytoop (Bentisch) & 58.78 & 37.06 & 67.14 & 74.6 & 45.14 & 28.51 \\
\hline kolblei & Eurytoop (Bentisch) & 84.33 & 57.43 & 15.56 & 12.5 & 18.92 & 0.09 \\
\hline blankvoorn & Eurytoop (Pelagisch) & 90.02 & 1.88 & 7.16 & 4.83 & 7.54 & 27.91 \\
\hline winde & Rheofiel (Pelagisch) & 94.07 & 0.01 & 4.59 & 2.6 & 15.06 & 25.48 \\
\hline snoekbaars & Eurytoop (Bentisch) & 97.28 & 2.33 & 3.63 & 3.42 & 3.67 & 3.9 \\
\hline barbeel & Rheofiel (Bentisch) & 98.72 & 0.19 & 1.08 & 0.65 & 8.42 & 9.24 \\
\hline hybride cyprinide & Eurytoop (Bentisch) & 99.02 & 0.41 & 0.4 & 0.21 & - & 0.05 \\
\hline roofblei* & Rheofiel (Pelagisch) & 99.19 & 0.07 & 0.11 & 0.05 & 0.01 & 2.97 \\
\hline bot & Limnofiel (Bentisch) & 99.33 & 0.23 & 0.04 & 0.18 & - & \\
\hline donaubrasem* & Eurytoop (Bentisch) & 99.45 & - & 0.01 & 0.25 & 0.09 & 0.47 \\
\hline rivierprik & Rheofiel (Bentisch) & 99.53 & 0.14 & 0.11 & 0.03 & 0.08 & \\
\hline pos & Eurytoop (Bentisch) & 99.61 & 0.03 & 0.03 & 0.17 & 0.07 & 0.01 \\
\hline baars & Eurytoop (Pelagisch) & 99.67 & - & 0.05 & 0.05 & 0.27 & 0.3 \\
\hline riviergrondel & Rheofiel (Bentisch) & 99.72 & 0.08 & 0.04 & 0.05 & - & \\
\hline sneep & Rheofiel (Bentisch) & 99.77 & 0.01 & - & 0.07 & 0.01 & 0.55 \\
\hline witvinriviergrondel* & Eurytoop (Bentisch) & 99.81 & - & - & 0.09 & 0.17 & 0.05 \\
\hline aal & Eurytoop (Bentisch) & 99.85 & 0.03 & - & 0.1 & - & \\
\hline blauwneus* & Eurytoop (Bentisch) & 99.89 & - & - & 0.12 & - & \\
\hline zwartbekgrondel* & Eurytoop (Bentisch) & 99.92 & - & - & - & 0.26 & 0.33 \\
\hline alver & Eurytoop (Pelagisch) & 99.94 & 0.04 & 0 & 0.01 & 0.05 & \\
\hline giebel & Eurytoop (Bentisch) & 99.96 & 0.07 & - & - & - & \\
\hline kesslers grondel* & Eurytoop (Bentisch) & 99.98 & - & - & 0.01 & 0.14 & 0.11 \\
\hline snoek & Eurytoop (Pelagisch) & 99.99 & - & 0.04 & - & - & \\
\hline pontische stroomgrondel* & Eurytoop (Bentisch) & 100 & - & - & 0 & 0.1 & 0.03 \\
\hline marmergrondel* & Eurytoop (Bentisch) & 100 & - & - & 0 & 0 & \\
\hline rivierdonderpad & Rheofiel (Bentisch) & 100 & 0 & 0 & - & - & \\
\hline
\end{tabular}


Tabel 3. Soortensamenstelling in percentages op basis van aantal in schepnetvangsten in de hoofdstroom van de Rijn per 5-jarige periode. De groepering geeft de ecologische indeling aan de hand van Noble et al. (2007) aan. Het cumulatief percentage geeft aan hoeveel de soorten over de gehele periode voorkomen op basis van de gesommeerde CPUE op basis van het aantal. Nul-percentages zijn naar beneden afgeronde waarden, $*=$ exoot.

\begin{tabular}{|c|c|c|c|c|c|c|c|}
\hline Soort & Groepering & $\begin{array}{l}\text { Cumulatief } \\
\text { percentage }\end{array}$ & $\begin{array}{r}1997- \\
1999 \\
\end{array}$ & $\begin{array}{r}2000- \\
2004 \\
\end{array}$ & $\begin{array}{r}2005- \\
2009 \\
\end{array}$ & $\begin{array}{r}2010- \\
2014 \\
\end{array}$ & $\begin{array}{r}2015- \\
2019 \\
\end{array}$ \\
\hline blankvoorn & Eurytoop (Pelagisch) & 44.74 & 36.27 & 47.29 & 74.89 & 24.26 & 67.95 \\
\hline zwartbekgrondel* & Eurytoop (Bentisch) & 60.2 & - & - & - & 53.56 & 4.94 \\
\hline alver & Eurytoop (Pelagisch) & 74 & 33.79 & 15.13 & 4.91 & 2.78 & 10.63 \\
\hline winde & Rheofiel (Pelagisch) & 79.55 & 2.38 & 5.14 & 7.74 & 5.48 & 10.03 \\
\hline brasem & Eurytoop (Bentisch) & 83.2 & 1.17 & 6.38 & 7.49 & 1.98 & 1.69 \\
\hline aal & Eurytoop (Bentisch) & 86.54 & 10.44 & 1.99 & - & 1.9 & 0.32 \\
\hline roofblei* & Rheofiel (Pelagisch) & 89.15 & 7.61 & 1.92 & - & 1.54 & 0.32 \\
\hline baars & Eurytoop (Pelagisch) & 91.11 & 0.35 & 3.51 & 1.19 & 2.26 & 1.94 \\
\hline kopvoorn & Rheofiel (Pelagisch) & 92.55 & - & 4.99 & 1.4 & - & - \\
\hline pos & Eurytoop (Bentisch) & 93.72 & 1.04 & 3.83 & - & - & \\
\hline serpeling & Rheofiel (Pelagisch) & 94.7 & - & 3.12 & 0.78 & - & 0.85 \\
\hline snoekbaars & Eurytoop (Bentisch) & 95.59 & 2.26 & 0.89 & 0.72 & - & 0.69 \\
\hline kesslers grondel* & Eurytoop (Bentisch) & 96.43 & - & - & - & 3.01 & \\
\hline kolblei & Eurytoop (Bentisch) & 97.16 & 2.39 & 0.62 & 0.36 & - & - \\
\hline barbeel & Rheofiel (Bentisch) & 97.72 & 0.28 & 2.01 & - & - & - \\
\hline sneep & Rheofiel (Bentisch) & 98.28 & 0.56 & 0.59 & 0.52 & 0.77 & \\
\hline pontische stroomgrondel* & Eurytoop (Bentisch) & 98.71 & - & - & - & 1.55 & \\
\hline driedoornige stekelbaars & Eurytoop (Pelagisch) & 98.97 & - & 0.75 & - & 0.26 & \\
\hline bittervoorn & Limnofiel (Pelagisch) & 99.19 & - & 0.6 & - & 0.26 & \\
\hline rivierdonderpad & Rheofiel (Bentisch) & 99.37 & - & 0.73 & - & - & \\
\hline atlantische forel & Rheofiel (Pelagisch) & 99.52 & 0.7 & - & - & - & \\
\hline snoek & Eurytoop (Pelagisch) & 99.67 & 0.16 & 0.17 & - & - & 0.65 \\
\hline bot & Limnofiel (Bentisch) & 99.8 & 0.59 & - & - & - & \\
\hline hybride cyprinide & Eurytoop (Bentisch) & 99.89 & - & 0.35 & - & - & \\
\hline dwergmeerval sp. & Overige & 99.96 & - & - & - & 0.26 & \\
\hline vetje & Limnofiel (Pelagisch) & 100 & - & - & - & 0.15 & \\
\hline
\end{tabular}


Tabel 4. Soortensamenstelling in percentages op basis van biomassa in schepnetvangsten in de hoofdstroom van de Rijn per 5-jarige periode. De groepering geeft de ecologische indeling aan de hand van Noble et al. (2007) aan. Het cumulatief percentage geeft aan hoeveel de soorten over de gehele periode voorkomen op basis van de gesommeerde CPUE op basis van de biomassa. Nul-percentages zijn naar beneden afgeronde waarden, $*=$ exoot.

\begin{tabular}{|c|c|c|c|c|c|c|c|}
\hline Soort & Groepering & $\begin{array}{l}\text { Cumulatief } \\
\text { percentage }\end{array}$ & $\begin{array}{r}1997- \\
1999 \\
\end{array}$ & $\begin{array}{r}2000- \\
2004 \\
\end{array}$ & $\begin{array}{r}2005- \\
2009 \\
\end{array}$ & $\begin{array}{r}2010- \\
2014 \\
\end{array}$ & $\begin{array}{r}2015- \\
2019 \\
\end{array}$ \\
\hline brasem & Eurytoop (Bentisch) & 31.06 & 16.69 & 26.01 & 56.78 & 19.12 & 2.59 \\
\hline winde & Rheofiel (Pelagisch) & 50.62 & 1.86 & 36.03 & 21.39 & 27.83 & 6.31 \\
\hline snoekbaars & Eurytoop (Bentisch) & 61.91 & 27.19 & 7 & 8.92 & - & 0.55 \\
\hline aal & Eurytoop (Bentisch) & 71.81 & 16.71 & 8.53 & - & 18.43 & 7.3 \\
\hline blankvoorn & Eurytoop (Pelagisch) & 81.26 & 9.49 & 12.22 & 9.98 & 4.02 & 20.06 \\
\hline snoek & Eurytoop (Pelagisch) & 86.44 & 10.97 & 0.46 & - & - & 56.4 \\
\hline zwartbekgrondel* & Eurytoop (Bentisch) & 89.65 & - & - & - & 15.72 & 2.07 \\
\hline roofblei* & Rheofiel (Pelagisch) & 92.57 & 1.9 & 0.44 & - & 11.72 & 0.16 \\
\hline kolblei & Eurytoop (Bentisch) & 95.25 & 9.98 & 0.04 & 0.12 & - & \\
\hline alver & Eurytoop (Pelagisch) & 96.68 & 2.9 & 1.62 & 0.29 & 0.63 & 3.77 \\
\hline kopvoorn & Rheofiel (Pelagisch) & 97.59 & - & 1.56 & 2 & - & \\
\hline baars & Eurytoop (Pelagisch) & 98.38 & 0.06 & 3.61 & 0.1 & 0.34 & 0.59 \\
\hline kesslers grondel* & Eurytoop (Bentisch) & 98.74 & - & - & - & 1.8 & \\
\hline atlantische forel & Rheofiel (Pelagisch) & 99.06 & 1.21 & - & - & - & \\
\hline bot & Limnofiel (Bentisch) & 99.27 & 0.8 & - & - & - & \\
\hline sneep & Rheofiel (Bentisch) & 99.46 & 0.06 & 0.14 & 0.39 & 0.1 & \\
\hline barbeel & Rheofiel (Bentisch) & 99.63 & 0.05 & 0.86 & - & - & \\
\hline serpeling & Rheofiel (Pelagisch) & 99.77 & - & 0.71 & 0.04 & - & 0.21 \\
\hline pos & Eurytoop (Bentisch) & 99.9 & 0.12 & 0.51 & - & - & \\
\hline pontische stroomgrondel* & Eurytoop (Bentisch) & 99.95 & - & - & - & 0.28 & \\
\hline rivierdonderpad & Rheofiel (Bentisch) & 99.98 & - & 0.19 & - & - & \\
\hline driedoornige stekelbaars & Eurytoop (Pelagisch) & 99.99 & - & 0.02 & - & 0.01 & \\
\hline bittervoorn & Limnofiel (Pelagisch) & 100 & - & 0.02 & - & 0.01 & \\
\hline hybride cyprinide & Eurytoop (Bentisch) & 100 & - & 0.01 & - & - & \\
\hline dwergmeerval sp. & Overige & 100 & - & - & - & 0.01 & \\
\hline vetje & Limnofiel (Pelagisch) & 100 & - & - & - & 0 & \\
\hline
\end{tabular}




\section{Bijlage 15 Rijn zijwateren}

Tabel 1. Soortensamenstelling in percentages op basis van aantal in boomkorvangsten in de zijwateren van de Rijn per 5-jarige periode. De groepering geeft de ecologische indeling aan de hand van Noble et al. (2007) aan. Het cumulatief percentage geeft aan hoeveel de soorten over de gehele periode voorkomen op basis van de gesommeerde CPUE op basis van het aantal. Nul-percentages zijn naar beneden afgeronde waarden, $*=$ exoot.

\begin{tabular}{|c|c|c|c|c|c|c|c|}
\hline Soort & Groepering & $\begin{array}{l}\text { Cumulatief } \\
\text { percentage }\end{array}$ & $\begin{array}{r}1997- \\
1999 \\
\end{array}$ & $\begin{array}{r}2000- \\
2004 \\
\end{array}$ & $\begin{array}{r}2005- \\
2009 \\
\end{array}$ & $\begin{array}{r}2010- \\
2014 \\
\end{array}$ & $\begin{array}{r}2015- \\
2019 \\
\end{array}$ \\
\hline brasem & Eurytoop (Bentisch) & 40.8 & 30.37 & 47.37 & 34.51 & 55.09 & 52.89 \\
\hline blankvoorn & Eurytoop (Pelagisch) & 80.77 & 32.29 & 31.84 & 50.28 & 31.13 & 17.1 \\
\hline pos & Eurytoop (Bentisch) & 93.29 & 27.01 & 14.07 & 11.39 & 4.39 & 1.87 \\
\hline snoekbaars & Eurytoop (Bentisch) & 96.01 & 4.28 & 2.66 & 1.8 & 2.61 & 15.9 \\
\hline kolblei & Eurytoop (Bentisch) & 97.35 & 3.91 & 1.81 & 0.55 & 1.12 & 0.35 \\
\hline baars & Eurytoop (Pelagisch) & 98.68 & 0.67 & 1.77 & 0.85 & 2.34 & 2.96 \\
\hline pontische stroomgrondel* & Eurytoop (Bentisch) & 99.01 & - & - & - & 1.54 & 3.29 \\
\hline hybride cyprinide & Eurytoop (Bentisch) & 99.28 & 0.96 & 0.16 & 0.22 & - & 0.45 \\
\hline zwartbekgrondel* & Eurytoop (Bentisch) & 99.52 & - & - & - & 1.09 & 3.03 \\
\hline aal & Eurytoop (Bentisch) & 99.59 & 0.39 & 0.05 & 0.02 & - & - \\
\hline witvinriviergrondel* & Eurytoop (Bentisch) & 99.65 & - & - & 0.14 & - & \\
\hline alver & Eurytoop (Pelagisch) & 99.71 & - & 0.03 & 0.1 & - & 0.47 \\
\hline donaubrasem* & Eurytoop (Bentisch) & 99.77 & - & - & - & 0.35 & \\
\hline roofblei* & Rheofiel (Pelagisch) & 99.83 & - & - & 0.07 & 0.08 & 0.42 \\
\hline winde & Rheofiel (Pelagisch) & 99.86 & 0.06 & - & 0.03 & 0.04 & \\
\hline kesslers grondel* & Eurytoop (Bentisch) & 99.89 & - & - & - & 0.18 & - \\
\hline snoek & Eurytoop (Pelagisch) & 99.92 & - & 0.12 & - & - & \\
\hline blauwneus* & Eurytoop (Bentisch) & 99.94 & - & - & - & - & 1.29 \\
\hline marmergrondel* & Eurytoop (Bentisch) & 99.96 & - & - & 0.04 & - & \\
\hline bot & Limnofiel (Bentisch) & 99.97 & - & 0.04 & - & - & \\
\hline riviergrondel & Rheofiel (Bentisch) & 99.98 & - & 0.04 & - & - & \\
\hline serpeling & Rheofiel (Pelagisch) & 99.99 & - & 0.03 & - & - & \\
\hline rivierprik & Rheofiel (Bentisch) & 99.99 & 0.06 & - & - & - & \\
\hline blauwband* & Limnofiel (Pelagisch) & 100 & - & - & - & 0.04 & \\
\hline
\end{tabular}

Tabel 2. Soortensamenstelling in percentages op basis van biomassa in boomkorvangsten in zijwateren van de Rijn per 5-jarige periode. De groepering geeft de ecologische indeling aan (Noble et al. 2007). Het cumulatief percentage geeft aan hoeveel de soorten over de gehele periode voorkomen op basis van de gesommeerde CPUE op basis van de biomassa. Nul-percentages zijn naar beneden afgeronde waarden, $*=$ exoot.

\begin{tabular}{|c|c|c|c|c|c|c|c|}
\hline Soort & Groepering & $\begin{array}{l}\text { Cumulatief } \\
\text { percentage }\end{array}$ & $\begin{array}{r}1997- \\
1999\end{array}$ & $\begin{array}{r}2000- \\
2004\end{array}$ & $\begin{array}{r}2005- \\
2009\end{array}$ & $\begin{array}{r}2010- \\
2014\end{array}$ & $\begin{array}{r}2015- \\
2019\end{array}$ \\
\hline brasem & Eurytoop (Bentisch) & 62.53 & 61.41 & 64.47 & 60.72 & 70.27 & 47.73 \\
\hline blankvoorn & Eurytoop (Pelagisch) & 78.73 & 9.42 & 15.66 & 22.23 & 16.57 & 14.33 \\
\hline snoekbaars & Eurytoop (Bentisch) & 91.89 & 15.4 & 11.86 & 11.5 & 8.24 & 34.01 \\
\hline kolblei & Eurytoop (Bentisch) & 96.25 & 10.57 & 2.66 & 2.78 & 1.08 & 0.32 \\
\hline pos & Eurytoop (Bentisch) & 97.28 & 1.03 & 1.07 & 1.33 & 0.57 & 0.08 \\
\hline baars & Eurytoop (Pelagisch) & 98.28 & 0.71 & 0.96 & 0.48 & 2.56 & 2.14 \\
\hline snoek & Eurytoop (Pelagisch) & 99.09 & - & 2.95 & - & - & \\
\hline hybride cyprinide & Eurytoop (Bentisch) & 99.46 & 0.8 & 0.25 & 0.31 & - & 0.28 \\
\hline aal & Eurytoop (Bentisch) & 99.73 & 0.63 & 0.05 & 0.34 & - & \\
\hline roofblei* & Rheofiel (Pelagisch) & 99.81 & - & - & 0.24 & 0.02 & 0.03 \\
\hline pontische stroomgrondel* & Eurytoop (Bentisch) & 99.86 & - & - & - & 0.31 & 0.08 \\
\hline blauwneus* & Eurytoop (Bentisch) & 99.9 & - & - & - & - & 0.96 \\
\hline donaubrasem* & Eurytoop (Bentisch) & 99.93 & - & - & - & 0.24 & - \\
\hline bot & Limnofiel (Bentisch) & 99.95 & - & 0.06 & - & - & \\
\hline alver & Eurytoop (Pelagisch) & 99.96 & - & 0 & 0.04 & - & 0.01 \\
\hline zwartbekgrondel* & Eurytoop (Bentisch) & 99.97 & - & - & - & 0.08 & 0.05 \\
\hline witvinriviergrondel* & Eurytoop (Bentisch) & 99.98 & - & - & 0.03 & - & \\
\hline $\begin{array}{r}\text { rivierprik } \\
\end{array}$ & Rheofiel (Bentisch) & 99.99 & 0.03 & - & - & - & \\
\hline winde & Rheofiel (Pelagisch) & 99.99 & 0 & - & 0 & 0.03 & \\
\hline kesslers grondel* & Eurytoop (Bentisch) & 100 & - & - & - & 0.04 & \\
\hline riviergrondel & Rheofiel (Bentisch) & 100 & - & 0 & - & - & \\
\hline serpeling & Rheofiel (Pelagisch) & 100 & - & 0 & - & - & \\
\hline marmergrondel* & Eurytoop (Bentisch) & 100 & - & - & 0 & - & \\
\hline blauwband* & Limnofiel (Pelagisch) & 100 & - & - & - & 0 & \\
\hline
\end{tabular}


Tabel 3. Soortensamenstelling in percentages op basis van aantal in schepnetvangsten in de zijwateren van de Rijn per 5-jarige periode. De groepering geeft de ecologische indeling aan de hand van Noble et al. (2007) aan. Het cumulatief percentage geeft aan hoeveel de soorten over de gehele periode voorkomen op basis van de gesommeerde CPUE op basis van het aantal. Nul-percentages zijn naar beneden afgeronde waarden, $*=$ exoot.

\begin{tabular}{|c|c|c|c|c|c|c|c|}
\hline Soort & Groepering & $\begin{array}{l}\text { Cumulatief } \\
\text { percentage }\end{array}$ & $\begin{array}{r}1997- \\
1999 \\
\end{array}$ & $\begin{array}{r}2000- \\
2004 \\
\end{array}$ & $\begin{array}{r}2005- \\
2009 \\
\end{array}$ & $\begin{array}{r}2010- \\
2014 \\
\end{array}$ & $\begin{array}{r}2015- \\
2019 \\
\end{array}$ \\
\hline blankvoorn & Eurytoop (Pelagisch) & 60.81 & 48.94 & 79.65 & 79.52 & 20.93 & 12.88 \\
\hline zwartbekgrondel* & Eurytoop (Bentisch) & 69.24 & - & - & - & 32.47 & 53.47 \\
\hline pos & Eurytoop (Bentisch) & 75.64 & 19.33 & 5.66 & - & 1.51 & \\
\hline winde & Rheofiel (Pelagisch) & 80.03 & 0.24 & 2.46 & 8.66 & 11.78 & 4.7 \\
\hline roofblei* & Rheofiel (Pelagisch) & 83.53 & 0.7 & 0.62 & - & 13.56 & \\
\hline baars & Eurytoop (Pelagisch) & 86.61 & 2.61 & 2.43 & - & 3.08 & 25.97 \\
\hline snoekbaars & Eurytoop (Bentisch) & 89.48 & 8.49 & 2.15 & 11.82 & 0.86 & \\
\hline aal & Eurytoop (Bentisch) & 91.75 & 7.89 & 1.41 & - & 1.49 & \\
\hline kesslers grondel* & Eurytoop (Bentisch) & 93.75 & - & - & - & 8.67 & 2.98 \\
\hline brasem & Eurytoop (Bentisch) & 95.36 & 1.52 & 2.36 & - & - & \\
\hline alver & Eurytoop (Pelagisch) & 96.39 & 2.65 & 1.01 & - & 0.25 & \\
\hline riviergrondel & Rheofiel (Bentisch) & 97.22 & 4.12 & 0.43 & - & - & \\
\hline marmergrondel* & Eurytoop (Bentisch) & 98 & - & - & - & 3.48 & \\
\hline kolblei & Eurytoop (Bentisch) & 98.43 & 1.82 & 0.3 & - & - & \\
\hline kopvoorn & Rheofiel (Pelagisch) & 98.84 & 0.97 & 0.47 & - & - & \\
\hline serpeling & Rheofiel (Pelagisch) & 99.17 & - & 0.4 & - & 0.41 & \\
\hline snoek & Eurytoop (Pelagisch) & 99.43 & - & 0.43 & - & - & \\
\hline kleine modderkruiper & Eurytoop (Bentisch) & 99.6 & - & - & - & 0.75 & \\
\hline pontische stroomgrondel* & Eurytoop (Bentisch) & 99.71 & - & - & - & 0.51 & \\
\hline $\begin{array}{rr}\text { rivierprik } \\
\end{array}$ & Rheofiel (Bentisch) & 99.78 & 0.24 & 0.06 & - & - & \\
\hline bittervoorn & Limnofiel (Pelagisch) & 99.85 & - & 0.11 & - & - & \\
\hline zeelt & Limnofiel (Bentisch) & 99.9 & - & - & - & 0.25 & \\
\hline bot & Limnofiel (Bentisch) & 99.93 & 0.24 & - & - & - & \\
\hline rietvoorn & Limnofiel (Pelagisch) & 99.97 & 0.24 & - & - & - & \\
\hline hybride cyprinide & Eurytoop (Bentisch) & 100 & - & 0.05 & - & - & \\
\hline
\end{tabular}

Tabel 4. Soortensamenstelling in percentages op basis van biomassa in schepnetvangsten in de zijwateren van de Rijn per 5-jarige periode. De groepering geeft de ecologische indeling aan de hand van Noble et al. (2007) aan. Het cumulatief percentage geeft aan hoeveel de soorten over de gehele periode voorkomen op basis van de gesommeerde CPUE op basis van de biomassa. Nul-percentages zijn naar beneden afgeronde waarden, $*=$ exoot.

\begin{tabular}{|c|c|c|c|c|c|c|c|}
\hline Soort & Groepering & $\begin{array}{l}\text { Cumulatief } \\
\text { percentage }\end{array}$ & $\begin{array}{r}1997- \\
1999\end{array}$ & $\begin{array}{r}2000- \\
2004\end{array}$ & $\begin{array}{r}2005- \\
2009\end{array}$ & $\begin{array}{r}2010- \\
2014\end{array}$ & $\begin{array}{r}2015- \\
2019\end{array}$ \\
\hline snoekbaars & Eurytoop (Bentisch) & 57.02 & 73.58 & 47.21 & 90.93 & 46.16 & \\
\hline blankvoorn & Eurytoop (Pelagisch) & 73.25 & 8.58 & 24.57 & 1.28 & 4.39 & 1.76 \\
\hline brasem & Eurytoop (Bentisch) & 79.85 & 9.3 & 6.88 & - & - & - \\
\hline aal & Eurytoop (Bentisch) & 86.1 & 5.64 & 5.85 & - & 18.38 & - \\
\hline snoek & Eurytoop (Pelagisch) & 92.11 & - & 11.26 & - & - & - \\
\hline baars & Eurytoop (Pelagisch) & 95.09 & 0.87 & 1.56 & - & 0.61 & 91.05 \\
\hline winde & Rheofiel (Pelagisch) & 97.93 & 0.8 & 1.78 & 7.79 & 15.72 & 1.49 \\
\hline zwartbekgrondel* & Eurytoop (Bentisch) & 98.54 & - & - & - & 6.74 & 5.07 \\
\hline pos & Eurytoop (Bentisch) & 98.99 & 0.51 & 0.51 & - & 0.22 & - \\
\hline kesslers grondel* & Eurytoop (Bentisch) & 99.34 & - & - & - & 4.55 & 0.63 \\
\hline roofblei* & Rheofiel (Pelagisch) & 99.6 & 0.02 & 0.13 & - & 2.54 & - \\
\hline riviergrondel & Rheofiel (Bentisch) & 99.71 & 0.24 & 0.07 & - & - & - \\
\hline kolblei & Eurytoop (Bentisch) & 99.76 & 0.11 & 0.04 & - & - & - \\
\hline bot & Limnofiel (Bentisch) & 99.81 & 0.15 & - & - & - & - \\
\hline alver & Eurytoop (Pelagisch) & 99.86 & 0.1 & 0.03 & - & 0.04 & - \\
\hline kopvoorn & Rheofiel (Pelagisch) & 99.9 & 0.05 & 0.05 & - & - & - \\
\hline serpeling & Rheofiel (Pelagisch) & 99.93 & - & 0.04 & - & 0.08 & - \\
\hline rivierprik & Rheofiel (Bentisch) & 99.95 & 0.05 & 0.01 & - & - & - \\
\hline marmergrondel* & Eurytoop (Bentisch) & 99.97 & - & - & - & 0.24 & - \\
\hline pontische stroomgrondel* & Eurytoop (Bentisch) & 99.98 & - & - & - & 0.18 & - \\
\hline hybride cyprinide & Eurytoop (Bentisch) & 99.99 & - & 0.02 & - & - & - \\
\hline $\begin{array}{r}\text { zeelt } \\
\end{array}$ & Limnofiel (Bentisch) & 100 & - & - & - & 0.1 & - \\
\hline kleine modderkruiper & Eurytoop (Bentisch) & 100 & - & - & - & 0.04 & - \\
\hline rietvoorn & Limnofiel (Pelagisch) & 100 & 0 & - & - & - & \\
\hline bittervoorn & Limnofiel (Pelagisch) & 100 & - & 0 & - & - & - \\
\hline
\end{tabular}




\section{Bijlage 16 Grensmaas hoofdstroom}

Tabel 1. Soortensamenstelling in percentages op basis van aantal in schepnetvangsten in de hoofdstroom van de Grensmaas per 5-jarige periode. De groepering geeft de ecologische indeling aan de hand van Noble et al. (2007) aan. Het cumulatief percentage geeft aan hoeveel de soorten over de gehele periode voorkomen op basis van de gesommeerde CPUE op basis van het aantal. Nul-percentages zijn naar beneden afgeronde waarden, $*$ = exoot.

\begin{tabular}{|c|c|c|c|c|c|c|c|}
\hline Soort & Groepering & $\begin{array}{l}\text { Cumulatief } \\
\text { percentage }\end{array}$ & $\begin{array}{r}1997- \\
1999\end{array}$ & $\begin{array}{r}2000- \\
2004\end{array}$ & $\begin{array}{r}2005- \\
2009\end{array}$ & $\begin{array}{r}2010- \\
2014\end{array}$ & $\begin{array}{r}2015- \\
2019\end{array}$ \\
\hline blankvoorn & Eurytoop (Pelagisch) & 23.81 & 26.73 & 53.25 & 12.98 & 13.48 & 10.89 \\
\hline zwartbekgrondel* & Eurytoop (Bentisch) & 42.97 & - & - & - & 1.88 & 54.07 \\
\hline kopvoorn & Rheofiel (Pelagisch) & 58.38 & 14.35 & 18.02 & 24.77 & 17.78 & 9.59 \\
\hline baars & Eurytoop (Pelagisch) & 66.23 & 5.35 & 4.39 & 10.7 & 12.37 & 7.55 \\
\hline aal & Eurytoop (Bentisch) & 73 & 25.33 & 7.89 & 13.4 & 3.78 & 0.66 \\
\hline marmergrondel* & Eurytoop (Bentisch) & 79.25 & - & - & 1.22 & 18.28 & 7.05 \\
\hline bermpje & Rheofiel (Bentisch) & 83.62 & 0.1 & 0.52 & 9.84 & 15.53 & $\overline{0.21}$ \\
\hline riviergrondel & Rheofiel (Bentisch) & 86.76 & 11.57 & 5.8 & 3.6 & 0.86 & 0.11 \\
\hline alver & Eurytoop (Pelagisch) & 88.9 & 7.63 & 2.72 & 0.29 & 1.63 & 1.11 \\
\hline barbeel & Rheofiel (Bentisch) & 90.76 & 2.72 & 1.68 & 5.36 & 2.73 & 0.18 \\
\hline kesslers grondel* & Eurytoop (Bentisch) & 92.03 & - & - & - & - & 3.67 \\
\hline pos & Eurytoop (Bentisch) & 93.25 & 0.99 & 0.65 & 4.18 & 2.37 & 0.13 \\
\hline rivierdonderpad & Rheofiel (Bentisch) & 94.38 & 0.19 & 0.63 & 5.7 & 1.56 & 0.12 \\
\hline sneep & Rheofiel (Bentisch) & 95.34 & 1.2 & 1.03 & 0.7 & 0.85 & 0.97 \\
\hline driedoornige stekelbaars & Eurytoop (Pelagisch) & 96.28 & 0.21 & 0.48 & 0.4 & 1.89 & 1.09 \\
\hline brasem & Eurytoop (Bentisch) & 97.02 & 1.85 & 0.54 & 3.09 & 0.47 & 0.03 \\
\hline winde & Rheofiel (Pelagisch) & 97.55 & 0.05 & 0.28 & 0.77 & 0.99 & 0.51 \\
\hline elrits & Rheofiel (Pelagisch) & 97.87 & - & 0.01 & 0.1 & 1.45 & 0.05 \\
\hline zeelt & Limnofiel (Bentisch) & 98.14 & 0.12 & 0.02 & 0.36 & 0.5 & 0.32 \\
\hline kolblei & Eurytoop (Bentisch) & 98.35 & 0.12 & 0.46 & 0.66 & 0.03 & 0.01 \\
\hline europese meerval & Eurytoop (Bentisch) & 98.54 & 0.03 & - & 0.02 & 0.29 & 0.37 \\
\hline snoek & Eurytoop (Pelagisch) & 98.73 & 0.27 & 0.25 & 0.36 & 0.28 & 0.02 \\
\hline serpeling & Rheofiel (Pelagisch) & 98.9 & 0.16 & 0.43 & 0.09 & 0.07 & 0.06 \\
\hline atlantische forel & Rheofiel (Pelagisch) & 99.06 & 0.07 & 0.09 & 0.07 & 0.05 & 0.32 \\
\hline kleine modderkruiper & Eurytoop (Bentisch) & 99.21 & 0.03 & 0.16 & - & 0.16 & 0.22 \\
\hline bittervoorn & Limnofiel (Pelagisch) & 99.35 & - & 0.02 & 0.26 & 0.21 & 0.18 \\
\hline snoekbaars & Eurytoop (Bentisch) & 99.47 & 0.08 & 0.21 & 0.22 & 0.09 & 0.08 \\
\hline zalm & Rheofiel (Pelagisch) & 99.57 & - & 0.12 & - & 0.15 & 0.11 \\
\hline hybride cyprinide & Eurytoop (Bentisch) & 99.66 & 0.46 & 0.17 & - & - & 0.01 \\
\hline roofblei* & Rheofiel (Pelagisch) & 99.73 & 0.05 & - & 0.13 & 0.17 & 0.05 \\
\hline blauwband* & Limnofiel (Pelagisch) & 99.8 & - & 0.01 & 0.07 & 0.04 & 0.13 \\
\hline zonnebaars* & Limnofiel (Pelagisch) & 99.86 & - & - & 0.6 & - & - \\
\hline karper & Eurytoop (Bentisch) & 99.9 & 0.21 & 0.03 & 0.03 & - & 0.03 \\
\hline rietvoorn & Limnofiel (Pelagisch) & 99.94 & 0.05 & 0.09 & 0.03 & 0.02 & 0.01 \\
\hline kwabaal & Eurytoop (Bentisch) & 99.98 & - & - & - & - & 0.11 \\
\hline giebel & Eurytoop (Bentisch) & 99.98 & - & 0.02 & - & - & - \\
\hline zalm/forel & Rheofiel (Pelagisch) & 99.99 & - & 0.02 & - & - & - \\
\hline vlagzalm & Rheofiel (Pelagisch) & 99.99 & - & - & - & - & 0.01 \\
\hline amerikaanse hondsvis* & Limnofiel (Pelagisch) & 99.99 & 0.03 & - & - & - & - \\
\hline goudvis* & Limnofiel (Bentisch) & 100 & - & 0.01 & - & - & - \\
\hline tiendoornige stekelbaars & Limnofiel (Pelagisch) & 100 & 0.03 & - & - & - & - \\
\hline
\end{tabular}


Tabel 2. Soortensamenstelling in percentages op basis van biomassa in schepnetvangsten in de hoofdstroom van de Grensmaas per 5-jarige periode. De groepering geeft de ecologische indeling aan de hand van Noble et al. (2007) aan. Het cumulatief percentage geeft aan hoeveel de soorten over de gehele periode voorkomen op basis van de gesommeerde CPUE op basis van de biomassa. Nulpercentages zijn naar beneden afgeronde waarden, * = exoot.

\begin{tabular}{|c|c|c|c|c|c|c|c|}
\hline Soort & Groepering & $\begin{array}{l}\text { Cumulatief } \\
\text { percentage }\end{array}$ & $\begin{array}{r}1997- \\
1999 \\
\end{array}$ & $\begin{array}{r}2000- \\
2004 \\
\end{array}$ & $\begin{array}{r}2005- \\
2009 \\
\end{array}$ & $\begin{array}{r}2010- \\
2014 \\
\end{array}$ & $\begin{array}{r}2015- \\
2019 \\
\end{array}$ \\
\hline barbeel & Rheofiel (Bentisch) & 26.4 & 23.92 & 29.39 & 31.74 & 25.44 & 0.1 \\
\hline kopvoorn & Rheofiel (Pelagisch) & 50.47 & 14.08 & 29.21 & 27.96 & 23.13 & 10.45 \\
\hline aal & Eurytoop (Bentisch) & 70.25 & 27.96 & 19.67 & 15.95 & 21.67 & 16.61 \\
\hline brasem & Eurytoop (Bentisch) & 77.08 & 6.48 & 3.27 & 12.11 & 4.74 & 2.57 \\
\hline snoek & Eurytoop (Pelagisch) & 81.63 & 4.12 & 5.82 & 2.58 & 8.1 & 0.31 \\
\hline europese meerval & Eurytoop (Bentisch) & 84.05 & 0.03 & - & 0.52 & 2.32 & 23.74 \\
\hline blankvoorn & Eurytoop (Pelagisch) & 86.39 & 2.74 & 4.41 & 0.38 & 1.29 & 5.47 \\
\hline snoekbaars & Eurytoop (Bentisch) & 88.56 & 1.56 & 3.14 & 1.18 & 1.29 & 6.38 \\
\hline sneep & Rheofiel (Bentisch) & 90.72 & 2 & 1.13 & 3.07 & 2.62 & 1.01 \\
\hline baars & Eurytoop (Pelagisch) & 92.81 & 1.49 & 1.23 & 1.11 & 4.28 & 4.76 \\
\hline karper & Eurytoop (Bentisch) & 94.29 & 9.91 & 0.26 & 0.02 & - & 0.11 \\
\hline zwartbekgrondel* & Eurytoop (Bentisch) & 95.6 & - & - & - & 0.15 & 16.9 \\
\hline winde & Rheofiel (Pelagisch) & 96.72 & 0.73 & 0.3 & 2.09 & 1.16 & 0.37 \\
\hline roofblei* & Rheofiel (Pelagisch) & 97.4 & 1.64 & - & 0 & 1.63 & 1.76 \\
\hline kesslers grondel* & Eurytoop (Bentisch) & 97.83 & - & - & - & - & 5.62 \\
\hline riviergrondel & Rheofiel (Bentisch) & 98.23 & 1.11 & 0.77 & 0.07 & 0.07 & 0.08 \\
\hline zeelt & Limnofiel (Bentisch) & 98.62 & 0.69 & 0 & 0.64 & 0.31 & 0.29 \\
\hline alver & Eurytoop (Pelagisch) & 98.95 & 1.19 & 0.34 & 0.02 & 0.16 & 0.47 \\
\hline bermpje & Rheofiel (Bentisch) & 99.17 & 0 & 0.03 & 0.16 & 0.81 & 0.07 \\
\hline pos & Eurytoop (Bentisch) & 99.29 & 0.07 & 0.06 & 0.12 & 0.26 & 0.05 \\
\hline kolblei & Eurytoop (Bentisch) & 99.4 & 0.14 & 0.19 & 0.13 & 0.01 & 0 \\
\hline hybride cyprinide & Eurytoop (Bentisch) & 99.51 & 0.08 & 0.08 & - & - & 0.94 \\
\hline zalm/forel & Rheofiel (Pelagisch) & 99.61 & - & 0.38 & - & - & - \\
\hline marmergrondel* & Eurytoop (Bentisch) & 99.7 & - & - & 0.01 & 0.3 & 0.4 \\
\hline atlantische forel & Rheofiel (Pelagisch) & 99.78 & 0.01 & 0.12 & 0.01 & 0.06 & 0.46 \\
\hline rivierdonderpad & Rheofiel (Bentisch) & 99.84 & 0.01 & 0.03 & 0.1 & 0.08 & 0.05 \\
\hline kwabaal & Eurytoop (Bentisch) & 99.89 & - & - & - & - & 0.67 \\
\hline serpeling & Rheofiel (Pelagisch) & 99.94 & 0.05 & 0.13 & 0 & 0.02 & 0.03 \\
\hline zalm & Rheofiel (Pelagisch) & 99.96 & - & 0 & - & 0.05 & 0.12 \\
\hline driedoornige stekelbaars & Eurytoop (Pelagisch) & 99.98 & 0 & 0.01 & 0 & 0.03 & 0.09 \\
\hline kleine modderkruiper & Eurytoop (Bentisch) & 99.98 & 0 & 0 & - & 0.01 & 0.04 \\
\hline $\begin{array}{r}\text { elrits } \\
\end{array}$ & Rheofiel (Pelagisch) & 99.99 & - & 0 & 0 & 0.02 & 0 \\
\hline rietvoorn & Limnofiel (Pelagisch) & 99.99 & 0.01 & 0.01 & 0 & 0 & 0 \\
\hline zonnebaars* & Limnofiel (Pelagisch) & 99.99 & - & - & 0.01 & - & - \\
\hline vlagzalm & Rheofiel (Pelagisch) & 100 & - & - & - & - & 0.03 \\
\hline bittervoorn & Limnofiel (Pelagisch) & 100 & - & 0 & 0 & 0 & 0.01 \\
\hline blauwband* & Limnofiel (Pelagisch) & 100 & - & 0 & 0 & 0 & 0.01 \\
\hline giebel & Eurytoop (Bentisch) & 100 & - & 0 & - & - & - \\
\hline amerikaanse hondsvis* & Limnofiel (Pelagisch) & 100 & 0 & - & - & - & - \\
\hline goudvis* & Limnofiel (Bentisch) & 100 & - & 0 & - & - & - \\
\hline tiendoornige stekelbaars & Limnofiel (Pelagisch) & 100 & 0 & - & - & - & - \\
\hline
\end{tabular}




\section{Bijlage 17 Grensmaas zijwateren}

Tabel 1. Soortensamenstelling in percentages op basis van aantal in schepnetvangsten in de zijwateren van de Grensmaas per 5-jarige periode. De groepering geeft de ecologische indeling aan de hand van Noble et al. (2007) aan. Het cumulatief percentage geeft aan hoeveel de soorten over de gehele periode voorkomen op basis van de gesommeerde CPUE op basis van het aantal. Nul-percentages zijn naar beneden afgeronde waarden, $*$ = exoot.

\begin{tabular}{|c|c|c|c|c|c|c|c|}
\hline Soort & Groepering & $\begin{array}{l}\text { Cumulatief } \\
\text { percentage }\end{array}$ & $\begin{array}{r}1997- \\
1999 \\
\end{array}$ & $\begin{array}{r}2000- \\
2004 \\
\end{array}$ & $\begin{array}{r}2005- \\
2009 \\
\end{array}$ & $\begin{array}{r}2010- \\
2014 \\
\end{array}$ & $\begin{array}{r}2015- \\
2019 \\
\end{array}$ \\
\hline bermpje & Rheofiel (Bentisch) & 59.19 & - & - & 47.88 & 56.35 & 70.18 \\
\hline marmergrondel* & Eurytoop (Bentisch) & 69.94 & - & - & 0.8 & 17.93 & 2.6 \\
\hline blankvoorn & Eurytoop (Pelagisch) & 80.03 & 4.09 & 10.61 & 12.74 & 8.47 & 12.34 \\
\hline kopvoorn & Rheofiel (Pelagisch) & 84.25 & 22.22 & 30.3 & 6.02 & 3.17 & 3.06 \\
\hline sneep & Rheofiel (Bentisch) & 86.94 & 14.04 & 27.27 & 1.31 & 1.09 & 2.83 \\
\hline baars & Eurytoop (Pelagisch) & 89.34 & 33.92 & 3.03 & 4.54 & 1.61 & 2.15 \\
\hline driedoornige stekelbaars & Eurytoop (Pelagisch) & 91.25 & - & - & 1.57 & 2.97 & 0.69 \\
\hline riviergrondel & Rheofiel (Bentisch) & 92.85 & 1.75 & 3.03 & 0.81 & 2.39 & 0.45 \\
\hline zwartbekgrondel* & Eurytoop (Bentisch) & 93.72 & - & - & - & 0.06 & 2.13 \\
\hline zeelt & Limnofiel (Bentisch) & 94.56 & 4.09 & 4.55 & 2.08 & 1 & 0.16 \\
\hline alver & Eurytoop (Pelagisch) & 95.37 & - & 9.09 & - & 0.19 & 1.17 \\
\hline serpeling & Rheofiel (Pelagisch) & 96.06 & 4.68 & 3.03 & 0.49 & 0.38 & 0.83 \\
\hline elrits & Rheofiel (Pelagisch) & 96.7 & - & - & 0.97 & 1.1 & 0.05 \\
\hline rivierdonderpad & Rheofiel (Bentisch) & 97.33 & - & - & 1.24 & 1.05 & 0.07 \\
\hline barbeel & Rheofiel (Bentisch) & 97.75 & 1.75 & - & 0.27 & 0.35 & 0.51 \\
\hline brasem & Eurytoop (Bentisch) & 98.08 & 7.6 & 3.03 & 1.84 & 0.18 & \\
\hline pos & Eurytoop (Bentisch) & 98.41 & - & - & 6.86 & 0.26 & 0.04 \\
\hline bittervoorn & Limnofiel (Pelagisch) & 98.69 & - & - & - & 0.53 & \\
\hline aal & Eurytoop (Bentisch) & 98.97 & 2.92 & - & 4.43 & 0.18 & 0.07 \\
\hline rietvoorn & Limnofiel (Pelagisch) & 99.12 & 1.17 & 3.03 & 0.27 & 0.01 & 0.08 \\
\hline winde & Rheofiel (Pelagisch) & 99.25 & - & - & 0.54 & 0.09 & 0.18 \\
\hline kleine modderkruiper & Eurytoop (Bentisch) & 99.37 & - & - & - & 0.2 & 0.03 \\
\hline kolblei & Eurytoop (Bentisch) & 99.49 & - & - & 1.08 & 0.17 & \\
\hline blauwband* & Limnofiel (Pelagisch) & 99.61 & - & - & 2.48 & 0.05 & 0.06 \\
\hline karper & Eurytoop (Bentisch) & 99.68 & - & 1.52 & - & 0.04 & 0.02 \\
\hline hybride cyprinide & Eurytoop (Bentisch) & 99.74 & - & 1.52 & - & 0.01 & 0.05 \\
\hline kesslers grondel* & Eurytoop (Bentisch) & 99.81 & - & - & - & - & 0.16 \\
\hline giebel & Eurytoop (Bentisch) & 99.86 & 1.75 & - & - & 0.05 & \\
\hline snoek & Eurytoop (Pelagisch) & 99.9 & - & - & 1.24 & 0.01 & 0.01 \\
\hline atlantische forel & Rheofiel (Pelagisch) & 99.93 & - & - & - & 0.01 & 0.07 \\
\hline zonnebaars* & Limnofiel (Pelagisch) & 99.96 & - & - & 0.53 & 0.02 & \\
\hline europese meerval & Eurytoop (Bentisch) & 99.97 & - & - & - & 0.02 & \\
\hline gestippelde alver & Rheofiel (Pelagisch) & 99.98 & - & - & - & 0.01 & - \\
\hline vetje & Limnofiel (Pelagisch) & 99.99 & - & - & - & 0.01 & - \\
\hline zalm & Rheofiel (Pelagisch) & 99.99 & - & - & - & 0.01 & \\
\hline roofblei* & Rheofiel (Pelagisch) & 100 & - & - & - & - & 0.01 \\
\hline
\end{tabular}


Tabel 2. Soortensamenstelling in percentages op basis van biomassa in schepnetvangsten in de zijwateren van de Grensmaas per 5-jarige periode. De groepering geeft de ecologische indeling aan de hand van Noble et al. (2007) aan. Het cumulatief percentage geeft aan hoeveel de soorten over de gehele periode voorkomen op basis van de gesommeerde CPUE op basis van de biomassa. Nulpercentages zijn naar beneden afgeronde waarden, * = exoot.

\begin{tabular}{|c|c|c|c|c|c|c|c|}
\hline Soort & Groepering & $\begin{array}{l}\text { Cumulatief } \\
\text { percentage }\end{array}$ & $\begin{array}{r}1997- \\
1999\end{array}$ & $\begin{array}{r}2000- \\
2004\end{array}$ & $\begin{array}{r}2005- \\
2009\end{array}$ & $\begin{array}{r}2010- \\
2014\end{array}$ & $\begin{array}{r}2015- \\
2019\end{array}$ \\
\hline kopvoorn & Rheofiel (Pelagisch) & 35.73 & 41.39 & 46.36 & 6.42 & 7.39 & 7.03 \\
\hline sneep & Rheofiel (Bentisch) & 59.21 & 29.01 & 29.01 & 0.04 & 1.5 & 13.23 \\
\hline zeelt & Limnofiel (Bentisch) & 68.58 & 8.92 & 13.33 & 0.42 & 1.3 & 0.27 \\
\hline blankvoorn & Eurytoop (Pelagisch) & 75.08 & 0.16 & 0.55 & 2.57 & 14.1 & 42.5 \\
\hline brasem & Eurytoop (Bentisch) & 81.03 & 10.17 & 3.13 & 30.3 & 10.56 & \\
\hline bermpje & Rheofiel (Bentisch) & 86.31 & - & - & 3.46 & 31.3 & 19.69 \\
\hline karper & Eurytoop (Bentisch) & 90.79 & - & 5.65 & - & 13.87 & 0.04 \\
\hline barbeel & Rheofiel (Bentisch) & 92.81 & 6.02 & - & 12.46 & 2.06 & 1.4 \\
\hline snoek & Eurytoop (Pelagisch) & 94.41 & - & - & 19.05 & 1.14 & 6.48 \\
\hline aal & Eurytoop (Bentisch) & 95.78 & 0.57 & - & 18.06 & 4.14 & 1.21 \\
\hline rietvoorn & Limnofiel (Pelagisch) & 96.91 & 1.7 & 1.41 & 0 & 0.01 & 0.09 \\
\hline baars & Eurytoop (Pelagisch) & 97.87 & 1.38 & 0.16 & 0.52 & 3.11 & 2.57 \\
\hline riviergrondel & Rheofiel (Bentisch) & 98.23 & 0.03 & 0.07 & 0.07 & 2.81 & 0.38 \\
\hline serpeling & Rheofiel (Pelagisch) & 98.58 & 0.16 & 0.06 & 0.06 & 1.79 & 1.02 \\
\hline alver & Eurytoop (Pelagisch) & 98.86 & - & 0.2 & - & 0.2 & 1.37 \\
\hline marmergrondel* & Eurytoop (Bentisch) & 99.11 & - & - & 0.05 & 2.4 & 0.23 \\
\hline winde & Rheofiel (Pelagisch) & 99.36 & - & - & 4.37 & 0.26 & 0.36 \\
\hline zwartbekgrondel* & Eurytoop (Bentisch) & 99.48 & - & - & - & 0.01 & 1.08 \\
\hline giebel & Eurytoop (Bentisch) & 99.58 & 0.49 & - & - & 0.08 & \\
\hline kesslers grondel* & Eurytoop (Bentisch) & 99.65 & - & - & - & - & 0.6 \\
\hline rivierdonderpad & Rheofiel (Bentisch) & 99.71 & - & - & 0.07 & 0.6 & 0.04 \\
\hline kolblei & Eurytoop (Bentisch) & 99.77 & - & - & 1.23 & 0.13 & \\
\hline pos & Eurytoop (Bentisch) & 99.83 & - & - & 0.78 & 0.22 & 0.02 \\
\hline atlantische forel & Rheofiel (Pelagisch) & 99.88 & - & - & - & 0.29 & 0.2 \\
\hline hybride cyprinide & Eurytoop (Bentisch) & 99.92 & - & 0.06 & - & 0.03 & 0.04 \\
\hline driedoornige stekelbaars & Eurytoop (Pelagisch) & 99.95 & - & - & 0.03 & 0.24 & 0.1 \\
\hline elrits & Rheofiel (Pelagisch) & 99.97 & - & - & 0.01 & 0.17 & 0.01 \\
\hline bittervoorn & Limnofiel (Pelagisch) & 99.98 & - & - & - & 0.12 & \\
\hline kleine modderkruiper & Eurytoop (Bentisch) & 99.99 & - & - & - & 0.09 & 0.01 \\
\hline blauwband* & Limnofiel (Pelagisch) & 99.99 & - & - & 0.02 & 0.01 & 0.01 \\
\hline europese meerval & Eurytoop (Bentisch) & 99.99 & - & - & - & 0.03 & \\
\hline roofblei* & Rheofiel (Pelagisch) & 100 & - & - & - & - & 0.02 \\
\hline zalm & Rheofiel (Pelagisch) & 100 & - & - & - & 0.02 & \\
\hline zonnebaars* & Limnofiel (Pelagisch) & 100 & - & - & 0 & 0.01 & \\
\hline gestippelde alver & Rheofiel (Pelagisch) & 100 & - & - & - & 0 & \\
\hline vetje & Limnofiel (Pelagisch) & 100 & - & - & - & 0 & \\
\hline
\end{tabular}




\section{Bijlage 18 Zandmaas hoofdstroom}

Tabel 1. Soortensamenstelling in percentages op basis van aantal in boomkorvangsten in de hoofdstroom van de Zandmaas per 5-jarige periode. De groepering geeft de ecologische indeling aan de hand van Noble et al. (2007) aan. Het cumulatief percentage geeft aan hoeveel de soorten over de gehele periode voorkomen op basis van de gesommeerde CPUE op basis van het aantal. Nul-percentages zijn naar beneden afgeronde waarden, $*=$ exoot.

\begin{tabular}{|c|c|c|c|c|}
\hline Groepering & Cumulatief percentage & $2005-2009$ & $2010-2014$ & 2015-2019 \\
\hline blankvoorn Eurytoop (Pelagisch) & 31.29 & 28.44 & 28.3 & 34.63 \\
\hline brasem Eurytoop (Bentisch) & 50.22 & 25.34 & 23.86 & 12.49 \\
\hline zwartbekgrondel* Eurytoop (Bentisch) & 61.36 & - & 2.43 & 22.42 \\
\hline baars Eurytoop (Pelagisch) & 69.65 & 3.65 & 16.81 & 5.88 \\
\hline pos Eurytoop (Bentisch) & 77.77 & 21.95 & 7.96 & 0.52 \\
\hline snoekbaars Eurytoop (Bentisch) & 82.98 & 4.87 & 4.44 & 5.86 \\
\hline kolblei Eurytoop (Bentisch) & 87.02 & 5.92 & 7.47 & 0.98 \\
\hline pontische stroomgrondel* Eurytoop (Bentisch) & 89.77 & - & - & 5.88 \\
\hline alver Eurytoop (Pelagisch) & 91.98 & 0.17 & 0.31 & 4.47 \\
\hline winde Rheofiel (Pelagisch) & 93.91 & 1.69 & 1.64 & 2.22 \\
\hline Rheofiel (Bentisch) & 95.35 & 2.4 & 3 & - \\
\hline witvinriviergrondel* Eurytoop (Bentisch) & 96.53 & 3.55 & 0.84 & 0.07 \\
\hline zalm Rheofiel (Pelagisch) & 97.31 & 0.55 & 0.22 & 1.24 \\
\hline marmergrondel* Eurytoop (Bentisch) & 97.98 & - & 0.72 & 1 \\
\hline spiering Eurytoop (Pelagisch) & 98.28 & 0.05 & 0.29 & 0.45 \\
\hline europese meerval Eurytoop (Bentisch) & 98.53 & 0.13 & 0.12 & 0.39 \\
\hline roofblei* Rheofiel (Pelagisch) & 98.75 & - & 0.2 & 0.36 \\
\hline $\begin{array}{ll}\text { rivierprik } & \text { Rheofiel (Bentisch) } \\
\end{array}$ & 98.97 & 0.68 & 0.11 & 0.03 \\
\hline kesslers grondel* Eurytoop (Bentisch) & 99.16 & - & 0.24 & 0.27 \\
\hline kopvoorn Rheofiel (Pelagisch) & 99.29 & 0.23 & - & 0.14 \\
\hline hybride cyprinide Eurytoop (Bentisch) & 99.4 & 0.12 & - & 0.18 \\
\hline aal Eurytoop (Bentisch) & 99.5 & 0.08 & 0.22 & 0.04 \\
\hline riviergrondel Rheofiel (Bentisch) & 99.59 & - & 0.05 & 0.17 \\
\hline karper Eurytoop (Bentisch) & 99.67 & - & 0.14 & 0.09 \\
\hline snoek Eurytoop (Pelagisch) & 99.75 & 0.07 & 0.12 & 0.06 \\
\hline kleine modderkruiper Eurytoop (Bentisch) & 99.81 & - & 0.14 & 0.03 \\
\hline barbeel Rheofiel (Bentisch) & 99.84 & - & - & 0.07 \\
\hline $\begin{aligned} & \text { sneep } \text { Rheofiel (Bentisch) } \\
&\end{aligned}$ & 99.87 & - & 0.05 & 0.03 \\
\hline donaubrasem* Eurytoop (Bentisch) & 99.89 & - & 0.11 & \\
\hline bermpje Rheofiel (Bentisch) & 99.91 & - & 0.06 & - \\
\hline giebel Eurytoop (Bentisch) & 99.93 & - & 0.06 & - \\
\hline blauwband* Limnofiel (Pelagisch) & 99.94 & 0.06 & - & - \\
\hline serpeling Rheofiel (Pelagisch) & 99.96 & 0.06 & - & \\
\hline rietvoorn Limnofiel (Pelagisch) & 99.97 & - & - & 0.03 \\
\hline driedoornige stekelbaars Eurytoop (Pelagisch) & 99.99 & - & 0.05 & \\
\hline bittervoorn Limnofiel (Pelagisch) & 100 & - & 0.05 & \\
\hline
\end{tabular}


Tabel 2. Soortensamenstelling in percentages op basis van biomassa in boomkorvangsten in de hoofdstroom van de Zandmaas per 5 -jarige periode. De groepering geeft de ecologische indeling aan de hand van Noble et al. (2007) aan. Het cumulatief percentage geeft aan hoeveel de soorten over de gehele periode voorkomen op basis van de gesommeerde CPUE op basis van de biomassa. Nul-percentages zijn naar beneden afgeronde waarden, $*$ exoot.

\begin{tabular}{|c|c|c|c|c|c|}
\hline Soort & Groepering & Cumulatief percentage & $2005-2009$ & $2010-2014$ & $2015-2019$ \\
\hline brasem & Eurytoop (Bentisch) & 49.13 & 66.23 & 44.58 & 35.14 \\
\hline blankvoorn & Eurytoop (Pelagisch) & 63.91 & 12.14 & 6.72 & 21.81 \\
\hline snoekbaars & Eurytoop (Bentisch) & 74.76 & 8.1 & 9.45 & 14.3 \\
\hline kolblei & Eurytoop (Bentisch) & 80.28 & 5.84 & 12.18 & 1.5 \\
\hline europese meerval & Eurytoop (Bentisch) & 85.27 & 0.76 & 1.66 & 10.93 \\
\hline winde & Rheofiel (Pelagisch) & 90.12 & 4.29 & 6.98 & 4.19 \\
\hline karper & Eurytoop (Bentisch) & 94.71 & - & 14.5 & 3.53 \\
\hline baars & Eurytoop (Pelagisch) & 96.85 & 1 & 1.62 & 3.54 \\
\hline snoek & Eurytoop (Pelagisch) & 97.79 & 0.46 & 0.22 & 1.79 \\
\hline zwartbekgrondel* & Eurytoop (Bentisch) & 98.16 & - & 0.05 & 0.92 \\
\hline aal & Eurytoop (Bentisch) & 98.47 & 0.07 & 0.94 & 0.18 \\
\hline pos & Eurytoop (Bentisch) & 98.69 & 0.36 & 0.34 & 0.04 \\
\hline barbeel & Rheofiel (Bentisch) & 98.9 & - & - & 0.52 \\
\hline alver & Eurytoop (Pelagisch) & 99.1 & 0.01 & 0.03 & 0.49 \\
\hline kopvoorn & Rheofiel (Pelagisch) & 99.31 & 0.47 & - & 0.06 \\
\hline roofblei* & Rheofiel (Pelagisch) & 99.44 & - & 0.04 & 0.32 \\
\hline pontische stroomgrondel* & Eurytoop (Bentisch) & 99.57 & - & - & 0.32 \\
\hline hybride cyprinide & Eurytoop (Bentisch) & 99.66 & 0.04 & - & 0.2 \\
\hline zalm & Rheofiel (Pelagisch) & 99.74 & 0.04 & 0.02 & 0.13 \\
\hline giebel & Eurytoop (Bentisch) & 99.81 & - & 0.33 & \\
\hline rivierprik & Rheofiel (Bentisch) & 99.86 & 0.11 & 0.03 & 0.01 \\
\hline donaubrasem* & Eurytoop (Bentisch) & 99.91 & - & 0.22 & \\
\hline witvinriviergrondel* & Eurytoop (Bentisch) & 99.94 & 0.07 & 0.02 & $\overline{0}$ \\
\hline kesslers grondel* & Eurytoop (Bentisch) & 99.96 & - & 0.01 & 0.05 \\
\hline rivierdonderpad & Rheofiel (Bentisch) & 99.98 & 0.02 & 0.04 & \\
\hline spiering & Eurytoop (Pelagisch) & 99.99 & 0 & 0 & 0.01 \\
\hline marmergrondel* & Eurytoop (Bentisch) & 99.99 & - & 0.01 & 0.01 \\
\hline riviergrondel & Rheofiel (Bentisch) & 99.99 & - & 0 & 0.01 \\
\hline rietvoorn & Limnofiel (Pelagisch) & 100 & - & - & 0.01 \\
\hline sneep & Rheofiel (Bentisch) & 100 & - & 0 & 0 \\
\hline serpeling & Rheofiel (Pelagisch) & 100 & 0 & - & \\
\hline kleine modderkruiper & Eurytoop (Bentisch) & 100 & - & 0 & \\
\hline bermpje & Rheofiel (Bentisch) & 100 & - & 0 & \\
\hline bittervoorn & Limnofiel (Pelagisch) & 100 & - & 0 & \\
\hline blauwband* & Limnofiel (Pelagisch) & 100 & 0 & - & \\
\hline driedoornige stekelbaars & Eurytoop (Pelagisch) & 100 & - & 0 & \\
\hline
\end{tabular}


Tabel 3. Soortensamenstelling in percentages op basis van aantal in schepnetvangsten in de hoofdstroom van de Zandmaas per 5-jarige periode. De groepering geeft de ecologische indeling aan de hand van Noble et al. (2007) aan. Het cumulatief percentage geeft aan hoeveel de soorten over de gehele periode voorkomen op basis van de gesommeerde CPUE op basis van het aantal. Nul-percentages zijn naar beneden afgeronde waarden, $*=$ exoot.

\begin{tabular}{|c|c|c|c|c|}
\hline Groepering & Cumulatief percentage & $2005-2009$ & $2010-2014$ & $2015-2019$ \\
\hline zwartbekgrondel* Eurytoop (Bentisch) & 68.69 & - & 32.62 & 89.38 \\
\hline blankvoorn Eurytoop (Pelagisch) & 78.35 & 36.29 & 20.23 & 2.98 \\
\hline aal Eurytoop (Bentisch) & 82.44 & 6.23 & 4.34 & 3.8 \\
\hline Eurytoop (Bentisch) & 85.92 & 1.78 & 9.74 & 1.16 \\
\hline Rheofiel (Bentisch) & 88.64 & 10.48 & 7.61 & 0.07 \\
\hline Eurytoop (Bentisch) & 91.15 & 18.57 & 5.07 & \\
\hline Eurytoop (Bentisch) & 93.18 & - & 5.92 & 0.67 \\
\hline Rheofiel (Pelagisch) & 94.9 & 4.53 & 3.03 & 0.94 \\
\hline Rheofiel (Bentisch) & 96.3 & 4.69 & 4.18 & - \\
\hline baars Eurytoop (Pelagisch) & 97.49 & 8.11 & 2.49 & 0.03 \\
\hline bittervoorn Limnofiel (Pelagisch) & 97.91 & - & 1.55 & - \\
\hline blauwband* Limnofiel (Pelagisch) & 98.26 & 0.26 & 0.56 & 0.28 \\
\hline kopvoorn Rheofiel (Pelagisch) & 98.5 & 0.87 & 0.61 & 0.03 \\
\hline alver Eurytoop (Pelagisch) & 98.7 & 2.32 & 0.05 & 0.07 \\
\hline pontische stroomgrondel* Eurytoop (Bentisch) & 98.88 & - & - & 0.27 \\
\hline zeelt Limnofiel (Bentisch) & 99.05 & - & 0.64 & \\
\hline snoekbaars Eurytoop (Bentisch) & 99.21 & 2.48 & - & - \\
\hline Rheofiel (Bentisch) & 99.35 & - & 0.55 & \\
\hline roofblei* Rheofiel (Pelagisch) & 99.48 & - & - & 0.19 \\
\hline snoek Eurytoop (Pelagisch) & 99.56 & 0.94 & 0.09 & \\
\hline brasem Eurytoop (Bentisch) & 99.64 & - & 0.28 & \\
\hline rietvoorn Limnofiel (Pelagisch) & 99.71 & 0.32 & - & 0.07 \\
\hline zalm Rheofiel (Pelagisch) & 99.77 & 0.91 & - & \\
\hline serpeling Rheofiel (Pelagisch) & 99.82 & 0.58 & 0.06 & \\
\hline witvinriviergrondel* Eurytoop (Bentisch) & 99.87 & 0.32 & 0.11 & \\
\hline $\begin{array}{ll}\text { rivierprik Rheofiel (Bentisch) } \\
\end{array}$ & 99.91 & - & - & 0.07 \\
\hline driedoornige stekelbaars Eurytoop (Pelagisch) & 99.95 & - & 0.15 & \\
\hline zonnebaars* Limnofiel (Pelagisch) & 99.98 & - & 0.11 & \\
\hline sneep Rheofiel (Bentisch) & 100 & 0.33 & - & \\
\hline
\end{tabular}


Tabel 4. Soortensamenstelling in percentages op basis van biomassa in schepnetvangsten in de hoofdstroom van de Zandmaas per 5-jarige periode. De groepering geeft de ecologische indeling aan de hand van Noble et al. (2007) aan. Het cumulatief percentage geeft aan hoeveel de soorten over de gehele periode voorkomen op basis van de gesommeerde CPUE op basis van de biomassa. Nul-percentages zijn naar beneden afgeronde waarden, $*=$ exoot.

\begin{tabular}{|c|c|c|c|c|c|}
\hline Soort & Groepering & Cumulatief percentage & $2005-2009$ & $2010-2014$ & 2015-2019 \\
\hline aal & Eurytoop (Bentisch) & 50.02 & 24.57 & 43.04 & 67.15 \\
\hline zwartbekgrondel* & Eurytoop (Bentisch) & 63.58 & - & 4.33 & 26.64 \\
\hline winde & Rheofiel (Pelagisch) & 74.68 & 21.03 & 14.68 & 3.81 \\
\hline snoek & Eurytoop (Pelagisch) & 82.32 & 0.46 & 23.01 & \\
\hline snoekbaars & Eurytoop (Bentisch) & 89.6 & 33.58 & - & \\
\hline blankvoorn & Eurytoop (Pelagisch) & 94.04 & 14 & 3.01 & 0.92 \\
\hline kesslers grondel* & Eurytoop (Bentisch) & 95.43 & - & 2.75 & 1.09 \\
\hline brasem & Eurytoop (Bentisch) & 96.61 & - & 3.58 & \\
\hline baars & Eurytoop (Pelagisch) & 97.36 & 0.75 & 1.8 & 0.01 \\
\hline kopvoorn & Rheofiel (Pelagisch) & 98.11 & 2.77 & 0.42 & 0.02 \\
\hline pos & Eurytoop (Bentisch) & 98.72 & 1.5 & 0.87 & \\
\hline bermpje & Rheofiel (Bentisch) & 99.16 & 0.62 & 0.95 & 0 \\
\hline marmergrondel* & Eurytoop (Bentisch) & 99.38 & 0.06 & 0.5 & 0.08 \\
\hline rivierdonderpad & Rheofiel (Bentisch) & 99.58 & 0.22 & 0.49 & \\
\hline barbeel & Rheofiel (Bentisch) & 99.67 & - & 0.27 & \\
\hline roofblei* & Rheofiel (Pelagisch) & 99.73 & - & - & 0.14 \\
\hline zeelt & Limnofiel (Bentisch) & 99.79 & - & 0.17 & \\
\hline zalm & Rheofiel (Pelagisch) & 99.84 & 0.24 & - & \\
\hline alver & Eurytoop (Pelagisch) & 99.87 & 0.06 & 0.01 & 0.04 \\
\hline rietvoorn & Limnofiel (Pelagisch) & 99.9 & 0 & - & 0.05 \\
\hline zonnebaars* & Limnofiel (Pelagisch) & 99.91 & - & 0.06 & \\
\hline serpeling & Rheofiel (Pelagisch) & 99.93 & 0.05 & 0.01 & \\
\hline pontische stroomgrondel* & Eurytoop (Bentisch) & 99.94 & - & - & 0.03 \\
\hline witvinriviergrondel* & Eurytoop (Bentisch) & 99.96 & 0.04 & 0.01 & \\
\hline bittervoorn & Limnofiel (Pelagisch) & 99.97 & - & 0.04 & \\
\hline blauwband* & Limnofiel (Pelagisch) & 99.98 & 0 & 0.02 & 0.01 \\
\hline rivierprik & Rheofiel (Bentisch) & 99.99 & - & - & 0.02 \\
\hline sneep & Rheofiel (Bentisch) & 100 & 0.04 & - & \\
\hline driedoornige stekelbaars & Eurytoop (Pelagisch) & 100 & - & 0 & \\
\hline
\end{tabular}




\section{Bijlage 19 Zandmaas zijwateren}

Tabel 1. Soortensamenstelling in percentages op basis van aantal in boomkorvangsten in de zijwateren van de Zandmaas per 5-jarige periode. De groepering geeft de ecologische indeling aan de hand van Noble et al. (2007) aan. Het cumulatief percentage geeft aan hoeveel de soorten over de gehele periode voorkomen op basis van de gesommeerde CPUE op basis van het aantal. Nul-percentages zijn naar beneden afgeronde waarden, $*=$ exoot.

\begin{tabular}{|c|c|c|c|c|c|}
\hline Soort & Groepering & Cumulatief percentage & $2005-2009$ & $2010-2014$ & $2015-2019$ \\
\hline blankvoorn & Eurytoop (Pelagisch) & 52.18 & 35.86 & 53.64 & 57.57 \\
\hline brasem & Eurytoop (Bentisch) & 71.09 & 25.24 & 21.79 & 14.25 \\
\hline pos & Eurytoop (Bentisch) & 81.34 & 24.8 & 10.69 & 4.14 \\
\hline baars & Eurytoop (Pelagisch) & 90.35 & 8.4 & 7.92 & 10.07 \\
\hline alver & Eurytoop (Pelagisch) & 92.57 & 0.16 & 0.45 & 4.35 \\
\hline snoekbaars & Eurytoop (Bentisch) & 94.78 & 3.32 & 1.52 & 2.29 \\
\hline zwartbekgrondel* & Eurytoop (Bentisch) & 96.45 & - & 0.31 & 3.34 \\
\hline pontische stroomgrondel* & Eurytoop (Bentisch) & 97.41 & - & 0.03 & 2.03 \\
\hline kolblei & Eurytoop (Bentisch) & 98.15 & 0.63 & 1.62 & 0.13 \\
\hline winde & Rheofiel (Pelagisch) & 98.63 & 0.29 & 0.51 & 0.54 \\
\hline spiering & Eurytoop (Pelagisch) & 99.05 & 0.29 & 0.75 & 0.23 \\
\hline roofblei* & Rheofiel (Pelagisch) & 99.33 & - & 0.08 & 0.55 \\
\hline hybride cyprinide & Eurytoop (Bentisch) & 99.49 & 0.46 & 0.19 & 0.03 \\
\hline marmergrondel* & Eurytoop (Bentisch) & 99.64 & 0.02 & 0.14 & 0.18 \\
\hline sneep & Rheofiel (Bentisch) & 99.73 & 0.02 & 0.01 & 0.18 \\
\hline rivierdonderpad & Rheofiel (Bentisch) & 99.78 & 0.17 & 0.06 & \\
\hline witvinriviergrondel* & Eurytoop (Bentisch) & 99.83 & 0.12 & 0.08 & \\
\hline aal & Eurytoop (Bentisch) & 99.88 & 0.11 & 0.08 & \\
\hline snoek & Eurytoop (Pelagisch) & 99.92 & 0.05 & 0.02 & 0.06 \\
\hline zeelt & Limnofiel (Bentisch) & 99.94 & 0.04 & 0.04 & \\
\hline europese meerval & Eurytoop (Bentisch) & 99.96 & - & 0.03 & 0.01 \\
\hline kesslers grondel* & Eurytoop (Bentisch) & 99.97 & - & 0.01 & 0.01 \\
\hline karper & Eurytoop (Bentisch) & 99.98 & - & - & 0.02 \\
\hline beekprik & Rheofiel (Bentisch) & 99.98 & - & - & 0.01 \\
\hline zonnebaars* & Limnofiel (Pelagisch) & 99.99 & - & 0.01 & \\
\hline $\begin{array}{ll}\text { rietvoorn } \\
\end{array}$ & Limnofiel (Pelagisch) & 99.99 & - & 0.01 & \\
\hline tiendoornige stekelbaars & Limnofiel (Pelagisch) & 100 & 0.02 & - & \\
\hline bermpje & Rheofiel (Bentisch) & 100 & 0.02 & - & \\
\hline
\end{tabular}


Tabel 2. Soortensamenstelling in percentages op basis van biomassa in boomkorvangsten in de zijwateren van de Zandmaas per 5-jarige periode. De groepering geeft de ecologische indeling aan de hand van Noble et al. (2007) aan. Het cumulatief percentage geeft aan hoeveel de soorten over de gehele periode voorkomen op basis van de gesommeerde CPUE op basis van de biomassa. Nulpercentages zijn naar beneden afgeronde waarden, * = exoot.

\begin{tabular}{|c|c|c|c|c|c|}
\hline Soort & Groepering & Cumulatief percentage & $2005-2009$ & $2010-2014$ & $2015-2019$ \\
\hline brasem & Eurytoop (Bentisch) & 44.61 & 55.27 & 53.98 & 24.15 \\
\hline blankvoorn & Eurytoop (Pelagisch) & 70.88 & 21.43 & 21.3 & 36.28 \\
\hline snoekbaars & Eurytoop (Bentisch) & 82.07 & 11.33 & 10.48 & 11.71 \\
\hline baars & Eurytoop (Pelagisch) & 88.65 & 4.73 & 2.67 & 12.36 \\
\hline kolblei & Eurytoop (Bentisch) & 91.97 & 1.95 & 7.48 & 0.72 \\
\hline karper & Eurytoop (Bentisch) & 94.19 & - & - & 6.75 \\
\hline pos & Eurytoop (Bentisch) & 95.45 & 1.51 & 1.38 & 0.88 \\
\hline alver & Eurytoop (Pelagisch) & 96.61 & 0.03 & 0.15 & 3.33 \\
\hline aal & Eurytoop (Bentisch) & 97.41 & 0.86 & 1.56 & \\
\hline snoek & Eurytoop (Pelagisch) & 98.13 & 0.94 & 0.2 & 0.99 \\
\hline winde & Rheofiel (Pelagisch) & 98.83 & 1.02 & 0.47 & 0.59 \\
\hline hybride cyprinide & Eurytoop (Bentisch) & 99.22 & 0.89 & 0.14 & 0.08 \\
\hline zwartbekgrondel* & Eurytoop (Bentisch) & 99.47 & - & 0.03 & 0.75 \\
\hline pontische stroomgrondel* & Eurytoop (Bentisch) & 99.63 & - & 0 & 0.47 \\
\hline europese meerval & Eurytoop (Bentisch) & 99.76 & - & 0 & 0.39 \\
\hline roofblei* & Rheofiel (Pelagisch) & 99.88 & - & 0.03 & 0.34 \\
\hline sneep & Rheofiel (Bentisch) & 99.93 & 0 & 0 & 0.16 \\
\hline spiering & Eurytoop (Pelagisch) & 99.97 & 0.01 & 0.05 & 0.04 \\
\hline zeelt & Limnofiel (Bentisch) & 99.98 & 0 & 0.04 & \\
\hline marmergrondel* & Eurytoop (Bentisch) & 99.99 & 0 & 0.01 & 0.01 \\
\hline kesslers grondel* & Eurytoop (Bentisch) & 99.99 & - & 0.01 & 0.01 \\
\hline rivierdonderpad & Rheofiel (Bentisch) & 100 & 0.01 & 0 & \\
\hline witvinriviergrondel* & Eurytoop (Bentisch) & 100 & 0 & 0 & \\
\hline beekprik & Rheofiel (Bentisch) & 100 & - & - & 0 \\
\hline bermpje & Rheofiel (Bentisch) & 100 & 0 & - & - \\
\hline tiendoornige stekelbaars & Limnofiel (Pelagisch) & 100 & 0 & - & - \\
\hline zonnebaars* & Limnofiel (Pelagisch) & 100 & - & 0 & - \\
\hline rietvoorn & Limnofiel (Pelagisch) & 100 & - & 0 & \\
\hline
\end{tabular}


Tabel 3. Soortensamenstelling in percentages op basis van aantal in schepnetvangsten in de zijwateren van de Zandmaas per 5-jarige periode. De groepering geeft de ecologische indeling aan de hand van Noble et al. (2007) aan. Het cumulatief percentage geeft aan hoeveel de soorten over de gehele periode voorkomen op basis van de gesommeerde CPUE op basis van het aantal. Nul-percentages zijn naar beneden afgeronde waarden, $*=$ exoot.

\begin{tabular}{|c|c|c|c|c|c|}
\hline Soort & Groepering & Cumulatief percentage & 2005-2009 & $2010-2014$ & $2015-2019$ \\
\hline zwartbekgrondel* & Eurytoop (Bentisch) & 36.84 & - & 4.23 & 60.65 \\
\hline blankvoorn & Eurytoop (Pelagisch) & 61.77 & 30.49 & 43.45 & 13.59 \\
\hline baars & Eurytoop (Pelagisch) & 71.26 & 30.9 & 11.23 & 5.45 \\
\hline marmergrondel* & Eurytoop (Bentisch) & 76.59 & 0.15 & 7.72 & 4.7 \\
\hline bermpje & Rheofiel (Bentisch) & 80.08 & 4.94 & 8.84 & 0.24 \\
\hline aal & Eurytoop (Bentisch) & 83.16 & 8.88 & 2.84 & 2.39 \\
\hline blauwband* & Limnofiel (Pelagisch) & 85.54 & 1.51 & 0.95 & 3.33 \\
\hline zeelt & Limnofiel (Bentisch) & 87.52 & 3.62 & 3.75 & 0.74 \\
\hline winde & Rheofiel (Pelagisch) & 89.37 & 1.53 & 3.3 & 1.07 \\
\hline kopvoorn & Rheofiel (Pelagisch) & 90.72 & 0.72 & 1.56 & 1.33 \\
\hline brasem & Eurytoop (Bentisch) & 92.06 & 0.83 & 3.46 & 0.2 \\
\hline pos & Eurytoop (Bentisch) & 93.34 & 5.5 & 1.59 & 0.5 \\
\hline driedoornige stekelbaars & Eurytoop (Pelagisch) & 94.38 & 1.59 & 1.58 & 0.65 \\
\hline rietvoorn & Limnofiel (Pelagisch) & 95.41 & 2.39 & 0.35 & 1.23 \\
\hline bittervoorn & Limnofiel (Pelagisch) & 96.33 & 0.65 & 0.87 & 0.99 \\
\hline kleine modderkruiper & Eurytoop (Bentisch) & 97.07 & 0.56 & 0.56 & 0.86 \\
\hline snoek & Eurytoop (Pelagisch) & 97.61 & 3.06 & 0.24 & 0.36 \\
\hline kesslers grondel* & Eurytoop (Bentisch) & 98.01 & - & 0.39 & 0.46 \\
\hline rivierdonderpad & Rheofiel (Bentisch) & 98.38 & 1.24 & 0.8 & \\
\hline kolblei & Eurytoop (Bentisch) & 98.66 & - & 0.11 & 0.42 \\
\hline alver & Eurytoop (Pelagisch) & 98.92 & 0.2 & 0.58 & 0.08 \\
\hline roofblei* & Rheofiel (Pelagisch) & 99.16 & - & 0.55 & 0.1 \\
\hline snoekbaars & Eurytoop (Bentisch) & 99.31 & 0.56 & 0.27 & 0.02 \\
\hline vetje & Limnofiel (Pelagisch) & 99.43 & - & 0.03 & 0.18 \\
\hline europese meerval & Eurytoop (Bentisch) & 99.52 & - & 0.08 & 0.12 \\
\hline hybride cyprinide & Eurytoop (Bentisch) & 99.61 & 0.42 & 0.15 & \\
\hline beekprik & Rheofiel (Bentisch) & 99.69 & - & - & 0.14 \\
\hline tiendoornige stekelbaars & Limnofiel (Pelagisch) & 99.77 & - & 0.11 & 0.06 \\
\hline sneep & Rheofiel (Bentisch) & 99.81 & - & 0.14 & \\
\hline rivierprik & Rheofiel (Bentisch) & 99.85 & - & 0.03 & 0.05 \\
\hline riviergrondel & Rheofiel (Bentisch) & 99.89 & - & 0.1 & \\
\hline barbeel & Rheofiel (Bentisch) & 99.91 & - & 0.08 & \\
\hline prik sp. & Rheofiel (Bentisch) & 99.94 & 0.21 & 0.03 & \\
\hline giebel & Eurytoop (Bentisch) & 99.97 & - & - & 0.04 \\
\hline serpeling & Rheofiel (Pelagisch) & 99.99 & 0.06 & - & 0.03 \\
\hline witvinriviergrondel* & Eurytoop (Bentisch) & 100 & - & 0.03 & \\
\hline
\end{tabular}


Tabel 4. Soortensamenstelling in percentages op basis van biomassa in schepnetvangsten in de zijwateren van de Zandmaas per 5-jarige periode. De groepering geeft de ecologische indeling aan de hand van Noble et al. (2007) aan. Het cumulatief percentage geeft aan hoeveel de soorten over de gehele periode voorkomen op basis van de gesommeerde CPUE op basis van de biomassa. Nul-percentages zijn naar beneden afgeronde waarden, $*=$ exoot

\begin{tabular}{|c|c|c|c|c|c|}
\hline Soort & Groepering & Cumulatief percentage & $2005-2009$ & $2010-2014$ & $2015-2019$ \\
\hline aal & Eurytoop (Bentisch) & 37.54 & 36.42 & 33.54 & 41.74 \\
\hline snoek & Eurytoop (Pelagisch) & 60.96 & 43.44 & 6.4 & 25.45 \\
\hline brasem & Eurytoop (Bentisch) & 71.81 & 3.14 & 27.02 & 1.7 \\
\hline snoekbaars & Eurytoop (Bentisch) & 77.76 & 6.68 & 9.94 & 2 \\
\hline zwartbekgrondel* & Eurytoop (Bentisch) & 83.01 & - & 0.74 & 12.53 \\
\hline blankvoorn & Eurytoop (Pelagisch) & 87.02 & 1.72 & 5.62 & 4.09 \\
\hline baars & Eurytoop (Pelagisch) & 90.96 & 2.57 & 5.46 & 3.48 \\
\hline winde & Rheofiel (Pelagisch) & 94.27 & 2.35 & 4.3 & 3.06 \\
\hline zeelt & Limnofiel (Bentisch) & 96.83 & 2.72 & 3.78 & 1.39 \\
\hline kesslers grondel* & Eurytoop (Bentisch) & 97.39 & - & 0.4 & 1.08 \\
\hline kopvoorn & Rheofiel (Pelagisch) & 97.88 & 0.13 & 0.31 & 0.88 \\
\hline europese meerval & Eurytoop (Bentisch) & 98.34 & - & 0.09 & 1.08 \\
\hline bermpje & Rheofiel (Bentisch) & 98.78 & 0.22 & 1.04 & 0.05 \\
\hline marmergrondel* & Eurytoop (Bentisch) & 99.05 & 0 & 0.42 & 0.3 \\
\hline pos & Eurytoop (Bentisch) & 99.28 & 0.31 & 0.25 & 0.18 \\
\hline kolblei & Eurytoop (Bentisch) & 99.41 & - & 0.11 & 0.21 \\
\hline rietvoorn & Limnofiel (Pelagisch) & 99.52 & 0.16 & 0.01 & 0.17 \\
\hline blauwband* & Limnofiel (Pelagisch) & 99.61 & 0.01 & 0.04 & 0.19 \\
\hline kleine modderkruiper & Eurytoop (Bentisch) & 99.7 & 0.01 & 0.06 & 0.16 \\
\hline roofblei* & Rheofiel (Pelagisch) & 99.76 & - & 0.14 & 0.04 \\
\hline rivierdonderpad & Rheofiel (Bentisch) & 99.82 & 0.07 & 0.12 & \\
\hline bittervoorn & Limnofiel (Pelagisch) & 99.86 & 0.01 & 0.04 & 0.06 \\
\hline driedoornige stekelbaars & Eurytoop (Pelagisch) & 99.9 & 0.01 & 0.05 & 0.03 \\
\hline alver & Eurytoop (Pelagisch) & 99.92 & 0 & 0.06 & 0.01 \\
\hline giebel & Eurytoop (Bentisch) & 99.94 & - & - & 0.06 \\
\hline barbeel & Rheofiel (Bentisch) & 99.95 & - & 0.03 & \\
\hline beekprik & Rheofiel (Bentisch) & 99.96 & - & - & 0.03 \\
\hline serpeling & Rheofiel (Pelagisch) & 99.97 & 0 & - & 0.02 \\
\hline riviergrondel & Rheofiel (Bentisch) & 99.98 & - & 0.02 & \\
\hline rivierprik & Rheofiel (Bentisch) & 99.99 & - & 0 & 0.01 \\
\hline hybride cyprinide & Eurytoop (Bentisch) & 99.99 & 0 & 0 & \\
\hline prik sp. & Rheofiel (Bentisch) & 99.99 & 0.01 & 0 & - \\
\hline vetje & Limnofiel (Pelagisch) & 100 & - & 0 & $\underline{0}$ \\
\hline sneep & Rheofiel (Bentisch) & 100 & - & 0.01 & - \\
\hline tiendoornige stekelbaars & Limnofiel (Pelagisch) & 100 & - & 0 & 0 \\
\hline witvinriviergrondel* & Eurytoop (Bentisch) & 100 & - & 0 & - \\
\hline
\end{tabular}




\section{Bijlage 20 Bovenloop Nederrijn hoofdstroom}

Tabel 1. Soortensamenstelling in percentages op basis van aantal in boomkorvangsten in de hoofdstroom van de Bovenloop Nederrijn per 5-jarige periode. De groepering geeft de ecologische indeling aan de hand van Noble et al. (2007) aan. Het cumulatief percentage geeft aan hoeveel de soorten over de gehele periode voorkomen op basis van de gesommeerde CPUE op basis van het aantal. Nul-percentages zijn naar beneden afgeronde waarden, $*$ = exoot.

\begin{tabular}{|c|c|c|c|c|c|c|c|}
\hline Soort & Groepering & $\begin{array}{l}\text { Cumulatief } \\
\text { percentage }\end{array}$ & $\begin{array}{r}1997- \\
1999 \\
\end{array}$ & $\begin{array}{r}2000- \\
2004 \\
\end{array}$ & $\begin{array}{r}2005- \\
2009 \\
\end{array}$ & $\begin{array}{r}2010- \\
2014 \\
\end{array}$ & $\begin{array}{r}2015- \\
2019 \\
\end{array}$ \\
\hline brasem & Eurytoop (Bentisch) & 48.6 & 48.13 & 56.64 & 23.79 & 21.21 & 29.8 \\
\hline blankvoorn & Eurytoop (Pelagisch) & 76.68 & 23.5 & 28.02 & 35 & 47.26 & 29.63 \\
\hline kolblei & Eurytoop (Bentisch) & 86.84 & 17.33 & 5.83 & 12.79 & 1.22 & 2.22 \\
\hline pos & Eurytoop (Bentisch) & 91.78 & 6.18 & 3.24 & 12.77 & 1.45 & - \\
\hline riviergrondel & Rheofiel (Bentisch) & 93.83 & 2.28 & 1.89 & 3.08 & 0.29 & 2.31 \\
\hline baars & Eurytoop (Pelagisch) & 95.11 & 0.53 & 1.58 & 1.84 & 1.93 & 3.42 \\
\hline snoekbaars & Eurytoop (Bentisch) & 96.1 & 0.93 & 0.83 & 1.41 & 1.48 & 3.1 \\
\hline pontische stroomgrondel* & Eurytoop (Bentisch) & 97.05 & - & - & - & 16.22 & 6.63 \\
\hline winde & Rheofiel (Pelagisch) & 97.84 & 0.13 & 0.9 & 0.62 & 1.47 & 11.79 \\
\hline alver & Eurytoop (Pelagisch) & 98.35 & 0.36 & 0.32 & 1.21 & 2.2 & - \\
\hline witvinriviergrondel* & Eurytoop (Bentisch) & 98.82 & - & - & 4.72 & 0.66 & 2.17 \\
\hline zwartbekgrondel* & Eurytoop (Bentisch) & 99.04 & - & - & - & 2.79 & 5.3 \\
\hline roofblei* & Rheofiel (Pelagisch) & 99.25 & 0.17 & 0.15 & 0.47 & 0.51 & 0.72 \\
\hline rivierprik & Rheofiel (Bentisch) & 99.38 & 0.02 & 0.02 & 1.43 & - & - \\
\hline aal & Eurytoop (Bentisch) & 99.52 & 0.03 & 0.24 & - & 0.08 & - \\
\hline hybride cyprinide & Eurytoop (Bentisch) & 99.63 & 0.13 & 0.11 & 0.13 & - & 0.37 \\
\hline sneep & Rheofiel (Bentisch) & 99.71 & 0.05 & 0.04 & - & 0.49 & 0.72 \\
\hline barbeel & Rheofiel (Bentisch) & 99.78 & 0.03 & 0.05 & 0.19 & 0.1 & 0.74 \\
\hline rivierdonderpad & Rheofiel (Bentisch) & 99.85 & 0.1 & 0.04 & 0.18 & - & - \\
\hline snoek & Eurytoop (Pelagisch) & 99.88 & 0.06 & 0.02 & - & 0.19 & - \\
\hline serpeling & Rheofiel (Pelagisch) & 99.91 & - & 0.05 & - & - & - \\
\hline kesslers grondel* & Eurytoop (Bentisch) & 99.94 & - & - & - & 0.35 & 0.37 \\
\hline rietvoorn & Limnofiel (Pelagisch) & 99.95 & 0.02 & 0.01 & - & - & - \\
\hline driedoornige stekelbaars & Eurytoop (Pelagisch) & 99.96 & - & - & 0.13 & - & - \\
\hline marmergrondel* & Eurytoop (Bentisch) & 99.96 & - & - & 0.06 & - & - \\
\hline bot & Limnofiel (Bentisch) & 99.97 & - & - & 0.06 & - & - \\
\hline blauwneus* & Eurytoop (Bentisch) & 99.97 & - & - & 0.06 & - & - \\
\hline kopvoorn & Rheofiel (Pelagisch) & 99.98 & - & - & - & - & 0.37 \\
\hline noordzeehouting & Limnofiel (Pelagisch) & 99.98 & - & - & 0.06 & - & - \\
\hline europese meerval & Eurytoop (Bentisch) & 99.99 & - & - & - & - & 0.34 \\
\hline vetje & Limnofiel (Pelagisch) & 99.99 & - & - & - & 0.09 & - \\
\hline kleine modderkruiper & Eurytoop (Bentisch) & 100 & 0.01 & - & - & - & - \\
\hline zeeprik & Rheofiel (Bentisch) & 100 & 0.01 & - & - & - & - \\
\hline
\end{tabular}


Tabel 2. Soortensamenstelling in percentages op basis van biomassa in boomkorvangsten in de hoofdstroom van de Bovenloop Nederrijn per 5-jarige periode. De groepering geeft de ecologische indeling aan de hand van Noble et al. (2007) aan. Het cumulatief percentage geeft aan hoeveel de soorten over de gehele periode voorkomen op basis van de gesommeerde CPUE op basis van de biomassa. Nul-percentages zijn naar beneden afgeronde waarden, $*=$ exoot.

\begin{tabular}{|c|c|c|c|c|c|c|c|}
\hline Soort & Groepering & $\begin{array}{l}\text { Cumulatief } \\
\text { percentage }\end{array}$ & $\begin{array}{r}1997- \\
1999\end{array}$ & $\begin{array}{r}2000- \\
2004\end{array}$ & $\begin{array}{r}2005- \\
2009\end{array}$ & $\begin{array}{r}2010- \\
2014\end{array}$ & $\begin{array}{r}2015- \\
2019\end{array}$ \\
\hline brasem & Eurytoop (Bentisch) & 51.89 & 49.58 & 54.98 & 55.03 & 27.58 & 56.47 \\
\hline kolblei & Eurytoop (Bentisch) & 71.35 & 25.17 & 19.31 & 19.66 & 8.75 & 1.48 \\
\hline blankvoorn & Eurytoop (Pelagisch) & 87.78 & 18.4 & 13.86 & 15.16 & 28.83 & 13.91 \\
\hline snoekbaars & Eurytoop (Bentisch) & 92.29 & 3.97 & 4.15 & 3.49 & 11.87 & 6.24 \\
\hline winde & Rheofiel (Pelagisch) & 94.88 & 0.12 & 1.52 & 1.93 & 9.08 & 15.11 \\
\hline barbeel & Rheofiel (Bentisch) & 96.67 & 0.01 & 1.83 & 2.66 & 6.19 & 4.58 \\
\hline baars & Eurytoop (Pelagisch) & 97.48 & 0.62 & 1.05 & 0.22 & 3.6 & 0.42 \\
\hline aal & Eurytoop (Bentisch) & 98.09 & 0.1 & 1.74 & - & 0.37 & \\
\hline pos & Eurytoop (Bentisch) & 98.67 & 0.67 & 0.66 & 0.62 & 0.27 & \\
\hline snoek & Eurytoop (Pelagisch) & 98.95 & 0.66 & 0.12 & - & 0.02 & \\
\hline roofblei* & Rheofiel (Pelagisch) & 99.16 & 0.04 & 0.06 & 0.61 & 0.78 & 0.27 \\
\hline hybride cyprinide & Eurytoop (Bentisch) & 99.37 & 0.25 & 0.29 & 0.1 & - & 0.05 \\
\hline riviergrondel & Rheofiel (Bentisch) & 99.55 & 0.2 & 0.27 & 0.11 & 0.03 & 0.02 \\
\hline pontische stroomgrondel* & Eurytoop (Bentisch) & 99.64 & - & - & - & 1.72 & 0.12 \\
\hline alver & Eurytoop (Pelagisch) & 99.73 & 0.04 & 0.08 & 0.11 & 0.54 & \\
\hline europese meerval & Eurytoop (Bentisch) & 99.8 & - & - & - & - & 0.84 \\
\hline witvinriviergrondel* & Eurytoop (Bentisch) & 99.85 & - & - & 0.2 & 0.06 & 0.04 \\
\hline zeeprik & Rheofiel (Bentisch) & 99.88 & 0.11 & - & - & - & \\
\hline rietvoorn & Limnofiel (Pelagisch) & 99.91 & 0.04 & 0.03 & - & - & \\
\hline sneep & Rheofiel (Bentisch) & 99.93 & 0 & 0.02 & - & 0.08 & 0.09 \\
\hline rivierprik & Rheofiel (Bentisch) & 99.94 & 0.01 & 0.01 & 0.05 & - & \\
\hline kopvoorn & Rheofiel (Pelagisch) & 99.96 & - & - & - & - & 0.21 \\
\hline zwartbekgrondel* & Eurytoop (Bentisch) & 99.97 & - & - & - & 0.16 & 0.06 \\
\hline kesslers grondel* & Eurytoop (Bentisch) & 99.98 & - & - & - & 0.08 & 0.08 \\
\hline bot & Limnofiel (Bentisch) & 99.99 & - & - & 0.02 & - & \\
\hline rivierdonderpad & Rheofiel (Bentisch) & 99.99 & 0 & 0 & 0 & - & \\
\hline serpeling & Rheofiel (Pelagisch) & 99.99 & - & 0.01 & - & - & \\
\hline noordzeehouting & Limnofiel (Pelagisch) & 100 & - & - & 0.02 & - & \\
\hline blauwneus* & Eurytoop (Bentisch) & 100 & - & - & 0.01 & - & \\
\hline marmergrondel* & Eurytoop (Bentisch) & 100 & - & - & 0 & - & \\
\hline driedoornige stekelbaars & Eurytoop (Pelagisch) & 100 & - & - & 0 & - & \\
\hline kleine modderkruiper & Eurytoop (Bentisch) & 100 & 0 & - & - & - & \\
\hline vetje & Limnofiel (Pelagisch) & 100 & - & - & - & 0 & \\
\hline
\end{tabular}


Tabel 3. Soortensamenstelling in percentages op basis van aantal in schepnetvangsten in de hoofdstroom van de Bovenloop Nederrijn per 5-jarige periode. De groepering geeft de ecologische indeling aan de hand van Noble et al. (2007) aan. Het cumulatief percentage geeft aan hoeveel de soorten over de gehele periode voorkomen op basis van de gesommeerde CPUE op basis van het aantal. Nul-percentages zijn naar beneden afgeronde waarden, $*=$ exoot.

\begin{tabular}{|c|c|c|c|c|c|c|c|}
\hline Soort & Groepering & $\begin{array}{l}\text { Cumulatief } \\
\text { percentage }\end{array}$ & $\begin{array}{r}1997- \\
1999 \\
\end{array}$ & $\begin{array}{r}2000- \\
2004 \\
\end{array}$ & $\begin{array}{r}2005- \\
2009 \\
\end{array}$ & $\begin{array}{r}2010- \\
2014 \\
\end{array}$ & $\begin{array}{r}2015- \\
2019 \\
\end{array}$ \\
\hline blankvoorn & Eurytoop (Pelagisch) & 53.17 & 60.71 & 48.24 & 71.56 & 20.23 & 63.1 \\
\hline baars & Eurytoop (Pelagisch) & 67.71 & 18.14 & 15.46 & 11.49 & 13.06 & 8.89 \\
\hline winde & Rheofiel (Pelagisch) & 78.73 & 2.61 & 16.29 & 8.52 & 2.63 & 13.04 \\
\hline zwartbekgrondel* & Eurytoop (Bentisch) & 83.78 & - & - & - & 51.01 & 6.44 \\
\hline pos & Eurytoop (Bentisch) & 87.53 & 6.62 & 4.22 & 2.27 & 1.39 & 0.11 \\
\hline alver & Eurytoop (Pelagisch) & 90.22 & 2.33 & 3.58 & 2.67 & 0.26 & 0.72 \\
\hline brasem & Eurytoop (Bentisch) & 92.18 & 0.81 & 3.09 & 1.22 & 1.01 & 0.11 \\
\hline kolblei & Eurytoop (Bentisch) & 94.02 & 0.86 & 3.31 & 0.19 & 0.26 & 0.38 \\
\hline aal & Eurytoop (Bentisch) & 95.39 & 3.7 & 0.66 & 0.23 & 2.89 & 1.59 \\
\hline kopvoorn & Rheofiel (Pelagisch) & 96.38 & 0.55 & 1.7 & 0.12 & 0.36 & 0.27 \\
\hline roofblei* & Rheofiel (Pelagisch) & 97.08 & 0.95 & 0.83 & 0.32 & 0.1 & 0.88 \\
\hline driedoornige stekelbaars & Eurytoop (Pelagisch) & 97.48 & 0.09 & 0.35 & 0.68 & 0.17 & 1.18 \\
\hline snoekbaars & Eurytoop (Bentisch) & 97.84 & 0.58 & 0.3 & 0.08 & 0.84 & 0.34 \\
\hline kesslers grondel* & Eurytoop (Bentisch) & 98.21 & - & - & - & 3.91 & 0.11 \\
\hline barbeel & Rheofiel (Bentisch) & 98.52 & 0.26 & 0.55 & - & - & \\
\hline snoek & Eurytoop (Pelagisch) & 98.79 & 0.43 & 0.21 & - & 0.51 & 0.79 \\
\hline serpeling & Rheofiel (Pelagisch) & 99.01 & 0.03 & 0.4 & 0.13 & - & \\
\hline marmergrondel* & Eurytoop (Bentisch) & 99.2 & - & - & 0.1 & 0.87 & 1.38 \\
\hline zeelt & Limnofiel (Bentisch) & 99.38 & 0.25 & 0.21 & 0.06 & 0.22 & \\
\hline hybride cyprinide & Eurytoop (Bentisch) & 99.51 & 0.38 & 0.13 & - & - & \\
\hline riviergrondel & Rheofiel (Bentisch) & 99.61 & 0.26 & 0.12 & - & - & \\
\hline bittervoorn & Limnofiel (Pelagisch) & 99.71 & - & 0.07 & 0.31 & 0.06 & \\
\hline sneep & Rheofiel (Bentisch) & 99.77 & 0.11 & 0.08 & - & - & \\
\hline rietvoorn & Limnofiel (Pelagisch) & 99.82 & 0.17 & 0.06 & - & - & \\
\hline europese meerval & Eurytoop (Bentisch) & 99.87 & - & - & - & 0.15 & 0.53 \\
\hline tiendoornige stekelbaars & Limnofiel (Pelagisch) & 99.92 & 0.04 & 0.05 & - & - & 0.13 \\
\hline rivierdonderpad & Rheofiel (Bentisch) & 99.95 & - & 0.07 & - & - & \\
\hline giebel & Eurytoop (Bentisch) & 99.97 & 0.06 & 0.03 & - & - & \\
\hline rivierprik & Rheofiel (Bentisch) & 99.99 & 0.07 & - & - & - & \\
\hline atlantische forel & Rheofiel (Pelagisch) & 99.99 & - & - & 0.04 & - & \\
\hline pontische stroomgrondel* & Eurytoop (Bentisch) & 100 & - & - & - & 0.06 & \\
\hline
\end{tabular}


Tabel 4. Soortensamenstelling in percentages op basis van biomassa in schepnetvangsten in de hoofdstroom van de Bovenloop Nederrijn per 5-jarige periode. De groepering geeft de ecologische indeling aan de hand van Noble et al. (2007) aan. Het cumulatief percentage geeft aan hoeveel de soorten over de gehele periode voorkomen op basis van de gesommeerde CPUE op basis van de biomassa. Nul-percentages zijn naar beneden afgeronde waarden, * = exoot.

\begin{tabular}{|c|c|c|c|c|c|c|c|}
\hline Soort & Groepering & $\begin{array}{l}\text { Cumulatief } \\
\text { percentage }\end{array}$ & $\begin{array}{r}1997- \\
1999\end{array}$ & $\begin{array}{r}2000- \\
2004\end{array}$ & $\begin{array}{r}2005- \\
2009\end{array}$ & $\begin{array}{r}2010- \\
2014\end{array}$ & $\begin{array}{r}2015- \\
2019\end{array}$ \\
\hline blankvoorn & Eurytoop (Pelagisch) & 23.98 & 32.66 & 25.01 & 45.62 & 2.08 & 15.59 \\
\hline snoek & Eurytoop (Pelagisch) & 39.61 & 8.89 & 15.44 & - & 17.84 & 52.67 \\
\hline brasem & Eurytoop (Bentisch) & 53.65 & 11.24 & 11.21 & 26.89 & 22.16 & 4.61 \\
\hline winde & Rheofiel (Pelagisch) & 65.16 & 6.6 & 13.45 & 10.05 & 17.28 & 4.13 \\
\hline aal & Eurytoop (Bentisch) & 74.8 & 16.98 & 4.88 & 4.3 & 11.37 & 15.81 \\
\hline baars & Eurytoop (Pelagisch) & 82.73 & 12.21 & 8.77 & 5.84 & 2.29 & 5.03 \\
\hline snoekbaars & Eurytoop (Bentisch) & 89.09 & 2.06 & 5.92 & 0.07 & 19.12 & 0.16 \\
\hline kolblei & Eurytoop (Bentisch) & 94.3 & 5.23 & 9.17 & 0.15 & 0.22 & 0.13 \\
\hline kopvoorn & Rheofiel (Pelagisch) & 95.78 & 1.06 & 2.56 & 0.02 & 0.75 & 0.02 \\
\hline pos & Eurytoop (Bentisch) & 96.79 & 1.23 & 1.34 & 1.18 & 0.22 & 0.04 \\
\hline zwartbekgrondel* & Eurytoop (Bentisch) & 97.79 & - & - & - & 5.25 & 1.21 \\
\hline atlantische forel & Rheofiel (Pelagisch) & 98.24 & - & - & 5.04 & - & \\
\hline alver & Eurytoop (Pelagisch) & 98.66 & 0.29 & 0.67 & 0.54 & 0.08 & 0.04 \\
\hline roofblei* & Rheofiel (Pelagisch) & 98.97 & 0.22 & 0.53 & 0.14 & 0.01 & 0.16 \\
\hline kesslers grondel* & Eurytoop (Bentisch) & 99.18 & - & - & - & 1.21 & 0.07 \\
\hline rietvoorn & Limnofiel (Pelagisch) & 99.37 & 0.4 & 0.21 & - & - & \\
\hline barbeel & Rheofiel (Bentisch) & 99.52 & 0.1 & 0.3 & - & - & - \\
\hline zeelt & Limnofiel (Bentisch) & 99.66 & 0.1 & 0.24 & 0.01 & 0.08 & \\
\hline hybride cyprinide & Eurytoop (Bentisch) & 99.76 & 0.3 & 0.06 & - & - & \\
\hline giebel & Eurytoop (Bentisch) & 99.85 & 0.37 & 0.01 & - & - & \\
\hline serpeling & Rheofiel (Pelagisch) & 99.9 & 0.01 & 0.11 & 0.06 & - & \\
\hline riviergrondel & Rheofiel (Bentisch) & 99.94 & 0.03 & 0.06 & - & - & \\
\hline europese meerval & Eurytoop (Bentisch) & 99.96 & - & - & - & 0.02 & 0.22 \\
\hline sneep & Rheofiel (Bentisch) & 99.97 & 0.02 & 0.02 & - & - & \\
\hline driedoornige stekelbaars & Eurytoop (Pelagisch) & 99.98 & 0 & 0.01 & 0.04 & 0 & 0.05 \\
\hline marmergrondel* & Eurytoop (Bentisch) & 99.99 & - & - & 0.03 & 0.02 & 0.05 \\
\hline rivierdonderpad & Rheofiel (Bentisch) & 99.99 & - & 0.01 & - & - & \\
\hline bittervoorn & Limnofiel (Pelagisch) & 100 & - & 0 & 0.03 & 0 & \\
\hline tiendoornige stekelbaars & Limnofiel (Pelagisch) & 100 & 0 & 0 & - & - & 0.01 \\
\hline rivierprik & Rheofiel (Bentisch) & 100 & 0 & - & - & - & \\
\hline pontische stroomgrondel* & Eurytoop (Bentisch) & 100 & - & - & - & 0 & \\
\hline
\end{tabular}




\section{Bijlage 21 Bovenloop Nederrijn zijwateren}

Tabel 1. Soortensamenstelling in percentages op basis van aantal in boomkorvangsten in de zijwateren van de Bovenloop Nederrijn per 5-jarige periode. De groepering geeft de ecologische indeling aan de hand van Noble et al. (2007) aan. Het cumulatief percentage geeft aan hoeveel de soorten over de gehele periode voorkomen op basis van de gesommeerde CPUE op basis van het aantal. Nul-percentages zijn naar beneden afgeronde waarden, $*$ = exoot.

\begin{tabular}{|c|c|c|c|c|c|c|c|}
\hline Soort & Groepering & $\begin{array}{l}\text { Cumulatief } \\
\text { percentage }\end{array}$ & $\begin{array}{r}1997- \\
1999\end{array}$ & $\begin{array}{r}2000- \\
2004\end{array}$ & $\begin{array}{r}2005- \\
2009\end{array}$ & $\begin{array}{r}2010- \\
2014\end{array}$ & $\begin{array}{r}2015- \\
2019\end{array}$ \\
\hline brasem & Eurytoop (Bentisch) & 41.69 & 55.98 & 52.92 & 39.97 & 20.89 & 10.34 \\
\hline blankvoorn & Eurytoop (Pelagisch) & 73.15 & 15.69 & 27.71 & 33.03 & 43.17 & 33.49 \\
\hline pos & Eurytoop (Bentisch) & 85.06 & 12.15 & 7.9 & 16.37 & 12.27 & 1.43 \\
\hline baars & Eurytoop (Pelagisch) & 91.58 & 4.54 & 5.37 & 2.68 & 13.63 & 32.14 \\
\hline kolblei & Eurytoop (Bentisch) & 94.18 & 7.14 & 2.76 & 2.69 & 0.28 & 0.57 \\
\hline snoekbaars & Eurytoop (Bentisch) & 96.49 & 3.28 & 1.54 & 2.83 & 1.26 & 7.27 \\
\hline zwartbekgrondel* & Eurytoop (Bentisch) & 97.57 & - & - & - & 4.12 & 12.31 \\
\hline alver & Eurytoop (Pelagisch) & 98.27 & - & 0.62 & 1.2 & 0.22 & \\
\hline pontische stroomgrondel* & Eurytoop (Bentisch) & 98.83 & - & - & - & 3.05 & 1.81 \\
\hline winde & Rheofiel (Pelagisch) & 99.2 & 0.11 & 0.94 & 0.06 & 0.08 & \\
\hline riviergrondel & Rheofiel (Bentisch) & 99.44 & 0.81 & 0.13 & 0.34 & - & 0.12 \\
\hline marmergrondel* & Eurytoop (Bentisch) & 99.62 & - & - & 0.42 & 0.18 & \\
\hline kesslers grondel* & Eurytoop (Bentisch) & 99.71 & - & - & - & 0.48 & 0.12 \\
\hline hybride cyprinide & Eurytoop (Bentisch) & 99.78 & 0.09 & 0.03 & 0.13 & 0.03 & \\
\hline roofblei* & Rheofiel (Pelagisch) & 99.82 & - & 0.04 & 0.03 & 0.08 & \\
\hline witvinriviergrondel* & Eurytoop (Bentisch) & 99.86 & - & - & 0.1 & - & - \\
\hline karper & Eurytoop (Bentisch) & 99.88 & - & - & - & 0.16 & \\
\hline snoek & Eurytoop (Pelagisch) & 99.9 & - & - & 0.02 & 0.04 & 0.17 \\
\hline aal & Eurytoop (Bentisch) & 99.93 & - & 0.04 & 0.01 & 0.03 & \\
\hline rivierdonderpad & Rheofiel (Bentisch) & 99.95 & - & - & 0.06 & - & \\
\hline bot & Limnofiel (Bentisch) & 99.96 & 0.09 & - & 0.03 & - & \\
\hline donaubrasem* & Eurytoop (Bentisch) & 99.98 & - & - & 0.02 & - & 0.21 \\
\hline rivierprik & Rheofiel (Bentisch) & 99.99 & 0.11 & - & - & - & \\
\hline serpeling & Rheofiel (Pelagisch) & 99.99 & - & - & 0.01 & - & \\
\hline spiering & Eurytoop (Pelagisch) & 100 & - & - & - & 0.03 & \\
\hline blauwneus* & Eurytoop (Bentisch) & 100 & - & - & 0.01 & - & \\
\hline
\end{tabular}


Tabel 2. Soortensamenstelling in percentages op basis van biomassa in boomkorvangsten in de zijwateren van de Bovenloop Nederrijn per 5-jarige periode. De groepering geeft de ecologische indeling aan de hand van Noble et al. (2007) aan. Het cumulatief percentage geeft aan hoeveel de soorten over de gehele periode voorkomen op basis van de gesommeerde CPUE op basis van de biomassa. Nulpercentages zijn naar beneden afgeronde waarden, $*=$ exoot.

\begin{tabular}{|c|c|c|c|c|c|c|c|}
\hline Soort & Groepering & $\begin{array}{l}\text { Cumulatief } \\
\text { percentage }\end{array}$ & $\begin{array}{r}1997- \\
1999 \\
\end{array}$ & $\begin{array}{r}2000- \\
2004 \\
\end{array}$ & $\begin{array}{r}2005- \\
2009 \\
\end{array}$ & $\begin{array}{r}2010- \\
2014 \\
\end{array}$ & $\begin{array}{r}2015- \\
2019 \\
\end{array}$ \\
\hline brasem & Eurytoop (Bentisch) & 46.62 & 58.34 & 48.68 & 47.45 & 39.68 & 33.61 \\
\hline blankvoorn & Eurytoop (Pelagisch) & 72.49 & 15.32 & 25.57 & 30.2 & 23.75 & 13.47 \\
\hline snoekbaars & Eurytoop (Bentisch) & 84.79 & 8.93 & 12.02 & 10.28 & 12.68 & 29.97 \\
\hline kolblei & Eurytoop (Bentisch) & 90.7 & 11.44 & 5.09 & 7.24 & 0.48 & 1.22 \\
\hline baars & Eurytoop (Pelagisch) & 95.8 & 4.25 & 4.95 & 2.26 & 12.12 & 14.08 \\
\hline pos & Eurytoop (Bentisch) & 97.32 & 1.48 & 1.94 & 1.46 & 1.94 & 0.22 \\
\hline karper & Eurytoop (Bentisch) & 98.22 & - & - & - & 7.04 & - \\
\hline snoek & Eurytoop (Pelagisch) & 99.08 & - & - & 0.54 & 0.55 & 6.63 \\
\hline alver & Eurytoop (Pelagisch) & 99.31 & - & 0.5 & 0.25 & 0.06 & - \\
\hline aal & Eurytoop (Bentisch) & 99.5 & - & 0.74 & 0.06 & 0.15 & \\
\hline zwartbekgrondel* & Eurytoop (Bentisch) & 99.65 & - & - & - & 0.8 & 0.62 \\
\hline winde & Rheofiel (Pelagisch) & 99.75 & 0.07 & 0.43 & 0.04 & 0.02 & - \\
\hline pontische stroomgrondel* & Eurytoop (Bentisch) & 99.83 & - & - & - & 0.58 & 0.11 \\
\hline hybride cyprinide & Eurytoop (Bentisch) & 99.91 & 0.12 & 0.04 & 0.11 & 0 & - \\
\hline roofblei* & Rheofiel (Pelagisch) & 99.94 & - & 0.02 & 0.04 & 0.01 & - \\
\hline kesslers grondel* & Eurytoop (Bentisch) & 99.96 & - & - & - & 0.15 & 0.02 \\
\hline bot & Limnofiel (Bentisch) & 99.97 & 0.01 & - & 0.02 & - & \\
\hline riviergrondel & Rheofiel (Bentisch) & 99.98 & 0.04 & 0.01 & 0.01 & - & 0.01 \\
\hline donaubrasem* & Eurytoop (Bentisch) & 99.99 & - & - & 0.01 & - & 0.04 \\
\hline marmergrondel* & Eurytoop (Bentisch) & 99.99 & - & - & 0.01 & 0 & \\
\hline witvinriviergrondel* & Eurytoop (Bentisch) & 100 & - & - & 0 & - & - \\
\hline rivierdonderpad & Rheofiel (Bentisch) & 100 & - & - & 0 & - & - \\
\hline blauwneus* & Eurytoop (Bentisch) & 100 & - & - & 0 & - & - \\
\hline serpeling & Rheofiel (Pelagisch) & 100 & - & - & 0 & - & - \\
\hline rivierprik & Rheofiel (Bentisch) & 100 & 0.01 & - & - & - & \\
\hline spiering & Eurytoop (Pelagisch) & 100 & - & - & - & 0 & - \\
\hline
\end{tabular}


Tabel 3. Soortensamenstelling in percentages op basis van aantal in schepnetvangsten in de zijwateren van de Bovenloop Nederrijn per 5-jarige periode. De groepering geeft de ecologische indeling aan de hand van Noble et al. (2007) aan. Het cumulatief percentage geeft aan hoeveel de soorten over de gehele periode voorkomen op basis van de gesommeerde CPUE op basis van het aantal. Nul-percentages zijn naar beneden afgeronde waarden, $*=$ exoot.

\begin{tabular}{|c|c|c|c|c|c|c|c|}
\hline Soort & Groepering & $\begin{array}{l}\text { Cumulatief } \\
\text { percentage }\end{array}$ & $\begin{array}{r}1997- \\
1999 \\
\end{array}$ & $\begin{array}{r}2000- \\
2004 \\
\end{array}$ & $\begin{array}{r}2005- \\
2009 \\
\end{array}$ & $\begin{array}{r}2010- \\
2014 \\
\end{array}$ & $\begin{array}{r}2015- \\
2019 \\
\end{array}$ \\
\hline blankvoorn & Eurytoop (Pelagisch) & 32.82 & 26.17 & 29.33 & 62.41 & 6.59 & 66.48 \\
\hline baars & Eurytoop (Pelagisch) & 60.45 & 43.34 & 37.76 & 17.47 & 9.05 & 15.68 \\
\hline zwartbekgrondel* & Eurytoop (Bentisch) & 72.82 & - & - & 0.13 & 61.93 & 10.3 \\
\hline winde & Rheofiel (Pelagisch) & 84.57 & - & 17.18 & 4.29 & 6.73 & 4.58 \\
\hline pos & Eurytoop (Bentisch) & 90.03 & 2.49 & 8.12 & 2.95 & 2.06 & \\
\hline kesslers grondel* & Eurytoop (Bentisch) & 91.44 & - & - & - & 7.11 & 1.05 \\
\hline kopvoorn & Rheofiel (Pelagisch) & 92.74 & 1.24 & 1.9 & 0.49 & 0.66 & 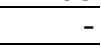 \\
\hline alver & Eurytoop (Pelagisch) & 93.97 & - & 0.6 & 5 & - & \\
\hline aal & Eurytoop (Bentisch) & 95.08 & 20.29 & 0.97 & - & 0.23 & \\
\hline marmergrondel* & Eurytoop (Bentisch) & 95.99 & - & - & 1.9 & 2.98 & \\
\hline snoek & Eurytoop (Pelagisch) & 96.86 & 3.05 & 0.76 & 1.41 & 0.45 & 0.62 \\
\hline brasem & Eurytoop (Bentisch) & 97.47 & 2.18 & 0.64 & 0.78 & 0.35 & \\
\hline driedoornige stekelbaars & Eurytoop (Pelagisch) & 98.05 & - & 0.54 & 1.26 & 0.26 & \\
\hline roofblei* & Rheofiel (Pelagisch) & 98.58 & - & 0.53 & 0.94 & 0.4 & \\
\hline kolblei & Eurytoop (Bentisch) & 98.86 & - & 0.47 & - & - & 0.28 \\
\hline snoekbaars & Eurytoop (Bentisch) & 99.09 & - & 0.13 & 0.7 & 0.18 & \\
\hline serpeling & Rheofiel (Pelagisch) & 99.28 & - & 0.35 & - & - & \\
\hline zeelt & Limnofiel (Bentisch) & 99.42 & - & 0.1 & - & 0.45 & \\
\hline bittervoorn & Limnofiel (Pelagisch) & 99.53 & - & - & 0.12 & 0.45 & \\
\hline tiendoornige stekelbaars & Limnofiel (Pelagisch) & 99.64 & - & 0.16 & - & 0.11 & \\
\hline barbeel & Rheofiel (Bentisch) & 99.73 & - & 0.18 & - & - & \\
\hline rietvoorn & Limnofiel (Pelagisch) & 99.8 & 1.24 & - & - & - & 0.62 \\
\hline hybride cyprinide & Eurytoop (Bentisch) & 99.85 & - & 0.1 & - & - & \\
\hline rivierdonderpad & Rheofiel (Bentisch) & 99.9 & - & 0.09 & - & - & \\
\hline riviergrondel & Rheofiel (Bentisch) & 99.94 & - & 0.07 & - & - & \\
\hline sneep & Rheofiel (Bentisch) & 99.98 & - & 0.03 & - & - & 0.41 \\
\hline bot & Limnofiel (Bentisch) & 100 & - & - & 0.13 & - & \\
\hline
\end{tabular}


Tabel 4. Soortensamenstelling in percentages op basis van biomassa in schepnetvangsten in de zijwateren van de Bovenloop Nederrijn per 5-jarige periode. De groepering geeft de ecologische indeling aan de hand van Noble et al. (2007) aan. Het cumulatief percentage geeft aan hoeveel de soorten over de gehele periode voorkomen op basis van de gesommeerde CPUE op basis van de biomassa. Nulpercentages zijn naar beneden afgeronde waarden, * = exoot.

\begin{tabular}{|c|c|c|c|c|c|c|c|}
\hline Soort & Groepering & $\begin{array}{l}\text { Cumulatief } \\
\text { percentage }\end{array}$ & $\begin{array}{r}1997- \\
1999 \\
\end{array}$ & $\begin{array}{r}2000- \\
2004 \\
\end{array}$ & $\begin{array}{r}2005- \\
2009 \\
\end{array}$ & $\begin{array}{r}2010- \\
2014 \\
\end{array}$ & $\begin{array}{r}2015- \\
2019 \\
\end{array}$ \\
\hline snoek & Eurytoop (Pelagisch) & 43.31 & 48.31 & 50.15 & 61.77 & 0.88 & 4.36 \\
\hline baars & Eurytoop (Pelagisch) & 65.97 & 15.91 & 16.09 & 11.02 & 50.88 & 77.07 \\
\hline winde & Rheofiel (Pelagisch) & 74.4 & - & 11.92 & 8.53 & 1.62 & 1.34 \\
\hline blankvoorn & Eurytoop (Pelagisch) & 81.11 & 1.05 & 6.88 & 10.21 & 1.74 & 14.66 \\
\hline aal & Eurytoop (Bentisch) & 87.77 & 34.2 & 7.36 & - & 1.09 & \\
\hline brasem & Eurytoop (Bentisch) & 90.73 & 0.02 & 0.05 & 0.09 & 20.29 & \\
\hline snoekbaars & Eurytoop (Bentisch) & 93.4 & - & 2.32 & 6.96 & 0.22 & \\
\hline zwartbekgrondel* & Eurytoop (Bentisch) & 95.47 & - & - & 0.03 & 13.8 & 1.88 \\
\hline pos & Eurytoop (Bentisch) & 96.5 & 0.15 & 1.59 & 0.47 & 0.44 & \\
\hline kopvoorn & Rheofiel (Pelagisch) & 97.42 & 0.06 & 0.94 & 0.3 & 2.44 & \\
\hline kolblei & Eurytoop (Bentisch) & 98.3 & - & 1.63 & - & - & 0.07 \\
\hline kesslers grondel* & Eurytoop (Bentisch) & 99.17 & - & - & - & 5.95 & 0.32 \\
\hline zeelt & Limnofiel (Bentisch) & 99.41 & - & 0.35 & - & 0.37 & \\
\hline hybride cyprinide & Eurytoop (Bentisch) & 99.59 & - & 0.33 & - & - & \\
\hline roofblei* & Rheofiel (Pelagisch) & 99.71 & - & 0.13 & 0.15 & 0.12 & \\
\hline alver & Eurytoop (Pelagisch) & 99.78 & - & 0.03 & 0.27 & - & \\
\hline barbeel & Rheofiel (Bentisch) & 99.84 & - & 0.12 & - & - & \\
\hline marmergrondel* & Eurytoop (Bentisch) & 99.87 & - & - & 0.06 & 0.13 & \\
\hline rietvoorn & Limnofiel (Pelagisch) & 99.9 & 0.29 & - & - & - & 0.15 \\
\hline serpeling & Rheofiel (Pelagisch) & 99.92 & - & 0.04 & - & - & \\
\hline bot & Limnofiel (Bentisch) & 99.95 & - & - & 0.11 & - & \\
\hline $\begin{array}{ll}\text { riviergrondel } \\
\end{array}$ & Rheofiel (Bentisch) & 99.97 & - & 0.04 & - & - & \\
\hline driedoornige stekelbaars & Eurytoop (Pelagisch) & 99.98 & - & 0.01 & 0.02 & 0.01 & \\
\hline sneep & Rheofiel (Bentisch) & 99.99 & - & 0.01 & - & - & 0.14 \\
\hline bittervoorn & Limnofiel (Pelagisch) & 99.99 & - & - & 0 & 0.03 & \\
\hline rivierdonderpad & Rheofiel (Bentisch) & 100 & - & 0.01 & - & - & \\
\hline tiendoornige stekelbaars & Limnofiel (Pelagisch) & 100 & - & 0.01 & - & 0 & \\
\hline
\end{tabular}




\section{Bijlage 22 Bovenloop Waal hoofdstroom}

Tabel 1. Soortensamenstelling in percentages op basis van aantal in boomkorvangsten in de hoofdstroom van de Bovenloop Waal per 5-jarige periode. De groepering geeft de ecologische indeling aan de hand van Noble et al. (2007) aan. Het cumulatief percentage geeft aan hoeveel de soorten over de gehele periode voorkomen op basis van de gesommeerde CPUE op basis van het aantal. Nul-percentages zijn naar beneden afgeronde waarden, * exoot.

\begin{tabular}{|c|c|c|c|c|c|c|c|}
\hline Soort & Groepering & $\begin{array}{l}\text { Cumulatief } \\
\text { percentage }\end{array}$ & $\begin{array}{r}1997- \\
1999\end{array}$ & $\begin{array}{r}2000- \\
2004\end{array}$ & $\begin{array}{r}2005- \\
2009\end{array}$ & $\begin{array}{r}2010- \\
2014\end{array}$ & $\begin{array}{r}2015- \\
2019\end{array}$ \\
\hline kolblei & Eurytoop (Bentisch) & 27.78 & 43.17 & 34.28 & 27.4 & 13.45 & 2.77 \\
\hline brasem & Eurytoop (Bentisch) & 52.71 & 22.62 & 21.63 & 30.73 & 17.44 & 22.01 \\
\hline blankvoorn & Eurytoop (Pelagisch) & 65.71 & 8.74 & 11.93 & 11.93 & 15.7 & 26.45 \\
\hline winde & Rheofiel (Pelagisch) & 72.56 & 1.65 & 9.03 & 4.91 & 17.14 & 4.55 \\
\hline $\begin{array}{ll}\text { riviergrondel } \\
\end{array}$ & Rheofiel (Bentisch) & 77.89 & 6.57 & 8.64 & 5.85 & - & 0.29 \\
\hline witvinriviergrondel* & Eurytoop (Bentisch) & 82.94 & - & - & 8.82 & 5.95 & 8.89 \\
\hline snoekbaars & Eurytoop (Bentisch) & 85.79 & 2.1 & 3.65 & 2.15 & 4.54 & 3.03 \\
\hline barbeel & Rheofiel (Bentisch) & 88.55 & 4.45 & 3.91 & 2 & 2.08 & 1.04 \\
\hline zwartbekgrondel* & Eurytoop (Bentisch) & 91.08 & - & - & 0.05 & 7.8 & 18.63 \\
\hline pos & Eurytoop (Bentisch) & 93.2 & 2.71 & 2.45 & 2.57 & 0.33 & 0.83 \\
\hline $\begin{array}{ll}\text { rivierprik } \\
\end{array}$ & Rheofiel (Bentisch) & 95.31 & 5.38 & 2.19 & 0.73 & 2.76 & 0.45 \\
\hline pontische stroomgrondel* & Eurytoop (Bentisch) & 96.75 & - & - & 0.23 & 7.6 & 3.97 \\
\hline roofblei* & Rheofiel (Pelagisch) & 97.12 & 0.43 & 0.46 & 0.17 & 0.99 & \\
\hline alver & Eurytoop (Pelagisch) & 97.49 & - & 0.37 & 0.23 & 0.67 & 1.34 \\
\hline bot & Limnofiel (Bentisch) & 97.84 & 0.27 & 0.48 & 0.33 & 0.51 & \\
\hline kesslers grondel* & Eurytoop (Bentisch) & 98.16 & - & - & 0.5 & 0.71 & 0.28 \\
\hline donaubrasem* & Eurytoop (Bentisch) & 98.46 & - & - & 0.38 & 0.34 & 1.28 \\
\hline baars & Eurytoop (Pelagisch) & 98.71 & 0.13 & 0.19 & 0.11 & 0.66 & 0.69 \\
\hline europese meerval & Eurytoop (Bentisch) & 98.95 & - & - & 0.25 & 0.8 & 0.45 \\
\hline hybride cyprinide & Eurytoop (Bentisch) & 99.14 & 0.29 & 0.36 & 0.16 & - & \\
\hline aal & Eurytoop (Bentisch) & 99.31 & 0.34 & 0.08 & 0.17 & - & 0.29 \\
\hline blauwneus* & Eurytoop (Bentisch) & 99.46 & - & - & 0.05 & - & 1.67 \\
\hline sneep & Rheofiel (Bentisch) & 99.6 & 0.22 & 0.07 & 0.1 & 0.19 & 0.29 \\
\hline rivierdonderpad & Rheofiel (Bentisch) & 99.72 & 0.66 & - & - & - & \\
\hline serpeling & Rheofiel (Pelagisch) & 99.8 & - & 0.08 & 0.06 & 0.17 & 0.27 \\
\hline zeeprik & Rheofiel (Bentisch) & 99.85 & 0.14 & - & 0.06 & - & \\
\hline driedoornige stekelbaars & Eurytoop (Pelagisch) & 99.9 & 0.14 & - & - & - & 0.26 \\
\hline snoek & Eurytoop (Pelagisch) & 99.94 & - & 0.09 & - & - & 0.28 \\
\hline atlantische forel & Rheofiel (Pelagisch) & 99.98 & - & 0.1 & 0.05 & - & \\
\hline bittervoorn & Limnofiel (Pelagisch) & 100 & - & - & - & 0.16 & \\
\hline
\end{tabular}


Tabel 2. Soortensamenstelling in percentages op basis van biomassa in boomkorvangsten in de hoofdstroom van de Bovenloop Waal per 5-jarige periode. De groepering geeft de ecologische indeling aan de hand van Noble et al. (2007) aan. Het cumulatief percentage geeft aan hoeveel de soorten over de gehele periode voorkomen op basis van de gesommeerde CPUE op basis van de biomassa. Nulpercentages zijn naar beneden afgeronde waarden, $*=$ exoot.

\begin{tabular}{|c|c|c|c|c|c|c|c|}
\hline Soort & Groepering & $\begin{array}{l}\text { Cumulatief } \\
\text { percentage }\end{array}$ & $\begin{array}{r}1997- \\
1999 \\
\end{array}$ & $\begin{array}{r}2000- \\
2004 \\
\end{array}$ & $\begin{array}{r}2005- \\
2009 \\
\end{array}$ & $\begin{array}{r}2010- \\
2014 \\
\end{array}$ & $\begin{array}{r}2015- \\
2019 \\
\end{array}$ \\
\hline brasem & Eurytoop (Bentisch) & 42.05 & 45.64 & 28.71 & 52.37 & 29.04 & 25.41 \\
\hline kolblei & Eurytoop (Bentisch) & 66.39 & 40.16 & 32 & 23.48 & 12.45 & 1.73 \\
\hline winde & Rheofiel (Pelagisch) & 82.08 & 3.17 & 20.09 & 10.09 & 37.32 & 15.56 \\
\hline barbeel & Rheofiel (Bentisch) & 87.5 & 3.5 & 8.78 & 4.69 & 5.19 & 6.33 \\
\hline europese meerval & Eurytoop (Bentisch) & 91.83 & - & - & 2.2 & 7.82 & 39.73 \\
\hline blankvoorn & Eurytoop (Pelagisch) & 95.36 & 3.45 & 3.44 & 3.98 & 2.34 & 3.7 \\
\hline snoekbaars & Eurytoop (Bentisch) & 98.4 & 2.1 & 4.95 & 2.15 & 4.4 & 2.74 \\
\hline rivierprik & Rheofiel (Bentisch) & 98.65 & 0.79 & 0.3 & 0.08 & 0.28 & 0.08 \\
\hline donaubrasem* & Eurytoop (Bentisch) & 98.86 & - & - & 0.25 & 0.14 & 1.36 \\
\hline $\begin{aligned} \text { roofblei* } \\
\end{aligned}$ & Rheofiel (Pelagisch) & 99.02 & 0.31 & 0.17 & 0.12 & 0.25 & \\
\hline witvinriviergrondel* & Eurytoop (Bentisch) & 99.15 & - & - & 0.19 & 0.1 & 0.41 \\
\hline $\begin{array}{ll}\text { riviergrondel } \\
\end{array}$ & Rheofiel (Bentisch) & 28 & 0.2 & 0.22 & 0.12 & - & 0.01 \\
\hline snoek & Eurytoop (Pelagisch) & 99.39 & - & 0.49 & - & - & 0.51 \\
\hline bot & Limnofiel (Bentisch) & 99.49 & 0.04 & 0.23 & 0.06 & 0.16 & \\
\hline hybride cyprinide & Eurytoop (Bentisch) & 99.59 & 0.12 & 0.42 & 0.01 & - & \\
\hline aal & Eurytoop (Bentisch) & 99.67 & 0.21 & 0.05 & 0.03 & - & 0.52 \\
\hline blauwneus* & Eurytoop (Bentisch) & 99.74 & - & - & 0 & - & 1.33 \\
\hline pos & Eurytoop (Bentisch) & 99.79 & 0.07 & 0.08 & 0.05 & 0 & 0.02 \\
\hline sneep & Rheofiel (Bentisch) & 99.83 & 0 & 0.03 & 0.06 & 0.04 & 0.01 \\
\hline zwartbekgrondel* & Eurytoop (Bentisch) & 99.87 & - & - & 0 & 0.14 & 0.33 \\
\hline baars & Eurytoop (Pelagisch) & 99.9 & 0.03 & 0.01 & 0 & 0.14 & 0.03 \\
\hline zeeprik & Rheofiel (Bentisch) & 99.92 & 0.18 & - & 0 & - & \\
\hline pontische stroomgrondel* & Eurytoop (Bentisch) & 99.95 & - & - & 0 & 0.1 & 0.09 \\
\hline kesslers grondel* & Eurytoop (Bentisch) & 99.97 & - & - & 0.03 & 0.03 & 0.01 \\
\hline alver & Eurytoop (Pelagisch) & 99.99 & - & 0.02 & 0.01 & 0.04 & 0.08 \\
\hline atlantische forel & Rheofiel (Pelagisch) & 99.99 & - & 0.02 & 0.01 & - & \\
\hline serpeling & Rheofiel (Pelagisch) & 100 & - & 0 & 0.01 & 0 & 0 \\
\hline rivierdonderpad & Rheofiel (Bentisch) & 100 & 0.01 & - & - & - & - \\
\hline driedoornige stekelbaars & Eurytoop (Pelagisch) & 100 & 0 & - & - & - & $\underline{0}$ \\
\hline bittervoorn & Limnofiel (Pelagisch) & 100 & - & - & - & 0 & - \\
\hline
\end{tabular}


Tabel 3. Soortensamenstelling in percentages op basis van aantal in schepnetvangsten in de hoofdstroom van de Bovenloop Waal per 5-jarige periode. De groepering geeft de ecologische indeling aan de hand van Noble et al. (2007) aan. Het cumulatief percentage geeft aan hoeveel de soorten over de gehele periode voorkomen op basis van de gesommeerde CPUE op basis van het aantal. Nulpercentages zijn naar beneden afgeronde waarden, $*$ =xoot.

\begin{tabular}{|c|c|c|c|c|c|c|c|}
\hline Soort & Groepering & $\begin{array}{l}\text { Cumulatief } \\
\text { percentage }\end{array}$ & $\begin{array}{r}1997- \\
1999 \\
\end{array}$ & $\begin{array}{r}2000- \\
2004 \\
\end{array}$ & $\begin{array}{r}2005- \\
2009 \\
\end{array}$ & $\begin{array}{r}2010- \\
2014 \\
\end{array}$ & $\begin{array}{r}2015- \\
2019 \\
\end{array}$ \\
\hline zwartbekgrondel* & Eurytoop (Bentisch) & 27.99 & - & - & - & 63.76 & 28.34 \\
\hline aal & Eurytoop (Bentisch) & 54.06 & 59.97 & 44.07 & 14.64 & 1.8 & 6.53 \\
\hline blankvoorn & Eurytoop (Pelagisch) & 71.26 & 19.8 & 22.82 & 35.04 & 4.56 & 36.82 \\
\hline winde & Rheofiel (Pelagisch) & 78.17 & 1.6 & 11.37 & 28.68 & 5.11 & 9.58 \\
\hline brasem & Eurytoop (Bentisch) & 84.19 & 4.13 & 0.56 & 3.63 & 12.25 & 1.93 \\
\hline alver & Eurytoop (Pelagisch) & 87.28 & 2.91 & 1.35 & 2.28 & 3.65 & 5.3 \\
\hline pos & Eurytoop (Bentisch) & 88.94 & 2.57 & 4.01 & - & 0.2 & - \\
\hline rivierprik & Rheofiel (Bentisch) & 90.43 & 0.51 & 4.56 & 5.88 & 0.29 & - \\
\hline snoekbaars & Eurytoop (Bentisch) & 91.88 & 0.74 & 0.3 & - & 0.93 & 6.61 \\
\hline barbeel & Rheofiel (Bentisch) & 93.03 & 1.28 & 2.69 & - & 0.47 & \\
\hline baars & Eurytoop (Pelagisch) & 94.17 & 0.72 & 1.72 & - & 0.46 & 2.85 \\
\hline kesslers grondel* & Eurytoop (Bentisch) & 95.3 & - & - & - & 2.77 & 0.56 \\
\hline roofblei* & Rheofiel (Pelagisch) & 96.22 & 0.69 & 0.54 & - & 1.41 & 0.74 \\
\hline kolblei & Eurytoop (Bentisch) & 96.98 & 1.83 & 0.91 & - & 0.07 & 0.74 \\
\hline serpeling & Rheofiel (Pelagisch) & 97.68 & - & 1.97 & 9.85 & 0.12 & - \\
\hline sneep & Rheofiel (Bentisch) & 98.35 & 1.46 & 0.87 & - & 0.35 & - \\
\hline kopvoorn & Rheofiel (Pelagisch) & 98.86 & 1.12 & 1.02 & - & - & - \\
\hline bot & Limnofiel (Bentisch) & 99.07 & 0.32 & 0.35 & - & 0.15 & - \\
\hline riviergrondel & Rheofiel (Bentisch) & 99.25 & - & 0.7 & - & - & - \\
\hline karper & Eurytoop (Bentisch) & 99.43 & - & - & - & 0.46 & - \\
\hline europese meerval & Eurytoop (Bentisch) & 99.59 & - & - & - & 0.43 & - \\
\hline snoek & Eurytoop (Pelagisch) & 99.72 & 0.36 & 0.18 & - & - & - \\
\hline pontische stroomgrondel* & Eurytoop (Bentisch) & 99.8 & - & - & - & 0.23 & - \\
\hline dunlipharder & Marien (Pelagisch) & 99.87 & - & - & - & 0.18 & - \\
\hline atlantische forel & Rheofiel (Pelagisch) & 99.92 & - & - & - & 0.12 & - \\
\hline bittervoorn & Limnofiel (Pelagisch) & 99.96 & - & - & - & 0.12 & \\
\hline witvinriviergrondel* & Eurytoop (Bentisch) & 100 & - & - & - & 0.1 & \\
\hline
\end{tabular}


Tabel 4. Soortensamenstelling in percentages op basis van biomassa in schepnetvangsten in de hoofdstroom van de Bovenloop Waal per 5-jarige periode. De groepering geeft de ecologische indeling aan de hand van Noble et al. (2007) aan. Het cumulatief percentage geeft aan hoeveel de soorten over de gehele periode voorkomen op basis van de gesommeerde CPUE op basis van de biomassa. Nulpercentages zijn naar beneden afgeronde waarden, $*=$ exoot.

\begin{tabular}{|c|c|c|c|c|c|c|c|}
\hline Soort & Groepering & $\begin{array}{l}\text { Cumulatief } \\
\text { percentage }\end{array}$ & $\begin{array}{r}1997- \\
1999 \\
\end{array}$ & $\begin{array}{r}2000- \\
2004 \\
\end{array}$ & $\begin{array}{r}2005- \\
2009 \\
\end{array}$ & $\begin{array}{r}2010- \\
2014 \\
\end{array}$ & $\begin{array}{r}2015- \\
2019 \\
\end{array}$ \\
\hline brasem & Eurytoop (Bentisch) & 27.42 & 26.63 & 0.01 & 17.26 & 33.43 & 13.14 \\
\hline europese meerval & Eurytoop (Bentisch) & 51.25 & - & - & - & 33.34 & \\
\hline aal & Eurytoop (Bentisch) & 64.12 & 47.79 & 56.89 & 15.16 & 0.55 & 20.46 \\
\hline winde & Rheofiel (Pelagisch) & 76.79 & 8.39 & 25.48 & 63.07 & 9.99 & 13.96 \\
\hline karper & Eurytoop (Bentisch) & 83.99 & - & - & - & 10.06 & \\
\hline snoekbaars & Eurytoop (Bentisch) & 90.47 & 1.07 & 2.43 & - & 4.58 & 44.9 \\
\hline barbeel & Rheofiel (Bentisch) & 93.16 & 0.06 & 7.48 & - & 2.54 & - \\
\hline roofblei* & Rheofiel (Pelagisch) & 95.25 & 0.12 & 0.02 & - & 2.9 & 0.08 \\
\hline blankvoorn & Eurytoop (Pelagisch) & 96.64 & 8.38 & 2.24 & 3.06 & 0.15 & 3.28 \\
\hline zwartbekgrondel* & Eurytoop (Bentisch) & 97.62 & - & - & - & 1.18 & 2.32 \\
\hline dunlipharder & Marien (Pelagisch) & 98.07 & - & - & - & 0.62 & \\
\hline kolblei & Eurytoop (Bentisch) & 98.51 & 2.83 & 0.69 & - & 0.14 & 0.02 \\
\hline rivierprik & Rheofiel (Bentisch) & 98.87 & 0.13 & 2.62 & 1.21 & 0.04 & - \\
\hline kopvoorn & Rheofiel (Pelagisch) & 99.13 & 2.05 & 0.62 & - & - & - \\
\hline baars & Eurytoop (Pelagisch) & 99.36 & 0.06 & 0.12 & - & 0.18 & 1.28 \\
\hline bot & Limnofiel (Bentisch) & 99.53 & 0.73 & 0.84 & - & 0 & \\
\hline alver & Eurytoop (Pelagisch) & 99.69 & 0.29 & 0.11 & 0.13 & 0.13 & 0.41 \\
\hline sneep & Rheofiel (Bentisch) & 99.78 & 0.6 & 0.05 & - & 0.04 & \\
\hline kesslers grondel* & Eurytoop (Bentisch) & 99.86 & - & - & - & 0.1 & 0.16 \\
\hline snoek & Eurytoop (Pelagisch) & 99.92 & 0.66 & 0.05 & - & - & - \\
\hline pos & Eurytoop (Bentisch) & 99.97 & 0.19 & 0.19 & - & 0 & - \\
\hline serpeling & Rheofiel (Pelagisch) & 99.98 & - & 0.13 & 0.12 & 0 & - \\
\hline atlantische forel & Rheofiel (Pelagisch) & 99.99 & - & - & - & 0.01 & - \\
\hline $\begin{array}{ll}\text { riviergrondel } \\
\end{array}$ & Rheofiel (Bentisch) & 100 & - & 0.03 & - & - & - \\
\hline pontische stroomgrondel* & Eurytoop (Bentisch) & 100 & - & - & - & 0 & - \\
\hline witvinriviergrondel* & Eurytoop (Bentisch) & 100 & - & - & - & 0 & \\
\hline bittervoorn & Limnofiel (Pelagisch) & 100 & - & - & - & 0 & \\
\hline
\end{tabular}




\section{Bijlage 23 Bovenloop Waal zijwateren}

Tabel 1. Soortensamenstelling in percentages op basis van aantal in boomkorvangsten in de zijwateren van de Bovenloop Waal per 5-jarige periode. De groepering geeft de ecologische indeling aan de hand van Noble et al. (2007) aan. Het cumulatief percentage geeft aan hoeveel de soorten over de gehele periode voorkomen op basis van de gesommeerde CPUE op basis van het aantal. Nul-percentages zijn naar beneden afgeronde waarden, * exoot.

\begin{tabular}{|c|c|c|c|c|c|c|c|}
\hline Soort & Groepering & $\begin{array}{l}\text { Cumulatief } \\
\text { percentage }\end{array}$ & $\begin{array}{r}1997- \\
1999\end{array}$ & $\begin{array}{r}2000- \\
2004\end{array}$ & $\begin{array}{r}2005- \\
2009\end{array}$ & $\begin{array}{r}2010- \\
2014\end{array}$ & $\begin{array}{r}2015- \\
2019\end{array}$ \\
\hline brasem & Eurytoop (Bentisch) & 66.27 & 68.79 & 66.27 & 73.96 & 64.88 & 49.17 \\
\hline blankvoorn & Eurytoop (Pelagisch) & 83.12 & 6.75 & 11.74 & 8.67 & 25.18 & 32.07 \\
\hline kolblei & Eurytoop (Bentisch) & 88.2 & 14.98 & 7.22 & 4.4 & 1.08 & 2.31 \\
\hline pos & Eurytoop (Bentisch) & 92.57 & 4.27 & 6.86 & 7.16 & 1.58 & 2.31 \\
\hline snoekbaars & Eurytoop (Bentisch) & 96.01 & 4.6 & 5.36 & 3.15 & 1.56 & 4.71 \\
\hline baars & Eurytoop (Pelagisch) & 97.79 & 0.3 & 2.01 & 1.23 & 2.16 & 3.08 \\
\hline pontische stroomgrondel* & Eurytoop (Bentisch) & 98.51 & - & - & - & 1.72 & 1.33 \\
\hline zwartbekgrondel* & Eurytoop (Bentisch) & 99.02 & - & - & - & 0.87 & 2.58 \\
\hline winde & Rheofiel (Pelagisch) & 99.2 & - & 0.09 & - & 0.31 & 0.74 \\
\hline alver & Eurytoop (Pelagisch) & 99.38 & - & 0.01 & 0.25 & 0.14 & 0.98 \\
\hline marmergrondel* & Eurytoop (Bentisch) & 99.51 & - & 0.1 & 0.48 & 0.01 & \\
\hline roofblei* & Rheofiel (Pelagisch) & 99.63 & - & 0.04 & 0.09 & 0.23 & 0.18 \\
\hline hybride cyprinide & Eurytoop (Bentisch) & 99.71 & 0.26 & 0.07 & 0.14 & 0.02 & - \\
\hline kesslers grondel* & Eurytoop (Bentisch) & 99.79 & - & - & 0.11 & 0.1 & 0.23 \\
\hline riviergrondel & Rheofiel (Bentisch) & 99.86 & - & 0.09 & 0.27 & - & - \\
\hline aal & Eurytoop (Bentisch) & 99.91 & 0.03 & 0.05 & - & 0.06 & 0.09 \\
\hline witvinriviergrondel* & Eurytoop (Bentisch) & 99.93 & - & - & 0.09 & - & 0.06 \\
\hline donaubrasem* & Eurytoop (Bentisch) & 99.95 & - & - & - & 0.04 & 0.04 \\
\hline snoek & Eurytoop (Pelagisch) & 99.96 & - & 0.03 & - & 0.03 & - \\
\hline bot & Limnofiel (Bentisch) & 99.98 & - & 0.02 & - & 0.01 & 0.06 \\
\hline rivierprik & Rheofiel (Bentisch) & 99.98 & 0.02 & 0.02 & - & - & - \\
\hline kopvoorn & Rheofiel (Pelagisch) & 99.99 & - & 0.02 & - & - & \\
\hline europese meerval & Eurytoop (Bentisch) & 99.99 & - & 0.02 & - & - & - \\
\hline bittervoorn & Limnofiel (Pelagisch) & 100 & - & 0.02 & - & - & - \\
\hline sneep & Rheofiel (Bentisch) & 100 & - & - & - & - & 0.04 \\
\hline
\end{tabular}


Tabel 2. Soortensamenstelling in percentages op basis van biomassa in boomkorvangsten in de zijwateren van de Bovenloop Waal per 5-jarige periode. De groepering geeft de ecologische indeling aan de hand van Noble et al. (2007) aan. Het cumulatief percentage geeft aan hoeveel de soorten over de gehele periode voorkomen op basis van de gesommeerde CPUE op basis van de biomassa. Nulpercentages zijn naar beneden afgeronde waarden, $*$ = exoot.

\begin{tabular}{|c|c|c|c|c|c|c|c|}
\hline Soort & Groepering & $\begin{array}{l}\text { Cumulatief } \\
\text { percentage }\end{array}$ & $\begin{array}{r}1997- \\
1999 \\
\end{array}$ & $\begin{array}{r}2000- \\
2004 \\
\end{array}$ & $\begin{array}{r}2005- \\
2009 \\
\end{array}$ & $\begin{array}{r}2010- \\
2014 \\
\end{array}$ & $\begin{array}{r}2015- \\
2019 \\
\end{array}$ \\
\hline brasem & Eurytoop (Bentisch) & 63.97 & 64.38 & 68.34 & 68.12 & 60.33 & 37.99 \\
\hline kolblei & Eurytoop (Bentisch) & 77 & 19.56 & 12.77 & 12.56 & 7.72 & 5.59 \\
\hline snoekbaars & Eurytoop (Bentisch) & 89.83 & 11.64 & 13.33 & 10.95 & 11.72 & 22.85 \\
\hline blankvoorn & Eurytoop (Pelagisch) & 95.84 & 2.37 & 3.39 & 5.7 & 10.7 & 21.45 \\
\hline baars & Eurytoop (Pelagisch) & 98.08 & 0.61 & 1.03 & 1.3 & 5.25 & 9.15 \\
\hline pos & Eurytoop (Bentisch) & 98.63 & 0.28 & 0.61 & 1 & 0.42 & 0.39 \\
\hline aal & Eurytoop (Bentisch) & 99.01 & 0.13 & 0.18 & - & 1.28 & 1.02 \\
\hline hybride cyprinide & Eurytoop (Bentisch) & 99.34 & 1.02 & 0.13 & 0.19 & 0.02 & \\
\hline winde & Rheofiel (Pelagisch) & 99.54 & - & 0.12 & - & 0.67 & 0.72 \\
\hline $\begin{array}{rr}\text { roofblei* } \\
\end{array}$ & Rheofiel (Pelagisch) & 99.65 & - & 0.02 & 0.06 & 0.52 & 0.05 \\
\hline pontische stroomgrondel* & Eurytoop (Bentisch) & 99.76 & - & - & - & 0.53 & 0.22 \\
\hline snoek & Eurytoop (Pelagisch) & 99.82 & - & 0.08 & - & 0.18 & \\
\hline zwartbekgrondel* & Eurytoop (Bentisch) & 99.88 & - & - & - & 0.24 & 0.28 \\
\hline donaubrasem* & Eurytoop (Bentisch) & 99.93 & - & - & - & 0.31 & 0.02 \\
\hline alver & Eurytoop (Pelagisch) & 99.97 & - & 0 & 0.05 & 0.06 & 0.2 \\
\hline kesslers grondel* & Eurytoop (Bentisch) & 99.98 & - & - & 0.03 & 0.03 & 0.04 \\
\hline bot & Limnofiel (Bentisch) & 99.99 & - & 0.01 & - & 0.01 & 0.03 \\
\hline riviergrondel & Rheofiel (Bentisch) & 99.99 & - & 0 & 0.02 & - & \\
\hline marmergrondel* & Eurytoop (Bentisch) & 99.99 & - & 0 & 0.01 & 0 & \\
\hline witvinriviergrondel* & Eurytoop (Bentisch) & 100 & - & - & 0.01 & - & 0.01 \\
\hline rivierprik & Rheofiel (Bentisch) & 100 & 0 & 0 & - & - & \\
\hline sneep & Rheofiel (Bentisch) & 100 & - & - & - & - & 0.01 \\
\hline europese meerval & Eurytoop (Bentisch) & 100 & - & 0 & - & - & \\
\hline kopvoorn & Rheofiel (Pelagisch) & 100 & - & 0 & - & - & \\
\hline bittervoorn & Limnofiel (Pelagisch) & 100 & - & 0 & - & - & \\
\hline
\end{tabular}


Tabel 3. Soortensamenstelling in percentages op basis van aantal in schepnetvangsten in de zijwateren van de Bovenloop Waal per 5-jarige periode. De groepering geeft de ecologische indeling aan de hand van Noble et al. (2007) aan. Het cumulatief percentage geeft aan hoeveel de soorten over de gehele periode voorkomen op basis van de gesommeerde CPUE op basis van het aantal. Nul-percentages zijn naar beneden afgeronde waarden, $*=$ exoot.

\begin{tabular}{|c|c|c|c|c|c|c|c|}
\hline Soort & Groepering & $\begin{array}{l}\text { Cumulatief } \\
\text { percentage }\end{array}$ & $\begin{array}{r}1997- \\
1999 \\
\end{array}$ & $\begin{array}{r}2000- \\
2004 \\
\end{array}$ & $\begin{array}{r}2005- \\
2009 \\
\end{array}$ & $\begin{array}{r}2010- \\
2014 \\
\end{array}$ & $\begin{array}{r}2015- \\
2019 \\
\end{array}$ \\
\hline blankvoorn & Eurytoop (Pelagisch) & 51 & 78.22 & 31.94 & 47.39 & 43.25 & 48.11 \\
\hline brasem & Eurytoop (Bentisch) & 61.68 & 7.96 & 2.27 & 11.27 & 20.16 & 0.52 \\
\hline winde & Rheofiel (Pelagisch) & 68.32 & 0.23 & 5.73 & 14.14 & 7.52 & 16.11 \\
\hline zwartbekgrondel* & Eurytoop (Bentisch) & 73.18 & - & - & - & 14.05 & 8.6 \\
\hline baars & Eurytoop (Pelagisch) & 77.95 & 3.62 & 8.56 & 2.69 & 2.79 & 13.01 \\
\hline marmergrondel* & Eurytoop (Bentisch) & 81.93 & - & 18.04 & 0.2 & 0.07 & 0.52 \\
\hline kolblei & Eurytoop (Bentisch) & 85.19 & 0.5 & 6.68 & 8.81 & 1.03 & 0.52 \\
\hline pos & Eurytoop (Bentisch) & 88.33 & 3.14 & 9.51 & 0.27 & 0.52 & 0.72 \\
\hline alver & Eurytoop (Pelagisch) & 90.94 & 1.3 & 0.62 & 10.52 & 0.73 & 5.91 \\
\hline aal & Eurytoop (Bentisch) & 93.18 & 3.11 & 5.07 & 0.41 & 0.55 & 1.5 \\
\hline kesslers grondel* & Eurytoop (Bentisch) & 94.57 & - & - & 0.2 & 4.21 & 0.82 \\
\hline roofblei* & Rheofiel (Pelagisch) & 95.79 & 0.5 & 0.46 & 0.74 & 2.71 & 0.42 \\
\hline kopvoorn & Rheofiel (Pelagisch) & 96.59 & 0.31 & 2.91 & 0.44 & - & 0.34 \\
\hline snoekbaars & Eurytoop (Bentisch) & 97.36 & 0.5 & 2.16 & 0.55 & 0.27 & \\
\hline snoek & Eurytoop (Pelagisch) & 98.04 & 0.19 & 2.38 & 0.66 & 0.05 & \\
\hline driedoornige stekelbaars & Eurytoop (Pelagisch) & 98.34 & 0.06 & 0.6 & - & 0.34 & 1.04 \\
\hline rietvoorn & Limnofiel (Pelagisch) & 98.63 & 0.08 & 1.09 & 0.07 & 0.07 & \\
\hline bittervoorn & Limnofiel (Pelagisch) & 98.9 & - & 0.03 & 1 & 0.26 & 0.52 \\
\hline pontische stroomgrondel* & Eurytoop (Bentisch) & 99.09 & - & - & - & 0.57 & 0.34 \\
\hline serpeling & Rheofiel (Pelagisch) & 99.26 & - & - & 0.13 & 0.41 & 0.37 \\
\hline bot & Limnofiel (Bentisch) & 99.43 & 0.13 & 0.05 & 0.23 & 0.26 & \\
\hline riviergrondel & Rheofiel (Bentisch) & 99.54 & - & 0.48 & 0.09 & - & - \\
\hline hybride cyprinide & Eurytoop (Bentisch) & 99.65 & - & 0.2 & 0.18 & 0.12 & \\
\hline zeelt & Limnofiel (Bentisch) & 99.73 & - & 0.29 & - & - & 0.2 \\
\hline rivierprik & Rheofiel (Bentisch) & 99.77 & 0.06 & 0.14 & - & - & - \\
\hline rivierdonderpad & Rheofiel (Bentisch) & 99.82 & - & 0.21 & - & - & \\
\hline sneep & Rheofiel (Bentisch) & 99.86 & - & 0.2 & - & - & \\
\hline kleine modderkruiper & Eurytoop (Bentisch) & 99.9 & - & 0.08 & - & - & 0.45 \\
\hline vetje & Limnofiel (Pelagisch) & 99.93 & 0.06 & 0.08 & - & - & \\
\hline bermpje & Rheofiel (Bentisch) & 99.96 & - & 0.14 & - & - & \\
\hline barbeel & Rheofiel (Bentisch) & 99.98 & - & 0.1 & - & - & \\
\hline blauwband* & Limnofiel (Pelagisch) & 100 & - & - & - & 0.05 & \\
\hline
\end{tabular}


Tabel 4. Soortensamenstelling in percentages op basis van biomassa in schepnetvangsten in de zijwateren van de Bovenloop Waal per 5-jarige periode. De groepering geeft de ecologische indeling aan de hand van Noble et al. (2007) aan. Het cumulatief percentage geeft aan hoeveel de soorten over de gehele periode voorkomen op basis van de gesommeerde CPUE op basis van de biomassa. Nulpercentages zijn naar beneden afgeronde waarden, $*$ = exoot.

\begin{tabular}{|c|c|c|c|c|c|c|c|}
\hline Soort & Groepering & $\begin{array}{l}\text { Cumulatief } \\
\text { percentage }\end{array}$ & $\begin{array}{r}1997- \\
1999 \\
\end{array}$ & $\begin{array}{r}2000- \\
2004 \\
\end{array}$ & $\begin{array}{r}2005- \\
2009 \\
\end{array}$ & $\begin{array}{r}2010- \\
2014 \\
\end{array}$ & $\begin{array}{r}2015- \\
2019 \\
\end{array}$ \\
\hline snoek & Eurytoop (Pelagisch) & 20.85 & 22.28 & 14.63 & 28.67 & 25.86 & - \\
\hline snoekbaars & Eurytoop (Bentisch) & 39.88 & 11.33 & 24.14 & 18.68 & 19.53 & \\
\hline brasem & Eurytoop (Bentisch) & 58.76 & 17.86 & 18.42 & 32.44 & 6.68 & 0.06 \\
\hline aal & Eurytoop (Bentisch) & 72.41 & 19.08 & 17.27 & 3.45 & 8.25 & 46.76 \\
\hline blankvoorn & Eurytoop (Pelagisch) & 84.5 & 20.64 & 9.29 & 6.16 & 15.32 & 21.8 \\
\hline winde & Rheofiel (Pelagisch) & 89.17 & 0.09 & 4.85 & 6.87 & 4.14 & 17.28 \\
\hline kolblei & Eurytoop (Bentisch) & 91.75 & 2.03 & 4.87 & 0.94 & 0.79 & 0.07 \\
\hline baars & Eurytoop (Pelagisch) & 94.12 & 3.54 & 3.09 & 0.63 & 1.41 & 5.47 \\
\hline kesslers grondel* & Eurytoop (Bentisch) & 95.56 & - & - & 0.18 & 7.57 & 1.09 \\
\hline zwartbekgrondel* & Eurytoop (Bentisch) & 96.98 & - & - & - & 7.15 & 4.52 \\
\hline pos & Eurytoop (Bentisch) & 97.92 & 1.34 & 1.63 & 0.06 & 0.27 & 0.36 \\
\hline bot & Limnofiel (Bentisch) & 98.51 & 0.66 & 0.02 & 1.24 & 1.01 & - \\
\hline roofblei* & Rheofiel (Pelagisch) & 98.86 & 0.2 & 0.15 & 0.22 & 1.11 & 0.16 \\
\hline marmergrondel* & Eurytoop (Bentisch) & 99.14 & - & 0.73 & 0.01 & 0 & 0.04 \\
\hline alver & Eurytoop (Pelagisch) & 99.36 & 0.16 & 0.18 & 0.23 & 0.11 & 1.6 \\
\hline rietvoorn & Limnofiel (Pelagisch) & 99.56 & 0.58 & 0.03 & 0.02 & 0.45 & \\
\hline kopvoorn & Rheofiel (Pelagisch) & 99.7 & 0.03 & 0.26 & 0.14 & - & 0.16 \\
\hline rivierprik & Rheofiel (Bentisch) & 99.8 & 0.17 & 0.16 & - & - & \\
\hline pontische stroomgrondel* & Eurytoop (Bentisch) & 99.85 & - & - & - & 0.25 & 0.23 \\
\hline riviergrondel & Rheofiel (Bentisch) & 99.89 & - & 0.1 & 0.03 & - & \\
\hline hybride cyprinide & Eurytoop (Bentisch) & 99.91 & - & 0.06 & 0 & 0.01 & \\
\hline serpeling & Rheofiel (Pelagisch) & 99.93 & - & - & 0.02 & 0.05 & 0.23 \\
\hline driedoornige stekelbaars & Eurytoop (Pelagisch) & 99.95 & 0.01 & 0.02 & - & 0.02 & 0.07 \\
\hline bittervoorn & Limnofiel (Pelagisch) & 99.96 & - & 0 & 0.03 & 0.02 & 0.03 \\
\hline barbeel & Rheofiel (Bentisch) & 99.97 & - & 0.03 & - & - & \\
\hline rivierdonderpad & Rheofiel (Bentisch) & 99.98 & - & 0.02 & - & - & \\
\hline zeelt & Limnofiel (Bentisch) & 99.99 & - & 0.02 & - & - & 0.06 \\
\hline sneep & Rheofiel (Bentisch) & 99.99 & - & 0.01 & - & - & \\
\hline bermpje & Rheofiel (Bentisch) & 100 & - & 0.01 & - & - & \\
\hline kleine modderkruiper & Eurytoop (Bentisch) & 100 & - & 0 & - & - & 0.02 \\
\hline blauwband* & Limnofiel (Pelagisch) & 100 & - & - & - & 0.01 & \\
\hline vetje & Limnofiel (Pelagisch) & 100 & 0 & 0 & - & - & \\
\hline
\end{tabular}




\section{Bijlage 24 Benedenloop Nederrijn hoofdstroom}

Tabel 1. Soortensamenstelling in percentages op basis van aantal in boomkorvangsten in de hoofdstroom van de Benedenloop Nederrijn per 5-jarige periode. De groepering geeft de ecologische indeling aan de hand van Noble et al. (2007) aan. Het cumulatief percentage geeft aan hoeveel de soorten over de gehele periode voorkomen op basis van de gesommeerde CPUE op basis van het aantal. Nul-percentages zijn naar beneden afgeronde waarden, $*=$ exoot.

\begin{tabular}{|c|c|c|c|c|}
\hline Soort & Groepering & Cumulatief percentage & $2010-2014$ & $2015-2019$ \\
\hline brasem & Eurytoop (Bentisch) & 26.42 & 39.16 & 18.01 \\
\hline blankvoorn & Eurytoop (Pelagisch) & 47.29 & 18.96 & 22.13 \\
\hline zwartbekgrondel* & Eurytoop (Bentisch) & 64.21 & 11.58 & 20.45 \\
\hline pontische stroomgrondel* & Eurytoop (Bentisch) & 72.69 & 13.01 & 5.49 \\
\hline alver & Eurytoop (Pelagisch) & 80.01 & 0.59 & 11.77 \\
\hline baars & Eurytoop (Pelagisch) & 84.51 & 3.67 & 5.04 \\
\hline winde & Rheofiel (Pelagisch) & 88.45 & 5.36 & 3.01 \\
\hline snoekbaars & Eurytoop (Bentisch) & 91.15 & 3.98 & 1.85 \\
\hline witvinriviergrondel* & Eurytoop (Bentisch) & 93.28 & - & 3.53 \\
\hline kolblei & Eurytoop (Bentisch) & 95.14 & - & 3.09 \\
\hline kesslers grondel* & Eurytoop (Bentisch) & 96.5 & 1.19 & 1.48 \\
\hline pos & Eurytoop (Bentisch) & 97.45 & 0.59 & 1.18 \\
\hline roofblei* & Rheofiel (Pelagisch) & 98.09 & 0.62 & 0.66 \\
\hline sneep & Rheofiel (Bentisch) & 98.6 & 1.29 & \\
\hline riviergrondel & Rheofiel (Bentisch) & 99.08 & - & 0.79 \\
\hline hybride cyprinide & Eurytoop (Bentisch) & 99.32 & - & 0.4 \\
\hline barbeel & Rheofiel (Bentisch) & 99.55 & - & 0.39 \\
\hline karper & Eurytoop (Bentisch) & 99.78 & - & 0.37 \\
\hline aal & Eurytoop (Bentisch) & 100 & - & 0.37 \\
\hline
\end{tabular}

Tabel 2. Soortensamenstelling in percentages op basis van biomassa in boomkorvangsten in de hoofdstroom van de Benedenloop Nederrijn per 5-jarige periode. De groepering geeft de ecologische indeling aan de hand van Noble et al. (2007) aan. Het cumulatief percentage geeft aan hoeveel de soorten over de gehele periode voorkomen op basis van de gesommeerde CPUE op basis van de biomassa. Nul-percentages zijn naar beneden afgeronde waarden, $*=$ exoot.

\begin{tabular}{|c|c|c|c|c|}
\hline Soort & Groepering & Cumulatief percentage & $2010-2014$ & 2015-2019 \\
\hline brasem & Eurytoop (Bentisch) & 52.84 & 60.06 & 48.3 \\
\hline blankvoorn & Eurytoop (Pelagisch) & 66.96 & 11.09 & 16.03 \\
\hline snoekbaars & Eurytoop (Bentisch) & 75.88 & 13.08 & 6.29 \\
\hline winde & Rheofiel (Pelagisch) & 84.36 & 10.77 & 7.05 \\
\hline karper & Eurytoop (Bentisch) & 89.64 & - & 8.59 \\
\hline barbeel & Rheofiel (Bentisch) & 93.33 & - & 6.02 \\
\hline kolblei & Eurytoop (Bentisch) & 95.86 & - & 4.12 \\
\hline baars & Eurytoop (Pelagisch) & 97.67 & 3.98 & 0.45 \\
\hline aal & Eurytoop (Bentisch) & 98.57 & - & 1.47 \\
\hline roofblei* & Rheofiel (Pelagisch) & 98.95 & 0.34 & 0.41 \\
\hline alver & Eurytoop (Pelagisch) & 99.27 & 0.02 & 0.51 \\
\hline $\begin{array}{ll}\text { zwartbekgrondel* } \\
\end{array}$ & Eurytoop (Bentisch) & 99.58 & 0.09 & 0.45 \\
\hline pontische stroomgrondel* & Eurytoop (Bentisch) & 99.76 & 0.31 & 0.09 \\
\hline sneep & Rheofiel (Bentisch) & 99.84 & 0.21 & \\
\hline kesslers grondel* & Eurytoop (Bentisch) & 99.91 & 0.05 & 0.09 \\
\hline witvinriviergrondel* & Eurytoop (Bentisch) & 99.95 & - & 0.06 \\
\hline pos & Eurytoop (Bentisch) & 99.97 & 0.02 & 0.03 \\
\hline hybride cyprinide & Eurytoop (Bentisch) & 99.99 & - & 0.03 \\
\hline riviergrondel & Rheofiel (Bentisch) & 100 & - & 0.01 \\
\hline
\end{tabular}


Tabel 3. Soortensamenstelling in percentages op basis van aantal in schepnetvangsten in de hoofdstroom van de Benedenloop Nederrijn per 5-jarige periode. De groepering geeft de ecologische indeling aan de hand van Noble et al. (2007) aan. Het cumulatief percentage geeft aan hoeveel de soorten over de gehele periode voorkomen op basis van de gesommeerde CPUE op basis van het aantal. Nul-percentages zijn naar beneden afgeronde waarden, $*=$ exoot.

\begin{tabular}{|c|c|c|c|c|}
\hline Soort & Groepering & Cumulatief percentage & $2010-2014$ & 2015-2019 \\
\hline zwartbekgrondel* & Eurytoop (Bentisch) & 65.27 & 60.2 & 67.38 \\
\hline blankvoorn & Eurytoop (Pelagisch) & 84.09 & 31.15 & 13.71 \\
\hline baars & Eurytoop (Pelagisch) & 87.38 & - & 4.65 \\
\hline aal & Eurytoop (Bentisch) & 90.34 & 1.14 & 3.71 \\
\hline winde & Rheofiel (Pelagisch) & 92.56 & 1.02 & 2.72 \\
\hline bittervoorn & Limnofiel (Pelagisch) & 94.3 & - & 2.46 \\
\hline alver & Eurytoop (Pelagisch) & 95.75 & - & 2.05 \\
\hline snoek & Eurytoop (Pelagisch) & 96.69 & 1.3 & 0.79 \\
\hline driedoornige stekelbaars & Eurytoop (Pelagisch) & 97.6 & 1.3 & 0.76 \\
\hline kesslers grondel* & Eurytoop (Bentisch) & 98.32 & - & 1.02 \\
\hline barbeel & Rheofiel (Bentisch) & 98.86 & - & 0.76 \\
\hline roofblei* & Rheofiel (Pelagisch) & 99.24 & 1.3 & - \\
\hline vetje & Limnofiel (Pelagisch) & 99.62 & 1.3 & - \\
\hline zeelt & Limnofiel (Bentisch) & 100 & 1.3 & - \\
\hline
\end{tabular}

Tabel 4. Soortensamenstelling in percentages op basis van biomassa in schepnetvangsten in de hoofdstroom van de Benedenloop Nederrijn per 5-jarige periode. De groepering geeft de ecologische indeling aan de hand van Noble et al. (2007) aan. Het cumulatief percentage geeft aan hoeveel de soorten over de gehele periode voorkomen op basis van de gesommeerde CPUE op basis van de biomassa. Nul-percentages zijn naar beneden afgeronde waarden, $*=$ exoot.

\begin{tabular}{|c|c|c|c|c|}
\hline Soort & Groepering & Cumulatief percentage & $2010-2014$ & $2015-2019$ \\
\hline snoek & Eurytoop (Pelagisch) & 58.94 & 89.5 & 40.18 \\
\hline aal & Eurytoop (Bentisch) & 87.69 & 1.15 & 45.69 \\
\hline zwartbekgrondel* & Eurytoop (Bentisch) & 96.2 & 6.53 & 9.73 \\
\hline blankvoorn & Eurytoop (Pelagisch) & 98.59 & 2.58 & 2.27 \\
\hline baars & Eurytoop (Pelagisch) & 99.14 & - & 0.89 \\
\hline winde & Rheofiel (Pelagisch) & 99.6 & 0.13 & 0.66 \\
\hline kesslers grondel* & Eurytoop (Bentisch) & 99.75 & - & 0.25 \\
\hline barbeel & Rheofiel (Bentisch) & 99.85 & - & 0.16 \\
\hline bittervoorn & Limnofiel (Pelagisch) & 99.91 & - & 0.09 \\
\hline alver & Eurytoop (Pelagisch) & 99.95 & - & 0.07 \\
\hline roofblei* & Rheofiel (Pelagisch) & 99.97 & 0.05 & - \\
\hline zeelt & Limnofiel (Bentisch) & 99.98 & 0.04 & - \\
\hline driedoornige stekelbaars & Eurytoop (Pelagisch) & 99.99 & 0.01 & 0.01 \\
\hline vetje & Limnofiel (Pelagisch) & 100 & 0.02 & - \\
\hline
\end{tabular}




\section{Bijlage 25 Benedenloop Nederrijn zijwateren}

Tabel 1. Soortensamenstelling in percentages op basis van aantal in boomkorvangsten in de zijwateren van de Benedenloop Nederrijn per 5-jarige periode. De groepering geeft de ecologische indeling aan de hand van Noble et al. (2007) aan. Het cumulatief percentage geeft aan hoeveel de soorten over de gehele periode voorkomen op basis van de gesommeerde CPUE op basis van het aantal. Nul-percentages zijn naar beneden afgeronde waarden, $*$ = exoot.

\begin{tabular}{|c|c|c|c|c|}
\hline Soort & Groepering & Cumulatief percentage & $2010-2014$ & $2015-2019$ \\
\hline brasem & Eurytoop (Bentisch) & 33.79 & 25.96 & 34.53 \\
\hline snoekbaars & Eurytoop (Bentisch) & 55.47 & 19.92 & 21.85 \\
\hline blankvoorn & Eurytoop (Pelagisch) & 66.8 & 6.81 & 11.76 \\
\hline baars & Eurytoop (Pelagisch) & 77.35 & 2.27 & 11.33 \\
\hline zwartbekgrondel* & Eurytoop (Bentisch) & 85.31 & 17.82 & 7.03 \\
\hline kolblei & Eurytoop (Bentisch) & 93.11 & 4.03 & 8.15 \\
\hline pos & Eurytoop (Bentisch) & 96.86 & 14.06 & 2.78 \\
\hline pontische stroomgrondel* & Eurytoop (Bentisch) & 98.44 & 4.6 & 1.29 \\
\hline kesslers grondel* & Eurytoop (Bentisch) & 98.87 & - & 0.47 \\
\hline alver & Eurytoop (Pelagisch) & 99.25 & 2.27 & 0.2 \\
\hline zeelt & Limnofiel (Bentisch) & 99.45 & 2.27 & \\
\hline winde & Rheofiel (Pelagisch) & 99.64 & - & 0.21 \\
\hline aal & Eurytoop (Bentisch) & 99.82 & - & 0.2 \\
\hline spiering & Eurytoop (Pelagisch) & 100 & - & 0.2 \\
\hline
\end{tabular}

Tabel 2. Soortensamenstelling in percentages op basis van biomassa in boomkorvangsten in de zijwateren van de Benedenloop Nederrijn per 5-jarige periode. De groepering geeft de ecologische indeling aan de hand van Noble et al. (2007) aan. Het cumulatief percentage geeft aan hoeveel de soorten over de gehele periode voorkomen op basis van de gesommeerde CPUE op basis van de biomassa. Nul-percentages zijn naar beneden afgeronde waarden, $*=$ exoot.

\begin{tabular}{|c|c|c|c|c|}
\hline Soort & Groepering & Cumulatief percentage & $2010-2014$ & $2015-2019$ \\
\hline snoekbaars & Eurytoop (Bentisch) & 32.27 & 25.38 & 32.76 \\
\hline brasem & Eurytoop (Bentisch) & 61.72 & 26.99 & 29.63 \\
\hline baars & Eurytoop (Pelagisch) & 77.23 & 0.23 & 16.59 \\
\hline kolblei & Eurytoop (Bentisch) & 88.57 & 38.63 & 9.41 \\
\hline blankvoorn & Eurytoop (Pelagisch) & 98.19 & 6.16 & 9.86 \\
\hline aal & Eurytoop (Bentisch) & 98.83 & - & 0.69 \\
\hline pos & Eurytoop (Bentisch) & 99.26 & 1.87 & 0.33 \\
\hline winde & Rheofiel (Pelagisch) & 99.64 & - & 0.4 \\
\hline zwartbekgrondel* & Eurytoop (Bentisch) & 99.85 & 0.19 & 0.22 \\
\hline pontische stroomgrondel* & Eurytoop (Bentisch) & 99.95 & 0.37 & 0.07 \\
\hline kesslers grondel* & Eurytoop (Bentisch) & 99.98 & - & 0.03 \\
\hline alver & Eurytoop (Pelagisch) & 99.99 & 0.12 & 0 \\
\hline spiering & Eurytoop (Pelagisch) & 100 & - & 0.01 \\
\hline zeelt & Limnofiel (Bentisch) & 100 & 0.07 & - \\
\hline
\end{tabular}


Tabel 3. Soortensamenstelling in percentages op basis van aantal in schepnetvangsten in de zijwateren van de Benedenloop Nederrijn per 5-jarige periode. De groepering geeft de ecologische indeling aan de hand van Noble et al. (2007) aan. Het cumulatief percentage geeft aan hoeveel de soorten over de gehele periode voorkomen op basis van de gesommeerde CPUE op basis van het aantal. Nul-percentages zijn naar beneden afgeronde waarden, $*$ =xoot.

\begin{tabular}{|c|c|c|c|c|}
\hline Soort & Groepering & Cumulatief percentage & $2010-2014$ & 2015-2019 \\
\hline blankvoorn & Eurytoop (Pelagisch) & 50 & - & 61.54 \\
\hline zwartbekgrondel* & Eurytoop (Bentisch) & 71.78 & 73.83 & 9.77 \\
\hline baars & Eurytoop (Pelagisch) & 80.93 & - & 11.25 \\
\hline winde & Rheofiel (Pelagisch) & 87.92 & 6.06 & 7.2 \\
\hline aal & Eurytoop (Bentisch) & 89.92 & 1.94 & 2.02 \\
\hline brasem & Eurytoop (Bentisch) & 91.7 & 4.12 & 1.23 \\
\hline snoek & Eurytoop (Pelagisch) & 93.28 & 1.09 & 1.7 \\
\hline driedoornige stekelbaars & Eurytoop (Pelagisch) & 94.49 & 1.94 & $\overline{1.04}$ \\
\hline pos & Eurytoop (Bentisch) & 95.49 & - & 1.23 \\
\hline pontische stroomgrondel* & Eurytoop (Bentisch) & 96.34 & - & $\overline{1.04}$ \\
\hline alver & Eurytoop (Pelagisch) & 97.13 & - & 0.98 \\
\hline kolblei & Eurytoop (Bentisch) & 97.93 & - & 0.98 \\
\hline bittervoorn & Limnofiel (Pelagisch) & 98.64 & 3.74 & - \\
\hline kopvoorn & Rheofiel (Pelagisch) & 99.23 & 3.15 & - \\
\hline marmergrondel* & Eurytoop (Bentisch) & 99.61 & 2.06 & - \\
\hline kesslers grondel* & Eurytoop (Bentisch) & 99.82 & 1.09 & - \\
\hline roofblei* & Rheofiel (Pelagisch) & 100 & 0.97 & - \\
\hline
\end{tabular}

Tabel 4. Soortensamenstelling in percentages op basis van biomassa in schepnetvangsten in de zijwateren van de Benedenloop Nederrijn per 5-jarige periode. De groepering geeft de ecologische indeling aan de hand van Noble et al. (2007) aan. Het cumulatief percentage geeft aan hoeveel de soorten over de gehele periode voorkomen op basis van de gesommeerde CPUE op basis van de biomassa. Nul-percentages zijn naar beneden afgeronde waarden, $*$ = exoot.

\begin{tabular}{|c|c|c|c|c|}
\hline Soort & Groepering & Cumulatief percentage & $2010-2014$ & $2015-2019$ \\
\hline snoek & Eurytoop (Pelagisch) & 37.22 & 4.05 & 43.49 \\
\hline baars & Eurytoop (Pelagisch) & 67.1 & - & 35.53 \\
\hline aal & Eurytoop (Bentisch) & 80.41 & 5.24 & 14.83 \\
\hline winde & Rheofiel (Pelagisch) & 91.23 & 64.27 & 0.72 \\
\hline blankvoorn & Eurytoop (Pelagisch) & 94.57 & - & 3.97 \\
\hline kopvoorn & Rheofiel (Pelagisch) & 97.02 & 15.4 & - \\
\hline zwartbekgrondel* & Eurytoop (Bentisch) & 99.41 & 9.47 & 1.05 \\
\hline brasem & Eurytoop (Bentisch) & 99.53 & 0.25 & 0.09 \\
\hline kolblei & Eurytoop (Bentisch) & 99.64 & - & 0.14 \\
\hline roofblei* & Rheofiel (Pelagisch) & 99.75 & 0.67 & - \\
\hline kesslers grondel* & Eurytoop (Bentisch) & 99.83 & 0.51 & - \\
\hline pontische stroomgrondel* & Eurytoop (Bentisch) & 99.89 & - & 0.08 \\
\hline pos & Eurytoop (Bentisch) & 99.94 & - & 0.06 \\
\hline driedoornige stekelbaars & Eurytoop (Pelagisch) & 99.96 & 0.03 & 0.02 \\
\hline alver & Eurytoop (Pelagisch) & 99.98 & - & 0.02 \\
\hline bittervoorn & Limnofiel (Pelagisch) & 99.99 & 0.08 & - \\
\hline marmergrondel* & Eurytoop (Bentisch) & 100 & 0.04 & - \\
\hline
\end{tabular}




\section{Bijlage 26 Benedenloop Waal hoofdstroom}

Tabel 1. Soortensamenstelling in percentages op basis van aantal in boomkorvangsten in de hoofdstroom van de Benedenloop Waal per 5-jarige periode. De groepering geeft de ecologische indeling aan de hand van Noble et al. (2007) aan. Het cumulatief percentage geeft aan hoeveel de soorten over de gehele periode voorkomen op basis van de gesommeerde CPUE op basis van het aantal. Nul-percentages zijn naar beneden afgeronde waarden, $*=$ exoot.

\begin{tabular}{rrrrr}
\hline Soort & \multicolumn{1}{c}{ Groepering } & Cumulatief percentage & $2010-2014$ & $2015-2019$ \\
\hline brasem & Eurytoop (Bentisch) & 38.29 & 35.23 & 38.84 \\
\hline blankvoorn & Eurytoop (Pelagisch) & 58.81 & 19.76 & 20.66 \\
\hline snoekbaars & Eurytoop (Bentisch) & 68.07 & 4.36 & 10.16 \\
\hline zwartbekgrondel* & Eurytoop (Bentisch) & 74.89 & 4.98 & 7.15 \\
\hline kolblei & Eurytoop (Bentisch) & 81.19 & 0.65 & 7.33 \\
\hline pontische stroomgrondel* & Eurytoop (Bentisch) & 84.45 & 5.62 & 2.83 \\
\hline donaubrasem* & Eurytoop (Bentisch) & 87.24 & - & 3.3 \\
\hline witvinriviergrondel* & Eurytoop (Bentisch) & 89.62 & 2.09 & 2.43 \\
\hline winde & Rheofiel (Pelagisch) & 91.99 & 10.67 & 0.86 \\
\hline aal & Eurytoop (Bentisch) & 93.84 & - & 2.18 \\
\hline pos & Eurytoop (Bentisch) & 94.97 & 5.92 & 0.26 \\
\hline baars & Eurytoop (Pelagisch) & 95.79 & 3.67 & 0.31 \\
\hline alver & Eurytoop (Pelagisch) & 96.57 & 0.75 & 0.78 \\
\hline sneep & Rheofiel (Bentisch) & 97.3 & 4.08 & 0.13 \\
\hline riviergrondel & Rheofiel (Bentisch) & 97.85 & - & 0.64 \\
\hline bot & Limnofiel (Bentisch) & 98.37 & - & 0.62 \\
\hline roofblei* & Rheofiel (Pelagisch) & 98.82 & 2.2 & 0.13 \\
\hline barbeel & Rheofiel (Bentisch) & 99.26 & - & 0.52 \\
\hline kesslers grondel* & Eurytoop (Bentisch) & 99.58 & - & 0.38 \\
\hline blauwneus* & Eurytoop (Bentisch) & 99.89 & - & 0.37 \\
\hline hybride cyprinide & Eurytoop (Bentisch) & 100 & - & 0.13 \\
\hline
\end{tabular}

Tabel 2. Soortensamenstelling in percentages op basis van biomassa in boomkorvangsten in de hoofdstroom van de Benedenloop Waal per 5-jarige periode. De groepering geeft de ecologische indeling aan de hand van Noble et al. (2007) aan. Het cumulatief percentage geeft aan hoeveel de soorten over de gehele periode voorkomen op basis van de gesommeerde CPUE op basis van de biomassa. Nulpercentages zijn naar beneden afgeronde waarden, $*=$ exoot.

\begin{tabular}{rrrrr}
\hline Soort & Groepering & Cumulatief percentage & $2010-2014$ & $2015-2019$ \\
\hline brasem & Eurytoop (Bentisch) & 54.4 & 73.82 & 42.87 \\
\hline snoekbaars & Eurytoop (Bentisch) & 64.85 & 2.31 & 15.28 \\
\hline winde & Rheofiel (Pelagisch) & 74.67 & 19.46 & 4.11 \\
\hline blankvoorn & Eurytoop (Pelagisch) & 81.72 & 2.85 & 9.53 \\
\hline kolblei & Eurytoop (Bentisch) & 87.5 & 0.21 & 9.09 \\
\hline barbeel & Rheofiel (Bentisch) & 91.46 & - & 6.31 \\
\hline aal & Eurytoop (Bentisch) & 95.15 & - & 5.89 \\
\hline donaubrasem* & Eurytoop (Bentisch) & 98.36 & - & 5.12 \\
\hline zwartbekgrondel* & Eurytoop (Bentisch) & 98.68 & 0.07 & 0.47 \\
\hline baars & Eurytoop (Pelagisch) & 98.98 & 0.29 & 0.31 \\
\hline sneep & Rheofiel (Bentisch) & 99.23 & 0.65 & 0.02 \\
\hline bot & Limnofiel (Bentisch) & 99.39 & - & 0.25 \\
\hline burytoop (Bentisch) & 99.52 & 0.05 & 0.17 \\
\hline pontische stroomgrondel* & Euryej* & 99.64 & 0.08 & 0.14 \\
\hline alver & Rheofiel (Pelagisch) & 99.73 & - & 0.14 \\
\hline pos & Eurytoop (Bentisch) & 99.8 & 0.06 & 0.09 \\
\hline Eurytoop (Bentisch) & 99.87 & 0.03 & 0.09 \\
\hline Eurytoop (Pelagisch) & 99.93 & 0.11 & 0.02 \\
\hline kesslers grondel* & Eurytoop (Bentisch) & 99.97 & - & 0.06 \\
\hline hybride cyprinide & Eurytoop (Bentisch) & 99.99 & - & 0.03 \\
\hline riviergrondel & Eurytoop (Bentisch) & 100 & - & 0.02 \\
\hline & Rheofiel (Bentisch) & &
\end{tabular}


Tabel 3. Soortensamenstelling in percentages op basis van aantal in schepnetvangsten in de hoofdstroom van de Benedenloop Waal per 5-jarige periode. De groepering geeft de ecologische indeling aan de hand van Noble et al. (2007) aan. Het cumulatief percentage geeft aan hoeveel de soorten over de gehele periode voorkomen op basis van de gesommeerde CPUE op basis van het aantal. Nulpercentages zijn naar beneden afgeronde waarden, * = exoot.

\begin{tabular}{rrrrr}
\hline Soort & Groepering & Cumulatief percentage & $2010-2014$ & $2015-2019$ \\
\hline blankvoorn & Eurytoop (Pelagisch) & 39.55 & 49.31 & 29.41 \\
\hline zwartbekgrondel* & Eurytoop (Bentisch) & 72.45 & 29.27 & 36.67 \\
\hline aal & Eurytoop (Bentisch) & 85.66 & 2.94 & 23.86 \\
\hline alver & Eurytoop (Pelagisch) & 90.17 & 8.32 & 0.56 \\
\hline winde & Rheofiel (Pelagisch) & 94.67 & 4.74 & 4.24 \\
\hline baars & Eurytoop (Pelagisch) & 96.35 & 1.25 & 2.13 \\
\hline kesslers grondel* & Eurytoop (Bentisch) & 97.27 & 0.71 & 1.13 \\
\hline roofblei* & Rheofiel (Pelagisch) & 98.17 & 1.65 & 0.14 \\
\hline snoekbaars & Eurytoop (Bentisch) & 98.77 & 0.49 & 0.7 \\
\hline serpeling & Rheofiel (Pelagisch) & 99.15 & 0.29 & 0.48 \\
\hline brasem & Eurytoop (Bentisch) & 99.51 & 0.58 & 0.12 \\
\hline bot & Limnofiel (Bentisch) & 99.7 & - & 0.39 \\
\hline pos & Eurytoop (Bentisch) & 99.78 & - & 0.17 \\
\hline Europese meerval & Eurytoop (Bentisch) & 99.84 & 0.12 & - \\
\hline karper & Eurytoop (Bentisch) & 99.9 & 0.12 & - \\
\hline sneep & Rheofiel (Bentisch) & 99.95 & 0.1 & - \\
\hline barbeel & Rheofiel (Bentisch) & 100 & 0.09 & - \\
\hline & & & &
\end{tabular}

Tabel 4. Soortensamenstelling in percentages op basis van biomassa in schepnetvangsten in de hoofdstroom van de Benedenloop Waal per 5-jarige periode. De groepering geeft de ecologische indeling aan de hand van Noble et al. (2007) aan. Het cumulatief percentage geeft aan hoeveel de soorten over de gehele periode voorkomen op basis van de gesommeerde CPUE op basis van de biomassa. Nulpercentages zijn naar beneden afgeronde waarden, $*$ = exoot.

\begin{tabular}{rrrrr}
\hline Soort & Groepering & Cumulatief percentage & $2010-2014$ & $2015-2019$ \\
\hline aal & Eurytoop (Bentisch) & 62.35 & 22.32 & 79.97 \\
\hline karper & Eurytoop (Bentisch) & 71.85 & 31.09 & - \\
\hline snoekbaars & Eurytoop (Bentisch) & 79.51 & 17.56 & 3.3 \\
\hline blankvoorn & Eurytoop (Pelagisch) & 84.34 & 6.84 & 3.94 \\
\hline zwartbekgrondel* & Eurytoop (Bentisch) & 88.99 & 7.21 & 3.53 \\
\hline brasem & Eurytoop (Bentisch) & 93.63 & 9.6 & 2.46 \\
\hline winde & Rheofiel (Pelagisch) & 98.1 & 0.89 & 6.03 \\
\hline roofblei* & Rheofiel (Pelagisch) & 98.93 & 2.68 & 0.02 \\
\hline grondel* & Eurytoop (Bentisch) & 99.32 & 0.72 & 0.25 \\
\hline baars & Eurytoop (Pelagisch) & 99.63 & 0.26 & 0.33 \\
\hline alver & Eurytoop (Pelagisch) & 99.87 & 0.67 & 0.05 \\
\hline serpeling & Rheofiel (Pelagisch) & 99.92 & 0.05 & 0.05 \\
\hline pos & Eurytoop (Bentisch) & 99.95 & - & 0.04 \\
\hline Eurlers & 99.97 & 0.07 & - \\
\hline buropese meerval & Eurytoop (Bentisch) & 99.99 & - & 0.03 \\
\hline Limnofiel (Bentisch) & 100 & 0.01 & - \\
\hline barbeel & Rheofiel (Bentisch) & 100 & 0.01 & - \\
\hline & Rheofiel (Bentisch) & & &
\end{tabular}




\section{Bijlage 27 Benedenloop Waal zijwateren}

Tabel 1. Soortensamenstelling in percentages op basis van aantal in boomkorvangsten in de zijwateren van de Benedenloop Waal per 5-jarige periode. De groepering geeft de ecologische indeling aan de hand van Noble et al. (2007) aan. Het cumulatief percentage geeft aan hoeveel de soorten over de gehele periode voorkomen op basis van de gesommeerde CPUE op basis van het aantal. Nul-percentages zijn naar beneden afgeronde waarden, * exoot.

\begin{tabular}{|c|c|c|c|c|}
\hline Soort & Groepering & Cumulatief percentage & $2010-2014$ & $2015-2019$ \\
\hline brasem & Eurytoop (Bentisch) & 36.8 & 43.59 & 34.23 \\
\hline blankvoorn & Eurytoop (Pelagisch) & 52.37 & 14.46 & 15.99 \\
\hline alver & Eurytoop (Pelagisch) & 67.12 & - & 20.33 \\
\hline zwartbekgrondel* & Eurytoop (Bentisch) & 78.43 & 16.3 & 9.42 \\
\hline snoekbaars & Eurytoop (Bentisch) & 84.91 & 5.2 & 6.97 \\
\hline baars & Eurytoop (Pelagisch) & 89.47 & 12.26 & 1.65 \\
\hline kolblei & Eurytoop (Bentisch) & 93.36 & 0.72 & 5.08 \\
\hline pontische stroomgrondel* & Eurytoop (Bentisch) & 96.37 & 3.55 & 2.81 \\
\hline pos & Eurytoop (Bentisch) & 98.93 & 2.98 & 2.4 \\
\hline aal & Eurytoop (Bentisch) & 99.23 & - & 0.41 \\
\hline kesslers grondel* & Eurytoop (Bentisch) & 99.41 & 0.14 & 0.19 \\
\hline bot & Limnofiel (Bentisch) & 99.57 & - & 0.23 \\
\hline donaubrasem* & Eurytoop (Bentisch) & 99.67 & - & 0.13 \\
\hline winde & Rheofiel (Pelagisch) & 99.76 & 0.16 & 0.06 \\
\hline snoek & Eurytoop (Pelagisch) & 99.84 & 0.28 & \\
\hline witvinriviergrondel* & Eurytoop (Bentisch) & 99.9 & - & 0.09 \\
\hline rietvoorn & Limnofiel (Pelagisch) & 99.96 & 0.2 & \\
\hline roofblei* & Rheofiel (Pelagisch) & 100 & 0.16 & \\
\hline
\end{tabular}

Tabel 2. Soortensamenstelling in percentages op basis van biomassa in boomkorvangsten in de zijwateren van de Benedenloop Waal per 5-jarige periode. De groepering geeft de ecologische indeling aan de hand van Noble et al. (2007) aan. Het cumulatief percentage geeft aan hoeveel de soorten over de gehele periode voorkomen op basis van de gesommeerde CPUE op basis van de biomassa. Nulpercentages zijn naar beneden afgeronde waarden, * = exoot.

\begin{tabular}{|c|c|c|c|c|}
\hline Soort & Groepering & Cumulatief percentage & $2010-2014$ & $2015-2019$ \\
\hline brasem & Eurytoop (Bentisch) & 48.16 & 36.28 & 50.75 \\
\hline snoekbaars & Eurytoop (Bentisch) & 68.99 & 30.16 & 18.8 \\
\hline kolblei & Eurytoop (Bentisch) & 80.4 & 7.69 & 12.22 \\
\hline blankvoorn & Eurytoop (Pelagisch) & 90.01 & 13.54 & 8.75 \\
\hline baars & Eurytoop (Pelagisch) & 93.61 & 4.93 & 3.31 \\
\hline aal & Eurytoop (Bentisch) & 95.89 & - & 2.78 \\
\hline zwartbekgrondel* & Eurytoop (Bentisch) & 96.98 & 1.7 & 0.96 \\
\hline alver & Eurytoop (Pelagisch) & 97.75 & - & 0.94 \\
\hline snoek & Eurytoop (Pelagisch) & 98.45 & 3.91 & \\
\hline pos & Eurytoop (Bentisch) & 99 & 0.67 & 0.52 \\
\hline donaubrasem* & Eurytoop (Bentisch) & 99.42 & - & 0.51 \\
\hline pontische stroomgrondel* & Eurytoop (Bentisch) & 99.73 & 0.75 & 0.21 \\
\hline bot & Limnofiel (Bentisch) & 99.88 & - & 0.18 \\
\hline kesslers grondel* & Eurytoop (Bentisch) & 99.93 & 0.03 & 0.05 \\
\hline winde & Rheofiel (Pelagisch) & 99.96 & 0.19 & 0.01 \\
\hline rietvoorn & Limnofiel (Pelagisch) & 99.98 & 0.11 & \\
\hline witvinriviergrondel* & Eurytoop (Bentisch) & 99.99 & - & 0.01 \\
\hline roofblei* & Rheofiel (Pelagisch) & 100 & 0.04 & \\
\hline
\end{tabular}


Tabel 3. Soortensamenstelling in percentages op basis van aantal in schepnetvangsten in de zijwateren van de Benedenloop Waal per 5-jarige periode. De groepering geeft de ecologische indeling aan de hand van Noble et al. (2007) aan. Het cumulatief percentage geeft aan hoeveel de soorten over de gehele periode voorkomen op basis van de gesommeerde CPUE op basis van het aantal. Nul-percentages zijn naar beneden afgeronde waarden, $*=$ exoot.

\begin{tabular}{|c|c|c|c|c|}
\hline Soort & Groepering & Cumulatief percentage & $2010-2014$ & $2015-2019$ \\
\hline blankvoorn & Eurytoop (Pelagisch) & 73.85 & 71.66 & 75.45 \\
\hline zwartbekgrondel* & Eurytoop (Bentisch) & 86.57 & 18.03 & 8.85 \\
\hline winde & Rheofiel (Pelagisch) & 91.98 & 3.02 & 7.14 \\
\hline baars & Eurytoop (Pelagisch) & 95.66 & 4.04 & 3.43 \\
\hline aal & Eurytoop (Bentisch) & 97.47 & 0.98 & 2.4 \\
\hline alver & Eurytoop (Pelagisch) & 98.11 & 0.81 & 0.53 \\
\hline roofblei* & Rheofiel (Pelagisch) & 98.65 & - & 0.94 \\
\hline brasem & Eurytoop (Bentisch) & 98.98 & 0.77 & \\
\hline snoekbaars & Eurytoop (Bentisch) & 99.25 & - & 0.46 \\
\hline kopvoorn & Rheofiel (Pelagisch) & 99.45 & - & 0.35 \\
\hline bot & Limnofiel (Bentisch) & 99.55 & 0.25 & \\
\hline pontische stroomgrondel* & Eurytoop (Bentisch) & 99.66 & 0.25 & - \\
\hline kesslers grondel* & Eurytoop (Bentisch) & 99.74 & 0.2 & \\
\hline driedoornige stekelbaars & Eurytoop (Pelagisch) & 99.81 & - & 0.12 \\
\hline kolblei & Eurytoop (Bentisch) & 99.88 & - & 0.12 \\
\hline serpeling & Rheofiel (Pelagisch) & 99.94 & - & 0.11 \\
\hline pos & Eurytoop (Bentisch) & 100 & - & 0.11 \\
\hline
\end{tabular}

Tabel 4. Soortensamenstelling in percentages op basis van biomassa in schepnetvangsten in de zijwateren van de Benedenloop Waal per 5-jarige periode. De groepering geeft de ecologische indeling aan de hand van Noble et al. (2007) aan. Het cumulatief percentage geeft aan hoeveel de soorten over de gehele periode voorkomen op basis van de gesommeerde CPUE op basis van de biomassa. Nulpercentages zijn naar beneden afgeronde waarden, $*$ = exoot.

\begin{tabular}{|c|c|c|c|c|}
\hline Soort & Groepering & Cumulatief percentage & $2010-2014$ & $2015-2019$ \\
\hline winde & Rheofiel (Pelagisch) & 31.69 & 34.33 & 30.08 \\
\hline aal & Eurytoop (Bentisch) & 53.19 & 15.09 & 25.41 \\
\hline blankvoorn & Eurytoop (Pelagisch) & 73.34 & 21.61 & 19.26 \\
\hline snoekbaars & Eurytoop (Bentisch) & 85.94 & - & 20.26 \\
\hline brasem & Eurytoop (Bentisch) & 92.77 & 18.05 & \\
\hline zwartbekgrondel* & Eurytoop (Bentisch) & 96.5 & 5.68 & 2.55 \\
\hline baars & Eurytoop (Pelagisch) & 99.12 & 4.72 & 1.34 \\
\hline roofblei* & Rheofiel (Pelagisch) & 99.33 & - & 0.34 \\
\hline alver & Eurytoop (Pelagisch) & 99.54 & 0.12 & 0.25 \\
\hline kopvoorn & Rheofiel (Pelagisch) & 99.71 & - & 0.28 \\
\hline pos & Eurytoop (Bentisch) & 99.82 & - & 0.18 \\
\hline pontische stroomgrondel* & Eurytoop (Bentisch) & 99.91 & 0.23 & \\
\hline bot & Limnofiel (Bentisch) & 99.95 & 0.11 & \\
\hline kesslers grondel* & Eurytoop (Bentisch) & 99.98 & 0.06 & \\
\hline serpeling & Rheofiel (Pelagisch) & 100 & - & 0.03 \\
\hline kolblei & Eurytoop (Bentisch) & 100 & - & 0 \\
\hline driedoornige stekelbaars & Eurytoop (Pelagisch) & 100 & - & 0 \\
\hline
\end{tabular}




\section{Bijlage 28 Getijden Lek hoofdstroom}

Tabel 1. Soortensamenstelling in percentages op basis van aantal in boomkorvangsten in de hoofdstroom van de Getijden Lek per 5-jarige periode. De groepering geeft de ecologische indeling aan de hand van Noble et al. (2007) aan. Het cumulatief percentage geeft aan hoeveel de soorten over de gehele periode voorkomen op basis van de gesommeerde CPUE op basis van het aantal. Nul-percentages zijn naar beneden afgeronde waarden, $*$ =xoot.

\begin{tabular}{|c|c|c|c|c|c|c|c|}
\hline Soort & Groepering & $\begin{array}{l}\text { Cumulatief } \\
\text { percentage }\end{array}$ & $\begin{array}{r}1997- \\
1999 \\
\end{array}$ & $\begin{array}{r}2000- \\
2004\end{array}$ & $\begin{array}{r}2005- \\
2009\end{array}$ & $\begin{array}{r}2010- \\
2014\end{array}$ & $\begin{array}{r}2015- \\
2019\end{array}$ \\
\hline brasem & Eurytoop (Bentisch) & 31.14 & 55.81 & 39.72 & 38.32 & 14.55 & 22.75 \\
\hline bot & Limnofiel (Bentisch) & 55.17 & 12.13 & 18.94 & 16.68 & 21.73 & 36.7 \\
\hline blankvoorn & Eurytoop (Pelagisch) & 65.15 & 8.02 & 13.45 & 9.78 & 16.67 & 4.36 \\
\hline pontische stroomgrondel* & Eurytoop (Bentisch) & 72.91 & - & - & 0.03 & 19.42 & 14.22 \\
\hline snoekbaars & Eurytoop (Bentisch) & 80.13 & 6.59 & 8.88 & 6.23 & 5.7 & 7.51 \\
\hline kolblei & Eurytoop (Bentisch) & 86.53 & 9.45 & 5.6 & 14.67 & 4.06 & 2.41 \\
\hline zwartbekgrondel* & Eurytoop (Bentisch) & 90.01 & - & - & 1.91 & 7.7 & 5.75 \\
\hline riviergrondel & Rheofiel (Bentisch) & 92.65 & 5.12 & 7.87 & 1.65 & - & - \\
\hline baars & Eurytoop (Pelagisch) & 95.19 & 0.93 & 2.63 & 1.96 & 3.8 & 2.56 \\
\hline witvinriviergrondel* & Eurytoop (Bentisch) & 97.02 & - & - & 5.17 & 2.39 & 1.36 \\
\hline winde & Rheofiel (Pelagisch) & 97.73 & 0.87 & 1.17 & 0.51 & 1.25 & 0.16 \\
\hline pos & Eurytoop (Bentisch) & 98.36 & 0.07 & 0.48 & 1.94 & 0.22 & 0.3 \\
\hline aal & Eurytoop (Bentisch) & 98.96 & 0.14 & 0.73 & 0.27 & 0.42 & 0.91 \\
\hline alver & Eurytoop (Pelagisch) & 99.2 & 0.07 & 0.09 & 0.13 & 0.54 & 0.28 \\
\hline roofblei* & Rheofiel (Pelagisch) & 99.38 & 0.28 & 0.19 & 0.17 & 0.23 & 0.12 \\
\hline spiering & Eurytoop (Pelagisch) & 99.53 & 0.06 & 0.04 & 0.2 & 0.5 & 0.06 \\
\hline kesslers grondel* & Eurytoop (Bentisch) & 99.64 & - & - & - & 0.24 & 0.22 \\
\hline hybride cyprinide & Eurytoop (Bentisch) & 99.73 & 0.3 & 0.14 & 0.1 & - & 0.02 \\
\hline driedoornige stekelbaars & Eurytoop (Pelagisch) & 99.78 & - & - & 0.03 & 0.19 & 0.04 \\
\hline donaubrasem* & Eurytoop (Bentisch) & 99.82 & - & - & 0.03 & 0.15 & 0.04 \\
\hline blauwneus* & Eurytoop (Bentisch) & 99.86 & - & - & - & 0.04 & 0.12 \\
\hline rivierprik & Rheofiel (Bentisch) & 99.9 & - & 0.05 & 0.06 & 0.07 & - \\
\hline zeebaars & Marien (Pelagisch) & 99.93 & - & - & - & - & 0.08 \\
\hline sneep & Rheofiel (Bentisch) & 99.94 & - & - & 0.03 & 0.08 & - \\
\hline karper & Eurytoop (Bentisch) & 99.96 & - & - & 0.03 & 0.04 & - \\
\hline zalm & Rheofiel (Pelagisch) & 99.96 & - & - & - & - & 0.02 \\
\hline rivierdonderpad & Rheofiel (Bentisch) & 99.97 & - & - & 0.03 & - & - \\
\hline marmergrondel* & Eurytoop (Bentisch) & 99.98 & - & - & 0.03 & - & - \\
\hline rietvoorn & Limnofiel (Pelagisch) & 99.98 & - & - & - & 0.04 & - \\
\hline giebel & Eurytoop (Bentisch) & 99.99 & - & - & - & - & 0.02 \\
\hline grondel sp. & Marien (Bentisch) & 99.99 & 0.07 & - & - & - & - \\
\hline serpeling & Rheofiel (Pelagisch) & 100 & 0.07 & - & - & - & - \\
\hline
\end{tabular}


Tabel 2. Soortensamenstelling in percentages op basis van biomassa in boomkorvangsten in de hoofdstroom van de Getijden Lek per 5-jarige periode. De groepering geeft de ecologische indeling aan de hand van Noble et al. (2007) aan. Het cumulatief percentage geeft aan hoeveel de soorten over de gehele periode voorkomen op basis van de gesommeerde CPUE op basis van de biomassa. Nulpercentages zijn naar beneden afgeronde waarden, $*=$ exoot.

\begin{tabular}{|c|c|c|c|c|c|c|c|}
\hline Soort & Groepering & $\begin{array}{l}\text { Cumulatief } \\
\text { percentage }\end{array}$ & $\begin{array}{r}1997- \\
1999 \\
\end{array}$ & $\begin{array}{r}2000- \\
2004 \\
\end{array}$ & $\begin{array}{r}2005- \\
2009 \\
\end{array}$ & $\begin{array}{r}2010- \\
2014 \\
\end{array}$ & $\begin{array}{r}2015- \\
2019 \\
\end{array}$ \\
\hline brasem & Eurytoop (Bentisch) & 48.96 & 76.79 & 43.21 & 46.26 & 35.2 & 37.37 \\
\hline snoekbaars & Eurytoop (Bentisch) & 67 & 6.91 & 21.58 & 15.16 & 27.63 & 23.96 \\
\hline blankvoorn & Eurytoop (Pelagisch) & 81.03 & 5.47 & 14.3 & 17.37 & 14.55 & 19.19 \\
\hline kolblei & Eurytoop (Bentisch) & 91.66 & 8.72 & 13.35 & 14.73 & 4.78 & 4.5 \\
\hline baars & Eurytoop (Pelagisch) & 95.02 & 0.77 & 4.32 & 3.87 & 3.96 & 3.58 \\
\hline winde & Rheofiel (Pelagisch) & 96.49 & 0.7 & 1.7 & 0.75 & 5.71 & 0.08 \\
\hline aal & Eurytoop (Bentisch) & 97.5 & 0.02 & 0.38 & 0.27 & 2.87 & 3.74 \\
\hline bot & Limnofiel (Bentisch) & 98.3 & 0.21 & 0.48 & 0.4 & 1.36 & 2.59 \\
\hline pontische stroomgrondel* & Eurytoop (Bentisch) & 98.8 & - & - & 0 & 1.66 & 2.34 \\
\hline roofblei* & Rheofiel (Pelagisch) & 99.07 & 0.03 & 0.18 & 0.2 & 0.89 & 0.41 \\
\hline hybride cyprinide & Eurytoop (Bentisch) & 99.24 & 0.27 & 0.12 & 0.33 & - & 0.02 \\
\hline zwartbekgrondel* & Eurytoop (Bentisch) & 99.41 & - & - & 0.11 & 0.52 & 0.6 \\
\hline riviergrondel & Rheofiel (Bentisch) & 99.54 & 0.1 & 0.3 & 0.07 & - & \\
\hline witvinriviergrondel* & Eurytoop (Bentisch) & 99.66 & - & - & 0.3 & 0.23 & 0.16 \\
\hline zalm & Rheofiel (Pelagisch) & 99.77 & - & - & - & - & 0.81 \\
\hline pos & Eurytoop (Bentisch) & 99.82 & 0 & 0.04 & 0.11 & 0.02 & 0.06 \\
\hline blauwneus* & Eurytoop (Bentisch) & 99.87 & - & - & - & 0.02 & 0.3 \\
\hline donaubrasem* & Eurytoop (Bentisch) & 99.91 & - & - & 0.01 & 0.27 & 0.09 \\
\hline rivierprik & Rheofiel (Bentisch) & 99.94 & - & 0.03 & 0.04 & 0.08 & \\
\hline kesslers grondel* & Eurytoop (Bentisch) & 99.96 & - & - & - & 0.07 & 0.07 \\
\hline alver & Eurytoop (Pelagisch) & 99.97 & 0 & 0.01 & 0.01 & 0.03 & 0.03 \\
\hline giebel & Eurytoop (Bentisch) & 99.98 & - & - & - & - & 0.06 \\
\hline karper & Eurytoop (Bentisch) & 99.98 & - & - & 0 & 0.07 & \\
\hline spiering & Eurytoop (Pelagisch) & 99.99 & 0 & 0 & 0.01 & 0.04 & 0 \\
\hline sneep & Rheofiel (Bentisch) & 100 & - & - & 0.02 & 0.01 & \\
\hline rietvoorn & Limnofiel (Pelagisch) & 100 & - & - & - & 0.02 & - \\
\hline zeebaars & Marien (Pelagisch) & 100 & - & - & - & - & 0 \\
\hline serpeling & Rheofiel (Pelagisch) & 100 & 0 & - & - & - & - \\
\hline driedoornige stekelbaars & Eurytoop (Pelagisch) & 100 & - & - & 0 & 0 & 0 \\
\hline marmergrondel* & Eurytoop (Bentisch) & 100 & - & - & 0 & - & \\
\hline rivierdonderpad & Rheofiel (Bentisch) & 100 & - & - & 0 & - & \\
\hline grondel sp. & Marien (Bentisch) & 100 & 0 & - & - & - & \\
\hline
\end{tabular}


Tabel 3. Soortensamenstelling in percentages op basis van aantal in schepnetvangsten in de hoofdstroom van de Getijden Lek per 5-jarige periode. De groepering geeft de ecologische indeling aan de hand van Noble et al. (2007) aan. Het cumulatief percentage geeft aan hoeveel de soorten over de gehele periode voorkomen op basis van de gesommeerde CPUE op basis van het aantal. Nul-percentages zijn naar beneden afgeronde waarden, $*$ = exoot.

\begin{tabular}{|c|c|c|c|c|c|c|c|}
\hline Soort & Groepering & $\begin{array}{l}\text { Cumulatief } \\
\text { percentage }\end{array}$ & $\begin{array}{r}1997- \\
1999 \\
\end{array}$ & $\begin{array}{r}2000- \\
2004 \\
\end{array}$ & $\begin{array}{r}2005- \\
2009 \\
\end{array}$ & $\begin{array}{r}2010- \\
2014 \\
\end{array}$ & $\begin{array}{r}2015- \\
2019 \\
\end{array}$ \\
\hline winde & Rheofiel (Pelagisch) & 27.74 & 16.84 & 27.13 & 39.74 & 18.33 & 36.73 \\
\hline blankvoorn & Eurytoop (Pelagisch) & 50.51 & 33.25 & 36.59 & 16.38 & 12.06 & 5.31 \\
\hline alver & Eurytoop (Pelagisch) & 67.33 & 15.15 & 10.71 & 3.9 & 31.2 & 22.95 \\
\hline aal & Eurytoop (Bentisch) & 76.97 & 10.55 & 5.73 & 11.59 & 7.32 & 19.99 \\
\hline brasem & Eurytoop (Bentisch) & 82.38 & 7.25 & 4.21 & 8.73 & 6.86 & 2.88 \\
\hline zwartbekgrondel* & Eurytoop (Bentisch) & 87.09 & - & - & 3.4 & 15.07 & 4.97 \\
\hline baars & Eurytoop (Pelagisch) & 90.63 & 6.26 & 5.47 & 2.8 & 2.01 & 0.5 \\
\hline bot & Limnofiel (Bentisch) & 93.01 & 0.29 & 0.79 & 5.68 & 3.53 & 2.86 \\
\hline pos & Eurytoop (Bentisch) & 94.72 & 1.11 & 3.84 & 0.76 & - & \\
\hline sneep & Rheofiel (Bentisch) & 95.68 & 0.29 & 1.88 & 0.08 & 0.21 & 0.72 \\
\hline snoekbaars & Eurytoop (Bentisch) & 96.39 & 3.99 & 0.3 & 0.65 & 0.91 & 0.11 \\
\hline roofblei* & Rheofiel (Pelagisch) & 96.97 & - & 0.23 & 1 & 0.74 & 1.08 \\
\hline barbeel & Rheofiel (Bentisch) & 97.5 & - & 0.59 & 1.52 & 0.12 & 0.38 \\
\hline serpeling & Rheofiel (Pelagisch) & 97.89 & 1.55 & 0.62 & 0.19 & - & \\
\hline riviergrondel & Rheofiel (Bentisch) & 98.24 & 0.87 & 0.65 & 0.21 & - & \\
\hline kolblei & Eurytoop (Bentisch) & 98.54 & 0.58 & 0.56 & 0.3 & - & \\
\hline karper & Eurytoop (Bentisch) & 98.8 & 0.87 & 0.04 & 0.49 & 0.34 & 0.26 \\
\hline snoek & Eurytoop (Pelagisch) & 99.04 & 0.87 & 0.11 & 0.58 & - & 0.3 \\
\hline kesslers grondel* & Eurytoop (Bentisch) & 99.21 & - & - & - & 0.62 & 0.22 \\
\hline driedoornige stekelbaars & Eurytoop (Pelagisch) & 99.38 & - & 0.25 & 0.11 & 0.23 & \\
\hline witvinriviergrondel* & Eurytoop (Bentisch) & 99.55 & - & - & 0.75 & 0.11 & 0.24 \\
\hline rietvoorn & Limnofiel (Pelagisch) & 99.63 & - & 0.09 & 0.17 & 0.1 & \\
\hline harders indet. & Overige & 99.7 & - & - & 0.32 & 0.13 & \\
\hline tiendoornige stekelbaars & Limnofiel (Pelagisch) & 99.77 & - & - & 0.52 & - & \\
\hline rivierdonderpad & Rheofiel (Bentisch) & 99.83 & - & 0.11 & 0.13 & - & \\
\hline hybride cyprinide & Eurytoop (Bentisch) & 99.87 & - & - & - & - & 0.25 \\
\hline zeebaars & Marien (Pelagisch) & 99.91 & - & 0.04 & - & - & 0.12 \\
\hline giebel & Eurytoop (Bentisch) & 99.94 & - & - & - & 0.12 & \\
\hline diklipharder & Marien (Pelagisch) & 99.96 & - & - & - & - & 0.13 \\
\hline kopvoorn & Rheofiel (Pelagisch) & 99.98 & - & 0.05 & - & - & \\
\hline spiering & Eurytoop (Pelagisch) & 100 & 0.29 & - & - & - & \\
\hline
\end{tabular}


Tabel 4. Soortensamenstelling in percentages op basis van biomassa in schepnetvangsten in de hoofdstroom van de Getijden Lek per 5-jarige periode. De groepering geeft de ecologische indeling aan de hand van Noble et al. (2007) aan. Het cumulatief percentage geeft aan hoeveel de soorten over de gehele periode voorkomen op basis van de gesommeerde CPUE op basis van de biomassa. Nulpercentages zijn naar beneden afgeronde waarden, $*=$ exoot.

\begin{tabular}{|c|c|c|c|c|c|c|c|}
\hline Soort & Groepering & $\begin{array}{l}\text { Cumulatief } \\
\text { percentage }\end{array}$ & $\begin{array}{r}1997- \\
1999 \\
\end{array}$ & $\begin{array}{r}2000- \\
2004 \\
\end{array}$ & $\begin{array}{r}2005- \\
2009 \\
\end{array}$ & $\begin{array}{r}2010- \\
2014 \\
\end{array}$ & $\begin{array}{r}2015- \\
2019 \\
\end{array}$ \\
\hline winde & Rheofiel (Pelagisch) & 39.46 & 17.67 & 39.15 & 35.85 & 44.53 & 43.29 \\
\hline brasem & Eurytoop (Bentisch) & 72.4 & 19.97 & 43.65 & 41.25 & 33.19 & 17.73 \\
\hline karper & Eurytoop (Bentisch) & 82.67 & 35.17 & 2.2 & 16.93 & 8.64 & 6.91 \\
\hline aal & Eurytoop (Bentisch) & 90.28 & 5.43 & 4.51 & 3.36 & 6.89 & 16.47 \\
\hline snoek & Eurytoop (Pelagisch) & 93.1 & 2.82 & 1.2 & 0.02 & - & 10.87 \\
\hline blankvoorn & Eurytoop (Pelagisch) & 94.99 & 5.63 & 4.03 & 1.18 & 0.46 & 1.01 \\
\hline snoekbaars & Eurytoop (Bentisch) & 96.29 & 8.04 & 1 & 0.22 & 1.42 & 0.3 \\
\hline baars & Eurytoop (Pelagisch) & 97.51 & 4.35 & 1.77 & 0.32 & 1.5 & 0.07 \\
\hline bot & Limnofiel (Bentisch) & 98.27 & 0.26 & 0.27 & 0.44 & 1.27 & 1.06 \\
\hline roofblei* & Rheofiel (Pelagisch) & 98.66 & - & 0.02 & 0.05 & 1.15 & 0.25 \\
\hline diklipharder & Marien (Pelagisch) & 99.01 & - & - & - & - & 1.6 \\
\hline alver & Eurytoop (Pelagisch) & 99.21 & 0.14 & 0.27 & 0.08 & 0.21 & 0.26 \\
\hline kolblei & Eurytoop (Bentisch) & 99.41 & 0.23 & 0.78 & 0.03 & - & \\
\hline zwartbekgrondel* & Eurytoop (Bentisch) & 99.59 & - & - & 0.16 & 0.43 & 0.11 \\
\hline rietvoorn & Limnofiel (Pelagisch) & 99.71 & - & 0.5 & 0 & 0 & \\
\hline giebel & Eurytoop (Bentisch) & 99.78 & - & - & - & 0.25 & \\
\hline pos & Eurytoop (Bentisch) & 99.85 & 0.07 & 0.28 & 0.02 & - & \\
\hline sneep & Rheofiel (Bentisch) & 99.89 & 0.02 & 0.17 & 0 & 0 & 0.01 \\
\hline barbeel & Rheofiel (Bentisch) & 99.93 & - & 0.07 & 0.06 & 0.01 & 0.02 \\
\hline serpeling & Rheofiel (Pelagisch) & 99.96 & 0.13 & 0.09 & 0 & - & \\
\hline kesslers grondel* & Eurytoop (Bentisch) & 99.97 & - & - & - & 0.04 & 0.01 \\
\hline riviergrondel & Rheofiel (Bentisch) & 99.99 & 0.05 & 0.04 & 0.01 & - & \\
\hline hybride cyprinide & Eurytoop (Bentisch) & 99.99 & - & - & - & - & 0.02 \\
\hline witvinriviergrondel* & Eurytoop (Bentisch) & 100 & - & - & 0.01 & 0 & 0 \\
\hline rivierdonderpad & Rheofiel (Bentisch) & 100 & - & 0.01 & 0 & - & \\
\hline spiering & Eurytoop (Pelagisch) & 100 & 0.01 & - & - & - & \\
\hline zeebaars & Marien (Pelagisch) & 100 & - & 0 & - & - & 0 \\
\hline driedoornige stekelbaars & Eurytoop (Pelagisch) & 100 & - & 0 & 0 & 0 & \\
\hline kopvoorn & Rheofiel (Pelagisch) & 100 & - & 0 & - & - & \\
\hline tiendoornige stekelbaars & Limnofiel (Pelagisch) & 100 & - & - & 0 & - & \\
\hline harders indet. & Overige & 100 & - & - & 0 & 0 & \\
\hline
\end{tabular}




\section{Bijlage 29 Getijden Lek zijwateren}

Tabel 1. Soortensamenstelling in percentages op basis van aantal in boomkorvangsten in de zijwateren van de Getijden Lek per 5-jarige periode. De groepering geeft de ecologische indeling aan de hand van Noble et al. (2007) aan. Het cumulatief percentage geeft aan hoeveel de soorten over de gehele periode voorkomen op basis van de gesommeerde CPUE op basis van het aantal. Nul-percentages zijn naar beneden afgeronde waarden, $*$ = exoot.

\begin{tabular}{|c|c|c|c|c|c|c|c|}
\hline Soort & Groepering & $\begin{array}{l}\text { Cumulatief } \\
\text { percentage }\end{array}$ & $\begin{array}{r}1997- \\
1999 \\
\end{array}$ & $\begin{array}{r}2000- \\
2004\end{array}$ & $\begin{array}{r}2005- \\
2009\end{array}$ & $\begin{array}{r}2010- \\
2014\end{array}$ & $\begin{array}{r}2015- \\
2019 \\
\end{array}$ \\
\hline brasem & Eurytoop (Bentisch) & 63.81 & 74.24 & 65.37 & 78.31 & 54.44 & 48.37 \\
\hline blankvoorn & Eurytoop (Pelagisch) & 84.69 & 12.01 & 19.73 & 8.55 & 35.61 & 8.23 \\
\hline snoekbaars & Eurytoop (Bentisch) & 89.05 & 7.17 & 6.25 & 4.19 & 1.42 & 5.72 \\
\hline baars & Eurytoop (Pelagisch) & 92.47 & 1.81 & 2.71 & 0.89 & 3.29 & 13.46 \\
\hline pos & Eurytoop (Bentisch) & 94.44 & 1.47 & 2.22 & 3.06 & 1.47 & 2.13 \\
\hline bot & Limnofiel (Bentisch) & 95.76 & 0.85 & 0.96 & 2.02 & 0.65 & 4.28 \\
\hline kolblei & Eurytoop (Bentisch) & 97.08 & 1.8 & 1.68 & 1.63 & 0.25 & 2.91 \\
\hline pontische stroomgrondel* & Eurytoop (Bentisch) & 97.99 & - & - & - & 0.84 & 6.91 \\
\hline zwartbekgrondel* & Eurytoop (Bentisch) & 98.85 & - & - & 0.08 & 0.67 & 6.71 \\
\hline winde & Rheofiel (Pelagisch) & 99.37 & 0.26 & 0.19 & 0.25 & 1.07 & 0.25 \\
\hline $\begin{array}{ll}\text { riviergrondel } \\
\end{array}$ & Rheofiel (Bentisch) & 99.58 & 0.15 & 0.54 & 0.36 & - & - \\
\hline witvinriviergrondel* & Eurytoop (Bentisch) & 99.67 & - & - & 0.26 & 0.05 & 0.41 \\
\hline aal & Eurytoop (Bentisch) & 99.75 & 0.02 & 0.06 & 0.12 & 0.04 & 0.3 \\
\hline spiering & Eurytoop (Pelagisch) & 99.82 & 0.03 & 0.08 & 0.07 & 0.08 & 0.05 \\
\hline alver & Eurytoop (Pelagisch) & 99.86 & - & 0.04 & 0.08 & 0.04 & 0.05 \\
\hline roofblei* & Rheofiel (Pelagisch) & 99.89 & 0.02 & 0.05 & 0.03 & 0.04 & - \\
\hline hybride cyprinide & Eurytoop (Bentisch) & 99.92 & 0.05 & 0.05 & 0.03 & - & - \\
\hline rivierprik & Rheofiel (Bentisch) & 99.94 & 0.08 & 0.03 & - & - & - \\
\hline kesslers grondel* & Eurytoop (Bentisch) & 99.95 & - & - & - & 0.02 & 0.04 \\
\hline sneep & Rheofiel (Bentisch) & 99.96 & 0.02 & 0.02 & - & - & - \\
\hline snoek & Eurytoop (Pelagisch) & 99.97 & 0.02 & - & 0.03 & - & - \\
\hline giebel & Eurytoop (Bentisch) & 99.97 & 0.02 & - & - & - & 0.05 \\
\hline blauwneus* & Eurytoop (Bentisch) & 99.98 & - & - & - & - & 0.08 \\
\hline karper & Eurytoop (Bentisch) & 99.99 & - & 0.01 & 0.02 & - & - \\
\hline kleine modderkruiper & Eurytoop (Bentisch) & 99.99 & - & - & - & - & 0.05 \\
\hline marmergrondel* & Eurytoop (Bentisch) & 99.99 & - & - & 0.02 & - & - \\
\hline rietvoorn & Limnofiel (Pelagisch) & 100 & - & 0.01 & - & - & - \\
\hline driedoornige stekelbaars & Eurytoop (Pelagisch) & 100 & - & - & - & 0.01 & - \\
\hline
\end{tabular}


Tabel 2. Soortensamenstelling in percentages op basis van biomassa in boomkorvangsten in de zijwateren van de Getijden Lek per 5-jarige periode. De groepering geeft de ecologische indeling aan de hand van Noble et al. (2007) aan. Het cumulatief percentage geeft aan hoeveel de soorten over de gehele periode voorkomen op basis van de gesommeerde CPUE op basis van de biomassa. Nulpercentages zijn naar beneden afgeronde waarden, $*=$ exoot.

\begin{tabular}{|c|c|c|c|c|c|c|c|}
\hline Soort & Groepering & $\begin{array}{l}\text { Cumulatief } \\
\text { percentage }\end{array}$ & $\begin{array}{r}1997- \\
1999 \\
\end{array}$ & $\begin{array}{r}2000- \\
2004 \\
\end{array}$ & $\begin{array}{r}2005- \\
2009 \\
\end{array}$ & $\begin{array}{r}2010- \\
2014 \\
\end{array}$ & $\begin{array}{r}2015- \\
2019 \\
\end{array}$ \\
\hline brasem & Eurytoop (Bentisch) & 51.25 & 55.49 & 49.81 & 57.69 & 45.79 & 38.51 \\
\hline snoekbaars & Eurytoop (Bentisch) & 70.34 & 21.23 & 20.56 & 19.39 & 11.76 & 17 \\
\hline blankvoorn & Eurytoop (Pelagisch) & 86.89 & 11.92 & 14.94 & 14.43 & 29.85 & 21.53 \\
\hline baars & Eurytoop (Pelagisch) & 93.89 & 6.71 & 9.12 & 2.87 & 6.71 & 8.18 \\
\hline kolblei & Eurytoop (Bentisch) & 96.74 & 3.19 & 2.86 & 2.78 & 0.78 & 5.3 \\
\hline aal & Eurytoop (Bentisch) & 97.43 & 0.26 & 0.28 & 0.32 & 1.63 & 3.29 \\
\hline karper & Eurytoop (Bentisch) & 98.01 & - & 1.38 & 0.5 & - & \\
\hline pos & Eurytoop (Bentisch) & 98.48 & 0.22 & 0.36 & 0.67 & 0.78 & 0.74 \\
\hline winde & Rheofiel (Pelagisch) & 98.84 & 0.16 & 0.27 & 0.31 & 1.21 & 0.16 \\
\hline bot & Limnofiel (Bentisch) & 99.15 & 0.07 & 0.09 & 0.37 & 0.58 & 1.41 \\
\hline pontische stroomgrondel* & Eurytoop (Bentisch) & 99.33 & - & - & - & 0.36 & 1.67 \\
\hline giebel & Eurytoop (Bentisch) & 99.45 & 0.24 & - & - & - & 0.85 \\
\hline zwartbekgrondel* & Eurytoop (Bentisch) & 99.58 & - & - & 0.01 & 0.32 & 0.99 \\
\hline snoek & Eurytoop (Pelagisch) & 99.69 & 0.13 & - & 0.45 & - & \\
\hline hybride cyprinide & Eurytoop (Bentisch) & 99.78 & 0.17 & 0.09 & 0.06 & - & \\
\hline rivierprik & Rheofiel (Bentisch) & 99.83 & 0.15 & 0.05 & - & - & \\
\hline roofblei* & Rheofiel (Pelagisch) & 99.88 & 0.01 & 0.09 & 0.01 & 0.09 & \\
\hline riviergrondel & Rheofiel (Bentisch) & 99.91 & 0.02 & 0.06 & 0.05 & - & \\
\hline alver & Eurytoop (Pelagisch) & 99.93 & - & 0.01 & 0.04 & 0.06 & 0.03 \\
\hline blauwneus* & Eurytoop (Bentisch) & 99.95 & - & - & - & - & 0.23 \\
\hline witvinriviergrondel* & Eurytoop (Bentisch) & 99.97 & - & - & 0.06 & 0.02 & 0.06 \\
\hline sneep & Rheofiel (Bentisch) & 99.98 & 0.03 & 0.01 & - & - & \\
\hline spiering & Eurytoop (Pelagisch) & 99.99 & 0 & 0.01 & 0.01 & 0.03 & 0.01 \\
\hline kesslers grondel* & Eurytoop (Bentisch) & 100 & - & - & - & 0.03 & 0.02 \\
\hline rietvoorn & Limnofiel (Pelagisch) & 100 & - & 0 & - & - & \\
\hline kleine modderkruiper & Eurytoop (Bentisch) & 100 & - & - & - & - & 0.01 \\
\hline marmergrondel* & Eurytoop (Bentisch) & 100 & - & - & 0 & - & \\
\hline driedoornige stekelbaars & Eurytoop (Pelagisch) & 100 & - & - & - & 0 & \\
\hline
\end{tabular}


Tabel 3. Soortensamenstelling in percentages op basis van aantal in schepnetvangsten in de zijwateren van de Getijden Lek per 5-jarige periode. De groepering geeft de ecologische indeling aan de hand van Noble et al. (2007) aan. Het cumulatief percentage geeft aan hoeveel de soorten over de gehele periode voorkomen op basis van de gesommeerde CPUE op basis van het aantal. Nul-percentages zijn naar beneden afgeronde waarden, $*=$ exoot.

\begin{tabular}{|c|c|c|c|c|c|c|c|}
\hline Soort & Groepering & $\begin{array}{l}\text { Cumulatief } \\
\text { percentage }\end{array}$ & $\begin{array}{r}1997- \\
1999 \\
\end{array}$ & $\begin{array}{r}2000- \\
2004 \\
\end{array}$ & $\begin{array}{r}2005- \\
2009 \\
\end{array}$ & $\begin{array}{r}2010- \\
2014 \\
\end{array}$ & $\begin{array}{r}2015- \\
2019 \\
\end{array}$ \\
\hline blankvoorn & Eurytoop (Pelagisch) & 60.87 & 63.33 & 81.07 & 13.38 & 37.32 & 20.3 \\
\hline zwartbekgrondel* & Eurytoop (Bentisch) & 74.53 & - & - & 14.85 & 42.83 & 40.38 \\
\hline baars & Eurytoop (Pelagisch) & 82.29 & 15.66 & 6.94 & 18.26 & 2.5 & 8.25 \\
\hline winde & Rheofiel (Pelagisch) & 87.4 & 4.32 & 3.28 & 11.56 & 4.64 & 16.77 \\
\hline aal & Eurytoop (Bentisch) & 91.38 & 4.29 & 2.75 & 12.84 & 3.83 & 7.12 \\
\hline driedoornige stekelbaars & Eurytoop (Pelagisch) & 92.75 & 0.3 & 0.15 & 0.35 & 5.33 & \\
\hline bot & Limnofiel (Bentisch) & 93.83 & 0.8 & 0.72 & 0.78 & 0.64 & 5.43 \\
\hline pos & Eurytoop (Bentisch) & 94.83 & 1.04 & 1.23 & 5.06 & 0.08 & \\
\hline snoekbaars & Eurytoop (Bentisch) & 95.76 & 2.42 & 1.09 & 0.54 & - & \\
\hline harders indet. & Marien (Pelagisch) & 96.64 & - & 0.09 & 20.46 & - & \\
\hline alver & Eurytoop (Pelagisch) & 97.41 & 2.46 & 0.29 & - & 0.93 & 0.58 \\
\hline brasem & Eurytoop (Bentisch) & 98.1 & 1.55 & 0.64 & 1.02 & 0.4 & \\
\hline roofblei* & Rheofiel (Pelagisch) & 98.48 & 0.34 & 0.41 & - & 0.57 & \\
\hline snoek & Eurytoop (Pelagisch) & 98.76 & 1.24 & 0.18 & - & - & \\
\hline kolblei & Eurytoop (Bentisch) & 99.03 & 1.17 & 0.19 & - & - & \\
\hline riviergrondel & Rheofiel (Bentisch) & 99.24 & 0.44 & 0.29 & - & - & \\
\hline rietvoorn & Limnofiel (Pelagisch) & 99.4 & - & 0.27 & - & - & 0.38 \\
\hline kesslers grondel* & Eurytoop (Bentisch) & 99.55 & - & - & - & 0.5 & 0.36 \\
\hline sneep & Rheofiel (Bentisch) & 99.66 & 0.12 & 0.12 & - & 0.17 & \\
\hline serpeling & Rheofiel (Pelagisch) & 99.75 & 0.4 & 0.06 & - & - & \\
\hline kopvoorn & Rheofiel (Pelagisch) & 99.81 & - & 0.08 & - & - & 0.24 \\
\hline pontische stroomgrondel* & Eurytoop (Bentisch) & 99.86 & - & - & - & 0.18 & 0.18 \\
\hline karper & Eurytoop (Bentisch) & 99.91 & 0.1 & - & 0.9 & - & \\
\hline hybride cyprinide & Eurytoop (Bentisch) & 99.95 & - & 0.07 & - & - & \\
\hline bittervoorn & Limnofiel (Pelagisch) & 99.97 & - & - & - & 0.09 & \\
\hline diklipharder & Marien (Pelagisch) & 99.99 & - & 0.04 & - & - & \\
\hline rivierdonderpad & Rheofiel (Bentisch) & 100 & - & 0.03 & - & - & \\
\hline
\end{tabular}


Tabel 4. Soortensamenstelling in percentages op basis van biomassa in schepnetvangsten in de zijwateren van de Getijden Lek per 5-jarige periode. De groepering geeft de ecologische indeling aan de hand van Noble et al. (2007) aan. Het cumulatief percentage geeft aan hoeveel de soorten over de gehele periode voorkomen op basis van de gesommeerde CPUE op basis van de biomassa. Nulpercentages zijn naar beneden afgeronde waarden, $*$ = exoot.

\begin{tabular}{|c|c|c|c|c|c|c|c|}
\hline Soort & Groepering & $\begin{array}{l}\text { Cumulatief } \\
\text { percentage }\end{array}$ & $\begin{array}{r}1997- \\
1999 \\
\end{array}$ & $\begin{array}{r}2000- \\
2004 \\
\end{array}$ & $\begin{array}{r}2005- \\
2009 \\
\end{array}$ & $\begin{array}{r}2010- \\
2014 \\
\end{array}$ & $\begin{array}{r}2015- \\
2019 \\
\end{array}$ \\
\hline blankvoorn & Eurytoop (Pelagisch) & 23.1 & 19.4 & 37.77 & 1.08 & 8.14 & 2.21 \\
\hline aal & Eurytoop (Bentisch) & 46.04 & 8.05 & 13.75 & 26.89 & 53.05 & 55.31 \\
\hline snoek & Eurytoop (Pelagisch) & 58.65 & 22.68 & 16.18 & - & - & \\
\hline baars & Eurytoop (Pelagisch) & 68.31 & 17.57 & 10.48 & 5.06 & 1.28 & 2.68 \\
\hline snoekbaars & Eurytoop (Bentisch) & 76.87 & 6.51 & 15.52 & 0.2 & - & \\
\hline karper & Eurytoop (Bentisch) & 85.4 & 17.6 & - & 57.07 & - & \\
\hline winde & Rheofiel (Pelagisch) & 92.68 & 3.85 & 2.22 & 6.48 & 14.24 & 30.87 \\
\hline zwartbekgrondel* & Eurytoop (Bentisch) & 95.56 & - & - & 2.37 & 14.65 & 6.12 \\
\hline brasem & Eurytoop (Bentisch) & 97.17 & 2.86 & 2.07 & 0.03 & 0.02 & \\
\hline roofblei* & Rheofiel (Pelagisch) & 98.45 & 0.11 & 0.62 & - & 6.71 & \\
\hline bot & Limnofiel (Bentisch) & 98.93 & 0.17 & 0.28 & 0.09 & 0.7 & 2.17 \\
\hline pos & Eurytoop (Bentisch) & 99.2 & 0.15 & 0.41 & 0.61 & 0.03 & \\
\hline kolblei & Eurytoop (Bentisch) & 99.44 & 0.69 & 0.16 & - & - & \\
\hline kesslers grondel* & Eurytoop (Bentisch) & 99.58 & - & - & - & 0.72 & 0.43 \\
\hline rietvoorn & Limnofiel (Pelagisch) & 99.67 & - & 0.17 & - & - & 0.1 \\
\hline alver & Eurytoop (Pelagisch) & 99.74 & 0.15 & 0.05 & - & 0.1 & 0.03 \\
\hline riviergrondel & Rheofiel (Bentisch) & 99.81 & 0.1 & 0.09 & - & - & \\
\hline hybride cyprinide & Eurytoop (Bentisch) & 99.87 & - & 0.14 & - & - & \\
\hline driedoornige stekelbaars & Eurytoop (Pelagisch) & 99.91 & 0 & 0 & 0 & 0.22 & \\
\hline sneep & Rheofiel (Bentisch) & 99.94 & 0.03 & 0.04 & - & 0.04 & \\
\hline serpeling & Rheofiel (Pelagisch) & 99.97 & 0.07 & 0.02 & - & - & \\
\hline pontische stroomgrondel* & Eurytoop (Bentisch) & 99.98 & - & - & - & 0.08 & 0.02 \\
\hline harders indet. & Marien (Pelagisch) & 99.99 & - & 0 & 0.12 & - & \\
\hline kopvoorn & Rheofiel (Pelagisch) & 100 & - & 0 & - & - & 0.04 \\
\hline bittervoorn & Limnofiel (Pelagisch) & 100 & - & - & - & 0.02 & \\
\hline rivierdonderpad & Rheofiel (Bentisch) & 100 & - & 0 & - & - & \\
\hline diklipharder & Marien (Pelagisch) & 100 & - & 0 & - & - & \\
\hline
\end{tabular}




\section{Bijlage 30 Getijden Maas hoofdstroom}

Tabel 1. Soortensamenstelling in percentages op basis van aantal in boomkorvangsten in de hoofdstroom van de Getijden Maas per 5-jarige periode. De groepering geeft de ecologische indeling aan de hand van Noble et al. (2007) aan. Het cumulatief percentage geeft aan hoeveel de soorten over de gehele periode voorkomen op basis van de gesommeerde CPUE op basis van het aantal. Nul-percentages zijn naar beneden afgeronde waarden, $*=$ exoot.

\begin{tabular}{|c|c|c|c|c|c|c|c|}
\hline Soort & Groepering & $\begin{array}{l}\text { Cumulatief } \\
\text { percentage }\end{array}$ & $\begin{array}{r}1997- \\
1999\end{array}$ & $\begin{array}{r}2000- \\
2004\end{array}$ & $\begin{array}{r}2005- \\
2009\end{array}$ & $\begin{array}{r}2010- \\
2014\end{array}$ & $\begin{array}{r}2015- \\
2019\end{array}$ \\
\hline brasem & Eurytoop (Bentisch) & 16.74 & 21.25 & 19.8 & 28.05 & 11.61 & 4.18 \\
\hline pos & Eurytoop (Bentisch) & 32.86 & 24.33 & 25.73 & 13.64 & 16.29 & 0.2 \\
\hline baars & Eurytoop (Pelagisch) & 48.5 & 4.19 & 8.71 & 13.71 & 11.85 & 41.11 \\
\hline zwartbekgrondel* & Eurytoop (Bentisch) & 61.2 & - & - & - & 34.01 & 23.54 \\
\hline blankvoorn & Eurytoop (Pelagisch) & 73.75 & 14.88 & 9.67 & 23.88 & 8.74 & 6.73 \\
\hline riviergrondel & Rheofiel (Bentisch) & 80.66 & 16.02 & 19.66 & 0.72 & - & \\
\hline snoekbaars & Eurytoop (Bentisch) & 84.75 & 4.65 & 4.71 & 2.75 & 4.24 & 4.07 \\
\hline rivierdonderpad & Rheofiel (Bentisch) & 87.67 & 2.57 & 5.36 & 7.03 & 0.15 & - \\
\hline alver & Eurytoop (Pelagisch) & 90.33 & 8.13 & 0.12 & 0.05 & 2.99 & 2.44 \\
\hline pontische stroomgrondel* & Eurytoop (Bentisch) & 92.92 & - & - & - & 1.59 & 11.88 \\
\hline winde & Rheofiel (Pelagisch) & 95.28 & 0.91 & 2.79 & 3.84 & 1.48 & 2.9 \\
\hline witvinriviergrondel* & Eurytoop (Bentisch) & 96.17 & - & - & 2.68 & 1.49 & 0.05 \\
\hline kolblei & Eurytoop (Bentisch) & 97.06 & 0.45 & 1.09 & 1.1 & 1.32 & 0.3 \\
\hline kesslers grondel* & Eurytoop (Bentisch) & 97.75 & - & - & - & 2.14 & 0.91 \\
\hline bot & Limnofiel (Bentisch) & 98.25 & 0.55 & 0.25 & 0.75 & 0.35 & 0.64 \\
\hline roofblei* & Rheofiel (Pelagisch) & 98.66 & - & 0.54 & 0.1 & 0.58 & 0.78 \\
\hline rivierprik & Rheofiel (Bentisch) & 98.99 & 0.18 & 0.6 & 0.59 & 0.28 & - \\
\hline spiering & Eurytoop (Pelagisch) & 99.26 & 1.04 & 0.13 & 0.05 & 0.19 & - \\
\hline aal & Eurytoop (Bentisch) & 99.44 & 0.24 & 0.55 & - & 0.08 & 0.05 \\
\hline sneep & Rheofiel (Bentisch) & 99.57 & - & 0.17 & 0.1 & 0.32 & - \\
\hline marmergrondel* & Eurytoop (Bentisch) & 99.7 & - & - & 0.41 & 0.15 & 0.05 \\
\hline hybride cyprinide & Eurytoop (Bentisch) & 99.78 & 0.05 & 0.04 & 0.2 & 0.12 & - \\
\hline snoek & Eurytoop (Pelagisch) & 99.85 & 0.05 & 0.08 & 0.2 & - & 0.05 \\
\hline driedoornige stekelbaars & Eurytoop (Pelagisch) & 99.92 & 0.29 & - & 0.05 & - & - \\
\hline serpeling & Rheofiel (Pelagisch) & 99.94 & 0.05 & - & 0.05 & - & - \\
\hline kopvoorn & Rheofiel (Pelagisch) & 99.95 & 0.05 & - & - & - & 0.05 \\
\hline donaubrasem* & Eurytoop (Bentisch) & 99.96 & - & - & - & 0.04 & - \\
\hline barbeel & Rheofiel (Bentisch) & 99.97 & - & - & - & - & 0.05 \\
\hline karper & Eurytoop (Bentisch) & 99.98 & 0.05 & - & - & - & - \\
\hline noordzeehouting & Limnofiel (Pelagisch) & 99.99 & - & - & 0.05 & - & - \\
\hline tiendoornige stekelbaars & Limnofiel (Pelagisch) & 100 & 0.05 & - & - & - & - \\
\hline
\end{tabular}


Tabel 2. Soortensamenstelling in percentages op basis van biomassa in boomkorvangsten in de hoofdstroom van de Getijden Maas per 5-jarige periode. De groepering geeft de ecologische indeling aan de hand van Noble et al. (2007) aan. Het cumulatief percentage geeft aan hoeveel de soorten over de gehele periode voorkomen op basis van de gesommeerde CPUE op basis van de biomassa. Nulpercentages zijn naar beneden afgeronde waarden, $*=$ exoot.

\begin{tabular}{|c|c|c|c|c|c|c|c|}
\hline Soort & Groepering & $\begin{array}{l}\text { Cumulatief } \\
\text { percentage }\end{array}$ & $\begin{array}{r}1997- \\
1999 \\
\end{array}$ & $\begin{array}{r}2000- \\
2004 \\
\end{array}$ & $\begin{array}{r}2005- \\
2009 \\
\end{array}$ & $\begin{array}{r}2010- \\
2014 \\
\end{array}$ & $\begin{array}{r}2015- \\
2019 \\
\end{array}$ \\
\hline brasem & Eurytoop (Bentisch) & 66.31 & 68.41 & 68.7 & 73.99 & 62.57 & 2.19 \\
\hline snoekbaars & Eurytoop (Bentisch) & 78.87 & 8.81 & 11.43 & 11.53 & 17.86 & 27.07 \\
\hline winde & Rheofiel (Pelagisch) & 84.18 & 3.14 & 8.01 & 4.47 & 3.19 & 4.73 \\
\hline blankvoorn & Eurytoop (Pelagisch) & 88.71 & 7.26 & 3.08 & 4.62 & 3.59 & 7.33 \\
\hline baars & Eurytoop (Pelagisch) & 92.12 & 1.52 & 0.95 & 1.81 & 3.5 & 42.76 \\
\hline kolblei & Eurytoop (Bentisch) & 93.73 & 1.03 & 2.32 & 1.36 & 1.36 & 0.42 \\
\hline roofblei* & Rheofiel (Pelagisch) & 95.21 & - & 3.25 & 0.15 & 1.5 & 1.28 \\
\hline karper & Eurytoop (Bentisch) & 96.09 & 4.56 & - & - & - & \\
\hline pos & Eurytoop (Bentisch) & 96.82 & 1.2 & 0.61 & 0.49 & 1.04 & 0.06 \\
\hline zwartbekgrondel* & Eurytoop (Bentisch) & 97.46 & - & - & - & 2.7 & 5.69 \\
\hline snoek & Eurytoop (Pelagisch) & 97.97 & 1.66 & 0.14 & 0.43 & - & 0.69 \\
\hline aal & Eurytoop (Bentisch) & 98.36 & 0.28 & 0.41 & - & 0.46 & 2.77 \\
\hline bot & Limnofiel (Bentisch) & 98.72 & 0.9 & 0.18 & 0.17 & 0.28 & 0.85 \\
\hline riviergrondel & Rheofiel (Bentisch) & 98.97 & 0.54 & 0.4 & 0.02 & - & \\
\hline rivierprik & Rheofiel (Bentisch) & 99.2 & 0.11 & 0.25 & 0.29 & 0.31 & \\
\hline hybride cyprinide & Eurytoop (Bentisch) & 99.37 & 0.14 & 0.12 & 0.39 & 0.01 & \\
\hline kesslers grondel* & Eurytoop (Bentisch) & 99.49 & - & - & - & 0.54 & 0.87 \\
\hline pontische stroomgrondel* & Eurytoop (Bentisch) & 99.6 & - & - & - & 0.15 & 2.2 \\
\hline alver & Eurytoop (Pelagisch) & 99.7 & 0.23 & 0.01 & 0 & 0.19 & 0.36 \\
\hline donaubrasem* & Eurytoop (Bentisch) & 99.76 & - & - & - & 0.45 & \\
\hline sneep & Rheofiel (Bentisch) & 99.82 & - & 0.07 & 0.07 & 0.11 & \\
\hline rivierdonderpad & Rheofiel (Bentisch) & 99.88 & 0.06 & 0.06 & 0.1 & 0 & \\
\hline witvinriviergrondel* & Eurytoop (Bentisch) & 99.93 & - & - & 0.09 & 0.18 & 0.03 \\
\hline kopvoorn & Rheofiel (Pelagisch) & 99.98 & 0.11 & - & - & - & 0.69 \\
\hline spiering & Eurytoop (Pelagisch) & 99.99 & 0.05 & 0 & 0 & 0.02 & \\
\hline noordzeehouting & Limnofiel (Pelagisch) & 100 & - & - & 0.01 & - & \\
\hline serpeling & Rheofiel (Pelagisch) & 100 & 0 & - & 0 & - & \\
\hline marmergrondel* & Eurytoop (Bentisch) & 100 & - & - & 0 & 0 & \\
\hline driedoornige stekelbaars & Eurytoop (Pelagisch) & 100 & 0 & - & 0 & - & \\
\hline barbeel & Rheofiel (Bentisch) & 100 & - & - & - & - & \\
\hline tiendoornige stekelbaars & Limnofiel (Pelagisch) & 100 & 0 & - & - & - & \\
\hline
\end{tabular}


Tabel 3. Soortensamenstelling in percentages op basis van aantal in schepnetvangsten in de hoofdstroom van de Getijden Maas per 5-jarige periode. De groepering geeft de ecologische indeling aan de hand van Noble et al. (2007) aan. Het cumulatief percentage geeft aan hoeveel de soorten over de gehele periode voorkomen op basis van de gesommeerde CPUE op basis van het aantal. Nul-percentages zijn naar beneden afgeronde waarden, $*$ = exoot.

\begin{tabular}{|c|c|c|c|c|c|c|c|}
\hline Soort & Groepering & $\begin{array}{l}\text { Cumulatief } \\
\text { percentage }\end{array}$ & $\begin{array}{r}1997- \\
1999\end{array}$ & $\begin{array}{r}2000- \\
2004\end{array}$ & $\begin{array}{r}2005- \\
2009 \\
\end{array}$ & $\begin{array}{r}2010- \\
2014 \\
\end{array}$ & $\begin{array}{r}2015- \\
2019 \\
\end{array}$ \\
\hline blankvoorn & Eurytoop (Pelagisch) & 37.91 & 29.59 & 47.53 & 42.49 & 40.82 & 32.58 \\
\hline zwartbekgrondel* & Eurytoop (Bentisch) & 55.91 & - & - & - & 7.89 & 41.87 \\
\hline winde & Rheofiel (Pelagisch) & 68.09 & 13.7 & 9.01 & 14.54 & 15.25 & 10.58 \\
\hline baars & Eurytoop (Pelagisch) & 80.04 & 8.03 & 13.36 & 25.31 & 14.69 & 6.33 \\
\hline alver & Eurytoop (Pelagisch) & 86.62 & 19.85 & 1.45 & 0.97 & 12.86 & 3.67 \\
\hline aal & Eurytoop (Bentisch) & 91.3 & 7.36 & 15.8 & 4.74 & 1.58 & 1.12 \\
\hline pos & Eurytoop (Bentisch) & 93.71 & 2.42 & 6 & 6.99 & 1.38 & \\
\hline driedoornige stekelbaars & Eurytoop (Pelagisch) & 95.03 & 8.33 & 0.52 & 1.08 & 1.31 & 0.07 \\
\hline kesslers grondel* & Eurytoop (Bentisch) & 95.99 & - & - & - & 1.41 & 1.64 \\
\hline brasem & Eurytoop (Bentisch) & 96.87 & 6.94 & 0.42 & 0.47 & 0.43 & 0.04 \\
\hline roofblei* & Rheofiel (Pelagisch) & 97.7 & 0.14 & - & - & 1.08 & 1.46 \\
\hline snoekbaars & Eurytoop (Bentisch) & 98.05 & 1.39 & 0.78 & 0.38 & - & 0.12 \\
\hline snoek & Eurytoop (Pelagisch) & 98.39 & 0.26 & 1.36 & 0.38 & 0.2 & \\
\hline rivierdonderpad & Rheofiel (Bentisch) & 98.64 & - & 0.78 & 0.9 & - & \\
\hline riviergrondel & Rheofiel (Bentisch) & 98.83 & - & 0.94 & 0.09 & 0.06 & 0.03 \\
\hline kolblei & Eurytoop (Bentisch) & 99.01 & 0.72 & 0.48 & - & 0.15 & \\
\hline marmergrondel* & Eurytoop (Bentisch) & 99.13 & - & - & - & 0.26 & 0.15 \\
\hline pontische stroomgrondel* & Eurytoop (Bentisch) & 99.25 & - & - & - & - & 0.3 \\
\hline bermpje & Rheofiel (Bentisch) & 99.35 & - & 0.25 & 0.47 & - & \\
\hline kopvoorn & Rheofiel (Pelagisch) & 99.43 & - & 0.53 & - & - & \\
\hline sneep & Rheofiel (Bentisch) & 99.52 & - & 0.23 & 0.18 & - & 0.06 \\
\hline bot & Limnofiel (Bentisch) & 99.6 & - & - & 0.15 & 0.26 & \\
\hline rietvoorn & Limnofiel (Pelagisch) & 99.67 & 0.13 & - & 0.09 & 0.23 & \\
\hline serpeling & Rheofiel (Pelagisch) & 99.74 & 0.19 & 0.18 & 0.19 & - & \\
\hline spiering & Eurytoop (Pelagisch) & 99.81 & 0.68 & - & - & - & \\
\hline witvinriviergrondel* & Eurytoop (Bentisch) & 99.85 & - & - & 0.19 & 0.08 & \\
\hline diklipharder & Marien (Pelagisch) & 99.89 & - & 0.07 & 0.22 & - & \\
\hline rivierprik & Rheofiel (Bentisch) & 99.92 & - & 0.1 & 0.1 & - & \\
\hline hybride cyprinide & Eurytoop (Bentisch) & 99.94 & 0.13 & - & 0.07 & - & \\
\hline barbeel & Rheofiel (Bentisch) & 99.96 & - & 0.13 & - & - & \\
\hline zalm/forel & Rheofiel (Pelagisch) & 99.97 & 0.16 & - & - & - & \\
\hline harders indet. & Marien (Pelagisch) & 99.99 & - & - & - & 0.06 & \\
\hline atlantische forel & Rheofiel (Pelagisch) & 100 & - & 0.07 & - & - & \\
\hline
\end{tabular}


Tabel 4. Soortensamenstelling in percentages op basis van biomassa in schepnetvangsten in de hoofdstroom van de Getijden Maas per 5-jarige periode. De groepering geeft de ecologische indeling aan de hand van Noble et al. (2007) aan. Het cumulatief percentage geeft aan hoeveel de soorten over de gehele periode voorkomen op basis van de gesommeerde CPUE op basis van de biomassa. Nulpercentages zijn naar beneden afgeronde waarden, $*=$ exoot.

\begin{tabular}{|c|c|c|c|c|c|c|c|}
\hline Soort & Groepering & $\begin{array}{l}\text { Cumulatief } \\
\text { percentage }\end{array}$ & $\begin{array}{r}1997- \\
1999\end{array}$ & $\begin{array}{r}2000- \\
2004\end{array}$ & $\begin{array}{r}2005- \\
2009 \\
\end{array}$ & $\begin{array}{r}2010- \\
2014\end{array}$ & $\begin{array}{r}2015- \\
2019\end{array}$ \\
\hline winde & Rheofiel (Pelagisch) & 31.38 & 40.13 & 30.7 & 41.03 & 14.43 & 12.34 \\
\hline aal & Eurytoop (Bentisch) & 53.57 & 4.63 & 33.02 & 18.94 & 38.14 & 43.41 \\
\hline brasem & Eurytoop (Bentisch) & 67.77 & 28.54 & 6.25 & 10.19 & 3.12 & 0.01 \\
\hline snoek & Eurytoop (Pelagisch) & 76.08 & 10.12 & 12.03 & 2.31 & 8.75 & \\
\hline snoekbaars & Eurytoop (Bentisch) & 81.73 & 3.89 & 10.5 & 12.5 & - & 0.26 \\
\hline blankvoorn & Eurytoop (Pelagisch) & 86.91 & 5.31 & 2.62 & 4.73 & 7.38 & 8.24 \\
\hline baars & Eurytoop (Pelagisch) & 89.92 & 0.72 & 2.36 & 6.64 & 4.28 & 6.82 \\
\hline zwartbekgrondel* & Eurytoop (Bentisch) & 92.91 & - & - & - & 2.36 & 23.83 \\
\hline zalm/forel & Rheofiel (Pelagisch) & 94.63 & 4.45 & - & - & - & \\
\hline roofblei* & Rheofiel (Pelagisch) & 96.32 & 0.01 & - & - & 11.63 & 1.25 \\
\hline bot & Limnofiel (Bentisch) & 97.42 & - & - & 2.15 & 6.23 & \\
\hline kesslers grondel* & Eurytoop (Bentisch) & 97.95 & - & - & - & 1.59 & 2.83 \\
\hline alver & Eurytoop (Pelagisch) & 98.39 & 0.35 & 0.05 & 0.06 & 1.53 & 0.74 \\
\hline pos & Eurytoop (Bentisch) & 98.82 & 0.15 & 0.77 & 1.02 & 0.38 & \\
\hline atlantische forel & Rheofiel (Pelagisch) & 99.12 & - & 1.25 & - & - & \\
\hline kolblei & Eurytoop (Bentisch) & 99.43 & 0.78 & 0.01 & - & 0.01 & \\
\hline rietvoorn & Limnofiel (Pelagisch) & 99.72 & 0.73 & - & 0 & 0.04 & \\
\hline hybride cyprinide & Eurytoop (Bentisch) & 99.76 & 0.11 & - & 0.01 & - & \\
\hline kopvoorn & Rheofiel (Pelagisch) & 99.8 & - & 0.14 & - & - & - \\
\hline driedoornige stekelbaars & Eurytoop (Pelagisch) & 99.83 & 0.05 & 0.01 & 0.03 & 0.04 & 0 \\
\hline riviergrondel & Rheofiel (Bentisch) & 99.86 & - & 0.04 & 0.06 & 0.06 & 0.05 \\
\hline rivierprik & Rheofiel (Bentisch) & 99.88 & - & 0.1 & 0.01 & - & - \\
\hline rivierdonderpad & Rheofiel (Bentisch) & 99.91 & - & 0.05 & 0.08 & - & \\
\hline sneep & Rheofiel (Bentisch) & 99.93 & - & 0.01 & 0.06 & - & 0.08 \\
\hline serpeling & Rheofiel (Pelagisch) & 99.94 & 0.01 & 0.03 & 0.05 & - & \\
\hline bermpje & Rheofiel (Bentisch) & 99.95 & - & 0.02 & 0.07 & - & \\
\hline barbeel & Rheofiel (Bentisch) & 99.97 & - & 0.05 & - & - & \\
\hline pontische stroomgrondel* & Eurytoop (Bentisch) & 99.98 & - & - & - & - & 0.09 \\
\hline spiering & Eurytoop (Pelagisch) & 99.99 & 0.02 & - & - & - & \\
\hline marmergrondel* & Eurytoop (Bentisch) & 99.99 & - & - & - & 0.02 & 0.03 \\
\hline witvinriviergrondel* & Eurytoop (Bentisch) & 100 & - & - & 0.05 & 0 & \\
\hline diklipharder & Marien (Pelagisch) & 100 & - & 0 & 0 & - & \\
\hline harders indet. & Marien (Pelagisch) & 100 & - & - & - & 0 & \\
\hline
\end{tabular}




\section{Bijlage 31 Getijden Maas zijwateren}

Tabel 1. Soortensamenstelling in percentages op basis van aantal in boomkorvangsten in de zijwateren van de Getijden Maas per 5-jarige periode. De groepering geeft de ecologische indeling aan de hand van Noble et al. (2007) aan. Het cumulatief percentage geeft aan hoeveel de soorten over de gehele periode voorkomen op basis van de gesommeerde CPUE op basis van het aantal. Nul-percentages zijn naar beneden afgeronde waarden, $*$ =xoot.

\begin{tabular}{|c|c|c|c|c|c|c|c|}
\hline Soort & Groepering & $\begin{array}{l}\text { Cumulatief } \\
\text { percentage }\end{array}$ & $\begin{array}{r}1997- \\
1999 \\
\end{array}$ & $\begin{array}{r}2000- \\
2004\end{array}$ & $\begin{array}{r}2005- \\
2009\end{array}$ & $\begin{array}{r}2010- \\
2014\end{array}$ & $\begin{array}{r}2015- \\
2019 \\
\end{array}$ \\
\hline baars & Eurytoop (Pelagisch) & 42.24 & 32.64 & 24.59 & 19.34 & 53.54 & 70.66 \\
\hline blankvoorn & Eurytoop (Pelagisch) & 66.37 & 12.63 & 50.46 & 27.74 & 22.49 & 9.94 \\
\hline brasem & Eurytoop (Bentisch) & 85.57 & 28.5 & 11.05 & 35.34 & 13.75 & 8.3 \\
\hline pos & Eurytoop (Bentisch) & 93.67 & 19.85 & 9.3 & 14.19 & 3.07 & 1.34 \\
\hline snoekbaars & Eurytoop (Bentisch) & 95.49 & 4.53 & 2.19 & 1.22 & 1.2 & 1.89 \\
\hline winde & Rheofiel (Pelagisch) & 97.23 & 0.44 & 2 & 1.84 & 1.05 & 2.42 \\
\hline zwartbekgrondel* & Eurytoop (Bentisch) & 98.27 & - & - & - & 2.2 & 2.13 \\
\hline alver & Eurytoop (Pelagisch) & 98.91 & 0.11 & - & - & 1.09 & 1.51 \\
\hline pontische stroomgrondel* & Eurytoop (Bentisch) & 99.32 & - & - & - & 0.63 & 1.04 \\
\hline kolblei & Eurytoop (Bentisch) & 99.49 & 0.57 & 0.17 & 0.12 & 0.23 & 0.06 \\
\hline kesslers grondel* & Eurytoop (Bentisch) & 99.61 & - & - & - & 0.12 & 0.34 \\
\hline hybride cyprinide & Eurytoop (Bentisch) & 99.69 & 0.03 & 0.04 & 0.01 & 0.31 & - \\
\hline roofblei* & Rheofiel (Pelagisch) & 99.75 & - & - & 0.02 & 0.11 & 0.13 \\
\hline riviergrondel & Rheofiel (Bentisch) & 99.8 & 0.26 & 0.13 & 0.01 & - & \\
\hline snoek & Eurytoop (Pelagisch) & 99.84 & 0.08 & - & 0.03 & 0.03 & 0.07 \\
\hline witvinriviergrondel* & Eurytoop (Bentisch) & 99.87 & - & - & 0.07 & 0.08 & - \\
\hline aal & Eurytoop (Bentisch) & 99.91 & 0.07 & 0.03 & 0.01 & 0.04 & 0.06 \\
\hline bot & Limnofiel (Bentisch) & 99.94 & 0.03 & - & 0.02 & - & 0.08 \\
\hline spiering & Eurytoop (Pelagisch) & 99.96 & 0.26 & 0.01 & - & - & 0.01 \\
\hline sneep & Rheofiel (Bentisch) & 99.98 & - & 0.03 & - & 0.04 & - \\
\hline marmergrondel* & Eurytoop (Bentisch) & 99.98 & - & - & 0.01 & 0.01 & 0.02 \\
\hline kleine modderkruiper & Eurytoop (Bentisch) & 99.99 & - & - & 0.02 & 0.01 & \\
\hline rivierdonderpad & Rheofiel (Bentisch) & 100 & - & - & 0.01 & - & \\
\hline zeelt & Limnofiel (Bentisch) & 100 & - & - & - & - & 0.01 \\
\hline
\end{tabular}


Tabel 2. Soortensamenstelling in percentages op basis van biomassa in boomkorvangsten in de zijwateren van de Getijden Maas per 5-jarige periode. De groepering geeft de ecologische indeling aan de hand van Noble et al. (2007) aan. Het cumulatief percentage geeft aan hoeveel de soorten over de gehele periode voorkomen op basis van de gesommeerde CPUE op basis van de biomassa. Nulpercentages zijn naar beneden afgeronde waarden, $*=$ exoot.

\begin{tabular}{|c|c|c|c|c|c|c|c|}
\hline Soort & Groepering & $\begin{array}{l}\text { Cumulatief } \\
\text { percentage }\end{array}$ & $\begin{array}{r}1997- \\
1999 \\
\end{array}$ & $\begin{array}{r}2000- \\
2004 \\
\end{array}$ & $\begin{array}{r}2005- \\
2009 \\
\end{array}$ & $\begin{array}{r}2010- \\
2014 \\
\end{array}$ & $\begin{array}{r}2015- \\
2019 \\
\end{array}$ \\
\hline brasem & Eurytoop (Bentisch) & 29.93 & 48.7 & 29.38 & 34.5 & 26.56 & 12.99 \\
\hline baars & Eurytoop (Pelagisch) & 53.18 & 13.02 & 15.52 & 16.72 & 28.2 & 41.42 \\
\hline blankvoorn & Eurytoop (Pelagisch) & 72.58 & 10.33 & 26.22 & 24.88 & 18.29 & 16.14 \\
\hline snoekbaars & Eurytoop (Bentisch) & 90.29 & 22.35 & 23.53 & 14.73 & 16.8 & 12.03 \\
\hline pos & Eurytoop (Bentisch) & 92.55 & 2.38 & 1.77 & 4.98 & 0.89 & 1.09 \\
\hline winde & Rheofiel (Pelagisch) & 94.32 & 0.29 & 1.28 & 2.34 & 0.91 & 3.66 \\
\hline snoek & Eurytoop (Pelagisch) & 95.91 & 0.83 & - & 1.38 & 1.8 & 3.76 \\
\hline aal & Eurytoop (Bentisch) & 97.04 & 0.46 & 0.14 & 0.07 & 2.09 & 2.87 \\
\hline alver & Eurytoop (Pelagisch) & 97.88 & 0.05 & - & - & 1.68 & 2.41 \\
\hline kolblei & Eurytoop (Bentisch) & 98.6 & 1.35 & 1.74 & 0.18 & 0.34 & 0.05 \\
\hline zwartbekgrondel* & Eurytoop (Bentisch) & 99.22 & - & - & - & 1.3 & 1.76 \\
\hline pontische stroomgrondel* & Eurytoop (Bentisch) & 99.45 & - & - & - & 0.37 & 0.75 \\
\hline kesslers grondel* & Eurytoop (Bentisch) & 99.63 & - & - & - & 0.17 & 0.7 \\
\hline hybride cyprinide & Eurytoop (Bentisch) & 99.76 & 0.1 & 0.35 & 0.15 & 0.07 & \\
\hline roofblei* & Rheofiel (Pelagisch) & 99.88 & - & - & 0.01 & 0.4 & 0.19 \\
\hline bot & Limnofiel (Bentisch) & 99.92 & 0.08 & - & 0.03 & - & 0.09 \\
\hline witvinriviergrondel* & Eurytoop (Bentisch) & 99.95 & - & - & 0.01 & 0.13 & \\
\hline zeelt & Limnofiel (Bentisch) & 99.97 & - & - & - & - & 0.08 \\
\hline sneep & Rheofiel (Bentisch) & 99.98 & - & 0.04 & - & 0.02 & \\
\hline riviergrondel & Rheofiel (Bentisch) & 99.99 & 0.02 & 0.02 & 0 & - & \\
\hline spiering & Eurytoop (Pelagisch) & 100 & 0.04 & 0 & - & - & 0.01 \\
\hline kleine modderkruiper & Eurytoop (Bentisch) & 100 & - & - & 0.01 & 0 & \\
\hline marmergrondel* & Eurytoop (Bentisch) & 100 & - & - & 0 & 0 & 0 \\
\hline rivierdonderpad & Rheofiel (Bentisch) & 100 & - & - & 0 & - & \\
\hline
\end{tabular}


Tabel 3. Soortensamenstelling in percentages op basis van aantal in schepnetvangsten in de zijwateren van de Getijden Maas per 5-jarige periode. De groepering geeft de ecologische indeling aan de hand van Noble et al. (2007) aan. Het cumulatief percentage geeft aan hoeveel de soorten over de gehele periode voorkomen op basis van de gesommeerde CPUE op basis van het aantal. Nul-percentages zijn naar beneden afgeronde waarden, $*=$ exoot.

\begin{tabular}{|c|c|c|c|c|c|c|c|}
\hline Soort & Groepering & $\begin{array}{l}\text { Cumulatief } \\
\text { percentage }\end{array}$ & $\begin{array}{r}1997- \\
1999 \\
\end{array}$ & $\begin{array}{r}2000- \\
2004 \\
\end{array}$ & $\begin{array}{r}2005- \\
2009 \\
\end{array}$ & $\begin{array}{r}2010- \\
2014 \\
\end{array}$ & $\begin{array}{r}2015- \\
2019 \\
\end{array}$ \\
\hline blankvoorn & Eurytoop (Pelagisch) & 88.95 & 40.4 & 93.63 & 64.8 & 33.38 & 45.1 \\
\hline baars & Eurytoop (Pelagisch) & 95.48 & 38.28 & 4.96 & 14.06 & 26.68 & 13.36 \\
\hline winde & Rheofiel (Pelagisch) & 97.3 & 6.67 & 0.45 & 11.03 & 16.38 & 18.86 \\
\hline zwartbekgrondel* & Eurytoop (Bentisch) & 98.01 & - & - & - & 4.78 & 15.11 \\
\hline alver & Eurytoop (Pelagisch) & 98.51 & 2.68 & 0.15 & 4.18 & 10.67 & 1.36 \\
\hline brasem & Eurytoop (Bentisch) & 98.89 & 0.32 & 0.38 & 0.43 & 0.77 & 0.12 \\
\hline aal & Eurytoop (Bentisch) & 99.22 & 2.99 & 0.16 & 2.71 & 1.41 & 1.18 \\
\hline pos & Eurytoop (Bentisch) & 99.42 & 4.2 & 0.11 & 0.78 & 0.06 & \\
\hline marmergrondel* & Eurytoop (Bentisch) & 99.52 & - & - & 0.11 & 0.87 & 2.02 \\
\hline roofblei* & Rheofiel (Pelagisch) & 99.61 & 0.14 & 0 & 0.33 & 1.29 & 1.3 \\
\hline snoek & Eurytoop (Pelagisch) & 99.68 & 1 & 0.02 & 0.05 & 1.04 & 0.21 \\
\hline driedoornige stekelbaars & Eurytoop (Pelagisch) & 99.74 & 2.03 & 0 & 0.21 & 0.28 & 0.18 \\
\hline kesslers grondel* & Eurytoop (Bentisch) & 99.8 & - & - & 0.08 & 1.46 & 0.83 \\
\hline snoekbaars & Eurytoop (Bentisch) & 99.85 & 0.54 & 0.04 & 0.08 & 0.06 & \\
\hline riviergrondel & Rheofiel (Bentisch) & 99.88 & - & 0.04 & 0.11 & - & \\
\hline rivierdonderpad & Rheofiel (Bentisch) & 99.91 & 0.3 & 0.01 & 0.36 & 0.15 & \\
\hline kopvoorn & Rheofiel (Pelagisch) & 99.93 & 0.04 & 0.02 & 0.13 & 0.39 & 0.02 \\
\hline kolblei & Eurytoop (Bentisch) & 99.94 & 0.05 & 0.01 & - & 0.06 & \\
\hline diklipharder & Marien (Pelagisch) & 99.95 & - & 0.01 & 0.06 & - & \\
\hline zeelt & Limnofiel (Bentisch) & 99.96 & 0.08 & 0 & - & 0.13 & 0.07 \\
\hline kleine modderkruiper & Eurytoop (Bentisch) & 99.97 & - & - & 0.11 & - & 0.12 \\
\hline hybride cyprinide & Eurytoop (Bentisch) & 99.97 & - & 0 & 0.05 & 0.1 & \\
\hline bot & Limnofiel (Bentisch) & 99.98 & 0.12 & 0 & 0.11 & 0.05 & \\
\hline rietvoorn & Limnofiel (Pelagisch) & 99.98 & - & 0.01 & - & - & 0.02 \\
\hline serpeling & Rheofiel (Pelagisch) & 99.99 & 0.05 & - & 0.08 & - & 0.02 \\
\hline pontische stroomgrondel* & Eurytoop (Bentisch) & 99.99 & - & - & - & - & 0.08 \\
\hline bermpje & Rheofiel (Bentisch) & 99.99 & - & 0 & - & - & \\
\hline tiendoornige stekelbaars & Limnofiel (Pelagisch) & 100 & 0.08 & - & - & - & \\
\hline vetje & Limnofiel (Pelagisch) & 100 & - & - & - & - & 0.04 \\
\hline bittervoorn & Limnofiel (Pelagisch) & 100 & - & - & 0.06 & - & \\
\hline witvinriviergrondel* & Eurytoop (Bentisch) & 100 & - & - & 0.04 & - & \\
\hline sneep & Rheofiel (Bentisch) & 100 & - & - & 0.04 & - & \\
\hline
\end{tabular}


Tabel 4. Soortensamenstelling in percentages op basis van biomassa in schepnetvangsten in de zijwateren van de Getijden Maas per 5-jarige periode. De groepering geeft de ecologische indeling aan de hand van Noble et al. (2007) aan. Het cumulatief percentage geeft aan hoeveel de soorten over de gehele periode voorkomen op basis van de gesommeerde CPUE op basis van de biomassa. Nulpercentages zijn naar beneden afgeronde waarden, $*$ = exoot.

\begin{tabular}{|c|c|c|c|c|c|c|c|}
\hline Soort & Groepering & $\begin{array}{l}\text { Cumulatief } \\
\text { percentage }\end{array}$ & $\begin{array}{r}1997- \\
1999 \\
\end{array}$ & $\begin{array}{r}2000- \\
2004 \\
\end{array}$ & $\begin{array}{r}2005- \\
2009 \\
\end{array}$ & $\begin{array}{r}2010- \\
2014 \\
\end{array}$ & $\begin{array}{r}2015- \\
2019 \\
\end{array}$ \\
\hline blankvoorn & Eurytoop (Pelagisch) & 61.2 & 10.44 & 76.27 & 21.3 & 9.34 & 13.65 \\
\hline aal & Eurytoop (Bentisch) & 71.76 & 11.98 & 6.03 & 43.77 & 13.68 & 37.69 \\
\hline baars & Eurytoop (Pelagisch) & 81.54 & 21.28 & 9.19 & 7.41 & 7.16 & 6.31 \\
\hline snoek & Eurytoop (Pelagisch) & 88.46 & 7.72 & 4.49 & 0.84 & 42.89 & 9.63 \\
\hline winde & Rheofiel (Pelagisch) & 94.8 & 32.4 & 1.53 & 17.86 & 14.14 & 17.42 \\
\hline snoekbaars & Eurytoop (Bentisch) & 96.92 & 6.71 & 1.39 & 6.5 & 4.82 & \\
\hline brasem & Eurytoop (Bentisch) & 97.64 & 4.87 & 0.28 & 0.11 & 2.41 & 0.03 \\
\hline zwartbekgrondel* & Eurytoop (Bentisch) & 98.35 & - & - & - & 1.24 & 10.14 \\
\hline kopvoorn & Rheofiel (Pelagisch) & 98.94 & 2.35 & 0.5 & 0.31 & 0.07 & 0.04 \\
\hline kesslers grondel* & Eurytoop (Bentisch) & 99.2 & - & - & 0.1 & 1.7 & 2.64 \\
\hline alver & Eurytoop (Pelagisch) & 99.41 & 0.3 & 0.07 & 0.93 & 1.11 & 0.49 \\
\hline pos & Eurytoop (Bentisch) & 99.57 & 0.96 & 0.09 & 0.37 & 0.01 & \\
\hline bot & Limnofiel (Bentisch) & 99.72 & 0.71 & 0.09 & 0.13 & 0.44 & \\
\hline roofblei* & Rheofiel (Pelagisch) & 99.84 & 0.04 & 0 & 0.08 & 0.49 & 1.29 \\
\hline zeelt & Limnofiel (Bentisch) & 99.88 & 0.05 & 0.01 & - & 0.22 & 0.17 \\
\hline riviergrondel & Rheofiel (Bentisch) & 99.91 & - & 0.04 & 0.03 & - & \\
\hline marmergrondel* & Eurytoop (Bentisch) & 99.94 & - & - & 0.03 & 0.12 & 0.31 \\
\hline rivierdonderpad & Rheofiel (Bentisch) & 99.96 & 0.1 & 0.01 & 0.09 & 0.03 & \\
\hline kolblei & Eurytoop (Bentisch) & 99.97 & 0.04 & 0 & - & 0.12 & \\
\hline driedoornige stekelbaars & Eurytoop (Pelagisch) & 99.98 & 0.04 & 0 & 0.01 & 0.01 & 0.02 \\
\hline hybride cyprinide & Eurytoop (Bentisch) & 99.98 & - & 0.01 & 0.02 & 0 & \\
\hline pontische stroomgrondel* & Eurytoop (Bentisch) & 99.99 & - & - & - & - & 0.08 \\
\hline serpeling & Rheofiel (Pelagisch) & 99.99 & 0.01 & - & 0.04 & - & 0.02 \\
\hline kleine modderkruiper & Eurytoop (Bentisch) & 100 & - & - & 0.03 & - & 0.04 \\
\hline $\begin{array}{r}\text { rietvoorn } \\
\end{array}$ & Limnofiel (Pelagisch) & 100 & - & 0 & - & - & 0.01 \\
\hline witvinriviergrondel* & Eurytoop (Bentisch) & 100 & - & - & 0.02 & - & \\
\hline bermpje & Rheofiel (Bentisch) & 100 & - & 0 & - & - & \\
\hline diklipharder & Marien (Pelagisch) & 100 & - & 0 & 0 & - & \\
\hline bittervoorn & Limnofiel (Pelagisch) & 100 & - & - & 0.01 & - & \\
\hline sneep & Rheofiel (Bentisch) & 100 & - & - & 0.01 & - & \\
\hline vetje & Limnofiel (Pelagisch) & 100 & - & - & - & - & 0 \\
\hline tiendoornige stekelbaars & Limnofiel (Pelagisch) & 100 & 0 & - & - & - & \\
\hline
\end{tabular}




\section{Bijlage 32 Afgedamde Maas hoofdstroom}

Tabel 1. Soortensamenstelling in percentages op basis van aantal in boomkorvangsten in de hoofdstroom van de Afgedamde Maas per 5-jarige periode. De groepering geeft de ecologische indeling aan de hand van Noble et al. (2007) aan. Het cumulatief percentage geeft aan hoeveel de soorten over de gehele periode voorkomen op basis van de gesommeerde CPUE op basis van het aantal. Nul-percentages zijn naar beneden afgeronde waarden, $*=$ exoot.

\begin{tabular}{rcrrr}
\hline Soort & Groepering & Cumulatief percentage & $2010-2014$ & $2015-2019$ \\
\hline baars & Eurytoop (Pelagisch) & 75.84 & 62.05 & 81.31 \\
\hline zwartbekgrondel* & Eurytoop (Bentisch) & 82.81 & 4.31 & 8.04 \\
\hline blankvoorn & Eurytoop (Pelagisch) & 87.81 & 9.84 & 3.08 \\
\hline brasem & Eurytoop (Bentisch) & 91.35 & 7.43 & 1.99 \\
\hline pos & Eurytoop (Bentisch) & 94.72 & 10.67 & 0.47 \\
\hline marmergrondel* & Eurytoop (Bentisch) & 96.28 & 0.41 & 2.02 \\
\hline kolblei & Eurytoop (Bentisch) & 97.38 & 1.63 & 0.9 \\
\hline pontische stroomgrondel* & Eurytoop (Bentisch) & 98.44 & 1.05 & 1.05 \\
\hline snoekbaars & Eurytoop (Bentisch) & 99.15 & 1.09 & 0.56 \\
\hline driedoornige stekelbaars & Eurytoop (Pelagisch) & 99.43 & 0.58 & 0.16 \\
\hline kesslers grondel* & Eurytoop (Bentisch) & 99.59 & 0.11 & 0.19 \\
\hline alver & Eurytoop (Pelagisch) & 99.72 & 0.02 & 0.16 \\
\hline rivierdonderpad & Rheofiel (Bentisch) & 99.77 & 0.2 & - \\
\hline kleine modderkruiper & Eurytoop (Bentisch) & 99.83 & 0.2 & - \\
\hline winde & Rheofiel (Pelagisch) & 99.88 & 0.1 & 0.02 \\
\hline roofblei* & Rheofiel (Pelagisch) & 99.91 & 0.11 & 0.01 \\
\hline bot & Limnofiel (Bentisch) & 99.94 & 0.06 & 0.02 \\
\hline bittervoorn & Limnofiel (Pelagisch) & 99.97 & 0.09 & - \\
\hline aal & Eurytoop (Bentisch) & 99.98 & - & 0.02 \\
\hline snoek & Eurytoop (Pelagisch) & 99.99 & 0.03 & - \\
\hline zeelt & Limnofiel (Bentisch) & 100 & 0.03 & - \\
\hline & & &
\end{tabular}

Tabel 2. Soortensamenstelling in percentages op basis van biomassa in boomkorvangsten in de hoofdstroom van de Afgedamde Maas per 5-jarige periode. De groepering geeft de ecologische indeling aan de hand van Noble et al. (2007) aan. Het cumulatief percentage geeft aan hoeveel de soorten over de gehele periode voorkomen op basis van de gesommeerde CPUE op basis van de biomassa. Nulpercentages zijn naar beneden afgeronde waarden, $*=$ exoot.

\begin{tabular}{rcrrr}
\hline Soort & Groepering & Cumulatief percentage & $2010-2014$ & $2015-2019$ \\
\hline baars & Eurytoop (Pelagisch) & 49.88 & 24.75 & 67.53 \\
\hline brasem & Eurytoop (Bentisch) & 65.96 & 33.79 & 3.64 \\
\hline blankvoorn & Eurytoop (Pelagisch) & 78.07 & 19.3 & 7.05 \\
\hline snoekbaars & Eurytoop (Bentisch) & 85.85 & 7.24 & 8.16 \\
\hline zwartbekgrondel* & Eurytoop (Bentisch) & 90.88 & 2.47 & 6.82 \\
\hline kolblei & Eurytoop (Bentisch) & 95.16 & 6.05 & 3.03 \\
\hline pos & Eurytoop (Bentisch) & 96.37 & 2.36 & 0.4 \\
\hline snoek & Eurytoop (Pelagisch) & 97.42 & 2.56 & - \\
\hline pontische stroomgrondel* & Eurytoop (Bentisch) & 98.28 & 0.26 & 1.27 \\
\hline kesslers grondel* & Eurytoop (Bentisch) & 98.75 & 0.26 & 0.62 \\
\hline aal & Eurytoop (Bentisch) & 99.02 & - & 0.46 \\
\hline bot & Limnofiel (Bentisch) & 99.27 & 0.47 & 0.11 \\
\hline alver & Eurytoop (Pelagisch) & 99.52 & 0 & 0.42 \\
\hline winde & Rheofiel (Pelagisch) & 99.73 & 0.04 & 0.33 \\
\hline marmergrondel* & 99.85 & 0.13 & 0.11 \\
\hline roofblei* & Rheofiel (Pelagisch) & 99.95 & 0.2 & 0.03 \\
\hline driedoornige stekelbaars & Eurytoop (Pelagisch) & 99.97 & 0.03 & 0.01 \\
\hline kleine modderkruiper & Eurytoop (Bentisch) & 99.99 & 0.04 & - \\
\hline rivierdonderpad & Rheofiel (Bentisch) & 100 & 0.02 & - \\
\hline bittervoorn & Limnofiel (Pelagisch) & 100 & 0.01 & - \\
\hline zeelt & Limnofiel (Bentisch) & 100 & 0 & - \\
\hline & & &
\end{tabular}


Tabel 3. Soortensamenstelling in percentages op basis van aantal in schepnetvangsten in de hoofdstroom van de Afgedamde Maas per 5-jarige periode. De groepering geeft de ecologische indeling aan de hand van Noble et al. (2007) aan. Het cumulatief percentage geeft aan hoeveel de soorten over de gehele periode voorkomen op basis van de gesommeerde CPUE op basis van het aantal. Nulpercentages zijn naar beneden afgeronde waarden, * = exoot.

\begin{tabular}{rcrrr}
\hline Soort & Groepering & Cumulatief percentage 2010-2014 2015-2019 \\
\hline zwartbekgrondel* & Eurytoop (Bentisch) & 63.14 & 57.38 & 66.98 \\
\hline blankvoorn & Eurytoop (Pelagisch) & 80.14 & 13.28 & 19.48 \\
\hline baars & Eurytoop (Pelagisch) & 90.51 & 14.32 & 7.74 \\
\hline winde & Rheofiel (Pelagisch) & 93.39 & 6.17 & 0.69 \\
\hline aal & Eurytoop (Bentisch) & 95.63 & 1.17 & 2.96 \\
\hline marmergrondel* & Eurytoop (Bentisch) & 97.17 & 2.39 & 0.97 \\
\hline kesslers grondel* & Eurytoop (Bentisch) & 97.95 & 1.45 & 0.34 \\
\hline snoek & Eurytoop (Pelagisch) & 98.32 & 0.78 & 0.09 \\
\hline roofblei* & Rheofiel (Pelagisch) & 98.66 & 0.65 & 0.13 \\
\hline alver & Eurytoop (Pelagisch) & 98.95 & 0.45 & 0.18 \\
\hline pos & Eurytoop (Bentisch) & 99.18 & 0.41 & 0.12 \\
\hline driedoornige stekelbaars & Eurytoop (Pelagisch) & 99.39 & 0.47 & 0.04 \\
\hline pontische stroomgrondel* & Eurytoop (Bentisch) & 99.56 & 0.17 & 0.16 \\
\hline brasem & Eurytoop (Bentisch) & 99.69 & 0.33 & - \\
\hline rivierdonderpad & Rheofiel (Bentisch) & 99.79 & 0.25 & - \\
\hline bittervoorn & Limnofiel (Pelagisch) & 99.85 & 0.08 & 0.04 \\
\hline riviergrondel & Rheofiel (Bentisch) & 99.89 & 0.11 & - \\
\hline serpeling & Rheofiel (Pelagisch) & 99.93 & 0.09 & - \\
\hline snoekbaars & Eurytoop (Bentisch) & 99.95 & - & 0.04 \\
\hline zeelt & Limnofiel (Bentisch) & 99.98 & - & 0.04 \\
\hline kleine modderkruiper & 100 & 0.05 & - \\
\hline & & &
\end{tabular}

Tabel 4. Soortensamenstelling in percentages op basis van biomassa in schepnetvangsten in de hoofdstroom van de Afgedamde Maas per 5-jarige periode. De groepering geeft de ecologische indeling aan de hand van Noble et al. (2007) aan. Het cumulatief percentage geeft aan hoeveel de soorten over de gehele periode voorkomen op basis van de gesommeerde CPUE op basis van de biomassa. Nulpercentages zijn naar beneden afgeronde waarden, $*=$ exoot.

\begin{tabular}{rrrrr} 
Soort & Groepering & Cumulatief percentage 2010-2014 2015-2019 \\
\hline aal & Eurytoop (Bentisch) & 40.22 & 16.77 & 52.63 \\
\hline zwartbekgrondel* & Eurytoop (Bentisch) & 68.44 & 31.31 & 26.58 \\
\hline snoek & Eurytoop (Pelagisch) & 81.06 & 16.94 & 10.33 \\
\hline baars & Eurytoop (Pelagisch) & 87.37 & 9.18 & 4.8 \\
\hline brasem & Eurytoop (Bentisch) & 92.55 & 14.96 & - \\
\hline winde & Rheofiel (Pelagisch) & 97.29 & 4.71 & 4.76 \\
\hline kesslers grondel* & Eurytoop (Bentisch) & 98.36 & 2.74 & 0.18 \\
\hline marmergrondel* & Eurytoop (Bentisch) & 99.24 & 1.9 & 0.35 \\
\hline roofblei* & Rheofiel (Pelagisch) & 99.38 & 0.28 & 0.07 \\
\hline pos & Eurytoop (Bentisch) & 99.52 & 0.31 & 0.04 \\
\hline zeelt & Lurytoop (Bentisch) & 99.62 & 0.24 & 0.04 \\
\hline alver & Eurytoop (Pelagisch) & 99.72 & 0.16 & 0.06 \\
\hline pontische stroomgronde* & 99.79 & 0.21 & - \\
\hline snoekbaars & Eurytoop (Bentisch) & 99.86 & 0.1 & 0.05 \\
\hline riviergrondel & Rheofiel (Bentisch) & 99.92 & - & 0.09 \\
\hline serpeling & Rheofiel (Pelagisch) & 99.94 & 0.06 & - \\
\hline rivierdonderpad & Rheofiel (Bentisch) & 99.96 & 0.06 & - \\
\hline kleine modderkruiper & Eurytoop (Bentisch) & 99.98 & 0.04 & - \\
\hline driedoornige stekelbaars & Eurytoop (Pelagisch) & 99.99 & - & 0.01 \\
\hline bittervoorn & Limnofiel (Pelagisch) & 99.99 & 0.02 & 0 \\
\hline & & 100 & 0.01 & 0 \\
\hline
\end{tabular}




\section{Bijlage 33 Afgedamde Maas zijwateren}

Tabel 1. Soortensamenstelling in percentages op basis van aantal in boomkorvangsten in de zijwateren van de Afgedamde Maas per 5-jarige periode. De groepering geeft de ecologische indeling aan de hand van Noble et al. (2007) aan. Het cumulatief percentage geeft aan hoeveel de soorten over de gehele periode voorkomen op basis van de gesommeerde CPUE op basis van het aantal. Nul-percentages zijn naar beneden afgeronde waarden, * exoot.

\begin{tabular}{|c|c|c|c|c|}
\hline Soort & Groepering & Cumulatief percentage & $2010-2014$ & $2015-2019$ \\
\hline baars & Eurytoop (Pelagisch) & 58.79 & 60 & 58.14 \\
\hline pos & Eurytoop (Bentisch) & 79 & 28.31 & 15.88 \\
\hline blankvoorn & Eurytoop (Pelagisch) & 92.49 & 3.44 & 18.86 \\
\hline brasem & Eurytoop (Bentisch) & 96.01 & 5.42 & 2.51 \\
\hline snoekbaars & Eurytoop (Bentisch) & 97.46 & 1.57 & 1.38 \\
\hline zwartbekgrondel* & Eurytoop (Bentisch) & 98.35 & 0.06 & 1.34 \\
\hline kolblei & Eurytoop (Bentisch) & 99.11 & 0.51 & 0.9 \\
\hline pontische stroomgrondel* & Eurytoop (Bentisch) & 99.51 & - & 0.61 \\
\hline winde & Rheofiel (Pelagisch) & 99.7 & 0.04 & 0.27 \\
\hline kleine modderkruiper & Eurytoop (Bentisch) & 99.8 & 0.26 & 0.01 \\
\hline marmergrondel* & Eurytoop (Bentisch) & 99.86 & 0.13 & 0.03 \\
\hline rivierdonderpad & Rheofiel (Bentisch) & 99.89 & 0.07 & \\
\hline snoek & Eurytoop (Pelagisch) & 99.91 & 0.01 & 0.02 \\
\hline bot & Limnofiel (Bentisch) & 99.93 & - & 0.03 \\
\hline driedoornige stekelbaars & Eurytoop (Pelagisch) & 99.94 & 0.03 & 0.01 \\
\hline roofblei* & Rheofiel (Pelagisch) & 99.96 & 0.04 & \\
\hline alver & Eurytoop (Pelagisch) & 99.97 & 0.04 & \\
\hline zeelt & Limnofiel (Bentisch) & 99.98 & 0.03 & \\
\hline aal & Eurytoop (Bentisch) & 99.99 & 0.01 & 0.01 \\
\hline giebel & Eurytoop (Bentisch) & 100 & 0.01 & \\
\hline hybride cyprinide & Eurytoop (Bentisch) & 100 & 0.01 & \\
\hline
\end{tabular}

Tabel 2. Soortensamenstelling in percentages op basis van biomassa in boomkorvangsten in de zijwateren van de Afgedamde Maas per 5-jarige periode. De groepering geeft de ecologische indeling aan de hand van Noble et al. (2007) aan. Het cumulatief percentage geeft aan hoeveel de soorten over de gehele periode voorkomen op basis van de gesommeerde CPUE op basis van de biomassa. Nulpercentages zijn naar beneden afgeronde waarden, $*$ = exoot.

\begin{tabular}{|c|c|c|c|c|}
\hline Soort & Groepering & Cumulatief percentage & $2010-2014$ & $2015-2019$ \\
\hline blankvoorn & Eurytoop (Pelagisch) & 40.87 & 10.65 & 53.33 \\
\hline baars & Eurytoop (Pelagisch) & 72.4 & 35.9 & 29.72 \\
\hline brasem & Eurytoop (Bentisch) & 83.95 & 29.69 & 4.08 \\
\hline snoekbaars & Eurytoop (Bentisch) & 91.08 & 12.53 & 4.89 \\
\hline pos & Eurytoop (Bentisch) & 96.39 & 7.28 & 4.5 \\
\hline kolblei & Eurytoop (Bentisch) & 97.7 & 2.05 & 1 \\
\hline snoek & Eurytoop (Pelagisch) & 98.48 & 0.63 & 0.85 \\
\hline zwartbekgrondel* & Eurytoop (Bentisch) & 98.92 & 0.11 & 0.58 \\
\hline winde & Rheofiel (Pelagisch) & 99.35 & 0.13 & 0.56 \\
\hline aal & Eurytoop (Bentisch) & 99.63 & 0.42 & 0.22 \\
\hline roofblei* & Rheofiel (Pelagisch) & 99.74 & 0.35 & \\
\hline bot & Limnofiel (Bentisch) & 99.84 & - & 0.14 \\
\hline pontische stroomgrondel* & Eurytoop (Bentisch) & 99.92 & - & 0.12 \\
\hline kleine modderkruiper & Eurytoop (Bentisch) & 99.94 & 0.05 & 0 \\
\hline hybride cyprinide & Eurytoop (Bentisch) & 99.96 & 0.05 & \\
\hline alver & Eurytoop (Pelagisch) & 99.97 & 0.05 & \\
\hline marmergrondel* & Eurytoop (Bentisch) & 99.98 & 0.03 & 0 \\
\hline zeelt & Limnofiel (Bentisch) & 99.99 & 0.02 & \\
\hline rivierdonderpad & Rheofiel (Bentisch) & 99.99 & 0.02 & \\
\hline giebel & Eurytoop (Bentisch) & 100 & 0.01 & \\
\hline driedoornige stekelbaars & Eurytoop (Pelagisch) & 100 & 0 & 0 \\
\hline
\end{tabular}


Tabel 3. Soortensamenstelling in percentages op basis van aantal in schepnetvangsten in de zijwateren van de Afgedamde Maas per 5-jarige periode. De groepering geeft de ecologische indeling aan de hand van Noble et al. (2007) aan. Het cumulatief percentage geeft aan hoeveel de soorten over de gehele periode voorkomen op basis van de gesommeerde CPUE op basis van het aantal. Nul-percentages zijn naar beneden afgeronde waarden, * =xoot.

\begin{tabular}{rcrrr}
\hline Soort & Groepering & Cumulatief percentage & $2010-2014$ & $2015-2019$ \\
\hline baars & Eurytoop (Pelagisch) & 34.74 & 31.29 & 39.39 \\
\hline blankvorn & Eurytoop (Pelagisch) & 68.07 & 43.89 & 19.09 \\
\hline winde & Rheofiel (Pelagisch) & 80.79 & 8.65 & 18.21 \\
\hline marmergrondel* & Eurytoop (Bentisch) & 87.35 & 2.81 & 11.62 \\
\hline zwartbekgrondel* & Eurytoop (Bentisch) & 90.53 & 2.6 & 3.97 \\
\hline snoek & Eurytoop (Pelagisch) & 92.47 & 2.48 & 1.21 \\
\hline kleine modderkruiper & Eurytoop (Bentisch) & 93.78 & 2.28 & - \\
\hline driedoornige stekelbaars & Eurytoop (Pelagisch) & 95 & 2.12 & - \\
\hline aal & Eurytoop (Bentisch) & 9.39 & 2.28 \\
\hline rietvoorn & Limnofiel (Pelagisch) & 96.19 & 0.19 & 1.52 \\
\hline zeelt & Limnofiel (Bentisch) & 96.98 & 0.25 & - \\
\hline bittervoorn & Limnofiel (Pelagisch) & 97.73 & 1.76 \\
\hline brasem & Eurytoop (Bentisch) & 98.31 & 1 & - \\
\hline roofblei* & Rheofiel (Pelagisch) & 98.86 & 0.96 & - \\
\hline alver & Eurytoop (Pelagisch) & 99.29 & 0.5 & 0.35 \\
\hline bivierdonderpad & Rheofiel (Bentisch) & 99.58 & 0.5 & - \\
\hline bot & Limnofiel (Bentisch) & 99.74 & 0.28 & - \\
\hline pontische stroomgrondel* & Eurytoop (Bentisch) & 99.87 & - & 0.3 \\
\hline
\end{tabular}

Tabel 4. Soortensamenstelling in percentages op basis van biomassa in schepnetvangsten in de zijwateren van de Afgedamde Maas per 5-jarige periode. De groepering geeft de ecologische indeling aan de hand van Noble et al. (2007) aan. Het cumulatief percentage geeft aan hoeveel de soorten over de gehele periode voorkomen op basis van de gesommeerde CPUE op basis van de biomassa. Nulpercentages zijn naar beneden afgeronde waarden, $*=$ exoot.

\begin{tabular}{rcrrr}
\hline Soort & Groepering & Cumulatief percentage & $2010-2014$ & $2015-2019$ \\
\hline snoek & Eurytoop (Pelagisch) & 67.33 & 73.5 & 61.4 \\
\hline aal & Eurytoop (Bentisch) & 83.41 & 3.77 & 27.91 \\
\hline brasem & Eurytoop (Bentisch) & 87.92 & 9.22 & - \\
\hline baars & Eurytoop (Pelagisch) & 91.99 & 4.69 & 3.46 \\
\hline blankvoorn & Eurytoop (Pelagisch) & 95.93 & 5.79 & 2.18 \\
\hline winde & Rheofiel (Pelagisch) & 97.63 & 1.64 & 1.76 \\
\hline zwartbekgrondel* & Eurytoop (Bentisch) & 98.52 & 0.51 & 1.25 \\
\hline bet & Limnofiel (Bentisch) & 98.85 & - & 0.63 \\
\hline zeelt & Limnofiel (Bentisch) & 99.15 & - & 0.6 \\
\hline marmergrondel* & Eurytoop (Bentisch) & 99.43 & 0.22 & 0.34 \\
\hline rietvoorn & Limnofiel (Pelagisch) & 99.67 & 0.13 & 0.34 \\
\hline kleine modderkruiper & Eurytoop (Bentisch) & 99.83 & 0.33 & - \\
\hline roofblei* & Rheofiel (Pelagisch) & 99.9 & 0.07 & 0.07 \\
\hline driedoornige stekelbaars & Eurytoop (Pelagisch) & 99.93 & 0.06 & - \\
\hline rivierdonderpad & Rheofiel (Bentisch) & 99.95 & 0.05 & - \\
\hline pontische stroomgrondel* & Eurytoop (Bentisch) & 99.98 & - & 0.05 \\
\hline alver & Eurytoop (Pelagisch) & 99.99 & 0.03 & - \\
\hline bittervoorn & Limnofiel (Pelagisch) & 100 & 0.01 & -
\end{tabular}




\section{Bijlage 34 Heusdensch Kanaal hoofdstroom}

Tabel 1. Soortensamenstelling in percentages op basis van aantal in boomkorvangsten in de hoofdstroom van het Heusdensch Kanaal per 5-jarige periode. De groepering geeft de ecologische indeling aan de hand van Noble et al. (2007) aan. Het cumulatief percentage geeft aan hoeveel de soorten over de gehele periode voorkomen op basis van de gesommeerde CPUE op basis van het aantal. Nul-percentages zijn naar beneden afgeronde waarden, * = exoot.

\begin{tabular}{|c|c|c|c|c|}
\hline Soort & Groepering & Cumulatief percentage & $2010-2014$ & $2015-2019$ \\
\hline baars & Eurytoop (Pelagisch) & 38.77 & 33.98 & 45.93 \\
\hline brasem & Eurytoop (Bentisch) & 62.84 & 33.49 & 9.98 \\
\hline blankvoorn & Eurytoop (Pelagisch) & 71.61 & 7.58 & 10.56 \\
\hline pos & Eurytoop (Bentisch) & 78.66 & 11.28 & 0.73 \\
\hline kolblei & Eurytoop (Bentisch) & 84.85 & 7.83 & 3.73 \\
\hline pontische stroomgrondel* & Eurytoop (Bentisch) & 89.58 & 0.3 & 11.35 \\
\hline zwartbekgrondel* & Eurytoop (Bentisch) & 94.11 & 0.81 & 10.1 \\
\hline snoekbaars & Eurytoop (Bentisch) & 98.56 & 3.57 & 5.75 \\
\hline winde & Rheofiel (Pelagisch) & 99.18 & 0.22 & 1.24 \\
\hline kesslers grondel* & Eurytoop (Bentisch) & 99.5 & 0.2 & 0.48 \\
\hline rivierdonderpad & Rheofiel (Bentisch) & 99.63 & 0.22 & \\
\hline alver & Eurytoop (Pelagisch) & 99.75 & 0.21 & \\
\hline snoek & Eurytoop (Pelagisch) & 99.87 & 0.2 & \\
\hline bot & Limnofiel (Bentisch) & 99.94 & - & 0.16 \\
\hline rietvoorn & Limnofiel (Pelagisch) & 100 & 0.1 & \\
\hline
\end{tabular}

Tabel 2. Soortensamenstelling in percentages op basis van biomassa in boomkorvangsten in de hoofdstroom van het Heusdensch Kanaal per 5-jarige periode. De groepering geeft de ecologische indeling aan de hand van Noble et al. (2007) aan. Het cumulatief percentage geeft aan hoeveel de soorten over de gehele periode voorkomen op basis van de gesommeerde CPUE op basis van de biomassa. Nul-percentages zijn naar beneden afgeronde waarden, * = exoot.

\begin{tabular}{rcrrr} 
Soort & Groepering & Cumulatief percentage & $2010-2014$ & $2015-2019$ \\
\hline brasem & Eurytoop (Bentisch) & 37.57 & 46.96 & 25.59 \\
\hline baars & Eurytoop (Pelagisch) & 56.71 & 16.82 & 22.12 \\
\hline snoekbaars & Eurytoop (Bentisch) & 74.99 & 13.5 & 24.37 \\
\hline blankvoorn & Eurytoop (Pelagisch) & 87.8 & 8.09 & 18.84 \\
\hline kolblei & Eurytoop (Bentisch) & 95.08 & 10.86 & 2.7 \\
\hline winde & Rheofiel (Pelagisch) & 96.1 & 0.12 & 2.18 \\
\hline zwartbekgrondel* & Eurytoop (Bentisch) & 97.03 & 0.15 & 1.93 \\
\hline snoek & Eurytoop (Pelagisch) & 97.92 & 1.58 & - \\
\hline pontische stroomgrondel* & Eurytoop (Bentisch) & 98.57 & 0.06 & 1.41 \\
\hline rietvoorn & Limnofiel (Pelagisch) & 99.1 & 0.94 & - \\
\hline pos & Eurytoop (Bentisch) & 99.58 & 0.75 & 0.12 \\
\hline bot & Limnofiel (Bentisch) & 99.83 & - & 0.58 \\
\hline kesslers grondel* & Eurytoop (Bentisch) & 99.94 & 0.06 & 0.16 \\
\hline alver & Eurytoop (Pelagisch) & 100 & 0.11 & - \\
\hline rivierdonderpad & Rheofiel (Bentisch) & 100 & 0.01 & -
\end{tabular}


Tabel 3. Soortensamenstelling in percentages op basis van aantal in schepnetvangsten in de hoofdstroom van het Heusdensch Kanaal per 5-jarige periode. De groepering geeft de ecologische indeling aan de hand van Noble et al. (2007) aan. Het cumulatief percentage geeft aan hoeveel de soorten over de gehele periode voorkomen op basis van de gesommeerde CPUE op basis van het aantal. Nul-percentages zijn naar beneden afgeronde waarden, $*=$ exoot.

\begin{tabular}{rcrrr} 
Soort & Groepering & Cumulatief percentage 2010-2014 2015-2019 \\
\hline zwartbekgrondel* & Eurytoop (Bentisch) & 60.27 & 60.78 & 60.08 \\
\hline blankvoorn & Eurytoop (Pelagisch) & 75.38 & 7.41 & 18.05 \\
\hline baars & Eurytoop (Pelagisch) & 85.88 & 17.85 & 7.69 \\
\hline winde & Rheofiel (Pelagisch) & 91.34 & 1.91 & 6.82 \\
\hline pos & Eurytoop (Bentisch) & 93.41 & 7.21 & 0.11 \\
\hline roofblei* & Rheofiel (Pelagisch) & 94.85 & - & 1.99 \\
\hline kesslers grondel* & Eurytoop (Bentisch) & 96.24 & - & 1.93 \\
\hline aal & Eurytoop (Bentisch) & 97.61 & 2.53 & 0.92 \\
\hline marmergrondel* & Eurytoop (Bentisch) & 9.72 & 0.99 \\
\hline brasem & Eurytoop (Bentisch) & 9.43 & 0.77 \\
\hline pontische stroomgrondel* & Eurytoop (Bentisch) & 99.27 & - & 0.38 \\
\hline alver & Eurytoop (Pelagisch) & 99.55 & - & 0.19 \\
\hline driedoornige stekelbaars & Eurytoop (Pelagisch) & 99.69 & - & 0.1 \\
\hline rivierdonderpad & Rheofiel (Bentisch) & 99.83 & 0.25 & - \\
\hline karper & Eurytoop (Bentisch) & 99.89 & 0.22 & - \\
\hline snoek & Eurytoop (Pelagisch) & 99.94 & 0.2 & - \\
\hline & & 100 & 0.2 & -
\end{tabular}

Tabel 4. Soortensamenstelling in percentages op basis van biomassa in schepnetvangsten in de hoofdstroom van het Heusdensch Kanaal per 5-jarige periode. De groepering geeft de ecologische indeling aan de hand van Noble et al. (2007) aan. Het cumulatief percentage geeft aan hoeveel de soorten over de gehele periode voorkomen op basis van de gesommeerde CPUE op basis van de biomassa. Nul-percentages zijn naar beneden afgeronde waarden, $*=$ exoot.

\begin{tabular}{|c|c|c|c|c|}
\hline Soort & Groepering & Cumulatief percentage & $2010-2014$ & $2015-2019$ \\
\hline karper & Eurytoop (Bentisch) & 25.75 & 39.77 & \\
\hline zwartbekgrondel* & Eurytoop (Bentisch) & 45.03 & 9 & 38.14 \\
\hline snoek & Eurytoop (Pelagisch) & 63.39 & 28.37 & - \\
\hline aal & Eurytoop (Bentisch) & 76.79 & 11.69 & 16.53 \\
\hline baars & Eurytoop (Pelagisch) & 86.89 & 2.06 & 24.86 \\
\hline winde & Rheofiel (Pelagisch) & 93.81 & 7.82 & 5.27 \\
\hline blankvoorn & Eurytoop (Pelagisch) & 97.49 & 0.66 & 9.23 \\
\hline kesslers grondel* & Eurytoop (Bentisch) & 98.87 & - & 3.92 \\
\hline roofblei* & Rheofiel (Pelagisch) & 99.32 & - & 1.26 \\
\hline pos & Eurytoop (Bentisch) & 99.69 & 0.56 & 0.03 \\
\hline pontische stroomgrondel* & Eurytoop (Bentisch) & 99.83 & - & 0.39 \\
\hline marmergrondel* & Eurytoop (Bentisch) & 99.9 & 0.04 & 0.14 \\
\hline brasem & Eurytoop (Bentisch) & 99.96 & - & 0.16 \\
\hline alver & Eurytoop (Pelagisch) & 99.99 & - & 0.07 \\
\hline rivierdonderpad & Rheofiel (Bentisch) & 100 & 0.02 & \\
\hline driedoornige stekelbaars & Eurytoop (Pelagisch) & 100 & 0 & 0.01 \\
\hline
\end{tabular}




\section{Bijlage 35 Noordwaard}

Tabel 1. Soortensamenstelling in percentages op basis van aantal in schepnetvangsten in de Noordwaard per 5jarige periode. De groepering geeft de ecologische indeling aan de hand van Noble et al. (2007) aan. Het cumulatief percentage geeft aan hoeveel de soorten over de gehele periode voorkomen op basis van de gesommeerde CPUE op basis van het aantal. Nul-percentages zijn naar beneden afgeronde waarden, * exoot.

\begin{tabular}{|c|c|c|c|}
\hline Soort & Groepering & Cumulatief percentage & $2015-2019$ \\
\hline vetje & Limnofiel (Pelagisch) & 23.39 & 23.39 \\
\hline blankvoorn & Eurytoop (Pelagisch) & 41 & 17.6 \\
\hline bittervoorn & Limnofiel (Pelagisch) & 53.75 & 12.75 \\
\hline baars & Eurytoop (Pelagisch) & 65.39 & 11.65 \\
\hline marmergrondel* & Eurytoop (Bentisch) & 73.76 & 8.37 \\
\hline zwartbekgrondel* & Eurytoop (Bentisch) & 79.47 & 5.71 \\
\hline rietvoorn & Limnofiel (Pelagisch) & 83.82 & 4.36 \\
\hline winde & Rheofiel (Pelagisch) & 86.93 & 3.1 \\
\hline driedoornige stekelbaars & Eurytoop (Pelagisch) & 89.39 & 2.46 \\
\hline brasem & Eurytoop (Bentisch) & 91.65 & 2.26 \\
\hline kleine modderkruiper & Eurytoop (Bentisch) & 93.71 & 2.06 \\
\hline zeelt & Limnofiel (Bentisch) & 95.01 & 1.3 \\
\hline tiendoornige stekelbaars & Limnofiel (Pelagisch) & 96.26 & 1.25 \\
\hline snoek & Eurytoop (Pelagisch) & 97 & 0.75 \\
\hline pontische stroomgrondel* & Eurytoop (Bentisch) & 97.72 & 0.71 \\
\hline kesslers grondel* & Eurytoop (Bentisch) & 98.3 & 0.58 \\
\hline roofblei* & Rheofiel (Pelagisch) & 98.8 & 0.5 \\
\hline kolblei & Eurytoop (Bentisch) & 99.12 & 0.32 \\
\hline bot & Limnofiel (Bentisch) & 99.43 & 0.31 \\
\hline aal & Eurytoop (Bentisch) & 99.69 & 0.27 \\
\hline alver & Eurytoop (Pelagisch) & 99.87 & 0.18 \\
\hline karper & Eurytoop (Bentisch) & 99.92 & 0.05 \\
\hline pos & Eurytoop (Bentisch) & 99.94 & 0.02 \\
\hline serpeling & Rheofiel (Pelagisch) & 99.96 & 0.02 \\
\hline snoekbaars & Eurytoop (Bentisch) & 99.98 & 0.02 \\
\hline zeeprik & Rheofiel (Bentisch) & 100 & 0.02 \\
\hline
\end{tabular}

Tabel 2. Soortensamenstelling in percentages op basis van biomassa in schepnetvangsten in de Noordwaard per 5-jarige periode. De groepering geeft de ecologische indeling aan (Noble et al. 2007). Het cumulatief percentage geeft aan hoeveel de soorten over de gehele periode voorkomen op basis van de gesommeerde CPUE op basis van de biomassa. Nul-percentages zijn naar beneden afgeronde waarden, $*=$ exoot.

\begin{tabular}{|c|c|c|c|}
\hline Soort & Groepering & Cumulatief percentage & 2015-2019 \\
\hline karper & Eurytoop (Bentisch) & 29.98 & 29.98 \\
\hline snoek & Eurytoop (Pelagisch) & 56.7 & 26.72 \\
\hline baars & Eurytoop (Pelagisch) & 67.94 & 11.24 \\
\hline blankvoorn & Eurytoop (Pelagisch) & 75.02 & 7.09 \\
\hline aal & Eurytoop (Bentisch) & 80.61 & 5.59 \\
\hline zeelt & Limnofiel (Bentisch) & 85.07 & 4.46 \\
\hline winde & Rheofiel (Pelagisch) & 88.71 & 3.64 \\
\hline zwartbekgrondel* & Eurytoop (Bentisch) & 92.22 & 3.5 \\
\hline bittervoorn & Limnofiel (Pelagisch) & 93.97 & 1.75 \\
\hline rietvoorn & Limnofiel (Pelagisch) & 95.37 & 1.4 \\
\hline vetje & Limnofiel (Pelagisch) & 96.33 & 0.96 \\
\hline marmergrondel* & Eurytoop (Bentisch) & 97.2 & 0.87 \\
\hline kesslers grondel* & Eurytoop (Bentisch) & 98.06 & 0.86 \\
\hline kleine modderkruiper & Eurytoop (Bentisch) & 98.61 & 0.55 \\
\hline $\begin{array}{r}\text { roofblei* } \\
\end{array}$ & Rheofiel (Pelagisch) & 98.98 & 0.37 \\
\hline brasem & Eurytoop (Bentisch) & 99.28 & 0.29 \\
\hline bot & Limnofiel (Bentisch) & 99.5 & 0.22 \\
\hline pontische stroomgrondel* & Eurytoop (Bentisch) & 99.69 & 0.18 \\
\hline kolblei & Eurytoop (Bentisch) & 99.84 & 0.15 \\
\hline driedoornige stekelbaars & Eurytoop (Pelagisch) & 99.93 & 0.09 \\
\hline tiendoornige stekelbaars & Limnofiel (Pelagisch) & 99.96 & 0.03 \\
\hline alver & Eurytoop (Pelagisch) & 99.98 & 0.02 \\
\hline zeeprik & Rheofiel (Bentisch) & 99.99 & 0.01 \\
\hline serpeling & Rheofiel (Pelagisch) & 99.99 & 0.01 \\
\hline snoekbaars & Eurytoop (Bentisch) & 100 & 0 \\
\hline pos & Eurytoop (Bentisch) & 100 & 0 \\
\hline
\end{tabular}


Tabel 1. Soortensamenstelling in percentages op basis van aantal in zegenvangsten in de Noordwaard per 5jarige periode. De groepering geeft de ecologische indeling aan de hand van Noble et al. (2007) aan. Het cumulatief percentage geeft aan hoeveel de soorten over de gehele periode voorkomen op basis van de gesommeerde CPUE op basis van het aantal. Nul-percentages zijn naar beneden afgeronde waarden, * = exoot.

\begin{tabular}{|c|c|c|c|}
\hline Soort & Groepering & Cumulatief percentage & 2015-2019 \\
\hline blankvoorn & Eurytoop (Pelagisch) & 59 & 59 \\
\hline baars & Eurytoop (Pelagisch) & 81.59 & 22.6 \\
\hline brasem & Eurytoop (Bentisch) & 85.87 & 4.27 \\
\hline roofblei* & Rheofiel (Pelagisch) & 88.99 & 3.12 \\
\hline winde & Rheofiel (Pelagisch) & 91.77 & 2.79 \\
\hline bittervoorn & Limnofiel (Pelagisch) & 93.77 & 2 \\
\hline rietvoorn & Limnofiel (Pelagisch) & 95.44 & 1.67 \\
\hline driedoornige stekelbaars & Eurytoop (Pelagisch) & 96.85 & 1.41 \\
\hline kolblei & Eurytoop (Bentisch) & 98.14 & 1.29 \\
\hline alver & Eurytoop (Pelagisch) & 98.77 & 0.63 \\
\hline pos & Eurytoop (Bentisch) & 99.03 & 0.26 \\
\hline marmergrondel* & Eurytoop (Bentisch) & 99.24 & 0.21 \\
\hline pontische stroomgrondel* & Eurytoop (Bentisch) & 99.44 & 0.2 \\
\hline snoekbaars & Eurytoop (Bentisch) & 99.63 & 0.2 \\
\hline zwartbekgrondel* & Eurytoop (Bentisch) & 99.76 & 0.12 \\
\hline snoek & Eurytoop (Pelagisch) & 99.86 & 0.1 \\
\hline hybride cyprinide & Eurytoop (Bentisch) & 99.9 & 0.05 \\
\hline kesslers grondel* & Eurytoop (Bentisch) & 99.94 & 0.04 \\
\hline zeelt & Limnofiel (Bentisch) & 99.96 & 0.02 \\
\hline bot & Limnofiel (Bentisch) & 99.97 & 0.01 \\
\hline kleine modderkruiper & Eurytoop (Bentisch) & 99.98 & 0.01 \\
\hline karper & Eurytoop (Bentisch) & 99.99 & 0.01 \\
\hline vetje & Limnofiel (Pelagisch) & 99.99 & 0.01 \\
\hline $\begin{array}{l}\text { giebel } \\
\end{array}$ & Eurytoop (Bentisch) & 99.99 & 0 \\
\hline tiendoornige stekelbaars & Limnofiel (Pelagisch) & 100 & 0 \\
\hline serpeling & Rheofiel (Pelagisch) & 100 & 0 \\
\hline blauwneus* & Eurytoop (Bentisch) & 100 & 0 \\
\hline
\end{tabular}

Tabel 2. Soortensamenstelling in percentages op basis van biomassa in zegenvangsten in de Noordwaard per 5jarige periode. De groepering geeft de ecologische indeling aan (Noble et al. 2007). Het cumulatief percentage geeft aan hoeveel de soorten over de gehele periode voorkomen op basis van de gesommeerde CPUE op basis van de biomassa. Nul-percentages zijn naar beneden afgeronde waarden, $*=$ exoot.

\begin{tabular}{|c|c|c|c|}
\hline Soort & Groepering & Cumulatief percentage & $2015-2019$ \\
\hline blankvoorn & Eurytoop (Pelagisch) & 34.84 & 34.84 \\
\hline brasem & Eurytoop (Bentisch) & 59.68 & 24.84 \\
\hline baars & Eurytoop (Pelagisch) & 71.69 & 12.02 \\
\hline roofblei* & Rheofiel (Pelagisch) & 78.58 & 6.88 \\
\hline rietvoorn & Limnofiel (Pelagisch) & 85.2 & 6.62 \\
\hline snoek & Eurytoop (Pelagisch) & 90.56 & 5.36 \\
\hline winde & Rheofiel (Pelagisch) & 92.98 & 2.41 \\
\hline snoekbaars & Eurytoop (Bentisch) & 94.96 & 1.98 \\
\hline kolblei & Eurytoop (Bentisch) & 96.15 & 1.2 \\
\hline karper & Eurytoop (Bentisch) & 97.35 & 1.2 \\
\hline alver & Eurytoop (Pelagisch) & 97.98 & 0.63 \\
\hline hybride cyprinide & Eurytoop (Bentisch) & 98.5 & 0.52 \\
\hline zeelt & Limnofiel (Bentisch) & 99.02 & 0.52 \\
\hline bittervoorn & Limnofiel (Pelagisch) & 99.36 & 0.34 \\
\hline pos & Eurytoop (Bentisch) & 99.59 & 0.23 \\
\hline pontische stroomgrondel* & Eurytoop (Bentisch) & 99.71 & 0.12 \\
\hline kesslers grondel* & Eurytoop (Bentisch) & 99.8 & 0.09 \\
\hline zwartbekgrondel* & Eurytoop (Bentisch) & 99.88 & 0.08 \\
\hline giebel & Eurytoop (Bentisch) & 99.92 & 0.05 \\
\hline driedoornige stekelbaars & Eurytoop (Pelagisch) & 99.97 & 0.04 \\
\hline marmergrondel* & Eurytoop (Bentisch) & 99.99 & 0.02 \\
\hline bot & Limnofiel (Bentisch) & 99.99 & 0.01 \\
\hline blauwneus* & Eurytoop (Bentisch) & 100 & 0.01 \\
\hline serpeling & Rheofiel (Pelagisch) & 100 & 0 \\
\hline vetje & Limnofiel (Pelagisch) & 100 & 0 \\
\hline kleine modderkruiper & Eurytoop (Bentisch) & 100 & 0 \\
\hline tiendoornige stekelbaars & Limnofiel (Pelagisch) & 100 & 0 \\
\hline
\end{tabular}




\section{Bijlage 36 Nieuwe Merwede hoofdstroom}

Tabel 1. Soortensamenstelling in percentages op basis van aantal in boomkorvangsten in de hoofdstroom van de Nieuwe Merwede per 5-jarige periode. De groepering geeft de ecologische indeling aan de hand van Noble et al. (2007) aan. Het cumulatief percentage geeft aan hoeveel de soorten over de gehele periode voorkomen op basis van de gesommeerde CPUE op basis van het aantal. Nul-percentages zijn naar beneden afgeronde waarden, $*=$ exoot.

\begin{tabular}{|c|c|c|c|c|c|c|c|}
\hline Soort & Groepering & $\begin{array}{l}\text { Cumulatief } \\
\text { percentage }\end{array}$ & $\begin{array}{r}1997- \\
1999\end{array}$ & $\begin{array}{r}2000- \\
2004\end{array}$ & $\begin{array}{r}2005- \\
2009\end{array}$ & $\begin{array}{r}2010- \\
2014\end{array}$ & $\begin{array}{r}2015- \\
2019\end{array}$ \\
\hline brasem & Eurytoop (Bentisch) & 32.72 & 66 & 39.26 & 22.56 & 14.02 & 34.46 \\
\hline bot & Limnofiel (Bentisch) & 46.77 & 7.18 & 29.87 & 21.65 & 12.22 & 4.18 \\
\hline blankvoorn & Eurytoop (Pelagisch) & 60.65 & 10.91 & 12.43 & 14.74 & 6.08 & 24.66 \\
\hline zwartbekgrondel* & Eurytoop (Bentisch) & 71.98 & - & - & 2.36 & 36.07 & 5.77 \\
\hline pontische stroomgrondel* & Eurytoop (Bentisch) & 77.61 & - & - & 0.1 & 13.35 & 8.57 \\
\hline snoekbaars & Eurytoop (Bentisch) & 81.97 & 2.08 & 3.28 & 4.37 & 3.93 & 7.01 \\
\hline kolblei & Eurytoop (Bentisch) & 85.99 & 4.25 & 4.47 & 7.34 & 2.92 & 2.42 \\
\hline riviergrondel & Rheofiel (Bentisch) & 89.2 & 7.94 & 5.66 & 5.93 & 0.03 & 0.07 \\
\hline witvinriviergrondel* & Eurytoop (Bentisch) & 91.61 & - & - & 8.57 & 2.68 & 0.99 \\
\hline baars & Eurytoop (Pelagisch) & 93.94 & 0.28 & 1.06 & 2.8 & 1.32 & 5.3 \\
\hline kesslers grondel* & Eurytoop (Bentisch) & 95.81 & - & - & 3.31 & 4.49 & 0.5 \\
\hline pos & Eurytoop (Bentisch) & 97.14 & 0.62 & 1.64 & 3.96 & 0.69 & 0.42 \\
\hline winde & Rheofiel (Pelagisch) & 98.41 & 0.34 & 1.65 & 0.99 & 0.72 & 2.4 \\
\hline donaubrasem* & Eurytoop (Bentisch) & 98.87 & - & - & 0.71 & 1.03 & 0.28 \\
\hline alver & Eurytoop (Pelagisch) & 99.31 & - & 0.06 & 0.11 & 0.07 & 1.6 \\
\hline karper & Eurytoop (Bentisch) & 99.49 & - & 0.04 & 0.02 & 0.03 & 0.69 \\
\hline roofblei* & Rheofiel (Pelagisch) & 99.64 & 0.02 & 0.15 & 0.04 & 0.18 & 0.27 \\
\hline aal & Eurytoop (Bentisch) & 99.74 & 0.12 & 0.09 & 0.06 & 0.06 & 0.17 \\
\hline hybride cyprinide & Eurytoop (Bentisch) & 99.81 & 0.16 & 0.14 & 0.04 & 0.05 & \\
\hline marmergrondel* & Eurytoop (Bentisch) & 99.86 & - & 0.04 & 0.14 & - & 0.07 \\
\hline snoek & Eurytoop (Pelagisch) & 99.89 & - & 0.04 & 0.06 & 0.01 & 0.05 \\
\hline rivierprik & Rheofiel (Bentisch) & 99.92 & 0.02 & 0.02 & 0.08 & 0.01 & 0.01 \\
\hline blauwneus* & Eurytoop (Bentisch) & 99.94 & - & - & - & 0.01 & 0.07 \\
\hline spiering & Eurytoop (Pelagisch) & 99.96 & 0.04 & 0.05 & 0.02 & - & \\
\hline rivierdonderpad & Rheofiel (Bentisch) & 99.97 & 0.02 & 0.04 & - & - & \\
\hline rietvoorn & Limnofiel (Pelagisch) & 99.97 & - & - & 0.02 & - & 0.01 \\
\hline serpeling & Rheofiel (Pelagisch) & 99.98 & - & - & 0.02 & - & \\
\hline barbeel & Rheofiel (Bentisch) & 99.98 & - & - & - & 0.01 & \\
\hline sneep & Rheofiel (Bentisch) & 99.98 & - & 0.02 & - & - & \\
\hline giebel & Eurytoop (Bentisch) & 99.99 & - & - & - & - & 0.01 \\
\hline elft/fint & Rheofiel (Pelagisch) & 99.99 & - & - & - & 0.01 & \\
\hline zeelt & Limnofiel (Bentisch) & 99.99 & - & - & 0.02 & - & \\
\hline kleine modderkruiper & Eurytoop (Bentisch) & 100 & - & - & - & - & 0.01 \\
\hline steur sp. & Overige & 100 & 0.02 & - & - & - & \\
\hline
\end{tabular}


Tabel 2. Soortensamenstelling in percentages op basis van biomassa in boomkorvangsten in de hoofdstroom van de Nieuwe Merwede per 5-jarige periode. De groepering geeft de ecologische indeling aan de hand van Noble et al. (2007) aan. Het cumulatief percentage geeft aan hoeveel de soorten over de gehele periode voorkomen op basis van de gesommeerde CPUE op basis van de biomassa. Nulpercentages zijn naar beneden afgeronde waarden, $*$ = exoot.

\begin{tabular}{|c|c|c|c|c|c|c|c|}
\hline Soort & Groepering & $\begin{array}{l}\text { Cumulatief } \\
\text { percentage }\end{array}$ & $\begin{array}{r}1997- \\
1999 \\
\end{array}$ & $\begin{array}{r}2000- \\
2004 \\
\end{array}$ & $\begin{array}{r}2005- \\
2009\end{array}$ & $\begin{array}{r}2010- \\
2014 \\
\end{array}$ & $\begin{array}{r}2015- \\
2019 \\
\end{array}$ \\
\hline brasem & Eurytoop (Bentisch) & 53.55 & 70.09 & 64.64 & 46.33 & 40.82 & 31.61 \\
\hline blankvoorn & Eurytoop (Pelagisch) & 68.47 & 8.7 & 8.39 & 26.05 & 16.24 & 21.97 \\
\hline snoekbaars & Eurytoop (Bentisch) & 82.71 & 6.47 & 11.27 & 14.3 & 20.2 & 24.71 \\
\hline kolblei & Eurytoop (Bentisch) & 90.91 & 12.41 & 11.67 & 4 & 5.23 & 4.09 \\
\hline winde & Rheofiel (Pelagisch) & 92.5 & 0.53 & 1.27 & 2.15 & 2.17 & 2.54 \\
\hline baars & Eurytoop (Pelagisch) & 93.93 & 0.14 & 0.63 & 2.32 & 1.98 & 3.28 \\
\hline zwartbekgrondel* & Eurytoop (Bentisch) & 95.02 & - & - & 0.15 & 4.52 & 1 \\
\hline bot & Limnofiel (Bentisch) & 95.78 & 0.21 & 0.86 & 0.94 & 1.21 & 0.6 \\
\hline pontische stroomgrondel* & Eurytoop (Bentisch) & 96.51 & - & - & 0.01 & 2.25 & 2.02 \\
\hline kesslers grondel* & Eurytoop (Bentisch) & 97.09 & - & - & 0.86 & 1.85 & 0.38 \\
\hline karper & Eurytoop (Bentisch) & 97.67 & - & 0.06 & 0 & 0 & 4.29 \\
\hline aal & Eurytoop (Bentisch) & 98.08 & 0.2 & 0.18 & 0.18 & 0.49 & 1.45 \\
\hline hybride cyprinide & Eurytoop (Bentisch) & 98.45 & 0.59 & 0.38 & 0.24 & 0.45 & - \\
\hline donaubrasem* & Eurytoop (Bentisch) & 98.8 & - & - & 0.36 & 1.24 & 0.24 \\
\hline snoek & Eurytoop (Pelagisch) & 99.03 & - & 0.11 & 0.27 & 0.37 & 0.64 \\
\hline pos & Eurytoop (Bentisch) & 99.24 & 0.07 & 0.16 & 0.51 & 0.2 & 0.18 \\
\hline witvinriviergrondel* & Eurytoop (Bentisch) & 99.45 & - & - & 0.76 & 0.29 & 0.14 \\
\hline riviergrondel & Rheofiel (Bentisch) & 99.64 & 0.33 & 0.26 & 0.25 & 0 & 0.01 \\
\hline roofblei* & Rheofiel (Pelagisch) & 99.83 & 0.06 & 0.09 & 0 & 0.44 & 0.44 \\
\hline steur sp. & Overige & 99.87 & 0.2 & - & - & - & \\
\hline alver & Eurytoop (Pelagisch) & 99.91 & - & 0.01 & 0.02 & 0.01 & 0.19 \\
\hline zeelt & Limnofiel (Bentisch) & 99.93 & - & - & 0.16 & - & \\
\hline rivierprik & Rheofiel (Bentisch) & 99.96 & 0 & 0.01 & 0.07 & 0.02 & 0.03 \\
\hline blauwneus* & Eurytoop (Bentisch) & 99.98 & - & - & - & 0.01 & 0.14 \\
\hline rietvoorn & Limnofiel (Pelagisch) & 99.98 & - & - & 0.04 & - & 0.02 \\
\hline giebel & Eurytoop (Bentisch) & 99.99 & - & - & - & - & 0.06 \\
\hline sneep & Rheofiel (Bentisch) & 100 & - & 0.01 & - & - & \\
\hline spiering & Eurytoop (Pelagisch) & 100 & 0 & 0 & 0 & - & \\
\hline marmergrondel* & Eurytoop (Bentisch) & 100 & - & 0 & 0 & - & 0 \\
\hline serpeling & Rheofiel (Pelagisch) & 100 & - & - & 0.01 & - & \\
\hline rivierdonderpad & Rheofiel (Bentisch) & 100 & 0 & 0 & - & - & - \\
\hline barbeel & Rheofiel (Bentisch) & 100 & - & - & - & 0 & - \\
\hline elft/fint & Rheofiel (Pelagisch) & 100 & - & - & - & 0 & \\
\hline kleine modderkruiper & Eurytoop (Bentisch) & 100 & - & - & - & - & 0 \\
\hline
\end{tabular}


Tabel 3. Soortensamenstelling in percentages op basis van aantal in schepnetvangsten in de hoofdstroom van de Nieuwe Merwede per 5-jarige periode. De groepering geeft de ecologische indeling aan de hand van Noble et al. (2007) aan. Het cumulatief percentage geeft aan hoeveel de soorten over de gehele periode voorkomen op basis van de gesommeerde CPUE op basis van het aantal. Nulpercentages zijn naar beneden afgeronde waarden, $*=$ exoot.

\begin{tabular}{|c|c|c|c|c|c|c|c|}
\hline Soort & Groepering & $\begin{array}{l}\text { Cumulatief } \\
\text { percentage }\end{array}$ & $\begin{array}{r}1997- \\
1999\end{array}$ & $\begin{array}{r}2000- \\
2004\end{array}$ & $\begin{array}{r}2005- \\
2009\end{array}$ & $\begin{array}{r}2010- \\
2014\end{array}$ & $\begin{array}{r}2015- \\
2019\end{array}$ \\
\hline blankvoorn & Eurytoop (Pelagisch) & 44.09 & 65.94 & 38.57 & 35.58 & 54.21 & 41.71 \\
\hline baars & Eurytoop (Pelagisch) & 71.75 & 9.74 & 45.94 & 24.14 & 10.78 & 6.41 \\
\hline winde & Rheofiel (Pelagisch) & 78.79 & 7.19 & 3.83 & 10.18 & 9.04 & 11.86 \\
\hline zwartbekgrondel* & Eurytoop (Bentisch) & 83.93 & - & - & 0.97 & 12.53 & 16.38 \\
\hline alver & Eurytoop (Pelagisch) & 88.14 & 6.72 & 1.92 & 9.4 & 4.16 & 6.38 \\
\hline aal & Eurytoop (Bentisch) & 90.58 & 1.93 & 3.01 & 1.36 & 0.54 & 4.58 \\
\hline roofblei* & Rheofiel (Pelagisch) & 92.71 & 0.89 & 0.96 & 3.32 & 3.13 & 4.05 \\
\hline bot & Limnofiel (Bentisch) & 93.79 & 0.77 & 1.66 & 0.75 & 0.25 & 0.94 \\
\hline brasem & Eurytoop (Bentisch) & 94.85 & 3.48 & 0.52 & 3.2 & 0.46 & 0.8 \\
\hline snoekbaars & Eurytoop (Bentisch) & 95.53 & 0.42 & 0.78 & 0.73 & 0.24 & 1.06 \\
\hline sneep & Rheofiel (Bentisch) & 96.11 & 0.04 & 0.09 & 0.28 & 1.98 & 0.55 \\
\hline kesslers grondel* & Eurytoop (Bentisch) & 96.68 & - & - & 3.66 & 0.63 & 0.25 \\
\hline kolblei & Eurytoop (Bentisch) & 97.22 & - & 0.32 & 0.53 & 0.33 & 1.88 \\
\hline pos & Eurytoop (Bentisch) & 97.7 & 0.32 & 0.83 & 0.32 & 0.18 & \\
\hline kopvoorn & Rheofiel (Pelagisch) & 98.15 & 0.29 & 0.54 & 0.81 & 0.23 & 0.36 \\
\hline snoek & Eurytoop (Pelagisch) & 98.6 & 0.88 & 0.32 & 1.36 & 0.13 & 0.39 \\
\hline marmergrondel* & Eurytoop (Bentisch) & 98.91 & - & 0.09 & 1.62 & 0.13 & 0.44 \\
\hline pontische stroomgrondel* & Eurytoop (Bentisch) & 99.12 & - & - & 0.01 & 0.31 & 0.99 \\
\hline rietvoorn & Limnofiel (Pelagisch) & 99.32 & 0.52 & 0.11 & 0.82 & 0.03 & 0.09 \\
\hline zeelt & Limnofiel (Bentisch) & 99.47 & 0.16 & 0.16 & 0.12 & 0.08 & 0.24 \\
\hline driedoornige stekelbaars & Eurytoop (Pelagisch) & 99.56 & 0.08 & 0.04 & 0.08 & 0.13 & 0.25 \\
\hline vetje & Limnofiel (Pelagisch) & 99.64 & - & - & - & 0.26 & 0.15 \\
\hline barbeel & Rheofiel (Bentisch) & 99.71 & - & 0.09 & 0.2 & 0.01 & 0.03 \\
\hline karper & Eurytoop (Bentisch) & 99.76 & 0.11 & 0.04 & 0.02 & 0.02 & 0.15 \\
\hline serpeling & Rheofiel (Pelagisch) & 99.81 & 0.18 & 0.05 & 0.02 & 0.05 & \\
\hline rivierdonderpad & Rheofiel (Bentisch) & 99.86 & 0.12 & 0.07 & 0.03 & - & - \\
\hline kleine modderkruiper & Eurytoop (Bentisch) & 99.89 & - & 0.01 & 0.09 & 0.08 & 0.06 \\
\hline hybride cyprinide & Eurytoop (Bentisch) & 99.93 & 0.04 & 0.02 & 0.18 & - & - \\
\hline bittervoorn & Limnofiel (Pelagisch) & 99.96 & - & 0.01 & 0.21 & 0.03 & - \\
\hline riviergrondel & Rheofiel (Bentisch) & 99.97 & 0.11 & 0.01 & - & - & - \\
\hline dunlipharder & Marien (Pelagisch) & 99.98 & - & - & - & 0.05 & \\
\hline rivierprik & Rheofiel (Bentisch) & 99.99 & - & 0.01 & - & - & 0.03 \\
\hline giebel & Eurytoop (Bentisch) & 99.99 & 0.04 & - & - & - & \\
\hline tiendoornige stekelbaars & Limnofiel (Pelagisch) & 100 & 0.04 & - & - & - & - \\
\hline harders indet. & Marien (Pelagisch) & 100 & - & - & - & 0.01 & - \\
\hline prik sp. & Rheofiel (Bentisch) & 100 & - & - & 0.01 & - & - \\
\hline
\end{tabular}


Tabel 4. Soortensamenstelling in percentages op basis van biomassa in schepnetvangsten in de hoofdstroom van de Nieuwe Merwede per 5-jarige periode. De groepering geeft de ecologische indeling aan de hand van Noble et al. (2007) aan. Het cumulatief percentage geeft aan hoeveel de soorten over de gehele periode voorkomen op basis van de gesommeerde CPUE op basis van de biomassa. Nulpercentages zijn naar beneden afgeronde waarden, $*$ exoot.

\begin{tabular}{|c|c|c|c|c|c|c|c|}
\hline Soort & Groepering & $\begin{array}{l}\text { Cumulatief } \\
\text { percentage }\end{array}$ & $\begin{array}{r}1997- \\
1999 \\
\end{array}$ & $\begin{array}{r}2000- \\
2004 \\
\end{array}$ & $\begin{array}{r}2005- \\
2009 \\
\end{array}$ & $\begin{array}{r}2010- \\
2014 \\
\end{array}$ & $\begin{array}{r}2015- \\
2019 \\
\end{array}$ \\
\hline winde & Rheofiel (Pelagisch) & 20.97 & 23.32 & 17.77 & 30.61 & 29.74 & 13.89 \\
\hline aal & Eurytoop (Bentisch) & 40.77 & 4.71 & 15.04 & 12.75 & 10.08 & 47.83 \\
\hline baars & Eurytoop (Pelagisch) & 54.31 & 5.32 & 25.02 & 6.41 & 5.84 & 5.63 \\
\hline snoek & Eurytoop (Pelagisch) & 65.78 & 31.55 & 5.98 & 16.41 & 5.56 & 12.54 \\
\hline blankvoorn & Eurytoop (Pelagisch) & 75.49 & 9.59 & 11.41 & 4.66 & 14.87 & 6 \\
\hline karper & Eurytoop (Bentisch) & 81.6 & 12.02 & 10.27 & 4.06 & 0.05 & 0.54 \\
\hline brasem & Eurytoop (Bentisch) & 85.79 & 6.62 & 2.49 & 7.66 & 2.67 & 5.17 \\
\hline snoekbaars & Eurytoop (Bentisch) & 88.68 & 1.99 & 1.89 & 2.38 & 8.94 & 1.31 \\
\hline kopvoorn & Rheofiel (Pelagisch) & 91.44 & 1.29 & 2.55 & 7.28 & 3.14 & 0.95 \\
\hline zeelt & Limnofiel (Bentisch) & 93.14 & 0.81 & 2.45 & 1.97 & 1.11 & 0.96 \\
\hline zwartbekgrondel* & Eurytoop (Bentisch) & 94.48 & - & - & 0.29 & 5 & 2.7 \\
\hline dunlipharder & Marien (Pelagisch) & 95.44 & - & - & - & 6.45 & - \\
\hline kolblei & Eurytoop (Bentisch) & 96.28 & - & 1.96 & 0.03 & 0.06 & 0.19 \\
\hline rietvoorn & Limnofiel (Pelagisch) & 97.03 & 1.58 & 1.29 & 0.43 & 0.05 & 0 \\
\hline bot & Limnofiel (Bentisch) & 97.78 & 0.33 & 0.7 & 0.35 & 1.91 & 0.49 \\
\hline roofblei* & Rheofiel (Pelagisch) & 98.41 & 0.26 & 0.32 & 0.73 & 1.23 & 0.91 \\
\hline kesslers grondel* & Eurytoop (Bentisch) & 99 & - & - & 3.28 & 0.9 & 0.21 \\
\hline alver & Eurytoop (Pelagisch) & 99.37 & 0.43 & 0.17 & 0.43 & 0.68 & 0.47 \\
\hline pos & Eurytoop (Bentisch) & 99.57 & 0.08 & 0.4 & 0.07 & 0.07 & - \\
\hline sneep & Rheofiel (Bentisch) & 99.7 & 0.01 & 0.03 & 0.03 & 0.67 & 0.08 \\
\hline harders indet. & Marien (Pelagisch) & 99.82 & - & - & - & 0.84 & - \\
\hline barbeel & Rheofiel (Bentisch) & 99.88 & - & 0.14 & 0.03 & 0.01 & 0 \\
\hline pontische stroomgrondel* & Eurytoop (Bentisch) & 99.91 & - & - & 0 & 0.07 & 0.09 \\
\hline hybride cyprinide & Eurytoop (Bentisch) & 99.94 & 0 & 0.07 & 0 & - & \\
\hline marmergrondel* & Eurytoop (Bentisch) & 99.96 & - & 0.01 & 0.11 & 0.01 & 0.01 \\
\hline serpeling & Rheofiel (Pelagisch) & 99.98 & 0.03 & 0.02 & 0 & 0.02 & \\
\hline kleine modderkruiper & Eurytoop (Bentisch) & 99.99 & - & 0 & 0.01 & 0.01 & 0.01 \\
\hline rivierdonderpad & Rheofiel (Bentisch) & 99.99 & 0.01 & 0.01 & 0.01 & - & \\
\hline driedoornige stekelbaars & Eurytoop (Pelagisch) & 99.99 & 0 & 0 & 0 & 0.01 & 0.01 \\
\hline $\begin{array}{l}\text { riviergrondel } \\
\end{array}$ & Rheofiel (Bentisch) & 100 & 0.02 & 0 & - & - & - \\
\hline vetje & Limnofiel (Pelagisch) & 100 & - & - & - & 0.01 & 0 \\
\hline rivierprik & Rheofiel (Bentisch) & 100 & - & 0 & - & - & $\underline{0}$ \\
\hline giebel & Eurytoop (Bentisch) & 100 & 0.01 & - & - & - & \\
\hline bittervoorn & Limnofiel (Pelagisch) & 100 & - & 0 & 0 & 0 & - \\
\hline prik sp. & Rheofiel (Bentisch) & 100 & - & - & 0 & - & - \\
\hline tiendoornige stekelbaars & Limnofiel (Pelagisch) & 100 & 0 & - & - & - & - \\
\hline
\end{tabular}




\section{Bijlage 37 Nieuwe Merwede zijwateren}

Tabel 1. Soortensamenstelling in percentages op basis van aantal in boomkorvangsten in de zijwateren van de Nieuwe Merwede per 5-jarige periode. De groepering geeft de ecologische indeling aan de hand van Noble et al. (2007) aan. Het cumulatief percentage geeft aan hoeveel de soorten over de gehele periode voorkomen op basis van de gesommeerde CPUE op basis van het aantal. Nul-percentages zijn naar beneden afgeronde waarden, $*$ exoot.

\begin{tabular}{|c|c|c|c|c|c|}
\hline Soort & Groepering & $\begin{array}{l}\text { Cumulatief } \\
\text { percentage }\end{array}$ & $\begin{array}{r}2005- \\
2009\end{array}$ & $\begin{array}{r}2010- \\
2014\end{array}$ & $\begin{array}{r}2015- \\
2019\end{array}$ \\
\hline blankvoorn & Eurytoop (Pelagisch) & 42.62 & 26.67 & 16.13 & 55.23 \\
\hline brasem & Eurytoop (Bentisch) & 74.62 & 25.05 & 64.89 & 20.99 \\
\hline baars & Eurytoop (Pelagisch) & 90.15 & 32.95 & 8.79 & 15 \\
\hline winde & Rheofiel (Pelagisch) & 92.71 & 2.15 & 0.42 & 3.42 \\
\hline pos & Eurytoop (Bentisch) & 94.38 & 9.28 & 2.21 & 0.15 \\
\hline roofblei* & Rheofiel (Pelagisch) & 95.77 & 0.26 & 0.08 & 2.07 \\
\hline zwartbekgrondel* & Eurytoop (Bentisch) & 97.08 & - & 2.11 & 1.24 \\
\hline pontische stroomgrondel* & Eurytoop (Bentisch) & 98.1 & 0.13 & 2.68 & 0.57 \\
\hline snoekbaars & Eurytoop (Bentisch) & 98.95 & 1.06 & 1.89 & 0.43 \\
\hline kolblei & Eurytoop (Bentisch) & 99.29 & 1.8 & 0.13 & 0.17 \\
\hline sneep & Rheofiel (Bentisch) & 99.56 & 0.22 & 0.06 & 0.35 \\
\hline marmergrondel* & Eurytoop (Bentisch) & 99.71 & - & 0.18 & 0.16 \\
\hline kesslers grondel* & Eurytoop (Bentisch) & 99.8 & - & 0.2 & 0.08 \\
\hline bot & Limnofiel (Bentisch) & 99.9 & 0.13 & 0.18 & 0.06 \\
\hline snoek & Eurytoop (Pelagisch) & 99.93 & 0.13 & - & 0.03 \\
\hline zeelt & Limnofiel (Bentisch) & 99.96 & 0.06 & - & 0.03 \\
\hline alver & Eurytoop (Pelagisch) & 99.98 & - & 0.03 & 0.02 \\
\hline serpeling & Rheofiel (Pelagisch) & 99.99 & 0.13 & - & \\
\hline hybride cyprinide & Eurytoop (Bentisch) & 100 & - & 0.03 & - \\
\hline
\end{tabular}

Tabel 2. Soortensamenstelling in percentages op basis van biomassa in boomkorvangsten in de zijwateren van de Nieuwe Merwede per 5-jarige periode. De groepering geeft de ecologische indeling aan de hand van Noble et al. (2007) aan. Het cumulatief percentage geeft aan hoeveel de soorten over de gehele periode voorkomen op basis van de gesommeerde CPUE op basis van de biomassa. Nulpercentages zijn naar beneden afgeronde waarden, * = exoot.

\begin{tabular}{|c|c|c|c|c|c|}
\hline Soort & Groepering & $\begin{array}{l}\text { Cumulatief } \\
\text { percentage }\end{array}$ & $\begin{array}{r}2005- \\
2009 \\
\end{array}$ & $\begin{array}{r}2010- \\
2014 \\
\end{array}$ & $\begin{array}{r}2015- \\
2019 \\
\end{array}$ \\
\hline blankvoorn & Eurytoop (Pelagisch) & 41.19 & 18.32 & 24.67 & 51.22 \\
\hline brasem & Eurytoop (Bentisch) & 63.51 & 14.28 & 46.6 & 14.7 \\
\hline baars & Eurytoop (Pelagisch) & 84.08 & 43.44 & 14.23 & 19 \\
\hline winde & Rheofiel (Pelagisch) & 87.11 & 2.2 & 0.66 & 4.06 \\
\hline snoekbaars & Eurytoop (Bentisch) & 89.64 & 2.03 & 5.53 & 1.49 \\
\hline snoek & Eurytoop (Pelagisch) & 91.97 & 4.39 & - & 2.85 \\
\hline roofblei* & Rheofiel (Pelagisch) & 93.96 & 0.21 & 0.13 & 2.98 \\
\hline zeelt & Limnofiel (Bentisch) & 95.28 & 7.08 & - & 0.82 \\
\hline pos & Eurytoop (Bentisch) & 96.58 & 5.66 & 2.3 & 0.19 \\
\hline zwartbekgrondel* & Eurytoop (Bentisch) & 97.73 & - & 1.66 & 1.15 \\
\hline pontische stroomgrondel* & Eurytoop (Bentisch) & 98.59 & 0.03 & 2.55 & 0.37 \\
\hline kolblei & Eurytoop (Bentisch) & 99.23 & 1.9 & 0.84 & 0.35 \\
\hline sneep & Rheofiel (Bentisch) & 99.59 & 0.26 & 0.06 & 0.49 \\
\hline kesslers grondel* & Eurytoop (Bentisch) & 99.83 & - & 0.39 & 0.23 \\
\hline hybride cyprinide & Eurytoop (Bentisch) & 99.88 & - & 0.21 & \\
\hline bot & Limnofiel (Bentisch) & 99.93 & 0.07 & 0.07 & 0.03 \\
\hline alver & Eurytoop (Pelagisch) & 99.96 & - & 0.06 & 0.02 \\
\hline marmergrondel* & Eurytoop (Bentisch) & 99.99 & - & 0.02 & 0.03 \\
\hline serpeling & Rheofiel (Pelagisch) & 100 & 0.13 & - & \\
\hline
\end{tabular}




\section{Bijlage 38 Hollandse IJssel hoofdstroom}

Tabel 1. Soortensamenstelling in percentages op basis van aantal in boomkorvangsten in de hoofdstroom van de Hollandse IJssel per 5-jarige periode. De groepering geeft de ecologische indeling aan de hand van Noble et al. (2007) aan. Het cumulatief percentage geeft aan hoeveel de soorten over de gehele periode voorkomen op basis van de gesommeerde CPUE op basis van het aantal. Nul-percentages zijn naar beneden afgeronde waarden, $*$ exoot.

\begin{tabular}{rrrr}
\hline Soort & Groepering & $\begin{array}{r}\text { Cumulatief } \\
\text { percentage }\end{array}$ & $\begin{array}{r}2015- \\
2019\end{array}$ \\
brasem & Eurytoop (Bentisch) & 30.12 & 30.12 \\
\hline bot & Limnofiel (Bentisch) & 45.48 & 15.36 \\
\hline zwartbekgrondel* & Eurytoop (Bentisch) & 60 & 14.53 \\
\hline kolblei & Eurytoop (Bentisch) & 72.9 & 12.9 \\
\hline snoekbaars & Eurytoop (Bentisch) & 85.28 & 12.38 \\
\hline aal & Eurytoop (Bentisch) & 91.86 & 6.59 \\
\hline pos & Eurytoop (Bentisch) & 94.67 & 2.81 \\
\hline blankvoorn & Eurytoop (Pelagisch) & 96.7 & 2.03 \\
\hline baars & Eurytoop (Pelagisch) & 97.89 & 1.19 \\
\hline haring/sprot & Marien (Pelagisch) & 98.54 & 0.64 \\
\hline alver & Eurytoop (Pelagisch) & 98.98 & 0.44 \\
\hline spiering & Eurytoop (Pelagisch) & 99.35 & 0.37 \\
\hline grondel sp. & Marien (Bentisch) & 99.63 & 0.28 \\
\hline driedoornige stekelbaars & Eurytoop (Pelagisch) & 99.82 & 0.19 \\
\hline winde & Rheofiel (Pelagisch) & 99.91 & 0.09 \\
\hline witvinriviergrondel* & Eurytoop (Bentisch) & 100 & 0.09 \\
\hline
\end{tabular}

Tabel 2. Soortensamenstelling in percentages op basis van biomassa in boomkorvangsten in de hoofdstroom van de Hollandse IJssel per 5-jarige periode. De groepering geeft de ecologische indeling aan de hand van Noble et al. (2007) aan. Het cumulatief percentage geeft aan hoeveel de soorten over de gehele periode voorkomen op basis van de gesommeerde CPUE op basis van de biomassa. Nulpercentages zijn naar beneden afgeronde waarden, $*=$ exoot.

\begin{tabular}{|c|c|c|c|}
\hline Soort & Groepering & $\begin{array}{l}\text { Cumulatief } \\
\text { percentage }\end{array}$ & $\begin{array}{r}2015- \\
2019 \\
\end{array}$ \\
\hline brasem & Eurytoop (Bentisch) & 63.36 & 63.36 \\
\hline snoekbaars & Eurytoop (Bentisch) & 75.88 & 12.52 \\
\hline kolblei & Eurytoop (Bentisch) & 86.08 & 10.2 \\
\hline aal & Eurytoop (Bentisch) & 94.46 & 8.38 \\
\hline blankvoorn & Eurytoop (Pelagisch) & 97.59 & 3.13 \\
\hline baars & Eurytoop (Pelagisch) & 99.14 & 1.55 \\
\hline zwartbekgrondel* & Eurytoop (Bentisch) & 99.5 & 0.36 \\
\hline bot & Limnofiel (Bentisch) & 99.75 & 0.25 \\
\hline pos & Eurytoop (Bentisch) & 99.87 & 0.12 \\
\hline winde & Rheofiel (Pelagisch) & 99.97 & 0.1 \\
\hline haring/sprot & Marien (Pelagisch) & 99.98 & 0.01 \\
\hline alver & Eurytoop (Pelagisch) & 99.99 & 0.01 \\
\hline spiering & Eurytoop (Pelagisch) & 100 & 0.01 \\
\hline grondel sp. & Marien (Bentisch) & 100 & 0 \\
\hline witvinriviergrondel* & Eurytoop (Bentisch) & 100 & 0 \\
\hline driedoornige stekelbaars & Eurytoop (Pelagisch) & 100 & 0 \\
\hline
\end{tabular}


Tabel 3. Soortensamenstelling in percentages op basis van aantal in schepnetvangsten in de hoofdstroom van de Hollandse IJssel per 5-jarige periode. De groepering geeft de ecologische indeling aan de hand van Noble et al. (2007) aan. Het cumulatief percentage geeft aan hoeveel de soorten over de gehele periode voorkomen op basis van de gesommeerde CPUE op basis van het aantal. Nulpercentages zijn naar beneden afgeronde waarden, * = exoot.

\begin{tabular}{rrrr}
\hline & Groepering & $\begin{array}{r}\text { Cumulatief } \\
\text { percentage }\end{array}$ & $\begin{array}{r}2015- \\
2019\end{array}$ \\
\hline Soort & & 21.54 & 21.54 \\
\hline aal & Eurytoop (Bentisch) & 41.25 & 19.71 \\
\hline zwartbekgrondel* & Eurytoop (Bentisch) & 58.09 & 16.85 \\
\hline winde & Rheofiel (Pelagisch) & 69.16 & 11.07 \\
\hline alver & Eurytoop (Pelagisch) & 79.05 & 9.89 \\
\hline rietvoorn & Limnofiel (Pelagisch) & 86.22 & 7.17 \\
\hline driedoornige stekelbaars & Eurytoop (Pelagisch) & 90.91 & 4.69 \\
\hline blankvoorn & Eurytoop (Pelagisch) & 93.57 & 2.66 \\
\hline brasem & Eurytoop (Bentisch) & 95.76 & 2.19 \\
\hline baars & Eurytoop (Pelagisch) & 97.76 & 2 \\
\hline roofblei* & Rheofiel (Pelagisch) & 97 & 0.7 \\
\hline bittervoorn & Limnofiel (Pelagisch) & 98.46 & 0.4 \\
\hline bot & Limnofiel (Bentisch) & 98.86 & 0.32 \\
\hline sneep & Rheofiel (Bentisch) & 99.18 & 0.3 \\
\hline snoek & Eurytoop (Pelagisch) & 99.4 & 0.22 \\
\hline kolblei & Eurytoop (Bentisch) & 99.59 & 0.19 \\
\hline kesslers grondel* & Eurytoop (Bentisch) & 99.74 & 0.14 \\
\hline marmergrondel* & Eurytoop (Bentisch) & 99.87 & 0.14 \\
\hline dunlipharder & Marien (Pelagisch) & 100 & 0.13 \\
\hline & & & \\
\hline
\end{tabular}

Tabel 4. Soortensamenstelling in percentages op basis van biomassa in schepnetvangsten in de hoofdstroom van de Hollandse IJssel per 5-jarige periode. De groepering geeft de ecologische indeling aan de hand van Noble et al. (2007) aan. Het cumulatief percentage geeft aan hoeveel de soorten over de gehele periode voorkomen op basis van de gesommeerde CPUE op basis van de biomassa. Nulpercentages zijn naar beneden afgeronde waarden, $*=$ exoot.

\begin{tabular}{rrrr} 
Soort & Groepering & $\begin{array}{r}\text { Cumulatief } \\
\text { percentage }\end{array}$ & $\begin{array}{r}2015- \\
2019\end{array}$ \\
aal & Eurytoop (Bentisch) & 84.96 & 84.96 \\
\hline snoek & Eurytoop (Pelagisch) & 91.45 & 6.49 \\
\hline brasem & Eurytoop (Bentisch) & 93.97 & 2.52 \\
\hline winde & Rheofiel (Pelagisch) & 95.97 & 2 \\
\hline zwartbekgrondel* & Eurytoop (Bentisch) & 97.89 & 1.92 \\
\hline blankvoorn & Eurytoop (Pelagisch) & 98.47 & 0.58 \\
\hline rietvoorn & Limnofiel (Pelagisch) & 99.03 & 0.56 \\
\hline baars & Eurytoop (Pelagisch) & 99.38 & 0.36 \\
\hline roofblei* & Rheofiel (Pelagisch) & 99.64 & 0.26 \\
\hline alver & Eurytoop (Pelagisch) & 99.82 & 0.17 \\
\hline driedoornige stekelbaars & Eurytoop (Pelagisch) & 99.88 & 0.07 \\
\hline kesslers grondel* & Eurytoop (Bentisch) & 99.94 & 0.06 \\
\hline sneep & Rheofiel (Bentisch) & 99.97 & 0.03 \\
\hline bot & Limnofiel (Bentisch) & 99.98 & 0.02 \\
\hline bittervoorn & Limnofiel (Pelagisch) & 99.99 & 0.01 \\
\hline kolblei & Eurytoop (Bentisch) & 100 & 0.01 \\
\hline marmergrondel* & Eurytoop (Bentisch) & 100 & 0 \\
\hline dunlipharder & Marien (Pelagisch) & 100 & 0 \\
\hline & & & 90
\end{tabular}




\section{Bijlage 39 Oude Maas hoofdstroom}

Tabel 1. Soortensamenstelling in percentages op basis van aantal in boomkorvangsten in de hoofdstroom van de Oude Maas per 5-jarige periode. De groepering geeft de ecologische indeling aan de hand van Noble et al. (2007) aan. Het cumulatief percentage geeft aan hoeveel de soorten over de gehele periode voorkomen op basis van de gesommeerde CPUE op basis van het aantal. Nul-percentages zijn naar beneden afgeronde waarden, $*$ =xoot.

\begin{tabular}{|c|c|c|c|c|c|c|c|}
\hline Soort & Groepering & $\begin{array}{l}\text { Cumulatief } \\
\text { percentage }\end{array}$ & $\begin{array}{r}1997- \\
1999\end{array}$ & $\begin{array}{r}2000- \\
2004\end{array}$ & $\begin{array}{r}2005- \\
2009\end{array}$ & $\begin{array}{r}2010- \\
2014\end{array}$ & $\begin{array}{r}2015- \\
2019 \\
\end{array}$ \\
\hline kolblei & Eurytoop (Bentisch) & 19.43 & 8.94 & 12.36 & 13.12 & 22.67 & 33.43 \\
\hline bot & Limnofiel (Bentisch) & 36.33 & 41.4 & 33.44 & 10.21 & 4.33 & 10.94 \\
\hline aal & Eurytoop (Bentisch) & 50.92 & 7.13 & 14.22 & 13.9 & 16.17 & 18.05 \\
\hline zwartbekgrondel* & Eurytoop (Bentisch) & 64.84 & - & - & 25.21 & 29.42 & 4.23 \\
\hline brasem & Eurytoop (Bentisch) & 78.49 & 25.43 & 20.72 & 13.29 & 7.47 & 8.76 \\
\hline snoekbaars & Eurytoop (Bentisch) & 86.25 & 8.33 & 9.5 & 9.26 & 6.11 & 6.39 \\
\hline blankvoorn & Eurytoop (Pelagisch) & 89.11 & 2.68 & 1.37 & 5.16 & 1.06 & 3.74 \\
\hline witvinriviergrondel* & Eurytoop (Bentisch) & 91.61 & - & - & 3.33 & 3.3 & 4.09 \\
\hline $\begin{array}{ll}\text { riviergrondel } \\
\end{array}$ & Rheofiel (Bentisch) & 93.68 & 3.86 & 4.11 & 2.44 & 0.7 & 0.61 \\
\hline pontische stroomgrondel* & Eurytoop (Bentisch) & 95.07 & - & - & 0.07 & 4.32 & 1.4 \\
\hline winde & Rheofiel (Pelagisch) & 96.27 & 0.61 & 1.03 & 1.58 & 1.74 & 0.71 \\
\hline baars & Eurytoop (Pelagisch) & 97.25 & 0.35 & 0.59 & 0.74 & 1.22 & 1.6 \\
\hline alver & Eurytoop (Pelagisch) & 98.15 & 0.26 & - & - & 0.13 & 3.62 \\
\hline rivierprik & Rheofiel (Bentisch) & 98.56 & 0.5 & 1.49 & 0.26 & 0.14 & - \\
\hline pos & Eurytoop (Bentisch) & 98.95 & - & 0.31 & 0.78 & 0.21 & 0.48 \\
\hline donaubrasem* & Eurytoop (Bentisch) & 99.11 & - & - & 0.07 & 0.15 & 0.46 \\
\hline barbeel & Rheofiel (Bentisch) & 99.26 & 0.14 & 0.37 & 0.22 & 0.08 & \\
\hline hybride cyprinide & Eurytoop (Bentisch) & 99.4 & - & 0.3 & 0.1 & 0.07 & 0.23 \\
\hline driedoornige stekelbaars & Eurytoop (Pelagisch) & 99.49 & 0.13 & - & - & - & 0.33 \\
\hline kesslers grondel* & Eurytoop (Bentisch) & 99.56 & - & - & - & 0.2 & 0.07 \\
\hline harders indet. & Marien (Pelagisch) & 99.62 & - & - & - & 0.07 & 0.21 \\
\hline roofblei* & Rheofiel (Pelagisch) & 99.69 & 0.12 & - & - & 0.07 & 0.14 \\
\hline snoek & Eurytoop (Pelagisch) & 99.74 & - & - & - & 0.22 & - \\
\hline grondel sp. & Marien (Bentisch) & 99.8 & - & - & - & - & 0.23 \\
\hline spiering & Eurytoop (Pelagisch) & 99.84 & - & 0.18 & 0.08 & - & - \\
\hline karper & Eurytoop (Bentisch) & 99.89 & - & - & - & - & 0.19 \\
\hline zeebaars & Marien (Pelagisch) & 99.92 & - & - & - & 0.14 & - \\
\hline rivierdonderpad & Rheofiel (Bentisch) & 99.95 & - & - & 0.1 & - & - \\
\hline noordzeehouting & Limnofiel (Pelagisch) & 99.97 & - & - & 0.09 & - & - \\
\hline rietvoorn & Limnofiel (Pelagisch) & 99.98 & 0.13 & - & - & - & - \\
\hline haring/sprot & Marien (Pelagisch) & 100 & - & - & - & - & 0.07 \\
\hline
\end{tabular}


Tabel 2. Soortensamenstelling in percentages op basis van biomassa in boomkorvangsten in de hoofdstroom van de Oude Maas per 5-jarige periode. De groepering geeft de ecologische indeling aan de hand van Noble et al. (2007) aan. Het cumulatief percentage geeft aan hoeveel de soorten over de gehele periode voorkomen op basis van de gesommeerde CPUE op basis van de biomassa. Nulpercentages zijn naar beneden afgeronde waarden, $*=$ exoot.

\begin{tabular}{|c|c|c|c|c|c|c|c|}
\hline Soort & Groepering & $\begin{array}{l}\text { Cumulatief } \\
\text { percentage }\end{array}$ & $\begin{array}{r}1997- \\
1999 \\
\end{array}$ & $\begin{array}{r}2000- \\
2004 \\
\end{array}$ & $\begin{array}{r}2005- \\
2009 \\
\end{array}$ & $\begin{array}{r}2010- \\
2014 \\
\end{array}$ & $\begin{array}{r}2015- \\
2019 \\
\end{array}$ \\
\hline kolblei & Eurytoop (Bentisch) & 32.34 & 15.71 & 24.38 & 14.95 & 37.72 & 55.77 \\
\hline brasem & Eurytoop (Bentisch) & 63.7 & 67.08 & 42.43 & 23.98 & 23.24 & 16.94 \\
\hline aal & Eurytoop (Bentisch) & 79.78 & 4.14 & 13.03 & 18.13 & 21.16 & 18.71 \\
\hline snoekbaars & Eurytoop (Bentisch) & 92.5 & 7.08 & 15.48 & 26.15 & 11.43 & 4.64 \\
\hline blankvoorn & Eurytoop (Pelagisch) & 96.24 & 3.3 & 1.76 & 11.11 & 1.5 & 1.52 \\
\hline winde & Rheofiel (Pelagisch) & 97.38 & 0.74 & 0.47 & 2.76 & 1.5 & 0.26 \\
\hline bot & Limnofiel (Bentisch) & 97.98 & 1.17 & 0.99 & 0.5 & 0.21 & 0.43 \\
\hline baars & Eurytoop (Pelagisch) & 98.46 & 0.25 & 0.43 & 0.77 & 0.06 & 0.8 \\
\hline zwartbekgrondel* & Eurytoop (Bentisch) & 98.84 & - & - & 0.8 & 0.85 & 0.11 \\
\hline barbeel & Rheofiel (Bentisch) & 99.19 & 0.01 & 0.15 & 0.38 & 1.11 & \\
\hline rivierprik & Rheofiel (Bentisch) & 99.36 & 0.19 & 0.6 & 0.12 & 0.06 & \\
\hline snoek & Eurytoop (Pelagisch) & 99.47 & - & - & - & 0.5 & \\
\hline donaubrasem* & Eurytoop (Bentisch) & 99.57 & - & - & 0.01 & 0.26 & 0.17 \\
\hline witvinriviergrondel* & Eurytoop (Bentisch) & 99.66 & - & - & 0.13 & 0.12 & 0.13 \\
\hline karper & Eurytoop (Bentisch) & 99.73 & - & - & - & - & 0.26 \\
\hline hybride cyprinide & Eurytoop (Bentisch) & 99.78 & - & 0.14 & 0.09 & 0 & 0.05 \\
\hline riviergrondel & Rheofiel (Bentisch) & 99.84 & 0.1 & 0.11 & 0.06 & 0.02 & 0.01 \\
\hline pontische stroomgrondel* & Eurytoop (Bentisch) & 99.89 & - & - & 0 & 0.14 & 0.07 \\
\hline roofblei* & Rheofiel (Pelagisch) & 99.93 & 0.11 & - & - & 0.06 & 0.07 \\
\hline pos & Eurytoop (Bentisch) & 99.95 & - & 0.02 & 0.03 & 0.01 & 0.02 \\
\hline rietvoorn & Limnofiel (Pelagisch) & 99.97 & 0.11 & - & - & - & \\
\hline kesslers grondel* & Eurytoop (Bentisch) & 99.98 & - & - & - & 0.05 & 0.01 \\
\hline alver & Eurytoop (Pelagisch) & 99.99 & 0.01 & - & - & 0.01 & 0.03 \\
\hline noordzeehouting & Limnofiel (Pelagisch) & 100 & - & - & 0.03 & - & \\
\hline spiering & Eurytoop (Pelagisch) & 100 & - & 0 & 0 & - & \\
\hline driedoornige stekelbaars & Eurytoop (Pelagisch) & 100 & 0 & - & - & - & 0 \\
\hline grondel sp. & Marien (Bentisch) & 100 & - & - & - & - & 0 \\
\hline haring/sprot & Marien (Pelagisch) & 100 & - & - & - & - & 0 \\
\hline rivierdonderpad & Rheofiel (Bentisch) & 100 & - & - & 0 & - & - \\
\hline harders indet. & Marien (Pelagisch) & 100 & - & - & - & 0 & 0 \\
\hline zeebaars & Marien (Pelagisch) & 100 & - & - & - & 0 & \\
\hline
\end{tabular}


Tabel 3. Soortensamenstelling in percentages op basis van aantal in schepnetvangsten in de hoofdstroom van de Oude Maas per 5-jarige periode. De groepering geeft de ecologische indeling aan de hand van Noble et al. (2007) aan. Het cumulatief percentage geeft aan hoeveel de soorten over de gehele periode voorkomen op basis van de gesommeerde CPUE op basis van het aantal. Nul-percentages zijn naar beneden afgeronde waarden, $*$ =xoot.

\begin{tabular}{|c|c|c|c|c|c|c|c|}
\hline Soort & Groepering & $\begin{array}{l}\text { Cumulatief } \\
\text { percentage }\end{array}$ & $\begin{array}{r}1997- \\
1999 \\
\end{array}$ & $\begin{array}{r}2000- \\
2004 \\
\end{array}$ & $\begin{array}{r}2005- \\
2009 \\
\end{array}$ & $\begin{array}{r}2010- \\
2014 \\
\end{array}$ & $\begin{array}{r}2015- \\
2019 \\
\end{array}$ \\
\hline alver & Eurytoop (Pelagisch) & 36.21 & 11.96 & 12.47 & 38.78 & 18.79 & 66.84 \\
\hline blankvoorn & Eurytoop (Pelagisch) & 52.17 & 15.71 & 39.72 & 9.37 & 11.53 & 2.66 \\
\hline winde & Rheofiel (Pelagisch) & 67.54 & 16.77 & 23.5 & 21.32 & 15.66 & 4.99 \\
\hline zwartbekgrondel* & Eurytoop (Bentisch) & 81.87 & - & - & 14.61 & 42.72 & 12.12 \\
\hline aal & Eurytoop (Bentisch) & 89.34 & 8.59 & 8.22 & 3.41 & 5.45 & 10.12 \\
\hline baars & Eurytoop (Pelagisch) & 92.61 & 13.89 & 5.22 & 4.78 & 1.36 & 0.55 \\
\hline brasem & Eurytoop (Bentisch) & 94.56 & 18.2 & 3.4 & 1.04 & 0.17 & 0.23 \\
\hline bot & Limnofiel (Bentisch) & 96.42 & 3.64 & 3.64 & 1.61 & 0.86 & 0.87 \\
\hline roofblei* & Rheofiel (Pelagisch) & 97.48 & 1.14 & 0.36 & 2.18 & 1.62 & 0.66 \\
\hline snoekbaars & Eurytoop (Bentisch) & 97.99 & 1.93 & 1.36 & 0.3 & 0.09 & \\
\hline vetje & Limnofiel (Pelagisch) & 98.25 & - & - & 1.04 & - & 0.19 \\
\hline sneep & Rheofiel (Bentisch) & 98.46 & - & 0.27 & 0.26 & 0.29 & 0.13 \\
\hline kolblei & Eurytoop (Bentisch) & 98.66 & 1.32 & 0.28 & 0.1 & 0.07 & 0.12 \\
\hline kesslers grondel* & Eurytoop (Bentisch) & 98.83 & - & - & 0.14 & 0.57 & 0.14 \\
\hline pos & Eurytoop (Bentisch) & 98.99 & 0.59 & 0.34 & 0.18 & 0.06 & \\
\hline snoek & Eurytoop (Pelagisch) & 99.14 & 1.58 & 0.15 & 0.17 & 0.04 & \\
\hline karper & Eurytoop (Bentisch) & 99.26 & 3.08 & - & - & - & \\
\hline pontische stroomgrondel* & Eurytoop (Bentisch) & 99.38 & - & - & - & 0.37 & 0.16 \\
\hline barbeel & Rheofiel (Bentisch) & 99.5 & 0.22 & 0.18 & 0.05 & 0.06 & 0.12 \\
\hline dunlipharder & Marien (Pelagisch) & 99.6 & - & - & 0.26 & 0.25 & 0.04 \\
\hline rietvoorn & Limnofiel (Pelagisch) & 99.69 & - & 0.22 & 0.05 & - & 0.06 \\
\hline driedoornige stekelbaars & Eurytoop (Pelagisch) & 99.76 & 0.35 & 0.19 & - & 0.05 & \\
\hline rivierdonderpad & Rheofiel (Bentisch) & 99.83 & 0.22 & 0.06 & 0.2 & - & \\
\hline zeebaars & Marien (Pelagisch) & 99.87 & - & 0.11 & 0.1 & - & \\
\hline kleine modderkruiper & Eurytoop (Bentisch) & 99.9 & - & 0.12 & - & - & \\
\hline kopvoorn & Rheofiel (Pelagisch) & 99.93 & - & 0.07 & 0.05 & - & \\
\hline serpeling & Rheofiel (Pelagisch) & 99.95 & - & 0.09 & - & - & \\
\hline zeelt & Limnofiel (Bentisch) & 99.97 & 0.44 & - & - & - & \\
\hline rivierprik & Rheofiel (Bentisch) & 99.99 & 0.35 & - & - & - & \\
\hline hybride cyprinide & Eurytoop (Bentisch) & 100 & - & 0.05 & - & - & \\
\hline
\end{tabular}


Tabel 4. Soortensamenstelling in percentages op basis van biomassa in schepnetvangsten in de hoofdstroom van de Oude Maas per 5-jarige periode. De groepering geeft de ecologische indeling aan de hand van Noble et al. (2007) aan. Het cumulatief percentage geeft aan hoeveel de soorten over de gehele periode voorkomen op basis van de gesommeerde CPUE op basis van de biomassa. Nulpercentages zijn naar beneden afgeronde waarden, $*$ exoot.

\begin{tabular}{|c|c|c|c|c|c|c|c|}
\hline Soort & Groepering & $\begin{array}{l}\text { Cumulatief } \\
\text { percentage }\end{array}$ & $\begin{array}{r}1997- \\
1999 \\
\end{array}$ & $\begin{array}{r}2000- \\
2004 \\
\end{array}$ & $\begin{array}{r}2005- \\
2009 \\
\end{array}$ & $\begin{array}{r}2010- \\
2014 \\
\end{array}$ & $\begin{array}{r}2015- \\
2019 \\
\end{array}$ \\
\hline winde & Rheofiel (Pelagisch) & 33.72 & 16.62 & 35.19 & 53.37 & 59.57 & 13.77 \\
\hline brasem & Eurytoop (Bentisch) & 55.28 & 25.4 & 35.28 & 17.45 & 1.47 & 4.78 \\
\hline aal & Eurytoop (Bentisch) & 72.21 & 2.33 & 15.37 & 7.32 & 18.5 & 68.97 \\
\hline karper & Eurytoop (Bentisch) & 83.58 & 40.22 & - & - & - & \\
\hline baars & Eurytoop (Pelagisch) & 87.48 & 2.92 & 3.6 & 7.27 & 5.22 & 0.82 \\
\hline snoek & Eurytoop (Pelagisch) & 90.65 & 7.15 & 1.52 & 2.41 & 2.16 & - \\
\hline dunlipharder & Marien (Pelagisch) & 93.11 & - & - & 8 & 6.91 & 2.06 \\
\hline snoekbaars & Eurytoop (Bentisch) & 94.58 & 1 & 3.82 & 0.14 & 0.01 & - \\
\hline blankvoorn & Eurytoop (Pelagisch) & 96.04 & 1.35 & 2.23 & 1.06 & 1 & 0.78 \\
\hline zwartbekgrondel* & Eurytoop (Bentisch) & 97.07 & - & - & 1.28 & 3.9 & 2.53 \\
\hline kolblei & Eurytoop (Bentisch) & 98.08 & 1.43 & 1.97 & 0.04 & 0.01 & 0.04 \\
\hline alver & Eurytoop (Pelagisch) & 99 & 0.04 & 0.23 & 1.1 & 0.36 & 5.35 \\
\hline zeelt & Limnofiel (Bentisch) & 99.41 & 1.44 & - & - & - & - \\
\hline bot & Limnofiel (Bentisch) & 99.66 & 0.07 & 0.5 & 0.07 & 0.09 & 0.45 \\
\hline $\begin{array}{l}\text { roofblei* } \\
\end{array}$ & Rheofiel (Pelagisch) & 99.8 & 0.02 & 0.08 & 0.17 & 0.43 & 0.23 \\
\hline kesslers grondel* & Eurytoop (Bentisch) & 99.86 & - & - & 0.05 & 0.26 & 0.12 \\
\hline kopvoorn & Rheofiel (Pelagisch) & 99.9 & - & 0.03 & 0.17 & - & - \\
\hline hybride cyprinide & Eurytoop (Bentisch) & 99.92 & - & 0.09 & - & - & \\
\hline sneep & Rheofiel (Bentisch) & 99.95 & - & 0.01 & 0.01 & 0.08 & 0.06 \\
\hline pos & Eurytoop (Bentisch) & 99.96 & 0.01 & 0.02 & 0.05 & 0 & - \\
\hline rietvoorn & Limnofiel (Pelagisch) & 99.97 & - & 0.03 & 0.01 & - & 0 \\
\hline barbeel & Rheofiel (Bentisch) & 99.98 & 0.01 & 0 & 0.01 & 0.01 & 0.02 \\
\hline rivierdonderpad & Rheofiel (Bentisch) & 99.99 & 0 & 0 & 0.03 & - & \\
\hline pontische stroomgrondel* & Eurytoop (Bentisch) & 99.99 & - & - & - & 0.01 & 0.03 \\
\hline zeebaars & Marien (Pelagisch) & 99.99 & - & 0.01 & 0 & - & - \\
\hline vetje & Limnofiel (Pelagisch) & 100 & - & - & 0.01 & - & 0 \\
\hline rivierprik & Rheofiel (Bentisch) & 100 & 0 & - & - & - & - \\
\hline serpeling & Rheofiel (Pelagisch) & 100 & - & 0 & - & - & - \\
\hline kleine modderkruiper & Eurytoop (Bentisch) & 100 & - & 0 & - & - & - \\
\hline driedoornige stekelbaars & Eurytoop (Pelagisch) & 100 & 0 & 0 & - & 0 & \\
\hline
\end{tabular}




\section{Bijlage 40 Oude Maas zijwateren}

Tabel 1. Soortensamenstelling in percentages op basis van aantal in boomkorvangsten in de zijwateren van de Oude Maas per 5-jarige periode. De groepering geeft de ecologische indeling aan de hand van Noble et al. (2007) aan. Het cumulatief percentage geeft aan hoeveel de soorten over de gehele periode voorkomen op basis van de gesommeerde CPUE op basis van het aantal. Nul-percentages zijn naar beneden afgeronde waarden, $*$ = exoot.

\begin{tabular}{|c|c|c|c|c|c|c|}
\hline Soort & Groepering & $\begin{array}{l}\text { Cumulatief } \\
\text { percentage }\end{array}$ & $\begin{array}{r}2000- \\
2004\end{array}$ & $\begin{array}{r}2005- \\
2009\end{array}$ & $\begin{array}{r}2010- \\
2014\end{array}$ & $\begin{array}{r}2015- \\
2019\end{array}$ \\
\hline blankvoorn & Eurytoop (Pelagisch) & 45.91 & 36.96 & 57.47 & 53.42 & 18.22 \\
\hline zwartbekgrondel* & Eurytoop (Bentisch) & 60.17 & - & 3.55 & 9.13 & 54.86 \\
\hline baars & Eurytoop (Pelagisch) & 69.6 & 8.08 & 7.41 & 13.07 & 4.14 \\
\hline winde & Rheofiel (Pelagisch) & 77.54 & 5.55 & 7.56 & 8.91 & 8.08 \\
\hline brasem & Eurytoop (Bentisch) & 82.9 & 9.83 & 6.05 & 5.13 & 1.14 \\
\hline bot & Limnofiel (Bentisch) & 86.34 & 14.66 & - & 1.29 & 3.97 \\
\hline roofblei* & Rheofiel (Pelagisch) & 89.34 & - & 4.86 & 3.53 & 1.63 \\
\hline aal & Eurytoop (Bentisch) & 91.91 & 7.83 & 1.69 & 0.93 & 3.43 \\
\hline alver & Eurytoop (Pelagisch) & 94.46 & 3.91 & 4.28 & 1.22 & 2.29 \\
\hline pos & Eurytoop (Bentisch) & 95.57 & 7.46 & - & - & - \\
\hline snoekbaars & Eurytoop (Bentisch) & 96.6 & 4.47 & 1.06 & 0.26 & \\
\hline rietvoorn & Limnofiel (Pelagisch) & 97.56 & 1.25 & 1.43 & 0.97 & \\
\hline snoek & Eurytoop (Pelagisch) & 98.21 & - & 1.97 & 0.2 & 0.52 \\
\hline driedoornige stekelbaars & Eurytoop (Pelagisch) & 98.84 & - & 1.08 & 0.84 & \\
\hline dunlipharder & Marien (Pelagisch) & 99.14 & - & - & - & 1.71 \\
\hline kolblei & Eurytoop (Bentisch) & 99.4 & - & 1.08 & - & \\
\hline bittervoorn & Limnofiel (Pelagisch) & 99.65 & - & - & 0.58 & \\
\hline riviergrondel & Rheofiel (Bentisch) & 99.88 & - & - & 0.52 & \\
\hline zeelt & Limnofiel (Bentisch) & 99.95 & - & 0.28 & - & \\
\hline sneep & Rheofiel (Bentisch) & 100 & - & 0.22 & - & \\
\hline
\end{tabular}

Tabel 2. Soortensamenstelling in percentages op basis van biomassa in boomkorvangsten in de zijwateren van de Oude Maas per 5-jarige periode. De groepering geeft de ecologische indeling aan de hand van Noble et al. (2007) aan. Het cumulatief percentage geeft aan hoeveel de soorten over de gehele periode voorkomen op basis van de gesommeerde CPUE op basis van de biomassa. Nulpercentages zijn naar beneden afgeronde waarden, * = exoot.

\begin{tabular}{|c|c|c|c|c|c|c|}
\hline Soort & Groepering & $\begin{array}{l}\text { Cumulatief } \\
\text { percentage }\end{array}$ & $\begin{array}{r}2000- \\
2004\end{array}$ & $\begin{array}{r}2005- \\
2009 \\
\end{array}$ & $\begin{array}{r}2010- \\
2014 \\
\end{array}$ & $\begin{array}{r}2015- \\
2019 \\
\end{array}$ \\
\hline winde & Rheofiel (Pelagisch) & 27.95 & 21.79 & 28.77 & 55.66 & 0.72 \\
\hline snoek & Eurytoop (Pelagisch) & 54.39 & - & 44.22 & 11.52 & 26.66 \\
\hline aal & Eurytoop (Bentisch) & 65.09 & 26.48 & 4.52 & 2.79 & 20.1 \\
\hline dunlipharder & Marien (Pelagisch) & 75.12 & - & - & - & 47.81 \\
\hline snoekbaars & Eurytoop (Bentisch) & 82.15 & 24.71 & 8 & 0.07 & \\
\hline brasem & Eurytoop (Bentisch) & 88.85 & 10.54 & 5.84 & 11.85 & 0.05 \\
\hline baars & Eurytoop (Pelagisch) & 92.03 & 10.12 & 2.9 & 1.87 & 0.19 \\
\hline blankvoorn & Eurytoop (Pelagisch) & 94.69 & 1.73 & 1.41 & 6.86 & 1.2 \\
\hline bot & Limnofiel (Bentisch) & 96.49 & 2.25 & - & 6.31 & 0.14 \\
\hline zeelt & Limnofiel (Bentisch) & 98.03 & - & 3.73 & - & \\
\hline zwartbekgrondel* & Eurytoop (Bentisch) & 99.07 & - & 0.17 & 1.54 & 2.95 \\
\hline rietvoorn & Limnofiel (Pelagisch) & 99.36 & 0.56 & 0.07 & 0.76 & \\
\hline pos & Eurytoop (Bentisch) & 99.62 & 1.73 & - & - & \\
\hline roofblei* & Rheofiel (Pelagisch) & 99.87 & - & 0.24 & 0.58 & 0.12 \\
\hline alver & Eurytoop (Pelagisch) & 99.93 & 0.11 & 0.05 & 0.06 & 0.06 \\
\hline kolblei & Eurytoop (Bentisch) & 99.97 & - & 0.08 & - & \\
\hline riviergrondel & Rheofiel (Bentisch) & 99.99 & - & - & 0.09 & \\
\hline bittervoorn & Limnofiel (Pelagisch) & 99.99 & - & - & 0.03 & \\
\hline driedoornige stekelbaars & Eurytoop (Pelagisch) & 100 & - & 0.01 & 0.01 & \\
\hline sneep & Rheofiel (Bentisch) & 100 & - & 0 & - & \\
\hline
\end{tabular}




\section{Bijlage 41 Hollandsch Diep hoofdstroom}

Tabel 1. Soortensamenstelling in percentages op basis van aantal in boomkorvangsten in de hoofdstroom van Het Hollandsch Diep per 5-jarige periode. De groepering geeft de ecologische indeling aan de hand van Noble et al. (2007) aan. Het cumulatief percentage geeft aan hoeveel de soorten over de gehele periode voorkomen op basis van de gesommeerde CPUE op basis van het aantal. Nul-percentages zijn naar beneden afgeronde waarden, * exoot.

\begin{tabular}{|c|c|c|c|c|c|c|c|}
\hline Soort & Groepering & $\begin{array}{l}\text { Cumulatief } \\
\text { percentage }\end{array}$ & $\begin{array}{r}1997- \\
1999\end{array}$ & $\begin{array}{r}2000- \\
2004\end{array}$ & $\begin{array}{r}2005- \\
2009\end{array}$ & $\begin{array}{r}2010- \\
2014\end{array}$ & $\begin{array}{r}2015- \\
2019\end{array}$ \\
\hline brasem & Eurytoop (Bentisch) & 33.44 & 55.12 & 31.47 & 39.51 & 19.75 & 21.56 \\
\hline snoekbaars & Eurytoop (Bentisch) & 51.51 & 20.7 & 19.07 & 16.89 & 13.94 & 20.05 \\
\hline blankvoorn & Eurytoop (Pelagisch) & 66.52 & 13.36 & 26.42 & 8.22 & 3.59 & 18.5 \\
\hline baars & Eurytoop (Pelagisch) & 78.99 & 0.73 & 8.76 & 17.46 & 18.59 & 17.47 \\
\hline zwartbekgrondel* & Eurytoop (Bentisch) & 86.47 & - & - & 2.39 & 29.88 & 10.42 \\
\hline bot & Limnofiel (Bentisch) & 91.59 & 3.05 & 9.48 & 3.92 & 2.97 & 3.3 \\
\hline pos & Eurytoop (Bentisch) & 93.94 & 0.99 & 1.27 & 4.18 & 3.1 & 2.28 \\
\hline aal & Eurytoop (Bentisch) & 95.85 & 2.71 & 1.66 & 2.74 & 0.77 & 1.74 \\
\hline kolblei & Eurytoop (Bentisch) & 97.41 & 2.63 & 0.62 & 2.24 & 1.43 & 1.35 \\
\hline pontische stroomgrondel* & Eurytoop (Bentisch) & 98.52 & - & - & - & 4.7 & 1.76 \\
\hline hybride cyprinide & Eurytoop (Bentisch) & 98.94 & 0.15 & 0.05 & 1.73 & 0.01 & 0.01 \\
\hline winde & Rheofiel (Pelagisch) & 99.23 & 0.04 & 0.79 & 0.01 & 0.03 & 0.31 \\
\hline kesslers grondel* & Eurytoop (Bentisch) & 99.43 & - & - & 0.11 & 0.72 & 0.3 \\
\hline spiering & Eurytoop (Pelagisch) & 99.62 & 0.43 & 0.15 & 0.06 & 0.29 & 0.06 \\
\hline donaubrasem* & Eurytoop (Bentisch) & 99.7 & - & - & 0.15 & 0.15 & 0.19 \\
\hline $\begin{array}{ll}\text { riviergrondel } \\
\end{array}$ & Rheofiel (Bentisch) & 99.77 & 0.05 & 0.1 & 0.12 & - & 0.03 \\
\hline driedoornige stekelbaars & Eurytoop (Pelagisch) & 99.83 & - & 0.01 & 0.01 & 0.01 & 0.34 \\
\hline witvinriviergrondel* & Eurytoop (Bentisch) & 99.88 & - & - & 0.16 & 0.03 & 0.07 \\
\hline alver & Eurytoop (Pelagisch) & 99.93 & 0.01 & 0.07 & 0.03 & 0.01 & 0.14 \\
\hline roofblei* & Rheofiel (Pelagisch) & 99.95 & 0.01 & 0.05 & 0 & 0 & 0.04 \\
\hline karper & Eurytoop (Bentisch) & 99.96 & - & 0.01 & 0.01 & 0.02 & 0.03 \\
\hline snoek & Eurytoop (Pelagisch) & 99.97 & 0.01 & 0 & 0.01 & 0 & 0.02 \\
\hline marmergrondel* & Eurytoop (Bentisch) & 99.98 & - & - & 0.04 & - & 0 \\
\hline rivierdonderpad & Rheofiel (Bentisch) & 99.99 & 0.02 & 0.01 & 0.01 & - & - \\
\hline rivierprik & Rheofiel (Bentisch) & 99.99 & 0 & 0 & - & - & 0 \\
\hline harders indet. & Marien (Pelagisch) & 99.99 & - & 0 & - & 0 & 0.01 \\
\hline europese meerval & Eurytoop (Bentisch) & 99.99 & - & 0 & 0 & 0 & \\
\hline kleine modderkruiper & Eurytoop (Bentisch) & 99.99 & - & - & 0 & - & 0 \\
\hline diklipharder & Marien (Pelagisch) & 100 & - & - & 0 & - & 0 \\
\hline tiendoornige stekelbaars & Limnofiel (Pelagisch) & 100 & - & 0 & - & - & \\
\hline sneep & Rheofiel (Bentisch) & 100 & - & - & - & - & 0.01 \\
\hline grondel sp. & Marien (Bentisch) & 100 & - & 0 & - & - & \\
\hline gevlekte rog & Marien (Bentisch) & 100 & - & - & - & - & 0 \\
\hline serpeling & Rheofiel (Pelagisch) & 100 & - & 0 & - & - & \\
\hline
\end{tabular}


Tabel 2. Soortensamenstelling in percentages op basis van biomassa in boomkorvangsten in de hoofdstroom van Het Hollandsch Diep per 5-jarige periode. De groepering geeft de ecologische indeling aan de hand van Noble et al. (2007) aan. Het cumulatief percentage geeft aan hoeveel de soorten over de gehele periode voorkomen op basis van de gesommeerde CPUE op basis van de biomassa. Nulpercentages zijn naar beneden afgeronde waarden, $*$ = exoot.

\begin{tabular}{|c|c|c|c|c|c|c|c|}
\hline Soort & Groepering & $\begin{array}{l}\text { Cumulatief } \\
\text { percentage }\end{array}$ & $\begin{array}{r}1997- \\
1999 \\
\end{array}$ & $\begin{array}{r}2000- \\
2004 \\
\end{array}$ & $\begin{array}{r}2005- \\
2009 \\
\end{array}$ & $\begin{array}{r}2010- \\
2014 \\
\end{array}$ & $\begin{array}{r}2015- \\
2019 \\
\end{array}$ \\
\hline brasem & Eurytoop (Bentisch) & 73.71 & 79.11 & 79.47 & 71.79 & 64.01 & 56.17 \\
\hline snoekbaars & Eurytoop (Bentisch) & 83.85 & 8.6 & 8.07 & 11.36 & 13.79 & 13.43 \\
\hline blankvoorn & Eurytoop (Pelagisch) & 90.82 & 5.54 & 6.47 & 7.99 & 5.08 & 11.73 \\
\hline aal & Eurytoop (Bentisch) & 93.99 & 1.43 & 2.33 & 4.13 & 2.83 & 8.42 \\
\hline kolblei & Eurytoop (Bentisch) & 97.09 & 4.19 & 1.89 & 2.1 & 5.6 & 4.84 \\
\hline baars & Eurytoop (Pelagisch) & 98.52 & 0.68 & 1.28 & 1.38 & 2.23 & 3.13 \\
\hline europese meerval & Eurytoop (Bentisch) & 98.87 & - & 0.01 & 0.25 & 2.6 & \\
\hline zwartbekgrondel* & Eurytoop (Bentisch) & 99.12 & - & - & 0.06 & 1.62 & 0.72 \\
\hline karper & Eurytoop (Bentisch) & 99.3 & - & 0.01 & 0.39 & 0.63 & 0.11 \\
\hline pos & Eurytoop (Bentisch) & 99.45 & 0.07 & 0.09 & 0.17 & 0.33 & 0.31 \\
\hline hybride cyprinide & Eurytoop (Bentisch) & 99.6 & 0.26 & 0.12 & 0.15 & 0.01 & 0.05 \\
\hline bot & Limnofiel (Bentisch) & 99.69 & 0.06 & 0.13 & 0.06 & 0.17 & 0.11 \\
\hline donaubrasem* & Eurytoop (Bentisch) & 99.76 & - & - & 0.04 & 0.41 & 0.2 \\
\hline snoek & Eurytoop (Pelagisch) & 99.83 & 0.05 & 0.03 & 0.09 & 0.02 & 0.29 \\
\hline pontische stroomgrondel* & Eurytoop (Bentisch) & 99.9 & - & - & - & 0.38 & 0.26 \\
\hline winde & Rheofiel (Pelagisch) & 99.95 & 0.01 & 0.09 & 0.01 & 0.11 & 0.1 \\
\hline kesslers grondel* & Eurytoop (Bentisch) & 99.98 & - & - & 0.01 & 0.16 & 0.1 \\
\hline roofblei* & Rheofiel (Pelagisch) & 99.99 & 0 & 0.01 & 0.01 & 0 & 0.02 \\
\hline spiering & Eurytoop (Pelagisch) & 99.99 & 0.01 & 0 & 0 & 0.02 & 0 \\
\hline riviergrondel & Rheofiel (Bentisch) & 100 & 0 & 0 & 0 & - & 0 \\
\hline witvinriviergrondel* & Eurytoop (Bentisch) & 100 & - & - & 0 & 0 & 0 \\
\hline rivierprik & Rheofiel (Bentisch) & 100 & 0 & 0 & - & - & 0 \\
\hline alver & Eurytoop (Pelagisch) & 100 & 0 & 0 & 0 & 0 & 0.01 \\
\hline driedoornige stekelbaars & Eurytoop (Pelagisch) & 100 & - & 0 & 0 & 0 & 0 \\
\hline sneep & Rheofiel (Bentisch) & 100 & - & - & - & - & 0 \\
\hline marmergrondel* & Eurytoop (Bentisch) & 100 & - & - & 0 & - & 0 \\
\hline rivierdonderpad & Rheofiel (Bentisch) & 100 & 0 & 0 & 0 & - & - \\
\hline kleine modderkruiper & Eurytoop (Bentisch) & 100 & - & - & 0 & - & 0 \\
\hline serpeling & Rheofiel (Pelagisch) & 100 & - & 0 & - & - & - \\
\hline tiendoornige stekelbaars & Limnofiel (Pelagisch) & 100 & - & 0 & - & - & - \\
\hline harders indet. & Marien (Pelagisch) & 100 & - & 0 & - & 0 & 0 \\
\hline grondel sp. & Marien (Bentisch) & 100 & - & 0 & - & - & - \\
\hline diklipharder & Marien (Pelagisch) & 100 & - & - & 0 & - & 0 \\
\hline
\end{tabular}


Tabel 3. Soortensamenstelling in percentages op basis van aantal in schepnetvangsten in de hoofdstroom van Het Hollandsch Diep per 5-jarige periode. De groepering geeft de ecologische indeling aan de hand van Noble et al. (2007) aan. Het cumulatief percentage geeft aan hoeveel de soorten over de gehele periode voorkomen op basis van de gesommeerde CPUE op basis van het aantal. Nulpercentages zijn naar beneden afgeronde waarden, $*$ = exoot.

\begin{tabular}{|c|c|c|c|c|c|c|c|}
\hline Soort & Groepering & $\begin{array}{l}\text { Cumulatief } \\
\text { percentage }\end{array}$ & $\begin{array}{r}1997- \\
1999\end{array}$ & $\begin{array}{r}2000- \\
2004\end{array}$ & $\begin{array}{r}2005- \\
2009\end{array}$ & $\begin{array}{r}2010- \\
2014\end{array}$ & $\begin{array}{r}2015- \\
2019\end{array}$ \\
\hline blankvoorn & Eurytoop (Pelagisch) & 56.8 & 49.73 & 47.41 & 52.25 & 62.59 & 63.54 \\
\hline zwartbekgrondel* & Eurytoop (Bentisch) & 69.76 & - & - & 10.25 & 22.77 & 13.25 \\
\hline winde & Rheofiel (Pelagisch) & 80.16 & 17.25 & 18.38 & 12.08 & 5.5 & 7.29 \\
\hline baars & Eurytoop (Pelagisch) & 86.01 & 5.15 & 9.9 & 8.83 & 3 & 4.31 \\
\hline aal & Eurytoop (Bentisch) & 90.77 & 10.32 & 9.78 & 4.7 & 1.53 & 4.27 \\
\hline bot & Limnofiel (Bentisch) & 93.56 & 3.09 & 7.42 & 2.51 & 0.28 & 3.53 \\
\hline roofblei* & Rheofiel (Pelagisch) & 95.97 & 1.13 & 1.32 & 4.27 & 2.28 & 2.45 \\
\hline brasem & Eurytoop (Bentisch) & 96.88 & 4.85 & 0.89 & 0.86 & 0.6 & 0.08 \\
\hline alver & Eurytoop (Pelagisch) & 97.67 & 4.58 & 0.39 & 1.24 & 0.41 & 0.16 \\
\hline snoekbaars & Eurytoop (Bentisch) & 98.17 & 0.8 & 1.75 & 0.18 & 0.03 & 0.3 \\
\hline kesslers grondel* & Eurytoop (Bentisch) & 98.46 & - & - & 0.52 & 0.42 & 0.22 \\
\hline driedoornige stekelbaars & Eurytoop (Pelagisch) & 98.7 & 0.19 & 0.6 & 0.34 & 0.06 & 0.08 \\
\hline sneep & Rheofiel (Bentisch) & 98.85 & 0.09 & 0.11 & 0.15 & 0.22 & 0.07 \\
\hline pos & Eurytoop (Bentisch) & 98.99 & 0.02 & 0.34 & 0.19 & 0.08 & \\
\hline karper & Eurytoop (Bentisch) & 99.11 & 0.74 & 0.25 & 0.04 & 0.02 & 0.09 \\
\hline marmergrondel* & Eurytoop (Bentisch) & 99.24 & - & 0.04 & 0.59 & 0 & 0.01 \\
\hline snoek & Eurytoop (Pelagisch) & 99.35 & 0.37 & 0.22 & 0.11 & 0.03 & 0.09 \\
\hline barbeel & Rheofiel (Bentisch) & 99.46 & 0.13 & 0.35 & 0.11 & 0.01 & 0.01 \\
\hline rietvoorn & Limnofiel (Pelagisch) & 99.56 & 0.63 & 0.14 & 0.1 & 0.01 & 0.03 \\
\hline harders indet. & Marien (Pelagisch) & 99.63 & - & 0.05 & 0.35 & - & \\
\hline kopvoorn & Rheofiel (Pelagisch) & 99.71 & 0.17 & 0.2 & 0.1 & 0.01 & 0.02 \\
\hline kolblei & Eurytoop (Bentisch) & 99.76 & 0.04 & 0.17 & 0.06 & - & 0.04 \\
\hline pontische stroomgrondel* & Eurytoop (Bentisch) & 99.8 & - & - & - & 0.09 & 0.03 \\
\hline kleine modderkruiper & Eurytoop (Bentisch) & 99.83 & 0.03 & 0.05 & - & 0.02 & 0.03 \\
\hline rivierdonderpad & Rheofiel (Bentisch) & 99.85 & 0.07 & 0.06 & 0.02 & - & - \\
\hline bittervoorn & Limnofiel (Pelagisch) & 99.87 & 0.06 & 0.04 & 0.03 & 0 & - \\
\hline dunlipharder & Marien (Pelagisch) & 99.89 & - & - & 0 & 0.04 & 0.01 \\
\hline hybride cyprinide & Eurytoop (Bentisch) & 99.91 & 0.02 & 0.03 & 0.05 & 0 & - \\
\hline serpeling & Rheofiel (Pelagisch) & 99.92 & 0.08 & 0.02 & 0.04 & 0.01 & - \\
\hline vetje & Limnofiel (Pelagisch) & 99.94 & 0.24 & - & - & 0.01 & - \\
\hline zeelt & Limnofiel (Bentisch) & 99.95 & - & 0.01 & - & - & 0.08 \\
\hline giebel & Eurytoop (Bentisch) & 99.97 & 0.04 & - & 0.05 & - & - \\
\hline diklipharder & Marien (Pelagisch) & 99.97 & - & 0.03 & - & - & - \\
\hline zeebaars & Marien (Pelagisch) & 99.98 & - & 0.02 & - & 0.01 & 0.01 \\
\hline riviergrondel & Rheofiel (Bentisch) & 99.99 & 0.05 & 0.01 & - & 0 & \\
\hline graskarper & Eurytoop (Pelagisch) & 99.99 & 0.09 & - & - & - & - \\
\hline tiendoornige stekelbaars & Limnofiel (Pelagisch) & 100 & 0.02 & - & 0.01 & - & - \\
\hline rivierprik & Rheofiel (Bentisch) & 100 & - & 0.01 & - & - & - \\
\hline europese meerval & Eurytoop (Bentisch) & 100 & 0.03 & - & - & - & \\
\hline goudharder & Marien (Pelagisch) & 100 & - & - & - & - & 0.01 \\
\hline
\end{tabular}


Tabel 4. Soortensamenstelling in percentages op basis van biomassa in schepnetvangsten in de hoofdstroom van Het Hollandsch Diep per 5-jarige periode. De groepering geeft de ecologische indeling aan de hand van Noble et al. (2007) aan. Het cumulatief percentage geeft aan hoeveel de soorten over de gehele periode voorkomen op basis van de gesommeerde CPUE op basis van de biomassa. Nulpercentages zijn naar beneden afgeronde waarden, $*$ = exoot.

\begin{tabular}{|c|c|c|c|c|c|c|c|}
\hline Soort & Groepering & $\begin{array}{l}\text { Cumulatief } \\
\text { percentage }\end{array}$ & $\begin{array}{r}1997- \\
1999 \\
\end{array}$ & $\begin{array}{r}2000- \\
2004 \\
\end{array}$ & $\begin{array}{r}2005- \\
2009 \\
\end{array}$ & $\begin{array}{r}2010- \\
2014 \\
\end{array}$ & $\begin{array}{r}2015- \\
2019 \\
\end{array}$ \\
\hline winde & Rheofiel (Pelagisch) & 19.26 & 12.29 & 22.41 & 34.52 & 8.75 & 12.46 \\
\hline karper & Eurytoop (Bentisch) & 36.68 & 39.12 & 17.96 & 6.24 & 7.17 & 19.55 \\
\hline brasem & Eurytoop (Bentisch) & 53.51 & 21.54 & 9.01 & 13.8 & 32.1 & 4.01 \\
\hline aal & Eurytoop (Bentisch) & 68.2 & 7.75 & 14.6 & 11.41 & 15.25 & 37.61 \\
\hline baars & Eurytoop (Pelagisch) & 78.13 & 7.07 & 13.77 & 15.25 & 5.05 & 1.4 \\
\hline blankvoorn & Eurytoop (Pelagisch) & 86.17 & 2.89 & 6.55 & 6.76 & 14.43 & 12.27 \\
\hline snoekbaars & Eurytoop (Bentisch) & 90.23 & 2.23 & 6.9 & 4.6 & 0.58 & 5.06 \\
\hline snoek & Eurytoop (Pelagisch) & 93.55 & 4.89 & 3.64 & 3.26 & 2.07 & 1.9 \\
\hline zwartbekgrondel* & Eurytoop (Bentisch) & 95.94 & - & - & 2.12 & 7.84 & 3.51 \\
\hline dunlipharder & Marien (Pelagisch) & 97.08 & - & - & 0.11 & 5.31 & 0.01 \\
\hline kolblei & Eurytoop (Bentisch) & 97.63 & 0.08 & 1.69 & 0.01 & - & 0.04 \\
\hline roofblei* & Rheofiel (Pelagisch) & 98.12 & 0.14 & 0.24 & 0.74 & 0.79 & 0.78 \\
\hline bot & Limnofiel (Bentisch) & 98.54 & 0.3 & 0.64 & 0.39 & 0.13 & 0.77 \\
\hline harders indet. & Marien (Pelagisch) & 98.97 & - & 1.08 & 0.42 & - & \\
\hline kopvoorn & Rheofiel (Pelagisch) & 99.27 & 0.79 & 0.49 & 0.01 & 0 & 0 \\
\hline diklipharder & Marien (Pelagisch) & 99.45 & - & 0.56 & - & - & \\
\hline kesslers grondel* & Eurytoop (Bentisch) & 99.59 & - & - & 0.2 & 0.36 & 0.26 \\
\hline graskarper & Eurytoop (Pelagisch) & 99.69 & 0.54 & - & - & - & - \\
\hline rietvoorn & Limnofiel (Pelagisch) & 99.79 & 0.26 & 0.14 & 0.02 & 0 & 0.01 \\
\hline barbeel & Rheofiel (Bentisch) & 99.86 & 0.01 & 0.18 & 0.03 & 0.01 & 0.01 \\
\hline alver & Eurytoop (Pelagisch) & 99.89 & 0.05 & 0.01 & 0.03 & 0.07 & 0.02 \\
\hline pos & Eurytoop (Bentisch) & 99.92 & 0 & 0.07 & 0.03 & 0.02 & - \\
\hline goudharder & Marien (Pelagisch) & 99.94 & - & - & - & - & 0.23 \\
\hline sneep & Rheofiel (Bentisch) & 99.96 & 0 & 0.01 & 0.01 & 0.05 & 0.02 \\
\hline marmergrondel* & Eurytoop (Bentisch) & 99.97 & - & 0 & 0.03 & 0 & 0 \\
\hline zeelt & Limnofiel (Bentisch) & 99.97 & - & 0 & - & - & 0.07 \\
\hline pontische stroomgrondel* & Eurytoop (Bentisch) & 99.98 & - & - & - & 0.02 & 0.01 \\
\hline hybride cyprinide & Eurytoop (Bentisch) & 99.98 & 0.01 & 0 & 0 & 0 & - \\
\hline serpeling & Rheofiel (Pelagisch) & 99.98 & 0 & 0 & 0.01 & 0 & - \\
\hline $\begin{array}{ll}\text { rivierprik } \\
\end{array}$ & Rheofiel (Bentisch) & 99.99 & - & 0.01 & - & - & - \\
\hline driedoornige stekelbaars & Eurytoop (Pelagisch) & 99.99 & 0 & 0.01 & 0 & 0 & 0 \\
\hline giebel & Eurytoop (Bentisch) & 99.99 & 0 & - & 0.01 & - & - \\
\hline kleine modderkruiper & Eurytoop (Bentisch) & 100 & 0 & 0 & - & 0 & 0 \\
\hline rivierdonderpad & Rheofiel (Bentisch) & 100 & 0 & 0 & 0 & - & \\
\hline bittervoorn & Limnofiel (Pelagisch) & 100 & 0 & 0 & 0 & 0 & \\
\hline riviergrondel & Rheofiel (Bentisch) & 100 & 0 & 0 & - & 0 & - \\
\hline europese meerval & Eurytoop (Bentisch) & 100 & 0 & - & - & - & - \\
\hline zeebaars & Marien (Pelagisch) & 100 & - & 0 & - & 0 & $\underline{0}$ \\
\hline vetje & Limnofiel (Pelagisch) & 100 & 0 & - & - & 0 & \\
\hline tiendoornige stekelbaars & Limnofiel (Pelagisch) & 100 & 0 & - & 0 & - & \\
\hline
\end{tabular}




\section{Bijlage 42 Haringvliet-West hoofdstroom}

Tabel 1. Soortensamenstelling in percentages op basis van aantal in boomkorvangsten in de hoofdstroom van het Haringvliet-West per 5-jarige periode. De groepering geeft de ecologische indeling aan de hand van Noble et al. (2007) aan. Het cumulatief percentage geeft aan hoeveel de soorten over de gehele periode voorkomen op basis van de gesommeerde CPUE op basis van het aantal. Nul-percentages zijn naar beneden afgeronde waarden, * exoot.

\begin{tabular}{|c|c|c|c|c|}
\hline Soort & Groepering & $\begin{array}{l}\text { Cumulatief } \\
\text { percentage }\end{array}$ & $\begin{array}{r}2010- \\
2014\end{array}$ & $\begin{array}{r}2015- \\
2019\end{array}$ \\
\hline baars & Eurytoop (Pelagisch) & 28.45 & 25.69 & 29.78 \\
\hline pos & Eurytoop (Bentisch) & 55.01 & 21.32 & 29.07 \\
\hline zwartbekgrondel* & Eurytoop (Bentisch) & 68 & 25.48 & 7 \\
\hline snoekbaars & Eurytoop (Bentisch) & 78.96 & 12.07 & 10.42 \\
\hline bot & Limnofiel (Bentisch) & 87.1 & 6.92 & 8.72 \\
\hline blankvoorn & Eurytoop (Pelagisch) & 92.3 & 0.48 & 7.46 \\
\hline brasem & Eurytoop (Bentisch) & 95.5 & 1.7 & 3.92 \\
\hline aal & Eurytoop (Bentisch) & 97.02 & 1.55 & 1.51 \\
\hline spiering & Eurytoop (Pelagisch) & 98.25 & 3.31 & 0.22 \\
\hline kolblei & Eurytoop (Bentisch) & 98.95 & 0.01 & 1.04 \\
\hline haring/sprot & Marien (Pelagisch) & 99.33 & 1.16 & 0.01 \\
\hline grondel sp. & Marien (Bentisch) & 99.5 & - & 0.25 \\
\hline winde & Rheofiel (Pelagisch) & 99.65 & 0.06 & 0.19 \\
\hline pontische stroomgrondel* & Eurytoop (Bentisch) & 99.78 & 0.15 & 0.12 \\
\hline driedoornige stekelbaars & Eurytoop (Pelagisch) & 99.82 & 0.01 & 0.05 \\
\hline witvinriviergrondel* & Eurytoop (Bentisch) & 99.85 & 0.01 & 0.04 \\
\hline snoek & Eurytoop (Pelagisch) & 99.87 & - & 0.04 \\
\hline blauwneus* & Eurytoop (Bentisch) & 99.89 & 0.01 & 0.02 \\
\hline karper & Eurytoop (Bentisch) & 99.91 & - & 0.02 \\
\hline rivierdonderpad & Rheofiel (Bentisch) & 99.92 & 0.02 & 0.01 \\
\hline donaubrasem* & Eurytoop (Bentisch) & 99.93 & 0.01 & 0.01 \\
\hline noordzeehouting & Limnofiel (Pelagisch) & 99.95 & 0.01 & 0.01 \\
\hline zeebaars & Marien (Pelagisch) & 99.95 & 0.01 & 0.01 \\
\hline vijfdradige meun & Marien (Bentisch) & 99.96 & - & 0.01 \\
\hline marmergrondel* & Eurytoop (Bentisch) & 99.97 & - & 0.01 \\
\hline wijting & Marien (Bentisch) & 99.97 & - & 0.01 \\
\hline rivierprik & Rheofiel (Bentisch) & 99.98 & 0.01 & 0 \\
\hline koornaarvis sp. & Marien (Pelagisch) & 99.98 & - & 0.01 \\
\hline kesslers grondel* & Eurytoop (Bentisch) & 99.98 & - & 0 \\
\hline harders indet. & Marien (Pelagisch) & 99.99 & 0.01 & - \\
\hline steenbolk & Marien (Bentisch) & 99.99 & - & 0 \\
\hline tong & Marien (Bentisch) & 99.99 & - & 0 \\
\hline zeeprik & Rheofiel (Bentisch) & 99.99 & 0.01 & - \\
\hline alver & Eurytoop (Pelagisch) & 100 & - & 0 \\
\hline kleine zeenaald & Marien (Bentisch) & 100 & - & 0 \\
\hline roofblei* & Rheofiel (Pelagisch) & 100 & - & 0 \\
\hline
\end{tabular}


Tabel 2. Soortensamenstelling in percentages op basis van biomassa in boomkorvangsten in de hoofdstroom van het Haringvliet-West per 5-jarige periode. De groepering geeft de ecologische indeling aan de hand van Noble et al. (2007) aan. Het cumulatief percentage geeft aan hoeveel de soorten over de gehele periode voorkomen op basis van de gesommeerde CPUE op basis van de biomassa. Nulpercentages zijn naar beneden afgeronde waarden, * = exoot.

\begin{tabular}{|c|c|c|c|c|}
\hline Soort & Groepering & $\begin{array}{l}\text { Cumulatief } \\
\text { percentage }\end{array}$ & $\begin{array}{r}2010- \\
2014\end{array}$ & $\begin{array}{r}2015- \\
2019\end{array}$ \\
\hline snoekbaars & Eurytoop (Bentisch) & 25.4 & 23.1 & 26.08 \\
\hline aal & Eurytoop (Bentisch) & 43.86 & 23.33 & 17.01 \\
\hline baars & Eurytoop (Pelagisch) & 62.1 & 18.27 & 18.23 \\
\hline brasem & Eurytoop (Bentisch) & 78.1 & 19.73 & 14.89 \\
\hline pos & Eurytoop (Bentisch) & 86.03 & 7.14 & 8.16 \\
\hline blankvoorn & Eurytoop (Pelagisch) & 92.33 & 0.65 & 7.98 \\
\hline zwartbekgrondel* & Eurytoop (Bentisch) & 94.57 & 5.54 & 1.26 \\
\hline bot & Limnofiel (Bentisch) & 96.63 & 1.38 & 2.26 \\
\hline kolblei & Eurytoop (Bentisch) & 98.22 & 0.02 & 2.05 \\
\hline snoek & Eurytoop (Pelagisch) & 99.16 & - & 1.23 \\
\hline karper & Eurytoop (Bentisch) & 99.37 & - & 0.27 \\
\hline blauwneus* & Eurytoop (Bentisch) & 99.53 & 0.02 & 0.19 \\
\hline winde & Rheofiel (Pelagisch) & 99.66 & 0.13 & 0.14 \\
\hline spiering & Eurytoop (Pelagisch) & 99.75 & 0.23 & 0.05 \\
\hline donaubrasem* & Eurytoop (Bentisch) & 99.81 & 0.01 & 0.07 \\
\hline pontische stroomgrondel* & Eurytoop (Bentisch) & 99.85 & 0.06 & 0.04 \\
\hline noordzeehouting & Limnofiel (Pelagisch) & 99.89 & 0.15 & 0.01 \\
\hline zeeprik & Rheofiel (Bentisch) & 99.92 & 0.12 & \\
\hline grondel sp. & Marien (Bentisch) & 99.94 & - & 0.02 \\
\hline haring/sprot & Marien (Pelagisch) & 99.96 & 0.07 & 0 \\
\hline rivierprik & Rheofiel (Bentisch) & 99.97 & 0.03 & 0.01 \\
\hline vijfdradige meun & Marien (Bentisch) & 99.98 & - & 0.01 \\
\hline wijting & Marien (Bentisch) & 99.98 & - & 0.01 \\
\hline steenbolk & Marien (Bentisch) & 99.99 & - & 0.01 \\
\hline driedoornige stekelbaars & Eurytoop (Pelagisch) & 99.99 & 0 & 0 \\
\hline witvinriviergrondel* & Eurytoop (Bentisch) & 99.99 & 0 & 0 \\
\hline kesslers grondel* & Eurytoop (Bentisch) & 99.99 & - & 0 \\
\hline roofblei* & Rheofiel (Pelagisch) & 100 & - & 0 \\
\hline zeebaars & Marien (Pelagisch) & 100 & 0 & 0 \\
\hline rivierdonderpad & Rheofiel (Bentisch) & 100 & 0 & 0 \\
\hline tong & Marien (Bentisch) & 100 & - & 0 \\
\hline marmergrondel* & Eurytoop (Bentisch) & 100 & - & 0 \\
\hline koornaarvis sp. & Marien (Pelagisch) & 100 & - & 0 \\
\hline alver & Eurytoop (Pelagisch) & 100 & - & 0 \\
\hline harders indet. & Marien (Pelagisch) & 100 & 0 & - \\
\hline kleine zeenaald & Marien (Bentisch) & 100 & - & 0 \\
\hline
\end{tabular}




\section{Bijlage 43 Haringvliet-West zijwateren}

Tabel 1. Soortensamenstelling in percentages op basis van aantal in boomkorvangsten in de zijwateren van het Haringvliet-West per 5-jarige periode. De groepering geeft de ecologische indeling aan de hand van Noble et al. (2007) aan. Het cumulatief percentage geeft aan hoeveel de soorten over de gehele periode voorkomen op basis van de gesommeerde CPUE op basis van het aantal. Nul-percentages zijn naar beneden afgeronde waarden, $*=$ exoot.

\begin{tabular}{rrrrr}
\hline & Groepering & Cumulatief & $2010-$ & $2015-$ \\
percentage & 2014 & 2019 \\
\hline haring/sprot & Marien (Pelagisch) & 78.14 & 81.08 & 68.65 \\
\hline baars & Eurytoop (Pelagisch) & 88.5 & 11.69 & 6.06 \\
\hline zwartbekgrondel* & Eurytoop (Bentisch) & 92.69 & 3.11 & 7.68 \\
\hline bot & Limnofiel (Bentisch) & 95.47 & 1.37 & 7.35 \\
\hline grondel sp. & Marien (Bentisch) & 96.96 & 0.05 & 6.15 \\
\hline blankvoorn & Eurytoop (Pelagisch) & 97.7 & 0.62 & 1.11 \\
\hline snoekbaars & Eurytoop (Bentisch) & 98.38 & 0.85 & 0.14 \\
\hline spiering & Eurytoop (Pelagisch) & 98.96 & 0.75 & - \\
\hline brasem & Eurytoop (Bentisch) & 99.17 & 0.14 & 0.46 \\
\hline winde & Rheofiel (Pelagisch) & 99.36 & 0.14 & 0.33 \\
\hline zeebaars & Marien (Pelagisch) & 99.54 & - & 0.74 \\
\hline brakwatergrondel & Marien (Bentisch) & 99.66 & - & 0.51 \\
\hline alver & Eurytoop (Pelagisch) & 99.73 & - & 0.33 \\
\hline glasgrondel & Marien (Bentisch) & 99.81 & 0.1 & - \\
\hline aal & Eurytoop (Bentisch) & 99.85 & - & 0.19 \\
\hline driedoornige stekelbaars & Eurytoop (Pelagisch) & 99.89 & - & 0.18 \\
\hline grote zeenaald & Marien (Bentisch) & 99.93 & 0.05 & - \\
\hline koornaarvis sp. & Marien (Pelagisch) & 99.97 & 0.05 & - \\
\hline pos & Eurytoop (Bentisch) & 100 & - & 0.14 \\
\hline & & &
\end{tabular}

Tabel 2. Soortensamenstelling in percentages op basis van biomassa in boomkorvangsten in de zijwateren van het Haringvliet-West per 5-jarige periode. De groepering geeft de ecologische indeling aan de hand van Noble et al. (2007) aan. Het cumulatief percentage geeft aan hoeveel de soorten over de gehele periode voorkomen op basis van de gesommeerde CPUE op basis van de biomassa. Nulpercentages zijn naar beneden afgeronde waarden, $*=$ exoot.

\begin{tabular}{rrrrr} 
Soort & Groepering & Cumulatief & $2010-$ & $2015-$ \\
percentage & 2014 & 2019 \\
\hline brasem & Eurytoop (Bentisch) & 27.93 & 38.08 & 0.68 \\
\hline haring/sprot & Marien (Pelagisch) & 53.21 & 19.85 & 39.86 \\
\hline baars & Eurytoop (Pelagisch) & 70.5 & 18.37 & 14.38 \\
\hline winde & Rheofiel (Pelagisch) & 83.67 & 17.87 & 0.57 \\
\hline zwartbekgrondel* & Eurytoop (Bentisch) & 90.8 & 4.19 & 14.99 \\
\hline blankvoorn & Eurytoop (Pelagisch) & 94.51 & 0.87 & 11.34 \\
\hline bot & Limnofiel (Bentisch) & 96.89 & 0.64 & 7.05 \\
\hline aal & Eurytoop (Bentisch) & 98.7 & - & 6.69 \\
\hline grondel sp. & Marien (Bentisch) & 99.39 & 0.01 & 2.5 \\
\hline zeebaars & Marien (Pelagisch) & 99.67 & - & 1.06 \\
\hline snoekbaars & Eurytoop (Bentisch) & 99.81 & 0.02 & 0.45 \\
\hline pos & Eurytoop (Bentisch) & 99.88 & - & 0.24 \\
\hline spiering & Eurytoop (Pelagisch) & 99.92 & 0.06 & - \\
\hline alver & Eurytoop (Pelagisch) & 99.95 & - & 0.11 \\
\hline glasgrondel & Marien (Bentisch) & 99.97 & 0.02 & - \\
\hline brakwatergrondel & Marien (Bentisch) & 99.98 & - & 0.05 \\
\hline driedoornige stekelbaars & Eurytoop (Pelagisch) & 99.99 & - & 0.04 \\
\hline koornaarvis sp. & Marien (Pelagisch) & 100 & 0.01 & - \\
\hline grote zeenaald & Marien (Bentisch) & 100 & 0 & - \\
\hline & &
\end{tabular}




\section{Bijlage 44 Zoommeer hoofdstroom}

Tabel 1. Soortensamenstelling in percentages op basis van aantal in boomkorvangsten in de hoofdstroom van het Zoommeer per 5-jarige periode. De groepering geeft de ecologische indeling aan de hand van Noble et al. (2007) aan. Het cumulatief percentage geeft aan hoeveel de soorten over de gehele periode voorkomen op basis van de gesommeerde CPUE op basis van het aantal. Nul-percentages zijn naar beneden afgeronde waarden, $*$ =xoot.

\begin{tabular}{rrrr}
\hline Soort & Groepering & $\begin{array}{r}\text { Cumulatief } \\
\text { percentage }\end{array}$ & $\begin{array}{r}2015- \\
2019\end{array}$ \\
\hline baars & Eurytoop (Pelagisch) & 87.71 & 87.71 \\
\hline brasem & Eurytoop (Bentisch) & 91.22 & 3.52 \\
\hline snoekbars & Eurytoop (Bentisch) & 94.19 & 2.97 \\
\hline zwartbekgrondel* & Eurytoop (Bentisch) & 96.73 & 2.54 \\
\hline blankvoorn & Eurytoop (Pelagisch) & 98.16 & 1.42 \\
\hline spiering & Eurytoop (Pelagisch) & 98.74 & 0.58 \\
\hline driedoornige stekelbaars & Eurytoop (Pelagisch) & 99.29 & 0.56 \\
\hline pos & Eurytoop (Bentisch) & 99.66 & 0.36 \\
\hline snoek & Eurytoop (Pelagisch) & 99.78 & 0.12 \\
\hline bot & Limnofiel (Bentisch) & 99.89 & 0.11 \\
\hline dunlipharder & Marien (Pelagisch) & 99.94 & 0.04 \\
\hline marmergrondel* & Eurytoop (Bentisch) & 99.97 & 0.04 \\
\hline aal & Eurytoop (Bentisch) & 100 & 0.03 \\
\hline & & &
\end{tabular}

Tabel 2. Soortensamenstelling in percentages op basis van biomassa in boomkorvangsten in de hoofdstroom van het Zoommeer per 5-jarige periode. De groepering geeft de ecologische indeling aan de hand van Noble et al. (2007) aan. Het cumulatief percentage geeft aan hoeveel de soorten over de gehele periode voorkomen op basis van de gesommeerde CPUE op basis van de biomassa. Nulpercentages zijn naar beneden afgeronde waarden, $*$ exoot.

\begin{tabular}{rrrr}
\hline & Groepering & $\begin{array}{r}\text { Cumulatief } \\
\text { percentage }\end{array}$ & $\begin{array}{r}2015- \\
2019\end{array}$ \\
\hline Soort & Eurytoop (Pelagisch) & 52.33 & 52.33 \\
\hline baars & Eurytoop (Bentisch) & 89.31 & 36.98 \\
\hline brasem & Eurytoop (Bentisch) & 95.03 & 5.72 \\
\hline snoekbaars & Eurytoop (Pelagisch) & 97.22 & 2.19 \\
\hline snoek & Eurytoop (Bentisch) & 98.15 & 0.93 \\
\hline aal & Eurytoop (Pelagisch) & 99.03 & 0.87 \\
\hline blankvoorn & Eurytoop (Bentisch) & 99.59 & 0.56 \\
\hline zwartbekgrondel* & Eurytoop (Bentisch) & 99.8 & 0.21 \\
\hline pos & Eurytoop (Pelagisch) & 99.92 & 0.13 \\
\hline spiering & Limnofiel (Bentisch) & 99.98 & 0.06 \\
\hline bot & Eurytoop (Pelagisch) & 100 & 0.02 \\
\hline driedoornige stekelbaars & Eurytoop (Bentisch) & 100 & 0 \\
\hline marmergrondel* & Marien (Pelagisch) & 100 & 0 \\
\hline dunlipharder & &
\end{tabular}


Tabel 3. Soortensamenstelling in percentages op basis van aantal in schepnetvangsten in de hoofdstroom van het Zoommeer per 5-jarige periode. De groepering geeft de ecologische indeling aan de hand van Noble et al. (2007) aan. Het cumulatief percentage geeft aan hoeveel de soorten over de gehele periode voorkomen op basis van de gesommeerde CPUE op basis van het aantal. Nul-percentages zijn naar beneden afgeronde waarden, $*=$ exoot.

\begin{tabular}{rrrr} 
& Groepering & $\begin{array}{r}\text { Cumulatief } \\
\text { percentage }\end{array}$ & $\begin{array}{r}2015- \\
2019\end{array}$ \\
\hline Swartbekgrt & & 54.94 & 54.94 \\
\hline aal & Eurytoop (Bentisch) & 92.8 & 37.85 \\
\hline baars & Eurytoop (Bentisch) & 97.17 & 4.38 \\
\hline bot & Eurytoop (Pelagisch) & 99.38 & 2.21 \\
\hline blankvoorn & Limnofiel (Bentisch) & 100 & 0.62 \\
\hline
\end{tabular}

Tabel 4. Soortensamenstelling in percentages op basis van biomassa in schepnetvangsten in de hoofdstroom van het Zoommeer per 5-jarige periode. De groepering geeft de ecologische indeling aan de hand van Noble et al. (2007) aan. Het cumulatief percentage geeft aan hoeveel de soorten over de gehele periode voorkomen op basis van de gesommeerde CPUE op basis van de biomassa. Nulpercentages zijn naar beneden afgeronde waarden, $*$ = exoot.

\begin{tabular}{rrrr}
\hline Soort & Groepering & $\begin{array}{r}\text { Cumulatief } \\
\text { percentage }\end{array}$ & $\begin{array}{r}2015- \\
2019\end{array}$ \\
\hline aal & Eurytoop (Bentisch) & 86.47 & 86.47 \\
\hline zwartbekgrondel* & Eurytoop (Bentisch) & 97.63 & 11.15 \\
\hline bot & Limnofiel (Bentisch) & 98.75 & 1.12 \\
\hline baars & Eurytoop (Pelagisch) & 99.84 & 1.1 \\
\hline blankvoorn & Eurytoop (Pelagisch) & 100 & 0.16 \\
\hline
\end{tabular}




\section{Bijlage 45 Zoommeer zijwateren}

Tabel 1. Soortensamenstelling in percentages op basis van aantal in schepnetvangsten in de zijwateren van het Zoommeer per 5-jarige periode. De groepering geeft de ecologische indeling aan de hand van Noble et al. (2007) aan. Het cumulatief percentage geeft aan hoeveel de soorten over de gehele periode voorkomen op basis van de gesommeerde CPUE op basis van het aantal. Nul-percentages zijn naar beneden afgeronde waarden, $*$ =xoot.

\begin{tabular}{rrrr}
\hline Soort & Groepering & $\begin{array}{r}\text { Cumulatief } \\
\text { percentage }\end{array}$ & $\begin{array}{r}2015- \\
2019\end{array}$ \\
\hline zwartbekgrondel* & Eurytoop (Bentisch) & 48.02 & 48.02 \\
\hline aal & Eurytoop (Bentisch) & 80.91 & 32.89 \\
\hline winde & Rheofiel (Pelagisch) & 90 & 9.1 \\
\hline marmergrondel* & Eurytoop (Bentisch) & 94.82 & 4.82 \\
\hline baars & Eurytoop (Pelagisch) & 98.71 & 3.88 \\
\hline roofblei* & Rheofiel (Pelagisch) & 100 & 1.29 \\
\hline
\end{tabular}

Tabel 2. Soortensamenstelling in percentages op basis van biomassa in schepnetvangsten in de zijwateren van het Zoommeer per 5-jarige periode. De groepering geeft de ecologische indeling aan de hand van Noble et al. (2007) aan. Het cumulatief percentage geeft aan hoeveel de soorten over de gehele periode voorkomen op basis van de gesommeerde CPUE op basis van de biomassa. Nulpercentages zijn naar beneden afgeronde waarden, * = exoot.

\begin{tabular}{rrrr}
\hline & Groepering & $\begin{array}{r}\text { Cumulatief } \\
\text { percentage }\end{array}$ & $\begin{array}{r}2015- \\
2019\end{array}$ \\
\hline Soort & Eurytoop (Bentisch) & 87.49 & 87.49 \\
\hline aal & Eurytoop (Bentisch) & 95.08 & 7.59 \\
\hline zwartbekgrondel* & Rheofiel (Pelagisch) & 98.98 & 3.91 \\
\hline winde & Rheofiel (Pelagisch) & 99.61 & 0.63 \\
\hline roofblei* & Eurytoop (Pelagisch) & 99.89 & 0.28 \\
\hline baars & Eurytoop (Bentisch) & 100 & 0.11 \\
\hline marmergrondel* & & 100
\end{tabular}




\section{Bijlage 46 Volkerak hoofdstroom}

Tabel 1. Soortensamenstelling in percentages op basis van aantal in boomkorvangsten in de hoofdstroom van het Volkerak per 5-jarige periode. De groepering geeft de ecologische indeling aan de hand van Noble et al. (2007) aan. Het cumulatief percentage geeft aan hoeveel de soorten over de gehele periode voorkomen op basis van de gesommeerde CPUE op basis van het aantal. Nul-percentages zijn naar beneden afgeronde waarden, $*$ =xoot.

\begin{tabular}{|c|c|c|c|c|c|}
\hline Soort & Groepering & $\begin{array}{l}\text { Cumulatief } \\
\text { percentage }\end{array}$ & $\begin{array}{r}2005- \\
2009 \\
\end{array}$ & $\begin{array}{r}2010- \\
2014 \\
\end{array}$ & $\begin{array}{r}2015- \\
2019 \\
\end{array}$ \\
\hline baars & Eurytoop (Pelagisch) & 75.22 & 2.49 & 83.54 & 74.66 \\
\hline zwartbekgrondel* & Eurytoop (Bentisch) & 90.26 & - & 8.8 & 16.85 \\
\hline snoekbaars & Eurytoop (Bentisch) & 92.93 & 12.93 & 4.75 & 1.96 \\
\hline blankvoorn & Eurytoop (Pelagisch) & 95.42 & 10.71 & 0.19 & 2.89 \\
\hline pos & Eurytoop (Bentisch) & 97.82 & 25.88 & 1.36 & 2.18 \\
\hline brasem & Eurytoop (Bentisch) & 98.98 & 34.43 & 0.71 & 0.6 \\
\hline bot & Limnofiel (Bentisch) & 99.39 & 2.59 & 0.34 & 0.37 \\
\hline spiering & Eurytoop (Pelagisch) & 99.55 & 0.62 & 0.15 & 0.16 \\
\hline kolblei & Eurytoop (Bentisch) & 99.69 & 8.85 & - & \\
\hline haring/sprot & Marien (Pelagisch) & 99.78 & - & - & 0.11 \\
\hline winde & Rheofiel (Pelagisch) & 99.84 & 0.69 & 0.02 & 0.06 \\
\hline snoek & Eurytoop (Pelagisch) & 99.89 & - & - & 0.07 \\
\hline aal & Eurytoop (Bentisch) & 99.93 & 0.09 & 0.09 & 0.03 \\
\hline driedoornige stekelbaars & Eurytoop (Pelagisch) & 99.96 & 0.4 & 0.07 & 0.01 \\
\hline pontische stroomgrondel* & Eurytoop (Bentisch) & 99.98 & - & - & 0.03 \\
\hline kleine modderkruiper & Eurytoop (Bentisch) & 99.99 & - & - & 0.01 \\
\hline hybride cyprinide & Eurytoop (Bentisch) & 100 & 0.19 & - & \\
\hline grondel sp. & Marien (Bentisch) & 100 & 0.13 & - & \\
\hline sneep & Rheofiel (Bentisch) & 100 & - & - & 0 \\
\hline
\end{tabular}

Tabel 2. Soortensamenstelling in percentages op basis van biomassa in boomkorvangsten in de hoofdstroom van het Volkerak per 5-jarige periode. De groepering geeft de ecologische indeling aan de hand van Noble et al. (2007) aan. Het cumulatief percentage geeft aan hoeveel de soorten over de gehele periode voorkomen op basis van de gesommeerde CPUE op basis van de biomassa. Nulpercentages zijn naar beneden afgeronde waarden, $*=$ exoot.

\begin{tabular}{|c|c|c|c|c|c|}
\hline Soort & Groepering & $\begin{array}{l}\text { Cumulatief } \\
\text { percentage }\end{array}$ & $\begin{array}{r}2005- \\
2009 \\
\end{array}$ & $\begin{array}{r}2010- \\
2014 \\
\end{array}$ & $\begin{array}{r}2015- \\
2019 \\
\end{array}$ \\
\hline baars & Eurytoop (Pelagisch) & 48.08 & 3.13 & 53.69 & 57.01 \\
\hline brasem & Eurytoop (Bentisch) & 65.71 & 51.39 & 24.05 & 9.01 \\
\hline snoekbaars & Eurytoop (Bentisch) & 76.95 & 18.79 & 13.55 & 9.17 \\
\hline zwartbekgrondel* & Eurytoop (Bentisch) & 84.98 & - & 4.06 & 10.51 \\
\hline snoek & Eurytoop (Pelagisch) & 89.58 & - & - & 6.44 \\
\hline blankvoorn & Eurytoop (Pelagisch) & 93.8 & 6.27 & 0.99 & 4.36 \\
\hline kolblei & Eurytoop (Bentisch) & 96.51 & 17.12 & - & \\
\hline pos & Eurytoop (Bentisch) & 98.2 & 1.51 & 1.22 & 1.82 \\
\hline aal & Eurytoop (Bentisch) & 98.95 & 0 & 1.66 & 0.75 \\
\hline bot & Limnofiel (Bentisch) & 99.62 & 0.62 & 0.7 & 0.67 \\
\hline winde & Rheofiel (Pelagisch) & 99.86 & 1.1 & 0.01 & 0.09 \\
\hline spiering & Eurytoop (Pelagisch) & 99.94 & 0.03 & 0.07 & 0.09 \\
\hline haring/sprot & Marien (Pelagisch) & 99.97 & - & - & 0.05 \\
\hline pontische stroomgrondel* & Eurytoop (Bentisch) & 99.99 & - & - & 0.03 \\
\hline hybride cyprinide & Eurytoop (Bentisch) & 99.99 & 0.02 & - & \\
\hline driedoornige stekelbaars & Eurytoop (Pelagisch) & 100 & 0.01 & 0 & 0 \\
\hline kleine modderkruiper & Eurytoop (Bentisch) & 100 & - & - & 0 \\
\hline sneep & Rheofiel (Bentisch) & 100 & - & - & 0 \\
\hline grondel sp. & Marien (Bentisch) & 100 & 0 & - & - \\
\hline
\end{tabular}


Tabel 3. Soortensamenstelling in percentages op basis van aantal in schepnetvangsten in de hoofdstroom van het Volkerak per 5-jarige periode. De groepering geeft de ecologische indeling aan de hand van Noble et al. (2007) aan. Het cumulatief percentage geeft aan hoeveel de soorten over de gehele periode voorkomen op basis van de gesommeerde CPUE op basis van het aantal. Nul-percentages zijn naar beneden afgeronde waarden, $*=$ exoot.

\begin{tabular}{|c|c|c|c|c|c|}
\hline Soort & Groepering & $\begin{array}{l}\text { Cumulatief } \\
\text { percentage }\end{array}$ & $\begin{array}{r}2005- \\
2009 \\
\end{array}$ & $\begin{array}{r}2010- \\
2014 \\
\end{array}$ & $\begin{array}{r}2015- \\
2019 \\
\end{array}$ \\
\hline zwartbekgrondel* & Eurytoop (Bentisch) & 63.59 & 1.7 & 65.86 & 55.85 \\
\hline aal & Eurytoop (Bentisch) & 84.66 & 82.15 & 18.13 & 36.1 \\
\hline baars & Eurytoop (Pelagisch) & 93.34 & 3.99 & 9.28 & 3.54 \\
\hline blankvoorn & Eurytoop (Pelagisch) & 96.91 & - & 4 & \\
\hline winde & Rheofiel (Pelagisch) & 97.5 & - & 0.56 & 1 \\
\hline karper & Eurytoop (Bentisch) & 97.95 & - & 0.43 & 0.84 \\
\hline rietvoorn & Limnofiel (Pelagisch) & 98.33 & - & 0.42 & - \\
\hline driedoornige stekelbaars & Eurytoop (Pelagisch) & 98.68 & 3.49 & 0.31 & - \\
\hline rivierdonderpad & Rheofiel (Bentisch) & 98.89 & 2.45 & 0.17 & \\
\hline brasem & Eurytoop (Bentisch) & 99.05 & - & 0.18 & \\
\hline snoek & Eurytoop (Pelagisch) & 99.21 & 0.66 & 0.12 & 0.5 \\
\hline marmergrondel* & Eurytoop (Bentisch) & 99.37 & - & 0.1 & 0.84 \\
\hline kleine modderkruiper & Eurytoop (Bentisch) & 99.52 & - & 0.16 & \\
\hline giebel & Eurytoop (Bentisch) & 99.65 & 2.15 & 0.1 & \\
\hline snoekbaars & Eurytoop (Bentisch) & 99.75 & - & 0.11 & \\
\hline bot & Limnofiel (Bentisch) & 99.84 & 1.13 & 0.03 & 0.5 \\
\hline pos & Eurytoop (Bentisch) & 99.91 & - & - & 0.84 \\
\hline harders indet. & Marien (Pelagisch & 99.96 & 2.27 & - & \\
\hline roofblei* & Rheofiel (Pelagisch) & 100 & - & 0.05 & \\
\hline
\end{tabular}

Tabel 4. Soortensamenstelling in percentages op basis van biomassa in schepnetvangsten in de hoofdstroom van het Volkerak per 5-jarige periode. De groepering geeft de ecologische indeling aan de hand van Noble et al. (2007) aan. Het cumulatief percentage geeft aan hoeveel de soorten over de gehele periode voorkomen op basis van de gesommeerde CPUE op basis van de biomassa. Nulpercentages zijn naar beneden afgeronde waarden, * = exoot.

\begin{tabular}{|c|c|c|c|c|c|}
\hline Soort & Groepering & $\begin{array}{l}\text { Cumulatief } \\
\text { percentage }\end{array}$ & $\begin{array}{r}2005- \\
2009\end{array}$ & $\begin{array}{r}2010- \\
2014\end{array}$ & $\begin{array}{r}2015- \\
2019\end{array}$ \\
\hline aal & Eurytoop (Bentisch) & 51.9 & 67.27 & 54.28 & 44.35 \\
\hline karper & Eurytoop (Bentisch) & 81.55 & - & 24.43 & 45.48 \\
\hline zwartbekgrondel* & Eurytoop (Bentisch) & 88.16 & 0.69 & 9.58 & 1.53 \\
\hline winde & Rheofiel (Pelagisch) & 94.02 & - & 6.24 & 6.09 \\
\hline brasem & Eurytoop (Bentisch) & 95.81 & - & 2.8 & - \\
\hline baars & Eurytoop (Pelagisch) & 96.93 & 0.27 & 1.69 & 0.1 \\
\hline snoek & Eurytoop (Pelagisch) & 97.86 & 8.05 & 0.39 & 0.81 \\
\hline harders indet. & Overige & 98.72 & 16.28 & - & \\
\hline bot & Limnofiel (Bentisch) & 99.24 & 0.31 & 0.01 & 1.61 \\
\hline giebel & Eurytoop (Bentisch) & 99.62 & 6.95 & 0.01 & \\
\hline blankvoorn & Eurytoop (Pelagisch) & 99.95 & - & 0.51 & \\
\hline rivierdonderpad & Rheofiel (Bentisch) & 99.96 & 0.1 & 0.01 & \\
\hline snoekbaars & Eurytoop (Bentisch) & 99.97 & - & 0.01 & \\
\hline pos & Eurytoop (Bentisch) & 99.98 & - & - & 0.03 \\
\hline driedoornige stekelbaars & Eurytoop (Pelagisch) & 99.98 & 0.08 & 0 & \\
\hline kleine modderkruiper & Eurytoop (Bentisch) & 99.99 & - & 0.01 & - \\
\hline marmergrondel* & Eurytoop (Bentisch) & 99.99 & - & 0 & 0.01 \\
\hline rietvoorn & Limnofiel (Pelagisch) & 100 & - & 0.01 & \\
\hline roofblei* & Rheofiel (Pelagisch) & 100 & - & 0 & - \\
\hline
\end{tabular}




\section{Bijlage 47 Volkerak zijwateren}

Tabel 1. Soortensamenstelling in percentages op basis van aantal in boomkorvangsten in de zijwateren van het Volkerak per 5-jarige periode. De groepering geeft de ecologische indeling aan de hand van Noble et al. (2007) aan. Het cumulatief percentage geeft aan hoeveel de soorten over de gehele periode voorkomen op basis van de gesommeerde CPUE op basis van het aantal. Nul-percentages zijn naar beneden afgeronde waarden, $*$ =xoot.

\begin{tabular}{rrrrr} 
Soort & Groepering & Cumulatief & $2010-$ & $2015-$ \\
percentage & 2014 & 2019 \\
baars & Eurytoop (Pelagisch) & 52.67 & 89.52 & 38.19 \\
\hline zwartbekgrondel* & Eurytoop (Bentisch) & 76.1 & 4.03 & 31.06 \\
\hline bot & Limnofiel (Bentisch) & 88.1 & 6.45 & 14.17 \\
\hline haring/sprot & Marien (Pelagisch) & 97.39 & - & 12.95 \\
\hline snoekbaars & Eurytoop (Bentisch) & 98.97 & - & 2.19 \\
\hline aal & Eurytoop (Bentisch) & 99.17 & - & 0.29 \\
\hline blankvoorn & Eurytoop (Pelagisch) & 99.38 & - & 0.29 \\
\hline driedoornige stekelbars & Eurytoop (Pelagisch) & 99.59 & - & 0.29 \\
\hline pos & Eurytoop (Bentisch) & 99.79 & - & 0.29 \\
\hline snoek & Eurytoop (Pelagisch) & 100 & - & 0.29 \\
\hline & & & &
\end{tabular}

Tabel 2. Soortensamenstelling in percentages op basis van biomassa in boomkorvangsten in de zijwateren van het Volkerak per 5-jarige periode. De groepering geeft de ecologische indeling aan de hand van Noble et al. (2007) aan. Het cumulatief percentage geeft aan hoeveel de soorten over de gehele periode voorkomen op basis van de gesommeerde CPUE op basis van de biomassa. Nulpercentages zijn naar beneden afgeronde waarden, $*$ = exoot.

\begin{tabular}{rrrrr}
\hline Soort & Groepering & Cumulatief & $2010-$ & $2015-$ \\
percentage & 2014 & 2019 \\
baars & Eurytoop (Pelagisch) & 58.7 & 96.32 & 46.82 \\
\hline snoekbaars & Eurytoop (Bentisch) & 68.52 & - & 12.92 \\
\hline zwartbekgrondel* & Eurytoop (Bentisch) & 77.65 & 1.15 & 11.64 \\
\hline bot & Limnofiel (Bentisch) & 85.22 & 2.52 & 9.18 \\
\hline snoek & Eurytoop (Pelagisch) & 91.79 & - & 8.64 \\
\hline aal & Eurytoop (Bentisch) & 97.41 & - & 7.41 \\
\hline haring/sprot & Marien (Pelagisch) & 99.7 & - & 3 \\
\hline pos & Eurytoop (Bentisch) & 99.85 & - & 0.21 \\
\hline blankvoorn & Eurytoop (Pelagisch) & 99.99 & - & 0.18 \\
\hline driedoornige stekelbaars & Eurytoop (Pelagisch) & 100 & - & 0.01 \\
\hline & & & &
\end{tabular}


Tabel 3. Soortensamenstelling in percentages op basis van aantal in schepnetvangsten in de zijwateren van het Volkerak per 5-jarige periode. De groepering geeft de ecologische indeling aan de hand van Noble et al. (2007) aan. Het cumulatief percentage geeft aan hoeveel de soorten over de gehele periode voorkomen op basis van de gesommeerde CPUE op basis van het aantal. Nul-percentages zijn naar beneden afgeronde waarden, $*=$ exoot.

\begin{tabular}{|c|c|c|c|c|c|}
\hline Soort & Groepering & $\begin{array}{l}\text { Cumulatief } \\
\text { percentage }\end{array}$ & $\begin{array}{r}2005- \\
2009 \\
\end{array}$ & $\begin{array}{r}2010- \\
2014 \\
\end{array}$ & $\begin{array}{r}2015- \\
2019 \\
\end{array}$ \\
\hline zwartbekgrondel* & Eurytoop (Bentisch) & 43.47 & - & 36.43 & 75.44 \\
\hline aal & Eurytoop (Bentisch) & 71.91 & 84.62 & 27.34 & 24.56 \\
\hline baars & Eurytoop (Pelagisch) & 82.76 & - & 14.22 & - \\
\hline blankvoorn & Eurytoop (Pelagisch) & 91.64 & - & 11.63 & - \\
\hline winde & Rheofiel (Pelagisch) & 98.83 & - & 9.43 & - \\
\hline rivierdonderpad & Rheofiel (Bentisch) & 99.28 & 15.38 & - & - \\
\hline brakwatergrondel & Marien (Bentisch) & 99.52 & - & 0.31 & \\
\hline brasem & Eurytoop (Bentisch) & 99.76 & - & 0.31 & \\
\hline roofblei* & Rheofiel (Pelagisch) & 100 & - & 0.31 & - \\
\hline
\end{tabular}

Tabel 4. Soortensamenstelling in percentages op basis van biomassa in schepnetvangsten in de zijwateren van het Volkerak per 5-jarige periode. De groepering geeft de ecologische indeling aan de hand van Noble et al. (2007) aan. Het cumulatief percentage geeft aan hoeveel de soorten over de gehele periode voorkomen op basis van de gesommeerde CPUE op basis van de biomassa. Nulpercentages zijn naar beneden afgeronde waarden, * = exoot.

\begin{tabular}{|c|c|c|c|c|c|}
\hline Soort & Groepering & $\begin{array}{l}\text { Cumulatief } \\
\text { percentage }\end{array}$ & $\begin{array}{r}2005- \\
2009 \\
\end{array}$ & $\begin{array}{r}2010- \\
2014 \\
\end{array}$ & $\begin{array}{r}2015- \\
2019 \\
\end{array}$ \\
\hline aal & Eurytoop (Bentisch) & 85.6 & 98.44 & 83.43 & 89.14 \\
\hline zwartbekgrondel* & Eurytoop (Bentisch) & 93.63 & - & 7.53 & 10.86 \\
\hline baars & Eurytoop (Pelagisch) & 96.06 & - & 3.49 & - \\
\hline winde & Rheofiel (Pelagisch) & 98.24 & - & 3.12 & \\
\hline blankvoorn & Eurytoop (Pelagisch) & 99.82 & - & 2.27 & - \\
\hline roofblei* & Rheofiel (Pelagisch) & 99.9 & - & 0.11 & - \\
\hline rivierdonderpad & Rheofiel (Bentisch) & 99.97 & 1.56 & - & - \\
\hline brasem & Eurytoop (Bentisch) & 100 & - & 0.03 & \\
\hline brakwatergrondel & Marien (Bentisch) & 100 & - & 0.01 & - \\
\hline
\end{tabular}




\section{Bijlage 48 Veerse Meer hoofdstroom}

Tabel 1. Soortensamenstelling in percentages op basis van aantal in boomkorvangsten in de hoofdstroom van het Veerse Meer per 5-jarige periode. De groepering geeft de ecologische indeling aan de hand van Noble et al. (2007) aan. Het cumulatief percentage geeft aan hoeveel de soorten over de gehele periode voorkomen op basis van de gesommeerde CPUE op basis van het aantal. Nul-percentages zijn naar beneden afgeronde waarden, $*$ =xoot.

\begin{tabular}{rrrr} 
Soort & Groepering & $\begin{array}{r}\text { Cumulatief } \\
\text { percentage }\end{array}$ & $\begin{array}{r}2015- \\
2019\end{array}$ \\
\hline grondel sp. & Marien (Bentisch) & 58.65 & 58.65 \\
\hline koornaarvis sp. & Marien (Pelagisch) & 74.54 & 15.88 \\
\hline zwarte grondel & Marien (Bentisch) & 83.15 & 8.62 \\
\hline brakwatergrondel & Marien (Bentisch) & 91.29 & 8.14 \\
\hline haring/sprot & Marien (Pelagisch) & 98.4 & 7.11 \\
\hline bot & Limnofiel (Bentisch) & 98.76 & 0.36 \\
\hline schol & Marien (Bentisch) & 99.02 & 0.26 \\
\hline grote zeenaald & Marien (Bentisch) & 99.18 & 0.16 \\
\hline aal & Eurytoop (Bentisch) & 99.34 & 0.15 \\
\hline botervis & Marien (Pelagisch) & 99.48 & 0.14 \\
\hline blonde grondel & Marien (Bentisch) & 99.61 & 0.13 \\
\hline tong & Marien (Bentisch) & 99.69 & 0.08 \\
\hline Eurientoop (Pelagisch) & 99.74 & 0.06 \\
\hline puitaal & Marien (Bentisch) & 99.8 & 0.05 \\
\hline steenbolk & Marien (Bentisch) & 99.84 & 0.05 \\
\hline griet & Marien (Bentisch) & 99.87 & 0.03 \\
\hline wijting & Marien (Bentisch) & 99.9 & 0.03 \\
\hline schar & Marien (Bentisch) & 99.92 & 0.02 \\
\hline glasgrondel & Marien (Bentisch) & 99.94 & 0.02 \\
\hline tarbot & Marien (Bentisch) & 99.96 & 0.02 \\
\hline zeebaars & 99.97 & 0.01 \\
\hline zeedonderpad & Marien (Pelagisch) & 9.98 \\
\hline goudharder & Marien (Bentisch) & 0.01 \\
\hline dwergtong & Marien (Pelagisch) & 99.99 & 0.01 \\
\hline Meedonderpad & Marien (Bentisch) & 99.99 & 0.01 \\
\hline & Marien (Bentisch) & 100 & 0.01 \\
\hline
\end{tabular}


Tabel 2. Soortensamenstelling in percentages op basis van biomassa in boomkorvangsten in de hoofdstroom van het Veerse Meer per 5-jarige periode. De groepering geeft de ecologische indeling aan de hand van Noble et al. (2007) aan. Het cumulatief percentage geeft aan hoeveel de soorten over de gehele periode voorkomen op basis van de gesommeerde CPUE op basis van de biomassa. Nulpercentages zijn naar beneden afgeronde waarden, $*=$ exoot.

\begin{tabular}{rrrr}
\hline & Groepering & $\begin{array}{r}\text { Cumulatief } \\
\text { percentage }\end{array}$ & $\begin{array}{r}2015- \\
2019\end{array}$ \\
Soort & Marien (Bentisch) & 35.62 & 35.62 \\
\hline grondel sp. & Limnofiel (Bentisch) & 49.33 & 13.71 \\
\hline bot & Eurytoop (Bentisch) & 57.41 & 8.08 \\
\hline aal & Marien (Pelagisch) & 64.43 & 7.02 \\
\hline koornaarvis sp. & Marien (Bentisch) & 71.44 & 7.01 \\
\hline zwarte grondel & Marien (Pelagisch) & 78.41 & 6.98 \\
\hline haring/sprot & Marien (Bentisch) & 84.52 & 6.1 \\
\hline tarbot & Marien (Bentisch) & 88.8 & 4.28 \\
\hline schol & Marien (Bentisch) & 92.79 & 4 \\
\hline griet & Marien (Bentisch) & 96.71 & 3.92 \\
\hline brakwatergrondel & Marien (Bentisch) & 98.06 & 1.35 \\
\hline steenbolk & Marien (Bentisch) & 98.75 & 0.68 \\
\hline wijting & Marien (Bentisch) & 99.29 & 0.54 \\
\hline tong & Marien (Bentisch) & 99.54 & 0.25 \\
\hline puitaal & Marien (Bentisch) & 99.74 & 0.2 \\
\hline grote zeenaald & Marien (Pelagisch) & 99.84 & 0.1 \\
\hline botervis & Marien (Bentisch) & 99.88 & 0.04 \\
\hline blonde grondel & Marien (Bentisch) & 99.9 & 0.03 \\
\hline schar & Marien (Bentisch) & 99.93 & 0.03 \\
\hline groene & Marien (Pelagisch) & 99.95 & 0.02 \\
\hline zeedonderpad & Marien (Bentisch) & 99.97 & 0.02 \\
\hline zeebaars & Eurytoop (Pelagisch) & 99.99 & 0.01 \\
\hline zeedonderpad & Marien (Bentisch) & 99.99 & 0.01 \\
\hline driedoornige stekelbaars & Marien (Bentisch) & 100 & 0 \\
\hline glasgrondel & Marien (Pelagisch) & 100 & 0 \\
\hline goudharder & & 0 \\
\hline
\end{tabular}




\section{Bijlage 49 Grevelingenmeer hoofdstroom}

Tabel 1. Soortensamenstelling in percentages op basis van aantal in boomkorvangsten in de hoofdstroom van het Grevelingenmeer per 5-jarige periode. De groepering geeft de ecologische indeling aan de hand van Noble et al. (2007) aan. Het cumulatief percentage geeft aan hoeveel de soorten over de gehele periode voorkomen op basis van de gesommeerde CPUE op basis van het aantal. Nul-percentages zijn naar beneden afgeronde waarden, $*$ = exoot.

\begin{tabular}{|c|c|c|c|c|c|}
\hline Soort & Groepering & $\begin{array}{l}\text { Cumulatief } \\
\text { percentage }\end{array}$ & $\begin{array}{r}2005- \\
2009 \\
\end{array}$ & $\begin{array}{r}2010- \\
2014 \\
\end{array}$ & $\begin{array}{r}2015- \\
2019 \\
\end{array}$ \\
\hline haring/sprot & Marien (Pelagisch) & 52.99 & 2.96 & 1.2 & 59.58 \\
\hline grondel sp. & Marien (Bentisch) & 75.18 & 37.87 & 55.74 & 19.21 \\
\hline koornaarvis sp. & Marien (Pelagisch) & 90.58 & 0.15 & - & 17.39 \\
\hline zwarte grondel & Marien (Bentisch) & 93.15 & 24.49 & 15.76 & 0.18 \\
\hline driedoornige stekelbaars & Eurytoop (Pelagisch) & 94.68 & - & 0.11 & 1.73 \\
\hline schol & Marien (Bentisch) & 96.16 & 12.95 & 10.81 & 0.1 \\
\hline brakwatergrondel & Marien (Bentisch) & 97.01 & - & 2.8 & 0.81 \\
\hline tong & Marien (Bentisch) & 97.67 & 9.43 & 0.34 & - \\
\hline schar & Marien (Bentisch) & 98.21 & 6.89 & 1.3 & 0.01 \\
\hline zeebaars & Marien (Pelagisch) & 98.72 & 0.64 & - & 0.53 \\
\hline grote zeenaald & Marien (Bentisch) & 99.02 & 0.2 & 0.62 & 0.29 \\
\hline puitaal & Marien (Bentisch) & 99.26 & - & 4.97 & 0.01 \\
\hline botervis & Marien (Pelagisch) & 99.45 & 0.07 & 3.6 & 0.01 \\
\hline glasgrondel & Marien (Bentisch) & 99.58 & 1.66 & - & 0.02 \\
\hline bot & Limnofiel (Bentisch) & 99.7 & 0.46 & 0.36 & 0.09 \\
\hline zeedonderpad & Marien (Bentisch) & 99.78 & 0.06 & 1.31 & 0.02 \\
\hline kleine zeenaald & Marien (Bentisch) & 99.82 & 0.38 & 0.34 & - \\
\hline vijfdradige meun & Marien (Bentisch) & 99.86 & 0.28 & 0.23 & 0.01 \\
\hline griet & Marien (Bentisch) & 99.89 & 0.45 & - & - \\
\hline steenbolk & Marien (Bentisch) & 99.91 & 0.31 & - & - \\
\hline spiering & Eurytoop (Pelagisch) & 99.93 & - & 0.24 & 0.01 \\
\hline wijting & Marien (Bentisch) & 99.94 & 0.23 & - & - \\
\hline tarbot & Marien (Bentisch) & 99.95 & 0.19 & - & - \\
\hline dwergtong & Marien (Bentisch) & 99.96 & 0.14 & - & - \\
\hline zandspiering sp. & Marien (Bentisch) & 99.97 & - & 0.13 & - \\
\hline ansjovis & Marien (Pelagisch) & 99.98 & - & 0.13 & - \\
\hline pitvis & Marien (Bentisch) & 99.98 & 0.09 & - & - \\
\hline adderzeenaald & Marien (Bentisch) & 99.99 & - & - & 0.01 \\
\hline goudharder & Marien (Pelagisch) & 99.99 & - & - & 0.01 \\
\hline kabeljauw & Marien (Bentisch) & 100 & 0.07 & - & - \\
\hline aal & Eurytoop (Bentisch) & 100 & 0.04 & - & - \\
\hline
\end{tabular}


Tabel 2. Soortensamenstelling in percentages op basis van biomassa in boomkorvangsten in de hoofdstroom van het Grevelingenmeer per 5-jarige periode. De groepering geeft de ecologische indeling aan de hand van Noble et al. (2007) aan. Het cumulatief percentage geeft aan hoeveel de soorten over de gehele periode voorkomen op basis van de gesommeerde CPUE op basis van de biomassa. Nulpercentages zijn naar beneden afgeronde waarden, * = exoot.

\begin{tabular}{|c|c|c|c|c|c|}
\hline Soort & Groepering & $\begin{array}{l}\text { Cumulatief } \\
\text { percentage }\end{array}$ & $\begin{array}{r}2005- \\
2009 \\
\end{array}$ & $\begin{array}{r}2010- \\
2014 \\
\end{array}$ & $\begin{array}{r}2015- \\
2019 \\
\end{array}$ \\
\hline haring/sprot & Marien (Pelagisch) & 59.76 & 1.24 & 1.36 & 81.21 \\
\hline grondel sp. & Marien (Bentisch) & 69.71 & 4.08 & 13.45 & 11.48 \\
\hline tarbot & Marien (Bentisch) & 75.88 & 28.05 & - & - \\
\hline schol & Marien (Bentisch) & 81.95 & 19.89 & 31.43 & 0.25 \\
\hline griet & Marien (Bentisch) & 86.71 & 21.65 & - & - \\
\hline koornaarvis sp. & Marien (Pelagisch) & 89.73 & 0.04 & - & 4.11 \\
\hline tong & Marien (Bentisch) & 92.21 & 11.25 & 0.24 & - \\
\hline zwarte grondel & Marien (Bentisch) & 93.82 & 4.92 & 8.17 & 0.18 \\
\hline zeebaars & Marien (Pelagisch) & 94.93 & 1.17 & - & 1.17 \\
\hline zeedonderpad & Marien (Bentisch) & 96.02 & 0.37 & 19.51 & 0.08 \\
\hline schar & Marien (Bentisch) & 96.79 & 2.31 & 5.2 & 0.02 \\
\hline bot & Limnofiel (Bentisch) & 97.49 & 0.94 & 0.93 & 0.62 \\
\hline puitaal & Marien (Bentisch) & 97.94 & - & 8.67 & 0.04 \\
\hline botervis & Marien (Pelagisch) & 98.37 & 0.04 & 8.62 & 0.01 \\
\hline steenbolk & Marien (Bentisch) & 98.75 & 1.7 & - & \\
\hline driedoornige stekelbaars & Eurytoop (Pelagisch) & 99.05 & - & 0.03 & 0.41 \\
\hline wijting & Marien (Bentisch) & 99.25 & 0.93 & - & - \\
\hline vijfdradige meun & Marien (Bentisch) & 99.43 & 0.57 & 0.79 & 0.03 \\
\hline brakwatergrondel & Marien (Bentisch) & 99.59 & - & 0.7 & 0.16 \\
\hline grote zeenaald & Marien (Bentisch) & 99.72 & 0.17 & 0.03 & 0.13 \\
\hline kabeljauw & Marien (Bentisch) & 99.84 & 0.52 & - & - \\
\hline adderzeenaald & Marien (Bentisch) & 99.9 & - & - & 0.08 \\
\hline spiering & Eurytoop (Pelagisch) & 99.93 & - & 0.38 & 0.02 \\
\hline ansjovis & Marien (Pelagisch) & 99.95 & - & 0.42 & - \\
\hline glasgrondel & Marien (Bentisch) & 99.97 & 0.08 & - & 0 \\
\hline pitvis & Marien (Bentisch) & 99.98 & 0.05 & - & - \\
\hline dwergtong & Marien (Bentisch) & 99.99 & 0.02 & - & - \\
\hline aal & Eurytoop (Bentisch) & 99.99 & 0.02 & - & - \\
\hline kleine zeenaald & Marien (Bentisch) & 100 & 0.01 & 0.02 & - \\
\hline zandspiering sp. & Marien (Bentisch) & 100 & - & 0.06 & \\
\hline goudharder & Marien (Pelagisch) & 100 & - & - & 0 \\
\hline
\end{tabular}




\section{Bijlage 50 Nieuwe Waterweg hoofdstroom}

Tabel 1. Soortensamenstelling in percentages op basis van aantal in boomkorvangsten in de hoofdstroom van de Nieuwe Waterweg per 5-jarige periode. De groepering geeft de ecologische indeling aan de hand van Noble et al. (2007) aan. Het cumulatief percentage geeft aan hoeveel de soorten over de gehele periode voorkomen op basis van de gesommeerde CPUE op basis van het aantal. Nul-percentages zijn naar beneden afgeronde waarden, $*$ exoot.

\begin{tabular}{|c|c|c|c|c|}
\hline Soort & Groepering & $\begin{array}{l}\text { Cumulatief } \\
\text { percentage }\end{array}$ & $\begin{array}{r}2010- \\
2014\end{array}$ & $\begin{array}{r}2015- \\
2019 \\
\end{array}$ \\
\hline schol & Marien (Bentisch) & 16.58 & 8.21 & 24.28 \\
\hline tong & Marien (Bentisch) & 30.7 & 11.83 & 16.22 \\
\hline steenbolk & Marien (Bentisch) & 44.44 & 8.18 & 18.85 \\
\hline wijting & Marien (Bentisch) & 58.02 & 15.44 & 11.87 \\
\hline grondel sp. & Marien (Bentisch) & 68.5 & 10.7 & 10.28 \\
\hline bot & Limnofiel (Bentisch) & 78.35 & 15.4 & 4.74 \\
\hline schar & Marien (Bentisch) & 86.46 & 11.3 & 5.18 \\
\hline spiering & Eurytoop (Pelagisch) & 89.3 & 4.02 & 1.74 \\
\hline zeedonderpad & Marien (Bentisch) & 90.92 & 2.78 & 0.56 \\
\hline harnasmannetje & Marien (Bentisch) & 92.48 & 2.86 & 0.37 \\
\hline zeebaars & Marien (Pelagisch) & 93.94 & 0.34 & 2.48 \\
\hline kabeljauw & Marien (Bentisch) & 95.18 & 2.34 & 0.24 \\
\hline vijfdradige meun & Marien (Bentisch) & 96.27 & 1.18 & 1.02 \\
\hline haring/sprot & Marien (Pelagisch) & 97.22 & 0.97 & 0.92 \\
\hline slakdolf & Marien (Bentisch) & 98.05 & 1.72 & 0.01 \\
\hline zwartbekgrondel* & Eurytoop (Bentisch) & 98.54 & 0.97 & 0.05 \\
\hline schurftvis & Marien (Bentisch) & 98.85 & 0.38 & 0.23 \\
\hline kleine zeenaald & Marien (Bentisch) & 99.06 & 0.24 & 0.19 \\
\hline aal & Eurytoop (Bentisch) & 99.27 & 0.11 & 0.3 \\
\hline botervis & Marien (Pelagisch) & 99.43 & 0.19 & 0.13 \\
\hline fint & Rheofiel (Pelagisch) & 99.52 & 0.18 & 0.01 \\
\hline grote zeenaald & Marien (Bentisch) & 99.59 & 0.1 & 0.04 \\
\hline driedoornige stekelbaars & Eurytoop (Pelagisch) & 99.65 & 0.09 & 0.05 \\
\hline rasterpitvis & Marien (Bentisch) & 99.7 & 0.1 & - \\
\hline glasgrondel & Marien (Bentisch) & 99.75 & 0.08 & 0.01 \\
\hline pitvis & Marien (Bentisch) & 99.78 & 0.04 & 0.02 \\
\hline kleine pieterman & Marien (Bentisch) & 99.8 & 0.04 & 0.01 \\
\hline rivierprik & Rheofiel (Bentisch) & 99.83 & 0.03 & 0.02 \\
\hline dunlipharder & Marien (Pelagisch) & 99.85 & - & 0.04 \\
\hline dwergtong & Marien (Bentisch) & 99.87 & 0.04 & - \\
\hline zandspiering sp. & Marien (Bentisch) & 99.89 & 0.02 & 0.01 \\
\hline puitaal & Marien (Bentisch) & 99.9 & 0.03 & \\
\hline zwarte grondel & Marien (Bentisch) & 99.91 & - & 0.02 \\
\hline griet & Marien (Bentisch) & 99.92 & 0.02 & 0.01 \\
\hline rode poon & Marien (Bentisch) & 99.94 & 0.02 & 0.01 \\
\hline vorskwab & Marien (Bentisch) & 99.95 & 0.02 & - \\
\hline zeeprik & Rheofiel (Bentisch) & 99.95 & 0.01 & 0.01 \\
\hline tarbot & Marien (Bentisch) & 99.96 & - & 0.01 \\
\hline brakwatergrondel & Marien (Bentisch) & 99.97 & - & 0.01 \\
\hline horsmakreel & Marien (Pelagisch) & 99.98 & - & 0.01 \\
\hline driedradige meun & Overige & 99.98 & 0.01 & - \\
\hline dwergbolk & Marien (Bentisch) & 99.99 & 0.01 & - \\
\hline tongschar & Marien (Bentisch) & 99.99 & 0.01 & - \\
\hline baars & Eurytoop (Pelagisch) & 99.99 & - & 0.01 \\
\hline gehoornde slijmvis & Marien (Bentisch) & 100 & - & 0.01 \\
\hline grauwe poon & Marien (Bentisch) & 100 & 0.01 & - \\
\hline
\end{tabular}


Tabel 2. Soortensamenstelling in percentages op basis van biomassa in boomkorvangsten in de hoofdstroom van de Nieuwe Waterweg per 5-jarige periode. De groepering geeft de ecologische indeling aan de hand van Noble et al. (2007) aan. Het cumulatief percentage geeft aan hoeveel de soorten over de gehele periode voorkomen op basis van de gesommeerde CPUE op basis van de biomassa. Nulpercentages zijn naar beneden afgeronde waarden, * = exoot.

\begin{tabular}{|c|c|c|c|c|}
\hline Soort & Groepering & $\begin{array}{l}\text { Cumulatief } \\
\text { percentage }\end{array}$ & $\begin{array}{r}2010- \\
2014\end{array}$ & $\begin{array}{r}2015- \\
2019\end{array}$ \\
\hline steenbolk & Marien (Bentisch) & 20.55 & 12.21 & 30.14 \\
\hline bot & Limnofiel (Bentisch) & 39.01 & 27.62 & 7.94 \\
\hline tong & Marien (Bentisch) & 53.82 & 14.96 & 14.63 \\
\hline schar & Marien (Bentisch) & 68.2 & 18.06 & 10.15 \\
\hline wijting & Marien (Bentisch) & 78.6 & 6.61 & 14.75 \\
\hline schol & Marien (Bentisch) & 83.17 & 1.98 & 7.55 \\
\hline kabeljauw & Marien (Bentisch) & 87.7 & 7.08 & 1.6 \\
\hline zeebaars & Marien (Pelagisch) & 91.93 & 1.16 & 7.77 \\
\hline zeedonderpad & Marien (Bentisch) & 95.48 & 5.7 & 1.08 \\
\hline spiering & Eurytoop (Pelagisch) & 96.71 & 1.63 & 0.77 \\
\hline aal & Eurytoop (Bentisch) & 97.9 & 0.65 & 1.8 \\
\hline vijfdradige meun & Marien (Bentisch) & 98.53 & 0.59 & 0.68 \\
\hline grondel sp. & Marien (Bentisch) & 98.92 & 0.32 & 0.48 \\
\hline harnasmannetje & Marien (Bentisch) & 99.15 & 0.37 & 0.06 \\
\hline slakdolf & Marien (Bentisch) & 99.37 & 0.39 & 0.03 \\
\hline zwartbekgrondel* & Eurytoop (Bentisch) & 99.51 & 0.22 & 0.05 \\
\hline haring/sprot & Marien (Pelagisch) & 99.62 & 0.09 & 0.13 \\
\hline schurftvis & Marien (Bentisch) & 99.7 & 0.09 & 0.06 \\
\hline griet & Marien (Bentisch) & 99.76 & 0.11 & 0.01 \\
\hline fint & Rheofiel (Pelagisch) & 99.81 & 0.03 & 0.07 \\
\hline botervis & Marien (Pelagisch) & 99.85 & 0.03 & 0.04 \\
\hline horsmakreel & Marien (Pelagisch) & 99.87 & - & 0.06 \\
\hline rivierprik & Rheofiel (Bentisch) & 99.9 & 0.02 & 0.03 \\
\hline tarbot & Marien (Bentisch) & 99.92 & - & 0.05 \\
\hline dunlipharder & Marien (Pelagisch) & 99.94 & - & 0.04 \\
\hline pitvis & Marien (Bentisch) & 99.96 & 0.01 & 0.01 \\
\hline kleine pieterman & Marien (Bentisch) & 99.96 & 0.01 & 0.01 \\
\hline puitaal & Marien (Bentisch) & 99.97 & 0.01 & - \\
\hline grote zeenaald & Marien (Bentisch) & 99.97 & 0 & 0.01 \\
\hline rasterpitvis & Marien (Bentisch) & 99.98 & 0.01 & - \\
\hline rode poon & Marien (Bentisch) & 99.98 & 0 & 0 \\
\hline dwergbolk & Marien (Bentisch) & 99.98 & 0 & - \\
\hline zandspiering sp. & Marien (Bentisch) & 99.99 & 0 & 0 \\
\hline kleine zeenaald & Marien (Bentisch) & 99.99 & 0 & 0 \\
\hline driedoornige stekelbaars & Eurytoop (Pelagisch) & 99.99 & 0 & 0 \\
\hline dwergtong & Marien (Bentisch) & 99.99 & 0 & - \\
\hline zeeprik & Rheofiel (Bentisch) & 99.99 & 0 & 0 \\
\hline zwarte grondel & Marien (Bentisch) & 100 & - & 0 \\
\hline vorskwab & Marien (Bentisch) & 100 & 0 & - \\
\hline baars & Eurytoop (Pelagisch) & 100 & - & 0 \\
\hline tongschar & Marien (Bentisch) & 100 & 0 & - \\
\hline driedradige meun & Overige & 100 & 0 & - \\
\hline glasgrondel & Marien (Bentisch) & 100 & 0 & 0 \\
\hline gehoornde slijmvis & Marien (Bentisch) & 100 & - & 0 \\
\hline grauwe poon & Marien (Bentisch) & 100 & 0 & - \\
\hline brakwatergrondel & Marien (Bentisch) & 100 & - & 0 \\
\hline
\end{tabular}




\section{Bijlage 51 Noordzeekanaal hoofdstroom}

Tabel 1. Soortensamenstelling in percentages op basis van aantal in boomkorvangsten in de hoofdstroom van het Noordzeekanaal per 5-jarige periode. De groepering geeft de ecologische indeling aan de hand van Noble et al. (2007) aan. Het cumulatief percentage geeft aan hoeveel de soorten over de gehele periode voorkomen op basis van de gesommeerde CPUE op basis van het aantal. Nul-percentages zijn naar beneden afgeronde waarden, $*=$ exoot.

\begin{tabular}{|c|c|c|c|c|c|}
\hline Soort & Groepering & $\begin{array}{l}\text { Cumulatief } \\
\text { percentage }\end{array}$ & $\begin{array}{r}2005- \\
2009 \\
\end{array}$ & $\begin{array}{r}2010- \\
2014 \\
\end{array}$ & $\begin{array}{r}2015- \\
2019 \\
\end{array}$ \\
\hline brasem & Eurytoop (Bentisch) & 15.06 & 16.31 & 4.4 & 18.49 \\
\hline bot & Limnofiel (Bentisch) & 29.88 & 4.65 & 4.33 & 21.31 \\
\hline snoekbaars & Eurytoop (Bentisch) & 40.24 & 12.89 & 4.95 & 11.58 \\
\hline tong & Marien (Bentisch) & 50.31 & 19.28 & 14.12 & 6.12 \\
\hline grondel sp. & Marien (Bentisch) & 59.93 & 13.11 & 14.79 & 6.83 \\
\hline haring/sprot & Marien (Pelagisch) & 67.86 & 1.65 & 22.53 & 4.48 \\
\hline kolblei & Eurytoop (Bentisch) & 73.27 & 8.6 & 2.5 & 5.57 \\
\hline spiering & Eurytoop (Pelagisch) & 77.8 & 2.7 & 14.34 & 1.56 \\
\hline baars & Eurytoop (Pelagisch) & 81.57 & 2.66 & 2.11 & 4.66 \\
\hline zeebaars & Marien (Pelagisch) & 84.96 & 0.4 & 0.74 & 5.15 \\
\hline schol & Marien (Bentisch) & 88.23 & 0.43 & 6.25 & 2.99 \\
\hline blankvoorn & Eurytoop (Pelagisch) & 91.32 & 5.09 & 0.74 & 3.38 \\
\hline steenbolk & Marien (Bentisch) & 93.92 & 1.6 & 3.05 & 2.7 \\
\hline zwartbekgrondel* & Eurytoop (Bentisch) & 95.76 & 8.08 & 1.76 & 0.18 \\
\hline wijting & Marien (Bentisch) & 96.95 & 1.1 & 0.64 & 1.4 \\
\hline aal & Eurytoop (Bentisch) & 97.6 & 0.75 & 0.54 & 0.67 \\
\hline schar & Marien (Bentisch) & 98.11 & 0.1 & 0.16 & 0.75 \\
\hline pos & Eurytoop (Bentisch) & 98.4 & 0.05 & 0.28 & 0.37 \\
\hline glasgrondel & Marien (Bentisch) & 98.66 & 0.13 & 0.68 & 0.13 \\
\hline brakwatergrondel & Marien (Bentisch) & 98.89 & - & - & 0.38 \\
\hline dunlipharder & Marien (Pelagisch) & 99.11 & 0.03 & - & 0.36 \\
\hline koornaarvis sp. & Marien (Pelagisch) & 99.22 & - & 0.02 & 0.16 \\
\hline harnasmannetje & Marien (Bentisch) & 99.31 & - & 0.41 & \\
\hline vijfdradige meun & Marien (Bentisch) & 99.4 & - & 0.04 & 0.12 \\
\hline kabeljauw & Marien (Bentisch) & 99.48 & 0.18 & 0.12 & 0.04 \\
\hline zeedonderpad & Marien (Bentisch) & 99.55 & - & 0.19 & 0.06 \\
\hline winde & Rheofiel (Pelagisch) & 99.62 & 0.04 & 0.05 & 0.08 \\
\hline rode poon & Marien (Bentisch) & 99.68 & - & 0.06 & 0.07 \\
\hline zwarte grondel & Marien (Bentisch) & 99.72 & 0.17 & - & 0.02 \\
\hline hybride cyprinide & Eurytoop (Bentisch) & 99.75 & - & 0.06 & 0.04 \\
\hline driedoornige stekelbaars & Eurytoop (Pelagisch) & 99.79 & - & 0.02 & 0.05 \\
\hline botervis & Marien (Pelagisch) & 99.82 & - & - & 0.05 \\
\hline horsmakreel & Marien (Pelagisch) & 99.85 & - & - & 0.05 \\
\hline naakte grondel & Marien (Bentisch) & 99.87 & - & - & 0.03 \\
\hline kleine zeenaald & Marien (Bentisch) & 99.89 & - & 0.08 & 0.01 \\
\hline rivierprik & Rheofiel (Bentisch) & 99.91 & - & 0.02 & 0.02 \\
\hline puitaal & Marien (Bentisch) & 99.92 & - & - & 0.02 \\
\hline diklipharder & Marien (Pelagisch) & 99.94 & - & - & 0.02 \\
\hline witte koolvis & Marien (Bentisch) & 99.95 & - & - & 0.02 \\
\hline goudharder & Marien (Pelagisch) & 99.96 & - & - & 0.01 \\
\hline slakdolf & Marien (Bentisch) & 99.96 & 0.04 & - & \\
\hline roofblei* & Rheofiel (Pelagisch) & 99.97 & - & - & 0.01 \\
\hline grauwe poon & Marien (Bentisch) & 99.97 & - & 0.02 & \\
\hline groene zeedonderpad & Marien (Bentisch) & 99.98 & - & - & 0.01 \\
\hline knorrepos & Marien (Bentisch) & 99.98 & - & 0.02 & \\
\hline karper & Eurytoop (Bentisch) & 99.99 & - & - & 0.01 \\
\hline pontische stroomgrondel* & Eurytoop (Bentisch) & 99.99 & - & - & 0.01 \\
\hline zwarte koolvis & Marien (Bentisch) & 100 & - & - & 0.01 \\
\hline rietvoorn & Limnofiel (Pelagisch) & 100 & - & - & 0.01 \\
\hline
\end{tabular}


Tabel 2. Soortensamenstelling in percentages op basis van biomassa in boomkorvangsten in de hoofdstroom van het Noordzeekanaal per 5-jarige periode. De groepering geeft de ecologische indeling aan de hand van Noble et al. (2007) aan. Het cumulatief percentage geeft aan hoeveel de soorten over de gehele periode voorkomen op basis van de gesommeerde CPUE op basis van de biomassa. Nulpercentages zijn naar beneden afgeronde waarden, * = exoot.

\begin{tabular}{|c|c|c|c|c|c|}
\hline Soort & Groepering & $\begin{array}{l}\text { Cumulatief } \\
\text { percentage }\end{array}$ & $\begin{array}{r}2005- \\
2009\end{array}$ & $\begin{array}{r}2010- \\
2014\end{array}$ & $\begin{array}{r}2015- \\
2019\end{array}$ \\
\hline snoekbaars & Eurytoop (Bentisch) & 28.85 & 42.06 & 27.57 & 26.83 \\
\hline brasem & Eurytoop (Bentisch) & 56.85 & 21.9 & 11.69 & 31.12 \\
\hline kolblei & Eurytoop (Bentisch) & 67 & 7.55 & 15.22 & 9.92 \\
\hline bot & Limnofiel (Bentisch) & 75.81 & 6.38 & 9.49 & 9.12 \\
\hline baars & Eurytoop (Pelagisch) & 80.73 & 5.65 & 4.99 & 4.79 \\
\hline blankvoorn & Eurytoop (Pelagisch) & 84.7 & 1.44 & 2.44 & 4.59 \\
\hline zeebaars & Marien (Pelagisch) & 87.85 & 0.09 & 0.12 & 4.04 \\
\hline tong & Marien (Bentisch) & 90.33 & 5.79 & 4.35 & 1.7 \\
\hline aal & Eurytoop (Bentisch) & 92.73 & 1.8 & 4.57 & 2.22 \\
\hline steenbolk & Marien (Bentisch) & 95.05 & 2.01 & 5.91 & 1.9 \\
\hline wijting & Marien (Bentisch) & 95.97 & 1.51 & 1.07 & 0.81 \\
\hline schol & Marien (Bentisch) & 96.83 & 0.12 & 4.02 & 0.57 \\
\hline haring/sprot & Marien (Pelagisch) & 97.39 & 0.1 & 2.98 & 0.32 \\
\hline karper & Eurytoop (Bentisch) & 97.93 & - & - & 0.7 \\
\hline spiering & Eurytoop (Pelagisch) & 98.37 & 0.49 & 3.09 & 0.09 \\
\hline schar & Marien (Bentisch) & 98.8 & 0.03 & 0.1 & 0.53 \\
\hline kabeljauw & Marien (Bentisch) & 99.02 & 1.2 & 0.29 & 0.06 \\
\hline zwartbekgrondel* & Eurytoop (Bentisch) & 99.24 & 1.17 & 0.56 & 0.02 \\
\hline winde & Rheofiel (Pelagisch) & 99.43 & 0.32 & 0.13 & 0.17 \\
\hline grondel sp. & Marien (Bentisch) & 99.62 & 0.29 & 0.56 & 0.12 \\
\hline hybride cyprinide & Eurytoop (Bentisch) & 99.68 & - & 0.26 & 0.04 \\
\hline dunlipharder & Marien (Pelagisch) & 99.73 & 0.04 & - & 0.06 \\
\hline vijfdradige meun & Marien (Bentisch) & 99.78 & - & 0.03 & 0.06 \\
\hline zeedonderpad & Marien (Bentisch) & 99.82 & - & 0.27 & 0.02 \\
\hline rode poon & Marien (Bentisch) & 99.85 & - & 0.07 & 0.03 \\
\hline witte koolvis & Marien (Bentisch) & 99.88 & - & - & 0.04 \\
\hline pos & Eurytoop (Bentisch) & 99.91 & 0.01 & 0.06 & 0.03 \\
\hline zwarte koolvis & Marien (Bentisch) & 99.93 & - & - & 0.02 \\
\hline rietvoorn & Limnofiel (Pelagisch) & 99.94 & - & - & 0.02 \\
\hline rivierprik & Rheofiel (Bentisch) & 99.95 & - & 0.03 & 0.01 \\
\hline knorrepos & Marien (Bentisch) & 99.96 & - & 0.06 & - \\
\hline harnasmannetje & Marien (Bentisch) & 99.97 & - & 0.06 & - \\
\hline roofblei* & Rheofiel (Pelagisch) & 99.97 & - & - & 0.01 \\
\hline puitaal & Marien (Bentisch) & 99.98 & - & - & 0.01 \\
\hline goudharder & Marien (Pelagisch) & 99.98 & - & - & 0.01 \\
\hline botervis & Marien (Pelagisch) & 99.98 & - & - & 0 \\
\hline horsmakreel & Marien (Pelagisch) & 99.99 & - & - & 0 \\
\hline glasgrondel & Marien (Bentisch) & 99.99 & 0 & 0.01 & 0 \\
\hline slakdolf & Marien (Bentisch) & 99.99 & 0.01 & - & - \\
\hline koornaarvis sp. & Marien (Pelagisch) & 99.99 & - & 0 & 0 \\
\hline groene zeedonderpad & Marien (Bentisch) & 99.99 & - & - & 0 \\
\hline diklipharder & Marien (Pelagisch) & 100 & - & - & 0 \\
\hline zwarte grondel & Marien (Bentisch) & 100 & 0.01 & - & 0 \\
\hline brakwatergrondel & Marien (Bentisch) & 100 & - & - & 0 \\
\hline pontische stroomgrondel* & Eurytoop (Bentisch) & 100 & - & - & 0 \\
\hline driedoornige stekelbaars & Eurytoop (Pelagisch) & 100 & - & 0 & 0 \\
\hline grauwe poon & Marien (Bentisch) & 100 & - & 0 & - \\
\hline naakte grondel & Marien (Bentisch) & 100 & - & - & 0 \\
\hline kleine zeenaald & Marien (Bentisch) & 100 & - & 0 & 0 \\
\hline
\end{tabular}




\section{Bijlage 52 Noordzeekanaal zijwateren}

Tabel 1. Soortensamenstelling in percentages op basis van aantal in boomkorvangsten in de zijwateren van het Noordzeekanaal per 5-jarige periode. De groepering geeft de ecologische indeling aan de hand van Noble et al. (2007) aan. Het cumulatief percentage geeft aan hoeveel de soorten over de gehele periode voorkomen op basis van de gesommeerde CPUE op basis van het aantal. Nul-percentages zijn naar beneden afgeronde waarden, $*$ exoot.

\begin{tabular}{|c|c|c|c|c|c|}
\hline Soort & Groepering & $\begin{array}{l}\text { Cumulatief } \\
\text { percentage }\end{array}$ & $\begin{array}{r}2005- \\
2009 \\
\end{array}$ & $\begin{array}{r}2010- \\
2014 \\
\end{array}$ & $\begin{array}{r}2015- \\
2019 \\
\end{array}$ \\
\hline grondel sp. & Marien (Bentisch) & 25.76 & 35.67 & 40.11 & 10.4 \\
\hline bot & Limnofiel (Bentisch) & 35.24 & 2.87 & 3.76 & 17.74 \\
\hline snoekbaars & Eurytoop (Bentisch) & 44.57 & 16.24 & 2.86 & 7.07 \\
\hline haring/sprot & Marien (Pelagisch) & 53.44 & 5.14 & 4.55 & 14.1 \\
\hline baars & Eurytoop (Pelagisch) & 61.24 & 1.23 & 2.94 & 15.62 \\
\hline zeebaars & Marien (Pelagisch) & 68.99 & 1.11 & 2.98 & 15.55 \\
\hline brasem & Eurytoop (Bentisch) & 75.56 & 13.43 & 4.94 & 1.88 \\
\hline tong & Marien (Bentisch) & 80.33 & 3.23 & 9.77 & 3.44 \\
\hline spiering & Eurytoop (Pelagisch) & 84.38 & 2.9 & 8.77 & 2.57 \\
\hline kolblei & Eurytoop (Bentisch) & 87.76 & 8.29 & 1.76 & 0.24 \\
\hline steenbolk & Marien (Bentisch) & 90.63 & 1.04 & 1.9 & 4.85 \\
\hline zwartbekgrondel* & Eurytoop (Bentisch) & 93.22 & 4.22 & 4.99 & 0.04 \\
\hline schol & Marien (Bentisch) & 94.74 & 0.66 & 1.73 & 2.1 \\
\hline koornaarvis sp. & Marien (Pelagisch) & 95.91 & - & 4.37 & 0.46 \\
\hline blankvoorn & Eurytoop (Pelagisch) & 96.86 & 1.12 & 1.44 & 0.56 \\
\hline aal & Eurytoop (Bentisch) & 97.73 & 0.88 & 0.34 & 1.14 \\
\hline glasgrondel & Marien (Bentisch) & 98.28 & 0.19 & 1.22 & 0.49 \\
\hline wijting & Marien (Bentisch) & 98.83 & 0.44 & 0.09 & 0.87 \\
\hline schar & Marien (Bentisch) & 99.12 & 0.34 & 0.3 & 0.24 \\
\hline zwarte grondel & Marien (Bentisch) & 99.28 & 0.16 & 0.37 & 0.04 \\
\hline pitvis & Marien (Bentisch) & 99.42 & 0.42 & - & \\
\hline driedoornige stekelbaars & Eurytoop (Pelagisch) & 99.53 & - & 0.09 & 0.2 \\
\hline kabeljauw & Marien (Bentisch) & 99.6 & 0.16 & - & 0.04 \\
\hline vijfdradige meun & Marien (Bentisch) & 99.67 & 0.11 & - & 0.07 \\
\hline dunlipharder & Marien (Pelagisch) & 99.73 & - & - & 0.14 \\
\hline zeedonderpad & Marien (Bentisch) & 99.78 & - & 0.25 & \\
\hline brakwatergrondel & Marien (Bentisch) & 99.82 & - & - & 0.1 \\
\hline kleine zeenaald & Marien (Bentisch) & 99.86 & - & 0.18 & \\
\hline puitaal & Marien (Bentisch) & 99.9 & - & 0.15 & \\
\hline rasterpitvis & Marien (Bentisch) & 99.93 & - & 0.15 & \\
\hline winde & Rheofiel (Pelagisch) & 99.96 & 0.08 & - & \\
\hline rietvoorn & Limnofiel (Pelagisch) & 99.98 & 0.07 & - & \\
\hline horsmakreel & Marien (Pelagisch) & 100 & - & - & 0.04 \\
\hline
\end{tabular}


Tabel 2. Soortensamenstelling in percentages op basis van biomassa in boomkorvangsten in de zijwateren van het Noordzeekanaal per 5-jarige periode. De groepering geeft de ecologische indeling aan de hand van Noble et al. (2007) aan. Het cumulatief percentage geeft aan hoeveel de soorten over de gehele periode voorkomen op basis van de gesommeerde CPUE op basis van de biomassa. Nulpercentages zijn naar beneden afgeronde waarden, * = exoot.

\begin{tabular}{|c|c|c|c|c|c|}
\hline Soort & Groepering & $\begin{array}{l}\text { Cumulatief } \\
\text { percentage }\end{array}$ & $\begin{array}{r}2005- \\
2009\end{array}$ & $\begin{array}{r}2010- \\
2014\end{array}$ & $\begin{array}{r}2015- \\
2019 \\
\end{array}$ \\
\hline snoekbaars & Eurytoop (Bentisch) & 23.35 & 29.46 & 13.87 & 19.82 \\
\hline brasem & Eurytoop (Bentisch) & 38.85 & 28.83 & 9.16 & 5.86 \\
\hline zeebaars & Marien (Pelagisch) & 52.5 & 1.54 & 1.14 & 24.9 \\
\hline bot & Limnofiel (Bentisch) & 62.57 & 3.52 & 22.5 & 13.53 \\
\hline baars & Eurytoop (Pelagisch) & 72.28 & 3.37 & 9.12 & 14.8 \\
\hline aal & Eurytoop (Bentisch) & 78.82 & 4.51 & 1.7 & 8.79 \\
\hline kolblei & Eurytoop (Bentisch) & 85.26 & 14.57 & 4.01 & 0.36 \\
\hline steenbolk & Marien (Bentisch) & 89.56 & 1.15 & 9.37 & 6.09 \\
\hline blankvoorn & Eurytoop (Pelagisch) & 91.93 & 3.58 & 8.31 & 0.61 \\
\hline tong & Marien (Bentisch) & 93.56 & 1.38 & 5 & 1.37 \\
\hline kabeljauw & Marien (Bentisch) & 95 & 3.36 & - & 0.13 \\
\hline grondel sp. & Marien (Bentisch) & 95.82 & 0.98 & 3.24 & 0.37 \\
\hline haring/sprot & Marien (Pelagisch) & 96.62 & 0.34 & 1.42 & 1.07 \\
\hline zwartbekgrondel* & Eurytoop (Bentisch) & 97.35 & 1.08 & 4.02 & 0.01 \\
\hline wijting & Marien (Bentisch) & 98.03 & 0.65 & 0.27 & 0.76 \\
\hline spiering & Eurytoop (Pelagisch) & 98.66 & 0.39 & 4.04 & 0.34 \\
\hline schol & Marien (Bentisch) & 99.12 & 0.09 & 1.5 & 0.63 \\
\hline winde & Rheofiel (Pelagisch) & 99.45 & 0.79 & - & \\
\hline schar & Marien (Bentisch) & 99.75 & 0.18 & 0.25 & 0.4 \\
\hline vijfdradige meun & Marien (Bentisch) & 99.81 & 0.11 & - & 0.04 \\
\hline zeedonderpad & Marien (Bentisch) & 99.86 & - & 0.69 & \\
\hline dunlipharder & Marien (Pelagisch) & 99.91 & - & - & 0.09 \\
\hline koornaarvis sp. & Marien (Pelagisch) & 99.93 & - & 0.2 & 0.01 \\
\hline pitvis & Marien (Bentisch) & 99.95 & 0.04 & - & \\
\hline rietvoorn & Limnofiel (Pelagisch) & 99.96 & 0.04 & - & - \\
\hline zwarte grondel & Marien (Bentisch) & 99.98 & 0.02 & 0.06 & $\overline{0}$ \\
\hline glasgrondel & Marien (Bentisch) & 99.99 & 0 & 0.06 & 0.01 \\
\hline horsmakreel & Marien (Pelagisch) & 99.99 & - & - & 0.01 \\
\hline driedoornige stekelbaars & Eurytoop (Pelagisch) & 100 & - & 0 & 0.01 \\
\hline rasterpitvis & Marien (Bentisch) & 100 & - & 0.04 & \\
\hline puitaal & Marien (Bentisch) & 100 & - & 0.02 & \\
\hline brakwatergrondel & Marien (Bentisch) & 100 & - & - & 0 \\
\hline kleine zeenaald & Marien (Bentisch) & 100 & - & 0 & \\
\hline
\end{tabular}




\section{Bijlage 53 Oosterschelde (DFS)}

Tabel 1. Soortensamenstelling in percentages op basis van aantal in boomkorvangsten in de Oosterschelde per 5-jarige periode. De groepering geeft de ecologische indeling aan de hand van Noble et al. (2007) aan. Het cumulatief percentage geeft aan hoeveel de soorten over de gehele periode voorkomen op basis van de gesommeerde CPUE op basis van het aantal. Nul-percentages zijn naar beneden afgeronde waarden, $*=$ exoot.

\begin{tabular}{|c|c|c|c|c|c|c|c|c|c|c|c|c|}
\hline Soort & Groepering & $\begin{array}{l}\text { Cumulatief } \\
\text { percentage }\end{array}$ & $\begin{array}{r}1970- \\
1974 \\
\end{array}$ & $\begin{array}{r}1975- \\
1979 \\
\end{array}$ & $\begin{array}{r}1980- \\
1984 \\
\end{array}$ & $\begin{array}{r}1985- \\
1989 \\
\end{array}$ & $\begin{array}{r}1990- \\
1994 \\
\end{array}$ & $\begin{array}{r}1995- \\
1999 \\
\end{array}$ & $\begin{array}{r}2000- \\
2004 \\
\end{array}$ & $\begin{array}{r}2005- \\
2009 \\
\end{array}$ & $\begin{array}{r}2010- \\
2014 \\
\end{array}$ & $\begin{array}{r}2015- \\
2019 \\
\end{array}$ \\
\hline grondels & Marien (Bentisch) & 32.68 & 42.4 & 32.46 & 21.54 & 16.51 & 34.47 & 20.99 & 44.76 & 44.83 & 28.51 & 44.18 \\
\hline schol & Marien (Bentisch) & 58.68 & 15.43 & 20.2 & 22.03 & 50.56 & 27.25 & 30.79 & 18.34 & 24.88 & 27.77 & 16.26 \\
\hline schar & Marien (Bentisch) & 72.27 & 20.7 & 25.3 & 30.2 & 17.84 & 15.14 & 8.92 & 7.17 & 6.42 & 2.07 & 1.32 \\
\hline steenbolk & Marien (Bentisch) & 78.81 & 1.34 & 6.66 & 5.07 & 5.02 & 10.45 & 13.6 & 9.72 & 3.43 & 2.52 & 3.55 \\
\hline tong & Marien (Bentisch) & 84.71 & 13.71 & 7.34 & 14.9 & 2.14 & 2.57 & 4.21 & 3.68 & 4.2 & 3.85 & 1.76 \\
\hline haring & Marien (Pelagisch) & 89.45 & 0.26 & 0.1 & 0.47 & 1.12 & 0.66 & 5.92 & 8.77 & 5.49 & 11.86 & 12.44 \\
\hline puitaal & Marien (Bentisch) & 90.77 & 0.16 & 0.15 & 0.4 & 1.32 & 2.53 & 2.52 & 1.07 & 2.02 & 2.24 & 1.09 \\
\hline zeenaalden & Marien (Bentisch) & 92.01 & 1.04 & 1.79 & 0.28 & 0.22 & 1 & 0.49 & 0.42 & 0.72 & 3.54 & 6.24 \\
\hline wijting & Marien (Bentisch) & 93.14 & 0.34 & 0.97 & 0.59 & 0.94 & 0.56 & 1.25 & 0.37 & 1.47 & 3.41 & 3.04 \\
\hline pitvis & Marien (Bentisch) & 94.26 & 0.41 & 036 & 0.19 & 0.78 & 2.56 & 1.74 & 2.34 & 1.02 & 0.45 & 0.47 \\
\hline zeedonderpad & Marien (Bentisch) & 95.33 & 0.95 & 0.78 & 0.96 & 1.77 & 0.45 & 1.46 & 0.42 & 0.65 & 3.17 & 0.44 \\
\hline harnasmannetje & Marien (Bentisch) & 96.14 & 0.89 & 1.6 & 0.87 & 0.73 & 0.57 & 0.47 & 0.63 & 0.32 & 2.44 & 0.55 \\
\hline sprot & Marien (Pelagisch) & 96.86 & 0.14 & 0.21 & 0.28 & 0.01 & 0.01 & 4.78 & 0.5 & - & - & 0.03 \\
\hline zwarte grondel & Marien (Bentisch) & 97.38 & - & - & - & 0 & 0 & 0.06 & 0.22 & 2.41 & 3.59 & \\
\hline bot & Limnofiel (Bentisch) & 97.88 & 0.57 & 0.48 & 0.4 & 0.22 & 0.52 & 1.26 & 0.28 & 0.52 & 0.41 & 0.4 \\
\hline zandspieringen & Marien (Bentisch) & 98.26 & 0.27 & 0.17 & 0.47 & 0.22 & 0.39 & 0.43 & 0.22 & 0.24 & 0.83 & 0.89 \\
\hline botervis & Marien (Pelagisch) & 98.57 & 0.15 & 0.06 & 0.02 & 0.09 & 0.11 & 0.15 & 0.18 & 0.11 & 1.1 & 1.8 \\
\hline zwartbekgrondel* & Eurytoop (Bentisch) & 98.86 & - & - & - & - & - & - & - & - & - & 3.98 \\
\hline aal & Eurytoop (Bentisch) & 99.12 & 0.54 & 0.65 & 0.92 & 0.05 & 0.17 & 0.17 & 0.05 & 0.1 & 0.02 & 0.02 \\
\hline tongschar & Marien (Bentisch) & 99.26 & 0.03 & 0.01 & 0.02 & 0.01 & 0.14 & 0.13 & 0.34 & 0.07 & 0.34 & 0.29 \\
\hline vijfdradige meun & Marien (Bentisch) & 99.38 & 0.15 & 0.11 & 0.04 & 0.01 & 0.11 & 0.08 & 0.07 & 0.22 & 0.41 & 0.12 \\
\hline slakdolf & Marien (Bentisch) & 99.47 & 0.21 & 0.1 & 0.14 & 0.07 & 0.05 & 0.07 & 0.02 & 0.01 & 0.18 & 0.17 \\
\hline kabeljauw & Marien (Bentisch) & 99.56 & 0.04 & 0.09 & 0.04 & 0.18 & 0.03 & 0.12 & 0.01 & 0.31 & 0.06 & 0.02 \\
\hline smelt & Marien (Bentisch) & 99.65 & 0.03 & 0.08 & 0.01 & 0.04 & 0.08 & 0.1 & 0.03 & 0.13 & 0.37 & 0.21 \\
\hline horsmakreel & Marien (Pelagisch) & 99.71 & 0.07 & 0.09 & 0.06 & 0.01 & 0.03 & 0.12 & 0.06 & 0.02 & 0.07 & 0.12 \\
\hline zeebaars & Marien (Pelagisch) & 99.77 & 0 & - & - & 0.02 & 0.01 & 0.02 & 0.07 & 0.07 & 0.27 & 0.16 \\
\hline koornaarvis & Marien (Pelagisch) & 99.81 & 0 & 0.01 & 0.01 & 0.02 & 0.02 & 0 & 0.04 & 0.07 & 0.08 & 0.25 \\
\hline griet & Marien (Bentisch) & 99.84 & 0.02 & 0.04 & 0.04 & 0.01 & 0.04 & 0.02 & 0.03 & 0.01 & 0.11 & 0.03 \\
\hline dwergbolk & Marien (Bentisch) & 99.87 & - & - & - & - & 0.03 & 0.06 & 0.08 & 0.02 & 0.01 & 0.01 \\
\hline rode poon & Marien (Bentisch) & 99.89 & 0.01 & 0.03 & 0.01 & 0 & 0.01 & 0.01 & 0.01 & 0.02 & 0.06 & 0.02 \\
\hline spiering & Eurytoop (Pelagisch) & 99.9 & 0.01 & 0.01 & 0 & - & - & 0 & 0.02 & 0 & 0.07 & 0.06 \\
\hline ansjovis & Marien (Pelagisch) & 99.91 & 0.02 & - & - & 0.06 & - & - & 0.01 & 0 & - & \\
\hline kleine pieterman & Marien (Bentisch) & 99.92 & 0 & 0 & - & - & 0 & - & 0.01 & 0.03 & 0.05 & 0.04 \\
\hline tarbot & Marien (Bentisch) & 99.93 & - & 0 & - & 0 & - & 0.04 & 0.02 & - & - & 0.01 \\
\hline grauwe poon & Marien (Bentisch) & 99.94 & 0.04 & 0.01 & 0.03 & - & - & - & 0 & - & - & \\
\hline driedradige meun & Marien (Bentisch) & 99.95 & 0.04 & 0.04 & 0.02 & - & - & - & - & - & - & \\
\hline dwergtong & Marien (Bentisch) & 99.96 & - & - & - & - & - & - & - & 0.07 & - & - \\
\hline riedoornige stekelbaars & Eurytoop (Pelagisch) & 99.96 & - & 0.07 & - & 0 & 0.01 & - & - & - & 0.02 & - \\
\hline mul & Marien (Bentisch) & 99.97 & - & - & - & - & 0 & 0.02 & 0.01 & 0.01 & 0.01 & \\
\hline rasterpitvis & Marien (Bentisch) & 99.97 & - & - & - & - & - & - & - & 0.04 & 0.02 & \\
\hline schurftvis & Marien (Bentisch) & 99.98 & - & - & - & - & 0 & - & 0.02 & 0 & 0 & 0 \\
\hline adderzeenaald & Marien (Bentisch) & 99.98 & - & - & - & 0 & 0.01 & 0 & 0 & 0.01 & 0 & 0.01 \\
\hline groene zeedonderpad & Marien (Bentisch) & 99.99 & - & - & - & - & - & - & 0 & 0 & 0.04 & 0 \\
\hline gevlekte pitvis & Marien (Bentisch) & 99.99 & - & - & - & - & - & - & - & 0.03 & - & \\
\hline harders indet, & Marien (Pelagisch) & 99.99 & 0 & 0.01 & - & - & - & - & 0.01 & - & - & \\
\hline pijlstaartrog & Marien (Bentisch) & 99.99 & - & - & - & - & - & - & - & 0 & 0.01 & $\underline{0}$ \\
\hline geep & Marien (Pelagisch) & 99.99 & - & - & - & - & - & - & - & - & 0.01 & $\underline{0}$ \\
\hline snotolf & Marien (Bentisch) & 100 & - & - & - & - & - & - & - & - & 0.01 & \\
\hline vorskwab & Marien (Bentisch) & 100 & - & - & - & - & - & - & 0 & 0 & - & - \\
\hline stekelrog & Marien (Bentisch) & 100 & 0 & - & 0 & - & - & - & - & - & - & \\
\hline witte koolvis & Marien (Bentisch) & 100 & - & - & - & - & - & - & - & - & - & 0.01 \\
\hline glasgrondel & Marien (Bentisch) & 100 & - & - & 0 & - & - & - & - & - & - & - \\
\hline vierdradige meun & Marien (Bentisch) & 100 & 0 & - & - & - & - & - & - & - & - & \\
\hline fint & Rheofiel (Pelagisch) & 100 & 0 & - & - & - & - & - & - & - & - & - \\
\hline gevlekte gladde haai & Marien (Bentisch) & 100 & - & - & - & - & - & - & - & - & 0 & \\
\hline zwartooglipvis & Marien (Bentisch) & 100 & - & - & - & - & - & - & 0 & - & - & - \\
\hline doornhaai & Marien (Pelagisch) & 100 & - & - & - & - & - & - & 0 & - & - & \\
\hline zonnebaars* & Limnofiel (Pelagisch) & 100 & - & - & - & 0 & - & - & - & - & - & \\
\hline zwarte koolvis & Marien (Bentisch) & 100 & - & - & - & - & - & 0 & - & - & - & \\
\hline ruwe haai & Marien (Bentisch) & 100 & - & - & - & - & - & - & - & 0 & - & \\
\hline
\end{tabular}


Tabel 2. Soortensamenstelling in percentages op basis van biomassa in boomkorvangsten in de Oosterschelde per 5-jarige periode. De groepering geeft de ecologische indeling aan de hand van Noble et al. (2007) aan. Het cumulatief percentage geeft aan hoeveel de soorten over de gehele periode voorkomen op basis van de gesommeerde CPUE op basis van de biomassa. Nul-percentages zijn naar beneden afgeronde waarden, * = exoot.

\begin{tabular}{|c|c|c|c|c|c|c|c|c|c|c|c|c|}
\hline Soort & Groepering & $\begin{array}{l}\text { Cumulatief } \\
\text { percentage }\end{array}$ & $\begin{array}{r}1970- \\
1974\end{array}$ & $\begin{array}{r}1975- \\
1979 \\
\end{array}$ & $\begin{array}{r}1980- \\
1984\end{array}$ & $\begin{array}{r}1985- \\
1989\end{array}$ & $\begin{array}{r}1990- \\
1994\end{array}$ & $\begin{array}{r}1995- \\
1999\end{array}$ & $\begin{array}{r}2000- \\
2004\end{array}$ & $\begin{array}{r}2005- \\
2009 \\
\end{array}$ & $\begin{array}{r}2010- \\
2014 \\
\end{array}$ & $\begin{array}{r}2015- \\
2019\end{array}$ \\
\hline schol & Marien (Bentisch) & 45.62 & 43.37 & 34.95 & 31.95 & 73.23 & 52.34 & 40.3 & 39.99 & 46.2 & 24.96 & 14.4 \\
\hline steenbolk & Marien (Bentisch) & 59.17 & 4.79 & 20.63 & 11.87 & 7.69 & 17.9 & 22.82 & 21.23 & 8.13 & 6.22 & 13 \\
\hline tong & Marien (Bentisch) & 69.01 & 17.45 & 14.08 & 25.89 & 2.19 & 4.45 & 6.12 & 10.13 & 6.35 & 10.48 & 6.72 \\
\hline schar & Marien (Bentisch) & 74.26 & 8.97 & 7.29 & 9.58 & 5.25 & 5.61 & 3.6 & 2.69 & 3.21 & 3.25 & 1.53 \\
\hline zeedonderpad & Marien (Bentisch) & 78.93 & 6.19 & 3.95 & 3.94 & 4.55 & 2.47 & 5.56 & 2.72 & 3.13 & 14.05 & 3.76 \\
\hline grondels & Marien (Bentisch) & 83.11 & 4.38 & 3.16 & 2.21 & 1.53 & 3.89 & 2.17 & 8.26 & 5.58 & 4.74 & 16.99 \\
\hline bot & Limnofiel (Bentisch) & 86.91 & 4.63 & 4.48 & 3.15 & 1.01 & 3.86 & 6.88 & 2.91 & 5.14 & 4.91 & 4.65 \\
\hline wijting & Marien (Bentisch) & 89.26 & 1.19 & 2.63 & 1.35 & 1.39 & 0.85 & 2.15 & 0.92 & 3.21 & 7.54 & 12.94 \\
\hline aal & Eurytoop (Bentisch) & 91.59 & 5.39 & 5.34 & 7.2 & 0.57 & 1.5 & 1.66 & 0.89 & 0.73 & 0.63 & 0.09 \\
\hline puitaal & Marien (Bentisch) & 93.81 & 0.28 & 0.14 & 0.43 & 1.13 & 2.65 & 3.01 & 1.64 & 9.15 & 2.29 & 1.95 \\
\hline haring & Marien (Pelagisch) & 94.84 & 0.13 & 0.05 & 0.23 & 0.21 & 0.14 & 1.26 & 2.4 & 0.88 & 2.74 & 6.07 \\
\hline pitvis & Marien (Bentisch) & 95.58 & 0.31 & 0.23 & 0.11 & 0.22 & 1.66 & 0.98 & 1.9 & 0.92 & 0.36 & 0.63 \\
\hline zeebaars & Marien (Pelagisch) & 96.1 & 0.04 & - & - & 0 & 0.19 & 0.9 & 0.85 & 2.13 & 0.61 & 0.68 \\
\hline pijlstaartrog & Marien (Bentisch) & 96.58 & - & - & - & - & - & - & - & 0.67 & 6.61 & 1.57 \\
\hline griet & Marien (Bentisch) & 97.05 & 0.33 & 0.27 & 0.65 & 0.13 & 0.72 & 0.17 & 0.57 & 0.16 & 1.98 & 1.35 \\
\hline kabeljauw & Marien (Bentisch) & 97.49 & 0.35 & 0.56 & 0.18 & 0.25 & 0.03 & 0.49 & 0.34 & 1.51 & 0.53 & 0.45 \\
\hline zeenaalden & Marien (Bentisch) & 97.81 & 0.17 & 0.69 & 0.21 & 0.07 & 0.56 & 0.14 & 0.41 & 0.31 & 0.73 & 1.23 \\
\hline zandspieringen & Marien (Bentisch) & 98.12 & 0.26 & 0.17 & 0.32 & 0.12 & 0.32 & 0.3 & 0.24 & 0.23 & 0.79 & 1.4 \\
\hline harnasmannetje & Marien (Bentisch) & 98.39 & 0.33 & 0.52 & 0.31 & 0.16 & 0.15 & 0.11 & 0.22 & 0.12 & 1.03 & 0.55 \\
\hline tongschar & Marien (Bentisch) & 98.6 & 0.07 & 0.04 & 0.11 & 0.06 & 0.28 & 0.24 & 0.7 & 0.08 & 0.4 & 0.16 \\
\hline botervis & Marien (Pelagisch) & 98.81 & 0.15 & 0.05 & 0.02 & 0.05 & 0.07 & 0.09 & 0.14 & 0.07 & 0.89 & 2.44 \\
\hline zwarte grondel & Marien (Bentisch) & 98.99 & - & - & - & 0 & 0 & 0.02 & 0.12 & 0.95 & 1.43 & \\
\hline zwartbekgrondel* & Eurytoop (Bentisch) & 99.18 & - & - & - & - & - & - & - & - & - & 5.21 \\
\hline smelt & Marien (Bentisch) & 99.36 & 0.05 & 0.15 & 0.01 & 0.08 & 0.1 & 0.2 & 0.1 & 0.33 & 0.81 & 0.76 \\
\hline vijfdradige meun & Marien (Bentisch) & 99.53 & 0.3 & 0.16 & 0.07 & 0 & 0.13 & 0.14 & 0.1 & 0.36 & 0.81 & 0.35 \\
\hline sprot & Marien (Pelagisch) & 99.61 & 0.05 & 0.07 & 0.05 & 0 & 0.01 & 0.36 & 0.07 & - & - & 0.04 \\
\hline tarbot & Marien (Bentisch) & 99.67 & - & 0.23 & - & 0.03 & - & 0.17 & 0.02 & - & - & 0.43 \\
\hline horsmakreel & Marien (Pelagisch) & 99.71 & 0.29 & 0.03 & 0.01 & 0 & 0.01 & 0.03 & 0.03 & 0.01 & 0.02 & 0.08 \\
\hline rode poon & Marien (Bentisch) & 99.75 & 0.02 & 0.05 & 0.02 & 0 & 0.06 & 0.04 & 0.03 & 0.05 & 0.21 & 0.03 \\
\hline doornhaai & Marien (Bentisch) & 99.78 & - & - & - & - & - & - & 0.23 & - & - & - \\
\hline gevlekte gladde haai & Marien (Bentisch) & 99.81 & - & - & - & - & - & - & - & - & 0.49 & \\
\hline slakdolf & Marien (Bentisch) & 99.83 & 0.08 & 0.04 & 0.04 & 0.01 & 0.01 & 0.01 & 0.01 & 0 & 0.04 & 0.07 \\
\hline dwergbolk & Marien (Bentisch) & 99.85 & - & - & - & - & 0.02 & 0.04 & 0.08 & 0.03 & 0.01 & 0.02 \\
\hline ruwe haai & Marien (Bentisch) & 99.87 & - & - & - & - & - & - & - & 0.22 & - & \\
\hline harders indet, & Marien (Bentisch) & 99.89 & 0.23 & 0 & - & - & - & - & 0 & - & - & $\overline{-}$ \\
\hline spiering & Eurytoop (Pelagisch) & 99.91 & 0.02 & 0 & 0 & - & - & 0.01 & 0.01 & 0 & 0.13 & 0.17 \\
\hline stekelrog & Marien (Bentisch) & 99.93 & 0.09 & - & 0.06 & - & - & - & - & - & - & - \\
\hline groene zeedonderpad & Marien (Bentisch) & 99.94 & - & - & - & - & - & - & 0.01 & 0 & 0.21 & $\underline{0}$ \\
\hline kleine pieterman & Marien (Bentisch) & 95 & 0 & 0 & - & - & 0 & - & 0.01 & 0.03 & 0.06 & 0.1 \\
\hline adderzeenaald & Marien (Bentisch) & 99.96 & - & - & - & 0.01 & 0.03 & 0.01 & 0.01 & 0.03 & 0 & 0.02 \\
\hline grauwe poon & Marien (Bentisch) & 99.97 & 0.05 & 0.01 & 0.02 & - & - & - & 0 & - & - & \\
\hline koornaarvis & Marien (Pelagisch) & 99.97 & 0 & 0 & 0 & 0 & 0 & 0 & 0 & 0.01 & 0.01 & 0.06 \\
\hline zwarte koolvis & Marien (Bentisch) & 99.98 & - & - & - & - & - & 0.03 & - & - & - & - \\
\hline vorskwab & Marien (Bentisch) & 99.98 & - & - & - & - & - & - & 0.02 & 0.02 & - & - \\
\hline zonnebaars* & Limnofiel (Pelagisch) & 99.98 & - & - & - & 0.02 & - & - & - & - & - & $\Xi$ \\
\hline driedradige meun & Marien (Bentisch) & 99.99 & 0.02 & 0.02 & 0.01 & - & - & - & - & - & - & \\
\hline witte koolvis & Marien (Bentisch) & 99.99 & - & - & - & - & - & - & - & - & - & 0.08 \\
\hline ansjovis & Marien (Pelagisch) & 99.99 & 0 & - & - & 0.01 & - & - & 0 & 0 & - & - \\
\hline gevlekte pitvis & Marien (Bentisch) & 99.99 & - & - & - & - & - & - & - & 0.02 & - & - \\
\hline schurftvis & Marien (Bentisch) & 100 & - & - & - & - & 0 & - & 0.01 & 0 & 0 & 0 \\
\hline $\mathrm{mul}$ & Marien (Bentisch) & 100 & - & - & - & - & 0 & 0 & 0 & 0 & 0 & - \\
\hline rasterpitvis & Marien (Bentisch) & 100 & - & - & - & - & - & - & - & 0.01 & 0.01 & - \\
\hline dwergtong & Marien (Bentisch) & 100 & - & - & - & - & - & - & - & 0.01 & - & 二 \\
\hline snotolf & Marien (Bentisch) & 100 & - & - & - & - & - & - & - & - & 0 & \\
\hline geep & Marien (Pelagisch) & 100 & - & - & - & - & - & - & - & - & 0 & 0.01 \\
\hline riedoornige stekelbaars & Eurytoop (Pelagisch) & 100 & - & 0 & - & 0 & 0 & - & - & - & 0 & \\
\hline vierdradige meun & Marien (Bentisch) & 100 & 0 & - & - & - & - & - & - & - & - & \\
\hline glasgrondel & Marien (Bentisch) & 100 & - & - & 0 & - & - & - & - & - & - & - \\
\hline fint & Rheofiel (Pelagisch) & 100 & 0 & - & - & - & - & - & - & - & - & \\
\hline zwartooglipvis & Marien (Bentisch) & 100 & - & - & - & - & - & - & 0 & - & - & \\
\hline
\end{tabular}




\section{Bijlage 54 Westerschelde (Ankerkuil)}

Tabel 1. Soortensamenstelling in percentages op basis van aantal in ankerkuilvangsten in de Westerschelde per 5-jarige periode. De groepering geeft de ecologische indeling aan de hand van Noble et al. (2007) aan. Het cumulatief percentage geeft aan hoeveel de soorten over de gehele periode voorkomen op basis van de gesommeerde CPUE op basis van het aantal. Nul-

percentages zijn naar beneden afgeronde waarden, * = exoot.

\begin{tabular}{|c|c|c|c|c|c|}
\hline Soort & Groepering & Cumulatief percentage & $2005-2009$ & $2010-2014$ & $2015-2019$ \\
\hline clupeidae & Marien (Pelagisch) & 54.06 & 62.91 & - & - \\
\hline haring & Marien (Pelagisch) & 95.05 & 36.63 & 78.47 & 47.43 \\
\hline sprot & Marien (Pelagisch) & 97.18 & 0.05 & 5.85 & 31.47 \\
\hline grondels indet. & Marien (Bentisch) & 98.37 & 0.32 & 5.79 & 7.72 \\
\hline kleine zeenaald & Marien (Bentisch) & 98.92 & 0 & 4.93 & 2.12 \\
\hline spiering & Eurytoop (Pelagisch) & 99.42 & 0.01 & 3.56 & 3.25 \\
\hline pelser & Marien (Pelagisch) & 99.64 & 0 & 0.15 & 4.23 \\
\hline kleine zandspiering & Marien (Bentisch) & 99.73 & 0.01 & 0.62 & 0.41 \\
\hline koornaarvissen indet. & Marien (Pelagisch) & 99.8 & 0 & 0.04 & 1.38 \\
\hline ansjovis & Marien (Pelagisch) & 99.86 & 0.02 & 0.22 & 0.55 \\
\hline slakdolf & Marien (Bentisch) & 99.9 & 0 & 0.1 & 0.49 \\
\hline zeebaars & Marien (Pelagisch) & 99.92 & 0.01 & 0.01 & 0.26 \\
\hline steenbolk & Marien (Bentisch) & 99.94 & 0 & 0.06 & 0.34 \\
\hline glasgrondel & Marien (Bentisch) & 99.96 & 0.01 & 0.04 & 0.07 \\
\hline wijting & Marien (Bentisch) & 99.97 & 0 & 0.01 & 0.12 \\
\hline driedoornige stekelbaars & Eurytoop (Pelagisch) & 99.97 & 0 & 0.05 & 0.01 \\
\hline rivierprik & Rheofiel (Bentisch) & 99.98 & 0 & 0.01 & 0.04 \\
\hline bot & Limnofiel (Bentisch) & 99.98 & 0 & 0.01 & 0.03 \\
\hline zeenaalden indet. & Marien (Bentisch) & 99.98 & 0 & - & 0 \\
\hline tong & Marien (Bentisch) & 99.99 & 0 & 0.01 & 0.01 \\
\hline smelt & Marien (Bentisch) & 99.99 & - & 0.02 & 0 \\
\hline schol & Marien (Bentisch) & 99.99 & 0 & 0.01 & 0 \\
\hline grote zeenaald & Marien (Bentisch) & 99.99 & 0 & 0.01 & 0.01 \\
\hline makreel & Marien (Pelagisch) & 99.99 & 0 & 0 & - \\
\hline harnasmannetje & Marien (Bentisch) & 99.99 & 0 & 0 & 0 \\
\hline fint & Rheofiel (Pelagisch) & 100 & 0 & 0 & 0.01 \\
\hline harders indet. & Marien (Pelagisch) & 100 & - & - & 0.02 \\
\hline brakwatergrondel & Marien (Bentisch) & 100 & - & 0.01 & 0 \\
\hline kleine pieterman & Marien (Bentisch) & 100 & 0 & 0 & 0 \\
\hline goudharder & Marien (Pelagisch) & 100 & 0 & - & 0 \\
\hline rode poon & Marien (Bentisch) & 100 & 0 & 0 & 0 \\
\hline dunlipharder & Marien (Pelagisch) & 100 & 0 & 0 & 0 \\
\hline snoekbaars & Eurytoop (Bentisch) & 100 & 0 & 0 & 0 \\
\hline vijfdradige meun & Marien (Bentisch) & 100 & 0 & 0 & - \\
\hline atlantische forel & Rheofiel (Pelagisch) & 100 & 0 & 0 & 0 \\
\hline zeedonderpad & Marien (Bentisch) & 100 & 0 & 0 & 0 \\
\hline schar & Marien (Bentisch) & 100 & 0 & 0 & 0 \\
\hline kabeljauw & Marien (Bentisch) & 100 & 0 & 0 & 0 \\
\hline horsmakreel & Marien (Pelagisch) & 100 & 0 & 0 & 0 \\
\hline geep & Marien (Pelagisch) & 100 & 0 & 0 & 0 \\
\hline grauwe poon & Marien (Bentisch) & 100 & - & 0 & 0 \\
\hline baars & Eurytoop (Pelagisch) & 100 & 0 & 0 & 0 \\
\hline aal & Eurytoop (Bentisch) & 100 & 0 & 0 & - \\
\hline adderzeenaald & Marien (Bentisch) & 100 & 0 & - & - \\
\hline botervis & Marien (Pelagisch) & 100 & 0 & - & 0 \\
\hline snotolf & Marien (Bentisch) & 100 & - & 0 & 0 \\
\hline zalm & Rheofiel (Pelagisch) & 100 & 0 & 0 & - \\
\hline brasem & Eurytoop (Bentisch) & 100 & - & 0 & - \\
\hline schurftvis & Marien (Bentisch) & 100 & - & 0 & 0 \\
\hline vorskwab & Marien (Bentisch) & 100 & 0 & - & - \\
\hline diklipharder & Marien (Pelagisch) & 100 & - & 0 & 0 \\
\hline groene zeedonderpad & Marien (Bentisch) & 100 & 0 & 0 & - \\
\hline griet & Marien (Bentisch) & 100 & - & - & 0 \\
\hline dwergtong & Marien (Bentisch) & 100 & - & 0 & - \\
\hline pontische stroomgrondel* & Eurytoop (Bentisch) & 100 & - & 0 & - \\
\hline zwartbekgrondel* & Eurytoop (Bentisch) & 100 & - & - & 0 \\
\hline zeeprik & Rheofiel (Bentisch) & 100 & 0 & - & - \\
\hline slijmvis & Marien (Bentisch) & 100 & 0 & - & - \\
\hline noorse zandspiering & Marien (Bentisch) & 100 & - & - & 0 \\
\hline puitaal & Marien (Bentisch) & 100 & 0 & - & - \\
\hline hondshaai & Marien (Bentisch) & 100 & - & - & 0 \\
\hline vierdradige meun & Marien (Bentisch) & 100 & 0 & - & - \\
\hline zonnevis & Marien (Bentisch) & 100 & - & - & 0 \\
\hline stekelrog & Marien (Bentisch) & 100 & - & 0 & - \\
\hline pos & Eurytoop (Bentisch) & 100 & - & 0 & - \\
\hline pitvis & Marien (Bentisch) & 100 & - & 0 & - \\
\hline
\end{tabular}


Tabel 2. Soortensamenstelling in percentages op basis van biomassa in ankerkuilvangsten in de Westerschelde per 5-jarige periode. De groepering geeft de ecologische indeling aan de hand van Noble et al. (2007) aan. Het cumulatief percentage geeft aan hoeveel de soorten over de gehele periode voorkomen op basis van de gesommeerde CPUE op basis van de biomassa. Nul-percentages zijn naar beneden afgeronde waarden, $*=$ exoot.

\begin{tabular}{|c|c|c|c|c|c|}
\hline Soort & Groepering & Cumulatief percentage & $2005-2009$ & $2010-2014$ & 2015-2019 \\
\hline clupeidae & Marien (Pelagisch) & 56.42 & 64.36 & - & \\
\hline haring & Marien (Pelagisch) & 94.42 & 34.7 & 62.5 & 60.77 \\
\hline spiering & Eurytoop (Pelagisch) & 95.93 & 0.06 & 14.93 & 9.77 \\
\hline sprot & Marien (Pelagisch) & 97.33 & 0.02 & 9.97 & 12.07 \\
\hline zeebaars & Marien (Pelagisch) & 97.98 & 0.27 & 0.37 & 5.41 \\
\hline grondels indet. & Marien (Bentisch) & 98.49 & 0.23 & 2.06 & 2.84 \\
\hline kleine zandspiering & Marien (Bentisch) & 98.79 & 0.04 & 4.21 & 0.72 \\
\hline wijting & Marien (Bentisch) & 99.05 & 0.04 & 0.2 & 2.83 \\
\hline bot & Limnofiel (Bentisch) & 99.21 & 0.04 & 1.1 & 0.93 \\
\hline $\begin{array}{r}\text { pelser } \\
\end{array}$ & Marien (Pelagisch) & 99.33 & 0 & 0.17 & 1.42 \\
\hline koornaarvissen indet. & Marien (Pelagisch) & 99.43 & 0 & 0.11 & 1.41 \\
\hline ansjovis & Marien (Pelagisch) & 99.53 & 0.01 & 1.23 & 0.37 \\
\hline makreel & Marien (Pelagisch) & 99.63 & 0.11 & 0.01 & - \\
\hline kleine zeenaald & Marien (Bentisch) & 99.72 & 0 & 1.5 & 0.26 \\
\hline goudharder & Marien (Pelagisch) & 99.76 & 0.04 & - & 0.06 \\
\hline fint & Rheofiel (Pelagisch) & 99.8 & 0.01 & 0.1 & 0.3 \\
\hline slakdolf & Marien (Bentisch) & 99.82 & 0 & 0.26 & 0.16 \\
\hline tong & Marien (Bentisch) & 99.85 & 0.01 & 0.14 & 0.13 \\
\hline steenbolk & Marien (Bentisch) & 99.87 & 0.01 & 0.22 & 0.09 \\
\hline rivierprik & Rheofiel (Bentisch) & 99.89 & 0.01 & 0.09 & 0.08 \\
\hline kabeljauw & Marien (Bentisch) & 99.9 & 0.02 & 0 & 0 \\
\hline geep & Marien (Pelagisch) & 99.91 & 0 & 0.11 & 0.08 \\
\hline grote zeenaald & Marien (Bentisch) & 99.93 & 0 & 0.1 & 0.08 \\
\hline glasgrondel & Marien (Bentisch) & 99.94 & 0.01 & 0.04 & 0.03 \\
\hline schol & Marien (Bentisch) & 99.95 & 0 & 0.13 & 0.02 \\
\hline atlantische forel & Rheofiel (Pelagisch) & 99.95 & 0.01 & 0.05 & 0.03 \\
\hline rode poon & Marien (Bentisch) & 99.96 & 0 & 0.07 & 0.03 \\
\hline aal & Eurytoop (Bentisch) & 99.97 & 0 & 0.04 & - \\
\hline snoekbaars & Eurytoop (Bentisch) & 99.97 & 0 & 0.01 & 0.04 \\
\hline smelt & Marien (Bentisch) & 99.98 & - & 0.07 & 0 \\
\hline driedoornige stekelbaars & Eurytoop (Pelagisch) & 99.98 & 0 & 0.06 & 0.01 \\
\hline schar & Marien (Bentisch) & 99.98 & 0 & 0.01 & 0.03 \\
\hline horsmakreel & Marien (Pelagisch) & 99.99 & 0 & 0 & 0 \\
\hline kleine pieterman & Marien (Bentisch) & 99.99 & 0 & 0.03 & 0.01 \\
\hline zeedonderpad & Marien (Bentisch) & 99.99 & 0 & 0.04 & 0.01 \\
\hline vijfdradige meun & Marien (Bentisch) & 99.99 & 0 & 0.01 & - \\
\hline harnasmannetje & Marien (Bentisch) & 99.99 & 0 & 0.01 & 0 \\
\hline zeenaalden indet. & Marien (Bentisch) & 100 & 0 & - & 0 \\
\hline griet & Marien (Bentisch) & 100 & - & - & 0.01 \\
\hline dunlipharder & Marien (Pelagisch) & 100 & 0 & 0.01 & 0 \\
\hline brakwatergrondel & Marien (Bentisch) & 100 & - & 0.01 & 0 \\
\hline zalm & Rheofiel (Pelagisch) & 100 & 0 & 0.01 & - \\
\hline grauwe poon & Marien (Bentisch) & 100 & - & 0.01 & 0 \\
\hline adderzeenaald & Marien (Bentisch) & 100 & 0 & - & - \\
\hline baars & Eurytoop (Pelagisch) & 100 & 0 & 0 & 0 \\
\hline snotolf & Marien (Bentisch) & 100 & - & 0.01 & 0 \\
\hline harders indet. & Marien (Pelagisch) & 100 & - & - & 0 \\
\hline groene zeedonderpad & Marien (Bentisch) & 100 & 0 & 0 & - \\
\hline zeeprik & Rheofiel (Bentisch) & 100 & 0 & - & - \\
\hline schurftvis & Marien (Bentisch) & 100 & - & 0 & 0 \\
\hline botervis & Marien (Pelagisch) & 100 & 0 & - & 0 \\
\hline brasem & Eurytoop (Bentisch) & 100 & - & 0 & - \\
\hline vierdradige meun & Marien (Bentisch) & 100 & 0 & - & - \\
\hline zonnevis & Marien (Bentisch) & 100 & - & - & 0 \\
\hline puitaal & Marien (Bentisch) & 100 & 0 & - & - \\
\hline stekelrog & Marien (Bentisch) & 100 & - & 0 & - \\
\hline pontische stroomgrondel* & Eurytoop (Bentisch) & 100 & - & 0 & - \\
\hline zwartbekgrondel* & Eurytoop (Bentisch) & 100 & - & - & 0 \\
\hline vorskwab & Marien (Bentisch) & 100 & 0 & - & - \\
\hline diklipharder & Marien (Pelagisch) & 100 & - & 0 & 0 \\
\hline dwergtong & Marien (Bentisch) & 100 & - & 0 & - \\
\hline noorse zandspiering & Marien (Bentisch) & 100 & - & - & 0 \\
\hline hondshaai & Marien (Bentisch) & 100 & - & - & 0 \\
\hline pos & Eurytoop (Bentisch) & 100 & - & 0 & - \\
\hline pitvis & Marien (Bentisch) & 100 & - & 0 & - \\
\hline
\end{tabular}




\section{Bijlage 55 Westerschelde (DFS)}

Tabel 1. Soortensamenstelling in percentages op basis van aantal in boomkorvangsten in de Westerschelde per 5-jarige periode. De groepering geeft de ecologische indeling aan de hand van Noble et al. (2007) aan. Het cumulatief percentage geeft aan hoeveel de soorten over de gehele periode voorkomen op basis van de gesommeerde CPUE op basis van het aantal. Nul-percentages zijn naar beneden afgeronde waarden, $*=$ exoot.

\begin{tabular}{|c|c|c|c|c|c|c|c|c|c|c|c|c|}
\hline Soort & Groepering & $\begin{array}{l}\text { Cumulatief } \\
\text { percentage }\end{array}$ & $\begin{array}{r}1970- \\
1974 \\
\end{array}$ & $\begin{array}{r}1975- \\
1979 \\
\end{array}$ & $\begin{array}{r}1980- \\
1984 \\
\end{array}$ & $\begin{array}{r}1985- \\
1989 \\
\end{array}$ & $\begin{array}{r}1990- \\
1994 \\
\end{array}$ & $\begin{array}{r}1995- \\
1999 \\
\end{array}$ & $\begin{array}{r}2000- \\
2004 \\
\end{array}$ & $\begin{array}{r}2005- \\
2009 \\
\end{array}$ & $\begin{array}{r}2010- \\
2014 \\
\end{array}$ & $\begin{array}{r}2015- \\
2019 \\
\end{array}$ \\
\hline grondels & Marien (Bentisch) & 50.02 & 53.79 & 49.63 & 68.46 & 41.02 & 67.66 & 52.94 & 38.17 & 35.65 & 38.81 & 57.76 \\
\hline schol & Marien (Bentisch) & 61.89 & 8.52 & 6.12 & 5 & 13.31 & 8.16 & 12.92 & 14.13 & 21.99 & 20.58 & 5.69 \\
\hline haring & Marien (Pelagisch) & 73.11 & 4.33 & 0.47 & 1.65 & 6.23 & 10.1 & 6.28 & 23.29 & 15.44 & 11.28 & 20.13 \\
\hline schar & Marien (Bentisch) & 81.6 & 12.14 & 24.88 & 12.26 & 31.54 & 2.85 & 5.02 & 3.75 & 1.7 & 0.08 & 0.04 \\
\hline tong & Marien (Bentisch) & 87.41 & 9.86 & 9.14 & 4.25 & 2.93 & 2.77 & 5.24 & 9.24 & 12.78 & 3.38 & 2.57 \\
\hline bot & Limnofiel (Bentisch) & 90.2 & 1.87 & 0.66 & 0.62 & 0.9 & 0.66 & 1.27 & 1.77 & 6.69 & 5.36 & 4.85 \\
\hline spiering & Eurytoop (Pelagisch) & 92.19 & 0.65 & 0 & 0.01 & - & 0.01 & 0.1 & 0.07 & 0.18 & 9.58 & 4.9 \\
\hline zeebaars & Marien (Pelagisch) & 93.71 & 0.01 & 0.01 & 0.01 & 0 & 1.62 & 1.24 & 4.01 & 1.59 & 2.76 & 2.15 \\
\hline steenbolk & Marien (Bentisch) & 95.16 & 0.73 & 2.84 & 1.86 & 0.37 & 2.93 & 3.45 & 2.5 & 1.1 & 0.32 & 0.11 \\
\hline sprot & Marien (Pelagisch) & 96.05 & 2.94 & 0.51 & 1.4 & 0.45 & 0.57 & 6.8 & 0.29 & 0 & 0.07 & 0.01 \\
\hline horsmakreel & Marien (Pelagisch) & 96.64 & 0.09 & 0.12 & 0.01 & 0.02 & 0.95 & 0.84 & 0.18 & 0.08 & 3.1 & 0.17 \\
\hline wijting & Marien (Bentisch) & 97.16 & 0.47 & 1.38 & 0.86 & 0.77 & 0.22 & 0.85 & 0.29 & 0.57 & 0.2 & 0.13 \\
\hline zeenaalden & Marien (Bentisch) & 97.68 & 0.26 & 0.4 & 0.27 & 0.75 & 0.11 & 0.18 & 0.1 & 0.23 & 2.18 & 0.22 \\
\hline pitvis & Marien (Bentisch) & 98.05 & 0.27 & 0.34 & 0.77 & 0.33 & 0.18 & 0.58 & 0.74 & 0.5 & 0.06 & 0.02 \\
\hline slakdolf & Marien (Bentisch) & 98.39 & 1.96 & 1.09 & 0.73 & 0.33 & 0.11 & 0.04 & 0.08 & 0.08 & 0.1 & 0.02 \\
\hline harnasmannetje & Marien (Bentisch) & 98.72 & 0.54 & 1.14 & 0.74 & 0.17 & 0.06 & 0.61 & 0.16 & 0.03 & 0.32 & 0.06 \\
\hline vijfdradige meun & Marien (Bentisch) & 98.93 & 0.36 & 0.21 & 0.22 & 0.13 & 0.54 & 0.16 & 0.12 & 0.39 & 0.12 & 0.09 \\
\hline zeedonderpad & Marien (Bentisch) & 99.15 & 0.1 & 0.04 & 0.26 & 0.15 & 0.07 & 0.36 & 0.09 & 0.13 & 0.66 & 0.17 \\
\hline zandspieringen & Marien (Bentisch) & 99.33 & 0.07 & 0.05 & 0.08 & 0.08 & 0.14 & 0.14 & 0.18 & 0.15 & 0.42 & 0.32 \\
\hline kabeljauw & Marien (Bentisch) & 99.46 & 0.17 & 0.47 & 0.12 & 0.22 & 0.02 & 0.2 & 0.07 & 0.17 & 0.01 & 0 \\
\hline aal & Eurytoop (Bentisch) & 99.57 & 0.55 & 0.31 & 0.12 & 0.09 & 0.1 & 0.29 & 0.12 & 0.03 & 0.01 & \\
\hline koornaarvis & Marien (Pelagisch) & 99.65 & 0.02 & 0.01 & 0.01 & 0.05 & 0.02 & 0.15 & 0.25 & 0.02 & 0.02 & 0.21 \\
\hline puitaal & Marien (Bentisch) & 99.72 & 0.12 & 0 & 0 & 0.02 & 0.01 & 0.02 & 0.02 & 0.1 & 0.19 & 0.1 \\
\hline smelt & Marien (Bentisch) & 99.77 & - & 0.01 & 0.05 & 0.03 & 0.03 & 0.09 & 0.04 & 0.08 & 0.09 & 0.05 \\
\hline snoekbaars & Eurytoop (Bentisch) & 99.81 & - & - & - & - & 0 & - & 0.16 & 0.15 & 0.04 & 0.01 \\
\hline kleine pieterman & Marien (Bentisch) & 99.84 & - & - & - & - & 0.01 & 0.03 & 0.02 & 0.05 & 0.06 & 0.08 \\
\hline griet & Marien (Bentisch) & 99.87 & 0.02 & 0.01 & 0.01 & 0.01 & 0.02 & 0.02 & 0.02 & 0.05 & 0.06 & 0.03 \\
\hline ansjovis & Marien (Pelagisch) & 99.89 & 0.03 & - & - & 0.07 & 0.07 & - & 0 & 0.03 & 0 & 0.01 \\
\hline rode poon & Marien (Bentisch) & 99.91 & 0.03 & 0.08 & 0.01 & 0.01 & 0.01 & 0.03 & 0 & 0.01 & 0.05 & 0.01 \\
\hline riedoornige stekelbaars & Eurytoop (Pelagisch) & 99.92 & 0.04 & 0.01 & 0.02 & 0 & 0 & 0.02 & 0.01 & - & 0 & 0.01 \\
\hline tarbot & Marien (Bentisch) & 99.93 & - & - & 0 & 0 & 0.01 & 0.02 & 0.04 & 0.01 & 0 & 0.01 \\
\hline grauwe poon & Marien (Bentisch) & 99.94 & 0.07 & 0.02 & 0.04 & - & 0 & - & - & - & - & \\
\hline fint & Rheofiel (Pelagisch) & 99.95 & - & - & - & 0 & - & 0 & - & - & 0.06 & $\underline{0}$ \\
\hline dwergbolk & Marien (Bentisch) & 99.96 & - & 0 & 0.07 & - & - & 0.01 & - & - & - & \\
\hline tongschar & Marien (Bentisch) & 99.96 & - & - & - & - & 0 & - & 0.05 & - & 0 & \\
\hline harders indet, & Marien (Pelagisch) & 99.97 & - & - & - & 0 & - & 0.08 & 0 & - & - & 0.01 \\
\hline botervis & Marien (Pelagisch) & 99.98 & 0 & 0 & 0.01 & 0 & - & - & - & 0 & 0.01 & 0.02 \\
\hline adderzeenaald & Marien (Bentisch) & 99.98 & - & - & 0.03 & - & - & - & - & 0 & - & 0 \\
\hline geep & Marien (Pelagisch) & 99.98 & - & - & - & - & 0 & - & - & - & 0 & 0.02 \\
\hline driedradige meun & Marien (Bentisch) & 99.99 & - & 0.02 & 0.01 & - & - & - & - & - & - & \\
\hline rasterpitvis & Marien (Bentisch) & 99.99 & - & - & - & - & - & - & - & - & 0.01 & \\
\hline blankvoorn & Eurytoop (Pelagisch) & 99.99 & - & - & - & - & - & - & 0 & 0.01 & - & - \\
\hline snotolf & Marien (Bentisch) & 99.99 & 0.01 & 0.01 & 0 & 0 & - & - & 0 & - & - & \\
\hline mul & Marien (Bentisch) & 99.99 & - & - & - & - & - & 0 & 0 & - & - & 0.01 \\
\hline stekelrog & Marien (Bentisch) & 99.99 & - & 0.01 & 0 & - & - & - & - & - & - & - \\
\hline zwartbekgrondel* & Eurytoop (Bentisch) & 99.99 & - & - & - & - & - & - & - & - & 0.01 & 0 \\
\hline franse tong & Marien (Bentisch) & 100 & - & - & - & - & - & - & 0.01 & - & - & \\
\hline \multicolumn{2}{|c|}{$\begin{array}{c}\text { franse tong Marıen (Bentisch) } \\
\text { baars Eurytoop (Pelagisch) }\end{array}$} & 100 & - & - & - & - & - & - & 0 & 0 & - & 0 \\
\hline rivierprik & Rheofiel (Bentisch) & 100 & - & 0 & 0 & - & - & - & - & - & - & 0 \\
\hline zeeprik & Rheofiel (Bentisch) & 100 & - & - & 0 & - & 0 & - & 0 & - & - & - \\
\hline gladde haai & Marien (Bentisch) & 100 & - & - & - & - & - & - & - & - & 0 & - \\
\hline gevlekte gladde haai & Marien (Bentisch) & 100 & - & - & - & - & - & - & - & - & - & $\underline{0}$ \\
\hline witte koolvis & Marien (Bentisch) & 100 & - & - & 0 & - & - & - & - & - & - & - \\
\hline zwarte koolvis & Marien (Bentisch) & 100 & - & - & - & 0 & - & - & - & - & - & \\
\hline doornhaai & Marien (Bentisch) & 100 & - & - & 0 & - & - & - & - & - & - & \\
\hline ruwe haai & Marien (Bentisch) & 100 & - & - & - & - & - & - & 0 & - & - & - \\
\hline dwergtong & Marien (Bentisch) & 100 & - & 0 & - & - & - & - & - & - & - & 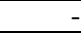 \\
\hline vierdradige meun & Marien (Bentisch) & 100 & - & - & 0 & - & - & - & - & - & - & 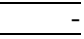 \\
\hline
\end{tabular}


Tabel 2. Soortensamenstelling in percentages op basis van biomassa in boomkorvangsten in de Westerschelde per 5-jarige periode. De groepering geeft de ecologische indeling aan de hand van Noble et al. (2007) aan. Het cumulatief percentage geeft aan hoeveel de soorten over de gehele periode voorkomen op basis van de gesommeerde CPUE op basis van de biomassa. Nul-percentages zijn naar beneden afgeronde waarden, * = exoot.

\begin{tabular}{|c|c|c|c|c|c|c|c|c|c|c|c|c|}
\hline Soort & Groepering & $\begin{array}{l}\text { Cumulatief } \\
\text { percentage }\end{array}$ & $\begin{array}{r}1970- \\
1974\end{array}$ & $\begin{array}{r}1975- \\
1979\end{array}$ & $\begin{array}{r}1980- \\
1984\end{array}$ & $\begin{array}{r}1985- \\
1989\end{array}$ & $\begin{array}{r}1990- \\
1994\end{array}$ & $\begin{array}{r}1995- \\
1999\end{array}$ & $\begin{array}{r}2000- \\
2004\end{array}$ & $\begin{array}{r}2005- \\
2009\end{array}$ & $\begin{array}{r}2010- \\
2014\end{array}$ & $\begin{array}{r}2015- \\
2019\end{array}$ \\
\hline schol & Marien (Bentisch) & 15.15 & 17.68 & 9.05 & 12.96 & 20.38 & 16.83 & 16 & 14.05 & 21.59 & 18.29 & 5.45 \\
\hline \multicolumn{2}{|c|}{ bot Limnofiel (Bentisch) } & 29.44 & 20.88 & 9.66 & 11.86 & 11.38 & 8.71 & 14.83 & 10.82 & 16.36 & 21.07 & 16.81 \\
\hline grondels & Marien (Bentisch) & 42.44 & 7.56 & 9.58 & 18.99 & 10.37 & 22.44 & 12.58 & 10.24 & 7.46 & 10.59 & 19.46 \\
\hline tong & Marien (Bentisch) & 54.75 & 10.68 & 8.66 & 12.11 & 5.63 & 9.06 & 13.75 & 15.08 & 20.61 & 12.93 & 10.82 \\
\hline schar & Marien (Bentisch) & 63.61 & 16.24 & 24.96 & 13.79 & 35.14 & 1.36 & 1.71 & 1.6 & 0.73 & 0.12 & 0.19 \\
\hline steenbolk & Marien (Bentisch) & 71.32 & 4.12 & 16.2 & 10.7 & 2.56 & 19.78 & 13.41 & 10.64 & 5.93 & 1.34 & 0.56 \\
\hline haring & Marien (Pelagisch) & 77.66 & 3.06 & 0.41 & 1.11 & 3.55 & 8.3 & 2.87 & 10.71 & 6.34 & 7.32 & 13.97 \\
\hline zeebaars & Marien (Pelagisch) & 83.84 & 0 & 0 & 0.08 & 0 & 3.35 & 5.99 & 14.8 & 8.42 & 2.53 & 18.18 \\
\hline \multicolumn{2}{|c|}{ spiering Eurytoop (Pelagisch) } & 86.82 & 2 & 0 & 0.01 & - & 0.06 & 0.61 & 0.13 & 0.49 & 13.27 & 8.82 \\
\hline wijting & Marien (Bentisch) & 89.62 & 2.68 & 7.97 & 5.2 & 4.13 & 1.34 & 3.44 & 1.08 & 2.42 & 0.92 & 0.64 \\
\hline kabeljauw & Marien (Bentisch) & 91.55 & 1.44 & 6.12 & 2.81 & 1.16 & 0.75 & 2.99 & 1.91 & 3.03 & 0.11 & 0.12 \\
\hline zeedonderpad & Marien (Bentisch) & 93.44 & 0.84 & 0.15 & 2.46 & 1.67 & 0.8 & 2.7 & 0.94 & 1.03 & 5.5 & 1.76 \\
\hline \multicolumn{2}{|c|}{ aal Eurytoop (Bentisch) } & 95.24 & 6.62 & 3.26 & 1.57 & 1.64 & 2.09 & 4.46 & 1.96 & 0.63 & 0.53 & \\
\hline pitvis & Marien (Bentisch) & 95.97 & 0.26 & 0.16 & 1.68 & 0.51 & 0.56 & 0.53 & 1.79 & 1.08 & 0.17 & 0.06 \\
\hline vijfdradige meun & Marien (Bentisch) & 96.62 & 0.93 & 0.6 & 0.98 & 0.26 & 2.02 & 0.39 & 0.26 & 1.05 & 0.28 & 0.18 \\
\hline griet & Marien (Bentisch) & 97.19 & 0.49 & 0.4 & 0.05 & 0.23 & 0.32 & 0.27 & 0.55 & 0.65 & 1.61 & 0.74 \\
\hline zandspieringen & Marien (Bentisch) & 97.53 & 0.08 & 0.09 & 0.17 & 0.16 & 0.27 & 0.24 & 0.26 & 0.24 & 0.81 & 0.72 \\
\hline \multicolumn{2}{|c|}{ snoekbaars Eurytoop (Bentisch) } & 97.82 & - & - & - & - & 0.01 & - & 1.41 & 0.69 & 0.17 & 0.12 \\
\hline horsmakreel & Marien (Pelagisch) & 98.1 & 0.03 & 0.05 & 0 & 0.27 & 0.75 & 0.43 & 0.33 & 0.14 & 0.73 & 0.07 \\
\hline sprot & Marien (Pelagisch) & 98.35 & 0.7 & 0.15 & 0.34 & 0.14 & 0.35 & 1.61 & 0.07 & 0 & 0.03 & 0 \\
\hline smelt & Marien (Bentisch) & 98.57 & - & 0.06 & 0.23 & 0.1 & 0.19 & 0.44 & 0.11 & 0.38 & 0.38 & 0.24 \\
\hline slakdolf & Marien (Bentisch) & 98.79 & 1.05 & 0.63 & 0.56 & 0.26 & 0.06 & 0.02 & 0.05 & 0.03 & 0.04 & 0.01 \\
\hline zeenaalden & Marien (Bentisch) & 99 & 1.94 & 0.07 & 0.25 & 0.08 & 0.08 & 0.04 & 0.05 & 0.09 & 0.15 & 0.13 \\
\hline harnasmannetje & Marien (Bentisch) & 99.2 & 0.26 & 0.64 & 0.77 & 0.11 & 0.02 & 0.16 & 0.04 & 0.02 & 0.14 & 0.04 \\
\hline tarbot & Marien (Bentisch) & 99.38 & - & - & 0.05 & 0.09 & 0.2 & 0.05 & 0.69 & 0.1 & 0.14 & 0.26 \\
\hline puitaal & Marien (Bentisch) & 99.51 & 0.26 & 0 & 0.01 & 0.07 & 0.07 & 0.03 & 0.03 & 0.18 & 0.37 & 0.19 \\
\hline stekelrog & Marien (Bentisch) & 99.63 & - & 0.78 & 0.53 & - & - & - & - & - & - & \\
\hline kleine pieterman & Marien (Bentisch) & 99.69 & - & - & - & - & 0.03 & 0.07 & 0.04 & 0.1 & 0.11 & 0.21 \\
\hline rode poon & Marien (Bentisch) & 99.75 & 0.06 & 0.16 & 0.14 & 0.02 & 0.04 & 0.06 & 0.05 & 0.03 & 0.04 & 0.01 \\
\hline adderzeenaald & Marien (Bentisch) & 99.79 & - & - & 0.27 & - & - & - & - & 0.03 & - & 0.01 \\
\hline grauwe poon & Marien (Bentisch) & 99.81 & 0.12 & 0.1 & 0.06 & - & 0 & - & - & - & - & \\
\hline dwergbolk & Marien (Bentisch) & 99.83 & - & 0.02 & 0.17 & - & - & 0.03 & - & - & - & \\
\hline tongschar & Marien (Bentisch) & 99.85 & - & - & - & - & 0.03 & - & 0.11 & - & 0.05 & \\
\hline harders indet, & Marien (Bentisch) & 99.87 & - & - & - & 0 & - & 0.27 & 0 & - & - & \\
\hline koornaarvis & Marien (Pelagisch) & 99.88 & 0 & 0 & 0 & 0.01 & 0 & 0.03 & 0.05 & 0 & 0.01 & 0.05 \\
\hline blankvoorn & Eurytoop (Pelagisch) & 99.9 & - & - & - & - & - & - & 0.02 & 0.1 & - & \\
\hline gladde haai & Marien (Bentisch) & 99.91 & - & - & - & - & - & - & - & - & 0.12 & \\
\hline botervis & Marien (Pelagisch) & 99.93 & 0.01 & 0.01 & 0.02 & 0 & - & - & - & 0.01 & 0.02 & 0.04 \\
\hline fint & Rheofiel (Pelagisch) & 99.94 & - & - & - & 0 & - & 0.01 & - & - & 0.08 & 0.01 \\
\hline ruwe haai & Marien (Bentisch) & 99.95 & - & - & - & - & - & - & 0.08 & - & - & \\
\hline ansjovis & Marien (Pelagisch) & 99.96 & 0 & - & - & 0.03 & 0.05 & - & 0 & 0.01 & 0 & 0.01 \\
\hline gevlekte gladde haai & Marien (Bentisch) & 99.96 & - & - & - & - & - & - & - & - & - & 0.06 \\
\hline geep & Marien (Pelagisch) & 99.97 & - & - & - & - & 0.06 & - & - & - & 0 & 0.02 \\
\hline rivierprik & Rheofiel (Bentisch) & 99.98 & - & 0.03 & 0.02 & - & - & - & - & - & - & 0.01 \\
\hline zwartbekgrondel* & Eurytoop (Bentisch) & 99.98 & - & - & - & - & - & - & - & - & 0.03 & 0.01 \\
\hline snotolf & Marien (Bentisch) & 99.99 & 0.01 & 0.02 & 0 & 0.01 & - & - & 0 & - & - & \\
\hline franse tong & Marien (Bentisch) & 99.99 & - & - & - & - & - & - & 0.03 & - & - & \\
\hline zeeprik & Rheofiel (Bentisch) & 99.99 & - & - & 0.01 & - & 0.01 & - & 0.01 & - & - & \\
\hline witte koolvis & Marien (Bentisch) & 99.99 & - & - & 0.02 & - & - & - & - & - & - & \\
\hline zwarte koolvis & Marien (Bentisch) & 99.99 & - & - & - & 0.02 & - & - & - & - & - & \\
\hline driedradige meun & Marien (Bentisch) & 100 & - & 0.01 & 0.01 & - & - & - & - & - & - & \\
\hline iedoornige stekelbaars & Eurytoop (Pelagisch) & 100 & 0 & 0 & 0 & 0 & 0 & 0 & 0 & - & 0 & 0 \\
\hline baars & Eurytoop (Pelagisch) & 100 & - & - & - & - & - & - & 0 & 0 & - & 0 \\
\hline rasterpitvis & Marien (Bentisch) & 100 & - & - & - & - & - & - & - & - & 0.01 & \\
\hline mul & Marien (Bentisch) & 100 & - & - & - & - & - & 0 & 0 & - & - & 0 \\
\hline vierdradige meun & Marien (Bentisch) & 100 & - & - & 0 & - & - & - & - & - & - & \\
\hline doornhaai & Marien (Bentisch) & 100 & - & - & 0 & - & - & - & - & - & - & \\
\hline dwergtong & Marien (Bentisch) & 100 & - & 0 & - & - & - & - & - & - & - & \\
\hline
\end{tabular}




\section{Bijlage 56 Eems-estuarium}

Tabel 1. Soortensamenstelling in percentages op basis van aantal in ankerkuilvangsten in het Eems-estuarium per 5-jarige periode. De groepering geeft de ecologische indeling aan de hand van Noble et al. (2007) aan. Het cumulatief percentage geeft aan hoeveel de soorten over de gehele periode voorkomen op basis van de gesommeerde CPUE op basis van het aantal. Nul-percentages zijn naar beneden afgeronde waarden, $*=$ exoot.

\begin{tabular}{|c|c|c|c|c|c|}
\hline Soort & Groepering & Cumulatief percentage & $2005-2009$ & $2010-2014$ & $2015-2019$ \\
\hline haring & Marien (Pelagisch) & 75.86 & 46.94 & 55.95 & 84.8 \\
\hline spiering & Eurytoop (Pelagisch) & 83.42 & 18.93 & 16.24 & 3.83 \\
\hline dikkopje & Marien (Bentisch) & 89.71 & 12.93 & 6.84 & 5.23 \\
\hline sprot & Marien (Pelagisch) & 92.25 & 0.61 & 2.2 & 2.9 \\
\hline brakwatergrondel & Marien (Bentisch) & 93.89 & 5.92 & 5.17 & 0.18 \\
\hline kleine zeenaald & Marien (Bentisch) & 95.53 & 4.39 & 5.02 & 0.41 \\
\hline wijting & Marien (Bentisch) & 96.36 & 3.23 & 0.42 & 0.6 \\
\hline clupeidae & Marien (Pelagisch) & 96.94 & - & 0 & 0.8 \\
\hline ansjovis & Marien (Pelagisch) & 97.45 & 1.65 & 0.18 & 0.43 \\
\hline slakdolf & Marien (Bentisch) & 97.95 & 1.83 & 1.12 & 0.17 \\
\hline fint & Rheofiel (Pelagisch) & 98.44 & 0.83 & 2.19 & 0.02 \\
\hline horsmakreel & Marien (Pelagisch) & 98.9 & - & 2.57 & 0 \\
\hline bot & Limnofiel (Bentisch) & 99.24 & 0.98 & 0.6 & 0.19 \\
\hline grondels indet. & Marien (Bentisch) & 99.41 & - & 0.11 & 0.22 \\
\hline schol & Marien (Bentisch) & 99.55 & 0.18 & 0.48 & 0.04 \\
\hline tong & Marien (Bentisch) & 99.61 & 0.15 & 0.19 & 0.01 \\
\hline schar & Marien (Bentisch) & 99.66 & 0.02 & 0.13 & 0.04 \\
\hline driedoornige stekelbaars & Eurytoop (Pelagisch) & 99.7 & 0.04 & 0.11 & 0.03 \\
\hline kabeljauw & Marien (Bentisch) & 99.74 & 0.34 & 0.03 & 0 \\
\hline rivierprik & Rheofiel (Bentisch) & 99.78 & 0.21 & 0.06 & 0.01 \\
\hline glasgrondel & Marien (Bentisch) & 99.82 & 0.21 & 0.08 & 0 \\
\hline lozano's grondel & Marien (Bentisch) & 99.86 & - & 0.02 & 0.04 \\
\hline steenbolk & Marien (Bentisch) & 99.89 & 0.24 & 0.04 & 0.01 \\
\hline geep & Marien (Pelagisch) & 99.91 & 0.14 & 0.01 & 0 \\
\hline rode poon & Marien (Bentisch) & 99.92 & 0.03 & 0.05 & 0 \\
\hline baars & Eurytoop (Pelagisch) & 99.93 & 0.02 & 0.02 & 0.01 \\
\hline vijfdradige meun & Marien (Bentisch) & 99.94 & 0.05 & 0.01 & 0 \\
\hline harnasmannetje & Marien (Bentisch) & 99.95 & 0.01 & 0.05 & 0 \\
\hline brasem & Eurytoop (Bentisch) & 99.96 & 0.04 & 0.02 & 0 \\
\hline aal & Eurytoop (Bentisch) & 99.97 & 0.03 & 0.01 & 0 \\
\hline zeedonderpad & Marien (Bentisch) & 99.97 & 0.01 & 0.02 & 0 \\
\hline snoekbaars & Eurytoop (Bentisch) & 99.98 & 0.01 & 0.01 & 0 \\
\hline brasemachtigen & Eurytoop (Bentisch) & 99.98 & - & 0.01 & - \\
\hline griet & Marien (Bentisch) & 99.98 & 0 & 0.01 & 0 \\
\hline snotolf & Marien (Bentisch) & 99.98 & 0.01 & 0 & 0 \\
\hline kolblei & Eurytoop (Bentisch) & 99.98 & 0.01 & 0 & 0 \\
\hline dunlipharder & Marien (Pelagisch) & 99.99 & 0.01 & 0 & 0 \\
\hline tarbot & Marien (Bentisch) & 99.99 & 0 & 0 & 0 \\
\hline ammodytes & Marien (Bentisch) & 99.99 & 0 & 0 & 0 \\
\hline zeebaars & Marien (Pelagisch) & 99.99 & 0 & 0 & 0 \\
\hline grote zeenaald & Marien (Bentisch) & 99.99 & 0 & 0 & 0 \\
\hline grauwe poon & Marien (Bentisch) & 99.99 & - & 0 & 0 \\
\hline winde & Rheofiel (Pelagisch) & 99.99 & 0 & 0 & 0 \\
\hline pos & Eurytoop (Bentisch) & 99.99 & 0 & 0 & 0 \\
\hline puitaal & Marien (Bentisch) & 100 & 0 & 0 & 0 \\
\hline pleuronectidae & Marien (Bentisch) & 100 & - & - & 0 \\
\hline dwergbolk & Marien (Bentisch) & 100 & - & 0 & 0 \\
\hline kleine pieterman & Marien (Bentisch) & 100 & 0 & 0 & 0 \\
\hline tiendoornige stekelbaars & Limnofiel (Pelagisch) & 100 & 0 & 0 & - \\
\hline atlantische forel & Rheofiel (Pelagisch) & 100 & 0 & 0 & 0 \\
\hline smelt & Marien (Bentisch) & 100 & - & 0 & 0 \\
\hline karper & Eurytoop (Bentisch) & 100 & - & 0 & 0 \\
\hline zeelt & Limnofiel (Bentisch) & 100 & 0 & 0 & - \\
\hline blankvoorn & Eurytoop (Pelagisch) & 100 & 0 & 0 & - \\
\hline zeeprik & Rheofiel (Bentisch) & 100 & 0 & 0 & - \\
\hline roofblei* & Rheofiel (Pelagisch) & 100 & - & - & 0 \\
\hline zwartbekgrondel* & Eurytoop (Bentisch) & 100 & - & - & 0 \\
\hline pelser & Marien (Pelagisch) & 100 & - & 0 & 0 \\
\hline hondshaai & Marien (Bentisch) & 100 & - & - & 0 \\
\hline makreel & Marien (Pelagisch) & 100 & - & 0 & 0 \\
\hline barbeel & Rheofiel (Bentisch) & 100 & 0 & 0 & - \\
\hline grote modderkruiper & Marien (Bentisch) & 100 & - & 0 & - \\
\hline tongschar & Marien (Bentisch) & 100 & 0 & 0 & - \\
\hline rietvoorn & Limnofiel (Pelagisch) & 100 & - & - & 0 \\
\hline snoek & Eurytoop (Pelagisch) & 100 & - & - & 0 \\
\hline adderzeenaald & Marien (Bentisch) & 100 & 0 & - & - \\
\hline europese meerval & Eurytoop (Bentisch) & 100 & - & 0 & - \\
\hline diklipharder & Marien (Pelagisch) & 100 & - & 0 & - \\
\hline koornaarvis & Marien (Pelagisch) & 100 & - & 0 & - \\
\hline $\mathrm{mul}$ & Marien (Bentisch) & 100 & - & - & 0 \\
\hline
\end{tabular}


Tabel 2. Soortensamenstelling in percentages op basis van biomassa in ankerkuilvangsten in het Eemsestuarium per 5-jarige periode. De groepering geeft de ecologische indeling aan de hand van Noble et al. (2007) aan. Het cumulatief percentage geeft aan hoeveel de soorten over de gehele periode voorkomen op basis van de gesommeerde CPUE op basis van de biomassa. Nul-percentages zijn naar beneden afgeronde waarden, $*=$ exoot.

\begin{tabular}{|c|c|c|c|c|c|}
\hline Soort & Groepering & Cumulatief percentage & 2005-2009 & 2010-2014 & 2015-2019 \\
\hline haring & Marien (Pelagisch) & 72.35 & 42.25 & 60.12 & 86.5 \\
\hline spiering & Eurytoop (Pelagisch) & 82.12 & 14.2 & 19.42 & 4.07 \\
\hline wijting & Marien (Bentisch) & 86.29 & 16.78 & 3.37 & 0.97 \\
\hline bot & Limnofiel (Bentisch) & 89.32 & 5.03 & 3.74 & 2.14 \\
\hline fint & Rheofiel (Pelagisch) & 91.28 & 3.71 & 3.67 & 0.68 \\
\hline dikkopje & Marien (Bentisch) & 93.04 & 2.38 & 1.4 & 1.76 \\
\hline ansjovis & Marien (Pelagisch) & 94.05 & 3.46 & 0.52 & 0.54 \\
\hline sprot & Marien (Pelagisch) & 95.04 & 0.17 & 1.39 & 1.05 \\
\hline schar & Marien (Bentisch) & 96.03 & 0.06 & 1.18 & 1.16 \\
\hline kabeljauw & Marien (Bentisch) & 96.72 & 3.35 & 0.47 & 0.04 \\
\hline rivierprik & Rheofiel (Bentisch) & 97.39 & 2.22 & 0.66 & 0.22 \\
\hline geep & Marien (Pelagisch) & 98.01 & 2.84 & 0.29 & 0.15 \\
\hline tong & Marien (Bentisch) & 98.35 & 0.76 & 0.66 & 0.08 \\
\hline aal & Eurytoop (Bentisch) & 98.64 & 0.54 & 0.52 & 0.12 \\
\hline horsmakreel & Marien (Pelagisch) & 98.86 & - & 0.82 & 0.01 \\
\hline schol & Marien (Bentisch) & 99.08 & 0.2 & 0.46 & 0.11 \\
\hline rode poon & Marien (Bentisch) & 99.21 & 0.33 & 0.22 & 0.04 \\
\hline kleine zeenaald & Marien (Bentisch) & 99.32 & 0.28 & 0.17 & 0.04 \\
\hline brakwatergrondel & Marien (Bentisch) & 99.42 & 0.21 & 0.21 & 0.02 \\
\hline steenbolk & Marien (Bentisch) & 99.51 & 0.5 & 0.02 & 0.01 \\
\hline vijfdradige meun & Marien (Bentisch) & 99.57 & 0.22 & 0.05 & 0.02 \\
\hline zeedonderpad & Marien (Bentisch) & 99.63 & 0.09 & 0.13 & 0.01 \\
\hline clupeidae & Marien (Pelagisch) & 99.67 & - & 0 & 0.07 \\
\hline tarbot & Marien (Bentisch) & 99.7 & 0.02 & 0.08 & 0.02 \\
\hline atlantische forel & Rheofiel (Pelagisch) & 99.73 & 0.02 & 0.05 & 0.03 \\
\hline driedoornige stekelbaars & Eurytoop (Pelagisch) & 99.76 & 0.01 & 0.03 & 0.02 \\
\hline brasem & Eurytoop (Bentisch) & 99.78 & 0.06 & 0.04 & 0 \\
\hline zeeprik & Rheofiel (Bentisch) & 99.8 & 0.06 & 0.04 & - \\
\hline grauwe poon & Marien (Bentisch) & 99.82 & - & 0 & 0.03 \\
\hline snoekbaars & Eurytoop (Bentisch) & 99.84 & 0.07 & 0.01 & 0.01 \\
\hline diklipharder & Marien (Pelagisch) & 99.85 & - & 0.06 & - \\
\hline hondshaai & Marien (Bentisch) & 99.87 & - & - & 0.03 \\
\hline harnasmannetje & Marien (Bentisch) & 99.88 & 0.01 & 0.04 & 0 \\
\hline grondels indet. & Marien (Bentisch) & 99.89 & - & 0.03 & 0.01 \\
\hline baars & Eurytoop (Pelagisch) & 99.91 & 0.02 & 0.02 & 0.01 \\
\hline kolblei & Eurytoop (Bentisch) & 99.92 & 0.02 & 0.01 & 0.01 \\
\hline griet & Marien (Bentisch) & 99.93 & 0.02 & 0.02 & 0 \\
\hline glasgrondel & Marien (Bentisch) & 99.94 & 0.03 & 0.02 & 0 \\
\hline lozano's grondel & Marien (Bentisch) & 99.95 & - & 0.01 & 0.01 \\
\hline dunlipharder & Marien (Pelagisch) & 99.96 & 0.02 & 0 & 0.01 \\
\hline makreel & Marien (Pelagisch) & 99.96 & - & 0.01 & 0.01 \\
\hline snotolf & Marien (Bentisch) & 99.97 & 0.02 & 0.01 & 0 \\
\hline grote zeenaald & Marien (Bentisch) & 99.97 & 0.01 & 0 & 0 \\
\hline zeebaars & Marien (Pelagisch) & 99.98 & 0 & 0.02 & 0 \\
\hline ammodytes & Marien (Bentisch) & 99.98 & 0.01 & 0 & 0 \\
\hline puitaal & Marien (Bentisch) & 99.99 & 0 & 0.01 & 0 \\
\hline kleine pieterman & Marien (Bentisch) & 99.99 & 0.01 & 0 & 0 \\
\hline karper & Eurytoop (Bentisch) & 99.99 & - & 0.01 & 0 \\
\hline smelt & Marien (Bentisch) & 99.99 & - & 0 & 0 \\
\hline mul & Marien (Bentisch) & 99.99 & - & - & 0 \\
\hline pos & Eurytoop (Bentisch) & 100 & 0 & 0 & 0 \\
\hline pelser & Marien (Pelagisch) & 100 & - & 0 & 0 \\
\hline winde & Rheofiel (Pelagisch) & 100 & 0 & 0 & 0 \\
\hline barbeel & Rheofiel (Bentisch) & 100 & 0 & 0 & - \\
\hline dwergbolk & Marien (Bentisch) & 100 & - & 0 & 0 \\
\hline grote modderkruiper & Marien (Bentisch) & 100 & - & 0 & - \\
\hline zeelt & Limnofiel (Bentisch) & 100 & 0 & 0 & - \\
\hline blankvoorn & Eurytoop (Pelagisch) & 100 & 0 & 0 & - \\
\hline adderzeenaald & Marien (Bentisch) & 100 & 0 & - & - \\
\hline roofblei & Rheofiel (Pelagisch) & 100 & - & - & 0 \\
\hline zwartbekgrondel & Eurytoop (Bentisch) & 100 & - & - & 0 \\
\hline rietvoorn & Limnofiel (Pelagisch) & 100 & - & - & 0 \\
\hline tongschar & Marien (Bentisch) & 100 & 0 & 0 & - \\
\hline tiendoornige stekelbaars & Limnofiel (Pelagisch) & 100 & 0 & 0 & - \\
\hline europese meerval & Eurytoop (Bentisch) & 100 & - & 0 & - \\
\hline koornaarvis & Marien (Pelagisch) & 100 & - & 0 & - \\
\hline snoek & Eurytoop (Pelagisch) & 100 & - & - & 0 \\
\hline
\end{tabular}




\section{Bijlage 57 Selectie en opwerking voor de trends Habitatrichtlijnsoorten}

Deze bijlage beschrijft de methodiek van gegevensselectie en -opwerking, voor het bepalen van de trends in de bestandgrootte van Habitatrichtlijnsoorten, zoals beschreven in hoofdstuk 4.

\section{Beschikbare gegevens en kaders}

\section{Kaders voor dataselectie en -opwerking}

De geselecteerde monitoringsgegevens moeten samen een representatief beeld geven van de landelijke populatieontwikkeling. De selectie en opwerking van de individuele metingen van alle monitoringen en gebieden naar één landelijke trend is zodanig, dat deze landelijke tijdreeks de best beschikbare schatting van de landelijke ontwikkeling in populatiegrootte is. De selectie en opwerking van geschikte monitoringsprogramma's, -locaties, -periodes vindt dus plaats op basis van biologische of ecologische argumenten. In de selectie en opwerking wordt ook rekening gehouden met de vereisten van het programma Trendspotter, waarmee, eens in de zes jaar, de statistische analyse uitgevoerd wordt (zie hoofdstuk 3.1.3).

Zoals beschreven in de artikel 17 guidelines, wordt de status van anadrome vispopulaties enkel vastgesteld op basis van gegevens uit terrestrische biogeografische regio's; alle zoutwatermonitoring valt hiermee af.

De analyse wordt sterk ingekaderd door de eigenschappen van de visgegevens:

1. Er zijn geen census-tellingen: niet de hele populatie wordt geteld. Slechts een klein deel van het bestand wordt geteld, vaak in een korte periode.

2. De meeste gegevensreeksen bevatten veel nulwaarnemingen. Van veel soorten wordt in de meeste trekken niks gevangen. Soms zijn er jaren waarin geen enkele vis van een soort gevangen wordt.

3. De bemonsteringsinspanning verschilt tussen jaren.

4. De bemonsteringinspanning per maand verschilt soms ook sterk tussen jaren. Bij voorkeur wordt hier in de analyse rekening mee gehouden, omdat diadrome vis in meerdere maanden per jaar migreert en daarmee elke maand als potentieel even belangrijk wordt ingeschat.

5. Monitoringen met passieve vistuigen zijn vaak aangepast en missen vaak jaren en/of maanden in de tijdreeks. Ook omvatten ze vaak niet de gehele periode van de laatste 12 jaar.

6. De relatie tussen de trefkans van een vis in twee verschillende monitoringen is onbekend. Deze trefkans kan sterk verschillen door verschil in tuig, periode en locatie.

\section{Kaders voor de statistische analyse}

Trendspotter kan een continue variabele zoals vangstsucces als responsvariabele hebben zolang deze normaal verdeeld is en niet te veel waardes dichtbij 0 heeft. Het is niet mogelijk andere verklarende factoren (zoals maand en inspanning) mee te nemen in de analyse. Trendspotter heeft dus een tijdreeks nodig met vangstsucces-waardes die allemaal vergelijkbaar zijn; elke waarde moet dezelfde verhouding tot de daadwerkelijke bestandsgrootte hebben.

In de gevallen waar de tijdreeks niet voldoet aan de voorwaarden van Trendspotter, zal de tijdreeks met expert judgement beoordeeld moeten worden. 


\section{Dataselectie en -opwerking}

\section{Selectie monitoringsprogramma's per soort}

\section{Niet-diadrome vis (barbeel)}

Voor barbeel worden de gegevens die verzameld zijn in monitoringsprogramma's met actieve vistuigen het meest geschikt geacht. Er zijn meerdere dergelijke programma's op de Rijkswateren. Echter, binnen de bemonsterde Rijkswateren is alleen het habitat in de Grensmaas geschikt voor barbeel; deze soort komt namelijk alleen voor in de midden-regionen van rivieren met kiezelbodem. Meer benedenstrooms van de Grensmaas, op de zandige locaties, komt de soort slechts op enkele plekken voor.

Zenderonderzoek heeft bovendien aangetoond dat dit hoogstwaarschijnlijk individuen zijn die hier tijdelijk verblijven en afkomstig zijn uit het kerngebied de Grensmaas (De Leeuw \& Winter 2008). Het betreft hier dus geen zelfstandige populatie. Ook in de Nederlandse delen van de Rijn zijn incidenteel vangsten met een onregelmatige frequentie. Hier gaat het zeer waarschijnlijk ook om individuen die afkomstig zijn uit geschiktere bovenstroomse kerngebieden in de Duitse Rijn en zijrivieren. In de Nederlandse Rijn is dus ook geen zelfstandige populatie, maar duiken op onregelmatige basis individuen op van de bovenstrooms aanwezige populatie(s). Welke factoren deze tijdelijke verplaatsingen naar benedenstroomse delen veroorzaken is niet goed bekend. In Nederlandse Rijkswateren komt de barbeel dus alleen in de Grensmaas in hogere dichtheden voor, en aangezien hier ook een lange monitoringsreeks (rivierenmonitoring met actieve tuigen ${ }^{7}$ ), is deze reeks het best bruikbaar en meest representatief voor de bepaling van trends voor barbeelpopulatie in Nederland.

\section{Diadrome vis}

Voor de diadrome soorten (fint, elft, houting, rivierprik, zalm, zeeprik) zijn de gegevens verzameld binnen monitoringsprogramma's met passieve vistuigen (fuiken en zalmsteken) het meest geschikt. Trekkende vis brengt weinig tijd door op een specifieke locatie en de trefkans is veel hoger met een passief vistuig dat lange tijd in het water aanwezig is. Diadrome soorten zijn daarnaast vaak zeldzaam waardoor de trefkans in actieve monitoringsprogramma's klein is. Er is daarom gebruik gemaakt van de gegevens afkomstig uit de passieve monitoringsprogramma's. Zie van Keeken et al. (2020) voor een uitgebreide uitleg van de verschillende programma's.

De zalmsteekbemonstering op de grote rivieren is specifiek opgezet voor de bemonstering van zalm en zeeforel, en loopt al minimaal 12 jaar (een consistente tijdreeks is beschikbaar voor de meeste locaties vanaf $1997^{8}$ ). De monitoring wordt uitgevoerd in migratiemaanden die belangrijk zijn voor deze soorten: juni, juli, oktober en november. Dit programma is door de soortspecifieke vangefficiëntie en lange looptijd dan ook het meest geschikt voor de analyse van zalm.

De diadromevissurvey is opgezet om de overige diadrome soorten te monitoren (en dan met name uittrek van schieraal), op de belangrijkste in- en uittrekpunten. Echter, deze monitoring is pas gestart in 2012 (najaar) of 2014 (voorjaar) of later (voorjaar Kornwerderzand). Deze reeks is dus niet lang genoeg voor een analyse van de laatste 12 jaar (2007-2019). Daarom wordt aanvullend gebruik gemaakt van de inmiddels gestopte vangstregistratie door aalvissers. Een nadeel van dat programma is het nietgebalanceerde karakter van de opzet: de dataset van de vangstregistratie door aalvissers bevat veel variatie in opzet door de jaren en over de locaties heen. Op veel locaties is op een bepaald moment het type tuig veranderd, is de visser gestopt en zijn/haar plaats ingenomen door een andere visser en/of is er veel variatie in de hoeveelheid inspanning per maand in een jaar en/of door de jaren heen. Voor de analyse van HR soorten zijn alleen de locaties gekozen die door dezelfde visser met hetzelfde vistuig zijn bevist gedurende de tijdserie. Vervolgens zijn voor deze locaties alleen de maanden geselecteerd die in de geselecteerde jaren consistent bevist zijn. Ook zijn alleen locaties gekozen die in de buurt liggen van

\footnotetext{
${ }^{7}$ In dit geval met het elektrisch schepnet als tuig, gezien de geringe diepte van de Grensmaas.

${ }^{8}$ De survey loopt vanaf 1994 in de Lek, Waal en Maas, maar in deze eerste jaren is de methodiek nog niet goed gestandaardiseerd en de inspanning vaak niet genoteerd. De survey in de IJssel is in 1997 gestart en in de Nederrijn in 2000.
} 
de monitoringspunten van de diadromevissurvey (Tabel 2): dit is immers de basis van de analyse in de toekomst.

De grootste opgave bij de opwerking is dat de methodiek van deze twee monitoringsprogramma's zo verschillend is, dat het vangstsucces (aantal gevangen vis per eenheid inspanning) niet vergelijkbaar is. Zelfs wanneer de twee monitoringen tegelijk zouden plaatsvinden resulteert dat waarschijnlijk in een verschillend vangstsucces. Ook is onbekend hoe de vangstsuccessen in deze twee monitoringsprogramma's zich ten opzichte van elkaar verhouden; er is geen weegfactor beschikbaar. Er is namelijk geen overlap in de tijdreeksen (een jaar waarin ze beide in hetzelfde gebied zijn uitgevoerd); er zit minimaal twee jaar tussen de twee tijdreeksen en er is over het algemeen veel jaar op jaar variatie. De enige situatie waarin een weegfactor aangehouden zou kunnen worden is als de trend over de missende tussenliggende jaren heen met redelijke zekerheid te schatten is; dus wanneer er weinig interjaarlijkse variatie en een duidelijke trend zichtbaar is. In alle andere gevallen kunnen de twee tijdreeksen niet betrouwbaar gekoppeld worden.

\section{Gegevensselectie per soort}

Per soort worden ten eerste de locaties geselecteerd die biologisch relevant zijn voor die soort (zie Figuur 1 voor een overzicht van alle geselecteerde locaties). Vervolgens worden voor de diadrome soorten de maanden geselecteerd waarin de adulten hoofdzakelijk migreren (Tabel 2) - of juist de maanden waarin een soort niet migreert (zie houting) afhankelijk van de soortspecifieke biologie. Een aanname in deze selectiemethode is dat in de migratiemaanden voornamelijk migrerende adulten gevangen worden in de fuiken. In de regel wordt een locatie alleen meegenomen in de analyse als alle migratiemaanden consistent door de jaren heen bemonsterd zijn. Als binnen een locatie niet alle migratiemaanden elk jaar bemonsterd zijn, valt deze locatie in principe buiten de selectie. Immers, jaar-op-jaar variatie in tijdstip van migratie binnen de hele migratieperiode kan betekenen dat variatie in aantal gevangen vis niet veroorzaakt wordt door veranderingen in bestandsgrootte, maar alleen in migratietijdstip. Echter, de niet-bemonsterde migratiemaand kan uit de analyse worden gelaten (en de locatie kan dan dus in de analyse worden gelaten) onder twee omstandigheden:

- $\quad$ als een eerste analyse laat zien dat de niet-bemonsterde migratiemaand niet erg belangrijk is binnen de hele tijdreeks (de soort wordt niet veel gevangen in die maand) of

- $\quad$ als een eerste analyse laat zien dat in de niet-bemonsterde migratiemaand grofweg even veel vis wordt gevangen als in één van de andere maanden.

Vangsten worden opgewerkt naar vangstsucces in aantal vis per fuiketmaal (in fuiken) of per km (in het elektroschepnet):

- Voor diadrome soorten wordt het vangstsucces per maand binnen een jaar berekend, omdat de visserij-inspanning niet gelijk verdeeld is over de maanden tussen de jaren in de passieve surveys en de precieze migratietijd kan verschillen van jaar op jaar.

- Voor de overige soorten, waarvoor geen tijdreeks van 12 jaar beschikbaar is, wordt per trek het vangstsucces berekend; het aantal gevangen vis per fuiketmaal. Vervolgens wordt het vangstsucces gemiddeld per maand en jaar (voor de diadrome soorten), en daarna per jaar (alle soorten).

Tabel 1 Maanden waarin een diadrome soort migreert

\begin{tabular}{ll} 
Soort & Maanden \\
Elft & $4,5,6$ \\
\hline Fint & $4,5,6$ \\
\hline Houting & $10,11,12$ \\
\hline Rivierprik & $10,11,12$ \\
\hline Zeeprik & $4,5,6$ \\
\hline Zalm & $6,7,10,11$ \\
\hline
\end{tabular}


Tabel 2 Locaties van de diadromevissurvey die jaarlijks worden bemonsterd, en de nabijgelegen locaties van de vangstregistratie aalvissers. Maanden en jaren betreffen de selectie waarbij een maand consistent elk jaar bemonsterd is. NB Noordzeekanaal wordt ook jaarlijks bemonsterd maar is biologisch niet relevant voor deze soorten, omdat het geen relevante in-/uittrekplek is. * Geen maanden 9-10 vanaf 2009, door gesloten aalseizoen

\begin{tabular}{|c|c|c|c|c|c|c|c|}
\hline \multirow[t]{2}{*}{ Locatie } & \multicolumn{4}{|c|}{ Diadromevissurvey } & \multicolumn{3}{|c|}{ Vangstregistratie aalvissers } \\
\hline & & $\begin{array}{l}\text { Jaren met } \\
\text { voorjaarmonitoring } \\
\text { (maanden tussen } \\
\text { haakjes) }\end{array}$ & $\begin{array}{l}\text { Jaren met } \\
\text { najaarsmonitoring } \\
\text { (maanden 9-11) }\end{array}$ & $\begin{array}{l}\text { Jaren met } \\
\text { december- } \\
\text { monitoring }\end{array}$ & & Maanden & Jaren \\
\hline Den Oever & $\begin{array}{l}\text { IJsselmeer } \\
\text { (Den Oever) }\end{array}$ & $\begin{array}{l}2014,2016-2019(3- \\
5)\end{array}$ & 2013-2019 & 2016 & Niet beschikbaar & & \\
\hline Kornwerderzand & $\begin{array}{l}\text { IJsselmeer } \\
\text { (Kornwerderzand) }\end{array}$ & $\begin{array}{l}2016-2017(3-6), \\
2019(4-6)\end{array}$ & $2014,2016-2019$ & 2014-2017 & 01 IJsselmeer & $5-10 *$ & $1994-2013$ \\
\hline Nieuwe Waterweg & Nieuwe Waterweg & $\begin{array}{l}2014(4-6) \\
2015(3-6) \\
2016-2019(3-5)\end{array}$ & 2014-2019 & 2014 & 19 Nieuwe Waterweg & $5-6$ & 1994-2010 \\
\hline Haringvliet & Haringvliet & $2014-2019(3-5)$ & $2014-2017$ & 2014,2016 & 28 Haringvliet & $4-6,9-10 *$ & $1996-2010$ \\
\hline Maas (zuid) & Maas (Belfeld) & $2014-2017(3-5)$ & 2014-2016 & & 24 Maas & $5-10 *$ & $1994-2010$ \\
\hline Rijn (oost) & Rijn (Lobith) & $2014-2019(3-5)$ & 2014-2015, 2017 & & 16 Rijn & 9 & $\begin{array}{l}1994-2000 \& \\
2007-2010 \\
1995-2009\end{array}$ \\
\hline
\end{tabular}




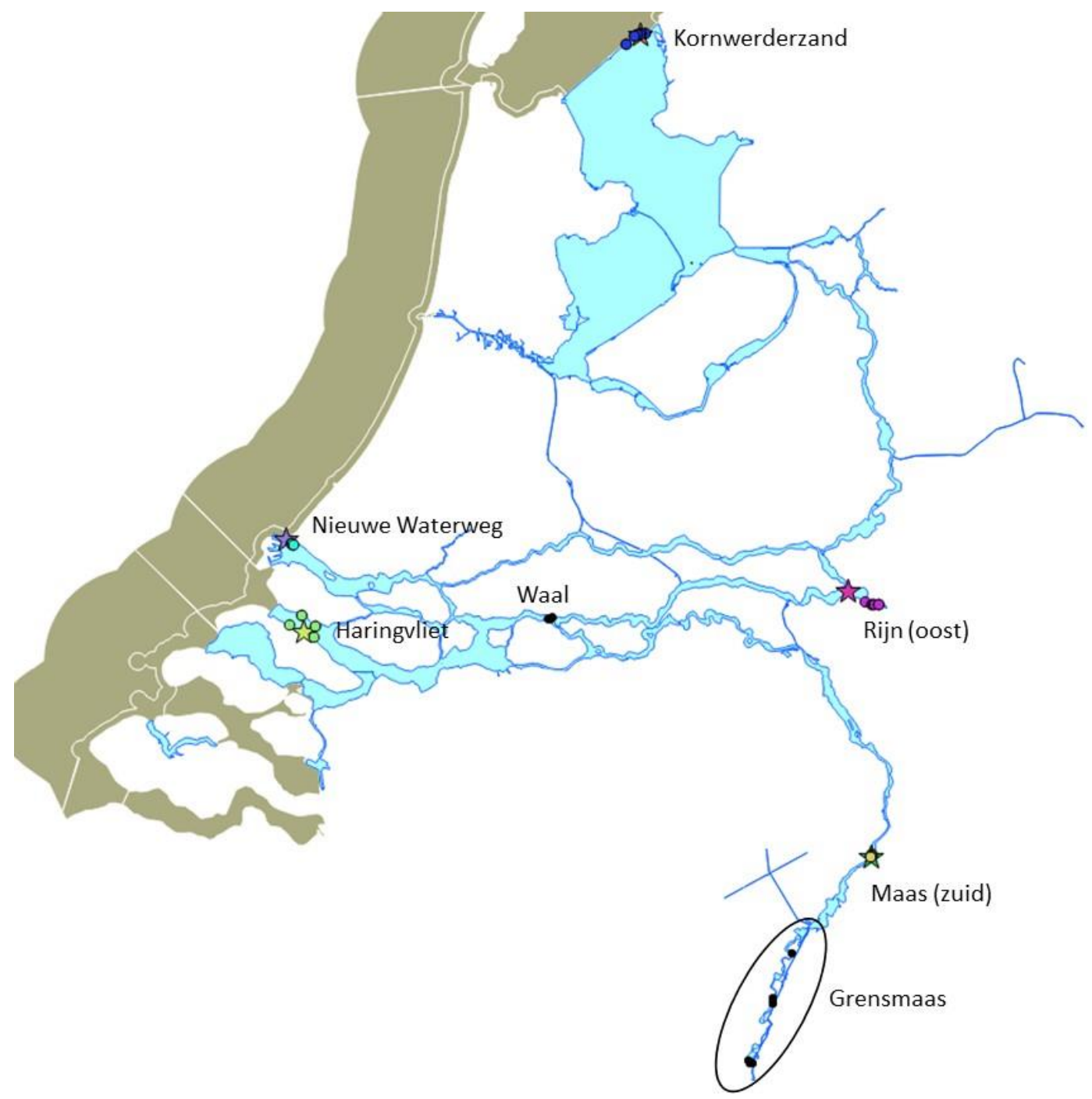

Figuur 1. Geselecteerde locaties van de monitoringprogramma's. Bemonstering met als tuig: Grensmaas = elektroschepnet (rivierenmonitoring met actieve tuigen), Waal = zalmsteek (zalmsteeksurvey), rest van de locaties met fuiken (vangstregistratie aalvissers (ster) en diadromevissurvey (cirkels)). 


\section{Barbeel}

Selectie van locatie en maanden, en opwerking naar één landelijke trend

Voor barbeel wordt de monitoringsreeks van de rivierenmonitoring met actieve tuigen uit de Grensmaas gebruikt. In dit gebied wordt bemonsterd met het elektroschepnet, in verband met de geringe gemiddelde diepte. De monitoring in de Grensmaas vond tot en met 2014 plaats in mei en vanaf 2015 in april. Aangezien barbeel een niet-diadrome soort is, kunnen gegevens verzameld in het hele jaar gebruikt worden; beide maanden zijn dus geschikt. Echter, omdat barbeel in het voorjaar paait en daarbij lokale migratie naar specifieke paaihabitats kan vertonen, zou deze verandering in bemonsteringsperiode mogelijk invloed op de hoeveelheid gevangen barbeel kunnen hebben. Deze verandering in bemonsteringsmethodiek moet worden meegenomen als potentiële factor in de interpretatie van de jaartrend.

\section{Zalm}

Selectie van locatie en maanden, en opwerking naar één landelijke trend Zalmsteekbemonsteringen zijn uitgevoerd in de Lek de IJssel, de Waal en de Maas. De reeks in de Waal in een vrij stromende sectie van de rivier bevat geen trendbreuken, en is daarmee het best bruikbaar.

Bij de bemonsteringsreeksen bij de Lek, IJssel en Maas hebben zich grote trendbreuken voorgedaan; in de IJssel heeft een verandering van monsterlocaties tussen IJssel en Nederrijn plaatsgevonden, en in de Lek en Maas is door de aanleg en aanpassing van vispassages bij stuwen de verblijftijd en daarmee de vangkans van optrekkende zalmen veranderd (Winter, 2009). Dit betekent dat een geschatte trend op deze plekken niet representatief is voor veranderingen in bestandsgrootte. Bovendien is de zalmpopulatie in de Maas afwezig tot zeer klein en heeft zenderonderzoek laten zien dat de zalmen in Nederland voornamelijk via de Waal naar de Duitse Rijn trekken (Hop \& Vriese 2019).

De bemonsteringsmaanden van dit programma zijn de maanden waarin zalm migreert (juni, juli, oktober, november). Er is geen verdere gegevensselectie nodig, omdat deze survey specifiek is gericht op migrerende zalm. Hierbij wordt in de analyse ook rekening gehouden met maandinvloed: de bemonsteringsintensiteit per maand varieert over de jaren en elke maand is potentieel even belangrijk qua zalmmigratie. Echter missen er in sommige jaren maanden in de bemonstering: oktober en november in 1997, november in 2002 en juli vanaf 2014.

\section{EIft}

Selectie van locaties en maanden

Elft migreert in april-juni. Zowel in de diadromevissurvey als de vangstregistratie aalvissers zijn deze maanden niet consistent op alle locaties bemonsterd. Ook zit er minimaal twee jaar zonder monitoringsgegevens tussen de twee programma's, en het is niet mogelijk om de vangstefficiëntie van elft in de twee monitoringprogramma's te koppelen. Echter, in de migratieperiode (april-juni) is tot nu in geen van beide programma's toe geen elft gevangen.

Elft is in de jaren veertig van de $20^{\text {ste }}$ eeuw uitgestorven als paaipopulatie in de Rijn en in 2010 (Scharbert \& Beeck 2010). Sinds 2010 is jonge elft uitgezet in de Duitse Rijn en kunnen er -als deze uitzettingen succesvol zijn- vanaf enkele jaren daarna voor het eerst volwassen terugkerende elften in het stroomgebied van de Rijn verschijnen. Elft zat tot op heden dus nog onder het detectieniveau van het meetnet van beide programma's. Er vanuit gaande dat het detectieniveau van de twee programma's niet veel van elkaar verschilt, kunnen de twee tijdreeksen dus in het geval van elft wel aan elkaar gekoppeld worden; voor alle missende maanden en jaren kan worden aangenomen dat 0 elft zou zijn gevangen. In de toekomst zal de huidige monitoring een signaleren als er wel elft gevangen wordt.

\section{Opwerking naar één landelijke trend}

De aanname is dat in de missende maanden en de missende jaren ook geen elft is gevangen. Met die aanname kunnen alle vijf locaties van de diadrome vismonitoring met de daaraan gekoppelde vangstregistratie-locaties worden meegenomen. Ook kunnen de missende jaren tussen de twee programma's hiermee geschat worden, en de missende maanden per locatie en programma (Tabel 3). Op alle locaties behalve Haringvliet mist april in de vangstregistratie van de aalvissers. Voor al deze situaties wordt aangenomen dat er ook in april geen elft is gevangen. 
Tabel 3 Monitoringsgegevens beschikbaar (1) of niet beschikbaar (0) voor elft

\begin{tabular}{|l|c|c|c|c|c|c|c|c|c|c|c|c|}
\hline & $\begin{array}{c}1994- \\
2000\end{array}$ & $\begin{array}{c}2001- \\
2005\end{array}$ & $\begin{array}{c}2006- \\
2010\end{array}$ & $\mathbf{2 0 1 1}$ & $\mathbf{2 0 1 2}$ & $\mathbf{2 0 1 3}$ & $\mathbf{2 0 1 4}$ & $\mathbf{2 0 1 5}$ & $\mathbf{2 0 1 6}$ & 2017 & 2019 \\
\hline & \multicolumn{5}{|c|}{ Vangstregistratie aalvissers } \\
\hline Haringvliet & 1 & 1 & 1 & 0 & 0 & 0 & 1 & 1 & 1 & 1 & 1 \\
\hline Kornwerderzand & 1 & 1 & 1 & 1 & 0 & 1 & 0 & 0 & 1 & 1 & 1 \\
\hline $\begin{array}{l}\text { Nieuwe } \\
\text { Waterweg }\end{array}$ & 1 & 1 & 1 & 0 & 0 & 0 & 1 & 1 & 1 & 1 & 1 \\
\hline Maas (zuid) & 1 & 1 & 1 & 0 & 0 & 0 & 1 & 1 & 1 & 1 & 0 \\
\hline Rijn (oost) & 1 & 0 & 1 & 0 & 0 & 0 & 1 & 1 & 1 & 1 & 1 \\
\hline
\end{tabular}

\section{Fint}

Selectie van locaties en maanden

Fint migreert in april-juni. Fint komt in Nederland alleen in de benedenstroomse delen van het rivierengebied en langs de kusten voor, en trekt niet verder stroomopwaarts dan de zoetwatergetijden gedeelten van rivieren. Derhalve zijn alleen de benedenstroomse locaties (Haringvliet, Kornwerderzand en Nieuwe Waterweg) voor deze soort relevant.

In de diadromevissurvey is Haringvliet niet bemonsterd in juni en vanaf 2016 Nieuwe Waterweg ook niet. Daarnaast is in de vangstregistratie van de aalvissers april niet bemonsterd in de Nieuwe Waterweg en Kornwerderzand. Omdat (a) alle drie locaties belangrijk zijn voor fintmigratie en (b) op basis van een eerste analyse mei de belangrijkste migratiemaand wordt geacht, is gekozen om alleen mei voor alle drie locaties te selecteren.

Er zit minimaal twee jaar zonder monitoringsgegevens tussen de twee programma's op elke locatie en het is niet mogelijk om de vangstefficiëntie van elft in de twee monitoringprogramma's te koppelen. Ook is het, gezien de variatie in vangsten tussen jaren, niet mogelijk om aannames te doen over de trend in de missende jaren. Met andere woorden, de twee tijdreeksen kunnen niet betrouwbaar gekoppeld worden. Daarom is ook een statistische analyse over de laatste 12 jaar momenteel niet mogelijk en is de trend over de laatste 12 jaar op basis van expert judgement beoordeeld.

\section{Opwerking naar landelijke trend, met trendbreuk}

Binnen de selectie missen jaren binnen locaties (Tabel 4). De enige locatie waar redelijke hoeveelheden fint zijn gevangen is Nieuwe Waterweg. Deze locatie wordt daarom leidend in de selecties en aannames om de tijdreeksen tussen de locaties gelijk te trekken:

1. Kornwerderzand 2011 en 2013 worden verwijderd

2. Kornwerderzand 2014 en 2015 vangstsucces wordt aangenomen gelijk te zijn aan die in 2016 en 2017 (0 fint gevangen).

Met deze selectie en aanname is een goed gebalanceerde tijdreeks tussen jaren en locaties beschikbaar, die vervolgens opgewerkt kan worden naar twee index-reeksen (1994-2010 en 20142017) voor de landelijke bestandsgrootte.

Tabel 4 Monitoringsgegevens beschikbaar (1) of niet beschikbaar (0) voor fint

\begin{tabular}{|l|c|c|c|c|c|c|c|c|c|c|}
\hline & $\mathbf{1 9 9 4 - 2 0 1 0}$ & $\mathbf{2 0 1 1}$ & $\mathbf{2 0 1 2}$ & $\mathbf{2 0 1 3}$ & $\mathbf{2 0 1 4}$ & $\mathbf{2 0 1 5}$ & $\mathbf{2 0 1 6}$ & $\mathbf{2 0 1 7}$ & 2019 \\
\hline & \multicolumn{1}{|c|}{ Vangstregistratie } & aalvissers & \multicolumn{5}{|c|}{ Diadromevissurvey } \\
\hline Haringvliet & 1 & 0 & 0 & 0 & 1 & 1 & 1 & 1 & 1 \\
\hline Kornwerderzand & 1 & 1 & 0 & 1 & 0 & 0 & 1 & 1 & 1 \\
\hline Nieuwe Waterweg & 1 & 0 & 0 & 0 & 1 & 1 & 1 & 1 & 1 \\
\hline
\end{tabular}


Mogelijk worden tijdens de migratiemaanden ook juveniele finten in jaarlijks sterk wisselende aantallen gevangen. Bij voorkeur worden alleen de volwassen finten meegenomen in de index, maar in de vangstregistratie van de aalvissers is geen informatie verzameld over paairijpheid of lengte. In de diadromevissurvey vanaf 2012 wordt de lengte van fint wel geregistreerd. Zodra deze reeks lang genoeg is om zelfstandig een tijdreeks van 12 jaar te creëren, dan zal deze selectie van volwassen finten worden gemaakt. Voor de beschikbare jaren in de diadromevissurvey is wel gekeken naar de invloed van juveniele fint op het totale vangstsucces: van de tien beschikbare jaar/gebied-combinaties is nergens jonge fint gevangen. Deze eerste analyse suggereert dus dat de invloed van juveniele fint op de index niet groot zal zijn. De meeste jonge fint verschijnt waarschijnlijk later in het seizoen dan in april-juni.

\section{Houting}

Selectie van locaties en maanden

Volwassen houting migreert in oktober-december naar de paaiplaatsen, waarbij de belangrijkste migratiemaand december is en in mindere mate november (Borcherding et al. 2014). Omdat deze primaire migratiemaanden voor houting niet overeen komen met de consistent bemonsterde maanden in de passieve monitoringsprogramma's, is het wat betreft houting niet mogelijk om trends tijdens de paaitrek te onderzoeken.

Voor houting kunnen wel de gegevens gebruikt worden die verzameld zijn buiten de paaitrek; tijdens het groeiseizoen. De meeste houting in Nederlandse zoete wateren leeft daar waarschijnlijk gedurende zijn hele leven, en trekt niet van zout naar zoet. Het deel dat wel naar zoute wateren migreert kent geen grote verspreiding vanuit de riviermondingen (Borcherding et al. 2008). De houting populatie in het Rijnstroomgebied bevindt zich dus jaarrond in de benedenstroomse delen van het stroomgebied in Nederland en heeft geen uitwisseling met andere deelpopulaties. De houting vangsten buiten het migratieseizoen zijn dus waarschijnlijk ook een goede weerspiegeling van de populatietrend van houting. Ook buiten de paaiperiode is er geen evenwichtige selectie te maken van dezelfde maanden over beide programma's en alle jaren. Echter, aangezien het niet-migrerende houting betreft, kan de trend van de vangsten op verschillende locaties wel gekoppeld worden, ondanks een verschil in bemonsteringsperiode. Het enige van belang hierbij is dat de maanden binnen een locatie wel consistent bemonsterd worden tussen jaren. Alle vijf locaties kunnen hierdoor worden meegenomen, maar met een andere selectie van maanden:

- In de diadromevissurvey zijn Haringvliet, Maas, Nieuwe Waterweg en Rijn consistent bemonsterd in mei en september, en Kornwerderzand in juni en september.

- $\quad$ In de vangstregistratie aalvissers zijn Nieuwe Waterweg en Haringvliet consistent bemonsterd in mei en juni en Maas, Rijn en Kornwerderzand in mei-augustus.

Er zit minimaal twee jaar zonder monitoringsgegevens tussen de twee programma's en het is niet mogelijk om de vangstefficiëntie van houting in de twee monitoringprogramma's te koppelen. Ook is het, gezien de variatie in vangsten tussen opeenvolgende jaren, niet mogelijk om aannames te doen over de trend in de missende jaren. De twee tijdreeksen kunnen dus niet betrouwbaar gekoppeld worden. Daarom is ook geen statistische analyse over de laatste 12 jaar momenteel mogelijk en zal de trend over de laatste 12 jaar op basis van expert judgement beoordeeld worden.

\section{Opwerking naar landelijke trend, met trendbreuk}

Binnen deze selectie missen jaren binnen locaties (5). De enige locatie waar redelijke hoeveelheden houting zijn gevangen is Kornwerderzand. Deze locatie wordt daarom leidend in de selecties en aannames om de tijdreeksen tussen de locaties gelijk te trekken:

1. 2011 en 2013 van de overige vier locaties: vangstsucces wordt aangenomen het gemiddelde van de twee jaar ervoor (2009 en 2010) te zijn.

2. 2001-2005 en 2016 van de Rijn: vangstsucces wordt aangenomen het gemiddelde van de twee jaar ervoor te zijn. In de hele selectie van de rijn is geen houting gevangen, dus het geschatte vangstsucces is altijd 0 .

3. 2017 Maas: vangstsucces wordt aangenomen het gemiddelde van 2016 te zijn

4. 2014 en 2015 van de overige vier locaties worden verwijderd omdat er geen informatie vanuit Kornwerderzand beschikbaar is. 
Met deze selectie en aanname is een goed gebalanceerde tijdreeks tussen jaren en locaties beschikbaar, die vervolgens opgewerkt kan worden naar twee index-reeksen (1994-2013 en 20162019) voor de landelijke bestandsgrootte.

Tabel 5 Monitoringsgegevens beschikbaar (1) of niet beschikbaar (0) voor houting

\begin{tabular}{|l|c|c|c|c|c|c|c|c|c|c|c|}
\hline & $\begin{array}{c}1994- \\
2000\end{array}$ & $\begin{array}{c}2001- \\
2005\end{array}$ & $\begin{array}{c}2006- \\
2010\end{array}$ & $\mathbf{2 0 1 1}$ & $\mathbf{2 0 1 2}$ & $\mathbf{2 0 1 3}$ & $\mathbf{2 0 1 4}$ & $\mathbf{2 0 1 5}$ & $\mathbf{2 0 1 6}$ & 2017 & 2019 \\
\hline & \multicolumn{7}{|c|}{ Vangstregistratie aalvissers } \\
\hline Haringvliet & 1 & 1 & 1 & 0 & 0 & 0 & 1 & 1 & 1 & 1 & 0 \\
\hline Kornwerderzand & 1 & 1 & 1 & 1 & 0 & 1 & 0 & 0 & 1 & 1 & 1 \\
\hline $\begin{array}{l}\text { Nieuwe } \\
\text { Waterweg }\end{array}$ & 1 & 1 & 1 & 0 & 0 & 0 & 1 & 1 & 1 & 1 & 1 \\
\hline Maas (zuid) & 1 & 1 & 1 & 0 & 0 & 0 & 1 & 1 & 1 & 0 & 0 \\
\hline Rijn (oost) & 1 & 0 & 1 & 0 & 0 & 0 & 1 & 1 & 0 & 1 & 0 \\
\hline
\end{tabular}

\section{Rivierprik}

Selectie van locaties en maanden en opwerking naar één landelijke trend

Volwassen rivierprik migreert in oktober-december (soms ook in januari) naar de paaiplaatsen, waarbij november en december het belangrijkst zijn en meegenomen dienen te worden in de selectie (Winter et al., 2013; Griffioen \& Winter 2014). De locaties van de vangstregistratie aalvissers zijn geen van alle consistent december bemonsterd. Alleen de tijdreeks van de diadromevissurvey is dus geschikt om bestandsontwikkelingen van rivierprik te volgen. Hierbij kunnen alleen die locaties en jaren waarin ook december is bemonsterd worden meegenomen: Haringvliet en Kornwerderzand. Het Haringvliet is in 2014 en 2016 in alle drie maanden bemonsterd, Kornwerderzand in 2014, 2016 en 2017 (Tabel 6). Aangezien beide locaties belangrijk zijn voor de intrek van rivierprik, worden 2014 en 2016 van beide locaties geselecteerd.

Tabel 6 Monitoringsgegevens beschikbaar (1) of niet beschikbaar (0) voor houting

\begin{tabular}{|l|c|c|c|c|c|}
\hline & 2014 & 2015 & 2016 & 2017 & 2019 \\
\hline & \multicolumn{5}{|c|}{ Diadromevissurvey } \\
\hline Haringvliet & 1 & 0 & 1 & 0 & 0 \\
\hline Kornwerderzand & 1 & 0 & 1 & 1 & 0 \\
\hline
\end{tabular}

\section{Zeeprik}

Selectie van locaties en maanden

Volwassen zeeprik migreert in april-juni naar bovenstroomse paaiplaatsen. Er is geen homing zoals bij bijvoorbeeld zalm (terugkeer naar dezelfde geboorteplek), waardoor de soort geen riviereigen populaties kent maar veel uitwisseling en menging tussen nabij gelegen riviersystemen (Bergstedt \& Seelye, 1995). Zeeprik kan dus op alle vijf locaties voorbijtrekken en alle locaties worden meegenomen in de selectie. Echter, in de diadromevissurvey is Haringvliet niet bemonsterd in juni en vanaf 2016 Nieuwe Waterweg ook niet. Daarnaast is in de vangstregistratie van de aalvissers april niet bemonsterd op alle locaties behalve Haringvliet. Omdat (a) alle vijf locaties belangrijk zijn wat betreft zeeprik migratie en (b) op basis van een eerste analyse de vangsten in april en mei niet veel verschilden en juni veel lagere vangsten toonde, wordt gekozen om mei en waar mogelijk ook juni, voor alle vijf locaties te selecteren.

Er zit minimaal twee jaar zonder monitoringsgegevens tussen de twee programma's op elke locatie en het is niet mogelijk om de vangstefficiëntie van zeeprik in de twee monitoringprogramma's te koppelen. Ook is het, gezien de variatie in vangsten tussen opeenvolgende jaren, niet mogelijk om aannames te doen over de trend in de missende jaren. De twee tijdreeksen kunnen dus niet betrouwbaar gekoppeld worden. Daarom is ook geen statistische analyse over de laatste 12 jaar momenteel mogelijk, maar zal met expert judgement de trend over de laatste 12 jaar beoordeeld worden. 
Opwerking naar landelijke trend, met trendbreuk

Binnen de selectie missen jaren binnen locaties (Tabel 7). De enige locatie waar redelijke hoeveelheden zeeprik zijn gevangen is Nieuwe Waterweg en Haringvliet. Deze locatie wordt daarom leidend in de selecties en acties om de tijdreeksen tussen de locaties gelijk te trekken:

1. Kornwerderzand 2011 en 2013 worden verwijderd

2. Kornwerderzand 2014 en 2015 vangstsucces wordt aangenomen gelijk te zijn aan die in 2016 en 2017 (0 zeeprik gevangen).

Met deze selectie en aanname is een goed gebalanceerde tijdreeks tussen jaren en locaties beschikbaar, die vervolgens opgewerkt kan worden naar twee index-reeksen (1994-2010 en 20142019) voor de landelijke bestandsgrootte.

Tabel 7 Monitoringsgegevens beschikbaar (1) of niet beschikbaar (0) voor zeeprik

\begin{tabular}{|l|c|c|c|c|c|c|c|c|c|c|c|}
\hline & $\begin{array}{c}1994- \\
2000\end{array}$ & $\begin{array}{c}\mathbf{2 0 0 1 -} \\
\mathbf{2 0 0 6}\end{array}$ & $\begin{array}{c}\mathbf{2 0 0 7} \\
\mathbf{2 0 1 0}\end{array}$ & $\mathbf{2 0 1 1}$ & $\mathbf{2 0 1 2}$ & $\mathbf{2 0 1 3}$ & $\mathbf{2 0 1 4}$ & $\mathbf{2 0 1 5}$ & $\mathbf{2 0 1 6}$ & 2017 & 2019 \\
\hline & \multicolumn{3}{|c|}{ Vangstregistratie aalvissers } \\
\hline Haringvliet & 1 & 1 & 1 & 0 & 0 & 0 & 1 & 1 & 1 & 1 & 1 \\
\hline Kornwerderzand & 1 & 1 & 1 & 1 & 0 & 1 & 0 & 0 & 1 & 1 & 1 \\
\hline $\begin{array}{l}\text { Nieuwe } \\
\text { Waterweg }\end{array}$ & 1 & 1 & 1 & 0 & 0 & 0 & 1 & 1 & 1 & 1 & 1 \\
\hline Maas (zuid) & 1 & 1 & 1 & 0 & 0 & 0 & 1 & 1 & 1 & 1 & 0 \\
\hline Rijn (oost) & 1 & 0 & 1 & 0 & 0 & 0 & 1 & 1 & 0 & 1 & 1 \\
\hline
\end{tabular}




\section{Bijlage 58 Wegingsfactoren waterlichamen EKR scoreberekening}

Tabel 1. Wegingsfactoren en oppervlaktes waterlichamen.

\begin{tabular}{|c|c|c|c|c|c|c|}
\hline waterlichaam & mlcident & oever & open_water & oppha & oeverha & openwaterha \\
\hline NL87_1 & NL87_NAUNSPDR & 0 & 1 & 2183 & 36.77385 & 2146.22615 \\
\hline NL89_GREVLEMR & NL89_GREVLGMR106 & 0 & 1 & 13930 & 37.1337 & 13892.8663 \\
\hline NL89_VEERSMR & NL89_VEERSMR01 & 0 & 1 & 4186 & 20.5554 & 4165.4446 \\
\hline NL89_VOLKERAK & NL89_NOORDGT & 0.0077 & 0.9923 & 6317 & 48.6409 & 6268.3591 \\
\hline NL89_ZOOMMEDT & NL89_ZOOMMMDN2 & 0.0118 & 0.9882 & 1663 & 19.66605 & 1643.33395 \\
\hline NL91BM & NL91_BM_A & 0.0055 & 0.9945 & 4247 & 23.4327 & 4223.5673 \\
\hline NL92_IJSSELMEER & NL92_VROUWZD & 0.0005 & 0.9995 & 114883 & 57.4415 & 114825.5585 \\
\hline NL92_KETELMEER-VOSSEMEER & NL92_KETMWT & 0.0052 & 0.9948 & 4236 & 22.0272 & 4213.9728 \\
\hline NL92_MARKERMEER & NL92_MARKMMDN & 0.0006 & 0.9994 & 69933 & 41.9598 & 69891.0402 \\
\hline NL92_RANDMEREN_OOST & NL92_VELWMMDN & 0.004 & 0.996 & 6487 & 25.8486 & 6461.1514 \\
\hline NL92_RANDMEREN_ZUID & NL92_EEMMDK23 & 0.0035 & 0.9965 & 4291 & 15.0185 & 4275.9815 \\
\hline NL93_IJSSEL & NL93_VEESSN & 0.025 & 0.975 & 12294 & 307.35 & 11986.65 \\
\hline NL93_TWENTHEKANALEN & NL93_STRVLCZD & 0.0572 & 0.9428 & 415 & 23.738 & 391.262 \\
\hline NL94_1 & NL94_HOLLANDSCHDIEP_A & 0.0036 & 0.9964 & 12815 & 46.134 & 12768.866 \\
\hline NL94_10 & NL94_BRABANTSEBIESBOSC_A & 0.0004 & 0.9996 & 5262 & 1.953133374 & 5260.046867 \\
\hline NL94_2 & NL94_DORDTSEBIESBOSCH_A & 0.01 & 0.99 & 2542 & 25.42 & 2516.58 \\
\hline NL94_4 & NL94_OUDMS_A & 0.0152 & 0.9848 & 6880 & 104.576 & 6775.424 \\
\hline NL94_5 & NL94_BENEDENMAAS_A & 0.0174 & 0.9826 & 4902 & 85.2948 & 4816.7052 \\
\hline NL94_6 & NL94_BERGSCHEMAAS & 0.0174 & 0.9826 & 1183 & 20.5842 & 1162.4158 \\
\hline NL94_7 & NL94_HOLLANDSCHEIJSSEL_A & 0.0055 & 0.9945 & 542 & 2.970885196 & 539.0291148 \\
\hline NL94_8 & NL94_NIEUWEMAAS_A & 0 & 1 & 4804 & 0 & 4804 \\
\hline NL99_VechtZwarteWater & NL93_Vechtdelta_C & 0.0427 & 0.9573 & 3403 & 145.3081 & 3257.6919 \\
\hline
\end{tabular}




\section{Bijlage 59 EKR Indicator \& deelmaatlatscores}

Tabel 1. Deelmaatlatscores $M$ wateren zonder fuikgegevens.

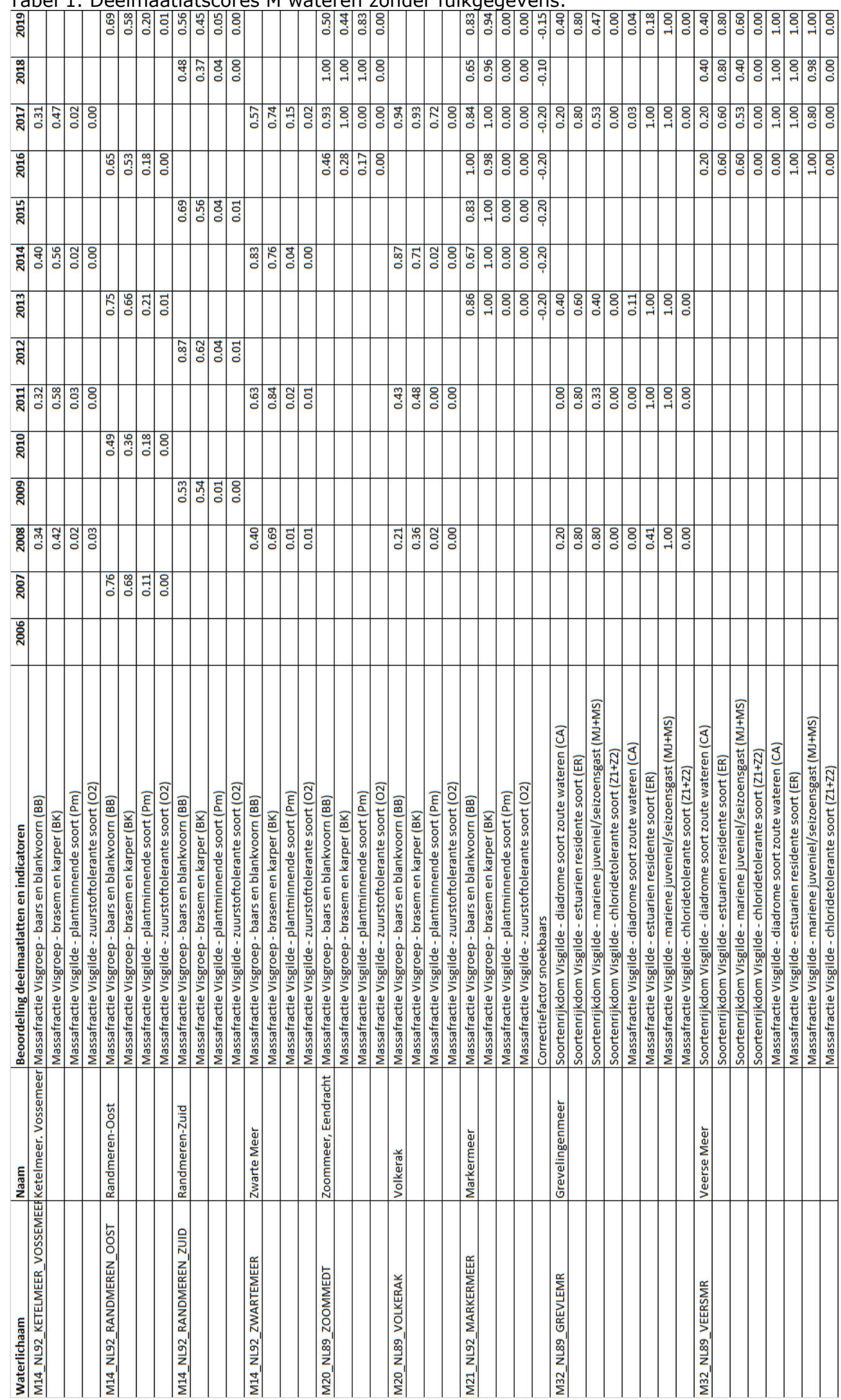


Tabel 2. Deelmaatlatscores R7 \& R16 wateren zonder fuikgegevens.

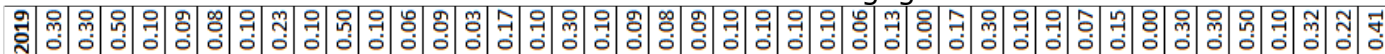

क्

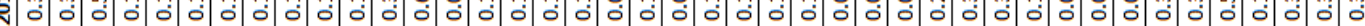

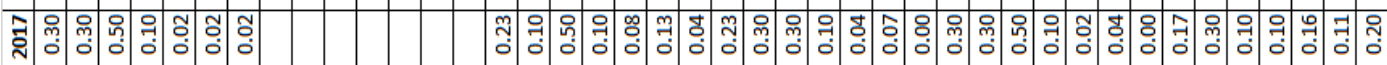

กั้

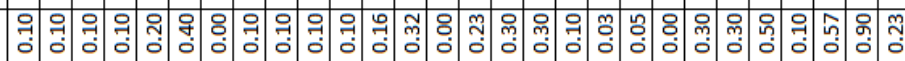

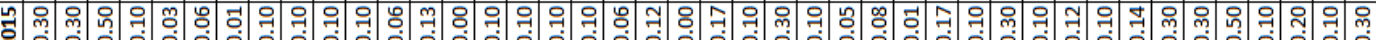
ปั่

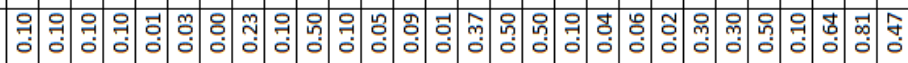

กี้ শึ่

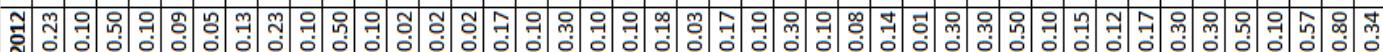

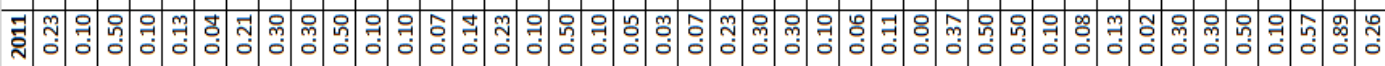

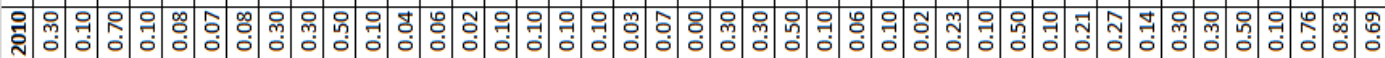

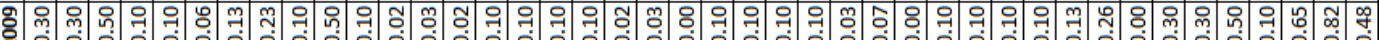

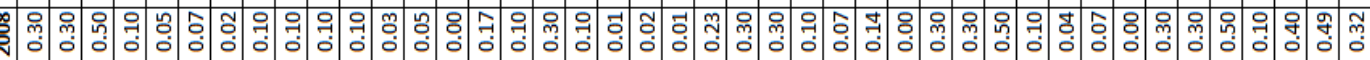

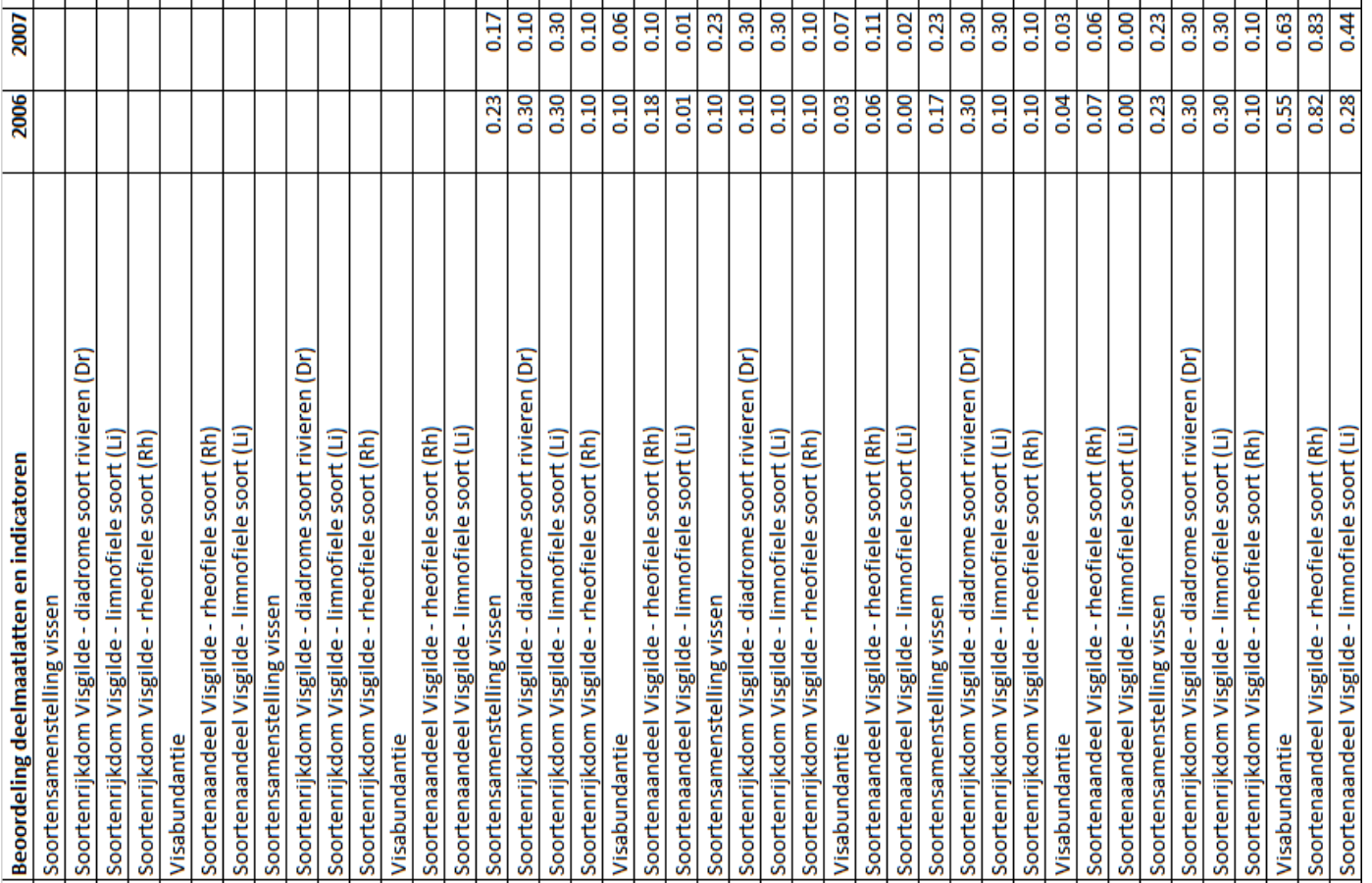

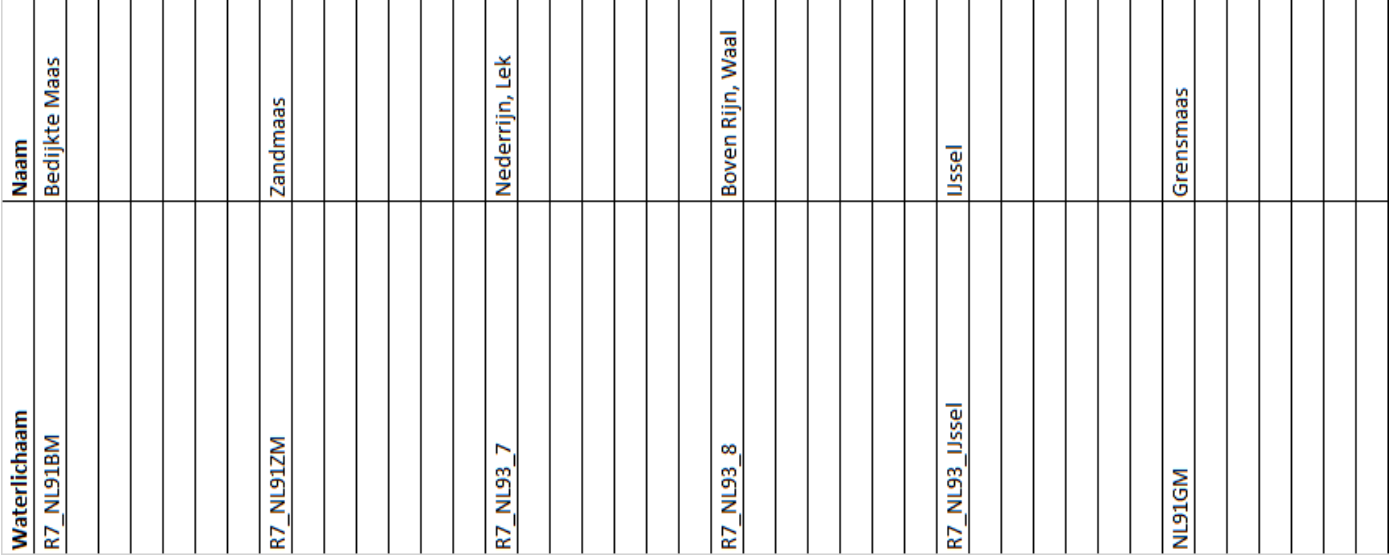


Tabel 3. Deelmaatlatscores R8 wateren zonder fuikgegevens.

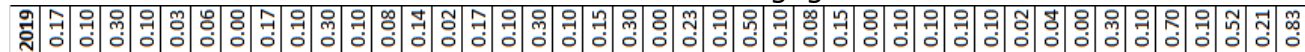

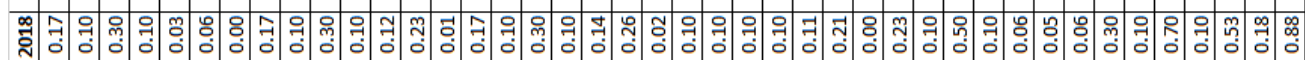

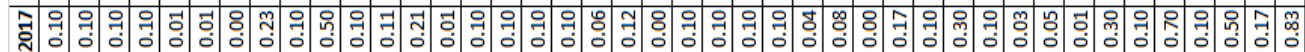

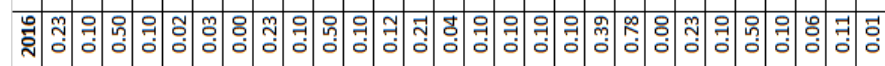

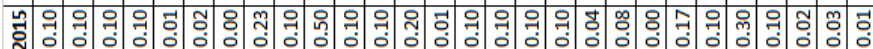

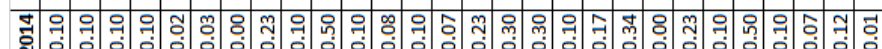

궁웡

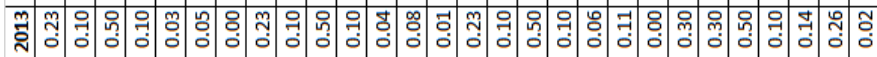

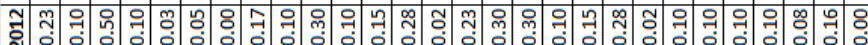

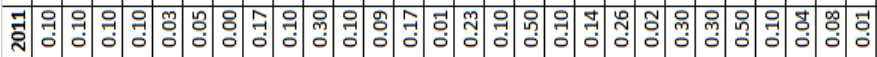

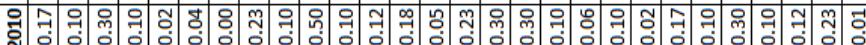

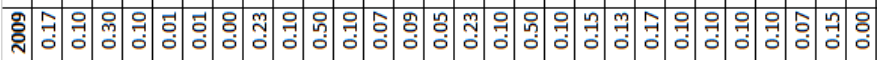

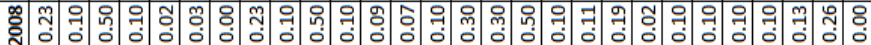

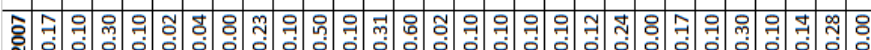

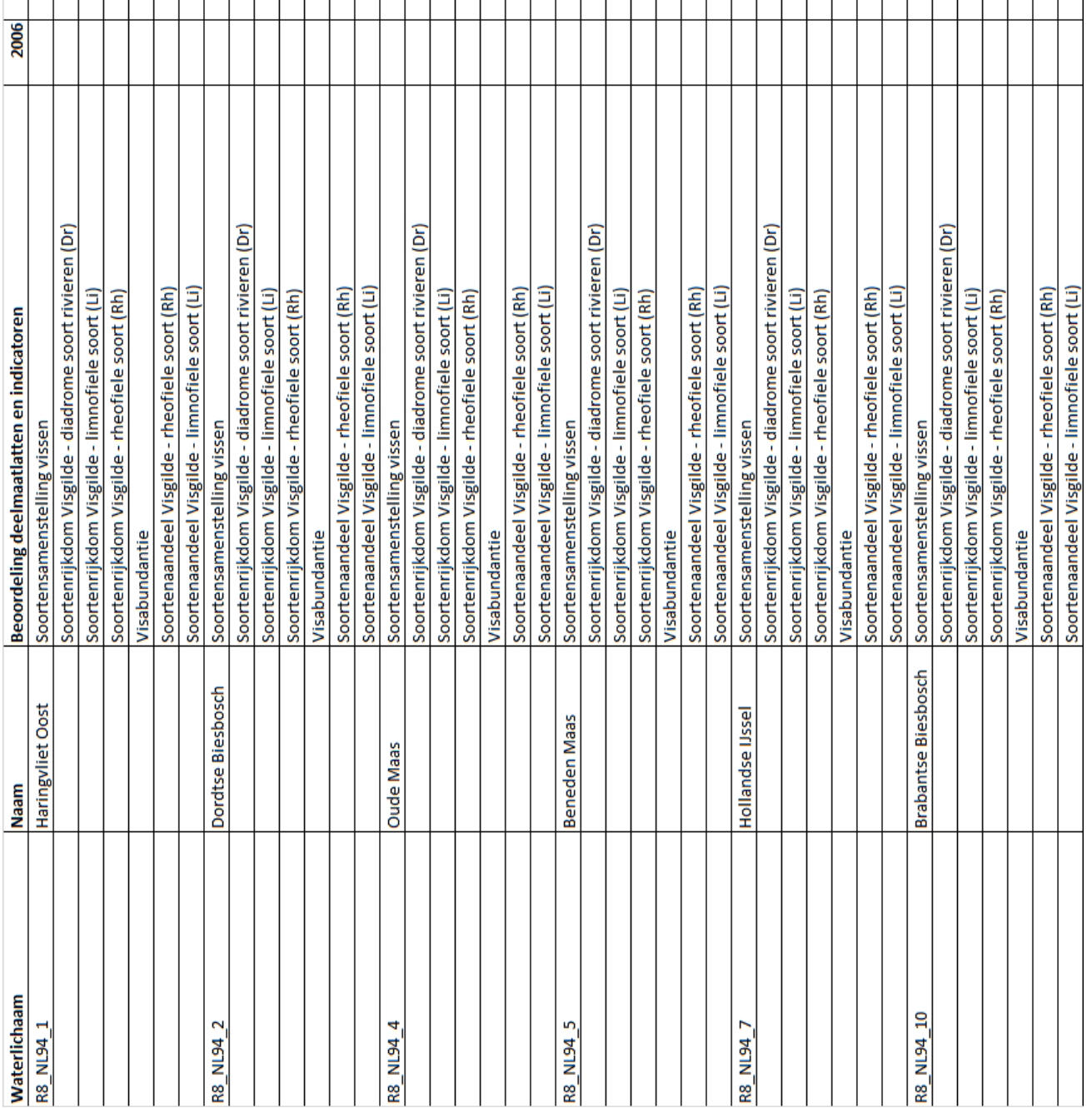


Tabel 4. Deelmaatlatscores O2b wateren met fuikgegevens.

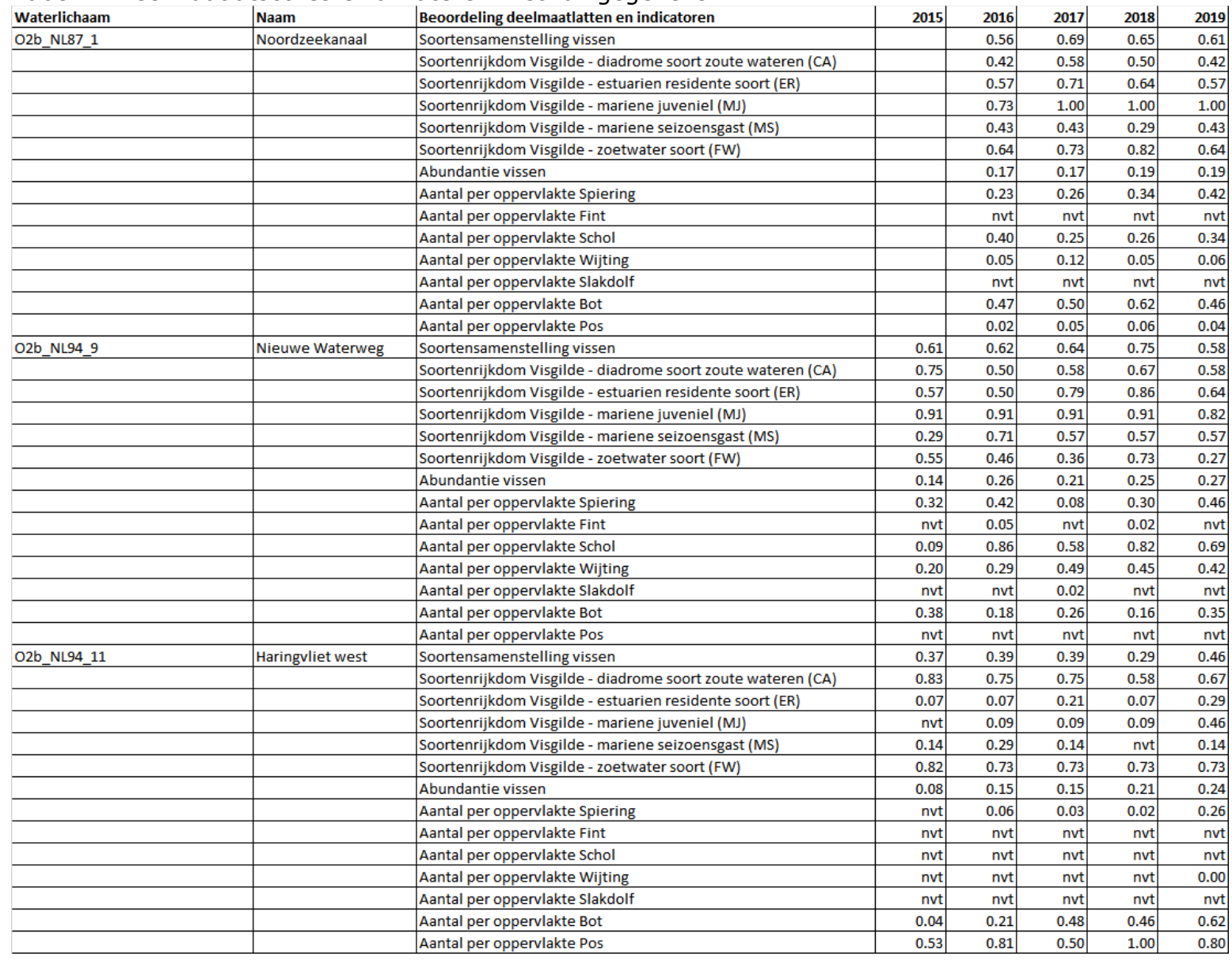

Tabel 5. Deelmaatlatscores M21b, met fuikgegevens.

\begin{tabular}{|c|c|c|c|c|c|c|c|c|c|}
\hline Waterlichaam & Naam & Beoordeling deelmaatlatten en indicatoren & 2013 & 2014 & 2015 & 2016 & 2017 & 2018 & 2019 \\
\hline \multirow[t]{6}{*}{ M21_NL92_IJSSELMEER } & Ijsselmeer & Soortenrijkdom Visgilde - diadrome soort rivieren (Dr) & 0.04 & 0.11 & 0.43 & 0.17 & 0.27 & 0.15 & 0.16 \\
\hline & & Massafractie Visgroep - brasem en karper (BK) & 1.00 & 1.00 & 1.00 & 1.00 & 1.00 & 1.00 & 1.00 \\
\hline & & Massafractie Visgilde - plantminnende soort (Pm) & 0.01 & 0.00 & 0.00 & 0.01 & 0.00 & 0.01 & 0.00 \\
\hline & & Biomassa Bot & 0.28 & 0.41 & 0.08 & 0.22 & 0.25 & 0.19 & 0.24 \\
\hline & & Gemiddelde lengte snoekbaars $(\mathrm{cm})$ & 17.97 & 19.39 & & 30.2 & 20.1 & 52.1 & \\
\hline & & Correctiefactor snoekbaars & -0.20 & -0.20 & & -0.20 & -0.20 & -0.05 & \\
\hline
\end{tabular}


Tabel 6. Deelmaatlatscores R7 \& R16 wateren, met fuikgegevens.

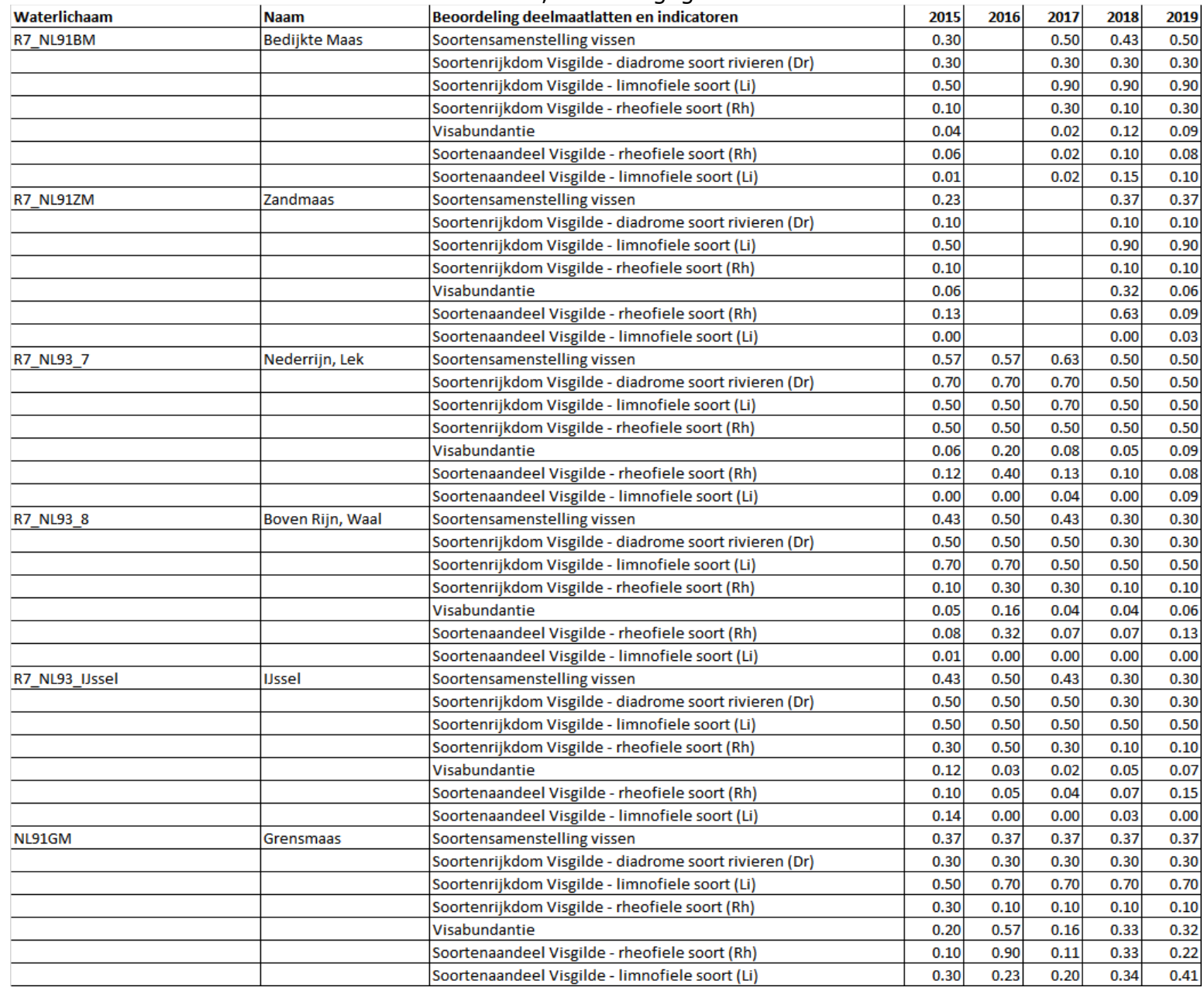


Tabel 7. Deelmaatlatscores R8 wateren, met fuikgegevens.

\begin{tabular}{|c|c|c|c|c|c|c|c|}
\hline Waterlichaam & Naam & Beoordeling deelmaatlatten en indicatoren & 2015 & 2016 & 2017 & 2018 & 2019 \\
\hline \multirow{3}{*}{ R8_NL94_1 } & & Soortenrijkdom Visgilde - limnofiele soort (Li) & 0.30 & 0.50 & 0.10 & 0.30 & 0.30 \\
\hline & & Soortenaandeel Visgilde - rheofiele soort (Rh) & 0.02 & 0.03 & 0.01 & 0.06 & 0.06 \\
\hline & & Soortenaandeel Visgilde - limnofiele soort (Li) & 0.00 & 0.00 & 0.00 & 0.00 & 0.00 \\
\hline \multirow[t]{5}{*}{ R8_NL94_2 } & Dordtse Biesbosch & Soortensamenstelling vissen & 0.30 & 0.23 & 0.30 & 0.23 & 0.23 \\
\hline & & Soortenrijkdom Visgilde - rheofiele soort (Rh) & 0.10 & 0.10 & 0.10 & 0.10 & 0.10 \\
\hline & & Visabundantie & 0.10 & 0.12 & 0.11 & 0.12 & 0.08 \\
\hline & & Soortenaandeel Visgilde - rheofiele soort (Rh) & 0.20 & 0.21 & 0.21 & 0.23 & 0.14 \\
\hline & & Soortenaandeel Visgilde - limnofiele soort (Li) & 0.00 & 0.04 & 0.01 & 0.01 & 0.02 \\
\hline \multirow[t]{3}{*}{ R8_NL94_4 } & Oude Maas & Soortensamenstelling vissen & 0.57 & 0.57 & 0.57 & 0.50 & 0.50 \\
\hline & & Soortenrijkdom Visgilde - diadrome soort rivieren (Dr) & 0.70 & 0.70 & 0.70 & 0.50 & 0.50 \\
\hline & & Soortenaandeel Visgilde - limnofiele soort (Li) & 0.00 & 0.00 & 0.00 & 0.02 & 0.00 \\
\hline \multirow[t]{7}{*}{ R8_NL94_5 } & Beneden Maas & Soortensamenstelling vissen & 0.37 & 0.37 & 0.30 & 0.30 & 0.30 \\
\hline & & Soortenrijkdom Visgilde - diadrome soort rivieren (Dr) & 0.50 & 0.50 & 0.50 & 0.30 & 0.30 \\
\hline & & Soortenrijkdom Visgilde - limnofiele soort (Li) & 0.50 & 0.50 & 0.30 & 0.50 & 0.50 \\
\hline & & Soortenrijkdom Visgilde - rheofiele soort (Rh) & 0.10 & 0.10 & 0.10 & 0.10 & 0.10 \\
\hline & & Visabundantie & 0.02 & 0.06 & 0.04 & 0.11 & 0.08 \\
\hline & & Soortenaandeel Visgilde - rheofiele soort (Rh) & 0.03 & 0.11 & 0.08 & 0.21 & 0.15 \\
\hline & & Soortenaandeel Visgilde - limnofiele soort (Li) & 0.01 & 0.01 & 0.00 & 0.00 & 0.00 \\
\hline \multirow[t]{4}{*}{ R8_NL94_10 } & Brabantse Biesbosch & Soortensamenstelling vissen & & & 0.43 & 0.37 & 0.37 \\
\hline & & Soortenrijkdom Visgilde - diadrome soort rivieren (Dr) & & & 0.50 & 0.30 & 0.30 \\
\hline & & Soortenrijkdom Visgilde - limnofiele soort (Li) & & & 0.70 & 0.70 & 0.70 \\
\hline & & Soortenrijkdom Visgilde - rheofiele soort (Rh) & & & 0.10 & 0.10 & 0.10 \\
\hline
\end{tabular}


Wageningen Marine Research

T: $+31(0) 317480900$

E: marine-research@wur.nl

www.wur. $\mathrm{nl} /$ marine-research

Bezoekers adres:

- Ankerpark 271781 AG Den Helder

- Korringaweg 7, 4401 NT Yerseke

- Haringkade 1, 1976 CP IJmuiden
Wageningen Marine Research levert met kennis, onafhankelijk wetenschappelijk onderzoek en advies een wezenlijke bijdrage aan een duurzamer, zorgvuldiger beheer, gebruik en bescherming van de natuurlijke rijkdommen in zee-, kust- en zoetwatergebieden. 